







\title{
DESCRIPTION S
}

OF

\section{NEW GENERA AND SPECIES OF COLEOPTERA.}

\author{
By Major T. Broun, F.E.S.
}

The following descriptions of three new genera and 115 species of New

Zealand beetles were prepared during the year 1909. With these are incorporated nineteen species that were published in Germany by Herr Reitter, and one by Dr. Sharp, which, unfortunately, had been inadvertently omitted in previous lists.

The new species recorded in my "Revision of the New Zealand Byrrhidae"* are not included in this paper.

During the previous year twenty new genera and 157 species were described by me. These were published in the "Annals and Magazine of Natural History," at London. Copies of these have been deposited in the library of the Auckland Museum.

The numbers from 2593 to 3021 were affixed to species described by me and published in the "Annals and Magazine of Natural History" between the years 1893 and 1909 .

\section{LIST OF NEW GENERA AND SPECIES.}

Group Anchomenidae.

3022. Tarastethus pretiosus Broun.

Group Feronidae.

3023. Trichosternus dissentaneus Broun.

Group Anisodactylidae. 3024. Gaioxenus pilipalpis Broun. 3025. Zabronothus oblongus Broun.

Group Bembididda.

3026. Bembidium waikatoense Broun.
3027. Bembidium tinctellum Broun.

3028. Anillus monticola Broun.

Group Lebitdae.

3029. Demetrida lateralis Broun.

Group Pericalidae.

3030. Scopodes nigripes Broun.

\section{Group Dryopidae.}

3031. Alloparnus scutellaris Broun.

* See New Zealand Institute Bulletin No. 2. 
(iroup II YomopHIIIHAE.

3(1):32. Stygnohydrus fomoralis Broun.

3013:3. Psephohoragus dispar Broun.

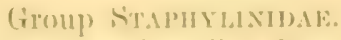

303.3. Q Quedius tinctellus Bronen.

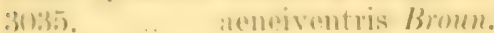

3usti. lomgiceps Bromm.

(iroup P’EDEIRIAR.

30137. Dimerus stilbus Broun.

30:38. Lithocharis erranipennis Broun.

Group Ussomiduat.

3:3!). Holotrochus laevigatus Broun.

$3(1) .10$.

$3(1)+1$.

$304 \%$.

3043 .

\section{Group Umalidae.}

3144. Omalium nemobium Broun. 3115. ", laetipenne Broun. 30146. Ischnoderus cognatus Broun. 301.7. arrecolius Broum.

Group Pselaphidae.

3018. Vidamus spinipes Broun. 3(1).9. Sagolonus impressus Broun. 3050). Zealandius usitatus Broun. 3(1):1. Tyrogetus palpalis Broun. 3052. Lupines lewisi Broun.

Group Histeridate.

30.53. Epierus rufescens Reitter.

Group Nitidulidae.

3054. Soronia oculator Reitler.

Group Cryptophagidal.

305.5. Telmatophilus vestitus Broun. 3(1)(f). Micrambina helmsi Reitter. :157. , insignis Reitter.

(iroup Lathiridinate.

30).8. Holoparamecus tenuis Reifler. 3059). Cortiearia illustris Reiller. 3orion. .. longula Bromu. 3ertil. molasoma Bromen.

306f2. Myromecroxenus atomaroides tiritler.

(iroup) ВутвแHI)AЕ.

301i3. Pedilophorus homsi Rerller.
(Houp) EUCXmMna.

306t. Neocharis lobitarsis Bromm.

3465. 'alerax spinitarsis Bromen.

Gromp Elateridal:

306if. Lomemus vittipennis Broun.

Group Dascrlatidat.

3067. Crphanus ocularius Broun.

3068 . maculifer Bromm.

30699. ". gramulosus Broun.

3070. Atopida grathami Broun.

3071 ..$\quad$ suffusil Brom.

3072. Veronatus granicollis Bromm.

3073. Nesocyphon tristis Broun.

Gromp Telemoridate.

3074 . Asilis collaris Broun.

3075. " brevicomis Broun.

3076. , opaculus Broun.

3077. ., egmontensis Broun.

3078. , punctipemnis Broun.

3079. , parallelus Broun.

Group Melytidae.

3080). Dasves veronicae Bromen.

Group ('Lemida.

3081. Phrmatophaea a b 11 or mis Broum.

Group Colydidas.

3082. Epistranus sharpi Reiller. $3083 . \quad$ fulvus Reitter.

3084. Coxelus helmsi Reitler.

3085. Phormesa costicollis Reitter.

3086. Notoulus varienomis Broun.

Group Cerylonidae.

3087. Philothermus bicavus Reilter.

Group BRONTIDAE.

3(188. Parabrontes rugicollis Broun.

3089. " picturatus licitter.

Group (uevinde.

30190. Picrotus pensus Broun.

(iroup Cissidat.

3091. Cis replandicus leciller.

30.92. Emmearthron boettgeri Reitter.

3093. Enmearthron obsolet $u$ m Rrilter. 
Group Diaperidae. 3094. Menimus humeralis Broun. 3095. " aemulator Broun.

Group Tenebrionidae. 3096. Lorelus latulus Broun. 3097. " tarsalis Broun. $3098 . \quad$ marginalis Broun. 3099. .. sternalis Broun. $3100 . \quad$.. nigrescens Broun.

Group Cxodalonidae. 3101. Artystona philpotti Broun. 3102. .. tinctella Broun. $3103 . \quad$., vicina Broun.

Group Helopidae.

3104. Pseudhelops substriatus Broun. 3105. nodosus Broun. 3106. Adelium femorale Broun. 3107. . titahiense Broun.

Group Cistelidae.

3108. Amarosoma violacea Broun.

Group Salpingidae. 3109. Salpingus cognatus Broun. $3110 . \quad$ " rugulosus Broun. 3111. ", tarsalis Broun. 3112. ", simplex Broun.

Group Melandryidae.

3113. Allopterus simulans Broun.

\section{Group Oedemeridae.}

3114. 'Techmessa rugicollis Broun.

3115. Techmessodes cephalotes Broun.

3116. Exocalopus nitidiceps Broun.

\section{Group Sicraptidda.}

3117. Xylophilus xenarthrus Broun.

\section{Group Otiorhynchidae.}

3118. Platyomida caudata Broun. 3119 . humeralis Broun. 3120 . tibialis Broun.

3121. Tigones philpotti Broun.

3122. Lyperobates waterworthi Broun.

3123. Lyperobates carinifer Broun. 3124. ardens Broun.

3125. Hygrochus cordipennis Broun. 3126. Catoptes constrictus Broun. 3127. Brachyolus sylvaticus Broun.
Group Rhyparosonitdae. 3128. Phrynixus longulus Broun. 3129. Araeoscapus fas ciculatus Broun.

3130. Araeoscapus mucronatus Broun.

3131. Araeoscapus punctipenn is Broun.

3132. Phyllodytes irregularis Broun.

\section{Group Molytidae.}

3133. Paedaretus rufulus Broun. 3134. Eiratus nitirostris Broun.

Group CylindrorhinidaE.

3135. Phaedropholus o' connori Broun.

Group Erirhinidae, Broun. 3136. Xerostygnus pullus Broun. 3137. Aneuma erubescens Broun. 3138. Etheophanus striatus Broun.

Group Cryptorhynchidae. 3139. Zeacalles binodosus Broun.

Group Cossonidate.

3140. Eucossonus antennalis Broun. $3141 . \quad$ discalis Broun.

Group Platypidae.

3142. Platypus inimicus Broun.

Group Axthribidae.

3143. Anthribus anguliceps Broun:

3144. " rugifer Broun.

3145 . .. maurus Broun.

3146 . ., suspectus Broun.

Group Cerambycidae.

31 47. Didymocantha cognata Broun.

Group Lanimidae.

3148. Adriopea pallidata Broun.

3149. Xylotoles gracilis Broun.

Group Galerucidae.

31:0. Luperus cheesemani Broun.

3iji. .. oloscurus Broun.

3152. , diversus Brom.

Group Chrysomelidae.

31.53. Chalcolampra sper:ulifera Shaip.

3154. Caccomolpus ornatus Broun.

Group ERotylidae.

315.5. Tritomidea rubripes Reitter.

3156. Cryptodacne ferrugata Reitter. 


\section{(OLEOP'TERA.}

\section{(romp ANCHOMExtide.}

3020. Tarastethus pretiosus sp. nov. Genus, Man. N.\%. Coleopt., p. 1003.

(ilossy, head rufescent, thorax dark fuscous but broadly testaceous at the sides; elytra rufo-fuscous but becoming darker behind, their sides and apices broadly testaceous; the legs, palpi, and basal joint of the antemnae also rellowish, remaining articulations and the tibiae slightly rufescent.

II cuel oviform, much narrower than the thorax, smooth, frontal impressions clongate; there are 2 well-marked setigerous punctures on the forehead and 1 near each eye. Thorax about a third broader than long, its sides distinctly marginated and rounded, but evidently sinuate and narrowed towards the slightly projecting posterior angles, which are without setae; disc slightly convex, its central furrow well marked, as are also the basal fossae; the hase is a little meven, but has only very few punctures. Scutellum obsolete. Ellytra moderately convex, much broader than the thorax, rather short, regularly rounded, and therefore less narrowed

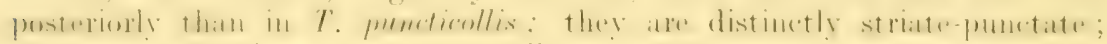
the sutural 2 striac on each are well marked, the others are less so on the middle but become deeper behind, the punetures are moderately large; the 3rd interstices are indistinctly bipunctate, the apical plicae moderately developed.

Underside shining, infuscate, paler near the sides of the abdomen. almost. quite smooth.

This is a rather small, very distinct, and rather pretty species, with somewhat flattened and finely granulated eres. but without any definite dilatation of the tarsi.

Length, 2 lines; hreadth, $\frac{7}{8}$ line.

Raturimu. January, 1909. Three specimens.

\section{(Group) FERONIDAE.}

3123. Trichosternus dissentaneus sp. nov. Gen., Man. N.\%. Coleopt., p. 31.

Rolust, nitid, aeneo-niger; the elytral margins, the head, and thorax viridescent; labrum fusco-piceous, with rufo-castaneous apical and lateral borders; legs and basal 4 joints of antennae piceous, remaining joints fuscorufous.

II oul larese, much contracted behind the prominent apss, with wellmarked frontal foveate. Thorax $4 \frac{1}{2}$ lines in width, in the midelle 3 in length, apex arcuate-emarerinate, hase subtruncate, widest hefore the middle, its sides almost regularly rounded, so that the posterior angles, though nearly rectangular, are not in the least prominent; disc convex, its median sulcus abhreviated in front. near which there is a slight curvate impression, basal fossace large and deep. the intervening space quite flat and depressed; marginal channels well developed, distinctly hroader behind than in front. Scutellum striate at the base. Elytre oblonir-oval, with dentiform shoulders, Ihe lateral chammels somewhat explanate, and twice as broad behind the posterior femoral as at the base: they are much narowed and simuated near 
the apices; they are distinctly striate; the interstices nearest the suture are plane, the others convex; on the 3rd there are 5 punctures, 2 of which are subapical; on the 7 th there are 7 ; the sides are multipunctate.

Femora robust, the intermediate obtusely subangulate below, near the extremity; the tibiae of the same pair with a posterior prolongation covering half of the hasal tarsal joint. Anterior tarsi with the basal 3 joints cordiform, the first elongate.

Underside shining, the head irregularly sculptured and viridescent, the rest black. Terminal ventral segment tripunctate at each side of the middle, at the extremity.

The evenly curvate sides of the thorax, without the slightest projection of the posterior angles, and the entire absence of punctures in the elytral striae distinguish this species from $T$. antarcticus.

๙. Length, 14 lines; breadth, 5 lines.

Ashburton. My specimen was discovered by Mr. W. IT. Smith.

Group Anisodactylidae.

\section{Gaioxenus gen, nov.}

Body navicular, slightly convex above, much more so along the middle underneath.

Head, including the moderately prominent eyes, as wide as front of thorax, with obsolete frontal impressions; 2 setigerous punctures on the forehead and 1 near cach eye. Labrum quadrate, rather elongate, its apex truncate or slightly rounded. Mandibles rather short, broad at the base, curvate and acute at the extremity, the right with a median tooth. Thorax transversal, narrowed anteriorly, its base resting on the elytra, which are as broad as the thorax at the base, but taper considerably towards the extremity; there is a single puncture on each side of the thorax, placed before the middle.

Mentum deeply emarginate, its wings acute at the apex, with a short obtuse median tooth; it is strongly bipunctate at the base. Palpi finely setose, terminal joints of the maxillary rather shorter than the 2nd, elongate, fusiform, and acuminate. Antenure elongate, filiform, attaining the intermediate femora; the basal 2 joints and half of the 3rd are glabrous, the 2nd, however, bears 3 or 4 slender apical setae and is about a third shorter than the following elongate one; joints 5-10 are thick, but not obconical.

Leys moderately elongate. Tibine straight, the front and middle pairs with spiniform setae along the outside. Anterior tursi with slender elongate 'setae above, and at each side of the basal 4 joints with a spiniform seta as long and nearly as stout as those along the tibiae; their hasal + joints dilated, 1st oblong, 2nd rather broader and subcordate, 3rd similar in form but a little shorter, th about as broad as the preceding one, incurved and excavate in front, medially grooved underneath. but not lobate above; their soles are covered with adpressed, grey, sponge-like restiture, which is overlaid with elongate longitudinally disposed setae. so that they appear to be finely ribbed. The intermediate tarsi are moderately dilated, and clothed like the anterior; the joints, however, are more elongated. The claws are simple.

Prosternum deeply and broadly concave towards the posterior angles. Metasternum rather short, so that the elongate curved coxae are only moderately separated from the intermediate pair.

This should be located in the vicinity of Zabromothes and Allocinopus, but is markedly distinet from both. 
31)24. Gaioxenus pilipalpis :sp. nov.

suboparque, piceous, mandibles and labrum reddish, palpi testaceons, femoral sometimes piceous: tibiate tarsi. and antennace pale ferruginons, the last 7 joints of these last with a central fuscous streak ; lateral margins of thorax piceo-rufous, the space near each posterior ande, owing to the thimmess of that part. appears rufescent and semitransparent.

Ilend smooth, the forchead olsoletely rugose: mandibles fincly striate. Thorar nearly a third hoader than long, widest at the base, its sides nearly straight towards the midcle and curvedy narrowed in front, sometimes they are gradually narrowed from the base to the blunt front angles; apex distinctly and widely incurved and finely marginated; posterior angles

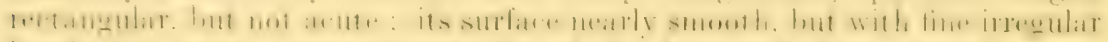

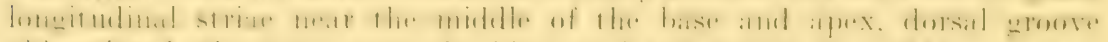

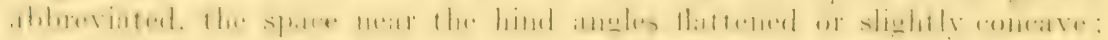
sometimes there is a shallow sulciform basal impression between the middle and each side. Elyfo with rather broader and more reflexed margins than the thorax, much narrowed, but only slightly sinuate posteriorly; their striae simple, the marginal chammels with large shallow setigerous punctures : interstices plane, densely and minutely sculptured.

I'mlerside piceous, slightly nitid, without evident sculpture, the sides

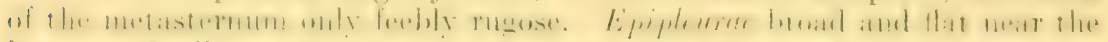
base, gradually narrowed, so that the onter and inmer margins coalesce before reaching the apex. Basal rentral segment in the middle, twice the length of the 2 nd or 3rd, the 4 th indistinctly bipunctate at the apex.

Fem.- Front tarsi simple, Ist joint oblong. 2nd and 3rd triangular, th cordiform.

Length, 33-1 lines; breadth, $1 \frac{5}{8}$ lines.

Raturimu. Five specimens were found by me in danuary, 1909, under logs.

\section{Zabronothus oblongus sp. nov. Gen., Man. N.Z. Coleopt., p. 1327.}

()hlong. rather narrow, moderately convex, nitid, nigro-piceous; the labrum, mandibles, and tibiae rufescent; the palpi, antemace and tarsi paler ; femora pitchy-red; elytral apices broally rufescent.

IIerel rather small, but little more than haif the width of the thorax, without definite impressions. Eyges only slightly prominent, yet large. Thoras subquadrate, aloout a fourth broader than long; the apex widely, the base medially. amarginate; it is slightly wider before the middle than elsewhere; posterior angles apparently obtuse, owing to the hasal margin heine slightly romded towards the sides; disc finely, irregularly, transversely lineate. the middle of the base with several longitudinal striate. the median sulcus fine and not reaching the apex, hasal fossae narrow, feebly

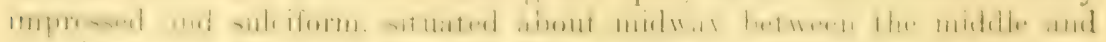
the sides. Scutellum very small. Elytra oblong. a little hroader than the thorax. humeral angles thickened but not distinctly dentiform, their sides obviously marginated hut not much rounded, curvedly narrowed and slightly sinuated towards the extremity : each with 7 impunetate, sharply impressed, discoidal striate interstices simple: the marginal punctures distinct. hut absent near the middle, and placed close together near the shomblers.

Unelersile piecous. The teminal erentral segmem with a single setigerous puneture at the alpex at eareh side, and with numerous small punctures across the middle. 
Of about the same size as $Z$. rufipes, less oviform, rather narrower, with appreciably stouter legs, and more strongly curved posterior tibiae. In that species the posterior angles of the thorax are rectangular, the basal margin being straight towards each side, the discoidal groove attains the base, the humeral angles are dentiform, and the anterior tarsi are more dilated.

In the present species there is a distinct setigerous puncture at each hind angle of the thorax, which seemingly is lacking in the other two species. The papery squamae underneath the front tarsi are very distinct, but the angles of the dilated joints are not prominent.

б. Length, $3 \frac{3}{4}$ lines; breadth, $1 \frac{3}{8}$ lines.

Broken River, Canterbury. My specimen was found by Mr. J. H. Lewis.

\section{Group Benbiditida.}

3026. Bembidium waikatoense sp. nov. Gen., Man. N.Z. Coleopt., p. 55.

Subovate, moderately convex, glossy; head and thorax aeneo-niger; elytra fuscous, the shoulders fusco-testaceous and smooth; this pale mark on each is faintly prolonged at the side and curved inwards near the middle; there is another irregularly formed transverse mark on each at the side, behind the posterior femora, which extends inwards as far as the th interstice; legs and antemme rufo-fuscous, the basal 2 joints of the latter more rufescent and shining, palpi piceous.

Head large, ovate, and, including the large eyes, as broad as the front of the thorax; interocular impressions rather narrow, and separated from the eyes by moderate ridges. Thorax slightly broader than long, the sides strongly rounded, much narrowed behind the middle, lateral margins somewhat widened medially. posterior angles indistinct: discoidal groove detinite hut abbreviated. hasal foreae well marked and placed close to the sides, the surface with some feeble linear impressions. Elytra oblong-oval, their margins well developed, quite evident even at the rounded shoulders; the sutural striae become fine and impunctate towards the extremity, the 2nd and 3rd are moderately impressed, the others much less so; all are rather coarsely punctured, and terminate behind the posterior femora; the 3rd interstices are bipunctate.

Male.-Anterior tarsi with thick suboblong basal joints, the 2nd only moderately dilated.

The nearest species is $B$. rotundicolle, but the basal 2 joints of the tarsi are strongly prominent at the inner angles, the posterior angles of the thorax are distinct, and the elytra are less oviform and more finely punctured.

3. Length, $1 \frac{5}{8}$ lines; breadth, quite $\frac{5}{8}$ line.

Mount Pirongia, Waikato. Unique.

\section{Bembidium tinctellum sp. nov.}

Elongate, slightly convex, shining violaceo-niger, sides of head and thorax and elytral magins aeneous; legs and antennae aeneo-piceous, the basal joint of the latter and the mandilules pitchy-red, tarsi rufo-piceous. palpi blackish.

Head, eyes inclusive, rather broader than apex of thorax, with long and rather broad interocular foveae. Thorax slightly broader than long, its sides distinctly margined and well rounded, quite as much narrowed hehind as in front, but just at the base they are straight with obtusely rectangular angles: the dorsal sulcus distinct, basal foveare small and rlose to the angles, it is finely longitudinally strigose at the base, and there are 
it few feeble impressions across the disc. Elylra oblong, slightly oviform, not depressed; moderately punctate-striate, the outer 3 striac on each indistinct, the sutural 2 converge at the base and unite at the apex; the punctation of the fith and ith almost ceases near the hind thighs, but in the others it extends a little further ; interstices plane, the 3rd tripunctate.

Mule.-Basal joint of anterior tarsi hroadly oblong, the 2nd distinctly prominent at the inner extremity.

Undoubtedly near $B$. tekitponse, but, independently of the violaceous surface, differing by the rather broader and more strongly rounded thorax and more convex elvtria. B. altenuatum, from the same locality, is more slender, with flattened and almost elongate-cordate and more finely sculptured elytrit.

Length, 21. lines; breadth, $\frac{7}{8}$ line.

A single specimen, brought from the Lake Tekapo region by Mr. T. F. Cheeseman.

3028. Anillus monticola sp. nov. Gen., Lacordaire, Hist. des Ins. Coleopt., tom. i, p. 380.

Glabrous, nitid, testaceous, elytra slightly and irregularly infuscate; the body a little convex.

II cail oblong, nearly as long as but much narrower than the thorax, apparently smooth, the frontal foveae well marked and rather large; the pallid transverse memhranous space between the forehead and subtruncate labrum straight and sharply margined in front. Mandibles stout and elongate, acute and arched at the extremity. Eyges minute, situated at the sides, midway between the antemae and thorax. Antemme slender and elongate; basal joint short and stout; joints 2-5 cylindric, decreasing in length, the 2nd being a third longer than the 5th; 8-10 oviform, each longer than broad; the terminal rather longer than 10th. Thorax of about equal length and breadth, cordiform, widest near the front, rounded there, gradually narrowed backwards, posterior angles somewhat obtuse, base and apex subtruncate; there is a fine dorsal groove, the basal fovea are shallow and indefunite, and a few minute punctures are discernible in front, the lateral margins are distinct. Elytra regularly oblong-oval, with rounded shoulders; they are broader than the thorax, with well-defined and somewhat explanate margins; they are broadly rounded at the apices, and cover the terminal abdominal segment; the suture is fine but distinct; there are no striae, but 3 or 4 discoidal series of distant, fine, shallow punctures may be seen with the aid of the microscope. Legs elongate; the anterior femorit remarkably incrassate, the tibiae gradually thickened, apparently marmed and not emarginate inwardly ; the other tibiae simple, their tarsi elongate and slender.

The presence of eves, though mere spectis only, should perhitps exclude this species from Anillus.

I. Length, $\frac{7}{8}$ line; breadth, $\frac{3}{8}$ line.

Ilomut Pirongia. A single specimen only.

\section{( TrOUP) LABHIDAE.}

3029. Demetrida lateralis sp. nov. Gen., Man. N.\%. Coleopt., p. 6.t.

bepressed, broad, shining, black, the legs and hateral margins of thorax somewhat infuscate rufo-piceous, tarsi and antennate pale ferruginous, terminal joints of the palpi much paler, mandibles and labrum pitchy-red.

IIead, eyes induded, as hroad as the thorax, with a few fine punctures whirh are most pereptible near the eyes, the elongate frontal impressions 
moderate, there are 2 large punctures near each eye and 1 close to each antennil. Thorax an eighth broader than long, its frontal half widest and rounded, the basal narrowed and subsinuate, with rectangular angles, the apex widely incurved; disc slightly convex, the median groove well marked throughout, with feeble undulating transverse striae and some fine distant punctures; the basal foveae well marked, and separated from the angles by slight elevations; the lateral channels broad and somewhat flattened, with several short transverse striae. Elytre a good deal wider behind than at the base, with slightly oblique apices; their striae deep near the suture, the outer $t$ on each more lightly impressed, the short scutellar sulci distinct; interstices plane, with numerous fine punctures, some, however, are larger, 1 at the base on the 2 nd and another on the $3 \mathrm{rd}$ near the apex are still larger. The terminal abdominal segment is finely punctate and pubescent above, and has 2 setigerous punctures at the extremity underneath.

Distinguished from $D$. ater by the broad and somewhat depressed marginal chammels of the thorax, rather less deeply impressed elytral sulci, by the almost testareous terminal joints of the palpj, and by the first 3 joints of the antennae not being piceous. In $D$. moesta the elytral striae are finer or obsolete, and the interstices, according to the description, are without impressions.

Length, $3 \frac{1}{4}$ lines; breadth, $1 \frac{3}{8}$ lines.

Mount Cook. Elevation about 2,500 ft. I am indebted to Mr. T. F. Cheeseman for my specimen.

Obs.-In my three specimens of Chaudoir's D. picea, obtained from the Otira Gorge and Ashburton, the legs, antennae, and palpi are testaceous or nearly so.

\section{Group Pericalidae.}

3030. Scopodes nigripes sp. nov. Gen., Man. N.Z. Coleopt., p. 67.

Subdepressed, nude, nigrescent; head and thorax shining cupreous ; elytra subopaque and slightly tinged with red: legs, antennae, and palpi fusco-niger.

IIead with very large prominent eyes, distinctly longitudinally strigose, more finely and irregularly in front. Labrum smooth and black; the neck not strigose, but with ill-defined sculpture. Thorax very much narrowed towards the obsolete posterior angles, strongly rounded and angulate near the front; the median groove well marked, moderately finely, transversely, and irregularly strigose, the middle of the apical portion and the base with punctiform sculpture. Elytia oblong, with rounded shoulders, their apices oblique towards the suture; the striae are shallow and somewhat indefinite, but the 3 foveae on each are large.

Allied to S. edwardsi, but with different coloration and sculpture. The thorax is much more dilated near the front, and similarly angulated there. the disc is less convex, so that there are no apparent frontal or basal impressions. The elytra are broader, but their striae and foveae are not so well marked.

Length, $2 \frac{1}{4}$ lines; breadth, $\frac{7}{8}$ line.

Waimarino. A single specimen, under bark, at an elevation of $2,700 \mathrm{ft}$.

\section{Group DRYOPIDAE.}

3031. Alloparnus scutellaris sp. nov. Gen., Man. N.Z. Coleopt., p. 1107.

Convex, oblong-oval, shining, fusco-piceous, sides of thorax and base of elytria rufescent; antennac, palpi, and tarsi? fusco-testaceous, tibiae 
red: with numerous otutstanding, slender, and elongate setae. some of which are pale, others infuscate, but without fine pubescence.

Ilend moderately (oarsely, rlosely, and more or less rugosely punctured. Thorec a third hroader than long, the sides distinctly marenined, curvedly narrowed near the fromt: anterior angles a little deflexed and nearly reetangular. the posterion directed backwards so as to clispl the shoulders;

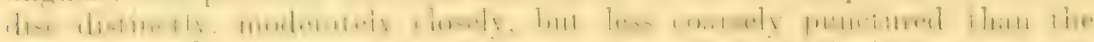
head, more fincly towards the base, which at the midelle is more convex than it is towards the sides: mear each side there is a well-marlied smooth groove, with sharp outer margins. Which hecomes less distinct towards the front. Sculllum smooth. quadrate, not at all transverse. Lilyliar of the sime width is the tholax, quite twice its length, narrowed posteriorly ; they are moderately and irregnatirly punctured; the striate are efficed on the

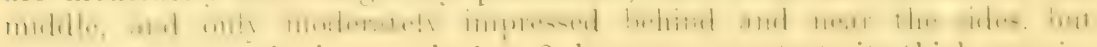
some are dere at the base, only 1 or 2 . lowever, penetrate its thick marrin.

Le'gs robust, hearing long erect hairs; the tibiae with fine yellow pubescence along the imer face. The hind claw of each of the anterior fursi is shorter than the other in one specimen.

Underside subopacte. Prosternum rather finely punctured. Abdomen covered with decumbent pale pubescence, very indistinctly punctured, the terminal segment, however, almost coarsely punctured and subgranulate, with longer: hairs, and medially elevated at the extremity.

The elytril striate are less distinct than in $A$ agrestis $(140)$ : the head is more coarsely and rugosely punctured, the thorax rather more finely. and it lacks the finer decumbent pubescence visible on that species. The sentellum is not transverse.

Length. 2 lines: hreadth, 3 line.

llaimarino. January. 1909. A pair found amongst leares, on the "nround.

Obs.- When drawing up the above description I carefully examined tlan

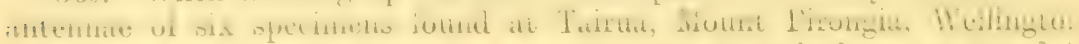
and Te Aroha: in all these the antennac are 11 -articulate, as stated in

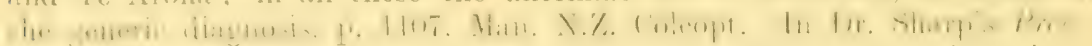
pames these oryans are described as 10 -jointed. No specimens hare bent sent to me as ret from Grevmouth, the recorded habitat of his species.

\section{(itoup) IfYDROpHLIt)As.}

30:3:. Stygnohydrus femoralis sp. nov. Gen. Man. N./. Coleopt. p. 13:36.

() val. very entex. ulabrous. shining: piceo-niger, slightly bronzed: the sides of thorax. Hhe suture, and apical portion of elytri somewhat

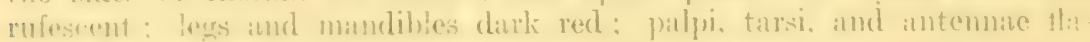
rescent : ruth dall and infuscate.

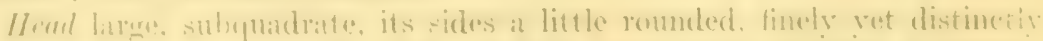

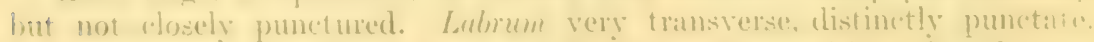
feehly amatrinited medially, marked off from the forehead by a deep furrow: Eves entire, very finely fieceted. Mlandibles very broad. hut slender and acoute at the extremity. Thores transverse, its hase subtrumeate and very

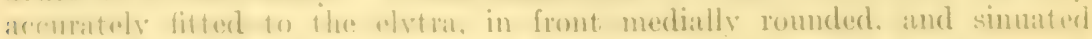
towards the slightly prominent but obtuse angles: the sides feebly curved and marginated, posterior andes rounded, luat just in front of them the

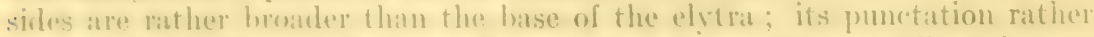
shatlow and distant. Somfellum triangular, finely punctate. Elylme irresnJarly: rather fincly, hut not elosely punctured, some punctures rather larger 
than others : at each side. hehind the middle, there are + or 5 series of coarser punctures: somewhat similar series can be seen on the posterior declivity, in front of which the sutural striae become obsolete.

Tibiae with several unequal spines at the extremity of the middle and hind pairs, the former pair with less-prominent ones along the outside. Posterior tarisi slightly compressed, joints $2-\frac{1}{4}$ with an elongate seta underneath, the claws not at all divaricate.

Underside castaneous, more rufescent at the sides. The metasternum and abdomen with fine longitudinally rugose sculpture. The ventral segments bear distinct yellow hairs.

Mesosternal process narrow, almost level with the front coxae. Intermediate coxae nearly, the others quite, contiguous. All the ventral segments ahout equal and on the same plane as the epipleurae. which throughout are linear. Femora grooved underneath, very broad but much narrowed towards the extremity, the posterior less narrowed, finely and distantly punctured and bearing distinct yellow setae. Mentum depressed, narrowed. and rounded in front. Antennal furrows quite distinct along the inner margin of the eyes.

Rather broader than $S$. nitidus (2343), with more elongate and slender posterior tarsi hut thicker legs, rather different and more distinct sculpture. the body darker and less aeneous.

Antennae 9-articulate; basal joint elongate, half of it concealed from above; 2nd thick and subglobular; 3rd slender, narrowed towards its base shorter than 2nd; 4-6 transverse : club triarticulate, its basal joint rather broader than long, narrowed towards the base, 2nd transversely quadrate, the terminal of the same width as the preceding one but distinctly longer.

Length, $1 \frac{3}{8}$ lines; breadth, 1 line.

Raurimu. January, 1909. A solitary specimen found amongst leaves on the ground. As its allies are rare and difficult to find, my specimen was carefully mounted and set out on its back, and the structure of the underside studied hefore drawing up the description of the upper surfare. The detail are recorded in full, and will be found useful to other students of this very troublesome group.

3033. Psephoboragus dispar sp. nov. Gen., Man. N.Z. Coleopt., p. 1402.

Nitid, glabrous, fuscous, the sides of the head and thorax and the base of the elytra broadly fusco-testaceous, as are also, more or less, the legs, antennae, and palpi.

Head closely and distinctly yet moderately finely punctured, more coarsely near the sides. Thurn strongly transverse, its sides slightly curved and gradually narrowed towards the obtuse front angles, posterior angles almost rectangular, lateral maruins fine but distinct ; disc much less closely and more finely punctured than the head, the punctures on the broad pate parts at the sides abruptly coarser, and with fine ones interposed, these coarse punctures quite as large as those of the elytral series. Elytra suboblong, curvedly narrowed behind; they are evidently striate-punctate, the strix more definite behind and along the sides than on the disc; interstices minutely and distantly punctate, and moderately convex near the extremity. Intermediate tibiae finely spinose externally.

Underside fusco-niger, the sides of the abdomen with a silky greyish gloss. Mesosternum marginated in front and with a carina there, the process before the coxae abruptly elevated and perpendicular.

Less robust than $P$. signatus, and lacking the variegated aspect of that species. The humeral angles seem more rectangular, the hind slope is 
more abrupt, and the sides of the elytrat are almost straight instead of being

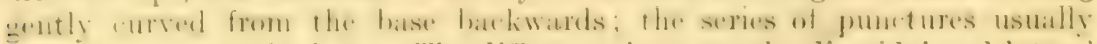
unite by pairs at the base. The difference between the discoidal and lateral sculpture of the thorax is strongly marked.

Length, $1 \frac{1}{1}$ lines; breadth, $\frac{5}{8}$ line.

Waimarino. January, 1909. A single individual. Found amongst decaying leaves in the forest.

Group STAPHYLINIDAE.

303t. Quedius tinctellus sp. nov. Gen., Lacordaire, Hist. des lıs. Coleopt., tom. ii, p. 8.4 .

Elongate, slightly convex, shining; black, the head and thorax slightly

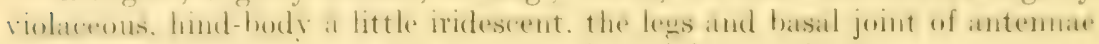
piceous, remaining joints, the knees, and tarsi fusco-rufous.

IIead elongate, oviform, distinctly but finely and not at all closely punctured, with 3 large punctures alongside each eye and 2 near the base. 'The clypeus pallid and membranous. Labrum deeply emarginate in the middle, and with a mass of conspicuous yellow setae in front. Mandibles and palpi piceo-rufous. Thorax nearly as long as broad, posterior angles obtusely rombled. its sides fincly maruined and gridually namowed anteriorly: the disc more finely punctured than the head, the sides more definitely; there are $t$ large apical punctures, 2 before the middle, about 6 at the base, and 1 at each side. Sculcllum large, moderately coarsely punctate. Elytra a fourth broader than long, apices oblique towards the suture, moderately coarsely and closely sculptured, and clothed with ash-coloured hairs. IIindbody elongate, rather more coarsely sculptured than the wing-cases and

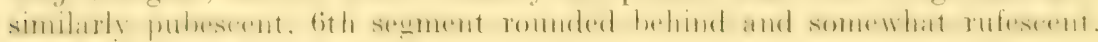
the styles dark and elongate.

Antenne quite as long as head and thorax, 2nd joint as long as the 3rd, the penultimate longer than broad. Eyges large, of normal form. Anterior Iarsi dilated.

We have no similar described species. When turned towards the light it is a heautiful insect.

3. Length, 5 lines; breadth, 1 line.

II aimarimo. I secured two males.

30:35. Quedius aeneiventris sp. $110 \mathrm{r}$.

subdepressed, moderately nitid; head and thorax cupreo-fuscous; elytra and abdomen pale hrown, the latter brassy and iridescent; the femora, tarsi, and basal joint of antemnae fusco-testaceous, remaining joints and the tibiae fuscous.

Ilend elongate, oval, with minute coriaceous sculpture: there are 3 punctures near each eye, I hehind each, and 4 mear the hase. Thorax of about equal length and hreadth. moderately rounded near the base and rradually namowed towards the front; the surface sculptured like the head; with 10 basal punctures, 6 discoidal, 2apical, and 1 at each side. Scutellum short, (dosely punctured. Elytre twice as broad as long, apices oblique towards the smooth suture, finely and (losely sculptured. Hindbedly elongate. with fine rugose srulpture, and in some isprects of a distinctly brassy lustie.

cligpens pale. Lolmum medially impressed in front. liges large, of the usual shape. Antenme, the basal articulation excepted, oparpe ; loth joint longer than hroad ; they reach hackwards to the hase of the thorax. 
Pubescence greyish, the outstanding hairs at the sides and apex of the abdomen are dark.

The coloration, longish elytra, and thoracic punctation are distinctive characters.

7. Length, $2 \frac{1}{2}$ lines; breadth, $\frac{1}{2}$ line.

Waimarino. Another of my captures in January, 1909; only one, unfortunately.

\section{Quedius longiceps sp. nov.}

Elongate, much narrowed anteriorly, moderately shining, rufo-fuscous, abdomen somewhat violaceous; the palpi, legs, and antennae testaceous, basal joint of these last paler; pubescence obscure yellowish.

Head long and narrow, the length double the breadth, tripunctate near each eye. Thorax of equal length and breadth, much narrowed towards the front, with 4 apical punctures, 2 antemedian, and 4 basal. Scutellum rather large, triangular, finely punctate. Elytra subquadrate, apices oblique towards the suture, distinctly but not coarsely punctured. Abdomen relatively very elongate, its sculpture like that of the elytra, but with the apical portion of the 3rd, 4th, and 5th segments nearly smooth.

Eyes elongate-oval, hardly half the length of the head. Antennae finely pubescent from the 4th joint onwards, 2nd joint longer than 3rd, the following 7 subquadrate, 11 th oviform, rather longer than the penultimate. Anterior tarsi only moderately expanded. Clypeus not pallid.

The peculiarly elongated head and the antennal structure are good differentiating characters.

Length, $2 \frac{5}{8}$ lines; breadth, $\frac{1}{2}$ line.

Raurimu. January, 1909. One female.

Obs.-Quedius ruficornis having been used before, I have renamed my No. 205 Q. manaiaensis. It somewhat resembles Q. tinctellus.

\section{Group Pederidae.}

\section{Dimerus stilbus sp. nov.}

Subcylindric, medially narrowed; head, thorax, and elytra shining, sanguineous; hind-body subopaque, castaneous, covered with slender yellowish-grey hairs; tarsi, tibiae, and antennae fulvescent, femora darker ; mandibles shining, red.

Head rather broader but shorter than thorax, the elongate frontal impressions separated from the eyes by cariniform elevations, the punctation rather irregular and coarse but nearly absent along the middle, forehead subtruncate between the antennae. Clypeus very short and pallid. Labrum very broad, finely serrate in front, and with a pair of spines at the middle. Eycs with coarse facets, quite lateral, half the length of the head, very nurrow. Mandibles falciform, as long as the head, very slender and acute towards the extremity, edentate at the base, but with a very long median tooth. Antennae implanted just above the base of the mandibles, 7 th joint very small and bead-like, the penultimate abruptly enlarged and subquadrate, the terminal longer. Thorax longer than broad, widest near the front, gradually narrowed towards the base, with a short basal neck; along each side of the middle, but not reaching the apex, there is a deep groove; there is a similar one near each side; between these, in front of the middle, there are 3 slight punctiform impressions; near the base 4 indefinite punctures can be seen; the pubescence, like that of the head, is very inconspicuous and scanty. Elytra about half the length of the thorax, much curvedly 
narrowed towards the hase, obliquely truncate towards the suture at the extremity, with sutural striate only, the pubescence very scanty and quite indistinct. Ifiml-body elongate, moderately transversely convex, not marginated, alosely sculptured, the terminal segment obconical, the others concolorous and subegual.

D. Irouni Fanvel is rather larere, the th abdominal sesment is invariably much darker than the others; the basit thoracic punctures (6) are

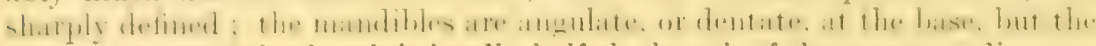
imner median tooth of each is hardly half the length of the corresponding one of 1 ). silbus.

Length (mandibles excl.), $1 \frac{1}{8}$ line; breadth, i line.

IVaimarino. January, 1909. My specimen was found amongst decaying leaves, on the ground.

3038. Lithocharis granipennis sp. nov. (ien., Man. X.Y. Coleopt., p. 11:3.

Elongate, only slightly nitid; head and thorax dark red; elytra and abdomen somewhat pitchy-red; legs and intermediate antemal joints infuscate; tarsi. palpi, and basal 2 joints of the antennae fusco-testaceous. terminal joint flavescent; the pubescence mostly dark fuscous.

IIend as large as thorax, rounded behind, closely and finely punctate. Thorax similarly sculptured, without iny definite smooth median line; it is rather longer than broad, with rounded angles. Elytra about a third shorter than thorax, gradually narrowed towards the base, apices subtruncate, without distinct sutural striae, their surface finely granulate. IIind-body olongate, funely sculptured but not distinctly granulate, basal 1 segments about equal and broadly marginated, 5th longer.

Antennae moderately elongate; basal joint cylindric, stout, about as long as the following 2 combined, these 2 elongate-obconical; 6th and 7 th

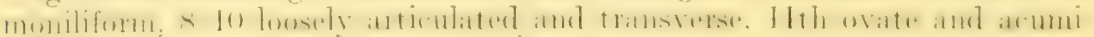
nate. Leys closely sculptured and pubescent. Anterior tarsi with 4 dilated joints, the 1st of the posterior longer than the 2 nd.

The coloration, and the granulation of the elvtra, differentiate this from Redtenbacher's $L_{\text {s. }}$ zealandicus.

Length, $1 \frac{7}{8}$ lines; breadth, $\frac{3}{8}$ line.

Waimarino. January. 1909. One.

Tar.-Hunua Range. Basal 2 segments of aldomen with a pale apical hand of minute dense fayose-like sculpture.

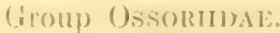

3039. Holotrochus laevigatus sp. nov. Gen., Lacordaire, Hist. des Ins. Coleopt., tom. ii, p. 113.

Cylindric, moderately shining, nearly nude, there being only some dark

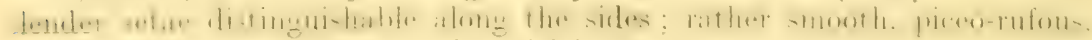
hind-bodv darker, antemate and tarsi fulvescent.

II end narrower than thorax, with very few fine punctures. Eyps small and flat. Thorr.x puadrate, base and apex truncite, its sides almost straight, being only feebly rounded in front, posterior angles rectangular. lateral

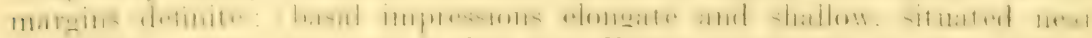
the sides: there are only it fer fine distant punctures on the surface. Scutcllum nearly smooth. Elytru much abhreviated, the width double the length, appices subtrumcate, shoulders closely applied to the lind angles of the thorax; sutural striace indistinct or onsolete, they are very remotely punctured. Ilind-body without lateral margins, alongate, ith segment longest, there are but a few fine punctures. 
Tibiae finely spinose externally. Antennae nearly as long as head and thorax; basal joint cylindric, evidently thicker and longer than 2nd; 3rd rather longer than 2 nd, narrowed towards its base; th smallest and beadlike: 5th of similar form, but slightly larger; 6-10 laxly articulated, broader than preceding ones; 11th conical.

Prosternum distinctly incurved near each side of the apex, the angles obtusely carinate and prominent, the centre in front of the coxae is also obtusely prominent. Fifth ventral segment unimpressed; in $H$. broumi this segment is medially deeply concave, and the basal one cariniform in the middle.

Similar to $I$. brevipennis in some respects. In it, however, the eyes are obsolete or altogether absent, the base of the thorax is widely emarginated. and the greyish-yellow pubescence, though scanty, is easily seen.

q. Length, $1 \frac{1}{2}$ lines; breadth, $\frac{3}{8}$ line.

Mount Pirongia. Both specimens found by myself amongst decaying leaves.

\section{Holotrochus caecus sp. nov.}

Cylindric, shining, sparingly clothed with slender yellowish-grey hairs: dark red, hind-body with indefinite darker spots, antennae and legs reddish.

Head smaller than thorax, with a few fine distant punctures. Antemne with fine grey pubescence, basal 3 joints elongate, 3rd slender, 5th and 6th obconical, broader than th, joints 7-10 larger. Thorax quadrate, finely margined laterally, finely and distantly punctured. Elytra transverse, subtruncate behind, with shallow indistinct sculpture. Hind-body elongate, basal + segments simple and equal, 5th large, with coriaceous minute sculpture.

Tibice stout, the intermediate moderately closely and finely spinose externally; the anterior with 5 or 6 , the posterior with the same number of fine setiform spines near the extremity.

The eyes I am unable to detect.

$H$. brevipennis is smaller and darker, with differently formed antennae, their 5th joint being oviform and rather larger than the contiguous ones. It is in a similar blind condition.

Length, $1 \frac{5}{8}$ lines; breadth, quite $\frac{3}{8}$ line.

Maketu, Hunua Range. A single specimen.

3041. Holotrochus gracilis sp. nov.

Shining, ferruginous, legs and antennae flavescent, pubescence also yellowish.

This is another sightless species, which is smaller and more slender than the preceding one, and distinguishable by the paler colour of all its parts. The sculpture seems similar but is even finer, and the suture of the transverse elytra is indistinct.

Length, $1 \frac{1}{4}$ lines; breadth, barely $\frac{3}{8}$ line.

Waitakerei Range. Found in March, 1909. Unique.

\section{Holotrochus nitidorsis sp. nov.}

Elongate, subcylindric, glabrous, glossy ; head and thorax rufo-fuscous. the area near the posterior angles of the latter usually paler; elytra and hind-body fusco- or rufo-piceous, the apical portion of the basal segments of a more or less metallic reddish-coppery hue; legs and antennae pitchyred. tarsi testaceous.

Head nearly as long as the thorax but obviously narrower, the forehead rounded in front, with a few distinct but not coarse scattered 
puncture's. Eyyes small and flat. Thome rather broador than long, its sides nearly straight, only slightly curved towards the obtuse anterior angles, the marens thin there but somewhat explanate behind, posterior angles obtusely rectangular, the base and apex widely incurved; dise convex, the space neat the hind angles flattened but not foveate, with a few distinct seattered punctures. Filylon of the same width as the thorax, their breadth almost double the length, the shoulders with thickened subdentiform margus, apices very slightly rounded, their surface feebly rugose and with very few rather indefinite punctures. Ilind-body elongate, without lateral margins, 5th segment longest; Gth short, half the width of the preceding one: 7 th obconical, its apex medially yet only moderately prominent. hut acutely prolonged at the sides; the few fine yet distinct punctures are almost atranged in 2 transverse series on the basal jo segments. Intermediate tibine setose externally, the posterior simple.

The hairless surface, short wing-cases, entire absence of thoracic foveae, the disposition of the punctures on the dorsal segments, and the strongly

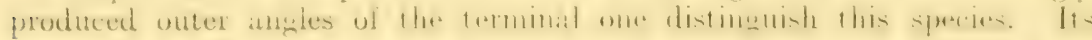
nearest ally is $I I$. lnevigatus.

Length, 13 lines; breadth, nearly $\frac{1}{2}$ line.

Greymouth. Three broken specimens, forwarded by Mr. J. H. Lewis.

30.43. Holotrochus montanus sp. nov. rufous.

Cylindric, nude, shining; black, the palpi, antennate, and legs piceo-

IIcad finely punctured, more distantly behind than in front. Eyges subdepressed hut distinct. Thorax quadrate, base and apex subtruncate, its sides finely margined and only slightly rounded, nearly straight from the

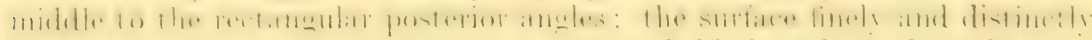
but not closely punctured, the fovea near each hind angle moderately large

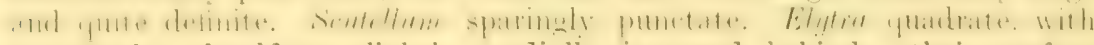
rectangular shoulders, slightly medially incurved behind; their surface with distinct but not seriate punctures, the sutural striate not quite straight. Ifind-borly without lateral margins, equal to the thorax and elytra conjointly in length; rather distantly, moderately finely, and somewhat irregularly punctured, the intervals not quite smooth; the Jth segment rather longer thin any of the others. Front and intermediate tibiae finely spinose extemally; the posterior more finely, and near the extremity only.

Antennae with tine pale pubsecence; 2nd joint more slender, but ats long as the exposed portion of the basal one ; Brd elongate, but not as long as the following 2 taken together; 6-10 difler but little from each other. rather broader than the preceding ones, and laxly articulated; the terminal sulosheronical.

The dirker colour, less-prominent humeral angles, more definite basal impressions on the thorax, and smaller size distinguish this from II. bromi.

Length. 13 lines; hreadth, 3 line.

Hount Cook. Two, discovered by Mr. 'T. F. C'heeseman, F.L.S.. near the Ilemitage; elevation, $2,500 \mathrm{ft}$.

\section{GMIIP OMALIIAE.}

3014. Omalium nemobium sp. nov. Gen., Man. N.\%. Coleopt., p. 115.

subdepressed, elongatte, nitid, pubescence yellowish-grey and inconspicnous; castaneous, hind-body fuscous, legs and palpi fusco-testaceous : the terminal 6 joints of the antennae dull fuscous, the others pale ferruninous. 
Head rather narrower than thorax, the sides of the forehead oblique, so that the middle seems somewhat prominent; it is distinctly and closely punctate, but the forehead is smooth and shining in front; there is a pair of foveae at the base containing the ocelli. Antennce with joints 6 -10 enlarged and densely pubescent, 11th largest and oval, the basal cylindric, 3rd more slender than 2nd and rather longer, 4th and 5th bead-like and small. Thorax transverse, widest and rounded before the middle, gradually narrowed behind, posterior angles rectangular but not acute. lateral margins distinct; its sculpture similar to that of the head. Scutellum smooth. Elytra rather broader than thorax and twice its length, the suture depressed near the base; their sculpture rather coarser than that of the thorax but not as close, and becoming finer towards the apices. Hind-body slightly longer than elvtra, its basal 4 segments about equal, with raised margins; 5th slightly longer; 6th narrowed behind, minutely and densely sculptured. and a little elevated along the middle; 7 th very narrow; these last 2 much paler than the others, which are rather finely but not at all closely punctured; the sides of the 2 nd, 3rd, and th are somewhat rufescent, on the middle of the 2 nd there is a pair of oblong greyish marks. Legs simple, slender.

In facies similar to $O$. micrarthrum, the pubescence less distinct, the forehead different, elytral suture not elevated, basal abdominal segment fully uncovered, lateral margins elevated instead of being flat.

Length, $1 \frac{3}{8}$ lines; breadth, $\frac{3}{8}$ line.

Waimarino. A single specimen only.

\section{Omalium laetipenne sp. nov.}

Elongate, subdepressed, moderately nitid; the head, thorax, and basal 4 dorsal segments fusco-piceous; the terminal 2 and apex of th rufofuscous ; elytra shining, flavescent, their extremity and an ill-defined basal patch fuscous; legs, antennae, and palpi testaceous.

Head gradually narrowed anteriorly, much and abruptly narrowed behind the large and prominent eyes, irregularly strigose, appearing almost smooth along the middle, but with a few fine scattered punctures. Thorax subquadrate, its sides with very slender margins and nearly straight, anterior angles rounded, the posterior obtuse yet nearly rectangular ; it is nearly smooth along the middle, and at the outer sides of the 2 shallow impressions. which, as well as the rest of the surface, are finely but not closely punctured, near the basal margin there are 2 more distinct punctures. Scutcllum small, triangular. Elytra oblong, with separately rounded apices, very slightly and gradually narrowed towards the base, the lateral margins fine; their punctation moderately fine, not close, subseriate, and appearing rather closer on the dark apical area. Hind-body hardly as long as the elytra, distinctly clothed with greyish hairs, the uncovered basal 3 segments with thick raised margins, the th with fine rims and more finely sculptured; there is a small median spot on the first exposed segment-the true second, no doubt -which is minutely granulate. Legs moderately elongate. Tibiae finely spinose. Tarsi with slender yellow setae, their last joint longer than the preceding 4 taken together.

Antennae pubescent; basal joint stout and elongate, narrowed towards the base; 2nd longer than broad, yet evidently shorter than the following one; th and 5th small, about equal; 6-11 enlarged and more densely pubescent ; 7-9 subquadrate; 10th transverse; 11th conical.

The ocelli are situated within the elongate foveae. 


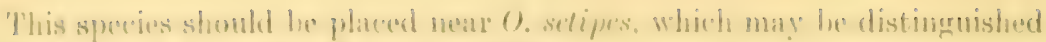
he the paler and more rufescent colorition.

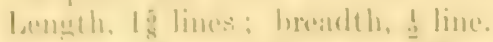

Riverton Beateh. (Mere, from Mr. A. Mhilpott.

:311i. Ischmoderus cognatus sp. $111 \mathrm{v}$.

lepressed. moderitely alongate and shining: ruforastamerons, hindbody datrer, its apionl sement somewhal testareous, alytra slighty suffused with hrown: terminal 6 joints of antenmae opmene and infuscate.

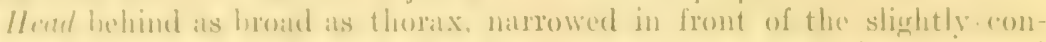
vex wes, lather flat, finely and rather irregularly punctate, interantemnal impressions shallow and indistinet, the intermediate sparee nearly smooth. median foreas small and narrow. the weolli situated hehind these. Neck shont and broad, minutely strigese. Theree transverse, condate-quadrate, widest near the front. romoled there, slightly sinuously narrowed hehind. josterior angles subrectamenlar ; the disc distimetly bi-impressed, the narrow ntervening spare and the horders nearly smooth. the surface clsewhexe fincly yet distinctly hut not clesely punctured; the lateral margins dis-

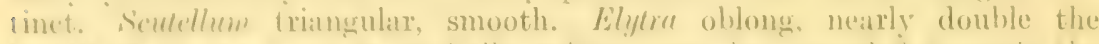

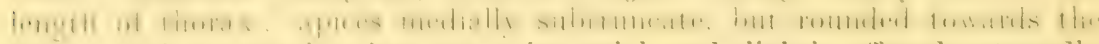
sides: their punctation fine, not quite serial, and slighty ellaced ontwandy neall the extremity. Ilimb-bedy a little narrower than the wing-anses, minutely sculptured. so as to appear coriacenus, the pubescence seanty. tine and rellowish. mearly smooth alone the middle, on other parts with a few minute scattered punctures; the basal 3 uncovered sements broadly

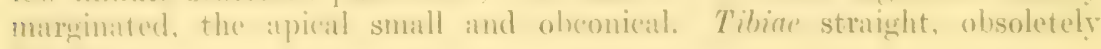
spunose.

Antenume inserted below the edges of the forehead: hasal joint stout. mueh natrowed tomarels its base, as long as the ond and 3rd combined : End

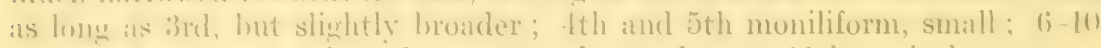

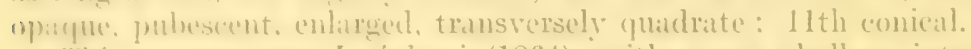

This romes near I. Jullomi (1S64), with more shallow interantemual impoussions: these on the thorax, however, are deeper, and the middle

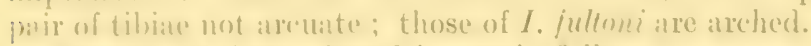

Lengeth. I lines; breadth, nearly o line.

West Plains, Inverearerill. Mr. A. Philpott. One.

\section{Ischnoderus arecobius sp. nov.}

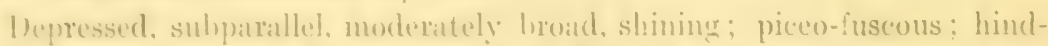

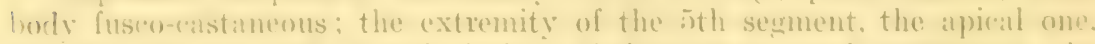
and the leass and hasal is articulations of the antemane rufo-testaceous: thu rematining joints dull fuseons.

llemil as hroud as and rather longer than therax. the genae rounded befind the prominent ares. in front of these much narrowed: forehead mimutery semptured yet shining, the rest of the surface rat lier closely and distinctly puncturesl, with of elongate hasal foveate, and hehind these the pair

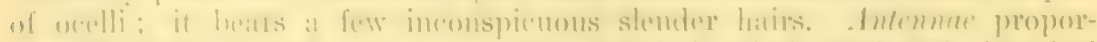

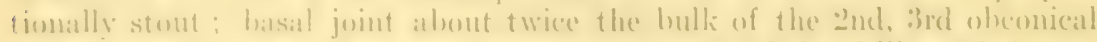
and atrout as lenes as the preceding one. Ith and ith bead-like, fith longer

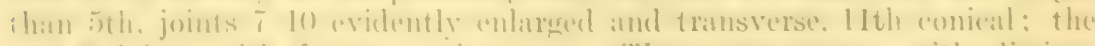
last of joints with fuscons puluescence. Therte transverses with distinct

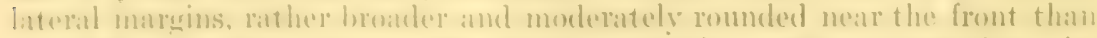
olsewhere, natrowed helind the midelle, persterier angles rectangular; its

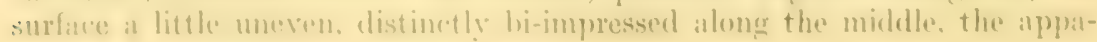


rently raised central line smonth. the outer borelers of the dopressions nearly so, the punctation and vestiture like those of the head. Elylra slightly. broader than thorax, oblong, parallel-sided, truncate behind; their punctation well marked and almost quite seriate, with somewhat irregular

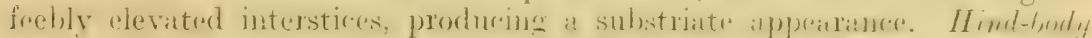
of about the same length and breadth as the elytra, slightly transversely

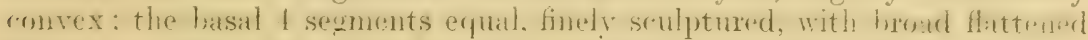
margins; 5th nearly smooth, rather longer than 4 th; the pubescence greyish and distinct.

This most nearly resembles $I$. morosus; it is smaller and even darker, but with paler legs. The median mark on the 2 nd dorsal segment is less distinct; in 1 . morosus it resembles a minute horse-shoe.

Length, $1 \frac{1}{8}$ lines; breadth, quite $\frac{1}{4}$ line.

Waitakerei Range. March, 1909. My specimen was caught under the bark of a decaying nikau log; others effected their escape.

\section{Group Pselaphidae.}

3048. Vidamus spinipes sp. nor. Gen., Rafiray, "Genera of Pselpahidae."

Nitid, fusco-rufous; the legs, antennae, and palpi paler; the pubescence yellowish, fine yet distinct.

Head large, as broad as thorax, subquadrate, but narrowed in front of the small but prominent eyes; it is broadly bisulcate; the antennal tubercles, though distant, appear nevertheless to form a broad continuous frontal margin; the slender hairs are disposed transversely. Thorax dilated laterally before the middle, much narrowed in frout, more gradually towards the base; at each side near the base there is a deep fovea, and an angular one between them, united by a curvate impression or groove. Elytra oblong, rather broader than thorax, a little narrowed towards the base; sutural striae deep and broad, the shoulders appear elevated owing to the presence of an elongated fovea alongside each, there is a minute basal fovea near each side of the suture, the dorsal striae are obsolete, their surface with shallow indistinct punctures. Hind-body nearly as large as the elytra, finely punctate, 2nd and 3rd segments equal, 4 th and 5th deflexed.

Lers elongate; intermediate tibiae on the inner side, between the middle and extremity, with a conspicuous spiniform process; the posterior simple.

Antennae about as long as head and thorax; basal joint stout; 2nd nearly as long as the exposed portion of 1st, but not quite as thick; 3rd slightly longer than broad; 1-8 moniliform; 4th and 5th rather larger than the others; 9th and 10th evidently broader, and narrowed towards the extremity; 11th large, subobconical.

This species can be recognised by the armature of the middle tibine.

7. Length, $\frac{7}{8}$ line; breadth, nearly $\frac{3}{8}$ line.

Broken River. My specimen was found by Mr. J. H. Lewis.

3049. Sagolonus impressus sp. nov. Gen., Rafi., "Genera of Pselaphidae."

Elongate, slightly convex, shining, rufous, elytra rather paler, legs obscure

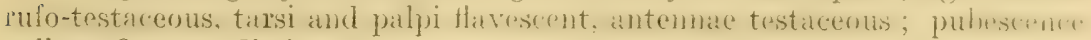
yellow, fine yet distinet.

Head large, much curvedly narrowed behind the prominent eves, and widest in line with them; antennal tubercles evidently separated, interocular foveae moderate, apparently prolonged forwards and convergent near the tubercles, with some fine punctures near the sides, smooth in front. Therrar longer than broad, widesi just inefore the middle. consinderable and 


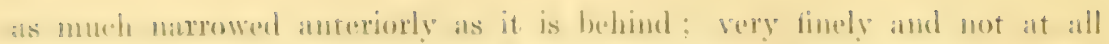
rosely punctate; median discoidal groove quite obsolete on the dise and fine bear the hase, near which there is a large transverse angular mesial depression, and a forea at eareh side, these are not mited by any linear impression. Elylia ample, subquadrate, sparingly and finely punctured. the sutural striate are broad near the base, with subearinate intervals separating them from the short foreiform impression near each shoukder. the base appears yuadrifoveolate. II imd-body rathes short, narrower than the alytrat. moderately convex, indistinctly punctate; the basal segment but little exposed, and covered with minute freyish squamate the 2nd with a transverse median depression. which is deep at the base, and separated from at smaller transwerse one at each side by a slight carinate interval only ; 3rd about as long as 2nd, but not discemibly impressed: "oth deflexed. Leys simple, elongate and slender.

Underside shining, rufo-castaneous, with fine pubescence. P'rosternum with a slender longitudinal canina. ('oxre with trochanters, the posterior well developed. Basal 2 rentral segments rather densely pubesent and depressed at the base, and at the middle slightly elevated and acutely angulate in front: End and 3rd largest, equal; 5th about as long as the the at the sides, but widely emarginate in front; 6 th short.

Antemace elongate, attaining the base of the thorax; basal 2 joints nearly equal, stout; joints 3-5 rather larger than 6-8, which are submoniliform; the 8th rather smaller than its predecessor; 9th and loth laxly articulated, atach twice the size of the 8 th; 11 th ather longer than the preceding 2 comlimed. subconical and acuminate.

Maxillary palpi moderately elongate; 2nd joint slender and stalk-like, hit clavate at the extremity ; 3rd short; th large, puliesent, subovate, and provided, apparently, with a bifid apical appendage.

This does not agree very well with Sagolomus, but there is no other place lor it.

7. Length, 1 line; breadth, $\frac{3}{8}$ line.

Broken River, Cinterbury. The deseription has been drawn up from a damaged male sent to me hy Mr. I. H. Lewis.

30)5). Zealandius usitatus sp. nov. Gen., Raft., "Generat of Pselaphidac."

Elongate, moderately convex, nitid; pubescence vellow, distinct; rastaneo-rufous; the elytra, legs, and antemae paler; palpi and tarsi testa(re)(1)

Ilead nearly as large as thorax, considerably, but not at all abruptly. narrowed anteriorly, its punctation not close and rather indefinite: there are 2 moderate foveate, which are not distimetly prolonged forwards: the antomal tubereks are small but distinct and widely separated. Eyes very small, with roarse facets. Mandibles falciform, and evidently denticulate. Maxillary palpi pubeserent. J'hurex cordiform. widest before the middle. base and apex of about refual width ; is finely and imenularly punctured. but nearly smooth on the middle; the rather lirond discoidal furrow is well marked. hut does not reateh the angular depression near the base: the lateral foveate are litre and distinctly separated from the angulat basal one. Elyglat rather lareser than thorax, uradually curvedly narrowed towards the hatse, their punctation like that of the thorax: the interval between the hroad sutural and dorsal striate on each appears slightly elevated : these striate are derepest. at the hatse ; there is also an indefinite broad shallow litteral strias. Mlimb-lmely rather longer than the alytrat, moderately trimsressely convex, very finely punelured; 2nd. Brol, and th semments of neatry 
equal size; the exposed part of the 1st covered with very minute pallid squamae, so as to seem membranous; the 2nd, close to its base, with a small indistinct semicircular impression. Leys moderate. Tibiae slightly arcuate outwardly.

Antennae moderately elongate; basal joint cylindric, twice as long as broad; 2nd nearly as stout as the 1st, more than half its length, a little narrowed towards the base; 3rd only about half the bulk of 2 nd; 5th slightly larger than the contiguous one; $4,6,7$, and 8 moniliform; 9 th transverse, yet not as large as 10th; 11th subovate, somewhat acuminate, larger than the 9th and 10th conjointly.

Larger and evidently more shining than $2478, Z$. obscurus. The punctation not at all dense and distinct.

Length, $\frac{7}{8}$ line ; breadth, nearly $\frac{3}{8}$ line.

Broken River. I am indebted to Mr. J. H. Lewis for my specimen.

3051. Tyrogetus palpalis sp. nov. Gen., Ann. Mag. Hist., September, 1893.

Sanguineous, tarsi and palpi testaceous; sparingly clothed with decumbent yellow hairs, apices of elytra thickly fringed.

Head oviform, shorter than thorax but as broad as it is, finely and distantly but not distinctly punctured, with a pair of interocular fovene; the antennal tubercles are somewhat approximated in front, but there is a distinct channel between them, which extends as far as the front of the eyes. Thorax convex, rather longer than broad, widest at or just behind the middle, moderately rounded there, more narrowed in front than behind. without definite sculpture. Elytir as wide as thorax at the base, gradually expanded so as to become twice as broad at the extremity, which is abruptly depressed and obviously ciliated; on each there is a well-marked sutural stria, and also a more shallow median one which becomes obsolete behind. Hind-body broadly marginated; basal segment large, as broad as hut hardly as long as the elytra, it is nearly horizontal; the following 3 are curvedly deflexed. Legs elongate, moderately slender.

Antennae long and stout, finely pubescent; basal 2 joints cylindrical, the 2nd evidently the shorter; 3-7 about equal, longer than broad; 8th and 9 th slightly shorter and broader than the preceding one; 10th distinctly broader and subrotundate; 11th largest, oblong-oval.

Prosternum deeply emarginate in front. The coxae elongate, prominent, and contiguous, situated close to the basal margin. Intermediate coxae slightly separated. Mesostermum with a carina between the middle and front coxae, the mesial depression and the sides with yellow pubescence. All the coxae about equidistant from front to rear. Intermediate trochanters elongate, the others shorter and thicker. Only 5 ventral segments are visible; the basal is larger than the other 4 combined.

When compared with $T$. optandus it will be seen that the 2nd joint of the maxillary palpi is more strongly dilated inwardly near the extremits. and therefore more knob-like than that of the typical species. The eyes, though prominent, have less-coarse facets.

The palpi are much longer than those of I amotuhes (Schaufuss) - Tychutyrus (Broun), and the basal portion of each joint is much more elongate and stalk-like.

Length, $\frac{3}{4}$ line; breadth, $\frac{1}{4}$ line.

Waimarino. January, 1909. My specimen, minus a leg, was taken amongst decaying leaves on the ground. 


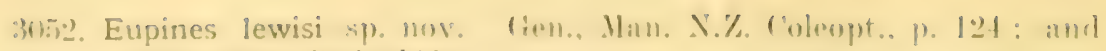
Ratli.. linn. Rsorluphidue.

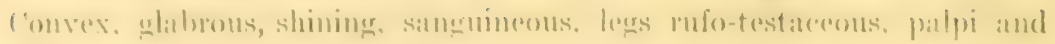
tarti Haveseant.

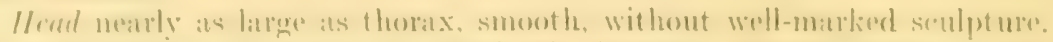

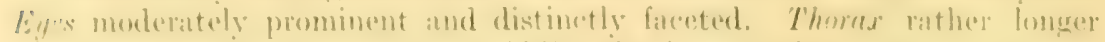

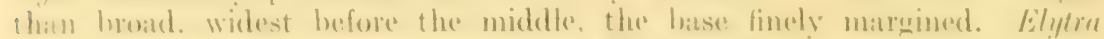
muth latwer than thorax, the suture well dethed, and seemingly slightly

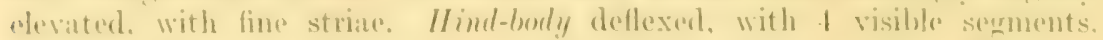

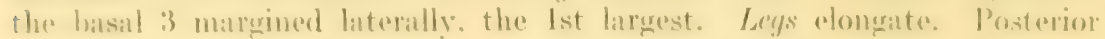
libien a little bent and thickened towards the extremity.

Inlenmer rufesent, stout, pubeseent: hasal joint thirk; end also stont. but smaller: Brd and th smatl, the latter moniliform. the former slightle longer than broad and narrowed towards its hase; 5th sulmilarl late and very large, apparently concave underneath: fith very smalls, a

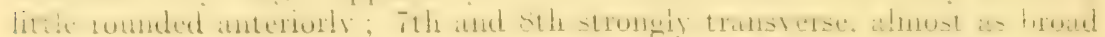
as the ath. the ith rather longer than the following one: 9th and loth daries than the others, minutely asperate, both suboblong and rather longere than the 5th: 10th rather longer than its predecessor.

There is no similar species. The 10-jointed antennate and their structure, and the enlarged 5 th. Sth, and loth joints particularly, are characteristic. I incong.

3. Length. 3 line; breadth, nearly 3 line.

Broken River, Canterbury. A single specimen, from Mr. J. H. Lewis, whose name it hears.

(GOU) HISTERIDAE.

:1.).3. Epierus rufescens Reitter. Gon., Man. N.\%. ('oleopt., p. 163.

(1)hong-oval, moderately convex, rufo-fuscous.

Heal very fincly punctured. Thorax twice as brond as long, considerably narowed anterioly, closely and finely punctured, the marginal line

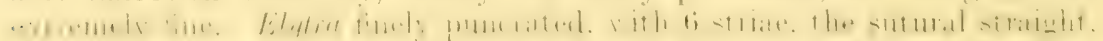

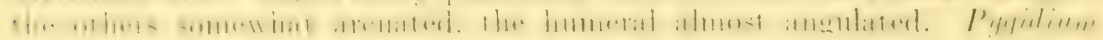
and fropygfidium scarcely visibly punctured. Tibine rather narow, not donticulated.

Length. $1.8 \mathrm{~mm}$.

(irermouth. Mr. R. Ilekms.

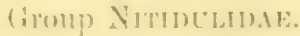

3(1).1. Soronia oculator Reitter. (ten., Ilan. X.\%. ('ulenpt., p. 171.

Similar to $S$. jeponica and the European s. yrisen, but narrower and more parallal. testaceous and ferruginous. The themax is more rounded near the middle. Where it is rather brouder than the wing-cases; it is cosely and finely punctured. Elygton variegated with blatek, each with a rounded median spot, vellowish or fermuinoms, placed mearel the suture than the sisle.

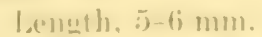

Gremsuth. Irr. R. Holms. 


\section{Group Cryptophagidae.}

3055. Telmatophilus vestitus sp. nov. Gen., Man. N.Z. Coleopt, p. 22\%.

Elongate, subdepressed, covered with slender decumbent greyish pubescence, slightly nitid; fuscous, legs fusco-testaceous.

Hearl distinctly but not coarsely punctate. Thomex much narrower thin the elytra. its length and breadth ihout equal. its sides nearly straight. with almost rectangular but not acute hasal angles, the base moderately rounded: its punctation moderately fine, not so close near the middle of the base, where there is an almost smooth spot; near each hind angle there is a slight transverse impression. Scutellum transversal. Elytra a little convex, base incurved; their sculpture like that of the thorax, but becoming a little finer behind, where there is a sutural stria on each.

Antennae fusco-testaceous, their terminal 2 joints rather darker; basal joint longer and much stouter than the 2nd. 3rd obviously longer than the contiguous ones, 5th and 7 th each a little longer than 6th or 8th, terminal 3 longer than broad.

Underside evidently pubescent, shining, fuscous, distinctly punctured. Metasternum broadly grooved behind.

The basal 3 tarsal joints are less strongly developed than in $T$. depressus : these, and the general appearance, are more like $T$. olivascens (1959), which. however, has a narrower head, differently formed antemnae, more flavescent clothing, and rather coarser, slightly rugose elytral sculpture.

Length, $1 \frac{1}{2}-1 \frac{3}{4}$ lines; breadth, $\frac{5}{8}$ line.

Mount Cook. Mr. T. F. Cheeseman. Eight specimens.

\section{Micrambina helmsi Reitter.}

Elongate, subparallel, rufo-testaceous, clothed with fine yellowish hairs, intermingled with longer erect ones on the elytra. Antennae moderately slender. attaining the base of thorax. the terminal 3 joints equally broar. nemultimate joints broader than long. II ead short. trigonal, and. including the eyes, narrower than front of thorax. closely punctured. Thorer transverse, about a third broader than long, narrowed posteriorly, front angles cailose. almost obliquely prominent, hind angles rectangular. dise sparsely punctated. obliquely impressed before the hase. Elytra somewhat willin than thorax, more than thrice its length, apices conjointly rounded, elongate and subparallel. moderately closely punctured almost in rows.

Length, $2 \mathrm{~mm}$.

Greymouth. Mr. R. Helms.

\section{Micrambina insignis Reitter.}

Elongate, shining ferruginous. Antennce slender, these and the legs testaceous; clothed with fine yellowish hairs intermingled with remarkably long erect ones. Thorax transversely cordate, front angles callose and a little defiexed, strongly ohliguely impressed near the bitse. with a mimate antescutellar fovea. Elytra distinctly broader than thorax, oblong-oval. finely punctured in rows, becoming obsolete behind, smoth on the mirlille. and distinctly transversely impressed before the middle.

Longth, $2 \mathrm{~mm}$.

Greymouth. Mr. R. Helms. 


\section{(iroup) LATHRIIHIAL:}

3058. Holoparamecus tenuis Reitter. Gen., Man. N.\%. Coleopt., p. 231.

Elongate, narrow, pale yellowish-red, leas and antennate testaceons. Antemae 11-articulate, chub 2-jointed. Head trigonal, somewhat narrower than thoma. Thorax almost as long ats broad, cordate, considerably constricted and transversely bisulcate near the base, the frontal one narrow. bifoveolate, the basal crenate, the sublateral carinae distinct, coarsely and distinctly punctured. Elytru convex, oblone-oval, broader than thorax. sufural striate fincly impressed.

lsength, $1.5 \mathrm{~mm}$.

(irermouth. Mr. R. Helms.

3059. Corticaria illustris Reitter. (7en., Man. N.Z. Coleopt., p. 23.

()blong, convex, fusco-ferruginous, pulescence griseous. Anlenne very slender, black, basal joint reddish, tarsi and apices of tibiae fuscous. Herid slightly narrower than thorax, coarsely and closely punctate. Thorux subtransverse, closely and coarsely punctured, dise longitudinally bifoveolate.

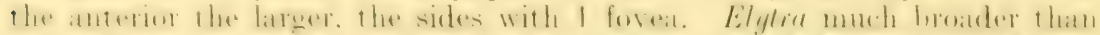

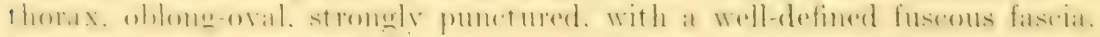
the sutural striae almost distinct. (' $7 u b$ 3-jointed, the basal 2 joints somewhat priform, the last oval and pointed. Legs ferruginous, the tibiae hecoming gradually darker towards the extremity.

Length, $1 \cdot 2-1 \cdot \dot{5} \mathrm{~mm}$.

Greymouth. Hr. R. Helms.

3060 . Corticaria longula sp. nov.

Elongate, slightly transversely convex, slightly nitid, with slender yet distinct ash-coloured pubescence; fusco-castaneous, the legs and antennae paler.

Ilead finely but not closely punctate. Eyges large and coarsely faceted. Antenuae elongate, basal joint thick, 3rd as long as 2nd but much more slender, the and 5th equal and evidently longer than broad, 6-8 small and head-like; club elongate, its 3 joints subrotundate. Thorax rather broader than long, moderately rounded laterally, and minutely or obsoletely denti(11)ated, but with 2. sometimes 3. small ret distinct denticles at each side near the base ; its surface distinctly, finely, but not closely punctured, and with a median fovea near the base. Scutllum broad, scemingly ridged across the middle. Elyfre distinctly broader than the thorax and quite

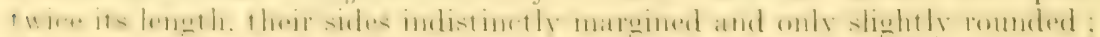

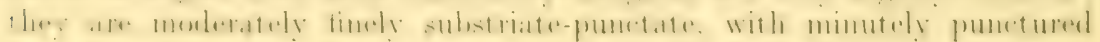
interstices, the sutural striae are well marked behind, but the others are obliterated there amongst the fine irregular punctation, in some lights the basal sculpture appears subgranular.

Cinderside infuscate, shining, and fincly pubescent. Prostermum moderately coarsely punctate, and with a well-marked transverse depression at ench side, in front. Metustemum with shallow, moderately coarse punctures, and a median linear impression behind. Ibelomen more fincly sculptured. segments "-4 equal, the basal largest.

'This is the most enongate-oblong species that has been under my observation.

Length, $\frac{7}{8}$ line; breadth, 3 line.

IIatitherei Range. 'Two found hy myself in 1875, and, some years later. as many by Mr. $\curvearrowright$. W. Fulton in Otago. It has also been found 
recently by Mr. W. L. Wallace in forest glades on the Kermadec Islands. There are about 250 minute members of this genus.

3061. Corticaria melasoma sp. nov.

Suboblong, slightly convex, shining, very scantily clothed with short and slender grey setae; fusco-niger, legs and antennae fuscous.

Head as broad as front of thorax, much constricted behind, with a distinct plica or transverse swelling at the back of each eye, its surface with minute coriaceous sculpture and a few indistinct punctures. Eyes of moderate size, obliquely oval, distinctly faceted. Antennae slender, basal 2 joints stout, 3-6 small, 7th and 8th rather larger; club laxly articulated. the intermediate joint smaller than the basal one, the last one largest. Thorrs of about equal length and hreadth. its sides regularly rounded, and with some minute denticles near the base; disc a little convex, minutely coriaceous, finely and distantly punctate, and with a well-marked median fovea near the base. Scutellum transverse. Elytra evidently broader than thorax at the base, elongate-oblong, finely seriate-punctate, the sutural striae distinct behind, interstices distantly and minutely punctured.

Legs indistinctly pubescent; basal 2 joints of the posterior tarsi rather small, apparently prolonged inwardly at the extremity, the terminal obviously stouter and longer than the basal 2 conjointly.

The nearly bald, dark, shining body renders its identification easy.

Length, $\frac{5}{8}$ line; breadth, $\frac{1}{4}$ line.

Mount Maungatua, Otago. My specimen was found by Mr. S. IV. Fulton, who in former years was one of our keenest entomologists.

\section{Myromecoxenus atomaroides Reitter.}

Oblong, finely and closely punctulated, densely clothed with short depressed griseous pubescence : fusco-ferruginous. antenmae and less dilute.

Head slightly narrower than thorax. Antennae rather slender, the terminal 2 joints thick, more so than in Corticaria illustris. Thorax transversely quadrate. very slightly narrowed hehind, anterior angles slightly rounded and deflexed. the posterior almost rectangular. the sides slightly o bliquely depressed. Elytra much bioader than thorax, more than twice as long as broad. Club of antennae triarticulate.

Length, $1.5 \mathrm{~mm}$.

Greymouth. Mr. R. Helms.

\section{Group ByrRHIDAE.}

3063. Pedilophorus helmsi Reitter. Gen., Man. N.Z. Coleopt,, p. 244.

Short, oval, very convex, smooth, finely and evenly punctured above ; glossy black. subaeneous. legs ferruginous, antennae elongate. these and the tarsi fusco-testaceous. Head nearly smooth on the middle, its sides coarsely punctured. Thorax very much narrowed anteriorly. front angles acute. Scutellum minute. Elytra acuminate behind.

Length, $3.7 \mathrm{~mm}$.

Greymouth. Mr. R. Helms.

\section{Group Eucxemidae.}

3064. Neocharis lobitarsis sp. nov. Gen., Man. N.Z. Coleopt., p. $27 \%$.

Elongate. somewhat narrowed towards both extremities, moderately shining. pubescence distinct, of a yellowish-grey : body black, legs fuscous. the knees and last $t$ joints of the tarsi reddish. antennae dull fusco-niger. 
Head finely hut not asely punctate. Eygrs large, oblique, oviform. Thaner in third broader than long, uradually narrowed anteriorly, convex. posterior angles alomgate and directed nearly straight hackiwards; it is distinctly yet finely lout not closely punctured. Elyglon elongate, as wide as thorax. each rounded at the base, shoulders a little elevated: substriate at the hase, sutural striae indistinct in front but becoming deep and straight meall the aproces. the pumctation moderate, not quite seriate, and appearing irregular owing to the mamerous finer punctures that are interposed.

Antenner robust, reaching backwards to the hind thighs, joints $t-10$ surate. End and Brd very short and, combined, equalling the the in leneth. Itth obviously larger than the preceding one.

Tursi with slender. indistinctly lobed penultimate joints: laisal joint of the posterior simple, almost as long as the following t, that of the anterior thicliened and sublobate towards the inner extremity the corresponding jomt of the intermediate with an immer lohe which at its margin appears mider the mirroseope to be minutely pectinate.

Nothing similar amonerst the Eucnemidae has come under my notice. The species in other respects resembles $\mathrm{X}$. concolor.

Leneth, 13 lines; breadth, in line.

Tairuat. One, found during my last expedition to that distriet.

\section{1ii). Talerax spinitarsis sp. nov. (Gen., Man. N.\%. C'oleopt., p. 279.}

Sulpparallel. elongate, clothed with fine elongate yellowish-erey pubesconce, nitid: black, legs fuscous, tarsi paler, palpi testaceous.

Ilead short, immersed up to the eyes. Antennal furrones deep and oblique, so that the forchead appears subtriancular. Thorax transversely quadrate, slightly narrowed towards the front, evidently convex, moderitely finely and distantly punctured, base hifoveate medially, apical matrin very distinct: posterior andes rohust and elongate, curved inwardly at the extremity. coarsely and closely sculptured. Scutellum oblong. Elytra r.longate. very gradually narrowed posteriorly, with intrahumeral impressions; the sutural striate are distinct at the base and apex, their punctation is distinct, rather close, slightly rugose, but not seriate, the aplices are subfoveate.

Male. Amemue elongate, filiform or only feebly serrate, reaching bawkards heyond the posterior femora, with slender outstanding pubesrence; basal joint thick and somewhat curvate in front, end very short. 3. Il about eynally clongate.

fiem.-Inlenmen thicker, just attaining the hind thighs, 3rd joint rather longere than 1th. Front lawi simple: elvtral punctation subseriate. pubes-

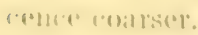

Legs: of moderate length. Tari with slightly excavate penultimate joints: the batsal joint of the front pair slightly acute at the extremity. that of the oflere pairs, the pesterior especially: with a romspicumes spiniform prolomgation at the immore extremity umblerneath.

The romarkithle tatsal structure is repeated in $T$. lemeis only, which. homerere is much smaller, whilst $T$. micans is a broader insoet. with short thick antromare. It shombl he lowated between these speries.

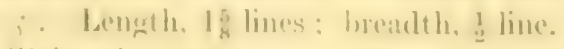

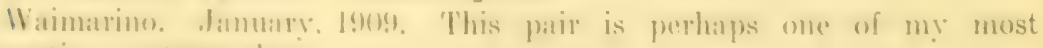
intopestinge capthers there. 


\section{Group Llateridae.}

3066. Lomemus vittipennis sp. nov. Gen., Man. N.Z. Coleopt., p. 290.

Elongate, narrow, moderately shining, pubescence distinct, flavescent; rufo-testaceous, the head, all the breast except the flanks of the prosternum, and a broad lateral space on each elytron extending from before the middle to the apex piceo-fuscous; antennae dull black, but with the basal 3 joints slightly rufescent.

IIead closely, distinctly, and somewhat rugosely punctate. Thorax of equal length and breadth, considerably yet cradually narrowed anteriorly, less closely but as distinctly punctured as the head. Elytra quite as broad as thorax at the base, gradually narrowed posteriorly, apices separately rounded; they are punctate-striate, the sutural striae are deep towards the extremity, the others are not; the suture and interstices have numerous fine punctures, and become quite rugose towards the sides and apices.

Antennae elongate, extending backwards to the middle femora; basal joint stout, 2nd and 3rd combined rather shorter than the 1st and barely half the length of the 4 th, joints +10 strongly serrate, 11 th elongate.

Rather more attenuate behind than L. elegans, its nearest ally, with rather longer antennae, the thorax more distinctly punctured; the elytra with deeper, broader, and quite definitely punctured striae, and with dark vittae, which are absent in that species.

Length, $3 \frac{3}{4}$ lines; breadth, quite $\frac{7}{8}$ lines.

Mount Pirongia. A single male in my own collection.

\section{Group Dascyllidae.}

3067. Cyphanus ocularius sp. nov. Gen., Man. N.Z. Coleopt., p. 308.

Subolong. moderately shining. slightly convex; pubesence relowish. distinct on the head, the sides of the thorax, and on the shoulders, finer and more depressed on the elytra; body rufo-castaneous, legs and antennae rather paler.

Herd broad, moderately closely and finely punctate, subgranulate towards the prominent and rather large eyes. Labrum exserted, emarginate at apex. Antennac elongate yet stout, 2nd joint short, 3rd hardly more than a third of the length of the th. Thorax only half as long as it is broad, with obtuse angles, the front very slightly medially rounded, and a little, yet widely, sinuate near the sides, these are explanate and slightly curved; the base is not lobate, but it is oblique or subsinuate towards the sides; its punctation rather finer and less distinct than that of the head; near the basal margin there are some fine granules. Elytra oblong, rather broader than the thorax, closely and evidently punctured. Labial palpi fureate.

Male.-Basal segment of abdomen normal, the last with 2 median impressions and 1 near each side.

The abbreviation of the 3rd antennal joint, the large and prominent eyes, and the presence of granulation near the sides of the head and base of the thorax differentiate this species from C. laticeps and C. punctatus.

Length, $3 \frac{3}{4}-1 \frac{1}{4}$ lines; breadth, $1 \frac{1}{2}-1 \frac{3}{4}$ lines. lection.

Waiorongamai and Mount Te Aroha. Two specimens in my own col-

3068. Cyphanus maculifer sp. nov.

Suboblong, slightly convex, a little nitid; pubescence moderately dense, slender, greyish-yellow; head and thorax pale ferruginous, the former behind the middle, the latter with a pair of large spots near the base, dark 
fuscous: antermate, leass, and olytrit fuseo-testareons, these last mottled with pale hrown.

Ilowel short and hroad, finely but not closely punctate, subgranulate lehind the exes. Labrum exposed, its apex distinctly emarginate. Anlennere elongate. and joint short. 3rd more thin half the length of the following one. Thorex with obtuse angles, the width double the length. it is slightly simute towards the sides in front, the middle of the base is broadly rounded, its sides are explanate, finely margined, and only slightly "urved: it is very finely and not at all alosely punctured, the pubescence near its sides, though slender. is suberect. Scutollum large, triangular. punctate. Elyfre rather wider than thorax, obloner, moderately closely and very distinctly punctured, a little depressed alongside the suture, bui quite ohsoletely tricostate.

The lightly dappled elytrat are similar to those of ('. mollis, but the diminution of bulk. the pair of well-marked blackish spots on the thorax. rather short 3rd joint of the antennate, and the obsolete costale are distinctive. ('. debilis, also with mottled wing-cases, though not alluded to in its description, can be easily separated by the granular sculpture of the thorix.

In one example the dark spots on the thotax are aceompanied by slight depressions.

Length, 3 ines: breadth, $1 \frac{1}{4}$ lines.

Iratakerei Range, and Hount Manatia, near Whangarei. A couple of specimens are all I could find.

3069. Cyphanus granulosus sp. $110 \mathrm{~V}$.

Oblong. rather broad, slightly convex, rither thickly clothed with rellowish decumbent hairs and erect slender setae; head and thorax subopaque, dark fusco-rufous; elytra moderately nitid, rufo-castaneous; legs and palpi dark fusco-testaceous, antennae ferruginous.

Ileml rither short, about as broad as the front of thorax, its sides slightly dilated behind the eyes, the surface finely granulate, more closely near the eyes, each gramule with a minute puncture. Thorax nearly

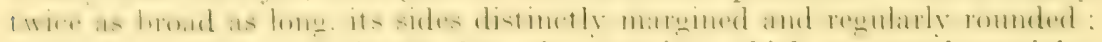
posterior angles more obtuse than the interior, which are nearly straight. though not at all prominent; the base a little sinuate, apex almost truncate towards the sides: dise densely and minutely punctate-granulate; the lateral slope not chamnelled, but less closely and more perceptibly granulate. Scutellum convex. Elytru broader than thorax at the base, gradually widened posteriorly, apices broadly rounded separately and leaving the axtremity of the abdomen uncovered; they are obsoletely costate, closely and moderately finely punctate, with the shoulders and basal margin cvidently paler and nearly smooth. Tibiae straight, finely setose.

Antemat clongate, pubescent ; hasal joint thick; 2nd short; 3rd elongrate. not much shorter than 1 th.

Cinderside finely pubescent and punctate; the stemum rufescent. abdomen fuscous. Terminal rentral seyment short, broadly and slightly impressed; the th on each side of the middle, with an obliçuely transverse cavity. with a tuft of olongate setae in each.

Labial palpi furcate, their 2nd joint finely setose, strongly prolonged hackwards. 3rd as lomg. attached to the outer and frontal part of the preceding one. Prostermal process hastate. medially punctate, or granulate. and projecting into the triangular cavity of the mesostemum, the intercoxal laminn slender and nearly vertical in front. 
This species is remarkable amongst its allies on account of the rather broad form, exposed terminal segment, the unusual sculpture of the head and thorax, rather flat eyes. and more elongate $3 \mathrm{rd}$ antemnal joint. The labial palpi, though furcate, are not formed as described in the generir diagnosis, p. 308, Man. N.Z. Coleopt. The somewhat rough-looking pubescence comes off readily on being brushed.

$\hat{3}$. Length, $3 \frac{1}{2}$ lines; breadth, $1 \frac{3}{4}$ lines.

Rangiahua, Hokianga. I am indebted to Mr. J. W. Graham for two specimens.

3070. Atopida grahami sp. nov. Gen., Man. N.Z. Coleopt., pp. 311, 1141.

Subdepressed, moderately elongate; vestiture pale, yellowish, conspicuous, mostly outstanding. finer and more scanty in front ; head, thoras, and scutellum subopaque, dark red: elytra glossy, castaneous. the suture fuscous; legs, palpi. and antennae testaceous. terminal joints of these last infuscate.

Head rather longer than thorax and nearly as broad, forehead subtruncate between the antemne. the oblique carina extending from the ere to the forebead most elevated in front: it is closely granulate near the sides, less so on the vertex. Thorax twice as broad as it is long, anterior angles somewhat prominent and acute, the posterior rectangular, its sides distinctly margined, and a little narrowed behind, subtruncate in front; it is rlosely punctate-granulose. but behind the middle more distantly; this area is moderately shining; the basal margin is depressed near the sides. Scutellum medially convex. Elytra oblong. evidently wider than thorax at the base, moderately coarsely but not very closely punctate. Tibiae finely setose, the posterior slightly incurved.

Antennae pubescent, reaching backwards beyond the base of elytra; basal joint thick; 2nd less so. longer than broad. oviform: 3rd elongate. yet shorter than the 4 th.

Underside castaneo-rufous, finely pubescent and sculptured.

Labrum large, strongly medially emarginate, it covers more than half of the mandibles during repose. Labial palpi furcate, the terminal joint rather thick. Eyes very slightly convex.

This should be placed next to $A$. hirta, but is easily separable by an examination of the sculpture of the thorax.

Length, 2 lines; breadth, $\frac{3}{4}$ line.

Rangiahua, Hokianga. A single specimen from Mr. J. W. (traham. after whom it is named.

3071. Atopida suffusa sp. nov.

Find

Subdepressed, moderately elongate; head, thorax, and scutellum subopaque, fusco-rufous; elytra shining, fusco-testaceous, the base, suture, and extremity infuscate; legs and palpi testaceous; mandibles and hasal joint of antennae rufescent, 2nd joint testaceous, the following ones more or less infuscate; clothed with slender yet conspicuous greyish-yellow suldecumbent and erect hairs.

Head as long as the thorax but rather narrower than it is, punctategranulose, more coarsely behind the eyes than on the vertex. Antennae pubescent; basal joint thick; 2nd subovate, stouter than 3rd. but only half as long. Thorax nearly twice as broad as long, widely but not deeply sinuate in front towards the acutely rectangular angles, which are somewhat depressed, its sides a little rounded, with rectangular hasal angles; its 
sondptwo like that of the head. less distinet and not ats elose in front ats at the sides. rather more distinet but not quite ats close near the basal marerin and hind angles. Scutellum slightly convex, subtriangular, with a few fine punctures. Elyglow boader than thorax, oblong. moderately coarsely hut not resely punetured, rather more tinely near the hase. Tibiur with short. preet parlisid setale.

latrene that A. grahami, with larger and more prominent eyes. the anterior angles of the thorax not projecting and more deflexed, the discoidal sempture differently arranged, that of the elytra much less coatse and rose, the Brd antemal joint quite as long as the following one. Ther lathrum is abbreviated, so that the mandihles are almost wholly exposed.

Lemeth, 2.5 lines: breadth. I line.

(ibemonth. Described from an single sperimen forwarded hy Mr. J. II. l, wis.

\section{2 . Veronatus granicollis sp. nov. (ren.. Man. N.\%. Coleopt., p. 314.}

Blongate, moderately shining, pubescence vellowish; fusco-rufous or ('astanceus, the antemase, palpi, and leas fulvescent.

Ilcul exserted. large, ret narrower than thorax, elosely and distinctly yet rasther fincly punctured, subopaque. Thorax subopaque, strongly transverse hut avidently narrowe than elvtra: widely emaromate towards the

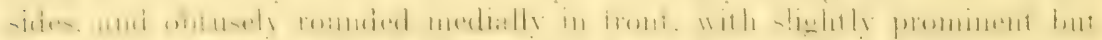

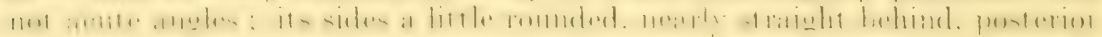
angles reatangular and subacute: the base subtruncate medially, but oblique or slightly sinuate towards the ameles; dise closely and moderately fincly hut distincty punctured, its sides punctate-gramulose, near the hind angles the granules are more distinct and not so close, each granule has a definite contral puncture; there is a shallow median impression. Scutcllum triangular. large. closely and minutely punctate. Elygtra elongate, subparallel. with rounded shonlders. their punctation rather fine and shallow: Closel at the base than elsowhere: they are without definite costae.

Antenume clongate, extending backwards just berond the intermediate femoral finely pubescent; basal joint thick; 2nd very small; 3rd slender, onls a little shorter than Ith.

The pate membranous frontal space is short. The labrum is exposed. punctate. medially emarginate, and distinctly ciliate in front. Mandibles prominent. Labial palpi not furcate.

Cmleiside rufo-castaneous, very finely and closely punctured, with stender pubescence. The 3rd rentral segment with a curvate median mark near its extremity, the 1 th with 2 distant oblique impressions behind, 5th medially impressed.

I. scubiosus hats granulite thoracie sentpture; it is smaller, more oviform.

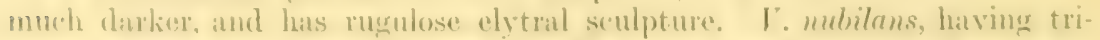
rostate elytra, more nearly resembles $\mathrm{V}$. longipalpis, but under the microseope the elytrial sculpture is seen to be punctate-indanulose. The alpine 1. nimplus may he at one identilied by the 2 transverse impressions on the llonits.

length. A lines: breadth, ynite 1! lines.

IVamarino. I seremed six specimens, almost all in the evening or early in the mornings.

O)s,- Having in former veats experienced great difliculty in obtaining

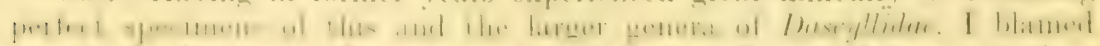

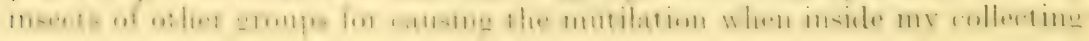


bottles. Recent investigations when at Waimarino proved that 1 had previously mistaken the cause. Early during a rainy morning I found about a dozen specimens under a plank lying on the ground. and thought I had secured a prize. No other insects accompanied them, and there were no nthers 'in the collecting-bottle. On examining them within an hour afterwards, I, to $m y$ intense disappointment. found every one mutilated. Finding a few more just at dusk, I placed two together in small tubes: the result was the same. After that experiment I placed one only in each. laurel tube, and in that way managed to secure perfect sperimens. I would. therefore, advise entomologists to carry separate tulses for the reception of these belligerent species. Veronatus longipalpis is the worst, as far as my tests are concerned.

\section{Mesocyphon tristis sp. nov. Gell., Man. N.Z. Coleopt, p. 316.}

Elongate, subdepressed, opaque, fuscous, the sides and base of thorax a little rufescent; the labrum, legs, and basal 5 joints of the antennae obscure rufo-testaceous; rather thickly clothed with fine yellowish-grey setae, which, on the elytra, are more or less concentrated in irregular patches; between these the hairs are finer and ash-coloured, and therefore apt to escape notice.

IIead moderately large, much and rather abruptly narrowed and prolonged in front; it is rather finely and closely granulate. Thorax transverse. subtruncate in front. anterior ansles deflexed and obtuse. the sides slightly rounded. biace oblinue towards the sides with subrectungular angles: its surface closely and finely yet quite. definitely granulate. Scutellum granulate. Elytra oblong, broader behind than at the base; there is at basal sutural depression which is curred outwardly before the middle of each elytron: they are finely and closely gramulate in front. the granulation becomes indistinct behind. The 2 nd joint of the anternat is nearly an long as the more slender 3rd.

Underside fuscous, densely and finely sculptured.

Darker and altogether more opaque than $\boldsymbol{M}$. monticola, near which it should be located. $M$. setiger and $M$. marmoratus are described as being finely punctured, but Dr. Sharp is mistaken on that point. as in my remaining specimens the sculpture is granular.

Length, $2 \frac{1}{8}$ lines; breadth, $\frac{7}{8}$ line.

Waimarino. January, 1909. Rather rare, but it may be otherwise during ordinary seasons. Durin: my visit only three or four of the shrubs were in blossom.

\section{Group Telephoridae.}

3074. Asilis collaris sp. nov. Gen., Man. N.'. Coleopt., pp. 326, 1147.

Elongate, narrow, shining, pubescence slender and suberect; head and thorax nigro-fuscous, elytra hiardi. with indistinct fuscous spots behind the middle and at the apices. the less and batsit joints of the antennate fuscous.

Head narrower than thorax, almost quite smooth. Thorax transverse, rounded in front and along the sides so as to form an almoit uninterrupted rurve from one posterior angle to the of her : these angles are merely slight projections of the basal margin; the lateral margins are thickened and reflexed behind, and rather more strongly rounded there than in front: dis. slightly uneven, with an ill-defined median impression and a large basal fovea near each side, it is apparently impunctate. but hats the usnal series of fine punctures close to the apicail and lasal maryins. Scrollum smooth.

2 -No. 1. 
Elygu hut little bronder than thorax, their margins somewhat explanate. ench with a row of well-marlied punctures; their whole surface very distinctly hut irregularly punctured, the intervals smooth and shining.

We possess no other described species like this. The peculiar form of

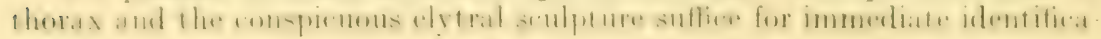
tion.

Length, 2 lines; breidth, sf line.

Mount Arthur. One example amongst a miscellaneous collection

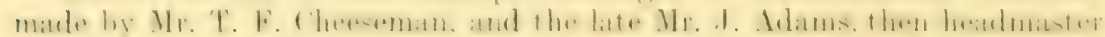
of the Thames Iligh School, whose loss as a genial friend I sincerely deplore.

\section{:075. Asilis brevicornis sp. nov.}

Nitid, nearly nude. black, antennate and leos fuscous, mandibles and (raws fulvescent.

Ilead rather narrower than front of thorax, opaque, seemingly without

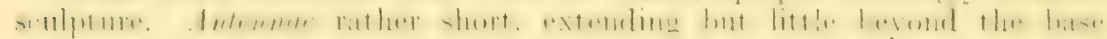
of elytra, their and and 3rd joints of equal length. Thorax transverse. apex slightly rounded, its sides nearly straight, with simple margins, which.

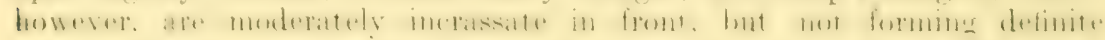
anterior angles; basal margin moderately rounded, and uniting with those along the sides without forming sharp angles; disc moderately convex. with a longitudinal impression on the middle, it seems to be impunctate but near the sides has minute close sculpture, the basal and frontal series of punctures are moderately distinct. Elyfra as wide as thorax at the base, a little dilated hehind the middle, their punctation moderately close and distinct, rather shallow and less evident near the shoulders and apices.

Differentiated by the abbreviated antemne; their 2nd and 3rd articulations are rather longer than the corresponding ones of A. parallelus. but the succeeding ones are shorter.

Length. 13 lines; breadth, nearly s line.

Clevedon, Humua Range. One of my own captures.

\section{:076. Asilis opaculus sp. nov.}

Depressed, elongate, yet rather broad, subparallel; pubescence ('lose, decumbent, slender, and ash-coloured; body black, thorax shining, elytra opaque; the antennae, patpi. and legrs nigro-fuscous, mandibles and claws

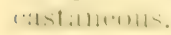

Meal half the width of thorax, with 2 shallow interocular foveate, mode-

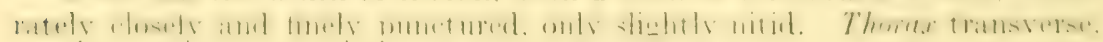
apex rounded, with elevated margins and obsolete angles: its sides moderately curved, with thick reflexed marrins which are rather broad at the middle; posterior angles rectangular but not acute, formed by the union of the hasal and lateral margins, the base oblique towards the sides: dise uneven, with a median antebasal impression, 22 obtuse elevations, and a transverse basal depression between the middle and each side, the surface fincly and moderately closely punctured, and with some larger but not coarse punctures near the basal and frontal margins. Sculellum not smooth. Vilyera a little broater than thorix, obtusely rounded behind. with dense. slightly rugose, gramular sculpture, which. however, is rather less distinet near the shoulders.

When compared with .1. gromipennis this speries may he recognised by

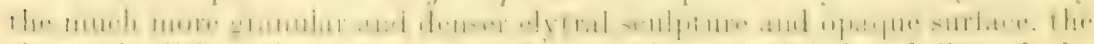
thorax is difterently sculptured and inlossy instead of being dull. and the 
post-median elevations are more like those of A. tumidus (1195), which. however, has slightly projecting posterior angles, and punctate elytra.

Length, $3 \frac{v}{8}$ lines; breadth, $1 \frac{1}{8}$ lines.

Mount Egmont and Midhirst. Three specimens in my own collection.

\section{Asilis egmontensis sp. nov.}

Elongate, rather narrow, black, head and thorax shining. elytra slightly so. thoracic margins castaneous, mandibles and claws testaceous, antennaf and legs fuscous, the knees paler, pubescence cinereous.

Hend of nearly the same breadth as the front of the thorax. finely punctate. Thorax transverse, broadly rounded in front, its margins rather fine there, with obsolete angles; the sides a little curved, the thick reflexed marins quite slender in front, posterior angles formed by the basal margin : base slightly rounded medially, but almost straight towards the sides; the surface very finely but not closely punctured, a little uneven, but without definite elevations: the male with a transverse basal depression near each side and a median one on the disc, the female with 2 basal foveae and a slight median longitudinal impression. Elytra as wide as thorax, somewhat attenuated posteriorly. with strongly romded apices. rlosely and finely rugose-punctate.

Fem.-Elytra not narrowed behind, apices obtusely rounded.

This is distinct from species with granulate elytra.

$\pi$. Length, $2 \frac{1}{2}$ lines; breadth, $\frac{7}{8}$ line.

Mount Egmont. One pair found by myself many years ago at an elevation of $3,500 \mathrm{ft}$.

\section{Asilis punctipennis sp. nov.}

Depressed, elongate, shining, pitchy-black, the palpi and legs pale fuscous, mandibles quite pallid.

Head narrower than thorax, rather shorter, indefinitely sculptured, slightly rugose ; finely granulate, with 2 interocular impressions. Wrandibles moderately elongate, minutely serrate inwardly. Antennae stout, not attaining the middle of the elytra, opaque, with dark pubescence; basal joint attached to a conical pallid prominence, a little longer and thicker than the 2nd, which is stouter but hardly longer than 3rd; joints 4-10 about equal, and a little dilated at the extremity, yet not distinctly serrate : the terminal elongate, oviform. Thorax strongly transverse, apex trun(ate, base slightly rounded, both with somewhat thickened margins; lateral margins explanate but not reflexed. obtusely prominent behind the middle. and with a smaller prominence behind, so that there seems to be an evident notch just in front of the acute hind angle; the disc with a few very minute distant granules, and close to the frontal and basal margins there are more distinct series, there is no well-marked median groove. Scutellum small, rounded behind. Elytia elongate, parallel, a little broader than thorax. aper rounded; they have closely placed series of moderately coarse punctures, which reach the apices. The pubescence is fine, scanty, and easily rubbed off.

There is but one species like this, the pale testaceous A. striata, which, however, has almost sulcate elytra.

Length, $1 \frac{1}{8}$ lines; breadth, $\frac{3}{8}$ line.

Raurimu. A single specimen, found in January, 1909. 
3079. Asilis parallelus sp. nov.

Depressed, clongate, sulpparallel, covered with slender decumbent cinereous pubescence: nitid, intensely hlack, legs and antennae opaque and fuscous. mitndibles testareous.

Head as hroad as front of thorax, almost quite smooth: Thorax transverse, fruncate in front; hase oblique towards each side, so that the middle seems rounded; its sides struight, or nearly so. with expanded margins which are thicliened and reflexed in front only; posterior angles formed hy the hasal marwin, there being a slight indentation between them and the sides; dise almost smooth, with an impression in front of the scutellum and a large one near each hind angle. Elytre of the same width as thorax.

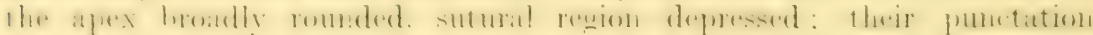
shallow, producing a slightly rugose appearance, but without any perceptible arranulation, the apical and humeral areas more finely sculptured.

Antemere densely pubescent, robust, extending backwards beyond the

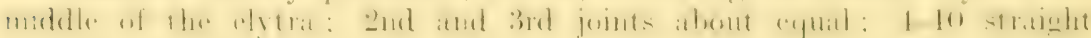
inwardly, slichtly curved ontwardly.

A. Ienuiculus (59.t) has finer elytral sculpture, its head is narrower, the thorax is broader behind than in front, and the antenmae are more slender. In 1196, A. piliventris, and A. apicalis, the head is dull with dense -uhture: the thorad amel antemate atow are different.

Length, $1 \frac{1}{2}$ lines ; breadth, $\frac{1}{2}$ line.

IIamarino. Elevation, 2,700 ft. Five were secured. I might have taken many, but they are pugnacious little wretches, with a predilection for maiming better insects than themselves when in a collecting-tube.

\section{Group HeLYRIDAF}

3080. Dasytes veronicae sp. nov. Gen., Man. N.Z. Coleopt., p. 328.

Slender, elongate; covered, the elytra especially, with slender decumbent cinereous hairs; the body blue, legs and antennae fusco-piceous, basal 2 joints of these latter and the claws rufescent.

IIead nearly smooth between the eyes, elsewhere densely and minutely sculptured and with some fine distant punetures the frontal impresions

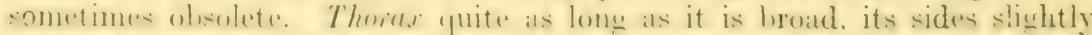
obtusely medially dilated; the surface a little uneven, transversely impresend at the lase. sometimes with a median impresion there asd a shallow one near each hind angle; with distinct but moderately fine and not close punctures. Sculellum broad, not smooth. Elytre elongate, subparallel,

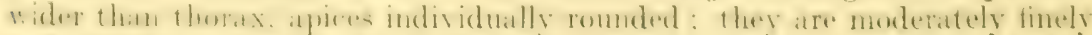

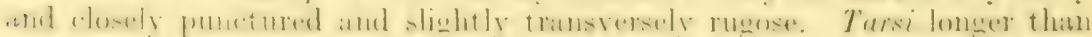
the tibiae, their basal joint but little longer thin the terminal one. Claus slender, without membranous appendages. Antennate pubescent, reaching backwards beyond the base of the thorax.

Var.-Shoulder's slightly clevated.

We have some similar species. D. constriclus has well-marked frontal impressions, and its thorax is much contracted anteriorly. In $D$. checsemani the impressions near the hind angles of the thorax are distinct, and it is much narrowed in front and rounded hehind, whilst the 6th ventral segment has only a small basal fovea. D. littoralis is a larger and more

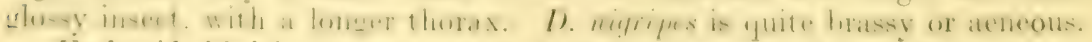

Undersile bluish, finely sculptured and pubescent; 6th rentral segment

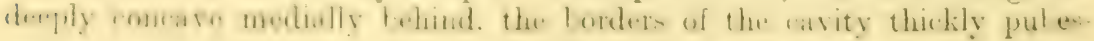
rent. 
The intervals between the punctures on the thorax are minutely and closely sculptured, and its pubescence is scanty, like that of the head.

- Length, $1 \frac{1}{2}-1 \frac{3}{4}$ lines; breadth, $\frac{1}{2}$ line.

Mount Cook. Several specimens taken off Veronicas by Mr. Cheeseman.

\section{Group Clenidae.}

3081. Phymatophaea abnormis sp. nov. Gen., Man. N.Z. Coleopt., p. 334.

Like the typical species, but exhibiting the following discrepances: Thorax shining, fulvescent, bearing yellowish setae, with smaller lateral prominences, its punctation indistinct or obsolete. Herd not bituberculate, the interocular space nearly plane, or only slightly bi-impressed. The shoulders are not nodiform, and the punctures behind them are smaller and more regular. Antennae elongate; basal joint stout, moderately long. curved in front; 2nd small, yet as long as broad; 3rd nearly as long as the 4th and 5th combined: 6th longer than its predecessor; 7 th smaller than the 2nd. C'lub large, its basal joint gradually expanded apically, and as long as the preceding 5 joints taken together; the next one rather shorter but more dilated; 3rd broadly oviform. but very slender near its base.

The structure of the antennae is due, no doubt, to malformation, as 1 can only detect 6 joints in one, though there are 7 in the other. instead of 8 , the normal number. The club is unusually elongate.

Length, 3 lines; breadth, $\frac{7}{8}$ line.

Waimarino. January, 1909. Unique.

\section{Group Colydidae.}

3082. Epistranus sharpi Reitter. Gen., Man. N.Z. Coleopt., p. 202.

Fusco-fulvous, antennae and legs rufous; rugosely tuberculate, the tubercles with short setae, variegated with chalky-white, thorax in front transversely sulcate. Like a highly arched Tarphius.

Thorax almost as long as broad, narrowed posteriorly, with a deep frontal arcuate furrow. Elytra not contiguous to thorax, a little longer than broad, rounded, nearly perpendicular behind, sculptured like the thorax, between the tubercles with a rough chalky case, forming a lunate sutural spot, there are also some smaller spots; and generally 4 white spots on the thorax; sometimes the chalky spots occupy most of the surface, so that the sculpture is thus rendered indistinct.

Length, $1.8 \mathrm{~mm}$.

Greymouth. Mr. R. Helms.

\section{Epistranus fulvus Reitter.}

Fulvous, tuberculate-rugose, the tubercles bearing setae, not at all chalky. Thorax before the middle transversely sulcate, and longitudinally canaliculate. Smaller than E. shorpi, reddish-yellow, similarly sculptured. Perhaps only a small variety of that species.

Length, $1.5 \mathrm{~mm}$.

Greymouth. Mr. R. Helms.

3084. Coxelus helmsi Reitter. Gen., Man. N.Z. Coleopt., p. 195.

Oblong, subparallel, nigro-piceous, variegated with red, covered with black and fulvous setae.

Thorax rather broader than long, sometimes quite ferruginous, the sides with short setae. Elytre wider than thorax, their margins hispid, 
narrowed just before the appices, these latter slightly produced, above uneven, with gramulated or closely punctured striae, with a tuft of blach bristles on the suture hefore the extremity.

L.ength, $2 !-3 \mathrm{~mm}$.

Greymouth. Mr. R. Helms.

\section{Phormesa costicollis Reitter.}

Rufo-ferruginous, elongate, moderately depressed, sulpubescent, lous bright rust-red.

Ilead narrower than thorax, with 2 slight broad impressions, behind dosely and distinctly punctured. Thorax transversely quadrate, sometimes narrowed in front, its sides nearly straight, anterior angles acutely prominent, the posterior straight; closely granulated, with 6 discoidal costae, the exterior medially arcuated, the interior abbreviated in front, arcuate, and approaching the middle. Elytre with several black spots, elosely crenatepunctate-striate; interstices narrow, the alternate ones sharply elevated.

Length, 3.2-3.8 mm.

Greymouth. Mr. R. Helms.

The genus was published by Pascoe in the "Journal of Entomology." ii, $1863, \mathrm{p}, 31$.

3086. Notoulus varicornis sp. nov. Gen., Man. N.Z. Coleopt., p. 183.

Convex, oblong, rather short and broad, thicky covered with yellowishurey sappy matter, legs pale ferruginous.

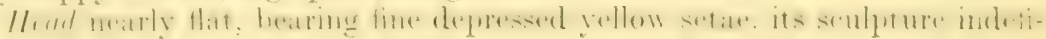
nite, apparently granular. Thorax slightly broader than it is long, its

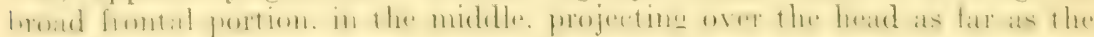
centre of the transverse eves, behind these deeply emaroinate; its sides bilobate: the anterior lobe extends quite half-way along the side, it is notched hehind the middle, and projects as far as the front of the eye ; the 2nd is dentiform: the posterior angle is almost rectangular, but does not touch the elytra; on the disc there is a large median angular depression which

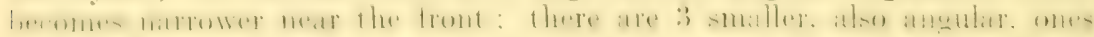
near the hase, the central one the smallest; there are also 2 in front; all these have thick raised borders; the setae are like those on the head, and the sculpture is similarly indistinct. Elytra oblong, broader than thorax at the base, subparallel, much narrowed and deflexed behind, with obtuse slightly divergent apices; on each, at the base, there is a slight prominence,

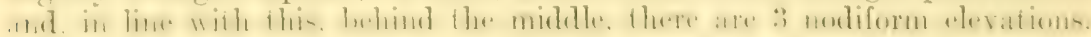
the hindmost being on the top of the declivity, there are 3 more near the side: the seriate sculpture appears to consist of granules or punctures, according to the point of view; the setae are curled and pallid. Tibine nearly striight, with fine curled setae. Antennae sparsely pubescent; the lasal '2 joints and the chub rufescent, the others fulvescent; and joint thick, but considerably narrowed at the base : 3rd slender, distinetly longer than

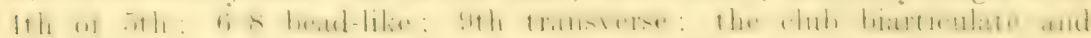
abruptly enlarged, its basal joint transwerse, more than twice the size of the !) H. Ilth subrotundate.

A rather convex thichset species, in form more like Proturphins indenlutus than any of its near allies. On a denuded spot the elytrib are fuscotestaceous.

Length, $1_{k}^{3}$ lines; breadth, \& line.

Dunedin. From Mr. A. Philpott's collection. Unigue. 


\section{Group Cerylonidae.}

3087. Philothermus bicavus Reitter. Gen., Man. N.Z. Coleopt., p. 210.

Rufo-ferruginous, narrow, subdepressed, shining. clytra at base and apex sometimes bronzed, with fine erect grey hairs.

Head somewhat narrower than thorax, finely punctate. Thorax rather longer than broad, slightly narrowed towards the base, subcordate. posterior angles anutely rectangular, sparsely and finely punctured, with 2 dorsal foveae. Elytra elongate-oval, rather wider than thorax at the base, finely punctate-striate to the apices.

Length, 2-2.2 $\mathrm{mm}$.

Greymouth. Mr. R. Helms.

Group Brontidae.

3088. Parabrontes rugicollis sp. nov. Gen., Man. N.Z. Coleopt., p. 220.

Depressed, elongate. slightly nitid, nigro-fuscous: antennae dull dark infuscate red, their basal 3 joints more shining; legs pale brown; the femora, extremity of tibiae, and tarsi paler, quite testaceous when alive; sparingly clothed with fine yellow hairs.

Head irregularly longitudinally rugose, with some coarse punctures behind; the forehead and raised antennary orbits nearly smooth; alongside these latter 2 longitudinal grooves with distinct margins extend towards the base. Thorax about as long as hroad. apex slightly rounded. base subtruncate; at each side, in front. there is a conspirnous angular projection. which is almost smooth and sometimes rufescent; the sides are broadly rounded behind the middle, where 3 or + minute tubercles or denticles are placed, but near the base they are obliquely narrowed and depressed, and do not form distinct angles; the disc has numerous obvious, irregular, more or less finely punctured rugae, there is scarcely any smooth space on the middle, near the sides the soulpture is distinctly granular. Scutellum broad. Elytra elongate, subparallel, evidently wider than thorax at the base; the suture, except at the base and apex, appears slightly elevated, owing to the broad depressions alongside : on each there are a scitellar and 7 series of moderately coarse punctures on the dorsum. Which lardly form striae, and become finer near the extremity; the interstices in line with the shoulders are subcarinate.

Antennae robust, reaching backwards to the hind femora, distinctly pubescent; basal joint thirk. longest: zond small. transverse. and suliglobular: $3 r d$ nearly twice the length of the 2nd. but at third shorter thatn the 4 th.

Underside shining, fuscous, sparingly and finely pubescent. Prosternum distinctly rugose-punctate, its flanks smooth and marked off hy rather deep oblique grooves. Metastermum more finely punctured. with a median sulcus. Abdomen finely and irregularly punctured.

$P$. silvanoides is described as $2 \frac{4}{5}$ lines long by $\frac{1}{2}$ line broad, with the 2nd and 3rd antemal joints of equal length. The thoracic scoulpture of $P$. rugicollis will at once lead to its identification.

Length, $2 \frac{3}{4}$ lines; breadth, $\frac{3}{4}$ line.

Waimarino. January, 1909. Three were caught under the bark of fallen trees.

3089. Parabrontes picturatus Reitter.

Depressed, with fine short pubescence; ferruginous, head and thorax often blackish, legs testaceous. 
Antemate extending to beyond the middle of the body, with elongate joints. 1st lonerest and rather thicker that the others. 2nd and Brd glohose. IIcad closely punctate, longitudinally striate in front. Thorax as long as broad, base and apex straight, the former somewhat elevated, closely and

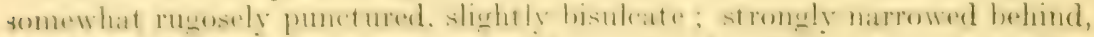

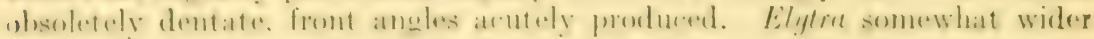
than thorax, variegated with black, punctate-striate to the extremity.

Similar to $P$. silvanoides, but differing in the structure of the antennae, colour, and seulpture.

Length, $6.5 \mathrm{~mm}$.

Greymouth. Mr. R. Helms.

Ohs.-P. setiger (1361) is, I think, identical.-T. B.

\section{Group Cucustosk.}

3090. Picrotus pensus sp. nov. Gen., Han. N.\%. Coleopt., p. 1097.

Convex, medially depressed, broadly ovial, shining, with a few slender grey hairs on the head; head and thorax red, elytra paler, legs testaceous, antennate ferruginous.

IIcal oblong, exserted, not half width of thorax, with 3 distinct punctiform impressions on the middle of its base, and 2 or 3 less-definite ones near the prominent eyes. the spate near the antemate finely and indistinctly rugose. Thorax subquadrate, a third broader than long in the middle, slightly curvedly narrowed anteriorly, apex subtruncate, with obtuse angres: lateral margins broad. flattemed, and raised. prolonged batekwards

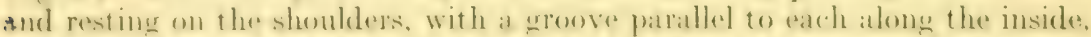
and somewhat expanded at the hatse. whehe is flat and depressed and widely ameralate at the middle, so that the very narrow extremity of the sedutellum

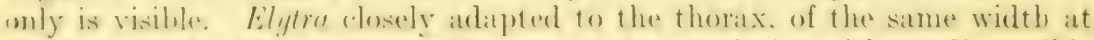
the hase. a third longere curvedly narowed posteriorly without disernible seulpture.

Antemae pubescent, relatively long and robust; 3rd joint longer than Ind or th; joints 5-9 subequal; 10th abruptly dilated, transverse, not as long as the terminal one. Tibier somewhat dilated and finely pubesent towards the extremity. T'arsi heteromerous, the front and intermediate pairs 5-articulate, the posterior with their basal 3 joints about equal, each marled off betou with a slender apinal sula, all :3 combined evidently shorter than the 4th.

Underside shining, pale red. Ilead proportionally rather coarsely punctate, and bearing fine yellow setae. Prosternum punctured, its flanks broad and smooth, its process broadly and deeply grooved behind. Melasternum with a few punctures, but smooth on the middle. Abdomen moderately fincly punctate, with fine yellow setae, which are most numerous on the terminal segment; basal segment, at the sides, not twice the length of the 2nd,

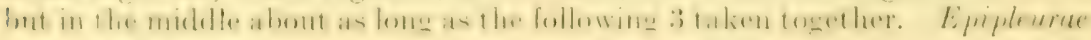
broad and smooth.

Less ohlong than P'. sanguimese (195:3), the thorax obviously shorter, its dise: without discernible punctures, the exposed portion of the scutellum much smaller, the terminal joint of the antemase rather longer. In 1953 there are several fine yet distinct punctures behind the antemnae, but at the back of the head there are only 2 indistinct impressions.

In form it more nearly resembles P'. Lhoracicus, from Westland, which, lomover. hiss the Ilth antennal joint smaller than the penultimate, whilst 
the 3rd apparently is as short as the following ones, and all the tarsi are 5-jointed.

Length, nearly $\frac{3}{4}$ line; breadth, $\frac{3}{8}$ line.

Raurimu. January, 1909. I could only find a single individual.

\section{Group Cissidae.}

3091. Cis zeelandicus Reitter. Gen., Man. N.Z. Coleopt., p. 346.

Subcylindric, brumneus, opacus; densely clothed with short, somewhat golden hairs. Antennae (except the fuscous club) and legs rufous. Head and thorax alutaceous, the former impressed in front which a median fovea, the latter transverse, lightly punctulated, the sides and posterior angles rounded, the anterior obtuse. Elytre finely yet deeply punctured in ilose series.

Male.-Clypers minutely bituberculate at apex, the tubercles moderately approximated.

Greymouth. Mr. R. Helms.

Ennearthron Mellie. Lacord., Hist. des Ins. Coleopt., tom. iv, p. 552.

Distinguishable from $C$ is by its 9-jointed antennae.

\section{Ennearthron boettgeri Reitter.}

Convex, oblong-oval, smooth, shining, black, sometimes rufescent, legss and antennae testaceous, club fuscous; head and thorax alutaceous, densely and obsoletely punctured. Thorax slightly transversal, margined laterally, its sides rourded, anterior angles very obtuse, the posterior almost rounded. Elytra thrice as long as thorax, densely and finely punctate.

Male.-C'lypeus reflexed, obtusely triangularly bidentate; basal segment of abdomen, in the middle, with an indistinct tomentose fovea.

Length, $1 \cdot 2-2 \mathrm{~mm}$.

Greymouth. Mr. R. Helms.

\section{Ennearthron obsoletum Reitter.}

Convex, oval, short, shining, smooth, castaneous, legs and antemnae testaceous, club fuscous; head and thorax alutaceous, sparingly and obsoletely punctate. Thorax subparallel transverse, margined near base, front angles obtuse, posterior rounded. Elytra densely and obsoletely punctured, not thrice as long as the thorax.

Male.-Clypeus reflexed, with 2 obtusely triangular teeth; basal seyment of abdomen with a distinct tomentose median fovea.

Length, $1.2 \mathrm{~mm}$.

Greymouth. Mr. R. Helms.

\section{Group Draperidae.}

3094. Menimus humeralis sp. nov. Gen., Man. N.Z. Coleopt., p. 360.

Convex, oviform, almost nude, glossy, piceo-rufous, legs fusco-testaceous, antennae more rufescent.

Head apparently smooth, having only a fow minute punctures, and bearing a few slender indistinct setae. Thorax at third broader than long. very cradually narfowed, but hardly perceptibly curved, towards the somewhat depressed and nearly rectangular front angles; lateral margins rather 
thin, and indistinct in front, apex slightly incurved near each side, the base a little hut widely hisinuate; its surface with a few minute, hardly discernible punctures. Sculellum finely punctate. Elygra fwice the length of the thorax, a good deal narrowed posteriorly; the lateral margins when fooked at from above seem indistinct, but at the shoulders are somewhat rxpanded and very shightly broader than the basal angles of the thorax: they have series of distinct but not coarse punctures, the sutural 2 on each are regular, the others are not, none reach the extremity, near the base there are a few additional punctures.

legs with slender yellowish hairs, those on the soles of the tarsi are out standing and elongate.

Antemate sparingly pubescent, hasal joint but little exposed, 2nd and Brd rither longer than the transverse 1 which follow, 8th and 9th enlarged. Ioth rounded, a little narrower but longer than the preceding one.

The eves are small and rather flat, like those of $M$. curlulus, which, howver, is i quite diflerent insect. $\boldsymbol{H}$. caceus has even smaller eyes, but it is of more oblong form, it is less convex, the base of the thorax is truncate, and its sides are moderately and regularly rounded, with well-developed margins.

Far.-Rufo-piceous, shorter and broader; the thorax seems broader in front, owing to the less-deflexed angles, and its margins are distinct in front. 'This may be the female.

Length, $13 \frac{3}{8}$ lines; breadth, 3 line.

Waimarino. Unique. Extracted from a decaying log.

\section{Menimus aemulator sp. nov.}

Shining, rufo-piceous, the legs and sometimes the thoracic margins pale fermerinous, antennate rufescent.

Head finely and distinctly punctured. Thorex similar to that of $\mathbf{M}$. humeralis, but with better-developed lateral margins, its punctation very fine and distant. Elytra of the same width as the thorax at the base. shoulders exactly adapted to the thoracic angles, they are a little dilated

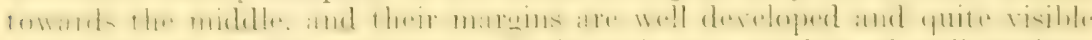
above almost to the extremity; their sculpture consists of well-marked. but not coarse, and somewhat irregular seriate punctures, which become indistinct near the apex.

In most respects like $\boldsymbol{M}$. humemlis. The thorax apparently broader in front, owing chiefiy to the more distinct angles. The humeral angles differ: and the sides of the elytra, between the base and the middle. are almost quite straight, yet perceptibly wider at the middle than elsewhere. The punctures on the head and thorax are visible without the aid of the microseope.

Vinderside rufo-piceous. The ential segments fincly and sparingly punctate and minutely pubescent, and rather strongly transversely convex

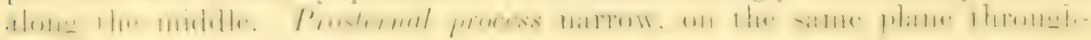
out. and extending between the intermediate coxac.

Lenenth, $1_{n}^{3}$ lines; breadth. $\frac{7}{8}$ line.

Fin--Head quite evidently and more coarsely punctate. Lateral marems less distinct. especially those of the elytrat these latter more rounded and not markedly wider at the middle. P'rohibly sexual variations. 1! by $\frac{7}{8}$ lines.

Wamarino. Three examples eut out of an old log, hat not the same in which $M$. humeralis wis found. 


\section{Group Tenebrionidae.}

3096. Lorelus latulus sp. nov. Gen., Man. N.Z. Coleopt., p. 380.

Rufo-castaneous, moderately nitid, tarsi and palpi testaceous: clothed with numerous minute brassy setae.

Head moderately coarsely, closely, and a little rugosely punctured. Eyes large, depressed, and strongly transverse. Antennae finely yet disfinctly pubescent, rather thick; the exposed portion of the basal joint not longer than the quadrate 2 nd; 3rd stout, not as long as the preceding 2 combined; 4th slightly longer than 5th, yet not longer than broad; 5-8 transverse; 9th and 10th rather broader: 11th larger than 10th. Thorax subquadrate, obviously transverse, its sides distinct. I margined and gently rurvedly narrowed towards the rectangular but not at all projecting hind angles; apex very slightly incurved, so that the obtuse angles appear a little prominent; its punctation similar to that of the head, but with the central linear space smooth. Scutcllum broad. Elytra evidently broader than thorax at the base, rather wider near the extremity, the suture depressed near the base, and near the apex also, their surface more coarsely punctured than the thorax, more finely at the extremity, where they are distinctly marginated and rather broad. Tressi normal ; the clans distinctly thickened at the base.

The transverse thorax, flattened eyes, and stouter, differently formed antennae distinguish this species from $L$. priscus. $L$. pubescens is more finely sculptured and shining, it bears slender. moderately elongate pubecence, and its eyes are more prominent. $L$. cressicornis is broader, more glossy and finely sculptured, with even thicker antemnae, and the sides of the thorax, near the front especially, are somewhat flattened. In $L$. quadricollis the sides of the thorax are nearly straight and quite explanate. and the seulpture is much finer.

Length, $2 \frac{1}{4}$ lines ; breadth, quite $\frac{3}{4}$ line.

Parua, Whangarei Harbour. One, in my own collection.

\section{Lorelus tarsalis sp. nov.}

Shining, castaneous, but infuscate rather than rufescent; the legs pale rufo-castaneous, with numerous slender and rather short yellowish setae.

Head moderately coarsely and closely punctured. Thorax transverse, subquadrate, slightly wider near the midale than it is elsewhere, slightly narrowed towards the front as well as the base, posterior angles sharply rectangular but not projecting; the apex feebly medially incurved, its angles not prominent; with a transverse depression at each side of the base and a slighter impression near each side just behind the middle, its punctattion is not very close, like that of the hack part of the head, more finely and less closely than in $L$. priscus. Elytra broader than the thorax and more coarsely punctured, the intervals not quite smooth, but with minute indefinite sculpture only.

Differs from L. priscus in having a shorter, differently sculptured thorax. less-prominent eyes, thicker antennate. with joints is 8 quite transverse, and thicker terminal tarsal joints.

Length, $2 \frac{1}{4}$ lines; breadth, quite $\frac{3}{4}$ line.

Otago. A single specimen, from Mr. 'T. Chalmers.

3098. Lorelus marginalis sp. nov.

Fusco-castaneous, the shoulders paler, legs fusco-testaceous, tarsi ra!lowish, antennae dark red; sparingly clothed with short slender setae. 
Head evidently narrower than thorax, the antenmal orbits short, disrimely raiced and redelish : its punctation molerately elose hut not coarse. E!ys small and nearly llat. Themer ahout a third broader than long, almost as whle in frout as at the midelle, slinhtly narrowed towards the rectangular

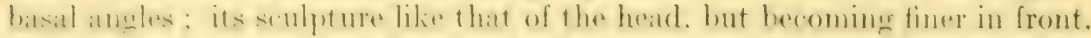
Elytra narrowed towards the base, which is, nevertheless, rather broader than that of the thorax; they are moderately coarsely but not very closely punctured, more finely behind.

This may be recognised by its rather narrow head, small almost depressed eyes, somewhat more open elytral sculpture, and rather short and thick terminal tarsal joints. The antennae are very nearly of the same thickness from joints 2 to 8 , the 3rd is slightly shorter than usual. The elytral margins are most distinct near the shoulders, which is not the case in L. priscus.

Length, 13 lines; breadth, 5 line.

Broken River, Canterbury. One, from Mr. J. H. Lewis.

\section{Lorelus sternalis sp. nov.}

Oblong, rather broad, moderately convex, nitid, pubescence yellowish, fine yet distinct; rufo-castaneous, tarsi and palpi testaceous.

Ilead narrower than thorax, forehead subtruncate; it is finely yet dis-

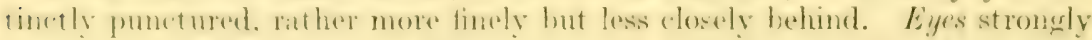
transverse, not prominent. Thorax about a third broader than long, apex arcuate-emarginate, base slightly bisinuate; the sides a little narrowed, withma ans sinuosity. lehimel. with well-developed reflexed margins and

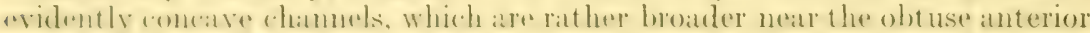
angles than elsewhere; the margins at the base are somewhat expanded and filtemed. and form shamply rectangular hut not projerting angles; the discoidal punctation is finer than that of the head, nowhere very close, and becomes rather more distant and finer towards the sides; at the base. between the middle and each side, there is a transverse impression. Sculellum transverse, rounded behind, smooth. Elylra oblong, wider than thorax at the base, the lateral margins very distinct, even at the shoulders,

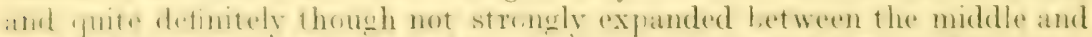
hind thighs. hut lea me l.ner behind: there is a distinet sutural depression meatr the hated : ther are more distineth hut less closely punctured than the

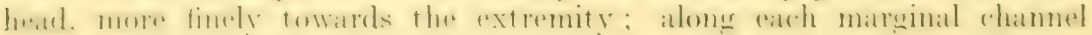
there is a series of rather coarser punctures.

Leys stout. Tibiae minutely calcarate at the extremity. Antennae

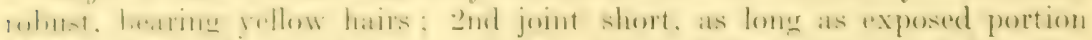

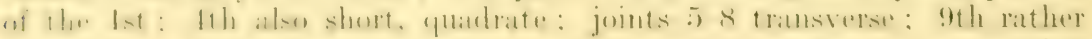
larger than 10th; the terminal subovate, not thicker than the preceding one.

Underside transversely convex, shining, very finely and sparingly pubescent. Prosternum distinctly punctate near the sides, its margins brond and flattened, its process sharply bisuleate between the coxate and depressed at the basal margin. Mesosternum on at lower plane than the raised rolges of the middle coxite, medially punctate; trochinters small. Mclestemum rather short, scarcely longer than the middle of the basal

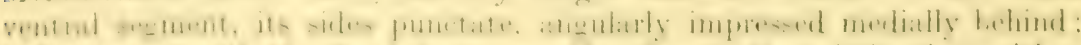

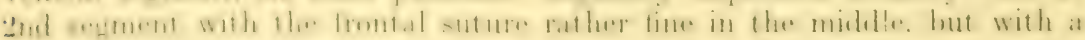
well-marlied transverse impression at each side; 3rd with an elongate foveiform impression at the sides; 4 th and 5 th short, the front of each on it 
lower level than the apex of the preceding one: the hasal 3 are more distinctly punctured near the sides than on the middle.

Altogether different from $L$. priscus; more nearly approaching $L$. crassicornis, but distinguishable therefrom by the less-prominent eyes and antennary elevations, distinct (especially in front) marginal rhammels. finer punctation, and evidently incurved apex, of the thorax, \&c.

Length, $2 \frac{1}{2}$ lines; breadth, quite $\frac{7}{8}$ line.

- Waitakerei Range. Two in my own collection.

\section{Lorelus nigrescens sp. nov.}

Subdepressed, elongate, sparingly clothed with short slender lirassy setae, moderately shining; fusco-niger, shoulders and apices of elytra slightly rufescent, legs pale castaneo-rufous, antennae rather darker red.

Head closely and moderately coarsely punctured. its sides distinctly thickened and elevated near the antemnae. Eyges strongly transverse. not prominent. Thorax about a third broader than long, distinctly marsined, widest near the middle, more narrowed, but not sinuate, towards the base than in front, the posterior angles acutely rectangular but not projecting, its punctation like that of the head. Scutellum hroad, punctate. Elytra subparallel, elongate, broader than thorax, nearly plane; modenately closely and coarsely punctured, more finely near the extremity. Legs stout. Tibine gradually and only slightly dilated towards the apices, and minutely bispinose there.

Antennae rather stout, 3rd joint obviously longer than 2nd, 1th and 5th slightly longer than broad, 6-8 almost transverse, 9th and 10th evidently larger than the preceding ones, the 11th longer.

The dark colour, more flattened dorsum, setose surface, thicker antennat, differently shaped thorax, and much less convex eyes distinguish this speries from $L$. priscus.

Length, $2 \frac{1}{4}$ lines ; breadth, $\frac{3}{4}$ line.

Mount Cook. One individual, found by Mr. 'T. F. Cheeseman.

\section{Group Cnodalonidae.}

3101. Artystona philpotti sp. nov. Gen., Man. N.Z. Coleopt., p. $38 t$.

Elongate, rather narrow, transversely convex, moderately shining; head and thorax nigro-piceous; elytra variable, in some specimens rufocastaneous, in others more piceous; labrum, legs, and antennae infuscate red; palpi paler.

Head distinctly but not at all closely punctate. Thorax quadrate, slightly transverse, anterior angles rounded, the posterior obtusely rectangular; its punctation moderately fine, a little finer than that of the head on some parts, not close, rather distant near the sides and hind angles, usually with 2 punctiform impressions between the middle and the base. Scutellum finely punctate. Elytra slightly wider than thorax at the base; not quite parallel-sided, usually slightly broader behind the middle; they are finely striate-punctate, interstices with distant serial punctures, not interrupted before the middle and only moderately nodose behind, the lateral margins are not broad.

Underside nitid, rufo-piceous; pubescence fine, scanty, and yollowish; flanks of prostermum rather coarsely, closely, and rugosely punctured the sides of the metasterium more closely, its central portion impunctate but finely transversely rugose, the epipleurae and sides of ventral segments less closely and much more finely sculptured along the middle, the terminal one slightly obtusely raised medially behind. 


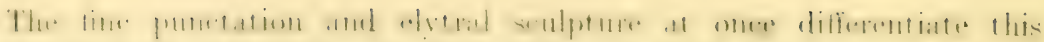
species from 1. wulefuldi. In A. linclella the head and thorax are more finely punctured, the former more distintly, the latter more closely. The whole insect is broader, the lows are more robust, and the.elvtral margins and general cololition difter. It is also distinct from 4 . obseurus. which

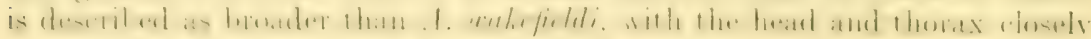
punctured and subopaque.

Length, $4 \frac{1}{2}$ lines; hreadth, 13 lines.

Inverearrill. Named in honom of Mr. A. Philpott, from whom I received it, as well as two or three sperimens which agree with Dr. Shatp's description of 1. olscurus.

\section{Artystona tinctella sp. nov.}

Elongate, transversely convex, a little shining; pitchy-black tinged with violaceous: antennate and tarsi rufo-piceous; the legs, palpi, and labrum hackish.

Heal transversely impressed in front of the eyes, finely and rather distantly punctured. Thorax quadrate, very slightly broader than long, with obtuse angles, finely and moderately closely punctured, more finely than

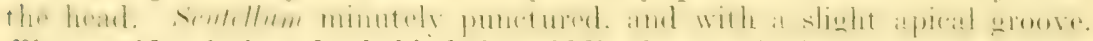
Elytra evidently broader behind the middle than at the base, lateral margins distinctly expanded for two-thirds of the entire length, and well developed even at the shoulders: they are finely striate-punctate, basal sculpture less definite; interstices distantly punctured, and only moderately interrupted and nodose towards the extremity; they bear numerous minute setae.

Easily distinguishable from A. wekefieldi by the fine sculpture of the

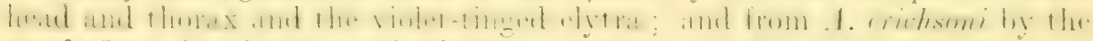
much finer, less interrupted, elytral sculpture, and the quite truncate apex of the thorax, which in A. erichsoni is widely and quite definitely incurved.

Length, 5 lines: breadth, $2 \frac{1}{8}$ lines.

West Plains. Southland. I am indebted to Mir. A. Philpott for my specimen.

\section{Artystona vicina sp. nov.}

Elongate, transversely convex, with very few slender vellowish setae: piceo-nigrer; legs, antennae, and palpi rufo-piceous; labrum rufescent: head and thorax subopaque; elytra moderately nitid.

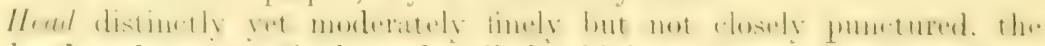
forehead rather more finely and a little shining. Thorax quadrate, very

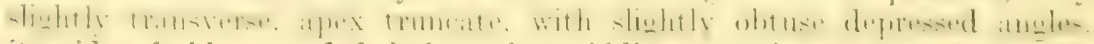
its sides feebly rounded before the middle, posterior angles obtuse, it is surface finely but not closely punctured. Scutellum nearly smooth. Elytru elongate, slightly wider than thorax at the base, a little wider behind the middle; with fincly punctured shallow striae, which, however, are effaced at the base, but become deeper behind; interstices with distant serial punctures, becoming more elevated behind. where thes are more or les interrupted and form olslong nodiform alevitions.

Underside nigrescent, moderately shining, finely punctured, and spaningly

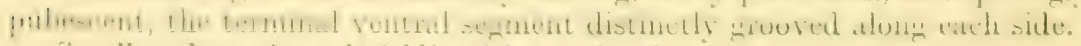

Smaller than .1. watefield, with the head and thorax very much more

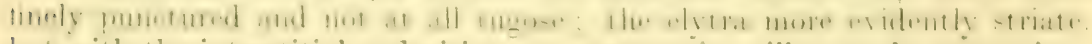
but with the interstitial nodosities not commeneing till near the extremity : the thoriax also diflers. 
Length, 5 lines; breadth, 2 lines.

Taieri, Otago. The only specimen I have seen was forwarded by Mr. S. W. Fulton.

\section{Group HelopidaE.}

3104. Pseudhelops substriatus sp. nov. Gen., Lacord., Hist. des Ins. Coleopt., tom. v, p. 441.

Convex, oblong-oval, glabrous, subopaque, the whole derm densely and minutely sculptured: ripreo-fuscous, legs rufo-fuscous, antennae and tarsi ferruginous.

Head, eyes included, of about the same width as front of thorax, a little uneven, its punctation shallow and indefinite. Thorax slightly broader than long, finely marginated. the sides gently rounded and but little narrower in front than behind: base feebly bisinuate and resting on the elytra, with rectangular but not acute angles; the apex subtruncate, with obtuse angles; disc moderately and evenly convex, very finely but not rlosely punctured. Scutellum rounded behind. Elytra slightly nitid, oviform, slightly wider than thorax at the base, still wider near the middle; each with 8 more or less interrupted striae, which do not reach the apex; interstices with numerous fine punctures or minute elevations, according to the point of view: the 3rd, 5th, and 7 th obtusely raised behind, but not definitely nodiform; the external one also a little elevated, and extending further back than the 7 th. Legs simple. Tibiae finely bispinose at the extremity, and bearing only a few minute setae.

Antennce sparingly and finely pubescent as far as the 7 th joint, which, like the 6 th, is rather longer than broad; the terminal 4 are distinctly larger, more evidently pubescent, and sculptured; joints $8-10$ are about as long as broad, and narrowed towards the base; 11th larger and ovate; the 2nd is as long as the exposed portion of the basal one, the 3rd distinctly longer than 4 th or 5th.

Underside piceous, shining, finely punctate. Prosternum and epipleurce nearly smooth.

The facies and structure of this species almost exactly correspond with Pseulhelops. The broad prosternal process does not extend beyond the hind-margin and at that point its sides are not at all sharply defined; it has 2 deep grooves, and the borders of these are distinctly elevated between the coxae. The intercoxal portion of the basal ventral segment is strongly rounded, and has raised margins. The soles of the tarsi are not very thickly pilose. The ligula is rather shorter, but much more exposed than in Cerodolus.

$P$. interruptus, from Camplell Island, most nearly resembles this species. The punctation of the head and thorax is more distinct, the elytral striae are deeper, and the antennae are longer than in $P$. substriatus.

Length, $3 \frac{1}{4}$ lines; breadth, $1 \frac{3}{8}$ lines.

Southland. Discovered by Mr. A. Philpott.

\section{Pseudhelops nodosus sp. nov.}

Subopaque, concolorous, castaneo-rufous.

('losely allied to $P$. substriatus, but differing therefrom by the punctation of the head and thorax being more distinct or sharply marked, and by the elytral interstices ending more abruptly behind, almost forming + nodosities. The antemnae are longer, joints 25 are relatively more elongate, the 2nd is almost as long as the 4th of $P$. substriatus. 
Leneth, 33 lines: breadth, lo lines.

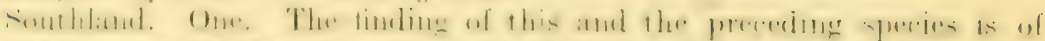

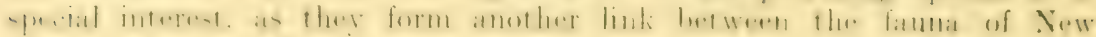
Zealand and that of the subantanetire islands.

3106. Adelium femorale sp. nov. (ien., Man. N.\%. Coleopt.. p. 386.

Elongate, subparallel, slightly convex, glabrous, shining: nigro-fuscous. slightly bronzed, sides and apices of elytra castameons, legs fusco-testaceons. the femora quite fuscous at the base, antemmae and palpi infuscate.

Ilead somewhat uneven. irregularly and distinctly punctate. Thorad quadrate, almost as long as broad, the apex, however, is evidently incurved. the base subtruncate and resting on the elytra: the sides are distinctly margined, a little rounded towards the obtuse front angles, the posterior

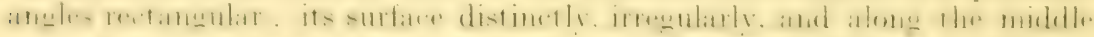

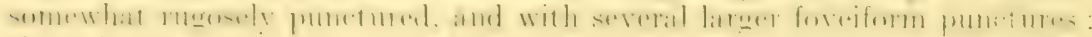
there is an amgular basal impression about midway between the middle and each side, and before the middle, near each side, there is a well-marked longitudinal depression. Scutellum broad. minutely punctured. Eily/ra distinctly margined and slightly rounded laterally, very slightly wider than thorax at the hase, very irregularly multi-punctate-striate, most imregularly beyond the 5th striae, towards the extremity the punctation becomes indistinct; interstices moderately narrow and finely punctate. Leys rather slender. Antenme gradually incrassate from the 5th joint onwards, and very small.

1. thoracicum usually measures $4 \frac{1}{2}$ by $1 \frac{3}{4}$ lines; it is more aeneous, the thorax in a specimen from the Otira Gorge is somewhat violaceous, the legs are much more robust, the striation of the elytra is more regular, and the sides of the thorax are sinuously narrowed behind. A. multistriatum is about a fourth larger than A. thoracicum, with deep regular elytral striac.

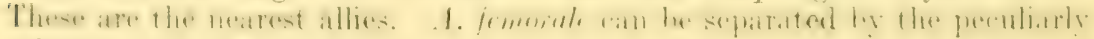
coloured, almost tawny femora.

Length, 35 lines; breadth, 112 lines.

Greenhills, Southland. Unique. Mr. A. Philpott.

\section{Adelium titahiense sp. nov.}

()hlong, moderately convex, glabrous, nitid; nigro-fuscous, slightlyhronzed: legs, antennae, and palpi fusco-rufous.

Ileud narrower than thorax, contracted behind the eyes, moderately finely but not closely punctate; the sides in front of the eyes nearly smooth and slightly raised, and marked off separately by a well-marked groove:

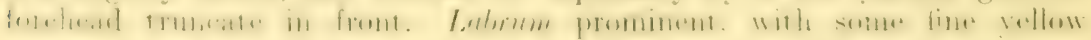
setace. Liyes strongly transverse, distinctly faceted. Thorax transversely quadrate, a third broader than long; apex fincly marned and widely incurved, with obtuse angles; its sides fincly margined. slightly curvedly narrowed in front, slightly and gradually narrowed towards the obtusely rectangular posterior angles; hasal margin subtruncate, touching but not rovering the elytral base; the surface moderately finely, rather evenly, but

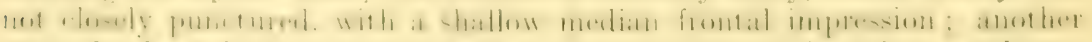
near the base is also longitudinal, and may perhaps in other specimens unite with the frontal one; near the hind angles there are also indefinite impressions. Scutellum small, olosolete. Lilylru rather broader than thorax at the base, their sides finely margined and nearly straight, a good deal

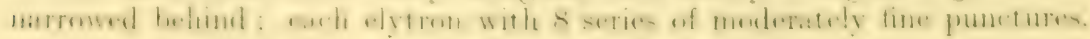


those near the suture and apex are sulistriate; interstices plane, with many minute distant punctures.

Tibiae finely hispid. nearly straight, bispinose at the extremity; basal joint of anterior tarsi subtriangular and evidently longer than 2nd, 4th small. Intennae finely pubescent; exposed portion of the basal joint scarcely longer than 2 nd; 3 rd shorter than 4th and 5th combined; 7 - 10 laxly articulated. moderately expanded, and subcordate; 11th large, subovate.

This should be placed in proximity to 690 , A. amaroides Bates (Pheloneis Pascoe), but it is differentiated from that species by the nearly straightsided thorax and indistinct scutellum. A. urquharti, another congener, may be distinguished by the coarser sculpture.

Length, $3 \frac{1}{4}$ lines; breadth, $1 \frac{3}{8}$ lines.

Titahi Bay, Southland. This is another of Mr. Philpott's captures. Unique.

\section{Group Cistelidae.}

3108. Amarosoma violacea sp. nov. (ien., Redtenbacher, Voy. "Novara," 1868.

Glabrous, nitid, blue; elytra faintly rufescent on some parts, head and thorax rather darker; antennae, palpi, and legs more or less rufo-piceous.

Head distinctly and irregularly but not coarsely punctured. Thorax widest as the base, widely but not deeply bisinuate there, much narrowed towards the front, which is a little emarginate, the lateral margins only visible from above near the base, hind angles subrectangular but obtuse; the surface very finely. distantly, and irregularly punctured; at the middle of the base there is a transverse impression, and between it and each side an angulate one, near these the punctation is more distant than on the disc. Scutcllum large, smooth. Elygtra oblong, narrowed posteriorly, the shoulders obliquely narrowed so as to be bat little broader than the thorax at the base ; the sutural region depressed at the base and with a short series of punctures there; on each there are 3 deep pun tate striae near the suture, these extend to the apex but do not reach the base, the outer series of punctures are slightly coarser but become indistinct behind, the interstices appear smooth.

Antennae unusually thick; 2nd joint half the length of the 1st, subquadrate; 3rd rather shorter than th. Tarsi moderately broad, the penultimate joint of the anterior with elongated lamellae, so that the 5th extends only about a third further. Claws finely pectinate.

Rather broader than 1. sophorac (699), the colour altogether different, antennae thicker, the epistome concex instead of being flat. In that species the elytral striae are well marked behind.

Length, 5 lines; breadth, $1 \frac{3}{4}$ lines.

Iitahi Bay, Southland. Described from a solitary individual found by Mr. A. Philpott, of Invercargill.

\section{Group Salpingidae.}

3109. Salpingus cognatus sp. nov. Gen., Man. N.'L. Coleopt., p. 398.

Shining, moderately convex, sparingly clothed with slender greyish hairs and, on the elytra, with many erect conspicuous ones; bright rufofuscous but becoming a little darlier behind, shoulders rather paler, legs pale testaceous, basal 6 joints of antemane rufescent, the remainder fuscous.

Head much narrowed anteriorly. rather elongate, and, including the large prominent eyes, rather wider than the front of thorax and more 3 -No. 1. 
rulesent than it is: relatively molerately coarsely and elosely pumeturesi and with fine transverse rugae between the antennae, the forehead and midale of rertes nearly smonth. the latter with a slight lomeitudinal groms. behind. Thorax cordiform, rather longer than broad, the sides behind the middle a good deal but not sinuously narrowed; its surface distinctly and evenly punctured. Scutcllum smooth. Elytra oblong, their sides only slightly curvate, each oblique towards the suture at the base so that the shomlders appear a little mominent and evidentle broader than the theras. they are evenly moderately convex, the scutellar region only being a little

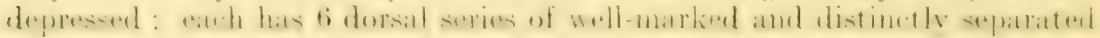
punctures, which, however, become indistinct behind.

Antemme sparsely pubeseent as fir as the 6th joint; the basat one much stouter but searcely at all longer than 2nd; 3rd distinctly more elongate than 4th or 5th; 6th and 7th longer than broad; 8-10 laxly articulated. broader than the preceding one, yet not transverse: 11th ovate.

Intermediate between $S$. lautus (705) and S. hirus (1407). The pubescence of the thorax less evident, that of the elytra more conspicuous than in the latter species, with less-developed elytral margins and less-curvate sides, but more prominent eyes, \&c. From the former it differs by the conspicuous restiture, by the absence of any trace of a smooth area along the middle of the thorax and any transverse elytral depression, and by disparities of seulpture and colour.

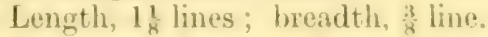

Waitakerei Range. March, 1909.

Obs.-S. bilunatus Pascoe var. Dark fuscous, with in trinsverse band before the middle, and a large apical arma on each elytron fusco-testaceous.

Length, 1 line; breadth, $\frac{3}{8}$ line.

Hunua Range.

\section{Salpingus rugulosus sp. nov.}

Elongate, subdepressed, rlabrous, nitid; variable in colour, head and thorax usually fusco-testaceous or rufescent; elytra fuscous, but with the lumeral area and a large antemedian space on each testaceous: the legs fusco-testaceous; antennae wholly rufescent.

Head trigonal, and, including the prominent and rather large eyes, almost as broad as the widest part of thorax, its frontal portion quite or nearly smooth, the hind part moderately coarsely punctured. Thorax widest near the front, considerably but gradually narrowed towards the base; its whole surface, except the smooth apical margin and median line. very irregularly, roarsely, and rugosely punctured; the sides a little uneven. with 3 or 4 obtuse denticulations. Filyer elongate-oblong, subparallel. broader than thorax, with series of coatre distinctly separated punctures, still coarser and mote approximated in some specimens, all, however, are effaced or indistinct hehind and where the sutural region is somewhat depressed.

Antmue very sparingly pubescent, not quite attaining the base of the thorax, joints 6 and 7 rather smatl and submoniliform. 8th obeonical, 9-11 broader than the preceding ones.

Underside fuscous, the breast, distinetly punctate, the metasternum. however, is nearly smooth along the middles and sides. The ventral seg-

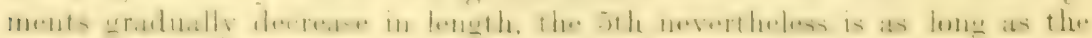
Ith; they bear some fine erey hairs; the punctation is shallow, with shagreened intervals, but the apical margins sore smooth. 
The sculpture of the disc and sides of the thorax is distinctive.

Length, $1 \frac{1}{8}$ lines ; breadth, $\frac{3}{8}$ line.

Waimarino. January, 1909. I obtained a good series.

\section{Salpingus tarsalis sp. nov.}

Nitid, moderately convex, elongate; head and thorax rufo-fuscous, elytra pale tawny brown. leigs fusco-testaceous, palpi and basal 6 joints of the antennae ferruginous, the terminal 5 piceo-fuscous; sparingly and finely pubescent, the elvtra. in addition, with long erect greyish hairs.

Head narrowed anteriorly. as lroad (the prominent eves inclusive) as the widest part of the thorax: ristinctly and moderately closely punctured. somewhat rugosely in front. lut the lahrum, epistone, and central space are nearly smooth. Thorax rather narrow, longer than broad, gradually narrowed from near the front to the base; the anterior angles obtuse ; it is distinctly, evenly, and bither sosoly punctured. Scutellum impunctate. Elytra elongate, oblong. transversely convex, the base evidently wider than thorax. ohligue towards the suture, whith slightly curved sides; their punc: tation seriate. only moderately roarse and continued to the top of the posterior declivity; which is smooth; a scutellar stria is interposed between the first series and the suture.

Legs stout; the tarsi nearly as long as the tibiae, the terminal joint of the posterior slightly longer than the basal 3 taken together, with thicl: claws. Palpi rather loner and stout. Inteniar elongate, joints 3-6 gradi. ally decrease in length. 7 -10 obconica! and gradually expanded, none tran versal.

In general contour somewhat similar to S. fossulatus; in it, however, the thorax is almost oviform, and has a pair of remarkable basal fossae.

Length, $1 \frac{1}{2}$ lines; breadth, $\frac{1}{2}$ line.

Tuakau, Auckland. Unique.

\section{Salpingus simplex sp. nov.}

Subdepressed, oblong, nearly nude, having only a few erect scattered hairs, moderately shining: fuscous. faintly cupreous, legs fusco-testaceons. the terminal 5 joints of the antemae piceo-fuscous, the others pats ferruginous.

Head rather large, somewhat broader than front of thorax, distinctly and rugosely punctured behind, and with an almost smooth rentral spoi there, in front more fincly and transversely rugose, the epistome and labrun smooth. Eyges prominent. Antennar moderate; 3rd joint slightly longer than the contiguons ones. hut much more slender than the 2 nd; 6 th almost bead-like; 7th longer: $8-10$ long (lam hroad, loosely articulated: 1Ith ovate, but hardly as broad as the preceding one. Thorax broadly cordate, rounded and widest near the apex, considerably narrowed behind; it is distinctly, moderately closely. and slightly rugosely punctured. Scutellim punctate. Elygira oblong. only a little lroader than the widest part of the thorax; but olvionsly broader than its base; they are slightly broadly impressed before the middle, and longitudinally depressed alongside the suture at the base, their punctation moderate and seriate, the apices smooth.

Allied to S. bilumens. the head and front of thorax obviously hroarler, and the hind-body concolorous.

Length, $1 \frac{1}{8}$ lines ; breadth, $\frac{3}{8}$ line.

Auckland Domain. December, 1908. A single individual only. 


\section{Group Melandrytuak.}

3113. Allopterus simulans sp. nov. Gen., Man. N.Z. Coleopt., p. 790.

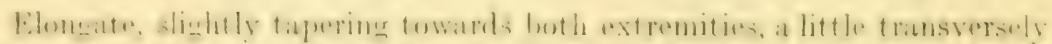

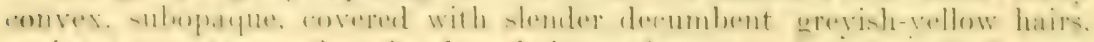

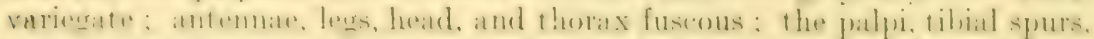

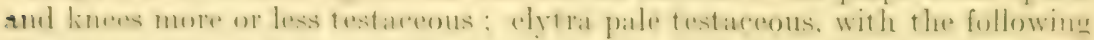
fuscous markis - a large cordiform one at the middle of their base; one at

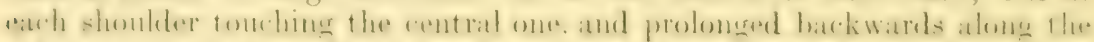

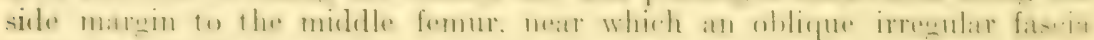
extends inwards but does not reach the suture; behind this a broad lut paler one, which is nearly straight in front but does not reach the apex. extends nearly right across the elytron.

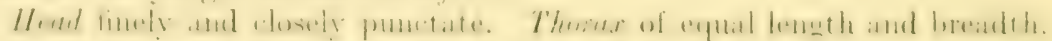
moderately narrowed towards the deflexed front angles, the base slightly. obtusely prominent at the middle, and a little sinuate towards the obtuse angles; a central linear impression at the base does not extend to the middle of the dise; there is a short oblique hasal impression near each side: its sculpture is fine, and seems to assume the form of short transverse lines. Scutellum transverse. Elytra with sharply separately rounded apices, the suture simple and a little elevated; their sculpture, near the base, is

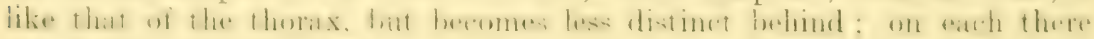
are 3 irregular feeble costae, and several series of fine shallow obsolete punctures.

Eyes large, strongly transverse, not notehed in front. Anemae fili-

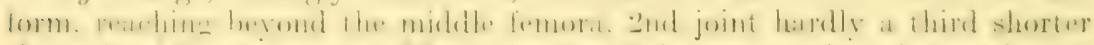

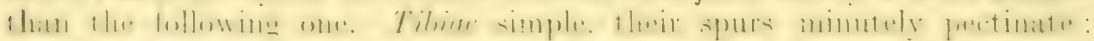

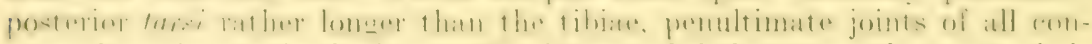
cave above but entire in front. Haxillary palpri elongate, subserrate, their terminal joint scarcely cultriform.

Underside fuscous and finely pubescent.

In coloration and elytral marks much resembling 4 . cuvelli, without the well-narked intrahumeral impressions of that species, which, moreover, is much smaller, with a shorter 2nd antennal joint and somewhat difierent sculpture.

Length, 3 lines; breadth, 3 line.

Wamarino. Found during January, 1909. Unique.

\section{Group ORDEMERIDAE.}

3114. Techmessa rugicollis sp. nov. Gen., Man. N.Z. Coleopt., p. 423.

Elongate, subdepressed, moderately shining; black, lecrs and palpi fuscous: head and thorax scantily clothed with slender, suberect, the ulytrit more closely with decumbent, asli-coloured pubescence.

II ored broader than thorax, much narrowed behind the large and promi-

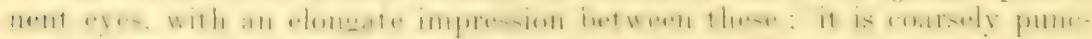
tured, but more fincly and very closely behind. Therax slightly broader than long, widest at or just before the middle, moderately rounded there but narrowed hehind; its surface with" small, slightly raised, smooth spots in front, and some irregular, almost smooth, linear spaces on the dise, which is much less closely punctured than the sides. Scutcllum closely and minutely punctate. Eilyerce nearly twiee the breadth of thorax at the base, subparallel, or only just perceptibly narrowed posteriorly; they are coarsely

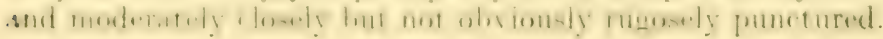


Antenuce stout, reaching to just beyond the intermediate femora ; 2nd joint evidently shorter than 3rd, which is only a third shorter than the 4th. Tarsi with the 3rd joint of the anterior pair rather short and triangular; 4th rather large, with short lobes; basal joint of the posterior elongate and slightly arched above; the claws with 2 distinct teeth.

The sculpture of the head is just the reverse of that of $T$. concolor, and that of the elytra is not "transversely confluently rugose," and the antennal structure differs. In $T$. attenuata there is a frontal median impression on the thorax of which there is no sign in $T$. rugicollis, but instead there are several distinct, though narrow, almost smooth lines which do not exist in the other two species alluded to.

Length, $3 \frac{1}{2}$ lines; breadth, $\frac{7}{8}$ line.

Waimarino. January, 1909. A single individual only.

3115. Techmessodes cephalotes sp. nov. Gen., Man. N.Z. Coleopt., p. 1173.

Elongate, depressed, with slender cinereous pubescence; variegate, moderately shining; head and elytra black, thorax yellow, legs pale-brown, tips of femora and basal portion of tibiae fusco-testaceous, antennae fusconiger but with the base of joints 4 to 11 pallid.

Head, including the large eyes, twice the breadth of the front of thorax, much narrowed behind, abruptly so in front, so that the epistome and labrum appear very small; it is distinctly but not closely punctured. Thorax relatively small, only about half the width of the elytra at the base, still narrower in front, slightly transverse, its sides moderately rounded at the middle; the surface moderately coarsely and irregularly punctured. Scutcllum blackish. Elytre elongate, very gradually and slightly widened behind; moderately coarsely, closely, and somewhat rugosely punctured.

Antennae filiform, extending backwards beyond the posterior femora; 2nd joint very short, hardly as long as broad; 3rd not quite the length of the 4th : in the female they just attain the hind thighs.

Undoubtedly allied to T. versiculw; ; in it, however, the scutellum is yellow, the antennae are less slender and only reach half-way down the elytra, the head is much narrower, and the eyes are smaller.

Underside shining, black, finely punctured and pubescent ; coxae pallid ; prosternum flavescent.

๙. Length, $2 \frac{1}{4}$ lines; breadth, $\frac{3}{4}$ line.

Waitakerei Range. December, 1908. Three specimens.

3116. Exocalopus nitidiceps sp. nor. Gen., Man. N.Z. Coleopt., p. 1170.

Depressed, with very scanty and slender ash-coloured pubescence; head and thorax intensely black and ylossy, elytra moderately shining black. palpi and antennae nigro-fuscous, legs fuscous, the knees paler.

Head much narrowed behind, and, including the large eyes, slightly broader than the thorax; it is closely and moderately finely punctate, the vertex, however, is almost impunctate and polished. Thorax strongly transrerse, base and apex subtruncate, its sides rounded and without definite angles; its surface uneven, there being a large irregularly shaped depression at each side, with the basal and inner borders nearly smooth and polished. and a small one near each posterior angle; the middle and sides are finely. yet distinctly punctured, but the front is nearly smooth. Scrlellum punctate. Elytra about double the width and six times the length of the 
thorax, nearly parallel-sided, not nurrowed posteriorly; closely, coursely. and slightly rumosely punctured.

Antennae pubescent, attaining nearly the middle of the elytra; basal

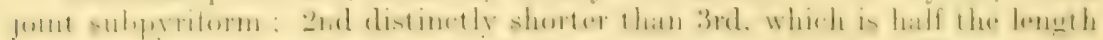
of the 4 th ; 5 - 10 gradually expanded so as to be subserrate. The epistome limited by a strongly curved groove, with sharp margins, between the antemnary orbits.

In the female of $E$. antemalis the vertex is broadly longitudinally impressed and punctate; the thorax is larger, with coarser punctures, and nowhere smooth; and the elytra are tinged with blue.

子. Length, 21 lines; breadth, $\frac{7}{8}$ line.

IV aimarino. January, 1909. I could only find a single specimen.

\section{Group S'CRAptidas.}

3117. Xylophilus xenarthrus sp. nov. Gen., Lacord., Hist. des Ins. Coleopt., tom. v, p. 584.

Sublong, slightly nitid, fusco-niger, legs pale brown; with very slender (inerous pubescence, which, on the elytra, is rather close.

IIead large, nearly twice the width of the thorax, very finely and indistinctly punctured. Eyes very large, subtruncate in front. Thorax of about equal length and breadth, the base moderately rounded and widest, its

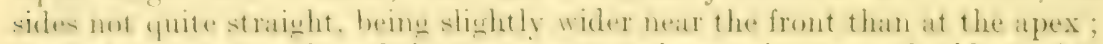
its surface uneven, there being a transverse impression at each side, and 2 shallow impressions near the middle of the batse. with a sliphthly raised linear

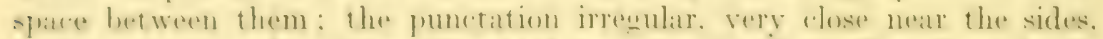

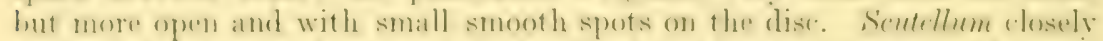
scolptured. Elyla ablong. nearly double the width of thorax, catch broadly obliquely depressed before the middle. moderately closely and more conarsely punctured than the thorax.

Antenue inserted on stalk-like prominences some distance from the front and inner margins of the eyes; basal joint large and thick, but narrowed towards the extremity; 2nd short, almost transverse; 3rd elongate, as long as the preceding two combined; $4-6$ clongate, yet each distinetly shorter than 3rd: the tith a litte expanded apically: ith and sth hosiely jointerl. mosmmetrical, the point of articulation being near the inner side, both of somewhat irregular form and transverse; 9th rather longer than broad; 10th ovate, larger than 9th.

This species represents a distinct genus, the remarkable antennae being sufficient for generic separation from its allies, but, as I could secure only a single damaged specimen, it is placed in $\mathbf{X}$ ylophilus at present.

Length, $\frac{7}{9}$ line; breadth, 3 line.

Raurimu. January, 1909.

\section{(Group OTORHYNCHIDA.}

3118. Platyomida caudata sp. nov. Gen., Man. N.\%. Coleopt., p. Hil (Eimparoles Pascoe).

Elongate, rather narrow, piceous, untennae and tarsi fusco-rufous: densely covered with small, flat, circular squamae of a pale-fawn colour: usually with metallic pink reflections; on the scutellum, the basal half of the sides of the elytrat and the middle of the porterior derdivity the scates are yellowish-grey, on the sides of the declivity there are pale-fuscous 
patches, on the femora there is usually a grey band; the decumbent setae are greyish or fawn-coloured.

Rostrum slightly shorter than thorax, moderately dilated apically, with a slight median carina extending to the middle of the eyes. Thorax cylindrical, of almost equal length and breadth, very slightly rounded laterally before the middle, base and apex truncate; a little uneven above, with a slight median ridge, its punctation hidden. Scutellum oblong. Elytra distinctly wider than thorax at the base, the shoulders not narrowed, they are gradually narrowed from the hind thighs to the dehiscent moderately prolonged apices; rather distantly seriate-punctate; the 3rd interstices slightly raised at the base. less so on the middle, but terminating on top of the posterior declivity in robust horizontal protuberances, jth slightly elevated behind.

Scape moderately stout, beuring greyish setae, and attaining the back of the eye. Funiculus sparsely hispid; basal 2 joints only moderately elongate and about equal; 3rd rather shorter ; 4-6 obconical, rather longer than broad; 7th slightly larger; club dull, infuscate, densely and finely pubescent, elongate-oval, triarticulate. Scrobes deep, quite open above in front, rather short, extending only half-way to the eyes, which are longitudinally oval. Ocular lobes obsolete. Tibiae flexuous, the anterior inwardly mucronate, the others expanded apically and minutely denticulate along the front face; posterior corbels with double ciliae, and a narrow truncate space outside.

Underside piceous, with greyish-yellow scales and setae. Prosternum subtruncate in front; mctasterum not longer than the basal ventral segment, with a foveiform impression behind; abdomen considerably narrowed posteriorly, finely punctate, 2nd segment shorter than 1st, both slightly flattened.

Fem. $-4 \frac{1}{4}$ by $1 \frac{3}{4}$ lines. The sides and apex of the elytra with fewer grey squamae.

This, owing to the abbreviated scrobes, should be placed near $P$. amota. It is, however, less uneven and asperate, the nodosities on the 3rd interstices behind the posterior femora are absent, those on the summit of the deciivity are not at all contiguous and less prolonged backwards, there are no tubercles on the 5th, and the shoulders are moderately prominent.

శ. Length (rostrum incl.), $3 \frac{3}{4}$ lines; breadth, $1 \frac{1}{4}$ lines.

Mount Quoin, Wellington. Found by Messrs. O'Connor and simmonds on Asteliae, at an elevation of about $3,900 \mathrm{ft}$.

Obs.-P. amota was described on p. 432 of the " New Zealand Journal of Science," 1883, and redescribed by Dr. Sharp as $P$. coronata in the "Transactions of the Royal Dublin Society," 1886.

\section{Platyomida humeralis sp. nov.}

Robust, piceous, densely covered with fawn-coloured squamae, of a somewhat metallic rufescent hue when alive; tarsi and antennae fuscorufous; the setae paler, quite grey on the legs; shoulders greyish.

Rostrum rather broad, subparallel, hardly at all dilated in front, the scrobes, nevertheless, quite open above near the apex, rather deep, and prolonged almost to the lower front of the eyes; there are 2 broad longitudinal impressions above, and a moderate carina between them; the punctation is hidden by the squamae. Thorax of nearly equal length and breadth, slightly wider before the middle than elsewhere, base and apex very slightly emarginate medially; the dise only slightly uneven, with a 
moderately broad mesial depression, its punctation apparently close but not coarse. Scutellum oviform, greyish-yellow. Elytra nearly twice the length but not twice the breadth of the thorax, the shoulders, however, are

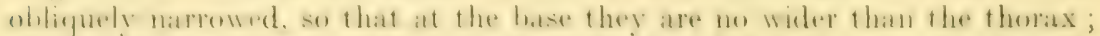

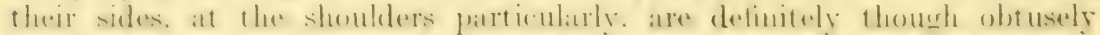
and only molerately elesited from the hatse to the hind thighe, they are narrowed towards the extremity but not produced or divergent there; the 3rd interstices are somewhat elevated at the base but not along the middle, and on top of the declivity on each there is a conspicuous nodiform elevation, there is a smaller one below; the 5th are somewhat interruptedly elevated behind, but not at all at the base, and the terminal elevation on each is longer but not as high as that on the $3 \mathrm{rd}$; at the suture, on a lower plane than the top of the declivity, there is a pair of elongate contiguous

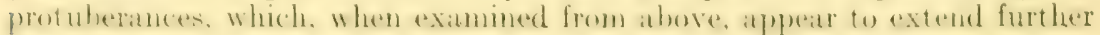
than the apices; the serial punctures are rather elongate, but not close to one another.

The broad rostrum, submarginated sides of the elytra, and the contiguous posterior projections are good differentiating characters. The serohes are as elongate as those of the trpical speries. P'. binules, but extend lower down. 'The antennae are stouter, the scape reaches the back of the eye; the basal 2 joints of the funiculus are equal in length; all the joints, however, are shorter and thicker. The thorax is without tuherenlar seulyture. The eyes are oblique, shorter longitudinally, and rather more prominent. The hind pairs of tibiae are not denticulated, as in $P$. caudata. The posterior corbels have double ciliae and a narrow external truncature.

Length (rostrum incl.), 5 lines; breadth, nearly 2 lines.

Mount Quoin. A single specimen, off an Astelia; elevation about 3,900 ft. Forwarded by Mr. O'Connor.

\section{Platyomida tibialis sp. nov.}

Piceo-niger. antennate fermeinous, leys rather darker : moderately shining. the squamate depressed. small and romded. for the most part of a greenishgrey: the setate scanty and of at tawny hue. but grevish on the lears, whith. however, also bear many small tawny scales.

Rostrum rather shorter than thorax, the median carina distinct, its pumetation lomeitudinally rugose. Thorar about a fourth longer than broad. subeylindrical. I roadly sulcate medially. punctate. hut only moderately

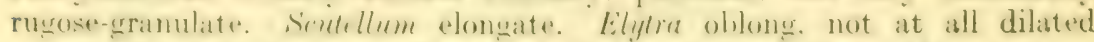
near the hind thighs. gradually natrowed posteriorly, with dentiform apices: dise moderately plane. the hind slope not alerupt: their series of punctures very distinct and regular, the 3rd interstices slightly elevated lout not at the base, strongly nodose behind, the 5th moderately.

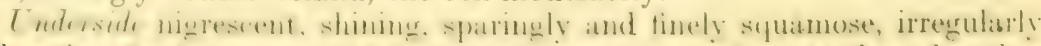

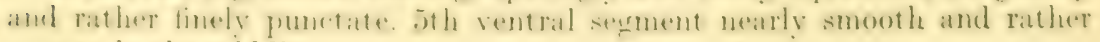
convex in the middle.

flifier- from l'. bimmles in heing natrower. rather Hatter, atud with at longer posterior slope. The thorax and scutellum are longer, the elytra

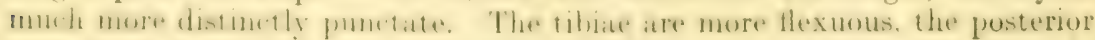
curved inwardly and more strongly produced at the inner extremity. it differs also in general appearance and vestiture.

Length (rostrum incl.), 5 lines; Ireadth. 13 lines.

IIaitakerei Runge. Unique. 
3121. Tigones philpotti sp. nov. Gen., Man. N.Z. Coleopt., p. 855.

Subopaque, moderately convex, covered with flat circular squamae of a pale-brown or cinereous hue, those on the sides of the thorax griseous; between the hind thighs a curved irregular fascia is formed of bluish-grey scales, and odd ones form specks on the dorsum ; the setae on the interstices are suberect, moderately fine, and somewhat testaceous; legs and antennae. obscure fusco-rufous.

Rostrum and head together of the same length as the thorax, the former broadly but feebly grooved and ridged longitudinally, the latter quite unimpressed. and with paler slightly flavescent scales. Thorax cylindric, of equal length and breadth, truncate in front, its sides only slightly rounded; apparently closely punctate; parallel with and near the apex there is a linear impression; along each side of the middle there is a sluallow impression, so that the middle appears to be obtusely ridged and rather darker than the rest of its surface. where the scales are of a faint coppery hue. Scutellum oblong, pale. Elytra oblong, nearly twice the width of the thorax, with simple apices; they are striate-punctate, the punctures not coarse and rather narrow, interstices plane, 3rd and 5th slightly broader than the others.

Legs covered with scales and setae; tibiae flexuous, inwardly mucronate at the extremity, the hind pairs denticulate along the inner face, the posterior corbels without any external truncature. The scape just reaches the thorax, and is very gradually thickened; the 2nd joint of the funiculus is more slender and rather shorter than the basal. joints 5-7 are moniliform: club elongate-oval, triarticulate.

Allied to $T$. antennalis. In it, however, the thorax is simple and the elytral apices acuminate. T. cervina has a slight median ridge on the thorax, the 5th elytral interstices are nodose, the apices divergent, and the club is oblong-oval.

Length (rostrum incl.), $2 \frac{3}{4}$ lines; breadth, 1 line.

Titahi Bay, Southland. Mr. A. Philpott. Unique.

\section{Lyperobates waterworthi sp. nov. (tenen., Man. N.Z. Coleopt., p. 1461.}

Suboblong, opaque, piceous, antennae and tarsi obscure castaneo-rufous ; densely covered with decumbent, elongate, tawny squamae, and some scattered setae, which are most conspicuous on the legs.

Rostrum and head combined of about the same length as the thorax, the former with 2 broad shallow grooves separated by an indistinct ridge, its sculpture indefinite, apparently rugose, it is densely squamose. Scrobes deep, somewhat sinuous, prolonged apically. Eyes prominent, longitudinally oval, widely separated above. Scripe slightly flexuous, setigerous; 2nd joint of funiculus moderately slender, longer than the basal one, joints 3-7 evidently longer than broad, about equal, all narrowed towards the base and bearing fine erect setae; club elongate, triarticulate, basal joint longest, slender at the base. 2nd subquadrate. the 3rd rather short and acuminate, the pubescence minute. Thorax as long as broad, widest before the middle, somewhat uneven above, with an ill-defined central ridge and $t$ depressions; no distinct punctures are visible, but there are a few shining black gianule; along the middle; the apex is truncate. Scutellum rather small. Elytra suboblong, widest behind the shoulders and in line with the top of the poiterior declivity; the shoulders obliquely narrowed, so that the base hirdly exceeds that of the thorax; they are on a rather higher plane than the thorax, but appear somewhat flattened ahove; on each there is an olituse 
hasal elevation, an obligne one extending from the side, before the middle, towards the suture: the area between this and the horizonital angular prominenee at the side of the nearly vertical declivity appears depressed; the disc is nearly truncate behind, hear's several slight inequalities, and the coarse serial punctures are hidden by the squamosity: the sides also are a little uneven, having a prominence behind the middle: the apex is obliquely narrowed.

Underside piceous, thickly syuamose, the 3 rd and th ventral segments more sparingly, but bearing coarse yellow setae. 'The herd glahrous, convex behind, but depressed between the eyes. Metustermm short, not foveate. Posterior corbcls with double ciliae, but only a narrow flattened surface.

When compared with $L$. asper, the type of the genus, this species is seen to latve more slender and elongate antennae, the rostral grooves are more shallow, the elytral dise is flatter, with less distinct and numerous nodiform inequalities, and without conspicuous setae on them; the squamosity; too. is less hair-like.

Length (rostrum incl.), $4 \frac{1}{2}$ lines; breadth, 2 lines.

Waitakerei Range. December, 1908. I found two amongst leaves on the ground. It is named in honour of Mr. A. Waterworth, of Northeote. who, thomeh not an entomologist. has freely rendered valuable services is the preduetion of miero-phutoeraphe for the illustration of my " Revision of the New Zealand Cossonidae" and of some other grenera of Coleoptera from the Auckland Islands.

\section{Lyperobates carinifer sp. nov.}

Opaque, nigrescent, covered with decumbent fusco-testaceous setiform scales and a few scattered greyish ones, antennae and tarsi fusco-rufous.

Rostrum and head together rather shorter than thorax; the rostrum with a slender shining black carina in front, and 2 broad shallow impres. sions behind. Scrobes normal, with apical prolongations. Thorax quite as long as it is broad, widest and obtusely prominent at the sides before the middle; uneven above, having 4 frontal and 2 post-median shallow im-

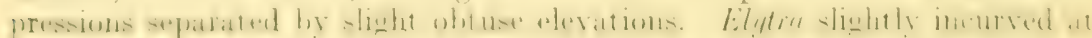
the base, and hardly any wider than the thorax there; shoulders obligue. just behind each of these an obtuse prommence extends as far ontwards as the horizontal one at the summit of the posterior declivity, and between these, at each side, there is a smaller nodosity; dise slightly flattened, yet

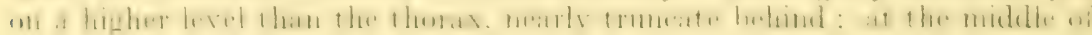
each. at the base, there is a nodiform elevation, and 2 others in line with it further back. the central one the smallest: hetween these and the side there are 2 more; the tip of the declivity is greysh; they are apparenty seriate-punctate; the declivity has some coarse punctures, it is not quite rertical. there are 2 or 3 modosities near each side of it. and the suture there is obtusely elevated.

This species is of more olongate ontline than $L$. "seper, with the elytral dise flatter and less asperate. It is more like $L$. virilis, which, however, is of a chocolate hue, with deeper rostral and thoracic impressions, and more outstanding humeral and posterior prominences, so that the sides of the elytra appear more deeply incurved; neither of these species has any distinct carina on the rostrum. The structure of the club in $L$. carinifer is

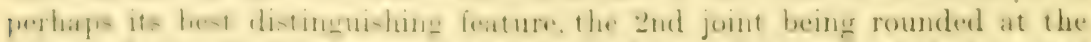
sule and thu- dintintly marked off from the hasal as wedl as the terminal 
one, whereas in the previously described species the club is simply elongateoval.

Length (rostrum incl.), $4 \frac{1}{2}$ lines; breadth, 2 lines.

Tarukenga. My specimen was taken on the high land near Rotorua.

\section{Lyperobates ardens sp. nov.}

Subopaque, rufo-piceous, legs and antennae fusco-rufous; densely covered with elongate flavescent squamae, which when touched with benzine resume their natural metallic and somewhat rufescent hue.

Rostrum with 2 broad grooves extending from the back of the eyes to the middle; it is of normal size. Thorax of about equal length and breadth, widest in line with the lateral protuberances near the front, its sides behind nearly straight yet slightly narrowed; dise uneven, with a rather sharply defined central ridge and near the middle a less-distinct transverse one. so that there seem to be 4 rather large cavities; the apex bears some coarse. erect, greyish setae. Elytra rather narrow and elongate, very uneven, with an interrupted oblique ridge on each extending from the post-humerab prominence to the suture; just in front of this a pair of nodiform elevations almost form another oblique ridge; at the middle of the base there is another nodosity; the prominences on top of the rounded posterior declivity are large and somewhat elevated at the sides; there are 2 smaller nodosities between these, which are greyish; all the other raised parts are more or less infuscate; some coarse, irregularly distributed punctures are visible.

This is the most brightly coloured member of the genus. It is differentiated by the more definite ridge and deeper impressions on the thorax. The elytra appear rather narrower than usual; the lateral prominences near the shoulders, the middle, and at the termination of the disc cause a muct interrupted outline; these last, being somewhat elevated, are in marked contrast to the broad horizontal protuberances of the other species. The superficial inequalities are all more strongly deve'oped. The eyes are subtruncate underneath. The funiculus is finely setose and shining red.

Length (rostrum incl.), 4 lines; breadth, $1 \frac{3}{8}$ lines.

Hunua Range, Auckland. Amongst leaves, on the ground. Unique, as yet.

3125. Hygrochus cordipennis sp. nov. Gen., Man. N.Z. Coleopt., p. 702.

Derm subopaque, piceous, legs dull rufo-castaneous, antennae rufescent. the funiculus shining, tarsi pale shining castaneous; clothed with smail depressed scales of a somewhat metallic coppery lustre, those on the sides of the thorax and in front of the scutellum yellowish; there are also many erect infuscate setae along the sides and apex of the elytra as well as on the legs and scape, but on the small posterior nodules they are grey.

Rostrum a third shorter than thorax, bi-impressed behind, obtusely carinate along the middle. Scrobes directed obliquely downwards clear of the eyes; these are very prominent and longitudinally oval. Club ovate, indistinctly quadriarticulate; joints 3 and 4 of the funiculus slightly longrer than broad, 5-7 moniliform. Thorax as long as broad, slightly wider before the middle than elsewhere, just a little uneven above, with a slight obtuse median ridge and a frontal impression near each side; there are no distinct granules or punctures. Scutellum small. Elytra subcordate, with obliqute humeral angles; the base, nevertheless, is rather wider than that of tho thorax, but is nearly double its breadth before the middle; their sides are a little uneven, yet without distinct prominences; the apex much 
narrowed; each elytron has 6 discoidal series of moderately liarge punctures; there are two small nodosities on top of the posterior declivity and a hasal one on the 3rd interstice.

In the type of this grenus the scrobes begin at the apex, are expanded

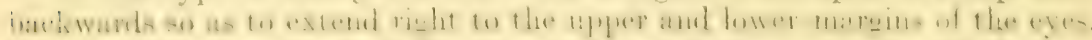

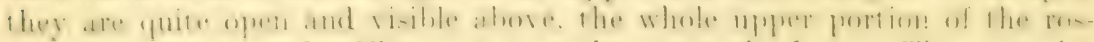
trum being narrowed. 'The eyes are subtruncate in front. 'The posterior corbels are concave, without any external truncate surface. There are no ocular lobes. 'This species, therefore, differs by the shape of the oves and scrobes, but in facies and other details accords exactly.

Length (rostrum incl.), $3 \frac{1}{8}$ lines; breadth, It lines.

Mount Te Aroha. A single individual, in my own collection. All the species are excessively rare.

3126. Catoptes constrictus sp. nov. Gen.. Man. N./. Coleopt., p. 428 ; and p. 4.13, Irenimus.

Convex, oblong, opaque, piceous ; covered with depressed fusco-griseous scales; elytra with decumbent, coarse, nearly white setae: tarsi and antonnao obscure fusco-rufous.

Rostrum parallel-sided, a third shorter than the thorax, about half the width of the short broad head, not carinate. Thorax of equal length and breadth. its anterior half broad and rounded, the basal much contracted and laterally compressed or broadly coneave below, the apex truncate: the surface uneven, but without well-marked elevations or depressions, and apparently impunctate. Elyfra very slightly wider than thorax at the base, somewhat bisinuate there, but without interstitial projections; their

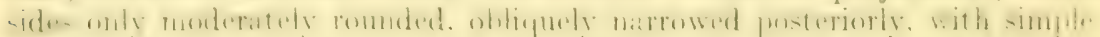
apices; they are striate-punctate, the sculpture, however, is rather shallow: the 3rd and 5 th interstices are very slightly elevated at the base, indistincty nodose on top of the posterior declivity, and with some fuscous squamie and setae there. their surface generally a little uneven but without definite tuliereles.

Legs elongate, with greyish scales and setae; libia flexuous, the anterior mucronate; posterior corbels rather flat, with a punctiform eavity for the tarsi, with single ciliae. Eyyes widely distant ahove, obliquely oval, free from the thorax. Ocular lobes moderately developed. Scutcllum invisible. Serobes subapical. quite open above. Hamdibular sear present. Prosternum deeply incurved in front: interior coxue contiguous.

Fim. in in lines. Less uneven above. Rostrum slightly carinate mediafly. Melusternum short. Basal rentral segment broad and truncate between the front of the widely separated posterior coxae; 2nd rather shorter than lst at the sides, hut a good deal medially rounded in front: these and the metasternum thickly covered with grey squamae and elongate whitish setae, many of which when cleaned with benzine become pink; 3rd and th short, with deep sutures; ith subtriangular, on a rather lower level than the preseding ones, with a well-marked elongated fovea behind.

We have no other species closely resembling this. The broad head and contracted basal portion of the thorax are good distinguishing characters.

3. Length (rostrum incl.), 23 lines; breadth, 1 line.

Titali Bay, Southland. A male and two damaged females found by Hr. A. Philpott. 
3127. Brachyolus sylvaticus sp. nov. Gen., Man. N.Z. Coleopt., p. 432.

Suboblong, covered with flat, rounded, greyish scales, but some dark ones form irregular spots behind; on the elytra there are depressed, elongate. sometimes slightly Havescent setae, but along the sides and on the more elevated parts these are more erect; the derm is nigrescent, the antennae and legs fusco-rufous.

Rostrum about a third shorter than the thorax, a little expanded in front, parallel behind, it is transversely convex, with a slight median carina, the apical portion bears slender setae only. Thorax about an eighth broader than long, widest betore the middle, its punctation hidden by the syuamae; it is somewhat meven. there being a broad shallow impression along the middle and one near each side, with obtuse intervening elevations, all, however, more or less ill defined. Scutellum invisible. Elytra about double the length of the thorax, the shoulders narrowed yet slightly wider than thorax at the base, the sides nearly straight, considerably contracted near the extremity, with slightly prolonged apices; the dorsum nearly plane, with only slight asperities; 3rd and 5th interstices only fcebly elevated, with horizontal nodosities, those of the former larger than the others and with fuscous squamae between them; the middle of the declivity is laterally compressed and prominent ; there are 2 series of moderately fine punctures along each side of the suture, 2 rather coarser series between the 3rd and 5 th interstices, and 2 nearer the sides.

Underside piceous, covered with greyish scales and elongate setae, the mesostemum with scales only. Prosternum deeply incurved in front. Metasternum but little longer than the 2nd ventral segment, 1st longer, both depressed but not concave, 5th reddish, rounded behind, closely and moderately finely punctured.

Var.-Hind-body unmistakably broader, more level, the squamosity more infuscate, but on the posterior declivity nearly white, with some dark spots there. Length (rostrum incl.), $2 \frac{5}{8}$ lines; breadth, $1 \frac{1}{4}$ lines.

The scrobes are deep, short, subapical, and open above. Eyes large, subdepressed, oblique, broadly oval, just free from thorax. Ocular lobes well developed. Corbels of posterior tibiae without any external flat area. Tibiae flexuous, mucronate. Tarsi with expanded and broadly bilobed penultimate joints. Secipe stout, very gradually thickened, just reibching front of thorax. Funiculus longer than scape, 1st and 2nd joints equally elongate ; 3-7 decrease in length, the last, however, as long as it is broad. ('hub elongate-oval, acuminate, triarticulate, but with an indistinct th joint.

The species, now numerous, referred to Catoptes, Inophloeus, and Brachyolus are not by any means clearly differentiated, so I have given the gencric characters of this species in full.

Length (rostum incl.), $2 \frac{1}{4}$ lines; breadth, $\frac{7}{8}$ line.

Waimarino. I took five specimens oft shrubs, all within a few feet, the variety included. It may be recognised by its rather long and nearly level elytral disc.

\section{Group Rhyparosomidae.}

3128. Phrynixus longulus sp. nov. Gen., Man. N.Z. Coleopt., p. 432.

Suboblong, rather elongate, convex, opaque; fusco-niger, antenuate and tarsi obscure fusco-rufous; unevenly clothed with rufescent or pale ferruginous depressed elongate squamae and curled squamiform setae, these latter concentrated so as to form elevated patches; behind the middle of the thorax round scales fill the punctures. 


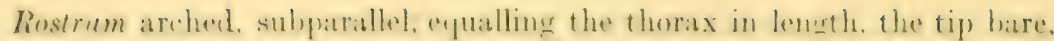
linely soulptured and rufo-piceous: it is forehly triearinate neat the antemnate and somewhat ridered hehind them. Thomer subohlones, apes slightly ineurved, with an clongate median basal depression, in front of which curled setae form a slight elongate crest : similat chate form an oblinue sories from each hind angle to near the middle of the apex, where they are more prominent; the punctation is coarse and rugose, hut almost lidden by the squamae. Elytra ovate-oblong, vertical behind, the base bisinuate, so that

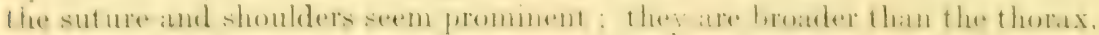
and their sides are not quite straight ; there are 2 basal crests between the suture and the sides, and in line with these 2 just behind the middle, and 2 more prominent tufts on top of the declivity; between this last pair the setae are concentrated in short lines; just lelow the summit there is another but widely distant pair with 6 series of short setale interposed; there is an elongate crest on each shoulder, and some smaller patches along the middle and sides; the sculpture is hidden, but seems to consist of series of oblong punctures, between some of which there are minute tubercles; the declivity is sulbstriate.

Legs elongate, bearing coarse curled setae. Scope flexuous, clavate at spox, with minute scales; 2nd joint of funiculus quite as long as the 1st, slender near the base, 3-6 transverse, 7th larger than the preceding one; chub ovate, finely pubescent, indistinctly triarticulate.

Underside dull black, the punctures covered with depressed, elongate, yellowish scales. Prostermum slightly emarginate in front. Hetasternum with its extremity truncate between the coxae. Basal central segment flat, rather larger than 2nd, their suture indistinct, oblique towards the sides; 5th medially concave and punctate, with concentrated setae at each side. This, doubtless, is the male.

This is one of a series of three nearly similar species; the others aro $P$. simplex and $P$. costirostris.

Length (rostrum incl.), $2 \frac{1}{8}$ lines; breadth, 3 line.

Var.-Elytra, along the middle, sparingly and finely squamose; the median pair of crests indistinet.

Raurimu and Waimarino. Four found during a week's collecting tour in January, 1909.

3129. Araeoscapus fasciculatus sp. nov. Gen., Ann. Mag. Nat. Hist., October, 1893.

Subovate, moderately convex, subopapue; fuscous, rostrum and an-

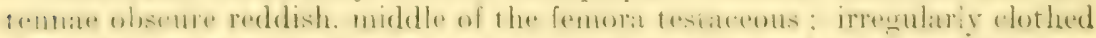
with yellowish stender scales or setale. which for the most prat are depressed. but hehind are curled and fasciculate.

Rostrum rather longer than thorax, strongly arched, its frontal half slightly broader than the basial, much bent, and moderately punctate; its hasal portion with 3 longitudinal lines of setare, so that the middle seems rislged. Scrape much bent at the bace, clavate at the extremity, and bearing minnte depressed setae; Ind joint of the funiculus more slender than 1st hut slightly longer, 3-6 transverse, 7th nearly twice the size of the 6th; lob indistinctly ammulate, narrowed towards the base. Eyges rather small and subrotundate, quite free from the thoracic maryin. Therex of equal fencth and breadth, its apex slinhtly ineurved, more narrowed in front than behind, base truncate; the surface ineven, with a large median basal depression. the punctures coarse, the setae along the middle, in front, and at the 
sides are suberect. Elytir just perceptibly wider than thorax at the bise, ovate-oblong, slightly uneven, with a large basal depression; there are 2 somewhat irregular series of punctures along each side of the suture, the punctures near the sides are more interrupted and intermingled with minute tubercles, they are striate behind; just in front and helow the top of the posterior declivity there are 2 nearly bare spaces; between these, right across the summit, there are 6 or 8 small patches of setae; a similar transverse series is placed lower down, but not sharply marked off from the irregular patches near the extremity; the setae on the disc are not evenly distributed.

Legs elongate, with depressed setae; femoru moderately dilated below: tibiae slightly mucronate and flexuous; tarsi short. basal 3 joints of equal width.

Underside opaque, fuscous, obsoletely punctate, with short setae. Prosternum deeply incurved in front. Hind coxrie widely separated, the inte:mediate moderately. Second ventral segnent medially depressed and strong!y curved in front, so that it is longer in the middle than the basal one; 3rd and 4th very short; 5th narrow, thickly alothed, between it and the terminal dorsal segment there is a very distinct broad lamina.

The suboblong elytra are very different from those of $A$. ovipennis, $A$. favipes, and A. ardens, all three being evidently broader at or before the middle, and considerably though gradually narrowed posteriorly. The setae on the tibiae are disposed in lines. A.thoracicus, and $A$. obscurus, so far' as the shape of the hind-body is roncened, more nearly approach A. fase culatus, which, notwithstanding its oblong elytra, is of the inale sex. The eyes, too, are invariably larger in the other species.

7. Length (rostrum incl.), 2 lines; breadth, $\frac{3}{4}$ line.

Waimarino. Two detected amongst leaves, on the ground, in Januarv. 1909.

\section{Araeoscapus mucronatus sp. nov.}

The female of this species is very much like the male of $A$. fasciculatus, but the rostrum has 2 slight rarina : the spare between these is subsulcato and covered with setae. The thorax is feebly bisinuate at the base. The elyta are rather broader hehind the posterion femora than they are in front. the hind slope is more abrupt, and the strice there are deeper. The thighs are more inflated; the tibiae bear suberect setae externally, and the imner extremity of the 2 hind pairs is acutely prolonged, the mucro of the posterior being longer than the basal tarsal joint.

In the male the rostrum is rather broader, the antennae are more robust. the scape reaches the middle of the eye, and the 4 hind tibiae are similarly obviously mucronate. This last character distinguishes this from all the other species.

Var.-A single specimen with indistinct discoidal punctation on the elytra, which are oblong-oval and rather longer.

Length (rostrum incl.), 2 lines; breadth, quite $\frac{3}{4}$ line.

Waimarino. January, 1909. One pair, amongst decaying leaves.

\section{Araeoscapus punctipennis sp. nov.}

Elongate, subovate, rather narrow, moderately convex, only slighth. nitid; fusco-rufous, legs obscure fusco-testaceous; scantily and irregulaply clothed with depressed and suberect flavescent setae. 
Rostrum as long as thorax, much arched. the portion in front of the antennae slightly broader than the basal, it is apparently smooth and shining; behind there are 3 shallow punctite grooves, and the same number of ill-defined carine, which do not extend to the base. Scupe inserted just. before the middle, bent near the hase, gradually incrassate, almost grabrous: 2nd joint of funiculus slightly longer than 1st, but more slender; joints 3-6 compact and transverse; Tth evidently larger, broader than the basal portion of the club, which is hroadest near the apex and indistinctly articulated there, it is densely pubescent. Thorax as long as broad, widest near the middle; base and apex subtruncite, with an irregular, elongate, median basal depression; it is elosely and coarsely punctured, with rugose intervals, the sculpture, however, becomes indistinct in front, the setire do not fill the punctures, the sides bear coarser setae. Eilylire of the same width as the thorax at the base, broadly rounded and widest at the middle, gradually yet considerably narrowed posteriorly, not at all vertical behind; there is

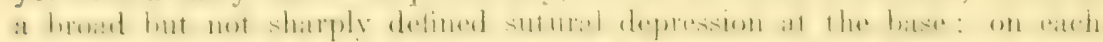
there are 3 discoidal series of well-marked punctures, 6 or 7 in each row ; the listeral sculpture is less recrular; on top of the hind slope there is an elongate nodiform elevation near each side of the suture, and 2 or 3 smaller ones in an oblique line towards the hind thigh; the declivity itself is not definitely striate, but has some small inequalities of surface; all these raised spots, in quite unrubbed and perfect specimens, are no doubt ornamented with curled yellow setae.

Legs elongate; the femora, beyond the middle, somewhat dilated above

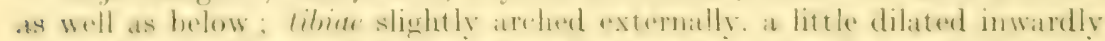
ahove the middle, minutely mucronate at the aluex: the lense are indistiretly setose.

Rather larger, less opaque, and more brightly coloured than A. ovipennis, near which it shomld he placed. The therate penetures are latere and deep. with rery narrow, irregularly rugers interstions. quite different from those of the typieal speries. The elytral punetures are more sharply marked and regular, and the pair of nodosities on the top of the hind slope are absent in that species, which, moreover, has larger basal depressions on the thomax and elytra, and the tibiae are straight externally.

Length (rostrum incl.), $2 \frac{1}{8}$ lines; breadth, $\frac{3}{4}$ line.

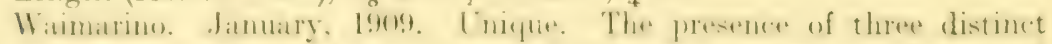
species in one locality leads me to helieve that several remain undiscovered in other parts of both Islands.

\section{Phyllodytes irregularis sp. nov. Gen., Man. N.\%. Coleopt., p. 1479.}

Elongate, moderately convex, shining; the pubescence scanty, decumbent, slender, and yellowish, the suberect setate pallid and less numerous: hody pale fuscous, femora fusco-testaceous, tibiae rither darker, tarsi fulvescent, funiculus reddish, the scape and club dark and opaque.

Restrum rather shorter than thorax, slightly narrowed medially, covered with slender setae, so that the punctation is concealed; the apex glabrous and nearly smooth. Thorax oblong, slightly rounded and broader before the middle than it is behind; it is irregularly punctured, very closely and roasely near the middle, with a central linear smooth space; near its widest part there are 2 elongate spots with some minute punctures, like those near the apex. Elyera elongate oblong-oval, a little wider than thorax at the base, incurved there, their sides zently rounded, at yood deal narrowed near the extremity; with a sutural dopression at the hatse, and moderately 
striate-punctate; the 2 sutural striae on each elytron are well marked, even more so on the declivity; interstices nearly impunctate.

Legs with a few grey setae. Antennae with similar setae; scape rather slender and very gradually thickened; 2nd joint of funiculus elongateobconical yet shorter than the basal one, 3-7 moniliform; club elongateoval, much narrowed towards the base, densely and finely pubescent.

Smaller and paler than the typical species (2558), and of similar cossonideous aspect. The antennae and legs are evidently more slender, the rostrum more narrowed towards the middle, the elytra more oviform and striate, and the thoracic sculpture is quite different.

Length (rostrum incl.), $1 \frac{5}{8}$ lines; breadth, $\frac{1}{2}$ line.

Waimarino. January, 1909. Unique.

Obs.-At the same time and place I found a varietal specimen of Sosyenes corinatus in which the rostrum is so constricted at the base as to appear halfsevered from the head.

\section{Group Molytidae.}

\section{Paedaretus rufulus sp. nov. Gen., Man. N.Z. Coleopt., p. 444.}

Subcylindric, narrowed anteriorly; subopaque, dark ferruginous, sparingly covered with erect yellowish setae, but without scales.

Rosirum quite half the length of thorax, a little narrowed behind the middle, medially trisulcate, bearing yellow setae along its sides and apex and 2 series above. Head immersed up to the eyes, globose underneath. Eyes lateral, obliquely oval, not prominent. Thorax of equal length and breadth, its sides moderately rounded, a good deal narrowed and almost constricted in front, base and apex truncate, apparently closely gramulose. punctate. Scutellum minute and narrow. Elytra rather broader than thorax and only a third longer, rounded and vertical behind; their striae are deep and regular, and appear to be formed by oblong, somewhat approximated punctures; interstices about as broad as the striae, and bearing series of setae.

Tibiae with strongly developed hooks, and acutely produced at the inner extremity. Scape very gradually incrassate, not quite attaining the eye, and bearing distinct setae in front. Funiculus elongate, basal joint largest, about double the length and breadth of the following one, 6th and 7 th broader than 5 th; club ovate, indistinctly annulate.

Underside punctate, with short yellow setae. Prostermum deeply emar. ginate in front; anterior coxae slightly yet distinctly separated. Basal ventral segment as long as the metasternum, subtruncate between the coxae; 2nd of similar length, its frontal suture sinuate.

Length (rostrum incl.), $1 \frac{3}{8}$ lines; breadth, $\frac{1}{2}$ line.

Tairua. Unique.

Obs.-Aldonida Broun and Paedaretus Pascoe were described simultaneously, but the latter was published first, and therefore must stand. Iy 901 becomes $P$. hispidus; 902 will stand as described above.

3134. Eiratus nitirostris sp. nov. Gen., Man. N.Z. Coleopt., p. 447.

Suboblong, subdepressed, opaque, with a few slender greyish hairs; rusco-piceous. lostrum slightly rufescent, tarsi and intennae piceo-rufous, club atrous.

Rostrum about as long as thorax, slightly arched, moderately stout, gradually and slightly narrowed behind, a little nitid, distinetly but not 
closely punctate. Mead shert, globose below, about double the width of the rostrum ahove, and with similar sculpture. Thorex of about equal length and hreadth, somewhat contracted, nearly impunctate, and of a dull reddish-coppery tint in front: with an indistinct median line, its punctation moderately coarse and close, the whole derm densely and minutely sculptured. Scutellum small, smooth. Elyfra slightly rounded individually and evidently broader than the thorax at the base, much narrowed behind; each has $f$ discoidal series of moderately close subquadrate punctures, which owing to the slightly raised interstices appear to form striae; the suture and 2nd interstices are rather broader than the others, and unite at the apex; the th are somewhat elevated and thickened just below the top of the declivity. hut do not reach the extremity; the 6th are slightly raised uear the base.

Undersidr nitid, fusco-piceous, moderately coarsely and closely punctured

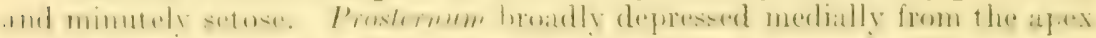
to the coxae, which are distinctly but not widely separated. Metastermum impressed behind.

Scape inserted midway between the middle and the apex, gradually incrassate, and barely reaching the eye. Funiculus 7 -articulate, basal joint largest, 2nd longer than broad, 3-6 become more transverse, 7th darker and nearly twice as broad as the preceding one. Club ovate, pubescent, indistimely articulated. nearly as long ats the funculus. Eygs just free from thoria. pliaced at wath side of the rostrum. somewhat flattened in frome

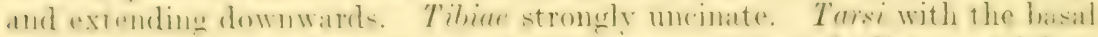

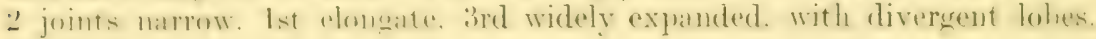
the terminal elongate.

Length (rostrum incl.), $1 \frac{1}{2}$ lines; breadth, 38 line.

Waitakerei Range.

\section{Group ('ylindrorhinidae.}

\section{Phaedropholus gen. nov.}

Body robust, oblong, moderately convex, densely covered with minuto sipuamate.

Rostmum rather shorter than thorax, considerably dilated, and incrassate

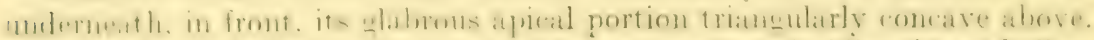

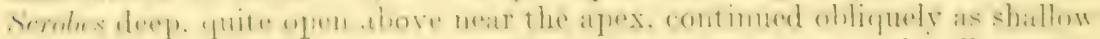
grooves nearly to the lower front of the eyes. Scape proportionally rather slender, attaining the front of the eye. Funiculus 7 -articulate, basal 2 joints moderately elongate. Club elongate-oval, triarticulate. Head gradually narrowed to width of rostrum. Eyes rather flat, slightly oblique, strongly. transwerse. truncate in front, distant from the thorax and each other. Thmoc subquadrate, hase and apex subtruncate, without ocular lobes. Senellum small, rotundate. Elytra oblong-oval, slightly hroader than thorax at the hase.

Lergs moderately alongate; frmora clavate; tibiar a little dilated hut unarmed at the oxtremity ; the posterior corbels without any external trum-

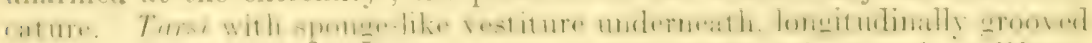
and bare along the middle, the basal 3 joints rather short and cordiform: their 3rd joint not at all expanded, with short lobes, the terminal distinctly shorter than the preceding 3 combined.

Prosternum incurved in front; anterim coxae prominent and contiguous. situated midway hetween the base and frontal emargination; intermedinte. 
coxte separated by the narrow cuneiform mesosternal process, the posterior widely separated. Metasternum short. Basal ventral segment in the middle evidently longer than the next one. or the metasternum, its hind suture a little sinuate; the 3rd and 4th together quite the length of the 2nd, with deep sutures: 5th as long as 2nd, truncate behind; 6th short but distinet. Epipleurae narrow. Buccal cavity closed. Palpi invisible.

Phacophanus, Anagotus, and Heteraomus possess ocular lobes, and therefore form a distinct section. In Sargon the posterior corbels have doable ciliae and a nitrow external truncature, the eyes are subrotundate, and the scape attains the back of the eye. In Pparchus the scrobes are oblicue and short, and the penultimate titrsal joint is deeply bilobed. In Phoxuteles the palpi are fully exposed, the scroles are short and directed to the lower surface, the eyes are placed near the thoracic margin, the bare 'lypeal portion of the rostrum is not perceptibly marked off, and, moreover, there are only 5 abdominal segments.

It has therefore been deemed expedient to establish this genus Phaedropholus for the systematic location of the only exponent at present known. Phoxoteles, in appearance, most nearly resembles it.

\section{Phaedropholus o'connori sp. nov.}

Derm dull fusco-niger, most discernible behind the eyes, and as a somewhat cruciform mark between the antennae; the mandibles, apex of rostrum, and numerous minute granules on the thorax and elytra are shining black; the squamosity is dense, minute, and depressed, mostly fuscoferruginous, on some parts slightly metallic, towards the posterior declivity and sides of the elytra the squamae become much paler, across the elytra there are 2 slightly infuscate much interrupted fasciae, and at each side of the declivity a darker space ; pallid scales form on the thorax a streak along the middle and one at each side, cover the scutellum, and border the inner side of the eyes; legs and tarsi similarly squamose and setigerous, the femora with a pale band.

Rostrum with a slight median carina, the apex and mandibles bear some elongate fulvescent setae; there is a narrow interocular impression. Thirax shightly dilated laterally before the middle; with a median ridge in front, and behind this a broad impression, which has obtusely raised borders towards its frontal portion; near each side, in front, a large flattened space is limited behind by a curvate ridge; these raised parts, and the sides, bear subdepressed setae; there is no visible punctation; the granules behind the middle are rather coarser and more numerous than elsewhere. Elytra slightly broader than thorax at the base, subtruncate there, not twice as broad at the middle, with slightly nodiform apices; on each elytron there are 6 discoidal series of comparatively small distant punctures, the outer series a little coarser, the 3rd and th end at the declivity, the sutural 2 become indistinct but substriate towards the apex; the 3rd interstices are only moderately and somewhat unevenly elevated, and a little nodiform behind the posterior femora and half-way down the declivity; the sth are nearly similar, but terminate at the dark subapical area, the suture is a little elevated behind; the sides of the dorsum are uneven, irregularly nodiform, and setose; on the basal portion, but not outside the 5th interstices, theres are series of minute granules.

Undersile shining, nigrescent; metastermum and basal 2 segments densely minutely squamose and setigerous, with granular sculpture; segments 3 to 5 with ferruginous setae, scanty on the middle, thick at the sides; 
Sth closely rugosely granulate, slightly raised hehind at each side" of the middle, with the setae rather more concentrated there; fith punctate; the Inasal segment broadly medially impressed. | $1 /$ : 8

Length (rostrum incl.), 10-11 lines; breadth, $3 \frac{1}{1}-1$ lines,

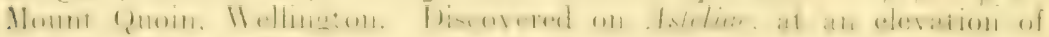
3.900 ft., by Ml. A. O'Connor, after whom this handsome species has been nitmed.

Gromp ERTRHINIDA.

3136. Xerostygnus, pullus sp. nov. Gen., Ann. Mag. Nat. Hist., July, 1903 .

Elongate, slightly convex, suhopaque, obscure mfo-piceous, tibiae and

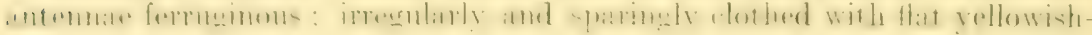
erey scales.

Rostrum moderately stout. parallel, punctate and indistinctly tricarinate hehind the antennae, with a short groove between these latter, slightly broader and finely punctate in front; it is almost nude. IIcad just the

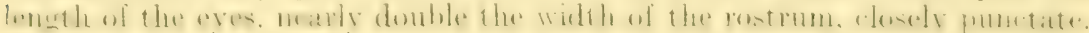
Thorax about a fifth broader than long, slightly constricted in front, its sides moderately rounded; it is distinctly and closely punctured, more finely and rlosely near the base, more sparingly and somewhat rufescent in front, with an almost smooth line on the middle, the squamae somewhat concentrated at the sides. Scutcllum convex, oviform, closely punctate.

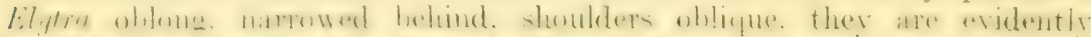

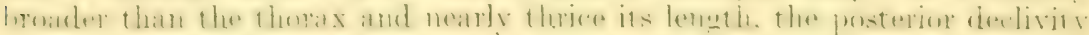
not at all abrupt; they are rather fincly punctate-striate; the interstices

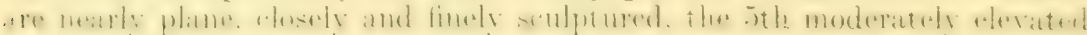
hehind and terminating abruptly near the extremity, but not definitely nodiform there.

Tibiae flexuous, mucronate, the lind pairs minutely calcurate at the outer extremity, more or less sparingly denticulate along the front or inner edge, and. like the femora. bearing decumbent setae. Scape moderately

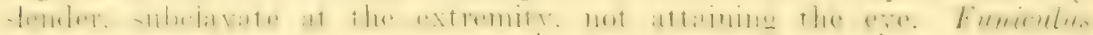
linely setose, basal joint longer than 2nd, both elongate-obconical, 4-6 amost as long as ther are broad, 7th slightly larger.

Underside like that of $\mathrm{I}$. binodulus; both males.

The persistent dense squamosity of the typical species, and the presence of distinct serial setate on the elytral interstices, distinguish it at a glance.

3. Length (rostrum incl.), 31 lines; breadth, 1 line.

IVamarino. January, 1909. My specimen was found on the swampy npen plain under a short hoard.

\section{Aneuma erubescens sp. nov. Gen., Man. N.Z. Coleopt., p. 455.}

Convex, nitid, red, elytra and leas rastanco-rufous, antennae fulvescent. rith opacue and densely pubesent; it is sparingly clothed with slender. subereet, yellowish pubescenco.

lenstrum moderately stout, arched, parallel, rather longer than thorax. fincly almost seriately punctate, but with very fow punctures along the middle. I/end more distinctly punctured. Scape inserted hefore the middle. it attains the front of the eye, very gradually and slightly incrassate. funiculus sparingly and finely setose, grey on the hasal joint, darker beyond 
it; Ist joint as long as the following 3 combined, thickened towards the extremity; 2nd and 3rd nearly equal, nearly twice as long as broad; 4 th and 5th subquadrate; 6th and 7th transverse. Club stout, ovate. Eyes rotundate. Thorax a third broader than long, rather narrower in front than behind, slightly curvate laterally, moderately coursely and closely punctured. Scutellum distinct. Elytra much broader than thorax, suboblong, base slightly biarcuate, evidently punctate-striate; the suture and interstices minutely seriate-punctate.

Femora minutely dentate; tibice straight, the anterior mucronate; tarsi densely clothed with fine grey setae. 3rd joint bilobed; clazos rather thick.

Underside shining, red, distinctly punctate, and finely pubescent. Prosternum emarginate-canaliculate, its angles subdentiform; the coxae contiguous. Metasternum medially grooved.

Length (rostrum excl.), $1 \frac{1}{8}$ lines; breadth, quite $\frac{1}{2}$ line.

Seven-mile Creek, near Greymouth. Mr. J. H. Lewis sent me a specimen of this easily recognised species.

3138. Etheophanus striatus sp. nov. Gen., Minn. N.Z. Coleopt., p. 1232.

Compact, convex, broad, subopaque, ferruginous; the elytra, just behind the middle, with dirk-fuscous spots almost forming an irregular interrupted fascia; on top of the posterior declivity there is a more continuous one, and there are other dark spots near the apices; the rostrum and thorax are more rufescent; the vestiture consists of pale-yellowish de"umbent setae, disposed transversely on the thorax. longitudinally on the wing-cases, and many outstanding fuscous setae.

Rostrum seriate-punctate and indefinitely grooved, with erect coarse fuscous setae and fine flavescent hairs. Eyes rather flat and coarsely granulated. Antennae inserted between the middle and the apex; 2nd joint of the funiculus smaller than the basal one, 3-7 almost equal, submoniliform and nearly transversal; club large, oblong-oval, not distinctly ammulate. Thror about as long as broad, the middle widest, more narrowed in front than behind, its punctation moderately close and distinct. Elytra hroad, subrotundate, depressed at the base, which is but little wider than the thorax; with shallow dorsal striae, which, however, become quite distinct and broad behind.

Legs long and robust, and bearing erect setae; tibiae with slender terminal hooks directed inwards; tursi thick, penultimate joints widely expanded and lobate.

This species has a differently formed and more strongly punctured thorax than the typical one (2171). striate elytra, a shorter rostrum. and different club.

Var.-..When denuded, the basal sculpture of the elytra appears finely seriate-punctate, the posterior punctate-striate. Sexual variation only. I believe.

Length (rostrum excl.), 1 line; breadth, $\frac{5}{8}$ line.

Waimarino. One pair, found by me in January, 1909.

\section{Group Cryptorhynchidae.}

3139. Zeacalles binodosus sp. nov. Gen., Ann. Mag. Nat. Hist., November, 1893.

Compact, subovate, much narrowed anteriorly, very convex, variegate, the derm slightly nitid, fusco-rufous; elytra with an elongate dark basal 


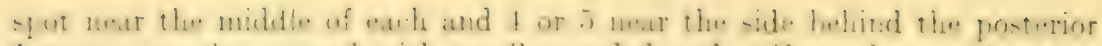

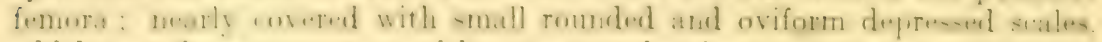
which are flavescent or grevish: "rrey scales form an almost continuous vitta near each side of the thorax and elvtrab, ending in a curvate prolongation towards the suture. in line with the hind thighs.

liustrum widely narrowed medially, deeply notched close to the eyes: basal half punctate and squamose, the frontal apparently impunctate, and bearing minute brassy setae. Thoras about as long is broad, slightly bisinuate ard widest at the hase, regularly and gradually narrowed anteriorly: without superficial inequalities, distinctly and closely punctured. Elyfer of the same width as thorax at the base, oviform, widest at or just before the middle. very convex. vertical behind; on each there are 3 rather irregular striae. and on top of the rounded posterior declivity a nodiform elevation covered with greyish erect elongated squamae; 2nd interstices just perceptibly thichened and elevated hefore the middle.

Leys with coarse setae. Tarsi with broadly expanded penultimate joints. Antemue medially inserted. Funiculus longer than the seape, its and joint slender and rather shorter than the basal one, 3-7 become shorter. 7th transverse. C'lub oblong-oval. its basal joint as large as the following 3 ; uswally it appears solid.

$Z$. le pilulus has nearly similar posterior nodosities, but in other respects is very different. The other described species are dissimilar.

Length (rostrum excl.). $\frac{7}{8}-1$ line; breadth, $\frac{1}{2}-\frac{5}{8}$ line.

Waimarino. I found two, amongst leaves on the ground. along with one of Z. exrius:

\section{(iroup) Cossonid.t.}

3140. Eucossonus antennalis sp. nov. Gen., Man. N.Z. Coleopt., p. 870.

Suldepressed, elongate, narrow; with distinct aureate setae disposed lengthways on the elytra but transversely or irregularly on the thorax and rostrum : opacue, darh fusco-rufous, antennae and tarsi much paler.

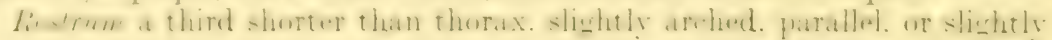
narrowed lehind, moderately but not deeply punctured, with minutely sculptured intervals. Thorax nearly twice as long as broad, deeply con-

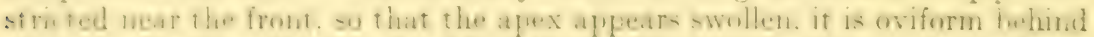

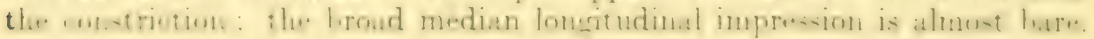
and not as deeply or closely punctured as the sides, the whole derm is minutely sculptured. Elytra slightly broader than thorax at the base. elongate. uradually contracted behind, their surface densely and minutely sculptured, so that the rather shallow punctate striac are rendered somewhat inderinite.

Leys elongate, the femoru especially: 3rd joint of the eursi cleft to the bases. with plongate lobes.

Antennae inserted at or just before the middle; scape robust, elongate. flexumus, and a rood deal thiskened towards the extremity; funiculus scantily puhescent: basal joint stouter but only slightly longer than 2nd. 3rd and fth rather longer than broad, atle submoniliform; club elongateovial.

Cinderside suboparque. nigro-fuscous, with very seanty fine pubescence. densely and minutely seulptured, and with coarse shallow punctures; the suture between the biasal '2 ventral segments distinct and sinuous, the frontal sutures of the 3rd and th deep and nearly as large as the segments. 
'This, the sixth species of the genus, is distinguished by the antennal structure and elongate tarsal lobes.

Length, $1 \frac{3}{4}$ lines; breadth, $\frac{3}{8}$ line.

Waimarino. January, 1909. One shaken out of a decaying Veronica; the other pair (damaged) from different trees.

\section{Eucossonus discalis sp. nov. Gen., Man. N.Z. Coleopt., 9. 870.}

Elongate, slender, subdepressed, slightly nitid; rostrum and thorax red, the latter rather dull, elytra infuscate, legs ferruginous. tarsi and antennae paler ; with conspicuous, but not coarse, yellow setae.

Rostrum a third shorter than the thorax, slightly dilated medially, shining, finely punctate, with a few very slender setae along its sides. Thorax with the oviform portion of about equal length and breadth, tho frontal constriction deep, the anterior portion much swollen and without perceptible punctation; the disc flat along the middle, nearly smooth there, but with some fine punctures; the setae, for the most part, disposed transversely, but absent along the middle. Elytra rather broader than the thorax at the base. moderately striate-punctate, interstices minutely scuiptured and rugose.

Antennae moderately stout; scape attaining the front of the thorax; 2nd joint of funiculus longer than the 1st. nearly twice the length of the 3rd; th and 5th moniliform. ( $M b$ large, elongate-oval, finely pubescent, with 2 indistinct apical joints.

The rather tine discoidal punctation, and the deeper frontal constriction of the thorax, more prominent eyes, and the less-definite elytral sculpture. distinguish this species from $E$. elegans.

Length, $1 \frac{1}{2}$ lines; breadti, $\frac{3}{8}$ line.

New River, Southland. I am indebted to Mr. A. Philpott, of Invercargill, for my specimen.

\section{Group Platypidae.}

3142. Platypus inimicus sp. nov. Gen., Man. N.Z. Coleopt., p. 539.

Cylindric, shiming, rufo-castaneous, the apical half of elytra piceo-fuscous : antennae and tarsi fulvescent. the leos rather darker; pubesence scanty. quite yellow.

Head subopaque, rather broader than thorax, with a fine central carina behind, and rather shallow elongate impressions which appear like punctures, and with some elongate hright-yellow hairs there: the forchead sloping, finely and distantly punctute, and with a small interantemal fovea. Eyes large, prominent, and suhrotundate. Antenno with thick. strongly outwardy curved hasal joints. 2nd rery slender at the hase. $3-5$ rery short and hroad. Club large, ovate, pubescent. Thorax nearly twice as long as broad, laterally excavate helind the middle. hase lisinuate and slightly medially angulate; the finely and densely punctured area in front of the base is indistinctly divided by a feehle groove: its punctation irregular, fine, and rather distant, most evident near the front. Elyger a little wider than, and double the length of, the thorax: moderatcly fincly striate-punctate, the sutural striae well marked throighent: 3rd interstices a little elevated and finely asperate near the base: the dopression ontside each of these is densely transversely strigose; the serial interstitial punctures are distant, fine, and sometimes absent: the declivity is thickly covered with yellow hairs. its external angles are slightly produced. hut the summit. though uneven. has no distinct projections. 
P. aracilis is the only near ally. Its head has different sculpture, the closely punctured space on the thorax is much narrower, the elytral striae are more distinct; in $P$. inimicus the striae beyond the $3 r d$ are represented by mere series of tine distant punctures.

Length, $2 \frac{1}{2}$ lines; breadth, $\frac{1}{2}$ line.

Raurimu. One, found during my collecting tour in January, 1909.

\section{Group ANтHRHBHa:}

3143. Anthribus anguliceps sp. nov. Gen., Man. N.\%. Coleopt., p. 545.

Suboblong, slightly nitid; fuscous, the sides and apex of thorax and the shoulders and posterior declivity paler; legs fusco-testaceous, the lower half of the tibiate fuscous; antennate pale brown, joints 3-6 and the chab rather darkier.

Rostrum rather longer than the head, a little dilated in front, slightly emarginate there, rather flat, longitudinally rugose, with some greyish hairs near the front of each eye. Scrobes just visible above, in front, their upper margins slender, medially incurved, hut forming a slight angle close to the eves. Head with irregular short rugae, so as to appear as if coarsely

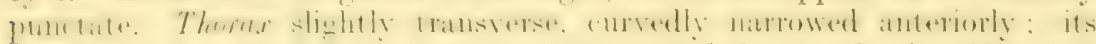
carina moderately distant from the base, rounded towards the sides, but not forming definite angles; the base narrowed and depressed, with an inconspicuous patch of grey hairs in the middle; dise with irregular rugae, nearly smenth in front. the sides with indistinet arey hatis. Elygur oblones. rather wider than thorax, not nodose or erested, but transversely impressed before the middle; they are striate-punctate, with seanty greyish pubescence. Pygidium short, vertical, flat behind.

Antemne inserted near the apex; basal 2 joints subpyriform and nearly

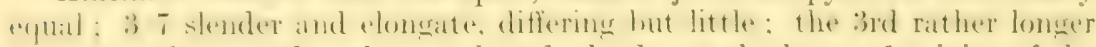
than the others; 8th as long as broad, slender at the base: 1st joint of the club triangular, 2nd nearly so, terminal ovate. Eyes entire, obliquely oval.

This small species must be placed near 961, A. brouni. The rostrum is relatively shorter and broader. The minute angulation close to each eye is a distinctive character. The sculpture of the head and thorax bears no resemblance to that of its allies.

Length (rostrum incl.), 1 line; breadth, quite $\frac{3}{8}$ line.

Parua forests, near Whangrei. Unique.

\section{Anthribus rugifer sp. nov.}

Head and thorax rufo-fuscons, the apex of the latter and the elytra oiscure fusco-testaceous, legs and antennae testaceous, the club only slightly infuscate.

Similar to A. anguliceps in structure and sculpture, but narrower. There are no grey spots near the eyes, which are rather smatler and less oblique. The elytri are unimpressed across the middle; they are narrower. much pater, and less distinctly punctured. The tibiae are immaculate.

Length, 1 line; breadth, nearly is line.

Woodhill, near Kisipara. Unique.

\section{Anthribus maurus sp), nov.}

Suboblong, convex, subopatgue, nigrescent; pubescence dark grey, hardly distinguishable from the derm itself; close to the front of each eye there is a minute grey speck, and amother on the seutellum; on the front of 
the thorax and the middle of the base there are some tawny setae : knees and tarsi dark red, the tibiae with a patch of fine grey setae above the middle ; antennae shining, ferruginous, the tips of joints 3-7 piceous; club opaque, finely pubescent, piceous.

Rostrum subquadrate, angularly emarginate in front; coarsely, closely, and rugosely punctate, as is the head. Thorax of equal length and breadth, gradually narrowed from behind the middle to the apex; the carina medially subtruncate, slightly sinuate towards the sides, bent forwards there but not angulate; its sculpture like that of the head; there are a few grey setae at the sides. Elytra oblong, a little wider than the thorax; on each there are 3 conspicuous nodosities or crests in line with the 3rd interstices-one basal, another behind the middle, the third on top of the declivity - these appear to be sooty-black, but the basal one has 2 grey specks, on the others a few crimson setae can be seen; outside the central one there are 2 slightly raised spots of the same sooty hue; they are seriately punctured. Pygidium subquadrate, flat behind, with depressed tawny setae, the apical margin, however, is bare.

In all structural details precisely similar to $966, \mathrm{~A}$. bullatus.

Length, $2 \frac{1}{8}$ lines; breadth, $\frac{7}{8}$ line.

Paparoa, near Howick.

\section{Anthribus suspectus sp. nov.}

Suboblong, subopaque, pubescence greyish ; coloration variable, usually piceous, posterior declivity greyish, legs pitchy or rufo-fuscous, tibiae with a grey spot above the middle, front and base of thorax with some tawny or fuscous setae, near each eye and on the scutellum there are grey specks.

Rostrum, head, and thorax coarsely, rugosely, and closely punctured. Elytra with irregular series of distinct punctures; each with 3 nodosities or crests, placed as in A. maurus.

I found five specimens of this species in different localities. The description of $A$. bullatus Sharp contains no allusion to sculpture beyond specifying the presence of 2 crests on each elytron. A. suspectus may be at once distinguished from that species by its trinodose elytra, and the entire absence of the conspicuous grey confluent patches which cover the greater portion of the rostrum. The generic characters are the same in both species.

Length, $1 \frac{3}{4}$ lines; breadth, $\frac{5}{8}$ line.

Hokianga, Parua, \&c.

Obs. - All my measurements of the Anthribidae include the rostrum.

\section{Group Cerambycidae.}

3147. Didymocantha cognata sp. nov. Gen., Man. N.Z. Coleopt., p. 568.

Elongate, subdepressed, shining, variegate, pubescent; head and thorax piceous; elytra fuscous, each with 3 large testaceous spots; antennae and femora ferruginous; tibiae and tarsi flavescent.

Head irregularly punctate, more finely behind than on the vertex, with numerous slender yellow hairs. Thorax of equal length and breadth, the lateral post-median tubercle acutely prominent; on the disc, behind the middle, there is an elongate smooth obtuse elevation, and near each side a flattened angular smooth space, before the middle a pair of distinct shining tubercles, and at each side, a little nearer the front, an indistiuct flattened tubercle; the pubescence on the middle is like that of the head, but at the sides is quite dusky; the punctation is moderately coarse and irregular. Scutellum triangular, medially impressed, testaceous. Elytra elongate, 
subparallel, broader than thorax, flat above, apices rounded and leaving the terminal segment uncovered; they are moderately coarsely but not seriately punctured. the punctures on the pale parts are rufescent, the shoulders moderately elevated; at the base, between the dark scutellar areib and the shoulder, there is a large testaceous spot which unites with a

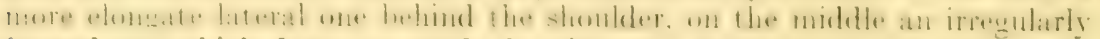
formed one which does not reach the side and is longest at the suture, the Brd is near the apex and is somewhat oblique: they bear numerous suberect yellowish setae.

Underside infuseate, with grey pubescence. Metosternum medially grooved and finely punctate.

Antennae with the ith joint shorter than the contiguous ones, the 10th joint attains the extromity of the elytra ; they bear distinet yellowish hairs, which become finer beyond the 5th joint: the terminal 2 are densely covered with fine pale pubescence.

Intermediate between $D$. picta and $D$. robusta, but not agreeing exactly with either.

Length, $6 \frac{1}{2}$ lines; breadth, $1 \frac{5}{6}$ lines.

Invercargill. Mr. A. Philpott.

\section{Group Laminda..}

Adriopea gen. nov.

Body elongate, narrow, moderately convex, finely pubescent. and, legs and antennae inclusive, bearing numerous erect slender setae.

Head vertical in front, concave between the raised antemnary orbits, the forehead incurved. Antennae stout, filiform, the terminal 2 joints reaching backwards beyond the body; basal joint elongate, subovate; 2nd short, 3rd rather longer than th, joints 5-11 nearly equal. Eyes reniform, with coarse facets. Thorux elongate-oval, with a small postmedian tubercle at each side. Scutellum large, curvilinearly triangular. Elytra rather wider that thorax at the bates. uratually narrowed posteriorly. apices simple.

Leys elongate; femora moderately dilated; libiae not emarginated, the posterior widely incurved.

Coxae, anterior and intermediate, globose and prominent, each with a narrow external lisiure. the posterior thick and extending to the epiplenrae. . Ill equatly distant from front to rear and moderately separated transversely. Metasternum not longer than the basal ventral segment at the sides; this segment triangular, and with raised margins between the coxae; $2-t$ derease in lemeth : ith lather longer, simple: the supplementary short and medially concave.

After comparing the type of this genus with many others, I see no other course than that of generic distinction. The antennal tubercles are more frominent than in l'orrillipe, hut the other chataters are entirely different. The form, barring the lateral thoracic tubercles. is more like that of Psilotronia, but there the resemblance ends.

\section{Adriopea pallidata sp. nov.}

T'estaceous, head castaneous, the thine with a dark hand above the middle; the elytra with in median transverse basal area dark fuscous, and a cordiform space of paler hrown, but interrupted by small pale spots, near the extremity; the tips of joints $3-10$ of the antennac slightly infuscate. The body is slightly nitid. 
Head finely and distantly punctate. Thorex longer than broad, with very distinct, moderately close, infuscate punctures, slightly uneven behind but without definite inequalities; it is very slightly tinged with red, and bears fine pale pubescence. which becomes closer at the sides. Elytra with pale pubescence and many erect setae; their punctures faintly rufescent, distinct, but not quite seriate, but finer and fewer towards the extremity; at the back of the dark basal space there is a pair of small rounded tubercles.

Breast rufo-testaceous; distinctly, regularly, hut not closely punctured. dbdomen fusco-testaceous, very finely and indistinctly punctate.

Length, 3 lines; breadth, $\frac{3}{4}$ line.

Waitakerei Range. March, 1909.

Obs.-When alive, my specimen appeared like ivory, its legs particularly. The terminal joints of the palni are acuminate. Its natural position is near Psilotrogia.

\section{Xylotoles gracilis sp. nov. Gen., Man. N.Z. Coleopt., p. 592.}

Slender, elongate, moderately transversely convex, slightly nitid; variegate, aeneo-fuscous, dark, base of femora and upper half of tibiae fuscotestaceous; the pubescence distinct, pallid, decumbent, and distributed unevenly, producing a somewhat spotted appearance on the elytra; antennae finely pubescent, basal joint infuscate, joints 2-11 fusco-testareous, the apex of the 3rd and about half of the following ones fuscous.

IIcad depressed between the antemne, with a well-marked median sulcus. Thorax cylindrical, its sides slightly rounded, quite a third longer than broad; densely and minutely sculptured, but without visible punctation, with a slender groove near and parallel with the basal as well as the apical margin. Scutellum large. Elytra elongate, of about the same width as the thorax, their sides slightly curved, with the apices separately strongly rounded; the sutural striae are distinct, and there are some scattered punctures before the middle.

Antennae filiform but stout; the 10th joint extends beyond the extremity of the elytra; the 3rd joint is elongate, being nearly a third longer than the 4 th; the following ones decrease in length.

We have no similar member of the genus. From all the others of nearly the same size this may be separated by the dusky colour, narrow contour, and elongate thorax.

Length, $1 \frac{7}{8}$ lines; breadth, $\frac{3}{8}$ line.

Titahi Bay, Southland. Mr. A. Philpott. Unique.

\section{Group Galerucidae.}

3150. Luperus cheesemani sp. nov. Gen., Man. N.Z. Coleopt., p. 631.

Elongate, rather narrow, shining bronzed, glabrous; legs and antennale fusco-testaceous, terminal joints of the latter and the femora darker.

Head uneven, smooth behind. Eyges oblique, longitudinally oval. Intemae finely pubescent, reaching backwards to the hind thighs: 2nd joint rather shorter than $3 \mathrm{rd}$, which is evidently shorter than the following ones. Thorax subquadrate, rather broader than long, base and apex truncate, lateral margins slightly rounded, anterior angles obtusely thickened so that there seems to be a slight sinuosity just behind each of them, the posterior nearly rectangular; its surface distinctly, somewhat irregularly, and moderately closely punctured, sometimes with a shallow longitudinal impression behind the middle. Scutellum nearly smooth, slightly violaceous. 
Elytra subpanallel, elongate, obviously brouder than thorax, the shoulders a little elevated, apices broadly rounded or subtruncate, so that the last dorsal segment is uncovered; their punctation evidently closer and rather finer than that of the thorax, and with numerous minute punctures interposed: they are very slightly impressed near the suture, and there seem a little rugose. Legs simple, pubescent.

Underside nigro-aeneous, finely sculptured, and pubescent. The 4th ventral segment is somewhat modially abbreviated; the 5th elongate, with a deep cuneiform impression, which is widest behind.

Fem.-Body rither broader, 5th segment conical and unimpressed.

Var. A.-Thorax subeyaneous.

Var. B.-Elytra of a reddish-coppery hue.

$L$. axyrochares most nearly resembles this species, which, however, is relatively narower, the elytra particularly; the thorax is more distinctly punctured, the eyes are more approximated, and the coloration is different.

3. Length, 13 lines; breadth, $\frac{5}{8}$ line.

Hount Cook. A good series found by Mr. T'. F. Cheeseman.

\section{Luperus obscurus sp. nov.}

Oblong, moderately convex, nudo above. shining, fuscous, legs and antennae fusco-testaceous.

llead nearly as broad as front of thorax. Antennae pubescent, stout,

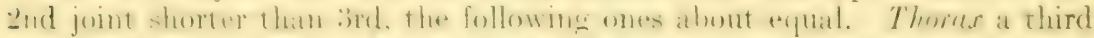

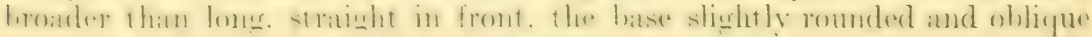
towards each side so that the posterior angles are not sharply defined, anterior angles slightly thickened but not prominent, lateral margins distinct, the sides a little rounded; its punctation verv irregular, distinct near the base and the middle, very much finer in front and between the middle and sides. Scutellum smooth. Elytra widely incurved at the base,

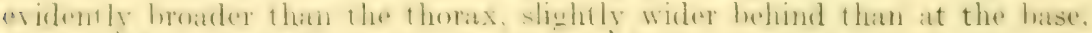

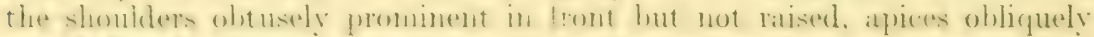

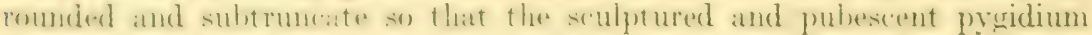
is exposed: they are irrenularly, distinetly. hut not very desely punctured. rather more distinetly near the extremity. Legs simple, pubescent.

This is obviously different from $L$. cheesemani, and, indeed, from any of our species.

Var.-Anterior angles of thorax not inerassate, elytra with less-prominent shoulders.

f. Length, 13 lines; breadth, is line.

Mount Cook. 'T'wo examples only. Mr. T'. F'. Cheeseman.

\section{Luperus diversus sp. nov.}

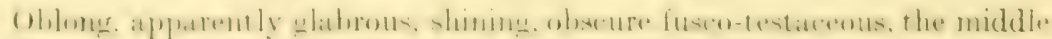
of thorax irregularly dark fuscous, a broad ill-defined vitta near each side of the elytra infuscate, as are also the last 6 antennal joints.

IIead, including the eyes, as broad as the front of the thorax. Antennae pubescent, their the joint not as long as the preceding '2 combined. Thorax broader than it is long, truncate in front, the base oblipuely rounded towards the sides so that its angles are ill defined though nearly rectangular, anterior angles not distinctly thickened, lateral margins fine and only a little rounded; the surface appears smooth, yet there are a few shallow punctures near the base and some minute distant ones in front. Elylra oblong.

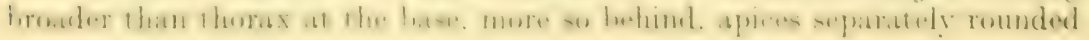


the pygidium visible at the suture only; their punctation distinct, mode. rately close and irregular, rather less evident near the sides and extremity. Legs simple, pubescent.

The thoracic and elytral sculpture are in marked contrast, the coloriation is somewhat indefinite, and there are no intrahumeral impressions, the shoulders not being at all raised. It should be located near L. uscurus. though quite distinct therefrom.

Length, $1 \frac{1}{2}$ lines; breadth, $\frac{5}{8}$ line.

Mount Cook. A single specimen, found by Mr. Cheeseman.

Note.-Luperus nigripes, 1111 (Nan. N.Z. Coleopt., p. 634), has been altered to L. fuscifroms, the former name having been used before in Europe.

\section{Group Chrysomelidae.}

3153. Chalcolampra speculifera sp. nov. Sharp, Trans. Ent. Soe., 1882, p. 73.

Oblongo-ovalis, sat convexa, testacea, elytris plagis magnis nitidissimis fusco-aeneis, antennarum basi fuscescente, pedibus geniculis nigris.

Long., $8 \mathrm{~mm}$. ; lat., $4 \mathrm{~mm}$.

Antennae slender and elongate, reaching half-way to the extremity of the wing-cases. Prothorax transverse, distinctly narrower than the elytra, the sides nearly straight, very finely and ovenly margined, the base unmargined, the front rather broadly margined, the surface rather finely and irregularly punctate. Scutcllum shining and impunctate. Elytra yellow, but each with 3 large and extremely highly polished spaces of a dusky brassy colour; one of these is situated near the scutellum, and is but little separated from its fellow of the other side; it is extended backwards along the suture, but is here less well defined and conspicuous till it joins the apical patch; this latter is very brilliant, and sends off externally towards the front a small prolongation, which nearly or quite unites with. the 3rd or lateral nirror; this is placed near but does not touch the side, and in front is prolonged as far as the shoulder; there is also a minute dark spot on the shoulder; the yellow portion of the wing-cases is rather coarsely and irregularly punctate; the apices are a little produced, and very distinctly truncate. The legs are yellow, with the knees broadly marked with black.

This remarkable insect is one of the most interesting of Mr. Helms's Greymouth captures, as it introduces us to a new feature in the New Zealand Coleoptera, and one which I had hitherto supposed to be quite wantingviz., the existence of true Chrysomelidae of Chapin's division Cycliques. The genus Chalcolampra is well represented in Australia, and has some species in Austro-Malasia.

Obs.-This description was inadvertently omitted in our lists, so that I made a mistake in describing a specimen found by Commander J. J. Walker, R.N., as Eualema walkeri.-T. B.

3154. Caccomolpus ornatus sp. nov. Gen., Man. N.Z. Coleopt., p. 1308.

Compact, convex, broadly oval, glabrous, glossy, variegate. is is

Head infuscate red, with a few fine punctures on the forehead; antennary orbits slightly and obtusely elevated; there are 2 interocular impressions. Eyes strongly transverse, large and prominent. Antennae dark rufo-testaceous, elongate, the terminal 5 joints with greyish pubescence; basal joint robust; 3rd distinctly longer than 2nd; joints $7-10$ thicker 


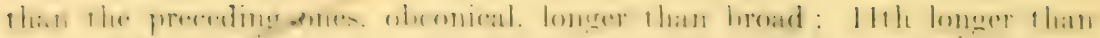
10th. Thorax rufo-fuscous, but becoming much paler near the sides; it is twice as broad as it is long, widest at the base. which is bisinuate, gradually narrowed anteriorly, with rather fine frontal and lateral margins; the punctation distinct, distant, and irregular, finer in front, obsolete or absent at the sides. Scutcllum oblong, smooth. Elytre with much of the dorsum testaceous, broadly infuscate along the middle; at the base nigro-fuscous.

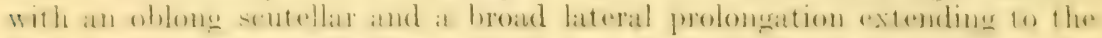
posterior femora equally dark; they are of about the same width as the thenas at the hase. Groader hehind it, a little romded and gradually narrowed posteriorly, with fine margins; their punctation fine, obsolete on sme parts. urot effaced at the apex. ome lateral series distimetly marked. the other series indefinite.

Legs ferruginous; the libiae, the hind pair particularly, widely dilated externally below the middle.

C. plagiaus Sharp, judging by its description, is undoubtedly the nearest species.

Length, $1 \frac{3}{4}$ lines; breadth, $1 \frac{1}{8}$ lines.

Waimarino. Notwithstanding. my exertions. I could not find more than one. amongst fallen leaves, on the ground.

\section{Group EROTYLIDAE.}

\section{Tritomidea rubripes Reitter.}

Elliptical, deep black, glossy, glabrous, obsoletely punctate, antennae and legs rufescent.

Allied to $T$. translucida Motsch., scatcely visibly punctured above. Head hrownish in front. Thoras twice as hroad as longe narrowed anteriorly.

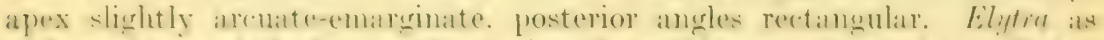
wide as thorax at the hase. widest hefore the middle. apex hownish. I' nderside almost smooth, hardly visibly punctured.

Length, 2.8-3 $\mathrm{mm}$.

Greymonth. Mr. R. Helms.

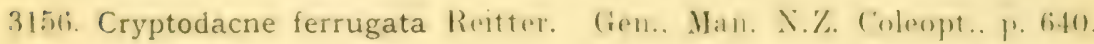
dilute.

Suboblong, convex, shining, almost glabrous; castaneous, legs slightly

Head smooth on the middle, strongly and closely punctured laterally. Theres nearly quadrate. net quite as long as hroad only slightle rounded

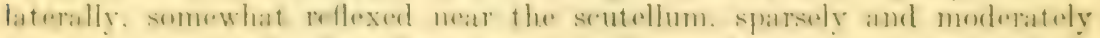
coarsely punctured. Scutellum smooth. Elytre elongate-oval, as broad as the thorax at the base; distantly and very finely seriate-punctate, interstices with punctures which are searcely smaller than those in the rows.

Antennae robust, with griseous hairs, with roundish joints, the first 2 of the chub slightly transverse.

Length, $4 \mathrm{~mm}$.

Greymouth. Mr. R. Helms. 


\title{
NEW ZEALAND INSTITUTE.
}

\author{
BULLETIN No. 1. (Pant 2.)
}

DESCRIPTIONS OF

\section{NEW GENERA AND SPECIES}

OF

\section{COLEOPTERA.}

(PART II.)

BY MA.TOR T. BROUN F.E.S.

\begin{abstract}
EDITED AND PUBLISHED UNDER THE AUTHORITY OF THE BOARD OF GOVERNORS OF THE INSTITUTE.
\end{abstract}

ISSUED 29th MAY, 1914.

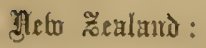

JOHN MACKAY GOVERNMENT PRINTER, WELLINGTON.

Wr. WESLeY AND SON, 28 ESSEX STREET, STRáid, LONDON W.C. 


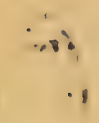

NEW \%EALAND INSTITUTE.

\section{BULLETINS.}

Under the title "Bulletins" the Board of Governors of the New \%ealand Institute hopes to issue, from time to time, paupers which for any reason it is deemed desirable not to include in the yearly volume of the Transactions. The bulletins will he uniform, in size and greneral style with the Transactions of the New Zealand Institute, hut will appear at irregular intervals, and each bulletin will ie complete in itself and be separately pagerl. The bulletuns will not be issued tree to members of the Institute, but may be obtained by them at a renluction on the published price. 


\title{
NEW ZEALAND INS'TTUTE.
}

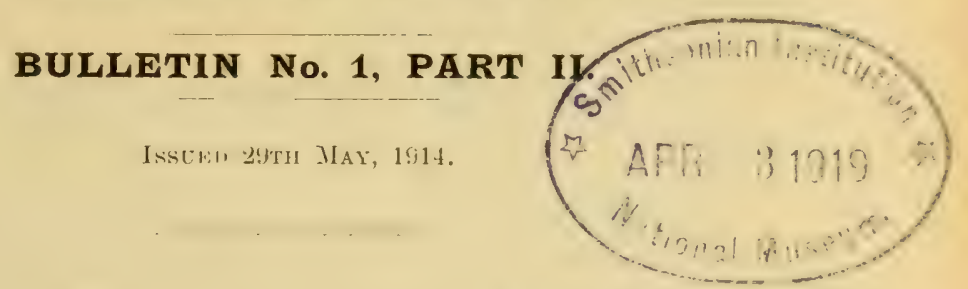

\author{
DESCRIPTION S \\ nF
}

\section{NEW GLNERA AND SPECILS OF COLEOP'LRA.}

\author{
By Major T. Broun, F.E.S.
}

\section{PART II.*}

$I_{N}$ this part there are descriptions of ten new genera and eighty-two species of New Zealand beetles. Rather more than half of the species were discovered amidst the mountainous regions of the South Island by Messrs. G. V. Hudson, A. Philpott, and J. H. Lewis; eight were found by $\mathrm{Mr}$. Hudson, and one by $\mathrm{Mr}^{\circ}$. A. O'Connor, near Wellington; nine were detected in a bagful of leaf-mould sent to me from the Great Barrier Island by Mr. F. Flynn; five were obtained on Mount Te Aroha by myself; and the remainder by Mr. W. J. Guinness and myself at different localities in the neighbourhood of Waimarino.

In order to avoid confusion, and to prevent the descriptions of many genera and species being overlooked, it is necessary to state that those numbered from 3157 to 3258 appeared in the "Transactions of the New Zealand Institute," vol. 44, and 3259 to 3360 in vol. 45. The names of the Byrrhidae, Nos. 3157-6.3 were included in the list of species published on page 380, vol. 44, "Transactions of the New Zealand Institute," but their descriptions appeared in Bulletin No. 2 of the New Zealand Institute, issued on the 30th August, 1910.

Section I of the following list consists of fifteen species of Faronini which were published in the "Annals and Magazine of Natural History" in October, 1911 (ser. 8, vol. 8, p. 488), and twelre species of Euplectini in ser. 8, vol. 8, p. 685 (December, 1911).

Section II contains the names of those which form the subject-matter of the present paper.

Section III is made up species that were describer, but not numbered, by Mr.J. H. Lewis in the "Transactions of the New Zealand Institute," vol. 34, p. 202.

Section IV denotes such new species as were described, but not numbered, in my "Revision of the New Zealand Cossonidne" ("Transactions of the New Zealand Institute," vol. 41, p. 151).

Mount Albert, Auckland.

13 th December. 1911.

* Part I of this series of papers on the New Zealand Coteoptera by Major Broun was issued as "Bulletin No. 1 " on the 30th August. 1910.-En. 


\section{I.IS'L OF NEW GENERA AND SPECIES.}

\section{SECTION I.}

Gromp Pselamidat.

33361. Sagula punoticepas Broun.

33ti2. " laticeps Broun.

3363. " angulifer Broun.

3364. .. nitida Broun.

3365 . " oognata Broun,

3366. . diverwa Broun.

$33137 . \quad$. latistriatil Broun.

3368. . basalis Broun.

3369. " longionllis Broun.

3370 . " punctionlis Broun.

3371. " auripila Broun.

3372. . orasicomis Broun.

3373. " guinnessi Broun.

3374. . oomnata Broun.

3375. " Iongipennis Broun.

3376. Eupleotopmis granulatus Broun.

$3377 . \quad . \quad$ fastigiatus Broun.

$3378 . \quad$. mueronellus Broun.

$3379 . \quad$ " tumidus Broun.

3380. Vidamus trochanteralis Broun.

3381. .. armiferus Broun.

33382. Zealandius raffrayi Broun.

3383. . illustris Broun.

3384. . fulgens Broun,

3385. Alloplectus picipennis Broun.

3386. . . Aubenecus Broun.

3387. Konocoelus dimorpluus Broun.

\section{SECTION TI.}

Group Cinacaxthidae.

3388. Mecorlema costipenne Broun.

\$389. .. angustulum Broun.

$3390 . \quad$.liswonum Broun.

Group Axehomentoa.

3391. Anchomenus libitus Broun.

Group Axisodictrlona.

3392. 'Tacunrthrus philpotti Broun.

Group di.ocharmat.

33913. Gy rophacna carinulata Broun. 33394. Aphytomo pictulus Broun.

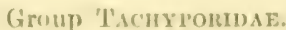

3395. Conurun nнperelluy Broun. 3396. . lactulus Broun.

\section{(iтич) ()Mat,II).}

33997. Omalium Longiceps Broun.

3398. . hilsтm Broun.

3399. ". Manguineum Broun.
Group Psimapindi:.

3Huo. Sagula clecta Broun.

3.401. Eupines nesobia Broun.

Group Pselaphixi.

3H12. Prelaphus pilifrous Brome.

\section{Gioup 'Iymix.}

Plesiotyrus gen. nov.

3403. Hamotulus fromtalis Broun.

\section{Group Corxidtoan.}

3404. Ulonotus philpotti Broun. 3405. Notoulus crassulus Broun. 3406. Heterargus subaequas Broun. 3407. Protarphius deenrus Broun.

\section{Group Pycxomeridas.}

3408. Pyenomeris arcuatua Broun.

3409 . . ocularius Broun.

\section{Group I.ATRIDIDAE.}

3410. Corticaria picicornis Broun.

\section{(iroup Mrcetormagida.}

3411. I'riphyllus constans Broun.

Group Histerman.

3412. Abracus phyllobius Broun.

Group Cokytormidat.

3413. Sacina lactans Broun.

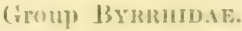

3414. Pedilophorus ormatus Broun.

3415. he humeralin Brom.

(iroup I, Ucasidate.

34lit. Linasen philpotti Broun.

(iroup Coprind:.

3417. Saphubius Inticollis Broun.

(iroup D.Ascradibat.

3418. Atupicla impressan Broun.

3419. Veronatus punetipennis Broun. 3420. Mfenoryphon eapito Broun. 3.421. .. ventitus Broun. 3422 . $\quad$ Iongicornia Broun. 3423. Cyphon deterius Broun. 
Group Cleridak.

3424. Phymatophaea soulptipennis Broun. 3425. ," fuscitaris Broun. 3426. ," breviclava Broun.

Group Melyridad.

3427. Dasytes laevulifrons Broun.

Group Helopidae.

3428. Adelium calcaratum Broun. 3429. , tinctum Broun.

Group Melandryidae.

3430. Axylita sericophora Broun.

3431. Allorchesia validipes Broun.

3432. Neorchesia divergens Broun.

3433. Mecorchesia spectabilis Broun.

3434. ", brevicornis Broun.

3435. Lyperocharis agilis Broun.

3436. Nothotelus ocularius Broun.

Group Anthromat.

3437. Anthicus flavitarsis Broun.

\section{Group Otiorhynchidae.}

3438. Platyomida verrucosa Broun. 3439. Aporolobus albosparsus Broun.

3440. Hygrochus scutellaris Broun.

\section{Group Rhyparosomidae.}

3441. Phrynixus rufiventris Broun.

3442. Sosgenes longicollis Broun.

3443. Bantiades suturalis Broun.

3444. " nodosus Broun.

3445. Araeoscapus brevicollis Broun.

Group Cylindrorhinidae.

3446. Tocris laevicostata Broun.

Group Molytidan.

3447. Lyperobius hudsoni Broun. 3448. Lyperopais alternans Broun.

Group HyLOBHDAE.

3449. Exeiratus setarius Broun. 3450. Geochus sulcatus Broun.

3451. morosus Broun.
Group Erirhinidae.

3452. Erirhinus pectoralis Broun.

Group Cryptorhynchidan.

3453. Aoalles flynni Broun.

3454. ," notoporhinus Broun.

3455. Xenacalles simplex Broun.

$3456 . \quad$ nodifer Broun.

3457. Scelodolichus flectipes Broun.

3458. Metacalles picatus Broun.

3459. Getacalles sparsus Broun.

3460. " fasciatus Broun.

3461. Atylodes foveiger Broun.

\section{Group Cossonidan.}

3462. Allaorus scutellaris Broun.

Group Anthribidae.

3463. Anthribus albiceps Broun.

3464. ., imitarius Broun.

Group Cerambycidat.

3465. Didymocantha hudsoni Broun.

Group Lamidde.

3466. Hybolasius eiliatus Broun.

3467. ", vittiger Broun.

Group Cryptocephalidae.

3468. Bryobates aeratus Broun.

3469 . " nigricans Broun.

\section{SECTION III.}

3470. Meoodema bullatum Lewis. 3471. ,, infimate Lewis.

3472. Lissotes acmenus Lewis.

\section{SEC'TION IV.}

3473. Stenotoura prolixa Broun.

3474. Eutassa fuscicollis Broun.

3475. Rhinanisus sulcirostris Broun.

3476. Macroscytalus crenatus Broun.

3477. Attarus tristis Broun.

3478. Agastegnus biimpressus Broun.

3479. Eucossonus rostralis Broun.

3480. Allaorus piciclava Broun.

3481. Pselactus ferrugineus Broun. 


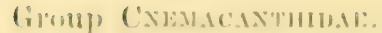

3388. Mecodema costipenne sp. Ins. Mecoleme Blitnchitrd, Matu. N.\%. Colcopt., p. 7.

Oblong, slightly convex, only moderately uitid, elytrat subopaque; nigrescent, legs, antennae, and palpi somewhat rufo-piceous.

Hearl, including the prominent eyes, almost as broad as the thorax, with numerous distinct punetures across it behind the eyes, vertex nearly smooth, its sides irregularly, the forehead longitudinally and deeply striate; labrom obtusely rounded and quadripunctate. Thoris nearly a third broader than long, widest near the front, gradually curvedly narrowed backwards, without any abrupt basal contraction, apex feebly incurved; its sides are not perceptibly crenulate, and the marwinal channels ale of about expal width throughout, but end just before the basal fossae, which are situated near the obtuse angles; there are some short, very lightly impressed, longitudinal striae near the front and base; the dise is nearly smooth, having only a few eurvate striae before the basal fossae; near the apex a shallow curved impression extends almost right across it; the median groove does not reach the frout or bise. Elytra oblong-oval, a little broarler than and twice the length of the thorax, broadly rounded at the extremity; each elytron is broadly and obviously tricostate, the suture also appears slightly raised, the additional lateral costa does not reach the shoulder, and all become obsolete towards the apex; the intervals between the costae have somewhat irregular, rather shallow, double series of punctures, the external, or 4 th, series of punctures are rather larger and deeper, yet not very coarse, and less distinctly duplicated, none attain the apex.

Legs moderately stout; the anterior and intermediate tibiae are only slightly, the posterior not at all, prominent at the outer angles. Antennate finely pulsescent beyond the the joint.

Underside shining, aluost smooth, with a pair of apical setigerous punctures at each side of the terminal ventral segment.

This species, owing to the conspicuously ribbed elytra, and almost regularly rounded siries of the thorax, is remarkably distinet. 14. rostellum, 2595, measures to mm. in length; its thorax is contracted and straight-sided at the base and the marginal channels are expander in front, the elytral costae are narrow, and the interstices are numerously and irregularly puncturerl.

․ Lenerth, 27 mom, ; brealleh, 9 1 mm.

liouteburn, lake Wakatipu. Deseribed from at damaged specimen found by Ifr. G. V. Hudson in February, 1911.

\section{Mecodema angustulum sp. nov.}

Elongate, moderately narrow, slightly convex, shining; black, tarsi, antennae, and palpi rufo-piceous, the labrum and femora more rufescent.

Head nearly as long lout hardly as broat as the thoritx, with prominent eyes; vertex nearly smooth, the sides irregularly, the forehead deeply Inngitudinally sulcate, finely transversely punctate behind the eyes; labrum subtemente, with 6 sutigurus punctures. Thurax apparently elougate, yet actually of equal length and breadth; its sides slightly cienulate, nearly straight towards the front, just perceptibly wider lehind the mirlde, narrowed hut not abruptly luhind, the base, lowever, has almost stribight sides, posterior ingles subrectangular, there 
are $n 0$ concave marginal channels, apex slightly but widely emarginate; the dorsal groove attains the short longitundinal striae, but not the apex, which is feebly rugose, and impressed near the angles only; the basal fossae are narrow and placed close to the sides; there are just a few slight linear impressions across its surface. Elytra twice the length of the thorax, rather broader, their sides gently curved but distinctly margined, the extremity strongly rounded; on each elytron there are 8 series of moderate, sometimes narrow and clongated punctures, which are continued, but become more confused, towards the apex; they are not connected by definite striae, and are not enlarged near the sides; the interstices are smooth and plane, and the usual smooth lateral area is not costiform.

Legs moderate; the intermediate tibae asperate, with obtusely prominent outer angles. Antennae sparingly pubescent from the 4th joint.

Underside shining. Flanks of prosternum distinctly punctate, the central line almost smooth, with a well-marked intercosal furrow. Abdomen more finely punctured near its sides, the terminal segment finely transversely strigose and bipunctate at each side of the extremity.

Nearly related to 1760 and 11 . nitidum, 2597, which perhaps is merely a loeal variety of the former, but differing from both by the finer sculpture; the thorax and middle of the head are almost smooth, the elytral punctures are seriate, rather narrow and fine, and the thoracic fossae are deep and narrow and extend to the basal maruin.

o. Length, $20 \mathrm{~mm}$.; breadth, $6 \mathrm{~mm}$.

Mount Arthur. Found by Mr. G. V. Hudson in February, 1911, at an altitude of $4,000 \mathrm{ft}$.

\section{Mecodema dissonum sp. nov.}

Elongate, medially narrowed, subdepressed; glossy black, slightly bronzed, legs, antennae, and palpi piceo-rufous, these last with fulvereent tips.

Head elongate, not quite as broad as the thorax, distinctly punctate in line with the back of the prominent eyes, its sides rather deeply and irregularly striate, the vertex with shallow transversal impressions, the forehear deeply longitudinally sulcate, and with a pair of setigerous punctures; labrum subtruncate, with a median groove, its apex sexpunctate. Thorax cordate, somewhat incurved in front, its margins a little flattened, without channels, and only obsoletely erenulate; it is only a trifle broader than long, its sides are gently rounded to behind the middle, and a good deal sinuously, though not abruptly, narrowed towards the almost rectangular posterior angles; disc nearly flat, very faintly transversely striate, the large elongate basal fossae, however, have short undulating striae, the frontal punctation is like that of the occiput but does not extend to the angles, near each of these there is a shallow depression, the basal seulpture is much less definite, the dorsal g'roove does not reach the base or apex, near each side before the middle there is a punctiform forea. Elytra more than double the length of the thorax, about a sixth broader than it is at the middle, their sides evenly and slightly curved, so that the extremity is nearly as wide as the base; along the middle of each elytron there is a pair of rather broad, indistinctly raised costae, another, nearer the side, is more or less interrupted; between these, and also alongside the broad suture, there are somewhat irregular double series of moderately fine punctures, 
the whole apical seupture is irregular, the marginal pusctation is hardly at all coarser than the dorsal, and the common smootl, lateral spatec does not reach the shoulder.

Antennat pubescent from the 4 th joint onwards. Legs moderately slender: intermediate tibiac asperate, and with slightly prominent outer angles.

Underside shining; its sides, as lin as the 2nd rentral senguent, are punctate, the prosternum most distinctly; the head is feebly seulptured, but behind the mentum has a pair of well-marked setigerous punctures; the last rentral segment is finely transversely striate and bipunctate at ench side of the apex.

Ne possess no similarly seulptured species. On the right elrtron the inmer costa is triforente, but on the other is entire.

l.ength, $20 \mathrm{~mm}$.; breadth, $6 \mathrm{~mm}$.

Ilump Ridge, Okaka, Southland. I am indebted to Mr. Alfred Philpott for the anly specinen, which he found, on the 28th December, 1910 , at a height of $3,500 \mathrm{ft}$.

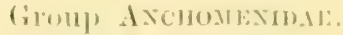

3391. Anchomenus libitus sp. nov. Anchomenus Bonelli, Iisn. X.\%. Coleopt., p. 20.

Oblong, rather slender, slightly convex, moderately nitid; fusconiger, lateral nurgins and channels castaneous; antennae, legs, and trochanters testaceous, tarsi and palpi a little more rufescent; mandibles and labrum piceo-rufous.

Head smooth, bipunctate alongside each of the prominent eyes, frontal impressions elongate; labrum deeply incurred. Thorax of almost equal length and breadth, widest just before the middle, more, yet hardly sinuously, narrowed behind than in front, posterior angles rectangular but not acute, base and apex subtruncate; lateral margins distinct and slightly reflexed, the channels moderately concare; dise a little convex, feebly transversely striate, the median groore fine and attaining both base and apex, near the front there is a well-marked impression at each side of the middle; basal fossate large and deep, with shallow anterior prolongations. Elytra oblong-oval, neary thrice the length and double the breadth of the thorax, gradually ret considerably narrowed towards the hase, their apices rounded, the posterior contraction oblique but hardly pereeptibly sinuate; they are only slightly ennvex, with fine, aluost impunctate striac and distinct scutellar striolate; interstices nearly quite plane, the 3rd tripunctate. Farsi elongate, the basal joint of the anterior and all but the terminal of the others bisculcate, 2 nd joint of the anterior oblong. 3rd and the cordiform. Terminal rentral semment, at the apex, with a single setigerous puncture at each side of the middle.

1. sopheronitis. 26(is. also form Southlame, is mope robust, with posteriorly simuate-andustate elytra, and, irrespective of coloration, may be reconnized by the envex bieurate vertex just before the eves, so that it is distinctly marked off from the depresised frontal portion of the hend.

o. Length, 10 mm, mealth, $3 \frac{1}{2} \mathrm{~mm}$.

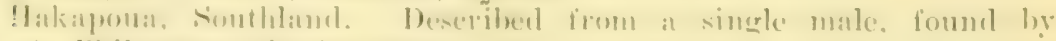
Mr. I. Philpott on the lst Wareh, 1911. 


\section{Group Anisodactritdat.}

\section{Taenarthrus gen. nov,}

Body apterous, subdepressed, and glabrous.

Mentum large, subquadrate, medially bifid and bisetose in front; lateral lobes divergent and dentiform at the extremity. Palpi elongate and filiform; basal joint of the maxillary short, 2nd somewhat curvate, thicker and longer than the next, which is a little shorter than the terminal; 2nd joint of the labial bisetose, the 3rd, like the 4 th of the maxillary, obtuse at the apex. Mandibles moderately elongate, curved and acute at the extremity, broad and deeply coneave at the base, with a single seta in the scrobe. Antennae filiform, reaching backwards to the shoulders, densely pubescent from the 5th joint onwards, the basal four glabrous; 1st joint cylindrical, as long as the 3rd but thicker, 2nd twice as long as broad, 4th rather shorter than contiguous ones. Eyes prominent.

Legs elongate, the hind pair longer and more slender than the others, femora simple, tibiae with numerous spiniform setae, the front pair thickest and emarginate at the inside. Tarsi setigerous at the sides, the anterior with sponge-like vestiture underneath the dilated basal three joints, which are cordiform, the 2nd slightly broader than the 1st, 4th narrow, deeply excavate in front, with its inner lobe distinctly more prominent than the outer; the intermediate pair with triangular articulations, the basal nearly as long as the 5th, the basal three with more or less spongy soles, the outer angle of the 4th prolonged; the posterior pair elongate and more slender, the outer angle of the penultimate joint rather more prolonged than that of the middle pair; claws simple.

Head about as long as the thorax but not quite as broad. Labrum transverse, feebly emarginate, with 6 setigerous punctures. Forehead subtrunctate and distinctly limited, with a pair of frontal setigerous punctures. Thorax without marginal setae, quadrate-cordate, its apex subtrunctate but with somewhat prominent angles; the base widely but not deeply incurved so that its angles appear to be directed backwards. Scutellum rounded behind. Elytra ample, slightly wider than thorax at the base, thrice its length nearly, curvedly narrowed but not at all sinuate behind, with obtusely rounded apices, which, however, do not cover the terminal abdominal segment.

The type of this genus is quite unlike that of any other in New Zealand, and I fail to find any similar form amongst my European or exotic Carabidae. The peculiar lobe-like prolongation of the penultimate joints of the tarsi, as well as the structure and vestiture of the antennae, are almost identical with those of Chaudoir's genus Loxomerus from our subantaretic islands, but in Taenarthrus the mentum is bificl, the mandibles near the base are more expanded and broadly concave with raised lateral margins, the thorax is different, its posterior angles paticularly, and the prgidium is uxposed. Notwitlostanding these disparities, I consider Loxomerus the nearest ally.

\section{Taenarthrus philpotti sp. nov.}

Shining, nigrescent; antennac, palpi, and tarsi picen-rufous.

Head nearly smooth, without definite impressions; a distinct lateral plica extends from the forehead to the eye, and alongside the eye there is a narrow groove, with a setigerous puncture near its terminal portion. Thorax nearly plane, with well-developed, somewhat reflexed, lateral margins and moderately broad channels; its sides are 
moderately romuded, and widest, before the middle, sinuated and nardowed behind, but almost straight towards the subacute posterior angles; the basal fossac are large, they extend nearly to the sides and are sparingly and minutely punctured, the mesial groove is slender and ends in a broad shallow impression before the base; its breadth hardly exceeds the length. Elvtra obloner-oval, subdepressed, widest near the hind thighs, but not obviously so, gently narrowed towards the base; the lateral margins are rery distinct and slightly reflexed near the shoulders but beene quite thin towards the apices, the marginal channels are only obsoletely seulptured; each elytron has 7 rather fine, minutely or indistinetly, punctured dorsal striate and plane inpunctite interstices, but there are no subapical carinae. Intermediate tibine slightly asperate, and fringed with lieghtereruginous sctac extermally below the midlle; the posterior sparingly hispid.

s. longth, $16 \mathrm{~mm}$. ; breatth, $5 \frac{1}{2} \mathrm{~mm}$.

Hump Rirlge, Southland. A single individual was secured, at an eleration of about 3,500 ft., in December, 1910, by Mr. A. Philpott, in whose honour this renarkible species has been named.

\section{Gromp, ALEOCHALIDAL.}

33933. Gyrophaena carinulata sp. nov. Gyrophueme Mammerheim, Man. N.Z. Coleopt., p. 87.

Lilungate-oblong, slimbly convex, shining; the head, thorax, lews, and antennate nore or less jiceo-lufous, elytra eastaneo-rufous, abdonen fuseo-piceous; pubescenee slender but distinet, subereet, of an ashy huc.

Head large, ret not yuite as broad as the thorax, finely punctate towards the eres, smooth along the middle. Thorax not twice as broal as long, the base rounded, with indefinite angles, its seulpture like that of the head. Elytrat of about the same width as the thorax, their apices oblique towads the suture, and the base somewhat incurred, so that in the midlle they are no longer than the thorax; they have well-marked sutural striae, but the muctation is rery fine and distant. Abdomen with its fire risible sements fincly punctate, ats broad as the elytrat, and double their length, the teminal segments retracted; 3rd and fth rather longer than the others, the 2nd at the base has about 8 longitudinal, rather short carrinate, the ord and th have al smaller number of less distinct ones.

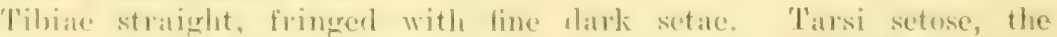
anteriog quadriarticulate, the others pentamerous. Maxillary palpi moderately long. The terminal joint acicular and distinct, the penultimate piceous, large, clongate-oval; the znd hut little shorter, arehed externally.

Antemate rather short, inserted near the front and inner part of the eyes; hatsal joint slightly thicker lout hardly longer than the oriform

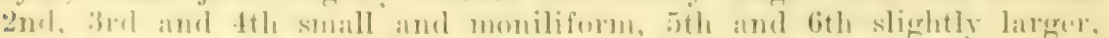
7-10 gradually expanded, 8-10 quite transrersal, 11th rather small and mot distinctly separaterl from the brouder renultimate.

There can be no great difliculty in identifying this species. The tesminal antennal joint and the transrerse sories of short earinate on the end ablomimal segment are distinetive.

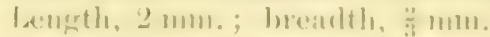

'Tishury, Invercangill. My specimen is me of Mr. A. Philpott's captures. 
Ohs.-Although several species belonging to this genus, and the allied Oligota, Leptoglossa, and Polylobus, occur in New Zealand, and have had specific names attached to them loy M. A. Fauvel, of Caen, no descriptions, so far as can be ascertained, have been published as yet.

3394. Aphytopus pictulus sp. nov. Aphytopus Sharp, Man. N.Z. Coleopt., p. 1024.

Elongate, moderately nitid; pubescence yellowish-grey, distinet, not very elongate, recumbent, thicker on the thorax and elytra than on the abdomen, the head nearly glabrous; head, thorax, and base of elytral pale rufo-castaneous, remainder of these last fuscous, basal segments of abdomen fulvescent, $3 r$ d to 5th piceous, the legs and basal two joints of the antennae testaceous, the following ones infuscate.

Head, including the large eyes, broader than the front of thorax, moderately narrowed backwards, neither closely nor very distinctly: punctured, the vertex very smooth. Thorax half the length of the elytra, broadest and slightly rounded at the base, the sides finely margined and nearly straight but curvedly narrowed anteriorly; moderately finely ret distinctly but not elosely punctate, without dorsal impressions. Elytra oblong, broader than thorax at the base, curvedly narrowed near the apices, which are oblique towards the suture; their punctation a little irregular, nowhere coarse, rather finer behind. Abdomen longer than the elytra, not as broad as they are, with fine, rather distant, granular sculpture.

Antennae rather longer than the head and thorax; 2nd joint elongate, quite as long as the 1 st but rather more slenter; joints $3-8$ almost alike, all longer than broad; 9 th and 10th moderately dilated, subquadrate and, together, rather longer than the elongate-conical terminal joint, these more distinctly pubescent than the preceding ones. Tibiae straight and, like the tarsi, distinctly pubescent.

Underside testaceous, but with the abdomen fuscous from the 2 nd segment backwards.

Allied to A. porosus, 3182, but more obviously variegated, with the thorax rather shorter and more narrowed anteriorly, differently formed and longer antennae, \&c.

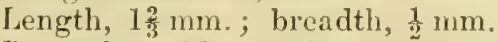

Retaruke. My specimen was found amongst dead leaves that were sent to me by Mr. W. J. Guinness in May, 1911.

\section{Group 'Tachypomide.}

3395. Conurus asperellus sp. nov. Conurus Stephens, Man. N.Z. Coleopt., p. 96.

Elongate, slightly convex, attenuate posteriorly, nitid; head, thorax, and clytra chestmut-red, aldomen of a brownish coppery hue; the mandibles, legs, and basal four joints of the antennae somewhat fulvescent, the succeeding joints slightly infuscate; pubescence slender, greyishyellow, mostly decumbent, suberect on the head, the abdomen, along its sides and on the terminal segment, with long, outstanding, blackish setre.

Head trigonal, with a slender, dark, slightly incurred, interocular line, and another along the centre of the vertex, but without distinct punctation. Thorax, at its base, about a fourth broader than it is 
long. maler gently narrowed anteriolly, finely margined laterally, the base medially trunciate, its rectangular angles direeted backwards and resting on the shoulders; very finely and irregularly punctured, so as in ilppenr snooth on some piats. Feutellum invisible. lilytra not quite as long as hoad, hatrly as wide as the thorax, their shoulders obtuse, the sides distinctly margined, nearly straight, slightly narrowed pesteriorly, the aprices oblique towalls the suture, with almost rectangular angles; their seulpture ill defined, apparently irregularly transversely strigose. Hind-body quite half of the whole length, its basal four serments finely punctite, the 1st longer than the 2nd, which

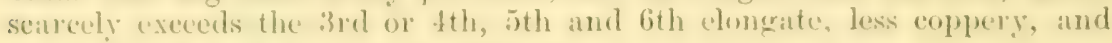
more or less longitundinally asperate.

Leas moderately dongate; anterior tibiae thicker than the others, with dense, rigid, external ciliae, the others straight, bearing very few erect sutale, and very coarsely fringed at the extremity; firont tarsi pubescent and setose, the basil three joints dilated, the 2nil and 3rd narrowed towads the base and yuite angulate there, the the very small and rather slender, the terminal nearly as long as the preceding ones combined; the posterior pair slender, finely ciliate, and exceeding the tibiae in length.

Antennae longer than the head and thorax, with fine pubescence and a few lark longish setae; basal two joints elongate, yet rather shorter than the $31 \mathrm{l}$ of 1 th, joints $5-10$ successively shortened and expanded, 8-10 yuite abconical, 17th suborate, evirlently lalger than the penultimate, obliquely natrowed outwardy.

This approaches (!. Uadius, 180, in many respects, but is difierentiaterl by its longer antennae, coppery abdomen, and asperate terminal segments.

langth, $6 \mathrm{~mm}$; beeadth, fully $1 \frac{\pi}{3} m m$.

lietaruke forest, near brua. One picked out of leaffrould kindly collected for me by Mr. W. J. Guinness, May, 1911.

\section{Conurus laetulus sp. nov.}

Nitid, castaneo-rufous, base of the thorax piceous, clytrit with a well-marked fuscous suturil spot near the base, and 2 or 3 less distinct ones; antennae and legs fusco-fulrous, tarsi paler; the restiture rellowish, distinct and suberect, the black sctae along the sides of the elytra and abrlomen and on the apical segment elongate and erect.

Hearl without definite marks. 'Thorax ennical, a third broader than long; base truncate, its obtusely rectangular angles a little wider than the shoulders but not prolonged over them; the apex somewhat medially rounded, sinuate towards the sides, with reetanguliur angles; the surface appears smooth, lateral margins feebly dereloped. Elytra a third longer than the thorax, similarly marginated, very slightly and gratually narmwed backwards, with feebly rounded subtruncate apices; their fine sculpture rendered indistinet ix the pubescence. Hind-body bright, gradually attenuate, half of the antire length, fincly punctate, sements $2-1$ of nearly the same length, 5th and 6th more elongate, the basal shorter than the 2 nd.

Thibe (the hind pairs) finely eiliate along the outside, coarsely at the extremity, and bearing very few spiniform setae externally, the intermediate pair inwardly narrowed at the base, and slightly bent near the mirlile. 
Antennae short, obviously incrassate towards the extremity; basal two joints about equal, their length double the breadth, 3rd rather shorter, 4th only slightly longer than broad, 5th and 6th shorter and broader than the preceding, joints $7-10$ gradually expanded, 9th and 10th short and strongly transverse, 11th conical, longer than its predecessor.

With the single exception of the northern $C$. brevicornis, 2450, we possess no species, as yet, with similarly formed antennae. In 2450 the 9th antennal joint is just perceptibly larger than the adjacent ones; this is not the case in the present species, which, moreover, is brighter, and has longer and more indistinctly sculptured wing-cases, \&c.

Length, $4 \frac{3}{4} \mathrm{~mm}$.; breadth, $1 \mathrm{~mm}$.

'Tisbury, Invercargill. I am indebted to $\mathbf{M r}$. A. Philpott for a mounted specimen.

\section{Group Oratidat.}

3397. Omalium longiceps sp. nov. Omalium Gravenhorst, Man. N.Z. Coleopt., p. 115.

Subdepressed, elongate, slightly nitid, nearly glabrous; head and thorax fusco-rufous, elytra and lind-lyorly rufo-piceous, the terminal segments castaneous, the legs and basal half of the antennae rufofulvous, joints 6 to 11 infuseate and opaque.

Head of about the same length as the thorax, rather narrower, abruptly constricted behind; minutely coriaceous and with some fine seattered punctures, interocular foveae rather deep, the ocelli situated within these at the base. Lyes not prominent, and not longer than the space between each and the antenna. Labrum testaceous, deeply emarginate in front. Thorax of about equal length and breadth, base and apex truncate, a little wider before the middle than it is elsewhere, its sides very finely margined, slightly rounded anteriorly, nearly straight, though a little narrowed, behind the middle; its sculpture is like that of the head, its median groove hardly reaches the base or apex, along each side of it there is an elongate impression which is broader at the base than in front. Sentellumi large, subtriangular. Elytra nearly twice the length of the thorax, the shoulders are curvedly narrowed, so that the base just exceeds that of the thorax in width, their apices are strongly rounded at the sides but oblique towards the suture; their sculpture is somewhat similar to that of the thorax but is more, though rather indefinitely, longitudinally linear. Hind-body rather longer than the elytra, nearly smooth, segments 2-4 are finely quadripunctate between the middle and sides, the 5 th is longer than its predecessor, the 6th is much narrower.

Tibiae nearly straight, the anterior very gradually expanded and minutely spinose externally near the apex, the other pairs are fringed with setae. Tarsi with conspicuous elongate pubescence; their basal joints are a little dilated and, together, shorter than the terminal joint.

Antennae densely pubescent from their 5th joint onwards, the basal joint is thicker but hardly longer than the $3 \mathrm{rd}$, the $2 \mathrm{nd}$ is about as long as the 4th or 5th, these last are evidently longer than broad.

The rather long head, somewhat flattened eyes, peculiar sculpture, and rather large size distinguish this from all other species.

Length, $6 \mathrm{~mm}$.; breadth, $1 \frac{1}{2} \mathrm{~mm}$.

Hakapoua, Southland. A pair from Mr. Alfred Philpott, found by him in March, 1911. 
3398. Onalium hilarum sp. nov.

Sibblepressed, elongate; pubesenee distinct, nore slender, less ereet, and of a brighter yellow on the elytrat than on the abdomen; body shining; the head, thorax, and base of elytra fusen-rufous; the bright fulvous hinder portion of these last marked of in front by a fuseous depression; lind-loody rufo-castaneous, legrs and palpi testaceous, antennate luseo-fulvous.

Heal nearly as large as the thorax; including the prominent eyes, fully ats broad as it is; much narrowed behind; frontal impressions broit and deep, basal foreate small, the ocelli placed close behind them; its punctation distinct but fine, rather closer near the eyes than along the mirldle, forehead smooth. 'Thorax subcordate, almost as long as broad, widest and rounded at or just before the middle, contracted near the base, but not narrower there than at the apex; dise strongly bi-impressed, more deeply and lroadly behind than in front, but not reaching the base or apex; its punctation rather coarser than that of the head, but somewhat irregular, so that the hinder part of the central space as well as the base appear nearly smooth; the lateral impressions are rather shallow. Sentellum triangular, quite smooth. Elytra oblong, broader than the thorax, scarcely twice its length, slightly narrowed towards the base, with truncate apices; their punctation a little finer than that of the thorax, still finer and more distant behind; along each side of the suture there is a well-marked impression, so that the suture itself appears distinctly elevated from the extremity to near the base; before the middle a dark impression is bent, and extends forwards inside each shoulder, so that the enclosed basal space seems

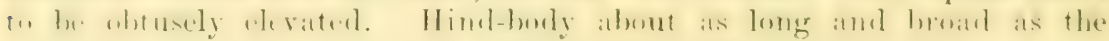
wing-cases, broadly margined, rather indistinctly punctured.

Antennae rather longer than the liead and thorax, with elongate slender setae; their 3rd joint slender and evidently shorter than the 1st; tthe and 5th small and moniliform, distinctly smaller than the thick 2nol; joints $6-10$ subpuadrate, broader than the preceling ones, the terminal chngate-conical, not twice the length of the penultimate.

This beantiful species may be mistaken for $O$. sugoloirle, 1851, only. Its desuription indicates a narrower, differently colomed insect, with at transwerse depression neal the base of the elytra. In the present species the somewhat curvate impression near each shoulder is hardly more defnite, though much darker, than that muning parallel with the suture.

l.ength, $2 \frac{1}{2} m m$; brealth, $\frac{2}{3} m m$.

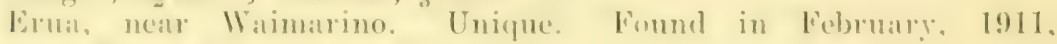
amongst decaying leaves, on the ground.

3399. Omalium sanguineum sp. nov.

shining, dark rufous, the elytra just a little lighter, lecrs and antenuate fulveseent, the litter more obsenrely so, palpi and tarsi yellowish.

Heitl ats bond, inchuling the eyes, as the middle of the thorax; fincly lut not closely punctured, forehead sumoth; frontal impressions latge, ucipital foreac punctiform and well marked, the ocelli placed close to them and very distinet. 'Thorax of about equal length and brearlth, widest before the middle, more abruptly narrowed behind than in front; the dise strongly bi-impressed, the intervening space nearly smunth, its punctation conser than that of the hearl, not elose, and 
becoming finer at the base; the lateral impressions shallow. Scutellum perfectly smooth, triangular. Elytra broader than the thorax and nearly twice its length, slightly expanded backwards, with truncate apices; they are depressed alongside the suture, which, therefore, seems elevated nearly to the base; there is also a transverse impression before the middle; their sculpture is like that of the thorax, but not quite as coarse and more distant. Hind-body not quite the length or breadth of the elytra, broadly margined, rather finely punctate.

Antennae rather longer than the head and thorax, with fine elongate setae; basal joint stout and nearly the length of the 2nd and $3 \mathrm{rd}$ combined, 4th and 5th evidently longer than broad, joints 6-10 moderately dilated and subquadrate, the terminal longer than the tenth.

This, on accsunt of the elevated suture, must be placed next to $O$. hilarum. Sharp's $O$. sagoloide, found at Picton, cannot be very similar, as in its description there is no allusion to the elytral suture. The 4th and 5th antennal joints are rather longer and more obconical than those of $O$. hilarum.

Length, $2 \frac{1}{3}-2 \frac{1}{2} \mathrm{~mm}$.; breadth, $\frac{2}{3} \mathrm{~mm}$.

Greymouth. 'Two examples, from Mr. J. H. Lewis.

\section{Group Pselaphidal.}

3400. Sagola electa sp. nov. Sagola Sharp, Man. N.Z. Coleopt., p. 134.

Elongate, subdepressed, nitid, finely and indistinctly punctate; head, thorax, and base of elytra rufous, their hinder portion bright fulvous; the legs, antennae, and palpi fulvescent; pubescence yellow, elongate, scanty in front, thicker behind, where there are also some long, outstanding hairs.

Head, including the prominent rotundate eyes, as broad as the thorax, obliquely narrowed anteriorly, its hind angles somewhat deflexed and rounded; the median furrow widest between the eyes, prolonged nearly to the base, but linear between the flattened antennal tubercles; occipital foveae rather small and subangular. Thorax of equal length and breadth, rounded and widest at or just before the middle; basal impression large and subquadrate, lateral foveae deep at the base and prolonged forwards beyond the middle, the base bipunctate. Elytra a third longer than the thorax; their sides, behind the middle, somewhat curved and broader than elsewhere; sutural striae deep, the dorsal ones abbreriated and not entire, being composed of a punctiform basal and more elongated hinder impression; between the striae, on each elytron, there is a distinct puncture. Hind-body as large as the elytra, its first visible segment slightly shorter than the 2nd or $3 \mathrm{rd}$, depressed and bearing minute brassy scales at its base; the penultimate and terminal together are broadly conical.

Femora stout, narrowed towards the extremity; anterior tibiae moderately and evenly curved externally, the middle pair rather less so, the posterior strongly eurvedly dilated near the middle, straight inwardly; terminal joint of the hind tarsi very large, gradually incrassate, subtruncate at apex, and just between the base of the claws provided with a short process; the posterior claws unequal, enormously developed, strongly arched above, the frontal thickened or marginated above for half its length, semitransparent, thin, and nearly straight below, bent and acute at the extremity, the other equally long but not as thick from above downwards. 
Antennac with slender outstanding pubescence, their basal joint red, cylindrical, and nearly as long as the following three; 2nd oblong-oval; 3.d small and obernical; joints $1-7$ transwerse, laxly articulated, and

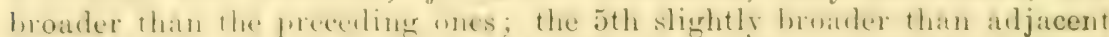
ones; Sth lingest of all; 9th and 10th transverse, yet hardly as large as the 7 th; the terminal joint, including its apieal appendage, conical.

Underside rufesent. Head with a transverse depression extending haterally beyond the base of the quadrate mentum, deeply and broadly hollowed backwards along the middle, with it forea behind each eye, and bearing some small tults of yellow hairs. Ventral segments distinctly pubescent, the th and 5th much more coarsely and thickly, the extremity of the former medially depressed, the 5th with a deep fissure along the middle partially concealed by the woolly clothing, 6th narrow.

o. l.ength, $2 \frac{3}{4} \mathrm{~mm}$; breadth, $\frac{3}{4} \mathrm{~mm}$.

Lirua. I found a single male anongst fallen leaves, at an altitude of $2,500 \mathrm{ft}$, in February, 1911 .

Allied to 5 . macrony $x, 2466$, but somewhat lirger, the head broader, more rounded behind, and its frontal channel more expander; elytra longer; interior tibiae not bent; 8 th joint of the antennae evidently larger, th to 7 th also quite definitely wider but not as broad as those of Reitter's S. monstrosa; the posterior tarsi and claws also different.

\section{Eupines nesobia sp. nov. Eupines King, Fam. Psclaphidae Rafiray, p. 206.}

Nitid, cunvex; liead, thorax, and antennae dark red, the elytra and legs pale castaneo-rufous, tarsi testaceous; elytra with short, suberect, slender, but not numerous setae; hind-body with a few elongate ones.

Heal subpuadrate, as broad as the thorax, slightly rounded behind the moderately prominent eyes; with a large interantennal depression, and a pair of distinct punctiform foveae between the eyes. 'Thorax quite as long as it is broad, widest at or just before the middle, smooth, somewhat flattened, but not distinctly forcate at the sides close to the base. Elrtra nearly double the length and breadth of the thorax, the shoulders, however, are only a little broader than its base, apices truncate; the suture is slightly elevated, but the strine are obsolete. Hindbody much deflexed.

Legs elongate; posterior tibiae a little curred and bent below the mirldle; basal joint of the hind tarsi with an elongate seta extending half-way underneath the 2nd.

Antennac stout and moderately long, their basal joint rather Ionger and thicker than the oblong 2nd; 3rd and the obconical, the former slightly the longer, neither quite as hroad as the jth; 6th moniliform and rather smaller than adjacent ones; 7 th rather longer, but hardly as broad as the Sth, both distinctly narrowed apically; 9th strongly transverse, yet not quite double the width of its predecessor; 10 th transversely quarliate, much larger than 9th; the terminal largest, conical, but not acmunate; these last three are more thickly pubescent than the others, and form in oblong club.

Undersirle chestnut-red, distinctly pubescent; the metasternum medially depressed hehind the middle, with some fine punctures; basal rentral sement longer than the following three in the middle.

fem.-Nhust exactly similar, metasternum unimpressed.

o. I.ength, $1 \frac{1}{2} \mathrm{~mm}$; breadth, $\frac{1}{2} \mathrm{~mm}$.

firent Barrier Island. 'Three picked out of leaf-mould sent by Mr. Flynn, March, 1911. 
Group Psfiathini.

3402. Pselaphus pilifrons sp. nov. Pselaphus Herbst, Gen. Ins. (Wytsm.), Pselaphidae, p. 304.

Subdepressed, interruptedly attenuate anteriorly, shining; castaneorufous, the tarsi, palpi, and terminal joint of the antennae fulvescent; pubescence yellow, somewhat curled, rather scanty, closer on the elevated parts of the head than elsewhere, triseriate on each elytron, moderately thick on the legs.

Head. narrowed behind, the neck large and smooth; widest in line with the large prominent eyes, its frontal portion parallel-sided; antennal elevations horizontal, and extending backwards as far as the front of the eyes; the frontal channel smooth, deep, narrow, expanded and terminating between the eyes; the occiput distinctly conrex. Thorax convex, obtusely dilated at the middle, hardly longer than broad, its base depressed, with duplicate, linear, transverse impressions; the lateral foveae single at one side, double at the other, the formier no doubt being the natural condition. Elytra as wide as thorax at the base, gradually expanded posteriorly, their length scarcely exceeding the breadth, with straight but not densely fringed apices; sutural striae well marked, deep and foveiform at the base, as is the dorsal stria on each, which though fine is definite and not abbreviated; between the striae there are some fine punctures. Hind-body quite as broad as the elytra, its basal segment horizontal and quite as long as all the others, with very few fine hairs.

Femora medially clavate; posterior tibiae somewhat curvedly dilated externally near the extremity; penultimate tarsal joint moderately thick.

Maxillary palpi elongate, but not very slender; 2nd and 4th joints flexuous, the terminal clavate portion of the latter nearly half of its whole !ength; 3rd strongly transverse.

Antennae as long as the head and thorax, finely pubescent; basal joint stout and cylindric, not twice the length of the oblong 2 nd ; joints 3-8 nearly equal, evidently longer than broad, 8th only slightly smaller than Tth; 9th fully as long, but hardly as broad as the obconical 10th; the terminal large, oviform, but obliquely narrowed at one side.

Underside sparingly clothed with slender yellow hairs, but the basal ventral segment and the spaces near the front and middle coxae are densely covered with coarser grey pubescence. IIead obliquely grooved from the front of each eye towards the back, the intervening space smooth and convex; 2nd ventral segment larger than all the following ones; 5th strongly incurved behind, so as to be scarcely visible in the middle; 6th moderately developed.

In P. meliusculus, 1868, the head is biforeate between the eyes, and there is a slender median groove behind. The dorsal striae of the elytra are abbreviated. The 3rd joint of the maxillary palpi is not at all transverse, being as long as it is broad and subobconical.

In Dr. Sharp's description of $P$. pauper, 226, there is no allusion to the legs or palpi, but the hind-body is described as being "rather densely set with very fine depressed hairs," and "the base of the thorax behind the deep curved impression is shining." It must, therefore, be different from $P$. pilifrons.

Length, quite $2 \frac{1}{2} \mathrm{~mm}$; ; breadth, $\frac{3}{4} \mathrm{~mm}$.

I'isbury, Invercargill. One, from $\mathrm{Mr}$. A. Philpott. 
This genus comprises ninety-severi species. New Zealand has now vielded twelve of them, luat one, I'. Inlcis, 115.3, has been inadrertently omitted in the last European catalogue.

\section{(iroup, 'T'Yrixt.}

\section{Plesiotyrus gen. $10 \mathrm{~V}$.}

Head subovate, as broad but hardly as long as the thorax, vertical and not prolonged anteriorly; antennal tubereles narrowly separated, not very prominent. Eyes moderately large, only slightly eonvex, placed at the middle of each side. Thorax oviform, relatively small, rather ionger than broad, without discernible impressions. Elytra not quite as long as broad, widest at the extrenity, curvedly narowed to the same width as the thorax at the base; with distinct sutural striae, the dorsal much less definite, both deepest, but not foreiform at the base. Hind-body as long as the elytra, segments $2-5$ deflexed, the basal largest, as broad as the elvtra, distinctly margined, obtusely conrex bebind, much depressed and thickly pubescent at the base. I Legs moderately elongate but thick.

Antennae of nearly uniform thickness from the basal joint to the penultimate, the terminal largest, as long as 9th and 10th united, obtuse at the apex; 2nd suboviform, and nearly as long as the cylindrical 1st; joints $6-8$ slightly smaller and more moniliform than the preceding three, none elomgate; 9 th and loth transwerse and rather bruader.

Maxillary palpi short, not longer than the head; basal joint short and slender, 2nd longest, its basal half very slender, the other elavate; 3rd subglobular, with a rery short, thin bisal stalk; th oblong-oval, larger than 3 rd, subtruncate at the extremity, with an acicular appendage proceeding from a minute forea molerneath, its basal stalk short and slender.

Prosternum deeply emarginate. Metasternum convex, but flattened behind the mirlde. Head with an incurved impression before the eres. Coxae, anteriol and intermediate, rotundate, the former subcontiguous. the latter moderately separated, their trochanters longer than those of the front pair, rather slender near the base, subclavate at the extremity : posterior coxae distant, with thick trochanters. Basal rentral secrment not visible, thickly covered with pubescence, "nd rather longer than the 3rd and 4th; 5th large, deeply semieircularly emarginate, its hind portion margined and romuled: the enclosed $6 \mathrm{th}_{\mathrm{s}}$ is large and subrotundate, with a median suture across it, the apieal portion no doubt is the supplementary segment of the male.

In facies it most nearly resembles 'Tyrogetus, but differs therefrom by the abbrevinted palpi, with their aciculate terminal appendages, lnrger eres, more robust legs, and thicker, differently formed antennae. 'Jyrogetus, Mr. Rafiray informs me, is a good genus, allied to Sauler's T'yropsis, a Chilian genus.

The trpe, 2345, now Plesiotyrus crassipes, still unique, is a shining dark-red insect, with seanty yellowish pubescence, distant and indistinct junctation, and opaque legs. It measures $1 \stackrel{2}{3} \mathrm{~mm}$. by $\frac{2}{3} \mathrm{~mm}$.

3403. Hamotulus frontalis sp. nov. Hamotulus Schaufuss, Gen. Ins. (Wytsm.), Pselıphidue. p. 390.

Shining, castaneo-rufous, tilsi and palpi fulvescent; pubescence clongate, yellowish, mostly erect. 
Head abruptly narrowed and prolonged anterioriy, not quite as broad as the thorax, obliquely narrowed behind the rather small but prominent eyes; frontal channel deep, only moderately broad, and ending just in front of the eyes; interocular foveate small and distinctly separated from the eres. Thorax of almost equal length and breadth, very : aghtly wider at the midcle than clsewhere, a good deal narrowed anteriorly; the groove near the base extends to the lateral impressions and, at the middle, forms a very small angular fovea. Elytra a third longer than the thorax, broader than they are long, considerably narrowed towards the base, which is just perceptibly wider than that of the thorax; sutural striae well marked, deep and foveiform at the bose, the dorsal impressions short but still deeper and broader, and only inclefinitely prolonged backwards. Hind-body nearly as long as the tytra, narrowed and gradually deflexed posteriorly, its basal three segments cqual, finely and distantly punctate.

Legs elongate, femora moderately clavate; anterior tibiae gently curved below the middle, the intermediate rather stouter, neither bent nor densely pubescent near the extremity, slightly arched externally, the postcrior similarly curved, with a conspicuous spine on the inside below the middle.

On comparison with the male of the northern $I I$. sternalis, 2744 (Ann. Mag. Nat. Hist., ser. 6, vol. 12, p. 168), it will be at once noticed that the head and thorax of this species are evidently narrower; the interocular foveae are only about half as large, and, instead of touching the eyes, they are distant from them; these organs are smaller; the 5 th and 6 th joints of the antennae are sightly longer, the terminal is subconical arid truncate at its base, whereas the corresponding joint in 2744 is oblong-oval and narrowed towards the base; the tibiae also differ, the intermediate pair of 2744 being slightly bent and obviously pubescent near the extremity, and the insect itself is more robust. The structure of the underside is nearly similar in both, but in this species the metasternum is more deeply concave longitudinally and the apical segment is large and subrotundate.

Fem.-Body stouter, with thicker antennae; the head and thorax more slender than in the same sex of 2744 .

o. Length, $2 \frac{1}{3} \mathrm{~mm}$.; breadth, $\frac{4}{5} \mathrm{~mm}$. Lewis.

Broken River, Canterbury. A specimen of each sex from Mr.J.H.

\section{Group Conydimal,}

3404. Ulonotus philpotti sp. nov. Ulonotus Erichson, Man. N.Z. Coleopt., p. 186.

Oblong, transversely convex, without tubercular elevations, variegate; head and thorax opaque, fusco-piceous, the explanate sides of the latter reddish, elytra pitchy-red, the bare spots shining; tarsi and antennae fusco-rufous, the legs variegated with coarse pale and fuscous setae.

Head flat between the elevated antennal tubercles, granulate, and bearing numerous erect, squamiform, flavescent setae. Thorax a third broader than long, granulate, with a small median basal depression; its fulvescent setae finer than those on the head and somewhat concentrated in patches, the most conspicuous being a pair of elongate frontal ones; the sides are fringed with coarse outstanding setae; the anterior lobe is large, and projects as far as the front of the eye; there is a 
"wide eritp between it and the small 2nd; the 3rd lobe is still smaller and much less prominent, it is directed ontwards and is distant from the shmuler. Soutellum subyuadrate. listra ololong, rounded at the extremity, of about the same with as the thorax, and quite twice its length; they are corasely seriate-punetate, more finely behind, with slightly uneven hut not distinctly granulay intervals hetween the punetures, these parts are nearly hare; on ench drtron there are 3 dorsal streaks of fine, decumbent, fusco-fulvous setic, and along the bart intervals usually 3 rounded spots of greyish setae; the hindmost is slightly forminent, as are 2 or 3 on the posterior declivity; the sides as well as the disc have nmmerous erect, hut not very conrse, fuscous setire.

Antomate sparingly setose, their and joint oblong, about as long but not as thick as the 1st, ind more clongate and slender, joints 4-6 obconical. Tth and Sth moniliform; club abruptly enlarged, oblong, its basal joints strongly transwerse, the terminal large and subrotumilate.

I secund (damaged) specinen measures + mm. by $1 \frac{1}{2}$ amm. 'The elytra are lull fusco-picens, but the thorax is slightly rufescent. The nearest species ate $1706,1707,1708$, and 1710 , each of which, howerer, has nodose elytrat, and may therefore be readily separated from $U$. phitpotti.

length, 5mm.; breadth, $2 \mathrm{~mm}$.

Tisbury, Southland. The name of its discoverer, Mr. Alfred Philpott. has been given to it.

3105. Notoulus crassulus sp. nov. Notoulus Broun, Min. N.Z. Coleopt., p. 183 (Ablabus).

Gblong, incrissite, evidently transversely convex; variegate, fuscous, with an angular hackish mark behind the middle of each elytron but not attaining the suturs, slightly rufescent before and behind these dink spots, legs and basal joints of antennite ferruginous, remaining joints and the tarsi testaceous; the setae short and slender, wreyishyellow, unerenly distributed, somewhat concentrated on the raised parts, but along each side of the elytral suture there is a line of fulvous setae; the head and thorax are without distinct granulation or punctation, and there is $n$ o definite seriate seulpture on the elytra.

Head smaller than the thorax, antennal tubereles only slightly clevaterl. Labrum prominent, rerldish. Eyes moderate. 'Thorax rather broader. than long, its sides a little explanate; the frontal lobe about half of the whole length, curredly narrowed, and forming a subacute angle which extends to the middle of the eye; the next obtusely angular, and separated from the former by a noteh only; the basal Ishe forms the posterior angle, but does not extend outwardly nearly as far as the others; the median impression is large, but narower in front. With irregularly elevated borders; a pair of foreac are situated neal the base and another close to the seutellum. Elytra about twice the length of the thorax, and hroaler than it is at the base. narrowed and rertical behind; on each there is a moderate basal elevation, and a pair of nodosities on top of the apieal declirity; the other inequalities are ineouspicuous.

Underside fuscous, with fine yellowish setae; the frosternum, metasternum, basal rentral surment, and the middle of the 2 nd are distinctly but not closely granulate, the remaining segments are nenrly smooth. Prosternal process bisulente. 
Antennae nearly glabrous, the broad biarticulate club, however, is distinctly pubescent; 2 nd joint stout and as large as the visible portion of the basal; 3rd slender, nearly twice as long as broad; 4th and 5th similar in form but rather shorter; joints 6-9 short and bead-like, the last slightly larger than the 8th; 10th atbruptly enlarged, thrice as wide as the 9th; the terminal large, obtusely rounded.

In $Y$. brevis, 1353, all the ventral segments are granulate; it is also different in other respects. $V$. demissus, 3224, has the sides of the thorax flatter, and its rentral lobe is narrow, quite cylindrical indeed, and widely separated, right to its base, from the others; the elytra are narrower at the base, and have distinct serial sculpture, de.

Length, $2 \mathrm{~mm}$. ; breadth, $1 \mathrm{~mm}$.

Nount Te Aroha. Two examples found in November, 1910.

\section{Heterargus subaequus sp. nov. Heterargus Sharp, Man. N.Z. Coleopt., p. 1085.}

Elongate-oblong, transversely convex, without nodosities, opaque; it seems nude, the flavescent setae being hardly discernible; fusco-piceous, faintly rufescent on some parts, antennae and legs infuscate red.

Head distinctly granulate behind but obsoletely on the flat forehead; labrum prominent, pitchy-red, almost smooth and shining, with a transverse series of minute setigerous punctures in front. Thorax slightly broader than long, its sides gently curved and somewhat flattened to beyond the middle, not perceptibly crenulate; base and apex strongly medially rounded, and sinuate near the sides, the posterior angles thick and directed backwards; its surface only a little uneven, having a shallow median impression, another near each side, and a pair of obscure basal elevations; it is covered with distinct though somewhat flattened granules. Elytra incurved at the base, no broader than the thorax, just double its length, gradually narrowed posteriorly; the granules are rearly quite seriate, and usually rather longer than broad; there is a slight basal elevation midway between the suture and each shoulder, but there are none along the disc.

Antennae rather short, 11-articulate; basal joint almost wholly exposed, 2nd nearly as thick but rather shorter, the next evidently longer than the 4th, joints 5-9 moniliform and small; club broad, biarticulate. Tibiae straight, with short slender setae.

Distinguishable from /I. rudis, 1935, by the less uneven, simply margined thorax; by the more slender granulation, and entire absence of irregularly raised series on the elytra; and by the distinct granular sculpture of the back part of the head, \&c.

Length, $3 \frac{1}{2} \mathrm{~mm}$. ; breadth, $1 \frac{1}{2} \mathrm{~mm}$.

Hakipoua, Southland. Unique. Found by Mr. A. Philpott on the 1st March, 1911.

3407. Protarphius decorus sp. nov. Protarphius Broun, Ann. Mag. Nat. Hist., ser. 6, vol. 12, p. 183.

Uneven, convex, oblong, shining, sparingly dad with pale slender setae which are most ensily seen on the elytral nodosities; head and thorax piceous, the front and sides of the latter rufous; elytra fuscotestaceous, their sides, the middle of the interstices, and a conspicuous spot just below the summit of the apical declivity dark fuscous, the 
bodosities shining rellow; legs fusco-rufous, the antennae, palpi, and intsi pale berruginous or fulvesent.

Head granulate. 'Jhorax broader than long, much contracted near the base, with subrectangular posterior angles, which, however, are directerl backwards; its sides widely explanate and studded with granules, so thit the edges seem irregularly serrate, the front projects as fir as the middle of the eyes; the hinder portion extends outwardly, leaving a deep gap between it and the shoulder, and just in front of it there is an exeision, there is also a smaller noteh near its middle edge; the dise is distinctly granulate, and has a broad depression along the middle with irregularly derated lateral loorless: at the centre of the base there is a small triangular depression with slightly raised margins; the apex has a pair of moderate elevations, and in the middle is olvionsly rounded, behind the eyes it is deeply sinuate. Elytra oblong, of the sane width as the flattened sides of the thorax, quite rertical and rounded behind, with obtusely rectangular shoulders, the lateral margins

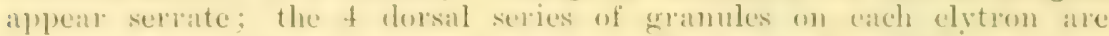
interrupted by the nodosities, of which there are 3 on the 2nd, the basal is elongate, that on top of the hind declivity is most prominent and projects backwards as well as upwards, the $3 \mathrm{rd}$ is placed in front of the last and is smaller; the modules on the 4 th series are smaller, the 1 st is situated on the middle instead of being at the base; the lateral sculpture also is granular, and the shoulders are somewhat nodiform.

'Tibae sliglitly curred externally, and bearing slender, ret distinct, greyish setae.

Antennac very finely and scantily setose, their basal joint invisible above, 2nd thick, 3rd evidently longer than broad, joints $4-6$ slightly longer than hroad and somewhat obennical, $7-9$ bead-like, the 9th rather shorter and broader than the Sth; club abruptly and considerably enlarged, biarticulate, its basal joint strongly transverse, the terminal rotundate.

In its natural state it is enerusted with dry sappy matter which conceals the real sculpture and eoloration. It then resembles 1167 , l'. crassus, more than any other species. 'The specimen deseribed above has been earefully seraped with the point of a needle and cleaned with benzine, and has thus beren transformerl inte a beantiful ubject for microscopical examination.

length, 2. mm. ; breadtl, nearly $1 \frac{1}{2} \mathrm{~mm}$.

Great Barrier Island. I found two amongst some leaf-mould kindly cullected for me by Mr. Frank Flynu in Mareh, 1911.

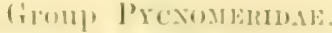

\section{Pycnomerus arcuatus sp. nov. Pycnomerus Erichson, M:11. N.\%. Colcopt., p. 208.}

likungate, subparallel, slightly convex, glabrous, mulerately nitid; rufo-picenus, legs and antennate dark red.

Head subpuadrate, narrower than the thorax, with deep interantennal fossace its punctation distinct. Thorax nearly a third longer than broad, very slightly narrowed towards the feebly rounded thickly margined base; apex truncate, hut with a short sinuation behind each "ree, so that the prominent angles do not project quite as far forwards as its middle portion; the distinet lateral margins become thinner, and are rery gently enrent inwally hehind the middle, the true sides, 
therefore, are quite visible outside then, the posterior angles, though rectangular, are situited on the surface instead of being at the sides; the surface is somewhat irregularly punctured, rather more closely and finely towards the front and sides than on the disc, which is only moderately bi-impressed longitudinally, the dividing-line is smooth and narrow. Elytra twice the length of the thorax, broader, gradually narrowed behind; the base is incurved. and the humeral angles project forwards beyond the base of the thorax; their striae are rather narrow, but not deep, along the middle but become deeper behind, as do the sutural pairs at the base; the punctures are clongate and cluse; interstices rather broad and plane, with minute, rather distant, serial punctures; the suture, at the extremity, is strongly curved and carinate towards the sides.

The 10th and 11th joints of the antennae form a distinctly stparated, biarticulate club; this species therefore must be located in the Penthelispa section. It is distinguishable from every species in it by the peculiar thoracic margins, prominent humeral angles, and elytral sculpture. The eyes are moderately large.

Length, $3 \frac{1}{2} \mathrm{~mm}$. ; breadth, $1 \mathrm{~mm}$.

Broken River, Canterbury. One from Mr. J. H. Lewis.

\section{Pycnomerus ocularius sp. nov.}

Elongate, slightly convex, nitid, with a few slender minute setae in the elytral striae; nigreent, lexs and antennac piceo-rufous.

Head smaller than the thoras, distinctly punctate, more finely in front, interantennal foreae large. Thorax slightly longer than broad, a little contracted towards the moderately prominent anterior angles, widest near the front, gradually narrowed backwards, lateral margins distinct, the base rounded, so that its rectangular angles do not touch the elytra; dise transversely convex, coarsely but not closely punctured, with smooth intervals, more closely and finely at the sides, along the middle there is an indistinct feebly raised line. Scutellum small. Elytra quite donble the length of the thorax, rather broader than it is at the base, with obtusely porrect shoulders, their sides only feebly roumderl but a good deal narrowed pesteriongy with distinctly punctate deep and regular striae; interstices narrow, with minute and distant serial punctures, the 2 nd, and sometimes the 4 th, do not reach the basal margin.

Antemnae fincly pubescent, stout, joints 2-9 about equal, transverse, the exposed portion of the 1st hardly longer than the 2nd; 10th abruptly enlarged, transverse, 11th narrower, the club therefore is distinctly biarticulate.

Underside shining, coarsely punctate, prosternum more closely and subopaque, metasternum with a broad median impression behind, the terminal rentral secmont smonth at the batse, sublepressed and elosely: punctate behind.

Most nearly resembles $P$. carinellus, 1598, rather larger, more shining, the thorax more convex, rather broader near the front, its discoidal punctation consser but not as close; the eves lirger and decidedly more convex. If 1598 be examined sideways it will be seen that its thorax is a little flattened along the middle.

Length, $3 \mathrm{~mm}$; ; breadth, $1 \mathrm{~mm}$.

Mrount Te Aroha. Three found in November, 1910. 


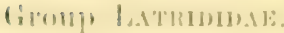

3410. Corticaria picicornis sp. nov. Corlicuriu Marsham, Man. N.'L. Coleopt., p. '234.

Variegate, moderately broad, slightly convex, nitid; pubescence scanty, pale-yellowish, subereet on the dythil, more slender on the hear amel thorax; elytrat flaresent at the base and behind, the whole central

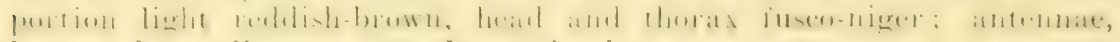
legrs, and seutellum more or less rufo-piceous.

Heal smaller than the thorax, moderately coarsely but not elosely punctured, with large prominent eves. 'Thorax rather broader than lome, witl rommlerl siles, its punctition slightly conser than that of the load; the lrontal fovea more oviform than that near the base, the lateral impressions, behind the midlle, large but not deep; just before the basal margin there is a well-marked transverse groove. Scutellum semicircular, rather large, smooth. Elytra suboblong, curedly narrowed behind, very slightly so near the base, fully twice the length of the thorax and ubromsly bromber than it is; with clistinet suturil striae, their coarse, distinctly separated, dorsal punctures beentere rather finer near the base, still more so behind. Tibiae straight; basal joint of anterior tarsi larger than the next, both tngether evidently shortel than the 3rd.

Antennate nearly as long as the head and thorix, with slender nutstanding setale; basal joint subpyxiform, thick, the next oviform but smaller, joints : $\ddot{-} T$ elongate and slender, 8th rather shorter; club rather slender, joints 9 and 10 being elongate-orate, the terminal somewhat honder.

The nearest ally is $C$. platyptera, 1606; its elrtra, howerer, are not only shorter and broalder, but, on each, a distinct sharply curved depression encloses an oblong hasal elevition botween the suture and the shoulder; the coloration and seulpture also differ.

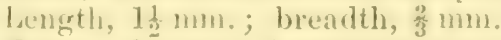

Erua. One fouml amongst leaf-moull in Jamuary, 1911.

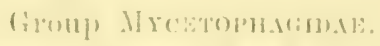

3411. Triphyllus constans sp. nov. Triphyllus Listreille, Lacord. Hist. des Ins. Coleopt., tom. 2, p. 445.

Oblong-oval, slightly convex, nitid; testacens, pubescence paler.

Head small, much narrowed and somewhat prolonged anteriorly, distinctly punctate. Eyes large and prominent. Thorax quite a third broader than long, gradually eurvedly narrowed towards the front, apex truncate, base bisinuate, posterior anerles obtusely triangular, lateral magins not visibly serlate; its surface moderately closely and distinctly punctured, and with a well-marked punctiform basal forea between the midelle and each side. Sientellum transwere. Elytrat nearly thrice the length of the thorax, of the same width as it is at the base, with distinet serial punctures, which, howerer, become obsolete towards the apices ; interstices finely punetate. 'Tarsi slender and hairy, tetramerous.

Antennae nearly as long as the lead and thorax, uniformly testaceous, with slender setae; basal joint rather thicker but hardly longer than the next. Bril elongate, ith slightly longer than th, both longer than broar, joints 6-8 moniliform; ciub eridently triarticulate, its basal joints obeonical, the terminal subrotundate.

Undersile somewhat infuscate, imegularly and finely punctate, femora inclusire, with greyish-yellow pubescence. 
This most nearly resembles $T$. punctulatus, 405, but is rather larger, distinctly seriate-punctate at the base of the elytra, more strongly bifoveate at the base of the thorax, and with more elongate antennae.

My 405 was published in June, 1880, and was redeseribed by Dr. Sharp as $T$. concolor in the Trans. Roy. Dub: Soc., 1886.

Length, $2 \frac{1}{2} \mathrm{~mm}$.; breadth, $1 \frac{1}{4} \mathrm{~mm}$.

Tisbury, Southland. Two from Mr. A. Philpott.

\section{Group UISTELIDAr.}

3412. Abraeus phyllobius sp. nov. Abraeus Leach, Man. N.Z. Coleopt., p. 166.

Subrotundate, moderately convex, glabrous, shining; piceo-niger, legs pitchy-red, the tarsi, palpi, and intermediate joints of the antennate fusco-testaceous, the club and basal joint fusco-piceous.

Head finely punctate. Thorax transverse, moderately curvedly narrowed anteriorly, the apex emarginate, with somewhat prominent and slightly deflexed angles, base slightly rounded; its surface moderately finely ret quite distinctly and evenly but not at all closely punctured. Elytra about twice the length of the thorax and closely adapted thereto, with truncate apices; their punctation is exactly like that of the thorax but becomes a little finer behind. Pygidium deflexed.

Tibiae without definite tarsal furrows; the anterior slightly curved and gradually incrassate, inwardly fringed with fine setae but not denticulate externally; the intermediate a little expanded, the posterior simple, these pairs with minute terminal spines. Tarsi pentamerous.

Antennae inserted at the sides of the forehead just before the eyes; basal joint laroe, subpyriform, notehed at the extremity; 2nd cylindric and moderately stout; 3rd much more slender, evidently longer than broad; 4th and 5th subquadrate; 6-8 small and moniliform; club large, ovate, its dense pubescence concealing the articulations.

Underside nitid, the sternum and basal ventral segment more coarsely punctured than the upper surface. Prosternum subtruncate in front, with well-marked cavities at the angles for the reception of the antennal club.

Elytra without marginal striae. Scutellum minute.

Length, $1 \frac{1}{2} \mathrm{~mm}$. ; breadth, fully $1 \mathrm{~mm}$.

Great Barrier Island. I found three in the leaf-mould sent in March, 1911, by Mr. Flynn. It is rather larger and less globular than No. 299.

Group Cortlophidat.

3413. Sacina laetans sp. nov. Sacina Broun, Man. N.Z. Coleopt., p. 1071 .

Glossr, oblong-oval, slightly convex; rufo-castaneous, but with at large space behind the middle of the elytra more rufescent, the front of the thorax testaceous and nearly transparent, and the antennae and tarsi also yellowish; it is sparingly clothed with elongate, decumbent, pale-yellowish pubescence.

Head small, entirely concealed above. Thorax finely margined, about as long as brosd, gradually curvedly narrowed anteriorly, its apex also rounded and prolonged over the head; the base resting on, but scarcely as wide as, the elvtra, slightly oblique towards each side, with rectangular angles; its surface is very finely and distantly punctured, and has a fine groove at each side behind the middle. Scutellum large, rounded 
behind, with linear implessions. Elytura hadly double the length of the thorax, their romeled apices not corering the prgidium, their punetation like that of the thorax.

laegs rather elongabe; tarsi slender, of alount the same lemgth as the tibiac, their terminal joint longer than the basal mes united.

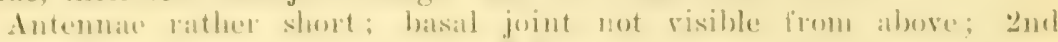
evlindric and moderately stout; Brol slender, evidently longer than broal ; fth very small; 5th and 7 th about equal, each as long as broad; fith nearly twice the brealth of aljacent ones; elub triarticulate, its last joint sabotumblate and longer than eithere of the others.

Hore glossy and brightly coloured than s. oblonga, 1913, and of more oritorm contour.

length, 1 is $11 \mathrm{~m}$.; brealth, nearly $1 \mathrm{~mm}$.

'Tisbury, Invereargill. Deseribed from a single example found by Mr. A. Philpott.

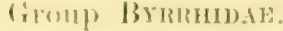

3114. Pedilophorus ornatus sp. nov. Pedilophores Ntrfïhny, Mitn. X.\%. Coleopt., p. 244.

Conves, broally oral, nitid; aneo-niger, the legs and 1st-joint of antennate dark rufous, renaining joints and the tarsi fulro-castaneous; with num rous erect, but not very elongate, infuseate or fulreseent setare, and, besiles these, more decumbent, fulvescent setale are thickly distributed "seer the surface, the head included, and on the drotra form irregular patches.

Head histinctly punctate, less closely on the rertex. Thorax about twice as long as broad, its sides straight but gradually narrowed towards the acute, depressed, anterior angles; apex sinuate near the sides, the base slightly bisinuate, with rectangular but not acute angles; it is moderately elosely and finely, yet quite distinctly, but irregularly punctured, rather more distantly near the centre. Scutellum triangular. punctate. Elytra moderately finely but distinctly and very irregularly punctured, so that some spots appear smooth and glossy; the posterior deelirity is nearly smooth, obturely elevated along the sides to the extremity, and at that part has a pair of foveiform depressions; towards the sides sone very obsolete broad striae, with equally indefinite longitudinal costae, may be seen.

licuora deeply grooved underneath, so that the anterior, at the extremity, seem to be armed with a frontal dentiform projection; tibian nearly straght, fringed with fine setale, grooved cxternally; 3rot tarsal joints with elongate membranes.

Antennae moderately elongate, basal joint thick, 2-5 elongate, 6th longer than broad, $7-10$ successively dilated, 11th elongate-conical.

Underside shining, with distinct fulveseent setas.

'This must be located in section 3, near P'. brynbins, 3163. Which, however, is more riridesent and shining, with well-marked punctation and very elongate outstanding setae.

l.ength, 5) mm. ; brealth, $2 \frac{3}{2} \mathrm{~mm}$.

IIakapona, Southland. I am indebted to Mr. A. Philpott for a specimen of this handsome species.

\section{Pedilophorus humeralis sp. nov.}

Nitid, aeneo-nieger, the legrs and hasal half of the antennate rufopiceous, apical portion of the latter somewhat infuscate; body broadly 
oval, moderately convex, with numerous minute, hardly discernible setae, the head and extremity of the eyltra bear a few that are more distinct, those on the labrum are quite yellow and conspicuous.

Head moderately coarsely and closely punctate, the labrum still more so. Thorax twice as broad as long, its straight sides gradually narrowed anteriorly, their margins a little thickened towards the base; apex slightly sinuate and margined behind the moderately prominent eyes, with subacute angles; the base obtusely rounded in the middle, feebly sinuate towards the sides, its angles rectangular but partly hidden by the shoulders; its sculpture rather finer than that of the head, near the base especially. Scutellum narrowly triangular, finely punctate. Elytra thrice the length of the thorax, the humeral angles thickly margined and bent inwards at the base thus to some extent overlapping the thoracic angles; their punctation along the sutural region is similar to that of the thorax, but becomes finer near the sides and obsolete near the apices; near each side of the suture, on the middle, there is a series of rather larger punctures, but there are no. other series, nor any indications of striae.

Tibae, externally and inwardly, fringed with short slender setae, the intermediate pair more curvate outwardly than the others; the anterior broadly grooved along the front or outer face; 3rd tarsal joint of each pair with a well-developed membranous appendage.

Antennae with distinct greyish pubescence, gradually expander from their 5th joint onwards, joints 8-10 quadrate, the terminal not quite as long as the preceding two combined.

Underside distinctly, though not densely, clothed with fine ashy hairs, those on the femora flavescent; its sculpture like that of $P$. opaculus, 3231, the metasternum moderately esarsely punctured, de.

$P$. opaculus, though similar, has dull elytra with somewhat coriaceous sculpture, and on each elytron 3 inner series of moderately coarse punctures and about 5 shallow, yet definite, outer striae. The posterior angles of the thorax are not overlapped by the shoulders, and the 7 th and 8 th joints of the antennae are obconical. Pascoe's Liochoria huttoni, 436, has the head, thorax, and underside "subtiliter punctatis"; it is therefore manifestly different from $P$. humeralis and $P$. opaculus.

Length, $9 \mathrm{~mm}$; ; breadth, $5 \frac{1}{3} \mathrm{~nm}$.

Wakatipu; January, 1910. Mr specimen was found by Mr. A. Philpott.

\section{Group lutcanidal:}

3116. Lissotes philpotti sp. nov. Lissotes Westwood, Man. N.Z. Coleopt., p. 254 .

Oblong, moderately convex and nitid; head and thorax nigrescent, elytra dark fuscous with obseurely rufescent sides, legs and antennae rufo-piceous.

Head irregularly and finely punctured, more closely and rather more distinctly near each side of the base, more distantly along the middle and on the broad depression before the eyes, it is widely depresser in front; its sides oblique in front, sinuate behind the eyes, with its hind angles projecting outwardly rather further than the front of the thorax. Labrum bisinuate at the apex, its outer angles obtusely ret obviously prominent. Thorax almost twice as broad as long, feebly bisinuate and fringed with slender hairs in frout, with obtuse angles; its sides slightly narrowed from the front to beyond the middle, from thence oblique, the posterior angles obsolete; lateral margins slightly reflexed near the 
minllle and, like the base, densely eiliate with short fulrescent setae; its punctation is like that of the hear, but more distant, and rather crarsel behind than in front. Elytra of the same width as the thorax at the base, just double its length, rounded posteriorly, their reflexed margins fringed with rather coarser setae than the thorax, and with short areet inlrous ones, which, howerer, are alsent from the dise: they are irregularly sculptured, some of the punctures being as fine as those on the thorax, the others, near the base and suture, are coalsers: each elytron is broadly, but only slightly, bicostate from the base to berond the middle.

Anterior tibiae, elongate and distinctly axcuate, with 5 external teeth, the frontal pair the most prominent, and, in addition to the projecting apical calcar, there are 2 protuberances on the inside, at the extrenity, the lower more spiniform than the upper; intermediate tibiae thickly setose, the upper and lower apical angles acutely prolnnged, with a distinct external tooth below the middle; the posterior sinilarly setose, with a small indistinct outer tooth, the apical angles less prodiced.

Scape flexuous, incrassate towards the extremity; basal joint of the inniculus distinctly smaller than the 2 nd or $3 \mathrm{rd}$, which are larger than the others, and, like them, obtusely produced inwardly; club densely pubescent.

IIandibles stout, strongly curved, the left slightly subangulate inwardly before the middle; the teeth just behind that point are large and prolonged inwardly so as to cross each other at the extremity, at some distance from the labrum; the upper teeth, directly orer the lower ones, are obtusely triangular, but, being much shorter, are distant from each other at the extremity.

Most nearly resembles the male of $L$. acmenus, 3.72. The mandibles ille of the same length as those of the smaller specimens of L. helmsi, 1:365. A careful inspection of the structure of the tibiae and labrum, withont reference to other details, will prove at once that this is miterially different from every other species of the genus.

o. longth (mandibles inclusive), $26 \mathrm{~mm}$; ; breadth, $12 \mathrm{~mm}$.

Hump Ridge, near Invereargill. It is with pleasure that I attach the name of its discoverer, ML. A. Philpott, to this species, which was found at an altitude of $3,500 \mathrm{ft}$. in February, 1911.

\section{(iToup) ('OPRIDAR}

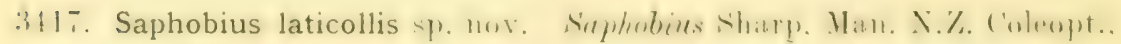
1). 255.

('onvex, short, oviform, nitid; sparingly clothed with fulvescent, moderatuly slender setale, which on the thorax are straight and depressed. but on the elvtri are distinctly curled; rufo-castaneous, legs rufescent. the postruior ilaker, antenme testaceous.

Hear distinctly but not very elosely punctured, evidently bidentate in front. 'Thorax widely emarginate at the apex, the breadth just double the length in the midslle, the rectinerular, though not acute. posterior angles slightly, ret quite definitely, wider than the base of the elytra, its sides nearly straight, but oblique near the acute anterior angles; its sculpture is not close, aud consists of oral rings, each of which has a minute centril puncture; the median groove does not reach the apex; there is a shallow oblique impression near each side in front. Elytra twice as long as the thmax, narrower than it is at the batse, with 
moderately rounded sides, their apical portion almost abruptly narrowed and deflexed ; each elytron with 6 very thin, lightly impressed striae, the sutural two, howerer" become pereeptibly broaled and deeper behind the middle.

Anterior tibine moderately curvate, quite oblique at the apex, obtusely inwardly prominent there, tridentate externally; the intermediate very gradually expanded; the posterior slightly flexuous.

The abnormal form of the thorax will at once lead to the discrimination of this species.

Length, $4 \mathrm{~mm}$. ; breadth, quite $2 \frac{1}{2} \mathrm{~mm}$.

Great Barrier Island. A single specimen found amongst leaf-mould collected for me in March, 1911, by Mr. Frank Flynn.

\section{Group DASCTLLidae.}

3418. Atopida impressa sp. nov. Atopida White, Man. N.Z. Coleopt., pp. 311 and 1141 .

Oblong, moderately convex, nitid, with distinct yet rather short yellow pubescence; hearl and thorax rufo-fuscous; elytra and legs testaceous, the former with a broadly triangular basal area slightly infuscate; antennae infuscate from the $3 \mathrm{rd}$ joint onwards, the basal ones paler.

Head subtruncate between the antennae, distinetly punctate-granulose, more closely near the eves; Iabrum deeply medially emarginate and but little exposed, with elongate yellow pubescence in front; mandibles uncovered, apparently obtusely "quadridentate inwardly; eyes prominent. Thorax somewhat uneven, narrower than the elytra, yet twice as broad as it is long, slightly sinuate behind the eyes; the sides finely margined, a little curved towards the subacute anterior angles, nearly straight behind, posterior angles rectangular; there is a broad oblique impression at each side of the middle, and a pair in front of the scutellum; the disc is distinctly but not closely punctate, but towards its sides the sculpture nearly resembles that of the head. Scutellum large, subcordate, finely punctured. Elytra four times the length of the thorax, distinctly and irregularly punctate.

Antennae finely pubescent, rather elongate, their basal joint stout and oblong, 2nd slightly longer than broad, joints $3-10$ about equally elongate, 11th longer.

There is no similar species. The uneven thorax is peculiar.

Jength, $5 \frac{1}{2} \mathrm{~mm}$; ; breadth, $2 \frac{1}{3} \mathrm{~mm}$.

Scaward Moss. Invercargill. Describer from a specimen on cardboard sent by Mr. A. Philpott.

\section{Veronatus punctipennis sp. nov. Veronatus Sharp, Man. N.Z. Coleopt., p. 314.}

Oblong, slightly convex, nitid, nearly glabrous, the sides of the head and thorax only with some slender yellowish pubescence; castaneo-rufous, most of the thoracie dise piceo-fuscous; the legs, antennae, and palpi fuseo-testaceous.

Head narrower than the thorax, finely punctate, a little more coarsely and elosely behind the eyes. Iabrum inedially notehed and distinctly ciliate in front, separated from the truncate forehead by a transversal membrane. Thorax a fourth of the length of the elytra, about twice as broad as it is long; brondly medially rounded in front, with obtuse 
angles, its siles tinely marginenl and only slightly curved, posterior angles obtuse; the surface is a little uncren, having a more or less definite linear impression along the middle and a lange shallow forea near the base; its punctiation is tine but not elose, with minutely coriaceous interstices. Sentellum cordiform, finely punctate. Elytra bromer than the thorax at the base, with rounded shoulders, distinctly, ret not eoursely, and moderately closely punctured; each elytron is feebly tricostate; the and and 3rd costale nearly reach the apex, where the punctation leemenes finer.

'Tibiate straight, fringed externally with spiniform setae, and bearing alsu slender pubescence.

Antennae elongate, basal joint short and thick, 2nd small, 3rd rather shorter than the the others about equally elongite.

In facies somewhat similar to $F$. longicornis, 566, lut with tricostate wing-cases like 567, and rather larger than either of these.

l.ength, $10 \mathrm{~mm}$; ; breadth, $4 \frac{1}{\mathrm{~m}} \mathrm{~mm}$.

IIount Arthur. Eommel by Mr. G. Y. Iludson, at a height of $t, 000 \mathrm{ft}$. A single individual.

34:1). Mesocyphon capito -p. nov. Mesoryphom Shatp, Hin. X.Z. ('uleopt.. p. 316.

Sublepressed, oblong-oral; head and thorax fuseo-rufous and opaque; elytra slightly nitid, variegated castaneous, rufescent near the base, fuscous behind, their pubescence distinct, unerenly distributed. for the nost part brassy, but intermingled with a few darkel hairs; femora and palpi fusco-testaceous, the tibire eastaneous.

Head rather large, molonged anteriorly, with a broal but shallow interoulat impression; its seulpture close, mather fine, gramular, and rogose; the pubesecence fince than that of the elytrat Antemnate with the basal joint thick, oblong, and reddish; 2nd and 3rd paler than the following castancous ones, the former quite half the length of the latter, the thin rather longer than the adjoining ones. Thorax strongly transrorie, the middle of the base and apex slightly rounded, its sides finely margined amd nearly straight, all the angles subrectangular; it is ratler finely punctate-gramulose. Elytra broader than the thorax and four times its length, finely and rather indefinitely sculptured, appearing punctate or minutely granulate according to the point of riew.

Vear M. monticola, 1727, larger than it is, the head larger, the eyes more distant from the thorax, and the granulation less obvious.

l.ength, $6 \frac{1}{2} \mathrm{~mm}$; ; breadth, $2 \frac{3}{3} \mathrm{~mm}$.

Kontolie, neis Mollington. My specimen is one of Mr. G. V. Hurlson's captures.

\section{Mesocyphon vestitus sp. nov.}

Subdepressed, elongate-oblong, slightly nitid; rather thickly covered with decumbent, distinct, pale-yellow pubeseence; of a light-chestnut hue, but with the head, palpi, and terminal joints of the antemae more infuscate.

Head with close, fine, indistinct seupture, the forehead truncate and extending beyond the antennae; labrum and mandibles reddish, the former promiment. 'Thomx evidently nirrower than the elytra, only a fourth of their length, rery little broader than it is long, apex subtruncate, its angles a little depressed and not at all prorrect; its side: are gently rombled, the bnse more strongly, the postering angles, there 
fore, are obsolete; its surface is destitute of perceptible sculpture. Scutellum large. Elytra oblong, incurved at the base, very slightly and gradually dilated posteriorly, so that their sides are nearly straight; they are feebly impressed before the middle, but the sculpture is so fine and ill defined that it cannot be accurately described.

Antennae moderately elongate, their lst joint short and thick, the next oblong, 3rd more slender and shorter than the elongate but moderately stout 4th, joints 5-10 finely and densely pubescent, each rather longer than broad and nearly similar to one another, the terminal rather longer than its predecessor.

Underside subopaque, fuscous, very finely and closely sculptured, and bearing fine greyish pubescence.

The almost uniform coloration and evenly pubescent surface, as well as that underneath, ally it to $M$. pallidus, 2024, which, however, is easily separable by its oval contour and distinct thoracic hind angles.

Length, $4 \frac{1}{2} \mathrm{~mm}$; ; breadth, fully $1 \frac{1}{2} \mathrm{~mm}$.

Hump Ridge, Okaka. Found at an elevation of 3,500 ft. by Mr. A. Plilpott, who sent me a pair of specimens.

\section{Mesocyphon longicornis sp. nov.}

Subdepressed, oblong-oval, subopaque; thickly covered with decumbent greyish-rellow pubescence; castaneous, leg's and antennae paler.

Head narrower than the thorax, prolonged, and truncate in front of the antennae, with rather indistinct fine granular seulpture. Thorax twice as broad as long, subtruncate in front, with obtuse angles there, its sides nearly straight, base bisinuate, with rectangular angles, the surface minutely granulate. Scutellum large. Elytra with rounded shoulders, so that the base seems to be but little wider than the thorax; they become broader behind the middle, and are of the usual length; they are somewhat flattened or longitudinally impressed along the basal half; there is an oblique, but not conspicuous, dark mark on each elytron from the hind thigh towards the suture, which bears finer ashy pubescence; their ill-defined sculpture is obscured by the vestiture.

Antennae elongate, filiform but not rery slender, basal joint thick and a little longer than broad, the slender $3 \mathrm{rd}$ not twice the length of the 2nd, 4th slightly longer than adjacent ones, joints 3 to 11 unusually elongate, each nearly thrice as long as broad.

Underside finely pubescent, the abdomen irregularly maculate with brown.

There need be no difficulty in identifying this species, the antennal structure of itself being distinctive.

Length, $6 \mathrm{~mm}$.; breadth, $2 \frac{1}{2} \mathrm{~mm}$.

Otira Gorge; Januar, 1911. Two examples from Mr. H. W. Simmonds, of Wellington.

\section{Cyphon deterius sp. nov. Cyphon Paykull, Man. N.Z. Coleopt.,} p. 318.

Oblong-oval, rather narrow, slightly convex, nitid; pubescence slender, yellowish-grey, evenly distributed on the elrtra; the head, a broad median space near the base of the elytra, and the thoracic disc fuscous; the rest of the elytra fusco-testaceous; the sides and basal margin of the thorax obscurely rufescent; the tibiae and basal five joints of the antennae testaceous; remaining joints of the latter, and the femora, infuseate. 
Heat evidently namower than the thomx, minutely, indistinetly, and distanty granulate. 'Thema nearly twice as broul as long, only a fouth of the length of, and hardly as broad at the base as, the elytra; its sides finely margined and slightly roumed, with subrectangular angles; its hase very distinctly matrined, rounded at the middle, and sinuated towards the sides; the sonlpture like that of the head. Seutellum triangular. Elytai ablong. slightly dilated behind the middle, distincty and moderately closely punctured in front, much more finely tomials the extremity, the disc only feebly impressed or flattened.

Antennate longer than the head and thorax, stout, finely pubescent, with their Lud joint nearly as long and thick as the 1st, the 3rd slender and evidently shorter than the fth, the terminal longer than the 10 th.

Underside fuscous, finely seulptured and pubescent. Subocular line absent.

'This belongs to the same section as $C^{\prime}$. grmniger, 584. and ' ' prefulus, j85, but difiers from both.

L.ength, $2 \frac{1}{4} \mathrm{~mm}$. ; breadth, $1 \mathrm{~mm}$.

Hump Ridge, Okaka. 'Two from Mr. d. Philpott. A third has the thorax entirely fuseous, and the datk basal natk of the clytra extends along the suture. The granulation is rather more definite.

\section{GPoup ('TARIDAR:}

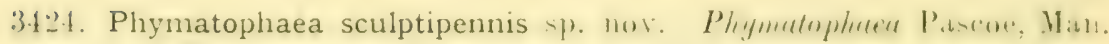 I.Z. Coleopt., p. 33t.}

Subdepressed, elongate, opayue; nigrescent, the legs and antemnae, except the densely pubescent elub, slightly nitid; sparingly clothed with suberect, incomspicums, dark-einereous pubesence; the hairs along the sicles and those on the legs thicker and more elongate; claws castaneous.

Head, including the large and prominent eyes, as broad as the thorax, very closely and coarsely but not reeply punctured. Thorax of about equal length and breadth, willest and rumded behind the middle, its sculpture slightly deeper than that of the head. Elytra rather broader than the thoraix at the base, gradually dilated posteriorly, with broally rounder apiess; their surface plane, distinetly but rery much less coarsely punctured than the thor:ax, the punctures distinctly separated from one another and beconing olssolete near the apices, the interrals dull, with dense minute seulpture.

Antennae evidently longer than the head and thorax, basal joint stont and eurvate, 2nd unsimmetrical and short, 3rd cylindrical, rather. Ionger than th, joints $4-6$ similar, ith slightly shorter than 6th, Sth but little longer than broad; club as long as the preceding joints combined, basal joint longer than the elongate-triangular intermediate one. the terminal elongate-ovate.

l'arsi with the hasal three articulations poulunered, and with more or less distinct membranous appendages molemeath, fth minute, the terminal slender and in the anterior pair almost as long as the others taken tngretler; chaws obrinusly thickenerl, but not dentate at the base.

I. alrata, 1202, is molerately shining, and has the dytral punetution rather close, enarse, and deepr.

I'. opurulu is easily separable by its rufo-riolacenus colorations.

length, of mm, ; beadth, mearly $2 \mathrm{~mm}$.

Kinori. Willington. My specimen, mounted on earlboard, is one rif Mr. 1:. V. Hurlson's dismreries. 
3425. Phymatophaea fuscitarsis sp. nov.

Variegate, moderately nitid, fusco-castaneous, the apex and base of thorax, the sides and apices of the elytra, paler; legs and basal joint of antennae testaceous, tarsi fuscous; pubescence grey, unevenly distributed, suberect.

Head very coarsely punctate, with linear interstices. Eyes very prominent, projecting beyond the widest part of the thorax. Antennae elongate, the club opaque, its terminal joint pyriform, much narrowed towards the base, and shorter than the penultimate. Thorax as long as it is broad, only moderately dilated and rounded behind the middle, its punctation not quite as coarse and close as that of the head. Elytra rather broader than the thorax at the base, only slightly expanded behind, subseriate-punctate, the punctures well marked, not quite regular, and becoming obsolete on the paler apical portion; their surface not quite plane, with a slight sutural depression near the base, but without well-clefined elevations or costae.

Tarsi similar to those of $P$. sculptipennis, but with the claws less thickened at the base. Pygidium uncovered and quite black.

This should be placed near Pascoe's $P$. opiloides.

Length, $6 \mathrm{~mm}$.; breadth, nearly $2 \mathrm{~mm}$.

Wainuiomata, Wellington. I am indebted to Mr. Gr. T. Hudson for a specimen.

\section{Phymatophaea breviclava sp. nov.}

Variegate, moderately shining; dark fuscous; the elytra with obscure greyish marks which form a pair of indefinite fasciae before the middle, these unite with an equally obscure longitudinal vitta near each side, apices similarly pallid; legs more or less fusco-testaceous, antennae and tarsi rather darker; irregularly clothed with slender greyish hairs.

Head and thorax closely and coarsely punctate; the former, including the large prominent eyes, is fully as broad as the thorax, which is dilated laterally behind the middle, and above bears a pair of small obtuse nodules near the front, and another even less distinct pair near the base. Elytra rather broader than the thorax, almost parallelsided; very slightly unlevel above, with deeper and more definite punctures than those on the thorax; these are subseriate, but the pale posterior part is only obsoletely sculptured.

Antennae only moderately elongate, of normal structure, but with an unusually short club, its basal joint being elongate-triangular, the 2nd scarcely any longer than it is broad, and the terminal subrotundate but hardly longer than its predecessor.

The structure of the club is distinctive; it is not, however, a sexual character; in other respects it is allied to the $P$. opiloides section of the genus.

Length, $4 \mathrm{~mm}$; ; breadth, nearly $1 \frac{1}{2} \mathrm{~mm}$.

Kaitoke, Wellington. The only available example is also from Mr. Hudson's collection.

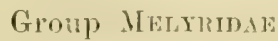

3427. Dasytes laevulifrons sp. nov. Dasyfes Paykull, Man. N.Z. Coleopt., p. 328.

Elongate, narrowed anteriorly, subopaque, sparingly clothed with short, curled, greyish hairs; uniformly dark cyaneous; the palpi, antemnae, and legs piceo-niger. 
Head gradually nurowed behind the large, moderately prominent cres, its frontal portion mearly plane and smooth, having only a few minute distant punctures there, but with dense minute sculpture behind the cres. Thorax widest and rounded at or just behind the middle, broadly constricted in front; with a shallow, medially interrupted, linear dorsal impression, its punctation very fine and remote, the intervals with minute coriaceous sculpture; lateral margins obsolete, the length and breadth about equal. Scutellum subquadrate. Elytra broader than thorax at the base, nearly thrice its length, slightly and gradually expanded posteriorly, the apex broadly rounded; near each shoulder there is a short impression, their punctation is rather fine, and in some aspects appears transversely rugose.

Legs elongate, the claws castaneous, and provided with membranous appendages. Antennae not longer than the head and thorax, somewhat nitid, joints $4-10$ subserrate, 11 th ovate, the $3 r$ as long as the 4 th.

D. orecheris, 2036, its nearest alley, has the head and thorax of a lighter blue, and the elytra are tinged with green. It is a larger insect, with similarly bent or curled setae, and its forehead, like the rest of the head, is densely and minutely sculptured.

Length, $51 \mathrm{~mm}$. ; breadth, nearly $2 \mathrm{~mm}$.

Routeburn, Wakatipu. One example, secured by II. G, T. Hudson during Februarr, 1911.

\section{Group Hitopida.}

3428. Adelium calcaratum sp. nov. Adelium Kirby, Man. N.Z. Coleopt., p. 386 .

Oblong-oval, moderately convex, nitid; fusco-niger, legs piceous, the tarsi and basal four joints of the antennae piceo-rufous, remaining articulations, castaneous; on the head and thorax a few upright, slender, pale setale are perceptible.

Hear immersed up to the eres, somewhat rounded anteriorly, slightly uneven, the forehead having a large shallow impression across it, the whole surface moderately finely and elosely punctate. Thorax, in the milldle, nearly twice as broad as long, its sides distinctly and evenly margined; it is only a little wider at the middle than elsewhere, slightly eurvedly narrowed towards the obtusely prominent anterior angles, and very slightly narrowed backwards, nearly straight indeed, with its rectangular posterior angles resting on the elytra; the base widely and feebly emarginate, the apex obviously arcuate-emarginate; it is moderately finely and closely punctured, much more finely and remotely near the sides; at the middle, near each side, there is an elongate impression, along the middle, behind, a shallow linear mark, and near each hind angle a transversal shallow depression. Scutellum short, triangular. Elytra somewhat broader than the thorax, nearly thriee its length, their sides nearly straight as far as the middle, from thence gradually narrowed posteriorly; on each elytron there are 8 series of modcrate, closely placed punctures, those nearest the suture are in striae; interstices plane, finely and irregularly punctate, the 3rd rather wider than the others, apical sculpture less distinct, none of the striae extending so far back.

T'ibiac feebly pubescent towards the extremity; the anterior incrassate and eurver; the intermediate gradually expanded, each, at its inner extremity, armed with a short ret quite definite calear; this is directer inwardly; the posterior pair are simple but more elongate. 
'Tarsi with fulvous setae, the front pair rather bruader than the others, basal joint of the hind paix longer than the 2nd and 3rd together.

Antennae as long as the head and thorax, with yellow pubescence, their 2nd joint subquadrate and nearly as long as the exposed portion of the thicker 1 st, 3 rd rather longer than 4 th or 5th, joints $7-10$ elongateobconical, the terminal elongate-oval.

Underside shining, finely sculptured, the basal ventral segment strongly rounded between the coxae.

This bears some resemblance to $A$. nigritulum, 1669 , but it is smaller, with quite regular elytral seulpture. The projection at the inner extremity of the intermediate tibiae distinguishes it, so far as I remember, from all the other species.

Length, $11 \mathrm{~mm}$.; breadth, $5 \mathrm{~mm}$.

Paradise, Wakatipu. I am indebted to Mr. G. V. Hudson for my specimell.

\section{Adelium tinctum sp. nov.}

Oblong-oval, slightly convex, shining, nearly glabrous, having only a few erect, slender setae; nigrescent, tinged with rufo-violaceous, legs piceous, tarsi fusco-rufous, antennate and palpi dull fuscous.

Head slightly uneven, rather finely yet distinctly and irregularly punctured. Thorax quite a third broader than long, widest near the middle, curvedly narrowed towards the obtuse front angles, slightly sinuously narrowed behind, with distinct lateral rims; the apex distinctly, the base only feebly, emarginate in the middle and subtruncate towards the sides, so that its straight angles, though resting on the elytra, do not project backwards; the median groove is shallow and ill defined; the rather large basal foveae are situated nearer to the angles than to the middle; in front of each of these there is a shallow, rather large, irregularly shaped impression, and nearer each side a smaller one; its punctation is like that of the head but becomes finer and more distant at the sides, there are also a few coarser punctures. Scutellum rounded behind. Elytra rather broader than the thorax and more than twice its length, slightly wider at the middle than at the base, considerably ret gradually narrowed posteriorly; their seulpture extremely irregular; near the suture, on each elytron, there are 2 or 3 , more or less interrupted, rather finely and closely punctured indefinite striae; berond these the sculpture consists of abbreviated series of fine punctures and linear impressions and very unequal smooth spots of variable form, but not elevated like those seen on $A$. bullatum.

Antennae with dusky pubescence, 2nd joint oblong, 3rd evidently longer than 4 th, joints $5-10$ differ but little, 11th oval, rather longer than 10th. Maxillary palpi with deeply concave terminal joints. Legs moderately stout, anterior tibiae moderately arched and bearing short Havescent setae near the inner extremity.

At once distinguishable from $A$. chalmeri by the riolaceous instead of reddish-copper colour, by the obliterated in place of well-marked thoracic groove, more attenuated hind-body, ife.

Length, $12 \mathrm{~mm}$.; breadth, $5 \frac{1}{2} \mathrm{~mm}$.

Paradise, Wakatipu. One from Mr. Hudson

Group MELANDRYIDAF.

Axylita gen. nov.

Body elongate, subcylindric. Eyes entire, or not perceptibly emarginate in front, widely separated above, occupying nearly the whole side 5-Bull. No. 1. 
of the head, their greatest bulk from abore downwark, moderately prominent, with rlistinct facets. T'arsi with bilobed penultimate joints, those of the intermediate and posterior minute. 'l'ibiae unequal, the anterior shortest, their fincly pectinate spurs very short, those of the hind pair hardly a fourth of the length of the bisal tarsal joint, which is considerably longer than the remaining ones united.

This belongs to Lacordaire's seeond division, consisting of the Mycctomides, Orchesides, and Synchroides, all of which are primarily fistinguished by the non-contiguity of the anterior coxae. From all the genera placed in that division, drylitn is differentiaterl by the character recorded above.

\section{Axylita sericophora sp. nov.}

Subopaque, fuscous; the legs, antennae, and palpi castaner-rufous; rather densely eovered with fulvescent, depressed, slender hairs; these are not disposed singly, several being attached to an equally slender main stem, so that the pubescence appears somewhat feather-like.

Head finely sculptured, the rufescent forehead prolonged, subquadrate and vertical. Thorax of equal length and breadth, eurvedly narrowed before the middle, apex also slightly curved so that the anterior angles are quite obsolete; the base with an obtuse central lobe, but nearly truncate towards the subrectangular angles; its sculpture fine, close, but ill defined, not punctiform, comsisting alpatrently of minute irregular

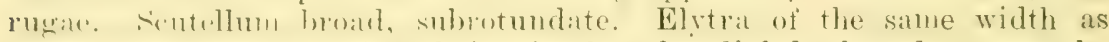
thorax at the base, fully thrice its length, slightly broader near the middle, gradually attenuate posteriorly, and a little dehiscent near the extremity, with sculpture nearly similar to that of the thorax.

Antennae inserted near the upper and inner part of the eyes, along the front of each of the latter there is a straight antennal groove; they reach backwards to the shoulders, their 2nd joint is distinctly smaller than the adjacent ones, $3 \mathrm{rd}$ as long as the 1 st but more dilated towards its extremity, 4th rather thicker than 5th; all the following ones longer than hroarl, narrowed basally ; 8-10 slightly smaller; the terminal rather longer than 10 th.

Legs elongate, bearing slender fulvescent setae; anterior tibiae slightly bent, the hinder pairs not at all asperate externally. T'arsi pubescent above; basal joint of the anterior largest, twice as long as it is broad; 2nd and 3rd moderately expanded, subquadrate; 4th about as long as 3rd, broadly excavate above, and bilobed; 5th implanted at the middle of the penultimate, slender but not very elongate; posterior filitorm, as long as the tibae.

Maxillary palpi with very elongate, but hardly cultriform, terminal joints, which, at the base, are exactly fitted to the subtriangular 3rd; the labial minute.

Length. 8 mm. ; breadth, $2 \frac{1}{3} \mathrm{~mm}$.

Tislury, Invereargill. One from Mr. 1. Philpott.

\section{Allorchesia gen. nov.}

Body moderately arched above, elongate-oval, finely pubescent.

Head retracted as far as the eves, nearly vertical in front, forehead prolonged and narrowed anteriorly; elypens very short; labrum prominent, its apex rounded. 'Thorax rather broader than long, hardy a third of the length of the elytra, curvedly narrowed towards the subtruncate apex, which is finely margined from the eyes downwards, the base slightly bisinuate but not at all lobate medially. Scutellum absent. 
Elytrat as broad as thorax at the base, gradually attenuate behind the middle, with acute but not divergent apices.

Eyes widely distant above, prominent, with distinct facets; they are large above, but taper downwards without any definite emargination. Antennae inserted before the middle of the eyes ; basal joint stout, crlindrical, nearly as long as the elongate $3 \mathrm{rd}$; 2 nd wort yet longer

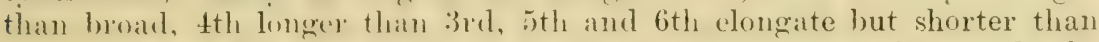
4th: Tth and sth distinctly longer thatn broad, natrowed towards the base; 9th and 10th obconical, rather broader but a little shorter than the preceding ones, the terminal joint broadly oval or subrotundate. 'Terminal joint of maxillary palpi subtriangular or broadly cultriform. Legs robust; tibiae not asperate externally, the interuediate longest, the posterior short, almost elongate-triangular, hardly longer than their equal, distinctly pectinate spurs, these nearly attain the extremity of the long basal joint of the tarsi, the terminal three are well developed and slender and together barely the length of the 1st, with slender claws. Anterior tarsi dilated, basal four joints cordiform, the 1st longest, 2nd and 3rd transverse, penultimate deeply emarginate above and below and therefore sublobate, the terminal moderately slender, inserted near the base of its predecessor and twice its length; penultimate joint of the intermediate pair with moderately elongate lobes.

Prosternal process prolonged to the extremity of the coxae, the mesosternal cariniform in front. Flanks of prosternum distinctly defined. Trochanters present.

The entire absence of the scutellum at once separates this from all its allies, whilst the differently formed eyes, antennae, and tarsi distinguish it from Orchesia. In Neorchesia the eyes are flat.

\section{Allorchesia validipes sp. nov.}

Nitid, elytra subopaque, and covered with depressed, slender, greyish-yellow pubescence, and bearing also, towards the extremity particularly, a few slender erect setae; body castaneo-rufous, legs and antennae somewhat fulvescent, anterior tarsi testaceous.

Head moderately closely, rather finely, yet quite definitely punctate. Thorax finely margined laterally behind the middle, a little rounded there, so that the base is not quite as broad; its sculpture as close as that of the head, the punctures not as well defined, and with a tendency to become transformed into fine irregular rugae near the sides. Elytra rather wider near the posterior femora than elsewhere, with slightly convex, acuminate apices, which are narrowly separated; their sculpture near the shoulders is similar to that near the sides of the thorax, but it is finer elsewhere; the sutural striae are very fine at the base, but well marked behind; the pubescence is feather-like near the middle.

Underside a little shining, reddish-chestnut, the abdomen paler, finely punctured, with fine yellow pubescence, its basal segment bipunctate between the middle and each side, the breast closely punctate.

o. Length, $5 \mathrm{~mm}$; ; breadth, $1 \frac{2}{3} \mathrm{~mm}$. 1911.

Erua, altitude $2,400 \mathrm{ft}$. A solitary male is all I conld find; January,

Ols.-3258, also unique, should be transferred to this genus, not only on account of similarity of structure, but also beause there is no scutellum. The insect itself', now Allorchesia guinnessi, is a good deal smaller, with more slender legs and less dilated anterior tarsi; this last character, to some extent at any rate, may be only sexual. 


\section{Neorchesia gen. nov.}

Body arched above, elongate-oval.

Head immersed up to the eyes, rounded and finely margined behind; the forehead truncate in front, and extending beyond the antennal insertion; epistome very short and straight; labrum prominent, its apex rounded. Thorax a trifle broader than long. Scutellum strongly transverse, round behind. Elytra elongate-oval, with individually acuminate and divergent apices.

Handibles bifid at the extremity. Maxillary palpi stout, basal joint small, the next broadly triangular, 3rd shorter and broader, both of these somewhat prolonged inwardly; the terminal large, broadly cultriform. Eyes widely distant above, emarginate below the middle in front, subreniform. Antennate inserted within the notehes of the eres, equalling the head and thorax in length; joints 8-11 slightly exprumbled; basal joint thick, 2ud shortest yet rather longer than broad, :3-5 elongate and nearly equal, 6 th and 7 th a little shorter. Tibiale wot asperate, the front and hind pairs short, middle pair more elongate; spurs of the posterior equal, distinctly pectinate, about as long as the tibiae, and almost the same length as the basal tarsal joint; those of the other pairs short. Ta:si hairy, the anterior dilated, basal joint largest, 2nd and 3rd cordiform, 4th rather longer than 2nd and bilobed; the intermediate moderately slender, penultimate joint rather longer than the 3rd and bilobed; the posterior slender, nearly double the length of the tibiae, basal joint twice the length of the $2 \mathrm{nd}$, which is about as long as the elongate 3 rd and 4th combined.

Coxae not contiguous, with trochanters; the anterior separated by a triangular, finely margined, gradually narrowed process which extends to their hind part, where it is met by the horizontal, moderately narrow, parallel-sided mesosternal process that separates the middle coxae. Front margin of the anterior cotyloid eavities almost touching that of the incurved front of the prosternum. Metasternum elongate, convex, but sulcate, along the middle, the epistema slightly narrowed posteriorly. Abdomen elongate, with 6 segments; basal four gradually dererasing; 5th rather longer than 4th, subtruncate behind; 6th much smaller, with a triangular depression having thickly ciliate margins.

Resembles II flobia velox, 710, in form, but structurally almost entirely different. The Amercian Synchroa is at once separable by its exserted head, Hallomenus by its emarginate labrum, Eustrophus by the denticulate tibiae. 'The only other exotic ally is Orchesia, which has only 5 abdominal segments and differently formed antennae. Comparison, through want of space, has been restricted to easily seen characters.

\section{Neorchesia divergens sp. nov.}

Subopaque, fuscous, clothed with depressed, slender, ashy pubescence; legs fusco-rufous; the palpi, front, and middle tarsi fulvescent; posterior tarsi and the antennae more infuseate.

Head moderately finely, yet quite distinctly, punctate. Thorax curvedly narrowed anteriorly, its apex also rounded, anterior angles deflexed and obsolete; the base subtruncate in the middle, sinuate outwardly, so that the subrectangular angles seem to be directed slightly backwards; the punctation on the dise is shallow and indistinct; it is rather more definite in front, and closer at the sides. Elytra as wide as the thorax at the base, considerably narrowed posteriorly, with a 
triangular sutural gap at the extrenity; their sutural striaie are obsolete rear the base but well marked behind; the seulpture is close but not sharply defined, in some lights appearing punctate; they are four times the length of the thorax.

Underside fuscous, minutely and elosely sculptured, and bearing fine yellowish pubescence.

The acuminate and divergent elytral apices will aid its identification. Length, $5 \mathrm{~mm}$.; breadth, $1 \frac{1}{2} \mathrm{~mm}$.

Raurimu. Unique. Found by myself in Janualy, 1910, at an elevation of $1,900 \mathrm{ft}$.

\section{Mecorchesia gen. nov.}

Body very elongate and nearly quite parallel.

Head immersed up to the eyes; foreherd much prolonged, nearly; perpendicular, riather longer thin broad and truncate; clypeus not distinctly marked off, almost linear and membranous; labrum rounded at apex, prominent. 'Thorax of about equal length and breadth, its base very feebly rounded medially and sinuate outwardly, appearing almost truncate, without anterior angles as viewed from above; when examined sideways a distinct margin is seen to extend from below the middle of the eye towards the middle of the prostermal apex. Scutellum extremely short, hardly visible. Elytra as wide as thorax at the base, very gently attenuate behind the middle, the extremity rounded.

Maxillary palpi robust, basal joint small; the next triangular, elongate and straight outwardly, sinuate and concave in front, its inner angle acute but not extending as far forwards as the outer; 3rd much shorter, similarly formed in front, rounded behind; the terminal cultriform, attached hehind the mislde to the onter ar front angle of the 3rd, so that its base appears inwardly prolonged. Eyes widely distant above, covering the whole sides of the head, slightly notched in front above the mirldle, where the antennat are inserterl in suleiform carities. Antennae filiform, very elongate, reaching backwards to the hind thighs; 2nd joint smallest, yet longer than broad; the lst gradually dilated but shorter than the $3 r d$; the others also elongate.

Legs elongate; the internediate and posterior tibiate evidently asperate externally, with pectinate spurs, those of the posterior half the length of the basal tarsal joint, which is nearly as long as the tibia; joints 2-4 slender and simple, gradually decreasing and, together, almost as long as the 1st: anterior tibiae rather shorter, tarsi rather longer, slightly expanded; basal joint largest; 2nd and 3rd oblong; 4th slightly shorter, deeply emarginate above, entire underneath; 5th slender, not longer than $3 r d$; penultimate joint of middle tarsi with short lobes: claws simple.

Prosternum medially subtruncate in front, without any sign of demarcation between the coxae and its Hanks, the cotyloid cavities rather distant from its apex; its triangular process projects acutely nearly to the tips of the coxae. Mesosternum remarkably elongate, equalling the metasternum in length; the process separating the middle coxae is moderately narrow, but in front is compressed and cariniform. Metatsternum elongate, obtusely convex and obviously sulcate along the middle; the episterna nearly twice as wide in front as behind. Trochanters distinet. Abdomen nearly twice as long as the metasternum, composed of 7 decreasing segments; 5th medially emarginate at its apex; 6th short, similarly cmarginate; the terminal short ret quite distinct and finely margined at the extremity. 
The unusually long mesosternum, eansing the front and middle legs to be further apart than the middle and posterior, very clongate antennae, the absence of any prosternal suture, and the presence of 7 abdominal semments instead of the normal 5 , are its most remarkable fentures.

\section{Mecorchesia spectabilis sp. nov.}

Furco-castaneous, slightly nitid, densely elothed with depressed yellowish hairs, those on the labrun bright yellow; the legs, antennae, jalmum. and palpi nore or less rufo-castaneons.

Head fincly punetate behind, with fine linear or rugose seulpture in fromt. Thorax nearly straight and very finely margined behind the middle, moderately curvedly narrowed towards the truncate apex, the hind angles subrectangular; Jather finely and closely punctate, the punctures, however, are not sharply defined; its length is only a fourth of that of the elytrat. Elytra not quite as broad as the micldle of the thorax, their broudly rounded apices not corering the paler prgidium; the sutural striae are distinet at the base, becone broader behind it, but do not reach the extremity; there are also about $t$ less definite dorsal striate on each elytron; the surface is finely and closely punctured, but near the base and sides the seulpture is a little coarser, and seens to consist of short transverse rugae.

Anterior tarsi densely pubescent; the middle and hind tibiae with small, somewhat rufescent, irregularly concentrated setae externally.

Underside shining, the breast slightly rufescent; abdomen fuscous, densely clothed with fine rellowish pubeseence, but becoming coarser near the extremity; midlle of prosternum smooth, the rest of the surface closely and finely punctate.

oे. Length, $11 \mathrm{~mm}$. ; breadth, $2 \frac{1}{2} \mathrm{~mm}$.

IVaitakerei Range. Deseribed from two specinens in nu own collecetion, both shaken oft shrubs.

\section{Mecorchesia brevicornis sp. nov.}

Elongate, narrow, moderately convex, a little shining; the clothing distinct, obscurely fulvescent; nigro-fuscous, but with an olivaceous tinge; the labrum, palit, antennae, and tarsi more or less rufocastaneous.

Head with fine, distinct, but not approximated punctures. Thorax of equal length and brealth, about a fouth as long as the elytra, gently curvedy narowed from the middle towards the truncate apex, nearly straight and finely margined laterally behind, the base fincly magined, jeebly angulate in the middle, slightly sinuate outwardy, with almost rectangular angles; its punctation fine and rather distant along the dise, but disposed in transverse series, so as to appear finely rugose, at the sides. Scutellum short and broad. Elytral gradually attenuate posteriorly, the extremity sharply rounded, corered with fine, irregular, transverse seulpture; cach elytron with a sutural and 4 dorsal striae, these latter are quite distinet at the base but do not extend much beromel the hind thighs, the sutural nearly reach the apex. Intennae filiform, attaining the intermediate femora, of normal structure, as are the leass. 
Underside rather more glossy than the dorsum, of the same colour. When compared with the typical species it will be noticed that this has the mesosternal process broader anci less convex behind though quite carinate in front; the middle of the prosternum, instead of being smooth and shining, is rather dull and finely and closely punctate; the abdonen has 5 segments only, the last being longer than the th and trumeate at the apex: in both species the posterior coxal laminae are nearly straight, and extend but little forwards at the sides.

Length, $11 \mathrm{~mm}$; brearlth, $1 \frac{1}{1} \mathrm{~mm}$.

Wellington. A single specimen from Mr. G. V. Hudson, marked $136 \mathrm{~A}$.

Obs.-It may be considered an aberrant species till other exanples can be found of both sexes; at any rate, there is no other place for it at present.

\section{Lyperocharis gen. nov.}

Budy alleded above, uninteruptedly dongate-uval, fincly pubescent; species minute.

Hearl immersed up to the eyes, just visible above, the forehead prolonged and incurved in front, clypeus indistinct, labrum prominent, its apex lounded. Thor:ax rather broader than long, curvedly narrowed from the base onwards, its apex rounded, the base medially truncate; but with its almost rectangular angles resting on the shoulders. Scutellum absent. Elytra of the same width as thorax at the base, apices distinctly rounded singly, so that the last abdominal segment is visible.

Eyes small, widely distant above, tapering downwards, teebly emarginate in front. Antennale inserted in foveiform, but not deep, cavities in front of the eyes, 11-articulate, gradually yet considerably incrassate from their "Tth joint onwards, they are rither longer than the head and trorax. Itasillary palpi with luge subsecuriform or triangular terminal joints, 2nd small and triangular, 3.r shorter and broader:

Legs moderately elongate; tibine not asperate, the posterior pair

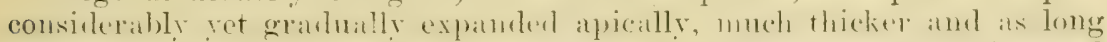
as the others; their mequal pectinate spurs as $\operatorname{long}$ as the tibiae and slightly exeecling the basal tarsal joint, the terminal is slightly lomere than the penultimate, the last three mited are labrlly the length of the 1st, the spurs of the ather pairs are very small; anterior tarsi not expander, all their joints, the apical includesl, of about equal brealth, 2-1 transverse, the basal rather larger; none of the penultimate joints bilobed; claws slender.

Prosternum strongly incurved, with distinctly marked-ofi flanks, the front margins of the cotyloid eavities in contact with the prosternal apex, the moderately broad process separating the oblong, oblique coxae extends behind them, and rests on the broad frontal portion of the mesosternal process, which, between the enxae, is not as broad as the prostcrnal. Metasternum elongate, laterally compressed, earinate and finely sulcate, without episterna. Suture of posterior coxal lamina very oblique, extending from the coxil to before the middle and outside of the metasternum. Abromen composerl of 5 segments. Trochanters distinet.

Independently of minor structural details, this genus is rendered remakably distinet not only by the robust subclavate antennae, but also by the absence of the seutellum and metathracic episterma. This is the only instance known to me in which both of these characteristics are lacking, though Allorchesia is also without the sentellum. 


\section{Lyperocharis agilis sp. nov.}

Body slightly nitid, varying from fusco-castaneous to an obscure fulvescent hue; legs chestnut-red or fulvescent, the anterior usually paler; palpi and basal joints of antennae nore or less testaceous, teminal joints of these latter fusenus; pubescence rellowish, slender: and deemmbent, but intermingled with a few slender ereet setae on the elveris.

Head rather elosely and finely, yet quite definitely, punctured; the thoras with nearly similat though rather finer senlpture. Elytrat

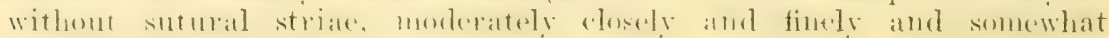
transversely rugose.

Antennate finely pubesecut, basal two joints stout and erlindrice, the Ist the longer, 3rd a little longer than broad, joints 4-8 almost trans-

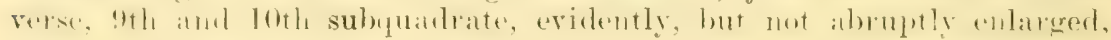
the terminal as broar as the penultimate but distinetly longer.

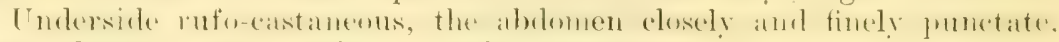
rather densely eovered with rellowish pubeseence.

Length, 1 $\frac{1}{2} \mathrm{~mm}$; breadth, $\frac{1}{2} \mathrm{~mm}$.

Waimarino; elevation, 2,700 ft. First found during January, 1909. afterwards at Erua in 1910 and 1911, and picked out of leaf-mould collected by Mr. WT. J. Guinness near Mount Ngauruhoe. Altogether

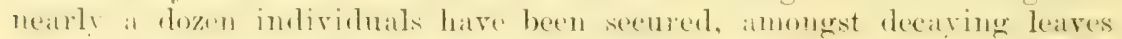
muly. The anility of this minute terestrial beetle is really womderful.

\section{Nothotelus gen. nov.}

Subcylindric. Head subrotundate, truncate in front of the antennae; epistome transversely quadrate, its frontal suture straight; labrum prominent, transverse. Lres, singly, broadly divided in the middle, the

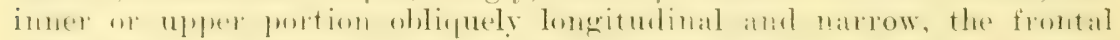
and lower is broader and situated below the antenna, the interval between these parts is as wide as either of them. Antennae longer than the head and thorax, moderately stout, each inserted in a rounded impression between and just in front of the separate parts of the eye; their basal two joints oblong and about equal; 3rd small, subquadrate; joints 4-10 differ but little, all are longer than broad, none expanded; 11 th also nariow. Thorax transverse, curvedly narowed anteriorly, with depressed and broadly rounded anterior angles, the posterior nearly rectangular; it is only a fifth of the length of the elytra. Scutellum triangular.

Thibiae straight, the posterior rather longer than the anterior, with short, minutely pectinate terminal spurs. Anterior tarsi moderately broad; batsal joint largest, oblong; 2ud quadrate; Brd subtriangulary; th short, apparently entire; 5th moderatcly slender, but not very

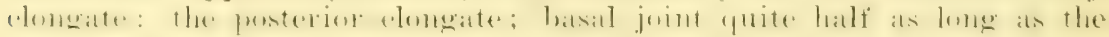
tibiae, considerably longer than the other's combined; 2nd rather longer than 4th; 3rd rather short and broad, entire, somewhat prolonged underneath: claws simple.

Palpi wibh elongate, eultriform terminal joints. that of the labial shorter and thinner than the maxillary.

Front coxale elongate and prominent, slightly separated in front by an acute angulation, which, however, is not elevated nor prolonged backwards; the tronchanters distinet; coxal caritics not open above, moderately distant from the incurved prosternal margin. Mesosternum not abbreviated, without any raised process, but acutely prolonged half- 
way between the large subcontiguous middle coxac. Metasternum transversely convex, medially impressed behind, the episterna not parallel, being narrowed backwards. Abdomen gradually narrowed medially, with 6 segments, the basal short, 4th rather shorter than the 3rd, 5th narrowed posteriorly, widely emarginate medially at its apex, 6th shorter, subtriangular.

This should be located after Lacordaire's Nothides and before the Oedemeridae. The remarkable eves and the labial palpi will lead to its recognition.

\section{Nothotelus ocularius sp. nov.}

Elongate, only slightly convex, a little nitid, sparingly clothed with decumbent, slender, yellowish hairs; pale flavo-fuscous; the legs, antennae, and palpi testaceous.

Head finely but not closely granulate. Thorax not twice as broad as long, widest near the base, which is indistinctly margined and slightly oblique towards the sides, with sculpture like that of the head. Elytra as wide as thorax at the base, slightly broader near the hind thighs, rounded behind; distinctly, moderately closely, and somewhat irregularly punctured, more finely near the extremity. Tibiae with pale pubescence, and some fine short setae, but not asperate externally.

Length, $3 \mathrm{~mm}$. ; breadth, $1 \mathrm{~mm}$.

Wallacetown. A single individual of this fragile species is all that I have seen. It was found by Mr. A. Philpott on the 14th November, 1909, and mounted by him on cardboard, but, having to be remored for examination of structural details, the hearl became detached, though not lost.

\section{Group An'rHicidak.}

3437. Anthicus flavitarsis sp. nov. Anthicus Paykull, Man. N.Z. Coleopt., p. 411.

Subdepressed, glossy black, tarsi flarescent, front and middle tibiae fusco-testaceous; thinly clad with slender, suberect, cinereous pubescence.

Head large, subquadrate, apparently smooth. Thorax deeply constricted behind the middle, much narrower than the elytra at the base, the larger anterior portion strongly rounded laterally, its surface with a few fine scattered punctures. Elytra twice the length of the thorax, their sides rery slightly, the apices individually obtusely rounded, the pygidium uncorered; they are rather distantly, finely, and indistinctly subseriate-punctate before the middle, but nearly smooth behind.

Legs moderately elongate; posterior tibiae with small terminal spurs, the basal joint of the corresponding tarsi nearly as long as the remaining three together.

Antemne shorter than the head and thorax, not very slender, their and joint rather stouter and longer than the 3rd but hardly as long as the 1st, joints $1-7$ longer than broad, $8-10$ slightly expanded yet oblong, the terminal longer.

Underside fusco-piceous, shining, finely and sparingly pubescent.

A. minor, 1670, is the only similarly small, slender species, but in it the penultimate joint of the anterior tarsi has more elongate lobes, joints $8-10$ of the antennae are shorter, and the coloration is very different.

Length, $2 \frac{1}{2} \mathrm{~mm}$; ; breadth, $\frac{1}{2} \mathrm{~mm}$.

Wallacetown. A single specimen from Mr. A. Philpott. 


\section{Gromp Otionhychidal:}

3438. Platyomida verrucosa sp. nov. Platyomida White (Eimpaeotes Pascoe), Man. N.Z. Coleopt., pp. 441 and 1186.

Piceo-niger, for the most part covered with small, depressed, rotundate scpumat, black, sleyish, colpery, and a few viridescent, and with some grerish setiform seales; antennae and tarsi obscure fusco-rufous, club infuscate and opaque.

Athough very similar to $P$. binodes, 776 , described by Pascoe as Emparotes crispatus, this exhibits certain differences. The tibiae are more prolonged at the inner extrenity. The thorax bears numerous coarse, black, wart-like elevations. The shoulders are quite oblique, and in addition to the prominent tubereles on the 3rd interstices, at the summit of the posterior declivity, there is also a nodiform elevation on each of the 5th. The numerous blackish seales on the elytra, and the similarly dark, bare wats on the thorax, produce an appearance which is in minked contrast to that of the well-known $I^{\prime}$. binodes.

l.ength (rostrum inclusive), $12 \mathrm{~mm}$. ; breadth, $4 \frac{1}{2} \mathrm{~mm}$.

Wadestorn, Wellington. I $\mathrm{am}$ indebted to Mr. G. T. Hudson for my specimen.

3439. Aporolobus albosparsus sp. nov. Aporolobus Sharp, Man. N.Z. Coleopt., p. 1186.

Subovate, moderately convex, without elevations, opaque; fuscous, the legs and seape obscrire infuseate red, funiculus shining ferruginous; squamosity dense, mostly pale brown on the thorax, much lighter, almost tarmy, on the elytra mingled with some dark spots, and, in addition thereto, on each elytron, with an oblong basal and irregular subapical patches that are almost quite white; the erect setae are short and slightly Havescent, and are seriate on the elytra, on the legs they are coarser.

Rostrum short and thick, covered with tawny seales. Thorax rather wider, but not angulate, before the middle than it is elsewhere, a little broader than long, without visible definite sculpture. Elytra oblong, arenate and broader at the base than the thorax, barely twice its length, rounded posteriorly; they are distinctly, yet rather finely, seriatepunetate, with the suture and 3 rd interstices somewhat elevated.

Scape long but rery thick, and bearing moderately coarse greyish setae; it is inserted near the apex, and extends backwards to the front of the thorax. Inunieulus scarcely longer than the scape, with fine setae; basal joint subpyriform, slightly longer and much stouter than the 2nd; 3-6 transverse and moniliform; 7th distinetly broader than 6th. Club abruptly enlarged, short, ovate, its basal joint very large, the atpical ones quite small.

In the type of the genus, Pascoe's Trachyphloeus irritus, 75t, the antennal club is narrow at the base, and therefore quite oral, joints 3-6 of the funiculus are less bead-like, and the 7th is not distinctly broader than the 6th. The elytra are subcordate, and the thorax is obtusely angulate laterally near the front.

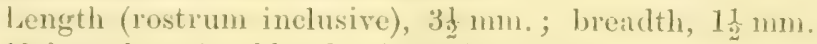

Mokomoka, Southland. Described from a mounted specimen sent by IIr. Philpott. Found on the 24th April, 1910. 
3440. Hygrochus scutellaris sp. nov. Hygrochus Broun, Man. N.Z. Coleopt.', p. 702.

Suboblong, slightly convex, without evident inequalities, subopaque; piceous, legs and seape dull fuser-kufous, funiculus and tarsi shining, the former rufous, the latter chestnut-red; densely covered with small but not rotundate brassy or light-coppery squamat of a slightly metallic lustre, on the scutellum and along the iniddle of the thorax especially; the setae, though numerous, are not very conspicuous, they are infuscate grey and somewhat irregularly concentrated on the after part of the elytrai.

Rostrume rather shorter than the thorax, half its width, with a slight carina extending from the bare apex as far as the eyes. Head short, not marked of from the rostrum. Eyes subrotundate, free from the thorax, rather small but prominent. Thorax slightly broader than it is long, rather broader near the front than elsewhere, base and apex truncate; disc just a little uneven, having a shallow impression near each anterior angle and a slight ridge along the middle; there is no visible punctation, bu a few minute blackish granules can be seen. Sentellum short, coveren with brassy seales. Elytra twice as long as the thorax, a little hroades. than it is at the base, where they are narrower than in the middle, moderately contracted but not quite rertical behind; ther are indefinitely seriate-punctate, and bear many minute granules; the $3 r d$ interstices are slightly and obtusely elevated at the base, and somewhat nodiform on top of the posterior declivity, where the 5th are also slightly raised; their surface is slightly meven, but there is no post-humeral dilatation.

Scape stout, gradually incrassate, with slender setae; it attains the back of the eye. Funiculus with fine greyish setae, basal two joints moderately elongate and about equal; joints 3-7 moniliform, not longer than broad, and scarcely differing from one another. Club oblong-oval, triarticulate, densely pubescent and dull.

Legs stout, thickly squamose and setose; tibiae flexuous and mueronate, posterior corbels without any external truncature.

Ocular lobes absent. Scrobes deep, quite open above, beginning at the apex and separated from the lower and front part of the eres by squamose intervals.

Length (rostrum inclusive), $6 \mathrm{~mm}$. ; breadth, nearly $2 \frac{1}{2} \mathrm{~mm}$.

Great Barrier Island. I picked one out of the bagful of leaf-monld sent to me by $M r$. F. Flynn in March, 1911.

'This differs from $I I$. oculatus, 2868, in having a shorter, broader, and less uneven thorax; the scutellum is covered with brassy scales; the eltrra have no dilatations behind the shoulder; and the antennal club is manifestly broader.

\section{Group Rhyparosomida.}

3441. Phrynixus rufiventris sp. nov. Phrynixus Pascoe, Man. N.Z. Coleopt., p. 432.

Subovate, convex, tuberculate or cristate, rufo-piceous, corered mostly with tawny scales and sctae.

Rostrum arched, about a third shorter than the thorax, its frontal half somewhat expanded, flattened, punctate, and obsoletely tricarinate, with very fine yellowish setae; there is a large crest near the base and a pair of small ones close behind the point of antennal insertion. Thorax rather longer than broad, a little contracted anteriorly, irregu- 
larly punctured, more coarsely and closely behind than in front, where there is a crest at ach side formed of coarse, woolly, pale-yellowish setae; it is tricristate across the middle; these crests are prominent and rotundate; another in line with these, but on the side, is much smaller; the mesial basal depression has obtusely raised lateral borders; this hind portion bear's decumbent, rather coarse and elongate, obseurely fulvescent squamae, but the setae at its sides are suberect. Elytra oriform, twice the length of the thorax, at the middle nearly double its width, with uneven, tuberculate or erested sides, they are much narrowed and nearly vertical behind; their punctures are irregular and coarse, but on the hind declivity become much finer and substriate; greyish woolly setae form an interrupted semicircular crest from one shoulder to the other, but leaving a sutural gap in line with the posterior femora, the median basal depression is crested at each side with fulveseent setae similar to those extending backwards along the suture; an oblique series of $t$ crests extends from before the middle of each side to within a short distance of the suture, the hindmost, just on top of the declivity, is the most prominent; a little lower down, at each side, there is at larger setigerous prominence.

Legs normal, bearing numerous coarse, curled, tawny setae; the tarsi are densely and finely clothed above.

Antennae with fine dense tawny vestiture; scape medially inserted and attaining the back of the eye, slender near the base, clavate at the apex; funiculus rufescent, its 2 d joint almost as elongate as the Ist, joints 3-6 subtransverse, 7 th distinctly enlarged, narrowed towards its base; club conieal, obsoletely articulated, not much larger than the preceding joint.

Underside dull fusco-piceous, but with the middle of the basal segments evidently rufeseent; these two are somewhat convex, rather evenly and coarsely punctured, and bear numerous coarse, rather elongate, bright-fulvous setae; the suture between the segments is oblique towards the middle and distinct throughout; the $2 n d$, in the middle, is as long as the 1st, and slopes abruptly downwards to the abbreviated $3 \mathrm{rd}$ and 4 th, which, as well as the 5th, are on a lower level, and bear finer setae.

When compared with its nearest ally, $P$. humeralis, 2544 , it will be at once separable by the presence of the rounded crests across the middle of the thorax and the abruptly clavate scape. 'The underside is materially different, being wholly nigro-fuscous in 2544 , with somewhat flattened basal ventral segments; the punctures on these are very irrecrular, so that some parts, near their junction in the middle particularly, are perfectly smooth; all the setae are very small, and their suture towards the middle is completely obliterated.

Length (rostrum exclusive), $4 \frac{1}{2}-5 \mathrm{~mm}$. ; breadth, $2-2 \frac{1}{2} \mathrm{~mm}$.

Hakapoua, Southland. Three specimens found by Mr. A. Philpott in .larch, 1911.

\section{Sosgenes longicollis sp. nov. Sosgenes Broun, Man. N.\%. Coleopt.,} p. 1476 .

Suberlindrie, subopaque, almost nude; piceo-rufous, rostrum quite rerl, antennae and tarsi fulvescent.

Rostrum about a third shorter than the thorax, stout, feebly arched, subparallel, slightly dilated at the antennal insertion so that the serobes, at that point, are open and quite visible above; it is finely sculptured, has a shallow median groove with slightly carinate lateral borders, and 
is abruptly depressed at the base; its clypeal portion is narrower, smooth, and shining. Thorax elongate, its length being a third more than the breadth; it is only slightly rounded at the middle and broadly but not deeply contracted near the front, which, though truncate, covers the head; a narrow, flattened, nearly smooth space extends from the base as far as the frontal constriction, the surface elsewhere is distinctly but not very closely punctate, its apex is rufescent. Elytra of the same width as thorax at the base, which is tiuncate and marginated, they are only very slightly dilated behind, where there are a few fine setae; along the middle of each elytron a carina extends from base to apex, the suture also is carinate, the interval has 2 series of rather large, suboblong, distinctly separated punctures; the series nearer the side are similar, but the earina between them is less definite, the posterior declivity is nearly smooth.

Seape straight, very gradually incrassate, inserted immediately beliind the smooth apical portion of the rostrum, but not reaching as far backwards as its base; basal joint of funiculus nearly twice the length of the 2 nd, but very little thicker, joints 3-6 subquadrate, 7 th slightly shorter and broader; club rather large, ovate, finely pubescent, with ill-defined apical articulations.

Legs stout and elongate, finely setose; anterior tibiae with a frontal prolongation which covers the basal joint of the tarsi; the other pairs have a few yellowish, rigid setae close to the extremity; the tarsi, underneath, bear outstanding setae.

There are no ocular lobes nor scutellum. The eyes are minute and hardly discernible, and appear to be placed at the sides, near the base of the rostrum.

Underside moderately shining, rufo-piceous, the last segment darker. Prosternum evenly concave from the frontal emargination to the coxae, the sides of the cavity finely carinate, and with a transverse carina in front of the coxae, which are contiguous, but there is no longitudinal median ridge almost dividing the cavity as is seen in $S$. carinatus, 2556 . Basal ventral segment broadly depressed longitudinally, in the middle, almost rlouble the length of the 2 nd, the suture between them is indistinct; the $3 \mathrm{rd}$ and 4 th with deep straight sutures, much abbreviated and, conjointly, only half the length of the 2nd; the terminal with relatively coarse shallow punctures.

The more parallel-sided outline, evidently longer and more cylindrical thorax, with its smooth longitudinal impression, the finer and more obviously separated elytral punctures, and the fact of the scrobes being expanded and open abore at the point of the antennal insertion, irrespective of other details, show that this species is abundantly distinct.

Length (rostrum inclusive), $2 \frac{1}{3} \mathrm{~mm}$.; breadth, nearly $\frac{2}{3} \mathrm{~mm}$.

Great Barrier Island. I detected a single specimen amongst leafmould kindly collected for me in Narch, 1911, by Mr. Frank Flynn.

\section{Bantiades suturalis sp. nov. Bantiades Broun, Man. N.Z. Coleopt.,} p. 1371 .

Subobiong, slightly nitid, thinly and unevenly clothed; the setae moderately fine, mostly curled and fulvescent, but in line with the posterior femora a pair of spots are nearly grey; elytra light brown, the thorax and legs fusco-testaccous, the antennae and apical portion of the rostrum somewhat rufescent.

Rostrum slightly longer than the thorax, arched, subparallel, a little dilated in front, the clypeus moderately distinctly marked off, and 
quite piceous; it is more or less definitely bisuleate between the antennae, and from that point the obtuse median earina becomes slightly thicker towards the base. Thorax of equal length and breadth, the anterior' contraction a third of the whole length, not quite straight behind, the sides being slightly trinodose, base and apex truncate; on the middle of the dise there is a short obtuse clevation, and a pair of oblique ones extending from that point towards the apex, the enclosed frontal space is flat, with fine and rather distant ret quite distinct punctures similar to those behind, the hinder portion also is somewhat uneven. Elytra twice as long as the thorax, their shoulders porrect and rather wider than it is at the base, a little broarler near the middle, with slightly uneren nodose sides, the posterior declivity not quite vertical but considerably narrowed; dise slightly convex, coarsely subseriate-punctate, not more than 6 punctures in each row, the declivity more finely striatepunctate; interstices nearly bare and smooth; the 3rd, at the base and summit of the declivity, are nodose; nearer the sides the nodosities are less distinct; the setre are almost confined to the sutural region and elevated spots.

Scape very gradually incrassate, with greyish setae, it is inserted near the anex, but does not quite reach the eyes; scrobes visible above near the apex only; funiculus as long as the scape, basal joint longer than the next, narrowed, towards its base, joints $3-7$ about equal, transversely quadrate; club ovate, its apical joints, together, only half the length of the large basal joint.

Femora with a very prominent tooth-like process underneath. 'T'ibiae externally arcuate above the middle, the anterior widely medially dilated inwardly, the others less distinctly so, all uncinate. "Tarsi with moderately dilated penultimate joints, excavate above but not definitely bilobed.

Underside dull rufo-castaneous, with some distinct flavescent setae. Prosternum deeply emarginate in front, the coxae nearly contiguous, separated by the cariniform margins of their carities. Intermediate coxae with a flat transverse, bipunctate interval between them. Metasternum short, medially Hattened, with a series of modcrately coarse punctures across the front and a less distinct series behind. First vental segment obtusely curved in line with the front of the widely distant posterior coxae; along the inner and hind part of each of these there is a distinctly punctate shallow impression, the rest of the abdomer is impunctute; the 2nd segment is almost as large as the basal, its frontal suture is well marked and strongly rounded, almost prominent, in the middle, but straight at the sides.

The specific name is intended to direct attention to the abdominal structure. The first portion of the description indicates some of the principal superficial disparities between this species and 3 . valgus, 2551. $B$. fuscata, 2396 , is a very different insect.

๙. Length (rostrum exclusive), $3 \frac{7}{3} \mathrm{~mm}$.; breadth, nearly $2 \mathrm{~mm}$.

Erua. My first specimen was found in January, 1910, amongst dead leaves; the second, now mounted on its back so as to study the underside carefully, in January, 1911.

Obs.-Foux specimens belonging to thee species were removed from their cards, eleaned and examined underneath, and remounted, in order to ascertain whether reliable sexual characters existed in this curious genus. The work occupied an entire day. The following notes show the result :- 
B. suturalis var., male, Mount Pirongia, December, 1909: Rufocastaneous; 2nd ventral segment with the frontal suture distinct, somewhat oblique, obtusely angulate in the middle; the lst with a shallow linear impression along the middle; all other details of sculpture similar to those of the female lescribed above, the rostrum only a trifle shorter and stouter.

B. suturalis var, male, Makatote, February, 1910: Uniformly darker, rufescent; 1st segment truncate in line with the front of the posterior coxae, with a broad groove behind the middle; 2nd shorter, its frontal suture deep at the sides, angulate but less distinet in the middle; other. details similar; 5th segment unmarked in all individuals of both sexes.

The others belong to $B$. nodosus, described below, and $B$. valgus, 2551. No single constant mark seerns to be available for sexual discrimination; that of the rostrum is useful, to some extent, when comparing specimens with an authentic type.

\section{Bantiades nodosus sp. nov.}

Opaque, fuscous, legs and antennae fusco-rufous; setae obseurely fulvescent, moderately coarse and suberect on the elevated parts, longer on the legs.

Thorax without discernible punctation, the central elevation indistinct, the oblique frontal ones prominent, there is a setigerous nodosity half-way between the middle and each side, and a smaller pair on the middle near the base, the sides are trinodose. Elytra slightly incurved at the base, with obtusely porrect humeral angles, their punctation coarse and interrupted; 3rd interstices with a basal and posterior nodosity, the basal more prominent than the other; on each elytron, between the middle and side, there are 6 unequal nodosities, the largest is situated on the top of the declivity, but nearer the side and not as far back as that on the 3 rd interstice.

Underside slightly nitid, rufo-fuscous, the last segment rufescent. Metastermum uneven, without transverse series of punctures. Basal ventral segment truncate and medially depressed in front, slightly medially impressed behind, not punctate near the coxae; 2nd shorter, its frontal suture obliterated in the middle, straight near the sides.

Allied to $B$. valgus, but distinguishable therefrom by the feeble central ridge of the thorax, and more prominent nodosities. The penultimate tarsal joint is excarate above, but not truly bilobed, being densely pubescent and entire below. In 2551 the basal ventral segment is not truncate between the coxae in my reversed specimen, being oblique towards the middle, as is the frontal suture of the $2 \mathrm{nd}$. The ocular lobes are obsolete in all the species.

I ength (rostrum exclusive), $3 \frac{1}{2} \mathrm{~mm}$.; breadth, $2 \mathrm{~mm}$.

Retaruke Forest. Two individuals picked out of decaring leaves that were forwarled to me by Mr. W. J. Guinness in May, 1911.

\section{Araeoscapus brevicollis sp. nov. Arueoscrpus Brom, Ann. Mrar.} Nat. Hist., ser. 6, vol. 12, p. 299.

Subopaque, moderately convex; rufo-castaneous, antennae rather lighter; sparingly and unevenly covered with coarse, somewhat curled, flavescent setre.

Rostrum strongly arched, subparalled, as long as the thorax, indefinitely seulptured, nearly smooth in front, with an indistinct median earina behind. Eyes very small, slightly convex, just free from thorax, 
longitudinally oval. Thorax rather broader than long, broadly oviform, widest at the middle, base truncate; its surface very slightly uneven, moderately coarsely but not deeply punctured behind, much more distantly and finely in front, with a shallow central impression at the base. Elytra oviform, widest at the middle, a third longer than broad, of the same width as thorax at the base, less than twice its length, the seutellar region indistincty impresied; with oldong serial punctures on the disc, posterior declivity striate; 2nd and th interstices slightly elevated near the base, the 5th more distinctly, almost nodiform, on top of the declivity.

Legs simple. Scape medially insertcd, attaining the eye, flexuous, clavate at extremity. Funiculus almost glabrous, 2nd joint hardly as thick but fully as long as the 1st, joints :3-6 quite transverse, 7th distinctly larger than 6th. Club olovate, rather densely pubescent, its apical articulations indistinct.

Underside subopaque, rufo-husenus, with some depressed, scale-like, yellowish setae. Prosternum short, its frontal emargination medially subtruncate. Metasternum unimpressed, punctate in front. Basal rentral segment transversely depressed between the coxae, smooth and slightly convex buhind; the 2nd rither longer, its frontal suture obtusely angulate and indistinct in the middle, deep towards the sides; 5 th nearly twice the length of $3 \mathrm{rd}$ and 4 th, with a well-marked central fovea near the extremity.

This differs from all of our northern species on account of its short thorax. The elytra of the only southern species are almost without sculpture.

Length (rostrum exclusive), $3 \mathrm{~mm}$. ; breadth, $1 \frac{1}{2} \mathrm{mmn}$. 1910 .

Tisbury, Invercargill. One found by Mr. A. Philpott in November,

\section{Group Cylindrorhinidat:}

3446. Tocris laevicostata sp. nov. Tocris Broun, Ann. Mag. Nat. Hist., ser. 7, vol. 14, p. 115.

Convex, oblong, slightly nitid; black, antennae and tarsi rufopiceous; very thinly clother with depressed, somwhat elongaterl, greyish squamae, which, however, are almost entirely absent along the middle.

Rostrum very broad, a third shorter than the thorax, dilated anteriorly, its apex and the lamelliform mandibles nearly perpendicular; it is rather closely and moderately coarsely punctate, broadly longitudinally impressed, so that its sides and an abbreviated central line appear obtusely, but only slightly, elevated. Head shorter than the rostrum, gently narrowed in front, its punctation shallow, rather fine and close, but also with a few larger punctures, between the flat eyes there is a cuneiform fovea. Thorax rather broader than long, its sides obtusely dilated near the front, where the punctation is fine and rather shallow, behind that part the surface is uneven, having some ill-defined obtuse elevations and coarse punctures, at the base the sculpture becomes irregular and rugose, but not granular; there is a short, smooth line behind the middle, where its sides are straight. Elytra oblong-oval, with feebly acuminate apices, nearly thrice the length of the thorax, and rather broader than it is at the base; on each elytron there are 2 double series of dorsal, well-marked, distinctly separated punctures; between these a pair of smooth, elevated costae extend as far as the hind declivity, where the sculpture becomes indefinite; between the $2 \mathrm{nd}$ costa and the side there are 2 series of coarse punctures which are almost divided by an indefinite carina, but the outer margin is formed by a distinct costa 
which is curved inwardly behind; the vertical sides have similar sculpture.

This species is smaller than $T$. aterima, 3288, and may be at once distinguished by the entire absence of granulation on the thorax and elytra.

T. latirostris, 2911, has more parallel-sided and differently sculptured elytra; the joints of the front tarsi are evidently longer and subtriangular, whereas the basal two in 'T'. Inevicostata are short and broad, and the antemnal club is more slender and a good deal narrowed towards its base; 2911, moreover, has a difierently sculptured thorax and a small yet distinct seutellum, but in the present species the sentellum is very narrow and hardly visible.

Length (rostrum inclusive), $14 \mathrm{~mm}$; breadth, $5 \frac{1}{2} \mathrm{~mm}$.

Humboldt Range; elevation, 5,600 ft. My specimen was found by Vir. G. V. Hudson.

\section{Group Nolytidae.}

3447. Lyperobius hudsoni sp. nov. Lyperobius Pascoe, Man. N.Z. Coleopt., p. 444.

Subovate, moderately convex, a little nitid; black, antennae and tarsi rufo-piceous; sparingly clothed with greyish, rather fine, decumbent squamae, "hich, on the elytra, are concentrated so as to form 4 longitudinal streaks on each.

Rostrum rather elongate, subparallel, and not dilated anteriorly, of about the same length as the thorax; distinctly punctate, with an elongate interantennal impression; there is a similar mark between, but in front of, the flat, strongly transverse eyes. 'Thorax unusually elongate for this genus, being quite as long as it is broad, only very slightly wider at or just before the middle than behind, where its sides are nearly straight; in front it is somewhat abruptly contracted; along the middle there is a shallow impression which is most distinct at the base and almost divided lengthways near the centre; the adjacent space is finely and distantly punctured, but, outside of it, the sculpture consists of large, very irregularly formed, shallow impressions; these are nearly covered with scales; near each side the punctation is coarser than that near the middle. Elytra oval, fully double the length of the thorax, and rather broader than it is at the base; each elytron, including the convex suture and lateral margin, is quadricostate; the 3rd costa does not reach the extremity; each of the flattened intervals has 2 series of moderately coarse punctures; these are placed close to the ridges, and are more or less intermingled with small granules, near the suture especially.

Femora medially dilated. Tibiae slightly flexuous, mucronate or spurred at the inner extremity, and with a second more slender spur a little further from the apex. Tarsi, excepting the $3 \mathrm{rd}$ joint, almost glabrous underneath, the basal two joints, however, at the apices, have concentrated patches of rigid setre, causing them in some aspects to appear unsymmetrical; in old abraded specimens these patches are absent.

Scape inserted near the apex, sliglitly flexuous, and extending backwards to the eye; basal two joints of the funiculus nearly equal and about twice as long as broad, 3-6 short but not moniliform, 7 th obeonical and evidently larger than the 6 th; club short, ovate, obliquely narrowed outwardly.

This species is remarkable on account of its elongated thorax, rostrum, and serobes. The ocular lobes are altngether absent or 
olisolete. The strueture of the funiculus difiers from that of Paseoe's type, 783. 'The elytra, though less oblong, in vestiture and sculpture most nearly resemble those of $/$. carinatus, 1236.

length (rostrum inclusive), 16-19 $\mathrm{mmn}$. ; breadth, $6 \frac{1}{2}-7_{\frac{1}{2}} \mathrm{~mm}$.

II muboldt liange; elevation, 5,600 ft. Named after its discoverer, Mr. G. V. Hudson, from whom a pair of specimens have been received. 'The scales are deciduous, or very easily rubbed off, so that the depressed intervals between the elytral ridges are sometimes quite bare.

\section{Lyperopais alternans sp. nov. Lyperopais Broun, Man. N.Z. Coleopt., p. 1222.}

subopaque, uniformly chocolate-red; tarsi piceo-rufous, antennal (chl) oparue; very thinly clad with small, depressed, yellowish-grey squamae.

Rostrum arched, subparallel, rather longer than the thorax, its frontal portion deflexerl and broadly but not at all deuply impressed above; with it short interantennal stria, behind which there is an indistinct carina and numerous shallow punctures. Head about twice as broad as the restrum, short, narrowed anteriorly, moderately finely and closely punctate, and with an clongate interocular fovea. Eyes widely separated above, nearly flat, transversely oval. 'Thorax rather broader than long, a little wider before the middle than it is elsewhere; moderately closely punctured, rather more distinctly than the head, with a shallow nedian impression at the base. Elytra almost thrice the length of the thorax, broader than it is at the base, only a little wider at the commencement of the posterior declivity, which is not at all abrupt, and, though considerably contracted laterally, is somewhat expanded below towards the obtusely prominent apices; they are moderately punctate-striate, with the $3 \mathrm{rd}$, 5th, and 7 th interstices, and the suture, rather more convex and broader than the others, the 5th are the most elerated behind.

Legs robust; tibiae flexuous but not mucronate, the anterior pair somewhat bent and obtusely prominent at the inner extremity, the posterior corbels expanded, but without any external truncature. Antennae of normal structure, the scape glabrous, the funiculus with a few infuscate setac, club elongate-oval, finely and densely pubescent but not perceptibly articulated.

Underside rufo-piceous, with very few small whitish scales; ventral segments 3 to 5 are sunk below the level of the linear epipleurae, the 3rd and th are well developed. Oenlar lobes moderately distinct.

Larger than the female of $L$. mirus, 2153, which has the hind tibiae inwardly notched at the base; in the male there is a prominent tooth there, and amother near the extremity of the femora; the same sex of 1. alternans has, no doubt, similar armature. 'The brightly variegated stpumae and simple elytral interstices of 2153 are quite distinctive.

o. Length (rostrum inclusive), $10 \mathrm{~mm}$; breadth, $4 \mathrm{~mm}$.

IIump, Ridge, Okaka. Shaken off a Dracophyllum (elevation, $3,500 \mathrm{ft}$.) by IIr. A. Philpott, from whom a single female has been receired.

\section{Group HrLoßinde.}

Exeiratus gen. nov.

Burly suborate, morlerately eonvex, without tubcreular elevations or ("walse sypumate.

liostrum areuate, stout, subparallel, rather longer than the thorax. Sorobes not open above, deep, begiming nenr the apex, expanded below 
and reaching the eyes. Head globose underneath, short above and rather broader than the rostrum. Eyes just free from the thorax, widely distant from each other, not prominent, oblique, their greatest bulk from above downwards. Scape inserted near the apex and attaining the eye, subclavate at the extremity. Funiculus 7 -articulate, basal joint thicker and slightly longer than the elongate 2 nd, joints :3-6 aloout equal and subquadrate, 7 th larger than 6th. Club ovate, obsoletely amnulate. Thorax without ocular lobes, subovate, base and apex truncate. Scutellum absent or obsolete. Elytra twice the length of and rather broader than the thorax, narrowed but not vertical behind.

Femoral dilated medially. Tibiae strongly uncinate. 'Tarsi moderately slender, sparsely setose underneath; 3rd joint slightly expanded, entire below, excavate above in front. Claws simple.

Prosternum moderately emarginate, the coxae slightly separated. Metasterum of moderate length. Basal ventral segment truncate between the coxae, which are far apart; 2nd rather shorter, its frontal suture fine and almost straight; 3rd and 4 th conjointly not as long as the 5th. Palpi short, quite visible underneath.

This may be located near Eiratus, but the tarsal structure is like that of Phrynixus, which, however, has foveiform scrobes but no tibial hooks.

\section{Exeiratus setarius sp. nov.}

Subopaque, sparsely clother with short, moderately coarse, subercet, Havescent setae; variegated fuscous, the sides of the thorax and the shoulders paler, elytra with some obsenrely rufescent spots, none, however, are well dofined; legs fusen-testacens, the tips of the fumora larker; funiculus and basal joints of the tarsi piceous, the terminal joint of the latter and the scape reddish.

Rostrum irregularly punctate, with linear interstices towards the apex; it is pale fusco-rufous and opaque. Thorax of about equal length and breadth, a little wider just before the middle than it is elsewhere, irregularly and coarsely punctured, more finely in front, the slender abbreviated carina along the centre ends in the distinct basal depression. Elytra evidently striate, the striae with indefinite punctures, those near the sides apparently have each a series of minute granules; interstices irregularly transversely rugose, the 5th slightly nodose behind, the suture distinctly broader along the declivity than at its summit.

legs with minute setae, the anterior tibiae almost straight, somewhat attenuate apically, the posterior pair slightly bent inwardly.

Underside coarsely punctate, with a few pale short setae.

Length (rostrum inclusive), $3 \frac{1}{2} \mathrm{~mm}$; breadth, $1 \frac{1}{3} \mathrm{~mm}$.

Hakapoua, Southland. A single specimen obtained by Mr. Alfred Philpott on the 1st Mareh, 1911.

\section{Geochus sulcatus sp. nov. Geochus Broun, Man. N.Z. Coleopt.,} pp. 445 and 1221.

Subopaque, broadly oval, moderately convex; tholax with depressed, elongate, yellowish-giey squamas; on the elytra they are placed on the interstices, and are suberect, but not numerous; on the legs they are finer; body fusco-piceous, the front of the thorax and rostrum ferruginous, legs rufo-fuscous, tarsi and antennae fusco-testaceous; club darker and finely pubescent.

Rostrum much shorter than the thorax, contracted behind, with slightly asperate indefinite seulpture. Eyes flat, with coarse facets, subrotundate, rather more distant from the thorax than they are from 
each other. Thorax a third broader than long, a good deal, and somewhat abruptly. narrowed anteriorly; its punctation proportionally coarse, not very elose, and rather irregular, along the middle there is an abbreviated smooth line. Elytra cordiform, oblique towards each side at the base, where ther acarcely exeed that of the thorax in width, they are broader near the middle, much narrowed and nearly, but not abruptly, perpendicular behind; ench with 3 deep and broad distinctly punctured striac near the suture from base to apex, the others nearer the side are less evident: interstices without nodosities.

lexgs robust and elongate; anterior tibine obliquely truneate from the midale to the acmminate inner extrenity. 'Tarsi triarticulate, basal two joints strongly transverse, the teminal not quite as broad, slightly excarate at the aper, but without claws.

Seape medially inserted, clavate at the extrenity, and extending backwris to the centre of the eve. Funiculus much longer than the seape, basal joint of about the same length but much thicker than the slender 'nd, both narrowed towards the base, 3rd and 4th slightly longer than broad, joints $5-T$ moniliform; club elongate-oval, its lst joint obviously smaller than and distinctly marked off from the large quadrate 2nd. the terminal acuminate.

Coxac wirlely separated. Prosternum plane, without any trace of rostral canal. Seutellum absent.

In form and structure it most nearly approaches $G$. rugulosus, 1672, which, howerer, is at brighter insect, a large portion of the elytra being chestnut-red; the thoracic line is more obvious; the elytra are not distinctly sulcate, the interstice nearest the suture is somewhat elevated, and the surface generally is more or less transversely rugose. $G$. setiger is also somewhat similar, but it is shining, its thorax is nearly smooth, and the setae borne by the elrtra are distant from each other, slender, and curled.

This is the fifteenth species now on record, and, all being small, their discrimination is not an easy matter.

Leneth (rostrum inclusive), $1 \frac{2}{3} \mathrm{~mm}$; breadth, $1 \mathrm{~mm}$.

Great Barrier Island. A single individual was picked out of a small bagful of leaf-mould sent to me by Mr. F. Flynn.

\section{Geochus morosus sp. nov.}

Subopaque, fusco-niger, antennae and tarsi rufo-castaneous, club piceous.

Rostrum minutely asperate, with a slight carina separating the shallow grooves, which are broadest in front. Thorax broader than long, not abruptly narrowed in front; a little uneven, broadly obliquely impressed before the middle, with a slightly raised median line not reaching the base, the punctures are distinct but irregular, some being

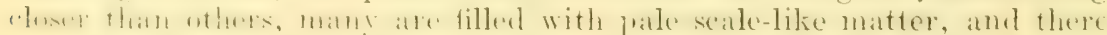
is a short basal fringe formed of a similar substance. Elytra nearly Hice as long as thorax, not broader than it is at the base, but quite a third broader in line with the posterior femora, obliquely narrowed

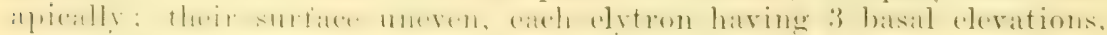
the humeral shorter than that on the 3rd interstice, the central not tonching the basal margin; an oblique series extends inwardly from behind the middle, the lateral is not prominent, the next is round and prominent, the innermost is largest and seems duplicate, there being a lividing mow of small punctures, it is situated on the top of the apical reclivity on the 3rd interstice; just below the last, but nearer the suture, another narower elevation projects backwards; the punctures are dis- 
tinct; the sutural series consists of 8 or 9), some of the other's in the middle of only' 2 or 3.

Legs robust, with fine, short, pale setae; tibiae obliquely narrowed near the extremity, but not angulate externally.

Funiculus elongate, 2nd joint about as long as the 1st but much more slender, the others almost obconical, each rather longer than broad, 7th slightly larger than 6th; club elongate-oval, its basal joint triangular, the next quadrate and rather broader, the teminal subacuminate.

In $G$. nodosus, 2152 , the nearest ally, the rostrum is without any perceptible sculpture, the thorax is less uneven and its punctures are more obviously separated, the elytral series are more regular and less interrupted, the elongate nodosities are much less elevated, the posterior ones on $G$. morosus may be termed tubercles. The coloration is altogether different, and the present species is broader.

Length (rostrum inclusive), $2 \frac{1}{2} \mathrm{~mm}$.; breadth, fully $1 \frac{1}{2} \mathrm{~mm}$.

Otira Gorge. One example from Mr. J. H. Lewis.

\section{Group ERTHITIDAR.}

3452. Erirhinus pectoralis sp. nov. Erirhinus Schoenherr, Man. N.Z. Coleopt., p. 449.

Nitid, sparingly clothed with short, slender, suberect greyish setae; the head, thorax, basal portion of elytra, the lower part of their sides, and a short vitta on the 5th interstice behind the middle of each elytron more or less rufo-fuscous; the rest of the elytrat and the legs testaceous; rostrum and antennate fusco-fulvous.

Rostrum moderately arched and slender, parallel, rather longer than the thorax, nearly smooth along the middle, the lateral seulpture linear. Thorax somewhat broader than long, the sides a little rounded, base and apex truncate, without ocular lobes; its surface distinctly and closely punctate, the intervals minutely sculptured. Scutellum distinct. Elytra evidently wider than the thorax at the base, twice its length, oblong; distinctly striate-punctate, interstices nearly plane, minutely and remotely punctured.

Femora slightly angulate underneath, the posterior pair subdentate.

Antennae slender, inserted just before the middle, basal joint of the funiculus much thicker than the next but not twice its length, 3 rd very little longer than broad, joints $4-T$ moniliform and small; club elongateoval and acuminate, about the length of the preceding five joints taken together.

Underside sparingly and finely pubescent; abdomen testaceous, the breast rufo-fuscous; the metasternum medially suleate, mesosternum with a few rather coarse punctures.

Somewhat similar to $E$. limbatus, 791 , but easily recognizable by its elongate acuminate club.

Length (rostrum exelusive), $2 \frac{1}{3} \mathrm{~mm}$; ; breadth, $1 \mathrm{~mm}$.

Wallacetown. A single individual from Mr. A. Philpott.

\section{Group Criptorhychidal.}

345:). Acalles flynni sp. nov. Acalles Schoenherr, Man. N.Z. Coleopt.. p. 488 .

Oral, compact, convex, without prominent crests or tubercles, slightly nitid; nigro-piceous, antennae and basal two joints of tarsi red, terminal joints of the latter pale castanco-rufous; the squamosity variegated, infuseate and blackish, nearly absent along the middle of the elytra; the sides of the thorax, and a broad lateral space extending 
firm each shoulder to between the middle and hind fomora and then probnged obliguely backwads almost to the suture, thickly covered with olscurely fulvescent seales, these also form a streak from the apex towards the summit of the declivity, the central pale area is bounded behind hy hack squanale; the erect setale are not conlse, nor very elongate, and correspond in eolour with the squanate where they occur.

Rostrum only slightly arched, of about the same length as the thorax, rather broad, equdually narowed posteriorly, moderately enarsely punetate, more fincly near its apex. Thorax rather broarler than it is long, not abruptly contracted anteriorly, base feebly bisinuate, the apex subtruncate and not prolonged; its surface distinctly but not very closely punetued. lilytra hardly at all broader than thorax at the base, cordiform, emsiderably narowed and nearly vertical behind; morlerately coarsely striate-punctate, the punctures distinctly separated, nearly hidden behind, along the suture and near the base some minute tubercles are risible.

ficape implanted behind the middle and attaining the eye, gradually incrassate, slightly flexuous, and bearing a fow coarse setae. Funiculus sparingly and finely retose, its basal two joints elongate and, together, about half of the whole length, $3-T$ moniliform, the last searcely transrerse. Clul, oblong-oval, finely pubescent, indistinetly quarlriaticulate, its 1 st joint about as long as the following ones combined.

Eyes free, rather flat, a little acuminate in front. Sertellum absent. Ocular lobes obsolete. legs thickly squamose.

The first portion of the diagnosis will lead to its recognition. It is pliced in my ealoinet in Section 1 of the genus, along with Nos. 872,

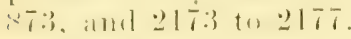

Jength (rostrum exclusive), $4 \mathrm{~mm}$. ; beadth, $2 \frac{1}{2} \mathrm{~mm}$.

Great Burrer Island. I picked out a specimen from leaf-mould which was collected for me in March, 1911, by Mr. Frank Flymn, after whom it has been named.

\section{Acalles notoporhinus sp. nov.}

Suborate, piceous, antemnae and tarsi fusco-rufous; thickly covered with infuseate sfuanate, those along the millle of the rostrum and clytra of a brighter and paler hue than the others; the erect squamiform setre are short and irregularly distributed, but are nore conspicuous on the legs and the front and sides of the thorax.

Rostrum arched, parallel, almost as long as the thorax, densels squamose cxcept just at the apex; it is evidently convex along the middle, and ends as a definite lidge at the Hattened space between the eyes, which are rounded behind but acuminate in front. Thorax a fourth broader than long, its hasal half with nearly straight sides, the frontal is distinctly but not very abluptly narowed, and rather more repressed; it is apparently closely and coarsely punctured, and has a slight ridge along the centre of the basal half; the base is somewhat bisinuate, and the seales elose to the sides are much darker than those on the disc. Elytrat twice the length of thorax and of the same width at the base, slightly wider near the hind thighs, much narowed and nearly rertical behind, and on a higher level than the thorax; they are lather coarsely subseriate-punetate and somewhat uneven, having a pair of distant, moderate erests on top of the apical declivity, and irregrular clevations on the 3 ded and 5 th interstices.

Scape medially inserted, just attaining the eye, not slender, very cradually incrassate, bearing depresserl, dongate, tawny seales and a 
few setae; funiculus elongate, with slender fuscous setae, its basal two joints equally elongate, 3rd and 4th evidently longer than broad, 5th rather shorter, 7th rather shorter and broader than the bead-like 6 th; club oblong-oval, densely pubescent, triarticulate.

Legs robust. Tarsi densely and finely setose underneath, the basal joint evidently longer than the next, the penultimate moderately dilated, medially exeavate above but not distinetly bilobed.

Underside densely clothed with tawny scales, so that the sutures between segments 2 to 5 are completely hidden; the basal ventral segment is broadly impressed in the middle, and nearly double the length of the 2nd. Pectoral canal profound, limited behind by raised borders just at the front of the intermediate coxae.

From all the New Zealand species of about equal bulk this is differentiated by the somewhat flattened thorax and distinctly ridged rostrum.

Length (rostrum exclusive), $5 \mathrm{~mm}$.; breadth, nearly $3 \mathrm{~mm}$.

Mount Te Aroha. Mr specimen was detected amongst decaring leaves in November, 1910. It must be located in Section 1, near 872.

3455. Xenacalles simplex sp. nov. Xenacalles Broun, Trans. N.Z. Inst., vol. 45, p. 146.

Convex, elongate, subovate, opaque, without distinct erests or nodosities; covered with depressed, infuscate, and obscure greyish squamae, and also many coarse but not very elongate erect setiform seales; the body piceous, tarsi and antennae ferruginous.

Rostrum arched, subparallel, nearly smooth along the middle, subseriately and distinctly punctate, rufescent near the tip, sparsely squamose at the base, not quite the length of the thorax. Eyes large, rather flat, free. Scape inserted just before the middle, but hardly attaining the front of the eye, rather slender, flexuous, and very gradually incrassate. Funiculus rather longer than the scape, basal joint thicker and slightly longer than the 2nd, 3rd and 4th longer than broad, joints $5-7$ shorter. Club elongate-oval, its 1 st joint largest. Thorax subconical, quite as long as broad, not abruptly narrowed anteriorly; closely but not very coarsely punctured. Scutellum distinct. Elytra elongate-cordate, very little broader than the thoras at the base, nearly twice its length, widest before the middle, gradually narrowed, somewhat laterally compressed, but not quite vertical behind; they are striate-punctate near the base, quite striate behind.

Legs elongate, slightly variegated, with numerous erect, but not very elongate, squamiform setae.

Underside thickly elothed with tawny and fuscous seales, these latter somewhat congregated on the middle of the intermediate segments, and bearing also a few white suberect ones. The rostral canal is profound, and extends to the front of the metasternum, which is short, closely punctate, and broadly depressed. Abdomen very elongate, its basal segment strongly rounded and subangulate in front, rather flat and closely punctured; the 2nd, in the middle, more than half the length of the 1st; 3rd and 4 th but little abbreviaterl, so that, conjointly, they are rather longer than the $2 \mathrm{nd}$, which is hardly the length of the 5th.

Distinguishable from the type of the genus, 1427 , by the obscurely coloured restiture, the absence of erests, more elongate antennae, broader tarsi, and by the elytra being Iess dilated near the base. In 1427 the basal ventral segment is oblique towards the front, and quite angulate there.

Length (rostrum exclusive), $4 \mathrm{~mm}$; ; breadth, $1 \frac{3}{1} \mathrm{~mm}$.

Hakapoua, Southland. Two eximples from Mr. A. Philpott. 


\section{Xenacalles nodifer sp. nov.}

Convex, elongate, widest near the shoulders, attenuate towards both cxtremities; thickly covered with an andmixture of fuscous and tawny squamae; many of the latter hue are longer, some being quite erect and

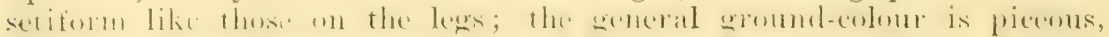
but, except on the rostrum, hardly visible; the antennae and feet are alumost pitehy-red.

liostrum a third shorter than the thorax, rather broad, slightly narrowed medially, subseriate-punctate near the sides, nearly smooth along the middle. 'Thorax widest at the base, gradually narrowed anteriorly, of about equal length and breadth, closely punctate, without conspicuous crests. Scutellum distinct. Elytra slightly broader than the thorax at the base (their widest part), much narrowed posteriorly, the declirity not quite perpendicular, and appearing to be nearly as long as the broader portion; they are indistinctly striate-punctate, the :3rd interstices are obtusely and slightly elevated, indistinctly crested near

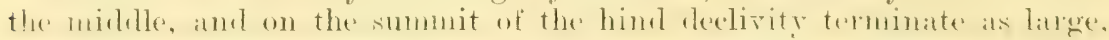
scaly, distant nodosities; the space between them is darker than the rest of the surface; a little lower lown there is a small central prominence.

In $X$. triangulatus, 1427 , the posterior crests are alnost contiguous, and the dark triangular area is situated in front of them; this dark mark in I. squamicentris from the Chatham Islands occupies the same position, but it is short and broad, and the crests are only feebly dereloped or obsolete. The funiculus, in structure, is similar to that of $X$. simplex, but the club is oblong-oral and rather broader, and the insect itself is very different.

Length (rostrum exclusive), $4 \frac{1}{2} \mathrm{~mm}$. ; breadth, $2 \frac{1}{4} \mathrm{~mm}$.

Mount Greenland. Found by Mr. H. Hamilton; and a single specimen, mounted on eardboard, forwarded to me by Mr. A. O'Connor, of Wellington.

\section{Scelodolichus flectipes sp. nov. Scelodolichus Broun, Man. N.Z. Coleopt., p. 495.}

Body transversely convex, rather elongate, somewhat nitid; fuscopiccous, elytral suture rufescent, the legs obscure fusco-rufous, antennae and talrsi ferruginous, rostrum shining pitehy-red; thorix rery scantily rhtherl with grey and fulvescent rather slender squamile, which usually form a pair of median patches; the elytra are more thickly covered with obseurely fulvescent slender squamae near the base, behind that part they are less evenly distributed and intermingled with grey; the sutural region is nearly bald, there are also a few blackish bare spots at the base and near the sides; there are numerous erect, moderately slender, dark setae also.

Rostrum shorter than the thorax, subparallel, slightly arched above, and fincly punctate in the female, moderately expanded towards the base and apex in the male, in both sexes it is siuamose at the base. Thorax of about the same length and breadth, rounded and rather wider behind the midrle than elsewhere, rather grabually narrowed anteriorly, its apex curvedly prolonged, so that the head is invisible from above, the base quite truncate and more or less obviously marginated; its punctation is distinct and moderately close, the carina along the middle does not extend as far as the base or apex. Elytra oviform, more elevaterl than the thorax, searcely wider than it is at the base, twice its length, 
the top of the posterior declivity is curved, but it is narrowed and vertical towards the extremity; ther are moderately coarsely substriate-punctate.

lexw long, the anterior pair particularly, with Hexuons tibiate; ard tarsal joint expanded and bilobed.

Seape inserted behind the middle and reaching the eye. Funiculus nearly double the length of the scape, its basal two joints about equally elongate, joints 3 to 6 evidently longer than broad, 7 th distinctly shorter and broader ; c'ub oblong-oval.

Underside subopaque, with flavescent hair-like scales, the breast and basal ventral segment chestmut-red, remaining segments piecous. Posterior coxae alnost in contact with the middle pair and the epipleural margins. Basal two abdominal segments longitudinally depressed in the middle, and on a higher level than the very short 3rd and 4th; the Ist, in the middle, nearly thrice the length of the 2 nd; the 5th rather elongate.

Nearly allied to 882 , but differentiated by the flexuous tibiae, brighter squamosity, and rather" stonter and less elongate legs.

Length (rostrum exclusive), $3 \frac{1}{2} \mathrm{~mm}$; ; breadth, $1 \frac{3}{4} \mathrm{~mm}$.

Great Barrier Island, March, 1911. Found amongst decayed leaves sent to me by Mr. F. Flynn, of Fitzroy Harbour.

3458. Metacalles picatus sp. nov. Metacalles Broun, Ann. Mag. Nat. Hist., ser. 6 , vol. 12 , p. 381.

Convex, subovate, narrowed anteriorly, opaque; fusco-niger, tarsi and antennae pitchy-red, club piceous; bearing many outstanding, moderately slender, fuscous setae, but ornamented, the thorax particularly, with numerous decumbent, rather elongate, bright-ferruginous setae, in strong contrast with the dark derm.

Rostrum slightly shorter than the thorax, parallel, shining rufopiceous, almost smooth in front, with double series of coarse punctures along its basal portion. Thorax as long as it is broad, distinetly, yet not abruptly, narrowed and depresserl before the middle, its apex rounded, the sides nearly straight behind, almost marginate and truncate at the base; without superficial inequalities, its punctation coarse but shallow. Elytra cordate, at the base slightly broader than the thorax, not twice its length, vertical behind; sutural striae well marked, the others obsolete; on each elytron there is a pair of prominent crests, the outer on the shoulder, the inner near the suture, there is another on the top of the apical declivity near the suture, and a 4 th near the hind thigh.

Scape short, implanted behind the middle, barely reaching the eye, a good deal incrassate towards the extremity; funiculus elongate and sparsely setose, basal joint largest, slender at the base, subclavate at the apex, the next short but longer than broad, joints 3-6 short and moniliform, 7th broader, quite transverse; club broad, ovate, densely pubescent, indistinctly annulate. Tarsi narrow, the penultimate joint moderately expanded, deeply exeavate above but not truly bilobed.

The quadricristate elytra and bright-foruginous setae are its distinguishing features.

Length (rostrum exclusive), $2 \mathrm{~mm}$; ; breadth, $1 \frac{1}{3} \mathrm{~mm}$.

Nount 'Te Aroha, November, 1910. ITnique.

3459. Getacalles sparsus sp. nov. Crefucrelles Broun, Man. N.Z. Coleopt., p. 1380 .

Oblong, convex, opaque; nigrescent, antennae and tarsi ferruginous; densely covered with small variegated squamae, which on the sides of 
the elytrat are dark fuscous, on the sides of the thorax and along the middle of the elytra pale ferruginous principally, but here and there intermingled with whitish spots; the setae are linited to the legs.

Rostrum about as long as the thorax, moderately axched, subparallel, stout, squanose at the base, fincly punctate in font. Thorax oblignely, rather than abrupty, eontracted anteriorly, behind that part the sides are nearly straight, though slightly namowed towards the base; the apex is broadly rounded, the base feebly ret widely bisinuate, so that the obtuse posterior angles rest on the elytra just inside the shoulders:

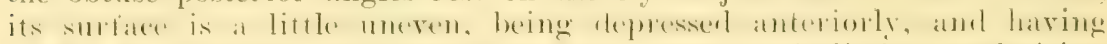

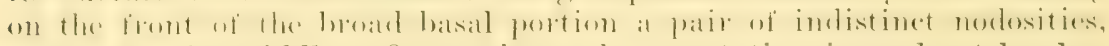
and along the middle a fine carina; the punetation is moderately elose and coarse but concealed by the squamae. Seutellum squanose. Elytra quite oblong, rertical behind, with obtusely prominent shoulders, their length double that of the thorax; they are coarsely seriate-punctate; the punctures, however, are obseured by the clothing, and beconse finer behind; the $3 \mathrm{rd}$ interstice on each elytrom is only indistinctly and irregularly raised, but is slightly binodose, longitulinally, neat the top of the rleclivity, the 5th also is similarly nodlose.

Legs elongate but robust; femora unarmed; tibiae strongly uncinate, oblique at the extremity; tarsi rather narow, finely pilose underneath, theil basal joint nearly twice the length of the 2 nd, the penultimate only moderately expanded and bilobed.

Scape elongate, inserted between the middle and apex and attaining the ere; funiculus rather longer, bearing fine grerish setae, its 2 nd joint as long as the basal but more slender, joints 3 to 6 subquadrate, th rather shorter; club oblong-oval, triarticulate.

Recognizable by the unasperate surface and unusually rufescent squamosity.

l.ength (rostrum exclusive), $4 \mathrm{~mm}$; ; brearth, $1 \frac{3}{4} \mathrm{~mm}$.

Thisury, Invereargill. The specimen, mounted on cardboard, from Ir. 1. Philpott, is, I believe, unique, and, judging br the simple femora and finely seulptued rostrum, is probably a female.

\section{Getacalles fasciatus sp. nov.}

Oblong-oval, transversely convex, without definite elevations, opaque; fusen-piceons, antennae and tarsi bright ferruginous; densely covered with small fuseous and coppery seales; those of the latter colour are most conspicuous near the sides of the thorax and along the declivous portion of the elytral suture; there are searcely any white ones on the dorsum, but white, suberect, squamiform setae form a fascia across the top of the posterior declivity; the setae on the lexs are mostly infuscate, but ncal the extremity of the tibiae they are more enncentrated, finer, and fulveseent.

Rostrum rather shorter than the thorax, abruptly eonstricted near the eres, slightly narrowed medially, finely punctate near the apex, more condsely behind, where it is squamose and has an indistinct, smooth, central line. Thorax slightly and obtusely prominent laterally just before the middle and at that part a little broader than long, somewhat oblinuely contracted, and depressed, anteriorly ; it is morlerately coarsely and closcly punctured, and has a centrall callna, which, howerer, does

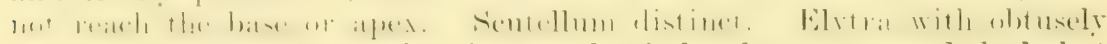
porrect shoulders, just twice the length of the thorax, a good real, but not abruptly, narrowed and deflexed behind; they are distinctly and cransely seriate-punetate, more finely on the declivity; the srol inter- 
stices are slightly elevated at the base, but there are no definite posterior nodosities.

In structural details it corresponds with G. sparsus, but it is smaller, more oriform, much less variegated, and has rather shorter antenuae; the 2nd joint of the funiculus is distinctly shorter than the 1st, and the seape is more inerassate apically. The white fascia across the summit of the posterior declivity is its most characteristic feature.

Length (rostrum exclusive), $3 \frac{1}{2}$ nmm.; breadth, $1 \frac{1}{2} 11 m$.

Tisbury. Another of Mr. P̈hilpott's uniques. Both species were found in November, 1911.

\section{Atylodes gen. nov.} small.

Bory subovate, without erests or nodosities, setigerous, the species

Rostrum about a thind shorter than the thorax, slightly dilated and laterally subearinate near the eyes. Thorax of about equal length and breadtli, rounded but not obviously contracted in front, base truncate, without ucular lobes. Scutellum absent. Elytra cordate or obovate, closely applied to the thorax, of the same width, or nearly so, as it is at the base.

Eyes small, subrotundate. Scape medially inserted, attaining the eyc, incrassate apically. Funiculus longer than the scape, basal joint stont, elongate-triangular, the next very slender and elongate, fully as long as the basal, 3rd shorter yet elongate, 4th and ith rather longer than broad, 6th and 7 th monililorm. Club ovite, densely pubescent, not visibly articulate.

Femora long and thick, but marmed. Tibiae unequal, the anterior flexuous, distinctly uncinate and longer than the others, which are without perecptible spurs. Tarsi densely setose underneath, subtriangular; basal joint rather small, triangular, 2nd short and broad, Brd large, widely expanded and bilobed, the last slender, with small claws.

Pectoral canal profound, extending as far as the middle of the intermediate coxae, with elevated borders there. Metasternum abbreviated, so that the middle and hind coxae are almost contiguous. Abdomen ample, half of the whole length; basal segment, in the middle, nearly thirice the length of the 2nd, convex, but depressed and broally rounded between the coxale, the suture between it and the 2nd completely obliterated in the middle; 3rd and 4th ver'y short, linear, with deep, straight sutures; 5th moderately elongate.

The asperate, thickly squamose surface of Acalles, in conjunction with its strongly uncinate tibiae, differently formed tarsi and antennae, and the abdominal structure, are not in acordance with the characters exhibited by the type of Atylodes.

\section{Atylodes foveiger sp. nov.}

Convex, slightly nitid; with numerous setae, the erect ones elongate and fuscous, the others flavescent and curled; near each hind angle of the thorax there is a patch of crean-eoloured squamat thorax and legs fusco-rufous, elytra rufo-castaneous but darker along the sides, rostrum pitchy-red, antennie fulveseent, club fuseous.

liostrum smooth and convex along the middle, bisuleate and punctate laterally to beyond the antennal insertion. Thorax moderately narrowed before the middle, coarsely and closely punctate. Elytra broadly cordate, slightly wider than the thorax at the base, much broater near the middle, narrowed and nearly vertical behind; punctate-striate, the striae more 
distinct than the punctures; the interstices nearest the suture, except just at the base, are a good deal and rather evenly elevated, causing the suture to appear depressed, the outer ones are less raised.

Underside piceons, with sone yellow setie, the metasternum with a

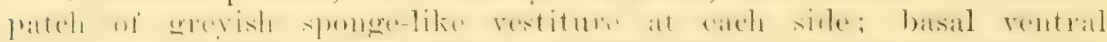
segments relatively coarsely but not deeply punctured, the jth eren less deeply, with a linge oblong median fovea; in my older specimen this serment is testaceous, the other is rufescent.

Length (rostrum exclusive), $2 \frac{1}{4} \mathrm{~mm}$.; breadth, $1 \frac{1}{4} \mathrm{~mm}$.

Hount 'Te Aroha. My first specimen was found about thirty years ago; another pair during my short visit in November, 1910. The recent captures are rather darker than that described above; all were found amongst head leaves, and have the same large fovea on the lant segment.

\section{Group Cossonidan.}

3462. Allaorus scutellaris sp. nov. Allaorus Broun, 'Irans. N.'\%. Inst., vol. 41, p. 208.

Elongate, suboviform, slightly convex, moderately nitid; of a faintly rufescent fuseo-testaceous hue, antennae ferruginous; very sparingly clothed with slender, greyish-yellow, decumbent pubeseence.

Rostrum eylindrical, nearly as long as the thorax, slightly arched, finely ret distinely punctate. Thoritx subenieal, grasually narrowerl anteriorly, rather longer than broad, obsoletely constricted near the front, which is a little rounded, apparently more elevated, and more finely sculptured than the moderately coarsely but not elosely puncturer dise. Scutellum distinct. Elytra nearly twice the length of the thorax, just a little broader than it is at the base, which is subsinuate; they are a good deal, and somewhat abruptly, narrowed near the extremity, which is broadly rounded; their surface is rather consely striate-punctate, mere evidently striate near the suture; interstices without distinct serial punctures; the 2 nd, as well as the suture, are only slightly raised.

Tibiale with strongly developed hooks; the apex of the anterior is emarginate and has an acute inner angle, but along the inside, near the middle, there is no fringe or emargination.

This agrees in nearly all essential particular's with Allaorus, but the larger eyes and distinet scutellum are good discriminative features.

Length (rostrum inclusive), $2 \frac{2}{3} \mathrm{~mm}$.; breadth, nearly $1 \mathrm{~mm}$.

Erua. My specimen was found amongst decaring leaves, on the ground, in January, 1911.

\section{Group Axthribidak.}

3463. Anthribus albicepssp). nov. Luthribus (fooffroy, Min. N.\%. ('uleopt. p. 545 .

Variegate, slightly nitid, light castanenus, rostrum piceous; the basal joint of the tarsi and joints $2-8$ of the antennate tetaceous; the basal joint of the latter, the tips of the intermediate, and the club, as well as joints 2-t of the tarsi and the apical portion of the tibiale, more or less infuscate; the pubescence almost white, rather slender, concentrated on the head, but unevenly and rather thinly distributed elsewhere.

Rostrum as long as the thorax, moderately slender, considerably dilated near the apex but very grablually towards its base, distinetly and rather closely punctate and longitudinally rugose. Thorax as long as it is broad, widest behind the middle, gently narrowed anteriorly, more abruptly behind; the base is margined and truneate but not definitely angulate; at a short distance in adrance, in line with the 
widest part, there is a slightly curved carina, which, however, becomes quite obsolete towarls the sirles: its punctation is fine, especially in front, but is slightly rugose and more irregular behind. Seutellum small, somewhat rounded. Elytra oblong, a little broader than the thorax at the base, which is oblique towards the suture, apices subtruncate, and not covering the vertical pygidium; they are distinctly, though not coarsely, seriate-punctate, and are without any definite nodosities or erests.

Antennae slender, reaching backwards to the shoulders, inserted near the apex in foveiform cavities, their basal joint barely half the length of the elongate $2 \mathrm{nd}$, which is norliform at the apex; joints 3-8 differ but little, all are elongate, the 8th, however, is rather shorter and a little expanded apically; 9th triangular, shorter and broader than its predecessol; 10th transverse; the terminal conical.

Eyes lateral, longitudinally oval, entire, occupying the whole side of the head and just touching the truncate thoracic margin.

In structural details, excepting the laterally obliterated carina of the thorax, this species is congeneric with $A$. sharpi, 963, which is larger, with thicker and somewhat maculate pubescence.

Length (rostrum inclusive), $3 \mathrm{~mm}$; ; breadth, quite $1 \mathrm{~mm}$.

Tisbury, Invercargill. My specimen was found by Mr. A. Philpott, in February, 1911.

\section{Anthribus imitarius sp. nov.}

Oblong, moderately convex and nitid; nigro-fuscous; the linces, middle of tibiae, the basal joint and claws of the tarsi greyish or pale castaneous; the antennae also light chestnut, but with fuscous tips to most of the joints; the pubescence pale, flavescent and grevish, unevenly distributed, so that the lower sides of the thorax are bare and blackish, as is also a broad space behind the posterior femora.

Rostrum as long as the thorax, its frontal half angularly expanded, closely and finely punctate-rugose, slightly ematrinate at the alfex, with a fine indistinct earina along the middle of the basal portion. Thorax rather broader than long, widest and rombled at the mirldle. somewhat irregularly and finely punctured; its carina hardly discernible, morlerately distant from the base, ant not forming littrial angles. Elytrat chlong, romeded behind, with subtruncate apice, the hase evidently broader than that of the thorax; with series of moderately fine punctures, but without perceptible inequalities.

Legs simple. Tarsi rather short, not very s'ender, basal joint longest, 3rd short, with elongate lobes; claws short and distinctly toothed.

Antennae sparingly pubescent, longer than the head and rostrum; basal two joints nearly equal, stont, subpyriform; joints 3-S decrease in length, the 8th obconical and rather broader than preceding ones; club distinct, its basal joint subtriangular, largest, the next transversal, the apical conical.

With a single exception this species closely resembles the female of A. brouni, 964, in structure. The eres are a little more rotundate and less prominent, the antennae are rather shorter, the vestiture is altogether lighter, there is no metallic tinge, the shoulders are obviously. more prominent, and the insect itself is much smaller. The exceptional feature is the obsolete thoracic earina. In both species the eres are just free from the thorax, but in the allied A. samlageri, 2224, these oreans are distant from it.

Length (rostrum inclusive), $3 \mathrm{~mm}$; breadth, $1 \frac{1}{5} \mathrm{~mm}$. 
Invereareill. Deseriber from a single specimen eaptured by Mr. A. Philpott during winter-August, 1911.

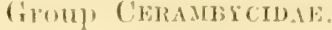

3465. Didymocantha hudsoni sp. nov. Didymocantha Newman, Misn. N.'/. Coleopt., p. 568.

subdepressed, dongate, moderately shining; head and thorax somewhat fulvescent; elrtra pale testaceous, each with a pair of ivory-like streaks extending fiom the base almost to the extremity; basal joint of antenmac distinetly punctate and rufous; remaining joints, palpi, and legs pale yollow.

Head distinctly and irregularly punetate, with some short interantennal grooves, the central linear impression is slender, the angulation before each eve is dark, and the mandibles are pitchy-red. Thorax rather broader than long, with a small, guite obtuse, tubercle at each side behind the middle, in front of this the side is gradually and slightly umcrenly narrowed, its apex is feebly emarginate and densely ciliate; the dise is without tubereles, the punctures are piceous, moderately corase, but rery irregulary distributed, with perfectly smooth intervals; the lateral sculpture of the basal half is a little finer, but closer, than that of the dise. Elrtra boader than the horax, four times its length, with individually romnded apices; they bear only a few short, slender, suberect hairs above, but the sides towards the extremity are thickly fringed with elongate pubcrecnce; each elytron has a pair of smooth, slightly raised costae along the midlle, the suture also is a little clovated behind, alongside it from the base to the middle there is a less definite ensta; the punctures on the longitudinal intervals are dark fuscous and rather irregular, but become shallow behind; the interstices, from the midlle backwards, ate rendered slightly uneven by short, irregular, but rather indistinct rugae.

Antennae criciently pubescent, their basal half with numerous longer lairs, the 9th joint attains the apex, the the is hardly perceptibly shorter than the arljoining ones.

In general appearance like 2252, but with the shape and seulpture of the thorax essentially different. In that species most of its surface is closely and fincly punctured, but in /). hudsomi the spaces between the dark and rather coarse punctures are smooth and polished.

Length, $15 \mathrm{~mm}$; ; brearlth, $3 \frac{1}{2} \mathrm{~mm}$.

Pipiriki. One example from Mr. G. V. Hudson, in whose honour it has been named.

\section{(GOHY) LAMIIDAE.}

3466. Hybolasius ciliatus sp. nov. IIybolasius Bates, Man. N.Z. C leopt., p. 609 .

Oblong, fusco-rutous, thickly covered with decumbent, elongate, testacerus and fulveseent hatirs, those of the latter colour predominating on the hinder part of the wing-cases; antennac and legs pale castaneous.

Head with a central sulcus, its dense pubescence rather pale and concealing the fine seupture. 'T'horix a third broader than long, more constricted at the base than in front: othe lateral tubereles, behind the middle, atre very obtuse, as ate also the median, somewhat transversal, forsal ones; its sonlpture is fine, and appears to be punctate-granulose. Flytlat oblong, very little narrowerl pesteriorly, with broadly roumled apices, and obtuscly prominent shoulders, their length about four times 
that of the thorix; the dorsum nearly plane, the basal tubereles being but slightly elevated; along the middle of each elytra, in rear of the hind thigh, there is a slight elongate devation; the punctation of the basal half is close and molerately fine, that of the hinder part distant and very coarse, quite foveiform.

Antennae with fine pubescence, and, as far as their 7 th joint, bearing also numerous outstanding, slender, almost white hairs; basal joint gradually clavate and thickly pubescent; the elongated srd joint is longer than the 4 th, which cxceeds the other following ones in length.

Legs m̧orlerate, with long, slender, whitish hairs.

In $H$. pedator the thorax is less transversal, it has more prominent tubercles, and the elytra are more attenuate behind, with the pubescence much paler on the midlde than it is elsewhere.

Length, $6 \frac{1}{2} \mathrm{~mm}$. ; breadth, $2 \frac{1}{2} \mathrm{~mm}$.

A second specimen is darker, with greyish clothing.

\section{Hybolasius vittiger sp. nov.}

Elongate, slightly convex, subopaque, fuscous; thickly covered with distinct rellowish or tawny pubescence, but on each elytron a dark broad streak extending alongside the suture from the base to beyond the middle, and at that point obliquely prolonged backwards to the side, bears only some finer and darker pubescence, and therefore appears hure; antennae fusco-testaceous, but with slightly rufescent basal joints; lews rather darker than the antennae, with elongate greyish hairs; the tibiae below the middle, the lower part of the femora, and the front face of the anterior pair more or less nigrescent.

Thorax rather broader than long, obtusely prominent or tuberculate at each side behind the middle; its surface only slightly uneven, and, like the head, usually closely but not coarsely punctate-granulose. Elytra nearly thrice the length of the thorax, evidently broader than it is at the base, with strongly rounded apices; distinctly punctured as far as the hind thighs, and with a few coarser impressions behind; a slight irregular elevation along the middle of each forms the lateral border of the dark vitta, but the common basal tubereles are very small.

Antennae thinly elad with grevish hairs, 3 rd and th joints very elongate; the latter almost reach the posterior femora, the 7 th the tip of the elrtra.

Underside fuscous, with grerish pubescence.

Although somewhat similar in appearance to $I /$. bellicospes, 1080 , it is materially different in habit, the five specimens receiver for examination being quite perfect, whereas almost every individual of. 1080 , first found by myself at Tairua nearly forty rear's ago, as well as many captured since then, were more or less badly mutilated, eridently by each other.

fuength, $4 \frac{1}{2} \mathrm{~mm}$; ; breadth, $1 \frac{1}{2} \mathrm{~mm}$.

Titahi Bar, near Wellington. Found by Mr. A. O'Connor.

\section{Gromp Cryptochimatidi:}

3468. Bryobates aeratus sp. nov. Bryobates Broun, Man. N.Z. Coleopt., p. 873 .

Glabrous, shining, bronzed, somewhat viridescent, the head feebly violaceous; antennac and tarsi fulrescent, terminal joints of both slightly infuscate.

Head hardly as wide as the thorax, minutely coriaceous behind but appearing nearly smooth. Thorax subyuadrate, a third broader than 
long, its sides finely margined and nearly striight, the apex subtruncate, with slightly obtuse angles; base finely matrined, nearly straight in front of the scutellum, somewhat curved towards each side, so that its angles are rather indefinite; the surfice with fine, dense coriaceous sculpture. Sicutellum large, broadly triangular. Elytra rather wider than thorax at the base, nearly thrice its length, very gradually expanded posteriorly, their apices oblique near the sides but obtusely rounder towards the suture, which, therefore, is open for some distance; they are closely, rather finely, and somewhat rugosely punctate. Pygidium incovered, plane, finely seulptured and pubeseent.

Legs stout, their p' escence rather thick and pale; tibiae nearly straight, the posterior ruther longer than the others; basal joint of the anterior tarsi longer than the 2nd, both narrowed towards the base. 3rd moderately dilatid and lobate, the terminal slender; claws appendiculate at the linse.

Antennae tinely pubescent, moderately stout yet elongate, inserted on the forchead in line with the front of the eyes, basal joint largest, gradually incrassate, 2nd shortest ret longer than broad, 3-10 about equal, all evidently longer than broad and gradually dilated apically, 11 th elongate-oval.

Obviously narrower than the type of the genus, $B$. coniformis, with altogether different sculpture and coloration.

Length, $4 \frac{1}{2} \mathrm{~mm}$. ; breadth, $2 \frac{1}{4} \mathrm{~mm}$.

Hump Ridge, Okaka. Found by Mr. A. Philpott at an altiturle of $3,500 \mathrm{ft}$.

\section{$3 \pm 69$. Bryobates nigricans sp. $110 \mathrm{v}$.}

Nitid, nude, black; antennae and legs fulvescent, joints 3-11 of the former becone gradually more infuscate, tarsi also infuscate.

Head with a distinet interantennal depression, its hind part relatively coarsely punctate and rugose. 'Thorax about a third broader than long, its sides distinctly margined, gently narrowed from the front backwards, base and apex subtruncate, neither marginated, posterior angles obsolete, the anterior obtuse and very slightly incrassate; there is a shallow median impression behind, and its surface is very distinctly but irregularly punctured, so that the smooth intervals are broader on some parts than on others. Scutellum large and smooth. Elrtra less than thrice the length of the thorax, nearly double its width bekind, and broader than it is at the base, their sides somewhat rounded, the apices very broadly rounded, rather obliquely so towards the delisisent suture; their whole surface moderately coarsely and irregularly punctured, rather more closely near the base, and with some oblique rugae behind the seutellum. Pygidium exposed and nearly smooth.

Antemnae finely pubescent, extending backwards to the posterior iemora; ther are rather stouter than those of $B$. aeratus.

Legs stout and elongate; tibiae distinctly pubescent towards the extremity; tarsi with elongate-oblong basal joints, 2nd narrower and evidently longer than broad.

Rather larger than 1555, not at all evaneous; the thorax more finely, the elytra more coarsely, closely, and irregularly punctured; the thorax has rather thicker margins, and differs somewhat in shape.

Length, 5 mm.; breadth, $2 \frac{3}{4}$ mm.

Owaka, Clutha. Unique. Found amongst moss many years ago by Mr. S. W. Fulton. 


\section{NEW ZEALAND INSTITUTL.}

BULLETIN No. 1. (Part 3)

DESCRIPT I ON S C.F

\section{NEW (GENERA ANI) SPECIES}

OF

\section{COLEOPTERA.}

(PART III.)

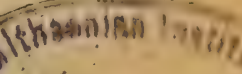

BY MAJOR T. BROU.Y, F.E.S.

EDITED AND PUBLISHED UNDER THE AUTHORTY OF THE HOAFD OF GOVERNORS OF THE INSTITUTE.

\section{ISSUED 29th MAY, 1914.}

Neto สีenlant:

JOHN MAOEAR, GOVERNMENT PRINTER, WELLINGTON.

Wa. Wesley and Son, 28 Essex Street, Strand, Londox W.C. 


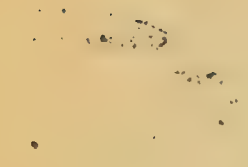

NEW ZEALAND INSTITUTE.

\section{BULLETINS.}

UNDER the title "Bulletins" the Board of Governors of the New Zealand Institute hopes to issue, from time to time, papers which for any reason it is deemed desirable not to include in the yearly volume of the Transactions. The bulletins will be uniform in size and general style with the Transactions of the New Zealand Institute, but will appear at irregular intervals, and each bulletin will be complete in itself and be separately paged. The bulletins will not be issued free to members of the Institute, but may be obtained by them at a reduction on the published price. 


\title{
NEW ZEALANI) INSTITUTE.
}

\section{BULLETIN No. 1, PART III.}

ISSUED 29TH MAY, 1914.

D ES S R I P T I O N S

oF

\section{NLW GENERA ANI) SPECIES OF COLLOPTERA.}

\author{
By Major T. Broun, F.E.S.
}

\section{PART III.}

'lus part contains descriptions of six new genera and 174 species of New Zealand beetles, and a copy of Dr. Sharp's paper on Scymnus circularis.

Almost all of these insects were discorered by Mr. A. Philpott, of Invercargill, and Mr. T. Hall, of Methven, within the past year (1912), which, as all our entomologists are aware, was a very unfavourable one for indigenous insects.

Naturalists who may read this paper can hardly fail to notice the remarkable number of species brought to our knowledge during the winter from the mountainous region near Methren by Mr. Hall, whose indefatigable devotion to scientific research, without pecuniary reward, should win the respect and admiration of all who love Nature.

The first section of the following list consists of new species of Pselaphidae, about eighty of which were sent to me from the British Museum on the 19th March, 1911, with a request that I would identify them. The deseriptions of Nos. 3482 to 3493 were published in Ann. Mag. Nat. Hist., ser, 8, vol. 10 (December, 1912), and of Nos. 3494 to 3503 in ser. 8, vol. 11 (February, 1913), under the supervision of the authorities of the British Museum, and copies, on arrival here, were forwarled to the colonial museums for reference.

Hount Albert. Auckland. 11th December. 1912.

6-Bull. No. 1. 


\section{LIST OF NEW GENERA AND SPECIES.}

Group PstelapHidid.

3482. Sagola carinata Broun.

3483. . ventralis Broun.

3484 . $\quad$ occiputalis Broun.

3485. , ", longula Broun.

3486. , pallidula Broun.

3487. , spiniventris Broun.

3488. ", grata Broun.

3489. ", bifoveiceps Broun.

3490 . ", biimpressa Broun.

3491. ," clavatella Broun.

3492. ", lawsoni Broun.

3493. " latula Broun.

3494. Euplectopsis sanguineus Broun.

3495. , duplicatus Broun.

3496. .. clavatulus Broun.

3497. Prectomorphus longiceps Broun.

3498 , , brevicomis Broun.

$3499 . \quad$," egenus Broun.

3500. Vidamus modestus Broun.

$3501 . \quad, \quad$ sternalis Brom.

3502. Zealandius fovealis Broun.

3503. Eupines simplex Broun.

Group CicINDELID AE.

3504. Cicindela waiouraensis Broun.

Group Cnemacanthidae.

3505. Mecodema puncticolle Broun. 3506. Metaglymma ovicolle Broun. 3507. Diglymma marginale Broun.

\section{Group Feronidat.}

3508. Triehosternus halli Broun. 3509. Pterostichus fossalis Broun. 3510 . ", burrowsi Broun.

Group Anisodactylidae.

3511. Lecanomerus labralis Broun. 3512 , , incertus Broun.

Group BEMBIDIIDAE.

3513. Anillus marginatus Broun.

35l4. , punctigerus Broun.

Group DRyopidan.

3.i1.. Hydora vestita Broun.

3.)li. , lanigera Broun.

3.517. , , subaenca Broun.

Group Pserapiudate.

3518. Sagola halli Broun.

3519. , colorata Broun.

3520 . ", dilucida Broun.

$3521 . \quad . \quad$ insueta Broun.

3522. suturalis Broun.

3523. ", fuscipalpis Broun.

3524. ," disparota Broun.

3525. " bituberata Broun.

3526. Euplectopsis tibialis Broun.

3527. ", terrestris Broun.

3528. " "

3\%29. ", eurvipemis Broun.

3530. Dalma gigantea Broun.

3.5i31. Vidamus bryophilus Broun.

35iz2. Zealandius basalis Broun.
35533. Zealandius spinifer Broun. 3534. Byraxis illustris Broun. 3535. , anisarthra Broun. 3536. " bisulcifrons Broun. 3537. Hamotulus angulipes Broun. 35:38. Pselaphus trifoveatus Broun.

Group Scaphidida.

3539. Baeocera sternalis Broun.

Group Corylopitidae.

3540. Sacina eurtula Broun.

Group Colydidda.

3541 . Ulonotus proprius Broun. 35+2. Notoulus truneatus Broun. 3543. " longipes Broun. 3544. Bitoma obsoleta Broun. 3545. Coxelus instabilis Broun. 3546. Heterargus parallelus Broun. 3547. Gathooles angulifer Broun. 3548. Protarphius pallens Broun.

Group Prcnomeridae.

3549. Pyenomerus tenuiculus Broun.

Group Lathrididae.

3550. Lathridius rugifrons Broun. 3551. ,, dualis Broun.

3552. Corticaria unicolor Broun.

3553. " vagepunctata Broun.

3554. " castanea Broun.

3555. ", robusta Broun.

3556. " " latulipennis Broun.

$3557 . \quad$, clavatula Broun.

3558. Lithostygnus serripennis Broun. 3559. ,, cuneiceps Broun.

Group Dermestidate.

3560. Trogoterma puncticolle Broun.

Group Byrrhidan.

3561. Synorthus substriatus Broun. 3562 . versipilus Broun. 3563. Pedilophorus aemulator Broun.

Group Dascyllid aE. 3564. Mesooyphon bifoveatus Broun. 3565 . ", lateralis Broun. $3566 . \quad$ halli Broun.

Group Telephoridae.

3.567. Asilis flavipennis Broun.

Group MLeLYridat.

3.)68. Dasytes fuscitaryis Broun. 3.)69. Arthracanthus fulvipes Broun. $3570 . \quad$.. fossicollis Broun. 3.71. , atriceps Broun.

\section{Group Clemidate.}

3572. Phymatophaea o'connori Broun.

Groxip) Ptinidae.

3573. Ptinus plagiatus Broun. 
Group Opatridae.

3574. Paraphylax exiguus Broun.

\section{Group Pythidae.}

3575. Salpingus semilaevis Broun. $3576 . \quad .0$ atrellus Broun.

3.577. , denticollis Broun.

Group MIelandritida.

3578. Neorchesia terricola Broun.

\section{Group OedemeridaE.}

3579. Metasclera nigricans Broun. $3580 . \quad$, arborea Broun.

3581. Sessinia stictica Broun.

Group OtIorhynchidaE. 3582. Nicaeana catoptoides Broun. 3583. " placida Broun. 3584. , gracilicomis Broun. 3585. Tigones humeralis Broun. 3586. , flectiscapus Broun. 3587. Protolobus granicollis Broun. 3588. Haplolobus frontalis Broun. $3589 . \quad$,, granulatus Broun. 3590. Catoptes spectabilis Broun. 3591. , subnitidus Broun. 3592. ", eurvatus Broun. 3593. ", carinalis Broun. 3594. , argentalis Broun. 3595. ", fumosus Broun. 3596. Brachyolus asperatus Broun. 3597. ,, fuscipictus Broun. 3598. Echinopeplus verrucatus Broun. $3599 . \quad$ dorsalis Broun. 3600. Inophloeus pensus Broun. 3601. ,, sulcicollis Broun.

\section{Group Rhyparosomidan.}

3602. Lithocia angustula Broun. 3603. Araeoscapus ocularius Broun. 3604. Bantiades cupiendus Broun. 3605. Abantiades nodipennis Broun. $3606 . \quad$, pusillus Broun. 3607. Clypeorhynchus nodiceps Broun.

\section{Group Hylobitda.}

3608. Bryocatus altemans Broun. 3609. ", jugosus Broun. 3610 . ", nodicollis Broun. 3611. ", nigrirostris Broun. 3612 ., amplus Broun.

Group Haplonychid AE. 3613. Geochus pyriformis Broun. 3614. ", suffusus Broun. 3615. ", variegatus Broun. 3616. " distinguens Broun. 3617. ", lateralis Broun.

\section{Group Erirhinidae.}

3618. Erirhinus sylvaticus Broun. 3619. Dorytomus fulvescens Broun. 3620 . ", melastictus Broun. 3621. ", albisetosus Broun. 3622. ", terrestris Broun. 3623 . $\quad . \quad$ floricola Broun. 3624. Neomycta seticeps Broun. 3625. Alloprocas muticus Broun.
3626. Simachus cuneipennis Broun. 3627. Etheophanus punctiventris Broun. 3628. Colabotelus dealbatus Broun. 3629. Hoplocneme propinqua Broun. 3630. Oreocharis carinulata Broun. 3631. ", latipennis Broun. 3632. , lineirostris Broun. 3633. Stephanorhynchus halli Broun. 3634. Stenopactola prolixa Broun.

\section{Group Cryptorhynchidae.}

3635. Acalles confusus Broun.

3636. " bicristiceps Broun.

3637. ," ignotus Broun.

3638. Tychanus squamosus Broun. 3639. Crisius latirostris Broun. 3640. Getacalles posticalis Broun. 3641. , fulvicornis Broun. 3642 . ", parvulus Broun. 3643. ., variellus Broun. 3644. , oblongus Broun. 3645. Onias albicristus Broun. 3646. Allanalcis laticollis Broun. 3647. Zeacalles carinellus Broun. 3648 . ", estriatus Broun.

\section{Group Cossonidan.}

3649. Pentarthrum brevicorne Broun. 3650. Tanysoma impressella Broun. 3651. ", aciphyllae Broun. 3652. Rhinanisus halli Broun. 3653. , , fusiformis Broun. 3654. Sericotrogus plexus Broun. 3655. Agastegnus concinnus Broun. 3656. $\quad$, thoracicus Broun. $3657 . \quad$, rugipennis Broun. 3658. Gaurocryphus mirandus Broun.

$$
\text { Group Anthribidae. }
$$

3659. Anthribus venustus Broun.

\section{Group LaMindaE.}

3660. Somatidia rubella Broun.

3661. , suturalis Broun.

3662. " " ruficornis Broun.

3663. ", halli Broun.

3664. Hybolasius lineiceps Broun.

\section{Group EumolpidaE.}

3665. Pilacolaspis rugiventris Broun. 3666. Aphilon impressa Broun. 3667. Caccomolpus flectipes Broun.

\section{Group Galerucidat.}

3668. Luperus insolitus Broun. 3669. ,,$\quad$ anthracinus Broun. 3670. ", bullatus Broun.

3671. ,. discrepans Broun.

3672. ". dilatatus Broun.

3673. .. iridescens Broun.

3674 . .. aurellus Broun.

\section{Group Coccinellidas.}

3675. Scymnus prolongatus Broun. 3676. ", halli Broun.

3677. ", cirevlaris Sharp.

$3678 . \quad$, nigritulus Broun. 


\section{Group Cítcindeimal.}

3504. Cicindela waiouraensis sp. nov. Cicindela Limné, Man. N.Z. Coleopt., p. 1.

Oblong, only slightly convex, subglabrous; head and thorax nitid, viridescent, tinged with purplish-red; elytra subopaque, more or less violaceous-black, with numerous metaliic-green spots, the larger ones irregularly distributed near the base and apex but forming a series near each side of the suture; the cream-coloured bands are moderately narrow, they form on each elytron a lateral curve from the shoulder to the middle thigh where it extends a little inwardly; united to this, but leaving a dark angular spot at the side, a prolongation to the hind thigh extends from the middle obliquely backwards nearly to the suture; the apical band does not reach the hind thigh, but extends obliquely forwards; legs and antennae somewhat infuseate and violaceous; labrum and base of mandibles of the same colour as the elvtral bands.

Head almost as broad as the thorax, obtusely elevated in front as far back as the middle of the eyes, distinctly but irregularly strigose. Labrum transverse, with 4 setigerous punctures, the central tooth broadly angulate, but not projecting further than the one at each side of it, the outer angles obtuse. 'Thorax slightly broader than long, abruptly enstricterl in fiont, firem thence gently warowerl, with slightly flattened and very distinctly margined sides; a broal deep turrow extends obliquely inwards from each anterior angle towards the middle, the base is abruptly depressed and contracted, the sculpture consists of distinct but very irregular rugae. Scutellum triangular, densely scuptured. Elytra oblong, nearly thrice the length of the thorax, broader than it is at the base, whiquely namowed behind, distinctly margined, their apios dirergent, morlerately acute but evidently reflexerl; the surface irregulitly studded with minute tuberels, the suture morlerately elevated throughout,

Underside dark violaceous, with many white setae on the breast; 5th ventral segment rounded towards the middle, which is angularly emarginate.

This, though resembling $C$. tuberculata, is nevertheless manifestly different. It is considerably larger. The head is less depressed between the eves. The central tooth of the labrum is not acutely produced. The thoracic dise is more elevated, so that the front and basc appear more abruptly constricted and depressed, and its sides are unmistakably marginate: The elytral apices, instead of being horizontally and sharply prolonged, are divergent, and evidently bent upwards.

o. Juength, $15 \mathrm{~mm}$. ; breadth, $5 \mathrm{~mm}$.

Wraiouru, near Mount Ruapehu. A somewhat damaged specimen is all I possess; it was presented to me in June, 1912, by Mr. A. C. O'Connor, who informer me that Mr. G. V. Hudson had captured several specimens.

\section{Gionip Camacanthidal.}

3505. Mecodema puncticolle sp. nov. Herodema Blanchard. Man. X.\%. Coleopt., p. 7.

Oblong, only slightly convex, morleritely nitid; black, antennae and tarsi nigro-piceous, tips of palpi fulveseent.

Ilead narrower than thorax, evidently punctate, more finely and distantly on the vertex; its sides and the forehead with deep longitudinal striae, and with a few feebly impressed transwerse ones between 
the eyes. 'Ihorax somewhat broader than. long, apex slightly yet widely emarginate, the sides slightly crenulate, gradually curvedly narrowed behind the middle, more strongly near the base, posterior angles obtusely rectangular; mesial groove well marked but not quite reaching the base or apex, both of these have short longitudinal striae, the basal fossae are leep and modrately large, the punctation is listinct, nowhere close, not at all rugose but rather irregular, there being very few punctures near the narrow malginal chatunch. Elytra oblong-oval, very little broader than the frontal portion of thorax, quite twice its length; each elytron is more or less distinctly quadricostate, the inner pair of costac, as well as the suture, are rather broad and nearly smooth but only very feebly elevated, the intervals between them are marked with irregular aciculate impressions; the space between the 2 nd and 3rd costae is distinetly but somewhat irregularly punetate, the sculpture between the 3rd and th consists of lirger punctiform impressions near the base, but at the mirlde they become smaller and biseriate; the th costa is smooth and convex but does not attain the shoulder; the marginal punctation is also coarse near the base and appear's irregularly biseriate near the middle, and the whole apical seulpture is very coarsely punctiform and irregular.

Underside shining, black; the head has transverse rugae on the middle and punctures at the sides. Prosternum smooth along the hinder part of the midlde, its flanks coarsely and rugosely punctured. Metasternum medially impunctate. Abdomen nouly smootli, haring only some moderately fine punctures at the base and fine transverse wrinkles on the terminal segment, which at the apex is bipuneate on each side of the middle.

Legs stout; anterior tibine slightly, the intermediate obviously, the posterior not at all, pominent at the outer axtronity. Antemate rather scantily pubescent from the the joint onwards.

This species, owing to its punctate head and thorax, bears some resemblance to $M$. sculpturatum, 13. The latter, however, is brightly bronzed, with rufeseent legs, and more convex eres; the head and thorax are rather closely and coarsely rugose-punctate, and the elrtra are corered with a multitude of remarkable, often radiating, rugae so that the inner costae are hardly discernible.

o. Jength, $24 \mathrm{~mm}$. ; breadth, $8 \mathrm{~mm}$.

Totara, Southland. I am indebted to Mr. A. Philpott, of Invereargill, for the only specimen as ret brought to light. It was found br him on the 3rd November, 1901.

3506. Metaglymma ovicolle sp. nov. Metaglymma Bates, Mrn. N.Z. Coleopt., p. 11.

Elongate-oblong, slightly convex, nitid; black; palpi, antenune, and legs picen-r'ufous.

Head nearly straight behind, with coarse, but not deep, irregular interocular rugae. Thorax suboviform, its length and breadth almost equal, a little wider near the middle than it is elsewhere, more narrowed, but not abruptly, behind than in front; lateral margins simple, rather thin, most distinct and somewhat elevated near the base, the apex widely but not very deeply-incurved; disc almost quite smooth, with some fceble wrinkles at the sides and a few short rugae at the middle of the bose, mesial groove well marked but not reaching the front, basal foveae deep, rather small, and situated close to the indefinite angles. Elytra 
rather broader than the thorax, more than clouble its length, slightly curvedy narowed near the base; their striae deep, regular, closely and rather coarsely punctured, the interstices near the suture are rather moader and flatter than the outer ones, the 9th is broad and smooth but does not extend to the shoulder, the marginal punctures lrecome irregular behind.

Underside nearly smooth; prosternal process broadly impressed between the coxat ; terminal ventral segment quadripunctate at the apex.

Antennae distinctly pubescent fiom their 5th joint onwards. Anterior tibiae moderately prolonged at the onter extremity, the intermediate strongly, the posterior hardly at all, angulate externally.

The oviform tholax and more elongate elytra distinguish this species from $\%$. doulli, 2611. In Sharp's $M$. sulcatum, 1764, the head is without rugae, and the thoracie margins are infringed on by the 6 sutigerous punctures at each side.

o. Length, $20 \mathrm{~mm}$.; breadth, $6 \mathrm{~mm}$.

Otaraia, near llartinborough. Deseribed from a specinen found by $\mathrm{M} r . \mathrm{A}, \mathrm{C}, \mathrm{O}^{\prime} \mathrm{Connor}$ in April, 1911.

35̃07. Diglymma marginale sp. nov. Diglymme Sharp, Min. N.Z. Coleopt., p. 980.

Elongate, only slightly convex, nitid; black, legs rufo-piceous.

Head, including the large and prominent eyes, quite as broad as the front of the thorax, depressed and finely punctate behind so that the vertex seems convex; labrum medially emarginate. Thorax apparently elongate, really just as broad as it is long; its sides trisetose, distinctly margined, only moderately rounded near the middle, sinuously narowed behind, yet straight near the rectangular posterior angles; basal fossae elongate, situated near the sides and extending to the base, the space between them with numerous distinct punctures, the middle of the basal margin has several very short striae; near the subtruncate apex there are some fine punctures and a shallow fovea near cach side, the central groove almost attains the base and apex. Elytra elongate-oval, twice the length of the thorax and rather broader than it is at the base, the lateral margins somewhat reflexed and thickened, near the rounded shoulders particularly; their striae are moderately deep and very finely punctate, but becone irregular towards the extremity, the half-dozen marginal punctures are rather coarse.

Underside glossy black, flanks of prosternum finely rugose and punctate, the abdomen with undulating slender rugae, its terminal segment quadripunctate at apex.

Antennae shorter than the head and thorax, 3rd joint rather longer than contiguous ones, chestnut-red and with distinct fulvous pubescence from the jth joint onwards.

'Tibiae withont any apical prolongation; middle tarsi almost as elongate and slender as the posterior.

Rather less convex, and with more strongly dereloped elytral margins than usual. Mentun tooth simple, triangular.

‥ Length, $14 \mathrm{~mm}$; breadth, $4 \frac{1}{2} \mathrm{~mm}$.

Ilmmp Ridge, near Invereargill; Februars, 1912. One from ILr. A. Philpott. 
Group Feroxida.

350. Trichosternus halli sp. nov. Trichosternus Chaudoir, Man. I.Z. Coleopt., p. 31.

Oblong, slightly convex, glossy; black, the elytra tinged with rect and their sides distinctly viridescent, the thorax along its sides and near the basal angles also greenish; legs piceous, the tarsi, antennae, and palpi rufo-piceous, these last paler at the extremity.

Head smooth, with well-developed frontal fovere; labrum emarginate. Eres prominent. 'lhorax a third broader than long, widest before the middle, only moderately rounded there, gradually but har ily at all sinuously narrowed towards the exactly rectangular posteriol' angles, its base slightly and widely incurved, the apex more strong?; mesial groove well marked, but not reaching the base or front, basil fossae large and expanded torards the angles, the dise nearly smooth, having only a few feebly impressed striae across it. Scutellum striate. Elytra oblong, slightly sinuate near the apices, not thrice the length of the thorax, a little broader than it is, with moderately dentiform shoulders; their striae though distinct are not very deep, and fincly Jet rather indistinetly punctate; the dorsal interstices are almost plane, the srd are rather broader than adjacent ones and are irregularly tripunctate, the 7 th are sex-punctate.

Legs normal, the middle tibiae somewhat compressed and pointer at the extremity.

Underside shining black, nearly quite smooth, the terminal rentral segment cyuaripunctate at the apex.

No described species is precisely similar. T. sylvius, 72 , as well as 71 and 73 , also from Canterbury, differ in convexity, in depth of elytral striar, and general appearance.

j. Length, $20 \mathrm{~mm}$; : breadth, $6 \frac{1}{2} \mathrm{~mm}$.

Hount Hutt, near Methren. This bears the name of its discoverer, Mr. T. Hall, who has, under unfavourable conditions, found many new species there.

3509. Pterostichus fossalis sp. nov. Pterostichus Bonelli, Man. N.Z. Coleopt., p. 31.

Elongate-oblong, slightly convex, shining; aeneo-niger, antennae and legs nigro-piceous, terminal joints of the former, the tarsi, and palpi more rufescent.

Hear, including the prominent eres, as broad as front of thorax, nearly smooth, with the common frontal impressions. Thorax nearly a third broader than long, apex moderately incurved, the base more slightly so in the middle; its sides distinctly margined, moderately rounded, rather wider before the middle than in front, a little sinuously narrowed towards the rectangular but not projecting posterior angles; disc very feebly wrinkled, its sides smooth, mesial groove well marked but not quite touching the apex, basal fossae large, each with a smaller inmression on its outer slope and extending right to the base. Scutellum striate. Elytra ololong-ural, at the hase slightly wider than the thoras, fully twiec its length, with dentiform hmmeral angles, they are somewhat bronder near the hind thighs than elsewhere, with slight subapical sinnosities; their striae are well marked and very finely punctate, there is no scutellar striole; the interstices are subequal, just perceptibly convex, and quite impunctate; on each elytron, between the sth stria 
and the rather narrow fincly seulptured marginal channel, there is a distinct groove with about 15 punctures.

Underside shining, the flanks of the prosternum finely, the mesosternum more closely and distinetly punctate; terminal ventral segment quadripunetate.

This belongs to the Trichostermus-like section, having a setigerous puneture at each side before the middle and another at the hind angle of the thorax, but is distinct from any species loeated in it on account of the elytral sculpture and the presence of the scondary thoracic foreae.

ㅇ. length, $21 \mathrm{~mm}$; brealth, $7 \mathrm{~mm}$. Philpott.

llump Ridge, near Inrereargill. A single female, found by Mr. A.

\section{Pterostichus burrowsi sp. nov.}

Elongate, moderitely slender, slightly eonvex, glossy; black, head and thorax faintly ateneus, lege picems; the palpi, mintilses, lalumu, tarsi, and antemne piceo-rufous.

Hearl nearly as large as the thorax, smooth, with rather shallow elongate frontal impressions and an angular forea on the vertex; there are 2 setigerous punctures near each eye and 6 at the trunente margin of the labrum; mandibles obliquely striate, the left strongly dentiform at the base. Eyes morlerately large and prominent. Thorax very slightly broader than long, base aud apex medially emarginate, a little

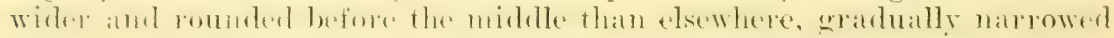
behind, with a slight sinuation near the rectangular posterior angles, the

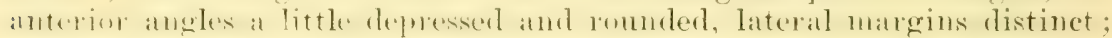
dise almost smooth, the central groove well marked but not attaining either base or apex, basal fossae rather narow, sencely more than a fourth of the whole length. Scutellum striate at the base. Elytra elongate-oval, nearly thrice the length of the thorax, rather broader than it is near the middle, slightly so at the base, the shoulders not dentiform, they are moderately sinuate behind, with broadly rounded apices; their striae are moderately impressed, with slender irregular punctures near the suture, and become more or less interrupted posteriorly, the outer three are similarly interrupted nearly throughout; 3rd and sth interstices very slightly wider than the other's, nearly plane, the former have each a single puncture at, or just behind, the posterior femora; the scutellar striolae are short.

Femora moderately stout; posterior trochanters elongate. Antennae pubescent from the middle of the 4 th joint onwards, not extending baekwards as far as the base of the thorax.

This belongs to the section consisting of species with 4 setae at each side of the thorax. It is somewhat similar to the northern P. praecor, 1470, which, however, is rither larger, with obviously longer antennae, less oral elytra, broader apices, and emarginate labrum. In Guerin's $P$. subrener, 79, the thoracie fossate are broud. and in $P$. vedienema Bates these fossae are duplicate; both, moreover, differ in other particulars.

ㅇ. length, 14 $\mathrm{mm}$; ; breadth, $4 \frac{1}{2} \mathrm{~mm}$.

Mount Hutt, near Methren. A single female, found under a stone, at a height of about $3,000 \mathrm{ft}$., by Mr. William Burrows, in whose honour it has been named. He accompanied Mr. Hall, and foumd several other species, when the mountain was coreved with snow a foot deep." In some spots they were up to the waist in snow. They started at 6 a.m., ascended 
to $4,200 \mathrm{ft}$, and returned at $9 \mathrm{p.m}$, on the 28 th October, 1912, with a considerible number of species.

\section{Group AisodactionaE.}

3511. Lecanomerus labralis sp. nov. Lecanomerus Chaudoir, Man. N.Z. Coleopt., p. 46.

Oblong, moderately convex and nitid; piceo-niger; labrum, mandibles, and thoracic margins pitchy-red; the margins of elytra behind the posterior femora fusco-rufous; the legs, palpi, and basal joints of antennae fulvo-testaceous, lemaining joints infuscate.

Head narrower than thorax, nearly smooth; labrum as long as broad. Thorax only a fourth broader than it is long, widest near the middle, its sides finely but distinctly margined, gently rounded, posterior angles obsolete, base and apex subtruncate; the surface almost smooth and unimpressed, there being only an abbreviated and rather slight groove along the centre. Elytra oblong, rather broader than the thorax and fully twice its length, slightly wider near the hind thighs than at the base, their sides a little flattened or expanded behind, only very feebly sinuate near the apices; their striae are regular, sharply impressed, and impunctate; with broad, plane interstices, on each of the $3 r^{\circ}$ there is a small puncture in line with the posterior femora; there are no scutellar striae.

Male.-Tarsi, intermediate and anterior, only moderately dilated, the 2nd joint of the latter pair rather longer but hardly broader than the transverse $3 \mathrm{rd}$, th distinctly smaller and not lobate; hind tibiae slightly curved and, like the middle pair, bearing several spiniform setae.

Differentiated from $95,9 \overline{7}$, and 1565 by the presence of punctures on the 3rd elytral interstices, the more elongate labrum, and details of sculpture and coloration. It most nearly resembles 1565 .

o. Length, $5 \mathrm{~mm}$. ; breadth, $2 \mathrm{~mm}$.

Epsom, base of Mount Eden. I single specimen obtained anongst decaring leaves on the rough seoria in December, 1911.

\section{Lecanomerus incertus sp. nov.}

Oblong-oval, only moderately convex, shining; nigro-piceous; the labrum, mandibles, and aper of thorax rufescent; the legs, palpi, and basal joints of antennae more or less fusco-testaceous, joints 3 to 11 of these latter infuscate and distinctly pubescent; the elytral margins broadly fulvo-testaceous behind but more narowly rufescent towards the base.

Head, including the large prominent eyes, slightly broader than front of thorax, with a small interocular fovea; labrum transverse. Thorax a third broader than long, base and apex subtruneate, its sides finely margined, moderately rounded in front, very gradually narrowed backwards, posterior angles rounded and obsolete; the central stria almost reaches the base and apex, but there are no other perceptible impressions. Elytra oblong-oval, widest in line with the lind thighs, hardly at all simate towards the extremity, almost thrice the length of the thorax and rather broader than it is at the base; their striae simple, narrow, and distinct; interstices broad, plane, and impunctate.

Male.-Anterior tarsi broadly dilated, basal joint small and subtriangular, 2nd largest and semicircular, 3rd equally broad but shorter 
and less rounded at the base, th smaller than $3 \mathrm{rd}$, emarginate in front; the middle pair of nearly similar structure.

This, no doubt, is most nearly related to $95, \mathrm{~L}$. latimanus Bates, but it is longer. 'There is no allusion to the prominent eyes in his description, but he stated that it has a short scutellar striole "between the lst and 2nd striae" on each elytron. In the present species the sutural striae do not attain the base, but at that point, and nearer to the suture, there is a pair of scutellar striae. The 2 nd stria of each, at the base, has a very distinct puncture, but there is no trace of a sentellar striole between it and the sutural stria.

ô. Iength, 5늘 $m m$. ; breadth, $2 \frac{1}{2} \mathrm{~mm}$.

Mount Hutt, near Methven. Described from a specimen found by Mr. 'T'. Hall, in December', 1911, at a height of about 3,500 ft.

Obs. - The eves are more prominent than those of $L$. fuliginosus, 98, which, perhaps, is near to $L$. latimanus Bates, who, as stated by Dr. Sharp (p. 1000, Man. N.Z. Colept.), named specimens found by me at Tairua as his L. latimanus. Subsequently my T'airua specimens were described by Dr. Sharp as a new species, 1794, L. marginatus. As Bates considered this latter species to be merely a variety of his $L$. latimanus, my 98 and $I$. incertus are evidently very different in some respects.

\section{Group Benibididals.}

35̃13. Anillus marginatus sp. nov. Anillus Jacquelin Duval, Lacord., Hist. des Ins. Col., tom. 1, p. 380.

Subdepressed, nitid, with dense, minute, subgranular sculpture; fulvescent, legs and antennae pale testaceous; bearing numerous distinct, erect, grerish setae, and also some scattered elongate ones.

Head slightly convex, oblong, as long as the thorax, a little narrowed and finely margined anteriorly; broadly but not deeply bisulcate; labrum transverse, entire. Eyes invisible. Thorax cordate, its length and breadth about equal, base and apex truucate, gradually narrowed behind the middle; lateral margins well developed but not forming definite posterior angles, these, however, are not broadly rounded; the dise with some fine scattered punctures, median groove moderately impressed, not reaching the front, owing to a slight elevation there, there are no basal forae, but there is an obsolete curvate impression near the middle of the base. Elytra twice as long as the thorax, evidently broader than it is at the base, with oblique romuded shoulders, their sides distinetly margined and nearly straight, gently narrowed posteriorly, apices very broadly rounded and leaving the broad pygidium uncovered; the dorsum is flat, without striae or other impressions, but on the middle of the base of each elytron there is a small granule.

Legs setigerous, moderately elongate; anterior tibiae stout, considerably bent near the extremity, deeply emarginate inwardly below the middle; joints $2-1$ of the corresponding tarsi small and cordiform, the 5th as long as the basal, with slender claws.

Antennae stout, reaching backwards to the thoracic base, with slender setae; basal two joints thick and of about the same length, 3rd nearly as long as the 2nd, somewhat abruptly contracted near the base; joints 4-10 subglobular and nearly equal, the terminal conical, not as long as the preceding two combined.

In A. pallidus, 1644, and A. phyllobius, 2678, the base of the thorax is arcuate-emarginate. In Sharp's Cillenum subcrecum, 1811, the thorax 
is transverse, with extremely obtuse hind angles, and the eyes, as is the case in 3028, 1. monticola, though minute, are quite discernible.

Length, $1 \frac{3}{4} \mathrm{~mm}$. ; breadth, quite $\frac{1}{2} \mathrm{~mm}$.

Invereargill. Deseriber from a specinen received from $\prod_{r}$. A. Plilpott in October, 1912.

\section{1t. Anillus punctigerus sp. nov.}

Subdepressed, nitid; fusco-testaceous, antennae and legs paler ; with numerous distinct, ereet, and some longer grevish-yellow setae.

Although very similar to A. marginatus in appearance and structure, this species differs considerably.

The head has rather deeper frontal furows. The thorax is not as long as broad, it is evidently broader, at the base particularly, and its surface is smoother; the lateral margins are bent inwards at the base so as to form obtuse angles, and there is a slight sinuosity just before each of them; the central groove attains the apex, and between it and each side there is a small shallow forea, the basal depression is angular and deeper and extends almost from one side to the other, so that there seems to be a fovea near each angle. On each elytron there is a puncture near the base, another near the middle, and a third behind but situated closer to the side. 'The tibiae are of the same form, but the basal joint of the anterior tarsi is broader, thoush not definitely prominent at the inner angle.

Length, $1 \frac{3}{4} \mathrm{~mm}$. ; breadth, quite $\frac{1}{2} \mathrm{~mm}$.

Mount Hutt, near Methven. Mr. T. Hall found a specimen of this fragile little beetle under a stone, at an elevation of $2,000 \mathrm{ft}$., on the 28 th October, 1912.

\section{Group Dryopidae.}

3515. Hydora vestita sp. nov. Hydora Broun, Mæn. N.Z. Coleopt., p. 672 (Pachycephala).

Elongate, slightly convex, subopaque; piceous, claws rufo-castaneous; densely covered with minute pale brassy scales, and short, slender, somewhat eurled greyish setae.

Head free, nearly as long as the thorax, almost abruptly narrowed in front of the eyes, indistinctly punctate. Eres rather linge, subrotundate, quite free from the thorax, widely distant from each other, and moderately prominent. Thorax widest and bisinuate at the base, gradually narrowed anteriorly, with acutely rectangular posterior angles; it is slightly longer than broad, a little uneven above, its basil half being just perceptibly on a higher plane than the front, usually with a linear impression along the middle but not reaching the base, which is bifoveate, near each side there is a distinct basal plica or carina, the sculpture is similar to that of the head. Scutellum subcordate, longer than broad. Elytra, at the base, rather broader than the thorax, almost thrice as long as it is, their sides finely margined and slightly expinded backwards; they are moderately finely and closely seriate-punctate for two-thirds of the length, the apical sculpture is indefinite, the apices slightly dehiscent.

Legs slender and elongate, with some fine greyish setae; tibiae almost straight.

Antennae hardly any longer than the head, implanted close to the front and inner margin of the eres, of normal structure. 
Claws thickened at the base, often closely applied to each other, and thus appearing like thick single claws.

Underside opaque, piceous, without visible seulpture, with many depressed, short, slender brassy setae. Anterior coxae prominent, distinetly separated, their earities open. Prosternal process projecting just beyond the coxae, and extending into the rather broad mesosternal cavity. Metasternum with a fine groove along the middle.

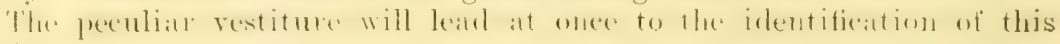
sprecies.

Length, tmm.; breadth, $1 \frac{1}{3} 1 \mathrm{~mm}$.

Methen, Canterbury. Discoreved by Mr. 'I'. Hall, who kindly sent me a dozen specimens in December, 1911.

\section{Hlycora lanigera sp. nov.}

Suboparque, fusco-piceous; the elytra and middle of thorax covered with decumbent and suberect slender brassy setae; the remainder of the body and the front tibiae with short dark woolly pubescence, on the head the hairs are coarser and ahmost form cilia over the eres; the basal two joints of the antennae and the claws are castaneous.

Head very elosely and finely punctured. Thorax, at the base, rather broader than it is long, gradually narrowed towards the front, with acutely rectangular posterior angles; its surface densely and finely yet quite distinctly punctate, but often smeared with sliny matter which conceals the sculpture; it is not uneven, having only a short linear impression along the middle, and rather indistinct basal plicae. Scutellum distinct. Elytra thrice the length of the thorax, very little broater thath it is at the base, their sides nearly stratght, the margins must listinet near the midhle; they are finely substiate-punetate nearly to the extremity, and near the base of each elytron, between the sutural and 2 nd striae, there is an oblique series of punctures.

Legs elongate, the tibiate unusually thick.

Antennae with their 2nd joint slightly stouter than but only about lalf the length of the 1st, both of these bear outstanding setie; 3rd nearly as long as the End but very slender near the base, joints $t-10$ sucessively expanded and abbreviated, the terminal conical and rather longer.

Underside finely and indistinctly sculptured, thinly clothed with rather elongate yellowish hairs. Terminal ventral segment as long as the basal, distinetly emarginate at the apex. Prosternal process searcely projecting beyond the coxae.

larger than $I I$. vestita, with evidently thicker ligs and tarsi. The - Hert womlly elothing of the anterior tibiare, the conase hairs that extend

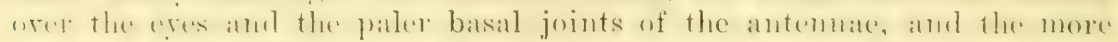
elongate pubescence of the under-surface render this species abundantly ristinet from any other.

Length, 5 mm. ; breadth, quite $1 \frac{1}{2}$ mm.

Ardagh, near Methren. Four individuals were forwarded by Mr. T'. IIall during January and February, 1912.

\section{Hydora subaenea sp. nov.}

Nitid, anco-piceous, legs rufo-piceous, tarsi more rufescent, the claws and basal joints of the antennae fulvescent; thinly clothed with eurled and suberect slender brassy setae. 
Head finely and rather distantly punctured. Eyes moderately large and prominent. Thorax of the usual form, considerably narrowed towards the front, slightly longer than broad; a little uneven, with a shallow longitudinal impression behind the middle and sometimes with a transverse curvate one near the base, its punctation like that of the head, the basal plicae moderately distinct. Elytra thrice the length of the thorax, rather broader than it is at the base, their sides margined and almost straight as far as the hind thighs; they are substriatepunctate, the punctures are rather coarse but become indistinct behind.

Legs elongate and moderately slender, with fine greyish setae. Antennae finely pubescent, their last joint evidently larger than its predecessor.

'This, in appearance, most nearly approaches $I I$. nitida, 1664, which, however, is rather larger and darker, with a shorter, less anteriorly narrowed thorax, and more regularly striate-punctate elytra. It has only been found in the south of Otago.

Length, $2 \frac{2}{3} \mathrm{~mm}$.; breadth, $1 \mathrm{~mm}$.

Clevedon, near Auckland. 'Two found by Mr. G. Campbell Munro.

\section{Group Pastaphide.}

3518. Sagola halli sp. nov. Sagola Sharp, Man. N.Z. Coleopt., p. 134.

Elongate, subdepressed, nitid; dark rufous, the legs and antennae paler, palpi and tarsi flavescent; pubescence yellow, slender, elongate, and suberect, that of the hind-body coarser and mingled with long, erect setre.

Head rather short, almost as broad as the middle of the thorax, with rounded hind angles; frontal channel broad and deep, a little expanded at the middle, and prolonged quite as far as the back of the eyes, basal foveae not sharply limited, subangulate; antennal tubercles slightly elevated and indistinctly punctate. Eyes moderately large, more prominent behind than in front. Thorax cordate, slightly broader than long; median fossa large, subquadrate, the basal pair of punctures small but distinet, lateral foveae deep and extending from the middle to the base. Elytra oblong, nearly double the length of the thorax; sutural striae deep and indistincty punctured, the intralsumeral interrupted, sometimes with a single puncture, in others bipunctate at the base, the posterior impression always elongate. Hind-body as broad as the elytra, rather shorter, its first visible segment without distinct brassy scales and hardly as long as the $2 \mathrm{nd}$ or $3 \mathrm{rd}$, the others narrowed and somewhat deflexed.

Antennae as long as the head and thorax, bearing slender elongate hairs, their basal joint hardly the length of the following three combined; 2nd oviform, rather longer than broad and a little thicker than 4 th, the $3 \mathrm{rd}$ distinetly smaller than contiguous ones, oviform or subglobular; 4th and 5th about equal, oblong-oval, joints 6-8 rather shorter and broader, 9 th and 10 th transversely quadrate ret only a trifle broader, the 11th larger, with a narrow apical appendage; their structure, however, is not exactly alike in all individuals. Legs simple.

Underside rufo-castaneous, distinctly pubescent. Head with a brightly fringed lamina behind the middle, and a well-marked fovea between each eye and the base. Basal ventral segment concealed by the femora, 2nd slightly shorter than $3 r d$ or 4 th, the 5th hardly as large as its predecessor; 6th broadly triangular, paler and longer than 
the 5th, with a very deep emargination which is aceupied by the oval operculum or supplementary segment.

Fem.-Head not as broad, with a median depression across it underneath. Terminal ventral segment, 6 th, simplo, a third of the width of the 5th. Elytra somewhat narrowed towards the base.

This must be placed in the same section as 5 . Taminata, 2469, which, however, in the male has a rather narrower head, without distinct foveae underneath; the elrtra are rather shorter, evidently narrowed before the middle, and, in both sexes, quite fulvous; the ventral segments differ, so do some minor details.

Length, $2 \frac{1}{2} \mathrm{~mm}$. ; breadth, $\frac{2}{3} \mathrm{~mm}$.

Pudding Hill, near Methren. About a dozen specimens were detected amongst leaf-mould in May, 1912, by . $\mathrm{Y}$. 'T. Hall, in honour of whom the species has been named.

\section{Sagola colorata sp. nov.}

Subdepressed, elongate, moderately nitid; head and thorax rufous, sparingly clothed with depressed, rery slender, elongate grevish hairs; elytra with a few longer, outstanding dark ones at the sides, castaneorufous; hind-body fuscous, with rellowish pubescence and long erect setae; antennae and legs infuscate red, tarsi fulvescent.

Head nearly as large as the thorax, feebly rounded behind, with obtuse hind angles; antennal tubercles rather that, frontal channel oblong, extending as far as the middle of the eyes, occipital punctures minute. Eyes rather large, quite a third of the length of the head, only slightly prominent. Thorax oviform, rather wider at the middle than elsewhere, the median depression near the base rotundate but not large, basal punctures small, lateral fovene deep but not extending forwards further than the middle. Elytra quite oblong, almost double the length of the thorax, indefinitely punctate, the sutural striae well marked throughout and with 2 or 3 basal punctures in each, alongside each there is an additional basal puncture, intrahumeral striae tripuncate. Hind-body of the same length as, but just perceptibly narrower than, the elytra, first visible segment rather shorter and more thickly pubescent than the other's, 2nd and 3rd subequal, th rather longer, rounded and fulvescent at the extremity, the 5th invisible.

Legs moderately elongate, tibiae a little dilated near the extremity.

Antennae as long as the head and thoxax, with fine elongate pubescence, very gradually thickened, their 1st joint barely twice as long as broad, 2nd as broad but shorter and subglobular, 3rd rather smaller than contiguous ones, joints $4-6$ subglobular, $7-10$ laxly articulated, 9th and 10th strongly transverse, 11th larger, conical, its distinct apical appendage marked off $b y$ a band of pale pubescence.

Underside fuscons, with distinct rellowish hairs, segments 2-t subequal, oth longer, rather widely emarginate behind, 6th conical. Metasternum convex.

After careful comparison with all the members of Section 1.t, to which it belongs, none were found to agree with it. The fuscous hindbody and lower surface, subovate hearl, elongate parallel-sided clytra, and apparent absence of the ith dorsal segment, in conjunction, will help entomologists to identify it.

Length, $2 \mathrm{~mm}$. ; breadth, $\frac{1}{2} \mathrm{~mm}$.

MeClennan's Bush, near ITethren. Described from a single female found on the 25th March, 1912, by Mr. T. Hall. 


\section{Sagola dilucida sp. nov.}

Shining, elongate, thinly elothed with pale-yellow, depressed, elongate pubescence, the hind-body and sides of elytra with longer erect hairs; fulvous, head and thorax more rufescent, legs and palpi yellow.

Head nearly as large as the thorax, slightly curvedly narrowed behind the moderately large and prominent eyes; antennal tubercles moderately elevated, the frontal channel oblong, extending as far as the middle of the eyes, occipital foveae well marked and punctiform, hind angles obtuse, not at all prominent. Thorax suboviform, rounded and widest just at or before the middle, of about equal length and breadth; discal depression angulate in front, basal punctures small, the lateral foreae prolonged forwards to the middle. Elytra subquadrate, slightly longer than broad, slightly narrowed towards the base, a third longer than, and nearly twice as broad as, the thorax, very slightly depressed before the middle; sutural striae distinct, minutely pluripunctate near the base, the dorsal rather short, each consisting of a basal puncture and lcnger impression. Hind-body as broad as the elytra, slightly longer, its uncovered segments slightly increase in length, the basal shortest.

Legs of moderate length; tibiae gradually dilated, the posterior with a short process at the inner extremity, directed backwards yet hardly projecting beyond the apex.

Antennae as long as the head and thorax, with slender hairs, gradually yet very distinctly incrassate from the 4th joint onwards; basal joint quite red, finely punctate, twice as long as broad, 2nd half as long, not as thick, suborate, 3rd smaller, subrotundate; joints 4-6 rather broader than long, subglobular, 7th and 8th rather broader, 9th and 10th strongly transverse, the terminal larger, with, in addition, a distinct apical appendage.

Underside sparsely punctate, with decumbent greyish pubescence. Metastomum elongipte, longitudinally impressed behind; 2 nd ventral segment slightly shorter than the :3rd, 5th rather longer than 4 th, the 6th broadly rounded behind, its central portion oviform and somewhat prominent or convex near the apex.

S. guinnessi, 3373, is the nearest species, but it is rather larger. Its frontal channel is remarkably short, hardly extending to the front of the eyes, the occipital foveae are more approximated, it has a basal puncture alongside each of the sutural striae, and the antennae are longer and less expanded near the extremity.

o. Length, $2 \mathrm{~mm}$; breadth, $\frac{1}{2} \mathrm{~mm}$.

Epsom, base of Mount Eden. A single male is all that I could find during four visits; January, 1912.

\section{Sagola insueta sp. nov.}

Elongate, subdepressed, shining, indistinctly punctate; light rufous, legs and antennae a little paler, tarsi fulvescent, hind-bodr fusco-rufous; pubescence yellowish, coarser on the abdomen, which, as well as the elytra, bears also long erect setae.

Head about as large as the thorax, slightly rounded behind the moderately large and prominent eyes, with obtuse hind angles; antennal tubercles slightly clevaterl, fontal chammel oblong and extending to behind the eres, occipital foveac well marked and punctiform. Thorax wirlest at of just hefore the middle, discal depresision molerate, subrotundate, basal punctures small but distinct, lateral fovene moderate, lardly extending forwards as far as the middle; it is rather longer than 
broad. Elytra oblong, slightly nurrowed townds the base, a third longer than the thorax and nearly twice as broad behind; they are slightly though broadly impressed before the middle, sutural striae deep throughout, a little expanded but without punetures at the base, dorsal striae of about half the whole length, not distinctly interrupted, having only an ill-defined basal puncture in one, and none at all in the other. Hind-body about as long and broad as the wing-eases, 2nd and 3rd visible segments largest, equal, th deflexed, bth narrow, the basal with minute brassy scales.

Antennae as long as head and thorax, distinetly pubescent, of nearly equal thickness from the th joint onwarls; basal joint fully twice as long as broad, 2nd and 3rd subovate, a little longer than broad, the latter about a third smaller; th and 5th oblong-oval, joints 6-8 moniliform and subequal, 9th and 10th subquadrate, 11 th conical, not double the length of the penultimate.

Underside chestnut-red, with distinct pubesecnce; metasternum convex; 2nd and 3rd ventral segments largest, כth truncate behind, 6th conical, simple.

- The presence of minute squamae on the basal dorsal segment without definite male characters underneath is very unusual. The rather long legs, oblong elytra with almost entire dorsal striae, taken together, will lead to its recognition.

Length, $2 \frac{1}{3} \mathrm{~mm}$. ; breadth, $\frac{2}{3} \mathrm{~mm}$.

Curiosity Gully, near Methven. One found amongst moss on the 6th July, 1912, by Mr'. 'I'. Hall. It should be located near the preceding species.

\section{Sagola suturalis sp. nov.}

Shining, rufous, elytra only slightly paler, legs and antennae light chestnut-red, tarsi and palpi yellow; pubescence flasrescent, slender and elongate, rather scanty, suberect even on the head and thorax.

Head rather small, the genae nearly straight, with obtuse hind angles; antennal tubercles nearly flat, very narrowly separated at the apex, frontal channel oblong, extending as far as the back of the eyes, occipital foreae small but slightly elongated. Eyes moderately small but convex. 'Ihorax of about equal length and breadth, morlerately rounded and widest at or just before the middle; diseal depression subrotundate, basal punctures small, lateral foveae deep and extending forwards to the middle. Elytra oblong, very gently narrowed near the base, a third longer and broader than the thorax, almost plane; sutural striae well marked throughout, minutely pluripunctate, fincly tripunctate alongside each near the base, the dorsal striae composed of a basal puncture and longer impression but not prolonged beyond the middle. Hind-body rather longer than the elytra, a little narrowed near the base, the terminal segments deflexed, the 1 st exposed segment with some minute brassy scales and only slightly shorter than the intermediate ones.

Legs slender, not very elongate; posterior tibiae somewhat arehed below the mirldle.

Antennae not as long as the head and thorax, only moderately stout; lasal joint red, twice as long as broad, and very slightly longer than broad, the next evidently smaller and subglobular, joints 4-8 subglobose, th and 5th fully as thick as the 2nd, 8th distinctly smaller, 9th and 10th transverse, laxly articulated, terminal subconical, hardly twice the length of the penultimate. 
Inderside castaneo-rufous, with distinct yellowish pubescence. Iletasternum witl a narrow angular fovea behind. Tentral segments 2-1 almost equal, rather broad, 5th rather shorter, depressed and slightly incurved behind, Gth rather shorter and slightly marginate, the supplementary short but quite definite, obtusely triangular and convex.

In is. insucta the liead is broader, the eyes though larger are less convex, the sculpture, of the wing-cases particularly, is different, and the antennate are longer and do not accord structurally.

o. Length, $2 \frac{1}{2} \mathrm{~nm}$. ; breadth, $\frac{2}{3} \mathrm{~mm}$.

Rakaia Gorge, near Methren. Mr. 'T'. Hall sent ne two exauples, found amongst leat-mould on the 5th June, 1912.

\section{Sagola fuscipalpis sp. nov.}

Elongate, subdepressed, nitid, dark fusco-rufous, elytra chestnut-red, the femora, middle of tibiae, and the palpi more or less infuseate, tarsi fulvescent; pubescence rellowish, elongate, suberect, mingled with longer ereet hairs behind.

Ilead rather smaller than the thorax, slightly narrowed behind, with obtuse angles; antennal tubercles nearly Hat, separated by a narrow groove, frontal chamnel oblong, extending as far as the back of the eyes, occipital foreae distinct. Eyes moderate. Thorax about as long as broad, moderately rounded and widest at or just before the middle; discal depression subquadrate or rotundate, not sharply defined, basal punctures small, lateral foveae deep, not prolonged as far as the middle. Elytra oblong, a third longer than the thorax, slightly narrowed near the base, nearly plane above; they are obsoletely punctured, the sutural striae are well marked, the dorsal are formed of a basal puncture and elongate impression and are about half the whole length. Hind-body of the same width as the elytra but slightly longer, 1st exposed segment a little shorter than the following ones, with some minute brassy scales, the terminal ones deflexed.

Antennae as long as the head and thorax, rather thick, gradually incrassate, with elongate pubescence, joints $\tau-11$, in addition thereto, are thickly studded with minute brassy setae; basal joint thick, red, twice as long as broad, 2nd as thick, nearly half as long, a little narrowed at the base, the next smaller than continguous ones ret not very small; joints $1-6$ quite as broad as the 2 nd but shorter, $7-10$ transversely quadrate, the terminal conical, longer but not broader than preceding ones, but without any definite apical appendage.

Underside chestnut-red, the coxae paler, with elongate yellowish pubescence, the terminal segment with very long, slender, erect setae. Metasternum convex; 3rd and 4th segments larger than the $2 \mathrm{nd}$, 5th as long as 4th at the sides, widely emarginate belind, 6th broadly sinuate near each side of the apex, the supplementary obtusely triangular.

Referable to the same section as $S$. misella and its allies, but with a narrower head, and thick, short antennac. It is distinguishable from North Island species by the infuseate legs and palpi, and the peculiar restiture of the last five joints of the antennae.

o. Jength, $2 \frac{1}{2} \mathrm{~mm}$. ; breadth, fully $\frac{1}{2} \mathrm{~mm}$.

Mount Hutt, near Methren. Three examples discovered by Mr. 'T'. Hall, on the 12th April, 1912, amongst decaying leares on the ground. 
3524. Sagola disparata sp. nov.

Shining, dark rufo-fuscous, drtra castaneo-rufous, the knees, extremity of tibiae, and the tarsi paler than the elytra; pubescence yellowish-grey, to a great extent slender and elongate, and outstanding even on the head and thorax.

Head considerably narrowed in front of the eyes, very slightly and curvedly behind them, posterior angles obtuse; antennal tubercles rather flat, frontal chamnel oblong, deep, extending as tar as the back of the eres, oceipital foveae punctiform. Lyes moderately large, not very conrex, situated at the sides just in front of the broad part of the head. Thorax subcordate, rounded and widest at or just before the middle, of about equal length and breadth; diseal depression subangulate behind, basal punctures distinct, lateral foveae rather small, not extending forwards to the middle. Flytra as broad behind as they are long, a good deal narrowed towards the base, a third longer than the thorax; their surface almost Hat, sutural striae well marked throughout, without adjacent basal punctures, intrahumeral striae a third of the whole length, indistinctly interrupted. Hind-body rather wider in line with the 3 rd risible segment than at the base, a third longer than the elytra, its segments only very slightly increasing in length.

Underside nitid, dark fusco-rufous, with elongate grerish pubescence. Head deeply inpressed across the middle. Mletasternum rather short and convex. Abdomen elongate, segments $2-4$ equal, 5 th distinctly shorter, 6th longer than 5th at the sides, deeply emarginate in the middle, the opereulum almost semicircular, with an oblique shallow stria.

Legs elongate, finely pubescent; tibiae slightly arched externally below the middle.

Antennae with short grey pubescence and longer outstanding hairs, as long as the head and thorax, rather thick from the th joint onwards; basal joint stout, its length hardly double the breadth, the next nearly as thick but only half as long; joints 3-7 laxly articulated, each having a slender basal stalk, the $3 \mathrm{rd}$ about as long as the contiguous ones but narrower, 5-10 distinctly transverse, equal, rather broader than the 4th, the terminal eonical, longer than preceding ones.

'This belongs to the same section ats Dr. Sharp's S. misella, 248. The bright wing-eases are in marked contrast to the rest of the borly. The basal articulation or stalk of the intermediate joints of the antennaie, their abrupt enlargement from the th joint onwards, and the structure of the terminal ventral segment, will enabic natmralists to separate it irom all the allied species.

Length, 2: $\mathrm{mm}$. ; breadth, $\frac{2}{3} \mathrm{~mm}$.

Old Man Range, Otago. One in the Dominion Museum at We!lington, another in my collection; both found by $\mathrm{Mr}$. J. H. Lewis.

\section{Sagola bituberata sp. nov.}

Elongate, subdepresserl, nitid; sanguincous, abdomen fusco-rufous, lecs and antennae paler, palpi and tarsi fulveseent; pubescence yellow, with many rery long, erect, slender setae on the elytra and hind-body.

Hear slightly narrowed behind the moderate eves, with obtuse angles; antennal tubercles flat, abruptly vertical in front, frontal channel extending as far as the middle of the eyes, narrow in front, a little expanded behind, oceipital foreae quite as large as the hind portion of the forntal channel. Thorax of about equal length and breadth, cordate, 
wirlest and rounded before the middle; discal depression subquadrate, basal punctures small, lateral foveae also small, not extending forwards

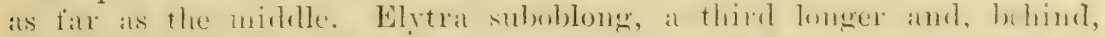

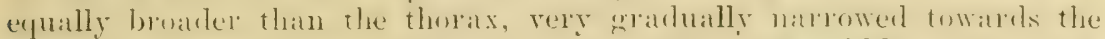
base; they are rery shohtly clepresised before the midhle, with wellmalkerl suturat striace, the thisal are half the whole length, each is composed of a basal puncture and elongate impression. Hind-body rather longer than the elrtin, slightly broader in line with the 3rd risible segment, which is slightly longer than the 2 nd, 4 th and 5 th deflexed, the basal bears minute brassy squamae.

Antennae thick, rather longer than the head and thorax, bearing slender grey setae; basal joint twice as long as broad, the next obconical and half as long, 3rd smallest, subglobose or obconieal; joints $4-10$ of about equal size, evidently bromler than the $31 \mathrm{rl}$, the and ith more or less obconical, 6-10 subquadrate, 6th and 7th slightly broader than 10th, terminal conical.

Legs rather elongate, tibiae very slightly arched externally.

Male.-Underside chestnut-red, with elongate yellow pubescence. Metasternum moderately short and convex. Abdomen elongate, the 2 nd segment rather shorter than the $3 \mathrm{rd}$; th longer, slightly but widely cmallowate behind, depresed in the midhle, and at the apex with a gair "fi prominent tubereles which are directed upwarks and batckwarls; jth with a median depression and emarginate behind, 6th slightly and obtusely prominent at each side, the operculum broadly conical.

The body, from the apex of the 3rd dorsal segment to the base of the elytra, is P'selephers-like, being gradually uarowed anterionly. It

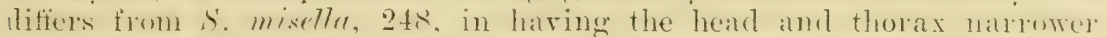
and the elytra longer. The frontal channel is decidedly narrower, especially in front, the sntemate are stouter, with more quadrate joints, and the ereet hairs on the borly are cridently more elongate. The 3rot rentral segment in $S$. prisca is bituberculate.

Length, $2 \frac{3}{4}-3 \mathrm{~mm}$.; breadth, $\frac{3}{4} \mathrm{~mm}$.

Greymouth. Three specimens in the Dominion Museum at Wellingtoil, found by Mr. J. H. Lewis.

\section{Euplectopsis tibialis sp. nov. Eupleciopsis Rafiray, Gen. Ins. (Wytsman), Pselaphidae, p. 82.}

Small, clongate, subdepressed, nitid; light chestnut-red, legs and antennae fulvescent; with distinct, but not elongate, decumbent, greyishrellow pubescence.

Head smaller than the thorax, narowed in front, genae short, nearly straight, with obtuse hind angles; antennal tubereles small, slightly elevated and distant, the surface nearly plane, moderately finely punctate, with small, indistinct interocular foreate. Thorax slightly longer than broad, oviform, moderately rounded and widest near the middle, its punctation not coarse, nor close, and somewhat irregular; lateral foveae oval, extending forwards to the middle and joined to the transverse basal fossa by a groove, discal stria abbreviated, not reaching the front or the hatsal depression. Elytra subquarluate, bonger and broater than the thorax, curvedly narrowed before the middle so that the base is but little broader than that of the thorax; indistinctly punctate, the broad sutural striae are punctiform at the base, dorsal striae also broad, tapering towards the middle and not attaining the extremity. IIind-body as long as the elytra, finely and on some parts closely puncturerl; basal three 
segments horizontal, slightly decreasing in length, the 1st transversely impressed at the batse.

Legs moderately elongate and slender; the front and middle tibiae

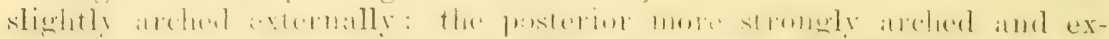

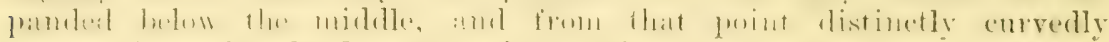
narrowed to the slender extremity, their tarsi rather longer than the others.

Antenuac nearly as long as the head and thorax, with very slender pubesence; 2nd joint stout, oblong-oval, alnost as lurge as the basal, Brd hardly longer than broad, distinetly narrowed at the base; joints

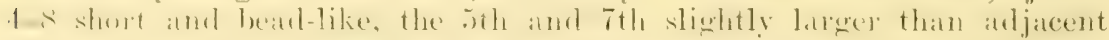
ones; 9th and 10th subquadrate, the former the smaller yet nearly double the bulk of the Sth; terminal conical, nearly the length of the preceding three mited.

Underside chestnut-red, with fine pubeseence. Prosternum carinate along the middle. Metasternum convex. Abdomen elongate, basal segment acutely angulate between the coxae, segments 2-4 slightly decrease; ith shorter than 4th in the middle but nearly as long at the sides, bits decply emarginate, shightly longer thatu the jth, the terminal longer, the opereulum oblong but rounderl at the extrenity.

The form of the posterior tibine is peeuliar, and will at once lead to its identification.

ô. Length, $1 \frac{1}{2} \mathrm{~mm}$; ; breadth, quite $\frac{1}{3} \mathrm{~mm}$.

Rose Hill, near Methven. One, taken out of leaf-mould on the 25th Mareh, 1912, by Mr. '1'. Hall.

\section{Euplectopsis terrestris sp. nov.}

Sublepressed, elongate, nitid; light eastaneo-rufous, elytra somewhat

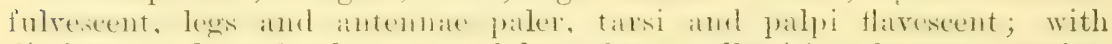
distinet, morlerately elongate, subdecumbent, yellowish pubeseence, rather conser on the abdomen and with a few upright setae there.

Head evidently smaller than the thorax, subovate, genae nearly straight, with obtuse hind angles; finely but not closely punctate, the foreae moderately large and deep, placed just behind the eyes, and more or less confluent with the depressed anterior portion, the antennal tubereles distant and a little elevated. Eyes moderate, placed behind the middle. Thorax rather longer than broad, moderately rounded and widest at or just betore the niddle, obliquely narrowed towards the apex and not as broad there as the head; it is finely and distantly punctured, the diseal channel is broad and deep and extends almost from the apex to the basal depression, which reaches the hind margin, lateral foveae deep so that the sides in front of them appear swollen, the transverse connecting groove is distinct. Elytra oblong, slightly narrowed near the base, broader and a third longer than the thorax, with somewhat illdefined punctures; sutural striae well marked, punctiform at the base, where there is a puncture near each; dorsal striae broad and moderately deep at the base, becoming indistinct towards the middle. Hind-body rather shorter than the elytra, the basal thee segments slightly increasing in length, the 1st with a median transverse depression at the base, terminal segments deflexed. Legs simple, moderately elongate.

Antemae of about the same length as the head and thorax, 2 nd joint chlong-oval and as long as the visible portion of the basal, 3rd rather longer than broal and distinctly narrowed near the base; joints 4-7 small and bead-like, the 5th and 7th slightly larger; 8-10 transversal, 
somewhat loosely articulated, the 8th slightly larger than its predecessor but not as broad as the following ones, the terminal conical and subacuminate, as long as the preceding two.

Underside pale chestnut-red, finely and distantly punctate, with distinct greyish pubeseence. Head and prosternum finely carinate along the middle, the former with many erect setae. Metasternum moderately elongate and conver. Ventral segments $2-4$ slightly decrease, 5th little more than half as lome as the the in the middle; foth ideply semicircularly

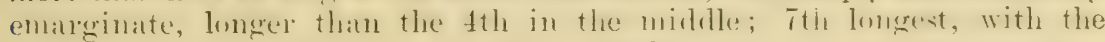
oblong opereulum cxtending its whole length.

This is distinct from lieitter's serien with a Videmus-like learl, such as his $F$. brevicollis, 3200 , and equally so from his $k$. longicollis, 3198, both of which he placed in Trichonyx. At present it may be located in the same section as $E$. monticola, 1648. The moderately enlarged 8th antemal joint and the rather laret ith ventral secoment will learl to its diserimination.

$\hat{o}$. Length, quite $1 \frac{1}{2} \mathrm{~mm}$. ; breadth, $\frac{1}{2} \mathrm{~mm}$.

bell Rock, near Methren. I single male found by Мl. T. Hall on the ground amongst dead leaves, כth September, 1912.

\section{3อั28. Euplectopsis femoralis sp. nov.}

Slender, subdepresserl, nitid, with irregular and not at all sharply defined punctures; light chestnut-red, legs and antennae paler, palpi and tarsi flavescent; sparingly covered with moderately short, subdecumbent, pale-yellowish pubeseence.

Head evidently smaller than the thorax, genae nearly straight, with obtuse posterior angles, antemnal tubercles small and distant; its sur-

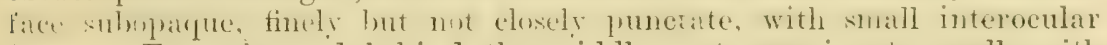
foveae. Eyes situated behind the niddle, not prominent, small, with coarse facets. Thorax alnost oblong-oral, more narrowed in front than behind, its apex narrower than the hearl, the punctation irregular and distant; the subrotundate lateral foreae united to the angular basal depression by a transrerse stria, the discal channel narrow and not reaching the basal fossa or apex. Elytra subquadrate, curvedly narrowed near the base, scarcely wider than the thorax there; sutural striae distinct, punctiform at the base, with a basal puncture near each; the dorsal striae also punctiform at the base, rather narrow and prolonged to the middle. Hind-body as long as the elytra, basal three segments almost horizontal and equal, the 1st with a short median depression at the base.

Legs robust; femora strongly incrassate, the front and middle pairs particularly; intermediate tibiae rather shorter than the posterior and considerably thicker.

Antennae shorter than the head and thorax, gradually thickened near the extremity; 2nd joint oblong-oval, quite as long as the stout basal; joints ;-8 small, 3rd subquadrate, 5th and 7 th slightly larger, 8th smallest; 9th larger than 8th but not as broad as the transverse 10th, the tominal conical and acuminate, as fonge as the preceding three together.

Underside with pale pubescence. Head and prosternum finely carinate along the middle. Metasternum very short. Abdomen elongate, segments 2- 1 gradually decrease, 5th very short in the middle only; the 6th semicircularly emarginate, the enclosed ith transrersely oval, its oblong operculum extending the whole length. 
The disproportionately developed legs and rather narrow body are in marked contrast, and form the listinguishing feature of the species. E. antiquus, 1898, is in some respeets the nearest species, but in it the thorax is quite oval, with clearly maked punctures, and its legs are much less inerassate.

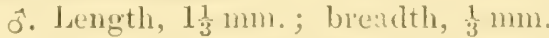

Pudding Hill, near Methren. Another of Mr. 'T. Hall's discoreries amongst decaring forest leares on the ground, on th $\mathrm{May}$, 1912, and, considering its minute size, ereditable to his skill and persererance. Enique.

\section{Euplectopsis curvipennis sp. nov.}

Nitid, elongate, but not slender, subdepressed, without perceptible punctation; pubescence distinet, greyish, and subdecumbent; castaneorufous, legs and antennae evidently paler, tarsi and palpi flavescent.

Head distinctly smaller than the thorax, a good deal narowed in front of the moderately large eyes, genae rather short, with rounded hind angles, antennal tubercles flattened; interocular foveae well marked and bather deeper than the depressed frontal portion. 'Thorax not longer than broad, almost regularly rounded from base to apex; the transverse stria in front of the base connects the angulate basal fossa and the rotundate lateral fovene, which are not at all prolonged forwards, mesial channel well marked throughout and nearly reaching the apex. Elytra rather lnoader and a third longer than the thoras, subquadrate, with gently curved sides, nearly as much narrowed behind as in front; sutural striae rather broad, punctiform at the base, where there is a separate puncture alongside each; intrahumeral impressions bipunctate at the base, distinctly duplicated, their inner portion narrower and more elongated than the outer. Hind-body of the same length as the clrtra, curvedly narrowed and deflexed near the extremity, its basal three segments slightly decrease in length.

Antennae rather slender, of nearly the same length as the head and thorax, with some elongate pubescence towards the extremity; 2nd joint oriform and almost as long as the basal, the next more slender, narrowed near the base, and evidently longer than broad; joints $t$ and , rather longer than the following ones, Tth subquadrate and rather larger than the small 8th; 9th and 10th subglobular and nearly as long as broar, the former the smaller, ret distinctly larger than the 8th, the terminal subconical, very slightly broader than the penultimate, but about as long as the preceding two combined.

Legs stont, intermediate tibiae more expanded towards the extremity than the others.

Reitter's E'. rotumdicollis, :3201, is smaller, but, owing to the shape of the thorax, might be mistaken for this species. Reitter's deseription implies a rotundate, finely punctured head, slightly impressed thoracic lateral grooves, and a punctate dorsal segment; none of these are applicable to E. curvipennis, besides which the antennae differ, and the eurvature of the elytral, though slight, is hardly likely to have escaped his nhservation

ô. I.ength, 1: $\mathrm{mm}$; breadth, quite $\frac{1}{2} \mathrm{~mm}$.

Greymouth. One found by Mr. J. H. Lewis.

:3530. Dalma gigantea sp. nov. Dalma Shirp, Man. N.7. Coleopt.. p. 132.

Robust, moderately nitid and convex, finely rut quite distinctly punctate; infuseate red, palpi and tarsi fulvescent; thinly elothed with 
inconspieuous, rather short and siensler, rellowish pulnescence, but the apices of the elytrat and dorsal segrnents are thickly eiliate with elongatte, rather coarse, bright-yellow setae.

Head as long as thorax, considerably narrowed behind the very prominent eyes; the pair of large rotundate foreae, situated between the eyes and base, are confluent with the depressed frontal portion, the occiput has an angular median emargination at its base. Thorax rather broader than long, narrower than elytra, rounded and widest at the middle, rery abruptly eontrieted and straight-sided behind, obliquely narrowed anteriorly; basal median fossa large and deep, tapering towards the front, and terminating as a fine stria near the apex; the lateral foveae extend forward as far as the middle, and from the inner margin of each a linear impression proceeds straight forward to the narrow frontal portion; the connecting transverse stria near the base is somewhat indefinite. Elytra a third broader than long, longer than the thorax; the shoulders rounded, each with a minute prominence behind, so that the side of each elytron appears sinuously narrowed before the middle; sutural striae well marked, foveiform at the base, with a slight plica between each and the deep broad impression inside the shoulder. Hind-body quite as long and almost as broad as elytra, basal three segments marginate and subequal, the other's deflexed, the Ist with a transverse basal depression.

Legs stout, distinctly punctate and pubescent; anterior and posterior tibiae a little incrassate below the middle, rather deeply excavate near the extremity, these cavities sharply margined, the intermediate pair groored externally, so that in both sexes the basal joint of the tarsi is almost concealed.

Male. - Antennae stout, finely pubescent, expalling the head and thorax in length; basal joint not twice as long as broad, 2nd fully as thick, moniliform, rather broater than long, the next smaller, alon bead-like; joints 4 to 7 transverse, slightly increasing in breadth, 8 th eridently shorter and a little hrodeler than the precerling ones; !th suhquadrate, rery large, almost wholly crneave underneath; loth small. hardly any larger than third; terminal joint elongate-conical and acuminate, rather narrower but more elongate than the 9 th.

Underside of head with numerous long erect setae, and a deep rotundate basal fovea. Prosternum carinate along the middle. Metasternum short and convex. Basal ventral segment corered by the femora but distinctly fringed behind, segments 2-4 subequal, 5th shorter, 6 th emarginate behind, 7 th moderate, with a central oblong operculum.

Maxillary palpi with the 2nd joint clongate, slender near the base. clavate at the extremity, 3rd stout and subtriangular, th pubescent, rather slender and elongate, slightly oval, not securiform.

Fem.-With 6 rentral segments. Joints $4-8$ of the antennae transversely moniliform and differing but little, 9th rather larger than 10th; the sides and apices of elytra fuscous. In other details like the male.

This is almost a giant amongst the ordinary Euplectini. When compared with $D$. pubescens, 244 , this is seen to be larger, it is nearly concolorous, quite perceptibly punctate, and with different vestiture. The head is more elongate, with more convex, outstanding eyes. The abrupt contraction of the basal portion of the thorax causes the hind part of the dilated middle portion to appear angulate. There is a lateral sinuosity behind each shoulder. The remarkable tibial excarations are rery distinct. The terminal joint of the maxillary palpi 
instead of being securiform-oval is rather slender. In Dr. Sharp's weneric diamosis it is stated that there are 6 ventral scuments: he had two males and a female. In a reversed male found near Auckland, and another from Mount Hutt, I find there are $\bar{T}$, the last with an oblong operenlum, as is the case in D. gifanter.

o. Length, $3 \mathrm{~mm}$; brearth, $1 \frac{1}{5} \mathrm{~mm}$.

Moment Hutt. I single female disenvered hy Mr. 'T'. Hall in April. 1912, unfer a stome near an ant's nest, at in cleration of $2,500 \mathrm{ft}$.

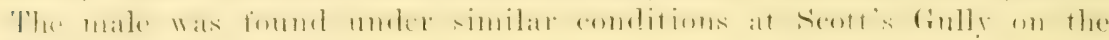
Lst March, 1913.

3531. Vidamus bryophilus sp. nov. Vidamus Rafiray, Gen. Ins. (Wytsman), Pselaphidae, p. 89.

liobust, moderately shining; fusco-rufous, legs piller, elytra of a brighter red; head and thorax finely, the elytra and hind-body thickly, pubescent, and also bearing elongate, upright setae, mostly yellow.

Head large, suboblong, as broad as the middle of the thorax, the gente slightly curvedly narrowed, hind angles rounded and obsolete; indistinctly punctate, the foveae large, prolonged and confluent in front. Eres moderate. Thorax slightly convex, widest before the middle, more gradually narrowed behind than in front, of about equal length and breadth; it is finely punctured, indistinctly near the middle; diseal fossa large, obtusely angular, and prolonged as a listinet groove to the basal matrin, which is distinctly bipunctate; lateral foreae largo and extending forwals, the flexuous groove connecting them with the merlian fossa rather shallow. Elytra nearly twice the length and breadth of the thorax, but a good deal narrowed towards the base, not pereeptibly punctate; sutural striae well marked, punciform at the base, where there is a puncture alongside each; intrahumeral impressions deep, short, and broad, more or less evidently duplicate and bipunctate. Hind-body as broad as the elytra but shorter, 3rd segment deflexed and rather shorter than the 2 nd, which is nearly as long as the basal.

'Tibiae slightly arehed and expanded towards the extremity, with distinct fulvous setae there, the intermediate somewhat thickened but not calearate inwardy at the apex.

Antennae as long as the hear and thorax, with slender outstanding setae; 2nd joint oblong-oval and nearly as long as the basal, joints 3, 4 , 5 , and 7 almost similar to the $2 n d$, 6th and 8th smaller, 10th subquadrate and rather broader than the 9th, the terminal conieal and subacuminate.

Underside fusco-rufous and finely pubescent; 2nd rentral segment distinctly longer than the next, th shorter than the 3rd but as long as the 5th, the 6th large, semicirculary emarginate, Tth also large, the opereulum well marked, oblong-oval. Anterior coxae prominent but not spined. 'l'rochanters all simple.

Rather larger and pereeptibly broader than $V$. calcaratus, 3210, and $V$. trochanteralis, 3380, without the inner calcar of the intermediate tibiae of the former and the spined trochanters of the latter.

o. Jength, $2 \frac{1}{2} \mathrm{~mm}$; ) breadth, $1 \mathrm{~mm}$.

Rakaia Gorge, near Methven. Unique. Fomd amongst moss on the 27 th September, 1912, by Mr. '1. Hall. 
35:3:. Zealandius basalis sp. nov. Zealundins Raffray, (Gen. Ins. (Wytsman), Pselaphidae, p. 111.

Elongate, slightly convex, nitid; custaneo-rufous, legs and antennae paler, tarsi and palpi flavescent; sparingly clothed with moderately elongate jellowish pubescence.

Head nearly as large as the thorax, gradually narrowed anteriorly, genae nearly straight, with obtuse hind angles; moderately fincly but not closely punctate; occipital foveae rotundate, not deep, and not perceptibly prolonged forwards; it is nearly plane in front, antennal tubercles small, distant, and a little elevated. Eyes situated near the middle, small but convex, with very few coarse facets. 'thorax oviform, hardly longer than broad, rounded and widest near the middle, nearly smooth in front, but with two series of distinct, yet not coarse, punctures across the base; discal groove moderately broad, extending from near the apex to the basal fossa, which is only indistinctly united to the rotundate lateral foreae. Elytra about as long as broad, behind much broader than the thorax, but curvedly narrowed hefore the middle so as to be but little wider than it is at the base; they are not smooth, being somewhat indefinitely sculptured; sutural striae broad throughout, deep at the base, and in some lights appearing duplicate; the dorsal almost similar but more shallow behind; interstices carinate. Hindbody about as long as the wing-cases, deflexed behind, basal three segments subequal, the 1st with a short impression at the middle of the base. Legs simple, moderately elongate, the anterior longest.

Antennae as long as the head and thorax, their 2nd joint oblong-oval, hardly as long or thick as the basal, 3rd distinctly narrowed at the base; joints 4-8 small and moniliform, the 5th and 7 th slightly larger than the others; 9th and 10th distinctly larger, transversely quadrate, the former the smaller; 11th conical, acuminate, as long as the preceding two together.

Underside shining, chestnut-red, with distinct rellowish pubescence on the abdomen. Prosternum with a sleuder longitudinal carina. Basal ventral segment partly uncovered, ciliate behind, the 2 nd with a distinct angular prominence extending quite half-way over the midrle of the $3 \mathrm{rd}$, which is somewhat concave between the centre and each sirle; th and 5th of almost equal length, the latter very slightly incurved behind, and with a minute median tubercle at its extremity; 6th much shorter, impressed across the middle, the 7 th transverse, the operculum indefinite.

This should be placed near $\%$. raffrayi, 3382, and its near allies, 3383 and $3: 384$, but it rlifferentiated by the characters of the male, and by the transverse series of punctures on the base of the thorax.

o. Length, $1 \frac{1}{2} \mathrm{~mm}$; ; biearth, nenrly $\frac{1}{2} \mathrm{~mm}$.

Curiosity Gully, Rakaia Gorge. A single male found amongrst dead leares on the ground, on 9th August, 1912, by Mr. 'T. Hall.

\section{Zealandius spinifer sp. nov.}

Subdepressed, moderately elongate, nitid; castaneo-rufous, legs and antennae fusco-fulvous, tarsi and palpi testaceous; pubescence vellowish. subdecumbent, rather short, abdomen with a few erect setae.

Hearl suboblong, as large as the thorax, genae curvedly narrowed behind, with obtuse hind angles; nearly smooth along the middle. finely puncturer at the sides, the foveat morterately large, situated behind the eyes, more or less distinetly prolonged and confluent in front, antennal 
tubereles widely separited and moderately elevated. Eyes minute, with coarse tacets, placed neal the middle. Thorax of about equal length and brealth, rounded and widest just before the middle, less nalowed behind than in front, where it is narower than the head, without pereptible punctation; lateral foveate large, indistinctly prolonged anteriorly, minted to the deep transverse basal fossa, diseal groore moderately broad and deep and attaining the apex. Lilytra suboblong, slightly narowed towards the rounded shoulders, rather broader and a third longer than the thorax, apparently smooth; sutural striae broad, deep and foveiform at the base, and just behind it appearing duplicate; the dorsal nearly similar, but becoming shallow behind; interstices carinate. Hind-body hadrdy as long as the elytra, basal three segments subequal, the other's deflexed.

laces morkrately elongate; intermediate tibiae rather thicker and more eurved than the others, somewhat notehed at the extremity, the outer angle slightly prolonged, the inner shorter, angulate and slightly projecting inwardly.

Antennate rather slender, shorter than the head and thorax; basal joint erlindric, its length double the breadth, second oval, distinetly longer than broad, the next small and narrowed towards the base; joints 4-s small and bead-iike, the 5th and 7 th slightly larger; 9th twice as large as its predecessor but not as broad as the transverse 10th, the terminal largest, subovate.

Underside chestnut-red, finely pubescent. Head with a large forea behind the middle and finely carinate in front. Prosternum earinate along the middle. Netasternum elongate, with a large rotundate inpression behind the middle. Basal ventral segment hidden by the fenorat, segments $2-5$ subequal, the 2 nd transversely elevated at each side of the middle, 5th widely emarginate, 6th large, widely impressed at the base, with an indistinct median, conical operculum. Intermediate trochanters with very prominent spines, those of the posterior much less distinet.

The finely sculptured shining surface prevents its being placed in the same section as the typical exponents of the genus, such as $Z$. obscurus, 2478 , and 2477 . It can be at once separated from \%. raffrayi, 3382, by the absence of the thick longitundinal carina at the base of the metasternum, which, moreover, has the operculum of the last ventral segment distinctly convex. 3383 is distinguished by its small, elosely punctate head, and 3384 by its broad Vidamus-like body.

ô. Length, $1 \frac{2}{3} \mathrm{~mm}$; breadtl, $\frac{1}{2} \mathrm{~mm}$.

Pudding Hill, near Methven. One found hy Mr. Hall on the th Mlay, 1912, amongst deand leaves on the ground.

\section{Byraxis illustris sp. nov. Byraxis Reitter, Gen Ins. (Wytsman), Pselaphidae, p. 193.}

shining, moderately convex, elongate, subovate, bearing some long, slender, erect grevish hairs; fuseo-rufous, elytra brighter red, tarsi and palpi fuseo-testaceous; antennae pitehy-red, their enlarged 9 th and 10 th joints nigreseent, minutely asperate, with short grey pubescence.

Head subquadrate, a little narrowed behind the moderately prominent eyes; slightly depressed between the small antennal tubereles, the interocular foveac obsolete or entirely absent. 'Thorax a little longer than broad, morlerately rounded and widest before the middle, with small lateral foveae. Elytra elongate, nearly double the length and 
breadth of the thorax, gently narowed towards the base; with distinct sutural striae, and a few shallow, indistinct punctures which are almost seriate. Hind-body as broad as the eltrra, but shorter and much darker.

Legs moderately elongate, posterior tibiae a little arehed below the middle.

Antemnae about as long as the head and thorax; basal joint stout, its length searcely double the breadth, the next subquadrate, joints $3-6$ of about equal wirth, the th, howerer, hardly longer that broarl, Tth and

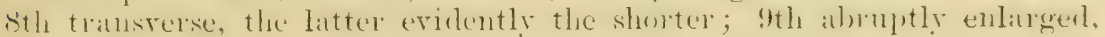
subquadrate, oblique at the extrenity, rather longer on the outer side than the inner, with a minute spinifom alpendige beatr its inner extremity; 10th rather larger, rounded outwardly, with a small lobe-like dilatation at the inner side of its base.

Underside dark red, with some fine rellowish pubescence, Metasternum broadly and deeply depressed along the middle; 2 nd ventral segment with a pair of large pominences extemling nearly the whole length, these are testaceous, finely ribbed and flattened on the surface, but somewhat tilted towards each other ; intermediate segments incurved behinf and very short in the midrle; sth wirlely emanginate behind and impressed across the middle; 6th large, transversely oval, finely yet quite distinctly punctate.

'The rather' elongate body, large terminal joints of the antennae, and peculiar proninences on the 2 nd ventral segment are its distinctire characters.

o. Length, $1 \frac{3}{4} \mathrm{~mm}$; breadth, $\frac{2}{3} \mathrm{~mm}$.

Bioken River, Canterbury. Two specimens, numbered 5170 and 5172 respectively, were sent to me several rears ago by Mr. J. H. Lewis, but as he informed me that he had also sent them to Dr. Sharp I declined to describe them then. As Dr. Sharp apparently has not named this species, I have now described it. Exactly the same remarks are applicable to the following species.

\section{Byraxis anisarthra sp. nov.}

Sanguineous, nitid, legs fusco-rufous, tarsi and palpi infuscate; sparingly clothed with slender, elongate, erect greyish hairs on the wingcases, more thickly on the abdomen with decumbent ones.

Head as long as the thorax but rather narrower, smooth, interocular foreae obsolete. Thorax of about equal length and breadth, widest and :ounded at the middle, without sculpture. Eltyra oblong, nearly double the length and breadth of the thorax, their sides slightly rounded, with well-mitrked sutural striat, and a few fine, indistinct, scatterent punctures. Hind-body rather narrower, and evidently shorter than the wing-cases, its basal segment slightly longer than the next, the others

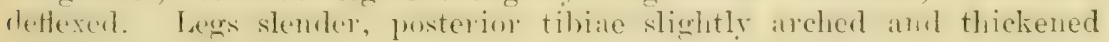
near the extremity.

Antennae shorter than the head and thorax, with short greyish pubescence; basal joint thick, not twice as long as broad, 2nd supquadrate,

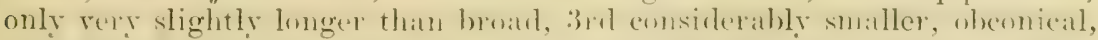
4 th very short, twice as broad as the Srd; 5th oblong, cnomously dereloped, a thim of the entire length, alplitrently with at hasal forea underneath; joints 6-8 small and transverse; 9th quadrate, double the width of the preceding one; 10th of the same breadth as the penultimate but a third longer, both of these together smaller than the 5th. 
Underside rufo-eastaneous. Metasternum depressed along the middle, the hollow, behind especially, with obtusely elevated lateral borders. Basal sugnent of the abdomen exposed, but very short and truncate in the midlle behind; 2nd large, unimpressed, with a pair of small ret distinct tubereles near the mirldle; :3-5 short but distinet, all inemved buhind; 6th large, with a small median fovea.

Fem.-Antennae with greyish pubeseence: 2nd joint shorter than the 1st; 3rd and th equal, smaller than the 2nd; 5th suboblong, broader than the jounts 6-8 successively but only morlerately dilated; 9th not as broat as the transverse 10th; 1 1 th largest, subconical.

ô. Length, nearly $1 \frac{1}{2} \mathrm{~mm}$. ; brearth, $\frac{1}{2} \mathrm{~mm}$.

Broken River. Mr. J. H. Lewis sent a male and a temale, numbered respectively 5366 and 5173 .

The strueture of the 5th and 9th antemnal joints and the sculpture of the underside distinguish it from B. lewisi, 3052, the only other species of the same section.*

\section{Byraxis bisulcifrons sp. nov.}

Shining, moderately convex; rufo-piceous, legs fuscous, tarsi and palpi a little paler; scantily clothed with greyish, dongate and slender, mostly upright setae.

Head smaller than thorax, gradually harrowed anteriorly, curvedly narrowed behind the eres; slightly longitudinally bi-impiessed in front, with 2 indistinct small interocular foven, and a central occipital puneture. Eyes situated, behind the middle, rather large, but only very moderately convex. Thorax about as long as broad, widest and rounded before the middle, without any perceptible sculpture. Elytra nearly double the length and breadth of the thorax, gently curvedly narrowed anteriorly, with somewhat oblique shoulders, so that the base hardly exceeds that of the thorax in width; sutmal striae well developed throughout, each elytron has some shallow indistinet punctures which almost form three irregular series. Hind-body evidently shorter than the elrtra, basal segment rather larger than any of the others, which are deflexed.

Legs moderately stout; posterior tibiae rather longer than the others, slightly curved and thickened towards the extremity.

Antennae shorter than the head and thorax, with slender setae; basal joint stout, not twice as long as broad, 2nd rather smaller, 3rd still smaller, 4th also short but distinctly broader than the 3rd; 5th remarkably large, its basal portion transversely quadrate and broader than the 4th, its larger apical portion subtriangular, strongly but not acutely

*'The original specimen of $B$. lewisi, not being in such a condition as to admit of manipulation, had to be described just as it was, gummed on cardboard. MIr. 'I'. Hall fortunately found two males on the mountains near llethren quite recently: these enable me to add a description of the lower surface.

\subsection{Byraxis lewisi.}

Mule-Anterior trochanters distinctly spined. Metasternum broadly depressed from base to apex, the eavity with distinctly but obtusely raised sides. Basal rentral segment covered; 2 nd large, medially depressod, with 2 tubereular elevations extending nearly the whole length, and rather widely separated behind; the 6th with a deep, large, subrotundate contral fovea. Ninth antennal joint somewhat concave underneath, and with a hook-like appendage near its inner extremity - this is not risible from above when mounted in the ordinary manner unless the antenna is twisted. 
expanded outwadly towards its extremity, where it is twiec as broad as the 9th; 6th small, seareely longer than broad, attached to the inner extremity of the 5th; 7th bead-like and rather broader than contignous ones; 9th moderately large, subtriangular, hardy broader than the 8th at its base, quite as large as the preceding two combined; 10th subovate, rather longer and evidently broader than the penultimate.

Underside nitid, fusco-rufous, sparingly and finely pubescent. Anterior coxae acutely prominent; the trochanters with small spines. Metasternum depressed along the middle, more narowly in front than behind. Second abdominal segment with a pair of moderate, subcontiguous tubercles, the 6th with a shallow transverse median fovea.

B. anisarthra may be separated at once by its quite oblong, enormously dereloped כth antennal joint. In $B$. lewisi the corresponding joint, though relatively large, does not exceed the 9th in bulk. 'The present species differs from both of these in many details, and may be distinguished by the lateral dilatation of the conspicuous 5th joint of the antennae.

o. Length, $1 \frac{1}{2} \mathrm{~mm}$. ; breadth, 学 $\mathrm{mm}$.

Mount Hutt. Mr. T. Hall forwarded two males, found on the 28th October, 1912, at an altitude of about :3,000 ft.; nome of the other sex were secured.

3537. Hamotulus angulipes sp. nov. Hamolulus Śchaufuss, Gen. Ins. (Wytsman), Pselaphidae, p. 390. Syn. Tychotym Broun, Ann. Mag. Nat. Hist., ser. 6, vol. 12, p. 168.

Subovate, irregularly narrowed anteriorly, moderately convex, nitid, impunctate; fusco-rufous, elytra of a brighter red, tarsi and palpi flavescent; elothed, but not thickly, with long and slender upright rellow setae.

Head moderately elongate and parallel in front, genne pubescent and distinctly narrowed behind, the occiput scarcely as wide as the thoracic apex; frontal channel well marked, ending in line with the front of the eyes, ocular foveae distinct. Eyes moderately large and very prominent Thorax about a third longer than broad, slightly contracted at the apex, a little wider before the middle than elsewhere, with a curvate impression near the base united to an elongate fovea at each side. Elytra

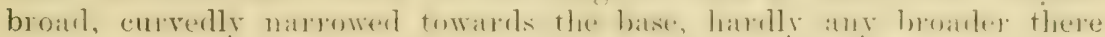
than the thorax, and about a third longer than it is; they are convex behind the middle, with distinct sutural striae which are deeply foveate at the base; intrahumeral impressions broad, leep and foreiform at the base, tapering and obsolete behind the middle. Hind-body of about the same length as the wing-cases, curvedly narrowed and deflexed posteriorly, convex along the middle.

Legs long and moderately slender, pubescent; anterior tibiae almost straight, intermediate somewhat curved below the middle; the posterior armed inwardly, just below the middle, with a triangular spiniform process, and below that point somewhat eurved inwardly.

Antennae longer than the head and thorax, rufo-testaceous, with infuseate pubescence; basal joint stout, cylindric, fully double the length of the oblong 2 nd, the next not quite as-thick but rather longer, 4 th distinctly shorter, scarcely longer than broad, 5th and 6th elongate, each

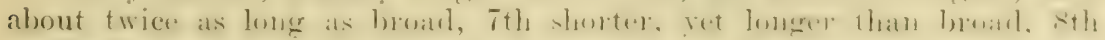
smallest, transrerse; 9 th and 10 th suberual, laxly articulaterl, subquadrate, both a little narrowed towards the base and nearly double 
the breadth of the sth; the temunal oblong-oral, not as long as the preeding two combined, foveate underneath.

Underside fuseo-rufous, with unevenly distributer rellowish pubescence. Metasternum nearly glabrous and depressed along the middle;

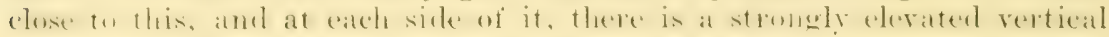
process which is bifid at the summit. Basal rentral segment pubescent and covered by the femora, 3rd slightly longer than the ardjoining ones;

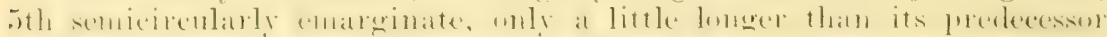

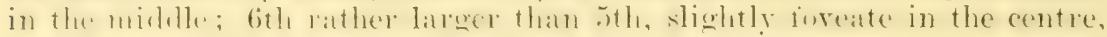
subtruncite behind; Tth minute, broadly triangular, and resting on the large operculum or terminal segment, which is rounded and distinctly margined behind.

II. sternalis, $27 \pm 4$, most nearly resembles this; in it, however, the head and thorax are shorter and broader. The metasternal process, at each side of the middle, is close to the internediate coxa, it is entire, and rertical in front; in $H$. angulipes each process is situated exactly at the middle, distant from the coxa, and is bifid at its extremity. In $274 t$ the 5 th ventral segment has a transverse median depression, and the 6th is concare for half of its whole width, the minute 7 th is broadly triangular.

o. Length, $2 \frac{1}{2} \mathrm{~mm}$; breadth, nearly $1 \mathrm{~mm}$.

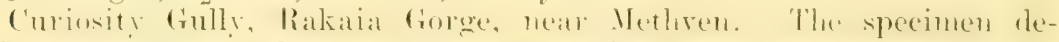
scribed abore was taken out of moss on the face of a rock by Mr. T. Hall on the 6th Julr, 1912, just about the middle of a rather severe winter.

3538. Pselaphus trifoveatus sp. nov. (Wytsman), Pselaphidae, p. 304.

Pselaphus Herbst, Gen. Ins.

Elongate, narrowed anteriorly, shining; castaneo-rufous, antennae, palpi, and tarsi more or less fulvescent; pubescence rellow, depressed, very thinly distributed, more thickly at the extremity of the elytra and almost forming a cilium there.

Head elongate, its sides nearly straight in front of the moderately large eres, much narrowed behind them, not quite smooth; the frontal channel extends as far back as the middle of the eres, it is slightly but not at all abruptly expanded there and almost touches the pair of fovea behind the eyes, its hind part is conver. Thorax convex, and, excluding the distinct minutely and densely sculptured neck, rather longer than broad, widest at the middle; with a curvate impression in front of the base and a small elongate fovea at each side. Elytra about a third longer than the thorax, widest behind, considerably narrowed towards the base, bearing only a few depressed straight hairs; the

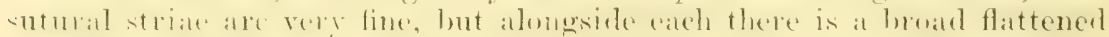
space, which is deep and foveiform at the base but obsolete towards the extremity, there is a similarly formed but much shorter impression near each slumbler. Hind-body as long and fully as broad as the elytra, hasal segment about as long as the other deflexed ones taken together, with a few fine, slightly curled hairs.

Legs clongate, femora subclavate, tibiae arched externally, thickened towards the extremity and distinctly pubescent there.

Antennae slightly longer than the head and thorax; basal joint red, its length double the breadth, 2nd nearly as thick and fully half as lung; Brd more slender and longer than the 2nd and distinctly longer than the 4th: joints $5-8$ nearly equal, all evidently longer than broad; 
9th and 10th distinetly stouter than the preceding ones, the terminal elongate-oval.

Male.-Underside chestnut-red. 'There is a patch of grey spongre-like restiture on the middle of the prosternum, another at each side of the elevated mesosternal process, and the short basal rentral segment is sinilarly covered. Metasternum medially convex, broadly depressed behind. Second ventral segment large, with an elongate merlian impression at the extremity, and a punctiform lovea between the middle and each side; $3 \mathrm{rd}$ and 4 th rery short in the middle, the 5 th barely visible at the middle but much prolonged outwardly, 6th large, deeply emarginate, the suborate opereulum with a small basal fovea.

Maxillary palpi elongate, 3rd joint short; the terminal flexuous, its clavate portion fully a third of its whole length.

The sculpture of the head distinguishes this species from Sharp's $P$. pauper, 226, and, moreover, the curled part of its clothing on the elytra and hind-body is inst the reverse of what it is in $P$. pauper.

o. Length, $2 \frac{1}{3} \mathrm{~mm}$. ; brearth, $\frac{2}{3} \mathrm{~mm}$.

IIcClenuan's Bush and Rakaia Gorge, near Methren. Both sexes obtained by Mrr. 'T'. Hall amongst dead leaves in March, 1912.

\section{Group) S'CAPHIDIDAR.}

3539. Baeocera sternalis sp. nor. Buencere Erichson, Man. N.Z. Colenpt., p. 665 .

Minute, convex, oval, glabrous, nitid, impunctate; nigro-piceous, leg's infuscate red, tarsi and basal joints of antennae usually fulrescent, remaining joints of the latter fuscous.

Head only half as broad in font as it is in line with the eres, with large antennal cavities. Thorax wiclest at the base, which is obtusely angulate at the middle, its sides with slender margins and curvedly narrowed towards the front. Sicutellum invisible. Elytrat of the same width as the thorax at the base and closely adapted thereto, about twice its length; with fine lateral margins, apices very broadly rounded; towards the extremity fine sutural striae can be seen. Pygidium reddish, conical, but not much exposed.

Underside shining, nigrescent, with a few very slender grevish hairs. Metasternum with dongate or punctiform impressions near its sides.

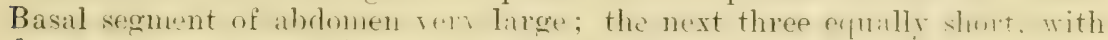
deep sutures, each finely bipunctate near the middle; Jth much narrowed, its apical suture verr fine; 6th short.

Antennae filiform, with a few slender setae, their 2nd joint about as long as the 1st, both moderately stout, joints 3-7 elongate and slender, Sth rather shorter, 9th to 11th darker and broader.

The large antennal cavities and metasternal sculpture distinguish this species. The body is rather narrowly oval.

Length, $1 \frac{2}{3} \mathrm{~mm}$; breadth, nearly $1 \mathrm{~mm}$.

Pudding Hill and McClennan's Bush, near Methren. Mr. T. Hall has forwarded a small series of specimens which he detected amongst leaf-mould in April and Mar, 1912.

\section{Group Conytopiman.}

3540. Sacina curtula sp. nov. Sacina Broun, Man. N.Z. Coleopt., p. 1071 .

Oblong, subdepressed, nitid; covered with dark ashy, decumbent,

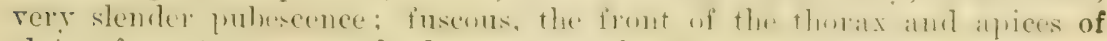
elytra fusco-testaceous, the legs more rufeseent. 
Thorax about a third broader than long, distinctly margined, bisinuate at the base, strongly rounded and almost transparent in front, its punctation fine and rather distant. Seutellum large, curvilinearly triangular, sparingly punctured. Elytra oblong, nearly double the length of the thorax, as wide as it is at the base, finely margined, gently narrowed posteriorly, with broadly rounded apices; finely but quite definitely punctured, with a slight impression behind the scutellum, but without sutural striate.

Underside with slender ashy pubescenee; breast and basal segment of abdomen fuscous, finely and moderately closely punctate, remaining segments more or less testaceous. Prosternal process ncuminate in front, the coxale distinctly but not widely separated. Mesosternum well developeci, hansverse, its fine posterior suture truncate between the widely distant coxale. Metasternum large, rather broader than long, quite straight behind; the exxae further apart than the intermediate ones and with a shallow elongate impression in front of each. Basal rentral segment not quite as linge as the metasternum, 2-4 about equally short, Jth fecbly emarginate, evidently longer than the 4 th in the male, 6th short and broad.

Antennae and head invisible from above, basal two joints stout and elongate, $3 \mathrm{r}$ d sleuder, the following fou indistinct; club rather large, triarticulate, its basal joint triangular, the next shorter, the terminal suboblong.

Fenora robust, tibiae simple; terminal tarsal joint rather longer than the others taken together'; claws minutely appendiculate at the brise.

Shorter and relatively broader than S. ablonga, 1913, with finer and darker pubesecuce.

Length, $1 \frac{1}{3} \mathrm{~mm}$; breadth, quite $\frac{2}{3} \mathrm{~mm}$.

Bell liock and other places near Methven. Seven specimens found by Mr. T. Hall in February and September, 1912.

\section{Group Colmdidan.}

3541. Ulonotus proprius sp. nov. Ulonotus Erichson, Man. N.Z. Coleopt., 1). 186.

Elong:ate-oblong, trinsrelsely convex, opaque; the thorax and elevations on the elrtra of a slightly rufescent fusco-testaceous hue; the remainder of the elytra, the head, and legs more or less infuscate; artennae fulvescent, tarsi darker; sparingly and irregularly clothed with short, somewhat currate, straw-colomed setae and greyish scalelike matter.

Head large, nearly plane, obtusely expanded, but not elevated, at the antenual insertion, its surface with granular seulpture. Eyes small but prominent. Thorax, exclusive of lobes, of about equal length and breadth, irregularly and indistincty granulate, with a rather broad and rleep chanel along the middle; anterior lobe large, extending from the middle of each side to the front of, but widely separated from, the eye, the 2nd very short yet projecting outwardly almost as far as the other. the posterior angles apparently formed of or armed with a pair of minute unequal spines. Elytria more than double the length of the thorax, rather broader than it is at the base, with nearly straight distinctly and regularly denticulate sides, they are gradually rounder behink, with simple apices; alongside the suture they are moderately coarsely seriate-punctate but irregularly elsewhere; on each elytron a 
narrow elongate ridge extends backwards from the middle of the base, in line with that there is an oblong nodule near the hind thigh, and on the summit of the posterior declivity a prominent nodosity, a pair of smaller ones outside the last extend towards the posterior femur, and on the middle, but nearer the side, there is a ridge similar to that near the base.

Antennae rather slender, as long as the thorax, their basal joint halfhidden above; 3rd elongate, as long as the 2 nd but much thinner; 4 th and 5th rather longer than broad; joints 6-8 short and bead-like; 9th larger than 8th but smaller than the quadrate 10th; the terminal conical, slightly narrower but rather longer than the 10th.

Legs with more or less curvate setae, the tibiae a little arcuate and thickened outwardly near the middle; tarsi simple, their basal three joints subequal and, together, shorter than the 4th.

A peculiar and rather slender species, having a rather narrow triarticulate antennal club. The thorax appears abruptly contracted near the base, the flattened anterior lobe is entire and unusually large, and its bispinose posterior angles are without precedent. It should be located near $U$. uropterus, 3222, which, howerer, is a much larger insect with strongly produced elytral apices.

Length, $2 \frac{1}{2} \mathrm{~mm}$. ; breadth, nearly, $1 \mathrm{~mm}$.

Rakain Gorge, near Methven. We are indebted to Mr. T. Hall for the detection of this interesting species. One individual, found amongst decaying leaves on the 5th June, 1912, is all I have seen.

\subsection{Notoulus truncatus sp. nov. Notoulus Broun, Man. N.Z. Coleopt..} p. 183 (Ablabus).

Oblong, moderately convex, variegate; fuscous, the front and explanate sides of the thorax, the antennae and tarsi more or less castaneorufous; unevenly clothed with slender, rather short, somewhat curled or suberect, yellow setae, which, on the elytra, are mingled witl greyish scale-like matter; on the middle of each elytron, behind the posterior femur, there is a fuscous spot; legs and club dull rufo-fuscous.

Head indistinctly granulate, only slightl elevated at the point of the antennal insertion. Thorax rather broader than long, its sides explanate and trilobed, the front lobe a little larger than the 2nd, the 3rd still smaller and situater between the middle and base, posterior angles obtuse and learing a gap between each and the shoulder, the apex deeply incurved near each side; disc uneven, indistinctly granulate, trifoveate in front, the central fovea narrower and not quite as large and deep as the others; on the middle there is an ill-defined impression, and the base is unequally triforeate. Elytra as broad as the widest part of the thorax, fully twice its length, obliquely narrowed and subvertical behind; their seulpture is entirely hidden by the vestiture, but appears to be seriate-punctate; at the middle of the base, on each elytron, there is a distinct nodiform elevation, and there is a pair of smaller ones behind, besides these there are 2 or 3 which are more obtuse and less easily seen. Legs rather short, tibiae straight, bearing curled setae.

Antennae shorter than the thorax, very scantily pubescent; their basal joint half covered by the lateral dilatation of the head, 2 nd thick and subobconical, $3 \mathrm{rd}$ as long as its predecessor but not half as stout, the following two slightly longer than broad, joints $6-8$ short and moniliform, 9th only slightly broader; club abruptly enlarged, densely pubescent, biarticulate. 
1. varicornis, 3086, most nearly resembles this species, which, on account of the indefinite seulpture, has been difficult to describe. When examined from above the pale elytra seem to be nearly plane and obtusely truncate at the top of the dark posterior declivity, on which, hall-way down, there is a pair of paler nodosities

Length, $3 \mathrm{~mm}$.; breadth, $1 \frac{1}{3} \mathrm{~mm}$.

McClennan's Bush, near Methren. 'T'wo examples sent to me by Mr. 'T'. Hall on the 15th March, 1912, both obtained from leaf-mould at a height of $1,500 \mathrm{ft}$.

\section{Notoulus longipes sp. nov.}

Oblong, opaque, fuscous; elytra covered with tawny curled setae, the head and thorax more thinly clothed with yellowish ones; legs and antennae ferruginous.

This species is like $Y$. truncatus, but is larger, with distinctly longer legs, more prominent eves, and differently formed antennae.

The elytra are almost flat along the middle, each, on top of the posterior declivity, is distinctly, contiguously trinodose; there is a smaller nodosity near the side and slightly in advance, and in line with this, but before the middle, a larger one, the basal elevation is more elongate, and the shoulders are somewhat prominent, the apices are slightly dehiscent, and the declivity is not nodose.

Antennae nearly glabrous, shorter than the thorax, their basal joint more than half-hidden, 2nd thick and hardly any longer than broad, 9th scarcely broader than the 8th; club large, its first joint transverse, the terminal as broad but nearly twice as long.

Underside dull rufo-fuscous, with numerous short, depressed yellowish setae; 3rd and 5th ventral segments finely and rather distantly granulate, the 3rd more distinctly near the sides, the 4th with a transverse series.

Length, $3 \frac{2}{3} \mathrm{~mm}$. ; breadth, $1 \frac{1}{2} \mathrm{~mm}$.

Hump Ridge, near Invercargill. Two examples found by Mr. A. Philpott in February, 1912.

\section{Bitoma obsoleta sp. nov. Bitoma Herbst, Man. N.Z. Coleopt.,} p. 192.

Elongate, subdepressed, opaque; nigrescent, legs and antennae infuscate, the former paler; irregularly and thinly clothed with distinct, decumbent pale-rellowish setae.

Head almost as large as the thorax, rather flat, with indistinct granular seulpture, very slightly elevated over the antennal cavities. Eves moderately prominent. Thorax of about equal length and breadth, widest at the obtuse anterior angles, which, however, do not extend as far forwards as the middle of the rounded apex; the sides are somewhat explanate in front, gradually narrowed backwards, and only indistinetly serrate. posterior angles indefinite, but not rounded; disc slightly uneven, with 5 shallow, ill-rlefined, obsolcte impressions, its granular seulpture hadly diseernible. Seutellum subquadrate. Elytra thrice the length of the thorax, rather broader than it is at the base, very gradually and slightly expanded posteriorly, with strongly rounded, feebly divergent apices; they are broadly but not at all deeply depressed before the middle, and seen to be finely seriate-punctate, or granulate, when examined in different ways; on each elytron there is a slight, elongate basal elevation, and further back, in line with the 1st, there 
are two equally indefinite, oblong inequalities; the surface appears a little uneven, so that the serial sculpture is somewhat interrupted.

Antennae shorter than the head and thorax; 2nd joint stout, oblong, as long as the uncovered portion of the basal, 3rd elongate and slender, 4th a little longer than the next, joints 6-8 small and subglobular, 9th slightly broader; club abruptly enlarged, terminal joint longer than the transverse 10 th.

Most nearly related to $B$. picicornis, 2762 , but much more slender; both are without thoracic lobes. In the type of 2762 the elytra, towards the sides, seem to have 3 or 4 slender castae - there is no trace of these in the present species; in the former, on each elytron, there is a conspicuous rotundate spot, formed of exceedingly minute white setae, near the base, and in a variety from the ricinity of Methren there are several white specks towards the extremity-all these are lacking in B. obsoleta.

Length, 2 mm.; breadth, $\frac{2}{3} \mathrm{~mm}$.

Rakaia Gorge, near Hethven. One foumd amongst dead leaves on the ground by Mr. 'T'. Hall on the 1st November, 1912.

3545. Coxelus instabilis sp. nov. Coxelus Libtreille, Mibn. N.Z. Coleopt., p. 195.

Elongate, subparallel, subopaque; piceous, the thorax and parts of the elytra usually more or less rufescent, antennae dark red, the club piceous, legs obscure fusco-rufous; the squamiform setae vary from fulvous to greyish, they are irregularly distributed and on most parts decumbent, but on the hind part of the elytra they are suberect, and in most specimens form 3 small spots or crests on each, the apparently bare portions of the dorsum bear finer inconspicuous hairs, and in most cases there is a thick basal patch on each elytron.

Head narrower than the thorax, with flattened granules, these, however, become indistinct in front. Eyes moderately large and prominent, setigerous. Thorax of about equal length and brearlth, slightly rounded and wider before the middle than near the gently narrowed basal portion, with rectangular, or slightly prominent, posterior angles; the lateral margins are not perceptibly crenulate, and the channels inside them are deeper and broader near the front than towards the base; the apex is sinuate near each side. lout its angles hardly project further than the middle; the surface is corered with granules, in each of these there is a minute puncture, there is a depression along the middle, in some cases narrow, in others expanded, and the basal region is more or less eridently trifoveate. Elytra quite double the length of the thorax, slightly wider than it is at the base, with subrectangular shoulders; sometimes they are inpressed along the midnlle so that the suture appears a little elevated, they bear series of granules and linear, sometimes indefinite interstices, the suture on top of the posterior declivity is somewhat thickened but not cresterl.

Antennae shorter than the thorax, their basal joint not visible from above; 2nd stout, oblong; 3rd nearly as long but much more slender; joints $t-8$ decrease in length; 9th obeonical, distinctly larger than 8th, club ahruptly enlarged, its hasal joint strungly transverse, the apical narrower and subrotundate.

Tibiae with short but distinct rellowish setae on the outside, those alung the inside very slender. 
Underside dark fuscous or somewhat rufescent, with numerous fine yellow setae, head punctate behind, the breast and abdomen distinctly and rather evenly granulate.

C. helmsi, 3018t, may be distinguished at a glance by the numerous erect blackish setae, and the pair of dark sutural erests on the summit of the hind slope. $\quad C$. elongatus, 2764 , is concolorous, slightly larger, and bears more evenly distributed vestiture. Its thorax is nearly a third longer, and its shoulders are obtuse.

Length, $3 \mathrm{~mm}$; breadth, quite $1 \mathrm{~mm}$.

HcClennan's Bush and Pudding Hill, near Methren. About twenty specimens were received from Mr. 'T'. Hall during April and Nay, 1912, all taken from leaf-mould at an elevation of about 1,500 ft. After spending an entire day in their examination, I came to the conclusion that they are representatives of a single variable species.

3546. Heterargus parallelus sp. nov. Heterorgus Sharp. Man. Х.\%. (10leopt., p. 1085.

Elongate, subparallel, only slightly convex, without nodiform eler:itions, subopaque; obseurely rufescent, the hinder part of elytra and sometimes the middle of thorax fuscous; thinly clothed with short, slender, yellow setae.

Head granulate behind, the forehead a little depressed and marked off by a curved interantennal impression, the clypeus very prominent. Thurax slightly broader than long, deeply sinuate near each side in front so that the angles appear prolonged as far as the minute eyes; its flattened sides are a little rounded near the front but only obsoletely serrate; base with a deep sinuosity near each side, its angles subicute and directed backwards; the surface is a little uneven, having a pair of short frontal and oblique basal elevations, and it is covered with somewhat flattened granules. Elytra twice the length of the thorax, scarcely at all broader than it is at the base, with subrectangular shoulders; they bear regular series of small suboblong granules; interstices linear, the 3rd slightly elevated near the base and behind, the 5th less distinctly so, not at all at the base.

Antennae shorter than the thorax, their basal joint almost wholly exposed, quite the length of the $2 \mathrm{nd}$, and rather thicker; 3rd slender, longer than broad; joints 46 subquadrate, 7th and 8th moniliform, 9th rather broader; club abruptly enlarged, biarticulate. Tibiae finelr setose.

Underside dull rufo-fuscous, with some minute setae, covered with flattened granules, the flanks of the prosternum included, bisulcate between the front coxae, the back of the head transversely rugose.

This most nearly resembles $H$. subaequns, 3406, which, however, is more slender, with less prominent shoulders, the base of the thorax is more rounded in the middle, and the sculpture is somewhat different.

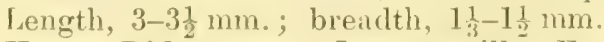

Hump Ridge, near Invercargill. Found by Mr. A. Philpott in February, 1912, at an altitude of $3,000 \mathrm{ft}$.

3547. Gathocles angulifer sp. nov. Gathocles Brom, Mibn. X.Z. r'oleopt., p. 1086.

Robust, oblong, moderately convex, subopaque; fuscous, the antennae. tarsi, the front and sides of the thorax and indefinite marks on the elvtra rufescent; sparingly clothed with erect, slender, rellowish setae. 
Head smooth in front, granulate behind. Thorax about a third broader than long, emarginate near each side of the apex, so that the angles, which extend to the midlle of the eves, appear prominent; its sides are moderately explanate and irregular but not denticulate, a little rounded in front and slightly sinuate behind, the posterior angles are prominent though not acute, and directed backwards and slightly outwards; the surface is distinctly granulate, less closely on the centre than elsewhere, there is a large impression along the middle and a pair of smaller ones at the base. Elytra only slightly broader than the thorax, not twice its length, with prominent humeral angles; their sculpture consists of nearly regular series of small granules and narrow longitudinal interstices, the $3 r$ of these latter atr a little elevated near the base, but there are no definite nodules anywhere.

Antennae shorter than the head and thorax; the uncovered portion of the basal joint is as stout and nearly as long as the $2 \mathrm{nd}$, which is twice the thickness of the equally elongate $3 r d$, joints $4-8$ gradually decrease in length, none however are transverse, 9th moniliform, slightly broarler than its predecessor; club broad, finely pubescent, biarticulate.

Legs with short setae; basal joint of the tarsi slightly longer than the 2 nd, the terminal longer than the basal three combined.

Underside dark fuscous, granulate, but the flanks of the prosternum are smooth, the last ventral segment nearly so, the head is densely and minutely sculptured and has some moderately coarse punctures. The prosternal process is bisulcate.

This differs from the type of the genus, 19:36, by the absence of nodiform elevations, and by the flat, not hollowed, and less anteriorly dilated sides of the thorax. There is an obvious gap near each sile, at the base of the thorax, so that the thoracic and humeral angles are remarkably distinct. The description has been drawn up from a pair of thoroughly cleaned specimens.

The spucies of this genus are more lobust and thickset than thmen of Heterargus and possess larger eyes.

Length, $3 \mathrm{~mm}$. ; breadth, $1 \frac{1}{2} \mathrm{~mm}$.

Mount Hutt and MeClennan's Bush, near Methren. A dozen individuals were secured from leaf-mould during April, 1912, at a height of $1,500 \mathrm{ft}$., by $\mathrm{Mr}$. T. Hall. In their natural condition they are encrusted with dried sappy matter.

\section{Protarphius pallens sp. nov. Prolarphius Broun, Ann. Mag. Nat.} Hist., ser. 6, vol. 12, p. 183.

Oblong, transversely convex, the body and legs fusco-testaceous; in its natural habitat covered with light-tawny sappy matter, through which slender, erect, yellowish setae protrude.

Thorax broader than long, very finely, distantly, and irregularly granulate, with a broad, somewhat angular, impression along the middle and a pair of basal foreae, its sides explanate and slightly rounded. Elytra rather broader than the thorax, twice its length; when carefully denuded the $3 r d$ interstices appear smooth, without any sign of granulation, and only s!ightly clevated on the dise but norlifom lechiml, the 5 th are only indistinctly raised, between the suture and each of these there are duplicate series of rather coarse, distinctly separated punctures, the sides are similarly punctate; before ther are cleaned the $3 \mathrm{r}$ d interstices appear obtusely elevated at the base, less so near the middle, and terminate in conspicuous nodosities on the top of the perpendicular 
declivitr, the 5th are less evidently nodiform and hardly at all elevated along the dise.

Underside rufo-fuscous. Metasternum with transverse series of gramules. Basal ventral segment granulate, rather longer than any of the intermediate ones, each of which has a well-marked transverse impression between the middle and sides, the 5th as well as the preceding two are without granules, all have deep sutures.

Antennie 11-jointed, the 1 st and 2 nd joints thick, $3 \mathrm{rd}$ about twice as long as broad, 4-9 small and submoniliform; club broad, biarticulate.

This may prove to be a local form of $2770, P$. tricavus.

Length, $2 \frac{1}{4} 11 m$. ; breadth, $1 \frac{1}{4} \mathrm{~mm}$.

Ifclennan's Bush, near Methven. Found by Mr. 'T. Hall amongst decaring leaves in April, 1912.

Obs.-P. ruficornis, 2768. From the sime source 1 have several specimens of a variety of this dark-legged and slightly larger species. These differ from $P$. pallens by the absence of the lateral depressions on the intermediate ventral segments, as well as in other details. I found my two speeimens of 2768 in the North Island, on Mount Pirongia, in December, 1892.

\section{Groul Proxomiridale.}

3549. Pycnomerus tenuiculus sp. nov. Pycnomerus Erichson, Min. N.Z. Coleopt., p. 208.

Elongate, subparallel, very slightly convex, grabrous, moderately nitid; piceo-rufous, antennae and legs rather paler.

Head narrower than the thorax, distinctly but not rery closely punctate, its sides obtusely elevated between the antennae and eyes. Thorax hardly any longer than broad, slightly wider near the front than behind, lateral margins distinct and forming the rectangular posterior angles; apex subtruncate in the middle, with a short sinuosity behind each ere, its subacute angles, however, do not extend further forwards than the middle; discal impression broad but not deep, longitudinally divided by a smooth line, as coarsely but not as elosely punctured as the sides. Elytra twice the length of the thorax, a little wider near the middle than at the base, a good deal narrowed towards the extremity; base arcuate-emarginate, the subacute humeral angles are but little wider than the thorax and seareely project beyond its base; their striae are moderately deep and regular, the pair at each side of the suture are deeper at the base, their punctures are distinctly separated and rather elongate but not coarse; interstices rather broader and less convex than the outer ones, with fine serial punctures; the suture is bent outwards and subcarinate at the apices.

'This most nearly approaches $P$. arcuatus, 3408 , but is smaller, more slender, and more rufescent. The thoracic impression is shallow, and the shoulders are not thickened and prominent.

Eres moderately large; terminal antennal joint rather narrower than the 10th and distinetly marked off.

Length, $2 \% \mathrm{~mm}$; breadth, $\frac{2}{3} \mathrm{~mm}$. 1912.

McClennan's Bush, near Methren. One from Mr. Hall, 23rd April, 


\section{Group I Lathrididar.}

3550. Lathridius rufifrons sp. nov. Lathridius Herbst, Man. N.Z. Coleopt., p. 232

Subovate, moderately clongate, only slightly convex, glabrous, nitid; head and thorax dark rufous; elytra, legs, and antennae more or less pale chestnut-red.

Head nearly as broad as the thorax, with a well-marked groove along the middle, moderately coarsely, closely, and rugosely punctured and rather dull. Eyes large and prominent. Thorax subquadrate, of about equal length and breadth, slightly wider in front than elsewhere, lateral margins a little explanate, indistinctly serrate, and feebly sinuate near the middle, posterior angles rectangular, the anterior obtusely rounded; the surface coarsely, closely, and somewhat rugosely punctate, with a broad groove, which is expanded behind, along the middle, the transverse impression near the base becomos foveiform at each side, before the middle but near each side there is a small rounded forea, its base is truncate. Scutellurn broad, small, concave in the middle. Elytra obovate, with distinct rims, arcuate-emarginate at the base, of the same width as the thorax there, fully thrice its length, widest before the middle, and a good deal narrowed posteriorly; they are slightly depressed behind the base, and very distinctly and regularly punctatestriate throughout.

Antennae nearly as long as the head and thorax, their basal joint nearly thrice the thickness of the oviform 2nd, 3rd evidently shorter than 4 th, which as well as joints $5-\tau$ are slender and elongate, 8th slightly shorter and broader; chb broad, its interuediate joint strongly transverse and broader than the basal, the terminal nearly twice as long.

At once recognizable from other species by its unusual coloration, obovate elytra, thoracic sculpture, and rather broad antennal club.

Lengtli, $1 \frac{1}{2} \mathrm{~mm}$. ; breadth, $\frac{2}{3} \mathrm{~mm}$.

Broken River, Canterbury. One from Mr. J. H. Lewis.

\section{Lathridius dualis $\mathrm{sp}$ nov.}

Elongate, subdepressed, shining, nude, variegate; head and thorax more or less fusco-rufous; elytra pale brown or fusco-testaceous, with a large, dark fuscous, depressed spot on each between the base and the middle, another of irregular shape across the top of the posterior declivitr, and a third at the side behind the shoulder; legs and antennae obscurely fulvescent.

Head rather coarsely punctate and rugose, with a distinct groove along the middle. Eyes moderate, prominent. Thorax a third longer than broad, deeply constricted near the base, which is paler and nearly smooth; along the middle of the coarsely punctate, rugose frontal portion there is a broad impression with slightly raised borders, the lateral margins are somewhat flattened. Scutellum transverse. Elytra obviously broader than the thorax at the base, more than double its length, rather broader near the hind thighs than at the hase, distinctly and closely punctate-striate, with smooth, slightly raised interstices, near each side there is a depression in line with the hind thigh.

Antennae shorter than the hear and thorax, basal joint twice as thick as the next, joints 3-8 distinctly longer than broad, the terminal longer than the 9 th and 10 th. 
Underside nitid, piceo-fuscous, neurly smooth and nude, basal rentral segment with a large, minutely seulptured depression extending from each side nearly to the middle.

With the exception of the Tasmanian J. nigromaculatus, no species I am acquanted with has similarly marked drtrat these, howerer, are

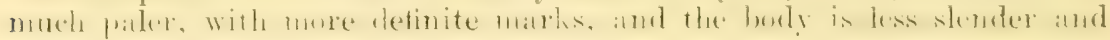
glosst:

liength, $1 \frac{2}{3} \mathrm{~mm}$; ; brealth, $\mathrm{m}$.

Ardagh, Meclemnan's Bush, and Methren. Screral specimens sent to me by Mr. 'T. Hall.

3552. Corticaria unicolor sp. nov. Certicurit Marsham, Man. N.Z. Coleopt., p. 234 .

Minute, nitid, rufo-eastaneous, antemnae and tarsi fulvescent, with series of inconspicuous, slender greyish hairs on the elytra.

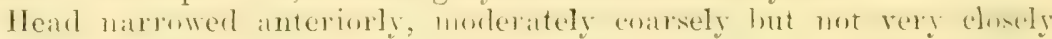
punctured. Eyes moderately convex, distinctly faceted, large, occupying fully half if ateh sille of" the heath. Thom ariform, slightly loner than broad, widest behind the middle, base finely margined, with a rotundate median forea near the base, its sculpture like that of the head. Elytra elongate, oviform, slightly arcuate-emarginate at the base. only slightly broader there than the thorax; ther are evidently subseriate-punctate, more finely hehind. with a sutural hepession it the base, and a less obvious one near each subearinate shoulder.

Antennae not as long as the head and thorax, their 2 nd joint oviform, nearly as long but only half as thick as the basal, joints :3-5 rather longei than broad, $6-S$ small and moniliform; chub looscly ationlated, its terminal joint not quite as long as the ?th and 10th combinerl.

Underside rufo-castaneous, relatively coarsely and closely punctate, the abdominal segments 2-5 more finely, these together hardly longer than the first. Thinly clothed with fine yellowish pubescence.

The first part of the description will enable this species to be separated from those already known.

length, $1 \frac{1}{33} \mathrm{~mm}$; breadth, $\frac{1}{2} \mathrm{~mm}$.

City Council's reserve, Methven. A solitary example was taken off a tree covered with moss and lichen, at an eleration of $2,300 \mathrm{ft}$, br .1r. 'T'. Hall, in Julr, 1912 .

\section{5?. Corticaria vagepunctata sp. nov.}

Subovate, minute, slightly convex, nitid; rufo-fuscous, head paler. the tibiae and basal joints of tarsi fusco-testaceons, the teminal joint of these latter and the antennal club infuscate; sparingly clothed with distinct, somewhat arched, grey hairs.

Head, including the eres, nearly as lroad as the thorax, distanty and finely punctured. Thorax rather broader than long, more narrowed in front than behind, its base distinetly margined; with a small shallow basal fovea, and a slight transverse impression near each side, its punctation distant and moderately fine. Sentellum broad. Elytra a little broader than the thorax at the base, neary thrice its length, with moderately rounded sides, their punctation distinct, rather distant, but not quite seriate.

Antennae searcely the length of the head and thorax, their 2 nd joint about as long as the 1 st but much thinner, joints ?-S slender, gradually 
decreasing in length; club laxly articulated, its teminal joint longer than either of the preceding ones.

Underside fusco-rufous, the head and last four abdominal segments more rufescent or paler, with depressed grevish hairs; metasternum and basal ventral segment distantly punctate.

Somewhat similar to $C$. erythrocephala, 1605, much nore distantly and finely punctured, with less prominent eres, much narrower hindbody, and difierent coloration.

Length, $1 \frac{1}{2} \mathrm{~mm}$; ; breadth, $\frac{1}{2} \mathrm{~nm}$.

Ardagh, near Methren. A single individual found near the residence of W. J. Dickie, Esq., M.P., on the 25th March, 1912, by Mr. T. Hall.

Obs.-From the same source I have three specimens of $C$. melasoma, 3061, originally found on Nount Maungatua, in southern Otago.

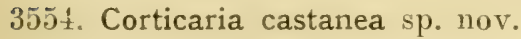

Subovate, slightly shining; pale castaneous, legs and antennae testaceous, chub infuseite; the elrtra with nunerous distinct, sublecunbent. yellowish-grey setae.

Head broader than the front of the thorax, distinctly but not closely punctured, with large, prominent eres. Thorax broader than long, rounded and widest behind the middle, broadly impressed towards the sides in front of the base, somewhat flattened but not foreate on the middle near the front, moderately marsely but not closely punctate. Scutellum broad. Elytra oblong-oval, slightly broader than the thorax at the base, thrice its length, in some cases with feebly raised shoulders and indefinite sutural striae, their punctation moderately coarse and regular yet not quite seriate.

Antennae as long as the head and thorax, their 2nd joint nearly as long but not as stont as the list, joints :3-7 slender, longer than broar?; Sth slortest: basal joint of the club rery slightly longer than the next, the terminal oviform, longer than the intermediate.

Underside somewhat nitid, fuscous, the head reddish, finely and distantly punctate, with slender grerish pubescence.

Distinguishable from $r$. mher, $41 \overline{5}$, and its allies by the conculofons body and pale legs, ire.

Length, $1 \frac{1}{2} \mathrm{~mm}$. ; breadth, quite $\frac{1}{2} \mathrm{~mm}$.

Methren and Ambah. Sis specimms from Mr. '1. Mall during January and February, 1912.

\section{Corticaria robusta sp. nov.}

Elongate, slightly convex and nitid; lufo-fuscous, the thorax, elytral rleclirity, and shoulders usually more rufescent, tarsi fusco-testaceous. antennae reddish, the elub darker; erenly but not thickly covered with distinet, moderately elongate, subdecumbent, rellowish-grer setae.

Head rather narower than the thorax, moderately coarsely but not dosely punetured. Eyes large, with conse facets. Thorax nearly a third broader than long. its sides rounded and distinctly denticulated, the basal margin contracted and depressed; its punctation rather deeper than that of the head, the basal forea large but not deep. Scutellum broad. Elytra oblong-oval, rather broader than the thorax at the base. more than thrice its length, without iemession or humeral plicae; ther are moderately coarsely but not seriately punctured and alpent feebly 
rugose, the sculpture becomes less distinct behind, and each, from the middle backwards, has a shallow sutural stria.

Antennae as long as the heud and thorax, joints 3-8 slender, gradually shortened, all, however, are elongate; 9 th and 10th obconical, their length about double the breadth, the terminal elongate-oval.

Underside nigro-fuscous; the breast moderately coarsely, the abdomen inore finely punctured; with numerous elongate, depressed grey setae; metasternum not longer than the basal ventral segment, with a median urroove behind the middle.

Male.-Legs elongate, basal joint of anterior tarsi oblong and somewhat dilated. Elytral apices narrower than those of the female, in which sex they are broad and obtusely rounded.

Manifestly larger than any other indigenous species, most nearly resembling $C$. longula, 3060, but with the sides of the thorax evidently denticulated from front to base.

Length, $3 \mathrm{~nm}$. ; breadth, fully $1 \mathrm{~mm}$.

Nethven; January, 1912. Half a dozen individuals sent by Mr. 'T. Hall, in company with 3060 .

\section{Corticaria latulipennis sp. nov.}

Convex, rather broad, nitid, very thinly clothed with rather short, slender, greyish, decumbent setae; elytra piceous, head and thorax somewhat rufescent, antennae and legs castaneous, tarsi testaceous but with infuscate terminal joints.

Head nearly as broad as the thorax, moderately coarsely punctured, less closely on the middle. Eyes prominent, occupying more than half of the sides of the head. Antennae equalling the head and thorax in length, with slender outstanding fuscous setae, 2nd joint oviform, nearly as long as the basal but only half as thick, joints, $3-8$ slender and elongate, the $3 \mathrm{rd}$ and 4 th not quite as long as the 5th or 6 th; club laxly articulated, with elongate-oval joints, the last thicker than the others. Thorax broader than long, widest and well rounded at the middle, without perceptible lateral denticles; it is coarsely and moderately closely punctured, lightly transversely impressed before the base, and with a punctate, distinct groove just in front of the basal margin, but without any discal foveae. Scutellum broad, rounded behind, sometimes bipunctate. Elytra rather broader than the thorax at the base, still broader near the middle, their sides moderately rounded, lateral margins hardly discernible from above; they are broadly impressed near the suture before the middle, the shoulders are a little rounded, finely margined, and distinctly elevated, the sutural striae are visible behind, their coarse punctation is irregular near the base but seriate beyond; the length is more than double that of the thorax.

Underside nigrescent, coxae castaneous; the breast and basal ventral segment are moderately coarsely punctured, the other segments indistinctly; pubescence scanty, but concentrated, so as to form a small patch on the terminal segment.

Somewhat similar to $C$. discoidea, 420 , in form, but there the likeness ends. In one example the hind-body is oviform and not so broad as the others; this, no doubt, is the male.

Length, $1 \frac{1}{2} \mathrm{~mm}$. ; breadth, $\frac{1}{2} \mathrm{~mm}$.

Epsom, near the base of Mount Eden. I searched the locality on three occasions, in October, November, and December, 1911, but could not find more than a single specimen each time. 
3557. Corticaria clavatula sp. nov.

Subovate, only moderately broad, nitid, with distinct yellowish pubescence; piceo-fuscous, head faintly rufescent, legs and antennae testaceous, club darker.

Head rather broader than front of thorax, moderately but not closely punctured. Eyes prominent, widely distant above, rather smaller than usual. Thorax broader than long, widest just behind the middle, rather more coarsely, but not closely, punctured than the head, transversely impressed near the base, without foveae, but with a transverse stria in front of the basal margin. Seutellum large, broad, rounded behind. Elytra more than twice the length of the thorax, somewhat broader than it is at the base, widest near the middle, lateral margins invisible from above; with subseriate, oblong, and rather distant punctures, shoulders obtusely elevated, the sutural striae moderately distinct throughout, in one example there is a longitudinal impression alongside the suture near the base.

Antennae scarcely as long as the head and thorax, with very slender setae; 2nd joint oviform, rather shorter and much thinner than the 1st; joints 3-7 slender, gradually decreasing in length; 8th small and moniliform; club rather short and broad, its basal joints obconical, 1st slightly longer than broad, the next shorter and broader, 3rd largest, ovate.

The moderately small rotundate eyes, broad sutural striae, the con colorus body and flavescent legs, together with the antennal structure are distirictive.

Length, $1 \frac{1}{3} \mathrm{~mm}$; breadth, $\frac{1}{2} \mathrm{~mm}$.

Epsom, Auckland. Two examples, November and December, 1911, amongst decaying leaves between rough scoria boulders.

\section{Lithostygnus serripennis sp. nov. Lithostygmus Broun. IIn. N.Z.} Coleopt., p. 950.

Slender, elongate, slightly convex, glabruus, shining; chestnut-red, antennae and tarsi fulvescent.

Head oblong, slightly narrowed anteriorly, with a pair of ill-defined carinae, these are somewhat curved from the eres towards the middle and then prolonged obliquely forwards, so as to become convergent in front, though not smooth there is no distinct sculpture.

Thorax not as long as broad, its sides broadly flattened and finely crenate, widest before the middle, uradually narrowed backwards, with acute posterior angles; a broad depression near the front has sharply elevated, but rather irregular, apical and lateral margins, behind it is obtusely bituberculate; another depression extends right across the disc, and is bounded by the obtuse, transverse hasal ridge. Elytra oblongoval, double the length of the thorax, hardly wider than it is at the base; on each elytron there are 2 slender dorsal costae, the outer forms the dorsal rim almost from the base to the extremity, the inner is nearly straight, it extends from the base and is rery slightly curred inwardly near the apex, the suture is just as distinctly rised throughout: between each of these there are double series of large, subquadrate, punctiform impressions; the lateral margins bear many minute rlenticles and therefore-appear serrate.

Antennae short, basal joint thick and subquadrate, 2nd of nearly similar form but much smaller, joints 3-9 slender, small and moniliform. 
the 4 th and 5th slightly longer than 3rd; club biarticulate, both joints oblong, the terminal the larger.

In L. minor, 2358, the elrtral costae are considerably more elevated and the punctation deeper and coarser. 'The sides of the head in front of the eres are distinctly margined. The antennal elub is shorter and broader, and the thoracic sculpture is difierent.

Length, $1 \frac{1}{2} \mathrm{~mm}$; ; breadth, nearly $\frac{1}{2} \mathrm{~mm}$.

Broken River, Canterbury. 'Two examples found by Mr. J. II. Lewis amongst dead leaves, 24 th March, 1908.

\section{Lithostygnus cuneiceps sp. nov.}

Slender, clongate, nude, nitill; chestnut-red, antennae and tarsi inlrescent.

Head oblong, gradually narrowed in front of the eyes, broadly bisulcatc longitudinally, and with an obtuse ridge along the midalle, the carina which starts from each eye, and is slightly curved near it, is obliquely prolonged torwards. Eyes small and convex, with coarse fincets, situated on the upper part of the sides, and with an obtuse projection behind each. Thorax broader than long, widest before the middle, well rounded there, gradually narrowed behind, posterior angles rectangular, its sides broadly explanate and fincly erenulate; disc very uneven, having a subquadrate depression near the front with irregularly carinate lateral margins, these form angles at their terminations, there is another depression near the base with an obtuse ridge behind it. Elytra oblong-oval, nearly twice the length of the thorax, and in the middle as broad as the widest part of the thorax, the shoulders are ublique, and behind each there is a more or less obvious sianosity, their finely serrate lateral margins become inrisible near the extremity; the imner costae are slightly curved near the apices but less so at the base, the outer form the dorsal margins behind but only begin between the middle and hind thighs, the suture is not elevated, between it and the inner costae there are double series of coarse punctiform impressions similar to those hetween the inner and outer costae.

Antennae glibrous, 2nd joint globular, not as large as the basal, joints :3-9 small and slcneler, th and 8th slightly longer than broad, the 31 d and 9 th shorter and globular; club not abruptly dilated, both joints suboblong.

Undersicle obseme fusco-rufous. Head transversely trisulcate in front.

Rather more slender than $/$. costatus. 1713, in which the thorax is abruptly contracted behind, the elytral costae are more prominent, the antennae differ, the club is broader, and its basal joint is cup-shaped or obconical.

The insect is generally covered with grevish sappr matter. The description has been drawn up from a carefully cleaned specimen. The sculptrure of the head is best seen when examined sideways.

Length, $1 \frac{1}{2} \mathrm{~mm}$; ; breadth, $\frac{1}{2} \mathrm{~mm}$.

Epsom. Nearly a dozen specimens were secured from dead regetable matter amongst native trees and shrubs at the base of Mount Erlen during the last three months of 1911 .

Ohs.-In the genus Metophthalmus, described by Wollaston ("Insecta Marlerensia," p. 192), the antennae are only 10 .rticulate, the head is laterally crenulate, and the eyes are so placed that the insect is incapable of seeing what may be beneath it. In Lithostygnus the eves 
are nearly as prominent below as they are above, the antennae are 11-jointed, and the sides of the head are simple.

\section{Group DeRMESTID.A.}

3560). Trogoderma puncticolle sp. nov. Trogodermu Latreille, Man. N.Z. Coleopt., p. 240.

Oblong, slightly transversely convex, subopaque; fusco-piceous, with a fell indetinite, obsculely rufescent spots, legs fusco-rufous; irregularly clothed with distinct greyish-yellow and finer cinereous pubescence.

Head rather' small, closely punctate. Eyes moderately large. 'Thorax much broader than long, curvedly narrowed towards the front; the base widely bisinuate and, at the middle, obtusely angulate and partly covering the scutellum, posterior angles acute and slightly directed backwards; its surface closely and distinctly punctured. Elytra of the same width as the base of the thorax, slightly narrowed near the extremity, with broadly rounded apices; they are feebly transversely impressed before the middle, rather finely and indefinitely punctured, more distantly and finely behind. Legs moderately slender, finely setose, with straight tibiae:

Antennae short, basal two joints short and stout, joints 3-6 slender and more or less testaceous, the 6 th shortest; 7-10 infuscate, not at all producerl inwardly, evidently broader than the preceding ones, ath and 10th transversely quadrate, 11 th conical, hardly twice the length of the penultimate. hairs.

Underside piceo-fuscous, sparingly clothed with slender yellowish

T. 4-fasciatum, 1692, from Mokohinau Island, is the nearest species, but in it the thorax is distantly and finely punctate, and its vestiture is entirely different.

Length, $3 \frac{1}{2} \mathrm{~mm}$; breadth, $1 \frac{2}{3} \mathrm{~mm}$.

Methren and Rakaia Gorge. Apparently rare. Found by Mr. T. Ha'l at an elevation of about 1,100 ft.

\section{Group BrRRHIDAE.}

3561. Synorthus substriatus sp. noi. Synorthus Broun, Bulletin No. 2, N.Z. Inst., p. 9.

Convex, subrotundate, or broadly oval, moderately shining; fuscocastanems, legs light fusco-rufons, tarsi and antennate flavescent; pubescence Jellowish-grey, slender and elongate and mostly decumbent on the elytra, rather coarser and irregularly disposed on the head and thorax.

Head about as broad as the thoracic apex, moderately finely, closely, and somewhat irregularly punctured, the forehead very broully rounded but not perceptibly margined. Thorax fully twice as broad as long, its sides finely matrgined and gradually narrowed towards the deflexed and subacute anterior angles; the apex widely, ret only rerr slightly, sinuate near each side, finely margined there, the base truncate, with acute angles; its surface moderately finely but not closely punctate. Sentellum absent. Elytra of the same width as the thorax at the base, more than double its length, curvedly narrowed and deflexed posteriorly; their punctation fine and distant for the most part, the basal portion with shallow, coarser, and slightly rugose sculpture, there are no sutural striae, but on each elytron there are 4 or 5 oblique, obsolete groores on the basal half. 
Tibiac finely sctose, the middle and hind pairs arched, and tapering towards the extremity, anterior with a short external groove near the apex. Membranous appendage of the 3rd tarsal joint well developed; claws dentate at the base.

Antennae shorter than the head and thorax, with very slender pubescence; basal joint reddish, punctate, oblong, rather longer and broader than the next, 3rd slender and almost as long as the following three, 7 th slightly broader than 6 th, joints $8-10$ transverse, the terminal about as long as the preceding two combined.

Underside nitid, rufo-castaneous, rather thickly clothed with depressed, elongate, slender yellowish hairs; closely and distinctly punctured, but with a smooth spot between the middle and each side of the 2 nd ventral segment, the frontal portion of the metasternum more coarsely but distantly punctured.

This must be placed in Section 3, next to 1608, from which it differs by the ateneous head, much finer and less upright clothing, more elongate antennae, and peculiar elytral sculpture.

Length, $3 \frac{1}{2} \mathrm{~mm}$. ; breadth, $2 \frac{1}{3} \mathrm{~mm}$.

Mount Hutt, near Methren. One found by Mr. 'T. Hall on the 28th" October, 1912, at a height of about $3,000 \mathrm{ft}$.

\section{Synorthus versipilus sp. nov.}

Convex, subrotundate, moderately nitid; fusco-niger, tibiae and antennae rufous, tarsi and palpi testaceous; pubeseence erect, elongate, and slender, principally pale greyish-yellow, but with many upright fuscous setae along the middle.

Head as broad as front of thorax, moderately finely and irregularly but not closely punctate; the forehead broadly rounded but not perceptibly margined. Thorax quite twice as broad as long, its sides finely margined and gradually narrowed anteriorly; apex widely sinuate near each side, its angles deflexed and acute, posterior angles sharply rectangular; the punctation like that of the head. Elytra of the same width as the thorax at the base, fully twice its length, curvedly narrowed and deflexed posteriorly, rather finely and distantly punctured.

Tibiae with slender pallid setae, the middle pair more distinctly arched externally than the others, all tapering towards the extremity, the membranous tirsil appendages well dereloped; cliws apparently simple.

Antennae with fine greyish setae, not as long as the head and thorax; 2nd joint evidently smaller than the basal; 3rd slender, nearly as long as the following three, which are about equal; 7th slightly larger than fith but distinctly smaller than the 8 th; 9 th and 10 th still broader, both transverse; terminal conical, not quite the length of the preceding two together.

Underside brownish-black. nitid, with decumbent, elongate, yellowish pubescence; abdomen closely and distinctly punctate, middle of metasternum with some coarser punctures.

Smaller than S. substriatus; the coloration, vestiture, and elytral sculpture different.

Length, $2 \frac{3}{4} \mathrm{~mm}$; breadth, $1 \frac{3}{4} \mathrm{~mm}$.

McClennan's Bush and Rose Hill, near Methren. Two examples forwarded by Mr. T. Hall during the present year. From the same source I have a variety of $S$. mandibularis, 3157. 
3563. Pedilophorus aemulator sp. nov. Pedilophorus Steffahny = Morychis, Man. N.Z. Coleopt., p. 244.

Convex, oval, glossy; aeneous; head, thorax, and base of elytra more or less rufescent; the legs, mandibles, and basal joint of antennte rufous, remaining joints fusco-fulvous, tarsi testaceous.

Head distinctly punctured, distantly along the middle, clusely near the sides, with many slender grey setae; forehead curved but not margined. Thorax fully twice as broad as long, base bisinuate, with acute angles; the sides straight but narrowed anteriorly, finely margined; apex sinuate near the sides, with acute, deflexed angles; its punctation distinct, very irregular, and rather distant, the median longitudinal space alnost smooth; it bears a few short, slender, greyish setae. Scutellum smooth, triangular. Elytra almost thrice the length of the thorax, of the same width as it is at the base; their sculpture like that of the thorax, irregular and distant, becoming nearly obsolete behind, the intervals minutely reticulate; some minute setae are discernible.

Tibiae finely setose, moderately arched externally, the posterior near the base only; the anterior broadly grooved along the outer part of their front face; tarsal appendages well developed; claws thickened at the base.

Antennae of about the same length as the head and thorax, finely pubescent; 2nd joint not quite as long as the basal, and more slender; joints 3-5 elongate, successively decreasing; 6-10 gradually expanded, the terminal conical, hardly as long as the preceding two combined.

Underside nitid, fusco-niger, with numerous fine greyish-yellow setae; abdomen finely and closely punctured, the middle of netasternum more coarsely and distantly. Trochanteral portion of coxal laminae nearly twice as long, from front to rear, as the lateral.

This most nearly resembles $P$. probus, 2793, which, however, has blackish legs; it is without setae on the head and thorax; the front tibiae, below the middle, have slightly expanded lateral margins; it has 2 smooth spots on the head, the thorax is less transverse and more closely and evenly punctured, and the tarsi are more slender and elongate.

Length, $4 \frac{1}{2} \mathrm{~mm}$; ; breadth, $2 \frac{1}{2} \mathrm{~mm}$.

Curiosity Gully, near Methven. Three specimens were picked out of leaf-mould by Mr. T. Hall on the 9th August, 1912. One of them is without the labrum, so that the mandibles are wholly exposed.

\section{Group Dascrllidae.}

3564. Mesocyphon bifoveatus sp. nov. Mesocyphon Sharp, Man. N.Z. Coleopt., p. 316.

Elongate, subdepressed, slightly nitid; fuscous, legs and antennae more or less rufo-testaceous, terminal joints of these latter slightly darker, labrum and mandibles rufescent; covered with decumbent, distinct, yellowish-grey, and more slender inconspicuous ashy setae.

Head almost as broad as the thorax, abruptly narrowed, and prolonged in front, unimpressed, closely and finely granulate. Labrum and mandibles prominent. Thorax small, a third broader than long, its sides slightly rounded, not at all flattened. finely margined; with subrectangular angles, the anterior somewhat deflexed; apex truncate, base slightly rounded; the surface rather finely punctate-granulose on some parts, simply granulate on others. Scutellum large, minutely 
granulate. Elytra four times the length of the thorax, not double its width, with rounded, slightly rufescent shoulders; their seulpture rather fine and indistinct, appearing punctate on some parts and granulate on others; near the suture, before the middle, there is a pair of subrotundate but not very deep foveae; the lighter pubescence, though unevenly distributed, does not form spots.

Antennae longer than the head and thorax, basal joint thick, the next almost oblong-oval, shorter but stouter than the elongate $3 \mathrm{rd}$, the 4 th still longer and stouter, joints 5-10 differ but little, each rather longer han broad, the terminal elongate-oval.

Underside nitid, fuscous, finely punetate and pubescent.

When placed alongside 11 . tristis, 3073, this species is seen to be smaller, more slender, and less oviform, its surface is more nitid; the thorax is smaller, not in the least explanate or flattened at the sides, which are more finely margined and rounded; the elytral foveae form another distinctive character.

Length, $4 \frac{1}{4} \mathrm{~mm}$. ; breadth, quite $1 \frac{1}{2} \mathrm{~mm}$.

Hump Ridge, Southland. Two individuals found by Mr. A. Philpott in February, 1912.

\section{Mesocyphon lateralis sp. nov.}

Ellongate, subovate, slightly nitid; fuscous, legs and antennae crstaneous, mandibles and labrum rufescent; covered with slender, depressed, dark-ashy, and rather thicker, less decumbent, yellowish-grey setae, these latter irregularly distributed and patchy.

Head moderately closely and finely granulate, the vertex with a more or less distinct depression. Thorax a third broader than long, widely bisinuate at the base, its sides almost straight, distinctly flattened but not broadly so, and finely margined, with obtusely rectingular angles; its surface rather closely granulate, not at all coilrsely, ret more distinctly than the head, and with an abbreviated linear impression along the middle. Seutellum large, not distinctly granulate. Elytra four times the length of the thorax, rather broader than it is at the base. gradually widened to beyond the hind thighs, their shoulders rounded; along the suture, near the base, there is a depression which is obliquely expanded before the middle; their sculpture is indefinite, on some parts appearing closely but finely rugose-punctate, but nowhere discernibly granular.

Antennae elongate, with dark pubescence; variable in colour, the base of the intermediate joints sometimes obscurely testaceous; $2 \mathrm{nd}$ oblong but evidently shorter than the more slender $3 \mathrm{r} d$, the next the lcngest, joints 7-11 elongate and rather narrower than the preceding ones.

Closely related to the North Island 11 . tristis, 3073, but less opaque, with the sides of the thorax flattened, and the elytra without any perceptible granulation.

Length, $5 \mathrm{mmn}$; breadth, $2 \mathrm{~mm}$.

Mount Hutt, near Methven. Found by Mr. 'T'. Hall on the 30th March, 1912, at a height of $3,500 \mathrm{ft}$. Apparently rare.

3566. Mesocyphon halli sp. nov.

Oblong-oval, subdepressed, nitid, variegate; rufo-eastaneous, head and thorax slightly infuscate, the posterior half of the elytra fuscons but with the suture there, and the apical margin obscurely fulvescent, 
labrum and riandibles rufescent; the pubescence distinct, depressed, of a pale-brassy lue for the most part, irregularly distributerl, and forming pale spots on the hinder part of the wing-cases.

Head nearly as broad as the thorax, narrowed and prolonged anteriorly, genac slightly rounded, rather finely and moderately closely granulate. Exes large, moderately prominent. Thorax quite a third broader than Iong, feebly bisinuate in front, more strongly at the base; anterior angles obtuse and slightly deflexed, the posterior alnost rectangular; its sides margined, nearly straight, and narrowly Hattened, its seulpture like that of the head. Elytra thrice the length of the thorax, a little broader than it is at the base, with rounded shoulders, gently expanled behind; their punctation shallow and indistinct, in some examples there are a few minute granules in front; the suture is depresserl near the base, and just before the middle this depression is furcate or curved outwardly, the enclosed sutural space is broadly oviform, but rather less elevated than the area near each shoulder.

Antennae moderately elongate, their th joint larger than the elongate $3 r d$. Tibiae with distinet spurs.

Underside fuscous, slight?y nitid, with slender rellowish pubescenee, its sculpture moderately close but indefinite, apparently granular.

Less parallel, more glossy and brightly coloured, and more evidently variegated than $1 /$. latemlis, and with somewhat difterent seulpture.

Length, $5 \mathrm{~mm}$; breadth, $2 \mathrm{~mm}$.

Iount Hutt, Six specimens found during Februar, 1912, by Mr. T. Hall, whose name it bears.

\section{Group T'ei Ephoridae.}

3567. Asilis flavipennis sp. nov. Asilis Broun, Man. N.Z. Coleopt., p. 1147.

subdepressed, clongate, parallel, nitid; head and thorax black, elytra testaceous, legs fuscous, antennae dull smoky black; pubescence on thorax ashy, depresserl, and extremely fine, that on the elytra coarser, suberect, and flavescent.

Head smooth. Thorax nearly twice as broad as long, apex subtruneate, with slightly raised margins, its angles obsolete; the sides moderately rounded, with strongly reftexed margins, which are broat in the middle but linear elsewhere; base finely ret distinctly margined, subtruncate and overlapping the scutellum in the middle but widely sinuate or oblique towards the sides, its angles subrectangular but rather indefinite; disc slightly uneven, its punctation rather fine but shallow and indistinct, with a basal impression at the middle, and another between it and each side. Scutellum triangular, very small. Elytra four times the length of the thorax, of the same width as it is at the base, their sides straight and finely marqined: they are noderately closely, slightly rogovely, and more coarsely punctured than the thorax.

Antennate filiom hut stout, reaching hackwards to the posterior femora, densely covered with short, ashy pubescence; basal joint subpyriform but not rery thick, 2nd nearly twice as long as broad yet rather shorter than the next, joints 4-11 elongate.

Tibiae straight, bearing short, suberect, einereous setae; tarsi moderately elongate, their jenultimate joints deeply clett above, membranous underneath, the 5th of the posterior hardly is long as the basal; claws distinctly appendiculate for half their length. 
Underside black. Basal ventral segment corered by the femora, segments 2-5 about equal, the 6th deeply semicircularly emarginate, 7 th subrotundate.

This differs from its nearest ally, A. pilicomis, 2821, by its broader lateral thoracic margins, less definite posterior angles, flavescent eltyra and pubescence, and less glossy surface.

o. length, $4 \frac{3}{3} \mathrm{~mm}$. ; breadth, $1 \frac{2}{3} \mathrm{~mm}$.

Pudding Hill, near Methven. A single specimen found by Mr. ' 1 '. Hall on the 1st February, 1912. He also found a few examples of A. pilicornis at Methven.

\section{Group Melitidae.}

3) (tik. Dasytes fuscitarsis sp. nol. Dusyles Pioliull. Minn. N.Z. Coleopt., p. 328 .

Subdepressed, elongate, moderately shining; nigrescent, elytra tinged with blue, legs and antennae fuscous; thinly clothed with inconspicuous, rather short and slender, suberect, dark-ashy pubescence.

Head rather broader, eyes included, than the front of the thorax; bi-impressed in front, distinctly but not elosely punctured, with minute, dense sculpture near the sides. Thorax slightly longer than broad, widest at the middle, a good deal narrowed in iront, nearly straight behind; lise slightly convex, its punctation distinct and, except on the midille, morlerately elose, the intervals minutely sculptured. Scutellum moderately large, rounded behind. Elytra thrice the length of the thorax, rather broader than it is at the base, slightly wider behind; they are closely punctured, more coarsely than the thorax, and in some lights appear slightly rugose, humeral impressions shallow.

Legs elongate; posterior tarsi as long as the tibiae.

Antennate hardly as long as the head and thorax, shorter in the female; 2 nd joint nearly as long as the basal, joints $3-5$ a little longer than the following ones.

In $D$. laticeps, 600, the thorax is not perceptibly contracted anteriorly, its punctation is coarser, and the pubescence is rellowish. D. constrictus, 1392, as well as 1393, have distinct yellowish setae. These are the nearest allies.

o. Length, $3 \frac{1}{2} \mathrm{~mm}$; ; breadth, $1 \frac{1}{4} \mathrm{~mm}$.

Rakaia Gorge, near Methven. T'wo males and a female were sent to me by Mr. Hall during Oetober and Norember, 1912.

3569. Arthracanthus fulvipes sp. nov. Arthracanthus Broun, Man. N.Z. Coleopt., p. 781.

Elongate, subdepressed, slightly nitid; elytra with numerous distinct, suberect, rather short, nearly white setae, those on the head and thorax more slender and disposed irregularly; head and thorax of a darkbronze colour, elytra less nigrescent, the suture faintly, the apices more distinctly fulvescent, legs and basal four joints of the antennae fulvous, the remaining joints and the palpi fuscous.

Head, including the large eves, as broad as the thorax, broadly biimpressed in front, rery minutely and densely sculptured, rather finely and distantly punctured on the middle. Thorax slightly broader than long, or of equal length and breadth, somewhat rounded and widest at the middle, moderately constricted near the front, with obtuse posterior angles; its sculpture like that of the head but with slightly more distinct punctures, it is transversely impressed at the base and obliquely 
so at each side. Scutellum very short. Elytra thrice the length of the thorax, evidently broader than it is at the base, very gradually and slightly expanded posteriorly, broadly rounded at the extremity; their punctation very distinct and rather close, intrahumeral impressions well marked.

Legs elongate and slender; posterior tarsi as long as the tibiae; basal joint of the anterior evidently shorter than the next, with a distinct hook-like process at its inner extremity.

Antennae longer than the head and thorax, 2nd joint stout but much shorter than the basal, 3rd and 4th about equally elongate, joints 5-10 slightly longer and thicker, a little dilated towards the extremity but not serrate, the terminal shorter.

Length, $2 \frac{2}{3} \mathrm{~mm}$. ; breadth, $\frac{3}{4} \mathrm{~nm}$.

Rakaia Gorge, near Methven. 'Two examples, found by Mr. 'T. Hall on the 19th October and 1st November, 1912.

\section{Arthracanthus fossicollis sp. nov.}

Elongate, shining; nigrescent, bronzed, legs and basal four joints of the antennae fulvescent.

Differs from $A$. fulvipes as follows:-

Head and thorax shining, without minutely sculptured intervals between the punctures. Thorax slightly longer than broad, its base unimpressed in the middle, but with a large oblique fossa at each side of it. Scutellum larger, Elytra concolorous, rather more coarsely punctured, without impressions near the shoulders. The spiniform process of the basal tarsal joint directed downwards, and therefore less perceptible from above.

Length, 3 $\mathrm{mm}$. ; breadth, $1 \mathrm{~mm}$. Hall.

Rakaia; 27th September, 1912. Unique. Also captured by Mr. T.

\section{Arthracanthus atriceps sp. nov.}

Elongate, subdepressed, glossy; head and thorax black, elytra somewhat cyaneous; antennae and legs piceous, the tarsi and extremity of tibiae reddish-chestnut; sparingly clothed with inconspicuous, slender, suberect, dark-ashy pubescence.

Head, including the large prominent eyes, rather broader than the thorax, finely and distantly punctate, the broad frontal impressions convergent behind and more or less obviously prolonged as a broad groove along the occiput. Thorax quite as long as broad, a little constricted near the front, widest at or just behind the middle; rather more distinctly punctured than the head, without definite posterior angles; near the base there is a shallow median impression and another at each side; these, however, are obsolete. Scutellum very short. Elytra fully thrice the length of the thorax, broader than it is at the base, almost or quite straight-sided, with broadly, singly rounded apices; they are closely punctured, much more coarsely than the thorax, and there is a distinct impression near each shoulder.

Legs elongate and slender; tarsi as long as the tibiae, basal joint of the anterior barely half the length of the 2nd, with a distinct curved spiniform process at the inner extremity.

Antennae longer than the head and thorax, their basal four joints castaneous, in structure like those of $A$. fulvipes. 
The slender inconspicuous pubeseence and uniformly blackish surface are distinctive leatures.

Length, $2 \%$ mm.; breadth, 3 mm.

Rakaia Gorge. 'Two examples from Mr. 'T'. Hall on the ?th October, 1912

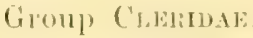

3572. Phymatophaea o'connori sp. nov. Phymatophaen Pascoe, Man. N.Z. Coleopt., p. 334.

Shining, moderately elongate, without inequalities of surface; thinly clothed with ereet, slender, elongate pubescence; dark-bluish or bronzed green, the tibiae, tarsi, and antennae cyaneous, club piceous.

Head distinctly punctate, more closely between the eyes than behind. Thorax of equal length and breadth, moderately rounded and widest behind the middle, much, but nure gradually, narrowed anteriorly than it is behind; distinetly punctured near the sides, more distantly and rather finely along the middle, with an angular impression in front of the subcordate scutellum and a transverse basal one near each side. Elytra thrice the length of the thorax, evidently broader than it is at the base, very gently expanded posteriorly; each with a more or less well-marked intrahumeral impression, their surface with dense coriaceous sculpture, and therefore rather less glossy than the thorax.

Antennae finely pubescent, basal joint stout, 2 nd oblong, joints 3-T elongate, Sth much shorter; club large, opaque, finely and densely pubescent, its basal joint rather longer than the next, the terminal oriform. Claws not dentate.

Var.-Femora chestnut-red, except at the cxtremity.

No recorded species is at all similar.

Length, $8 \frac{1}{3} \mathrm{~mm}$.; breadth, $3 \mathrm{~mm}$.

Silverstieam, near Wellington. T'wo specimens have been presented to me br IIr. A. C. O'Connol, who captured them during November, $1 ! 11$

\section{Group Prisidar.}

3573. Ptinus plagiatus sp. nov. Ptinus Limné, Man. N.Z. Coleopt, p. 337.

Convex, slightly nitid; fusco-rufous, but with a large subangular blackish spot, on each elytron, about a third of the whole length, extending from the middle of the side but not reaching the suture; legs and antennae chestnut-red; thickly covered with depressed, tawny, and longer rufo-fulvous setae, those on the thorax more erect, irregularly disposed, and coarser.

Head smalles than the thorax, prolonged in front of the prominent eyes, apparently punctate. Thorax of about equal length and breadth. widest hefore the middle, a good deal narrowed behind, aper rounded; the median chammel extends from the apex, and becomes somewhat foveiform at the base, its pronetation is irregular, for the most part hidden by the rough restiture, but in one example there is a series of punctures across the base. Sentellum oblong. Elrtra twice the length of the thorax, a third broader, shoulders curvedly narowed. sides nearly straight, apex rounded; they are distinctly and closely seriate-punctate along the centre, indistinctly elsowhere, but the dark areas seem impunctate and bear only a few slender fulvous hairs. 
Leus elongate; tibiae nearly straight, a little thickened towards the extremity, with flavescent setae; basal joint of the tarsi rather longer than the next, th smallest, jth as long as the preceding three, with slender elaws.

Antennae elongate, moderately slender, with yellow pubescence; basal joint stout, 2nd but little shorter than the next, joints $4-10$ about equal, each longer than broad and a little clilated berond the base, the terminal longer than the 10 th.

Fem. $-31 \frac{1}{3} \mathrm{~mm}$. by quite $1 \frac{1}{2} \mathrm{~mm}$. The clothing alnost entirely tawny, elytral punctures rather slender, the antennae less elongate but thicker.

o. Length, $2 \frac{1}{2} \mathrm{~mm}$.; breadth, nearly $1 \frac{1}{2} \mathrm{~mm}$.

liakaia Gorge, near Methren. One male found by Mr. 'T'. Hall on the 9th August, 1912; the female found by Mr. A. Philpott on the Hump Ridge, near Invercargill, in December, 1911.

A specimen sent to the British Museum for comparison with the extensive series of types of this cosmopolitan genus was kindly returned to me with the information that it was unknown there. It may be readily identified by the conspicuous nigrescent space on each elytron.

'The widespread l'tinus fur and the Tasmanian $l$ '. tectus have been found at Methren by Mr. Hall feeding on the common laurel shrubs.

\section{Group OraTrIDAN}

\section{Paraphylax exiguus sp. nov. Paraphylax Broun, Man. N.Z.} Coleopt., p. 354 .

Suboblong, rather broad, subopaque; covered with, on the sides of the thorax particularly, depressed greyish scale-like matter, and erect infuscate and greyish setae; fusco-piceous, antennae and tarsi fuscorufous, legs variegate, the tibiae fuscous near the middle but pale near the base and extremity.

Head nearly as long as the thorax, with very prominent coarsely granulated eyes. Thorax a third broader than long, a little wider before the middle than behind, with somewhat flattened uneven sides. the base oblique towards each side, without definite angles; disc uneren, depressed along the middle, its sculpture entirely concealed. Elytra subquadrate, nearly a third longer than broad, but little wider than the thorax, their sides slightly rounded, subvertical behind; the dorsum on a higher plane than the thorax, but depressed at the base; they are rather finely seriate-punctate near the suture, and bear some very small irregular crests.

Antennae rather longer than the head and thorix, with numerous. moderately coarse, outstanding fuscous setae, their basal joint subquadrate and fully exposed, the next almost similar, 3rd rather longer than broad, joints 46 subequal, 7 th and 8 th distinctly longer than broad ret quite stout, 9th rather longer than 10 th, the terminal subrotundate.

This is little more than half the bulk of any of the other species, its thorax is without frontal prominences, and the elytral base is much less deeply emarginate and depressed in the middle. It is most like $P$. varius, 645 .

Length, $3 \frac{1}{\mathrm{~s} m} \mathrm{~m}$; ; breadth, $2 \mathrm{~mm}$.

Curiosity Gully, near Rakaia Gorge. One found amongst leaf-mould by Mr. 'T. Hall on the 6th July, 1912. 
Group Prthidat.

357). Salpingus semilaevis sp. nov. Sulpingus Illiger, Man. X.Z. ('oleopt., p. 398 .

Elongate, rery slightly conves, ghlosis, neally grabous, having only

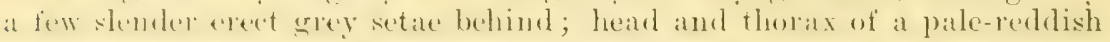
coppery-brown; elytra fuscous at the middle of the base and behind the posterior femora, their central portion and the shoulders pale testaceous; antennae rufous but becoming darker towards the extremity, the legs somewhat fulvescent.

Head as broad as the front of the thorax, narrowed anteriorly, nearly smooth on the middle, with moderately coarse punctures near the sides, distinctly margined from the ejes to the antennae. Eyes very prominent, trinsversal. 'Thorax cordate, the length and breadth subequal, aluex truncate, widest near the mont, with deep lateral fovea at the base, so that the sides seem somewhat abruptly narrowed there; it is moderately coarsely, not at all closely, and irregularly punctured, quite smooth in front, across the base there is a slender groove, there are no perceptible lateral margins. Scutellum rounded behind, twice as broad as long. Elytra with subquadrate shoulders, evidently broader than the thorax at the base and nearly thrice its length, with finely margined, nearly straight sides; they are bi-impressed alongside the suture at the base, broadly yet feebly impressed before the middle, their punctation is like that of the thorax but subseriate, and ceases abruptly in line with the hind thighs.

Legs elongate, tibiac finely bispinose at the apex.

Antennae with the basal joint much thicker than the next, joints $3-5$ longer than broad, 6th and 7 th shorter, all these feebly and scantily pubescent; the following darker ones are distinctly pubescent, laxly articulated, and broader, the 8 th is rather smaller than the 9th, the 11 th is oviform.

Of about the same size as $S$. angusticollis, 704, yet differing from it and its nearest allies in most details. The abrupt cessation of the elytral sculpture is an aid to identifieation, though the smaller $S$. perpunctatus, 702, belonging to the North Island, is somewhat similar in that respect.

Length, $2 \frac{1}{2} \mathrm{~mm}$. ; breadth, $\frac{3}{4} \mathrm{~mm}$.

Mount Hutt, and McClennan's Bush, near Methven. One from each locality; both found by Mr. T. Hall in February, 1912.

\section{Salpingus atrellus sp. nov.}

Elongate, rather narrow, shining, nigro-piceous, slightly aeneous, tibiae and antennae infuscate red.

Agrees in most details with $S$. semilaevis, but with less prominent eyes. The thorax is less rounded, narrower near the front, appears longer, and therefore less cordiform. 'The punctation everywhere is rather finer, that of the wing-cases being more regularly arranged in rows.

Length, $2 \frac{1}{2}$ mim. ; breadth, nearly $\frac{5}{3} \mathrm{~mm}$.

Mlount Hutt. A single individual from Mr. T. Hall.

\section{77. Salpingus denticollis sp. nov.}

Nitid, nearly glabrous, having only very few erect setae, variegate; thorax fusco-rufous, head darker; elytra piceo-fuscous, each with an indistinct fusco-testaceous mark extending backwards from the shoulder 
and curved inwards near the middle, and a subapical spot of similar colour; legs and antennae infuscate red.

Head moderately coarsely punctured, less so on the middle. Eyes prominent. Thorax cordate, about as long as broad, coarsely and irregulirly punctate, with a smooth linear space along the middle, each side with 3 or more dentiform projections. Scutellum broad, generally punctate. Elytra broader than thorax at the base, more than twice its length, coarsely and subseriately punctured to beyond the hind thighs.

Underside nitid, nigro-fuscous, the head and coxae rufescent. Sternum moderately coarsely but not closely punctured, the abdomen distantly and more finely and bearing some suberect, slender, yellowish setae.

This should be placed between $S$. perpunctatus, 702, and S. ornatus, 2848 , but differs from both by the presence of the lateral thoracic prominences. It is darker than either of these. The pale marks on the elytra, though similar in shape to those of 2818 , are much less distinct, whilst those of 702 are flavescent and occupy half of their surface.

Length, $2 \mathrm{~mm}$; ; breadth, quite $\frac{1}{2} \mathrm{~mm}$.

Rose Hill, and McClennan's Bush, near Methren. Nearly a dozen specimens found by Mr. T. Hall during February and March, 1912.

\section{Group Melandridde.}

3578. Neorchesia terricola sp. nov. Neorchesia Broun, N.Z. Inst., Bulletin No. 1, Part 2, p. 114.

Subopaque, fuscous; femora, tarsi, and basal joints of antennae more or less fusco-testaceous; densely covered with depressed, slender, and elongate ashy pubescence; body slightly convex, suboviform, very elongate.

Head finely, yet distinctly, and moderately closely punctured, rounded and margined behind. Thorax about a third broader than long, curvedly narrowed towards the front, which is obtusely rounded; base slightly bisinuate, its angles subrectangular; with transversely undulating minute granular sculpture, between the middle and each side there is a shallow basal fovea. Scutellum strongly transverse. Elytra four times the length of the thorax, of the same width as it is at the base, somewhat broader near the middle, gradually narrowed posteriorly, with subacute, slightly divergent apices; sutural striae very narrow, their sculpture finer than that of the thorax, less distinctly granular.

Antennae densely pubescent, rather longer than the head and thorax, implanted close to the frnnt of the eves; 3rd joint slightly longer than either of the preceding two or following ones, joints 4-7 slightly diminish, the 7 th nevertheless is longer than broad, 8-10 subquadrate, the terminal longer.

Tibiae not asperate; the posterior shortest, subtriangular, hardly the length of the pectinate apical spurs; basal tarsal joint thicker and rather longer than the following three united, with slender claws.

Underside fuscous, closely and minutely sculptured, with rellowish pubescence. Metasternum distinctly groored along the middle. Prosternal process broad in front and acuminate behind, almost touching that of the mesosternum.

Considerably smaller than $N$. divergens, 3 342, with manifestly different thoracic sculpture.

Length, $3 \frac{1}{2} \mathrm{~mm}$. ; breadth, $1 \frac{1}{3} \mathrm{~mm}$. 
Ilonnt II tht and Rakaia Gorge. Eight specimens fumd amongst decaring leaves on the ground during february and llay, 1912, hy Ir. I. Hall. Sone are paler, and in one the scutellum is invisible; this, however, is, I think, owing to the thorax being tilted up in front when mounted on cardboard.

\section{Group Ondianman.}

Metasclera gen. $110 \mathrm{~V}$.

Antemne implanted on minute prominences between, and in line with, the front of the eyes, subfilifornt basal joint prriform, 2nd small and oviform; 3rd as long as th, these and the following six about equally elongate, the terminal elongate-oval. Maxillary palpi with cultriform terminal joints. Eyes entire, oval, transverse, moderately prominent. Epistome short, not distinctly marked of from the forehead. Labrum transverse. Legs slender, posterior fenora very slightly clavate; tibiae without distinct terminal spurs, the intermediate flexuous in both sexes. Tarsi moderately slender, penultimate joints considerably prolonged underneath.

The above characters, conjointly, differentiate this genus from the Sonth American C'ycloderus, and the New Zealand T'echmessa, Techmessodes, and Phytilea.

\section{Metasclera nigricans sp. nov.}

subdepressed, elongate, slender, moderately nitid; nigrescent, antennae and legs fuscous, palpi and tarsi fusco-testaceous; sparingly clothed with distinet, short, suberect, whitish hairs, and also bearing some upright, s'ender, elongate setae.

Head short, broader than the thorax, widest in line with the eyes, much narrowed behind; moderately eoarsely and elosely punctured, less clisely on the verter. Thorax truncate at the base and apex, sometimes longer than broad, in other examples subquadrate, a little constricted hefore the middle; its punctation not close but moderately coarse; at each side in frout there is a subrotundate impression, a transverse one near the base, and an elongate one along the middle, none, however, are sharply defined. Seutcllum oblong. Elytra thrice the length of the thorax and about a third broader, subparallel, rounded behind; more crarsely punctured than the thorax, more finely behind.

Legs finely pubescent; the tibiae more distinctly near the apices, the intermediate pair bent inwarly near the extremity.

Antemue more than half the length of the body, with distinet dark pubeseence.

Underside blackish; the abdomen finely punctate, the metasternum nome contrely and with a well-marked median depression behind. Structural details similar to those of Techmessa.

length, $2 \frac{1}{2} \mathrm{~mm}$. ; breadth, $\frac{2}{3} \mathrm{~mm}$.

Ardach and MeClennan's Bush, near Methren. Nearly a dozen speeimens of this mattractive, fragile insect were found by Mr. T. Hall during the early part of 1912.

\section{Metasclera arborea sp. nov.}

Elongate, subdepressed, moderately closely and coarsely punctate throughout, nitid; nigrescent; antennae, palpi, and legs fuscous; thinly corered with inconspicuous, slender, decumbent ashy pubescence. 
Head broader than the thorax, narrowed behind; the epistome marked off by a distinct basal groove. Eyes entire, subrotundate, rather large and prominent. Thorax truncate at the base and apex, of variable length, sometimes slightly longer than broad, somewhat narrowed anteriorly; with a well-marked impression at each side in front, a groove along the middle, and usually with a broad fossa near the base. Elytra parallel-sided, rounded behind, with obtuse shoulders, broader than the thorax and four times its length, the sutural region depressed near the base, their punctation slightly rugose.

Legs elongate and slender as seen from above; but in a reversed specimen the posterior femora are widely emarginate at the base, considerably dilated and obtusely angulate in the middle, and from there tapering towards the extremity; this undoubtedly is a male; unfortunately both tibiac had been bitten off before I secured the specimen. Tarsi slender, simple, their claws distinctly thickened near the base.

Antennae half the length of the body, inserted like those of $M$. nigricans; 2nd joint subglobose and very short, joints 3-10 equally elongate, each slightly dilated towards the extremity, the terminal even thicker near its apex.

Underside elosely and moderately finely punctate, with slender greyish pubescence, metasternum with a median depression behind.

It is unlikely that it will be permanently associated with $M$. nigricans, from which it may be easily separated, irrespective of structural details, by its larger size and slender cinereous pubescence.

Length, $3 \frac{1}{2} 11 \mathrm{~m}$.; breadth, $1 \mathrm{~mm}$.

Waimarino and Erua. Five examples, all more or less mutilated, were taken off shrubs at an eleration of about 2.700 ft., during January, 1909 and 1910 .

3581. Sessinia stictica sp. nov. Sessinia Pascoe, Journ. Entom., 2, p. 45 .

Elongate, subdepressed, slightly nitid, covered with slender, decumbent, rellowish hairs; fulvescent, elytrat testaceous; the tips of the femora nigrescent, as are also an oviform spot on each side of the thorax before the middle, another on each shoulder, and 4 pairs on the elytra near the suture, the 1 st pair at the base, the subapical very small.

Head nearly as long as the thorax, its punctation moderately close and shallow. 'Thorax nearly a third longer than broad, rather wider neal the front than at the base, its sides sinuate behind the middle, base and apex finely margined; the surface slightly uneven, having an elongate angular basal impression, and an obtuse median elevation towards the front, its sculpture similar to that of the head. Scutellum subquadrate. Elytra four times the length and nearly double the width of the thorax, with rounded shoulders, their apices entirely covering the abdomen; they are more closely and finely punctured than the thorax, and each is more or less perceptibly quadricostate.

Antennae filiorm, finely and densely pubescent, slightly longer than the elytra, inserted at the sides in front of the eres; basal joint a little archerl and about as long as the $3 \mathrm{rd}$; 2nd small, yet oblong; joints $3-10$ nearly equal, the terminal rather shorter, its apical portion distinctly narrower than the middle.

Legs slender and elongate, the tibiae fincly bicalcarate at the extremity. 'Tarsi elongate, basal joint longest, 3rd triangular, th morlerately expanded, broadly excavate above, feebly emarginate at the 
apex, but not bilohed, 5th slender; claws slightly thickener at the base; posterior tarsi quadriarticulate, the basal joint longer than the other taken together.

Maxillary palpi moderate, penultimate joint subtriangular, much shorter than the preceding one, the terminal cultriform and equalling the 2nd in length.

Eyes large and prominent, with coarse facets, subtruncate or only feebly emarginate in front.

This, owing to the structure of the palpi, must be placed next to $S$. thoracica, 2853, but it differs from every other New Zealand species of the group by its obvious maculation.

Length, $11 \mathrm{~mm}$; breadth, $2 \frac{1}{33} \mathrm{~mm}$.

Motueka, Nclson. A single specinen, mounted on cardboard, in the Dominion Museum, at Wellington, is the only one I have seen.

\section{Group OtionhrNChidae.}

3582. Nicaeana catoptoides sp. nov. Nicaeana Pascoe, Man. N.Z. Coleopt., p. 427.

Oblong-ovate, rather elongate, moderately convex; fusco-piceous, legs and antennae ferruginous; thickly covered with depressed tawny squamae, which, however, become darker on the hind-body, where there are also some erect grey setae.

Rostrum short and stout, finely carinate along the middle. Thorax rather longer than broad, slightly rounded near the middle, without ocular lobes, base and apex truncate, its granular sculpture indistinct in front. Scutellum small. Elytra subcordate, about twice the length of the thuras, just perceptibly broader at the base than it is, obliquely narrowed behind, with strongly rounded apices; they are distinctly striate-punctate but, owing to the squamosity, appear striate.

Legs moderately elongate, bearing greyish scales and setae; tibiae somewhat flexuous, the anterior mucronate; tarsi setose, their penultimate joint dilated and deeply lobed.

Antennae moderately elongate, setose; scape somewhat bent, moderately stout, implanted near the apex, and reaching backwards to the thoracic apex; basal joint of the funiculus not longer than 2nd, joints 3-6 obconical, longer than broad, th rather shorter; elub densely pubescent, elongate-oval, indistinctly quadriarticulate.

Underside piceous, slightly nitid, with white scales and slender elongate setae. Prosternum incurved in front. Abdomen with transversely rugose sculpture.

Fem.-Almost entirely covered with tawny scales, having only an interrupted dark fascia near the top of the posterior declivity. This sex is broader and nore Catoptes-like than the male.

'The eyes are more prominent than those of Pascoe's $N$. modesta, 749, so that the continuity of the head and rostrum appears somewhat interrupted. The scape is rather more elongate, but as that of $N$. nesophila, 3259 , is just as long this new species cannot be sitisfactorily separated from Nicaeana.

o. Length (rostrum inclusive), $3 \frac{1}{2} \mathrm{~mm}$; ; breadth, nearly $1 \frac{1}{2} \mathrm{~mm}$.

Rakaia Gorge, near Methven. Five individuals have been examined, all found amongst decaying leaves and fine sand on the 5th June, 1912, by $M r$. T. Hall. 
3583. Nicaeana placida sp. nov.

Suboblong, only moderately convex, opaque; piceous, leg's and antenuac fusco-rufous; covered with flat, pale-tawny squanae, which along. the sides become nearly grey; the setae are numerous, moderately coarse, suberect, and grey.

Rostrum parallel, slightly, but not abruptly, narrower than the head, about half the length of the thorax, not carinate. Eyes free from the thorax, widely distant above, nearly flat, subrotundate. Thorax very slightly wider at the middle than elsewhere, of about equal length and breadth, base and apex truncate, without inequalities, its punctation invisible. Scutellum indistinct. Elytra arcuate-emarginate at the base, a little wider than the thorax there, quite twice its length, their sides gently rounded, not abruptly declivous behind; rather finely striatepunctate. interstices simple, rather plane.

Scape straight, only moderately stout, gradually thickened, attaining the back of the eye; 2 nd joint of funiculus more slender and slightly shorter than the 1 st, joints $3-5$ subequal, scarcely longer than broad, 6th and 7 th slightly shorter; club oblong-oral, indistinetly quadriarticulate.

Legs with coarse white setae; tibiae flexuous.

Ocular lobes absent. Posterior corbels not cavernous. Scrobes more lateral than in the type of the genus, 749, and the contour of the head and thorax less continuous.

Jength (rostrum inclusive), $4 \frac{1}{2} \mathrm{~mm}$.; breadth, quite $1 \frac{1}{2} \mathrm{~mm}$.

Methren. Unique. Found during December, 1911, by Mr. T. Hall

\section{Nicaeana gracilicornis sp. nov}

Oblong-oval, moderately conver, subopaque; piceo-fuscous, antennae infuscate red, legs more obscurely so, the terminal tarsal joint darker; thickly covered with flat grer squamae, and bearing also many erect white setae. those on the limbs and antennae more slender.

Rostrum about half the length of the thorax, with a fine carina extending from the antennal insertion as far as the back of the eves; these are moderately prominent and subrotundate. Thorax of almost equal length and hreadth, base and apex truncate, the sides only slightly rounded, its surface indistinctly punctate. Scutellum indistinct. Elytra subeordate, with gently rounded, obsolete shoulders, which are just discernibly broader at the hase than the thorax, twice its length. much narrowed but not vertical behind, rather indefinitely substriatepunctate.

Tibiae slightly flexuous, mucronate; posterior tarsi more slender than the intermediate.

Antennae rather slender and elongate; scape somewhat bent, very gently incrassate towards the extremity, reaching the thoracic margin: basal two joints of funiculus moderately elongate and almost equal, $3 \mathrm{r}$. rather longer than the next, 7 th obennical and slightly larger than 6 th: club elongate-oral and acuminate.

The scrobes are normal, but the eves and antennae are like those of $N$. catoptoides, and there are no ocular lobes. The rostral carina is unusually long. The thorax is rather shorter, and the elytra are less distinctly sculptured than in $Y$. catoptoides which has much darker clothing.

Length (rostrum inclusive), $4 \mathrm{~mm}$; ; breadth, $1 \frac{2}{3} \mathrm{~mm}$.

Curiosity Gully, near Methren. My specimen was found by Mr. T. Hall amongst decaying leares on the ground, on the fith ,Julv, 1912 
3585. Tigones humeralis sp. nov. Tigones Brom, Man. N.Z. Coleopt., p. 855. Syn. Protophormus Sharp, p. 1178.

Robust, only slightly convex, opaque; piceous, antennae and tarsi dark fusco-rufous, the penultimate joints of the latter piceous; almost wholly covered with tawny grey spuamae, there being only rery few darker ones; the setae moderately elongate, subdecumbent, alnost seriate on the elytra.

Rostrum a third shorter than the thorax, pterygiate, with a distinct carina along the middle, and a broad groove on each side of it. Eyes moderately convex. Thorax of equal length and breadth in the male, slightly broader than long in the other sex, subcrlindric, rery litlle narrowed anteriorly; its sullate merem. having an irregulat thougls slight aleration along the mildle, and rmme other inewlualities, but the punctation is concealed. Seutellum ristinct. Elytra evidently broader than the thorax at the base, rather more than double its length, their sides nearly straight to beyond the hind thighs, with rounded apices, the shoulders obtusely prominent; they are distinctly seriate-punetate, the 3rd interstices are obtusely elerated at the base, indistinctly so along the middle, and terminate as clongate nodosities at or just below the top of the posterior declivity, the ,th are slightly raised from before the middle backwards, and end as nodosities which are nearly as large as those on the $3 \mathrm{rd}$, the 7 th are less distinctly nodiform behind.

Legs squamose and bearing outstanding grey setae; tibae flexuous, mucronate, more or less finely denticulate inwardly, the posterior corbels with a narow external truncature.

Scape finely setose and attaining the thoracic apex; 1st and 2nd juints of funiculus spual, the others ubonicial, all longel than broad; club elongate-oval, acuminate, indistinctly quadriarticulate.

Easily separable from Sharp's Protophormus binodulus, 2090, by the wreater bulk, by the abruptly broader clytral base, larger eres, and bisulcate rostrum. $3 \mathrm{~mm}$.

$\hat{o}$, Length (rostrum inclusive), $7 \mathrm{~mm}$; breadth, $2 \frac{1}{2} \mathrm{~mm}$. $q, 7 \frac{1}{3} \mathrm{~mm}$. by

Pukling Hill, ncar Methren; February, 1912. Thee found by Ml. 'T'. Hall. Also a varietal form at MeClennan's Bush on the 15th March.

\section{Tigones flectiscapus sp. nov.}

Elongate, slightly convex, subopaque; piceous, antennae and legs infuscate red; covered with depresed syuamae, most of which are grey tinged with pink, the others ale light boun and imenularly distri-

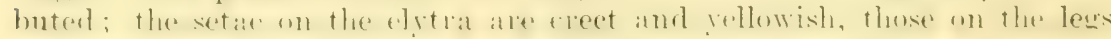
and tarsi are almost white.

Rostrum at third shorter than the thorax, moderately dilated in front, rufescent and bearing white setae there, squamose elsewhere. Eyes more distant from each other than they are from the thorax, longitudinally oval, rather prominent. Thorax subeylindric, closely punctate, witliout irregularities or rugae, its length and breadth cqual, only rery slightly wider near the middle than elsewhere. Fitellum oblong. Elytra with obtusely prominent shoulders, at the base fully a third broader than the thorax, just thrice its length, their siles straight as far as the hind thighs, gradually narrowed but not rertical behind, with subacuminate apices; their striae are fine and apparently impunctate, 
the suture is obtusely elerated behind, the ind interstices are slightly raised, but not nodose, at the top of the declivity, the 5th lower down.

Tibiae finely denticulate inwardly, flexuous, the anterior considerably bent near the extremity; posterin corbels not perceptibly cavernous.

Scape somewhat bent, gradually incrassate, just attaining the thoracic apex; joints 2 and 3 of the funiculus equal and, singly, almost as long as the 1st, joints 4-6 rather longer than broad, 7th slightly shorter and broader; club very elongate-oval, triarticulate, densely pubescent.

'This is, I have no doubt, nearly related to Sharp's Protophormus gracitis, 2089, but differs in vestiture and other details, the scape is quite distinctly bent near the middle, and the anterior tibiae are more flexuous throughout, and more bent inwardly than in any other species.

Length (rostrum inclusive), $5 \frac{1}{2} \mathrm{~mm}$.; breadth, $1 \frac{3}{4} \mathrm{~mm}$.

McClennan's Bush, near Methren. My specimen was sent to me by Ir. 'T. Hall on the 26th February, 1912.

\section{Protolobus granicollis sp. nov. Protolobus Sharp, Man. N.Z.} Coleopt., p. 1188.

Opaque, moderately elongate, slightly convex; the derm when denuded appears slightly nitid and fuscous or pitchy-red, in its natural state it is concealed by the dense covering of depressed tawny squamae and coarse erect white setae; tarsi and antennae fusco-rufous, the tibiae sometimes fusco-testaceous.

Rostrum not as broad as the head, somewhat transversely depressed at the base, shorter than the thorax, with some slender setae at the extremity. Thorax of about equal length and breadth, its sides a little rounded, narrower at the base than at the middle; somewhat uneven above, being transversely impressed near the front and longitudinally at the middle of the base, its sculpture granular. Elytra suboblong, with slightly rounded shoulders, not abruptly narrowed behind, they are rather broader than the thorax at the base, but not twice its length; on each, alongside the suture, there is a listinct series of punctures, the interstice outside is obtusely elevated from the base to the top of the posterior declivity, the next interstice is separated by 2 series of punctures, it is obsolete near the base but becomes nodiform behind, between these but half-way down the declivity there is a more prominent nodosity.

Legs thickly clothed; the anterior tibiae with fine yellowish setae near the extremity, the extremity of the posterior diluted, ciliate externally, but without any visible external truneature; penultimate tarsal joint expanded and strongly bilobed.

Scape implanted near the apex, gradually incrassate, bearing some moderately coarse setae and reaching the back of the eye. Funiculus rather more elongate, with finer setae, its 2 nd joint as long as the 1st, joints 3-7 moniliform and of about equal size; club elongate-oral, subacuminate, densely and finely pubescent, indistinctly triarticulate.

Underside densely covered with flat tawny scales and nearly quite white elongate setae. Prosternum strongly incurved in front, so that the contiguous coxae occupy the space between the emargination and the base. Metasternum as long as the 2 nd ventral segment, which is slightly medially angulate in front.

The mandibular scar is visible. The ocular lobes, as seen from abore, are only slightly developed. The eres are lateral and quite flat, so that the continuity of the head and rostrmm is scarcely at all interrupted. 
'The type of the genus, Sharp's L'. obscurus, 2104, is not in my collection as ret, but its elongate thorax and short 2nd joint of the funiculus, independently of other cletails, show that it is very different fion this species. Pascoe's L'rechyphloens porculns, also referable to Protolobus, has, according to its description, bicalearate anterior tibiae and slender setae.

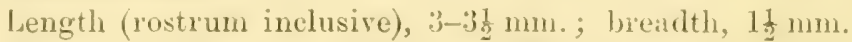

Rakaia Gorge, near Methven. 'Three examples secured from leafmould on the 1Sth May, 1912, by Mr. 'T. Hall. Until at least partially cleaned the sculpture cannot be seen; the shape of the body, too, could not be determined until freed from particles of sand and sappy matter.

\section{Haplolobus frontalis sp. nov. Haplolobus Broun, Man. N.Z. Coleopt., p. 1198.}

Opaque, rather elongate, only moderately convex; fusco-piceous, antennae and tarsi more or less pitchy-red; evenly and closely covered with tawny grey depressed squamae, and numerous grey setae which are suberect on the thorax but decumbent and seriate on the elytra.

Rostrum stout, quite a third shorter than the thorax, with a slight transverse impression just in firont of the eyes; squamose, except at the setigerous apex, indistinctly carinate along the middle. Head short, becoming gradually broader than the rostrum. Thorax truncate at the base and apex, suberlindric, slightly longer than broad, a little wider before the middle than elsewhere, with well-developed ocular lobes, but without definite seulpture. Elytra subcordate, twice the length of the thorax, a little broader than the thorax at the base and slightly arcuateemarginate there, rather gradually narrowed posteriorly; they are substriate-punctate, the $3 r d$ and 5 th interstices are slightly elevated but nowhere nodiform.

Scape inserted near the apex, in caremous scrobes that are situated on the upper surface; it is moderately stout, very gradually thickened, and attains the thoracic margin. Funiculus setose, the ist and 2nd joints about equal, joints $3-T$ obconical, successively shortened; club elongate-oral, acuminate, finely pubescent, quadriarticulate, the apical joint, however, is small or indistinct.

Rather larger than $I I$. saevus, 2122, the antennae and thorax longer, in 2122 the latter is broader than long. The eyes are slightly convex, the outline of the head and thorax therefore appears less continuous than in $I I$. stevus. The basal impression of the rostrum serves as a good discriminative character. The head and rostrum are very much like those of Nicaeana, which, however, is without ocular lobes.

Length (rostrum inclusive), $7 \mathrm{~mm}$; breadth, $2 \frac{1}{2} \mathrm{~mm}$.

Mount Hutt. Unique. Found br Mr. 'T'. Hall, at an altitude of $3,500 \mathrm{ft}$. on the $30 \mathrm{th}$ Warch. 1.912

\section{Haplolobus granulatus sp. nov.}

Subopaque, fusco-niger, antennae and tarsi piceo-rufous; sparingly clothed with decumbent greyish setae, which, on the legs and tarsi, are more slender, numerous, and nearly quite white.

Rostrum fincly carinate along the middle, with an oblique feeble impression at each side of its base. Eyes moderately convex. Thorax rather longrer than broad, of the usual form; its sculpture consists of small, closely placed granules, in most of these there is a minute puncture. Sentellum smooth but minute. Elytra seriate-punctate, 3rd interstices slightly elerated, the :th even less distinctly, the suture 
obtusely raised behind, apices rounded and just visibly dehiscent, their whole surface is granulate, but much less evidently than the thorax.

In general form and structure this agrees with $H$. frontalis, but in appearance more nearly resembles $\|$. athiops, 2123 , which, however, is somewhat nitid, its thorax is broader than long, with rugose sculpture; the elytral apices are lightly poduced, but the shoulders are more rounded; its eyes are flat, and the scrobes are broader above, the funiculus is shorter, and the tarsi are more slender.

Length (rostrum inclisive), $6 \frac{1}{2} \mathrm{~mm}$; ) breadth, $2 \frac{1}{2} \mathrm{~mm}$.

Mount Hutt. One individual. Another of Mr. 'T'. Hall's captures during bad weather; 30th Warch, 1912 .

3590. Catoptes spectabilis sp. nov. Catoptes Schoenherr, Man. N.Z. Coleopt., p. 428. Syn. Irenimus Pascoe, Msn. N.Z. Coleopt., p. 443 .

Body moderately elongate and convex, oparue; piceous, antennae and tarsi fusco-rufous, legs darker; entirely covered with tawny squamae and paler, moderately elongate setae, which are suberect on the thorax, but on the elytra are decumbent and subseriate.

Rostrum about a third shorter than the thorax, slightly dilated near the apex, finely setigeruus there, with a carina along the middle. Thorax of nearly equal length and breadth, base and apex subtruncate, slightly wider before the middle than elsewhere; its surface just a little uneven, having an oblique frontal impression near each side, with indistinct punctate-granulose sculpture. Scutellum small and indistinct. Elytra subcordate, rather elongate, not quite straight at the base, which is slightly broader than that of the thorax in the male, more evidently in the other sex, more than double the length of the thorax, with somewhat obliquely narrowed shoulders, the posterior declivity attenuate and vertical ; owing to the squamosity they appear rather indistinctly seriatepunctate, but on denuded spots the sculpture is well marked; the 3rd interstices are unevenly and slightly elevated, the 5th even less raised, both terminate in moderate nodosities on the top of the declivity, the suture is prolonged backwards so as to form a contiguous pair of remarkable horizontal protuberances which project over the laterally compressed declivity.

Legs elongate, rather slender, with grey setae; tibiae flexuous, mucronate; tarsi rather narrow, their penultimate joint moderately expanded and bilobed.

Antennae rather slender; scape implanted near the apex and reaching the back of the eye, with nearly white scales and a few erect setae; hasal joint of funiculus a little thicker but not longer than the 2nd. joints 3-7 obconical, 3rd and 4th distinctly longer than broad; elub elongate-oval, triarticulate, finely pubescent.

Underside with many elongate grey setae; the 2 nd ventral segment, in the middle, almost as long as the 1st; 5th subtriangular, fully the length of the $3 r d$ and th combined, with a rather large and deep angular fovea near the base.

Scrobes apical, risible above, inclistinctly furolonged obliquely downwards. Eres just free from the tholax, oblique, not prominent. Ocular lobes only feebly developed. Posterior corbels simple, without any external truncature.

The remarkable sutural protuberances at the summit of the posterior declivity enable it to be at once separable from erery species except 
1'. posticatis, 2100, which, however, differs in the darker squamae and rather minute setae. Its rostrum is much broader, the antemnae are distinctly thicker, and the 2nd joint of the funiculus is shorter than the 1st, the eres are litger, the legs are stouter, with manifestly broader tarsi; the elytra are arcuate-emarginate at the base, so that the shoulders seem obtusely prominent, and the sutural prominences have a downward curvature.

Length (rostrum inclusive), $6 \frac{1}{2} \mathrm{~mm}$. ; breadth, $2 \frac{1}{2} \mathrm{~mm}$.

Mount Hutt, near . Methren. 'Three specimens found by Mr. 'I'. Hall during lebruary, 1912, at a height of $3,500 \mathrm{ft}$.

\section{Catoptes subnitidus sp. nor.}

Elongate, moderately convex, piceous, antennae and tarsi fuscolufous; thickly covered with depressed, slightly glossy squamae, ehiefly

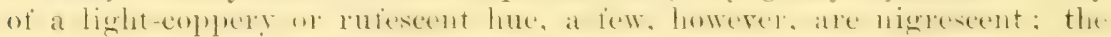
setae are suberect but not elongate, rather santy, and quite grer.

Rostrum subyarallel, a third shorter than the thorax, with an indistinct central carina. Eyes moderately large. 'Thorax with gently rounded sides, slightly wider near the middle than at the base, only a fifth broader than long. without superficial ineyualities. its punctation completely hirlden. Scutellum minute, nitid. Elytra narow, nearly thrice the length of the thorax, vert little broader than it is anywhere, of the same width as it is at the base, their sides very slightly curved, gradually narowed and shoing bhind: they are seriate-punctate, the 3rol interstices are slightly and unevenly elevated and end abruptly at the commencement of the posterior declivity, they are not, however, listinctly nodiform there, the 5th are even less elevated, the suture is moderately raised half-way down the declivity.

Legs and tarsi with elongate grey hairs; tibiae distinetly Hexuous, not thick; 2nd tarsal joint narrow, nearly as long as the basal, the penultimate broadly expanded and deeply divided.

Antennae rather slender and elongate, setigerous; basal two joints of funiculus equally elongate, 3rd nearly as long as the 2nd, joints 4-7 gradually decrease, all longer than broad; elub rery elongate-oval, indistinctly annulate.

$C$. tibialis, 1519 , and $C$. stolidus, 1520 , are, as regards form, the nearest allies. The former has its rostrum shorter, more apically incrassate, and distinctly carinate, its antennae are less slender and clongate, but the tarsi are broader, and the elothing is different.

In 1520 the thorax, being narrower, appears longer, the elytra are broader than the thorax at the base, the tarsi and antennae are thicker, and the restiture is quite dissimilar.

Length (rostrum inclusive), 5 r $2 \mathrm{~mm}$. ; brearth, $2 \mathrm{~mm}$.

Purlding Hill, near Methren. Unique. Captured on the 1st February, 1912, by $\mathrm{Mr}$. 'T. Hall.

\section{Catoptes curvatus sp. nor.}

Elongate, moderately conrex, "paque, piecous; squamosity dense, flat, light tawny brown, much darker across the top of the posterior declirity, distinctly paler but not griseous below it; setae not numerous, pale, rather short and erect; antennae and tarsi fusco-rufous.

Rostrum finely carinate along the midrlle, slightly dilated, punctate, and rufn-picenus in front. Eyes rather litre, transverse, but little conrex. 'Thorax rather wider before the middle than elsewhere, its sides 
nearly straight but gently narrowed behind, about a fifth bronder than long, broadly impressed in front, and with an oblong impression at the middle of the base, not at all asperate, its fine and rather distant punctation concealed. Scutellum indistinct. Elytra elongate, subeordate, just double the length of the thorax, hardly any broader than it is at the areuate-emarginate base, only about a fourth broader at the middle, the declivity laterally compressed; they are distinctly yet not coarsely seriate-punctate, the $3 \mathrm{l}$ interstices are slightly elevated and terminate behind in small blackish nodosities, the "5th less distinctly so, the sutural region forms an obtusely but distinctly elevated curve along the declivity.

Antennae setigerous, rather elongate and slender; scape very gradually thickenerl and attaining the thoracic margin; sur joint of the funiculus as long as the 1st, joints $3-6$ evidently longer than broad, 7 th subtriangular, shorter than preceding ones; club elongate-oval, quadriarticulate.

Legs and tarsi with grey setae; tibiae flexuous, the posterior somewhat bent inwardy at the middle; 2nd tarsal joint subtriangular, longer than broad.

Fem.-Broader, $2 \frac{3}{4} \mathrm{~mm}$., with darker clothing, her thorax distinctly broader than long, the interstices obsoletely elevated, their nodosities more distinct, the curvature of the posterior declivity like that of the nıale.

The males of three species, 1519,2384 , and 2875 , bear some resemblance to that of this species. The first is more brightly variegated, with shorter antennae and broader tarsi, its scutellum is distinct, and the suture along the declivity is not prominent. The second has much thicker legs, the femora especially, joints 3-6 of the funiculus are much shorter, the rostral carinat is more strongly developed, and the posterion. declivity is subrertical and simple. The third, $C$. spermophitus, is a more rolust insect, the female particularly. The male has a distinct rostral carina, a more or less evident linear impression along the iniddle of its thorax, stouter legs, and the declivity differs. In none of these are the scrobes as broad and open above at the apex as they are in C. curvatus. The ocular lobes are moderately developed.

o. Length (rostrum inclusive), $6 \frac{1}{2} \mathrm{~mm}$.; breadth, $2 \frac{1}{4}$ mm.

Mount Hutt and Pudding Hill, near Methven. A male and two fcmales received from Mr. T. Hall.

Var.-Paler, anterior tibiae denticulate, rostral carina indistinct; one individual.

\section{Catoptes carinalis sp. nov.}

Opratue, fuscous, covered with depressed variegate scaldes. principally pale brown. with irregular blackish s lwts which almost form an irregular curve on the top of the hind declivity, this, mderncuth, is bordered by grerish ones, there are also some indefinite crey spots on the dorsum, and a better-marked elongate one on the nindale of the thorax; the setae are mostly grey, moderately elongate, and erect; antennae and tarsi fusco-rufous.

Rostrum a third shorter than the thorax, sliglitly dilated and rufescent in front. with a very distinct, rather thick carina along the middle. Eyes moderately large, nearly flat. Thorax rery slightly wider near the middle than elsewhere, nearly a fourth broader than long, without ine'pualities, its sides covered with yellowish-grey squamae. Scutellum 
indistinct. Elytra slightly incurved at the base, hardly any broader there than the thorax, fully twice its length, with oblique shoulders, near the middle about a third broader than the widest part of the thorax; they are seriate-punctate, with simple interstices.

Legs with grey setae; tibae more flaveseent than the femora, slightly flexuous; 2nd tarsal joint much smaller than the 1st, the penultimate nearly double its breadth and cleft almost to the base.

Antennae moderately elongate, bearing outstanding fuscous setae, the scape with some slender grey ones also; 2nd joint of the funiculus quite the length of the 1st, joints 3-6 obconical, rather longer than broad, 7th somewhat shorter and broader; club elongate-oval, quadriarticulate, finely pubescent.

Of about the same size and shape as 2112,2113 , and 2114 , but differing from that series by the speckled vestiture, more slender antennae, and the eonspicuns rostral arina. Structural charaters mormal.

Length (rostrum inclusive), $5 \mathrm{~mm}$.; breadth, $2 \mathrm{~mm}$.

Pudding Hill, near Methren. I solitary male from Mr. T. Mall, 1st February, 1912.

\section{Catoptes argentalis sp. nov.}

Suboblong, narrowed anteriorly, moderately convex, subopaque, piceous, legs and antennae rufu-fucous; corepod mostly with depressed silvery-grey squamae, but some light-chocolate ones form a pair of basal spots on the thorax, and a few less definite ones on the wing-cases, the most distinct being a pair near the suture on top of the declivity; the setae are more numerous behind than elsewhere, ther are nearly quite white and suberect.

Rostrum subparallel, more than half the length of the thorax, not carinate. Eyes quite free from the thorax, widely distant above, transrersely oral. 'Thorax rery little broaler than long. its sicles crently and evenly rounded, the punctation invisible. Elytra oblong, a little alcuate-enarginate at the bise, which is slightly wider than that of the thorax, fully twice its length, with slightly rounded shoulders; they are finely seriate-punctate, with moderately broad enodose interstices.

Scape moderately stout, gradually thickened, finely setose, almost reaching backwards to the thorax; and joint of the funiulus as long as the basal, joints 3-7 moniliform; club oblong-oval, indistinctly quadriarticulate.

Scrobes subapical, slightly prolonged obliquely downwards. Ocular lobes feebly developed. Posterior corbels without any distinct external truncature.

This cannot well be mistaken for any other species, unless, perhaps, Sharp's $C$. brevicornis, 2112 , but its elytra seem to be without punctation, their sutural region is for the most part fuscous, and the 2nd joint of the funiculus is shorter than the 1st.

Length (rostrum inclusive), $4 \mathrm{~mm}$.; breadth, $1 \frac{3}{4} \mathrm{~mm}$.

Taieri, Otago. Unique. Forwarded by Ir. S. W. Fulton.

\section{Catoptes fumosus sp. nov.}

Suborate, moderately convex, opaque, fusco-piceous, legs fuscous, antennae and tarsi piceo-rufous; covered with depressed, inconspicuous, cinereous squamae, and some yellowish-grey setae, which on the 3rd and 5th interstices and the hinder part of the elytra are erect and longer than the others. 
Rostrum a third shorter than the thorax, very slightly dilated at the extremity, with a slender carina along the middle; it is a little nitid, with almost quite grey scales, and bears elongate fulvescent setae at the apex. Head short and convex. Thorax of equal length and breadth, slightly wider just before the middle than elsewhere; without inequalities of surface, indistinctly punctate-granulose. Scutellum oblong. Elytra subcordate, rather more than twice the length of the thorax, broader than it is at the base, with slightly rounded sides and shoulders, and simple apices; their sculpture shallow, substriate-punctate near the suture, 3rd interstices unevenly and slightly elevated from the base backwards but not distinctly nodose behind, the óth even less so, the suture is only a little elevated below the summit of the declivity.

Tibiae flexuous, minutely denticulate along the lower edge; posterior corbels with double cilia but not distinctly truncate between them.

Scape straight, inserted near the apex, and attaining the thoracic margin; 2nd joint of the funiculus almost as long as the lst, joints 3-7 obconical, gradually shortened; club elongate-oval and triarticulate.

Serobes subapical, open above, with a slight downward prolongation towards the middle. Ocular lobes very feebly developed. Eyes obliquely oral.

As this cannot be permanently located either in Inophloeus or Catoptes, it must be placed near 2879 , Catoptes duplex, which in structure it most nearly resembles. It is, however, a broader insect, the rostral carina is very slender, without any trace of grooves alongside it.

Length (rostrum inclusive), $8 \mathrm{~mm}$.; breadth, $3 \frac{1}{2} \mathrm{~mm}$.

Rakaia Gorge, near Methven. One found by Mr. T. Hall on 29th September, 1912 .

\section{Brachyolus asperatus sp. nov. Brachyolus White, Man. N.Z.} Coleopt., pp. 432 and 1194.

Opaque, moderately broad; piceous, antennae and tarsi fusco-rufous, legs less rufescent, the hind pairs with blackish spots; closely covered with depressed tawny and dark-fuscous scales, those of the latter colour cover a large space on the side of each elytron and form small irregular spots on the dorsum and declivity, the suture, however, is somewhat coppery red; the setae are suberect, moderately coarse, grey and fuscous, but not numerous.

Rostrum a little dilated near the extremity, nearly as long as the thorax, tricarinate above. Head short, obliquely narrowed anteriorly. Eyes rather large, flat, oblique, and transverse. Thorax slightly broader than long, a little wider near the front than elsewhere; somewhat uneven, having an oblique frontal impression near each side and 3 irregular basal ones. Elytra with narrowed shoulders, so that the base. which is oblique towards the sides, does not exceed in width that of the thorax, they are fully twice its length and, at their widest part, about a third broader, their sides are only feebly curved and the posterior declivity is nearly vertical and somewhat obliquely contracted. with slightly acuminate and divergent apices; the dorsum appears a little asperate, having several small irregular nodiform inequalities, and series of moderately coarse but not very regular punctures; the $3 \mathrm{rd}$ interstices are slightly, on some parts not at all, elevated, but terminate on top of the declivity as prominent nodosities, the 5th are not perceptibly elevated and their nodosities are much smaller; along the upper half of the declivity the suture is slightly eurved and prominent. 
Scape distinctly setose, rather stout, gradually incrassate, a little shorter than the funiculus, and attaining the thoracic margin; 2nd joint of funiculus as long as the basal, joints :3-5 evidently longer than

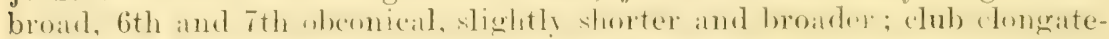
oval, triarticulate.

Legs and tarsi with grey setae; tibiae flexuous, the anterior almost straight outwardly; posterior femora with a pale spot above, near the extremity.

Dr. Sharp described five species, 2116-20, inclusive; none of these are in my collection, and some will probably be placed in distinct genera. After studying their deseriptions $I$ find that $B$. asperatus does not agree with any one of them. The $3 \mathrm{rd}$ interstices do not project over the base of the thorax as in 2117 and 2118; in 2116 the 3rd and 5th interstices are united behind so as to form, on each elytron, a large triangular nodosity; in "2119 the sth interstices are nodiform behind hut the 3rol are not; whilst in 2120 the sides of the thorax are distinctly plicate or submarginate behind.

Length (rostrum inclusive), 5 $\mathrm{nm}$. ; breadth, $2 \mathrm{nmm}$.

MeClennan's Bush, near Methven. A single male found by Mr. 'T. Hall on the 26th February, 1912.

Var.-'Three specimens secured by $\mathrm{Mr}$. Hall on the 1 st of the same month at Pudding Hill measure $6 \mathrm{~mm}$. by $2 \frac{1}{2} \mathrm{~mm}$; the elytra are not asperate, alomg the millle they are nearly plane, the sipumosity is much less variegate, and the 3rd and th tarsal joints are usually piceous. I treat these as representing a variety intermediate between this and the following species.

\section{Brachyolus fuscipictus sp. nov.}

Opaque, piceous, antennac and tarsi dark fuseo-rufous; the elothin: pale brown, somewhat coppery along the midnle of the elytra. light tawny or greyish on the thorax and sides of the apical declivity, dark fuscous on top of the latter and along the side of each elytron; the setae greyish.

Rostrum nearly a third shorter than the thorax; distinetly carinate along the middle, its sides obtusely and less evidently. Thorax slightly broader than long, a little wider before the middle than elsewhere; a little uneven, broadly obliquely impressed in front towards the sides, tri-impressed near the base, and with a slight median carina before the middle. Elytra double the length of and quite a third broader than the thorax but, owing to the rounded shoulders, hardly broader than it

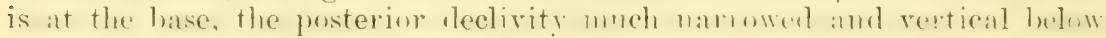
the middle; their broad sutural area is nearly plane and indistinedy punctate, the punctures near the sides are seriate, moderately coarse and distant; the 3rd interstices are only obtusely projecting at the base. they are moderately and unevenly elevated backwards and their terminal nodosities are thick and prominent, the 5th are simple and have smaller nodosities behind; the suture, along the upper half of the declivity, is obtusely elevated and thickened and almost curvate, below that point it is perpendicular, apices subacuminate.

Legs clothed and marked like those of B. asperatus, but the anterior tibiae are evenly and gently curved externally. Antennae similar.

Underside with fuscous and tawny seales, and many long and rather coarse setae, but those on the fincly punctate reminal segment are much finer on the middle; the basal abdominal segment is broadly depressed and longer than the next, which is medially angulate in front, the 3rd 
and 4th together are as long as the 2nd. Nentum depressed and almost filling the buccal cavity. Mandibular scar well marked.

Distinguishable from $B$. asperatus by the greater bulk, the shorter and less evidently tricarinate rostrum, by the absence of small nodiform dorsal inequalities, the thoracic ridge, and nearly flat sutural region of the elytra.

Length (rostrum inclusive), $6 \mathrm{~mm}$, ; breadth, $2 \frac{1}{2} \mathrm{~mm}$.

Pudding Hill. Mr. T. Hall is the discoverer.

3598. Echinopeplus verrucatus sp. nov, Echinopeplus Broun, Man. N.Z. Coleopt., p. 851.

Body dilated posteriorly, oparque, piceous, densely covered with depressed greyish squamae.

Rostrum as long as the thorax, its apical portion gradually expanded and setigerous, behind that point parallel-sided; with a fine carina along the middle. Eyes very slightly convex, transversil. Thorax truncate at the base and apex, nearly as long as broad, a little wider before the middle than elsewhere, its sides almost straight behind; the surface with irregular, moderate wart-like sculpture. Scutellum indistinet. Elytra twice the length of the thorax, scarcely any wider than it is at the base, emarginate there; their sides slightly uneven, each having about 4 obtuse nodosities, they are gradually dilated towards the top of the posterior declivity; the dorsum is not quite flat, it is seriate-punctate alongside the suture but the sculpture elsewhere is somewhat similar to that of the thorax; on the summit of the posterior declivity, which is rertical and considerably narrowed, there is a pair of large, nearly horizontal protuberances, these project slightly beyond the declivity and between them there is an evident sutural gap; the olotuse lateral prominence on each elytron does not extend so far back as the other, and there is a wide oblique sinuation between them.

Legs clongate, bearing many grey setae as woll as scales; tibae flexuous, mucronate, denticulate along the inner face; tarsi with close brush-like vestiture underneath.

Scape inserted close to the apex and attaining the front of the ere, gently inclassate, and covered with grey decumbent setae; funiculus with fine grey and outstanding infuseate setae, its 2nd joint equals the lst in length, joints 3-7 obconical, quite as long as broar, the 7 th slightly broader than its predecessor; club elongate-oval, acuminate, quardiarticulate, the terminal joint small, and, owing to the fine dense pubescence, sometimes indistinct

Ocular lobes well developed. Scrobes quite open above at the apex and prolonged along the lower surface towards but not reaching the lower part of the ere. Posterior corbels simple, without any external truncature.

The type of this genus, E. dilatatus, 1515, is differentiated by the more infuscate clothing, shorter and more apically dilated rostrum, which, moreover, has a thick central ridge and a groove along each side of it. The legs and antennate are evidently thicker. The elrtral punctation is more distinct, and the dorsum terminates behind, on each elytron, in the form of a large oblique dilatation, with a wide sutural interval between it and its fellow of the other elrtron. Its posterior corbels are cavernous, having duplicate cilia, with a narrow, truncate intervening space.

Jenerth (rostrum inclusive), $8 \mathrm{~mm}$; breadth (maximum), $3 \frac{2}{3} \mathrm{~mm}$. 
Rakaia Gorge, near Methven. Described from a single indiridual found by Mr. 'T. Hall on the 18th May, 1912.

\section{Echinopeplus dorsalis sp. nor.}

'l'he description of $\vec{E}$. vermucatus, with the following exceptions, is applicable to this species.

squanosity more infuscate, rostrum and thorax rather longer, elytrat shorter, legs and tarsi notably thicker.

Thorax subcylindric, hardly any broader in front than it is behind, its sides nearly straight, the surface with tubercular and closer sculpture, and with a well-narked channel along the middle. Elytra almost parallel-sided from the base to the posterior elevations, 3rd and 5th interstices elevated from the base towards the middle, these when examined sideways are seen to consist of series of rounded tubercles; the dorsum terminates as il pair of widely separated subrotundate elevations which do not project backwards, the outer nodosity, on each elytron, extends outwardly, and between it and the subsutural one there is a deep but not wide sinuosity.

Underside shining, piceous, covered with white scales and elongate decumbent setae; terminal ventral segment with many minute as well as coarser punctures. Prosternum incurved in front. 'The mentum fills the buccal cavity, and the lunate basal impression has its front margin slightly raised.

Dr. Sharp's species of lleterodiscus, 2121 and 2590 , have 4 distinct grooves on the rostrum, and the form of the elytral dilatations is materially different. His genus Heterodiscus is synonymous with Echinopeplus.

Length (rostrum inclusive), $8 \frac{1}{2} \mathrm{~mm}$. ; breadth (maximum), $3 \frac{1}{2} \mathrm{~mm}$.

Rakaia Gorge. My specimen was discovered on the 26th June, 1912, by $\mathrm{Mr}_{\mathrm{r}}$ 'T. Hall.

3600. Inophloeus pensus sp. nov. Inophloeus Prscoe, Man. N.Z. Coleopt., p. 439 .

Oblong, rather broad, slightly convex, opaque; nigrescent, antennae and tarsi piceo-rufous; covered with depressed, rather sulall, dark, and obscure tawny scales, those on the rostrum and sides of the thorax of a more or less pinkish hue; the setae are slender, decumbent, and preyish, but are nore conspicums and ereet on the posterior declivity.

'Rostrum a third shorter than the thorax, slightly dilated in front, with a distinet but slender earina along the middle, broadly impressed alongside it, the lateral carinae obtuse. Head short, with a narrow and rather small interocular fovea. 'Thorax a little wider and rounded before the middle than behind, slightly broader than long, without inequalities, and with only a few fine punctures visible. Scutellum subtriangular, small. Elytrat thrice the length of the thorax, rather broader than it is at the hatse, with entrenlly natrowed shoulders, their sides nearly straight as far as the hind thighs, considerably narowed behind, with

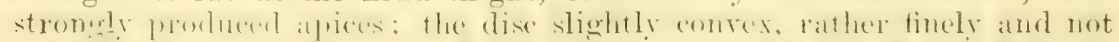

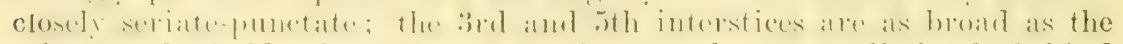
others, only feebly elevated near the base, rather more distinctly behind and, though ending abrupty at the summit of the declivity, not pro-

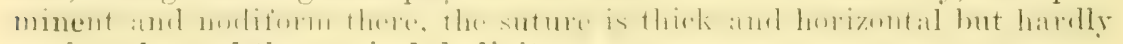
projects beyond the vertical declirity. 
Tibiae flexuous, not denticulate, with fulvescent setae at the extremity; the posterior corbels with duplicate external cilia and narrow truncate intervals.

Scape elongate, just attaining the thoracic apex; 2nd joint of the funiculus as long as the basal, 3rd nearly as long, the next rather shorter, joints $5-7$ obconical and rather longer than broad; club finely pubescent, elongate-oval, acuminate, quadriarticulate, its terminal joint smallest.

Eyes transverse and slightly oblique. Ocular lobes well developed. Scrobes subapical, deep and open above, with a shallow downward prolongation.

Nearly as long as $l$. sulcifer, 1618 , with relatively broader and shorter elytra, more prolonged apices, and very much finer punctation, but lacking the almost dentiform projections of the $3 \mathrm{rd}$ interstices and the thoracic groove. In 1618 the scape is much thicker, and only reaches the middle of the eye.

o. Length (rostrum inclusive), $11 \mathrm{~mm}$; breadth, $4 \frac{1}{2} \mathrm{mmm}$.

Mount Hutt, near Methren. A single individual found by Mr. 'T'. Hall, at a height of $3,500 \mathrm{ft} .$, on the $30 \mathrm{th}$ March, 1912.

\section{Inophloeus sulcicollis sp. nov.}

Elongate, rather narrow, slightly convex, opaque; piceous, antennae and tarsi piceo-rufous; thickly covered with tawny-grey squamae, and with a few decumbent, rather short, greyish setae.

Rostrum nearly a third shorter than the thorax, a little dilated at the apex, without definite grooves, but with a slender carina along the middle. Thorax of equal length and breadth, only slightly broader before the middle than elsewhere; a little uneven, not at all coarsely punctate, with a rather broad, well-marked channel extending from base to apex. Scutellum oblong, slightly flavescent. Elytia not quite truncate at the base and hardly broader than the thorax there, nearly thrice its length, with slightly rounded sides and shoulders, consirlerably narrowed and subvertical behind, with obtuse and slightly divergent but not at all prolonged apices; dise nearly plane, subseriate-punctate; $3 \mathrm{rd}$ and 5 th interstices slightly but unevenly elevated, and terminating as obtuse horizontal prominences on top of the declivity, the suture also is horizontally prominent but does not project beyond the declivity; the discal sculpture in one specimen is somewhat interrupted by irregular, obtuse, transverse rugae.

Tibiae flexuous, finely denticulate along the lower face, with distinct fulvous setae at the extremity; posterior corbels with narrow intervals between the double external cilia.

Scape inserted near the apex and just reaching the thoracic margin; basal joint of the funiculus longer than the next, joints 2-t moderately elongate and slightly successively shortened, $5-\bar{T}$ obconical and rather shorter than preceding ones; club densely pubescent, elongate-oral, acuminate and triarticulate.

Ocular lobes well developed. Eyes nearly flat, obliquely oval. Scrobes subapical, deep and open above, obliquely prolonged but not reaching the lower part of the eyes.

l. longicornis, 2886, is the nearest species, but it is a good deal larger, with longer antennae, a bisulcate rostrum, the thorax is rugose or subtuberculate, and the elytra have prominent posterior nodosities. 
ơ. Length (rostrum inclusive), 8 mm.; brendth, quite $2 \frac{1}{2} \mathrm{~mm}$.

Curiosity Gully, near Methven. Only two examples have been seen both found amongst dearl leaves on the 9th August, 1912, by Mr. 'T. Hall

Obs.-Inophloens is divisible into two sections; in the first the seape attains the middle of the eye, in the second the thoracic apex.

\section{Group linyparosomidae.}

3602. Lithocia angustula sp. nov. Lithocin Broun, Man. N.Z. Coleopt., p. 1470 .

Suboblong, rather narrow, slightly convex and nitid; thinly elothed with erect, moderately slender, fulvescent and fuscous setae; rufocastaneous, the base and apex of the femora sometimes infuscate.

Rostrum without distinct orests, as long as the thorax, arched; with a carina along its basal half, its frontal portion somewhat expanded and finely bicarinate; scrobes deep, foveiform, and quite open above. Head short, narrowed anteriorly. Eyes rather Hat, just free from the thorax, subrotundate. Thorax as long as it is broad, widest and obtusely prominent before the middle, somewhat abruptly narrowed anteriorly, quite gradually behind, base and apex truncate; the disc coarsely and irrecularly but not closely punctured, quite finely near the apex, rather indistinctly at the sides. Elvtra subovate, neirly double the length of the thorax, humeral angles woderately porrect and clasping the base of the thorax, posterior declivity not vertical; on ench there are 6 series of coarse, distinctly separated punctures, these, however, become finer on the declivity, which is substriate; the 3rd interstices are distinctly elerated at the base, but there are no perceptible nodositien or crests elsewhere.

Legs moderately elongate, bearing numerous pale or fulvous setae; tibiat distinctly mucronate at the inner extremity; 3rd tarsal joint slightly dilated, excavate above, emarginate in front, but not bilobed.

Scape inserted before the middle, attaining the back of the eve, gladually incrassate, with fuscous setae; 2nd joint of funiculus rather shorter than the basal, 3-6 nearly equal, broader than long; club subrotundate, finely pubescent, indistinctly articulated.

Underside obsenre rufons, with fine yellow setat. Prosternum deeply emarginate. Metasternum short, rugosely punctate. Basal ventral segment truncate between the coxac, bifoveate there, finely punctate on the middle, eoarsely at the sides; 2nd nearly the length of the 1st, its frontal suture sinuate, fincly and distantly punctured, but with a transverse series of conser punctures behind; jth simple, longer than the abbreviated 31 d and th together.

'This is a narrower insect than the typical species, I. fumbriata, 2549, and lacks its conspicuous woolly restiture.

The tawny enerustration of its natural condition alnost entirely conceals the true coloration, sculpture, and clothing. The specimens deseribed above have been scraped with the point of a needle and brushed with benzine.

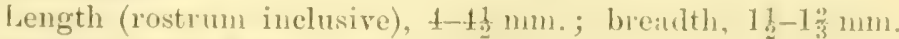

McClennan's Bush, near Methven. Seren individuals obtained amongst decaying leaves, on the ground, during April, 1912, by Mr. T. Hall. 
3603. Araeoscapus ocularius sp. nov. Araeoscupus Brom, Ann. Mag. Nat. Hist., ser. 6, vol. 12, p. 299.

Convex, moderately elongate, subopanue; fuscous, the rostrum, thorax, antennae, and legs somewhat rufescent; irregularly and rather thinly elothed with depressed and suberect curled yellow setae.

liostrum arehed, elongate, as long as the thorax, its frontal half moderately expanded, shining and glabous at the extrenity, the basal portion slightly ridged along the middle. Eyes small, lateral, more distant firon each other than they are from the thorax. Seape Hexusus, minutely setose, gradually incrassate, implanted before the middle and attaining the eye, 2 nd joint of funiculus as long as the 1 st, joints $3-6$ short and subquadrate, Tth evidently larger than preceding ones, as broad as the base of the club, which is ovate but short, densely pubescent, and with indefinite apieal articulations. Thorax about a third longer than broad, suboviform, somewhat contracted in front; the disc a little uneven, having a longitudinal elevation on the middle and a pair of oblique ones before the base; its punctation is rather indistinct and irregular, neither coarse nor close, but finer in front than it is elsewhere. Elytra suboviform, humeral angles not at all porrect and only very slightly wider than the base of the thorax, twice its length, not quite vertical behind; they are rather coarsely seriate-punctate, substriate behind, with the scutellar region broadly but not deeply depressed; the $3 r d$ interstices are moderately elevated, less distinctly, sometimes not at all, towads the top of the posterior declivity, but always slightly outwardly curved near the middle, the 5th in some cases have short basal elevations; across the summit of the declivity, and near the sides, the setae are usually more or less concentrated, but the sutural region is nearly bare.

Underside dull dark fuscous; basal ventral segment fully as long as the 2nd, broadly impressed behind, distantly punctate, and bearing some short decumbent greyish setae; the 2nd often impunctate, but obviously merlially angulate in front; כth longer than the much abbreviater $3 \mathrm{r}$ and th conjointly. Prosternum deeply emarginate in front.

The specinens, though somewhat variable, and in their natural state often smeared with an exudation, are, I think, referable to a single species, distinguishable from its allies by the small eyes and the slight, ret constant, outward curvature of the 3rd elytral interstices. The foveiform scrobes are quite visible from above. In one or two examples the elytral punctures are shallow and hardly discernible, in others the basal portion of the thorax is minutely subtuberculate.

Length (rostrum exclusive), $3 \frac{1}{3} \mathrm{~mm}$. ; breadth, $1 \frac{1}{2} \mathrm{~mm}$.

Ionnt Hutt, Pudding Hill, and IfeClemnan's Bush, lesar Methren. Several specinems oltained foun leaf-mould by Mr. T. Hill. at an altitude of 1,500 ft., during April and May, 1912.

3604. Bantiades cupiendus sp. nov. Bantiades Bromn, Man. N.Z. Coleopt., p. 1371 .

Oblong, slightly convex, subopaque; elytra dark fuscous and slightly nitid, thorax obseurely rufescent, the antenine and tarsi castaneo-rufous, the front pair of legs and the middle of the other pairs of femora reddish; irregularly clothed with fine decumbent rellowish and grey sctae, those of the latter colour most apparent behind; on each elytron, on the 3rd interstice, near the middle, a spot is formed of slightly 
coarser and brighter setae; the legs bear slender outstanding greyish setae.

Rostrum subparallel, moderately arehed, as long as the thorax and about a third of its width, covered with tawy seale-like matter, indefinitely tricarinate. Head retracted, so that the widely separated transverse eres are not wholly exposed. Thorax of equal length and breadth, molerately contracted in front, with nearly straight sides behind, its base a little rounded; disc obsoletely, the front distinctly and elosely punctured, it is somewhat meven, having an obtuse oblong elevation on the middle and a shallow impression along each side of it. Elytra suboblong, narrowed near the extremity, areuate-emarginate at the base, twien the leneth of the thoras and rather boader than it is at the base; their punctures are coarse and distinctly separated, but only the sutural pair of rows on each elytron are seriate, the posterior declivity is substriate; the shoulders are slightly prominent, the $3 \mathrm{rd}$ interstices are distinctly elevated at the base and subnodose on top of the declivity, the 5th has also a small nodosity but it is not placed as far back; the posterior vestiture is patchy but does not form definite crests.

Scape normal; funiculus with outstanding slender grevish setae, 2nd joint oblong but hardly as long as the 1st, the following ones compact, nearly equal, almost transversely quadrate; club ovate, densely pubescent, its apical articulations small and indistinct.

Somewhat similar to $B$. fuscatus, 2396 , but with the rostrum and thorax longer; the legs and scape, though alike in structure, are more slemele, and the seuplure of the thorax and dytrat is quite different. It can hardly be mistaken for 2551,3443 , or 3444 .

Length (rostrum exclusive), $4 \mathrm{~mm}$; ; breadth, $2 \mathrm{~mm}$.

McClennan's Bush, near Methven. I am indebted to Mr. T. Hall for my specimen, which was found amongst decaying leares on the ground in April, 1912.

\section{Abantiades gen. nov.}

Suboblong, uneven, slightly convex, setigerous.

Pintrum parallel, monlerately arched and stender, as long as thotax. ferules lateral, beginning between the middle and apex, and prolonged underneath to the front and lower part of the eyes. Head deeply immersed. Eyes just free, flat, transrerse, truncate inwardly, distant from each other. Thorax without ocular lobes, truncate in front, slightly bisinuate at the base, the length and breadth nearly equal. Scutelium absent or indistinct. Elytra subcordate, oblong, broader than the thorax at the base, not vertical behind.

Scape elongate and slender, implanted between the middle and apex, not reaching backwards as far as the eyes. Funiculus 7 -articulate, moderately stout, basal joint rather thicker but not longer than 2nd,

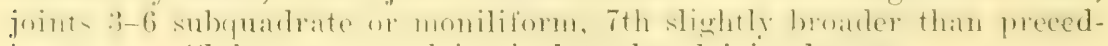

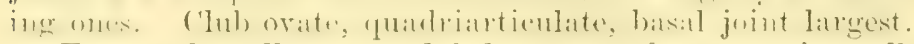

Femora broadly grooved below near the extrenity, all with a prominent median tooth. Tibiae uncinate, strongly areuate above the middle, posterior and middle corbels quite open and ciliate. 'Tarsi rather narrow, the penultimate joint moderately expanded and bilobed; claws small.

Prosternum subangularly emarginate from the front half-way to the eoxac, these are continguous, prominent, and situated near the base. Intermediate coxae moderately separated by the distinct, slightly raised mesosternal process; the posterior widely distant. IIctasternum short. 
Basal ventral segment subtruncate between the coxae, not longer than the 2 nd, 3 rd and 4 th rather short. Mentum transverse, peduncle cuneiform.

Nearly related to Bantiades (Nan. N.\%. Coleopt., p. 1371), but differentiated therefrom by the elongate and slender rostrum and scape, the rectilinear serobes, which are not at all open above, by the contiguous front coxae, the mesusternal process, less strongly dentate thighs, and the more distinctly lobate penultimate tarsal joint.

\section{Abantiades nodipennis sp. nov.}

Suboblong, uneven, opaque; fuscous, covered with a film of tawny sappy matter, and decumbent, minute, scale-like brassy setae; antennae, legs, and rostrum more or less pale rufo-castaneous or flavescent.

Rostrum fuscous near the apex, finely tricarinate and bisulcate along the mildle. Scape nearly glabrous, having only a few slender, inconspicuous setae, somewhat thickened near the extremity. Thorax slightly wider near the front than elsewhere, a little contracted just at the apex, very gradually narrowed behind; its frontal portion slightly depressed and closely punctured. Elytra twice the length of the thorax, their sides broadly expanded just behind the base, somewhat sinuate at the middle, gradually narrowed but not acuminate behind; they are subseriate-punctate, the $3 \mathrm{rd}$ interstices are distinctly nodiform at the base and the summit of the declivity, but less distinctly in the middle; there are 3 nodosities near each of the hind thighs, besides other smaller inequalities above, and there is another half-way down the declivity at each side.

Underside fuscous, with flavescent setae.

Length (rostrum exclusive), $3 \mathrm{~mm}$.; breadth, $1 \frac{1}{2} \mathrm{~mm}$.

Curiosity Gully, Rakaia Gorge. Deseribed from a single example found on the 6th July, 1912, by Mr. 'T. Hall, amongst dead leaves on the ground.

\section{Abantiades pusillus sp. nov.}

Suboblong, moderately convex, subopaque; testaceous, irregularly clothed with very short, decumbent, rellowish setae.

Rostrum slightly arched, parallel, equalling the head and thorax in length, indistinctly punctate, with a fine carina along the middle. Thorax of the same length and breadth, subquadrate, abruptly contracted and quite truncate at the apex, which, however, is nearly double the width of the head; its surface slightly uneven, the punctation very irregular, rather coarse yet indistinct. Elytra subcordate, rather wider than the thorax at the base, which is bisinuate, gradually narrowed posteriorly; alongside the suture they are seriate-punctate, but more irregularly beyond; the 3rd interstices are prominent or nodiform at the base, and slightly olotusely elevated as far as the top of the declivity, but not distinctly nodose there; the 5th are trinodose on one elytron, but indistinctly so on the other; the sides, just behind the shonlder, are somewhat thickened.

Eyes small, transverse, oblique, hardly free from the thorax, situated at the sides. Club broadly oral.

Searcely more than half the bulk of the typical species, and with different sculpture. The only specimen found is a little immature; older ones, therefore, mat be darker in colour.

I ength (rostrum exclusive), $2 \mathrm{~mm}$; ; breadth, $1 \mathrm{~mm}$. 
Rakaia Gorge, near Methven. the 5th June, 1912 , by Mr. Hall.

Discovered amongst leaf-mould on

3607. Clypeorhynchus nodiceps sp. nov. Clypeorhynchus Sharp, Min. N.Z. Coleopt., p. 1210.

Convex, subopaque, thinly and unevenly clothed with short, hair-like, fulvous scales, a few of which are suberect; fusco-castaneous, the rostrum, antennae, ligs, front of thorax, and basal elevations of the elytra more or less rufescent.

Rostrum nearly the length of the thorax, its clypeal portion glabyous, finely ret quite distinctly punctate, the basal half obtusely ridged along the mirldle, with somewhat rugose lateral sculpture. Head short, with a pair of distinct, rotundate, interocular nodules. Thorax about half the length and breadth of the elytra, nearly a fourth longer than it is broul, widest lefore the mildle, sinumsly narrowed behind, with a short apical contraction; the surfice nueven, a little nitirl, listinctly but not elosely punctured in front, the punctures elsewhere less sharply defined; an impression extends from the apex but does not reach the base, near each side, in line with the dilated portion, there is a large tubercle. Elytra suboblong-oval, with oblique shoulders so that the base is no wider than that of the thorax; on each there is a fine, simple, sutural stria, the other striae are interrupted or irregular; near the middle of the base there is a nodiform elevation and another on the shoulder, and between these and the top of the hind declivity there are several unequal, irregularly placed ones, near the suture a series of distant minute granules can be seen, others are irregularly distributed, the posterior declivity is subpunctate-striate.

'This remarkable species may be at once separated from all the others by the interocular nodules and prominent thoracic tubereles.

Length (rostrum exclusive), $6 \frac{1}{2} \mathrm{~mm}$, ; breadth, $3 \mathrm{~mm}$.

Hump Ridge, near Invercargill. Mr. A. Philpott kindly gave me the only specinen he found in February, 1912.

\section{Group Hrlobitdae.}

Bryocatus gen. nov.

Minute, subovate, slightly convex.

Rostrum moderately arched and stout, never very slender, parallel, as long as thorax. Scrobes deep, lateral, beginning near the apex, and prolonged underneath to the eyes. Scape straight, inserted between the middle and apex and extending backwards to the front of the eye, slender at the base, gradually incrassate towards the extremity. Funiculus 6-articulate; basal joint obconical, stout, largest; the next much smaller, only slightly, sometimes not at all, longer than broad; joints 3-6 transrerse, gratually beenuing thicker. ('lub abmutly enlarged, oblomgoval, indistinetly triarticulate. Head short, narrowed anteriorly, globose belwe. Eyes just free from thorax, widely distant above, flat, rathere small, oblique, their greatest bulk from above downwards. Thorax oval, of about equal length and breadth, base and apex truneate, without ocular lobes. Scutellum absent or obsolete. Elytra emarginate and slightly broader than thorax at the base, and at least twice its length.

Legs moderately stout and elongate; femora subelarate, nearly stright below but arched above, unarmed; tibiae somewhat flexuous, with well-developed apical spurs, the intermediate and posterior with. in adrition, a small calcar at the outer as well as the inner extremity. 
Tarsi short, basal joint obconical, 2nd strongly transverse, penultimate broadly dilated and bilobed, the terminal short and thick, with small claws.

Prosternum emarginate in front, the coxae prominent and contiguous. Intermediate coxae moderately, the posterior widely separated. Metasternum short. Basal ventral segment subtruncate between the coxae, it as well as the 2nd rather large, but without any well-marked suture between them, 3rd and th short and, together, hardly half the length of the 5th.

The rather stout rostrum, small eyes, 6-jointed funiculus, rather elongate oviform thorax, the absence of the scutellum, and the peculiar armature of the tibiae form a combination of characters not met with in any genus of the group known to me. It should be placed near Eiratus.

\section{Bryocatus alternans sp. nov.}

Subopaque, fuscous, without inequalities of surface; legs fuscotestaceous, as are a vitta along the middle and each side of the thorax, the elytra with several specks formed apparently of minute pale setae; antennae and tarsi nigrescent, the rostrum sometimes reddish.

Thorax slightly longer than broad, feebly impressed and constricted in front, oval, with flat squamae, and moderately coarse shallow punctures. Elytra slightly broader behind the posterior femora than at the base, their sides, however, are nearly straight, though the declivity is much narrowed; their striae are rather deep and extend to the apices, but appear impunctate; the interstices are minutely asperate or rugose, the 3rd and 5th, and the suture, are broader than the others; under the microscope numerous minute flavescent setae can be seen.

Underside castaneo-rufous, with pale squamae. Metasternum and basal ventral segment depressed along the middle, the 2nd nearly as long as the 1st but sloping backwards and medially impressed, the 5th obtusely elevated at each side.

Length (rostrum inclusive), $2 \mathrm{~mm}$; breadth, $\frac{2}{3} \mathrm{~mm}$.

Curiosity Gully, near Rakaia Gorge. This remarkable little weevil, apparently very rare, was discovered during winter-6th July, 1912by Mr. T. Hall, under moss growing on the face of a rock.

Obs.-Since the above descriptions were prepared the following species have been discovered, also under moss.

\section{Bryocatus jugosus sp. nov}

Subovate, rather broad, uneven, opaque; fusco-piceous, the legs, but not the tarsi, light brown; thickly covered with minute, depressed, tanny-grey squamae.

Rostrum parallel, arched, evidently longer than the thorax, punctate and bearing some short setae in front. Thorax rather broader than long, widest near the middle, more abruptly narrowed in front than behind; uneven, with an irregular, interrupted ridge along each side of the middle, and rather coarsely and somewhat rugosely punctured. Elytra arcuate-emarginate, and but little broader than the thorax at the base, a third longer than it is, wider near the middle, posterior declivity vertical; they are striate, with more or less elevated interstices, the $3 \mathrm{rd}$ and 5 th broadest; the $3 \mathrm{rd}$ are ridged, but interrupted in the middle, in other specimens they are more irregular and nodose; the 5th are trinodose, the sides are also slightly uneven. 
Femora robust; anterior tibiae arched externally, a little thickened inwardly at the middle, and distinctly uncinate at the extremity.

Scape gradually incrassate, rather short, hardly attaining the eye; funiculus with a few dark setae, basal joint stout and about a third of the whole length, joints 2-4 small and subquadrate, 5th and 6th bead-like and transverse, broader and shorter than the preceding ones; club large, oblong-oval, indistinctly articulated.

Underside densely covered with greyish scales and a few slender setae. Prosternum deeply emarginate in front. Basal ventral segment longer than the next, the suture moderately definite, the 5th rather short, with a rotundate fovea at its extremity.

'The broader form, rough surface, shorter thorax, and vertical posterior declivity are sufficiently distinctive.

Length (rostrum inclusive), $2 \frac{1}{3} \mathrm{~mm}$. ; breadth, $1 \mathrm{~mm}$.

Bell Rock, near Methven. 'T'hree examples found by Mr. 'T'. Hall, under moss, 5th September, 1912.

\section{Bryocatus nodicollis sp. nov.}

Subovate, opaque, of a pale yellowish-chestnut hue, the squamae, or scale-like matter, on the elytral interstices slightly greyish, there are also a few distinct suberect grey setae; tarsi only a little infuscate, antennae darker but not nigrescent, the slender portion of the scape paler.

Rostrum parallel, arched, rather longer than the thorax; with a few fine greyish setae, those on the apparently impunctate apex more conspicuous. Thorax of about the same length and breadth, with moderately rounded sides, rather broader near the middle than elsewhere; no distinct punctation is visible, but on each side of the middle there is a somewhat flattened nodosity, and a little in advance there is another at each side, these are best seen from the front. Elytra obovate, a third longer than the thorax, emarginate at the base, and scarcely any wider than the thorax there, broader just before the middle, not vertical behind; they are striate, but not perceptibly punctate; the 3rd and 5th interstices are not distinctly broader than the others, and none are speckled.

Smaller than $B$. alternans, the rostrum rather shorter and thicker, the thorax shorter and with different sculpture, the elytra not at all straight-sided and with simple interstices; the scape is a little shorter, slender near the base but more clavate at the extremity; the tarsi are narrower, and the penultimate joint less expanded.

Length (rostrum inclusive), $1 \frac{3}{4} \mathrm{~mm}$. ; breadth, $\frac{2}{3} \mathrm{~mm}$.

Bell Rock. A single individual found amongst moss on the 15th September, 1912, by Mr. 'T. Hall.

\section{Bryocatus nigrirostris sp. nov.}

This resembles $B$. alternans, but the following disparities necessitate its separation:-

Rostrum nitid, nearly nude, subcarinate along the middle, rather more elongate, and slightly, though quite definitely, narrowed towards its base. Scape evidently longer and more slender throughout. 'Thorax broader, not longer than it is broad, for the most part fusco-testaceous, with an oblong blackish spot at each side of the middle, at the base, and with the greater part of each side similarly dark. 
Underside piceous, nearly glabrous. Metasternum and basal two ventril segments coarsely and closely punctate and impressed along the mirdle, jth segment nore finely sculptured, with short grey setae, about half of its surface occupied by a rotundate fovea.

Length (rostrum inclusive), $2 \frac{1}{3} \mathrm{~mm}$.; breadth, $\frac{2}{3} \mathrm{~mm}$.

Curiosity Gully, near Methven. Mr. 'T'. Hall obtained a pair of specimens from moss on the 6th August, 1912.

\section{Bryocatus amplus sp. nov.}

Subopaque, piceo-rufous, funiculus and tarsi nigrescent; unevenly covered with depressed, "pale tawny'grey squamae.

Rostrum stout, parallel, slightly longer than the thorax, nearly smootlı along the middle in front, its punctation irregular, moderately distinct but becoming shallow towards the base. Thorax widest and obtusely prominent before the middle, more obliquely narrowed in front than behind; moderately coarsely, but not deeply, and closely punctured, with minutely sculptured intervals, the length and breadth about equal. Elytra evidently broader than the thorax at the base, not twice its length, with gently rounded and gradually narrowed sirles, the posterior declivity subvertical; they are nearly plane along the middle but somewhat uneven towards the sides; with narrow, apparently impunctate striate, interstices punctite and slightly rugose, the 3rd rather broader than the inner ones, obtusely elevated near the base and subnodose at the summit of the declivity; near the middle of each elytron an oblique depression extends towards the shoulder, this interrupts the 5th and outer interstices, the 5 th otherwise would resemble the $3 \mathrm{rl}$; the declivity is narrowed and sharply striate.

Scape slightly flexuous, barely attaining the eye, and with a short but quite definite basal articulation; 211 joint of funiculus alnost as long and stout as the 1st, 3rd slightly longer than broad; joints 4-6 short and moniliform, rery gradually dilated; club large, indistinctly articulated. Legs normal.

Metasternum as long as the basal ventral segment, both broadly depressed, 5th nearly as long as the preceding two, with an oblong median fovea.

Very different from all the preceding species, about twice the size, the thorax proportionally shorter, the elytra much broader. There is a minute granule which inay represent the scutellum; it does not, however, so far as I can see, penetrate between the wing-cases. The short, bent, stalk-like articulation at the base of the scape is also peculiar.

Length (rostrum inclusive), $3 \frac{1}{2} \mathrm{~mm}$; breadth, $1 \frac{1}{2} \mathrm{~mm}$.

Pudding Hill, near Methven. One individual only, secured by .Yr. T. Hall on the 4th May, 1912.

\section{Group HAPLONYCHIDAF.}

3613. Geochus pyriformis sp. nov. Geochus Broun, Man. N.Z. Coleopt., p. 445 (Geophilus).

Convex, widest near posterior femora, rounded and subvertical behind, cridually narrowed anteriorly, nitid; sparingly and irregularly clothed with distinct, but not coarse, decumbent, straw-coloured setae; rostrum opaque, piceous, more rufescent at the tip, thorax and tarsi castaneo-rufous, elytra and antennae fulvescent, the club and legs iuscous: on each elytron a blackish mark extends from the midrle of the base as far as the hind thigh, it is then curred inwardly to the 
$3 \mathrm{rd}$ interstice, and near the side almost unites with al less distinct lateral mark.

Rostrum nearly plane, about half the length of the thorax, in front not as broad as the head, much narrowed behind, feebly tristaleate. Eres flat, with coarse facets, longitudinally oval, situated in front, on the upper surface, the interval between them not more than the width of each. Thorax slightly broader than long, widest at the base, where

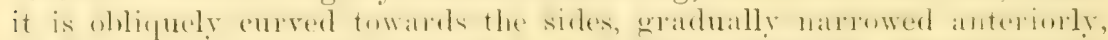

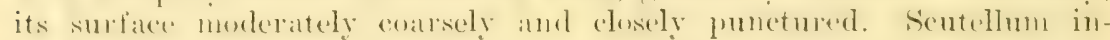
visible. Elytra twice the length of the thorax, the base arcuateemarginate, closely adapted to the thorax and no wider than it is there, but nearly twice as broad behind the middle, their sides are moderately rounded, but not at all explanate or margined, and considerably narrowed below and near the apices; each has jo dorsal, moderately coarsely punctured but not deep striae, and slightly elevated simple interstices.

Legs stout, with a few fine, rather short, decumbent grey setae, the hind pairs of tibiat with rellow outstanding cilia near the extremity, the anterior pair widest at the middle, and much narrowed externally towards the extremity, with small terminal spurs; tarsi normal.

Scape glabrous, implanted just before the middle and reaching the back of the eve, slightly curved, rather slender, but subclavate at the extremity; basal joint of funiculus considerably thicker but hardly longer than the 2nd, 3rd and 4th just a little longer than broad, 5th and 6 th bead-like, 7 th very slightly larger; club oblong-oval, finely pubescent, its 1st joint subtriangular, the next largest and subquadrate, the Brd narrower.

The pyriform contour, dark elytral marks, and the form and position of the eyes are its distinctive features.

Length (rostrum inclusive), $2 \frac{1}{2} \mathrm{~mm}$.; breadth, $1 \frac{1}{2} \mathrm{~mm}$.

Mount Hutt, near Methren. One, found amongst dead rata leaves on the ground, on the 12th April, 1912, by Mr. T. Hall.

\section{Geochus suffusus sp. nov.}

Subovate, moderately convex and shining; sparingly and irregularly clothed with distinct, but not coarse, suberect straw-coloured setae, which are most numerous, ret not concentrated, on the after part of the clytra; thorax almost wholly, elytra partly rufescent, the sides and parts of the dise of these latter more or less fusco-piceous, and usually with a fulvescent or reddish band just below the top of the posterior declivity; rostrum dull piceous, legs fuscous, tarsi and antennae fusco-rufous, the latter sometimes fulvescent.

Rostrum about half the length of the thorax, of normal shape, with 3 indistinct carinae which become convergent behind. Eves moderately large, coarsely granulate, extending to the sides of the head. Thorax rather broader than long, widest at the base, gradually narrowed towards the front, only obsoletely constrieted there, coarsely and elosely punctate, its base oblique towards the sides. Elytra closely applied to the thorax, of the same width as it is at the base, twice its length, their sides rounded, widest near the middle, the declivity subvertical; they are coarsely punctate-striate near the suture, and the interstices there are slightly elevated, near the sides the striae are less distinct.

Legs rather long, with slender and rather short decumbent greyish setae; anterior tibiae broad above, not angulate below the middle, 
narrowed towards the extremity, with small spurs; tarsi nblong, of normal structure. Antennae similar to those of $G$. pyriformis.

Ifanifestly different from $G$. pyriformis in shape and coloration, with larger eves, shorter thorax and rostrum, fe.

Underside subopaque, rufo-piceous, the last three dorsal segments rufous, with a few small slender grey setae, rather coarsely but not very closely punctured. Prosternum plane, without any trace of rostral canal, deeply and widely incurved in iront, the coxac widely separated, but not as far apart as the hind pairs. Metasternum very short, with a slight straight ridge in front. Basal segment of abdomen flat, subtruncate between the eoxae, medially sinuate behind, rather larger than the next, 3rd and 4 th with very deep straight sutures and, together, fully the length of the 5th. Nentum rather small, subquadrate, the peduncle transverse.

Length (rostrum inclusire), $2 \mathrm{~mm}$; breadth, 1-1 $\frac{1}{3} \mathrm{~mm}$.

Nount Hutt. About a dozen individuals secured by $\mathrm{Mr}_{\mathrm{r}} \mathrm{T} \mathrm{T}$. Hall on the 12th April, 1912. Found amongst leaf-mould.

\section{Geochus variegatus sp. nov.}

Nitid, for the most part light castaneo-rufous, the posterior declivity fuscous; across each elytion, near the hind thigh, a dark transverse spot appears depressed; rostrum and antennal club piceous; the setae are yellowish, very distinct, somewhat curled, more numerous and suberect across the commencement of the declivity.

Rostrum quite half the length of the thorax, dilated in front, contracted behind, finely tricarinate, opaque. Eyes moderately large, flat, extending to the sides of the head. Thorax nearly a third broader than long, rather wider at or behind the middle than it is at the base, somewhat contracted in front; moderately coarsely and closely punctate, with a slight ridge along its anterior portion. Elytra twice the length of the thorax, nearly double its width near the mirldle, their sides rounded so as hardly to exceed the breadth of the thorax at the base, the declivity subvertical and obliquely narrowed at its sides; dise somewhat flattened but a little uneven, with broad, coarsely punctured striae, and irregularly elevated interstices which, across the top of the hind declivity, are more or less evidently nodiform, the declivity itself is more finely, yet quite definitely punctate-striate.

Legs stout, femora with fine depressed setae, those on the tibae erect; anterior tibiae thick, obliquely narrowed externally below the middle.

Antennae of normal structure.

Though nearly similar to $G$. posticalis, 3291, this may be separated therefrom by the brighter appearance, the elytra being fulvescent, they are also abruptly broader than the thorax, and have more definite striae and interstices.

Length (rostrum inclusive), 2-21 $\mathrm{mm}$; ; breadth, $1 \frac{1}{2} \mathrm{~mm}$.

Mount Hutt and Pudding Hill. One from each of these places; both

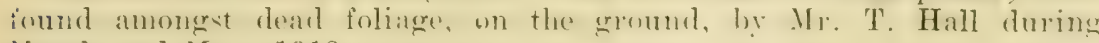
Ilarch and IIay, 1912.

\section{Geochus distinguens sp. nov.}

Conver, nitid, broadest behind the shoulders; mostly chestnut-red, the sides and front of the thorax, the sutule, a pair of transverse marks, and a large apical triangular mark an each elrtron, more or less dark brown; legs dull fuscous, antennae fulvescent; the setae rellow, distinct, 
rather thinly and evenly distributed, mostly decumbent, fine and greyish on the legs.

Rostrum quite half the length of the thorax, contracted near the uniddle, obsoletely tricarinate. Eyes large, nearly flat, with coarse facets, extending to the sides of the head. Thorax a third broader than long, widest at the base, distinctly but not abruptly narrowed before the middle; moderately finely and rather distantly punctured, with a smooth, indistinctly elevated line along the middle. Elytra widely areuate-emarginate at the base, of the same width there as the thorax, double its length, broader and more convex just behind the oblique shoulders than they are elsewhere, curvedly narrowed behind, the dorsum sloping backwards; they have series of rather distant moderate punctures, some of the interstices are slightly elevated near the base but not on the dark spots, which seem depressed, the declivity is striate.

Legs thick, anterior tibiae obliquely narrowed close to the extremity, not at all prominent externally at the middle. 'Tarsi and antennae like those of $G$. pyriformis.

No similar species has been described.

Length (rostrum inclusive), $2 \mathrm{~mm}$. ; breadth, $1 \frac{1}{2} \mathrm{~mm}$.

Epsom, on the lower slope of Mount Eden, Auckland. A solitary individual found by me on the 12 th February, 1912, amongst decaying leares on the scoria, which at that place is exceedingly rough.

\section{Geochus lateralis sp. nov.}

Nitid, castaneo-rufous, the middle of each elytron sometimes infuscate, antennae fulvescent; sparingly clothed with distinct yellowish setae, which on the thorax are depressed, on the elytra suberect; the body widest just behind the posterior femora, moderately conrex along the middle, elytra somewhat flattened towards the sides and apex.

Rostrum evidently shorter than the thorax, broad, narrowed behind, opaque, indistinctly tricarinate. Eyes flat, of moderate size, reaching the sides of the head. Thorax nearly a third broader than long, widest at the base, which is oblique at each side of the middle; it is much narrowed towards the front, and distinctly but not elosely punctate. Elytra of the same width as the thorax at the base, closely fitted to it, and nearly twice its length; their sides are flattened, very distinctly margined, moderately rounded, gradually expanded; the declivity not quite vertical, considerably narrowed but not margined; they are moderately coarsely seriate-punctate, substriate behind.

Scape glabrous, clavate at extremity; funiculus very thinly and finely pubescent, 2nd joint of about the same length as the 1st but much more slender, joints 3-5 short, 6th and 7th rather larger; club distinctly pubescent and articulated, elongate-oval.

Anterior tibiae slightly prominent above the middle, gradually narrowed towards the extremity.

Underside slightly nitid, with a few short, slender setae; the breast and basal abdominal segment coarsely but rather distantly punctured, remaining segments minutely and densely sculptured. Prosternum plane. Metasternum short, with a straight ridge across its front. Basal rentral segruent on a slightly higher level thin the end, truncate between the coxae, slightly incurved behind.

The sharply marked elytral margins, the absence of nodiform elevations on the interstices, the more convex basal ventral segment, and difierent tibiae distinguish this from the northern $G$. marginalis, 2541. 
Length (rostrum inclusive), $1 \frac{2}{3} \mathrm{~mm}$. ; breadth, $1 \frac{1}{3} \mathrm{~mm}$.

Mount Hutt, near Methren. Found on the ground amongst decaying leaves, 23rd April, 1912, by Mr. 'T'. Hall.

\section{Group Erminidate}

3618. Erirhinus sylvaticus sp. nov. Erirhinus Schoenherr, Man. N.Z. Coleopt., p. 449.

Elongate, suborate, moderately convex and nitid; castaneous, thorax paler along the middle and sides, rostrum piceous; legs fuso-testaceous, the tips of the femora and tibiae a little darker, antennae obscurely fulvescent, elub fuscous; sparingly elothed with inconspicuous, slender, somewhat curled yellowish setae.

Rostrum quite as long as the thorax, moderately stout and arched, its anterior half slightly expanded, substriate-punctate. Head immersed up to the eyes, globose below. Thorax very slightly longer than broad, a little constricted in front, its sides nearly straight, the apex truncate, base nearly so; it is moderately coarsely and closely punctured. Elytra nearly double the length of the thorax, each elytron oblique at the base, so that the shoulders, though obtuse, appear slightly prominent, their sides are feebly rounded, but behind gradually narrowed; they are regularly and moderately coarsely striate-punctate, more distinctly striate near the suture and behind, with rather narrow interstices.

Legs robust, femora simple, anterior tibiae minutely mucronate, the posterior somewhat bent inwardly; penultimate tarsal joints bilobed but only slightly dilated.

Scape moderately slender, very gently incrassate towards the extremity, inserted half-way between the middle and apex and attaining the front of the eye; basal joint of funiculus stout, narrowed towards its base, as long as the following three united, 2nd rather longer than broad, joints 3-6 subquadrate, 7th more moniliform and shorter; club large and broad, oblong-oval, triarticulate, densely pubescent.

In form and general appearance like 2917, E. spadiceus, but considerably smaller, with the tibiae not at all strongly mucronate. The scrobes are just perceptible above, in front. The eyes are flat and obliquely oval. There are no ocular lobes. The scutellum is obsolete or altogether absent. 'The club is abruptly marked.

Length (rostrum exclusive), $2 \mathrm{~mm}$. ; breadth, nearly $1 \mathrm{~mm}$.

MoClennan's Bush, near Methven, A single specimen found by Mr. 'T. Hall on the 23rd April, 1912.

3619. Dorytomus fulvescens sp. nov. Dorytomus Stephens, Man. N.Z. Coleopt., p. 453.

Elongate, only slightly convex, moderately shining, uniformly fulvescent, sparingly clothed with rather short, slender yellowish setae.

Rostrum arched, slender, parallel, more than twice the length of the thorax; finely and distantly punctured in front, substriate-punctate behind. Thorax a third broader than long, rounded and widest at the middle, more gradually narrowed in front than behind, base and apex truncate; distinctly and moderately closey punctate. Scutellum suboblong. Elytra very slightly oblique at the base towards the obtuse shoulders, rather broader than the middle of the thorax, almost four times its length, with singly rounded apices; regularly and distinctly striate-punctate, the interstices bent at or near the extremity and minutely but obsoletely punctured. 
l.egs moderately stout, all the femorat angulate and moderately dentate mderneath; tibiate slightly flexuous and mucronate; tarsi setose underneath, :3rel joint dilated and deeply bilobed, the teminal longer than the 1st: elaws appendienlate at the base.

Scape slender, medially inserted, barely reaching the eye; basal joint of funiculus largest, narrowed towards its base, 2nd evidently more slember and sherter but distinetly longer than the mest, joints f 6 moniliform, The broater than its predecessors; club oblong-oval, indistinctly qualliartienlate.

There are no ocular lobes. Eyes obliquely oval, with distinet facets. Inndibles slightly prominent, eurved externally, acute at the extremity. Palpi risible above.

Somewhat similar to the North Island D. merinus, 3295, but more flavescent, with narrower eyes, the sides of the thorax more strongly rounded, with less distinetly striate elytra, the posterior tibiae less bent and incrassate, and with differently formed antennal joints.

․ Length (rostrum exclusive), $2 \frac{2}{3} \mathrm{~mm}$; ; brendth, $1 \frac{1}{4} \mathrm{~mm}$.

Hump Ridge, near Invercargill. Unique. Discovered by Mr. A. Philpott in fiebruary, 1912.

\section{Dorytomus melastictus sp. nov.}

Elongate-ovate, slightly convex, subopaque; pale testaceous, the rostrum, antennae, and tarsi slightly fulvescent; a streak along the middle of the thorax, but not reaching the apex, and a rotundate spot midway between it and each side nigro-fuscous, between the hind thighs there are 6 rlark, less sharply marked spots; elytra thickly covered with decumbent, rather coarse and moderately elongate, pale-yellowish setae, those on the thorax more slenter and elongate, of a brigher rellow, and arranged transversely.

Rostrum rather longer than the thorax, moderately slender, arched. parallel; smooth but not distinctly earinate along the middle, seriatepunctate at the sides. Thorax slightly broader than long, rounded and wislest at or just before the midille, eomsiderably narrowed in front: morlerately but not elosely punctured. Scutellum oblong. Elytra with obtuse shoulders, not quite truncate at the base, broader than the thorax there, nearly thrice its length, gradually narrowed posteriorly, with indiridually rounded apices; they are striate-punctate, their sculpture, howerer, is rendered indefinite by the restiture; interstices minutely punctured, the internediate terminate abruptly at the commencement of the hind slope, they are not nodiform there, but just below them there appears to be a depression on each elytron. Pygidium exposed, rather broad. closely punctate and fincly setose.

Femora clavate and angulate underneath, the hind pairs more dentiform than the anterior; tibiae mueronate and somewhat flexuous, the front pair rather longer than the others; penultimate tarsal joints widely bilobed; claws subdentate at the base.

Scape slender, thicker near the extremity, incerted near the apex and just attaining the front of the ere; basal joint of the funicle largest, $2 n$ slender and evidently dorter; joints $3-6$ diminish, the 7 th rather shorter and broader; club quadriarticulate, oblong-oral.

Underside testacenus, but a streak along cach side of the prosternum. the sides of the metasternum and lst abdominal segment and a large portion of segments 2-4 are nigrescent. Metasternum depressed and sulente along the middlc, rather longer than the 1st segment, which is 
broadly medially impressed, and rounded between the coxae, 2nd hardly as long as the 3rd and th combined, the 5th longer, subtruncate at the apex, broadly impressed in the middle, 6th short.

More like $D$. sudus, 1255, from the far north, than any other species; rather larger, differently marked, with more robust legs, longer antennae, more elongate and almost euneiform elytra. The exposure of the prgidimm is a very unusual character.

o. Length (rostrum exclusive), $3 \frac{1}{2} \mathrm{~mm}$; ; breadth, quite $1 \frac{1}{3} \mathrm{~mm}$.

Mount Hutt, near Methven. 'T'wo speeimens found by Mr. T. Hall, at an elevation of $3,500 \mathrm{ft}$, on I th February, 1912.

\section{Dorytomus albisetosus sp. nov.}

Elongate, slightly convex and nitid; nigro-fuscous, legs and funiculus paler, scape testaceous; irregularly covered with decumbent, distinct, almost white, and a few less conspicuous flavescent setae, those on the thorax more slender and disposed transversely.

Rostrum moderately slender, subparallel, arched, longer than the thorax; substriate-punctate, nearly smooth in front. Head retracted up to the eyes, globose below. 'Thorax a third broader than long, base and apex truncate, its sides rounded, rather more narrowed in front than behind; moderately finely but not closely punctured, and, owing to the clothing, appearing somewhat transversely rugose. Scutellum small but rlistinct, subrotundate. Elytra thrice the length of the thorax, rather broader than it is at the base, their sides nearly straight as far as the middle, gradually narrowed posteriorly; distinctly striate-punctate, interstices with minute serial punetures.

Legs stout; anterior femora subclavate, the other pairs angulate and minutely dentate below; tibiae flexuous and mucronate; penultimate tarsal joints moderately expander and bilobed; the claws appendiculate at the base.

Scape inserted midway between the middle and apex, extending to the front of the eye, rather slender and flexuous and thickened near the extremity; basal joint of funiculus pale, stout, largest, as long as the following two combined, narrowed towards the base, 2nd of similar form but much more slender, joints $3-6$ short and subequal, Tth transverse and bearl-like; club olblong-rval, densely hairr, inrlistinctly artienlaterl.

Eyes subrotundate, inwardly truncate. Without ocular lobes.

II ypotagea variegata, 806, most nearly resembles it in facies.

Length (rostrum exclusive), $2 \frac{1}{3} \mathrm{~mm}$; ; breadth, $1 \mathrm{~mm}$.

Curiosity Gully, near Methren. One found by Mr. T. Hall on the 9 th September. 1912.

3622. Dorytomus terrestris sp. nov.

Elongate, slightly convex and nitid; obscure fusco-rufous, legs fuscotestaceous, funiculus and club more or less infuscate; elytra thickly covered with decumbent rather coarse rellowish-grey setae, the thorax with more slender and elongate irregularly arranged pubescence.

Rostrum shining, double the length of the thorax, rather slender, arched, parallel, seriate-punctate behind, nearly smooth in front. Thorax slightly constricted and impressed in front, a little broader than long, its sides gently rounded; distincty and noderately closely juncturer. Scutellum subtriangular. Elytia oblong, more than twice the length of the thorax, broader than it is, feehly biareuate at the base. curvedly narrowed behind; regularly and distinctly striate-punctate, interstices minutely punctate. 
Legs stout; femora morlerately clavate, all minutely dentate underneath; anterior tibiae nearly straight, finely mucronate; tarsi normal, claws appendiculate.

Seape slender and elongate, inserted hohind the middle and just reaching the front of the eye; basal joint of funiculus very elongate and gradually thickencel, 2nd also clongate, vet little more than half the length of the 1st; joints 3, 4 , and 6 rather longer than broad, 7 th wather shorter than preceding ones; club very elongate and rather narrow, about as long as joints $t-7$ of the funicle combined, quadriarticulate, densely pubescent.

Eyes moderately large, not at all prominent, nearly obliquely oval. No ocular lobes.

Another ally of $D$. maorinus, 3295, but less parallel and elongate, and at once recognized by the thickly and rather coarsely clothed hindbody. The antennal insertion differs and the club is more elongate. 'The elrtra are shorter and froarder, and the interstices are much less sharply defined. In all these speeies the front legs are rather longer than the others.

ㅇ. Length (rostrum exclusire), $3 \mathrm{~mm}$. ; breadth, nearly $1 \frac{1}{2} \mathrm{~mm}$.

Rakaia Gorge, near Ifethen. I have seen two specimens, both found by $\mathrm{Mr}$. 'T'. Hall during June, 1912, amongst decaying leaves on the ground.

\section{Dorytomus floricola sp. nov.}

Elongate, subovate, slightly convex, subopaque; fuscous, legs fuscotestaceous, scape somewhat fulvescent; elytra thickly clothed with yellowish-grey, decumbent, hair-iike scales or setae, which render the rather ill-defined maculation still more obsenre; the setae on the thorax are slender and disposed transversely.

Rostrum parallel, moderately stout and arched, a third longer than the thorax, not at all dilated towards the extremity, punctate along the sides, with fine, rather indistinct setae, those on the head coarse. Thorax a third broader than long, its sides but little rounded, more narrowed, but not abruptly, in front than hehind, distinctly but not very elosely punctured. Scutellum distinet. Elytra oblong, slightly emarginate at the base, broader there than the thorax, quite twice its length; they are moderately finely punctate-striate; interstices nearly plane, finely punctured, the $3 \mathrm{rd}$ and 5 th confluent, somewhat thickened and prominent at the commencement of the hind slope; a large testaceous space extends backwards from each shoulder and then inwardly to the suture, there is also a median one behind, these, however, are not very definite.

Scape inserted near the apex, rather slender, attaining the front of the eye; basal joint of funiculus largest, incrassate at apex, 2nd slender and a little longer than the next, $4-6$ nearly equal, 7 th slightly bronder and moniliform; club oblong-oval, triarticulate.

Femora angulate below, the hind pairs also minutely dentiform; tibiae stout, nearly straight, mueronate; tarsi finely setose underneath. claws subdentate.

Underside nitid, piceous, moderately and distantly punctate, 5th segment more closely. Metasternum somewhat rugose and flattened in the middle; basal segment rather longer than the 2nd, both flat in the middle, their suture sinuate, 3rd and 4th together as long as the basal. 5th truncate behind, 6th very short, concave at the base. Setae distinct. greyish. 
Fem.-Rostrum rather longer and more slender, smooth along the middle, punctate at the sides, nearly glabrous, scape implanted before the middle.

The scale-like vestiture of the elytra, and their rather vague markings, will aid in identification.

$\hat{o}$. Length (rostrum exclusive), $2 \frac{3}{4} \mathrm{~mm}$. ; breadth, $1 \frac{1}{3} \mathrm{~mm}$.

liakita rorge. Shaken off Howering-shrubs by Mr. T. Hall on the 20th Novemler, 1912. Two males and one female.

3624. Neomycta seticeps sp. nov. Neomycta Pascoe, Man. N.Z. Coleopt, p. 457.

Nitid, rufescent, legs and scape fulvescent, funiculus infuscate; elytra with distinct suberect grey setae, those on the thorax elongate, much more slender and decumbent, the head with coarse white setae.

Rostrum as long as the thorax, moderately and gradually expanded towards the extremity, indistinctly bicarinate, and seriate-punctate Head broader than long, punctate. Thorax subquadrate, only slightly broader than long, its sides gently roumderd, distinctly and elosely punetured. Ficutellum triangular. Elytra oblong, evidently broader than the thorax, nearly thrice its length, curvedly narrowed behind; disc slightly conver, regularly and distinctly striate-punctate, with simple interstices.

Legs moderately elongate and stout, the anterior rather longer than the others; front femora with a minute denticle underneath, the others subangulate; tibiae mucronate at the extremity, the hind pairs flexuous.

Scape inserted near the apex and reaching the eye, gradually incras sate; basal joint of the funiculus paler and larger than the others, narrowed towards its base; 2nd slender, shorter than the ist but longer than the next, joints 3-6 slightly decrease, 7th bead-like but not broader than long; club oblong-oval, triarticulate.

Unclerside chestnut-red, with grey hairs, distinctly and distantly punctate, the prosternum closely. Anterior coxae contiguous, large and prominent, leaving only a short space uncovered either before or behind them. Metasternum as long as the basal two segments united; 1st segment strongly rounded between the coxae, sinuate behind, the next rather shorter and not quite as long as the 3rd and 4th together.

The scrobes are slightly open and visible above. Eyes rotundate, slightly prominent, and nearly as far from the thorax as they are from each other. Without ocular lobes.

This species is of a darker red than any part of Pascoe's $N$. pulicaris, 807 , but not as dark as 808 , with whiter and slightly coarser setae, on the head especially. The rostrum is broader and dilated in front, and the sides of the thorax are less rounded.

o. Length (rostrum exclusive), $2 \frac{1}{2} \mathrm{~mm}$.; breadth, quite $1 \mathrm{~mm}$.

Mount Hutt, near Methren. Änother unique from Mr. T. Hall, found at a height of $3,500 \mathrm{ft}$. on the 14th February, 1912. From the same source several of 807 have been received.

3625. Alloprocas muticus sp. nov. Alloprocas Broun, IIan. X.7. Coleopt.. p. 1375 .

Oblong, slightly convex and nitid; with slender yellowish-grey setae, these are decumbent on the head and thorax, but suberect and rather shorter on the hind-body; fusco-testaceous, rostrum, antennae, and legs faintly rufescent, the lower half of the front tibiac distinctly nigrescent, the other pairs less so. 
Rostrum moderatcly stout and arehed, subparallel, as long as the thorax, nearly smooth in flont, seriate-punctate behind. Head inserted ip to the cres. Thorax nearly as long as broad, a little narrower in hont than behind, its sides but little rounder, base and apex truncate; its punctation close but only moderately coass. Scutellum oblong, punctate. Elytra oblong, with obtuse shoulders, broader than the thorax, more than double its length; regularly and distinctly striateminctate, the interstices with fine serial punctures.

Femora marmed, tibiae mueronate, the anterior ratler longer than the hind pair; penultimate tarsal joints widely bilobed; claws appendieulate.

Scape rather slender, implanted near the apex and attaining the front of the cre; basal joint of the funicle largest, joints $2-5$ successively decrease, all, howcrer, are longer than broad, the 2nd shorter than the 1st, fith and Tth moniliform but not transrerse; club elongateoral, quadriarticulate, densely pubescent and fuscous.

Underside fusco-testaceous, moderately but not closely punctate, with greyish setae. Metasternum rather longer than the basal segment of the abdomen, which latter is subangulate between the coxae and somewhat sinuate behind, 2nd rather shorter, hardly longer than the 3rd and 4th together. The merlian emargination of the prostermum, in front, has dentiform ingles.

Eyes rotundate, rather large, just free, with distinct facets, situated almost entirely on the upper surface. Ocular lobes absent.

More robust than A. rufus, 2399, the coloration altogether paler, and differentiated from all the pecies of closely allied genera by the nigrescent lower half of the anterior tibiae.

Length (rostrum exclusive), $3 \frac{1}{2} \mathrm{~mm}$. ; breadth, $1 \frac{1}{2} \mathrm{~nm}$.

Hump lidge, ncar Invereargill. Two examples found by Ir. A. Plilpott in Februar, 1912.

\section{Simachus cuneipennis sp. nov. Simachus Broun, Man. N.7. Coleopt., p. 963.}

Elongate, subfusiform, only slightly convex and nitid; castaneofuscous, rostrum rufescent, legs and antennae more or less fusco-rufous, club piceous; pubeseence grer, distinet and lecumbent, more slender and disposed transversely on the thorax.

Rostrum arched, slender, longer than the thorax, striate-punctate behind, more finely and distantly punctured in front. Head immersed up to the eres, globose underneath. Thorax truncate at the base and apex, rather broader than long, its sides moderately rounded, widest near the middle: distinctly punctured, more closely near the sides than on the middle. Sentellum small. Glytra nearly thrice the length of the thorax, ratler wider than it is at the hase, gradually narrowed towards the obtuse extremity; they are distinctly and moderately closely substriate-punctate, with simple interstices.

Femora subclivate but manmed; tibiale gently expanded towards the extrenity, quite mutic there. 'larsi fincly setose underneath, penultimate joints moderately dilated and bilobed, the terminal longer than the basal; claws appendiculate at the base.

Scape slender, incrassate at the apex, implanted just before the middle and reaching the ere. Funiculus firticulate, basal joint stont, twice as long as broad, narrowerl towards the base; 2nd smaller, yet rather longer than broad, sid subpuadrate, th and ith moniliform 
and slightly shorter, 6th transverse, broader than preceding ones; club large, ovate, oĺsoletely triarticulate.

Underside rufo-fuscous, distinctly but not closely punctate, with slender grey setae. Prosternum widely emarginate in front. Metasternum half as long as broad. Basal ventral segment slightly longer

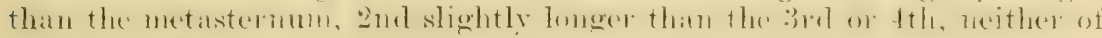
which is abbreviated, being together as long as the lst.

Evidently more slender than S. montanus, 1739, the pubescence grey instead of being yellow, the rostrum more slender, the antennal insertion rather further from the anex, the sentellum less distinet, and the elytra more elongate but not distinctly striate.

Length (rostrum exclusive), $2 \frac{1}{3}$ mmi. ; hreadth, $\frac{3}{4} m m$.

Moment Hutt, near Methven. Five individuals fonnd by Mr. T. Hall during February and March, 1912, at an altitude of $3,500 \mathrm{ft}$.

\section{Etheophanus punctiventris sp. nov. Etheophanus Brom, Minn.} N.Z. Coleopt., p. 1232.

Compact, convex, subovate, niticl; rufescent; the rostrum, base of thorax, an interrupted band across the hinder part of the elytra, and the posterior declivity fusco-piceous; antennae and tarsi pale ferruginous or fulvescent; sparingly elother with slender, suberect, flavescent, and numerous upright fuscous setae.

Rostrum quite as long as the thorax, very slightly broader in front than behind, longitudinally ruguse, but not definitely eallinate of striate. Head inserted up to the oblique transrerse eyes. 'Thorax of about equal length and breath, nore, ret gradually, narrowed in fiont than behind, only slightly broader near the middle than at the base; moderately coarsely and closely punctured, more finely in front, with searcely any slender subdepressed setae. Elytra nearly twice as broad and long as

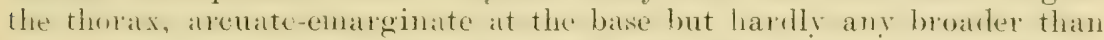
the thorax there, their sides rounded, the himd dedivity subvertical; they are rather coarsely striate-punctate, with about 6 punctures only in each of the dorsal striae.

Femora stout and elongate, and, like the tibine, with coarse outstanding setae; penultimate tirsal joints broadly expanded and bilobed.

Scape inserted near the apex and barely reaching the eye, incrassate near the extremity; 2nd joint of funiculus slender and shorter than the basal, 3rd and th subquadrate, $5-7$ shorter and broader; elub finely pubescent, short, ovate, indistinctly articulate.

Underside nearly plane, fuscous, terminal ventral segment rufescent, with numerous depressed slender yellowish setae. Prosternum deeply emarginate in front; anterior coxile slighty separated, the posterior very widely. Metasternum very short, truncate behind. Basal ventral segment largest, rather coarsely and closely punctate, 2nd rather shorter and less closely punctured, its frontal suture distinct and sinuate; the next two short, with deep sutures, the Jth shorter than the preceding two combined, with about 6 coarse punctures.

Distinguishable from $E$. pinguis, 2171, by the coarse seulpture of the under-surface and subcontiguous front eoxac; and from E. striatus, 3138, by the more shining surface, rather narrower form, distinct elytral punctation, almost complete absence of the finer restiture, and the less elongate erect setae.

Length (rostrum exclusive), $2 \mathrm{~mm}$; breadth, $1.1 \mathrm{~mm}$. 
Mount Hutt, and McClennan's Bush, near Methven. Apparently rane, three specincms only having been found by Mr. T'. IIall, during March and April, 1912, amongst dead leaves on the ground.

\section{Colabotelus gen. nov.}

Rostrum slightly arched, fully as long as the head and thorax combined, half the wielth of the head, parallel. Mamdibles porrect, not curvate. Serobes subloveitorn, visible abore, situiter between the middle and apex, not perceptibly prolonged backwards. Seape slender, straight, attaining the front of the eye. Funiculus 7-articulate, basal two joints equally domgate, juints : $3-T$ grallually decrease in length, all longer than broad. (Mub elongate-oval, triarticulate. Head short. Lyes rotundate, moderately large and prominent, more widely distant from each other than they are from the thoracic margin. 'Thorax without ocular lobes, base and apex truncate, sometimes broader than long, moderately constricted in front. Scutellum triangular. Elytra broader than thorax at the base, attenuate posteriorly, with rounded apices. Prgidium exposed.

Femora elongate, moderately clavate, unamed. Tibiae simple. 'larsi with squamose soles; elongate, their basal joint longer than 2 nd, srd unexpanded, eleft to the base, the terminal slender, nearly the length of the others taken together. Claws large, thickened near the base.

Mentum large, oblong, filling the buccal cavity, but leaving the rigid palpi exposed. Prosternum medially convex, coxae prominent and contiguous; the intermediate coxae evidently, the posterior widely separated. Metasternum moderately elongate. Abdomen elongate, basal segment as long as the metasternum, slightly longer than the next, subtruncate between the coxae, medially sinuate behind; $3 \mathrm{rd}$ and 4 th together longer than the 2 nd and as long as the cuneiform 5th.

The exposure of the pygidium is of rare oceurrence even in Exugnomus and IIoplocneme; both of these, however, have strongly dentate femora.

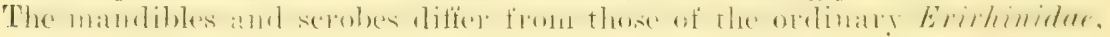
in which group, nevertheless, this genus should be located.

\section{Colabotelus dealbatus sp. nov.}

Opaque, moderately convex; piceous, densely covered with depressed, mostly eireular squamae, greyish, pale chocolate, and tawny, the dark ones usually cover a large irregular space before, and another behind, the middle of the elytra, and a portion of the thorax; antennae and legs fusco-rufous.

Rostrum with a slight carina along the middle, its punctation rather

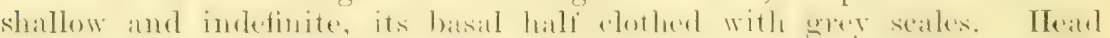

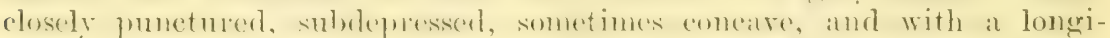
tudinal groove between the eyes, near the front and inner part of each of these a minute crest is visible. 'Thorax slightly broader than long, a good deal narrowed or constricted in front, distinctly and elosely punctured, with a slight ridge along the middle. Elytra about thrice the length of the thorax, evidently broader than it is at the base, gradually narrowed backwards, with distinct, regular, closely punctured striae.

Scape and basal joints of the funiculus more or less finely squamose, remaining joints sparingly setose.

Underside piceous, covered with almost quite white oval scales, the terminal ventral segment fringed with greyish setae at the extremity. 
The male is rather smaller, its rostrum is rather shorter, and the thorax is a third broader than long.

f. Length (rostrum exclusive), $4 \mathrm{~mm}$; ; breadth, $1 \frac{1}{2} \mathrm{~mm}$.

Alexandra. Three examples were kindly placed at my disposal by Mr. A. C. O'Connor. 'They were found on the 12 th December, 1911.

\section{Hoplocneme propinqua sp. nov. Hoplocneme IThite, Han. X.Z. Coleopt., p. 461.}

Body moderately nitid, very thinly clothed with short, fine, cinereous hairs; cyaneous, antennae and femora piceous, the tibiae and tarsi more rufescent.

Rostrum slightly longer than the head, half its width, with a few distinet punctures. Head subquadrate, not as broad as it is long, with obtuse angles; very distinctly punctate, rather distantly on the middle. Eyes widely separated above, slightly prominent, only moderately large. Thorax of nearly equal length and breadth, constricted in front, very gently widened backwards; closely and rather coarsely punctured, with narrow, somewhat transversely rugose intervals. Scutellum distinet. Elytra oblong, with rounded apices, twice the width of the thorax at the base and four times its length; their punctation is not quite seriate, it is ats coarse as that of the thorax, but becomes less definite behind, the intervals though small are distinct and smooth. Pygidium nigrescent, punctate.

Scape slender, very gradually thickened, almost reaching the back of the head; funiculus rather shorter, basal joint evidently the largest, 2nd slightly longer than broad, joints 3-6 small and subquadrate; club as long as joints 2-6 of the funiculus united, finely pubescent, quadriarticulate, the terminal joint small. Posterior femora dilated, strongly angulate and dentiform underneath; the other pairs simple.

The trpe of the genus, II. hookeri, 818, is larger, its eyes are twice as large, and the elytra are regularly striate-punctate: $H$. punctatissima, 819 , is deusely punctured, the punctures on the elytra are irregularly crowded together without smooth interstices.

Length (rostrum inclusive), $3 \frac{1}{2} \mathrm{~nm}$. ; breadth, $1 \frac{1}{5} \mathrm{~mm}$.

MeClennan's Bush, near Methren. A single individual taken by Mr. T. Hall on the 15th March, 1912.

\section{Oreocharis carinulata sp. nov. Oreocharis Broun, Man. N.Z. Coleopt., p. 864.}

Elongate, subovate, moderately convex, somewhat nitid; nigrescent, the scape, lnees, and tarsi more or less castaneo-rufous; the squanae depressed, rather coarse, nearly pure white, mevenly distributed, and intermingled with slender cinereous setae.

Rostrum rather longer than thorax, but not half its breadth, slightly arched, subparallel, moderately coarsely punctate. Head of about equal length and breadth, narrowed anteriorly. Thorax subconical, about as long as it is broad; distinetly but not very closely punctured, the seales somewhat concentrated along the middle and sides. Seutellum distinet, squamose. Elytra evidently broader than the thorax at the base and fully twice its length, narrowed posteriorly, their rounded apices not covering the pygidium; they are striate-punctate, and each elytron is more or less distinctly bicarinate.

Scape sparingly pubescent, attaining the back of the eye. Funiculus slender, shorter than the seape; basal joint stout, largest, about as long 
as the 2nd and 3rit combined, both of these suboblong, 4th to 6th transverse; club oblong-oral, almost equalling the funiculus in length, its 3rd joint as long as both of the basal ones but not perceptibly annulate.

liemora elongate, the anterior simple, the intermediate obtusely, the posterior acutely angulate underneath; hind tibiae scarcely at all dilated.

Eyes only moderately prominent, almost is distant from the thorax as they are from each other. 'Thorax without ocular lobes.

Underside with elongate white scales; 5th ventral segment as long as the preceding three together.

This bears some resemblance to 2164 and 3300 only; both of these, however, are double its size, they are quite dull, with strongly angulate and dentiform posterior femora, and neither has carinate elytra.

ㅇ. Length (rostrum exclusive), $3 \frac{1}{4} \mathrm{~mm}$.; breadth, $1 \frac{1}{4} \mathrm{~mm}$.

Hump Ridge, near Invereargill. Two were obtained by Mr. A. Philpott in February, 1912, the male, measuring $2 \frac{3}{4} \mathrm{~mm}$. by $1 \mathrm{~mm}$., has been returned to him.

\section{Oreocharis latipennis sp. nov.}

Subopaque, rufo-eastaneous; the head, all but the rufeseent apical portion of the rostrum, the elub, and the terminal joint of the tarsi more or less piceous, antennae infuscate; sparingly clothed with slender, deemmbent, yellowish-grey setre, and a few elongate, grer, scattered squamiate.

Rostrum as long as thorix, a little arched, quite half the width of the hear, slightly constrieted behind the antennal insertion, rugosely punctate. Head unimpressed, moderately coarsely punctured. Thorax slightly broader than long, a little constrieted near the apex; its punctation rather coarse and close. Scutellum oblong. Elytra fully thrice the length of the thorax, almost double its width at the base, with straight sides to beyond the posterior femora, their apices rounded and learing uncovered the testaceous prgidium; they are punctate-striate, with closely asperate interstices; on the top of the hind slope of each, on the ind interstice, there is a very small dark crest, and behind this the surface is irregularly infuscate.

Femora elongate, the anterior simple, the intermediate notehed near the extremity molerneath; the posterior more elongate and armed with a very prominent dentiform angulation, the tibiae of this pair somewhat arehed and dilated along the front below the middle.

Antennae slender; funiculus shorter than the scape, its basal joint largest, 2nd rather longer than $3 r d$, joints 4-6 small; club large, oblong, almost the length of the funicle, its $3 r d$ joint apparently entire and longer than the preceding ones combined.

Nore opaque than $O$. mirriceps, 1540, with different vestiture, the elvtra not narrowed before the posterior declivity, their interstices rough, the antennae more slender, fo.

length (rostrum exelusive), $3 \frac{1}{3} \mathrm{~mm}$; ; breadth, $1 \frac{1}{2} \mathrm{~mm}$.

Ionnt Hutt, near Methren. One found by Mr. 'T?. Hill, at an altitude of $3,500 \mathrm{ft}$. , on the 30 th Narch, 1912.

\section{Oreocharis lineirostris sp. nov.}

Elongate, slightly nitid, fulvescent, head and thorax reddish, club only a little infuscate; pubescence very distinct, not slender, rellowishgrey, thorax with a few white scales along the middle, sentellum similarly squamose. 
Rostrum fully the length of the thorax, more than half the width of the head, a little narrowed between the antennae and the middle; more finely punctured than the head, slightly flattened alome the midelle, this part bordered at each side by a slender line. Head rather narrow and closely punctate. Thorax as long as it is broad, moderately constricted near the apex, closely punctured, more coarsely than the head, but more finely in front. Elytra nearly four times the length of the thorax, not twice its width at the base, almost straight as far as the hind thighs, their apices rounded and not covering the closely sculptured quite red pygidium; they are striate-punctate, the interstices are finely rugose, and the 2nd, on each, bears a small crest on the summit of the declivity.

Femora of unequal length, the anterior shortest, notched at the extremity and dentate underneath, the intermediate strongly dentiform, the posterior still more so.

Scape flexuous, gradually thickened and attaining the back of the eye; funiculus nearly as long as the scape, basal joint moderately thick but only very little longer than the elongate 2nd, 3rd slightly longer than broad; joints 4-6 moniliform, hardly at all transverse; club large, not equal to the funiculus in length, its 3rd joint apparently entire, subacuminate, hardly exceeding its precedessor in length.

Differs from $O$. latipennis in most details, in its more elongated thorax and elytra particularly; the antennae are longer and stouter, the club is more distinctly annulate and tapers towards the extremity. and the eyes are more longitudinally oval. In general contour it more nearly resembles $O$. uniformis, 3303, which, however, is thickly covered with circular fulvous seales.

o. Length (rostrum exclusive), $4 \mathrm{~mm}$; ; breadth, $1 \frac{1}{2} \mathrm{~mm}$.

Iount Hutt. This is another of Mr. Hall's discoveries on the :30th March, 1912. Described from a single specimen.

\section{Stephanorhynchus halli sp. nov. Stephrnorhynchus White, Mibn}

N.Z. Coleopt., p. 462.

Robust, without erests or tubercles; densely covered with depressed. elongate, testaceous scales, and some grey ones which, on the elytra, are disposed in series; along the middle of the thorax there is a fuscour streak, and another, much less distinct, near each side, the sides of the head and elytra are similarly marked, and the depressed parts of the elytral disc are also streaked but rather more glossr; antennae rufocastaneous.

Rostrum arehed, as long as the thorax, morlerately ridged from behind the antennae to the front of the eyes, with a groove along each side of the ridge, the apical portion darker and bearing some fulrous setae. Head rather shorter than the rostrum, not abruptly constricted behind, with a well-marker channel from the eres to its base, so that its sides near the middle appear ridged. Eyes very convex and prominent.

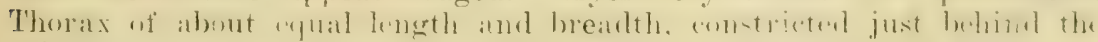
raised apical margin, rery slightly and broadly implessed along the

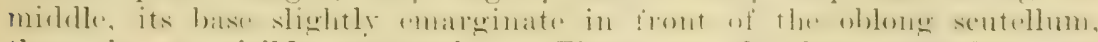
there is no visible punctation. Elytra at the base exceeding the thorax by half its width, thrice its length, with rounded shoulders. they are oblong, or only very erradually barowed backwards, with simple apices; they are moderately striate-punctate, the subdepresser? sutural portion indistinetly so; the $3 \mathrm{rd}$ interstices, reckoning the suture as the first, are broader and more elevated than the others, and at the extremity unite with the indistinctly raised outer ones. 
Legs with irregular fuscous spots; femora, the anterior included, with strongly dentiform angulations underneath; all the tibiae flexuous, the posterior most strongly, with fulvescent setae near the extremity.

Antennae slender, basal two joints of funiculus equal; club quadriarticulate, its 2 nd joint only slightly longer than the 1st.

Underside piceous, with dense testaccous restiture, consisting of coarse hairs on the metasternum and base of abdomen but of elongate scales elsewhere; basal ventral segment rather longer than 2 nd, broadly ret slightly depressed, its alpex widely sinuate, 3rd and 4 th with reep sutures, together as long as the 5th, which is innpressert along the mildile and strongly rounded behind, the supplementary segment broadly margined.

Readily distinguishable from S. costifer, 2170, by its very convex ontstanding eres, by the wrooves alongsirle the brobler rostral ridge, the more obrously chanmelled hatr, rather thicker and more briently coloured clothing, and larger size.

S. insolitus, with similar eyes, may be at once recognized by examining it sideways, when it will he seen that the ridge along the rostrum is gradually elevated backwards and terminates abruptly and vertically at the front of the eyes, thus leaving a very evident gap between it and the convex hinder part of the head; the elytral disc is nearly plane, and the vestiture is grey. There are no other similar species.

Length (costrum exclusive), $9 \mathrm{~mm}$; ) breadth, $3 \frac{1}{2} \mathrm{~mm}$.

Momint Intt, near. Vethren. Fommd feeding on myrte, at an elevation of $3,500 \mathrm{ft}$. , by Mr. T. Hall, whose name has been attached to it.

\section{Stenopactola gen. nov.}

Body squamose. Rostrum not distinctly narrower than the front of the head, parallel, evidently shorter than the thorax. Scrobes subapical, extending obliquely downwards about half-way to the eyes. Scape flexuous, gradually incrassate, inserted between the middle and apex and attaining the back of the eye. Funiculus $T$-articulate, basal joint stout, largest, 2nd rather longer than broad, joints 3-6 small and moniliform, the 7 th rather broader. Club oblong-oval, about half the length of the funiculus, quadriarticulate, its terminal joint very small. Head short, as broad as the front of thorax. Eyes lateral, only slightly prominent, twice as distant from each other as they are from the thorax, subrotundate, with distinct facets. Thorax cylindrical, without ocular lobes. Scutellum minute. Elytra, at the base, oblique towards the sides, very elongate-oval, covering the prgidium. Femora elongate, unequal, the posterior longest, only slightly angulate underneath. 'libiae much shorter, unarmed, somewhat areuate externally. Tarsi short, with pubesent soles, penultimate joint brourly expander and bilohed, the terminal rather longer than the basal; claws thickened at the base.

Prosternum incurved in front, the coxae contiguous and equidistant from the base and apex. Intermediate coxae only moderately, the posterior widely separated. Metasterum hardly as long as broad. Abdomen elongate, basal segment truncate between the coxae, slightly sinuate behind, obriously longer than the 2 nd, 3rd and 4 th together equally as long as the 5 th.

Nearly related to Pactola Pascoe, but differentiated by the elongate form and total absence of superficial inequalities. In the type of his genus (Man. N.\%. Coleoptera, 1). 465) the rostrum is abruptly narrower 
than the liead, the eyes are larger and placed more on the upper surface; the posterior femora are very strongly dilated, with a large dentiform angulation underneath, similar to those of Stephanorhynchus; and the oblong-quadrate elytra are nearly thrice the width of the thorax at the base, but in Stenopactola the elytral base is senrcely at all broader than that of the thorax.

\section{Stenopactola prolixa sp. nov.}

Narrow, very elongate, the hind-body twice the length of the rostrum, head, and thorax combined, without erests or tubercles, only slightly convex; obscure fusco-rufous, legs fulvescent, antennae testaceous, club infuscate; densely covered with small, depressed, circular squamae of a bright-tawny hue, and a few suberect, rather longer, greyish ones; sometimes the thorax along the middle and the sides of the elytra are infuscate.

Rostrum and head together sightly shorter than the thorax, the first nearly glabrous and pitchy-red at the apex. Thorax nearly a third longer than broad, apex feebly rounded, its base somewhat oblique towards the sides, only indistinctly constricted before the middle, its punctation concealed by the squamosity. Elytra quite thrice the length of the thorax, but not any broader at the base; regularly and rather finely striate-punctate, with moderately broad, nearly plane interstices. Legs squamose.

Underside fusco-testaceons, distinctly but not very closely. punctate, bearing depressed setae along the middle but scales near the sides and on the last ventral segment.

Length (rostrum inclusive), $3 \frac{1}{2} \mathrm{~mm}$.; breadth, $1 \frac{1}{5} \mathrm{~mm}$.

Mount Hutt. Three individuals forwarded by Mr. 'T. Hall, who found them on the 30th March, 1912. One of these is less brightly coloured, and appears greyish.

\section{Group Criptorhynchidae.}

3635. Acalles confusus sp. nov. Acalles Schoenherr, Man. N.Z. Coleopt., p. 488.

Subovate, opaque, elytra more convex than the thorax; covered with variegated, depressed, tawny and grey scales, and bearing also numerous erect ones, in some specimens those on the thoracic disc are brighter; fusco-piceous, antennae and tarsi fusco-fulvous, the tibiae somewhat similar.

Rostrum moderately arched, stout, parallel, nearly as long as the thorax, lufescent and finely setose near the apex. Head broader than the rostrum, but not abruptly so, minutely bicristate between the flat eyes. Thorax widest just behind the frontal contraction, slightly narrower towards the truncate base, rather broader than long; it is distinetly and closely punctate, the squamae near the sides and front are suberect. Elytra subcordate, nearly rertical and considerably narrowed behind, nearly double the length of and much broader than the thorax, but, owing to the oblique shoulders, searcely at all wider than it is at the base; they are evidently striate-punctate, the erect squamae usually form a distant pair of crests on top of the posterior declivity, the sides are a little uneven, sometimes small clusters of scales cause a few asperities nearer the middle, those on the shoulders are often ferruginous.

Legs stout and elongate, the tibiae with short outstanding squamae. Tarsi setose, not sponge-like below, their basal joint almost the length of the terminal, the penultimate somewhat expanded and bilobed. 
Scape inserted between the middle and apex, not extending back. wards as far as the eve, gradually inerassate; 2nd joint of funiculus nearly the length of the 1 st but much more slender, 3rd slightly longer than broad, joints $1-6$ bead-like, 7 th rather broader; club elongate-oral, fincly pubescent, triarticulate.

Underside thickly covered with rather coarse, depressed greyish squamae. Pectoral canal deep, and cxtending to the front of the intermerliate coxac. Hetasternum abbreviated, so that the posterior and middle coxae almost touch each other. Basal ventral seginent nearly twice the length of the $2 n d$, both broadly channelled along the middle, $3 r d$ and the on a rather lower plane and, together, longer than the 2 nd, 5th also coarsely squamose.

The scutellum is absent, the scrobes and eyes are normal, the insect nevertheless differs from all the other New Zealand species in facies.

Length (rostrum exclusive), $2-2 \frac{1}{3} \mathrm{~mm}$; breadth, $1 \frac{1}{3} m m$.

Rakaia Gorge, near Methven. Half a dozen specimens were found anongst decaring leaves and fine sand by Mr. 'T. Hall on the 18th May, 1912 .

\section{Acalles bicristiceps sp. nov.}

Convex, subovate, the thorax abruptly narower than the elytra, opacque, uneven; fusco-piceous, antennac and tarsi fulvescent; thickly covered with slightly variegated, chiefly light-brown or tawny squamae, the seutellar region nigrescent; tibiae obseurely reddish.

Rostrum moderately arched, subparallel, longer than the thorax, subseriate-punctate near the middle, more finely and closely near the somewhat rufescent apex. Head short, bieristate between the subrotundate eyes. Thorax somewhat abruptly contracted in front for half its length, closely but not coarsely punctured, bicristate at the apex, quadricristate across the front of the broad basal half, its greatest length and breadth about equal. Elytra more convex than the thorax, considerably broader, but with obligue shoulders, so that the base hardly exceeds that of the thorax in width, their sides are but little rounded, and the posterior declivity though not vertical is much narrowed; they are striatepunctate in reality, but, owing to the squanate, appear indistinctly striate; the $3 r$ interstices are bicristate, the jth tricristate; half-way down the hind declivity there is usually a transverse series of dark erect scales. Jeers moderately elongate and bearing subereet variegated scales; tarsi rather narrow, basal joint evidently longer than the next, the penultimate only moderately expanded and bilobed; they are covered with decumbent slender setae.

Scape rather sleuder, gradually incrassate, implanted at or just before the middle, and attaining the front of the ere. Funiculus elongate, 2nd joint slightly longer but more s?ender than the basal, joints $3-7$ hecome shorter and broader, the last is of the same width as the club, which is very elongate-oval, densely pubescent, and with its basal joint as long as the following two.

Underside densely squamose, to a crreat extent nigro-fuscous, but with numerous nearly white scales also. Prosternal canal cavernous behind, and limited between the intermediate coxale by raised borders. Metasternum hardly longer than the 2nd abdominal segment, the basal a thind lomere. Brd and the together almost as long as the 2nd, 5th small.

sentellum absent Oenlar lobes moderate.

fongrth (rostrum exclusive), $3-3 \frac{1}{1} \mathrm{~mm}$; breadth, $1 \frac{2}{3} \mathrm{~mm}$. 
Bell Rock, near Methven. Four examples obtained from leaf-mould on the 15th September, 1912, by Mr. 'T'. Hall.

None of the northern species resemble it, and, though differing greatly in appearance, it should be located near A. confusus.

\section{Acalles ignotus sp. nov.}

Compact, convex, rather elongate, attenuated towards both extremities, without conspicuous crests or inequalities, opaque; thickly covered with depressed, oviform, principally light-brown squamae, but with paler ones behind; on the suture, from the summit of the posterior declivity to the apex, overlapping grey scales form a pair of contiguous streaks, and a single one on each elytron near the side; antennae and tarsi fusco-rufous, rostrum dark red.

Rostrum moderately arched, nearly as broad as the head, gently narrowed towards the centre, of nearly the same length as the thorax; feebly carinate along the middle, distinctly and elosely punctate in front, squanose behind. Head short, globose underneath. Eyes quite Iateral, subrotundate, only obtusely pointed. 'Thorax very little broader than long, gradually narrowed towards the front, obsoletely constricted there; its punctation invisible, the apical scales are erect, and a rair of small dark spots may be seen near each side. Elytra almost double the length of the thorax, of the same width as it is, and closely adapted to it at the base, they are gradually narrowed posteriorly, and the declivity is curved; their sculpture seems to consist of rather distant serial punctures.

Legs robust, thickly clothed with variegated scales; femora elongate, deeply grooved underneath; tarsi rather narrow, with slender yellow setile above and below, their 3rd joint moderately expanded and bilobed.

Antennae finely setose; scape gradually incrassate, medially inserted, hardly reaching the eye; funiculus more elongate, its basal joint stouter and rather longer than the next; neither very elongate, $3 \mathrm{r} d$ and 4th slightly longer than broad, joints 5-7 short, successively dilated so that the last is as broad as the base of the elub, which is suboblong and triarticulate, its basal joint quite half of the entire length.

Underside densely covered with tawny or fuscous scales. Pectoral cinal profound, with strongly rounded elevated borders between the midile coxae. Metasternum short and medially depressed. Abdomen elongate, distinctly and closely punctured; basal segment obtusely angulate in front, broadly depressed, very large; 2nd segment apparently no longer than the moderately developed $3 \mathrm{rd}$ or 4 th, but without any well-marked frontal suture; 5th as long as the preceding two combined.

In general form and structure this approaches Xenacalles triangulatus. 1 $42 T$, but the absence of the seutellum excludes it from that genus.

Length (rostrum exclusive), $3 \mathrm{~mm}$.; breadth, $1 \frac{1}{2} \mathrm{~mm}$.

Rakaia Gorge. Describer from two eximples found by Mr. T. Hall amongst dead leaves on the ground in June, 1912. Another specimen found recently is darker.

3638. Tychanus squamosus sp. nov. Tychanus Pascoe, Man. N.Z Coleopt., p. 498.

Subovate, conver, opaque; thickly covered with depressed and suberect squamae, those near the sides and hinder part are piceo-fuscous, the others are fusco-testaceous, they overlap one another and ocenpy 9 -Bull. No. I. 
a large portion of the thoracic dise and an oblong basal space on the middle of the elytra, but behind are more irregularly distributed; antennae and tarsi fusco-rufous.

Rostrum parallel, slightly arched, half the width of the head, of about the same length as the thorax, and squamose almost to its extremity. Head immersed up to the eyes, plane between these. Thorax contracted anteriorly, but not abruptly, for nearly half of the whole length, fully a thind broader than long; somewhat flattened above, without distinct erests, its coarse punctation hidden by the tilted squamae. Scutellum concealed. Elytrat oblong, gradually narrowed and subvertical behind, not perceptibly wider at the base than the thorax, twice its length; they are coarsely seriate-punctate near the suture, but more irregularly beyond; the 3rd interstices are slightly raised near

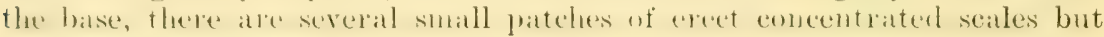
no conspicuous erests.

Seape medially inserted, attaining the eye, clothed with pale elongated scales and a few setae. Funiculus with slender setale, its 2nd joint slightly longer than the elongate 1 st and, combined, quite equalling the srape in length, 3id and the equal and evirlently longer than broarl, the 7 th shorter than the 5th or 6th; elub oblong-oval and acuminate, its dense pubescence concealing the articulations.

Legs with depressed and outstanding squamae, all the femora dentate underneath; tarsi with elongated seales above, their basal joint at long as the terminal, the $3 \mathrm{rd}$ moderately expanded and bilobed.

The pale tilted squamae on the dorsum form its prineipal peculiarity; there is some evidence of this in 2944, which, on account of its subdentate femora, would find a more fitting place near this speeies than in Acalles.

Length (rostrum exclusive), $5 \frac{1}{2} \mathrm{~mm}$; ; breadth, $3 \mathrm{~mm}$.

Pudding Hill, near Methven. Deseribed from a specimen found on the 4th May, 1912, by Mr. 'T. Hall.

\section{Crisius latirostris sp. nov. Crisius Pascoe, Man. N.Z. Coleopt,} p. 500 .

Convex, subovate, uneven, rufo-fuscous; densely covered with depressed squamae of a tawny, sometimes fulvescent, hue, but usually the median basal space of the elytra, as well as the nodosities, are dark fuscous; antennae and legs fusco-rufous.

Rostrum rather broad, arched, subparallel, as long as the thorax, constricted at the base; pitchy-red and fincly punctate near the extremity, squamose behind, obsoletely carinate along the middle. Head globose and rufescent underneath, distinetly impressed between the eyes. Thorax nearly a third broader than long, abruptly contracted in front, which is obtusely produced and slightly bicristate; it has a median pair of rounded erests and in some examples a minute pair behind, no punctation is visible. Elytra subcordate, evidently more convex than the thorax, twice its length, but hardly broarler than it is at the base, their posterior declivity subvertical; they are indistinctly seriate-punctate, on each elvtron, near the base, there is an irregular elongate elevation, the summit of the declivity is trinodose, and a single nodosity is placed near the side but more in arlvance, sometimes the declivity itself is minutely trinodose, the dorsum elsewhere is somewhat uneven. 
Scape inserted just before the middle and reaching backwards to the eye, slightly clavate at the extremity; 2 nd joint of the funiculus slender but only a little longer than the 1st, 3rd generally rather longer than broad, the following two moniliform, 6th and 7 th broader, transverse; club large, densely pubescent, triarticulate. Femora obtusely dentiform underneath, the anterior more distinctly.

Underside more or less coarsely punctate and bearing numerous tawny setae; basal ventral segment ample, the next, in the middle, but little longer than the $3 \mathrm{rd}$ or 4 th. The raised border of the pectoral canal extends as far as the back of the intermediate coxae. Metasternum very short.

The unusually broad rostrum, interocular depression, subvertical posterior declivity, obtusely or obsoletely dentate thighs, and rather short 2 nd joint of the funiculus are its distinguishing features. It may be placed near $C$. signatus, 2156.

Length (rostrum exlusive), $4 \mathrm{~mm}$; breadth, $2 \frac{1}{2} \mathrm{~mm}$.

MeClennan's Bush, near Methren. Four from Mr. 'T'. Hall, found amongst leaf-mould on the 23rd April, 1912.

\section{Getacalles posticalis sp. nov. Getacalles Broun, Man. N.Z. Coleopt., p. 1380.}

Oblong, convex, opaque; fuscous, legs obscurely rufescent, antennae and tarsi castaneo-rufous; densely covered chiefly with decumbent tawny squamae, along the middle of the thorax there is an indefinite white streak, and many whitish ones, depressed and erect, are scattered over the elytra; across the suture, near the top of the hind declivity, there is a dark-fuscous spot, and other small specks elsewhere.

Rostrum parallel-sided, moderately arched, as long as the thorax, its apex with yellow setae only. Thorax a third broader than long, its anterior half abruptly contracted, with a pair of obtuse elevations near the middle in front of the broad basal portion, which, at the sides, bears outstanding squamae, its punctation is close and coarse but hardly discernible. Scutellum grey. Elytra oblong, vertical behind, quite double the length of the thorax, their obtusely prominent shoulders rather exceed the base of the thorax in width; alongside the suture the coarse punctures are seriate, but towards the sides they become irregular and are intermingled with obscure elevations; there is, on each elytron, a short basal elevation of the $2 \mathrm{nd}$ interstice, the $3 \mathrm{rd}$ is somewhat unevenly raised from near the base and subnodose just in front of the declivity, below this there is a smaller nodosity, and in line with it, at the side, a more conspicuous one.

Legs squamose, and also with erect squamiform setae; femora obtusely dentate; tarsi finely setigerous.

Scape inserted between the middle and apex, attaining the front of the eye, gradually thickened; 2nd joint of funiculus as long as the 1 st but more slender, 6th and 7 th rather broader than preceding ones. Club ovate, basal articulation large, oblong, the other's small.

The nearest species, G. ventralis, 1682, originally placed in Tychanus, is larger and darker, with stonter legs and antennae, the punctation of the elytra is more distinct but the posterior declivity is less rertical.

Length (rostrum exclusive), 3-31 $\mathrm{mm}$. ; breadth, $1 \frac{2}{3}-2 \mathrm{~mm}$.

McClennan's Bush, near Methren. 'Two specimens found amongsot decared leaves in April, 1912, by Mr. T. Hall. 


\section{Getacalles fulvicornis sp. nov.}

Oblong, compact, convex, opaque; fusco-piceous, legs fusco-rufous, antennae and tarsi fulvescent; thickly covered with depressed tawny and erect paler squamae, the latter predominate near the sides and form several small tufts on the elytra.

Rostrum stout, parallel, somewhat arched, as long as the thorax, its sculpture hidden by the squamosity. Thorax slightly longer than broad, contracted and a little depressed in front for nearly half its length, closely and moderately coarsely punctured. Scutellum grey. Elytra truncate at the base, just perceptibly broader than the thorax there, twice its length, their sides straight as far as the top of the subvertical declivity; they are striate-punctate alongside the suture and behind, elsewhere coarsely but irregularly seriate-punctate; there are about a dozen small, irregularly placed crests on the dorsum; on the $3 \mathrm{rd}$ interstices there are 2 small nodosities, the smaller on top of the hind declivity, the other just below it, there is another on the 5th; these, however, as well as the discal punctation, are invisible until the surface has been denuded.

Legs with pale depressed and erect scales. 'Tarsi rather narrow, penultimate joints only slightly dilated and bilobed.

Scape inserted near the apex, attaining the front of the eye, rather slender near the base, gradually incrassate beyond, almost glabrous; funiculus finely pubescent, 2nd joint scarcely twice as long as broad, nearly as long as the 1 st but more slender; joints $3-7$ subquadrate and about equal; club densely pubescent, elongate-oval, quadriarticulate.

The fulvescent antennae and tarsi, and evidently more elongate club, the rather longer rostrum and differently sculptured elytra distinguish this species from $G$. minor, 2411, the nearest species.

Length (rostrum exclusive), $2 \frac{2}{3} \mathrm{~mm}$. ; breadth, $1 \frac{1}{2} \mathrm{~mm}$.

Curiosity Gully and Rakaia Gorge, near Methren. Three found by Mr. 'T'. Hall during lugust and September, 1912, amongst decaying vegetable matter, on the ground.

\section{Getacalles parvulus sp. nov.}

Oblong, convex, opaque; fuscous, legs somewhat rufescent, antennae and tarsi fulvescent; densely clothed with depressed tawny and greyish scales, and with more elongate erect greyish ones near the sides and forming about ten small tufts on the after part of the elytra.

Rostrum rather longer than the thorax, squanose. Thorax about a third broader than long, moderately contracted in front, closely punctate. Elytra oblong, subtruncate at the base, and, owing to the obtuse but slightly prominent shoulders, appearing a little broader than the thorax there, they are almost twice its length, and striate-punctate.

Underside densely squamose and punctured. Rostral canal profound, extending to the middle of the intermediate coxae. Metasternum excessively short, so that the middle and posterior coxae are in contact. Basal ventral segment twice the length of the 2 nd, its hind suture sinuate, the next two short and on an abruptly lower level, the 5th longer than the 2nd. Soles of the tarsi finely setose. Palpi visible, short and thick.

Considerably smaller than G. fulvicornis, the restiture finer and more variegated with grey, with a shorter thorax, the sentellum indistinct or sunken, the legs relatively more slender, joints $3-\tau$ of the funicle quite moniliform, and the club shorter. 
Length (rostrum exclusive), $2 \mathrm{~mm}$. ; breadth, $1 \mathrm{~mm}$.

Rakiaia Gorge. Another of the minute ground-weevils discovered by Mr. 'T. Hall. 'Two specimens, 27 th September, 1912.

\section{Getacalles variellus sp. nov.}

Convex, oblong, rather elongate, opaque, variegate; fuscuus, legs fusco-rufous, antennae light ferruginous; covered with depressed tawny, grey, and pale reddish-brown squamae; numerous short, erect, blackish setiform scales are distributed over the surface, and there are 4 equally dark spots just below the top of the posterior declivity; erect grey scales are unequally concentrated here and there, and form 6 small crests near the top of the declivity.

Rostrum hardly as long as the thorax, of normal form, piceous and nearly bare at the apex, covered with short rufo-fuscous squamae elsewhere. 'Thorax of equal length and breadth, abruptly contracted before the middle, without distinct crests or elevations, but with a slight earina along the middle, its punctation entirely concealed. Scutellum grey. Elytra oblong, nearly double the length of the thorax, a little broader than it is, with slightly prominent shoulders, the posterior declivity narrowed but not vertical; they are moderately coarsely seriate-punctate, but towards the sides the punctures are less regular, the declivity appears to be sulstriate. liemora subdentate.

Underside moderately coarsely but not closely punctate; with depressed greyish-yellow squamate on the breast, those on the abdomen are fulvescent and closer, but the sides from the middle of the 2 nd segment to the 5th are quite black. Rostral canal rery leep, extending to the front of the intermediate coxae, and with elevated border's there. Metasternum medially depressed, very short, so that the middle and hind coxae touch each other. Basal rentral regment largest, its hind suture oblique towards the sides, 31 and 4 th morlerately abbreviated and, together, nearly as long as the 2 nd. Soles of the tarsi with silky vestiture .

Of decidedly more elongate contour than $G$. posticalis, its surface less asperate, the posterior declivity not perpendicular, the thorax without median nodosities. The 2nd joint of the funiculus is quite as long as the basal but more slender, 3rd rather longer than the next, 6th broader than 5th, the 7 th still broader; club elongate-oval, its terminal three articulations, together, hardly as long as the first. This species, indeed, is different from any other in several particulars.

Length (rostrum exclusive), $4 \frac{1}{3} \mathrm{~mm}$. ; breadth, $2 \mathrm{~mm}$.

Rakaia Gorge. A single specimen obtained from lat-muld on the 9th October, 1912, by Mr. T. Hall.

\section{6t4. Getacalles oblongus sp. nov.}

Oblong, convex, opaque; fuscous, the rostrum, front of thorax, and elytral punctures somewhat rufescent, tarsi and antennae rufo-castaneous; covered with depressed tawny and slightly variegate erect squamae, legs inclusive.

Rostrum nearly as long as the thorax, moderately coarsely, longitudinally, rugosely punctate. 'Thorax nearly a third broader than long, abruptly narowed before the middle; somewhat uneren, but without well-marked crests or elevations, with a slender median carina behind, rather coarsely and elosely punctured, less so near the apex. Seutellum grer. Elytra oblong, fully twice the length of the thorax, a little wider than it is at the base, with slightly prominent shoulder's; near the suture they are coarsely striate-punctate, more fincly on the hind declivity; 
the interstices are rather narrow and a little uneven, the 3rd and 5 th are slightly thickened and elevated, but not distinetly nodiform, near the top of the declivity, where they are bordered behind by short blackish setale; the lateral sculpture is irregular, consisting of coarse punctures and obtuse intervals.

Scape inserted between the middle and apex and barely reaching the ere, it is rather slender, flexuous, and gradually incrassate. Funieulus Icnger than the seape, its 2nd joint hardly longer but more slender than the basal, 3rd and 4th slightly longer than broad, 7th transverse and rather broader than the preceding ones; club densely pubescent, elongateoval, its apical articulations small.

Underside elothed mostly with tawny scales, but on the middle of the abdominal segments $2-5$ they are fulvescent, those on the sides nigrescent.

The quite oblong form, the absence of crests and definite marks, and substriate elytra are distinetive.

Length (rostrum exclusive), $4 \frac{1}{2} \mathrm{~mm}$. ; breadth, 2 mm.

MeClennan's Bush, near Methven. One found by Mr. 'T. Hall on the 231 April, 1912, amongst leaf-mould.

36t5. Onias albicristus sp. nov. Onias Broun, Ann. Mag. Nat. Hist., ser. 8, vol. 4, p. 153, August, 1909.

Convex, subovate; the derm slightly nitid; piceous, rostrum shining, pitchy-red, antennate and tarsi fulveseent; nearly covered with variegated depressed squanate, ehiefly light brown, and numerous long, outstanding dark setae; across the top of the posterior declivity, slightly shorter and thicker setae, usually form 4 small white tufts; and there are a few white setae on the front of the thorax; on the elytra a few nigrescent spots can be seen.

Rostrum about as long as the thorax, gradually expanded towards the extremity; smooth along the middle, finely punctured near the sides. Thorax oviform, rather narrow, evidently longer than broad, a little wider behind the middle than elsewhere; without inequalities of surface, coarsely and moderately elosely punctate. Elytra subovate, of the same width as the thorax at the base, widest near the hind thighs, nearly, but not abruptly, vertical behind, they are more convex than the thorax and about a third longer; the disc is seriate-punctate, their hinder portion striate; there is a black spot inside each shoulder, another near the middle of each elytron, and a transverse series just in front, and another below the white crests, these series, however, are mere specks.

Legs long and slender, with erect elongate setae; tarsi narrow, their basal and terminal joints nearly equal, the penultimate bilobed and moderately expanded.

Scape short, gradually thickened, implanted at or just behind the raiddle; funiculus more elongate, basal joint much thicker and slightly longer than the 2nd, joints :3-5) slender, successirely shortened, the 5th, howerer, is not transverse, 6th and 7 th broader; club ovate, triarticulate.

Underside nigrescent, with coarse greyish setae. Basal rentral segment flat, coarsely punctate, subtruncate between the coxae, twice the length of the metasternum; Jth reddish, nearly smooth, almost straight behind, the 6 the short, obtusely rounded.

Somewhat similar to $O$. latisulcalus, 2967, in form and vestiture, but lacking the conspicuous central thoracie groove; it is further differentiated by the white tufts across the top of the hind declivity, and other detrils. 
Length (rostrum exclusive), 2-2! $\mathrm{mm}$. ; breadth, $1 \frac{1}{3} \mathrm{~mm}$.

Bell Rock, near Methren. Mr. Hall sent three specinsus which he picked out of leaf-mould on the 5th September, 1912

3646. Allanalcis laticollis sp. nov. Allanalcis Broun, 'Trans. N.Z. Inst., vol. 45, p. 141.

Convex, subovate, opaque, piceous, antennac and tarsi fusco-fulvous; densely covered with depressed squamae which, for the most part, are dark or light fuscous, those on the rostrum and sides of the thorax are somewhat testaceous, as are a small spot on each shoulder and more irregularly placed ones on the elytra.

Rostrum piceo-rufous, about as long as the thorax, very graclually and slightly narrowed towards the middle, moderately subseriate-punctate in front. Head deeply immersed; eyes rather small and wirlely distant above. 'Thorax of nearly the sime length and breadth, a good deal, but not sharply contracted in front, its apex subtruncate and broader than the head, the basal two-thirds with gently rounded sides; the middle of the dise is nearly flat, and its moderately coarse and close punctation is entirely hidden. Elytra obovate, widest near the middle, much narrowed and subvertical behind, not double the length of the thorax, subtruncate or feebly areuate and hardly any broader than the thorax at the base; on each there are 4 well-marked, apparently simple, dorsal striae; the $3 r$ interstices are slightly more elevated than the others but are not perceptibly nodiform or erested on top of the declivitr.

Legs squamose; femora very long and thick; tibiae abruptly incrassate above but very slender at the base, the anterior pair slightly bent inwardly.

Scape inserted at or just behind the middle, gradually incrassate, not quite attaining the ere; 2 nd joint of the funiculus as long as but more slender than the 1st, joints $3-7$ short, slightly increasing in thickness; club finely pubescent, oblong-eral, its basal joint much larger than the apical ones taken together.

There are only two somewhat similar species, A. aulacus, 2570, and A. allostethus, 2571 , both of which are much lighter in colour. In the former the hind-body is broader and subrotundate, the thorax is more gradually narrowed to the width of the head and therefore subconical, the eves are larger and more approximated above, the scape is rather shorter, the penultimate tarsal joint is more expanded but the the is more slender. 2571 may be at once separated by the smooth line along the middle of the thorax.

Length (rostrum exclusive), $2 \mathrm{~mm}$; breadth, $1 \frac{1}{4} \mathrm{~mm}$.

Rakaia Gorge, near Methven. Three individuals, one minus the head and rostrum, were forwarded by Mr. T. Hall on the 18th Mar, 1912, and were taken out of leaf-mould.

3647. Zeacalles carinellus sp. nov. Zeacalles Broun, Amn. Mag. Nat. Hist., ser. 6, vol. 12, p. 379.

Compact, very convex, elongate-ovate, subopaque, variegate; cistaneo-rufous, legs mole infuseate, tarsi and antenule paler, rustrum nitid, dark red; covered for the most part with depressed fulvescent squamae, but grey ones form a broad ill-defined streak along each side

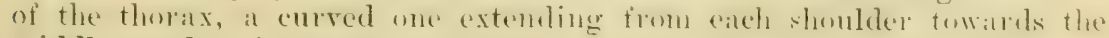
middle, and 3 irregular transrerse ones further back, none of these, however, are sharply marked; at the hase of each chitlon there is in blackish streak, the suture also is dark there, and there is a similar 
mark at each side behind the posterior feurar; whitish seales form a pair of small erests near the suture on the top of the posterior declivity.

Rostrum rather broad, slightly narrowed towards the middle, a little arched, as long as the thorax, constricted at the base, seriate-punctate along the sides. Thorax of equal length and breadth, gradually narrowed towards the front, base subtruncate; apparently moderately and closely punctured, with a slight carina extending from the base to beyond the centre. Elytrat of the same width as the thorax at the base, twice its length, rather broader before the middle than elsewhere, vertical behind; on each there is a sutural stria which reaches the apex, the other striae are slender and less definite, or are represented by series of narrow punctures; interstices broad and plane, the 2nd somewhat nodiform on the summit of the declivity, which, lower down, bear's some erect infuscate set:ie.

Fenorat elongate but stout, the anterior pair longest; tibiae shorter, with outstanding external setae; tarsi thickly setose underneath, their penultinate joint widely expanded, subtruncate at the extremity, grooved abore but not distinctly lobate.

Scape medially inserted, gradualy incrassate, attaining the eye; funiculus longer, its 2nd joint as long as the 1st but more slender, the next slightly longer than broad, the 7 th shorter and broader than the preceding ones; club oblong-oval, pubescent, its basal joint as long as the indistinct terminal ones.

Though resembling $\%$. binodsus, 3139, this species is larger, differently marked, with narrow elytral striae and broader tarsi, and it has at fine thoracic earina of which there is no trate whaterer in 3139 .

Length (rostrum exchsive), $2 \mathrm{~mm}$. ; breadth, $1 \frac{1}{4} \mathrm{~mm}$.

IfeClennan's Bush, near Methren. Found anongst decaring leares on the ground, at an altitude of $1,500 \mathrm{ft}$., during April, 1912, by IIr. 'T'. Hall.

\section{Zeacalles estriatus sp. nov.}

Opaque, fuscous, antennae and tarsi somewhat fulvescent, legs rather clarker, rostrum ferruginous; closely covered with depressed, variegated scales, chiefly flavescent intermingled with grey, but without forming definite spots; on eich elytron there is a dark, oblong, median basal spot, near the sides there are moderately coarse, crect setale which are darker than those on the legs.

Rostrum "panue, morlerately corasely and irregularly punctate. Elytra without striae, having only, on each, 3 discal series of elongate pinetures.

This is close to $Z$. carinellus, but it is differentiated by the absence of the thoracic carina, its opaque rostrum, elytral sculpture, more indistinct erests, more slender legs, and less variegate surface.

L.ength (rostrum exchsive), $2 \mathrm{~mm}$. ; breadth, $1 \mathrm{~mm}$.

Unique. From the sance souree as the preceding species.

\section{Group Cossoxidsl:}

3649. Pentarthrum brevicorne sp. nov. Pentarthum Wollaston, Man. N.Z. Coleopt., p. 508; Broun, "Revision of the New Zealand Cossomidae," Trans. N.Z. Inst., vol. 11, p. 155.

Lusiform, nitid; rostrum, thorax, and antenmate light rufous, elytra and legs pale castaneous; very seantily elothed with suberect, short and slender, inconspicuous greyish setre. 
Rostrum half the length of the thorax, subparallel, broad, slightly impressed along the middle, moderately coarkely but distantly punctite behind, more fincly in front, longitudinally lugose at the sides; occiput with a few fine punctures. 'Thorax slightly convex, ovate-triangular, very little longer than broad, slightly constricted in front, sonewhat contracted at the base; disc noderately enarsely but not closely punctured, more elosely and rugosely at the sides, the apex nearly smooth. Seutellum distinct. Elytra hadly wider than the thorax at the base, searcely double its length, their sides not quite straight, gradually narrowed posteriorly, with simple apices; they are distinctly substriatepunctate, quite striate behind; interstices with fine serial punctures and very slightly rugose; on each shoulder, above, there is a minute swelling that can hardly be called a nodule.

Scape straight, medially inserted, very short, gradually incrassate; and joint of funiculus shorter than the 1st, yet lather longer than the following transverse ones; club rather short, ovate.

Legs short and stout; penultimate tarsal joints excavate above but not lobed.

Wollaston's $P^{\prime}$. sericatum, 905, which I have not seen, is differentiated by its subcylindrical form and subopaque pale rufescent surface. This species is distinguishable from his $P$. zealandicum by its shorter and paler body, more triangular and less constricted thorax, and manifestly shorter legs and antennae.

o. Length (rostrum inclusive), $3 \frac{1}{3} \mathrm{~mm}$; brealth, quite $\frac{8}{3} \mathrm{~mm}$.

Wairiri, Kaikoura. One found by Mr. W. I. Wallace.

365). Tanysoma impressella sp. nov. Tanysoma Broun, Trans. Y.Z. Inst., vol. 41, p. 166.

Elongate, subparallel, subdepressed, slightly nitid; dark rufocastaneous, antennae and tarsi of a lighter hue; sparingly elothed with slender, decumbent, inconspicuous, greyish-yellow pubescence.

Rostrum shorter than the thorax, broader near the front than behind, slightly dilated at the point of antennal insertion, just before the middle; finely and irregularly but not closely punctate. Head narrowed anteriorly, not elongate, rather more distinctly punctured, the occiput included, than the rostrum. Thorax a third longer than broad, distinctly constricted near the apex, its sides nearly straight, but somewhat eurvedly narrowed near the base; its surface only moderately coarsely and closely punctured, less closely along the middle, which is Hattered or feebly impressed. Scutellum small, yet quite distinct. Elytra twice the length of the thorax, hardly as broad as it is, truncate at the base, gradually narrowerl behind the mirdle, with simple apices; they are distinctly and regularly striate-punctate, the interstices are moderately narrow, with indistinct serial punctures, and appear slightly rugose,

Legs elongate yet stout, tibiae distinctly pubescent near the extremity; the lobes of the penultimate tarsal joints all well developed.

Antennae elongate; scape slightly eurved, gradually incrassate; 2nd joint of the funiculus of about the same length as the basal, 3rd quite as long as broad, 5th transverse, rather shorter and broader than its predecessor; club rather narrow and elongate, its apical articulations small, with fine pubescence.

When compared with the same sex of 'T. angusta, 1626, this is seen to have rather more slender antennae, with an evidently narower club, 
the thorax is shorter, more curved near the base, and, instead of having a smooth obsoletely elevated line along the middle, it is flattened or impressed behind the middle.

+. Length (rostrum inclusive), $3 \frac{3}{3}$ nm. ; breadth, $\frac{\ddot{3}}{3} \mathrm{~mm}$.

Ilount Hutt, near Methren. Deseribed from a single female found by Mr. T. Hall, at an altitude of $3,500 \mathrm{ft}$, on the $12 \mathrm{th}$ April, 1912.

\section{Tanysoma aciphyllae sp. nov.}

Subdepressed, elongate, only very slightly nitid; fusco-rufous, antemnae and tarsi paler; thinly covered with subdecumbent, slender yellowish hairs.

Rostrum more than half the length of the thorax, moderately stout, considerably but not abruptly narrowed behind the middle, truncate at the apex; rather dull, with dense minute sculpture, and rather finely but distantly punctured in front, more distinetly behind. Head sculptured like the basal portion of the rostrum, the post-ocular dilatations indistinct. 'Thorax a third longer than broad, constricted in front, slightly wider behind the middle than elsewhere, eurvedly narrowed near the base; only moderately coarsely aud not very elosely punctate, with an abbreviated smooth line along the middle, the apex also smooth in the middle, but the intervals between the discal punctures are more or less minutely sculptured. Scutellum distinet, but small. Elytra double the length of the thorax, of about the same breadth, slightly narrowed behind, with simple apices, the base subtruncate; they are regularly and moderately striate-punctate, the interstices have minute serial punctures and appear slightly rugose. Legs normal; the penultimate joint of the auterior tarsi with well-developed lobes, the lobes of the other pairs less expanded.

Scape inserted between the middle and apex, rather stout, incrassate for half its length; 2nd joint of the funiculus as long as the basal, $3 r d$ subquadrate, 4th and 5th slightly shorter and broader; club oblongoval, with sinall apical articulations.

Fem.-More nitid, and of a slightly lighter red. The form and sculpture of the rostrum similar to those of the same sex of 1626 . Antennae medially inserted, rather longer and more slender than those of the male, the joints of the funiculus more sharply defined, the club slightly longer and narrower; thorax without any central line but more distantly punctate; the lobes of the anterior and intermediate tarsi moderately expanded, the posterior pair less distinctly.

Underside moderately coarsely and closely punctured. Metasternum nearly as long as the basal two ventral segments combined, the suture between these latter indistinct.

The smaller size, more flavescent vestiture, and less evidently lobed pesterior tarsi will enable cntomologists to distinguish either sex from 1626 .

o. Length (rostrum inclusive), $3 \mathrm{~mm}$.; breadth, $\frac{1}{2} \mathrm{~mm}$.

Rakaia Gorge, near Methven. 'Two females and one male taken out of the flower-stems of spear-grass, on the 18th May, 1912, by Mr. T'. Hall.

3652. Rhinanisus halli sp. nov. Rhinamisus Broun, Trans. N.Z. Inst., vol. 41, 1. 171.

Elongate, subparallel, subdepressed, slightly nitid; rufous, antennae and tarsi obseurely fulvesecnt; sparingly clothed with slender, subrecumbent, yellowish-grey pubescence. 
Rostrum bioad and parallel for half its length in front, distinctly narrowed behind, very slightly arched; closely and moderately coarsely punctured, rather more tinely and distantly in front, distinctly depresserl along the midelle, hardly nore than half the length of the thorax. Heanl narrowed anteriorly to the same width as the base of the rostrum, similarly sculptured to behind the eyes, the oceiput not quite smooth. Eyes not prominent. Thorax a third longer than broad, widest behind the middle, very gradually narrowed anteriorly, a little constrieted near the apex; usually broadly impressed or flattened along the middle, where the punctation, though moderately coarse, is not as close as it is near the front and sides, the middle of the apex is almost smooth. Seutellum small but distinct. Elytra truncate at the base and scarcely wider than the thorax there, twice its length, their sides almost quite straight, very gradually narrowed posteriorly, with simple apices; they are plane, distinctly and closely seriate-punctate; interstices with minute serial punctures and, in some aspects, appearing rugose.

Legs moderately stout; anterior tibiae flexuous, distinctly uncinate, and acutely angulate at the inner extremity; tarsi slender, penultimate joints slightly dilaterl, deeply exeavate above and subbiloberl.

Seape gradually incrassate, inserted before the middle; 2 mil joint of the funicle not quite as long as the bassil and more slender, the next not quite as long, th and 5th rather shorter and boroder ; club ublougoval, with small apical articulations, pubescent.

Underside shining, rufo-castaneous, fincly pubescent, moderately conrsely and closely punctured, the last three segments rather more finely; basal ventral segment a little longer than the 2nd, broadly depressed aloug the middle, its apical suture straight but fine, these segments together are rather longer than the metasternum.

fem. - Letes robust, the rostrum nore slender, distinetly narrowed behind, and more finely seulptured. Scape medially inserted.

Rather more robust than the other members of the genus. It most nearly resembles the male of $R$. elongatus, 2980 , but is evidently broader, and has the rostrum almost canaliculate.

§. Length (rostrum inclusive), $3 \mathrm{~mm}$; breadth, $\frac{1}{2} \mathrm{~mm}$.

Bell Rock, near Methren. Six males and two females found amongst dearl leaves on the ground, on 5th September, 1912, hy Mr. T. Hall, whose name has been given to it.

\section{Rhinanisus fusiformis sp. nov.}

Fusiform, nitid; the rostrum, thorax, and legs piceous, elytra castaneous, antennate and tarsi pale ferruginous; pubescence scantr, suberect, short, slender, and greyish.

Rostrum half the length of the thorax, subparallel, broad and slightly arched in front, evidently contracted towards the eyes; finely and distantly punctured on the middle in front, rather closely, coarsely, and somewhat rugosely behind, and as far as the back of the eyes. Head gradually narrowed to the width of the rostrum, the oceiput with a few fine punctures. Eyes nearly flat, lateral, subrotundate. Thorax moderately rounded and widest quite behind the middle, gradually narrowed anteriorly, slightly constricted in front; the dise only slightly flattened, moderately coarsely but not closely punctate, smooth at the ap $2 x$; curvedly narrowed near the base. Scutellum small but distinct. Elytra feebly areuate at the base and just a little broader than the thorax there, gently narrowed behind, with, individually, slightly 
rounded apices; they are substriate-punctate, the sutural striae only are moderately distinct; interstices with fine serial punctures, the $3 \mathrm{rd}$ bent outwardly at the extremity.

legs moderately stout; tibiae strongly uncinate; penultimate tarsal joints hollowed above and sublobate.

Scape implanted before the iniddle, nearly straight, very gradually and slightly thickened; 2nd joint of the funiculus smaller than the 1st but rather longer than the next, 5th subquadrate; club densely pubescent, oblong-oval, of about the same length as the last three joints of the funiculus combined.

With the exception of the more convex, fusiform body, this species agrees structurally with Rhinanisus. 'The first part of the description will lead to its recognition.

o. Length (rostrun inclusive), nearly $2 \frac{2}{3} \mathrm{~mm}$; breadth, fully $\frac{2}{3} \mathrm{~mm}$.

Curiosity Gully, near Methren. One found by Mr. 'T'. Hall on the 9th August, 1912, amongst leaf-mould.

\section{Sericotrogus plexus sp. nov. Sericotrogus Wollaston, Man. N.Z.} Coleopt., p. 521.

Elongate, rarrow, slightly conves, subopaque; fusco-piceous, legs dark fusco-rufous, antenuae and tarsi light chestnut-red; sparingly clothed with yellow, rather long and slender, subdecumbent hairs and a few ashy inconspicuous ones.

Rostrum nealy a third shorter than the thorax, slightly arched, moderately stout, gently narrowed behind the antennal insertion, nearly smooth along the middle, finely punctate near the sides, more distinctly and elosely towards its base. Eyes hardly at all prominent. 'Thorax suboviform, a third longer than broad, a little rounded and wider just behind the iniddle than elsewhere, gradually narrowed anteriorly, slightly constricted near the apes, not at all depressed; distinctly but not very closely punctate, with very minutely sculptured intervals. Scutellum small but distinct. Elytra without depressions, subparallel, rather wider than the thorax at the base, more than twice its length, narrowed near the obseurely rufescent, singly slightly rounded apices; they are moderately closely striate-punctate, the sutural striae most distinct and becoming deeper behind; interstices with almost duplicate series of minute punctures and appearing rugose, the $3 \mathrm{rd}$ do not reach the extremity, but are bent and prolonged forwards at the sides.

Legs stout and moderately elongate; penultimate joints of anterior tarsi morlerately expanded and evidently bilobed, those of the other pairs less distinetly.

Scape inserted just before the middle, somewhat curved, moderately incrassate towards the extremity; 2nd joint of the funiculus nearly as long as the basal, joints 3-5 obconical, 3rd very slightly longer than broad; club finely pubescent, clongate-oral, about as long as joints $2-5$ of the funiculus taken together.

Infferentiated prineipally from Agastegmus by the manifestly bilobed anterior tarsi and the unimpressed thorax and elytra; and from Sericotrogus by the long, indistinctly quadruaticulate club, more elongate antennae and curvate scape, longer rostrum, and less prominent eres.

Length (rostrum inclusive), $3 \frac{1}{2} \mathrm{~mm}$. ; brearth, $\frac{2}{3} \mathrm{~mm}$.

Bell Rock, near Methren. One found by Mr. 'T. Hall, on the 15th September, 1912, amongst decaying leaves on the ground. 
As I have alleady instituted no fewer than forty new genera in this group, it is not advisable to create others unless necessary for specially distinct species.

3655. Agastegnus concinnus sp. nov. Agusleqnus Broun, Trans. N.Z. Inst., vol. 41, p. 182.

Subdepressed, moderately broad, nitid, variegate; the head, front of thorax, and club piceo-fuscous; antennae, rostrum, legs, and remainder of thorax more or less rufeseent; elytra testaceous, but reddish at the sides, and with a faintly infuscate spot on the middle of each elytron, and another on the summit of the posterior declivity, both, however, are obsolcte; the elytra bear some rather short inconspicuous greyish hairs, but those on the head and thorax are elongate, slender, depressed, and bright yellow.

Rostrum rather shorter than the thorax, moderately broad and parallel in front, gently narrowed behind the middle, slightly arched; more finely punctured in front than behind, nowhere closely. Head distantly punctate, the occiput nearly smooth. Thorax rather longer than broad, moderately rounded and widest behind the middle, more gradually narrowed in front than behind, constricted near the apex, the basal margin thickened at the sides and almost forming distinet angles; it is moderately coarsely but not elosely punctured, but the dark apical space is almost smooth; there is an oblong basal inpression, with a smooth central line proceeding from it as far as the frontal constriction. Scutellum distinct, smooth. Elytra truncate at the base, distinctly broader than the thorax there, trice its length, gradually narrowed near the extremity; they are nearly plane and without dorsal depressions, closely and distinctly striate-punctate, more evidently striate behind; interstices with minute serial punctures, the $3 \mathrm{rd}$ somewhat thickened and elevated towards the extremity, sharply bent and angulate there, and extending for a short distance along the side, the space enclosed by the fork thus formed is distinctly depressed.

Scape inserted before the middle, slightly flexuous, a good deal thickened near the extremity; 2nd joint of funiculus nearly as long as the basal, joints 4 and 5 transverse; club large, oblong-oval, densely pubescent.

The North Island A. coloratus, 1630, is the only similar species; this one, howerer, is a trifle more robust, it is more brightly coloured; its thorax is more gradually narrowed anteriorly, and the discal impression does not extend forwards; the elytra are less abruptly narrowed posteriorly, and their pubescence in 1630 is quite elongate; the legs and rostrum are stouter, but the eres are less prominent. The penultimate tarsal joints are slightly dilated, excavate above at the extremity, but not bilobed.

o. Length (rostrum inclusive), $3 \mathrm{~mm}$.; breadth, $\frac{2}{3} \mathrm{~mm}$.

Mount Hutt, near Methren. Described from a solitairy individual found by Mr. T. Hall, at a height of $3,500 \mathrm{ft}$, on the 14th February, 1912.

\section{Agastegnus thoracicus sp. nov.}

Sibdepressed, elongate, narrowed anteriorly, shining; red, antennae and tarsi a little paler; very scantily clothed with suberect grey pubescence. 
Rostrum slightly arched, rather shorter than the thorax, subcylindric, just perceptibly narrowed before and behind the middle; finely punctate, rather more closely and coarsely behind, and as far as the back of the rather flat subrotundate eyes. Thorax rather longer than broad, moderately rounded and widest behind the middle, gradually narrowed towards the apical constriction; moderately coarsely but not closely punctured, more finely and distantly at the apex; with a rather deep impression, which is broadest at the base and nearly reaches the apex, and occupies fully a third of the entire width. Scutellum distinct. Elytra just twice the length of the thorax, a little broader than it is at the base, but not quite as broad there as near the hind thighs, gradually narrowed behind; they are only obsoletely bi-impressed across the disc, but distinctly striate-punctate, the suture is subcarinate and divergent near the extremity; interstices finely rugose but without definite serial punctures, the $3 r$ d somewhat thickened and elevated behind, sharply bent at the extremity and prolonged forwards at the sides.

Legs moderately elongate; penultimate tarsal joints grooved above but not distinctly bilobed.

Scape medially inserted, Hexuous, very little incrassate at the extremity; 2nd joint of funiculus as long as the basal, 31 d and th very slightly longer than broad, oth shorter, all obconical; club densely pubescent, elongate, nearly as long as joints $2-5$ of the funicle.

Somewhat similar to A. femoralis, 1751, from llount Egmont, but in that species the rostrum and thorax are more finely sculptured, the scape is more curvate, and the club is shorter. The apical sculpture of the elytra is almost exactly the same in both species; it may, indeed, be considered a generic character. The remarkable thoracic impression distinguishes this species at a glance.

ㅇ. Length (rostrum inclusive), $3 \mathrm{~mm}$.; breadth, $\frac{2}{3} \mathrm{~mm}$.

Mount Hutt, near Methren. Found by Mr. T. Hall, at an elevation of $3,500 \mathrm{ft}$., on the $30 \mathrm{th}$ March, 1912. The specimen is somewhat mutilated, and it is probable that better ones will be more thickly pubescent.

\section{Agastegnus rugipennis sp. nov.}

Elongate, rather narrow, slightly convex and nitid; seantily elothed with rather short and slender cinereous setae; piceous, rostrum and antennae, but not the club, rufous, legs and base of elytra pitchy-red, tarsi paler.

Rostrum rather shorter than the thorax, a little arched and parallel in front, fecbly dilated at the point of antennal insertion, slightly narrowed towards the base; finely and distantly punctate in front, more coarsely and closely behind. Head rather short, its sculpture like that of the rostrum to behind the eyes, more distantly on the middle, and with an elongate impression there; occiput smooth but short. Eyes very slightly convex. Thorax rather longer than broad, its sides only moderately rounded, a little wider behind the middle than elsewhere, and somewhat contracted at the apex; coarsely but not closely punctured, slightly impressed along the middle, the contracted portion more finely punctured, and nearly smooth on the centre. Scutellum distinct. Elytra subeylindric, feebly biarcuate at the base, slightly broader than the thorax there, twice its length, narrowed near the extremity, with singly rounded apices, thus forming a slight sutural notch; disc nearly plane, striate-punctate, the striae deeper behind; interstices with fine 
serial punctures and rugose, the 3rd raised and bent outwardly at the extremity; in some lights the striae appear to be crenate-punctate.

Femora stout, subclavate; tibiae rather short, with strongly developed apical hooks; penultimate tarsal joints a little dilated, excavate above, but not perceptibly lobed.

Scape medially inserted, attaining the middle of the eye, slightly flexuous and incrassate towards the extremity; 2nd joint of the funiculus smaller than the basal, joints $3-5$ successively shortened and expanded; club densely pubescent, oblong-oval, nearly as long as joints $2-5$ of the funicle taken together.

Underside shining, nigro-piceous; metasternum and basal two ventral segments moderately coarsely punctate, the former distinctly longitudinally grooved behind, the latter, together, nearly the length of the metasternum, both slightly impressed in the middle, their suture indistinct.

This does not accord very well with the typical members of the genus, but after prolonged study I see no more suitable place for it at present.

Length (rostrum inclusive), $3 \mathrm{~mm}$.; breadth, $\frac{2}{3} \mathrm{~mm}$.

Bell Rock, near Methven. Two individuals obtained from leafmould on the 15th September, 1912, by Mr. T. Hall.

3658. Gaurocryphus mirandus sp. nov. Gaurocryphus Broun, Trans. N.Z. Inst., vol. 41, p. 185.

Fusiform, moderately nitid; castaneo-rufous, antennae and tarsi fer'ruginous; pubescence conspicuous but not dense, bright yellow, slender, very elongate and decumbent on the rostrum and thorax, suberect on the elytra.

Rostrum slightly arched, half the length of the thorax, a little contracted behind the middle; very distinctly. and moderately closely punctate in front, more coarsely, closely, and quite rugosely behind, and as far as the back of the eyes; occiput short, distantly but distinctly punctured. Thorax widest and rounded near the base, curvedly narrowed there, gradually towards the front, constricted near the apex, its length a third more than the breadth; it is only very slightly conrex, moderately closely and rather coarsely punctured. Scutellum smooth, small but distinct. Elytra very little wider than the base of the thorax, not twice its length, a good deal narrowed behind; they are nearly plane above, moderately coarsely striate-punctate, quite striate behind; interstices with serial punctures and rugose. Legs stout; penultimate tarsal joints slightly expanded, excavate but not lobate.

Scape inserted just before the middle, stout, gradually incrassate, straight; joints $2-5$ of the funicle subtransverse and nearly equal; club oblong-oval, hardly as long as the preceding three joints together.

The rostrum is relatively longer and narrower than that of the male of Pentarthrum zealandicum, 903, the thorax is longer but the elytra are shorter, the eyes though smaller are more convex, the scape is shorter; and the rostrum of the female of G. auricomus, 1302, is only slightly narrower but longer than that of the male, and therefore essentially different in structure from that of Pentarthrum. These notes will be more useful to students than my comparing this species with 1302 , of which I obtained two examples during forty years.

o. Length (rostrum inclusive), $3 \frac{2}{5} \mathrm{~mm}$. ; breadth, $\frac{2}{3} \mathrm{~mm}$.

MeClennan's Bush, near Methren. I am indebted to Mr. T. Hall for my specimen, which was found on the 15th March, 1912. 


\section{Group ANTHRIBIDAE.}

3659. Anthribus venustus sp. nov. Anthribus Geoffroy, Man. N.Z. Coleopt., p: 545 .

Variegate, subopaque, the derm, however, is shining; antennae light brown, but with the basal joint and half of the next blackish; pubescence decumbent, elongate, mostly dark grey and intensely black and somewhat patchy on the elytra; coarser flavescent hairs form a fascia across the top of the posterior declivity, a pair of contiguous spots on each elytron before the middle, 3 small ones on the base of thorax, and a much larger sublinate spot near each side in front of the earina, the scutellum and middle of the tibiae are similarly clothed, and there is a minute speck near each eye; the frontal portion of the thorax is covered with reddish-brown pubescence.

Rostrum as long as the thorax, a good deal dilated and obtusely angulate in front, slightly emarginate behind the small labrum; its surface closely, moderately coarsely, and somewhat rugosely punetured, and with a slender carina along the middle. Thorax a fifth broader than long, gradually narrowed anteriorly, more abruptly at the base, its punctation fine in front, but, owing to the vestiture, indistinct elsewhere; the carina moderately distant from the elytra, subtruncate at the middle, rounded at the sides. Scutellum small. Elytra oblong, rather broader than the thorax and twice its length, with broadly rounded apices; they are only slightly convex, without perceptible crests, and only indistinctly punctate. Prgidium short and vertical.

Antennae inserted at the sides, near the front, slightly longer than the hear and thorax; their 2nd joint rather longer than the exposed portion of the basal, subclarate at the extremity; joints $3-8$ gradually decrease in length, all evidently longer than broad; club oblong, triarticulate, finely pubescent, its basal joint subtriangular, the intermediate transversely quadrate, the terminal conical.

Underside shining black, with fine grey pubescence.

This is congeneric with 'Sharp's A. brouni, 964. The eyes are un(marginate, moderately prominent, and broadly oral. It is the prettiest and most conspicuously marked species as yet found in New Zealand, and cannot, therefore, be mistaken for any other.

Length (rostrum inclusire), $4 \frac{1}{2} \mathrm{~mm}$. ; breadth, $1 \frac{2}{3} \mathrm{~mm}$.

Invercargill. Caught by Mr. A. Philpott on the 10th August, 1912, and generously presented to me for description.

\section{Group I IAMIIDAE.}

3660. Somatidia rubella sp. nov. Somatidia Thomson, Man. N.Z. Coleopt., p. 600 .

Nitid, convex, much narrowed and depressed towards the junction of the thorax and elytra; irregularly clothed with distinct decumbent and suberect fulvous hairs, but destitute of erect conspicuous setae; almost wholly fusco-rufous, the elytra rather more infuscate, tarsi and tibiae more or less obscurely fulvescent, these latter pale brown near the base and apex.

Head broader than the front of the thorax, with a few distinct punctures, the intervals minutely sculptured. Thorax of about equal length and brearth, subglobular, its sides strongly romuded and rather more narrowed and depressed towards the base than it is in front; it is moderately coarsely but rather distantly punctured, a little more 
closely in front. Scutellum triangular, small. Elytra elongate-oval, widest at or just before the middle, their shoulders yuite obsolete and not exceeding in breadth the base of the thorax, which is barely half their length; their punctation is scanty and irregular.

Antennae concolorous, finely pubescent, and bearing also numerous longer hairs; they extend backwards beyond the posterior femora, their long 3rd joint attains the base of the elytra, the 4 th and 5 th are abunt equal and only very slightly longer than the following ones. Femora moderately clavate, the tibiae with elongate greyish setae.

Underside shining, rufo-castaneous, the coxae and terminal ventral segments fulvescent, sparingly clothed with slender yellow hairs. Abdomen very finely transversely rugose; basal segment fully as long in the middle as the following three combined; 5th longer than 4th, finely margined, ciliate, and subtruncate at the extremity; supplementary segment deeply transversely concave at the base, as long as the penultimate, scantily pubescent.

'The female measures $3 \frac{1}{2} \mathrm{~mm}$. by $1 \frac{1}{2} \mathrm{~mm}$., is less convex, usually darker, and has the thorax less rotundate.

The first part of the description, and the more distant thoracic punctation, will enable this species to be separated from $S$. ptinoides, 1051 , which somewhat resembles it in form.

o. Tength, $3 \frac{3}{4}-4 \mathrm{~mm}$; ; breadth, $1 \frac{1}{2} \mathrm{~mm}$.

Mount Hutt and McClennan's Bush. Half a dozen specimens sent to me by Mr. T. Hall, who found them amongst decaying leaves on the ground, at an elevation of 1,500 ft., in April, 1912.

\section{Somatidia suturalis sp. nov.}

Convex, nitid; head and thorax fusco-rufous, elytra darker, antennae and legs concolorous chestnut-red; sparingly covered with slender grevish-yellow hairs, and, on the elytra, with some short erect setae.

Head distinctly punctate. Thorax as long as broad, subglobular, moderately closely punctured, rather more coarsely than the head. Elytra quite double the length of the thorax, not any wider than it is at the base, with almost regular series of moderately coarse punctures, which, howerer, do not reach the apices; the suture is slightly raised and somewhat cariniform.

Antennae pubescent, and with numerous pale slender setae; their 3rd joint though elongate does not extend backwards as far as the base of the thorax, the 4 th and 5th are subequal, the 11 th barely attains the top of the hind slope.

Tibiae with some elongate setae, which are darker and more congregated along the external emargination of the intermediate pair than elsewhere.

This must be placed near S. rubella, but it is smaller, with differently formed antennae, the thorax is more evenly and closely punctured, the elytral punctation is seriate, and the suture subcarinate.

§. Length, $3 \mathrm{~mm}$; ; breadth, $1 \mathrm{~mm}$.

Rose Hill, near Methren. A single indiridual from Mr. T. Hall on the 25th March, 1912.

\section{Somatidia ruficornis $\mathrm{sp}$. nov.}

Nitid, moderately broad and convex; dark fuscous or coppery, the thorax more rufescent; antennae immaculate, rufous, becoming paler towards the extremity; tibae obscurely fulvescent, the basal and apical 
marks rather darker but not fuscous; the vestiture decumbent, fulvous, moderately coarse and dense but leaving nude the sides of the thorax, the humeral region, and a curved streak between the hind thighs with a broad sutural prolongation behind it; the erect setae though numerous are slender but not very elongate.

Head distantly punctate, the vertex plane. 'Thorax slightly broader than long, widest and rounded near the middle, gradually narrowed behind, moderately elosely and coarsely punctured. Elytra somewhat broadly oval, fully twice the length of the thorax, almost double its width in the middle, but hardly at all broader than it is at the base; they are irregularly and distantly punctate.

Antennae finely pubescent and bearing also many longer hairs, and reaching backwards to beyond the hind thighs; their elongate $3 r$ joints attain the shoulders, the 5th is just perceptibly, if at all, longer than the 4th.

Femora subclavate but slender at the base; intermediate tibiae slightly thicker than the others, with elongate greyish setae near the external emargination.

Underside dark fuscous, with fine close sculpture, and greyish pubescence; 5th ventral segment reddish, longer than the 4th, subtruncate at the apex.

T'he species most nearly approaching this in bulk and facies are S. signata, 2275, and S. lineata, 3000. Both, however, are armed with a denticle at each side of the thorax. In 2275 the tips of the antennal joints are infuscate, there seems to be a slender line along the middle of the thorax, the surface is rather flatter and less shining. In 3000 there is a distinct stria on the head. S. latula, 2582, though similarly marked, is a much more robust insect.

length, $4 \frac{1}{2}-5 \mathrm{~mm}$. ; breadth, $2 \mathrm{~mm}$.

Pudling Hill and McClennan's Bush, near Methren. Found amongst leaves on the ground during April and May, 1912, by Mr. T. Hall. Apparently rare.

\section{Somatidia halli sp. nov.}

Elongate, convex, moderately nitid, without crests, tubercles, or outstanding setae, variegate; thorax and elytra fuscous, the frontal portion of the former much paler, the latter with an irregularly formed testaceous finscia between the hind thighs and mottled with greyish pubescence behind; the vertical forehead, antennal tubercles, and basal three joints of the antennae bright ehestnut-red; femora infuseate, their slender basal portion much paler; tibiae and tarsi yellow, the former with a blackish band above, and a small dark spot near the extremity; joints 5-11 of the antennae pale-reddish or testaceous at the base, fuscous beyond; the body unevenly clothed with very fine, depressed, greyish pubescence, but on the darker parts corresponding with the derm in colour.

Head distinctly but not elosely punctate in front, the vertex flat and dull black. Thorax convex, slightly longer than broad, widest and rounded before the middle, gradually narrowed backwards; its punctation distinct, nowhere very close, somewhat irregular, but not leaving definite smooth spots. Scutellum elongate-triangular, covered with rellowish pubescence. Elytra clongate-oval, a fourth wider in line with the posterior femora than the broadest part of the thorax, of the same breadth as it is at the base, the hind slope not at all abrupt and gradually 
attenuate; near the base each is slightly bi-impressed longitudinally, they are rather more coarsely punctured than the thorax, almost seriately alongside the suture, but much more finely and remotely near the sides of the fascia.

Antennae with pale pubescence and some longer hairs underneath, reaching backwards quite as far as the top of the hind declivity; 3 rd joint elongate, equalling the following two together and attaining the base of the thorax, the 4th slightly longer than the 5th.

Underside infuscate and finely pubescent; 5th ventral segment shorter than its predecessor, truncate or feebly emarginate at the extremity.

F'em.-Length, $6 \frac{1}{2} \mathrm{~mm}$. ; breadth, quite $2 \frac{1}{2} \mathrm{~mm}$. 'The thorax rather broader than long, sparingly and irregularly punctate so that the middle, a large spot near each side, and the base seem smooth. Elytra not longitudinally impressed near the base. 'The general colour darker. Fifth rentral segment rounded behind, longer than 4th.

o. Length, $5 \% \mathrm{~mm}$; breadth, $2 \mathrm{~mm}$.

Pudding Hill, near Methven. Described from a pair taken together, so that there can be no doubt respecting the sexes.

In addition to these, three mutilated males were found on Mount Hutt; two are almost entirely of a pale-chestnut hue, the other is but little darker but has two light-brown marks on each elytron.

'This species, another of Mr. 'T'. Hall's numerous discoveries, now bears his name.

366t. Hybolasius lineiceps sp. nov. Hybolasius Bates, Man. N.Z. Coleopt., p. 609 .

Subdepressed, elongate, subopaque; fuscous, the elytral suture and costae somewhat rufescent; with slender, elongate, mostly decumbent, yellow pubescence, and a few erect grey setae; antennae and tibiae dark iusco-rufous, the femora lighter.

Head rather narrow, with small flat eyes; finely granulate, depressed between the antennae, and with a distinct central stria nearly reaching the clypeus, which, together with the labrum and mandibles, are red. Thorax quite as broad as long, elosely and finely punctategranulose; lateral tubercles obtuse, its sides near the base somewhat abruptly narrowed; the dise slightly uneven, not definitely tuberculate, and with a shallow angular impression near the middle. Elytra gradually tapering towads the strongly rounded, slightly dehiscent apices, at the base evidently broader than the thorax, thrice its length; their whole surface distinetly and noderately closely punctured; on each elytron there is a basal prominence, behind which the surface seems depressed, near the hind thigh an obtuse longitudinal clevation extends backwards, and another, but shorter one, more distant from the suture, is placed near the apex.

Antennae concolorous, with finely, closely, and rugosely sculptured basal articulations, $3 \mathrm{rd}$ and 4 th joints very long, extending beyond the intermediate and posterior femora respectively, the 6th reaches the apex. 'libiae nearly straight.

H. piceus, 15.53, is almost wholly rufo-piceous, its head though rather narrow is unimpressed, its thorax is shorter, and the posterior tibiae are distinctly bent.

Length, $5 \mathrm{~mm}$.; breadth, $1 \frac{1}{2} \mathrm{~mm}$.

Rakaia Gorge. One found on the 5th June, 1912, by Mr. 'T. Hall. 
Group Eumolpidat.

3665. Pilacolaspis rugiventris sp. nov. Pilacolaspis S'harp, Man. N.Z. Coleopt, p. 1305.

Oblong, moderately convex, nitid, ruther thickly covered with distinct pale-brassy pubescence; fuscous, slightly bronzed; palpi, antennae, and legs testaceous.

Head narrower than front of thorax, moderately finely and closely punctate, more sparingly behind, where there is a linear longitudinal impression. Eyes subrotundate, prominent. Thorax about a third broader thin long, widest and rounded at the middle, somewhat sinuate behind; posterior angles rectangular, the anterior a little depressed and prominent; the basal and lateral margins more distinct than the frontal; its surface a little uneven, being feebly bi-impressed near each side, the punctation like that of the head, not coarse, but moderately close. Scutellum quadrate, with a few fine punctures. Elytra nearly thrice the length of the thorax, slightly broader than it is at the base, a little broader near the hind thighs, with rounded apices; their punctation irregular, hardly any coarser than that of the thorax, the sutural striae obsolete near the base and only slightly impressed behind.

Teess stout; tibiae a little dilated and excavate near the extremity; claws appendiculate.

Artennae stout, reaching backwards to the middle thighs, 2nd joint stubghbular, the following ones clongate, $3 \mathrm{rd}$ as long as 4 th, the terminal ones rather more slender.

Underside fuseo-testaceous, slightly aeneous, with distinct greyish pubescence, finely transversely rugose, the penultimate and terminal ventral segments punctate.

Length, $4 \frac{1}{2}-5 \mathrm{~mm}$; breadth, $2-2 \frac{1}{2} \mathrm{~mm}$.

Methven. Three found by Mr. 'T. Hall during November and December, 1911. In one the sides of the thorax are obtusely angulate; this no doubt is the male. P. huttoni, 1100, is the nearest species, but it has grey pubescence, and the seutellum is more triangular and closely punctured.

3666. Aphilon impressa sp. nov. Aphilon Sharp, Man. N.Z. Coleopt., p. 629 .

(onvex, broadly oriform, glabrous, shining; nigro-neneous, antenna and legs testaceous.

Head, including the convex eyes, almost as wide as front of thorax; slightly hi-impressed butwen the eres, and with a short, longitudinal, median groove behind. Thorax twice as broad as long, widely but not deeply emarginate in front, its sides finely margined, scarcely at all rounded but gradually narrowed anteriorly, the base feebly bisinuate, with rectangular but not prominent angles; in front there is a short gloove on the middle, and between it and each side a large foveiform somewhat transversal impression, near the base it is slightly bi-impressed; its punctation is fine, shallow, and distant, near the base, however, there are numerous coarser punctures. Scutellum distinct, smooth, and subcordate. Elytra of the same width, at the base, as the thorax, closely applied thereto, thrice its length; their sides finely margined, only moderately rounded, rather wider near the middle than elsewhere; they are without any obvious sculpture, but in certain lights vague indica tions of irregular striae may be detected. 
Antennae equalling the head and thorax in length; their basal joint stoutest, straight along the outer side, the inner archerl; 2nil cylindric, slender, shorter than the $3 \mathrm{rd}$, which, as well as the 4 th, is twice as long as broad; joints $5-7$ rather shorter, 8th and 9 th slightly shorter and broader, and somewhat oviform; 10th suboblong; 11th elongate-oval, almost as long as the 9 th and 10 th combined.

'Tibiae moderately stout, slender near the base, curved externally, slightly impressed at the onter extremity. 'T'arsi thick, of normal structure.

Underside shining, piceo-niger, bearing short, depressed, greyish setae. Abdomen finely and irregularly punctate; its basal segment as long as the following three conjointly; 5th nearly double the length of its predecessor, subtruncate at apex, so that there appears to be a short, apically rounded, supplementary segment.

From all the species of about equal bulk this is distinguishable by the thoracic impressions and apparently smooth elytra.

l.ength, $3 \frac{1}{2} \mathrm{~mm}$; breadth, $2 \mathrm{~mm}$.

McClennan's Bush, near Methven. Mr. 'I'. Hall, on the 25th March, 1912, sent me a specimen which he found amongst leaf-mould. It is the first of this genus that has been secured in the South Island.

\section{Caccomolpus flectipes sp. nov. Cuccomolpus shalp, Man. I.Z. Coleopt., p. 1308.}

Convex, subrotundate, glabrous, nitid; atieo-niger, legs and palpi dark rufous, antennae and tarsi chestnut-red.

Head rather narrower than front of thorax, slightly impressed or flattened and finely rugosely punctate on the middle, its sides smooth. Thorax more thin twice as broad as it is long, gently curvedly narrowed anteriorly, the apex widely incurved and nearly as distinctly margined as the sides, the base slightly rounded; its punctation fine, distant, and irregular. Seutellum moderately large, triangular, smooth. Elytra, at the base, just a trifle broader than the thorax, thrice is length; they are only moderately, but not at all regularly seriate-punctate.

Antennae slightly and gradually thickened, longer than the head and thorax, finely pubescent from the 4 th joint onwards; basal joint stoutest, 2nd rather shorter than 3rd yet twice as long as broad, joints 3-10 distinctly longer than broad, the terminal rather more elongate than the penultimate.

Legs stout, only the tips of the femora visible from above; intermerliate and posterior tibiare moderately slender near the base, somewhat twisted and bent at the middle, considerably dilated below that point; the anterior not. twisted, much less incrassate, grooved at the outer oxtremity, and bearing yellow pubescence.

Underside immaculate, bronzed black, with numerous fine grey setae, sparingly and finely punctured.

This species is chiefly remarkable for the tibial structure. It should be placed near C. pullatus, 2299, which, howerer, is smaller, more distinctly and closely punctured, and with ordinary tibiae. The species numbered 2297 and 2298 must be very different, judging by their descriptions; but I have not seen either of them.

Length, $5 \mathrm{~mm}$; ; breadth, $3 \frac{1}{2} \mathrm{~mm}$.

Mount Hutt, near Methven. One discovered by Mr. T. Hall, at an elevation of $3,500 \mathrm{ft}$, , on the $30 \mathrm{th}$ March, 1912. The large basal joints of the tarsi show that it is a male. 


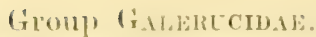

3668. Luperus insolitus sp. nov. Luperus Geofiroy, Min. N.Z Coleopt., p. 631. Syn. Adoxia.

subdepressed, elongate, nitid; cyaneous, the elytra slightly riridescent, their basal and apical portions and the suture faintly aeneous, legs and antennae fuscous; sides of thorax and hinder part of elytra with a few slender ereet greyish setale.

Head ats broad as the tholax, smooth behind, with a few interocular punctures, the tubereles almost that and slightly brassy. 'Thorax tranrersely quadrate, only a fourth broader than long, apex truneate; base somewhat rounded near the sides so that its angles are not sharply maked, the anteriol scarcely at all thickened, the sides well margined and nearly straight; its punctation distinct, moderately close and irreanlar, the intervals not quite smooth, in front of the scutellum there are some very slender transverse rugae. Seutellum depressed. Elytra thrice the length of the thorax, a little wider than it is at the base, their sides almost quite straight, apices broad and rounded, their margins more easily seen from above than those along the sides; ther are impressed near each shoulder and alongside the suture, the latter is very distinctly elevated throughout, their punctures are rather finer and closer than those on the thorax, with densely and minutely seulptured intervals, towards the extremity the sculpture is more coriaceous. Prgidiun vertical, just visible, with distinct white setae.

Legs unusually stout, with grey setae; tibiae slightly bent inwardy, gradually incrassate towards the extremity.

Antennae densely pubescent, extending to beyond the middle femora; basal joint slightly rufescent, rather longer than the next two united; 2nd oviform and evidently shorter than the $3 \mathrm{rd}$, which is shorter than any of the following ones; joints $4-10$ about equally clongate and slightly expanded apically; the terminal rather longer than its predecessor, aemminate.

The Southland beetles almost invariably present some well-marked differentiating features. This one is no exception to the rule. The ordinary interocular tubereles are Hattened, the elytral suture is rather sharply and obviously elevated, the tibiae are bent in the opposite direction, and the 2 nd antennal joint is short and oriform.

Length, $4 \mathrm{~mm}$; ; breadth, $1 \frac{1}{2} \mathrm{~mm}$.

Hump Ridge, near Invereargill. One was found by Mr. A. Philpott in February, 1912, at an altitude of 3,500 ft. Infortunately the collecting season was a very bad one; hardly any of the alpine plants were in flower, and insects generally were rery scarce.

\section{Luperus anthracinus sp. nov.}

Elongate, subdepressed, glabrous; glossy, intensely black, legs and basal three joints of antennae fuscous, remaining articulations dull smokr-black, terminal joint of tarsi nitid and nigrescent.

Head nearly as broad as the thorax, indefinitely seulptured, the tubereles very slightly elevated. Eyes rather large and moderately prominent. 'Thorax nearly twice as broad as long, base and apex truneate, widest before the middle, posterior angles olotuse, the anterior slightly incrassate, lateral marrins well developed; the surface just a little meren, withont definite impressions or punctation. Sentellum broad and smooth. Elytria subparallel, with broadly rounded apices, shoulders ohtuse; they are broarke than the thorax and rather more than four 
times its length, and are very distinctly, irregularly, closely, and slightly rugosely punctured right to the extremity; there is a wellmarkeil basil depression near eateh shoulder. Proidinum entirely covered.

Legrs elongate, with short greyish setae; posterior tibiae arched externally, their tarsi nearly as long; claws appendiculate.

Antennae, filiform, equalling the body in length, finely pubescent; hatsal joint slightly enred, moderately thickened, at long as the succeedine two together, 2 nl shorter than 3ro, joints 4-10 elongate, 11 th rather shorter.

We have no other recorded species like it.

Length, $3 \mathrm{~mm}$. ; breadth, $1 \frac{1}{4} \mathrm{~mm}$.

Hump Ridge. Unique. Taken br Mr. A. Philpott in February, 1912 , at a height of $3,500 \mathrm{ft}$

\section{Luperus bullatus sp. nov.}

Elongate, subdepressed, glabrous, nitid; aeneous, thorax and scutellum feebly rufescent, antennae and legs infuseate, femora paler at the base.

Head smooth behind, iridescent between the eyes, with moderate tubercles. Thorax nearly twice as broad as long, apex truncate, widest just before the middle, its sides distinctly margined, more gradually narrowed behind than in front, anterior angles thickened and a little proninent; base finely margined, truncate, but slightly oblique near the sides, so that its angles, though slightly incrassate, are not quite rectangular: dise with exceedingly minute dense seulpture, remotely and very finely punctured on the middle; rather more distinctly towards the sides and centre of the base. Scutellum triangular, smooth. Elytra rather broader than the thorax, four times its length, with straight sides, narrowed near the extremity, apices obtuse or subtruncate; they are somewhat transversely rugose, with close, irregular, moderately fine punctures; inside each shoulder and along the basal portion of the suture there is a depression, the space between these is obtusely elevated. Pygidium invisible.

Antennae filiform, reaching backwards to the middle of the elytra; basal joint moderately thickened towards the extremity, 2nd rather shorter than the next, these together hardly longer than the 1st or 4th; joints 5-10 about equally elongate, 11th as long as 10th, apparently with a narrow apical appendage or false joint. Posterior tibiae slightly arched externally; front claws with elongate basal teeth.

In general contour this approaches the beautiful L. princeps, 2310, but the colour and sculpture are altogether dissimilar and its legs are much shorter.

Length, $4 \frac{3}{1} \mathrm{~mm}$. ; breadth, $2 \mathrm{~mm}$.

Mount Hutt. A single specimen was found lying on the snow, at an elevation of $4,200 \mathrm{ft}$., br Mr. T. Hall, on the 28th Oetober, 1912.

\section{Luperus discrepans sp. nov.}

Flongate, slightly convex, nitid, with a few fine grey setae on the front of the head, elytral apices, and prgidium; nigrescent, elytra of a greenish hue, the head and two spots on the thorax with a coppery gloss.

Head deeply and broadly sulcate along the middle, less so at its base, it is as broad as the front of the thorax, finely sculptured but impunctate. Eves large and prominent. Thorax nearly twice as broad as long, its sides very distinctly margined and gently rounded, the 
anterior angles only slightly thickened and more nearly rectangular thate the justerion; the dise elosely and minutely seulptured and at little uneven, latring a pail of subcontignous, yet only slight, median elevations, ledind these, but widely distant lrom each other, there ale 2 aven less elevited, of a jufescent or coppery hue, the space between these is finely rugose, some shallow punctures are visible near the base. Scutellum triangular, glossy. Elytra five times longer than the thorax, rather broader than it is at the base, very gradually expanded posteriorly, with broadly rounded apices; there is a broad sutural depression near the base and another within each shoulder, between these depressions the punctation is a little finer and not quite as close as that of the rest of their surface. Prgidium uncovered, nearly horizontal, and somewhat cyaneous.

leegs more or less fuscous, elongate; tibiae nearly straight, the grey setae slender above but becoming coarser towards the extremity, they are without spurs; tarsi rather broad, their terminal joint piceous; claws appendiculate at the base.

Antennae filiform, thickly pubescent, nearly attaining the posterior femora, of a more rufescent and paler brown near the base than beyond; 2nd joint nearly twice as long as broad ret evidently shorter than the next, joints $1-8$ distinctly longer than the $3 \mathrm{rd}$, the 9 th and 10 th rather shorter than the 4 th.

Nearly related to 3356 , also from the 'lararua Range; more obviously narrowed anteriorly, the thorax more uneven and less perceptibly punctured, the basal depressions of the elytra deeper but their punctures a little finer, the tarsi evidently broader, and the head more broadly gioover but not at all brassy.

Length, $6 \frac{1}{2} \mathrm{~mm}$; ; brealth, $2 \frac{1}{2} \mathrm{~mm}$.

Jount Dennan. One from IIr. A. C. O'Commol. A second measures $5 \frac{1}{2} \mathrm{~mm}$. by $2 \frac{1}{2} \mathrm{~mm}$. and is, I believe, the female. Both were captured on the 26th December, 1910.

\section{Luperus dilatatus sp. nov.}

Subdepressed, shining, with very few fine grey setae on the forehead, elytral apices, and pygidium; elytra cyaneous and considerably dilated behind the middle, head black, thorax also dark but somewhat aeneous; legs light yellowish-brown, antennae fuscous, their basal joints paler.

Head smooth, interocular tubercles moderately elevated, separated by a rather broad deep groove. Eyes large and prominent. Thorax a third broader than long, with rather broadly margined, nearly straight sides; anterior angles very slightly thickened and not at all prominent, the posterior somewhat incrassate just in front of the true basal margin, which is oblique near the sides; its punctation very fine and distant. Scutellum small. Elytra fully four times the length of the thorax, quite double its breadth near the hind thighs, much narrowed towards the base, with rounded apices; they are closely and distinctly punctured throughout, and rather broadly impressed inside each shoulder. Pygidium horizontal, short, broadly rounded behind, densely and minutely sculptured.

Legs moderately stout and clongate; tibiae nearly straight, with slender greyish setae, the posterior indistinctly serrate externally; tarsi moderately stout, claws appendiculate.

Antennac filiform, not attaining the hind thighs; 2nd joint not quite as long as the $3 \mathrm{rd}$, joints $1-11$ elongate. 
The dark-blue posteriorly dilated elytra, and the amost perfectly smooth glossy tholax, taken together, distinguish it from every other species.

Length, $4 \frac{1}{2}$ mm. ; breadth, nearly $2 \frac{1}{2} \mathrm{~mm}$.

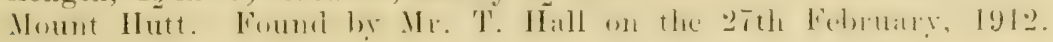
Unique.

3673. Luperus iridescens sp. nov.

Llongate, subdepressed, glabrous, nitid; aneous, the head and thorax distinctly, elytra slightly rufeseent, legs and antennae pale brown.

Head nearly as broad as thorax, smooth behind, with moderately small tubereles. Eves large and prominent. Thorax a third broader than long, its sides distinctly margined, almost straight behind the middle, a little narrowed towards the incrassate laterally prominent anterior angles, the base slightly rounded near the sides so that its angles are only obtusely rectangular; dise finely and distantly punctate, the intervals very minutely sculptured. Scutellum small. Elytra nearly four times the length of the thorax, rather broader than it is at the base, slightly wider near the hind thighs, with rounded apices; they are closely and distinetly but not at all coarsely punctured throughout, with only slight impressions near the shoulders, but the suture near the basc is more evidently depressed. Pygidium deflexed, strongly curved, minutely seulptured, and bearing a few grey setae.

Legs moderately elongate and slender; tibiae nearly straight, with distinct grey setae, the posterior minutely serrate exterially; basal two joints of the tarsi rather narrow, 3rd short and moderately expanded; claws appendiculate.

Antennae filiform, not reaching the posterior femora, 2nd joint almost as long as the 3rd, 4-11 about equally elongate.

Smaller than 7. leuvis, :3017, evidently iridecent, the thorax less strongly tansverse, the elytra viridesent, the scutellum smaller. 'Tlhe unusually thick and laterally prominent anterior angles of the thorax isolate these two species. Sharp's $J_{\text {. }}$ aenescens, 2316 , which I have not seen, is deseribed as having the thorax twice as broad as long, with only slightly thickened front angles, and a long narrow prcgidium; it must, therefore, differ considerably from $L$. iridescens.

Length, $4 \mathrm{~mm}$.; breadth, $1 \frac{2}{3} \mathrm{~mm}$.

Mount Hutt. Another of Mr. 'T'. Hall's discoveries on the 27th February, 1912. A solitary individual.

3674. Luperus aurellus sp. nov.

Elongate, slightly convex, shining; of a golden coppery hue, the forehead riridescent; legs and basal joints of antennae pale brown, remaining articulations and the last joint of the tarsi darker.

Head nearly as broad as the front of the thorax, with some slender grey setac on the forehead, without definite punctation, the tubereles well developerl. Eyes large and prominent. Thorax a third broader than long, the sides distinctly margined, very little wider before the middle than elsewhere, anterior angles slightly incrassate and subrectangular, the base marginate and a little rounded near the sides so that its angles are not quite straight; disc very minutely and densely sculptured, its punctation fine, distant, and irregular, rather more distinct, ret not at all coarse, near the base. Scutellum subtriangular. Elytra rather broader than thorax at the base, four times its length, with 
obtuse shoulders, slightly expanded posteriorly, apices broadly rounded; the sutural and humeral impressions moderate, their punctation distinct, but not coarse, even to the extremity, and moderately close. Pygidium a little exposed, almost glabrous, bluish.

l.egs moderately elongate; tibiae nearly straight, the almost white setale on the two hind pairs much thicker than those on the anterior, the posterior finely serrate along the outside, more coarsely near the extrenity; tarsi not broad, their claws appendiculate.

Antennae filiform, not extending as far as the hind thighs; 2nil joint almost as long as the next, joints $1-11$ about equally elongate.

The first pate of its deseription will enable it to be sepallaterl from every other New Zealand species. The fine serration of the posterior tibia: is observable in the series from 2:305 to 2:309, and may herenfter prove useful in diriding the members of the genus into sections. In general form and senpture it comes near /. aeneus, 1114, from Lindis Pass, Otago.

Length, 4.2 min.; brearth, nearly $2 \mathrm{~mm}$.

IIount Hutt. One only, eaptured by $M[1$. T. Hall on the $]+t h$ Fubruary, 1912. Infortunately, the bud weather prevented more than one or two individuals of any of these flower-frequenting species being found.

\section{Grolly) ('OCCINEt,LidAl:}

3675. Scymnus prolongatus sp. nov. Scymmus Kugelmann, Man. N.\%. Coleopt., p. 645.

Semi-opaque, broadly oval, convex; pubeseence subdecumbent, distinct, yellowish-grey, finer on the elytral disc; olivaceo-niger, the leys and basal three joints of the antennate light chestnut-red, remaining joints and the tarsi more or less infuseate, thoracic apex pallid.

Head punctate. Thorax nearly twice as broad as long, the bave rounder in the middle but oblique towads the rectangular angles, its sides finely margined and culvedly narrowed near the obtuse anterior angles, the apex widely emarginate; its surface shining, moderately finely but not closely punctured, rather more closely near the sides. Scutellum triangular, punctate. Elytra dull, with moderately coarse and close but shallow punctures, and finely rugose interstices, each with 2 or 3 obsolete basal striae, and with the suture slightly thickened alongside the scutellum; they are of the same width as the thorax at the base, a little broader behind the shoulders, distinetly matrined, emsirlerably, almost obliquely, narrowed and depressed near the extremity, and with distinetly though obtusely prolonged apices.

legs stout, finely pubescent; claws simple.

Antennae nearly as long as the head and thorax, 2 nd joint rather shorter than the thicker 1st or the more slender :3rd; joints $4-8$ nearly equal, all rather longer than broad; 9 th and 10th distinetly enlargert, slightly longer than broad, straight externally but gradually dilated inwarly towards the extremity, the teminal not as broad as the penultimate.

This species is remarkable on aceount of the dull, slightly asperate or coriaceous seulpture of the dytria, and their emepienously prolonged apices.

Length, $3 \frac{1}{2} \mathrm{~mm}$; ; brearth. $2 \frac{1}{3} \mathrm{~mm}$.

Curiosity Gully, near Methrom. One fomm amongest dearl leares on the groumd by Mr. T. Hall, 9th Angust. 1912. 


\section{Scymnus halli sp. nov.}

Robust, broadly oval, convex, moderately nitid; black, the knees, basal joint of the tarsi, and the antennae more or less rufo-castaneous, front margin of thorax pale-yellowish; irregularly elothed with greyish, moderately elongate, subereet and decumbent hairs, which run in different directions.

Head elosely and finely punctate. Thorax twice as broad as long, similar to that of $S$. prolongatus in form, moderately closely and finely punctured, with distinct lateral margins. Elytra fully thrice the length of the thorax, wider than it is in the middle, broadly rounded at the extremity; they are more distinetly punctured than the thorax, nore finely behind, and there is an obtuse elevation near each shoulder.

Tibiae moderately dilated near the midd'e but tapering towards the base and apex. 'T'arsi stout, their 2 nd joint much prolonged underneath, the terminal nearly as long as the preceding ones combined; all the claws appendiculate for quite half their length, their apieal fortion slender and much curved.

Underside finely punctate and pubeseent, the abdomen rufo-fuscous. Prosternal process cuneiform and distinetly margined.

Length, $5 \frac{1}{3} \mathrm{~mm}$. ; breadth, $3 \frac{1}{2} \mathrm{~mm}$.

Mount Hutt, and Ardagh; February and Nareh, 1912. A single specimen from each locality, found by $\mathbf{I I}_{\mathrm{x}}$. 'T. Hall, of Methren. This, the largest species of the genus known to me, is named in honour of its discoverer, who during an inclement year has systematically investigated the insect fauna of his neighbourhood.

3677. Scymnus circularis Sharp, "Insect Life," vol. 1, p. 1889.

liotundatus, convexus, nigerrimus, pube longiore pallide-grisescente irregulariter vestitus, fortiter punctatus; abdomine rufescente, antennis tarsisque Havis, ad apices fuscis.

Long., $3 \mathrm{mmn}$.

Thorax sparingly punctured, with a very small flavescent mark on the anterior margin on each side. Elytra rather coarsely and not closely punctured, bearing fine, rather long, almost white pubescence; this pubescence is not depressed, and the individual hairs do not take a straight or parallel direction. Prosternal lines subparallel, slightly curvate at the anterior margin, and slightly sinuate behind. Hetasternum sparingly and rather coarsely punctate; hind coxae very widely separated. Front and middle claw with a long appendage extending the greater part of the length of the claw, and with free sharp extremity, so that the claw appears bidentate; claw of hind foot with shorter lobe.

A species smaller in size, but very similar in colour and outline

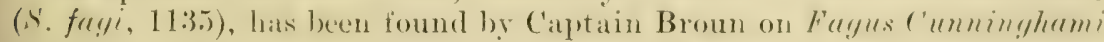
in the North Island. S. circularis is smaller and of much more circular form than S. restitulor, and differs in the structure of the claws and other important particulars.

Picton. Found by Mr. Richard Helms in 1884.

\section{Scymnus nigritulus sp. nov.}

Oblong-oval, moderately convex, nitid; nigrescent, the front of the head and sides of thorax fusco-testaceous, antennae and tarsi similarly pale, legs more or less infuseate; rather thickly clothed with conspieuous, suberect, rellowish-grey hairs. 
Head distinctly and moderately closely punctured. Eyes large, prominent and subrotundate, with coarse ficets. 'Thorax a third broader than long, apex subtruncate, base rounded; the sides finely margined, slightly flattened and gently rounded, more uarrowed in front than behind, posterior angles rectangular, the anterior obtuse; its punctation irregular, much finer and more listant on the middle than near the sides. Elytra twice the length of the thorax, rather broader, with slightly eurvedly narrowed shoulders; they are moderately closely punctured, rather more coarsely than the thorax, in some instances the longitudinal space between the mithlle and base of each elytron is more finely sculptured.

intennae shorter than the head and thorax, fincly pubeseent; 2nd joint shorter and much narrower than the basal, 3rd rather elongate, 4th and 5th nearly equal, rather longer than joints 6-8; club triarticulate. Claws appendiculate at the base.

Underside dark fuseous, finely pubescent; metasternum longitudinally grooved behind the middle, not at all coarsely and hardly as closely punctured as the abdomen. Basal segment as long as the following two united; 5th shorter than 4th, feebly emarginate and finely margined behind; the 6 th almost semicircularly emarginate.

The almost uniformly brownish-black borly, and the thick, irregularly disposed pubescence form good distinguishing features. The more convex S. picinus, 1140 , besides being considerably larger, is more rotundate and usually aeneous.

Length, $3 \mathrm{~mm}$. ; breadth, $1 \frac{1}{2} \mathrm{~mm}$.

Iethven, and adjacent localities. Apparently sufficiently common during January and February to be serviceable to agriculturists. This is another of Mr. 'T. Hall's novelties.

John Mackar, (fovernment Printer, Wollington,-19]4. 


\title{
NEW YEALANI) INSTITUTE
}

\author{
BULLETIN No. 1. (Pait it)
}

D E S C R I P T I O N O F

\section{NEW (GENERA ANI) SPECIES}

OF

COLEOPTEPA

(PART IY.)

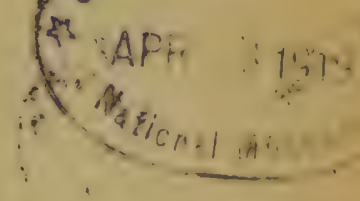

BY MA.JOR T. BROU,N, F.E.S.

FDITED AND PUBLISHED UNDER THE AUTHORITY OF THE BOAID OF GOVERNORS OF THE INSTITUTE.

ISSUED 17th FEBRUARY, 1915.

Meto 光calinit:

JUIX MACAY, GOVERYIEXT PISITER, WELLIYATON.

W M. WESLEY AYD SON, 28 E'BSEX STREET, STRAND, I.ONHON, W.C. 
NEW ZEALAND INSTITUTE.

\section{BULLETINS.}

UNDER the title "Bulletins" the Board of Governors of the New Zealand Institute hopes to issue, from time to time, papers which for any reason it is reemed desirable not to include in the yearly volume of the Transactions. The bulletins will be uniform in size and general style with the Transactions of the New Zealand Institute, but will appear at irregular intervals, and each bulletin will be complete in itself and be separately paged. The bulletins will not be issued free to members of the Institute, but may be obtained by them at a reduction on the published price. 


\title{
NEW ZEALANI) INSTITUTE.
}

\section{BULLETIN No. 1, PART IY.}

ISSUED 17 TH FEBRUARY, 1915.

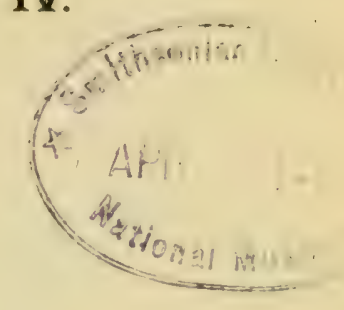

\section{DE S C R I P T I O N S}

\author{
OF
}

\section{NEW GENERA AND SPECIES OF COLEOPTERA.}

By M*Jor T. Broun, F.E.S.

[Read before the Auckland Institute, 3rd December, 1913.]

\section{PART IV.}

THE researches of Messrs. A. Philpott, of Invercargill; II. O. Pasco, of Queenstown; F. R. Field, of Opotiki; W. and L. Burrows, of Nethven; and Mr. T. Hall, within the past twelve months, have enabled me to prepare the following record.

Exclusive of fifteen species of Pselaphidae in my own collection, one from Mr. A. Brookes, of Mount Albert, and two of the Carabidae from Mr. Field, these six kew renera and 105 species were almost all found in the South Island, half of them by Mr. T. Hall whilst he resided at Methven.

In the following list the numbers are in continuation of those in Bulletin No. 1, Part III. published by the New Zealand Institute. 


\section{LIS'T OF NEW GENERA AND SPECIES.}

Group Cnemacantmidie.

3(iz!). Mecodema halli Broun.

$3680 . \quad$, huttense Broun. 368i. , ", perseulptum Broun. 3682. ", ambiguum Broun. 368:3. Netaglymma curvidens brown. 3684. Oöpterus basalis Broun.

Group Ferroxido.te.

3685. Trichostermus blandcllus Broun. 3686. Pterostichus paseoi Broun.

$3687 . \quad$, bullatus Broun.

3688 . ", ficldi Broun.

\section{Group /\%OLINI.}

3689. Zolus subopacus Broun.

Group HrinophLtDa.

3690. Gitocyloma nigratus Broun.

\section{Group Staphylinidan.}

3691. Quedius inurrowsi Broun.

$36 ! 32$. "hirtipemnis l'roun.

\section{Group Omalidal.}

3693. Ischnoderus curtipennis Broun. 3694. Omalissus scutosus Bromm.

\section{Group FARONINI.}

3695. Siugola socia Broun.

3696. ,, setiventris Broun.

3:397. ," crassulipes Broun.

36iss. ", opereularis Broun.

3699. , brevistemis Broun.

3700. ", rustica Broun.

3701. ". confu:a Bruun.

3702. , longipes Broun.

3703. " indiscrota Broun.

3704. ", rotundiceps Broun.

3705 . , fulvipennis Broun.

3706. ," bifida Broun.

3707. , posticalis Broun.

3708. .. lactula Broun.

3709. ,, concolorata Broun.

Group Euplectini.

3710. Euplectopsis perpunctatus Broun 3711 . " nitipennis Broun. $3712 . \quad$ duplex Broun. 3713. ", cuneiceps Broun. $3714 . \quad$.. bryocharis Broun. 3715. .. blandiatus Brom. 3716. , , impressus Broun. $3717 . \quad$ ", dorsalis Broun. $3718 . \quad$ " elongellus Broun
3719. Plectomorphus laminifer Broun. 3720. Vidamus congruus Broun. 3721. " clavipes Broun. 3722. ", punetulatus Broun. 372:3. Zealandius brookeci Broun. 3724 . 3725. Eleusomatus ovicollis Broun.

$$
\text { Group 'IYrini. }
$$

3726. Hamotulus robustus Broun. 3727. " $\quad$ fuscipalpis Broun. $3728 . \quad$, cornutus Broun.

Group SCydianNidae. 3729. Scydmaenus angulifrons Broun. $3730 . \quad$, sulciferus Broun. 3731. , latuliceps Broun. 3732. " fragilis Broun. 3733. Adrastia clavatella Broun. 3734. Phagonophana alacer Broun. 3735. , , halli Broun. 3736. , palpalis Broun 3737. sinuata Broun.

('roup) Nitidulida.

37:38. Cyclaxyra impressa Broun.

Grolip 'T'rogositida E.

3739. Promanus pulchellus Broun.

Group Colydiddas.

3740. Ulonotus planiceps Broun.

Group ByrRHIDaE.

3741. Synorthus rectifrons Broun.

3742. Pedilophorus nigrescens Broun.

Group Melolontuidae.

3743. Odontria puncticollis Broun.

Group Dascrlidiak.

3744. Veronatus tarsalis Broun. 37.45 ., fulgidulus Broun. 3746. Cyphon eincticollis Broun.

$3747 . \quad$.9 granulicollis Broun.

37.4s. ", plumatellus Broun.

374 !). . burrowsi Bromen.

Group MeltridaA.

37.il. Dasytes philpotti Broun.

Grotip 'Texebrionida.

3751. Pheloneis appositus Broun. 3752. Philpottia maculatus Broun. 
Gir up Melandritida.

3753. Hylobia sexnotata Broun.

3754. ", aeuminata Broun.

375.5. " arboricola Broun.

Group OTIORHYXCHDAE.

3756. Zenagraphus metallescens Broun.

3757. Inophloeus aplorhinus Broun.

$3758 . \quad$. tricostatus Broun.

\section{Group Cylindrorhinidae.}

3759. Mecosargon costipennis Broun.

3760. Pparchus halli Broun.

3761. Liparogetus sulcatissimus Broun.

\section{Group Hylobidda.}

3762. Bryocatus burrowsi Broun.

Group RHyparosomida.

3763. Clypeorhynchus striatus Broun.

3764. Phygothalpus nitidulus Broun.

376.5. " " majusculus Broun.

3761i. Nestrius crassicornis Broun.

Group Erirrhuxidat.

3767. Erirrhinus cordipennis Broun.

3768. Dorytomus methvenensis Broun.

3769. Oreocharis pleuralis Broun.
Group BeLIDAE.

3770. Pachyura aenescens Broun.

Group Cryptorhynchidan.

3771. Acalles furvus Broun.

3772 . " bicinctus Broun.

3773. \%eacalles scaber Broun.

3774. ", sparsus Broun.

\section{Group Lamildae.}

3775. Hybolasius sculpturatus Broun.

Group Cryptocephalidae.

3776. Arnomus fulvis Broun.

3777., vicinus Broun.

Group C'Hrysomelidae.

3778. Cyrtonogetus crassus Broun.

Group Galerdeidat.

3779. Luperus nodicollis Broun.

3780. , dilutipes Broun.

3781. ," pubicollis Broun.

3782. Allastena piliventris Broun.

ADDENDUM.

3206. Euplectopsis eruensis Broun. Description of male, p. 294. 


\section{Group Cnemacanthidae.}

3679. Mecodema halli sp. nov. Mecodema Blanchard, Man. N.Z. Coleopt., p. 7.

Subdepressed, moderately broad; glossy black, legs, antennae, and mandibles piceo-rufous.

Head, eyes included, almost as broad as thorax, with deep rugate on the forehead, almost unimpressed elsewhere, but with the usual setigerous punctures near each eye; labrum medially emarginate. Thorax widest near the front, curvedly narrowed backwards, more so behind. the base with almost straight sides; lateral marcrins entire, the channels only slightly broader in front than behind, with several setigerous punctures; it is only a sixth broader than long, almost smooth, having only a few short, rather fine, longitudinal striae at the base, which, like the apex, is only slightly emarginate, median groove narrow, not attaining the base or apex, basal foveae deep and subrotundate. Elytra oblong-oval, widest near the posterior femora, gently narrowed towards the base, rather broader there than the thorax, $2 \frac{1}{4}$ times its length; their striae regular and distinct, deeper and broader near the sides, moderately coarsely punctured there, rather finely near the suture ; interstices almost plane, the outer ones more convex, 3rd and 5th slightly wider than the others, the 7 th sometimes tripunctate near the base, the common lateral space smooth, apical sculpture less regular and coarser.

Posterior tibiae simple, the others moderately prominent at the outer angles, the intermediate asperate. Intennae pubescent from their sth joint onwards.

Underside shining black, nearly smooth, the terminal ventral segment quadripunctate at the apex.

In size and appearance this most nearly resembles 11 . commatum, 2603, but it is rather broader, the thorax is differently formed, with broader lateral channels, deeper and more rotundate basal fossae, more distinctly punctate-striate elytra, and with 4 instead of 6 punctures on the extremity of the last ventral segment.

Length, $24-25 \mathrm{~mm}$.; breadth, $8-8 \frac{1}{2} \mathrm{~mm}$.

Mount Hutt, near Methven. Named in honour of Mr. T. Hall, who found his first specimen on the 10th January, 1913, at an elevation of $3,500 \mathrm{ft}$. ; two or three more were obtained on other occasions at $4,500 \mathrm{ft}$.

3680. Mecodema huttense sp. nov.

Elongate, moderately nitid; hlack, tarsi. antemnae, and palpi piceous. these last with rufescent tips.

Hearl rather narower than thorax, distinctly punctured behind the eres. and with some finer punctures on the vertex. forehead with lomgitudinal rugae, those near the eyes somewhat curved. 'Thorax about a fourth broarler than bonge its sides indistinctly crenulate only slightly rounded, stradually narrowed behind the middle, more strongly hit not abruptly near the base. Where its sides ale noarly straght, the rounderd anterior angles are a little explanate. the hate and apex foebly emarginate and with short longiturlinal striar: dise without obsious transierse st riare. rentral groose marked but scarcely reaching the hase or apex, hasal fossace derepe extending to the sides and basal margin, there are several distinct punctures near the fossae but only a few on the intervening spares, the front and sides are distantly, the anterior angles more rlosely punctate. Elytra oblong-oval, double the 
length of thorax; on each there are 5 feebly impressed fincly punctured striae with plane interstices, which are more or less finely wrinkled behind the middle, the 6th stria is broader and irregularly sculptured, some of the punctures near the base and extremity being larger than the others, the 7 th and 8th striae are shallow but their punctation is (lose, that of the former rather coarser than the latter, the lateral punctures behind the middle are very coarse and distant, the whole of the apical sculpture is coarse and irregular.

Antennae with distinct pubescence on the 5th and following joints. Front and middle tibiae with prominent outer angles, the latter asperate, the posterior simple. Terminal joint of maxillary palpi truncate at the extremity but only moderately thick. Mentum tooth minutely bifid.

Tnderside shining black. Flanks of prosternum distinctly but not very closely punctured. Abdomen finely wrinkled near the sides, the last segment transversely strigose, bipunctate at each side of the middle at the apex.

This hardly at all resembles $M$. halli, and is unlike any other in $m y$ collection. Castelnau's $M$. impressum, 16, from Dunedin, is described as being of a rather brilliant dark-copper colour, with the front angles of the thorax covered with a dense punctation, and with 3 or 4 rather large punctiform impressions between the 7 th and 8 th elytral striae. In $M$. huttense the interval between these striae is so narrow, and almost obliterated behind the middle, that only very minute punctures could be plared there. Although I have not seen $\dot{M}$. impressum, I have no doubt it is the nearest ally of M. huttense.

$\hat{o}$. Length, $21 \mathrm{~mm}$. ; breadth, $6 \frac{1}{2} \mathrm{~mm}$.

Mlount Hutt. Unique; one caught by Mr. T. Hall on the 15th March, 1913, at a height of $4,500 \mathrm{ft}$.

\section{Mecodema persculptum sp. nov,}

Subdepressed, elongate. moderately shining; black, legs, antennae. and palpi piceous.

Head rather narrower than thorax and, including the mandibles, equalling it in length; densely, coarsely, and irregularly rugose in front, corarsely and closely punctate, and with short rugose interstices behind: labrum subtruncate, with an obvious basal depression. Eyes prominent, about equidistant from the thorax and antennae. Thorax a fifth broader than long, its sides finely crenulate, not expanded, slightly rounded for twothirds of the length, a good deal curvedy narrowed behind, the base much contracted and straight-sided, with obtuse angles: disc rlosely. coarsely, and irregularly rugose, the rugae here and there interrupted by short lomgitulinal impressions and more or less finely punctured: biase and apex slightly emarginate, both sored with deep longitudinal. somewhat irregular striae, the hase, in addition thereto, with numerous punctures: median furrow well marked but abbreviated, basal fossae deep but not large. Elytua ohlong-owal, only a sixth hroader than thorax. 2! times its lenorth. rather wider than it is at the base, only moderately narrowed behind: their sculpture consists of roarse biblong or punctiforin impressions. these are subseriate near the suture hut berome more rotundate and irregular, and a little deepere towards the sides. the usual smonth lateral spare is narrow.

Tnderside shining black. Prosternum slightly wrinkled and punctate in the midrlle. its flanks more corarsely punctured. its process broarlly erowerel. Metasternum and posteriop roxar ruesese. Abromen nearly smoroth alone the middle. with some fine punctures and irregular wrinkles near the sider, 
the terminal segment transversely strigose and quadripunctate at the extremity.

Antennae shorter than the head and thorax, finely pubescent from their it joint onwards. Front and middle tibiate only moderatedy, the posterior not at all prominent at the extremity, the intermediate somewhat dilated inwardly below the middle and asperate externally.

In Sharp's M. rugiceps, 1759, which is not represented in my collection. the thoracic disc is "evenly covered with deep, quite uninterrupted transverse lines." $M$. mitidum, 2597 , is smaller and more brilliant, with finer and much less dense sculpture on the head and thorax, and the intermediate tibiae instead of being dilated inwardly are nearly quite straight there. These are the nearest species.

$\hat{o}$. Length, $19 \frac{1}{2} \mathrm{~mm}$; breadth, $6 \mathrm{~mm}$.

Lake Mackenzie. Otago. Described from ome eximple found h. Ir. M. O. Pasco, of Queenstown, on the 3rd November, 1912.

\section{Mecodema ambiguum sp. nov.}

Elongate, somewhat attenuate behind, nitid; black, legs and antennae piceous, tips of palpi rufescent.

Head rather narrower than thoracic apex, without definite frontal or interocular rugae, moderately finely punctured behind. Thorax hardly a sixth broader than long, base feebly, the apex more widely but not at all deeply emarginate; its sides not crenulate, gently rounded in front, more curvedly narrowed behind the middle. the base much contracted and stratghtsided. lateral channels narrow and of almost equal width throughout. with several setigeroms punctures: dise very slightly comvex. smonth, with at simple shallow impression near each anterior angle, hasial fosise moderately large and deep, the central groove well marked but not reaching the base or apex. Elytra oblong-oval, about a sixth broader than thorax, nearly twice its length, a good deal curvedly narowed near the extremity : with slightly impressed and finely punctured striae and almost plane interstices on the middle; 6 th and 7 th striae deeper, their punctures moderately coarse and subquadrate, with convex interstices, 8th striae rather shallow, their punctation a little finer; the common broad lateral space on each is smooth, marginal channels distinctly punctate, the apical sculpture irregular.

Legs normal, front and middle tibiae moderately prominent at the outer extremity, the latter pair somewhat asperate, the posterior simple. Antennae pubescent from the 5th joint onwards.

Underside glossy black, flanks of prosternum moderately punctate but without rugae; terminal ventral segment bipunctate at each side of the apex.

Castelnau's $M$. impressum, 16, is described as having the anteriol angles of the thorax covered with a dense punctation. M. laevicolle, 3166, from Bold l'eak, is smaller and more glossy, the elytra are broader behind, the 4 or 5 inner striae on each are indefinite, obsolete at the base, the 7 th and 8th interstices are scarcely at all carinate, and the prosternum is rugose; with these exceptions, it is certainly very similar. The common frontal longitudinal striae, as well as the interocular ones, are absent; this forms another aid to identification.

;. Length (mandibles inclusive), $25 \mathrm{~mm}$. : bresdth, $7 \underset{2}{1} \mathrm{~mm}$.

Ben Lomond, Otago. One from Mr. A. Philpott, found early in December, 1912. 
3683. Metaglymma curvidenssp. nov. Metagiymma Butes, Ent. Mu. Matr.. 1867, p. 78, snd Min. N.Z. Coleopt., p. 10.

Elongate, slightly convex, moderately nitid; black, antennae, palpi, and tarsi rufo-piceous.

Head rather narrower than thorax, depressed and obsoletely wrinklert behind the prominent eyes, with well-marked irregular rugae, and a setigerous puncture, near each of these; forehead minutely punctate and broadly trisulcate; labrum almost semicircular, with 6 setigerous punctures; mandibles curvate, distantly punctured. Thorax apparently elongate, yet of exactly equal length and breadth, the sides finely margined, indistinctly crenulate, nearly straight to behind the middle, somewhat abruptly contracted and parallel near the base; disc nearly plane, with fine transverse striae, median groove distinct but not attaining the apex, bisal foveae moderate, situated close to the lateral margins. Elytra oblongoval, twice as long as thorax, rather broader than it is at the base, a little wider near the hind thighs, gradually narrowed posteriorly; each elytron with 8 moderate, finely and rather indistinctly punctured striae, these are deeper at the base, but become obliterated by the rugose irregular apical sculpture: interstices almost plane, the $3 \mathrm{rd}, 5$ th, and sutural slightly broader than the others, the 7 th unipunctate near the hind thigh, the broad space between the external striae and lateral margin is smooth.

Antennae extending backwards to the middle of thorax, joints 5-7 scantily, the following ones more evidently pubescent, 3rd rather longer than contiguous ones.

Tibiae, anterior and intermediate, prominent at the outer extremitr, the posterior less so, the middle and hind pairs somewhat asperate.

Flanks of prosternum, the mesosternum, and terminal ventral segment finely transversely striate; this last segment quadripunctate at the apex.

IIentum tooth triangular, acute and curved upwards at the extremity, with a pair of conspicuous setigerous punctures at its base. Palpi stout, their terminal articulations suboriform, truncate at apex, double the length of the penultimate.

The elongate form, indefunitely punctate elytral striae, the interfemoral punctures, and the peculiar mentum tooth, conjointly. distinguish this from every described species.

o. Length, $20 \mathrm{~mm}$; ; breadth, nearly $6 \mathrm{~mm}$.

Opotiki. A single female received during December, 1912, from Mr. F. R. Field, together with some other species of Coleoptera.

3684. Oöpterus basalis sp. nov. Ö̈pterus Guerin, Møn. N.Z. Coleopt., p. 54.

Nitid, piceous, lateral margins of the thorax and elytra, and the suture of the latter, piceo-rufous, head and thorax sometimes equally rufescent, legs and antennae chestnut-red. palpi infusate pale near the extremity.

Head with well-marked interocular furrows, and, including the large slightly convex eyes, as broad as the thoracic apex. Antennae stout, attaining the shomlders. Ist and 2 nd joints glahous. Brd and 4 th more scantily pubescent than the following ones. Thorax slightly broader than long, rounded and widest at or just before the middle. eradually but eridenty. narrowed behind, with distinctly rectangular posterior angles: dise a little convex, almost smooth. median grouve well marked hut not reaching either base or apex: hasal foreate molerately larwe. mot prolonged forwards, each 
separated from the lateral margin by a slight rarina, the whole basal region punctate. Elytra oviform, broader than and nearly thrice the length of the thorax. with strongly lounded shoulders and distinet marginal rhannels; sutural striae well marked throughout, the next pair less so, and more or less finely punctured, those beyond are less definite and beconte obsolete posteriorly; 3rd interstices tripunctate, the usual apical carinae are well developed.

Male-Basal joint of anterior tarsi oblong, its inner extremity prolonged, the next similar but shorter.

Fem.-Basal joint oblong, 2-4 cordiform but smaller.

O. pygmeatus, 2618 , has a cordiform, impunctate thorax, with narrower lateral margins and less distinct posterior angles, and the basal foveate are somewhat prolonged anteriorly. It is the nearest species.

Length, $3 \frac{1}{2} \mathrm{~mm}$. ; breadth, $1 \frac{1}{2} \mathrm{~mm}$.

Ben Lomond, Otago. One of each sex found by Mr. 1. Philpott, of Invercargill, in December, 1912.

\section{Group Feronidae.}

3685. Trichosternus blandellus sp. nov. Trichostemus Chaudoir, Man。 N.Z. Coleopt., p. 31 .

Elongate-oblong, only slightly convex, shining, variegate; the nigrescent parts faintly violaceous, the lateral channels and basal fossae of the thorax and the sides of elvtra bright metallic green, the head and thoracis disc slightly viridescent, elytra somewhat cupreous on the middle: antennae, labrum, mandibles, leos, and palpi more or less rufo-piceous, these last with rufescent tips.

Head rather narrower than thorax, smooth, fontal impressions moderately deep and elongate; with a setigerous puncture at each front angle of the forehead and a pair near each eye; labrum widely emarginate. Eyes prominent, the genae somewhat swollen below them. Thorax a third broader than long, widest before the middle, moderately rounded there, gradually narrowed towards the rectangular posterior angles, its apex moderately incurved, the base less so: dise almost quite smooth. with a slight impression near each front angle, basal fossae large and deep, extending almost to the angles and with a slight impression between them. median groove hardly attaining the apex: lateral margins and chamels well developed, the latter somewhat expanded behind. Seutellum almost smooth. Elytra oblong, with dentiform shoulders, a little wider than thorax at the base, hardly thrice its length, moderately sinuate and narrowed towards the extremity, their sides broadly explanate hehind: they are finely punctate-striate, and have short scutellar striolae; interstices plane near the suture, convex towards the sides, 3rd, 5th, and 7 th evidently broader than the others, these last usually distinctly sexpunetate, the 3rd bipunetate hehind the middle.

Legs moderate, intermediate tibiae laterally compressed and prolonged at the extremity.

Underside brilliant black, head viridescent, prosternal process setigerous, forminal rentral segment quadripunctate at apex.

When placed alongside the male of $T$. antarcticus, 65 , this species is seen to be narower and lese convex. the altemate interstices of the elytrat are unmistakably broader, so that the 4 th and 6 th are little more than half the width of the 3 rd or 5 th, whilst the sutural ones are flat; the coloration also is dissimilar. No other species resembles it. 
o. Length, $25 \mathrm{~mm}$; breadth, $8 \frac{1}{2} \mathrm{~mm}$.

Fem. $-25 \mathrm{~mm}$. by $9 \mathrm{~mm}$. Head and thorax almost wholly viridescent, elytral disc more fusco-cupreous, alternate interstices nearly plane, the 4 th and 6 th much less narrowed. This is even less like the female of 65 than the male is.

Mount Hutt. Found by Mr. 'T. Hall at an elevation of 4,500 ft., one male on the 15th March, 1913, and the female on the Ist January, 1913.

3686. Pterostichus pascoi sp. nov. Pterostichus Bonelli, Man. N.Z. Coleopt., p. 44 (Feronia).

Subdepressed, elongate-oblong, slightly nitid: black, palpi, antennae, and legs nigro-piceous.

Head rather narrower than thorax, smooth, with rather deep frontal inıpressions and an abbreviated interocular groove; labrum emarginate. Eyes prominent, their orbits not swollen. Thorax in the middle nearly a third shorter than the greatest width, which is just before the middle, the sides considerably sinnously narrowed behind, with quite rectangular posterior angles, base and apex evidently medially emarginate; its surface smooth, the central groove attains both base and apex, parallel with the latter a well-marked curvate impression terminates in a transversal fovea behind each eye, basal fossae deep. Scutellum striate at base. Elytra oblong-oval, with dentiform shoulders, almost thrice the length of thorax, rather broader than it is at the base, somewhat wider near the hind thighs, sinuously narrowed towards the extremity; their striae are rather shallow near the suture, a little deeper at the sides, all very finely punctate; interstices almost plane, the 3 rd with 3 , 5th with 2 , 7 th with 6 or 8 rather larger punctures.

Intermediate tibiae with the apical portion laterally compressed, turned slightly inwards, and prolonged over the basal joint of the tarsi.

When compared with the same sex of 1776 , this is seen to be less glossy, rather broader, and less convex. The mandibles are less curved and acute at the extremity. Thorax without transverse discal striae, but with a distinct frontal impression. Elytra flatter, broader behind the posterior femora, with finer and less perceptibly punctate striae. Legs more robust. The last ventral segment at each side of the middle, at the apex, has only a single setigerous puncture, whereas in 1776 , and its varietal form, 2636, $P$. oneroaensis, there are always two.

ô. Length, $29 \mathrm{~mm}$.; breadth, $10 \mathrm{~mm}$.

Ben Lomond, Otago. One, received on the 28th February, 1913, along with several other novelities, chiefly weevils, from $M_{r}$. M. O. Pasco, of Queenstown, in whose honour this fine species has been named.

\section{Pterostichus bullatus sp. nov.}

Robust, oblong, moderately convex, nitid; nigrescent, marginal channels of thorax and elytra somewhat violaceous, legs, antemnae and palpi rufopiceous, elytra with a few erect ferruginous setae.

Head large, almost as broad as front of thorax, nearly smooth, with moderate frontal impressions, the labrum widely enarginate. Eyes prominent. Thorax subcordate, emarginate at base and apex, so that the length in the middle is but little more than half of the greatest width, near the front, the sides are strongly margined and gradually narrowed from before the middle to the restangular but not at all prominent posterour angles; dise nearly smooth, having only a few obsolete undulating striate 
and some longitudinal ones at the centre of the base, the lateral channels are well developed, the slight frontal curvate impression is subfoveate behind each ere, the median sulcus extends from the basal margin almost to the apex, basal fossae large, with a shallow impression between them; there is a setigerous puncture at each hind angle and another before the middle. sertellum striate at hase. Elytra oblong-oval, less than thrice the lenerth of thorax, their dentiform shoulders slightly broader than its base, rather wider near the hind thighs, distinctly narrowed towards the broad apices; their fine sutural striae are minutely punctate and entire, the others are irregular ; the $3 \mathrm{rd}$, 5th, and 7 th interstices are broad and moderately convex but so interrupted that each appear's to consist of from 5 to 7 distinctly separated more or less oblong elevations; the marginal channels are seriatepunctate.

Underside shining black, nearly smooth. 'Terminal ventral segment obtusely elevated behind and bipunctate at each side of the middle at the apex.

․ Length, $28 \mathrm{~mm}$; breadth, $11 \mathrm{~mm}$.

Greenstone Flat, near Queenstown. A single female found by Mr. M. O. Pasco on the 1st November, 1912.

The remarkable elytral sculpture distinguishes this from every other species of our Feronidae.

\section{Pterostichus fieldi sp. nov.}

Elongate, slightly convex, nitid; black, antennae, palpi, and tarsi piceorufous.

Head rather narrower than thorax, smooth, with well-marked frontal impressions, bipunctate alongside each eye; labrum feebly emarginate, quarlipunctate; mandibles somewhat rufescent, deeply obliquely striate. Eres moderately prominent. motundate, their orbits swollen behind. Thorax of equal length and breadth, apex deeply incurved, with olutuse angles, the base widely but not deeply emarginate, its angles acutely rectangular; the sides distinctly marginate. evenly and moderately rounded to behind the middle and distinctly sinuate towards the base; dise nearly smooth, with a few fine longitudinal striae at the base and apex, median groove well immessed but not reaching the fornt, hasal foreas deep. only moderately broad. wituated nearer the sides than the middle. Serutellum striate at hase. Elytra oblong-oval, hardly double the length of thorax, a little broader, with simple gradually narowed shoulders, sinuously but not abruptly contracted towards the moderately broad extremity; on each there are 7 deep. regular. very finely, almost impereptibly punctured striae: interstices noarly plame, slighty convex towards the sides, the Brd, sthe and 7th a little broader than the others.

Underside glossy black. Flanks of prosternum finely and irregularly munctate. Terminal rentral seoment obtusely angulate medially at the extremity, subtruneate near the middle, sinuate towards the sides, with a single apical puncture near each side.

Femora robust, the posterior angulate, almost dentiform underneath, tibiae slightly curved and dilated towards the extremity. Antennae normal.

This differs from $P$. hybritus, 1469, in having the thorax broader near the front, distinctly sinuate behind, and with acutely rectangular posterior angles; the elytral striae are not at all interupted. $P$. pellax, 1147 , the only other close ally, has a more quadrate thorax, irregularly punctured elytral striae, and convex interstices. All have, or had, 4 setae at each side 
of the thorax, and therefore belong to the same section. These setae, however, are often displaced when the insect has to be freed from dirt.

o. Length, $14 \mathrm{~mm}$; ; breadth, $4 \frac{1}{2} \mathrm{~mm}$.

Opotiki. A single specimen, discovered by Mr. F. R. Field, whose name has been given to it.

\section{Group ZoLini.}

3689. Zolus subopacus sp. nov. Zolus Sharp, Man. N.Z. Coleopt., p. 1000 .

Oblong-oval, slightly convex, rather dull; fusco-niger, the forehead, mandibles, elytral margins, and basal joint of antennae piceo-rufous, remaining articulations, tibiae, and tarsi more or less infuscate-red, femora darker, palpi fulvous.

Head, including the large moderately prominent eyes, nearly as broad as front of thorax, with a few feeble rugae, the elongate impression near each ere is not deep, and the plica obtuse, the forehead has 2 setigerous punctures and a small median fovea. Thorax subquadrate, a fourth broader than long, base truncate, apex slightly and widely emarginate; the sides very distinctly and evenly margined, a little wider before the middle than elsewhere, gently curvedly narrowed in front, nearly straight and only slightly narrowed behind, posterior angles rectangular: median groove not abbreviated but rather slender, basal foveae large, with a distinct plica between each and the side, there are no punctures, only a few obsolete longitudinal striae near the base and short transverse ones on the middle of the disc. Scutellum broad. Elytra oviform, widest near the middle, a good deal but not abuptly narrowed posteriorly, they are more than double the length of the thorax and a little broader than it is at the base; they are feebly striate, quite obsoletely towards the sides, with almost quite flat interstices, the $3 r$ are finely tripunetate, the suture is slightly convex, the apical carinar are distinct, and the marginal channels well developed, there are 4 lateral punctures behind each shoulder and about the same number towards the extremity.

Antennae pubescent from the middle of the $3 r d$ joint onwards, and extending to just beyond the middle femora. Tarsi with fine yellow setae above.

The subopaque surface, impunctate and subquadrate thorax, and feebly impressed elytral striae distinguish this from the other species.

․ Length, $7 \frac{1}{2} \mathrm{~mm}$; ; breadth, $3 \mathrm{~mm}$.

Ben Lomond, Otago. A single specimen found by Mr. A. Philpott, of Invercargill, early in December, 1912.

\section{Group HydrophiLIdAE.}

\section{Gitocyloma gen. nov.}

Body oblong-oval, only moderately convex. Labrum invisible. Eyes slightly prominent, finely faceted. Antemnae 8-articulate, hasal joint elongate, fully the length of the following four united, 2nd oblong. Brd nearly as long as 2 nd but more slender near its base, fth small and transverse. 5t $h_{1}$ also short but twice as broad; rlublarge, 3-jointed. laxly articulated. Maxillary palpi moderately short, their basal joint concealed from above. 2nd large and rlavate, the next twice as long as broad, thickened towards the extremity, terminal of nearly the same length and thickness as its predecessor.

Mentum transversely quadrate, subtruncate in fromt. medially depressed. Intennal cavities large, extending from the front of and alongside the 
subtruncate inner margin of the eyes. Prosternum widely emarginate at the apex, somewhat obtusely elevated but not definitely earinate along the middle, and projecting acutely as far as the middle of the contiguous coxae, and with a distinct curved groove proceeding from each of these half-way towards the side. Mesosternal process narrow, quite vertical in front; intermediate coxae slightly separated. Metasternum moderately elongate, obtusely and angulary elevated in the middle. Abromen with 5 segments, the basal rather larger than the next, without any trace of median carina. Femora distinctly punctate and pubescent underneath. Tibiae finely spinose externally, bicalcarate at the extremity. 'Tarsi elongate, setose below, basal joint of the posterior evidently shorter than the next. Claws simple.

Cyloma and Psephoboragus are the only other New Zealand genera with 8-jointed antennae. Both are distinguishable by the more convex and subrotundate body, ematrinate mentum, different mesosternal procesis. and shorter metasternum.

'The cosmopolitan Cercyon more nearly resembles it in form, but it has 9-jointed antennae, a broad horizontal mesosternal process, and the basal ventral segment and prosternum are medially carinate, \&c.

\section{Gitocyloma nigratus sp. nov.}

Glabrous, nitid, nigro-piceous, the sides of thorax and margins of elytra castaneo-rufous, the apical portion of these latter paler, tibiae rufous, antennae and tarsi infuscate, claws testaceous.

Head immersed up to the eyes, almost as broad as front of thorax, the forehead truncate; its surface finely, yet distinctly, and moderately closely punctate. Thorax quite twice as hroad as long. gently curvedly narowed anteriorly, with obtuse anches, the apex very slightly rounded in the middle and sinnate towards the sides. the base subtruncate and rosely applied to the elytra, lateral margins slender; its punctation similar to that of the head. Scutellum rather large, subtriangular, finely punctured. Elytra oblong, rounded behind, thrice the length of the thorax; the sutural striae distinet near the extrenity but becoming quite obsolete before the middle: on each elytron there are about 5 more or less regular dorsal series of moderately fine punctures, the intervals are rather more finely punctate near the middle.

Tibiae with very few setiform spines. T'arsal vestiture yellow. Antennal club opaque, its last joint with a foveiform cavity underneath.

Underside subopaque, nigrescent, elosely and minutely sculptured, and bearing inconspicuous, fine, ashy pubescence.

Length, $4 \mathrm{~mm}$. ; breadth, $21 \mathrm{~mm}$.

Mount Hutt. I am indebted to Mr. 'T. Hall for the two specimens, which he found on the 25th January, 1913.

\section{Group Staphylinidae.}

3691. Quedius burrowsi sp. nov. Quedius Stephens, Lacord. Hist. des Ins. Coleopt., tom. 2, p. 84.

Elongate, black, head and thorax shining, with outstanding fuscous setae along the sides, elytra and abdomen clothed with elongate depressed ashy pubescence; mandibles, antennae, and legs rufo-piceous.

Head oviform, narrower than thorax, medially bipunctate in line with the middle of the eyes, and at the inner margin of each, quadripunctate 
behind them, and with a pair of punctures at the basal margin; clypens membranous, short and dark; labrum not emarginate but with a broad groove along the centre. Eyes longitudinally oval, nearly flat, covering more than half of the sides of the head. Thorax slightly longer than broarl, base and hind angles rounded, its sides finely inargined, nearly straight, but very gently narrowed anteriorly, apex widely emarginate, with obtuse somewhat deflexed angles; dise distinctly quadripunctate along each side of the middle, more finely tripunctate near each side of the apex, between each side and the submedian series there are 9 irregularly placed punctures, and there are some fine ones on the basal margin. Scutellum large, triangular, with minute, distant, subgranular seulpture. Elytra rather broader than long, apices with rounded angles but oblique towards the suture, with moderately close punctiform sculpture. Hind-body elongate, irreguarly and rather finely punctate, terminal styles moderate.

Tibae finely spinose, anterior tarsi only moderately expanded.

Antennae not as long as the head and thorax, their 3rd joint rather shorter than the basal but slightly longer than 2nd, joints 4.10 subequal, dull and minutely pubescent, the penultimate rather longer than broad.

The thorax is like that of $Q$. puncticollis, 270)3, but it is emarginate in front, the head is evidently elongate-oval, the mandibles are shorter, the labrum is more prominent and has a well-marked rentral gronve, and the insect itself is larger.

The New Zealand species in my cabinet are divided into sixteen sections; these two belong to Section VI.

ㅇ․ Length, $9 \frac{1}{2} \mathrm{~mm}$. ; breadth, $1 \frac{3}{4} \mathrm{~mm}$.

Pudding Hill, near Methven. One female, found on the 13th April, 1913, during a wet, stormy day, by Mr. L. Burrows, of Methven, after whom it has been named.

\section{Quedius hirtipennis sp. nov.}

Elongate, head and thorax glossy aeneo-niger, with some long fuscous setae, elytra thickly covered with decumbent yellowish hairs, hind-body slightly variegated chestnut-brown, with less conspiruous pubescence; legs fusco-testaceous, basal joint of antennae yellow, 2-4 less so, 5-11 infuscate.

Head oviform, narrower than thorax, smooth along the middle, bipunctate alongside the eyes, rlosely and fincly punctate behind them, and with an oblique pair of punctures there. Eyes ocrupying half the sides of the head. Thorax rather broader than long, base and posterior angles romonderl. its sides slightly curverly narrowed towards the truncate apex, anterior angles obtuse and deflexerd: dise bininctate at each side of the mirldle. the lateral and hasal margins with a few fine punrtures: near earh sirle there is a shallow rotundate fovea in front, and an colongate improssion farther bask. Srutellum larce, trianenlar, of a palo-chestnut hue, pubescent and finely punctate. Elytra subquadrate, with oblique apices, their close punctation much concealed hy the vestiture. Hind-hody gradual!y attenuate posteriorly, rather more than half tire whole length. somewhat irregularly and finaly puncturerl. braring many lone nigresent setate towards the extremity, its last segment stromgly jounderl belind, terminat appendages of moderate length.

Anterion tarsi with strongly dilatenl transicerse hasal artirulations, the terminal joint slender. 
Antennae shorter than the head and thorax, basal 4 joints of nearly equal length, loth slightly longer than broad. the terminal still longer and oviform.

The broadly expanded anterior tarsi and flaveseent wing-ases distinguish this speres from (). comlis, 207, and the other speries, 208 and 206 . belonging to Section VII.

o. Length, $7 \mathrm{~mm}$.; breadth, $1 \frac{1}{3} \mathrm{~mm}$.

Pudding Hill, near Nethven. A single male caught by Mr. T'. Mall on the 4th May, 1912.

\section{Group Omalidae.}

3693. Ischnoderus curtipennis sp. nov. Ischnoderus Fauvel, Hist. Nat. Nouv. Caledon., Caen, 1867, p. 46.

Elongate, parallel, subdepressed, nitid; light castaneo-rufous, legs, antennae, and palpi somewhat flavescent; pubescence scanty. grevish, short, slender, and suberect, but longer and more conspicuous on the abdomen.

Head large, obcordate, its obtuse hind angles slightly wider than the thorax, very gradually narrowed towards the minute eres, more narrowed in front, base medially emarginate, the forehead not quite truncate, being a little oblique towards the sides; it is moderately coarsely and irregularly but not closely punctate, with a pair of distinct elongate foveae behind. the space between these, like the bi-impressed forehead, is almost smooth. Neck short, about half the width of the occiput. 'Thorax a third broader' than long, widest and slightly curved before the middle, gently narrower towards the rectangular posterior angles, its sides distinctly margined and slightly explanate, base and apex truncate: its punctation similar to that of the head, the dise broadly, longitudinally, but not deeply bi-impressed, the interval smooth. Elytra very short, scarcely longer than thorax, gently narrowed anteriorly, apices with rounded angles and oblique towards the suture; they are coarsely, irregularly, and distantly punctured, and without sutural striae. Hind-body elongate, nearly half the entire length, indistinctly sculptured, with broad margins, basal segment usually short, terminal small, subtriangular, and yellowish, the intermediate ones about equal.

Tibiae slightly expanded towards the extremity, finely setose. Tarsi slender, basal joints of the posterior short and compact, only 3 visible above, and together hardly any longer than the claws, the terminal elongate.

Antennar rather shorter than head and thorax, with slender outstanding setae; basal joint pyriform, very thin at the base, 2nd oviform, evidently smaller than the bassal, the next as long as the 2nd but more slender and rradually narrowed towards its base, the and ith small and moniliform, joints 6-10 abruptly broader, somewhat laxly articulated, 8 10 strongly transverse, terminal conical, not quite as long as preceding two combined.

The minute eves, obsolete ocelli, indefinite scutellum, and abbreviated olytra are its most obvious characteristies: these are indications of generic differentiation. The fith ventral segment of the male is short and without incision, the 7 th narrow and subeoneave. The head of the female is rather less dilated than that of the other sex.

o. Length, $2 \mathrm{~mm}$. ; breadth, nearly $\frac{1}{2} \mathrm{~mm}$.

Pudding Hill, near Methen. One female found amongst dead leaves on the ground, at a height of $3.000 \mathrm{ft}$., on the 13th April, 1913, by Messirs. 'I. Hall and L. Burrows; the other sex on the 28th November, 1912. 
3694. Omalissus scutosus sp. nov. Omalissus Broun, Man. N.Z. Coleopt., p. 1042.

Elongate, subdepressed, almost parallel-sided, moderately nitid; picercastaneous, head and thorax darker, lateral margins of the latter and a large indefinite space on each elytron obscurely rufescent; mandibles, antennae, and legs chestnut-red, tarsi flavescent; thorax and elytra with minute, slender, suberect greyish setae, the head and hind-horly with moderately elongate, decumbent greyish-yellow pubescence.

Head as long as thorax but rather narrower, nearly straight hehind the eyes, obliquely contracted anteriorly, forehead subtruncate and smooth, the rest of the surface moderately finely, distantly, and irregularly punctured, and with a pair of small shallow frontal impressions. Eyes quite lateral, rather large, but not at all conspicuous. Thorax about a third broader than long, a little rounded and depressed in front, gradually narrowed behind, with rectangular posterior angles, base and apex subtruncate, with fine lateral rims; its punctation rather fine and distant on the middle, more distinct near the sides. Scutellum moderately large, subtriangular, finely punctate. Elytra slightly longer than broad, a third longer than the thorax, apices truncate but with rounded outer angles; there is a slight depression near the scutellum, behind this the suture is somewhat elevated, their sculpture is like that of the thorax but more or less irregularly subseriate. Hind-borly as wide as the elytra but rather longer, finely but not closely punctate, basal four segments broadly marginate, 25 slightly increase in length, the 1st shorter, terminal sriall, triangular, and much paler.

Tibiae nearly straight, with external spiniform setae.

Antennae rather short, very gradually incrassate, basal joint twice as long as broad yet only slightly longer than the next, 3rd rather shorter, 4 th and 5 th short and bead-like, joints 6-10) transversely quadrate, terminal subovate, not as long as 9 th and 10 th combined.

Labrum prominent, semicircularly emarginate. Nandibles broar near the base, curved and acute at the extremity.

Independently of minor details this species is at once separable from O. castaneus, 1865 , by its well-developed scutellum.

Length, $3 \mathrm{~mm}$.; breadth, $\frac{3}{4} \mathrm{~mm}$.

Pudding Hill, near Methven. One, amongst a miscellaneous collection from Messrs. T. Hall and L. Burrows, on the 13th April, 1913.

\section{Group Faronini.}

3695. Sagola socia sp. nov. Sagola Shistp, Mi.n. X.\%. Coleopt.. p. 13.4.

Elongate, subparallel, sublepressed, indistinctly punctate, nitid:

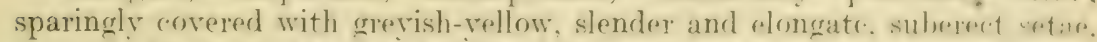
more thickly on the hind-hody ; light chestnut-red, leoss and antrnnare paler, tarsi and palpi fulvescent.

Head rather smaller than thorax, genae nrarly straight. with obtuse hind angles: frontal channel modrately broad, extroding from hack part of thr. eyes but beroming narrow between the flattened antminal tulwales. oreipital foveae small but distinct. Eyes moderately larege. Thorax of about oepual length and breadth. widest and remended before the middle: lateral and median hasal foseare subrotumolate. hasal margin hipunetate. Bitra subquarlrate. hardly a third loneser than thorax. a esord deal narmowd hefore the middle ret rather broader at the base than the throrax : situral striar

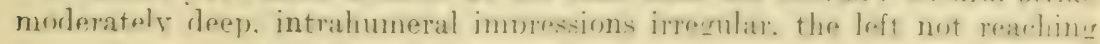


the base, the right comsists of a basal punetare and elomgate stria which is prolomered heyond the middle. Ilind-body neaty a third lonerer than elytra. 3rd segment slightly longer than 1 st or 2 nd, the others deflexed.

Legs moderately elongate and slender, tibiae only slightly curved externally.

Antemate rather longer than head and thorax, with slender outstanding setate: basal joint erlindrie, not double the lenerth of the next; 3rd small and head-like, hardly half the size of 2 nd. Ith and 5th about as broad as the end but shorter: fith abruptly anlarged, broadest, rounded at the

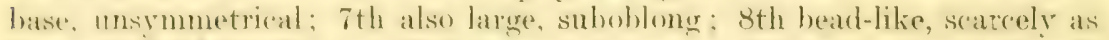
large as the 5th; 9th and 10th somewhat larger: 11th conical, not pointed. shorter than preceding two.

Underside with elongate yellow pubescence. Head with a transverse depression at each side just behind the mentum, another extends right across between the eyes, and there is a more shallow one behind. Ventral serments 24 subequal, 5th widely emalrginate. mureh shorter than 1 th in the middle; 6 th longer, subtruncate behind, 7 th obtusely triangular.

In Section VI there is only a single species, S. anisarthra, 1884. 'This must be placed with it, but 1884 is almost pitchy-red, the frontal channel of the head is deeper and broader, there is a basal puncture between each of the sutural and dorsal striae, and joints 4 to 7 of the antennae are unequally enlarged, these are transversely moniliform, the 4 th and ith are the largest and are very diflerent in shape from the 6th and 7 th of si. sorein. These species, therefore, can be easily identified.

o. Length, $2 \frac{1}{2} \mathrm{~mm}$. ; bresdth, $\frac{2}{3} \mathrm{~mm}$.

Pudding Hill, near Wethren. I'nique: foumd amongst decaring snowgrass, at an elevation of $3,500 \mathrm{ft}$, by Mr. T. Hall, on the 10 th December, 1912.

\section{Sagola setiventris sp. nov.}

Subdepressed, irregularly narrowed anteriorly, elongate, shining, obsoletely punctate: castaneo-rufous, legs and antemnare paler, tarsi and palpi yellow; with distinct, decumbent, yellowish pubescence, and a few long erect setae behind.

Head smaller than thorax, very slightly curvedly narrowed behind the moderately prominent eyes, posterior angles ohtuse: frontal chamnel deep. relatively broad, barely extending as far as the back of the eyes, and beconing mueh narrowe between the antemal tubereles, oncipital foveare deep and moderately laree. Thorax rounded and widest just before the middle, very little longer than broad, suboviform; median basal fossa subrotumdate. lateral foreace deep at the base and extending forwards almost to the middle, base bipunctate. Elytra a third longer than thorax, gently narrowed towards lie base ret rather wider than it is there, fincly and indistinctly punctured; sutural striae moderately broad, deepest at the base, intrahumeral impressions also deep there, prolonged backwards to the middle, apparently entire. Hind-body as long as elytra and as broad at the batse its first visible serment rather shorter than end or 3rd, the terminal very narrow.

Legs simple, moderately clongate and slender.

Antennae as long as head and thorax, rather slender, slightly and gradu-

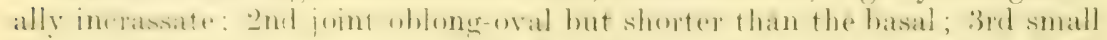
but as long as broad: joints $4-6$ moniliform, not transverse; 7 th and 8 th 
fardly any larger but narrowed apically ; sth and loth transversely quadrate, the latter the larger; 11 th conical, larger than the penultimate.

4th ventral segment a good deal larger than 2 nd or : Srd: Gth short and narrower than 5th, its a piral suture indefinits, 7 th only. half the width of fith. strongly pounded behind, mimutely and densely srolpitured, both of these hear very elongate grey setar. Inderside of head with a deep groove across it just in front of the eyes.

Rather smaller than $S$. guinnessi, 3373, with nore slender anternare and legs. smaller eres. much longer frontal rhannel, intrahumeral impressions nof divided. and witheut hasal pometures heotween them and the sutural striar. It is the nearest ally.

స. Length, $2 \mathrm{~mm}$. ; breadth, quite $\frac{1}{2} \mathrm{~mm}$.

Erua. January, 1911. One in my own collection.

\section{Sagola crassulipes sp. nov.}

Subdepressed, elongate, of interrupted outline, nitid; head, thorax, and hasal joint of antennate rufous, amaining joints, legs, and hind-body light rhestnut-red, clytra bright fulvous. tassi and palpi flaveserent: grubrescencer vellow. elongate. slenrler on head and thorax, disposed transversely on thr. former, thirker. Ionerer, and more or less arect on the elotrat and hind-bods.

Head as broad as thorax in line with the prominent erese a little narroweal just behind these. hind angles rounded and obsolete : antronnal tubereles distinctly elevaterl and separated in front by a very thin grome, the rhannel behind these is deep, of almost equal width throughout and noarly rearhe: the base, which is finely bipunctate. Thorax of ahout the same length and breadth, widest and roinded before the middle, rordate. without discrenible. punctation: median basal fossa deep and somewhat narrowed belind, the base distinctly bipunctate, lateral foveae deepe at the base and prolongred to the middle. Elytra nearly a third broader helind than they are long. (onsiderably narrowed towards the base, the suture and base finely punctate: sutural striae deej, intrahumeral impressions also deep and extending barkwards to the niddle. ear.h cronsists of a hasal puncture and elongate impression. Hind-body parallel, as broad as elytra and nearly twice their length. 2nd segment slightly longer than contiguous ones.

Legs robust, pubescent; anterior femora with a semicircular basal exrision, its inner angles arute: front tibiae slightly curved externally, the posterior less so, intermediate bent inwardly below the mirdle and thickener towards the extremity.

Antennae longer than head and thorax, stout; basal joint cylindric, not quite as long as following three rombined, 3rd smallest and grobular joints 2, 1, and 5 almost ergual and subrotundiate. (ith and ith slightly broarler, narrowed in front: \& to 10 a little broarlese subtranswerese. nearly equal: the terminal quadrate. hut with a pubeserent appiral appendage sie as to appear conical.

Unaerside with conspicuous yellow pubescence, femora and tarsi inchusive. Head minute? sculptured in fromt. the smorth aurate impres. sion rxtending half-way areses the middle has a entral prominene be hind. Ventral segments 2-i subequal, 5th shorter, slightly incurved at the extremity, as is the shorter 6th, the supplementary finely yet ciistinctly punctate, its operculum subovate.

This spereses. on acrount of the deepe enargination of the front thighs.

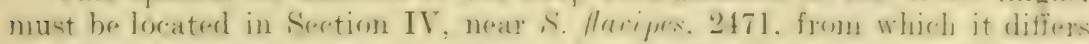
in rolour, its antemnare are manifestly thickere the eletra are lowes distinetly 
punctured, the legs are stouter; in 2471 the tibiae taper towards the extremity, just the reverse of their structure in $S$. crassulipes, and the lower surface of the head is materially different.

j. Length, $2 \frac{1}{2} \mathrm{~mm}$.; breadth, $\frac{2}{3} \mathrm{~mm}$. 1912.

Epsom, base of Mount Eden. Unique; found on the 12th February,

3698. Sagola opercularis sp. nov.

sublepressed, olongate, of intermpted rontour, shining; light chestnutred, legs and antennae paler, tarsi and palpi yellow; pubescence distinct, yellowish, thickex on hind-bexty. and with longresert setare there and along the sides of elytra.

Head rather short and, including the moderately prominent eyes, almost as wide as thorax, obliquely or slightly curvedly narrowed behind; frontal channel deep and moderately broad, extending from behind the eres, but beroming narower and distinetly separating the slightly raised antennal tubercles; occiput moderately bipunctate. Thorax quite as broad as long, widest and rounded in front of the middle, much narrowed behind; basal median fossa subquadrate, base bipunctate, lateral foveae deesp but hardly reaching the middle. Elytra suboblong, a third longer than thorax. gratually but slightly narrowed towards the base: sutural striat deene. punctiform at base, where there is a distinet puncture near earh, intrahumeral striae prolonged beyond the middle, each bipunctate at the

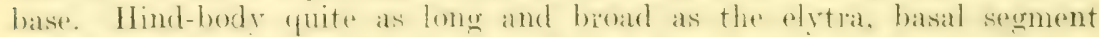
rather sherter than following ones. with a few minute brassy sables near its base.

Legs moderately elongate and slender: tibiate slightly expanded towards the extremity.

Antennae somewhat longer than head and thorax, moderately slender, slightly incrassate from the the joint onwards; 2 nd joint obconical, but little more than half the length of the basal, 3rd rery small ret slightly longer than broarl: Ith and 5th oblong-oval, 6th shorter, joints 710 more or less transverse, terminal conical, not much longer than the penultimate.

Underside pubescent. Head with a transverse depression between the eves and a central flattened elevation behind. Abdomen distinctly but not ciosely punctate, appearing minutely granulate in some lights, 3rd and th segments rach rather longer than 2 nd, 5th a liftle shorter than 4 th, 6th deeply emaresinate. the operulum convex, elongate-oval, broadly grooved along the middle.

This differs considerably from S. insuetus, 3521, and other species from the neighbourhood of Methven. It should be placed in Section IX, after S. nitidn. 336.t. which, however, is larger, with stouter and differently formed antemme and thicker leass, the frontal chammel nearly attains the oceiput the intervals between the sutural and intrahumeral striae are at least bipunctate, and the terminal ventral segments are obviously dissimilar.

3. Length, $2 \mathrm{~mm}$. ; breadth, nearly $\frac{2}{3} \mathrm{~mm}$.

Rakatia (ionere, near Methren. I solitary individual, found by Mr. T'. Hall on the 27 th December, 1912.

3699. Sagola brevisternis sp. nov.

Elongate, slightly convex, not parallel, very glossy; castaneo-rufous, legs and antennae much paler, tarsi and palpi yellow; very thinly clothed with suberect, slender yellowish pubescence and a few outstanding setae. 
Head almost as broad as thorax, feebly rounded but not narrowed behind the moderately prominent eyes; frontal channel deep, extending beyond the back of the eyes, much narrowed there, less so in front, ocripital forear. elongate: antennal tubercles somewhat elevated, contiguous in front, distinctly separated behind, with a few fine punctures. Thorax widest and rounded before the middle, much narrowed behind; hasal median fossa subquadrate, base finely bipunctate, lateral foveae deep and prolonged to the middle. Elytra of equal length and breadth, a good deal narrowect towards the hase, slightly longer than thorax; sutural striae deepe, apparently bipunctate at base, the suture minutely pluripunctate, intrahumeral strias composed of a basal puncture and elongate impression hardly extending as far as the middle, there is no basal puncture between these and the sutural striae. Hind-hody twire as long as elytra, basal thres segments subecqual, the broad margins of the list and 2 nd distinctly incrassate and somewhat prominent towards the extremity, the terminal quite unfolderl, neaty horizontal and obtusely triangular.

Legs elongate and slender. tibiae distinctly pubescent, a little arreherl externally below the middle.

Antennae a third longer than head and thorax, moderately slender, 2nd joint oblong-oval, evidently shrorter than the basal, 3rd narrower than adjacent ones, obconical, distinctly longer than broad: joints 4 and 5 oblongoval but shorter than 2nd, fith and 7 the rather shorter, the latter a little broader than tith and narrowed apically: sth and sth almost transwersely quadrate yet hardly as broad as 10 th, 11 th eonical. larger than the jeriultimate.

Underside rather densely and evenly pubescent. Head with a deep interocular depression. Metasternum convex, very short in comparison with the abdomen. Basal ventral segment quite concealed, $2 \mathrm{nd}$ to ith large, with deep sutures, somewhat convex, 5th rather shorter, fith ohtusely triangular.

The form of the hear comes within the definition of Surction $V$. but nome. of its members agree with it. The unique male of s.laticeps, 33062 . from Greymouth, belonging to Section III. more nearly resembles it in greneral appearance, but the shape of the head and rigrag outline of the bacal dors:sl segments are entirely dissimilar.

‥ Length, $2 \frac{1}{2} \mathrm{~mm}$.; breadth, $\frac{2}{3} \mathrm{~mm}$.

Pudding Hill, near Methven. (One, found on the 1th May, 1912. W. Ir. T. Hall, but held in reserve, hroping that the male might be found.

\section{Sagola rustica sp. nov.}

Subdepressed, elongate. not parallel, nitid: rather thickly chotherl. recept the head and thorax, with elongate yellow pubescence and lone upright setae: castaneo-rufous, legs and antennate murh palen', tarsi and palpi yellow.

Head only very slightly namowed behind the moderately prominent res, with obtuse angles, almost as broad as thorax : fromtal channel broard

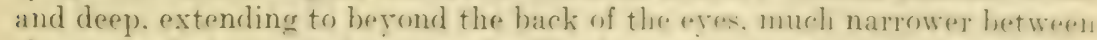
the somewhat elevated antemnal tuberdes. oreiput rather finely ret distinctly hipunetate. Thorax abrut as long as broal. widest and rounderd before the middle: basal median fossa deepe and subrguarlrate. hase hipunetate. lateral fovare deep and prolomered to the mirldle. Elytra of expual lingerth and hreadth. nearly a third longer than thorax. With slightly rounded hind 
angles, gradually narrowed before the middle; sutural striae déep, punctiform at base, with a basal puncture near each, intrahumeral striae composed of a bisial puncture and elongate impression extending to beyond the middle. Hind-body a third longer than elytra, fully as broad but a little narrowed at the base, its basal three seginents subequal, the apical deflexed and moderately broad.

Legs elongate and slender, tibiae slightly curved externally towards the extremity.

Antennae rather longer than head and thorax, moderately slender; Ind joint subovate, little more than half the length of the lst, 3 rd small obeonieal, very slightly longer than broad, the obeonieal. joints 5 to s beadlike and nearly alike; 9th and 10th transverse, rather broader than 8th, 11 th subconical, not elongate.

Underside with distinct yellow pubescence. Ventral segments 2-1 subequal, 5th rather shorter, truncate behind, 6th short and broad, semicircular behind.

Easily distinguishable from S. brevisternis by its smaller size, much less irregular contour, longer intrahumeral impressions. with a basal juncture between each and the suture, by the shorter, flatter, and more parallel hindbodr, smaller rotundate oceipital punctures. the different antennal structure and broad terminal ventral segment. Both may be placed together until the males are found.

․ Length, $2 \mathrm{~mm}$.; breadth, quite $\frac{1}{2} \mathrm{~mm}$.

Rakaia Gorge. A single female discovered by Mr. T. Hall on the 18th May, 1912.

\section{Sagola confusa sp. nov.}

Subdepressed, elongate, shining; rufous, legs and antennae light chestnut-red, tarsi and palpi yellow; thinly clothed with decumbent yellowish pubescence and a few long erect setae.

Head apparently smooth, subquadrate, slightly narrower than thorax, genae very feebly curved, with rounded hind angles; antennal tubercles a little elevated, in front almost in contact, frontal channel deep and broad, a little narrowed between the tubercles, extending as far as the back of the eyes, occipital foveae moderately large. Thorax cordate, rather broader than long, minutely and distantly punctate; median basal fossa large, subrotundate, lateral foveae deep, not prolonged beyond the middle, base finely but distinctly bipunctate. Elytra subquadrate, rather broader and a third longer than thorax, slightly narrowed before the middle; sutural striae simple, with a basal puncture close to each, intrahumeral striae composed of a basal puncture and longer impression just reaching the middle: outside each of these some small punctures seem to form an additional stria, the suture is minutely punctate. Hind-body as broad as but rather lonese than the elytrat, distantly and finely punetate, basal sement shorter than 2nd or 3 rd.

Legs moderately elongate and slender, tibiae slightly dilated towards the extremity.

Antennae equalling the head and thorax in length, basal joint red, nearly twice as long as broad, 2nd as thick and fully half as long, 3rd subglobular and very small; 4th and 5th rather longer than broad, 6-8 rather shorter and somewhat narrowed apically, 9 th and 10 th rather larger, subquadrate, terminal conical, not as long as preceding two. 
Underside scantily pubescent. Head with an interocular furrow. Ventral segments 2 to 4 slightly increase, 5th as long as 4th, 6th shorter, narrower and truncate behind, 7 th short, obtusely triangular.

This belongs to Section V, but differs from every species in it. When examined from behind, the occipital foveae appear almost confluent with the frontal channel, and thus approach the furcate form of Raffray's S. punctulata. The distinct basal punctures near the sutural striae and the outer punctures or additional striae are somewhat similar to those of Raffray's $S$. frontulis, but in his species these striae are situated near the middle of each side. These together are good distinguishing characters.

Var. 0 . Elytra rather longer, without basal punctures near the sutural striae, the hind portion of intrahumeral impressions shorter. Howick.

o. Length, $2 \mathrm{~mm}$. ; breadth, $\frac{2}{3} \mathrm{~mm}$.

Hunua Range, Clevedon. Unique; one of my own captures; in it the 6 th ventral segment is nearly nude.

\section{Sagola longipes sp. .nov.}

Subdepressed, elongate, of interrupted outline, nitid, distantly and minutely punctate; light chestnut-red, elytra and legs somewhat fulvescent, palpi and tarsi yellow; very thinly clothed with rather short, decumbent, greyish pubescence.

Head almost as broad as thorax, gradually narrowed anteriorly, genae not narrowed, with rounded hind angles; frontal channel only moderately broad and deep, hardly extending as far as the back of the eyes, narrowed between the somewhat flattened tubercles, occipital foveae elongate. Thorax slightly broader than long, widest and strongly rounded before the middle; considerably narrowed behind, obliquely so in front, where it is about half the width of the occiput; basal fossa deep and subrotundate, lateral foveae of similar form, hardly attaining the middle, the base distinctly bipunctate. Elytra of equal length and breadth, a third longer than thorax, widest and slightly rounded behind, distinctly narrowed before the middle; sutural striae entire, punctiform at base, intrahumeral impressions short, consisting of a pair of punctures, the posterior the larger. Hind-body not quite as broad as elytra at the base, nearly double their length, basal three segments horizontal, the 1st shorter than 2 nd or 3rd. terminal ones much narrowed.

Legs rather elongate, moderately slender, tibiae only slightly expanrled below the middle, but becoming slender at the extremity.

Antennae a third longer than head and thorax, a little thickened apically : basal joint red, its length fully twice the breadth, 2 nd haif as long, 3rd moderately small, rather longer than broad: th and sth obloner. 6-8 very slightly shorter and broader, 9 th and 10 th transversely quadrate, the terminal conical, longer than the penultimate.

Ventral segments 2 to 4 evidently increase, 5th slightly Ionger than 1 th. much narrowed apically, 6th shorter and narrower, obtusely triangular.

Of irregular contour, the antennae, legs, and hind-body rather elongate. and differing otherwise from the species composing section $T$. S. oscrilan: 1576, is a male, it has a broader head with less obtuse angles, its frontal chamnel is deeper but taper's behind, the thorax is gradually narrowed towards the base. In S. fulva, 1881, the head is more like that of 1576. S. rectipes, 187. has the head gralually narrowed in front of the cyes. as in s. Inmgipes. but it is not as broad, and its elytra are oblong, \&c. These are the nearest species in my collection. 
ㅇ. Length, nearly $2 \frac{1}{2} \mathrm{~mm}$. ; bresdth, $\frac{2}{3} \mathrm{~mm}$.

Woodhill, Kaipara Railway. Found on the underside of a log nearly thirty years ago, and set aside in the hope of finding a male. The locality has been "cleared"; it is now smothered with pennyroyal (Hedeosoma), a plant abhorred by native insects, so it is probable that this useful heetle has been exterminated.

Obs.-A decoction of pennyroyal and some oily or resinous substance, applied when warm. would. I believe. deter wood-borers. codlin-moth. and other destructive insects from depcsiting their eggs on fruit-trees.

\section{Sagola indiscreta sp. $110 \mathrm{v}$.}

Subdepressed, elongate, irregularly narrowed anteriorly, indistinctly punctate, nitid: light rufous, olytra, legs and antennate somewhat fulvescent, palpi and tarsi yellow; pubescence yellowish, slender and suberect.

Head nearly as broad as thorax, gradually narrowed in front of the moderately prominent eyes, straight hehind these. with obtuse angles; antennal tubercles a little elevated, slightly separated in front, median channel deep and moderately broad, nearly reaching the occiput, narrowed there, basal foveae elongate. Thorax as long as broad, rounded and widest before the middle, gradually namered behind: hasal fossa deep and suhrotundate, lateral foveae also deep, not prolonged beyond the middle, base distinctly bipunctate. Elytra of equal length and breadth, a third longer than thorax, somewhat narrowed before the middle; sutural striae deeper and broader before the middle than behind, with a small basal puncture near each, intrahumeral striae deep, extending to the middle, each composed of a basal puncture and elongate impression. Hind-body slightly longer than elytra, basal segment not quite as broad as and rather shorter than following ones, with minute, depressed grey scales, terminal segments deflexed, only moderately narrow.

Legs elongate, tibiae finely ciliate, and more slender near the extremity than at the middle.

Antennae quite a third longer than the head and thorax, very gradually and slightly thickened; basal joint red, its length double the width, 2nd oviform, hardly longer than broad, 3rd smallest, oviform, slightly longer than hroad. Ith and 5th oblong-oral. joints 6 to s slightly boader, laxly articulated. sth and loth subquadrate. broader than preceding ones. terminal, conical, shorter than 9th and 10th together.

Underside light chestnut-red, with elongate yellow pubescence. Head with a deep curvate impression across it in front of the eyes. Ventral segments 2 t eradually increase, 5 th lomger in the midlle, much narrowed and slightly pombled behind, fth short and narrow, impressed aloner the middle, 7 th short and broad.

This comes near $S$. rectipes, 1878 , in Section $\mathrm{V}$, but is rather larger, manifestly darker, with more olongate, differently formed antennae, nearly similarly shaped head. but the thorax is broader and the elytra are not oblonge. In iste the hasal joint of the antemnae is shorter. the 3rd is small and short. joints 4 to 8 are distinctly narrowed apically, and the 9 th and 10 th are transverse. S. mestica differs in being smaller and darker, it has shorter antennae, smaller occipital foveae, a rather narrower thorax with the basal fossa subquadrate, \&c.

;. Length, $2 \frac{1}{2} \mathrm{~mm}$. ; breadth, $\frac{2}{3} \mathrm{~mm}$.

Howick, near Auckland. One in my own collection, taken off the underside of a $\log$ in December, 1885. 
3704. Sagola rotundiceps $\mathrm{sp}$. $110 \mathrm{v}$.

Nitid, subdepressed, elongate, of interrupted contour, minutely and distantly punctured; infuscate-red, elytra, legs, and antemne light chestnutred, palpi and tarsi yellow; pubescence scanty, elongate, greyish-yellow:

Head nearly as large as thorax, subrotundate, widest in line with the moderate eyes, curvedly narrowed behind these, hind angles obtuse ; frontal channel moderately deep, rather narrow, extending beyond the back of the eyes, occipital foveae well marked and slightly elongate. Thorax cordate, of about equal leneth and breadth, rounded and widest before the middle, distinctly narrowed behind; basal fossa deep and subrotundate, lateral fovea large and deep, extending to the middle, base distinctly bipunetate. Elytra subquadrate, slightly rounded and widest behind the middle, grarlually narrowed towards the base, a third longer than thorax; sutural striae rather deep and broad, intrahumeral impressions apparently undivided, deep, prolonged nearly to the middle. Hind-body rather narrower than elytra at the base, longer than they are, basal segment with minute, depressed brassy scales, rather shorter than 2nd or 3rd, the terminal narrow, obtusely triangular.

Legs moderately elongate and slender, simple.

Antennae rather longer than head and thorax, basal joint fully twice as long as broad, 2nd oviform, barely half the length of 1st, 3rd more slender, obconical, small, rather longer than broad, 4th oviform; joints 5 to 8 slightly broader, narrowed apically, 9th hardly as broad as the transverse 10 th, the terminal conical, rather longer than penultimate.

Ventral segments 2-4 normal, 5th slightly longer, 6th shorter and narrower, 7th almost as long, obtusely triangular. Head with an interocular groove.

This, owing to the moderately narrow frontal channel, does not agree with any of the species in Section IX; it is, however, evidently broader than the slender linear stria of $S$. lineata, 2719, belonging to Section VTI. It is more elongate and less parallel than S. nitida, 3364, with more slender, longer, and differently formed antennae, and with very different elrtral sculpture. The other species from Mount Egmont, s. diversa, 3366, beiongs to Section II. The nearest ally is 3364 .

o. Length, $3 \mathrm{~mm}$; breadth, $\frac{2}{3} \mathrm{~mm}$. a $\log$.

Stratford, base of Mount Egmont. Unique; taken off the underside of

\section{Sagola fulvipennis sp. nov.}

Elongate, elytra and abdomen subparallel, shining, very finely and distantly punctate; head and thorax rufous, elytra fulvous, but more rufescent near the base, hind-body chestnut-red, legs paler. tarsi and palpi flavescent; distinctly clothed with elongate, suberect, crrevish-yellow hairs, and with some longer upright setae behind.

Head nearly as broad as thorax, hardly at all narrowed behind the moderately prominent eyes, with obtuse angles; frontal chamel deep, broad near the slightly elevated tubercles, becoming narrower and almost penetrating the basal margin, oceipital foveae small and punctiform. Thorax subcordate, rounded and widest at or just before the middle: hasal fossa deep and subquadrate, lateral foveae also deep and extending to the middle, base distinctly bipunctate. Elytra of about equal leneth and hreadth, a third longer than thorax, feebly rounded behind, a little narrowed toward: the base, broady impressed or flattened there: sutural striae deep and 
finely punctate near the base, with a puncture alongside each, intrahumeral impressons tripunctate. hardly rearhing the middle, their front materin sexpundate. llind-body rather longer than elytra, basal segment rather shorter that 2 nd or ind, with minute depressed brassy scales, the terminal very narrow.

Legs moderately elongate, tibiae feebly arched externally.

Intennae as long as head and thorax, basal joint red, not twice the length of the subovifom 2 nd. Brd small and subglobular. 4 th oviform, joints 5 . 8 slightly increase in width, narrowed in front: Sth and loth distinctly broader, transverse, 11 th ronical. not as long as preceding two together.

Inderside fincly punctate, with suberect grevish pubescence. Head with a transverse groove midway between the mentum and eyes and a deep central groove behind. Ventral segments 2-4 normal, 5th nearly as long ats trh. bth short, truncate behind: 7 th much longer. rather broad, rounded behind, slightly concave, with a flat almost semicireular basal lamina occupying about half of its whole area.

Distinguishable by its bright-fulvous elytra, tripunctate intrahumeral impressions, and by the peruliar lamina within the terminal ventral segment. The head is rather narrower than in the older members of Section $\mathrm{V}$, and the thorax being almost as much oviform as cordate it may at present be located near S. spinifer, 2723, in Section XIV.

j. Length, $2 \frac{1}{2} \mathrm{~mm}$. ; breadth, $\frac{2}{3} \mathrm{~mm}$.

Tairua, Auckland. December, 1874; one found on the lower side of a $\log$.

\section{Sagola bifida sp. nov.}

shining, subdepressed, elongate, of irregular outline, finely and distantly punctate; light chestnut-red, elytra and legs flavescent: sparingly dothed with elongate, suberect, pale pubescence and upright setae.

Head, including the rather prominent eves, almost as hroad as thorax. gradually curvedly narrowed behind, its angles obsolete : antennal tuber les distinctly elevated, slightly separated in front; frontal channel deep, widest in front, very narrow on reaching the well-marked, somewhat elongated ocripital foveae. Thorax of equal length and breadth, rounded and widest before the middle, considerably narrowed behind; basai fossa deep and subrotundate, lateral foveae deep and attaining the middle, base evidently bipunctate: Elytra short, rather broader than long, a good deal narrowed towards the base; sutural striae deeper at the base than behind, intrahumeral impressions entire, deep, reaching the middle but not touching the base. Hind-body not quite as wide as elytra at the base. nearly twice their length, basal three segments horizontal, the 1st slightly shorter than the others, the terminal narrow, with a distinct median notch so as to appear obtusely bifid at the extremity.

Legs elongate, moderately stout, tibiae slightly arched externally.

intennae stout, scarcely as long as head and thorax, basal joint punctate. its leneth domble the breadth, the next short and oviform, 3rdobernical but small; joints $4-8$ subequal, as thick as the 2 nd, all narrowed apically ; 9th and 10th distinctly broader, transverse, the terminal conical, rather longer than the penultimate.

Ventral segments 2-4 increase, 5th rather shorter, 6th rather shorter than 5th, widely emarginate, 7 th subquadrate, widely notched at the extremity, and its base with a flat, broad, obtusely triangular lamina oscupying half of the whole surface. 
The prominent, obtusely bifid apex of the last dorsal segment is its principal differentiating feature. 'The ventral segments, in structure, most nearly resemble those of $S$. fulvipennis. The elytra in shaje are like those of S. sulcator, 1575, which belongs, as does the present species, to Section IX, but 1575 has a broader and more rotundate head, its frontal channel is prolonged right to the base, and the occipital foveare are minute and apt to be overlooked.

f. Length, $2 \frac{3}{4} \mathrm{~mm}$. ; breadth, $\frac{3}{4} \mathrm{~mm}$.

Woodhill, Kaipara Railway. One found on the underside of a $\log$ by myself many years ago.

\section{Sagola posticalis sp. nov.}

Elongate, subparallel, subdepressed, nitid, finely and irregularly punstate; fusco-rufous, antennae and legs paler, palpi and tarsi vellow; thinly clothed with suberect greyish pubescence.

Head almost as broad as thorax, contracted in front, very slightly rurvedly narrowed behind, with obtuse angles, eres moderately prominent; antennal tubercles nearly plane, finely yet distinctly punctured, frontal channel deep. moderately broad, narrowed anteriorly, extending as far as the back of the eyes, occipital foveae small and punctiform. Thorax of about equal length and breadth, rounded and widest just before the middle, apex much narrower than the occiput: basal fovea subrotundate, the lateral ones deep, hardly reaching the middle, base finely bipunctate. Elytra flat, suboblong, slightly narrowed before the middle, a third longer than thorax; sutural striae deep, with a basal puncture alongside each, intraliumeral striae deep, prolonged to the middle, usually tripunctate. Hindbody as long and broad as elytra, basal segment much shorter than 2nd or 3rd, apical segment short and broad, subangulate at extremity.

Legs moderately elongate, tibiae slightly expanded below the middle.

Antennae longer than head and thorax, moderately slender, very slightly and gradually thickened; basal joint red, not double the length of the oviform 2nd; 3rd small, very little longer than broad; 4th oviform, evidently smaller than 2nd; joints 5-7 narrowed apically; 8-10 laxly articulated, transverse, only slightly broader than preceding ones. the terminal conical, not twice the length of penultimate.

Ventral segments 2-5 normal, 6th as long as 5th, unusually broad, semicircularly emarginate, enclosing the very small subrotundate 7 th.

Fem.-6th segment short, broadly triangular.

Like S. suturalis, 3522, Section $\mathbf{X}$, in some respects, but smaller and of a lighter hue. The head manifestly broader. Elytra rather more narrowed near the base, and therefore less perfectly oblong; intrahumeral striae murh longer and tripunctate, but with a single puncture only hetween them and the suture. The rather broad, medially anculate apical dorsal segment will lead to its separation from other species.

o. Length, $2 \mathrm{~mm}$. ; breadth, nearly $\frac{2}{3} \mathrm{~mm}$.

Wairiri, Kaikoura. A somewhat mutilated specimen of each sex found by Mr. W. L. Wallace.

\section{Sagola laetula sp. nov.}

Alossy, subdepressed, not pereeptihly punctate, elytra and hind-body farallel: castaneo-rufous, elvtra fulvescent. leas slightly more infuscate than elytra, palpi and tarsi yellow: very thinly envered with fine yellowishgrey pubescence and upright elongate setae. 
Head almost as broad as thorax, genae nearly straight, hind angles as wide as the eres, obtuse, not at all prominent: antemal tubercles nearly phane. frontal chammel deep. moderately broad, slightly narrowed in front, extending just berond the batek of the eves, orcipital foreace slightly elongate. Thorax cordate, about as lone as broad: hasal fossa subquadrate, lateral foveae deep, prolonged to the middle, base distinctly bipunctate. Elytra suboblong, not double the length of thorax, somewhat narrowed before the middle; sutural striae deep, subpunctiform at the base, with a small basal puncture near each, intrahumeral striae composed of a basal puncture and more elongate impression reaching the middle. Hind-body as long as shtrat, mimutely and distantly punctate, hasal segnent shorter than end or $3 \mathrm{rd}$, the last obtusely triangular.

Legs moderately elongate and slender, tibiae slightly expanded towards the extremity.

Antennae rather longer than head and thorax, only moderately stout, slightly and gradually incrassate: 2nd joint subovate, quite half as long as the basal ; 3rd small yet slightly longer than broad; 4 th and 5 th oblongoval: 6th rather shorter but not quite as short as 7 th: joints s-10 subquadrate, nearly alike; 11 th conical, longer than 10 th.

Ventral segments 2-4 normal, 5th as long as 4th; 6th shorter, medially truncate, prolonged at the sides: 7 th as long as 6th. hrod, obtusely triangular.

S. sobrina, 1877, near which this species should be placed, has short elytra, they are much narrowed towards the base, with short intrahumeral impressions; the basal thoracic fossa is subrotundate and the adjacent punctures are small; the frontal channel is broader in the middle, but becomes slender near the base, \&c.

;. Length, $2 \frac{1}{3} \mathrm{~mm}$. ; breadth, nearly $\frac{2}{3} \mathrm{~mm}$.

Hunua Range, near Clevedon. One found amongst leaf-mould during my second visit to the locality.

The underside of the head has a broad central lamina, which is curved, but not ciliate behind, and therefore differs from S. laminata, 2469, in Section XII.

\section{Sagola concolorata sp. nov.}

Shining, almost wholly chestnut-red, the legs but little paler, tarsi and palpi yellow; sparingly clothed with greyish pubescence; body subdepressed, elytra and hind-hoty subparallel. finely, distantly, and irregularly punctured.

Head rather short, smaller than thorax, gradually narrowed anteriorly, genae nearly straight, with obtuse angles, these, however, are just perceptibly less prominent than the eyes; antennal tubercles nearly plane, separated in front by a distinct groove, frontal chamnel deep, moderately broad throughout, extending as far as the back of the eves, occipital foveae well marked and slightly elongate. Thorax about as long as broad, rounded and widest before the middle, distinctly narrowed behind; lateral foveae deep, less so at the middle, basal punctures small but distinct, almost confluent with the subquadrate fossa. Elytra oblong, a third longer than thorax, very slightly narrowed towards the base; sutural striae deep, with a small basal puncture alongside each, intrahumeral striae hardly attaining the middle, consisting of a basal puncture and more elongate impression. Hind-body rather shorter than elytra, basal segment rather short, bearing 
depressed, minute greyish setae, the next slightly shorter than 3rd, the terminal narrow, obtusely triangular.

Legs elongate, moderately stout, tibiae a little expanded below the middle.

Antennae not longer than head and thorax, only moderately thick: basal joint red, hardly twice as long as broad; the next stout, suboviform. quite half the length of 1 st; $3 \mathrm{rd}$ small, not longer than broad; th oviform, laxly articulated; joints 5-7 subequal, slightly shorter: sth nearly as broar as the transverse 9 th or 10 th, the terminal conical, longer than the penultimate.

Ventral segments 2-5 normal; 6 th shorter than 5 th, very much narrower, semicircularly emarginate; 7th short, transversely oral. Head with a curved depression across it in front of the eyes.

This, along with $S$. incliscieta, may be placed in a separate section on account of the somewhat Vidamus-like head. It is nearer S. indiscrete than any other species in Section $\mathrm{V}$, but has a relatively broader, less anteriorly prolonged head, a shorter frontal channel; stouter, differently formed antennae, and larger but less prominent eyes.

o. Length, $2 \frac{1}{3} \mathrm{~mm}$.; breedth, nearly $\frac{2}{3} \mathrm{~mm}$.

Tairua, near Auckland. One in my own collection, taken oft the underside of a $\log$ during 1874.

\section{Group Eupleutisi.}

3710. Euplectopsis perpunctatus sp. nov. Enplectopsis Raffray, Gen. Ins.

(Wytsm.), Pselaphidae, 1908, p. 82.

Subopaque, very slightly convex, elongate, subparallel; dark ruf sus, legs and antennae chestnut-red, tarsi and palpi yellowish; pubescence distinct, greyish, mostly decumbent.

Head small, contracted in front of the moderately large eyes, genae straight, with obtuse angles: rather closely and distinctly punctate, interorular foreae obsolete, antennal tubercles small and distant, its pubescence very slender. Thorax oviform, slightly longer than broad, its apex nearly as wide as the occiput; very distinctly, closely, rather deeply and sharply punctured, the median basal impression and lateral foveae rather shallow. the discal groove more distinct but not quite attaining either the base or apex. Elytra subquadrate, with curvedly narrowed shoulders, somewhat broader and a third Ionger than thorax, much more finely and irregularly punctured; sutural striae well marked, punctiform at base, alongside each an additional slender stria extends from the base to beyond the middle, intrahumeral impressions not very deep and indistinctly prolonged backwards. Hind-body finely punctured, of about the same length and breadth as elytra, basal three segments nearly equal and horizontal, the Ist transversely impressed at the base.

Femora robust; tibiae moderately arched externally, the intermediate with a distinct, rather thick. oblique prolongation of the immer extrenity.

Antennae shorter than head and thorax, 2nd joint oblong-oval, as long as the basal, 3rd obconical, very little longer than broad; joints 4-8 short and moniliform: 9th evidently broader than 8 th, but not as large as loth. the terminal large, conical and acuminate, equalling the 9 th and 10 th in length, these three distinctly pubescent and forming a well-marked club.

Underside nitid, chestnut-red, with yellow pubescence. Prosternum carinate. Metasternum with an obvious fovea behind the middle. Basal ventral segment densely fringed, quite visible, acutely projecting between 
the coxae; segments 2-4 diminish; 5 th much shorter in the middle, widely incurved behind; 6th nearly twice as long in the middle, semicircularly emarginate; 7 th transversely oval, its operculum oblong.

seares any part of the sculpture corresponds with that of previously recorded species. The absence of interocular foveae, the stout calar-like process at the inner extremity of the middle tibiae, and the deep sharply defined thoracie punctation are distinctive. E. pusillns. 27:32, in Section XI. is perhaps the nearest species.

j. Length, $1 \frac{1}{2} \mathrm{~mm}$.; breadth, nearly $\frac{1}{2} \mathrm{~mm}$.

Papakura Bush, near Auckland. Found by myself on the 3rd March, 1893, amongst dead leaves on the ground (one only).

\section{Euplectopsis nitipennis sp. nov.}

Subdepressed, elongate, sparingly clothed with rather short greyish pubescence; head and thorax rather dull dark red, elytra shining, of a light bright red, ahdomen slightly nitid, antemme and legs light chestnutred, tarsi and palpi flavescent.

Head small, slightly narrowed but not curved behind the moderately large eyes, distinctly and moderately closely punctured, without foveae, antennal tubercles small and widely separated. Thorax oviform, scarcely Ionger than broad, widest and rounded at the middle; very distinctly and moderately closely punctured, apex nearly smooth and narrower than the occiput; the transverse basal impression not deep and not distinctly connected with the small shallow lateral foveae, median groove quite definite but not quite reaching the apex. Elytra subquadrate, somewhat broader and a third longer than thorax, slightly rurvedly narowed before the middle: irregularly and finely punctate. sutural striae well marked and appearing duplicate, having a slender groove at the outside as far as the middle, intrahumeral impressions foreiform at the base, each with a shallow prolongation. Hind-body finely punctured, a little rounded at the sides, hardly as long or broad as the elytra, basal three segments subequal.

Legs moderately stout, tibiae very slightly arcuate.

Antennae shorter than head and thorax, nearly similar to those of $E$. perpunctatus, their 3rd joint shorter.

A little smaller and less parallel than $E$. peipunclatus, the elytra of a much hrighter red, hind-hodr not straight-sided and less horizontal, the legs not as stout. and the intermediate tibiae without the couspicuous inner prolongation of the extremity. The structure of the underside almost exactly alike in both species.

o. Length, $1 \frac{1}{2} \mathrm{~mm}$.; breadth, quite $\frac{1}{3} \mathrm{~mm}$.

Auckland Domain. One in my own collection, found during January, 1908 , amongst leaf-mould, on the ground.

Euplectopsis eruensis Broun, 3206, Trans. N.Z. Inst., vol. 14, p. 408.

Hale.-Antennae rather shorter than head and thorax, 2nd joint oblongoval, fully the length of the exposed portion of the basal; 3rd obconical, slightly longer than broad but much smaller than 2nd; joints 4 , 6 , and 8

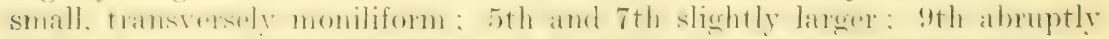
enlaresef, suldewadrate, distinetly larger than the transwerse loth. the terminal gradually attenuate, subeonical, as long as preeding two combined.

Legs robust, intermediate tibiae moderatcly expanded, with an angular process near the inner extremity, the outer portion more prolonged. 
Underside pubescent. Head distantly and finely gramulate, with upright setae and a slender median carina. Prosternum carinate. Metasternum convex, hroadly depressed along the middle. Ventral segments 2 to 4 diminish; 5th widely incurved, very short in the middle; 6 th twice as long; semicircularly emarginate; 7 th large, transversely oval, its operculum oblong.

The nearest ally, Euplectopsis fastigiatus, 3377, has prominent outstanding eyes. The thorax is somewhat ridged between the sides and the more sharply margined groove along the middle, and the lateral foveae have well-marked frontal prolongations. The sutural and intrahumeral striae are more deeply impressed at the base. The intermediate tibiae are more expanded towards the extremity, and are deeply notched there.

The description of the female will be found on page 408, Trans. N.Z. Inst., vol. 44, but the male was not secured till the year following.

o. Length, $2 \mathrm{~mm}$; ; breadth, $\frac{2}{3} \mathrm{~mm}$.

Erua. Described from specimens in my own collection.

\section{Euplectopsis duplex sp. nov.}

Subdepressed, elongate, nitid ; light rufous, elytra somewhat fulvescent, legs and antennae paler, tarsi and palpi yellow; sparingly covered with distinct, decumbent, rather short greyish setae.

Head rather smaller than thorax, slightly narrowed behind the moderately large eyes, with obtuse angles; interocular foveae large, slightly prolonged and convergent in front, vertex nearly smooth and obtusely angulate in the middle, its sides closely but not very distinctly punctured; antennal tubercies small and distant, the interval truncate. Thorax oviform, moderately rounded and widest near the middle, rather more narrowed in front than behind, about as long as broad, irregularly and distinctly but not coarsely punctate; median groove well marked, narrowed towards but not quite reaching the apex, basal fossa angulate and prolonged almost to the basal margin, with a transverse stria connecting it with the broad but not deep lateral foveae, which extend nearly to the front. Elytra oblong, broader than and double the length of the thorax, their punctation shallow and indefinite, obsolete behind; sutural striae broad, deep at the base, their outer portion as deeply impressed as the inner to beyond the middle and appearing duplicate; intrahumeral impressions short and broad, deep at the base. Hind-body almost as broad as elytra but a third shorter, deflexed and rounded behind, finely and indistinctly punctate; 2nd segment only slightly longer than 1st, both with deepish basal sutures, 3rd as long as 2 nd.

Legs simple, of moderate length, tibiae slightly arched outwardly.

Antennae as long as head and thorax, rather slender, club evidentiy triarticulate; 2nd joint oblong-oval, not twice as long as broad. nearly as stout and loner as the basal: joints 38 moniliform and small, 5th and 7 th slightly hoader than contiguous ones, 9th more than domble the width of the small 8th, 10th still more transversal: terminal laresest. conical, fully equalling preceding two in length.

Underside of head moderately coarsely punctate, wroosed along the middle. Prosternum carinate. Ventral segments 2 to 1 slightly diminish; 5th shorter in the middle, widely incurved behind: 6th almost circulary emarginate, enclosing the narrow 7 th and its oblong operculum.

Manifestly different from the nine Auckland speciess in Section VI, smaller than any of them: more in accord with the description of $E$. duplicalus. 
3195, a Greymouth specimen in the British Museum, but the structure of the ventral segments is very different; the elytra of 3495 are subquadate, and the lateral thorare foreate are teep and subrotumdate but not probonged anteriorly.

$\hat{j}$. Length, $l_{3}^{\frac{1}{3}} \mathrm{~mm}$.; breadth, quite $\frac{1}{3} \mathrm{~mm}$.

Epsom, base of Hount Eden. One male in my own collection, 17th November, 1912, and a female on the 9th December, 1912.

\section{Euplectopsis cuneiceps sp. nov.}

Elongate, subparallel, only slightly convex, very glossy; dark rufous, legs and antemne light chestnut-red, tarsi and palpi rellow; very thinly clothed with decumbent greyish pubescence.

Head much smaller than thorax, with obtuse hind angles, gradually narrowed anteriorly: finely and irregularly punctate frontal depression furcate and terminating farther back than the eyes in a pair of distinct foveae, antennal tubercles well separated, the occiput somewhat convex, and with a minute angular depression behind. Eyes situated behind the middle, small. romposed of very ferr coarse facets. Thorax oviform, slightly lomere than hroad. moderately rounded and widest at the middle, its ape. hardly as broad as the ocriput: it is distantly, quite perceptibly and irregularly punctured, discal longitudinal groove well marked but not reaching the aprex, hasal fossal angular, not distinctly united to the lateral foveate, these are moderately large and deep, each with a feebly curved linear prolongation, so that in some aspects the middle of each side seems a little swollen. Elytra subquadrate, gently curvedly narrowed near the base, hardly broader than the thorax there, of about the same length as it is ; they are indistinctly punctate, sutural striae well marked, foveiform at the base, intrahumeral impressions deep at the base, prolonged but more shallow at the middle. Hind-body of the same length and breadth as elytra, indistinetly punctate, hasal three segments subequal, the lst with a small median basal depression.

Legs moderately elongate, simple, tibiae only very slightly curved externally.

Antennae shorter than the head and thorax, 2nd joint oblong, longe. than the basal, the next very little longer than broad, joints 4 to 8 short and moniliform; 9th rather broader than 8th, but not as broad as the 10th; the terminal large, coniral and acuminate, equalling the preceding three in length.

Underside rufescent, finely pubescent. Prosternum not carinate. Basal ventral segment covered by femora, 2nd and 3 rd rather longer than the next, Jth shorter. Widely hit not deeply mareinate: fith large, rounded behind.

The cuneiform head, sculpture of thorax and elytra, glossy surface, and absence of the prosternal carina show that the only specimen discovered as yet, a female, is most likely the exponent of a distinct genus. It must be located in a section by itself.

․ Length, $1_{2}^{1} \mathrm{~mm}$.; breadth, nearly $1 \mathrm{~mm}$.

Epsom, base of Mount Eden. Found amongst dead leaves on very rough scoria in November, 1911.

\section{Euplectopsis bryocharis sp. nov.}

Elongate, slightly convex, nitid; fusco-rufous, legs and antennae paler, tarit and palpi rellow: rather thickly avered, exerpt the head and thorax, with subdepressed, distinct, greyish pubescence. 
Head subquadrate, very slightly narrowed behind the moderately prominent eyes, it sides punctate, ocriput nearly smooth; interocular foveae not deep, prolonged and confluent in front, antennal tubercles small and distant. Thorax oviform, rounded and widest at the middle, of about equal length and breadth, finely and distantly punctured: the ante-basal impression with a broad groove extending almost to the basal margin, lateral foveae subrotundate, each with a slight linear anterior prolongation and the usual transverse basal connecting stria, median furow moderately hroad but not attaining the apex. Elytra subquadrate, slightly narrowed near the hase, a third longer than thorax, rather broader than it is, irregularly but not closely or very definitely punctate; sutural strice deep and punctiform at. the base, the basal puncture alongside each with a short slender stria proceeding from it, intrahumeral impressions broad, deep at the base, hardly extending backwards as far as the middle, their imner margins slightly carinate, the shoulders more elevated. Hind-body rather shorter than elytra, much rounded and deflexed posteriorly, finely and distantly punctate, hasal three segments slightly increase, the list with a transverse impression at the base.

Legs moderately elongate, tibiae slightly arched.

Fem.-Antennal joints 9 and 10 transverse, almost equal.

Male. Antennae as long as head and thorax, 2nd joint oblong, 3rd short and obconical, joints 4 \& short and subglobular, 5th and 7 th slightly larger; 9th and 10th evidently broader, the latter more transversal than the subquadrate 9th; I1th conical, subacuminate, equalling the preceding two in length.

Underside nitid, chestnut-red. Metasternum convex, longitudinally impressed behind. Basal ventral segment densely ciliate with yellow pubescence, the next three diminish, 5th as long as 4 th, widely incurved behind, 6th rather longer. semicircularly emarginate, 7th transversely oval, its oblong operculum rather large.

E. tibialis, 3526, has a smaller and much more anteriorly contracted head, and strongly arched posterior tibiae. E. terrestris, 3527, is a more stoutly built insect, the interocular and thoracic impressions are manifestly deeper, and the 8th antennal joint being distinctly larger than its predecessors the club is almost 5 -articulate.

Length, $1 \frac{1}{2} \mathrm{~mm}$. ; breadth, nearly $\frac{1}{2} \mathrm{~mm}$.

Bell Rock, near Methven. One of each sex taken from moss on the face of a rock, the male somewhat damaged, on the 15th September, 1912, by Mr. T. Hall.

\section{Euplectopsis blandiatus sp. nov.}

Elongate, moderately robust, shining, elytra and hind-body parallel, head and thorax narrower; light chestnut-red, tarsi and palpi yellow; sparingly clothed with flaresent hairs, those on the lind-body longer and suberect.

Head small, including the moderately large and prominent eyes, nearly as broad as the thorax, slightly narrowed behind these, much more so in front; finely punctate, interocular foreare woll marked and somewhat prolonged anteriorly, the oceiput triangulary impressed behind, antemal tubercles small and distant. Thorax oviform, widest and moderately rounded at the middle, its apex a little narrower than the occiput; finely yet quite definitely, rather irregularly but not dosely punctured: lateral foveae oviform, oceupring fully half of each side. eachi with a linear frontal 
prolongation; basal median depression subangulate, nearly reaching the basal marerin. commected with the lateral foveate by a transverse stria, discal greove distinet hut not attaining the apex. Elytra oblong. broader and quite a thid longer than thorax, with rounded shoulders: less evidently punctured than the therax, sutural striae dreep, punctiform at the base, with a distinct basal puncture near each; intrahumeral impressions bipunctate at base, somewhat duplicate, the outer portion deep and rather short, the inner longer but less distinct. Hind-body as broad as elytra but rather shorter, finely and indistinctly punctate, 2nd and 3rot sements slightly longer than the unimpressed 1st.

Leess elongate and moderately stout: tibiae nearly straight, the intermediate with a small moress near the inner extremity.

Antemate almost equalling head and thorax in length, 2nd joint oblong, nearly as long as the basal : 3rd obconical and rather shorter; joints 4 to 6 small and bead-like: 7 th and 8 th more transversal, the latter slightly the larger; 9th rather broader than 8th but not quite the width of the 10th; the terminal not at all broader than penultimate. elongate and acmminate. as long as preceding three together.

Inderside nitid, finely pubescent. Prosternal carina obsolete. Metasternum depressed along the middle. Ventral segments 2-4 gradually diminish; 5th widely incurved. half the length of 4 th in the middle: 6 th twice as long as 5th, distinctly impressed transversely, vireularly emarginate; 7 th transversely oval, its operculum distinet, oblong.

The only sperimen of Enplectopsis clacutulus, 3496, from Grevmonth, is in the British Musemm, and without doubt is the nearest ally. This speecies is rather larger, the antennare are somewhat different, so also are the lateral thoracic foveae; the metasternum and 6 th ventral segment are distinctly impressed, and the prosternal carina seems to be absent.

ô. Length, $1 \frac{3}{4} \mathrm{~mm}$.; breadth, $\frac{2}{3} \mathrm{~mm}$.

Scott's Gully, near Methven. One found on the 15th March, 1913, by Mr. 'T. Hall, amongst leaf-mould, and two or three others on Pudding Hill.

\section{Euplectopsis impressus sp. nov.}

Elongate, of interrupted outline, slightly convex, shining; castaneorufous. legs and antemnae paler, talsi and palpi yellow: pubescence grerishyellow, rather scanty, distinct. suberect on elytra and hind-body.

Head rather smallep than thorax, a little emredly narrowed behind the moderately laree eyes, indistinctly punctate: interocular foreate well marked and confluent in front, occiput convex, triangularly impressed behind, antennal tubercles small and distant. Thorax rounded and widest near the middle. its apex nearly as broad as the oceiput, finely, irregularly, and distuntly punetured : median groove very distinet, extending from the basal marein nearly to the apex, hut intermpted br the subangular median basal impression. lateral foveas subrotundate but with a sulciform prolongation in front of each. both connected by the usual transverse ante-basal stria. Elytra fully a third longer than thorax, widest behind the middle, curvedly narrowed neap the base, their punctation fine and irregular : sutural striae deep, punctiform at base, with a basal puncture near each; intrahumeral foware duplirate. bipunetate at hase. broad and deep there but beeoming shallow towards the middle. Hind-body finely punctate, rather shorter than elytra, basal thee segments subequal, the 1st with a transverse basal depression. 
Legs moderately stout and elongate, tibiae nearly straight, simple.

Antennae about as long as head and thorax, 2nd joint oblong, 3rd obconical, hardly longer than broad, joints $4-6$ small; 7 th slightly larger than 6 th, but not as broad as the 8 th, which is nearly as broad as the transverse 9 th ; the terminal conical, equalling the preceding two.

Underside distinctly pubescent. Prosternum carinate. Metasternum simple; 6th ventral segment unimpressed, circularly emarginate, the others like those of $\boldsymbol{E}$. blandiatus.

Recognizable at once by the depression on the basal dorsal segment, rather thicker though nearly similar antennae, and the unimpressed metasternum and 6th ventral segment, and carinate prosternum.

Fem.-8th antennal joint very small.

o. Length, $1 \frac{1}{2} \mathrm{~mm}$.; breadth, $\frac{1}{2} \mathrm{~mm}$.

Rakaia Gorge, near Methven. Described from a male found by Mr. 'T'. Hall on the 9th October, 1912, and a pair from Mount Hutt on the 28th of the same month. These two are more thickly pubescent than the first one.

\section{Euplectopsis dorsalis sp. nov.}

Nitid, fulvescent, indistinctly punctate; thinly covered with suberect straw-coloured hairs, and a few longer ones on the hind-body.

Nearly related to $E$. impressus. The head less quadrate, more narrowed anteriorly, with more prominent eyes. Median thoracic groove shorter. Elytra and hind-body more parallel, the 2nd dorsal segment with a basal impression similar to that of the 1 st; 6 th ventral segment twice as long as the 5th, more deeply emarginate; 7 th transversely oval, its operculum large, oblong; 4 th and 6 th antennal joints smallest, 8 th broader than 7 th.

o. Length, $1 \frac{1}{2} \mathrm{~mm}$. ; breadth, $\frac{1}{2} \mathrm{~mm}$.

Rakaia Gorge. Unique; found by Mr. T. Hall on the 18th May, 1912.

\section{Euplectopsis elongellus sp, nov.}

Shining, slightly convex, elongate, elytra and hind-body parallel; light chestnut-red, antennae and legs paler, tarsi and palpi rellow; somewhat thickly clothed with rellowish-grey, moderately elongate, suberect pubescence.

Head smaller than thorax, genae almost straight, with obtuse angles, occiput convex and angularly impressed behind; interocular foveae not very deep, more or less confluent in front, antennal tubercles small and distant, the punctation fine. Eyes moderately large. Thorax rather longer than broad, subovate, moderately rounded and widest at or just before the middle, irregularly, rather distantly, and finely punctured, smooth in front and narrower there than the head; lateral foveae deep, oviform, extending to the middle, with a slight anterior prolongation, the connecting transverse stria deep and angulate at the middle and extending nearly to the basal margin, median groove distinct, much narrowed towards but not reaching the apex. Elytra suboblong, a third longer than thorax, a little narrowed near the base, irregularly and finely punctate; sutural striae deep, punctiform at base, with a basal puncture near each, intrahumeral impressions duplicate, broad and deep at the base, hipunetate there, the outer puncture sometimes indefinite, they are prolonged to the middle. Hind-body rather shorter than elytra, finely punctate: apical secments deflexed, basal three subequal, the first with a median basal depression.

Legs moderately elongate and slender, tibiae nearly straight.

$$
\text { 11-Bull. No. } 1 .
$$


Antennae as long as head and thorax, moderately slender, gradually incratsate; 3rd joint obconical, slightly longer than broad; joints 46 small and subtransversely moniliform, 5th slightly enlarged: 7th rather larerer than 6th, but not quite as broad as the 8th; 9 th nearly as broad as the transverse 10th, the terminal large, conical, obtusely pointed, as long as preceding two together.

6 th ventral segment unimpressed, twice the length of 5th, circularly emarginate, 7 th transversely oval, its operculum large, oblong.

The shape of the thorax is like that of Reitter's Trichonyx longicollis, 3198 , belonging to Section I, but it is a much darker insect, with differently formed antennae. These organs more nearly resemble those of E. blandiatus, but their last joint is obviously shorter and less acuminate, the intermediate tibiae are simple, and the 6 th ventral segment has no depression, \&c.

o. Length, quite $1 \frac{1}{2} \mathrm{~mm}$. ; breadth, nearly $\frac{2}{3} \mathrm{~mm}$.

Rakaia Gorge. Two examples from Mr. T. Hall, found on the 9th October, 1912.

3719. Plectomorphus laminifer sp. nov. Plectomorphiss Raffray, Gen. Ins. (Wytsm.), Pselaphidae, 1908, p. 105.

Stout, moderately elongate and nitid, slightly convex; castaneo-rufous, legs and antennae paler, tarsi and palpi flavescent: rather thickly clothed with decumbent yellow pubescence and a few long outstanding setae.

Head evidently narrower than thorax, still more so in front, as long as it is, gently obliquely narrowed behind the small prominent eyes, with obtuse angles: it is finely but irregularly punctate, the forehead plane, the pair of moderate foveae placed farther back than the eyes; antennal tubercles widely separated, not prolonged backwards. Thorax rather broader than long, rounded and distinctly widest before the middle, obliquely narrowed anteriorly, more gradually behind: it is impunctate, discal furrow moderately deep and attaining the apex, lateral foveae deep, prolonged forwards as grooves at some distance from the sides; basal fossa deep, almost semicircular and with obtusely elevated hind margins, the transverse stria connecting it with the lateral fovea well marked. Elytra oblong, nearly double the length of thorax, slightly curvedly narrowed near the base, with somewhat rounded shoulders; sutural striae distinct, foveiform at the base and, in some lights, appearing duplicate there; intrahumeral impressions deep at the base but becoming shallow behind the middle. Hind-body rather darker, as broad as the elytra but much shorter, basal segment unimpressed, 2nd also horizontal but rather shorter, the others deflexed.

Femora robust, the posterior rather less so. Tibiae straight, the intermediate a little thicker than the others, armed inwardy near the extremity with a short process directed obliquely inwards, so that the thinner outer portion appears more prolonged.

Antennae about as long as the head and thorax, basal joint cylindric, rather longer than the oblong-oval 2 nd; joints $3-5$ almost equal, about twice as long as broad; 6th and 7 th less elongate; 8th still smaller and bead-like; 9th nearly twice as large as 8th, rather longer than the more transverse 10th; the terminal largest, conical, and acuminate; the club, therefore, is triarticulate, and more thickly pubescent than the other joints.

Luderside nitid. bearing distinet rellow pubescener. Head with a large basal foveae and a fine frontal carina. Prosternum carinate along the middle. Intermediate trochanters spined at the immer angle. Basal ventral 
segment short, acutely angulate between the coxae; 2nd largest, with an upright lamina across the middle in front, this should be examined from the side: segments 35 decrease, 6th large, semicircularly emarginate, hardly longer than 1 th in the middle; 7 th large, its oblong operculum with a distinct groove at one side.

This species, owing chiefly to the form of the head, most nearly resembles the larger North Island $P$. optandus, 3212, but in it the median and lateral thoracic grooves are deeper, the 1st dorsal segment has a well-marked transverse depression at its base, and the outer portion of the intermediate tibiae is hardly longer than the inner. The remarkable lamina on the 2 nd ventral segment distinguishes $P$. laminifer.

o. Length, $2 \mathrm{~mm}$.; breadth, quite $\frac{1}{2} \mathrm{~mm}$.

Pudding Hill, about nine miles from Methven. Described from a specimen found among leaf-mould by Mr. W. Burrows on the 30th March, 1913.

3720. Vidamus congruus sp. nov. Vidamus Raffray, Gen. Ins. (Wytsm.), Pselaphidae, 1908, p. 89.

Slender, elongate, subdepressed, nitid; with distinct, mostly decumbent, yellowish-grey pubescence; chestnut-red, legs and antennae fulvescent, tarsi and palpi yellowish, hind-body somewhat infuscate.

Head as broad as thorax, very slightly rounded behind the moderately large but not very convex eyes, with obtuse hind angles; apparently smooth, antennal tubercles extending inwardly and subcontiguous in the middle, interocular foveae distinct, prolonged and confluent in front. Thorax rather longer than broad, widest and moderately rounded before the middle. its apex hardly half the width of the occiput, without perceptible punctation; the transverse ante-basal impression unites the rotundate lateral foveae and angular median fossa, which has a broad groove extending to the basal margin. Elytra about a third longer than broad and as much longer than the thorax, their sides somewhat rounded, widest near the middle, finely and irregularly punctured; sutural striae broad, deep and foveiform at the base, intrahumeral foveae short and deep. Hind-body rather narrower and shorter than elytra, finely punctate, its basal three segments subequal, the 1 st with a very short, sometimes indistinct, hasal depression, the 2 nd somewhat swollen in the middle and with a shallow transverse impression near each side.

Legs moderately stout; intermediate tibiae armed with a distinct spiniform process near the inner extremity.

Antennae shorter than head and thorax, with slender setae; 2nd joint nearly as thick but shorter than the basal, the next a little longer than broad and usually narrowed towards its base; joints $4-8$ small and beadlike, 5th and 7 th slightly larger than the others; 9 th and 10th distinctly transverse, the former broader than the 8 th but smaller than the 10th ; 11th conical and acuminate, rather broader than the penultimate and nearly as long as the preceding three together.

2nd ventral segment longer than the next, th distinctly shorter in the middle, and slightly shorter than 5th; 6th large, emarginate behind; 7 th transversely oval, its operculum indistinct. Intermediate trochanters with prominent spines.

Fem. -Hind-body longer and more horizontal, its 2nd segment simple, tibiae unarmed.

Y. armiferns, 3381, having similarly spined tibiae, and heing of about the same size, is without doubt the nearest ally; but it is nearly pitchy-red, 
its thorax is more oviform, and the hind-body is decidedly broader; the lower surface also differs, and I have been unable to detect trochanteral spines.

o. Length, $1 \frac{1}{2} \mathrm{~mm}$. ; breadth, quite $\frac{1}{3} \mathrm{~mm}$.

Scott's (iully, near Methven; also found on Pudding IIill, amongst fallen leaves, in March, 1913, hy Mr. T. Hall. Five specimens altogether.

\section{Vidamus clavipes sp. nov.}

Subdepressed, moderately robust and elongate, nitid, very finely and distantly punctate; chestnut-red, tarsi and palpi flavescent; sparingly covered with yellowish, mostly decumbent, somewhat unequal pubescence, very slender and elongate on the head, coarser on the hind-body.

Head nearly as large as thorax, the genae hardly at all rounded, hind angles obtuse; interorular foveae large and deep, prolonged and confluent in front, antennal tubercles extending inwardly; the short neck scarcely half the width of the head. Eyes moderate. Thorax a little longer than broad, widest and rounded in front of the middle: lateral foveae deep. connected with the median fossa by an irregular stria, the thick basal margin tripunctate. Elytra subquadrate, a third longer than thorax, slightly narrowed towards the arcuate-emarginate base; sutural striae hroad and deep, foveiform at the base, with a basal puncture alongside each, intrahumeral foveae short, bipunctate at base. Hind-body nearly as broad as elytra but rather shorter, basal two segments equal, simple, 3rd rather shorter, the others deflexed.

Legs robust, femora clavate; tibiae thick, the hinder pairs with a very short process at the inner extremity directed straight backwards.

Antennae shorter than head and thorax, with elongate pubescence; 2nd joint nearly as large as the lst, 3rd evidently longer than broad; joints 4 to 8 short and moniliform, 5th and 7 th rather larger than adjoining ones; 9 th broader than 8 th, but smaller than 10 th; the terminal conical and acuminate, a little broader than the penultimate, but hardly the length of its three predecessors.

Underside with distinct yellow pubescence. Trochanters simple. Basal ventral segment quite visible and thickly ciliate, $2-5$ decrease; 6 th large, semicircularly emarginate, the operculum of the 7th broad and unsymmetrical.

The robust legs, clavate femora, rather elongate 3rd antennal joint, tripunctate base of thorax, and the basal puncture near each of the sutural striae differentiate this from the other members of Section I.

o. Length, $2 \mathrm{~mm}$. ; breadth, nearly $\frac{2}{3} \mathrm{~mm}$.

Mount Hutt. One male, found amongst decaying snow-grass on the 28th December, 1912, by Mr. T. Hall.

\section{Vidamus punctulatus sp. nov.}

Nitid, slightly convex, elongate, subparallel; dark chestnut-red, legs and antemae much paler, tarsi and palpi testaceous: sparingly rovered with rather short greyish pubescence.

Head as long and nearly as broad as the thorax, not narrowed behind the moderately large eyes, with obtuse hind angles: finely punctate, interocular foreace latge and deep, prolonged and confluent in front, the base with a small triangular depression. Thorax rather small, as broad as it is long, widest and rounded at the middle, finely punctured, its apex much narrowed than the head; median fossa angular, with a groove extending 
to the hind margin, with a distinct transverse stria connecting it with the deep rotundate lateral foveae, the basal margin distinctly bipunctate. Elytra subquadrate, nearly double the length of thorax, slightly narrowed before the middle, with rounded shoulders, base incurved, irregularly punctate; sutural striae broad and deep, subfoveiform at the base, with a basal puncture near each, intrahumeral impressions duplicate, their outer portion deep and short, the inner elongate but shallow. Hind-body about as broad but rather shorter than elytra, indistinctly punctate, 2nd segment slightly longer than the 1 st or 3rd, the others deflexed.

Legs moderately elongate, simple; tibiae a little arched externally.

Antennae nearly equalling the head and thorax in length, similar in structure to those of $V$. clavipes, but with the $3 \mathrm{rd}$ joint shorter.

Underside castaneo-rufous, finely pubescent; basal ventral segment much exposed and acutely projecting between the coxae, 2nd and 3rd about equal; 4th shorter, 5th more so, both widely but not deeply emarginate; 6 th large, without any definite suture between it and the 7 th, the operculum oblong; trochanters simple.

The rather dark-red, finely punctured surface, small subrotundate thorax with its hind margin bipunctate, the duplicate intrahumeral impressions, simple legs and trochanters, in conjunction, will enable this to he separated from the other species belonging to Section I.

o. Length, $2 \mathrm{~mm}$; breadth, quite $\frac{1}{2} \mathrm{~mm}$.

Invercargill. Found by Mr. A. Philpott on the 6th August, 1894, and at that time set aside as a varietal female of Sharp's Euplectus conrexus, 254.

3723. Zealandius brookesi sp. nov. Zealandius Raffray, Gen. Ins. (Wytsm.), Pselaphidae, 1908, p. 111.

Elongate, slightly convex and nitid, head subopaque castaneo-rufous; legs and antennae paler, tarsi flavescent; pubescence distinct, subdepressed, rather short, yellowish-gres, elytra and hind-body with a few elongate erect setae.

Head almost as long as thorax but not as broad, gradually narrowed in front of the small, prominent eyes, its hind angles rounded; it is distinctly and closely punctate, interocular foveae rather shallow and apparently prolonged anteriorly. Thorax about as long as broad, strongly rounded and widest at or just before the middle; its punctation moderately coarse and close at the base and sides, but distant and irregular on the central and anterior portion of the disc; median furrow deep and broad but rather less so near the apex, lateral foveae occupying half the length and indistinctly united to the transverse median basal fossa. Hiytra subquadrate, with rounded shoulders, about a third longer and broader than thorax, indistinctly punctate; sutural striae broad, deep and foveiform at the base, and appearing duplicate along the middle, dorsal striae not quite so deep behind, with carinate inner margins, the external stria obsolete. Hindbody as broad but rather shorter than elvtra, 2 nd and srd segments a little longer than the 1st, the others deflexed.

Legs simple, finely pubescent.

Antennae shorter than head and thorax, hearing slender elongate setae; 2nd joint elongate-oblong but not quite the length of the basal ; joints 3-s submoniliform, 5th distinctly, 7 th slightly larger than contiguous ones; 9 th nearly twice the breadth of the $8+h$, loth still hoader, hotb transrerse; the terminal ronical and acuminate, about as long as preceding three combined. 
Underside chestmut-red, finely pubescent. Head with a large basal depression and a slender longitudinal carina. P'rostermum finely carinate along the middle, its flanks covered with mimute setae. Motasternmm with a central fovea. Basal ventral segment indistinct, hidden by the femora; 2 to 4 subequal, 3rd with a transverse median impression; 5th shorter, widely but slightly emarginate; 6 th as long as 5th at the sides, semicircularly emarginate: Tth transversely oviform. longer than bith in the middle, obtusely angulate hehind. Intermediate trochanters prominent but not definitely spined.

This differs from the eight recorded members comprising Section I by the remotely punctate frontal portion of the thoracic dise. somewhat differently formed antennate. mose shining surface, and abdominal structure.

Length, quite $1 \frac{1}{2} \mathrm{~mm}$. ; breadth, $\frac{1}{2} \mathrm{~mm}$.

Titirangi, Waitakerei Range. A simple specimen found amongst dead leaves on the ground, collected by Mr. A. Brookes, of Mount Mllort, on the 21st March, 1913. It bears the discoverer's name.

\section{Zealandius tuberalis sp. $110 \mathrm{v}$.}

Nitid, castaneo-rufous, legs and antennae paler, tarsi and palpi testaceous; distinctly clothed with fine yellowish-grey subdepressed setae. some of which are quite short: there are also a few elongate erect ones.

Head rather smaller than thorax, gently narrowed behind the small convex eyes, its hind angles obtuse; it is moderately and irregularly punctured, the interocular foreare are well marked but not distinctly confluent with the rather broad frontal channel, at the middle of its base there is a small angular depression. Thorax of about the same length and breadth, widest and rounded at or just before the middle, its smooth apex evidently narrower than the head, without visible punctation, basal fossa deep and more or less connected with the subrotundate lateral foveae, mesial furrow broad and deep but becoming narower near the apex. Elytra subquadrate, a little narrowed towards the base, rather wider there than the thorax, about a third longer; they are only obsoletely punctate, their striae are broad and deep at the base, with carinate outer borders, the sutural are duplicate, the dorsal shallow behind, the lateral obsolete. Hind-body rather shorter than elytra, basal three segments equal, the others deflexed, the lst with a transverse median depression, which, however, is sometimes covered by the elytra.

Legs moderately elongate, pubescent; tibiae slightly arched externally, simple.

Antennae with slender erect setae; 2nd joint oblong-oval but shorter than the 1st; joints 3-8 small and, except the 3rd, bead-like, the 4th, 5th, and 7 th slightly larger; sth evidently larger than sth, but uot as broad as the 10th; terminal elongate-conical and acuminate; they are just the length of the head and thorax. .

Underside shining, with fine pubescence, which, however, is very slender and elongate at the extremity. Head with a deep basal fovea and a fine longitudinal carina. Prosternum similarly carinate. Netasternum convex, impressed behind the middle: and ventral sexment swollen in the middle and somewhat angulate behind, 3rd with a lunate basal depression, 4th rather shorter, 5th at the extremity with a small suberect tubercle, 6th shorter than 5th, feebly impressed transversely, subtruncate behind, the operculum of the 7 th subrotundate. 
This belongs to Section II. The only species at all like it is Z. illustris, 3383 , which nevertheless has a relatively longer, narrower, and more distinctly punctured head, its thorax is moderately coarsely punctured at the sides and base, there is an angular projection near the inner extremity of the intermediate tibiae, and the abdominal characters are materially different.

ふ. Length, $1 \frac{1}{2} \mathrm{~mm}$. ; breadth, $\frac{1}{2} \mathrm{~mm}$.

Mount Hutt, 25th January, 1913, and Pudding Hill, 13th April, 1913. The few individuals secured by Messrs. T. Hall and $\mathrm{L}$. Burrows are nearly all males.

3725. Eleusomatus ovicollis s]. nov. Elensomatus Raffray, Gen. Ins. (Wytsm.), Pselaphidae, 1908, p. 112.

Elongate, subdepressed, narrowed towards both extremities, nitid, more or less finely punctate; light chestnut-red, legs and antennae flavescent, tarsi and palpi paler; sparingly clothed with decumbent greyish pubescence.

Head much smaller than thorax, considerably narrowed in front of the eyes, genae straight, with obtuse angles, finely punctate; vertex distinctly bifoveate, antennal tubercles widely separated. Eves situated hehind the middle, convex, with coarse facets. Thorax oviform, rather longer than hroad, widest near the middle, moderately rounded; with a rotundate fovea near each side united by a transverse stria. median hasal fovea angulate and almost touching the basal margin, the central longitudinal groove absent. Elytra subquadrate, curvedly narrowed near the base, broader but hardly longer than the thorax, finely punctate; sutural striae well marked and foveiform at the base, intrahumeral impressions short. Hindhody horizontal, evidently longer than the elytra, gradually attenuate posteriorly, basal three segments distinctly marginate, 2nd nearly as long as the basal, the next rather shorter, 4th and 5th together as long as the 3rd: the 1st with a basal depression. Legs moderately elongate.

Antennae shorter than the head and thorax, 2nd joint stout, oviform, as large as the basal, 3rd obconical and rather small; joints 4-8 moniliform. 5th and 7 th rather larger than the others: 10th broader than the transverse 9 th, the terminal largest and acuminate.

Head, underneath, studded with erect setae. Basal rentral segment just visible between the coxae, $2-4$ large and of nearly equal length, the next half the length of its predecessor, 6th obronical and almost as long as the 4 th.

The small head, oviform thorax, without the least trace of the usual longitudinal groove along the middle, will at once enable this species to be distinguished from 1890 , the type of the genus.

Length, $1 \frac{1}{2} \mathrm{~mm}$. ; breadth, nearly $\frac{1}{2} \mathrm{~mm}$.

Bell Rork, near Methven. Described from a single specimen found amongst decaying leaves by Mr. T. Hall on the 30th March, 1913.

\section{Group Tyrini.}

3726. Hamotulus robustus sp. nov. Hamolulus sichatufuss, I886i. (ion). Ins. (Wytsm.), Pselaphidae, p. 390. Syn. Tychotyrus Broun. 1893, Ann. Mag. Nat. Hist., ser. 6, vol. 12, p. 168.

Elongate, subovate, moderately convex, shining; rufous, abdomen darker, tarsi and palpi fulvous; clothed with elongate suberect yellow setae, and many longer outstanding ones near the sides. 
Head densely ciliate and distinctly yet gradually narrowed hehind the prominent eyes, more abruptly contracted and parallel in front; with a distinct fovea near each eye, the chamnel between the horizontal antenmal tubereles mederately deep and broad and extending as far as the front of the exes. Thorax slightly longey than broad, a litile contracted in front, its sides nearly straight; with a curved transverse groove before the base extending to the forea at each side. Elytra with some fine scattered punctures, a third longer than thorax, twice its breadth, gently curvedly narrowed towards the base, apices tuncate; sutural striae well marked throughout, deeper at the base, and with a large impression, which does not attain the middle, near each slightly raised shoulder. Hind-body as long as elytra, gradually narrowed and deflexed posteriorly, somewhat convex along the middle, its basal three segments marginate and equal, the 4th longest.

Logs stout and elongate, finely pubescent; intermediate tibiae distinctly arched externally and slightly bent inwardly at the extremity; the posterior on the inside, at a third of the length from the apex. with at stout spiniform process.

Antennae stout, a third longer than the head and thorax, evidently pubescent; 2nd joint oblong and quite half the length of the basal, 3id and 1 th longer than 2 nd yet somewhat shorter than the 5th or 6 th, both of which are quite twice as long as broad; 7th longer than the subquadrate 8 th, but obviously shorter than the preceding ones; 9 th slightly wider than 8th at its base, distinctly broader at its apex; 10th more transverse; the terminal conical, broader than and double the length of its predecessor, with a fovea underneath.

Underside chestnut-red. with vellow pubescence: metasternum broadly medially depressed, with a thick spiniform tubercle just behind each of the intermediate coxae. Abdomen rather longer than the metasternum, segments 2-t about equal, 5th much longer at the sides than in the middle, unimpressed there: 6th large, smooth and concave in the centre, pubescent at the sides, the supplementary very short.

More robust than the Auckland $H$. stemalis, 2744, with differently formed antennae. Metasternum broadly impressed instead of longitudinally, with abuptly upright frontal tubercles; 5th ventral segment withour a median transverse depression.

Fem.-Metasternum with a shallow rotundate depression behind the middle; 5th ventral segment rather longer than 4th, 6th at the apex obtusely angulate in the middle.

Length, $21 \mathrm{~mm}$. ; breadth, quite $1 \mathrm{~mm}$.

Rose Hill, near Methven. Another of Mr. T. Hall's numerous novelties. Both sexes found amongst dead leaves on the groumd on the 20 th November, 1912. In one male, joints 3-7 of the antennae are nearly alike, the 5th and 6 th being slightly longer and the 7 th rather shorter.

\section{Hamotulus fuscipalpis sp. nov.}

Shining, head and thorax piceo-rufous, elytra rufescent, abdomen, legs, and antennae fusco-rufous, tarsi and palpi infuscate; pubescence yellow, more or less erect and elongate.

Resembles $H$. robustus. 'The outstanding and more convex eyes are separtated from the deeper foreate by the more sharply marked sides of the head. Elytra with latge intrahumeral imprescions, extending nearly as far back as the middle. Spones of posterior tibiae slightly thicker. Basal joint of antennae more than twice as long as broad, joints 2 to 7 elongate, 5 th 
and 6th longest, 8th not perceptibly broader than 7 th, 10 th distinctly more transverse than corresponding joint of $H$. rolustus. Metasternum longitudinally depressed along the middle but similarly tuberculate. 5th ventral segment as long as 4 th, broadly impressed in the iniddle, 6th deeply hollowed, 7 th nearly semicircular, small, its centre concave.

In every other known member of the genus the palpi and tarsi are yellow or fulvescent.

ô. Length, $2 \frac{1}{2} \mathrm{~mm}$.; breadth, quite $1 \mathrm{~mm}$.

Mount Hutt. Found by Mr. T. Hall amongst dead leaves on the ground (altitude, 4,500 ft.) on the 12th April, 1912.

\section{Hamotulus cornutus sp: nov.}

Convex, nitid; head, thorax, and hind-body fusco-rufous, elytra, antennae, and legs chestnut-red, middle of femora fuscous, tarsi testaceous, palpi yellow; pubescence yellow, more or less erect.

Antennae a third longer than head and thorax, 2nd joint quite half the length of the basal, slightly thicker but hardly longer than 3rd; joints 3-6 differ but little, all oblong; 7 th rather shorter than preceding ones yet longer than the bead-like 8th; 9th subquadrate, slightly broader than 8 th at its base, still broader in front; 10 th of similar form, but wider; 11th large, about the length of the preceding two together.

Posterior tibiae less curved than the intermediate, with a thick spine below the middle.

Wetasternum deeply and broadly concave along the middle; the tubercles are laterally compressed, their base seems to occupy the side of the metasternum, they are strongly but gradually raised behind, vertical in front, and close to the intermediate coxae; towards the summit they have a slight backward curvature and appear horn-like there.

Ventral segments $2-t$ ciliate behind, 5th simple, semicircularly emarginate; 6th not at all concave, only slightly impressed; 7 th concealed by the protuding genital appendage.

Like $H$. robustus in most respects, but smaller, with entirely different sternal tubercles, which, indeed, are far more prominent. It is more nearly allied to $H$. spinipes, 2459 , and still more closely to $H$. frontatis, 3403 , from Broken River. The former, however, has a broader head and straight posterior tibiae; the latter differ's in minor details, particularly underneath.

J. Length, $2 \frac{1}{4} \mathrm{~mm}$. ; breadth, $\frac{3}{4} \mathrm{~mm}$.

Mount Hutt. Described from a single male taken on the 12th April, 1912, by Mr. T. Hall.

\section{Group Scyduandidae.}

3729. Scydmaenus angulifrons sp. nov. Scydmaenus Labtreille, Min. N.Z. Coleopt., p. 144.

Elongate, narrow, convex, shining, finely and distantly punctate near the sides; nigro-piceous, palpi, antennae and legs castaneo-rufous; sparingly clothed with distinct, elongate, suberect yellowish pubescence.

Head elongate, widest in line with the small eyes, considerably but rery gradually narrowed backwards; with a rather large and deep triangular frontal depression, so that the forehead appears angulate immediately behind each antenna. Thorax oviform, of almost equal length and breadth, truncate at apex, its sides moderately rounded, with a large shallow 
impression at rath hehind the middle, which, therefore, sems somewhat contracted, the base with a transverse stria ending in a small punctiform imprexion near arch side. Elytra elongate-oval, nearly thice the length of thoma, of about the same widh as it is at the base, with obliquely truncate apices. Pygidium exposed, punctate, pubescent and reddish.

Legs elongate, finely setose; femora gradually thickened; basal joint of anterior tarsi oblong.

Antennae as long as head and thorax, 2nd and 3rd joints elongate yet rather shorter than the 4 th or 5th, which are the longest; joints 6 s slightly decrease, 9th and 10th rather broader than preceding ones, the 10th the shorter, the terminal conical.

Underside rufo-piceous, more or less finely punctate, with elongate vellow pubescence. Ifesosternal process distinct, extending to beyond the iniddle of internediate coxae. Metasternum elongate, hi-impressed behind. Basal segment of abdomen truncate between the coxae, 6th as long as th and 5th combined, much narrowed posteriorly. Posterior coxae far apart.

Maxillary palpi with the penultimate joint elongate, thicker near the extremity than at the base, the terminal short, broad, and indistinct.

The rather large size, nigrescent body, and triangular frontal depression of the head form good differentiating characters.

Length, $3 \frac{1}{2} \mathrm{~mm}$.; breadth, quite $1 \mathrm{~mm}$.

Hump Ridge, Southland. Two examples, taken by Mr. A. Philpott in December, 1911.

\section{Scydmaenus sulciferus sp. 110v.}

Convex, narrow, elongate, nitid, indistinctly punctate; sparingly clothed with long, upright, slender yellow setae, those on the head subdepressed and less conspicuous; body red, legs, antennae, and palpi of a lighter chestnut-red.

Head elongate-oval, broadest in line with the small eyes, considerably curvedly narrowed behind these; nearly plane above, with a shallow stria along the hinder half. Thorax rather longer than broad, widest and rounded before the middle, much narrowed towards the base, which is bifoveate between the centre and each side; from the outer fovea there proceeds a stria which extends forward as far as the middle. Flytra elongate-oval, fully twice the length of thorax, double the breadth at the middle than at the base, with singly rounded apices, the suture near the base forms a linear depression. Pygidium exposed, smooth.

Legs elongate, femora subclavate near the extremity.

Antennae quite the length of head and thorax, with elongate slender pulescener: basal joint ryindrie. slightly stouter but scarcely longer than the elongate 2ud. joints is 7 almost equally long, the sth rather shorter, bth and loth distinctly broader and subquadrate, 11th longer and sub conical.

Maxillary palpi with the 3rd joint elongate, much thicker at the extremity than at the base, the 4 th indistinct but not aciculate. Mesosternal process distinct, piolonged nearly to the extremity of the intermediate coxae.

'Though somewhat similar to the northern $S$. elongellus, 2347, this may he reatlily separated by the linear depressions on the head, thorax, and base of elytra.

Length, $2 \frac{1}{2} \mathrm{~mm}$. ; breadth, $\frac{2}{3} \mathrm{~mm}$.

Ben Lomond, Otago. A single specimen, found by Mr. A. Philpott early in December, 1912. 


\section{Scydmaenus latuliceps sp. nov.}

Nitid, moderatly robust and convex; rufous, legs and antennae cliestuutred, tarsi and palpi fulvescent; pubescence yellow, conspicuous and elongate, rather rougher and irregular on the head and thorax.

Head almost as broad as thorax, rounded behind the moderately prominent eyes, its pubescence covering the obtuse hind angles. Thorax slightly longer than broad, a little dilated and rounded before the middle, obliquely narrowed in front; at each side a large foveiform impression occupies more than half its length, the pair of median basal foveae though small are well marked and somewhat oval. Elytra oviform, twice the length of thorax and a third broader in the middle; shoulders somewhat elevated, inside each of these there is a broad impression, this is deep at the base and more or less distinctly bipunctate at the basal margin; on the disc, before the middle, there is an oviform impression. Pygidium covered.

Legs elongate, femora gradually thickened; tibiae straight, with some coarse setae towards the inner extremity.

Antennae stout, as long as the head and thorax, gradually incrassate, pubescent: their 2nd joint hardly longer than the basal, 3rd subquadrate, 4th and 5th evidently longer than broad, 6th and 7 th very similar to the 3rd, 8th almost as broad as 9th and slightly longer than the transverse 10th, the terminal conical, hardly the length of preceding two united.

Maxillary palpi with the penultimate joint elongate and gently narrowed towards the base, 4 th small and acicular.

Underside chestnut-red, with yellow pubescence. Prosternum emarginate. Mesosternal process slender, extending to the middle of intermediate coxae. Metasternum large, with a median impression behind. Basal four segments of abdomen short, with very deep sutures, the lst acutely triangular between the coxae; 5 th large, its apical suture very fine; 6th rather longer, rounded, finely purictate and ciliate at the extremity, the supplementary deeply medially concave, with well-developed margins. Posterior coxae distinctly separated, but subcontiguous at the base.

Somewhat similar in appearance to $S$. allocerus, 2748 , which may be readily separated by its much shorter differently formed antennae, their last joint is broad but very obliquely cut away towards the extremity. The remarkable ventral sutures of $S$. latuliceps will also aid identification.

Length, $2 \mathrm{~mm}$. ; breadth, $\frac{2}{3} \mathrm{~mm}$.

Hount Hutt, 4,500 ft.. amongst decaying leaves: and in moss on growing trees on the City Council's reserve near Methven. Another of Mr. T. Hall's discoveries.

\section{Scydmaenus fragilis sp. nov.}

Elongate, slender, subdepressed, moderately nitid, finely and indistinctly punctate; light chestnut-red, legs and antemiate somewhat testaceous, tarsi and palpi yellow; pubescence distinct and flavescent, almost decumbent on elytra, more irregular on head and thorax.

Head subquadrate, nearly as broad as thorax, with rounded hind angles. Eyes minute and rather flat. Thorax rather longer than broad, widest at or just before the middle; rather finely medially bipunctate near the base, and with a fovea at each side. Elytra oviform and covering the pyidium, double the length of thorax, broader than it is at the middle, each with at deep and rather broad basal fovea.

Legs elongate and slender, finely pubescent. femora morlerately dilated.

Antennae as long as head and thorax, with slender elongate rrey hairs. their apical four joints moderately expanded; 2 nd as long as 1st.; joints 
3- 4 small and moniliform but not transversil ; 7 th slightly larger; 8th broader than its predecessor and, like it, narrowed appically; 9th and 10th transverse and laxly articulated; terminal conical, as hroad as the loth but hardly twice its length.

Maxillary palpi with acicular th joints, the penultimate suboblong-oval.

Prosternum deeply emarginate. Mesosternal process extending half-way hetween the middle coxac. Metasternum large, unimpressed. Posterior coxae slightly separated. Ventral segments with fine sutures.

This approaches S. heterarthrus, 2751, and S. antennalis, 1902. 'The latter may be known by its dark colour, more distinct basal thoracic punctures, broader penultimate joints of maxillary palpi, longer antennae, \&e. ; the former by the more elongate elytral impressions, elevated shoulders, and by the last antennal joint being narrower than the 10th. Both of these are Auckland species.

Length, $1 \frac{1}{2} \mathrm{~mm}$. ; breadth, nearly $\frac{1}{2} \mathrm{~mm}$.

Pudding Hill, near Methven. Four examples found by Messis. 'T'. Hall and L. Burrows on the 13th April, 1913, amongst decaying forest leaves, at an elevation of $3,200 \mathrm{ft}$., and a few others $b y$ the former amongst moss and lichen on standing trees at Bell Rock, near Methven.

3733. Adrastia clavatella sp. nov. Adrastia Broun, Mən. N.Z. Coleopt., p. 663 .

Elongate, rather narrow, slightly convex, shining, smooth; rufous, legs and antennae light rhestmut-red, tarsi and palpi fulvescent: sparingly clothed with slender, elongate, suberect greyish hairs.

Head suboblong, rather narrower than thorax, with rounded hind angles. Eyes small, only very slightly prominent. Thorax a third longer than broad, rounded and widest before the middle, curvedly narrowed in front, gradually behind, base distinctly margined and slightly rounded, with a small punctiform fovea near each hind angle. Elytra elongate-oval, searcely double the length of the elongate thorax and only a little broader than it is at the middle, with broadly, individually rounded apices, without basal impressions. Pygidium broad and much exposed.

Legs elongate, femora somewhat dilated, tibiae finely setose.

Antennae elongate, equalling the head and thorax in length, and joint about as long as basal, joints $3-6$ almost equally elongate, 7 th and 8 th smaller: sth and loth subquadrate, evidently broader than preceding oness and more obviously pubescent; 11th conical, rather shorter than preceding two together.

Underside of head broadly depressed along the middle. Mesosternal proress prolonged beyond the middle of intermediate coxae. Metasternm elongate. Posterior coxae widely separated. Maxillary palpi stout, with short conical terminal joints, 3rd slightly narrowed towards the base.

Like Adrastia laetans, 1158, but with the head narrower and more oblong, the thorax and elytra also narrower and more elongate, the former vithout definite posterior angles. Antemnal club distinctly triarticulate.

Length, $1_{3}^{2} \mathrm{~mm}$. ; breadth, $\frac{1}{2} \mathrm{~mm}$.

Mangawhare, North Wairoa. One example, found by Mr. G. Campbell Munro, formerly of Clevedon.

3734. Phagonophana alacer sp. nov. Phagonophana King, 'linus. Ent. Soc. N.S. IV., vol. 1, p. 92.

Robust, moderately convex, nitid; head and thorax dark sanguineous, elytra lighter red, legs and antennae more or less castaneo-rufous, tarsi 
fulvescent; clothed with elongate, suberect, flavescent setae, those on the head directed băckwards.

Head oblong, not as broad as thorax, slightly narrowed behind the prominent eyes. Thorax slightly longer than broad, a little contracted near the base, its sides only moderately rounded; bifoveate near each side of the base, the inner subtransversal, the outer smaller and close to the somewhat prominent angle. Elytra oviform, twice the length of the thorax, a third broader than it is at the middle; each elytron with a broad basal impression between the suture and shoulder; their punctation distant, rather shallow and indistinct. Pygidium entirely covered.

Legs elongate, femora gradually incrassate, tibiae straight, the front and middle pairs coarsely setose inwardly towards the extremity.

Antennae equalling the head and thorax in length, very slightly and gradually thickened, stout, with elongate pubescence; 2nd joint rather longer than the basal but hardly as thick, 3rd and 4th just oblong, 5th and 6th slightly shorter, 7 th and 8 th very little broader than preceding ones, each narrowed apically, 9th and 10th transverse, 11th subconical, nearly twice the length of penultimate.

The northern $P$. angulata, 2487, may be discriminated by its less convex eyes, shorter elytra, and differently formed antennae; their terminal half, moreover, is dilated.

In Sharp's $P$. setosa, 267, the shape of the head is very different, being broader near the eyes and considerably curvedly narrowed behind them, and the vertex is rather convex; the basal impressions of the thorax are not transverse, and those of the elytra are somewhat elongate and situated near the shoulders; the 2nd antennal joint is not longer than the 1st, and the penultimate joint of the maxillary palpi is gradually narrowed towards the base, whereas in this species it is oblong and contracted at the base only.

Length, $2 \frac{1}{2} \mathrm{~mm}$. ; breadth, $1 \mathrm{~mm}$.

Rose Hill, near Methven. I am indebted to Mr. T. Hall for my specimen. He found it amongst dead leaves on the ground on the 25th February, 1912.

\section{Phagonophana halli sp. nov.}

Robust, moderately convex and elongate, shining; varying in colour from sanguineous to castaneo-rufous, legs and antennae paler, tarsi fulvescent; clothed with conspicuous, elongate, suberect yellow setae.

Head large, suboblong, as broad as thorax, with rounded, quite obsolete hind angles. Eyes moderate, rather flat. Thorax a little longer than broad, slightly rounded before the middle, somewhat sinuate behind; with a distinct, subrotundate basal fovea at each side of the middle, but without any definite external puncture; the fine lateral carina near the base extends obliquely outwards and forms the posterior angle. Elytra oviform, quite double the length of thorax, a third broader than it is at the middle; at the base, near each shoulder, there is a deep fovea, and between it and the suture a smaller punctiform impression usually extends a short distance alongside the suture; on the dise, beginning before the middle of each elytron there is an elongate curved impression, the suture therefore appears somewhat elevated along the middle.

Tibiae setose, the intermediate with a calcar-like process near the inner extremity.

Antennae as long as the head and thorax, gradually incrassate; and joint longer than the basal, joints 35 distinctly longer than broad, 6th 
rather smaller ; 7th and sth broader, both narrowed apically, 9th and 10 th transverse, these four somewhat laxly articulated; terminal conical, hardy as long as the preceding two combined.

Inderside chestnut-red, with yellowish pubescence. Prosternum deeply incurved. Mesosternal process distinct, attaining the hind part of intermediate coxae. Penultimate ventral segment of about the same length as 6th, evidently longer than any of the preceding ones. Mandibles robust, curved and acute at the extremity, each strongly bidentate inwardly. Maxillary palpi finely pubescent. penultimate joint suboblong-oval, slender near the base, truncate at apex, the 4th small but distinct, subacuminate.

The rather broad head, nearly Hat eyes, and the well-marked elytral impressions are constant distinctive features.

Length, $2 \frac{1}{2} \mathrm{~mm}$.; breadth, $1 \mathrm{~mm}$.

Mount Hutt, Pudding Hill, and McClennan's Bush, near Methven. Several specimens, without good sexual characters, found between November, 1912, and April, 1913, by Mr. T. Hall, aided by Mr. L. Burows, amongst leaf-mould. Mr. Hall's name has been attached to it.

Obs.-This genus is distinguished from Scylmenens by having biarticulate labial palpi, which, however, cannot be seen without dissecting the head, and by the contiguity of the posterior coxae. The maxillary palpi vary in structure according to the species, but in all that have been described by me the pygidium is covered by the wing-cases.

\section{Phagonophana palpalis sp. nov.}

Rohust, elongate, distinctly narrowed anteriorly, ronvex, shining; head and thorax piceo-rufous, elytra, legs, and antennae lighter red, tarsi and palpi fulvescent; clothed with yellowish, mostly erect setae, which are rather coarser on the head and thorax than on the elytra.

Head rather elongate, narrower than thorax, deflexed in front, convex and on a higher level behind than the thorax, slightly obtusely elevated close to each antenna, gently narrowed behind the prominent eyes, its hind angles obsolete. Thorax evidently longer than broad, very slightly wider at the base than elsewhere, only obsoletely sinuate behind, distinctly curvedly narrowed anteriorly, base truncate, with rectangular angles; median basal fovea large and deep, the lateral elongate. Elytra oviform, near the middle double the width of thorax, twice its length, covering the pygidium; sutural region depressed about half the length from the base backwards, there is a deep suboblong depression near each shoulder, and near each side of the suture a small punctiform fovea.

Legs long and stout, femora only gradually incrassate; tibiae setose, the intermediate distinctly narrowed near and somewhat bent and acuminate at the inner extremity; tarsi moderately slender.

Antennae stout, of about the same length as the head and thorax, pubescent, their terminal half a little thickened; 2nd joint oblong, nearly twice the length of the 1st; joints $3-6$ subquadrate and about equal; 7-10 rather larger, but little different, each narowed apically; teminal conical, evidently longer than the penultimate.

Inderside chestnut-red, with distinct yellow pubescence. Mesosternal process extending from the anterior coxac almost to the extremity of the intermediate. Iletasternum hardly longer than abdomen. Posterior coxae contiguous. 
Maxillary palpi with the 2 nd joint elongate and thickened at the extremity, 3rd broadly oval, with a short slender basal stalk, the 4 th short and moderately thick.

This stands alone. It differs from $P$. setosa in almost all its details, the femora are not clavate, the basal joint of the antennae is much shorter, the thorax appears to be gradually narrowed towards the front, and the penultimate joint of the maxillary palpi is essentially different.

o. Length, $2 \mathrm{~mm}$. ; breadth, $\frac{3}{4} \mathrm{~mm}$.

Erua, near Waimarino. One male found amongst decaying forest leaves, at an elevation of $2,400 \mathrm{ft}$., in January, 1910 . Also a single female with simple intermediate tibiae and less broadly oval 3rd joints of maxilliary palpi.

\section{Phagonophana sinuata sp. nov.}

Nitid, elongate, moderately robust and convex; castaneo-rufous, legs and antennae paler, tarsi and palpi fulvescent; clothed with elongate, principally erect, yellow hairs.

Head not quite as broad as thorax, very gently narrowed behind the small, somewhat convex eyes, its hind angles rounded. Thorax a little longer than broad, widest and rather strongly rounded before the middle, deeply and widely sinuate behind; the median basal pair of foveae well marked and suboblong but not large, the lateral deep and subrotundate. Elytra oviform, twice the length and at the middle double the width of the thorax, a good deal narrowed towards the base, with a short basal impression on each. Pygidium scarcely visible.

Legs elongate, femora gradually incrassate, tibiae finely setose.

Antennae rather longer than head and thorax, moderately thick, distinctly pubescent; 2nd joint somewhat longer than 1st, joints 3-6 elongate-subovate and nearly equal, 7th and 8th rather larger, 9th and 10th subquadrate, a little broader than 8th; terminal conical, obviously longer than 10th.

Mesosternal process not prolonged to anterior coxae. Metasternum much larger than abdomen. Posterior coxae subcontiguous.

P. sanguinens, 1905, an Auckland species, has a manifestly larger head and larger but less convex eyes, the thorax is somewhat longer but not so strongly rounded or dilated before the middle, and the elytra are more oblong-oval-i.e., much less curvedly narrowed towards the base.

Penultimate joint of maxillary palpi gradually narrowed towards the base, 4th small.

Length, $2 \mathrm{~mm}$.; breadth, $\frac{2}{3} \mathrm{~mm}$.

Hump Ridge, Southland. A solitary individual found by Mr. A. Philpott.

Obs.-The contiguity of the posterior coxae in many cases, particularly when single specimens only are available, is very difficult to determine with accuracy. The coxae are often pubescent, and in their natural condition frequently smeared with sappy matter, in each case they appear contiguous, but in many instances when thoroughly cleared of pubescence and extraneous substances with the point of a needle and brushed with benzene, they are found to be more or less distinctly separated. The maxillary palpi vary considerably in structure, the penultimate and terminal joints especially. The head and thorax differ greatly in form. The providium is usually covered by the elytra, but in my genus dillastia. which has widely separated posterior coxae, and in several New Zealand species referred to scydmuems, it is often fully exposed. 
In Lacordaire's work (1854) seven grenera were described. In Gemminger and Harolds catalogue (1868) seventeen genera are enmmerated, but, of course, not described. In Wytsman's new work on Colcopteru, now in preparation, the number of genera will douthtless be greatly increased, and until it is issued it is impossible for us in New Zealand to attempt the revision of the numerous species already found to exist here.

\section{Group NitidulidaE.}

3738. Cyclaxyra impressa sp. nov. ('yclaxyra Broun, Man. N.Z. Coleopt., p. 1076.

Convex, compact, subrotundate, glabrous, shining: black, head slightly rufescent, the margins of thorax and elytra more distinctly so, legs and antennae castaneo-rufous, club infuscate and opaque.

Head almost as broad, including the eyes, as the front of the thorax. sparingly and finely yet quite distinctly punctured. Thorax considerably broader than long, the sides shorter than the middle, finely margined and rurvedly narrowed anteriorly, the front angles obtuse, the posterior rectangular, base subtruncate in the middle but oblique towards the sides; its punctation unevenly distributed, nowhere close, rather finer than that of the head. Scutellum large, smooth. Elytra double the width of the thorax, of the same width as it is at the base, strongly rounded and deflexed behind, their fine margins as distinct there as at the sides; their punctation is shallow, fine, distant and indefinite, there are no sutural striae, but there is an elongate impression behind the scutellum. Legs moderately slender, with a few fine setae; anterior tibiae gradually dilated towards the extremity.

Antennae sparingly pubescent, their 2nd joint as long but not as thick as the 1st; 3rd elongate, shorter than the preceding but rather longer than the 4th or 5th, both of which are distinctly longer than broad: joints 6-8 shorter; club abruptly enlarged, oblong, triarticulate.

Smaller and more rotundate than the type of the genus (1165), more intensely black, but with paler red legs and antennae. The eyes are not distinctly marked off inwardly, the front and middle tarsi are broader, but the basal antennal joint is not as thick, and in 1165 there is no scutellar impression.

Length, $1_{5}^{4} \mathrm{~mm}$; breadth, $1 \frac{1}{3} \mathrm{~mm}$.

Greymouth. One from Mr. J. H. Lewis on the 5th December, 1907.

\section{Group Trogositidae.}

3739. Promanus pulchellus sp. nov. Promanus Sharp, Man. N.Z. Coleopt., p. 180.

Oblong, slightly convex, sparingly clothed with erect, elongate, slender yellow setale; head and thorax subopaque, infuscate-red, the broad lateral margins of the latter, and the legs, more or less testaceous; elytra nitid, the sides and extremity testaceous, the dorsum fusco-violaceous, but about half of the area corered with incegularly formed, indistinetly raised, somewhat aeneous-green spots.

Head about half the width of thorax; densely, coarsely, but not deeply punctured, with very narrow interstices. Eyes large and prominent. Thorax almost twice as broad as long, its sides broadly explanate, obsoletely serrate, cradually curvedly narrowed anteriorly, with obtuse angles; apex widely ematrinate, the base oblique towards the sides; disc with a large 
median depression, its sculpture shallow, similar to that of the head. Scutellum pubescent Elytra thrice the length of thorax and of about the same width as it is throughout; very distinetly, rather deeply, but not densely punctate, with subserrate margins.

Antennae fuscous, shorter than the head and thorax; basal joint stouter than the next, 3rd longer than either of the following ones, 6th and 7 th small and bead-like, 8th very short and transverse; club densely pubescent. oblong, abruptly enlarged, triarticulate.

This beautiful little species cannot very well be mistaken for any other, except perhaps the more minute 1593, which bears grey pubescence, and its less transverse thorax is without any central depression.

Length, $3 \frac{1}{2} \mathrm{~mm}$. ; breadth, $1 \frac{1}{2} \mathrm{~mm}$.

Tisbury, near Invercargill. One, captured by Mr. A. Philpott, on the 18th January, 1913.

\section{Group Colydiddae.}

3740. Ulonotus planiceps sp. nov. Ulonotus Erichson, Man. N.Z. Coleopt., p. 186.

Oblong, moderately convex, opaque; obscure fuscous, the hasal joints of antennae, front of head and thorax, and the legs more or less slightly rufescent; irregularly clothed, legs included, with rather short and thick yellowish-grey setae.

Head subquadrate, quite as broad as the base of thorax, truncate in front, nearly flat, with a few granules on the forehead, antennal elevations slightly prominent; labrum reddish, distinct, finely punctate and setose. Thorax a little broader than long, the frontal lobes nearly a third of the whole length and projecting as far as the front of the eyes, the 2nd much smaller, not as far from the frontal ones as they are from the base, which is narrow and simple; disc convex, with a large impression from the apex to the middle, a pair of elongate ones behind, and a median punctiform fovea at the base; its granular sculpture scarcely discernible. Elytra oblong. considerably curvedly narrowed behind, with oblique shoulders, so that the base is only as wide as that of the thorax, ther are double its length, with serrate margins, the apices are not prolonged but there is a slight notch between them; there is a triangular scutellar depression, behind this the disc is nearly level along the middle, and bears, on each side of the suture. a pair of ill-defined, rather small series of granules, these, however, in some aspects look like punctures, as is often the case in Coxelus; there are two elongate basal elevations, a pair of distinct nodosities at the top of the hind slope and a smaller in front of these; outside these, on each elytron, there is a larger one near the hind thigh and a second behind it.

Legs stout and elongate; tibiae slightly arched extemally, with curled setae there.

Antennae shorter than the head and thorax, the exposed portion of the basal joint scarcely longer than the stout suboblong 2 nd, the next elongate, Ith slightly longer than broad, joints 5.8 obeonical or submoniliform: (lub pubescent, triarticulate, its intermediate joint broadest, the last subrotundate.

Underside dull fuscous, with thick, decumbent greyish setae.

After comparison with all the other members of the genus I fail to fincl any that are at all similar.

Length, $2 \frac{2}{3} \mathrm{~mm}$.; breadth, quite $1 \mathrm{~mm}$.

Longwood Range, Southland. One example found by Mr. A. Philpott in January, 1913. 
3741. Synorthus rectifrons sp. nov. Synorthus Broun, Bulletin 2, N.Z. Inst., p. 9, 1910.

Convex, broad, subovate, shining, with distinct greyish-yellow, decumbent and suberect pubescence disposed in different directions; black, head somewhat aeneous, legs and hasal joint of antennate rufous, remaining joints, palpi, and tarsi fulvescent.

Head short and broad, moderately finely yet quite definitely and somewhat irregularly punctured; the forehead subtruncate in the middle, oblique and finely maruined towards the eyes, which are moderately prominent in front. Thorax mot quite twice as broad as long, the sides finely margined and gradually narrowed anteriorly, with subacute rectangular angles, its surface moderately finely but not closely punctate. Scutellum absent. Elytra of the same width as thorax at the base, quite twice its length, gradually rounded posteriorly; their punctation similar to that of the thorax, but rather coarser on the middle of their basal half.

Intennate very sparingly pubescent, 2nd joint stout yet evidently smaller - than the basal. 3rd slender and elongate, not quite as long as the following three combined, th and 5th slightly longer than broad, 6th a little shorter, 7 th broader than preceding ones, joints $8-10$ about equally transverse, broader than 7 th, terminal as long as preceding two, the club therefore is 5 -articulate.

Tibiae finely setose, the posterior slightly arched, narrowed towards the extremity, the anterior widened below the middle, somewhat obliquely narrowed beyond, with short, quite lateral tarsal grooves, the apices minutely bicalcarate; tarsi normal.

Underside nitid, piceous, slightly iridescent, the greyish-yellow pubescence absent from the middle of the metasternum, which part is more coarsely but less closely punctate than the rest of its surface. Prosternal process broad, closely and finely punctured; the coxae and femora rufeseent.

This must be located in Section III, near S. villosus, 1608, which, however, is rather smaller, with obviously shorter and differently formed antennae, more strongly curved tibiae, and more elongate outstanding elytral vestiture. S. versipitus, 3562, is smaller, and belongs to Section IV.

Length, $3 \frac{2}{3} \mathrm{~mm}$.; breadth, $2 \frac{1}{2} \mathrm{~mm}$.

Nount Hutt. Unique as yet; found on the 25th January, 1913, by Mr. 'T. Hall.

3742. Pedilophorus nigrescens sp. nov. Pedilophorks Steffahny, Man. N.Z. Coleopt., 244 (syn. Morychus).

Convex, oval, widest behind the shoulders, considerably attenuate posteriorly, shining; bronzed-black, legs and basal joint of antemne rufous, remaining joints of the latter, the tarsi, and palpi more or less flavescent.

Head distinctly and rather distantly punctured, more closely near the eves minly smosth on the middle: forehead slightly medially rounded, indistinctly marginate towards the eyes. Thorax twice as broad as long, its sides finely margined and parallel but gradually narrowed towards the deffexed. alentely prominent anteriog angles, posterior angles restangular; distinctly iresilaty and remotely punctate. Elytra thries the length of thorax, of the same width at the base, widest before the middle, much but gradually narrowed towards the extremity, with fine coriaceous sculpture. 
Tibiae with slender grevish setae, the anterior nearly straight, grooved along the outer face, the intermediate more strongly curved than the posterior ; tarsi with well-developed membranous appendages.

Antemnae finely pubescent, 2 nd joint half the length of the 1st, narrowed apically, the next slender and almost equalling the following three together, joints 710 successively dilated and subquadrate, the terminal elongateconical and acuminate, that of the other antenna quite obtuse.

Underside nigrescent, finely setose, the last abdominal segment rufescent and densely clothed. Metasternum ample, distinctly but not closely punctate; hind coxal laminae very closely and finely punctured.

The minute, slightly raised scutellum, subtruncate thoracic base, slender ret quite discernible scattered setae, and different form differentiate this from $P$. creperus, 2792.

Length, $4 \frac{1}{2} \mathrm{~mm}$. ; breadth, $2 \frac{3}{4} \mathrm{~mm}$.

Ben Lomond, Otago. One found by Mr. A. Philpott, December, 1912.

\section{Group Melolonthidae.}

\section{Odontria puncticollis sp. nov. Odonfria White, Man. N.Z. Coleopt.} p. 265 .

Subovate, broadest near hind thighs, moderately convex, somewhat nitid; head and thorax reddish-chestnut, elytra rather paler, legs fuscotestaceous; sparingly covered with distinct, decumbent, rather short yellowish hairs, and with longer erect ones along the sides, the base of elytra thickly ciliate with elongate pubescence.

Head coarsely and moderately closely punctured except at its extreme base, forehead broadly rounded, with well-developed reflexed margins. Eyes only slightly convex, hyaline. Thorax almost twice as broad as long. its sides finely margined, nearly straight and only slightly narrowed behind the middle, gently curvedly narrowed towards the acute and prominent anterior angles, posterior angles obtuse; base widely bisinuate, rounded in the middle, apex subtruncate; its surface very distinctly and moderately closely punctate, sometimes with a smooth linear space along the middle. Scutellum punctate, cordate or suboblong. Elytra thrice the length of thorax, as wide as it is at the base, their apices widely rounded outwardly, much less so near the suture; each elytron with 9 fine striae, the outer ones less distinct, the intermediate obsolete near the base; interstices plane, their punctation distinct, yet rather finer than that of the thorax. Pygidium broad, with distant, indistinct subgranular sculpture.

Underside more or less finely punctured, fusco-testaceous, abdomen a little shining and often fuscous; the sternum with numerous elongate, slender fulvescent setae, those on the femora erect.

Male.-Antennae rather short, basal joint moderately elongate, somewhat bent, gradually incrassate, oblique at extremity ; 2nd nearly as thick as the 1st but only half its length; 3rd rather slender; 4th stouter and longer, angularly produced, sometimes acutely dentiform medially in front ; club minutely and densely pubescent, composed of $t$ nearly equal leaflets.

Fem.- 4th antennal joint simple, 5th very short, but more or less prolonged in front; club triarticulate.

In the rather larger, much paler, and rather more glossy $O$. nitidula, 3233, the posterior angles of the thorax are more rectangular, but the anterior are less acute; the sutural striae only are well marked, and the antennae also differ. 
Length, 12-14 mm. ; breadth, 7-9 $\mathrm{mm}$.

Rotorua. Several specimens were forwarded during February, 1913, by the (fovermment Biologist, Mr. A. II. C'ockayne, who informed me that this species is very abundant, and has destroyed many thousands of young larch-trees.

\section{Group Dascyllidae.}

3744. Veronatus tarsalis sp. nov. Vercnatus Sharp, Mən. N.Z. Coleopt., p. 314 .

Elongate, subparallel, moderately nitid, variegate; chestnut-red, legs, antennae, and palpi paler, elvtra with indefinite infuscate marks, thorax for the most part dark fuscous: pulescence scanty, distinct and flavescent on the head, thorax, shoulders, and apices of elytra, the setae in the elytral punctures minute and slender.

Head large, nearly as broad as front of thorax, slightly rounded behind the moderately prominent eyes, broadly feebly bi-impressed in front, finely but not closely punctate, rather distinctly in front. Thorax almost twice as broad as long, its sides and base finely margined, the former gently, the latter more distinctly rounded in the middle, but sinuate towards the obtuse angles, the apex subtruncate but a little emarginate near the rounded angles; its surface less distinctly punctured than the front of the head, with an elongate median impression, sometimes with a pair of shallow foveae behind. Scutellum subcordate or triangular, finely punetate and pubescent. Elytra five times the length of thorax, about a third broader, but with rounded shoulders; their punctation distinct but not close, finer on the shoulders and near the apices, each indefinitely tricostate.

Tibiae with distinct terminal spurs, finely spinulose; tarsi rather narrow.

Antennae pubescent, attaining the middle of elytra, 3rd joint about a third shorter than 4 th.

Tnderside paler than the dorsum, finely punctured, thickly pubescent, 3rd ventral segment with a shallow median impression.

$V$. punctipennis, 3419, a larger and manifestly broader insect, with less prominent eyes, stouter legs, and thicker tarsi, is the nearest ally.

Length, $7 \frac{1}{2} \mathrm{~mm}$. ; breadth, $3 \mathrm{~mm}$.

Var.-Fusco-castaneous, sides and front of thorax and base of elytra paler, elytral suture rufescent.

Mount Hutt. Three examples forwarded by Mr. T. Hall on the 28th December, 1912.

\section{Veronatus fulgidulus sp. nov.}

Glosss, castaneous, mandibles and front of head rufescent, thorax dark fuscous but, like the base of elytra, with the front and sides somewhat testaceous, leas and antemnae light fusco-rufous; head and apices of elytra rather thickly clothed with slender yellowish pubescence, elsewhere nearly nude.

Head evenly convex, rather strongly rounded, forehead nearly vertical in front; finely but not closely punctured, more finely on the middle, densely helhind the eves, with a pair of angular interocular foveae. Thorax finely matreined throughout, its length half the breadth, sides very little rounded and just pereeptibly narrowed hehind, base and apex sinuate towards the sides, the former inore medially rounded than the latter, anterior 
angles rounded, the posterior less so; its punctation fine and distant, least distinct on the middle, and with a pair of distant foveae near the base, but without any central impression. Scutellum subcordate, finely punctate and pubescent. Elytra more than four times the length of thorax, hardly a third broader, with rounded shoulders; they are distinctly but not closelv punctured, more finely at the shoulders and extremity.

Legs moderately stout, tibiae like those of $V$.tarsalis, tarsi rather shorter but not broad.

Antennae with the 4 th joint somewhat shorter than the contiguous ones, thicker but hardly longer than the third; they scarcely reach the middle of the elytra.

Evidently more shining than $V$. tarsalis, the eyes less prominent, the head of more rotundate outline behind the antennal cavities, legs stouter, elytra more coarsely punctate but not at all costate, the head and thoras bifoveate. We have no other species like it.

Length, $7 \frac{2}{3} \mathrm{~mm}$. ; breadth, $3 \mathrm{~mm}$.

Mount Hutt. Unique; found by Mr. T. Hall at the same time as V.tarsalis.

\section{Cyphon cincticollis sp. nov. Cyphon Paykull, Man. N.Z. Coleopt.,} p. 318 .

Subovate, broad, only slightly convex, moderately nitid; head and thorax light brown, the latter, except at the middle of the apex, with fuscofulvous borders, scutellum also fulvescent; the legs and 2nd and 3rd joints of the antennae reddish-chestnut, the other articulations and the middle of the femora infuscate; elytra nigro-fuscous, covered with fine, depressed, inconspicuous ashy pubescence, that of the head and thorax flavescent.

Head, eyes included, not quite as broad as front of thorax, much narrowed anteriorly; very finely but not closely granulate, rather more distinctly near the eyes, and with a pair of shallow interocular foveae. Thorax fully twice as broad as long, apex subtruncate, with rounded angles, its sides finely margined and gently curvedly narrowed anteriorly; the base subtruncate in the middle, finely margined and evidently sinuate towards the subrectangular angles; its surface minutely, distantly, and rather indistinctly granulate. Scutellum triangular, large, Elytra five times the length of the thorax, of the same width as it is at the hase, but nearly twice as hroad behind, finely marginate; their sculpture moderately close but indefinite, appearing to consist of very fine punctures or granules.

Antennae moderately stout and pubescent, basal joint thick, 2nd and 3rd not perceptibly different from each other, both rather longer than broad, joints 4-7 about equally elongate, the rest broken off.

Tibiae straight, with short yellowish setae, the calcar of the posterior half the length of the basal tarsal joint, which equals in length the following three combined.

Eyes as long as the broad basal portion of the head, subrotundate, moderately prominent, finely granulate, their inner central portion nigrescent, the rest distinctly paler, a very rare feature.

Allied to C.amplus, 582 ; less rotundate and conver, the thoracic apex not at all medially lobed, and the coloration altogether different.

Length, $5 \frac{1}{4} \mathrm{~mm}$. ; breadth, $3 \mathrm{~mm}$.

Ben Lomond, Otago. Unique; found by Mr. A. Philpott early in December, 1913. 


\section{Cyphon granulicollis sp. nov.}

Subovate, moderately convex and nitid; castaneo-fuscous, legs light redelish-chestnut. antennate infuscate, base of intermediate joints paler ; covered with greyish-yellow conspicuous pubescence.

Head rather narrower than front of thorax, with large eyes which are most prominent in front; its surfare closely and distinctly but not corarsely eranulate. Thorax twice as broad as long. the apex a little sinuate towards the obtuse angles, its sides finely margined and slightly rounded. base somewhat rounded in the middle and simuate towards the sides, with obtusely rectangular angles; its sculpture like that of the head. Scutellum large, subtriangular. very finely gramulate. Hlytra four times the length but not double the width of the thorax, of the same breadth as it is at the base; rather closely and distinctly but not coarsely punctate.

Tibiae with numerous slender spines along the outer edge, unequally bicalcarate at the extremity, those of the posterior quite half the length of the basal tarsal joint, which is hardly as long as the next three.

Antennae longer than the head and thorax, basal joint stout, 2nd longer than broad, almost as long as the more slender 3rd, joints $4-11$ equally elongate, with distinct dusky pubescence.

Rather smaller and less rotundate than C. cincticollis, concolorous, head and thorax evidently granulate, and with nore conspicuous pubescence.

Length, $4 \frac{2}{3} \mathrm{~mm}$. ; breadth, $2 \frac{2}{3} \mathrm{~mm}$.

Mount Hutt, near Methven. One, found on the 27th Frebuary, 1913, by Mr. T. Hall.

\section{Cyphon plumatellus sp. nov.}

Oblong-oval, slightly convex, a little shining; covered with distinct greyish-yellow feather-like pubescence; light fuscous, legs chestnut-red, antennae infuscate, the tips of the joints paler.

Head normal, finely and indistinctly granulate. Thorax twice as broad as long. subtruncate in front, with broadly rounded anterior angles, the sides finely margined and curvedly narrowed towards the front, the base oblique towards the sides, its angles obtuse; its sculpture ill defined, consisting of minute distant punctures or granules. Scutellum large, triangular. Elytra quite four times the length of thorax. not double its breadth, as wide near the shoulders as at the hind thighs, a cood deal curvedly narrowed behind, their punctation fine but not close.

Tibiae thirkly puhescent, and with series of slender external spines, the calcar of the posterior half as long as the basal tarsal joint, which equals the length of the following three together.

Antemnae distinctly pubescent, Ist joint stout, 2nd slightly shorter than the next, 4-11 elongate.

Although this is our largest species its sculpture is very indefunite, hut the decumbent vestiture is feather-like.

Length, $6 \frac{1}{2} \mathrm{~mm}$; breadth, $3 \frac{1}{2} \mathrm{~mm}$.

l'udding Hill, near Methren. A single example, secured by Mr. T'. Hall on the 10th December, 1912.

\section{Cyphon burrowsi sp. nov.}

Oblong-oval, slightly convex, moderately nitid; thickly clothed with conspicuous. suberect grevish-yellow puhescence; head fuscous, antemae, thorax, and elytra light yollowish-bown, legs testaceous; elytra with a dark- 
fuscous humeral spot, and another, but smaller, on each elytron, about equidistant from the base and suture, behind the middle much larger irregularly. formed spots almost form two fasciae, the posterior just on top of the declivity.

Head large, almost as broad as thorax, closely and obviously granulate. Eyes large, slightly convex, subrotundate. Antenmae nearly as long as head and thorax, basal joint darkest, stouter and longer than the next, 3rd slender as long as the 2nd but evidently shorter than the thick 4th, which is rather longer than the following ones. Thorax about twice as broad as long, longer in the middle than at the sides, base finely margined and slimhtly bisinuate; anterior angles rectangular, the posterior obtuse; its granular sculpture a little finer than that of the head. Elytra thrice the length of thorax, rather broader, gently narrowed towards the base, with a slight median oblique impression near each side of the suture; their punctation distinct but not close.

This must be placed in the section composed of species with the subocular line indistinct. It differs from C. oscillans. 580, and C. aequalis, 581, in coloration and marks, and by the head as well as the thorax being distinctly granulate.

Length, $3 \mathrm{~mm}$.; breadth, nearly $1 \frac{1}{2} \mathrm{~mm}$.

Pudding Hill, near Methven. One example, captured on the 8th March, 1913, by Mr. L. Burrows, of Methren, whose name has been attached to it.

\section{Group Melyridae.}

3750. Dasytes philpotti sp. nov. Dasyfes Paykull, Man. N.Z. ('oleopt., p. 328.

Elongate, narrow, subparallel, slightly nitid; nigrescent, faintly tinged with purple, more distinctly near the sides, legs and antennae piceous, claws castaneous; pubescence greyish-vellow. slender and elongate on the head and thorax, shorter and rather thicker on the elytra, and, near their sides, suberect or curled.

Head, including the large eyes, almost as broad as the middle of thorax, narrowed behind; minutely and densely sculptured, with only a few fine punctures, broadly bi-impressed in front. Thorax a little convex, slightly broader than long, its moderately dilated basal half finely margined, with rounded posterior angles; disc sculptured like the head, and with a varue median fovea near the base. Scutellum somewhat quadrate. Elitra four times the length of the thorax, rather broader than it is at the hase, subparallel, with hroad singly rounded apices; with close finely rugose transversal sculpture but without definite punctation, the impression near each shoulder very slight.

Antennae rather longer than the head and thorax, finely pubescent, 2nd joint scarcely longer than broad, joints $3-5$ distinctly serrate, 6 th rather shorter than following ones.

Legs elongate; posterior tarsi as long as the tibiae, basal joint of the anterior shorter than the next, with a thick spiniform process at the extremity underneath.

More parallel, less opayue, and much less obviously violaceous than D. helmsi, 2035, with different vestiture and elytral apices.

3. Length, $5 \mathrm{~mm}$.; breadth, quite $1 \frac{1}{2} \mathrm{~mm}$.

Ben Lomond, Otago. My specimen was captured early in December. 1912, by Mr. A. Philpott, of Invercargill, after whom it is named. 
Obs... I am indebted to the same gentleman, as well as Mr. M. O. Pasco, of (umeenstown. for a few specimens of a varietal form of $D$. orcocharis. 2036 , with piceous antennate and legs. In the male the basal joint of the anterior tarsi has the same sort of spiniform process as 1$)$. philpotli. This is also the case with Dr. Sharp's D. helmsi, 2035.

\section{Group 'T'enebrionidae.}

3751. Pheloneis appositus sp. nov. Pheloneis Pascoe, Journ. Ent. 11, 1866, p. 483.

Suboblong, slightly convex, nitid, glabrous; fusco-niger, legs piceous, antennae, palpi, and tarsi fusco-rufous.

Head short, immersed up to the middle of eyes, forehead obtusely rounded in the middle: its surface irregularly and distinetly but not coarsely punctured, with a longitudinal interocular impression and a smooth space between the antennae. Thorax $3 \mathrm{~mm}$. long by $4 \frac{1}{2} \mathrm{~mm}$. broad in the middle, which is widest, well rounded but hardly angulate, its sides with distinet simple margins, gradually narrowed towards the obtuse anterior angles, similarly narrowed, but not distinctly sinuate behind, the rectangular posterior angles resting on the elytra; apex moderately deeply arcuateemarginate, more distinctly margined than the subtruncate base; the punctation of the dise is a little irregular, moderately close, and rather finer than that of the head, there is a shallow fovea near each side of the base. usually an elongate irregular impression at each side, and a shallow, sometimes obsolete groove along the middle. Ficutellum short, smooth, subtriangular. Elytra with well-developed margins. more than double the length of the thorax, rather broader than it is at the base, their sides very slightly rounded and widened as far as the hind thighs, but considerably narrowed towards the extremity; they are finely and regularly substriate-punctate near the suture. rather more finely noar the sides, but on the intervening dorsal space the sculpture is sometimes interrupted yet withont elevations, the interstices are finely and moderately closely punctured, though to the maided eye they seem smooth.

Legs nearly glabrous, having only some fine fulvescent setae near the extremity of the tibiae, the anterior pair more curvate than the others: the front femora obtusely angulate or dentiform.

Intenmae with distinct vellowish pubescence from the 3rd joint onwards, that joint twice as long as the 2 nd and evidently longer than the 4 th.

Tnderside moderately closely, rather finely and irregularly sculptured, Hanks of prosternum ninutely and distantly punctate. Posterior intercoxal process broadly rounded.

Most nearly resembles $P$. nigritulus, 1669; smaller, less oblong, the sculpture finer throughout, the thoracis apex less deeply emarginate with more rounded angles; in 1669 these angles are subacute and more prominent and the forehead is medially truncate. In I'. henseni, 1668, the elytral striae are unusually deep and regular.

Length, $11 \frac{1}{3} \mathrm{~mm}$. ; breadth, $5{ }_{2}^{1} \mathrm{~mm}$.

Ben Lomond, Otago. 'Three examples taken in December', 1912, by Mr. A. Philpott.

Obs.-Pheloneis was instituted by Pascoe in 1866 for the reception of

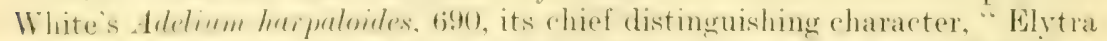
prothoraci arete applicata," eorrectly describes that part of the New Zeatland species placed in Adelium he Pascoe himself. Bates, Dr. Sharp, and all excrpt two (6s:) and 1495) of those described by myelf. The antennal 
structure of 690 is, however, somewhat different, the 94 t and 10 th joints being transverse, whereas in the other species referred to these artirulations are evidently longer than broad. In Mr. H. J. Carter's admirable "Revision of the Australian Species of Adelirm" (Pror. Linn. Sor. N.S.IY. 1908) the author, in my opinion, justifies the separation of the New Zealand species from the true Adelia of Australia by placing ours in Pheloneis. As that has now been done by Dr. H. Gebien in Junk's " ('oleopterorum Catalogus," part 28, issued on the 2.th March, 1911, I think New Zealand entomologists should acquiesce in that decision.

\section{Philpottia gen nov.}

Allied to Chalcodrya, but essentially different in several details.

Maxillary palpi with distinctly cultriform terminal joints, these hroadly grooved along the front; penultimate short, 2nd elongate. Antennae shorter, not attaining the base of thorax, basal joint twice as long as broad, (5th and 8th joints subquadrate, $3 \mathrm{rd}, 4 \mathrm{th}$, 5th, and 7 th not elongate yet longer than broad, 9th rather larger than 7 th or 10th, terminal elongateoval. Head in line with the eyes as wide as the thoracic apex. Labrum transverse. subtruncate in front. Eves transverse, subrotundate, smaller and less prominent than those of Chalcorlygu. Thorax transversely quadrate, base and apex subtruncate; anterior angles not projecting, obtusely rectangular, the posterior rounded and obsolete.

Tibiae minutely bicalcarate. Tarsi elongate and narrow, penultimate joint simple, that of the anterior only half the length of the basal, which is shorter than the 5th: rlaws thickened but not distinctly dentiform at the base.

Anterior coxae prominent, situated very close to the base of the prosternum, as distinctly separated from each other as the intermediate pair. Mesosternum broadly, angularly, and medially concave, the depression with elevated latera! borders. Metasternum elongate. Abdomen composed of 6 segments, the basal very short and partly covered by the femora; 2nd and 3rd about equal, 4th and 5th rather shorter, the former medially (marginate behind, the latter nearly straight, the terminal strongly rounded and shorter.

This genus is named in honour of Mr. Alfred Philpott, of Invercargill, who throughout a long course of years has discovered a great many new species, some of which are the types of new and interesting genera

Obs.- This genus should, I think, together with Chalcodrya and Onysins, be placed in a section distinct from the ordinary Tenebrionidae. My genus Onysins was published in April, 1886 (Man. N.Z. (oleopt.. p. 843), its type O. anomalus, 1499, is the same insect as that subsequently described by Dr. Sharp as Malacodrya pictipes (Trans. Roy. Dublin Soc., 1886).

\section{Philpottia maculatus sp. nov.}

Elongate, subparallel, only slightly convex, suboparque: elytra of a palegrevish testaceous hue, becoming faintly viridescent towards the extremity, rariegated with several ohlong and short irregularly formed violaceous spots, which are nude, the rest of their surface is corered with decumbent somewhat silvery-grey pubescence: head. thorax. tarsi, and antemare more or less fuscous, the base of neary all the joints of these last paler : terminal joints of the palpi, the fenora. and the claws rufo-fuseous; tibiae pale green, but vellowish at the hase and apex: the pubescence of the head and thorax is like that of the elytra. 
Head about as long as the thorax, deflexed in front; closely but not coarsely punctate, subgranulate towards the sides. Thorax about a fourth broater than long. its sides maremed and neaply straight, gently rounded behind, the base with finer margins; it is moderately finely and very irmegularly punctured, leaving some spots almost smooth, and in some lights numerous indistinct granules can be seen, there is a well-marked impression along its frontal half. Scutellum broad. Elytra parallel-sided, with rounded apices, of the same width as the thorax at the base, four times its length: they are finely substriate-punctate, the suture and alternate interstices are very slightly elevated, almost costiform behind the middle, and more or less confluent towards the extremity, near which the purplish spots appear more depressed.

Underside infuscate, with greyish pubescence.

Length, $10 \frac{1}{2} \mathrm{~mm}$.; breadth, $3 \mathrm{~mm}$.

Longwood Range, Southland. Mr. Philpott spent three days on the top of the range in January, 1913. During that time there was almost constant rain, hail, or snow. He, nevertheless, secured nearly twenty speecies of Colcoptera, half of which proved to be new. There was only one of this species.

Var.- $P$. viridipennis, measuring $10 \mathrm{~mm}$. by $2 \frac{1}{2} \mathrm{~mm}$. Head and thorax rufo-fuscous, elytra dull green with mumerous irregularly formed purplish spots. Palpi testaceous, the terminal joint longer and narrower.

Mr. A. C. O'Connor, of Wellington, gave me a specimen minus antennae and almost all the legs, about the best specimen in his possession, in Iune. 1912, but its generic characters could not then be determined.

No. 1734, placed provisionally in Chalcodrya, must now be transferred to the genus Philpottia. It has thicker legs and antennae, rather flatter eyes, and somewhat different coloration and vestiture.

\section{Group Melandryidae.}

3753. Hylobia sexnotata sp. nov. Hylobia Broun, Man. N.Z. Coleopt., p. 403.

bilongate, slightly narrowed towards both extremities, moderately convex and shining; thinly covered with slender ashy pubescence: nigro-fuscous. posterion tibial spurs testareous : elytra with ti flavescent spots, the median largest, obliquely transserse, not reaching the side or suture, the other pair. on each elytron, subrotundate and subapical, sometimes confluent.

Head finely punctate. Thorax a third broader than long, curvedly narrowed anteriorly, base very broadly rounded or subrotundate in the middle, widely sinuate towards the sides; its surface with very fine linear sculpture, and a shallow indistinct basal impression at each side of the middle. Scutellum subquadrate. Elytra nearly five times the length of the thorax, of the same width as it is at the base, with strongly rounded apices; their seulpture minute and coriaceous, with indistinct sutural striae behind the middle.

Antennae rather longer than the head and thorax, basal two joints nearly equal, joints 3-5 rather slender, 6-11 gradually thickened.

Tibiae simple externally; spurs of the middle pair short, those of the posteriog pertinate and more than half the length of the hasal tarsal joint: penultimate joint of the anterior and intermediate tarsi with rathere elongate lobes; claws thickened at base. 
Underside fuscous, very finely punctate, with depressed slender ashy pubescence. Basal and 2nd ventral segments a little longer than the following ones, 5th subtruncate at the extremity.

Head immersed up to the eyes, with a slender carina behind these, and with a pair of elongate fovae underneath. Anterior coxae prominent, their ravities almost touching the apical margin, the intervening process triangular and acutely prolonged between the coxae. Mesosternal process elongate, broader in front than behind, extending to the hind part of and separating the intermediate coxae. Metasternum elongate, convex, grooved along the centre.

The three spots on each elytron are distinctive.

Length (head exclusive), $3 \mathrm{~mm}$. ; breadth, $1 \mathrm{~mm}$.

Longwood Range, Southland. My specimen was found in January, 1913, by Mr. A. Philpott.

\section{Hylobia acuminata sp. nov.}

Elongate, attenuate towards both extremities, moderately arched above. subopaque; rlothed with slender, inconspicuous, decumbent yellowish-grer pubescence; the head, all but the apex of the thorax, the basal portion of the elytra, a pair of subcontiguous spots on each elytron towards the extremity, and the apex itself fuscous; the rest of the surface, including a small humeral spot, more or less fusco-testareous, legs and antennae similarly variegated.

Head moderately finely yet quite distinctly punctate. Eyes large, transversal, slightly emarginate in front, with coarse facets. Thorax a little lroader than long, curvedly narrowed anteriorly, the apex broadly rounded, base widely bisinuate, but obtusely rounded in the middle: its sculpture indefinite, not punctiform, somewhat undulate: at each side of the middle there is a large, shallow fovea, the lateral pubescence is feather-like. Scutellum transverse, finely punctured. Elytra four times the length of the thorax. of the same width as it is at the base, gradually but considerably narrowed posteriorly, with subacute apices: sutural striae well markerl throughout, their sculpture resembles that of the thorax.

Legs finely pubescent; posterior tibiae slightly shorter than the basal joint of the tarsi, their pectinate spurs equal, almost as long as that joint: spurs of the intermediate half the length of the 1 st tarsal joint : penultimate joint of the front and middle pairs of tarsi distinctly bilobed.

Antennae filiform, reaching just beyond the shoulders: 2nd joint slightly shorter than the basal, both oblong, neither very thick, remaining articulations elongate, very gradually and slightly thickened and successively shortened, 11th elongate-oval.

In stemal structure similar to $H$. sernotata, but with the hind-body mueh more attenuate posteriorly. The surface rather less nitid, the eves rather larger and with coarser facets, the elytral striae distinct. The coloration is more like that of $H$. muleculosu, 712 , but the marks are entirely different: the antennae of that species are shorter and thicker, joints $7-10$ being subquadrate.

Length (head exclusive), $3 \frac{1}{2} \mathrm{~mm}$; ; breadth, $1 \frac{1}{5} \mathrm{~mm}$.

Longwood Range, Southland. Unique; another of Mr. Philpott's eaptures in January, 1913.

\section{Hylobia arboricola sp. nov.}

Elongate, slightly arched above, moderately narrowed towards the extremities, mather glossy: covered witl decumbent, slender, yet quite distinet, 
rellowish pubescence : fusco-testaceous, terminal joints of antennae fuscous ; chroa at the hase nigro-fuseous for a third of their leneth hut leaving the shoulders rellowish. the hind part of this dark mark irrecular; from the middle of each elytrom a hroad hlarkish mark extends alone the suture, but at some distance from the apex is bent outwards, and at the side is slightly prolonged forwards; there are no other spots.

Head finely punctured; the sharply defined margin just behind the eyes demotes the limit of retration. Thorax a third broader than long, rurvedly narrowed anteriorly, with deflexed and rounded angles there, the hase broally rounded in the middle and sinuate towards the subrectangular angles: the dise without definite punctation but with mumerous irregular transverse marks; midway from each side and the middle there is a rather large, angular basil depression. Scutellum broad. Elytra closely adapted to the thorax, four times its length, very little wider near the dark posterior mark than at the base, gradually narrowed behind, with strongly rounded, deliscent apices; their sculpture, near the base especially, is rather coarser and more punctiform than that of the thorax.

Antennae and tibiae similar to those of $H$. acrminata; the eyes, however, are smaller.

The coloration and marks most nearly resemble those of the northern H. bifasciata, 716 .

Length (head inclusive), $3 \mathrm{~mm}$.; breadth, $1 \mathrm{~mm}$.

Mount Hutt. I am indebted to Mr. T. Hall for my specimen, found by him on the 15th March, 1913.

Obs.-From the same source 1 possess a pale straw-coloured individual of $H$. undulata, 711 , in which the elytra are feebly striate, and their apices sharply rounded, hut I do not ronsider it sufficiently distinet for separation as a species.

\section{GrOUP OTIORHYNCHDAE.}

Zenagraphus gen. nov.

Body oblong, moderately convex, densely squamose. Rostrum thick, not quite as hroad as the head. shorter than thorax. somewhat pteryate, the triangular apical portion without well-marked lateral grooves, with a single median carina. Mandibles vertical in front, curved at the apex, strongly and subacutely bidentate at the inner extremity. Scrobes subapieal, deep and open above, extending obliquely towalds but not reaching the lower and front part of the eyes. Scape inserted near the apex, gradually thickened, attaining the centre of the eye. Funiculus also stout, 7-articulate, basal two joints nearly equal, not twice as long as hoard. joints 3- 6 moniliform and subtransverse. 7th rather larger. ('lub densely pubescent. as iong as the terminal three joints of funiculus, closely articulated, ovate and subacuminate. Hyes quite free from thorax, slightly convex, obliquely oval. Thorax truncate in front, without ocular lobes. base feebly rounded. Scutellum small. Elytra oblong, somewhat areuate-emarginate at base.

Legs stout, moderately elongate ; tibiae slightly flexuous and mucronate ; prosterior corbels with duplicate cilia and very narrow external truncature. Tarsi with dense brush-like soles. not elongate, their penultimate joint somewhat expanded and bilobed.

Ientum large, occupying the buccal cavity and concealing the palpi. Prosternum only slightly emarginate. Front coxae prominent and contiguous. intermediate slightly, the posterion moderately widely separated. Metasternum short. Basal rentral seconent rather longer than meta- 
sternum, truncate between the coxae, feebly sinuate behind, the next shorter: but rather longer than the well-developed 3rd or the the 5th quite the length of the 2nd. Mandibular scar distinct.

After a careful inspection of my exotic and indigenous weevils I fail to find any similar form. and therefore regard the specimen as the type of a distinct genus belonging to the division without ocular lobes, near Tigones.

\section{Zenagraphus metallescens sp. nov.}

Derm nigrescent, covered with small depressed squamae, some of which are dull and blackish, but the greater number are somewhat metallic, lightcoppery and viridescent: there are also a few short suberect setae: on the legs and tarsi bluish-green scales and grevish setae predominate; antemnae, mandibles, apex of rostrum, and tarsi rufo-piceous.

Rostrum a third shorter than the thorax, with an ohtuse carina along the middle, its apical portion finely punctate and glabrous, the remainder densely scaly so that its coarser punctation is concealed. Thorax of equal length and breadth, widest and obtusely rounded before the middle, gradually narrowed behind, with a distinct but not sharply defined channel from base to apex : its sculpture consists of very irregular, rather large, sometimes confluent depressions and elevated intervals. Elytra oblong, $2 \frac{1}{2}$ times the length of the thorax, one-half broader near the middle, posterior declivity much narrowed but not abruptly vertical, the shoulders gently narrowed yet broader than the thorax at the base; dorsum coarsely substriatepunctate, 3rd and 5th interstices costiform. neither much more prominent on the summit of the declivity than at the base.

Underside nigrescent, with numerous elongate depressed greenish and coppery scales and greyish setae, these last most conspicuous on the terminal segment. Metasternum transversely rugose, abdomen irregularly punctate.

Length (rostrum inclusive), $9 \mathrm{~mm}$.; breadth, $4 \frac{1}{2} \mathrm{~mm}$.

Remarkables, near Queenstown. I am indebted to Mr. M. O. Pasco for a specimen taken by him on the 28th December, 1912 .

\section{Inophloeus aplorhinus sp. nov. Inophoelus Pascoe, Man. N.Z. Coleopt., p. 439.}

Suboblong, rather broad, only slightly convex, opaque: piceo-fuscous, antennae rufo-piceous. tarsi somewhat ferruginous; densely covered with depressed rotundate squamae, which on the thoracic dise are mostly fuscous, there being only a central spot of the same tawny hue as those at the sides and on the rostrum; elrtral squamosity pale brown, not at all flavescent, darker on top of the posterior declivity, and with some irregular lateral spots grevish; the series of rather short grey setac on the alternate interstices are suberect, near the sides they are more numerous.

Rostrum a third shorter than thorax, slightly dilated anteriorly, quite obsoletely carmate. Thorax rather wider near the front than elsewhere. its length and breadth equal. without superficial inequalities, having only a shallow Iongitudinal median impression near the base. its fine punctation quite hidden. Scutellum minute. Elytra oblong, base arcuate-emarginate and rather wider than thorax, fully twice its leneth, their sides almost straight, only a little narrowed near the shoulders, posterior declivity nearly rertical and considerably contracted, with simple apices: they are moderately striate-punctate, $3 \mathrm{rd}$ and joth interstices a little and irregularly elevated, terminating ahruptly and almost hori\%ntally at the summit of 
the derelivity the bth do not extend as far back as the : Bd but behind form the thick sides of the dorsum; when brushed with benzene some coppery-red scales are seen on the suture near the base-their natural colour, no doubt.

Scape finely setose, very gradually thickened, attaining the back of the "re: 2nd joint of funieulus elongate. vet hardly pereeptibly longer than the hasal, Brd rather longer than 1th, and, like it. obconical: club opaque, minutely and densely pubescent, elongate-oval and triarticulate.

Legs with fuscous and greyish scales and setae, tibiae flexuous, the anterior not distinctly mucromate posterior corbek with duplicate external cilia and narrow intervals.

Underside piceous, with dull-tawny scales and moderately elongate grey setae. Prosternum deeply emarginate. Metasternum short. Basal ventral segment truncate between the coxae and somewhat depressed there, medially incurved behind, yet, in the middle, rather longer than the 2nd, 5th broadly depressed along the centre.

shorter and relatively hroader than the female of $I$. pensus, 3600, from the same locality, the elytra with a gentle downward slope towards the top of the hind declivity, as broad there as at the shoulders and without any apical prolongation. The form of the hind-body, with the 5th instead of the 7 th interstices forming the raised sides at the commencement of the apical declivity, in conjunction with the absence of the common rostral carinae distinguish this from all the other species of this complex genus.

․ Length (rostrum inclusive), $8 \frac{1}{2} \mathrm{~mm}$.; breadth, $3 \frac{1}{2} \mathrm{~mm}$.

Male.-Body and legs concolorous, pale tawny-brown, antennae piceorufous. Rostrum slightly shorter, broadly convex along the middle. Elytra narrower, with less rounded shoulders, apices not prominent but strongly rounded singly and slightly dehiscent. Anterior tibiae more evidently mucronate. Basil ventral segment less sinuate behind, rather flatter, 5th as long as preceding two together. rounded behind, with suberect yellow seta. $7 \frac{1}{2} \mathrm{~mm}$. by $2 \frac{1}{2} \mathrm{~mm}$.

Mount Hutt. One of each sex found on 25th January, 1913, at an altitude of 4,500 ft., by Mr. 'T. Hall. The male a little immature.

\section{Inophloeus tricostatus sp. nov.}

Subopaque, nigrescent, antennae fusco-rufous, tarsi rufo-piceous; head, rostrum, and front of thorax with a few depressed, quite grey squamae; elytra with only a few, the legs with numerous rather fine setae.

Rostrum a third shorter than thorax, irregularly and rather finely punetate, broadly bisulcate, and distinctly tricarinate almost as far as the interocular fovea. Thorax of equal length and breadth, widest and moderately reunded at or just before the midde, gradually narrowed behind: without inerpualities. very irregularly and finely punctured. rugose at the sides. Sirutellum small. Elytra oblong. thrice the length of thorax, gently narowed near the base and slightly broader there than the thorax, posterior declivity rertical and considerably narrowed, with prolonged apices: dorsum slightly convex. with regular series of molerately large well-marlsed punctures, the sutue plane. only slightly and quite horizontally prominent on top of the declivity; 3rd, 5th, and 7 th interstices costate, the first of these slightly, the next not at all elevated behind, the 7 th moderately distinct near the middle, obsolete elsewhere.

Antennae rather slender, scape attaining back of eye; 2 nd joint of funiculus as long as the Ist, both elongate, 3rd shorter, but evidently longer than following ones; club very elongate oval. 
Underside black, nitid, with fine grey setae. Metasternum depressed behind. Basal sesment of abdomen longer than 2 nd, brodly impressed, medially incurved behind, 3rd and 4 th with deep sutures, and, together, as long as 2 nd, 5th deeply notched behind.

In appearance like $I$. sulcifer, 1618 , yet really quite different in most details; agreeing better with the same sex of the densely clothed and larger I. pensus, 3600 , which can be readily distinguished by its unicarinate and broader rostrum, relatively broader thorax, much finer elytral punctures, and thicker legs, but with similar structural characters.

$\hat{0}$. Length (rostrum inclusive), $10 \mathrm{~mm}$.; breadth, $3 \frac{1}{2} \mathrm{~mm}$.

Mount Hutt. Unique; one of Mr. T. Hall's discoveries on the 28th December, 1912.

\section{Group Cylindrorhinidae.}

Mecosargon gen. nov.

Body apterous. Rostrum moderately elongate and stout, considerably dilated at apex, tricarinate above. Scrobes quite open above at the apex, extending obliquely downwards more than half-way towards the eyes. Scape inserted near the apex, moderately slender, scarcely attaining the ere. Funiculus 7 -articulate, rather longer than scape, basal two joints equal but only moderately elongate, joints 3-7 distinctly longer than broad. Club triarticulate, elongate-oval. Eves strongly transverse, nearly flat, quite free from thorax. Thorax of almost equal length and breadth, base and apex subtruncate, widest near the front, with only feebly developed ocular lobes. Scutellum very small. Elytra slightly wider than thorax at the base, nearly four times its length, with vertical sides, posterior declivity not abrupt, middle of dorsum plane.

Legs moderately elongate; tibiae a little dilated but only feebly mucronate at the extremity, posterior corbels simple. Tarsi with dense spongelike vestiture underneath; penultimate joint not expanded, deeply excavate above, with short lobes, apparently entire below.

Prosternum emarginate in front. Metasternum shorter than the basal rentral segment. Abdomen elongate, Ist segment rounded between the coxae, in the middle rather longer than 2 nd and medially incurved behind, 3rd and 4th rather shorter, singly, than 2 nd, both well developed, 5 th bent upwards and hardly visible.

The unique exponent of this genus should be located between Anagotus, 2144, and Inophloeus imus, 771, which latter in size and form it most nearly resembles, but the more apically expanded rostrum, more oblique and abbreviated scrobes, strongly transverse eves, shorter scape, indefinite ocular lobes, simple posterior corbels, and more elongated 3rd and 4 th ventral segments render it abundantly distinct. It differs greatly from inagotus in facies in its broader but less abruptly dilated rostrum, shorter and less slender legs, less developed ocular lobes, different tarsal vestiture and abdominal structure, \&e. In the genus Placoplanus the ocular lobes are rather strongly developed, and the 3rd and 4th segments short.

\section{Mecosargon costipennis sp. nov.}

Elongate, slightly convex, subopaque. very seantily clad with depressed, setiform, pallid scales; nigrescent, antennae and tarsi rufo-piceous.

Rostrum very little longer than thorax, in front half its width. coarsely and rugosely punctate, much more finely and bearing yellow setae at the apex; external carinae thick, most elcrated in front, somewhat convergent 
behind, the central one indistinct in front, smooth near the base. Head short, globose below, of the same width as the thoracic apex, narrowed anteriorly, moderately finely and closely punctured, and with a distinet median depression. Thorax abotit an eighth broader than long, wider near the front than elsewhere, its sides somewhat sinuate behind the middle; disc slightly uneren, withont distinct elevations, broadly impressed between the middle and hase, frontal sculpture fine and rlose but mingled with a few more distinct punctures, the rest of its surface, as well as the sides, is coarsely and irregularly punctured. with short rugose intervals. Elytra very elongate-ovate, the narrow shoulders but little wider than the base of the thorax, posterior declivity not quite vertical, gradually narrowed, with obtusely prominent, dehiscent apices; sutural region almost quite flat, 3rd interstices costiform, gradually raised backwards and ending verv abruptly at the top of the declivity; 5th nearly similar but gradually becoming obsolete before reaching the declivity, the sides also are costiform except at the base, they are slightly curved inwardly towards the extremity but do not touch the central costue: between these costae there are duplicate series of well-marked, distinctly separated punctures. which become finer near the extremity; there are similar series alongside the suture.

Tibiae nearly straight, only slightly incrassate near the extremity, with pale-yellowish setae.

Underside black, finely and closely punctate, with pale setae; basal rentral segment broadly impressed in the middle.

Length (rostrum inclusive), $20 \mathrm{~mm}$. ; breadth, $6{ }_{2}^{1} \mathrm{~mm}$.

Ben Lomond, Otago. One individual found by Mr. M. O. Pasco, of Queenstown, on the Ist December, 1912. When received it was smeared with mud: it may therefore be deemed to be another curious ground-weevil.

3760. Pparchus halli sp. nov. Pparchus Broun, Ann. Mag. Nat. Hist., ser. 7, vol. 14, 1904, p. 114.

Robust, subovate, convex, opaque; nigrescent, almost entirely covered with minute. depressed tawny squamae, but leaving uncovered numerous slightly nitid, black granules; antennae and rostral apex rufo-piceous.

Rostrum as long as thorax, depressed along the middle, with a fine rentral and obtuse sublateral carinae. these latter somewhat convergent at the base, its apex closely and finely punctate and bearing only a few fulvescent setae. Thorax very little broader than long, widest and obtusely mrominent near the front, somewhat constricted behind the middle, base and apex truncate: its surface uneven, having a moderate, longitudinal, median ridge in front. a pair of obtuse elevations near the middle, and one near each of the lateral prominences, the numerous granules are very irregularly distributed. Scutellum small. Elytra oblong-oval, large, thrice the length of thorax, twire as broad near the middle lout searcely at all wider than thorax at the base, with simple apices: each elytron is unevenly bicostate and the suture is slightly elevated behind; the inner costa is more distinct than the other but becomes obsolete on top of the declivity, the 2 nd extends a litte farther back, it is slightly mominent there, but is less obvious, sometimes obselete near the base: the rather indistinet subseriate punctures are placed near the costare, three are numerous antanules on the dorsum, these become finer behind the middle and are absent from the declivity.

Legs moderately elongate, squamose; femora rather slender, near the hase particularly: tibiare nearly straight, with simple apices, bearing short setae. 
Underside blackish, covered with minute, slightly nitid pinkish-grey scales.

․ Length (rostrum inclusive), $21 \mathrm{~mm}$; breadth, $8 \frac{1}{2} \mathrm{~mm}$.

Male.-.-Elytra narrower, more strongly and closely granulate, almost asperate. Underside with dull-tawny squamae. 5th ventral segment as long as the 3rd and 4th combined, truncate behind; 6th short and broad, rounded behind.

o. Length (rostrum inclusive), $20 \mathrm{~mm}$; ; breadth, $7 \frac{1}{2} \mathrm{~mm}$.

Mount Hutt, near Methven. The type, a female, was detected by Mr. T. Hall, with the aid of a lantern, crawling over a rock amongst the snow, at an elevation of 7,000 ft.. at midnight on the 28th December, 1912; another of the same sex was caught in a trap at a height of $5,400 \mathrm{ft}$. on the $15 \mathrm{th}$ February; and a male was secured in the same way on the 15th March, 1913.

The calm courage and the indifference to toil and hardship displayed by the discoverer of the type merit more than the simple honour of having his name conferred on the species.

P. levisi, 2910, is smaller. $17 \mathrm{~mm}$. by $6 \mathrm{~mm}$., and may be at once separated by its elongate grey clothing and substriate elytra.

\section{Liparogetus gen. nov.}

Rostrum fully half the length of thorax, a third narrower than head, subparallel, its apical portion deflexed and simple, not at all pterygiate. Scrobes just visible from above, beginning between the middle and apex, deep there, extending towards but not quite reaching the front of the eyes. Scape stout, gradually incrassate, inserted before the middle and attaining ihe centre of the eye. Funiculus 7 -articulate; 2 nd joint rather longer than broad and fully half the length of the basal, 3rd and th as long as broad, 5th and 6th moniliform, the 7 th rather larger. ('lub oblong-oval, triarticulate, terminal joint longest. Lyes quite free from thorax, slightly prominent, lateral, subovate, transverse. Thorax without perceptible ocular lobes, truncate at base and apex, of equal length and breadth. Scutellum small. Elytra oblong, nearly thrice the length of thorax, distinctly wider than it is at the base.

Legs moderately elongate; femora stout and subclavate; tibiae flexuous, the anterior mucronate, the others strongly bent and produced inwardly at the extremity. Tarsi with brush-like soles, but glabrous along the middle; 2nd joint short, penultimate dilated and bilobed, the terminal as long as the others combined, with simple claws.

Prosternum widely emarginate. Front coxae contiguous, the inter mediate moderately, posterior widely separated. Metasternum short. Basal ventral segment truncate between the coxae, slightly sinuate behind; 2nd quite half as long, and only slightly longer than the 3rd or 4 th ; 5th rather shorter than the basal, subtruncate and finely ciliate behind; 6th very short.

The different scrobes, as well as the apical structure of the tibiae prevent the type of this genus being placed in Lyperobius.

\section{Liparogetus sulcatissimus sp. nov.}

Subovate, moderately convex, nitid; nigrescent, antennae and tarsi piceous; vestiture white, scanty and hair-like, confined principally to the elytral striae.

Rostrum finely but distinetly punctate in front, more distinetly and closely elsewhere; it is nearly flat or feebly bi-impressed near the middle, 
from each antenna a broad groove proceeds backwards, these grooves become convergent at the base and ahmost reach the rather deep, elongate interocular impression. Head rather short, almost as broad as the thoracic apex, distinctly and moderately closely punctured. Thorax slightly and obtusely dilated before the middle, gently narrowed behind, the base submarginate and with almost rectangular angles, its apex somewhat constricted; its surface is a little uneven, being tri-impressed near the base, and having also a median frontal impression, the punctation is moderately fine on the middle but becomes rather coarser and closer and somewhat rugose towards the sides. Elytra about a third broader than the thorax, with slightly curvedly narrowed shoulders; on each elytron there are 6 deep, broad, punctate dorsal grooves, with equally broad, smooth, costiform interstices, the 3rd and 5th are only slightly more convex than the others, which are more or less irregularly confluent near the extremity; the vertical sides are similarly seulptured.

Tibiae more or less minutely denticulate and setose inwardy. Antemae sparsely pubescent.

We have no other allied weevil with such deeply and regularly sulcate elytra.

Underside shining black, with some short, slender, depressed setae; rather finely punctate, the lst and 5th segments of the abdomen most distinctly, the former broadly depressed; head slightly transversely lugose.

o. Length (rostrum exclusive), $10 \mathrm{~mm}$. ; breadth, $4 \mathrm{~mm}$.

Remarkables, near Queenstown, Otago. The only specimen I possess was presented to me by Mr. M. O. Pasco, who discovered it on the 28th December, 1912.

\section{Group HyLobindae.}

3762. Bryocatus burrowsi sp. nov. Bryocalus Broun, Bulletin No. 1, Part III,. N.Z. Inst., p. 218.

Convex, subovate, moderately broad, opaque; densely covered with small, depressed, mostly greyish-tawny squamae, but with a broad whitish streak along the middle of the thorax, and also bearing some coarse grey scales; fuscous, basal half of the scape and the claws slightly rufescent, remainder of antennae and the tarsi blackish.

Rostrum very slightly and gradually narrowed towards the setose apex, at its base fully half the breadth of the front of thorax and rather longer than it is. Thorax nearly a third broader than long, distinctly wider at the midhle than elsewhere, its sides obliquely narrowed, base slighty romded, apex sharply truncate; the disc is moderately convex and the front a little depressed, there are no other inequalities, and the punctation is invisible. Elytra subcordate, almost twice the length of thorax, arcuate-emarginate and slightly broader than it is at the base. widest near the middle, subvertical and considerably narrowed behind; they are striate, 3rd interstices with a pair of subeontiguons nodosities neal the hase, and 2 rather larger, distinetly separated ones behind; 5th trinodose behind the middle, the sides less evidently trinodose.

Legs elongate and stout, very similar to those of $B$. jugosus, 3609. Scape incrassate near the extremity, hardly reaching the eve. ('lub oblong-oval.

This most nearly accords with $B$. jugosus, but the outline is interrupted at the junction of the thorax and elytra, there are no thoracic ridges, the shatpe and sculpture of the elytra differ, the club is rather longer, and the basal half of the scape is reddish. From all the other members of the genus it is markedly diflerentiated by the presence of some scattered, coarse, con- 
spicuous grey scales overlaying the finer vestiture; there are about 10 of these on the thorax, and many on the legs.

Length (rostrum inclusive), $2 \frac{1}{3} \mathrm{~mm}$. ; breadth, $1 \mathrm{~mm}$.

Pudding Hill, near Methven. One found amongst moss and lichen, on the 8th March, 1913, by Mr. W. Burrows, whose name has been given to it.

\section{Group Rhyparosomidae.}

3763. Clypeorhynchus striatus sp. nov. Clypeorhynchus Sharp, Ma1r. N.Z. Coleopt., p. 1210.

Elongate, moderately convex, opaque; rufo-fuscous, elytral dise darker. antennae, tibiae, and tarsi chestnut-red; irregularly clotlied with coarse as well as slender flavescent setae.

Rostrum arched, rather shorter than thorax, finely tricarinate, coarsely punctured, and covered with decumbent setae behind, its apical portion shining, rufous, distinctly punctate, with only a few slender erect setae. Head short, with an elongate interocular fovea. Eyes subdepressed, just free, obliquely transverse. Thorax with feebly developed ocular lobes, hardly any longer than broad, a little broader, and moderately rounded, near the front than elsewhere; its surface slightly uneven, impressed at each side near the apex, rather marsely and moderately closely punctured; bearing a few fine short setae on the middle, but coarser ones form an oblique streak near each side; the broad median channel is deepest in front. Elytra fully double the length of thorax, of the same width as it is at the base, with slightly oblique shoulders, behind these very gradually and just perceptibly narrowed to beyond the hind thighs; their striae appear broad and are distantly punctured, interstices somewhat uneven but not granulate: dis" thinly rothed with subdepressed, moderately fine setile, ther are more concentratert on the shoulders but are coarsor mol form patrhes on the posterior derlivity, there are also many infuscate erect setale.

Legs elongate, femora clavate and fuscous near the middle, slender and rufescent at the base; tibiae with outstanding setae, the anterior more strongly flexuous and mucronate than the posterior. Tarsi with pilose soles, their penultimate joint cleft to the base.

Scape flexuous, attaining the back of the eye, bearing some fine erect setae; basal joint of funiculus very elongate and slender, a third longer than 2nd, joints 3-6 decrease in length, 7 th bead-like; club elongate-oval. triarticulate, densely pubescent.

Underside slightly nitid, with numerous fine yellow setae. Rostrum broadiy bisulcate. Prosternum coarsely punctate, deeply emarginate in front. Metasternum very short, medially depressed. Basal ventral seg

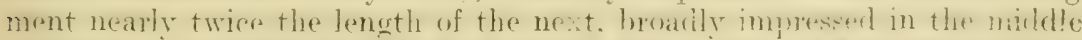

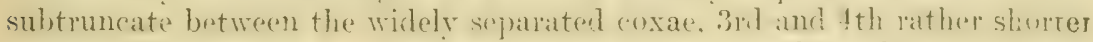
than 2nd, 5th as long as the 1st, truncate behind and much more closely punctured there than in front, the 6th distinct, but short and broad.

This cannot be Sharp's C. gracilipes, 2138, as the rostrum and thorax are described as rugose, and the former evidently is without carinae. It comes nearer to $P$. impressus, 2141 , from Taieri, which has numerous spots formed of conerrecrated setar, interspersed with granular clevations on the elytra, so that their surface appears more asperate, and their striae art indefinite or obsolete. The thorax is rather inroarler before the middle ani more rugosely sculptured, and the whole insect is of a more dusky hue

Length (rostrum inclusive), 8 smm. ; breadth, $2 \frac{1}{2} \mathrm{~mm}$. 
Mount Hutt. My specimen was found by Mr. 'T. Hall on the 15th March, 1913, at an elevation of $4,500 \mathrm{ft}$.

376t. Phygothalpus nitidulus sp. nov. Phygolhalpus Bromn. Trans. N.Z. Inst., vol. 45, p. 117.

Elongate, slightly convex, somewhat shining; sparingly clothed with decumbent, moderately short, flavescent setae, and a few erect ones on the posterior declivity; elytra fuscous, rostrum and thorax piceous, legs and antennae rufo-castaneous.

Head and rostrum nearly as long as thorax; the rostrum dilated before the middle so that the deep scrobes at that part are quite open above, its frontal portion somewhat deflexed and rather fincly punctate. hut without any suture near the antennae, behind these distinctly punctured but only indefinitely tricarinate in the male, quite obsoletely in the female; head with a narrow interocular fovea, less distinct in the male. Thorax shining, subtruncate at base and apex, of almost equal length and breadth, rather wider before the middle than elsewhere, nearly straight ret slightly narrowed behind; disc evenly, distinctly, but only morlerately closely punctured, the median groove rather fine and interrupted near the middle. Scutellum small. Elytra nearly thrice the length of thorax, rather broader than it is, and somewhat incurved at the base. their sides but little curved, gradually narrowed and deflexed behind; dorsum regularly and evidently striatepunctate, more distinctly striate towards the extremity, with broad, nearly plane, finely punctate interstices.

Scape subclavate near the extremity, reaching just beyond the middle of the eye, finely and scantily setose; basal joint of funiculus double the length of the next, which is hardly twice as long as broad; remaining joints more or less moniliform, 3rd scarcely longer than 4 th, the 7 th slightly hroader than fith: club distinetly triarticulate and pubescent. subarmminate.

Tibiae flexuous, the anterior mucronate and bent inwards, the others, in the male, dilated and acutely biangulate at the extremity.

Underside shining, nigrescent, moderately finely but not closely punctate, with some fine rellowish setae: metasternum broadly impressed behind, basal segment of abdomen subtruncate between the roxile, broadly repressed along the middle. where it is rather longer than the metasternum. its suture sinuate behind, 2nd medially depressed towards the front, evidently shorter than the lst. Wut slighty longer than the well-eleveloped

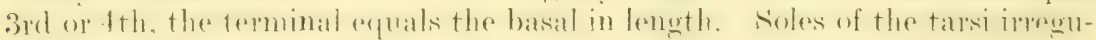
larly and finely setose, the penultimate joint most thickly.

Considerably larger than the type of the genus, $P$. sulcicollis, 3287 , the rostrum indefinitely carinate, the thorax more finely punctate, with an interrupted slender central groove, the elytra not distinctly striate, the scape obviously thicker, the antennae and legs concolorous, and the tibiae differing in structure.

In Clypeorhynchus the shoulders are oblique; in this genus ther are only a little curvedly narrowed.

o. Length (rostrum inclusive), $8 \mathrm{~mm}$.; breadth, $3 \mathrm{~mm}$.

Remarkables, Otago. I am indebted to Mr. M. O. Pasco, of Queenstown, for one of each sex, found by him on the 28th December, 1912.

3765. Phygothalpus majusculus sp. nov.

Subopaque, fusco-piceous, antennae and tarsi piceo-rufous; covered with decumbent infuscate setae, the elytra, in addition, with many erect paler ones 
Rostrum and head as long as thorax; the former indistinctly tricarinate, with longitudinally rugose sculpture and a well-marked interantennal depression: the head closely punctate. Thorax widest hefore the middle, gradually narrowed behind, obliquely impressed near the front, with a rather broad, uninterrupted median channel, its punctation shallow but rather coarse and irregular. Scutellum indistinct, sunken. Elytra slightly wider than thorax at the base, nearly thrice its length, rather distantly and coarsely striate-punctate, with slightly asperate interstices, apices hardly at all dehiscent.

Legs robust, setose; tibiae minutely denticulate inwardly, the anterior slightly curverl externally, their apical structure like that of $P$. mitidulus.

Scape stout, gradually incrassate, attaining the back of the eve; hasal joint of funiculus subnodose at the apex, almost double the lenirth of the obconical 2nd, joints 3-7 moniliform; club oblong-oval.

Duller, the thorax especially, than $P$. nitidulus, the sculpture of the rostrum and thorax manifestly different, the elytra less striate, with coarser and less regular punctures, the structure of the scape and basal joint of funiculus dissimilar, and the pubescence closer and darker, \&c.

o. Length (rostrum inclusive), $9 \frac{1}{2} \mathrm{~mm}$. ; breadth, $3 \frac{1}{3} \mathrm{~mm}$.

Ben Lomond, Otago. Another of Mr. M. O. Pasco's captures on 1 st December, 1912

\section{Nestrius crassicornis sp. nov. Nestrius Broun, Ian. N.Z. Coleopt.,} p. 1480 .

Elongate, moderately convex, subopaque; very scantily clothed with tawny suberec sctae, those on the rostrum more flavescent and depressed; dark fuscous, legs and antennae fusco-rufous.

Rostrum rather shorter than thorax, a little arched above, rufescent and nearly smonth. Scrobes lateral, broad and deep, beginning near the apex, where they are quite visible above, but not reaching the eyes. Thorax of equal length and breadth, suboviform, slightly wider before the middle than elsewhere, truncate at base and apex, the dise with a few very coarse deep punctures. Elytria oblong. fully twice as long as thorax. slightly wider than it is, and medially emarginate at the base, with obliquely narrowed shoulders. posterior declivity narrowed and vertical; each elytron is rather coarsely triseriate-punctate, outside these the punctation is less regular: there is a slight sutural depression at the base, so that the 2nd interstices appear obtusely elevated there, the 3rd from behind the shoulders barkwards are subcarinate, sometimes interrupter? or obsolete, the declivity is distinctly striate-punctate.

Legs setose, femora subclavate: tibiae nearly straight, obsoletely mucronate, not serrate inwa dly; tarsi moderately narrow, with slender outstanding setae underneath, penultimate joint hardly at all expanded but distinctly bilobed.

Scape thick, with erect setae, inserted near the apex and reaching the thoracic margin; funiculus with slender grey setae. basal joint quite twice as long as broad and rather longer than the next joints 37 suloquadrate; club abruptly enlarged, subrotundate, triarticulate.

Underside with some straw-coloured setae, rather coarsely and irregularly punctate, but the $3 \mathrm{rd}$ and th rentral segments have only a single transverse series of punctures, and the rufescent 5 th is smooth and shining; the 2 nd segment is rather shorter than the lst and on a slightly lower plane, otherwise the suture would be indistinct; metasternum nearly smoot! und 
depressed in the middle: prostermm much paler than other parts, anterior coxae contiguous.

Eyes minute but convex, free from thorax. Handibles curved and acutely bifid at extrenity. Mentum small and subquadrate. Palpi hardly discernible. There are no ocular lobes.

This species, though resembling $N$. servipes, 2559, female, in facies, has much thicker antennae; these, indeed, are almost similar to those of A porololus, one of the Otiorhynchidae, but with a subrotundate rlub. The sexual characteristics are recorded in Ann. Mlag. Nat. Hist., 1893, ser. 6, vol. 12, p. 302 .

․ Length (rostrum inclusive), $3 \frac{1}{2} \mathrm{~mm}$. ; breadth, $1 \frac{1}{3} \mathrm{~mm}$.

Pudding Hill, near Methren. Three females, found amongst decaring leaves on the ground, at a height of 3,000 ft., on the 13th April, 1913, by Messrs. T. Hall and L. Burrows, during very stormy weather.

\section{Group Erirrhinidae.}

3767. Erirrhinus cordipennis sp. nov. Erimhimus Schomherr, Man. N.7. Coleopt., p. 449.

Ovate, moderately convex and nitid; legs and elytra testaceous, these latter with an irregular fuscous fascia hetween the hind thighs and extrenity but not reaching the sides, and bearing a few coarse, rather short, erect grevish setae: thorax fusco-testaceous. slightly rufescent, with rather finer yet not slender setae; head and rostrum dull brownish-black, the apex of the latter a little shining; tarsi and antennae somewhat fulvescent, club fuscous.

Rostrum as long as the head and thorax, stout, parallel, slightly arched, with irregular linear sculpture. Head immersed up to the eyes, short, nearly twice the width of the rostrum. Thorax without ocular lobes, base and apex truncate, of about equal length and breadth, rather more narowed in front than behind; relatively moderately coarsely but not closely punctured. Scutellum small or indistinct. Elytra quite cordate, slightly emarginate and broader than thorax at the base, twice its length, not abruptly declivous helind: rather coarsely and regularly punctate-striate. with simple slightly raised interstices.

Scape implanted between the middle and apex, clavate at extremity, attaining the eve: funiculus rather longer. hasal joint twice the size of the next. joints 37 transverse and equal ; club rather large ohlong-oval, densely pulesent, indistinctly articulate. Hyes subdepressed, with coarse facets. Legs robust. with fine grevish setae: tihiae slightly flexums and marmed; tarsi mother short and broad. hasal two joints trinsverse. the penultimate broadly expanded and bilobed.

The coloration and perfectly cordiform hind-hody distinguish this small species from all its allies.

o. Length (rostrum exclusive), $1 \frac{2}{3} \mathrm{~mm}$.; breadth, nearly $1 \mathrm{~mm}$.

Longwood Range, Southland. One, found by Mr. A. Philpott in January, 1913.

3768 . Dorytomus methvenensis sp. nov. Dorylomus (remmit, Minn. N.Z. Coleopt., p. 453.

Subovate. moderately convex. nitid. sparingly clothed with slender decumbent grevish setae: rostrum and thorax lierht rufo-fuseous, leus and elytra pale testareous. these latter with the lateral margins and a broad 
vitta on each between the middle and extremity dark fuscous, the suture is somewhat rufescent, and the middle of the base sometimes slightly infuscate.

Rostrum as long as the head and thorax, moderately stout, subparallel, punctate and feebly tricarinate, nearly smooth in front. Thorax without ocular lobes, base and apex truncate, slightly broader than long, its sides somewhat rounded, moderately coarsely and closely punctured. Scutellum sumall but distinct. Elytra oblong, nearly thrice the length of thorax, evidently broader than it is at the base, rounded but not vertical behind; distinctly and regularly punctate-striate, intermediate interstices confluent behind.

Scape inserted between the middle and apex, very gradually thickened, just reaching the front of the eye ; basal joint of funiculus twice as long and broad as the 2 nd, joints 3-6 small and subquadrate, 7 th slightly broader and more moniliform ; club large, oblong-oval, triarticulate. Eyes subrotundate, very slightly prominent. Femora more or less angulate and dentate below; tibiae slightly flexuous, the anterior mucronate; basal two joints of tarsi short, the 3rd dilated and bilobed.

This nearly approaches 1528, Erirhinus thomsoni, in general appearance, but has paler yellow, differently marked elytra, and a rather stouter tricarinate rostrum.

Length (rostrum exclusive), $2 \mathrm{~mm}$. ; breadth, $1 \mathrm{~mm}$.

Bell Rock, near Methven. Mr. T. Hall found two specimens on the 19 th November, 1912.

3769. Oreocharis pleuralis sp. nov. Oreocharis Broun, Man. N.Z. Coleopt., p. 864 .

Subopaque, variegate, the head, rostrum, thoracic disc, sides of elytra, femora, terminal tarsal joints, and antennal club more or less fusco-piceous ; remaining parts rufo-castaneous; the vestiture irregular, consisting of slender, inconspicuous, suberect ashy setae on the thoiax and along the middle of the elytra, but a broad streak near the side of each elytron and lower part of the side itself bear depressed, elongate, yellowish-grey squamae, the sides of the thorax covered with somewhat more rotundate and darker scales.

Rostrum rather longer than thorax, a little dilated near the front, behind about half the width of the occiput, slightly arched, feebly carinate along the middle, the seriate punctures separated by indistinctly raised lines. Head as long as broad, gradually narrowed anteriorly, moderately closely and distinctly punctured, slightly depressed between the eyes; these are distant from the thorax, longitudinally oval and moderately prominent. Thorax nearly a third broader than long, constricted close to the apex, with gently rounded sides; its punctation a little coarser than that of the head. Scutellum oblong. Elytra evidently broader than thorax at the base, fully thrice its length, gradually curvedly narrowed posteriorly, with slightly rounded rufescent shoulders; they are distinctly striate-punctate, interstices minutely subseriate-punctate. Pygidium broad, finely punctate.

Legs with fine greyish setae. Femora clavate, the intermediate distinctly angulate underneath, the posterior strongly dentate and bearing a few scales. Hind tibiae somewhat arched above, and a good deal dilated below that point along the front.

Scape implanted near the apex, rather slender, attaining the centre of the eye; basal joint of funiculus stout, evidently longer than 2nd, the next 
rather longer than broad, joints 4-6 short and bead-like; club densely pubescent, as long as the funiculus.

linderside with grevish setale. Basal ventral sewment flattened.

The dark, somewhat shining sides of the elytra. bordered above by squamose pale vittae, will lead to its recognition.

Length (rostrum exclusive), $3 \frac{1}{3} \mathrm{~mm}$. ; breadth, nearly $11 \mathrm{~mm}$.

Longwod Range. Southland. A single specimen obtained by Mr. A. Philpott in January, 1913.

\section{Group Belidae.}

3770. Pachyura aenescens sp. nov. Pachyura Hope, (ien. Ins. (Wytsm.), Belinae, 1909, p. 7.

Elongate, slightly convex, nitid; dark aeneous, head and rostrum rufoviolaceous, antemnae and legs castaneo-rufous: elytra sparingly clothed with fine. rather short, infuscate hairs, but on the hasal and apical portions there are some coarser', depressed. cream-coloured setae. similar setae form an irregular interrupted fascia between the hind thighs. and another farther back: on the head and thorax the setae are slender and elongate and thinly distributed. but the sides of the latter, as well as the under-surface of the body are thickly covered with setae like those composing the elytral fasciae.

Rostrum glossy, subrolindrical. gradually and slightly dilated anteriorly. angulirly prominent at the sides near the base, it equals the thorax in length, is very finely punctured in front, more closely and coarsely behind, it is without any basal carina, but is distinctly bidentate at the apex. Head broad, subquadrate, very roarsely and closely punctured. with a short slender frontal interocular carina. Eyes large and prominent. Thorax a third broader than long, curvedly narrowed towards the truncate apex, strongly bisinuate at the base: "oarsely, closely, and somewhat transversely rugosely punctate. Srutellum subrotundate closely punctured. Elytra very slightly and gradually expanded posteriorly, with simple apices, five times the length of thorax and, owing to the oblique shoulders, not any wider than it is at the base; each elytron is medially rounded at the base so as to overlay the thorax there; their sculpture consists of distinct, slightly irregular, transverse rugae and punctate intervals; on each there is a shallow broad impression near each shoulder.

Antennae longer than the head and thorax, straight; their 2nd joint rather longer than broad yet shorter than the subpyriform 1st, joints 3-7 elongate and rather slender: sth rather longer than sth or 10th, all elongate and narrowed towards the base, but broader than preceding ones, the terminal longer than 10th, subacuminate.

Lexs elongate, distinctly pubescent; tihiae nearly straight, finely serrate inwardly, the hind pairs bicalcarate at the inner extremity. Tarsi stout, basal joint of the anterior oblong-oval, the next elongate-triagular, penultimate broad and dereply hilobed. th fully as long as the lst.

Most nearly allied to the considerably smaller $P$. albocoma, 2172, which for the most part is coppery-red with quite white scale-like hairs. The rostrum is carinate hehind. the head and thorax have gramular sculpture, and the thorax is relatively narrower and longer.

Length (rostrum inclusive), $10 \mathrm{~mm}$. ; breadth, $3 \mathrm{~mm}$.

Ben Lomond, Otago. One example from Mr. M. O. Pasco, of Queenstown, labelled 7 th December, 1912. Another specimen sent previously for inspection, so far as I can remember, is more brilliant and iridescent. 


\section{Group Cryptorhynchidae.}

3771. Acalles furvus sp. nov. Acalles Schoenherr. Man. X.Z. Coleopt., p. 488 .

Elongate medially narrowed, only moderately convex, without crests or elevations, subopaque; obscure rufo-fuscous, sometimes picens, antemnae paler : irregularly covered with depressed tawny-grey scales. hut with some erect ones on the elytra.

Rostrum nitid, smooth along the middle. with fine setae and punctures near the sides, squamose at the base: it is rather shorter than the thorax and only indistinctly narrowed near the middle. Thorax slightly longer than broad, widest and rounded behind the middle. a good deal hut not abruptly narrowed anteriorly, hase truncate. apex broadly rounded; disc impressed longitudinally behind, my second sperimen only flattened there, its punctation rather close and coarse. Elytra a third longer than the thorax, hardly any wider than it is at the hase. shoulders a little rounded. nowhere broader than the middle of the thorax, their sides nearly straight, considerably narrowed but not at all vertical behind; with only moderately impressed striae, the sutural deeper behind, all are more or less crenate-punctate.

Scape medially inserted and attaining the eye, gradually incrassate; funiculus longer, basal joint elongate. gradually thickened, much stouter and rather longer than the next, 3rd and th slightly longer than brod, joints 5-7 smaller and nearly equal: rlub elongate-roval. densely puliescent, indistinctly articulate.

Legs rather long and stout, squamose. tibiae uncinate; tarsi with setiform vestiture underneath, their hasal joint triangular. penultimate broadly lobed.

Cnderside fusco-piceous, coarsely punctate and nearly nude: terminal three segments somewhat rufescent and finely setose. Pertoral canal deep, extending to berond the middle coxae, and with elevated borders there. Metasternum moderate. Basal ventral segment large, truncate between the coxae, flat, medially incurved hehind, rather longer than the next. 3rd and 4th with deep sutures.

There are no ocular lobes. Head immersed nearly to the subdepressed, longitudinal eyes.

The most natural position for this species is near A. contractus, 3318, which, however, is rufescent, with yellowish squamae, oviform elytra, and thicker femora.

During the process of cleaning much of the coarse squamosity disuppears, but the depressed grevish scales on two basal spots on the elytra and those along the suture remain.

Length (rostrum exclusive), $2 \mathrm{~mm}$. ; breadth, $\frac{3}{4} \mathrm{~mm}$.

Longwood Range, Southland. Three individuals secured by Mr. A. Philpott in January, 1913.

\section{Acalles bicinctus sp. nov.}

Convex, almost uninterruptedly oriform, subopayue. without distinct crests or inequalities: fuscous, leass and antemnae rufo-fuscous, rostrum rufo-piceous; covered with small, depressed, elongate-oval, somewhat fulvescent squamae: the thoracic disc more thinly. but with a curved band along each side extending forwards to beyond the middle, and another. similarly curved but shorter, just inside it. composed of slichtly longer and more concentrated scales. 
Rostrum as long as thorax, moderately broad, slightly narowed towards the middle, with a slight median carina, its seriate punctures with irregularly linear interstices. Head immersed nearly to the eves, broadly impressed hetween these. Thorax a little hroader than lome, widest behind, moderately but not sharply contracted in front, base subtruncate; disc nearly plane behind, with an almost smooth line along the middle, only moderately coarsely and closely punctate. Elytra twice the length of thorax, as wide as it is at the base, rather broader near the middle, the posterior declivity rounded above; they have regular series of well-marked distinctly separated punctures and a few specks of erect scales but no definite crests; on the basal margin there are three small yet distinct equidistant yellow spots.

Leg stout, squamose, anterior femora longest; tibiae strongly arched and slender at the base, with a few coarse erect greyish setae, the hinder pairs with a patch of bright-fulvous ones at the extremity; tarsi rather narrow.

Scape inserted before the middle, flexuous, attaining the front of the eye; funiculus rather longer, hasal joint slightly thicker hut not longer than the elomgate 2nd, 3rd and 5th subpuadrate. Ith slightly longer, 6th and 7 th broader: ; club oval, triarticulate.

Underside fuscous and squamose. Pectoral canal bounded behind with elevated borders between the middle coxae. Metasternum very short, with a deep semicircular depression behind. Basal ventral segment largest. distinctly punctured and depressed in front. the next not double the length of $3 \mathrm{r}$ ir ith. the terminal moderately large. with a distinct depression at each side.

Belongs to Section $\mathrm{I}$. The duplicate bands at each side of the thorax and the equidistant spots on the elytral base will lead to its recognition.

Length (rostrum exclusive), $4 \frac{1}{2} \mathrm{~mm}$. ; breadth, $2 \frac{1}{2} \mathrm{~mm}$.

Mount Hutt. Inique: discovered by Mr. T'. Hall on the loth January, 1913, amongst dead leaves on the ground, at an altitude of $4,500 \mathrm{ft}$.

3773. Zeacalles scaber sp. nov. Zeacalles Broun, Ann. Mag. Nat. Hist., ser. 6 , vol. 12,1893, p. 379.

Oval, compact, convex, opaque; rufescent, antemae and tarsi fuscotestaceous; thickly but irregularly covered with comparatively coarse, elongate, depressed and erect squamae, for the most part of a tawny hue, but mingled with greyish setae on the elytra.

Rostrum rather longer than thorax, gradually and slightly narrowed near the middle. punctate near its sides. more or less finely quadricarinate, and with a few scales behind, it is dark red and shining. Thorax a little broader than long, widest at the base, gradually narrowed towards the rounded apex; morlerately coarsely punctate. without inequalities of surface, the disc covered with depressed elongate scales, the sides with numerous erect syuamiform setale. Elytra closely applied to the thorax, of the same width at the hase, twice its length, more convex than it is, broader near the middle, vertical behind; on each elytron there is an elongate elevation near the hase and a romoded nodosity on the summit of the posterior declivity, these bear yellowish erect scales; the sutural striae are broad and deep, the others are rendered indistinct by the syuamosity, the declivity when denuted is seen to be distinctly striate. Leas and antennae of normal structure.

The scabrous surface will lead to its discrimination.

Length (rostrum exclusive), $2 \mathrm{~mm}$. ; breadth, $1 \frac{1}{3} \mathrm{~mm}$. 
Rose Hill, near Methven. Inique: detected by Mr. T. Hall amongst decaying leaves on the ground on the 30th March, 1913.

\section{Zeacalles sparsus sp. nov.}

Compact, very convex, ovate, subopaque; rostrum and thorax pitchyred, elytra and less paler, antennae and tarsi olscurely fulvescent; vestiture variegate, thorax thinly covered with derumbent, fulvescent and grevish, elongate stuamae, and with coarse curled setae at the sides: on the elytra the clothing for the most part is fulvescent, but there is a small nigrescent spot on the hase at the suture. a straight elongate mark between the middle and each shoulder, and a few other less definite dark spots; some erect, grer setiform scales, some of which are much smaller than others, form at transverse spot near the middle of each side and 5 minute rrests near the top of the posterior declivity: there are also a few erect srattered blarkish setae; the legs bear erect greyish squamae.

Rostrum as long as thorax, moderately broad, rather closely and distinctly punctate, more finely in front. Thorax of equal length and breadth. subtruncate and widest at the hase, gradually narrowed anteriorly. closely and rather coarsely punctate. Elytra almost double the length of thorax, of the usual form. with deep and broad sutural striae, the other's indistinct.

Not at all like $Z$. scaber. More nearly resembling the larger northern Z. varius, 2957, which, however, is without visible sutural striae; it is quite differently "lothed and marked. unabraded sperimens having, on each elytron, a distinct semicircular nigrescent band extending from inside the shoulder to the suture, and a pair of slightly raised dark spots hetween the middle and each side of the thorax, \&c.

Length (rostrum exclusive), $1 \frac{1}{2} \mathrm{~mm}$. ; breadth, nearly $1 \mathrm{~mm}$.

Pudding Hill, near Methven. One, amongst other terrestrial Coleoplera collected by Mr. T. Hall and Mr. L. Burrows on the 13th April, 1913, at a height of about $3,200 \mathrm{ft}$., during a heavy thunderstorm.

\section{Group Lamidda.}

3775. Hybolasius sculpturatus sp. nov. Hybolasius Bates, Man. N.Z. Coleopt., p. 609.

Elongate, subdepressed, only slightly nitid; rufo-castaneous, the micidle of head, thoracic disc, base of elytra, and tarsal claws somewhat fuscopiceous; pubescence slender, for the most part decumbent, feather-like, and greyish, forming on earh elytron an irregular curve from the shoulder to the suture but not as far back as the middle, an oblique fascia near the hind thigh extending hackwards towards the side. and a large apical patch: the intervals bear slender, inconspicuous infuscate pubescence: the whole surface is closely and finely punctate.

Head depressed along the vertex. Thorax of ahout equal length and breadth, with a large obtusely rounded prominence at the middle of each side; disc convex and a little uneven but not at all tuberculate, with a transverse depression near the base and apex. Scutellum large, pubescent. Elytra evidently broader than thorax, thrice its length, parallel for threefourths of their length. with strnngly rounded, somewhat dehiscent arpices ; there is a broad impression behind the scutellum with ohtuse but not at all tubercular lateral borders; the suture is broad and slightly elevated from before the middle to the extremity, and alongside it, on each elytron, a broad impression is bordered externally by a feebly raised obscure costa; there 
are numerous coarse punctures near the base and a few irregular series extending as far back as the oblique fasciae.

Antennae concolorous, minutely seulptured, very scantily pubescent, and bearing only a few rather short dark setae; their 3rd joint attains the shoulder, the 10th almost reaches the apex.

Legs with fine grey hairs, internediate and posterior tibiae fringed externally below the middle with nigrescent setae.

The absence of thoracic tubercles and the slight basal elevations of the elytra remove this from the neighbourhood of the more typical speries. whilst the coloration. sentpoture. and feather-like vestiture distinguish it from the others.

ㅇ. Length, $7 \mathrm{~mm}$; breadth, $2 \mathrm{~mm}$.

Mount Hutt. Unique; captured by Mr. 'I'. Hall at an elevation of about $4,500 \mathrm{ft}$., on the 25th January, 1913.

\section{Group Cryptocephalidae.}

3776. Arnomus fulvus sp. nov. Arnomus Sharp, Man. N.Z. Coleopt,, 1). 619 .

Oblong, slightly convex, nitid, glabrous; fulvous, slightly aeneous, head. and thorax more rufescent than the elvtra. which last are a little infuscate towards the extremity, terminal joints of antennae still darker.

Head rather finely yet quite distinctly but not at all closely punctured, with a shallow longitudinal median impression behind; it is, including the large prominent eyes, rather wider than the thoracic apex. Antennae nuch longer than the head and thorax, a little pubescent towards the extremity: basal joint subpyriform, not as long as the 3rd, 2nd still shorter, joints 3-11 about equally elongate. Thorax twice as broad as long, apex truncate, the base widely hisinuate, with ahmost arutrely rectangular angles: sides finely mareinerd. widest hehind the middle. straight ret Eradually narrowed anteriorly, more abriptly near the hase. which is finely margined: its surliace slightly uneven, distinctly punctate, much more coatsely than the head, very irregularly and somewhat distantly on some parts. Sicutellum modterately large. subtriangular. quite snowoth. Elytra a little hroaler than thorax at the base, four times its length, slightly expanded posteriorly, with broady rounded apices: they are noderately chosely punctured. rather more coarsely than the thorax, more distantly behind, and there is an impression near each shoulder. Pygidium much exposed, with fine grey pubescence.

Legs stout and very elongate, tibiae straight; basal joint of tarsi subr.lindric and longer than the following two combined. the 3rd with elongate lobes.

Underside fulvous, the penultimate ventral segment with a large subapical fovea.

A. signatus, 3008, the nearest ally, may be at once distinguished by the dark occiput and sutural region of the elytra, by the more obviously punctate head, and much less prominent eyes.

Length, $1 \frac{1}{2} \mathrm{~mm}$.; breadth, $2 \mathrm{~mm}$.

Longwood Range, Southland. One only, found in January, 1913, by Mr. A. Philpott, during a wet and stormy sojourn of three days.

\section{Arnomus vicinus sp. nov.}

Shining, fulvous, head and thorax rufescent, the back of the former, middle of the latter, and the scutellar region aeneo-fuscous. 
This species to a great extent agrees with 1 . fulves, but it is a good deal smaller, the head is moderately coarsely punctured but is without any occipital impression: the thoracic punctation is close throughout, the sides are gently rounded except just. at the base, where they are somewhat narrowed and nearly straight; the elytra are of equal width throughout, with rather finer sculpture, and there is a distinct depression behind the smooth scutellum. Pygidium just visible.

A. signatus, 3008, from Mount Arthur, may be easily separated by its obviously less conver eyes, irregular thoracir punctation, some spots being smooth, and by the greater bulk of the insect itself.

Length, $3_{2}^{1} \mathrm{~mm}$.; breadth, $1 \frac{1}{2} \mathrm{~mm}$.

Mount Te Aroha. One, found by myself during November, 1893, at an elevation of $2,500 \mathrm{ft}$.

\section{Group Chrysonielidae.}

\section{Cyrtonogetus gen. nov.}

The type of this genus is nearly related to Allocharis (Han. N.Z. ('oleopt, p. 1306), but the body is not at all elongate-oval, being robust and oblong. The metasternum has the front margin distinctly elevated and truncate between the coxae. instead of being strongly, almost sharply rounded. The basal ventral segment is hardy as long as the following three. and its frontal suture is nearly quite straight. The posterior coxae are only a little farther apart than the intermediate. Tibiae gradually incrassate towards the extremity, each with a broad external groove there. Tarsi stout, basal two joints cordiform, 3rd entire and densely setose underneath, slightly emarginate, the claws of the terminal appendiculate at the base.

In sternal structure it is similar to Caccomolpus, which, however, is composed of small subrotundate species with differently formed legs.

\section{Cyrtonogetus crassus sp. nov.}

Oblong, moderately convex and nitid, with a few fine setae on the labrum; aeneo-niger, legs piceo-castaneous, labrum and antennae rufescent.

Head immersed up to the eres, finely punctate, more closely on the forehead, with a smooth angular space behind, the interantennal suture strongly curved. Eyes subdepressed, distinctly faceted, very transverse. Thorax finely marginate except at the middle of the base and apex, the latter feebly emarginate. with obtuse but somewhat prominent angles, the base rery slightly rounded. with rectangular angles; it is hardly twice as broad as long. a little wider near the middle than elsewhere, gently narrowed but not curved behind; its surface finely and rather irregularly punctured, the space between the middle and each side more distantly. Scutellum broadly triangular, smooth. Elytra closely applied to the thoras. fully double its length. slightly broader than it is at the hase, their sides finely margined, gently rounded, widest neal the hind thighs, more curvedly narrowed posteriorly; on each elytron there are 9 somewhat irregular series of fine punctures, the sutural series alone reaches the extremity and is bent outwardly near the base, where there is a short scutellar series.

Antennae stout, rather longer than the head and thorax; their basal three joints nearly glabrous, the others bear fine pubescence: Ind joint smallest, a little longer than broad, albout half the bulk of the darker lst, 3rd slightly longer than sueceeding ones. joints \& to 11 rather more slender than preceding ones, the terminal elongate-oval. 
Legs stont, tibiae unarmed, covered with short fulvous hairs near the extremity.

Inderside of the same colour as the upper surface. but rather more glosst, the coxae reddish; it is finely setose and irregularly punctate, the last secrment more thickly puhescent than the other's.

Length, $6_{2}^{1} \mathrm{~mm}$. ; breadth, $3_{2}^{1} \mathrm{~mm}$.

Remarkables. near Queenstown, (Otaso. One example, found by Mr. MI. O. Pasco on the 28th December, 1912.

\section{Group Galerucidae.}

3779. Luperus nodicollis sp. nov. Luperus Geoffroy, Lacord., Hist. des Ins. Coleopt., tom. 11, p. 186. Syn. Adoxia, Man. N.Z. Coleopt., p. 631.

Oblong, subdepressed, shining, glabrous; the body and basal joint of antennae violaceo-cyaneous, remaining joints dull piceous, legs piceocyaneous.

Head aeneous behind, longer and, including the eyes, rather narrower than the thorax, fmely rugose behind the eyes, the interocular channel well marked. Thorax almost twice as broad as long, its sides very gently curved near the front, with distinct lateral margins and channels, apex truncate, with almost rectangular but not incrassate angles, base slightly rounded towards the sides so that its angles are obtuse; disc purple, very uneven, with a pair of smooth central nodosities, its punctation distinct, rather distant and very irregular. Sroutellum curvilinearly triangular, smooth. Elytra oblong. subjarallel. four times the length of thorax, evidently boader than it is at the base, broadly rounded at the extremity; their suture narrow and sharply marked, they are very irregularly, rather closely but not very coarsely punctured, with short irregularly ragose intervals, the seulpture becomes much coarser towards the apex but at the base it is finer and less rugose, the shoulders are a little elevated and rounded. Pygidium subtriangular, distantly punctate.

Antennae moderately stout, attaining the hind thighs, 2nd joint rather longer than broad, sod longer. but slorter than the following ones.

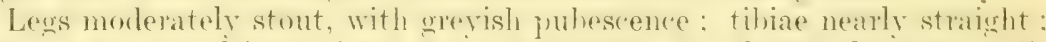
tarsi narrow, penultimate joint short. expanded and hilobed, raws appendiculate at base.

L. asperellus, 3020, may be readily separated by its metallic purplish-red tints, very much coarsei and closer punctation. of the thorax particularly. Both belong to the same section of the genus.

Length, $6 \frac{1}{2} \mathrm{~mm}$. ; breadth, $2 \frac{3}{4} \mathrm{~mm}$.

Ben Lomond, Otago. The only specimen I have seen was captured on the 1st December, 1912, by Mr. M. O. Pasco.

\section{Luperus dilutipes sp. nov.}

Subdepressed, moderately elongate, nitid; nearly nude, having only a few grey hairs on the head and short dark ones on the sides of the thorax; arenens. sumewhat viridescent. the legs. coxare and hasal joints of antennae fusco-testaceous, remaining joints of these last darker.

Head almost as broad as front of thorax, slightly cyaneous, with a few punctures, occiput smooth, the interocular furrow well marked. 'Thorax a

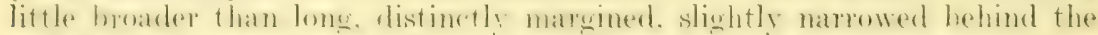

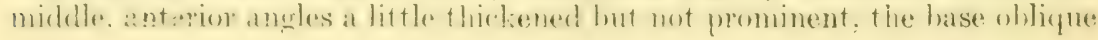


near each side, with obtuse angles; its surface distinctly, irregulirly, but neither closely nor coarsely punctured, usually with a central fovea. Scutellum small and smooth. Elytra nearly thrice the length of thorax, rather broader than it is at the base, subparallel, with broadly rounded apices; they are distinctly and moderately closely punctured to the extremity, with minutely sculptured, feebly rugose intervals; there are no definite intrahumeral impressions, but are somewhat flattened alongside the suture, which, however, appears elevated. Pygidium covered.

Antennae extending beyond the middle thighs, 2nd joint oviform, shorter than 3rd, joints 4-10 elongate, the terminal apparently with a short conical apical appendage.

Legs stout, tibiae almost straight; basal joint of tarsi oblong, rather broad, the 2nd of the anterior pair but little longer than broad, claws appendiculate.

Male.-5th ventral segment equalling the preceding three conjointly in length. deeply and broadly furrowed along the middle and bisinuate at the extremity, the supplementary broadly conical, concave in the middle. with slender, sharply marked margins.

Owing to the elevated elytral suture, this species should be placed near $L$ insolitus, 3668, which, however, is subcvaneous, with fuscous antennae and legs, it has no distinct interocular furrow, the impression near each shoulder though not deep is quite definite, its legs are longer and thicker, the 2 nd joint of the front tarsi is distinctly longer than broad, and the insect itself is rather larger.

Length, $3 \frac{1}{3}-3 \frac{1}{2} \mathrm{~mm}$. ; breadth, $1 \frac{1}{4} \mathrm{~mm}$.

Ben Lomond, Otago. Three examples found early in Derember, 1912, by Mr. A. Philpott, of Invercargill.

\section{Luperus pubicollis sp. nov.}

Elongate, subdepressed, moderately shining; sparingly clothed, head and thorax inclusive, with erect and decumbent slender grevish setae; head and thorax fuscous, lateral margins of the latter. the elvtra, legs, and hasal three joints of antennae obscure fusco-testaceous.

Head a little uneven, indistinctly punctate, with a broad median longitudinal groove; it is as broad, including the large eves, as the front of the thorar. Antennae with elongate grey pubescence, extending hackwards berond the middle femora, 2nd and 3rd joints equal and. trugethor. fully as long as the 4th. Thorax twice as broad as long; dise a little uneven, with very irregular. somewhat ill-defined, rather coarse and shallow punctures: its sides only slightly rounded, with distinct margins, anterior angles not incrassate, the posterior subrectangular. Scutellum subtriangular. large, smooth. Elytra elongate, parallel, rather broader than the thorax and nearly five times its length. with rounded apices: there is a slight sutural depression at the base and another near each shoulder. their punctation is distinct, moderately coarse and close, somewhat rugose, and hecomes rather coarser towards the sides and extremity.

Legs normal, posterior tibiae very slightly arched; tarsi moderately narrow.

The distinct thoracic pubescence is its chief distingruishing chatracter, one almost unknown amougst its allies. A varietal damaged specinem is. except the legs, almost wholly fuscous.

Length, $3 \frac{1}{2} \mathrm{~mm}$. ; breadth, $1 \frac{1}{2} \mathrm{~mm}$. 
Takitimu Mountains. One found by Mr. A. Philpott, of Invercargill, on the 3rd January, 1913.

373.2. Allastena piliventris sp. nov. Allastema Broun. Man. N.'\%. ('oleopt., p. 1318.

Oblong. subdepresised, nitid: hearing only very fow fine suberect greyish setare; hronzed-hlark, legs and hasal joint of antennae fusco-testareous, the other joints and the tarsi more infuscate.

Head almost as broad, eyes included, as front of thorax, nearly smooth. Thorax hardly a third boader than long, its sides and base distinctly margined: the latter straight in the middle but a little curved near the sides with imdistinct angles, apex truncate, its angles obtusely rectangular but hardly at all incrassinte. the sides slightly nomowed behind; its punctation inregular, rather shallow. moderately close, more distinct near the base, with very finely sculptured intervals. Scutellum smooth, broad, triangular. Elytrat oblong, parallel. with hroadly rounded apices, quite thrice the length of the thorax and evidently broader than it is at the base; they are distinctly and closely punctured, and in some aspects appear transversely rugose, with very shallow humeral impressions. Pygidium broad, bluish, but little exposed, finely punctate, with numerous elongate grey hairs, near the sides especially.

Antennae finely pubescent, rather shorter than the body, 3rd joint rather longer than 2 nd, but shorter than succeeding ones.

Legs moderately elongate; tibiae gradualiy thickened, the posterior bent inwardly, more incrassate at the extremity, and with a well-marked groove there for the reception of the laterally compressed tarsal joint; basal joint of the other tarsi oblong and rather broad, the next very slender at the base. the penultimate moderately expanded and bilobed. the claws subdentate at the base and rather small.

More nigrescent than the type of the genus, 2318, the legs and tarsi darker, the thorax more transverse, with coarser and closer punctation, its front angles not distinctly thickened. the scutellum larger, but chiefly remarkable on account of the thickly pubescent terminal segment of the hind-body.

Length, $3 \mathrm{~mm}$. ; breadth, $1 \frac{1}{4} \mathrm{~mm}$.

Ben Lomond, Otago. A single individual from Mr. A. Philpott, of Invereargill, early in December, 1912.

Jomn Machay, Government Printer, Wellington.--1915.

$1300 / 2 / 15-2235$ 


\title{
NEW ZEALANI) INSTITUTE.
}

\author{
B ULLETIN No. 1. (Pant 5)
}

DESCRIPTIONS OF

\section{NEW GENERA AND SPECTES}

(IF

\section{COLEOPTERAN}

(PART Y.)

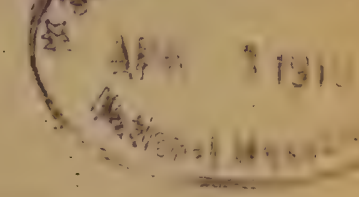

IYY MA.TOR TT. BROUN. T.E.S.

FDITED AND PUBLISHED UNDER THE AUTHORITY OF THE BOARD OF GOVERNORS OF THE INSTITUTE.

ISSUED 26th JUNE, 1917.

Ilclu cैealimi :

MARCUS F, MARIS, GOVERNMENT PRINTER, WELIIAGTON.

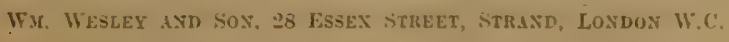




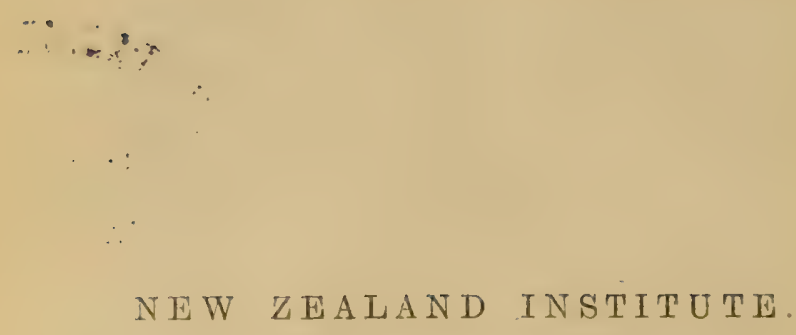

\section{BULLETINS.}

UxDEr the title "Bulletins" the Board of Governors of the New Zealand Institute hopes to issue, from time to time, important papers . which for any reason it is deemed desirable not to include in the yearly volume of the Transactions. The bulletins will be uniform in size and general style with the Transactions of the New Zealand Institute, but will appear at irregular intervals, and each bulletin will be complete in itself and be separately paged. The bulletins will not be issued free to members of the Institute, but may be obtained by them at a reduction on the published price. 


\title{
NEW ZEALAND INSTITUTE.
}

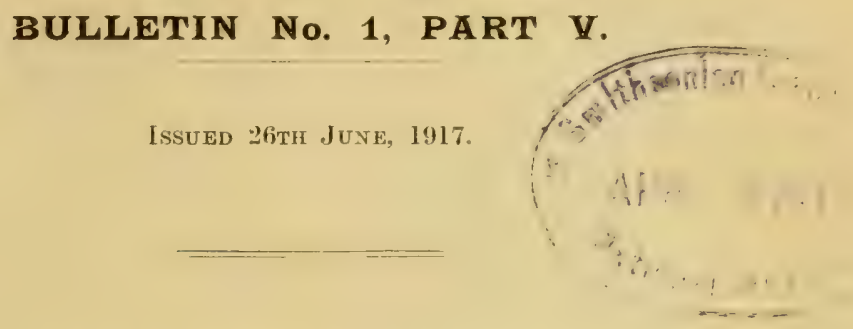

D E S C R I P T I O N S

OF

\section{NEW (GENERA AND SPLCTES OF COLEOPTERA.}

\author{
By Major T. Broun, F.E.S,
}

\section{PART V.}

THIs paper represents the arduous work accomplished during the year 1914. The preparation of descriptions, owing to the large number of minute species of complex structure now recorded, becomes increasingly difficult. It should be understood that before any new forms can be detected amongst the collections got together in variou, parts of the country a large number of specimens must be carefully mounted on cardboard, labelled, and examined, processes which, together, occupied about half of the whole year.

The ten new genera and 197 species herein described form a total of 3,979 species of New Zealand Coleoptera now known; and, as it was impossible to examine all the specimens that were mounted and preserved, there can be no doubt that these remaining ones, when named, will increase the number to four thousand.

On reference to the descriptive part of the paper it will be seen that by far the greater portion of these new species were obtained by Mr. T. Hall within the mountainous areas of Canterbury, Lake Wakatipu, and Nelson: whilst Mr. A. Philpott, Mr. J. H. Lewis, and Mr. M. O. Pasco of the South Island, Mr. A. E. Brookes of Mount

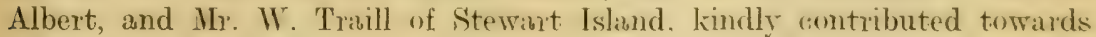
the general result.

Mount Albert, Auckland.

19 th January, 1915.

13-Bull. No. 1 . 


\section{LIST OF NEW GENERA AND SPECIES.}

\section{('ICINDEITINA.}

3783. (vieindela halli Bromen.

\section{(NAMACINTHIDAE.}

3784. Tecodema laterale Broun.

3785. .. chiltoni Broun.

:3786. „, politanum Broun.

$3787 . \quad$. 3 rubripes Broun.

$3788 . \quad$.. erratieum Broum.

3789. ․ Eratum Broun.

$3790 . \quad$ ". Patulum Bromen.

3791. .. affinum Broun.

3792. .. indiseretum Broun.

3793. . trailli Broun.

3794. .. mutabile Broun.

$3795 . \quad$.. gordonense Broun.

3796. Diglvmma basale Broun.

:3797. .. thoracieum Brom.

\section{LTCINIDAE.}

3798. Dichrochile insignis Broun.

$3799 . \quad$.. rugicollis Broun.

3800. .. Havipes Broun.

\section{F" BRONIDAE.}

3801. P'terost iehus aciphyllae Broun.

$3802 . \quad$. $\quad$ egregialis Broun.

3803. .. sentpturalis Broun.

$3804 . \quad$.. maiaci Brome

\section{P'OGONIDAE.}

3s0\%. (Oöpterus minor Broun.

:3806. .. latifossus Broum.

3807 . .. suavis Bromm.

3s08. \%olus ocularius Broun.

3809. Tarastethus convexus Brome.

3810 . . diversus Bromn.

38II. .. halli Bromm.

3812. .. fovealis Brom.

3813. .. longulus Broun.

$3814 . \quad$.. propinquus Bronn.

$3815 . \quad$ optatus Broun.

3816. Sympiestus frontalis Brome

\section{LEBIITAF.}

3817. Demetrida sinuata Broun.

PFRTCALIDAF.

3818. Seopodes instabilis Broun.

\section{SHIALRIDIDAF.}

3819. Stygnohydrus posticalis Broum.

\section{STAPHYTAIDAL.}

3r:-0. Quedius hallianus Brom.

3i-1. .. recticeps Broun.

35:3. ", megophthahus Broun.

3.2.3. Dimorus bisulciceps Broun.

\section{Firirontst.}

3.424. Exoirarthra angustula Broun. 382\%. "Iongicens Broun.
3826. Sagola unicalis Broun.

3827. .. dickensis Broun.

$3828 . \quad$.. robustula Broun.

3829. . hectorii Broun.

WUTP.CTEN.

38:30. Vidamus erracilipes Broun.

\section{Psemapifini}

38:31. Pselaphus urquharti Broun. 38:32. . oviceps Broun.

TYRINI.

38333. Phormiobius halli Broun.

38:34. Acratvrus fulvihirtus Broun.

\section{SHUPHIDAE.}

38:35. Inocatops spinifer Broun.

3836. . granipennis Broun.

3837. .. elongellus Broun.

$3838 . \quad$., separatus Broun.

3839. Keagyrtes vitticollis Broun.

3840 . Kenocolon laevicollis Bronn.

TronOSITIDAF

3841. (Arynoma setigera Broun.

3842. .. elavalis Broun.

384\%. .. proxima Broun.

$38+4 . \quad$." pallidula Broun.

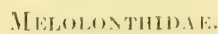

3845. Lusoma eximia Broun.

3846. Odontria obsoleta Broum.

LUCANIDAE.

3847. Mitophyllus mandibularis Broun.

3848 . .. eristatellus Broun.

'T'GNEBRTONIDAE.

3849 . Syrphetodes variegatus Broun.

3850. Pheloneis halli Broun.

38.5. .. angulatus Broun.

3852. . . dubitans Broun.

3853. .. curtulus Broun.

385t. ('ouclolus tuberculatus Broun.

$3855 . \quad$. eapitalis Broun.

3856. $\quad$.. sulcistermus Bromn.

3857. Mesopatrum duhium Broum.

\section{()EOLMLRIDIF}

3858. Sessinia hrookesi Broun.

\section{()TIORHY NCHIDA.}

3859. Nieaeana crassifrons Broun.

3860). Cecyropa sulcifrons Broun.

386il. ... striatella Broum.

3862. .. jucunda Broun.

3863. Iaticollis Broun.

3864 . Tigones nasalis Broun.

386io. .. citimus Broun.

3866. .. thoraciea Broun.

386i7. .. variata Broum. 
3868. Tigones nurina Broun.

3869. ", assimilis Broun.

3870. , setosa Broun.

3871. ", longiceps Broun.

3872. Epitimetes cupreus Broun.

$3873 . \quad$, foveiger Broun.

3874. Platyomida dorsalis Broun.

3875. . cuprealis Broun.

3876. .. fuscella Broun.

$3877 . \quad$." rectirostris Broun.

$3878 . \quad$, hystricula Broun.

3879. ", sulcicollis Broun.

$3880 . \quad$.. latipennis Broun.

3881. Protolobus nodosus Broun.

3882. Catoptes subplicatus Broun.

3883. . . dehiseens Broun.

3884 . .. robustus Broun.

3885. " albosparsus Broun.

3886. .. pallidipes Broun.

3887. .. Haviventris Broun.

$3888 . \quad$, nigricans Broun.

3889. Brachyolus bicostatus Broun.

$3890 . \quad$. $\quad$ terricola Broun.

3891. Bryodrassus miricollis Broun.

3892. Inophloeus fuscatus Broun.

3893. ". collinus Broun.

RHYPAROSOMIDAE.

3894. Lithocia ciligera Broun.

389). .. setirostris Broun.

3896 . .. basalis Broun.

3897. .. rectisetosa Broun.

3898. " nigrierista Broun.

3899. Abrotheus placitus Broun.

3900. Halliella squamipes Broun.

3901 . .. antennalis Broun.

3902 . . . longicollis Broun.

3903. Bantiades morosus Broun.

3904. . "eylindricus Broun.

3905. " notatus Broun.

3906. Abantiades gratulus Broun.

3907. Rachidiscodes altipennis Broun.

3908. Allaorops carinatus Broun.

3909. Clypeorhynchus clarulus Broun.

3910. merus Broun.

$3911 . \quad$.. setosus Broun.

3912. .. nitidellus Broun.

3913., halli Broun.

3914. Dermotrichus multicristatus Bronen.

3915. ," elegantalis Broun.

3916. Phygothalpus philpotti Broun.

$3917 . \quad$.. granissimus Broun.

3!)18. " suleipennis Broun.

3919. Nestrius sulcirostris Brom.

3920 . " prolixus Broun.

3921. Inososgenes longiventris Broun.

3922. Sosgenes discalis Broun.

3923. Rystheus notabilis Broun.

3924. Toeris pascoi Broun.

\section{TOLYTID A}

3925. Lyperobius aciphyllae Broun.

3926. . fallax Broun.

$3927 . \quad, \quad$ spedenii Brom.

13*-Bull. No. 1
ERIRHINIDAE.

3928. Erirhinus celmisiae Broun. 3929. Eugnomus bryobius Broun. 3930. ", alternans Broun. 3931. " tristis Broun.

3932. Oreocharis fasciata Broun.

393:3. ., congruens Broun.

C'RYPTORHY YCHIDAE.

39:34. Tychanus lunalis Broun.

3935. Eetopsis foveigerus Broun.

3936. Getacalles baccatellus Broun.

3937. „, foveiceps Broun.

3938. Crisius posticalis Broun.

3939. Xenacalles nigricans Broun.

3940. Keacalles speciosus Broun.

3941. Acalles sternalis Broun.

3942. ", nodigerus Broun.

3943. .. zenomorphus Broun.

3944. .. dentigerus Broun.

Cossontdate.

3945. Allaorus impressus Broun.

\section{LAMIIDAF.}

3946. Somatidia spectabilis Broun.

3947. . flavidorsis Broun.

$3948 . \quad$.. suffusa Broun.

3949 . . . femoralis Broun.

$3950 . \quad$.. $\quad$ oscillans Broun.

3951. " ". obesula Broun.

3952. .. laevinotata Broun.

3953. .. parvula Broun.

Cryptocephalmate.

3954. Bryobate: rugidorsis Broun.

ChrysomeltuAt.

395.5. Allocharis praestans Broun.

$3956 . \quad$.. subsuleata Broun.

$3957 . \quad$., nigricollis Broun.

3958. .. picticornis Broun.

3959. .. media Broun.

$3960 . \quad$.. fuscipes Bronen,

3961. . robusta Broun.

396.. ,, tarsalis Broun.

3963. Caccomolpus nigristernis Broun.

$3964 . \quad$.. $\quad$ hallianus Broun.

3965. $\quad$.. $\quad$ tuscieornis Broun.

$3966 . \quad$.. $\quad$ substriatus Broun.

$3967 . \quad$.. $\quad$ tibialis Broun.

39ks. .. virideseens Broun.

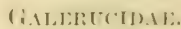

3969. Allastena eminens Broun.

3970. Luperus halli Broum.

3971. .. dilucidus Broun.

3972. .. eyanescens Broun.

3973. .. gracilipes Broun.

$3974 . \quad$.. minor Broun.

$3975 . \quad$.. quadricollis Broun.

$3976 . \quad$.. $\quad$ xenoscelis Broun.

3977. .. perplexus Broun.

3978 . . $\quad$ pygidialis Broun.

3979. .. medineris Broun. 


\section{Group Cicindelidae.}

3783. Cicindela halli sp. nov. Cicimlela Limné, Man. N.Z. ('oleopt., p. 1.

"Subdepressed, oblong, subopacque; head and thorax viridescent, the forehead bright metallic green.

Head broadly depressed between the prominent eyes, finely longitudinally strigose alongside these, elsewhere densely but more finely seulptured thain in C. tuberculata. Thorax a fourth broader than long, base and apex slightly sinuate towards the sides so that both appear a little prominent in the middle. its sides finely ret definitely margined and moderately rounded: it is obliquely impressed in front, transversely and more deeply at the base, the median stria becomes obsolete before the middle, and the dise. though densely, is even more fuely seulptured than the head. Elytra very gradually narrowed towards the base but evidently broader there than the thorax, almost four times its length; they are without tubercles, the general sround-colour is purplish-brown variegated with numerous shallow cyaneous punctiform spots, the larger spots are greenish-blue but more or less rufescent or brassy in the centre, they are less numerous but much more inegularly distributed than the others: the humeral lunule extends but little inwardly and is distinetly separated from the whitish, often pale testaceous, lateral band which, behind the middle, is prolonged inwardly and then bent backwards near the suture, the lateral space between the broad apical and median portions is much narrowed, occasionally interrupted; all the pale band, on each elytron, is distinctly punctate, and its apical portion has several obvious, round, viridescent or fuscous spots.

The slender white setae are more concentrated on the basal 3 joints of the anterior tarsi of the male, and on the forehead, than on the rest of the head, the basal joints of the antemne, the thorax and legs, and a few can be seen on the elytra; there are many on the sternum and along the sides and extremity of the abdomen.

Labrum usually pale fuscous, a little sinuate towards the rounded angles, and with a distinct median tooth in front.

Male.-Elytra with a slight noteh at the imner extremity and short sutural spines.

Fem.-Apices of elytra obtuse, with a distinct gap between them there, the sutural spines do no project further than the front of the gap.

Abundantly distinct from 3504, and all the older species from 1 to 10 , as well as 1451 and 1757. Three species described by Dr. W. Horn, of Berlin (I)eutsche lint. Toits., January, 1892 and 1900), (Y. incognita, C. noeve seelandica, and C. circumpictoitles, also differ in appearance and sexual details, so far as I can judge he the (reman deseriptions, which were kindly translated for me by Professor Chilton. It is probable that one or two of these species were not found in New Zealand.

\section{Group Cnemacanthidae.}

3784. Mecodema laterale sp. nov. Mecodema Blanchard, Man. N.\%. Colcopt., p. 7.

Elongate, only moderately convex; black, palpi, tarsi, and antennae piceous; head and thorax shining, elytra less so.

Head narrower than thorax, with prominent eyes, deeply longitudinally sulcate in fromt, irregularly and somewhat transwersely near the sides, almost smooth on the middle, distinetly rugosely punctate hehind. with a setigerous 
puncture near each eye and on the side of the forehead. Thorax of about equal length and breadth, base and apex subtruncate, its indefinitely crenulate sides rather wider near the front than elsewhere, gradually narrowed backwards, more strongly behind the middle, nearly straight at the base, and with distinct, rectangular, subacute angles there; dise nearly plane, obsoletely transversely striate, with many short, distinct, longitudinal striae in front, those near the base less regular, the central channel well marked but not attaining the base or apex; basal fossae rather large and deep, a third of the entire length, more or less rugosely punctate, similar but finer sculpture exists near the anterior angles, and near each side, before the middle, there is a more ol: less obvious fovea: the lateral rhannels are somewhat expanded in front. Elytra oblong-oval, rather more than double the length of thorax, a third broader, with curvedy narrowed shoulders: they slope gradually towards the sides, so that the margins and nearly Hat chamnels are quite onspicuous throughout when looked at from above; they are not pereeptibly striate, but each has 4 inner series of fine punctures. the 5th and 6th are slightly enarser, and the latter is bordered externally $\mathrm{b}$ an indefinite costa, the lateral 3 series of punctures are more irregular and a little larger but neither very deep nor coarse, and the usual smooth space near the side is absent or hardly discernible: interstices nearly plane, with dense, fine coriaceous sculpture.

Legs moderately stout, anterior and intermediate tibiae somewhat prominent at the outer extremity, posterior simple. Antemae pubescent from the 5th joint onwards, their last joint reaches the middle of the thorax.

Thderside glossy black, the sides of the breast and basal rentral segment more or less irregularly but not coarsely punctured, remaining segments finely transversely strigose, the teminal with a pair of apical punctures at each side of the middle.

A careful examination of the elytra, of their sides particularly, will at once enable students to separate this from our recorded species.

Length, 30-32 $\mathrm{mm}$. ; breadth, $10 \mathrm{~mm}$.

Hollyford, worth-west of Lake Wakatipu. Mr. T. Hall found four, half of them damaged, at a height of $3,500 \mathrm{ft}$., on the 19th February, 1914.

\section{Mecodema chiltoni sp. nov.}

Elongate, moderately onver and nitid: black, tips of palpi rufescent, elytral interstices faintly so.

Head narrower than the thoracic apex, with longitudinal rugae in front and a few irregular ones near the prominent eres, elsewhere smooth and impunctate. Thorax a fourth broader than long, base and apex subtruncate and with fine ferruginous eilia, verv gradually narowed from the front backwards, somewhat abruptly contracted near the base, but without sharply defined angles there: dise apparently smonth, the central groove well marked but hardly reaching the base or ajex, basal fossate rather small lateral margins simple, the channels rather broader in front than behind Elytra clongate, rather wider than the thorax and almost thrice its length each tricostate, 3rd little more than half the breadth of the lst and with 4 or 5 punctures, the intermediate sometimes bipunctate: between these and the almost exually rostiform suture there are double series of rather indistinct fine punctures. on the interval between the $3 \mathrm{rd}$ costa and the usual smooth sublateral space the punctation is very irregular. and, though coarser, not very deep; the whole senlpture becomes indistinet near the extremity. 
Legs and antennae and the setigerons punctures on the head similar to those of $M$. laterale.

Linderide shining moderately finely lout not closely punctate near the cides of the sternum and hasal aldominal segment, teminal segment quadripunctate at the apex.

II. costellum (2595), from Stephen Istand, is of about "qual siz": in it. however, the seulpture of the head and thorax is very different, the eletral costae are much less elevated and almost linear, and the interstices are distinctly, closely, and irregularly punctured.

M. costipenne (3388) is obviously less elongate, the sculpture of the head and thorax is dissimilar, the sides of the latter are almost regularly "urvedly narrowed backwards so that the basal angles arre almost obsolete. and the pmetation of the elytral interstices more nearly resembles that of 1I. costellum.

Length, $36 \mathrm{~mm}$; ; breadth, $11 \mathrm{~mm}$.

Mount Dick, Lake Wakatipu. One found on the 11th March, 1914, by Mr. T'. Hall, who shares my pleasure in being able to name this handsome insect in honour of Professor Charles Chilton.

\section{Mecodema politanum sp. nov.}

Oblong, slightly convex; very brilliant black, antemnae, tarsi, and palpi piceous, these last paler at the extremity.

Head, including the prominent eyes, as broad as the front of thorax, almost quite smooth, having only a few minute seattered punctures behind: there are no interocular rugae, and only a single broad groove on each -ide of the forehead: when under a powerful lens many minute puncture may be detected. Thorax of almost equal length and breadth, widely but not deeply ineurved in front, base subtruncate; sides finely crenulate, gently curved, distinetly narrowed behind the middle, deeply sinuate near the base, with subacute prominent angles; dise apparently smooth, with some very short basal striae, a slight impression near each anterior angle, and the common abbreviated discal groove, basal fossae deep, neither rotundate nor very elongate. Elytra oblong-oval, rather broader than thorax, not thrice its length, nearly as broad behind as at the middle; on

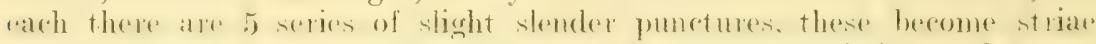
hehind but obsolete at the base, 6th series rather more distinet and deeper and separated from the 7 th by the subcostate interval, the 7 th and 8 th form somewhat irregular but distinctly though not very coarsely punctured striae; the side is smooth above but has some coarse distant punctures below, the apical sculpture is irregular and coarsely punctiform; the dorsal interstices are plane, but the 7 th has 3 or 4 very conspicuons punctiform impressions.

Legs stout, posterior tibiae simple, the other's prominent at the outer (extremity. Last 6 joints of antennae obviously pubescent.

Underside glossy, nearly smooth, having only a few fine shallow punctures, last segment of abdomen with fine transverse wrinkles and quadripunctate at apex. Mentum obtusely convex in the middle, with a deep frontal puncture, but not distinctly bifid there.

Readily distinguishable from $M$. laevicolle (3166) by its broader form,

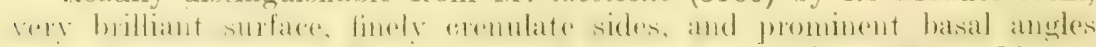
of the thorax, and different elytral sculpture; and from $M$. ambigum (3682) by its lustre, deeply simuate sides and prominent posterior angles of 
thorax, rather broader and less attenuate hind-body, conspicuous punctiform impressions on the 7 th interstices, almost smooth prosternum, and crenulate thoracic margins, \&c.

o. Length, $24 \mathrm{~mm}$.; breadth, $8 \mathrm{~mm}$.

Stairease, southern part of Remarkahles, near Lake Wakatipu. One only, found by Mr. T. Hall, at an elevation of $3,500 \mathrm{ft}$. on the 15 th March, 1914.

\section{Mecodema rubripes sp. nov.}

Elongate, narrow, moderately convex, brilliant aeneo-niger ; the femora, front pairs of coxae, posterior trochanters, and glabrous hasal joints of antemnae rufous: remaining joints of these last. the tibiae, and tarsi mores or less rufo-piceous.

Head namower than front of thorax, a third shorter, somewhat closely and distinctly punctate in line with the only moderately prominent eyes, alsewhere almost quite smooth; epistome widely emarginate, broadly tri-impressed; labrum short, subtruncate in front. Thorax slightly longer than broad but appearing elongate, hase and apex somewhat cmarginate: lateral margins simple, gently curvedly natrowed backwards. but contracted and straight-sided at the base, with rectangular angles there; disc nearly smooth, median sroove, in some aspects, apparently not abbreviated, there is a slight transverse impression near the front, this is more or less distinctly punstured, hasal region similatly punctate, with rather elongate and deep fossae. Elytra double the length of thorax, rather broader than it is even at the base, gradually narrowed behind; on each there are 6 moderately deep, irregularly interrupted dorsal striae, which, on some parts, seem to consist of unequal series of punctures, the 7 th and 8 th are nearly similar; 31 d and 5th interstices evidently broader than the others, 7 th with 1 or 5 setigerous punctures, the lateral space almost smooth, the suture and interstices are more ox less costiform and confluent near the apex.

Underside glossy. Prosternum nearly smooth on the middle, rather roarsely and elosely punctured elsewhere, mesosternum similarly sculptured throughout, metasternum less deeply; the abdomen with elongate impressions near the sides.

Palpi, tibiae, and antennae of normal strueture, the terminal 6 joints of these last less thickly pubescent than usual.

$\hat{\jmath}$. Length, $14 \frac{1}{2} \mathrm{~mm}$.; breadth, $4 \mathrm{~mm}$.

Stewart Island. The sole representative of this edsily recognized species has lost an antenna and foreleg. It was discovered by $\mathrm{Ir}_{\mathrm{r}}$. $\mathrm{W}$. Traill in 1913, and forwarded recently to me by Professor Chilton.

3788. Mecodema erraticum sp. nov. piceous.

Lilongate, moderately convex; glossy black, antemne, tarsi, and palpi

Head narrower than thorax, with irregular interocular rugae, vertex smooth. forehead indistinctly suleate: labrum slightly romeled. broadly medially imperesed behind. 'Thorax rery litte broader than longe, base and apex subtrunsate, its sides evenly margined. indistinctly erenulate, a little romded, moderately auredly namowed behind the midelle. more so. but not abruptly, near the base, with obtuse posterior andeste dise crenly convex, with a few obsolete transverse striae, base and apex with short but not deep fongitudinal ones. basal fossale rather small and shallow. with 
a few rugae or punctures near each, mesial groove almost entire. Elytra oblong-oval, more narrowed near the base than behind, their shoulders cbsolete and but little broader than the base of thorax, their whole length quite twice that of the thorax: abch with siseries of moderately fine distant punctures; these are a little more irregular but only slightly coarser neal the sides, but beeome rather eoarser and more irregular near the apex: interstices nearly plane, with some fine aremblate impressions which berome more distinct behind.

Underside shining. Head more irregularly regose than the prosternum. Terminal abdominal segment with a single puncture at each side of the middle, at its extremity.

Legs rather stout, and, like the antennae, quite normal. Lyes prominent.

The nearest species, $\boldsymbol{M}$. aeneoniger (1453), is more brilliant and slender and considerably nore attenuate posteriorly; the elytral punctation is more irregular and remote, and the 5th and 6th series are obsolete; it, moreover, has very obvious rugae on the forehead.

o. Length, $17 \mathrm{~mm}$. ; breadth, $50.1 \mathrm{~mm}$.

Clipping's, about seven miles north-east of Kingston. One caught rumning on a track during bright sunshine by Mr. T. Hall on the 28 th January, 1914

\section{Mecodema gratum sp. nov.}

Elongate, narrow, moderately convex; glossy aeneo-niger, antennas, tarsi, and palpi piceous, terminal joints of these last rufescent.

Head, inchding the moderately prominent eres. as broad an the thoraris apex, usually indistinctly leneitudinally striate in front, distinctly punctured behind the eres, with irregular interosular rugate. the pristome wide emarginate. Thorax subelongate, yet hardly any longer than broad, base and apex widely but not deeply emarginate. lateral marems narmo. rot crenulate, very gently curvedly narrowed backwards, more, but not at all abruptly, narrowed towards the nearly straight sides of the base, with subrectangular angles there; basal fossae moderately deep and elongate, the intervening spare punctate, the rest of its surfare smooth. dorsal groowe hardly attaining the apex. Elytra double the length of thorax, rather wider than it is at the base; cach elytron with 8 series of rather fine, mostiy elongate, unequal punctiform impressions; these usually become finer towards the sides but coarser behind: between the 7 th and 8 th there are 2 or 3 larger punctures behind and another near the base; interstices smooth but not at all sharply defined, the lateral space nearly smooth but with some larger punctures near the margin.

Underside closely and rugosely punctate near the sides, mesostemum wholly so, abdomen less distinetly, its terminal segment with some well. malked transterse striae and hipunetate near each side of the alpex.

Outer angles of anterior and middle tibiae only moderately prominent, the posterior simple; last 6 joints of antennae thinly pubescent.

'This is undoubtedly distinet from $M$. erraticum, being not only much smaller and more erlindrical. but also differenty seulptumed. The thomax appear more clongate. and is without longitudinal sulei at the batse or the apex, its fossae are deeper and more elongate, its sides are simple, and the elytral senlpture much more irregular. Sometimes there are a few indistinct punctures near the front angles of the thorax.

o. Length, $14 \mathrm{~mm}$. ; breadth, $3 \frac{3}{4}-4 \mathrm{~mm}$. 
Mount Alfred, near Paradise, north of Lake Wakatipu, at elevations of from $200 \mathrm{ft}$. to $3,000 \mathrm{ft}$. Three examples from Mr. T. Hall between the 4 th and 9th February, 1914, and another from Harris Saddle farther north-west.

\section{Mecodema latulum sp, nov.}

Oblong, slightly convex, nitid; black, legs and antennae piceous.

Head, including the moderately prominent eyes, equalling the thoracic apex in width; vertex minutely and distantly, occiput distinctly and closely punctate; interocular striae subtransversal and shallow, epistome very minutely and densely punctured, its longitudinal grooves not deep. Thorax moderately incurved in front, quite truncate at the base, a sixth broader than long in the middle; its sides indistinctly crenulate and moderately rounded, distinctly but not abruptly narrowed behind the middle, the base with straight sides and rectangular angles; disc nearly plane, with shallow striae across it, base and apex without well-marked longitudinal ones, the latter with a few punctiform impressions near its angles, basal fossae deep but not elongate. Elytra more than double the length of thorax, a sixth broader, slightly narrowed towards, yet rather broader than, the base of the thorax, hardly at all narrower behind; they are finely substriate-punctate near the suture, with plane interstices; the outer 4 series, 6th and 7th particularly, are more deeply, though not very coarsely, punctate-striate, with convex interstices; sublateral space smooth above, but rather coarsely and irregularly punctate below; apical sculpture irregular and coarser than that of the disc.

Legs, antennae, and palpi normal.

Prosternum nearly smooth along the middle, its flanks distinctly and moderately closely punctured, sides of mesosternum more closely, metasternum nearly smooth, sides of abdomen with fine irregular wrinkles, apex of last segment bipunctate at each side of the middle.

In shape somewhat similar to $\boldsymbol{M}$. huttense (3680), but much less narrowed posteriorly, and with very different sculpture.

†. Length, $22 \mathrm{~mm}$.; breadth, $7 \mathrm{~mm}$.

Ben Lomond. One discovered by Mr. T. Hall on the 3rd March, 1914, at a height of about $4,000 \mathrm{ft}$.

\section{Mecodema affinum sp. nov.} below.

Nearly related to $\boldsymbol{M}$. latulum, but differing therefrom as detailed

Body less shining. Thorax rather more rounded, slightly wider at the middle than elsewhere ahruptly contracted at the hase; smosth above, with very few fine punctures near its anterior angles. Elytra rather more narrowed behind, with well-marked regular striae; these are quite distinctly and regularly punetured throughout, the outer ones rather more coarsely; 3rd interstices rather broader than the of hers, and, like the suture, subeostate behind, 6th and 7 th quite costiform. sth still narrower. all more or less confluent behind.

ㅇ. Length, $23 \mathrm{~mm}$. ; breadth, $7 \frac{1}{2} \mathrm{~mm}$.

Mount Dick, west of Lake Wakatipu, near Kingston. Tnique. Found by Mr. T. Hall, at an elevation of $2.500 \mathrm{ft}$, on the 27 th February, 1914. 


\section{Mecodema indiscretum sp. nov.}

Oblong, slightly nitid.

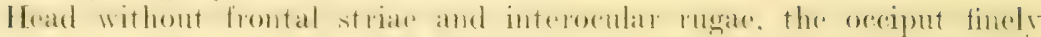
but not closely punctured. 'l'horax with simple and rather narrow margins, smooth above. Elytra rather broader behind than in $\mathbf{M}$. affimm, not at all distinctly punctate-striate.

Distinguishable from $M$. latulum by its emarginate base, narrow lateral margins, and smooth dise of the thorax. The elytral seulpture is nearly similar, being finely substriate-punctate near the suture, but the 6th striae

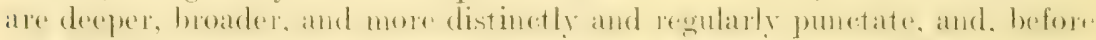
the middle. ale obviously and eoalsely quadripmetate. The labrum. instead of being plane, has a broad, oblong, central groove.

These are not sexual variations, as the types of $M$. latulum, $\boldsymbol{M}$. affimum. as well as this species are females.

․ Length, $24 \mathrm{~mm}$; breadth, $8 \mathrm{~mm}$.

Mount Eamslaw, north of Lake Wakatipu. A single specimen found by Mr. 'T. Hall on the 6th February, 1914.

\section{Mecodema trailli sp. nov.}

Elongate, only moderately convex, nitid; black, antemnae and legs piceous.

Head rather narrower than thoracie apex, with deep longitudinal frontal sulci, those near the eyes also deep but irregular, and between these latter there are some fine transversal ones; it is elosely and distinctly punctured behind the eyes but smooth at its base. Thorax a fifth broader than long, base and apex subtruncate, its sides slightly crenulate, moderately

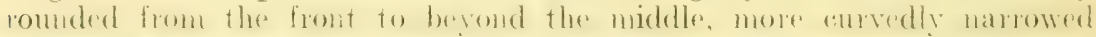
behind. its base more rontracted. with almost straight sides and obtuseds restangular angles; the surfare with rery fine striat arosis it. basal and apical longitudinal striae quite obsolete; there is a foveiform impression near each anterior angle, mesial groove nearly entire, basal fossae deep and moderately clongate. Elytra clomgatr-oval, a good deal namowed

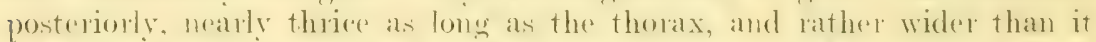
is at the base; their striare regular, almost equally finely punctured from the suture to the sides, the 7 th with 3 or 4 rather larger setigerous punctures, their sides nealy vertical, with shallow indefinite imperescions; interstices nearly plane near the suture, moderately convex towate the siden: the apical seulpture irregular.

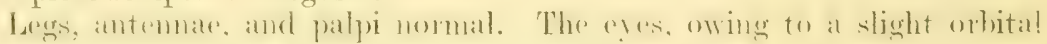
dilatation underneath, appear less prominent than usual.

Thderside shining. Prosternum smeoth on the middle. its flanh:moderately punctured, sides of mesosternum more closely, abdomen furely and irmenalaly whinked, fongitudinally at the sides, its last segment transversely, its apex with 3 setigerous punctures near one side but only 2 at the other.

This bears more resemblance to the northem $M$. scitulum (2593), measuring $29 \mathrm{~mm}$. by $9 \mathrm{~mm}$., than to any South Island species. The present species is much more slender, its thorax is relatively broader, more contracted at the base, and the lateral chamels are no wider in front than behind the middle: the antennae and legs are a little stouter, and the sculpture of the underside differs considerably.

ô. Length, $25 \mathrm{~mm}$.; breadth, 7! $\mathrm{mm}$. 
Stewart Island, 5th October', 1914. 'This is the second species now known to occur there, both discovered by Mr. Wr. Traill, whose name is attached to this one.

\section{Mecodema mutabile sp. nov.}

Elongate, slightly convex, shining; black, legs and antennae piceous.

Head and mandibles rather longer than thorax and, inchding the prominent eyes, as broad as it is; occiput very distinctly and moderately closely punctured, the punctation extends forward as far as the antennae, but it is funer, more irregular and distant there, interocular rugae and frontal striae also irregnlar. Thorax of about equal length and breadth, a little emarginate at base and apex, its sides indistinctly crenulate, nearly straight or only slightly eurved as far as the middle, curvedly narrowed behind it. the base contracted, with short straight sides and rectangular angles; disc: nearly smooth, its mesial groove abbreviated, basal fossae deep but not elongate; the basal region, sides, and sometimes the front distinetly but irregularly punctured, in some specimens there are a few fine purctures along the middle; lateral rims a little expanded and impressed in front. Elytia oblong-oval, not thrice the length of thorax, rather broader than it is at the base, moderately narrowed behind; each with 6 dorsal, moderately well-marked and punctured striae, the 6th with deeper and more quadrate punctures; intersices nearly plane, but especially behind, with numerous irregular serateh-like marks; 7th interstice costiform, the outer series of punctures more irregular and coarser than the 6th, the sublateral smooth space is costiform, the side is vertical, with many punctiform impressions, the apical sculpture is rather shallow.

Prosternum nearly smooth along the middle, its flanks distinctly and somewhat rugosely punctured, mesosternum more closely; metasternum and abdomen more finely and irregularly, terminal segment transversely finely striate, quadripunctate at apex.

This species is the most common near Lake Wakatipu, and exhibits much variation. In some individuals the thorax has fine transverse striae, in other's it is almost impunctate, but the sculpture of the elytra is nearly always the same.

o. Length, $25 \mathrm{~mm}$; breadth, $7 \frac{1}{2} \mathrm{~mm}$.

Mount Dick, Ben Lomond, Mounts Earnslaw and Alfred. Several found by Mr. T. Hall between the 25th January and 17th Narch, 1914.

3795. Mecodema gordonense sp. nov.

Robust, subdepressed, nitid; nigrescent, somewhat bronzed, legs and antennae nigro-piceous.

Head coarsely and deeply longitudinally rugose in front, irregularly near the eyes, bohind these very irregularly winkled and rather coarsely punctate; labrum medially emarginate. Thorax a fifth broader than long, base and apex only slightly emarginate, gradually curvedly natrowed from the front to behind the middle, considerably contracted behind, with straight sides at the base, which has rectangular angles; lateral margins moderately erenulate, rather thick and reflexed, the channels concare and slightly broader in front; diseal groove distinct, attaining the base and apex, both moderately longitudinally striate, the dise rather funcly irregularly transversely striate, more deeply near the sides; basal foreac deep, the oblique impression near each slightly prominent anterior angle rather shallow. 
Elytra oblong-oval, a little wider than thorax at the base, nearly thrice its length; along each olvtron there are these somewhat indefinite. irregulas. smooth dorsal lines, these are distinct at the base but become obsolete behind; the sculptwre between the suture and 2nd is irregularly but not deeply punctiform, that beyond consists of more or less transverse but very irregular impressions, these are sometimes divided into suboblong areas by smooth, transerse. linear commetions between the and and 3rol longitudinal lines; the common smooth costa near the side is narrow, it does not reach the apex, and, before the middle, is quite obliterated by the coarse lateral sculpture.

At first sight, owing to the elytral sculpture, this may seem like $M$. lewisi (2604), but as the thoracic margins are crenulate it really belongs to a different seetion of the genus. The thorax is differently shated. and instead of having rathere thin, nearly Hat lateral margins as in M. lewisi. they are thicker and slightly reflexed.

Length, $34-37 \mathrm{~mm}$; breadth, 10-11 $\mathrm{mm}$.

Gordon's Knob, near Belgrove. Four individuals received from Mr. 1. Hall, who spent three days on the mountain in November, 1914.

\section{Diglymma basale sp. nor. Diglymma shanp. Man. N.Z. Coleopt. p. 980 .}

Elongate, narrow, moderately convex, nitid; black, mandibles, legs, and antennae rufo-piceous, tarsi and palpi more rufescent.

Head nearly as broad as front of thorax, somewhat depressed and punctate behind the eyes, generally with a few finer punctures alongside the broad plical near each ere. Thorax apparently elongate, really of almost equal length and hrodelo, hase and apex truncate. its sides distinctly and erenly margined, moderately romded. more strongly behind so that the straight-sided bise seems it gond doal rontrated. posterion angles rectangular; dise almost smooth. having mly some fereble. oftert obsolete striae aerosis it, hasal fossae elongate and deep and situated elow to the sides, the intervening space finely and sparingly punctured, the middle of the apex with similar punctures and obedete longitudinal strias. mesial groove well marked but not reaching the base or apex. Elytra oblong-oval. double the length of thorax, broader near the middle. their whoulders gently enred, ret a little wider than the thoracic base and with rather thicker margins than the sides; their funely but distinetly punctured striae are moderately deep near the suture, sometimes obsolete near the apices, the sides with several large punctures; interstices almost plane.

Intermediate tibare slender at the base, expanded below the middle.

Underside shining. Flanks of prosternum rather distantly punctate: the abedomen less distinetly near the sides. apex of last segment quadripunctate.

D. marginale (3507) is distinguishable by the long sinuation of the side of the thorax towards the more sharply marked posterior angle, by the

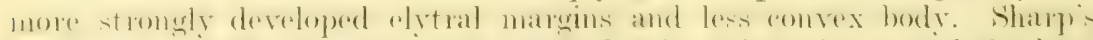
I). oriperene (1766) has apparently more deeply striate elytrat, and the base of the thorax and its angles seem different.

Length, 12-15 $\mathrm{mm}$. ; breadth, 4-5 $\mathrm{mm}$.

Ben Lomond, Nount Alfred, and Routeburn. Several specimens were found by Mr. 'T'. IIall, at elevations of $2,000 \mathrm{ft}$. to $1.000 \mathrm{ft}$, during Fehruary. 1914. 
3797. Diglymma thoracicum sp. nov.

Elongate, moderately convex and nitid; piceo-niger, legs and antemna" piceo-rufus; palpi castaneous, all the joints testaceous at the extremity.

Head, eyes included, only a fifth narrower than the middle of thorax, depressed and with a series of moderate punctures behind the eyes, the vertex minutely, indistinctly, and distantly punctate; labrum deeply medially emarginate. Thorax elongate, just an eighth broader than long, hase and apex truncate, its sides distinctly and evenly marginate, very slightly rounded, more evidently, but not at all abruptly, near the base so that its angles are obsolete; discal channel apparently entire when examined from above, a little shallower near the base and apex, with some scattered but not coarse punctures across the base and front, basal fossar deep and elongate. Elytra nearly thrice the length of thorax, a third broader before the middle than it is, gradually but obviously narrower behind that point, apices not at all broad, lateral margins distinct, rather more so near the curvedly narrowed shoulders; their striae rather fine yet quite definite nearly to the extremity, they are finely but not closely punctured; interstices simple, the sides with about 5 coarse setigerous punctures.

Terminal articulations of maxillary palpi quite elongate-oval, obtuse at the extremity, less slender than those of Sharp's $D$. ovipenne or $D$. dubium.

Antennae pubescent from the 4 th joint onwards, extending to the middle of the thorax, joints 5-10 submoniliform.

After carefully comparing the only available specinen, a female saturated with alcohol, with all the types in my collection I failed to find any exactly like it. D. obtusum (1454), D. punctipenne (1768). and others with obtuse or obsolete posterior thoracic angles present more or less distinct disparities. $D$. basale, and others belonging to the same section, can be readily separated by looking at the hind angles of the thorax.

Length, $10 \mathrm{~mm}$.; breadth, $3 \frac{1}{3} \mathrm{~mm}$.

Stewart Island. Described from a single female found during the summer of 1913 by Mr. W. Trail.

\section{Group LicinidaE.}

3798. Dichrochile insignis sp. nov. Dichrochite Guérin, Man. N.Z. Coleopt., p. 16.

Suboblong, moderately convex, nitid; black, femora piceous: tibiae. tarsi, antennae, epistome, and labrum more or less piceo-rufous; palpi fusco-fulvous.

Head and eyes as broad as front of thorax, oviform, somenhat uneven. finely obliquely wrinkled and opaque between the "yes. Thorax quite cordate, a third broader than long, its apex widely emarginate. so that the obtuse angles extend forwards beyond it; the sides with reflexed well-developed margins, evidently rounded as far as the middle, rather deeply sinuate towards the subrectangular and slightly prominent angles. base medially incurved; its surface somewhat uneveri. basal fossace large. situated between the middle and sides, sometimes intermptedly prolonged nearly to the apex, mesial furrow deep, abbreviated in front. Elytra. oblong-oval, thrice the length and nearly double the width of thorax. broader than it is at the base, curvedly narrowed but not sinuate posteriorly, with broadly rounded apices; their impunctate striae deep near 
the suture. with slightly convex interstices there, especially behind, the 3rd usually bipunctate; the outer striae more slender, with flatter interstices, lateral margins reflexed, with narrow chammels before the middle, and just above these there is an irregular series of large punctiform impressions on each; scutellar striae well marked.

The strongly sinuate sides, and unnsually prominent posterior angles of the thorax, rather convex hind-body, and the individually broadly romded apices render this species abundantly distinct.

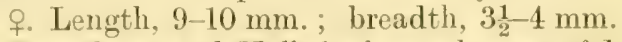

Routeburn and Hollyford, north-west of Lake Wakatipu. Two females obtained by Mr. 'I'. Hall in February, 1914.

Obs. It S'areliff, Mistake Basin, and Mount Algidus, over fifty miles west of Methven, in Canterbury, Mr. Hall found three specimens, one of them a male, measuring $10 \mathrm{~mm}$. by $4 \frac{1}{2} \mathrm{~mm}$. These are not satisfactorily differentiated from the larger type of $D$. thoracica (2662), and are therefore labelled "var. 2662." All the species of the genus are very rare.

\section{Dichrochile rugicollis sp. nov.}

Subdepressed, oblong, nitid; black, tarsi rufo-piceous.

Head and large eyes slightly broader than front of thorax, nearly smooth on the middle, with numerous fine yet distinct irregular striae. Thorax transverse, a third broader than long, widest just before the middle, a little rounded there, gradually and slightly narrowed behind, its base subtruneate but slightly curved and oblique at the sides so that its angles are obtuse. apex widely but not depply emarginate; disc with fine transverse striae. the base densely finely irregularly longitudinally striate, the apex more deeply but less closely; basal fossae large but not sharply limited so that the sides appear unevenly depressed. Elytra oblong, more than thrice the length of thorax, a fourth broader, with curvedly narrowed shoulders, and oblique, distinctly sinuate apices; each has 6 moderately deep, obsoletely punctate striae, and slightly ennex interstices, the 3 rd are bipmetate.

Doubtless closely allied to $D$. aterrima (37), but as Bates in his description does not allude to the sculpture of the head and thorax, which he would not be likely to disregard, and as the elytral apices are evidently sinuate, I think this must be a valid species.

․ Length, $10 \mathrm{~mm}$.; breadth, nearly $4 \mathrm{~mm}$.

Oakden, near Mount Algidus. One found by Mr. 'T'. Hall or Mr. Roderick Urquhart when collecting together on the latter's property on the 9th October. 1913.

\section{Dichrochile flavipes sp. nov.}

Oblong-oval, subdepressed, nitid, head and thorax rather less so ; these are infuseate-black, elytra fusco-castaneous, sides of the latter and of the thorax flavo-fuscous; legs, antennae, palpi, and labrum more or less testaceous, mandibles rufescent.

Head longer but rather narrower than thorax, with a single setigerous puncture near the inner and back part of each eye. Thorax widely emarcrinate in frout. the batse more derely in the middle, the length between these only half of the greatest width, at or just before the middle, moderately rouredly narrowed anteriorly. aradually narowed behind: posterior angles obtuse but not broadly romded, the anterior some what prominent; dise feebly iregularly striate. sometimes longitudinally near the middle of 
the base and apex. mesial groove distinct but not reaching the front, basal impressions shallow and rather broad. Elytra four times the length of the middle of thorax, a third broader, with rounded shoulders, obliguely narrowed towards the singly rounded, not at all prolonged apices; thejp striae though distinct are slender and very finely and indistinctly punctured, they become deeper behind ; interstices plane, the sod usually tripunetate: there are no pereeptible seutellar strolade, the dorsal striae are indistinct at the base.

D. cephalotes (2660) most nearly resembles this species, which, however, is smaller, the head especially; the coloration differs; the thoracic apex is more deeply ('marginate so that its angles are more advaneed, the basal foveare are not at all linear, and its hind angles are less rounded, the lateral margins are finer and but little reflexed. The minute dense sculpture is only visible under the microscope.

Length, 8-8 $\frac{1}{2} \mathrm{~mm}$.; breadth, $3 \frac{1}{2} \mathrm{~mm}$.

Gordon's Knob, near Belgrove; 15th November, 1914; Mr. Hall spent three days on the mountain during bad weather, but seceured two speeneme.

\section{Group Feronidae.}

3801. Pterostichus aciphyllae sp. nov. Pterostichus Bonelli, Man. N.Z. Coleopt., p. 31.

Oblong, moderately convex; plain shining black, legs and antennae nigro-piceous, tips of the palpi rufescent.

Head and eyes almost as broad as front of thorax, its surface nearly smooth, with elongate frontal impressions, the genae somewhat swollen beneath the eres; labrum truncate or slightly emarginate. Thorax somewhat emarginate at base and apex, a third broader than long, its sides with reflexed margins. moderately rounder to behind the middle. sradually. narrowed and a little sinuate towards the rectangular posterior angles: smooth, or with faint striae across it, the mesial groove apparently reaching both base and apex, there is a shallow impression near each anterior angle, basal fossae well marked. Scutellum striate at base. Elytra oblongoval, with dentiform shoulders, which are a little wider than base of thorax. they are almost thrice its length, rather strongly sinuate and narrewed near the extremity; each with a short scutellar and 7 finely yet quite distinctly punctate, rather deep, not at all filiform striae; interstices moderately convex, the 3 rd with 3 , the 7 th with 5 or 6 setigerous punctures, 7th stria less regular; latexal margins slightly reflexed, the sides more expanded and flattenes behind and with several large punctiform impressions.

Underside nearly smooth, with some fine short irregular rugae, also on the femora, terminal segment quadripunctate at the apex.

Intermediate tibiae with the hind margin bent inwardly and acutely prolonged at the extremity.

Much less robust than P. pescoi (3686), in which the median sroove of the thorax is only lightly impressed, but the transverse subapical one is well marked. 3176 ( $P$. hamiltoni), represented by a single female, is the nearest ally. This belongs to the Trichosternus-like section with 2 setar on each side of the thorax.

o. Length, $26 \mathrm{~mm}$.; breadth, $9 \mathrm{~mm}$.

Clipping's Bush, near Kingston. Found amongst spear-grass roots by Mr. T. Hall on the 28th January, 1914, at an altitude of 2,500 ft. 


\section{Pterostichus egregialis sp. nov.}

Elongate, subparallel, moderately convex, brilliant black, slightly bronzed; legs and antemnae nigro-pieeous, mandibles and labrum piceorufous, palpi with rufescent tips.

Head smooth, with elongate but not deep frontal impressions, and, inchuding the eyes, equalling the thoraeic apex in width, labrum emarginate, senae a little dilat d below the eyes. Thorax subovate, the length fivesixths of the breadth in the middle, base and apex slightly emarginate; its sides very gently rounded, not at all sinuate, and nearly straight though slightly narrowed behind, with minutely prominent posterior angles, the base and apex of about the same width; dise with feeble undulating striae across it, and a shallow impression near each anterior angle, medial groove well maked but abbreviated; ba wal fossae rather longer than broad, placed al little nearer the sides than the middle, where there are a few very short punctiform striac. Elytra with their dentiform shoulders slightly exeeding the thoracie angles in width, fully double the length of thorax, their sides hardly at all curved at the middle, slightly simuate posteriorly, yet rather broad at the extremity ; each has 6 dorsal series of rather fue pumetures, those near the suture almost form slender striae, the others are rather more distant and less regular, apical seulpture irregular and coarser; their sides subvertical, with some coarse punctiform impressions, there are no scutellar striae.

Scutellum deeply striate at base. Thorax with 5 setae at each side. Logs stout, posterior femora angulate bolow. Antemae pubescent from their th joint onwards. Anterior tarsi with their 4 basal articulations cordiform.

1 careful examination of the shape of the thorax and peculiar elytral sculpture will enable any entomologist to identify this species.

o. Length, $13 \mathrm{~mm}$. ; breadth, nearly $4 \mathrm{~mm}$.

Staircase, south end of the Remarkables. Unique. Discovered by Mr. T. Hall on the $15 \mathrm{th}$ March, 1913, at a height of 3,500 ft. These mountains, situated along the eastern side of Lake Wakatipu, batween Kingston and Queenstown, have already yielded several remarkable beetles, and more remain to be found.

\section{Pterostichus sculpturalis sp. nov.}

Elongate, slightly convex, shining black, slightly bronzed; legs and antennae piceous, basal 3 joints of the latter glabrous and at the base rufescent, mandibles pitchy-red.

Head, its prominent eyes exclusive, narrower than front of thorax, uneven, irregularly punctate and rugose near and behind the eyes, lateral imprescions elongate, extending from the back of the eyes to the base of the mandibles; labrum emarginate. Thorax subquadrate, rery slightly broader than long, base and apex emarginate, a little wider before the middle than elsewhere, gradually and slightly narrowed towards the posfrrior angles; dise rather uneven, with some fine irregular transverse striae, at pair of foveiform impressions near each side of the middle, and another near each anterior angle; basal fossae large, indistinctly duplicate, the imner portion longer than the outer, they are uneven, with rugose or punctiform sentpture, the space between them at the basal margin has some irregular Iongitudinal striat ; the deep dorsal sroove extends from the base nearly to the apex. Elytra more than twice the length of thorax, and, including 
the dentiform shoulders, only slightly wider than it is at the base, they are oblong-oval, moderately sinuate and narrowed near the extremity; their sculpture is very irregular, consisting of fine striae or series of punctures so irregular and interrupted that they enclose unequal, chiefly elongate-oval areas over most of their surface, their sides have coarse punctiform impressions.

Scutellum striate at base. Basal 3 joints of antennae glabrous. 'Terminal joints of maxillary palpi elongate-oval, with obtuse apices. Legs. stout, posterior femora dilated and angulate undemeath. Anterior tarsi with their basal 4 joints cordiform and successively diminishing, the outer angles of the first 3 evidently prolonged. Scutellar striae present.

Belongs to the section bearing 2 setae at each side of the thorax, but easily separable from all of its members by the distinctive sculpture.

o. Length, $13 \mathrm{~mm}$. ; breadth, quite $4 \mathrm{~mm}$.

Mount Dick, Lake Wakatipu. A solitary individual obtained by Mr. T. Hall on the 10th March, 1914.

\section{Pterostichus maiaei sp. nov.}

Oblong, slightly convex, glossy; head and thorax black tinged with red, the latter brilliant brassy near the basal fossae and anterior angles, marginal channels viridi-aeneous; elytral interstices fusco-cupreous, their striae and sides viridescent; tarsi and antennae piceous.

Head, including the prominent eyes, as broad as the thoracic apex, more or less irregularly and finely wrinkled, the frontal foveae not extendin beyond the front of the eyes. Thorax a third broader than long in the middle, the base medially, the apex widely arcuate-emarginate, its sides distinetly margined, rounded and widest at or just before the middle. moderately sinuously narrowed towards the rectangular posterior angles; obsoletely transversely wrinkled in the male, more definitely yet finely in the female, the short longitudinal basal striae usually more perceptible than the apical, mesial furrow well marked but not attaining the apex. basal fossae rather deep and elongate, the space between each and the side slightly convex, the impression near each front angle quite definite. Scutellum striate at base. Elytra oblong-oval, with dentiform shoulders. their widest part very little broader than that of the thorax, almost thrice its length, moderately sinuate-angustate behind; scutellar striae short, the dorsal well marked, closely, finely, but distinctly punctate: interstices only moderately convex, the $3 \mathrm{rd}$, 5 th, and 7 th slightly broader than the others. the furst of these distinetly tripunctate, the last with 5 punctures. both sometimes with an additional apical one, marcinal sculptur. irregular.

Underside shining black, basal articulations of trochanters rufescent. the terminal segment, in both sexes, quadripunctate at the apex.

Fem.-Slightly broader, elytral interstices less convex.

The nearest species, $P$. grassator (1463), from rastorn Otago, is very differently and less brilliantly coloured, with reddish legs ; its clytral striai are more shallow and finer, mear the suture especially, and the 3rd and 5th interstices of the male are broader but less convex.

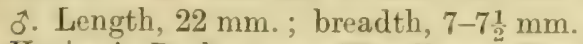

Kuriwai Bush, near Wyndham, Southland. Named in honour of Mrs. J. H. Lewis, who also made interesting contributions to the collections forwarded from Greymouth many years ago by Mr. J. H. Lewis. This fine species was sent to me on the 6th October, 1914. 


\section{Group l'ogionidat.}

:3805. Oopterus minor sp. nov. Ö̈pterus Guérin. Man. N.Z. Coleopt. p. 54 .

Glossy, moderately convex, of irregular contour; elytra piceous, with pitchy-red margins; head and thorax rufo-piceous, legs and basal joints of antemnae light rufo-castaneous, palpi paler.

Hearl. and the larene moderately convex eyes, at litte wider than front of thorax, smooth, with shallow frontal impressions. Thorax subcordate, linely matrgined. widest and reunded at or just before the midele, pradually narrowed towards the rectangular, slightly prominent hind angles, base and a pex subtruncate, it is about a fourth broader than longe dise smonth. the well-marked central groove not reaching the apex, basal fossae of mederate size, situated near the angles, with about 4 punctures between them, the lateral plicae obsolete; the seta at each side, in front of the middle, and the other at the hind angle sometimes missing. Elytra broadly oval, in the middle double the width and thrice the length of the thorax,

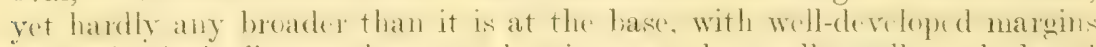
and subajucal plicar ; the sutural stria on each nsually well marked an d punctate, the others more or less obsolete; interstices plane, the 3rd tripunctate.

Male--Anterior tarsi with the basal 2 joints dilated, and prolonged at inner extremity. Antennae reaching backwards to intermediate femora.

(). pygmeatus (2618) hats oblong-oval dytra. O. parulus (2617) is rather smaller, and the sides and apices of the elytra are broadly testaceous. In $O$. basalis (3684) the elytra are more oblong, with much more definite sculpture, and the whole base of the thorax is punctate. These are the only near allies.

ô. Length, $3 \frac{1}{2} \mathrm{~mm}$; ; breadth, $1 \frac{1}{3} \mathrm{~mm}$.

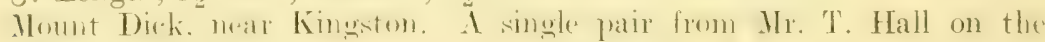
10th Hareh, 1914.

\section{Oöpterus latifossus sp. nov.}

Nitid, slightly convex; piceous, elytral margins pitchy-red, their apices fusce-testarens; legs and antemae light rhestnut-1ed, the glabrous joints of the latter and the palpi fulveseent; labrum and mandibles dark rufous.

Hearl rather narower than thoracie apex, smoeth. with wongate interocular impressions; eyes large but not very convex. Thorax cordiform, a third broader than long, widest just before the middle, well rounded there, somewhat sinuously narrowed towards the subacute and slightly

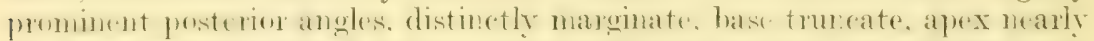

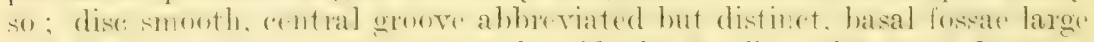

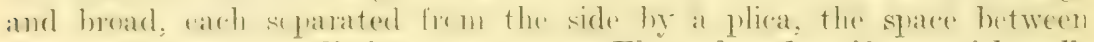
then with numerous distinct punctures. Elytra broad, oviform, with welldeveloped rims, thrice the length but hardly double the width of the rather broad thorax; their striae moderately deep and distinctly punctate, but becoming obsolete ncar the individually rounded apices, the outer striae and punctation less obvious ; interstices very slightly convex, 3rd tripunetate, apical carinae distinct.

Male-Anterior tarsi with the 2 nd joint little more than half the length of the 1st, both dilated, and slightly prolonged at the inner extremity. Iaxillary palpi setigerous. Thorax with a single seta at each side near the middle, and another at the hind angle. 
O. probus (2616), from Westport, is the species most resembling this, but it is smaller, the thorax is ineurved in front, and narrower; the elytra are more attenuate posteriorly, the brighter testaceous apical marks extend nearly to the hind thighs, their outer striae are obsolete, and there are no punctures on the 3rd interstices.

Length, $5 \frac{1}{2} \mathrm{~mm}$. ; breadth, $2 \frac{1}{2} \mathrm{~mm}$.

Ioa and Mistake Basins, near Mount Algidus. A male and two females. discovered by Mr. T. Hall on the 20th October, 1913.

\section{Oöpterus suavis sp. nov.}

Glossy, moderately convex; rufo-piceous, the lateral margins, base of thorax, clytral suture, labrum, and mandibles piceo-rufous; femora somewhat testaceous; palpi fulvescent; tibiae and basal joints of antennae more or less light fusco-rufous, remaining articulations of the latter darker; elytral apices sometimes pallid.

$\mathrm{H}$ ad, with its large, moderately convex eyes. rather broader than front of thorax, smooth, with elongate frontal impressions, labrum subtruncate. Thorax subcordate, distinetly margined, a fourth broader than long, widest at the middle, well rounded to beyond that point, gradually and slightly sinuously narrowed behind, posterior angles just rectangular, base and apex subtruncate; dise usually almost smooth, having only some very obsolete striae across it, the central groove in some aspects appears to attain both base and apex, basal fossae moderately large and deep, their outer borders carinate, the base irregularly and finely but quite perceptibly punctured. Seutellum triangular. Elytra oval, broadly margined, thrice the length but not double the width of thorax in the middle, slightly broader than it is at the base, with distinctly singly rounded apices, which are sometimes testaccous; the sutural stria on each is rather deep and finely punctate, the 2nd less so, the others are indistinct; interstices nearly flat, the 3rd tripunctate; the suture is bent outwardly at the extremity and prolonged forwards as a carina nearly in line with the 5th interstice.

Underside like the dorsum in colour, but with rufescent coxae and trochanters. Last segment of abdomen in the male, at the apex, with a single setigerous puncture at each side of the middle; in the female bipunctate there.

O. latifossus may be easily separated by its less convex body, by its thorax being broader in front, more sinuate behind. with sharper hind angles, broader fossae, and more eoarsely punetured base, and materially diff rent elytral sculpture. None of the subantaretic islands species closely resembles ours.

o. Length, 5-5 $5 \frac{1}{2} \mathrm{~mm}$. ; breadth, nearly $2 \frac{1}{2} \mathrm{~mm}$.

Routeburn and Hollyford. S veral sperimens secured at night off mosscovered trees by Mr. T. Hall during February, 1914.

3808. Zolus ocularius sp. nov. Zolus Sharp, Man. N.Z. Colenpt., p. 1000.

Nitid, rongate-oval, of somewhat interrupted contour, slightly convex; piceous, the lateral margins, elytral suture, and sometimes the head and base of thorax piceo-rufous; legs and antemme usually rufo-castaneous, basal joints of these latter and the palpi fulvescent.

Hi ad oviform, almost as long as thorax but obviously narrower. with nearly flat eyes. Thorax nearly a fourth broader than long, widest near the middle, curvedly narrowed anteriorly, gently but not curvedly narrowed 
behind, posterior angles rectangular, base truncate, apex slightly emarequate, lateral rims well devoloped; dise smooth, mesial groove well marked hut hardly attaining the base or apex; basal region distinctly punetate. its fossare apparently duplieate. the onter without a defonite external plicas. the immer broader and forming a depression towards the central groove. seotellum triangular, rather small. Filyta elongate-oval, widest before the middle, a good deal narrowed posteriorly, almost thriee the length of thorax, only slightly wider than it is at the hase: their finely yet distinet ly punctate striae are deeper near the suture than at the sides; interstices

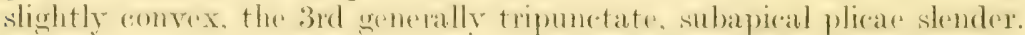

The narrow head, inconspicuous eyes, feebly developed basal plicae, and almost deplieated fossate of the thorax distinguish this sprecies from all that are known as yet.

Length, $7 \frac{1}{2} \mathrm{~mm}$. ; breadth, quite $2 \mathrm{~mm}$.

Routuburn. Ifollyford, and Jount Eantislaw. Five during February: 1914 ; also about a dozen from more southern localities of $Z$. subopacus (3689) were found by Mr. T. Hall.

"80\%. Tarastethus convexus sp. Wr. Turastethes Sharp, Man. N.Z. Coleopt., p. 1003.

Convex, moderately short and broad, nitid; piceo-eastaneous, the head, thorax, base, and suture of elytra more rufescent; lateral margins and apices of elytra, and the legs, pale flavo-castaneous; antemae, tarsi, and palpi more or less fulvescent.

Ifead moderately olongate and. including the only slightly convex eyes: rather narrower than the thoracic apex, with a few fine punctures in the elongate frontal impressions. Thorax subeordate, nearly a third broader than long, widest mear the middle. weell remonded and margined there, rather stemgly sinuonsly narrowed towards the rectangular posterior angles. base trunceate apex slightly anarginate : mesial groove not attaining either base "1r apex and somewhat expanded behind, the whole basal resion moderately

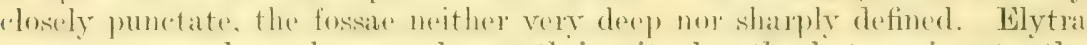
more convex than thorax, almost thrice its length, but, owing to the ruvedly narowed shoulders. but little broader than it is at the base. their sides obvionsly lenuded, with mefexed margins, they ate evidently broadex than the thorax in the middle, somewhat sinuously narrowed and indistinctly margined behind; their striae are rather deep near the suture, less so towards the sides, all rather strongly punctured; interstices a little convex, more or less confluent behind, the 8th plicate.

'This comes near Sharp's T'. puncticollis (1799), but the head is narrower and impunctate along the middle, the eyes are rather smaller and less convex, the hind-body is more oviform, and the outer striae are more shallow and irregular, and the coloration is altogether dissimilar.

o. Length, $5 \mathrm{~mm}$; ; breadth, $2 \mathrm{~mm}$.

Routehum, north of Lake Wakatipu. Two examples found on the 13th February, 1914, by Mr. 'T. Hall.

\section{Tarastethus diversus sp. nov.}

Shining, nearly similar in colour to $T$. comrexus, but the thorax more nigrescent; the body more elongate and much less convex.

Head rather namower than front of thorax, smooth, labrum distinctly amarginate: eyes musually small, sighty convex. Thorax only a sixth 
broader than long, widest near the middle. only moderately curved towards the front, very gently sinuate towards the rectangular hind angles; its surface smooth rexept near the base, where it is distinctly and relosely punctured. fossae rather shallow and not well limited, the dorsal croove normal. Elytra oblone-oval. only slightly convex, more than double the length of thorax, rather broader than it is at the base; their striae only moderately deep. finely and indistinetly punctate; interstices slightly convex, the 3rd feebly bipunctate, the common apical plicae present.

This is intermediate between T. convexus and Sharp's T. debilis (1802). which latter I have not seen, but which apparently has equally small eyes. $T$. diversus has a less transversal thorax than $T$. convexus, it is much less rounded before the middle, and, theogh somewhat narrowed, is hardly perreptibly sinuate behind. 'The elytra are much flatter and very differently sculptured.

Length, $6 \mathrm{~mm}$.; breadth, nearly $2 \frac{1}{2} \mathrm{~mm}$.

Moa Basin, west of Mount Algidus, Canterbury. Unique. Another of Ir. T. Hall's novelties, on the 20th October, 1913. In the same neighbourhood he secured a few specimens of $T$. puncticollis; these are larger than Sharp's type, measuring $6 \mathrm{~mm}$. by $2 \frac{1}{2} \mathrm{~mm}$.

\section{Tarastethus halli sp. nov.}

Nitid, castaneo-piceous; the base, latral margins, and apices of elvtra. the coxale, and trochanters more or less chestnut-red; palpi, antemnare, and tarsi somewhat fulvescent.

This should be located near $T$. convexus, but the elytra are manifestly different, being much less convex, quite oblong-oval, with less curvedly narrowed shoulders; their striae are nearly as deep towards the sides as they are near the suture, but their punctation is a good deal finer, and, indeed. becomes quite indistinct belind; the interstices are nearly plane. the 3rd gemerally bipunetate. the sth are plicate. and near earh side there is a series of well-marked punctures. The thorax is nearly a third broader. being nearly $2 \mathrm{~mm}$. instead of $1 \frac{1}{2} \mathrm{~mm}$., it is less narrowed anteriorly, the basal punctation is rather coarser and closer; the posterior angles are somewhat reflexed and subacute in place of being flat, and the minute setar on these. which are quite discemible in $T$. convexus, rannot be detected in $T$. halli. The head is a little broader, with rather larger but not very prominent eyes, and the impressions between these are broader but impunctate; the labrum is emarginate.

The male has a single setigerous apical punceture at rach side of the last ventral segment, and the anterior tarsi are a little more dilated than in the other sex, but are without visible squamae underneath. Flanks of pusternum with moderately earse shallow punetures abdomen smonth.

Length, 6-6 $\frac{1}{2} \mathrm{~mm}$. ; breadth, quite $2 \frac{1}{2} \mathrm{~mm}$.

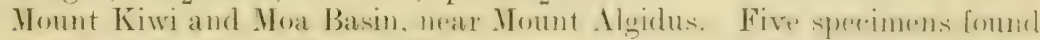
on the 20th October, 1914. This species is named in honour of its discoverer, Mr. 'T. Hall.

\section{Tarastethus fovealis sp. nov.}

Shining. nigro-piceous; antemnae, tarsi, and palpi fulveserent; femora fusco-fulvous. the tibiae fuseous, but with obseurely rufesernt apices: elytral margins and suture, the mandibles, and labrum piceo-rufous. 
Head rather narrower than front of thorax, almost smooth, with shallow frontal impressions. labrum trumeate. Eyes moderately large, slightly convex, with fine facets. 'Thorax subcordate, only about a fifth broader than long. base and apex subtruneate. widest just before the middle. rounder there. only slightly enrved and gradually narrowed anteriorly, distinetly and widely sinuate towards the rectangular posterior angles; dise impunetate. with fune irregular striac across it. the dorsal groove raches the front. it is somewhat expander behind, but terminates at some distaner from the base; the fossae are oblong and definite but not deep; the lateral median seta at each side is distinct, that on the hind angle small and slender. Elytra oblone-eval, twiee the length of thorax, a third broader in the miedde. just a little wider than it is at the base. with rather broad lateral margins: their striae rather slender, deeper behind, all very finely punetured. the narginal punctation irregular ; interstiees nearly plane, the plieare normal.

Less robust than $T$. puncticollis (1799). the thorax less transverse, elytrat relatively longer, and the whole sculpture different. The simple thoracic fossae, the extension of the dorsal groove to the apex, scantily pubescent antennae, and unusually strong contrast in coloration of the femora and tibiae prevent its being mistaken for any other described species.

Length, $5 \frac{1}{2} \mathrm{~mm}$. ; breadth, nearly $2 \frac{1}{4} \mathrm{~mm}$.

Ben Lomond. Unique. Found by Mr. T. Hall on the 6th March, 1914, at a height of nearly $4,000 \mathrm{ft}$.

\section{Tarastethus longulus sp. nov.}

Elongate, only slightly envex, moderately nitid; rufo-piceous, the base. suture, lateral margins, and apex of elytra and the mandibles more rufescent; legs, antennae, and palpi more or less fulvescent.

Head narrower than thorax, nearly smooth, sometimes with a few fine punctures in the rather short frontal impressions, labrum emarginate; eyes moderate, not prominent. Thorax subcordate, nearly a third broader than long. widest at or just be fore the middle, its sidns rather finely margined. only moderately rounded, gradually narrowed but not sinuate behind, postrior angles slightly prominent but not acute; base subtruncate. only very indistinctly (urvate towads the sides; apex slightly emarginate or subtruncate: the hasal resion fincly and moderately closely punctate, without definite fossae. dorsal groove abbreviated and rather slender; hind angles without setar. Elytrit oblong-eval. nearly a third broader in the middle than the thorax, thries its length, with the eommon subapieal plieas ; their striac regular. distinet, though rather narrow, funcly punctured; interstices almost plane.

Underside dark ehestnut, trochanters and coxae somewhat fulvescent. Prosternum distinetly but irregularly punctate; terminal segment with a single setigerous apical puncture at each side of the middle.

Though Sharp's description of the thorax of 'T'. debilis (1802) is applicable to this species, that of the elytra is not, and as we are led to infer that his species is of the typical short and convex form, $T$. longulus must differ considerably.

Length, 5-5:2 $\mathrm{mm}$.; breadth, nearly $2 \mathrm{~mm}$.

('lipping's Bush, mar Kingstom. Two found at an elevation of about 2,000 ft. on the 28th January, 1914, by Mr. T. Hall. 
3814. Tarastethus propinquus sp. nov.

Nigro-piceous, legs and mandibles piceo-rufous. antennae and tarsi light fusco-rufous, palpi fulvescent.

In form like $T$. longulus, rather larger, uniformly darker. Thorax longer, almost as long as broad, with finer margins; its base medially. ('marginate. distinetly but not strongly curved towards the slightly prominent angles, which are setigerous; it is without basal punctation or fossat. Elytral striae apparently impunctate, sharply impressed near the sutur. obsolete towards the sides. The eyes rather more prominent.

Underside smooth, terminal segment of abdomen bipunctate at each side of the apex.

Anterior tarsi of the male with the basal 3 joints a little dilated, and provided underneath with greyish squamae.

T. simplex (2656), found by Commander J. J. Walker, R.N., at Port Chalmers. measures $5 \mathrm{~mm}$. by $2 \mathrm{~mm}$. Its thorax is decidedly cordate, a gond deal broader and more rounded before the middle, with minute longitudinal sculpture at its base. The male has the same tarsal vestiture as T. propinquus.

o. Length, $6 \mathrm{~mm}$. ; breadth, nearly $2 \frac{1}{2} \mathrm{~mm}$.

Ben Lomond. Another of Mr. T. Hall's discoveries; two examples on about the 6th March, 1914.

\section{Tarastethus optatus sp. nov.}

Oblong, slightly convex, nitid; fusco-niger, the sides, but not the margins, and apices of elytra and the femora fusco-testaceous; palpi. antemae, and tarsi more or less fulvescent; mandibles pitchy-red; tibia: obscurely rufescent.

Head rather narrower than front of thorax, eyes inclusive, interocular impressions rather large and deep, the interval between each and the sharply marked lateral groure obtusely alevated: epistome truncate, and with 4 or 5 small punetures: labrum defely emarginate; eyes large but only moderately prominent. Thorax a third broader than long. base' trum eate, apex a little incurved, its sides with distinct, slightly reflexed maroins. widest and rounded at the middle. onenty namowed towards the slightly. projerting hind angles: the surfare (xhibits some ferble transerese striae. the central groove is slender, and does not reach the apex, basal fossae shallow and indefinite and ferbly rugose. Elytra oblong-oral. ratler hrader than therax, twice its length, with very distinet, some what reflexed maregins. and broadly rounded apices; their striae apparenty impunetate, the sufural three, on each elytron, not deep but reaching the extremity, the outer ones shallow and obsolete near the base; interstices plane, the 3rd feebly tripunctate, subapical carinae distinct.

Like $T$. oxygonus (1456); in it, however, the margins of the thorax and elytra are broadly testaceous; the thoracic fossae are sulciform and well marked, and the elytral striae are punetate and distinet. Both speries aw without setare at the posterior angles. T. ophatus has ohtuse teminal joints of the palpi; in 1456 they are acuminate.

․ Length, $6 \frac{1}{2} \mathrm{~mm}$. ; breadth, quite $2 \frac{1}{2} \mathrm{~mm}$.

Mount Dick. Unique. Found by Mr. Hall on the 17th March, 1914. 
3816. Sympiestus frontalis sp. nox. Siympiestus Sharp. Man N.Z. Coleopt., p. 1006.

Elongate, not parallel, slightly ronvex, shining; black, lateral margins of elytra. the legs, and mandibles rufo-piecous, antemnae and tarsi fuseorufous, palpi fulvescent.

Head narrower than thoracic apex, not including the large prominent eyes; frontal impressions broad, rather shallow and finely punctured, extending from the front of the eyes to the forehead. Thorax subquadrate, very slightly broader than long. base and apex subtruncate, the sidis gently rounded to behind the middle, a little sinuate behind, with rect angular posterior angles; dorsal groove rather slender, not reaching the apex, basal fossae sulciform and alongate, the intervening space not quite smooth. Elytra oblongeval, twiee the leneth of thorax, rather broader than it is at the base; the 3 inner striae. on each, moderately deep, finely yet distinetly but not very elosely punctured, the sutural one reaches the apex. the otheis do not, the outer striae beeme obsolete towards the side.

Sharp's S. syntheticus (1804), as well as S. oculatus (2439), and S. modestus (2655) are easily distinguishable by their long, deep, smooth frontal impressions, and S. ruficormis (1338) by its much less convex eyes.

Length, $6 \mathrm{~mm}$.; breadth, $2 \mathrm{~mm}$.

Scarcliff, near Mount Algidus. A single specimen found by Mr. T. Hall on the 20th October, 1914.

\section{Group Lebitdae.}

3817. Demetrida sinuata sp. nov. Demetrida White, Man. N.Z. Coleopt., p. 64 .

Subdepresscd, nitid; black, the forehead, mandibles, and most of the antemnae ferruginous, basal joints of these last, the legs, and palpi more or less fulvescent.

Head smooth. Thorax elongate, as long as broad, widest at or just before the middle, moderately rounded there, widely and distinctly simuate bohind, with acute almost prominent posterior angles; base subtruncate. a little oblique at each side; dise almost smooth, having only some obsoInte transverse striae, basal fossae prolonged as broad chammels inside the reflexed margins almost to the apex, mesial groove not abbreviated, the apex subtruncate or only slightly emarginate. Elytra more than double the length of thorax, widest behind the middle, their curvedly narrowed shoulders wider than the thoracic hase. apices somewhat oblique; on each there is a well-marked basal puncture on the 2nd interstice, there are no pereptible sentellar striar, the indistuetly punetate dorsal striae are well marked near the suture, less so near the sides; interstices almost flat, withsut discenthbe seriat: punctation, the 3rd usually tripunctate. Pyogdium finely punctate and pubescent.

Underside shining, piceo-niger, with a few fine setae; coxae and trochanters fulvescent.

Wrell differentiated from D. picere (125) by the more elomente thorax, its obviously sinuate sides and acute posterior angles, by the oblique elytral

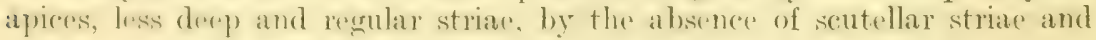
minute serial interstitial punctures.

Length, 7-8 mm. ; breadth, $2 \frac{1}{2} \mathrm{~mm}$. 
Clipping's Bush and Staircase, from 1,500 ft. to 3,500 ft. Ten found by Mr. T. Hall during January and March, 1914, and one from Mr. ML. (). Paseo, found on Ben Lomond.

\section{Group Pericalidat.}

3818. Scopodes instabilis sp. nov. Scopodes Erichson. Man. N.\%. Coleopt.. p. 67 .

Subdepressed, glossy black, slightly aeneous; legs, antemnate, and palpi nigro-piceous.

Head large, smooth, the space between the hind part of the eyes as wide as the thoracic apex, the frontal portion rather narrower. Eyes larye and prominent, extending outwardly as far as the middle of thorax. Thorax of about equal length and breadth, widest before the middle, slightly and obtusely angulate, and with a setigerous puncture there, at cach side. gradually narrowed behind; lateral margins distinct, ending just before the true base, and there bent inwardly, and more slender, for a very short distance only. without forming angles; its surface apparently smooth, ret densely and ver minutely sculptured, mesial groove distinct. extending from the basal depression to the oblique frontal impressions. Elytra fully thrice the length of thorax, twice its breadth behind the middle, with rurvedly narrowed. distinctly margined shoulders, and subtruncate, slightly oblique apices; their striae shallow, sometimes obsolete towards the sides, more distinct near the suture, interstitial punctures usually indefinite.

S. laevigatus (135), which I have not seen, is described as being, as is also the head, unusually narrow, with a short, rounded, cordate thorax. S. laevistriatus (1474) may be at once separated by its nearly obsolete humeral margins. S. cognatus (1570), from south-east Otago, has wellmarked longitudinal striae on the head; the thorax is evidently broader before the middle, distinctly angulate there, and more obliquely narrowed behind, and there are some fine striae across it.

Length, $3 \frac{3}{4} \mathrm{~mm}$. ; breadth, $1 \frac{2}{3} \mathrm{~mm}$.

Moa Basin, west of Mount Algidus. The type was found by Mr. T. Hall in the 20)th October, 1913, and after diligent explorations of Point Hill and Mistake Basin the following varietal forms were obtained: (a) Head unisulcate near each eye, feebly striate, the thorax transversely so; (b) similar, but with an interceular fovea; (c) lateral margins of thorax more or less distinetly prolonged half-way across the true base. Mr. Hall also secured several specimens of 132, a pair of 131, and another of 1813 .

\section{Group Sphaerididde.}

3819. Stygnohydrus posticalis sp. nov. Stygnohydrus Broun, Man. N.Z. Coleopt., p. 1336.

Ovate, attenuate posteriorly, very convex, glabrous, glossy aeneo-niger ; thoracic lateral margins, the elytral suture along the posterior declivity only, and their apices, dull rufo-castaneous : tibiae dark rufous; palpi and antemae testaceous, but with the club sometimes a little infuscate and opaque ; tarsi fusco-rufous.

Head large, a little rounded, funely yet distinctly but not closely punctate. Eyes with numerous fune facetis. Thorax evidently transverse, base 
subtruncate, with strongly rounded angles; the apex slightly rounded in the middle but sinuate near the sides; its surface somewhat irregularly, finely, but distinctly punctured, rather more finely along the middle towards the base. Seutellum large, triangular, with some fine punctures. Filytat more than double the length of thorax. finely and distantly punetate along the middle of the dise, and on each elytron, near the side behind the middle, with about 5 series of coarser punctures, the intervals between these more closely and distinctly punctured than the dise; their apical portion is substriate, and the sutural striae are distinct from the apices to the summit of the declivity.

Closely allied to the northerm S'. femoralis (3032), rather larger, usually more narrowed but less vertical behind, the surface more glossy, with finer seulpture, and the margins less broadly rufescent.

Underside blackish, the sides and the last abdominal segment not rufescent, more or less evidently punctate; femora with slender, depressed, ashy hairs in front in addition to the flavescent setae.

Length, $4 \mathrm{~mm}$.; breadth, $2 \frac{1}{4} \mathrm{~mm}$.

Hollyford. I doyen individuals obtained from leaf-monld by . $\mathrm{H}$. 'T'. Hall, about the 19th February, 1914.

\section{Group STAPHLLINAA.}

3820. Quedius hallianus sp. nov. Quedius Leach, Hist. des Ins. Coleopt. Lacold., vol. 2, p. 84 .

Elongate, black, head and thorax slightly bronzed, hind-body iridescent; legs and basal joint of antennae piceous; remaining joints, mandibles, palpi, and tarsi more or less fusco-rufous; elytra and hind-body with depressed, elongate, infuscate pubescence.

Head broadly oval, shining, quadripunctate alongside each eye, distantly bipunctate at the base. Labrum medially emarginate, thickly ciliate with

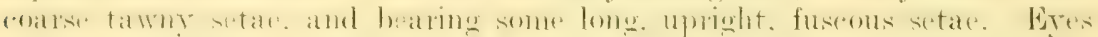
oval, covering more than half of each side of the head. Thorax slightly hroader than lone a little harrowed anteriorly. with rounded hind angles: shinime. with 2 pairs of setigerous apheal muretures. a median pair befor. the middle, and about 6 at the base, lateral margins setigerous but indistinctly punctate. Scutellum large, triangular. Elytra rather broader than long, apices oblique towards the suture, so that in the middle the length is about a third less than the breadth and just as much shorter than the thorax; their seulpture is close but indefinite, consisting apparently of transverse series of minute granules. Hind-body elongate, with long terminal styles, the seulpture subpunetiform.

Antemne nearly as long as lead and thorax, joints 2-11 nearly equal. Anterior tarsi widely expanded and coarsely pubescent.

Owing to the short wing-eases this species may be located in section ix in my cabinet, but those already there, such as Q. emensis (3189), are considerably smaller. Those in section ii have the head and thorax finely punctate, but of herwise more nearly resemble this species in general appearance.

Length, 11-13 $\mathrm{mm}$.; breadth, $2 \mathrm{~mm}$.

Dyer's Pass, near (hristehureh. Two individuals found on the 23rd dugust. 1914, by Mr. 'T'. Hall, whose name it bears. 


\section{Quedius recticeps sp. nov.}

Elongate, nitid; head and thorax fusco-piceous, elytra and abdomen blackish, the latter evidently iridescent, its lateral margins and basal segments somewhat fusco-rufous; antemae and legs more or less infuscate; tarsi and mandibles fulvescent.

Head oblong, parallel, with a pair of small shallow punctures behind. and a lateral groove at the back of each eye. Labrum testaceous, slightly medially emarginate. Clypeus short, mmbranous. Mandibles curved and acute at extremity, each with a sharp inner tooth, that of the left smaller and with 2 or 3 denticles in front of it. Thorax rather broader than long. wently curvedly narrowed towards the subtruncate apex, base sonewhat rounded, with obtuse angles; dise apparently smooth, with a pair of fine shallow frontal punctures. Scutellum triangular. Elytra in the middle nearly a third broader than long, not as wide as the thrrax, widely incurved behind, with minute granular sculpture and slender, depressed, ashy pubesrence. Hind-bedy elongate, attenuate pesteriorly, with more conspicuous hairs than the wing-cases, its sculpture fine, apparently gramular, 6th segment longest. smooth and rounded behind, and bearing long outstanding blackish setae.

Legs moderately slender, tibiae with a few dark setae; anterior tarsi slightly expanded. Antennae as long as head and thorax, basal joint fuscotestaceous, as long as but thicker than the 3rd; joints 4-10 diminish, dull. with fine pubescence, the terminal oviform. Eyes small, longitudinally oval. situated near the front.

Section xi in my cabinet is represented by the North Island $Q$. xenophaems (3190), but is differentiated by the coloration and labral structure

Length, $6 \frac{1}{2} \mathrm{~mm}$. ; breadth, $1 \frac{1}{2} \mathrm{~mm}$.

Mistake Basin, Canterbury. One found amongst dead leaves during October, 1913, by Mr. T. Hall.

\section{Quedius megophthalmus sp. nov.}

Nitid, head and thorax aeneo-fuscous, the former darker; elytra and hind-body brassy chestnut-red. with elongate yellow pubescenfer ; antemnat and legs nearly castaneo-rufous.

Head broadly oval, rather wider than thorax, with a straight series of about 5 distinct punctures alongside each eye, and a pair behind. Eyes very large, oblong-oval, almost entirely covering the sides of the head. Thorax of about equal length and hreadth. a little narowed towards the rounded, somewhat depressed front angles. the base slightly rounded and finely margined, with curvate angles; with 2 pairs of punctures before the middle, and an equal number across the base. Seutellum large. Elytra scarcely as wide as thorax, nearly a third broader than long, their. apices obliquely shortened towards the suture; ther are somewhat indefinitely but not minutely sculptured. Hind-body elongate, very little narrowed posteriorly, with thick terminal styles and ill-defined sculpture.

Antennae shorter than head and thorax, basal joint testaceous, elongate, but not double the length of 2 nd. 3rd and 1 th lomerer than broad. joints 5-10 subquadrate. Anterior tarsi slightly expanded, basal joint of the posterior fully as long as the next. Labrum truncate in front, with a distinct groove along the middle. Palpi rather short.

Underside. except the nigresent head, rastaneous, with yellowish pubescence. 


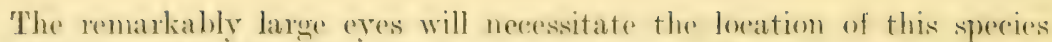
in a section apart from the others.

Length, $3 \frac{1}{2}-4 \frac{1}{2} \mathrm{~mm}$. ; breadth, $\frac{2}{3}-1 \mathrm{~mm}$.

Routeburn, 11th February, 1914, and Hollyford, 19th Februare 1914. Shaken off mossy trees at night by $M r$. 'T'. Hall. 'Three examples.

3823. Dimerus bisulciceps sp. nю.

Dimerus Fauvel, Trans. N.Z. Inst.. vol. 44, p. 400.

Elongate, nitid; head and thorax light chestnut-red, elytra rufous, hind-body rufo-rastaneous : legs fuseo-testareous, antemmate, palpi, and tarsi fulveserent; the hind-body with subereet yellow pubescencee.

Head larege, quite as broad as thomax, distinetly bisuleate from the front to beyond the middle: irregulary, fimely, hut quite pereeptibly punetate. longitudinally regese at the sides: it bears a few fome inconspieduous flavesrent hairs. "Thorax a third longer than broad, a little wider before the middle than elsewhere. gradually narrowed behind; broadly quadrisuleate from the base to near the apex, the inner pair bent ontwardy in front, with about 8 basal and a pair of frontal punctures. Elytra slightly broader than long, curvedly narrowed towards the base; they are impunctate, but have well-marked sutural striae. Hind-body very elongate, finely punctured, basal segment largest.

Legs slender and elongate. T'arsi pentamerous, basal 2 joints of the anterior oblong, slightly longer than $3 r d$, the posterior pair very elongate and slender.

Antennae 11-articulate, inserted below the sides a short distance in front of the eyes, 2nd oblong, fully as long as the exposed portion of the list and stouter than the following 5 . 9th moniliform. rather broader than the small sth, eoth suboblong. the terminal harerer and subarmminate.

Mandibles falciform, as long as the head, each with a central tooth, but as they ate dirested forwads along the inside, instead of projecting

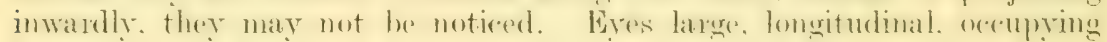
fully half of the sides.

In D. brouni Fauvel the 4th dorsal segment is much darker than the others, the elytral striae are indefinite, and the sculpture of the head is very different.

Length, $3 \mathrm{~mm}$. ; breadth, $\frac{1}{2} \mathrm{~mm}$.

Noa Basin, Cantexbury. I single individual olotamed hr Mr. T'. Iatl on the 20th October, 1913.

\section{Group Faronini.}

3824. Exeirarthra angustula sp. now. Exeirathin 13rom, Man. X.\%. Coleopt., p. 1054.

Elongate, slender, nitid; castaneo-rufous, legs and antemmae rufo-

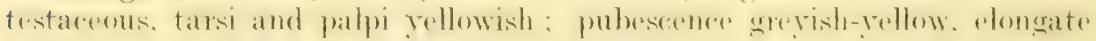
and slender, subdepressed, longer and more erect behind.

Head smaller than thorax, distinctly obliquely narrowed in front of the prominent eyes. nearly straght behind them, hind angles obtuse : fonely and indistinetly punctate antemual tubereles slightly clevated in front and separated by a narrow groove which hardly extends as far as the front of the eyes; it is distinctly bifoveate behind. Thorax oviform, of about equal length and breadth, its apex narrower than the occiput, with an 
angular fovea near the base almost connected by a linear impression with the smaller fovea at each side. Elytra very little longer than broad, slightly narrowed near the base yet slightly broader than thorax there, finely punctate: with obvious sutural striae which are deeper at the base, where there is a minute puncture near each: dorsal striae short, about a third of the whole length, formed usually of 3 punctiform impressions. Ifind-body finely punctate, horizontal, rather longer than elytra, of about the same width, lst risible segment shorter than the next. 3rd largest. 5th small, deflexed.

Legs moderately slender, tibiae somewhat arched externally.

Antennae as long as head and thorax. slightly thickened towards the extremity, with very slender erect setae; basal joint not twice as long as broad, mureh therer near the base than at its apex, 2nd oblong-oval, 3rd similar but much more slender, the and 5th oblong-oval, joints of-s rather shorter, 3 th and 10th transverse, the terminal ruadrate but with a broad apical appendage.

Underside finely punctate, with yellow pubescence. Head with a broad groove in front of the eyes. Fourth ventral segment longer than 2nd or 3rd, 5th as long as 2nd, slightly medially depressed behind. 6th with a deep angular exeision in the middle, 7th broadly oval.

Hore slender than our northern E. enigma (1885)). the elytra narrower and with smaller dorsal impressions. the hind-bodr lomger. and the antemnae somewhat different.

Ђ. Length, $1 \frac{4}{5}-2 \mathrm{~mm}$. ; breadth, $\frac{1}{2} \mathrm{~mm}$.

Glenhope, near Nelson. Found by Mr. 'T. Hall on or before the 10th December, 1914, amongst dead leaves.

\section{Exeirarthra longiceps sp. nov.}

Elongate. subderoressed. nladually but somewhat interuptedly narrowed anteriorly, nitid; castaneo-rufous, legs and antemnae rufo-testaceous, tarsi and palpi flavescent; pubeseence grevish-yellow, elongate and slender. mostly decumbent. and bearing a few longer erect hairs on the hind-bodt.

Head evidently longer than broad. almost cuneiform, wradually narrowed anteriorly, with obtuse hind angles: antemnal tubereles somewhat elevated in front, separated by a deee narrow groove which seareoly extends as far as the front of the eyes, near which there are some fine punctures, it is distinetly bipunetate behind. Thorax oviform. about a third longer than broad: the median forea near the base is angular and laree. it has a transverse groove connecting it with the small fovea at each side, the punctation is fine and indistinct. Elytra slightly longer than broad. gradually yet ronsiderably narowed towards the base which hardly exeeds that of the thorax in width, indistinctly punctate near the sides: sutural striae deep. finely punctured, the dorsal consisting of a basal puncture and elongate impression not prolonged as far as the middle. Find-body nearly twice the lemeth of elytra, cradually and slightly expanded posteriorly. finely pumstate, 3rd segment nearly twice the leneth of the basal. 5th narrow and deflexed.

Antennae rather elongate and slender, a little incrassate towards the extremity, with slender outstanding grevish hairs; basal joint stout, not double the length of the oviform 2nd. the next much smaller vet rathes longer than broad, joints 46 oblong-oval, 710 laxly articulated and surcessively dilated. the terminal subyuadrate. but with a distinct pubeseent apical appendage. 
Ventral segments 2-4 increase, 5th shorter, 6th obtusely triangular, its actual structure concealed by some glutinous substance.

A remarkably distinct species. The elongate head, quite oval thorax, basally namowed elytra, and long hind-body at once distinguish it from the type of the genus.

o. Length, $2 \frac{1}{4} \mathrm{~mm}$. ; breadth, nearly $\frac{1}{2} \mathrm{~mm}$.

Hollyford, north of Lake Wakatipu. A single individual discovered by Mr. T. Hall on the 19 th February, 1914.

3:26. Sagola unicalis sp. nox. Siryolu Sharp. Gen. Ins. (Wytsm.), Pselaphidae, p. 16.

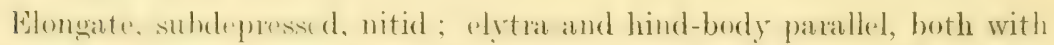
numerous elongate, suberect, flavescent hairs, head and thorax more finely clothed; castaneo-rufous, antennae and legs paler, tarsi and palpi yellowish.

Head subquadrate, smaller than thorax, genae almost straight, with ubtuse hind angles; median channel moderately broad and deep, extending to beyond the back part of the eyes, and indistinctly prolonged as a stria towards the base. occiput bipunctate; frontal tubercles almost horizontal, distinctly separated. Thorax cordiform, rather broader than long, its apex narrower than the head; with a subrotundate median fovea near the base, which is bipunctate, lateral foveae deep but not prolonged to the middle. Eilytra oblong, almost double the length of thorax, very slightly narrowed fowards the base, finely and indistinctly punctate; sutural striae deep, with a distinet basal puncture alongside each, dorsal striae interrupted. consisting of a hasal puneture and elongate impression extending backwards to the middle. Hind-body hardly as long as elytra, similarly punctate, its 1 st visible segment evidently shorter than 2nd or 3rd, with minute squamae.

Legs moderately slender, tibiae straight inwardly, slightly expanded below the middle externally, curvedly narrowed near the extremity.

Antemae longer than head and thorax, finely pilose; basal joint stout, twice as long as broad, 2nd subrotundate, as broad as the 1st but only a little more than half its length; 3rd distinetly smaller than adjoining ones yet quite as long as broad, 4th rather smaller than 5th or 6th; 7 th oblong, comsiderably molared. broder than and about as long as the preeding 2 combincd; joints 8-10 laxly articulated, each shorter than 6th, transrersal; the terminal subconical, evidently smaller than $7 \mathrm{th}$.

Underside finely pubescent. Head with a deep groove between the

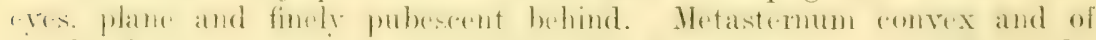
nearly the same length as the abdomen. Basal segment covered by the femora, ciliate behind, the next slightly shorter than 3rd or 4th, 5th widely

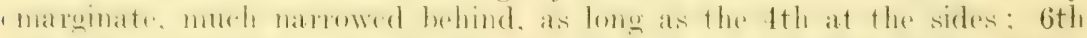
whtusely promiment in the middle bethind and sinuate tewats the sides: ith obtusely triangular, its opereulum oviform.

The abrunt anlatrement of a single joint of the antemale. the 7 the will cxclude this species from every section of the genus; it must therefore be placed in another by itself.

o. Length, $2 \frac{1}{2} \mathrm{~mm}$; ; breadth, $\frac{2}{3} \mathrm{~mm}$.

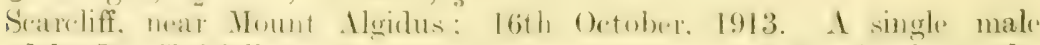
found by Mr. 'T'. Hall, and another damaged specimen at Moa Basin on the 20 th of the same month. 
3827. Sagola dickensis sp. nov.

Shining, dark rufous, legs and antemnac light chestnut-red, tarsi and palpi fulvescent; pubescence yellow, slender and elongate, suberect.

This most nearly resembles S. anisartha (1881), belomging to sertion vi.

Head nearly straight behind the moderately prominent eyes. oblicuely narrowed in front. and, like the thorax, similarly sculptured. Elyt rat rather longer than broad, slightly narowed near the base, aluost plane; sutural striae deep, usually bipunctate near each at the base; the dorsal striae romposed of 2 basal punctures and a longer impression which hardly rearlese the middle. Hind-body shightly longer and broader than elytra. Ist visible segment rather shorter than 2 nd or $3 r d$, with minute brassy seales across its base.

Underside with distinct yellow pubescence. Head with a transverse groove in front of the eyes. Metastemum convex in front, with an elongate fovea behind the middle. Ventral segments 3 rd and 4 th with an oviform impression along the rentere neither distinetly longer than the 2nd, 5th shorter, 6th also short, deeply emarginate in the middle, $7 \mathrm{th}_{\mathrm{l}}$ obtusely triangular, its operculum narrow and convex. In the unique specimen of 1884, found near the lighthouse at Moeraki, the operculum is Hat and subrotundate.

๙. Length, $2 \frac{1}{2} \mathrm{~mm}$. ; breadth, $\frac{2}{3} \mathrm{~mm}$.

Mount Dick, near Kingston. Eight "Xamples found by Mr. T'. Hall on the 10th March, 1914. amomest decaring learess. at a horight of $1.050 \mathrm{ft}$.

\section{Sagola robustula sp. nov.}

Robust, subdepressed, nitid. alytra and hind-body subparallel: loead and thorax rufous, elytra of a lighter red, antennae and hind-body fuscorufous. legs paler, tarsi and palpi flavesent: pubesconces rellow. slender and elongate, subdepressed, but with longer erect hairs behind.

Head broad, not narrowed behind the moderately large eyes, its obtuse hind angles not perceptibly narrower than the middle of thorax; frontal channel deep, extending as far back as the eyes, narrowed towards both extremities, antennal tubereles, slightly alevated. finely punctate. obliquely truncate and only slightly separated in front. the orcipital foreare distant. elongate and subangular. Thorax cordate, of about equal length and breadth. median fovea large and subquachate. these at the sides also deep but not prolonged beyond the middle. the base finely bipunctate. Elytra a little depressed before the middle, rather longer than broad, slightly narrowed towards the base. apparently smooth; sutural striate deep. with a moderately elongate basal impression alongside earlo. the dorsal censist of a basal puncture and elongate impression not prolonged as far as the middle. Hind-body as long as elytrat. seoments $2-1$ subequal. 5tt: narrow and deflexed. the true 2 nd with minute bratsiy stales.

Underside chestnut-red, finely pubescent. Head with a broad angular. somewhat $\mathrm{T}$-shaped impression across the middle behind the eves, its thick margins oblique but in the middle truneate behind. Ventral segments 2-4

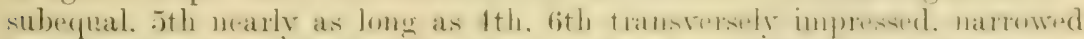

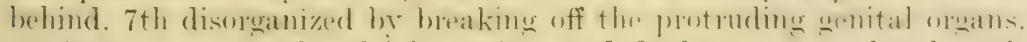

Antennae stout, basal joint rufous and finely punctate, barely twice as long as broad, the next as thick but shorter, 3rd obconical, not very much smaller than adjoining ones; joints $t-6$ moniliform and of about equal 
length and breadth, Tth and sth rather shorter, ith and loth transversely yuadrate. laxly artienlated. the teminal. with its broad apieal appendage. conical.

After comparison with the descriptions of twelve species, the types of whirh awe in the British Musemm, and ten allied species in my own collertion, this proves to be distinct from any of them. An examination of the form and sculpture of the head, below as well as above, and of the nearly equally stout antennal joints, will lead to its recognition. It belongs to section $\mathrm{v}$, according to my arrangement.

ô. Length, $3 \mathrm{~mm}$. ; breadth, $\frac{4}{5} \mathrm{~mm}$.

| Routeburn, north of Lake Wakatipu; 19th February, 1914. One perfcet and one damaged male found by Mr. T'. Hall.

\section{Sagola hectorii sp. nov.}

Robust, subdepressed, shining; rufous, legs and antennae rather paler; tarsi and palpi flavescent; thinly clothed with slender, elongate, principally erect, yellowish hairs.

Head trigonal, its hind angles extending straight outwards a little farther than the widest part of the thorax and feebly depressed at the extremity; antennal tubercles somewhat elevated and separated by a distinct groove in front; median channel deep and angular, prolonged as far as the back of the eyes, narrowcd there, occipital foveae elongate but indefinite; res moderately larese and prominent. Thorax slightly broader than long, widest just before the middle; median fovea subrotundate, base bipunctate, lateral foveae deep, hardly extending forwards as far as the middle. Eilytra about a third broader than long. narrowed towards the base, yet rather wider than the thorax there; sutural striae well marked, with a basal puncture near each, the dorsal apparently entire, short, scarcely prolonged to the middle, the suture minutely punctate. Hindhody evidently longer than elytra. lst visible segment shorter than followinc omes, with simple pubecenee, sth obtusely triangular.

Underside shining, its pubescence yellow. Head with a transverse roove in front of the eyes, its central portion depressed and flat but with distinctly elevated lateral borders, the hind angles only feebly impressed. Ibdomen finely and indistinctly punctate, 2nd segment shorter than the three following ones, which are subequal, 6th almost as long as 5th, truncate behind, 7th obtusely triangular, its operculum indistinct.

Legs and antemmae similar to those of 2724 (S. eminens), but in other respects very different. S. angulifer (3363), another Auckland species, is the nearest ally, but in it the head is gradually expanded behind the eyes, and the extremity of its angles is convex or obtusely subtuberculate; the frontal channel is prolonged as an obvious stria right to the back of the hearl: there are no basal punctures between the sutural and dorsal striae of the elytra; the 1 st joint of the antennae is longer and thinner, and the 7 th ventral segment is oblong and rather narrow.

j. Length, $2 \frac{2}{3} \mathrm{~mm}$.; breadth, $\frac{3}{4} \mathrm{~mm}$.

Belgrove, near Nelson. Another of Mr. 'T. Hall's numerous discoveries; 7th November, 1914. 'This notable species is dedicated to the late Sir James Hector, as a substitute for 2740 , which proves to be merely a varietal form of Bryaxis diversa. 


\section{Group Euplectini.}

3830. Vidamus gracilipes sp. nov. Vidamus Raffray, Gen. Ins. (Wytsm.), Pselaphidae, p. 89.

Nitid, rufous, legs and antennae light chestnut-red; pubescence yellow, distinct and subereet.

Head as large as thorax, the pair of large foveae deeply prolonged and confluent in front. Thorax subcordate, of about equal length and breadth, widest before the middle; with a distinct, transverse, angulate depression near the base, prolonged as a groove to basal margin, which is bipunctate. lateral foveae extending forwards to the middle. Elytra a third longer and broader than the thorax, somewhat curvedly narrowed near the base; sutural striae deep and broad, punctiform at the base, and with a small punctiform impression there near each, dorsal impressions large and deep, bipunctate at the base, not extending backwards to the middle. Hindbody as long as elytra, narrowed and deflexed posteriorly, basal 3 segments subequal.

Legs moderately slender, intermediate tibiae with a small spiniform process at the inner extremity.

Antennae with slender outstanding pubescence; 2nd joint oblong, rather shorter than the basal; joints 3-7 rather more slender, oblong; 8th evidently smaller, 9th a little longer yet smaller than 10th, terminal large and subconical.

Underside firely pubescent. Metasternum broadly impressed in the middle. Basal segment distinctly ciliate behind, earinate between the coxae, segments 2-4 successively diminish, 5th still shorter, 6th large, slightly transversely impressed at the base, semicincularly emarginate behind, 7 th broadly triangular, its operculum oblong.

Fem.-Metasternum unimpressed. 6th ventral segment simple. Iroadly triangular, intermediate tibiae unarmed.

Closely allied to V. calcaratus (3210), a North Island species, but the elytra and hind-body are narrower and more parallel, the forehead is less elevated between the antennal tubercles, the eyes are less convex, the pubescence is more conspiruous. and the legs are nore slender. the middla femora especially.

o. Length, $2 \frac{1}{2} \mathrm{~mm}$. ; breadth, $\frac{2}{3} \mathrm{~mm}$.

Mount Alfred, Heaven's Gate, and Mount Earnslaw, all north of Lake Wakatipu. Several found by Mr. T. Hall during February, 1914.

\section{Group Pselaphini.}

3831. Pselaphus urquharti sp. nov. Pselaplus Herbst., Gen. Ins. (Wytsm.), Pselaphidae, p. 304.

Elongate, interruptedly narrowed anteriorly, nitid; light castaneomfous, palpi and tarsi fulveseent; sparingly elothed with subdepressed, slender, pale-yellowish setae.

Head elongate-oval, widest in line with the small, not at all prominent eyes, curvedly narrowed behind, moderately convex and finely punctate there: the smonth central rhannel roneiform. beenming namewer yet quite distinct in front, there are no perceptible foveae. Thorax oviform, nearly twiere as lomg as broad. widest behind the middle. very gradually narrewed anterioly, the small forea at the centre of the base withent any distinet impression between it and the larger one at each side. Elytra of about

14-Bull. No. 1. 
equal length and breadth, curvedly narrowed towards and of the same width as thorax at the base; with fine sutural striae and a short basal impression alongside each. Hind-body as hroad as elytar. hasal segment almost as long as they are, broadly margined, horizontal, and bearing a very shont band of sponge-like greyish elothing at its base. the other seaments deflexed.

Legs elongate and slender, femora medially subclavate; posterior tibiae straight and very slender above but with a third of their apical portion slightly expanded externally.

Antennae rather slender and elongate, finely pubescent; basal joint cylindric, stout, nearly twice the length of the next, joints 3-8 almost equally elongate, 9th and 10 th thicker and slightly longer; the terminal larger, straight at one side, the other widest behind the middle and gradually attenuate towards the extremity.

Maxillary palpi slender, shorter than the antennae, 2nd joint eurved, more eradually inerassate near the extremity than at the base. Brd thiek and very short, 4th half of their whole length, thicker near the base than at the middle, its clavate apical portion a third of its whole length.

Male. Mesosternum pubescent, grooved along the middle, with carinate edges there. Metasternum strongly convex along the middle. Basal seg- ment shont, with yellowish sponge-like vestiture; 2nd very large, not very broadly depressed medially, the sides of the depression strongly elevated and forming laterally compressed tubercles near the apex; 3rd and 4th short and widely emarginate; 5th semicircularly, hardly visible in the middle; 6th as long as the preceding 3 combined, apparently punctate, and bounder behind by the last dorsal seoment. Troblanters rery elomgate, extending beyond the sides of the body and quite visible from above.

In $P$. ventralis (2742) the mesosternum has a simple mesial carina. The metasternum is a good deal shorter, and the 2nd ventral segment is concave for half of its width but is not tuberculate behind.

Length, $2 \mathrm{~mm}$.; breadth, quite $\frac{1}{2} \mathrm{~mm}$.

Oakden, near Mount Algidus. Discovered by Mr. Roderick Urquhart, along with sone other coleroptere. on the g5th September. 1913. and named in his honour.

\section{Pselaphus oviceps sp. nov.}

Nitid, fusco-rufous, palpi and tarsi testaceous; sparingly covered with subdepressed, slender, brassy setae.

Head ovate, widest in line with the slightly convex eyes, almost as broad as the middle of thorax there; median channel deep, extending as far as the basek part of the eres, somewhat expanded between these: oceiput eonvex, antennal tubereles horizontal. Thorax. exeluding the broad neck, rather lomger than broad, widest near the middle; with a small punctiform fovea at the middle of the base, the larger lateral ones shallow. Elytra of the sime width as thorax at the hase. gradually expanded hehind, slightly broader than long; with fine sutural striae, alongside each of these there is a deep, short, basal depression with subcarinate outer edges. Basal segment of hind-body nearly as long as the elytra, rather broader near its extremity.

Antennae fincly pubescent, their 2 nd joint quite half the length of the basal, joints 5-8 rather longer than 3rd or 4th, 10th slightly shorter than 9 th. 
Male.-Metastemum ronvex in front. distinctly and broadly growved along the middle. Basal ventral segment covered with greyish sponge-like vestiture, 2 nd large, indistinctly impressed, with a small tubercle on the middle of its apex.

A trifle smaller than $P$. urquharti and easily distinguishable from it, and its allies, by the manifestly different metasternum and 2 nd ventral segment. The head is shorter, the eyes rather more prominent and situated near the middle, and the thorax and elytra are also a little shorter.

Length, $1 \frac{4}{5} \mathrm{~mm}$. ; breadth, quite $\frac{1}{2} \mathrm{~mm}$.

Routeburn and Hollyford, north of Lake Wakatipu. Eight examples taken on the 16th and 19th February, 1914, at elevations of $1,000 \mathrm{ft}$. and $3,500 \mathrm{ft}$., from decaying vegetable matter, by Mr. T. Hall.

\section{Group TyriNi.}

\section{Phormiobius gen. nov.}

Body slightly convex, narrowed anteriorly. Head subovate, not broad, quite the length of thorax, somewhat prolonged in front of the antennae, vertex convex. Antennal tubercles stout and elongate, almost lorizontal. separated by a distinct groove which does not extend as far as the front of the eyes. Thorax small, oval, a good deal narrowed towards the base and apex, the former trifoveate. Elytra subtriangular, short, their length only lialf of the breadth. considerably narmwed towards the base. which is no wider than that of the thorax. Hind-body suboviform, large, about half of the whole length; 1st visible segment narrower and shorter than the next. 3rd largest. there broady marginate; th and 5th deflexed. the latter small and rurvilinearly triangular, the former nearly as long as the $3 \mathrm{rd}$.

Lews elongate and slender, unamed, hind tibiate slightly flexums. Tarsi narrow basal joint minute. 3rd rather longer than the elongate 2 ud ; rlaw: unequal, the 2nd short, very slender and indistinct.

Antennae stout, as long as head and thorax; basal 2 joints oblong, the 2ud rather shorter and narwwer. joints $3-8$ small and subquadrate. 9th quadrate. not as broad as the transverse loth. the teminal largest, subovate.

Maxillary palpi nearly the length of the head; basal artirulation minute. 2nd elongate. slender, slightly rurved. clavate at the extremity; :3rd shorter. more gradually incrassate: terminal elongate. as long as znd. elongateoval, a little more arched at one side than the other.

Femule with 6 ventral segments, the hasal short and areutely produced between the coxae. 2nd and 3rd each distinctly shonter than this, which is the largest, 5th not longer than 2nd, 6th short and broad.

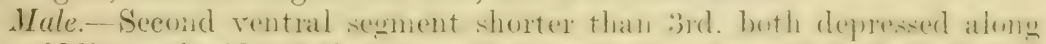

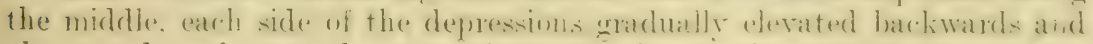
almost tubereulate at the extremity; 4th shorter than 2nd in the middle, semicircularly emarginate; 5th moderately medially depressed, decply

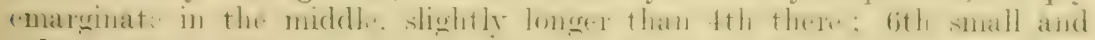
subrotundate, bounded behind by the terminal dorsal segment. Pro-

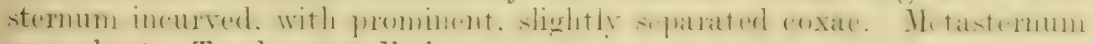
very short. Trochanters distinct.

14*-Bull. No. 1. 
The greatly abbreviated elytra, without dorsal striae, the large 3rd dorsal segment, and the more elongate, differently formed palpi will at a glance, without reference to structural details, enable it to be separated from Tyrogetus, its nearest New Zealand ally.

\section{Phormiobius halli sp. nov.}

Nitid, dark fusco-rufous, antennae and legs rather paler, tarsi and palpi fulvous: thinly alothed with slender, elongate. subdepressed. flaveseent pubescence; the punctation very fine and indistinct.

Head, eyes included, about as broad as the middle of the narrow thorax,

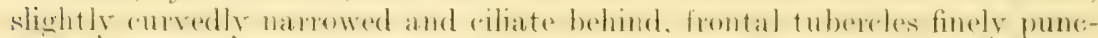
tate. Eyes situated bethed the middle, rather low down, small and slighty prominent. Thorax a liftle longer than broad. strongly monded in the middle, convex there, somewhat depressed at the base, which has a distinct median fovea and another at each side of it. Elytra depressed towards the base, bi-impressed there, the sutural striae distinct there but obsolete behind.

Fem.-Hind-body rather broader than that of the male; basal 3 ventral segments transversely depressed and thickly fringed behind.

Mule. Basal 2 ventral segments with fulvous rilia but mot depressed behind. Posterior trochanters on the inner side with a thick spiniform process directed backwards.

Length, $2 \mathrm{~mm}$. ; breadth, $\frac{2}{3} \mathrm{~mm}$.

Belgrove, near Nelson. Mr. T. Hall secured a dozen specimens, but only three males, amongst decaying flax-leaves, during October, 1914.

\section{Agatyrus gen. nov.}

Allied to Plommiobius, but exhibiting the following disparities:-

Maxillary palpi thicker, their 2 nd articulation with the basal half slender and curved, the other considerably enlarged and subsecuriform; 3rd almost as long. slender and salk-like at the hase. madually dilated fowads the extremity; 4th as long as its predecessor, stalk-like near the base, its longer apical portion securiform and provided with a small apical acicular appendage.

Basal joint of tarsi small but distinct, 2nd slightly and gradually thickened, apparently grooved above and prolonged nearly half-way underneath the 3rd, which is about as long, but its base is implanted on top of and just about the middle of the 2 nd ; the claws are of equal length, though one is rather more slender than the other. In other allied genera the 3rd tarsal joint is attached to the apex of the 2nd, and both are slender and filiform.

Elytra less abbreviated with well-marked dorsal and sutural striae. First visible dorsal segment quite as long as any of the others. Ventral secrments 2 t, in the female. depressed and thekly eiliate behind, sth short and widely (matrinate, (ith also short, obtusely angularly prominent at the middle of the extremity.

Male.-Metasternum with a transversely quadrate lamina in the middle, this is elevated in front and finely margined there and at the sides. Anterior coxae distinctly, the posterior very widely separated. Trochanters elongate, each of the hind pair with a cylindrical process directed backwards. Basal ventral segment truncate between the widely distant 
coxae. the following 3 broadly depressed alome the middle and ronsely frinered behind; sth short. truncate in the middle, larger at the sides. medially depressed at the base; 6th rather larger, medially emarginate: behind, depressed at the hase; 7 th flat. subrotundate. surmonded by the terminal, inflexed, dorsal segment.

\section{Agatyrus fulvihirtus sp. nov.}

Body slightly convex, intermptedly narrowed anteriorly, nitid: mfous, elytra. legs and antennae light r.hestnut-red, tarsi and palpi fulrescent; sparingly covered with subdepressed, rather short. brisht fulvous setar.

Head oviform, vertical in front, curvedly narrowed and ciliate behind, in line with the eyes as broad as the thorax, these are moderately prominent and large, and are placed between the antennae and its base; it is almost abruptly narrowed in front, vertex convex, finely but distinctly and moderately closely punctate: fromtal tubereles loniznial. ajparently connate in front, with a shallow impression between them near the middle. Thorax oviform, longer than broad, a little wider near the middle than elsewhere; its punctation like that of the head, with a small punctiform fovea at the middle of the base and a slightly larger one at each side. Elytra a third broader than long, curvedly narrowed towards the base and of the same width as the thorax there; irregularly, less distinctly and closely punctured than the thomax. their doral and sutural striar distinct throughout, deeper and subforeiform at the base. Hind-londy at the base as broad as the hind part of elytra, about a third longer, somewhat deflexed behind, basal 3 segments broadly margined and about equal.

Legs elongate, the intermediate rather longer than the uthers. anterion tibiae nearly straight, the others slightly flexuous.

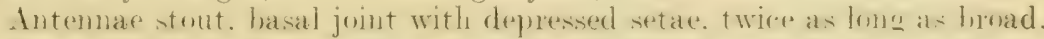

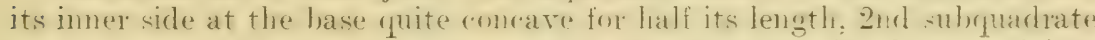
or only slightly longer than broad, 3rd a little narrower but longer; joints 4-6i subquadrate. fith and 7 th sherter, sthe evirlently larger than sth but not as broad as the transverse 10th, the terminal oblong, a little thicker than the 10th and nearly as long as the preceding three united.

Length, $2 \mathrm{~mm}$.; breadth, $\frac{3}{4} \mathrm{~mm}$.

Gordon's Knob, Nelson. Another of Mrr. T. Hall's discoveries, amongst decaying leaves on or about the 15th October, 1914. One male and two females, one of the latter mutilated.

\section{Group Silphidae.}

3835. Inocatops spinifer sp. nox. Imoratop.s Broun. Man. N.Z. Felerpt., p. 1066.

Convex, oblong-oval, nitid; castaneo-rufous, antennae and legs fulvescent, tarsi and palpi gellow; clothed with elongate. sender. rellow hairs. those on the hind-body suberect.

Head very small, almost cuneiform. Eyes minute, with distinct facets.

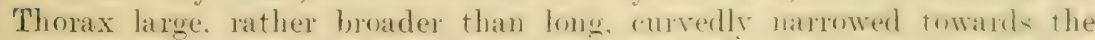
subtruncate ajex, anterior angles obsolete. lateral maroms very fine: hase

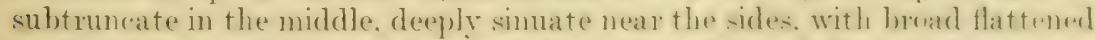
angles, these are directed somewhat backwards and fit into transwise basal impressions inside the shoulders; disc evenly conver, minutely; distantly, and obsoletely punctate. Seutellar region sunken, large, tri- 
angular. Elytra almost double the length of thorax, depressed and of about the silue width as it is at the base, rather natrower and more

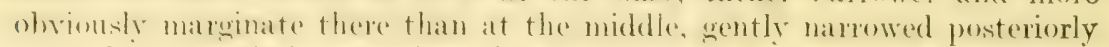
and alnost entirely covering the pyoidiun; the suture is somewhat depressed, but there is no perceptible sculpture.

Antennae stout, rather longer than the head and thorax, finely pulusent: and jomt elongate. rather longer than the thicker. oblome lst; the next nearly twice as long as broad; 5th somewhat larger than either of

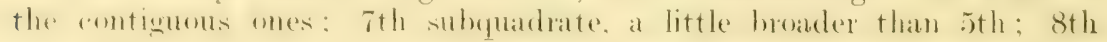
equally broad but very short; 10th quadrate, rather larger than 9th, the terminal subconical.

Legs finely setose; tibiae straight inwardly, gradually expanded, ohliguely narowed outwadly near the extremity. the intermediate pair obtusely subangulate below the middle; front and middle tarsi with dilated basal joints, those of the former pair cordiform and emarginate at apex, those of the latter broadly oblong, their 4 th joints minute; the posterior tarsi slender and elongate.

Underside with yellow pubeseence. Prosternum deeply emarginate. Abdomen more or less finc ly punctate, hasal segment rather longer than the next. its apoical suture somewhat whliterated in the middle. straight at the sides; 2nd with a spiniform process extending to the apex of the 3rd, 5th slightly longer than 4th, 6th deeply emarginate.

Fem.-Tibiae, tarsi, and 2nd ventral segment simple.

I. concinmes (273) is broader, with somewhat differently formed antennae and tibiae, and the flat process of the 2nd segment is distinetly bisulcate. I. compactus (1907) is considerably larger, and represented by a single female only.

$\hat{\jmath}$. Length, 21 mm. ; breadth, quite $1 \mathrm{~mm}$.

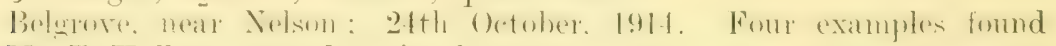
by Mr. T. Hall amongst decaying leaves.

3836. Inocatops granipennis $\mathrm{sp}$. nov.

Oblong-oval, moderately convex; head and thorax shining ehestnut-

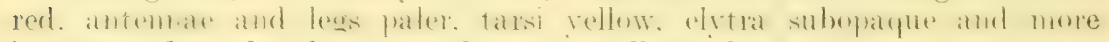
infuscate than the thorax; pubescence yellow, elongate.

Somewhat similar to the female of $I$. spinifer, the space near the posterior angles of the thorax smaller, less flattened and prolonged backwards. Elvtra almost elongate-cordate, a little wider before the middle than those of $I$. spinifer, distinctly rounded there, somewhat obliquely narrowed behind, the declivity longer and, when examined siderays, appearing flatter; disc nearly plane, the suture not depressed, their whole surface covered with small flattened granules, many of these have a mimute central puneture.

q. Length, $21 \mathrm{~mm}$; breadth, quite $1 \mathrm{~mm}$.

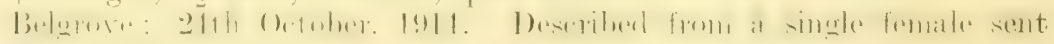
by Mr. 'I'. Hall.

3837. Inocatops elongellus sp. not.

Elongate-oval, only moderately convex, nitid; castaneo-rufous, antennae paler, legs fulvescent or testaceous, tarsi and palpi yellow; thickly clothed with elongate, suberect, flavescent hairs. 
Differentiated from $I$. spinifer by the rather less convex but more elongate body; the elytra ane quite double the length of the thorax, elongatecordate, wider before the middle than at the hase. very gradually narowed posteriorly; the legs and antennae, moreover, are materially different.

Antemae longer, basal joint eylindric, rather longer than the elongate 2nd, 3rd eridently longer than broad, 4th and 5th abrut equal. rather longer than broad; 6th and 7th subquadrate, the latter the linger, sth transverse yet distinctly narrower than adjoining ones, 9th and 10 th transrersely quadrate, terminal unsynmetrical, usually prominent at the miter extremity.

Legs more elongute, anterior tibine straight inwardly. ('urved outwardly, the others not quite straight along the inside. somewhat anved and dilated below the middle and, instead of being onlique near the extrenity. they are curvedly narrowed and slightly bent inwardly, the hind pair are minutely serrate.

Underside evidently pubescent, its punctation distinct but not deep. Basal segment with its hind suture obliteraterl in the middle. 2nd slightly longer than 3rd or the the next longer than th, 6th apparently depressed and emarginate in the middle at the apex, the terminal present but rendered indefinite by the pubescence and sappy matter.

Fem.-Slightly shorter; tibiae straight along the inside, slightly and gradually expanded. Ahdomen with 6 segments, the sth ristinctly longer than 4th, 6th short, rounded behind and on a lower level.

o. Length, $3 \frac{1}{2} \mathrm{~mm}$. ; breadth, $1 \frac{1}{2} \mathrm{~mm}$.

Mount Dick, Wakatipu: 10th IIarch, 1914. Found amongst decaring leaves on the ground by Mr. T. Hall at an elevation of 1,100 ft. Four individuals.

\section{Inocatops separatus sp. nov.}

Oblong-oval, moderately convex, shining; castaneo-rufous, tarsi and palpi fulvescent; with numerous elongate, conspicuous, more or less erect yellow hairs.

In this species the characters of 1 . spinifer are to a great extent reproduced, but the body is rather broader, the tibiae of the male are materially different. being like those of the smaller $I$. flectipes (19018). the antennal structure also differs, and, moreover, the spiniform process of the 2 nd ventral segment is altogether absent.

Antemme stout, basal joint erlindrir and as long as the elongate 2 nd, the next twice as long as broad, the and 5th oblong. 6th smaller than contiguous ones, 8th transverse, as broad as the 7 th but shorter: 9th and 10th large, about equal, both transversely quadrate; 11 th unswmmetrical, sometimes appearing conical, generally most prominent at the outer part of the apex.

Anterior tibiae slightly arched externally, straight inwardly; intermediate pair nearly straight inside, gradually dilated ontwardy to below the middle, obliquely narrowed towards the slender inner extremity; the posterior a little dilated at the middle of the inner side. incurved helow, and bent inwardy near the extremity, nearly straight along the ontside but obliquely narrowed towards the inner apex. Anterior and intermediate tarsi with expanded basal joints, with sponge-like restiture underneath: the posterior pair elongate and clemer, their basal articulation ahmut as long as the next three together. 
Inderside usually darker, more finely clothed; abdomen indistinetly punctate. basal segment seareely longer than the next, 3rd and 4 th each slightly shorter than 5th, 6th narrower but as long, medially emarginate, 7 th concave along the middle.

Fem.-Tibiae straight along the imner side, slightly arehed externally, oblique near the extremity. Abdomen with 6 segments, the basal convex but not carinate along the middle, 5th longer than its predecessor, 6th short and broad.

j. Length, $2 \frac{1}{2} \mathrm{~mm}$. ; breadth, $1 \frac{1}{4} \mathrm{~mm}$.

Jount Hutt, (anterbury, 25th March, 1912; Bell Rock and Rose Hill the following year. Six males and two females altogether. Another of Mr. 'T. Hall's novelties.

\section{Zeagyrtes gell. nov.}

Maxilary palpi short, suberlindrie, arched externally, hasal joint longer than 2nd, narrowed towards the base, 3rd suboblong, a little longer but not broader than its predecessor, the terminal nearly as long as the 3rd, tapering towards the extremity. Mesosternal carina not vertical in front. Tarsi pentamerous, their basal joints unexpanded. Abdomen of the male with 7 segments, the 6th medially emarginate.

Intermediate between Choleva and Mesocolon.

\section{Zeagyrtes vitticollis sp. nov.}

Oblong-oval, only moderately convex, nitid; head, thorax, and basal joint of antennae fusco-testaceous, the elytra more or less so near the apex, the thorax with a broad dark streak along the middle; elytra and remaining joints of antemnae fusco-piceous or nigrescent, the former sometimes paler near the base: legs more or less infuscate; pubescence elomgate and suberect, principally dark, but with some grey hairs near the base, on the middle, and across the top of the hind slope; these, however, do not form fascire.

Head much narrowed in front of the large, prominent, obliquely oval eyes, distantly punctate. Thorax about a third broader than long, with fine lateral margins, more curvedly narrowed anteriorly than near the base, which is slightly rounded in the middle, with subrectangular angles, the apex trumeate; dise moderately coarsely and irregularly punctured. Scutellum subtriangular. Elytra of the same width as thorax at the base, thrice its length, with singly rounded apices, so that the pygidium is sometimes exposed; sutural striae distinct, their sculpture consists apparently of fine transverse serial punctures and limes.

Antennae longer than head and thorax, rather slender, bearing numerous outstanding dark setae; basal joint rather longer than the elongate 2nd, 3rd a little shorter than 4th, 5th and 6th about equally slender; remaining joints. exrept the rather shorter and more slender sth. longer and rather thicker than the 6th.

Tibiae slender, elongate, and finely setose, the posterior straight, the others slightly arched, the hind pairs finely bispinose at the extremity.

Underside shining, dark fuscous, with slender, grey pubescence. An terior coxie prominent and contiguous.

Length, $2 \frac{1}{2} \mathrm{~mm}$. ; breadth, $1 \frac{1}{4} \mathrm{~mm}$.

Waitakerei Reservoir, near Auckland. Eight specimens found amongst leaf-mould on the 26th October, 1914, by Mr. A. E. Brookes, of Mount Albert. 


\section{Zenocolon gen. nov.}

Compact, convex, oblong-oval. Maxillary palpi with slender basal articulations ; 3rd short, transverse ; 4th large, nearly straight outside, on the inside strongly curved and dilated near the base, curvedly narowed towards the extremity, which has a minute terminal appendage. Tarsi pentamerous, rather slender, without any dilatation of their joints.

Prosternum deeply emarginate in front, concave at the sides, with prominent, contiguous coxae. Intermediate coxae embedded, separated by the mesosternal carina, which is broader, concave, and subvertical in front. Abdomen with 6 distinct segments, the basal longer than the 2 nd, the last rounded behind.

This genus should be located between Camiarus and Choleva. The peculiar shape of the terminal joint of the maxillary palpi, neither oval nor securiform, is one of its chief characteristics.

\section{Zenocolon laevicollis sp. nov.}

Nitid, light castaneo-rufous, palpi fulvescent; sparingly clothed with slender, suberect, yellow pubescence.

Head small, a good deal narrowed in front of the small, prominent, obliquely oval eyes, which have relatively coarse facets. Thorax closcly applied to the elytra, truncate at the base, curvedly narrowed anteriorly, fully a third broader than long, its sides finely margined, posterior angles rectangular and directed slightly backwards, the dise smooth. Scutellum triangular. Elytra of the same width as thorax at the base, more than twice its length, their sides finely margined, nearly straight as far as the hind thighs, gradually narrowed behind; sutural striae rather: fine and indistinct behind, obsolete elsewhere; their punctation subseriate, fine. less distinct towards the extremity.

Tibiae moderately slender, nearly straight, intermediate and posterior finely bispinose, with fine yellow setae.

Underside rufescent, its pubescence fine, depressed, and yellowish.

Antennae almost as long as the head and thorax, 2nd joint as elongate as the basal; 3rd shorter, yet rather longer than the 4th or 5th, these are nearly equal and distinctly longer than broad; 6th as long as hroud, narrowed towards its base; joints 7-11 form an enlarged club, the sth. though very short, being ahout as broad as the atdjacent ones.

Length, $2 \mathrm{~mm}$. ; breadth, $1 \mathrm{~mm}$.

Ina Basin, Canterbmy. I single speemen found hy Mr. T. Diall amongst decaying leaves on the ground, at a leight of about 4,000 ft.

\section{Group T'rogositidae.}

38t1. Grynoma setigera sp. nov. Giynoma Sharp, Man. X.Z Gulenpt. ?). 181.

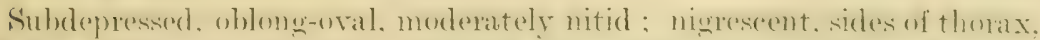

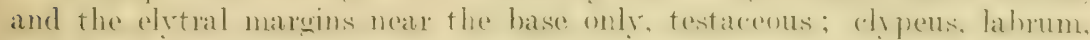
and basal 2 joints of antennae rufo-testaceous, remaining joints and the legs fuscous: there is scabrely any depressed white pubescence. the surfices being almost antirely. yot thinly. alothed with erest. alongate and slender. ashy setae.

Head ahmost as broad as front of thorax, indistinctly and closely punc:tate. Thorax twice as broad as long, apex subtruncate, its obture angles 
mot fonment : the sides moderately explanate nearly st laight hut gradually narrowed anteriorly, posterior angles broadly rounded, base slightly bisinuate; discal punctation fine, rather sharply marked, nearly absent along the middle, the lateral sculpture coarser and closer. Elytra very little wider than thorax at the base, four times its length, gradually yet quite evidently curvedly narrowed from the hind thighs backwards; the

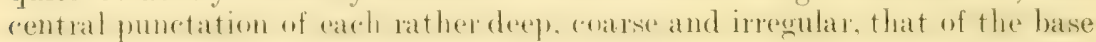
finer and closer, the sutural seriate.

Antennae with robust basal joints, $3-6$ slender and elongate, 7 th rather shorter, club with moderately elongate joints.

This differs in most details from the type of the genus, Sharp's G. fusca (322), the vestiture, coloration, broader head, more prominent eyes, and attenuate elytra particularly.

Length, $5 \mathrm{~mm}$.; breadth, $2 \frac{1}{2} \mathrm{~mm}$.

Ina Basin. Canterhury. Tnique. Diseovered by Mr. T'. Hall on the 20th Oetober, 1913.

\section{Grynoma clavalis sp. nov.}

Oblong, subparallel, depressed, subopaque; piceous, about half of the thomax ontside the middle, and the sides of elytra somewhat rufescent; the marginal channels of these latter, as well as the intermediate and posterior tibiae, fusco-testaceous; pubescence grey, scanty on the thorax, rather dense and depressed, but a little irregular on the elytra. and intermingled with erect, slender, infuscate setae, the lateral setae elongate and white.

Head rather namower than the thoracie apex. moderately but not elosely punctured on the middle. Thorax slightly and widely emarginate in front. with obtuse angles: rather wider behind the middle than elsewhere slightly curvedly narxowed anteriorly, almost straight near the base, so that the posterior angles appear rectangular: its sculpture shallow. composed of ring-like infuressions with a minute puncture in the cente of many of them. Elytra alont fom times the length of thomax. with individually rounded aphes: they have imegular coarse, and moderately close punctures: these. however, become obsolete towards the apices and sides, which nevertheless are not smooth, their sides are explanate.

Antennae with the basal 2 joints thick and rufescent, 3rd distinctly longer than 4 th, 5th and 6th subquadrate, 7 th transverse; club large, its basal 2 joints transverse.

This species can be identified by the rather dense, depressed, silvery pubescence of the hind-body, the effacement of its lateral punctation, and the abbreviated basal joints of the club.

Length, $4 \frac{1}{2} \mathrm{~mm}$. ; breadth, $2 \mathrm{~mm}$.

Hoa Basin. I single example from Mr. T'. Hall: 20th oretober. 1914.

\section{Grynoma proxima sp. nov.}

Nearly allied to $G$. clavalis as regards form, coloration, and vestiture. The thorax has similar ring-like sculpture but less rectangular posterior angles. The elytral punctation is not obliterated near the sides, these are less explanate, the apices are simple, and the shoulders obtusely elevated. The structure of the antennal club is essentially different, its basal joint being evidently longer than broad and narrowed towards the base, the next, though slightly shorter and broader, is not transverse. 
Length, $43-5 \mathrm{~mm}$. ; breadth, $2 \mathrm{~mm}$.

Point Hill, near Mount Algidus. One from Mr. T. Hall on or about the 20 th Oetober, 1913.

3844. Grynoma pallidula sp. nov.

Depressed, slightly nitid; labrum, forehead, thoracic disc, and basal 2 joints of antennae light rufo-castaneous, elytra and sides of thorax paler; palpi and club piceous, tibiae testaceous, tarsi infuscate.

Head narrower than front of thorax, with close, coarse, shallow sculpture like that of $G$. clavalis. Thorax twice as broad as long, its sides explanate and slightly"ahmost regularly rounded, with subrectangular basal angles; its sculpture similar to that of the head. Elytra thrice the length of thorax, moderately coarsely and closely subseriate-punctate.

Pubescence grey, slender, rather short, suberect, evenly distributed, and intermingled with some upright, slender. fuscous setae. but along the sides the setae are white and elongate.

Antennae rather short, 3rd joint elongate and longer than 4 th, joints 4-6 smaller yet longer than broad; basal 2 joints of the club obconical, together rather longer than broad, the terminal elongate-oval.

The light coloration is in marked contrast to that of other species, the elytral pubescence is more evenly distributed and, being of a less silvery hue, is less conspicuous than in the preceding species.

Length, $4 \frac{1}{2} \mathrm{~mm}$. ; breadth, $1 \frac{2}{3} \mathrm{~mm}$.

Mount Alfred, north of Lake Wakatipu; height, 4,000 ft. The only specimen as yet known was found by Mr. T. Hall on the 4th February, 1914.

\section{Group Melolonthidae.}

\section{Eusoma eximia sp. nov. Eusoma White.}

Oblong, subparallel, slightly convex, moderately nitid, variegate, with a few outstanding setae along the sides; fusco-testaceons, head picorous. more rufesent in front; thorax to a large extent but verw irrenulaty aeneo-fuscous, elytral interstices more or less fusco-violaceous.

Head moderately finely and sparingly punctured behind, more contisely and with reflexed margins in front. Thorax in the middle nearly twice as broad as long, apex deeply emarginate, the base bismuate: sides finely margined, slightly wider near the middle than elsewhere, very gently rounded there and behind so that the obtuse posterior angles appear to be tumed slightly inwards, more obliquely narowed anterion : its surface irregularly but not closely punctate, more finely and distantly near the middle and sides. Sroutellum almost smooth. Elytra just thrice the length of thorax, not quite as wide as it is at the base, their truncate apices not wholly covering the pysidino; they are moderately fincly. though not very regularly, subpunctate-striate above; the 2nd. 4t li. and 6 th interstices are rather broader than the others, nearly flat, and have some coarse punctures, the suture is obtusely elevated throughout.

Legs elongate, anterior tibiae bidentate near the extremity, tarsi much longer than tibiae.

Tnderside testaceous, very thinly pubescent, femora with elongate setate. Basal segment of abdomen covered by the femora, 2-5 subecqual. 5th with an ancrular apical depression, 6th with distinct slender setae and a transverse basal impression. 
Antennae 8-articulate, 2nd joint as thick as the basal but not half its leneth. th has longas Brd, its base attarked to the apex of the 3rd, but being a little the ker it appears but only just pereeptibly, to project backwards; club densely pubescent, with elongate leaflets.

Distinguishable from $E$. aenealis $(2806)$ and Sharp's sericospilus advena (1987) by its distinctly more anteriorly narrowed head, more rounded sides of thorax. trumeate apices of elytra. hiv their more regular substriate seulpture and less uneven surface. It may be at once separated from 1987 by the structure of the th antennal joint.

$\hat{o}$. Length, $10 \mathrm{~mm}$; breadth, $4 \frac{1}{2} \mathrm{~mm}$.

Stewart Island. I am indebted to Mr. A. Philpott, of Invereargill, for a specimen found by him during January, 1914.

\subsection{Odontria obsoleta sp. nov. Odontria White, Man. N.Z. Coleopt, p. 265.}

Subovate, only slightly convex, opaque; of a pale greyish-chestnut hue, the head and legs more or less light eastaneous; the thorax, scutellum, and base of elytra thickly covered with very long decumbent hairs of about the same colour as the derm; remainder of wing-cases with more slender suberect pubescence; the outstanding lateral setae are numerous and somewhat ferruginous.

Head very coarsely punctate, less closely behind; clypeus with reflexed margins, subtruncate in front. Thorax nearly twice as broad as long, widest near the middle, nearly straight behind, with obtuse angles, gradually and slightly narrowed towards the subacute anterior angles; base bisinuate. apex widely but not deeply emarginate; its punctation very fine and distant. Elytra widest behind the posterior femora, with subtruncate apices: their striae shallow and indistinct, the punctation fine and obsolete.

Antennae rather short, their 3rd and 4th joints of about equal length, the latter the thicker, 5th very short.

Underside indistinctly sculptured, abdomen fusco-testaceous; sternum thickly clothed with elongate pubescence.

In 1667 (O. sandageri) the pubescence is less slender but shorter. In 2514, which is most like 1667, the clypeus is strongly rounded from one eye to the other. The present is recognizable by its pale colour and obsolete sculpture.

F. Length, $14 \mathrm{~mm}$; ; breadth, $7 \frac{1}{2} \mathrm{~mm}$.

Scareliff, west of Mount Algidus. My specimen is one of Mrr. 'I'. Hall's captures on the 20th October, 1913.

\section{Group Lucanidat.}

:37. Mitophyllus mandibularis sp. nov. Mitophyllus l'arry, Man. N.Z. Coleopt., pp. 252 and 1112.

Oblong, slightly convex, subopaque; fusco-piceous, legs piceo-rufous, the tips of the palpi and the basal joints of antennae and tarsi more rufescent.

Head rather narrower than front of thorax, obtusely prominent just

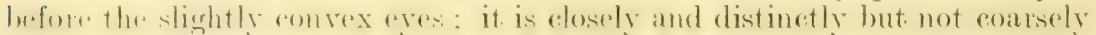
punctate. Thorax nearly twice as broad as long, its sides gently rounded, a little more curvedly narrowed in front than behind, anterior angles not prominent, the base moderately bisinuate, with obtuse angles; disc mode- 
rately finely but not elosely punctured, rather more coarsely near the sides, with a shallow median frontal impres ion, and a smooth longitudinal sface on its basal half. Scutellum squamose. Elytra oblong, as wide as thorax at the base, nearly thrice its length, broadly rounded behind, their punctation like that of the thoracic dise.

Mandibles simple, as long as the head, bidentate at apex, rather narow, the enclosed area oviform, without any basal dilatation; they bear numerous fine setae.

Antennae with a few slender setae on the basal joint, 3rd sightly longer than 2 d but more slender, joints 46 short, 7 th darker and a litfle broader; club densely pubescent and opaque, as long as the preceding joints together.

Tibiae minutely denticulate externally, the anterior with a distinct median tooth and another at the extremity.

Body irregularly clothed with depressed, elongate, straw-coloured squamae.

M. comognathus (2812), from Westport, is the nearest species; in it, however, the thorax is more curvedly narrowed anteriorly, and it has broad, concave, marginal channels of which there is no trace in this species. the squamae are shorter and less numerous; the mandibles appear tridentate near the extremity; the hindmost tooth, however, is upright instead of being horizontal and is situated near the middle; the eres are flatter, and the 3rd antennal joint is hardly any longer than the 4 th.

Length, $7 \mathrm{~mm}$.; breadth, $3 \mathrm{~mm}$.

Point Hill, west of Mount Algidus. One found by Mr. T. Hall, at a height of 3,500 ft., in December, 1913.

\section{Mitophyllus cristatellus sp. nov.}

Oblong, subdepressed, slightly nitid; nigrescent, tarsi and antennae rufo-piceous: very irregularly clothed with decumbent. but only moderately elongate, testaceous squamae, and some erect greyish ones which form about 6 small crests on each elytron, a pair on the thorax near the scutellum, and entirely cover its hind angles.

Head nearly as broad as front of thorax, laterally angulate in front of the slightly convex eyes; it is coarsely and very elosely punctured. 'Thorax subtruncate at apex, a little bisinuate at the base, a third broader than long, with slightly enred sides: anterior angles not at all prominemt, the posterion hidden by the spuamosity : it is nearly smooth along the nidd!e and on a pair of spots between it and each side, the rest of its surface is irregularly punctured, almost as coarsely but much less closely than the head; there are some coarse erect setae at the sides. Scutellum squamose. Elytra nearly thrice the length of thorax, as broad as it is at the base; each

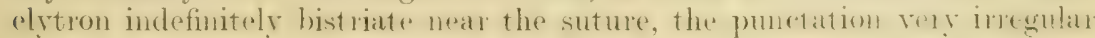
but similar to that of the thorax.

Mandibles thick, rather longer than the head, evidently bidentate at the extremity, nearly parallel inwardly; each with a laterally compressed median prominence on the incide, and a larese, prominent but ohtuesextemal angulation at the base.

Tibsare denticulate externally, the anterios with a spiniform tooth below the middle and another at the apex, the intemendiate with a median denticle. Intermediate joints of tarsi rather short.

Antennae with their 3rd joint small, hardly at all longer than broad; club densely pubescent, about equalling all the other joints in length. 
No speries we possess resembles this. Bate: C'eralogmathes albogultatus (447) is not a New Zealand species; its real habitat is Moreton Bay.

Length, $9 \mathrm{~mm}$. ; breadth, $33_{2}^{1} \mathrm{~mm}$.

Routeburn, north of Lake Wakatipu. One found by Mr. T. Hall, under a log, minus an antenna, on the loth February, 1914.

\section{Group Tenebrionidae.}

3849. Syrphetodes variegatus sp. nov. Sygrpletode's Pascoe, Man. N.Z. Coleopt., p. 351.

Uneven, opaque; fuscous, antennae and tarsi fusco-rufous; covered with small, depressed, tawny, and ferruginous squamae, antemae and legs inclusive; the club densely and finely pubescent.

Head only half the width of thorax, without discernible punctation. Thorax: in the middle, fully a third broader than long, but with the anterior angles projecting as far as but distant from the front of the eyes, it is rounded and widest near the middle, slightly and widely sinnate anterionly, a good deal narrowed behind, with reetangular basal angles: apex deeply sinnate near each side, emarginate in the niddle and with a pair of obtuse elevations there, and another pair of contiguous ones just behind the middle of the dise, these are separated by a bare linear impression extending to the base, there is a nearly hare, oblique frontal depression midway between the middle and each side, there are no visible punctures; the sides are explanate. Scutellum strongly transverse. Elytra subcordate, about double the length and neally twice the width of thorax at the base, which is somewhat oblique towards the obtusely laterally prominent shoulders: their sides are explanate and minutely serrate, somewhat sinuate behind the shoulders, with obtuse divergent apices; the surface is uneven, very irregularly punctate, but subseriately near the suture behind, there are several granules near the base, and along each side about 8 coarse foveae; on each elytron there is a basal elevation, and behind this a large obtuse tubercle, just outside the latter a smaller nodosity is covered with rufescent scales; near the other large tubercle on top of the posterior declivity there is an inner and a pair of outer ones, all smaller and covered with reddish squamat, near the extremity there is a less distinct, sometimes elongate elevation. 'Tibiae only slightly flexuous.

In Pascoe's S. marginatus (640) there seem to be no large tubercles before the middle of the elytra. Sharp's S. bullatus (2039) is described as having a sharp tuberele, directed outwards, behind each shoulder, the dorsum has 4 large and a pair of smaller basal tubercles, but nothing is said about punetures or granules. S. crenatus (641), deseribed from a much damaged specimen forty years ago, is certainly the nearest species.

Length, $10 \mathrm{~mm}$. ; breadth, $5 \frac{1}{2} \mathrm{~mm}$.

Routeburn. Shaken off mossy trees at night by Mr. T. Hall. Two examples.

\section{Pheloneis halli sp. nov. Pheloneis Pascoe.}

Oblong, slightly convex, nitid, subglabrous; of a reddish copperybronze hue, legs rufo-piceous, tarsi and basal joints of antennae fuscomufous. remaining articulations and the teminal of the palpi dull fuscous.

Had a little meven, distinctly and closely punctate in front, less elosely behind; the epistome with 4 coarser setigerous punctures. Thorax, in 
the middle, a third broader than long, apex medially trumeate but obliguely prolonged at the sides, its obtuse angles extending to the middle of the eyes; the sides distinetly and evenly margined, sently romded at and before the middle, narrowed but with straight sides near the base, which is: feebly and widely emarginate, with rectangular angles; dise; moderately finely and elosely punctured, more irregularly and less closely at the sides, discal groove shallow and abbreviated, with a broarl but not very definite impression near each of the anterior and posterior angles and a median fovea at each side. Seutellum broad, nearly smooth. Elytra almost clongate-cordate, rather wider than thorax at the base, their well-developed lateral margins beconing slender towards the apices; their sculpture very irregular, consisting of interupted, moderately funely punctured striae near the suture, but along the greater portion towards the sides the striae are so much abbreviated and interrupted that they leave elongate, almost confluent, irregularly formed, nearly flat spaces, almost quitesmooth. There are a few slender suberect setae, and very minute ones can be detected on the thorax.

Anterior tibiae stout, evenly curvate externally, with short flavescent setae below the middle of the inner side. Penultimate tarsal joint excavate above but not truly bilobed.

$P$. chalmeri (1405), which most nearly resembles this in coloration, is really very different in other details.

Length, $11 \mathrm{~mm}$. ; breadth, $4 \frac{1}{2} \mathrm{~mm}$.

Hollyford, north of Lake Wakatipu. A single specimen of this eonspicuous species was captured on the 19th February, 1914, at a height of $3,500 \mathrm{ft}$., by Mr. T. Hall, in whose honour it has been named.

\section{Pheloneis angulatus sp. nov.}

Suboblong-oval, only moderately convex, shining; fusco-niger, faintly aeneous, legs piceous, antennae and tarsi piceo-rufous.

Head slightly uneven, broadly impressed between the antennae, distinctly and irregularly punctured, the epistome more finely. Thorix almost a third broader than long near the middle but appearirg more elorgate; its base rather wider than the apex, subtruncate, but with its quite rectangular angles projecting slightly bickwards; the sides obturely subirgulate. behind the middle, obliquely but not curvelly narowed anterioly, ipex deeply emarginate, with obtuse but unusually prominent angles; disc somewhat irregularly, moderately closely and finely punctured, marginal channels broad and shallow, the margins distinct and reflexed, the basal and apical less developed, discal groove obsolete. Sentellum subtriangular. moderately large, nearly smooth. Elytra rather wider than thorax at the base, more than twice its length, their sides nearly straight for half their length, gradually attenuate posteriorly; each with 8 moderately finely punctured striae, which, however, become somewhat irregular towards the sides and apices; interstices nearly plane, finely and moderately closely punctate, the 3rd broader than the others.

The shape of the thorax is somewhat similar to that of a Syrphetodes; there is, therefore, sufficient justification for its separation from $P$. appositus (3751), to which otherwise it is most nearly related.

Length, $12 \mathrm{~mm}$. ; breadth, $51 \mathrm{~mm}$.

Mount Dick. A solitary individual found by Mr. T. Hall on the 26th January, 1914. 


\section{Pheloneis dubitans sp. nov.}

Elongate-oblong, moderately convex, nitid; aeneo-niger, legs rufopiceous, antennae and tarsi fusco-rufous; with a few slender erect setae, the thorax with minute pubescence.

Head moderately elosely and finely punctate, with an elongate interocular fovea. Thorax about a third broader than long in the middle, distimetly marginate. almost quite straight from the rectangular posterion angles to near the middle, moderately curvedly narrowed anteriorly, apex cridently and widely inemverd. the base less so: its punctation like that of the head, with an elongate depression at each side behind the middle and a small basal fovea between the middle and side. Sentellum strongly transverse. Elytra of about the same width as thorax at the base, nearly thrice its length, curvedly narrowed behind; each with about 10 dorsal finely punctured striae, those near the sides less distinct; interstices with numerous fine punctures.

Underside shining, minutely pubescent, the legs more distinctly. Prosternum almost smooth, mesosternum closely punctured, the terminal segment more closely and distinctly punctured than other parts of the abdomen.

It first sight I thought this might be shatpis Adelinm simplex (2049). but as the elytmal interstices are described as almost impunetate, but the striae rather coarsely punctate, and as it scems to be destitute of pubescence, I now consider it distinct. No. 1401, from Mount Arthur, is another near ally, but it has a longer thorax with several coarse punetures like those of $P$. thoracieus (694).

Length, $8 \frac{1}{2}-9 \mathrm{~mm}$.; breadth, $3 \frac{1}{2} \mathrm{~mm}$.

Mount Diek. Five examples from Mr. 'T. Hall, some imperfect, taken on the 10th March, 1914. 'The erect setae seem to be easily rubbed off. A specimen from Ben Lomond, on the 6th March, 1914, measures $10 \mathrm{~mm}$. by $4 \frac{1}{3} \mathrm{~mm}$.

\section{Pheloneis curtulus sp. nov.}

Oblong, subparallel, moderately convex, nitid, apparently glabrous : aeneo-niger, legs piceo-rufous, antennae and tarsi slightly paler.

Head finely and closely punctate. Thorax subquadrate, about a third broader than long in the middle, its sides distinctly margined, nearly straight, a little curvedly narrowed before the middle, apex widely emarginate, base subtruncate, posterior angles somewhat obtuse; its surface regularly, finely, and closely punctured, with an elongate impression near each side before the middle, and a small basal fovea near each side. Scutellum transverse, with some minute punctures. Elytra very slightly wider than thorax at the base, rather more than double its length; rather closely and fincly punctured, each elytron with about 4 fine, irregular, nearly obsolete striae; these, however, scarcely extend further back than the posterior femora.

$P$. lentum (692) has a triangular excision at the base of the thorax, but nevertheless the scutellum is invisible. otherwise this seems to be little more than a varietal form.

Length, $7 \mathrm{~mm}$; ; breadth, $3 \frac{1}{4} \mathrm{~mm}$.

Ben Lomond; 31st January, 1914. Mr. 'T. Hall is the discoverer. 
3854. Cerodolus tuberculatus sp. mo. Cerodolus Sharp, Ian. I.7. Coleopt., p. 1161.

Convex, oblong, suboval, shining; head and thorax aeneo-niger, hindbody viridescent, legs rufo-piceous, tarsi and antennae rather paler : some very minute setae are discernible, and in certain aspects parts of the surface appear faintly iridescent.

Head evidently narrower than thorax, fincly and moderately closely punctured. Thorax only a fifth broader than long, hase and apex trunrate; its sides with slender margins, only slightly jounded and widest noar the middle, gently narrowed but not sinuate behind, with obtusely rectangular posterior angles; it is morlerately rosely and fincly junctate. Scutellum usually small and triangular. Elytra of the same width as thorax at the base, not thrice its length; each with a scutellar and 8 other series of punctures, those near the suture nore numerous and finer than the ones composing the 4 th or 5 th series, the interstices finely and irrestulariy punctate; the top of the posterior declivity near the sides is trituberculate, and there is another, sometimes smaller, tubercle nent earkh of the apices.

Underside glossy blark, sparingly and finely pubesent: abroman punc: tate and longitudinally rugose; prosternal process bisulcate.

The thorax differs in form from that of 2058, the type of the genus, and is withrut definite basal sinuosities, the scutellum is not transverse. the prostemal proress is bisulate, whilst the tuberculation of the olytra of itself is distinctive.

Length, $7 \mathrm{~mm}$. ; breadth, $3 \frac{1}{2} \mathrm{~mm}$.

Moa Basin, Canterbury. Three taken off moss-covered trees on the night of the 3rd December, 1913, at an altitude of 3,50) ft., hy . Mr. T. Hall.

\section{Cerodolus capitalis sp. nov.}

Oblong-oval, only moderately convex, glabrous; head and thorax nigrescent and suboparque; elytra somewhat viridesent: legs, antemuae. and scutellum piceo-rufous.

Head almost as wide as front of thorax, fincly and moderately rovely punctured, the forehearl more minutely; the fine yet rlistinct suture is subtruncate in the middle but extends obliquely forwards to the front of the antennal orbits, there is a transverse median fovea behind. Thorax subquarlate, a fifth brosder than longs: its sides fincly marcinate almost

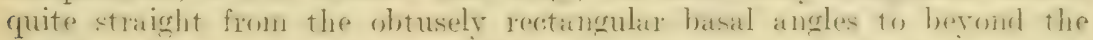
middle and from thence very slightly arvedly narrowed anteriorly: apex subtruncate, the base bisinuate; its whole surface very finely, evenly, and moderately closely punctate, with a shallow punctiform fovea near each side, at the middle. Scutellum quite transverse, smooth. Elytra very

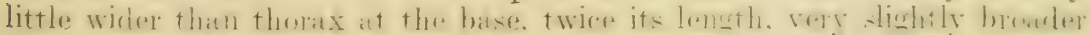

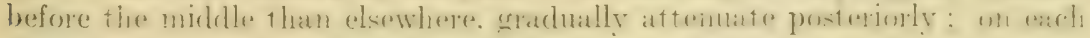
there are 6 dorsal series of unequal punctures, those near the suture are moderately fine, the 4 th series is larger but not coarse, all become irregular and indistinct near the base, but striate behind; interstices fincly and

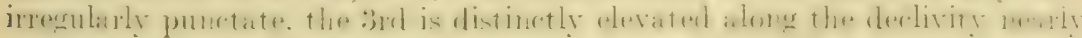
to the extremity, and the side, on top of the declivity, is trinodose.

Antennae with the uncovered portion of the basal joint scarcely longer

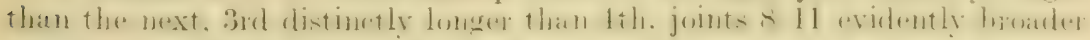
and more pubescent than the others. 
The nearest species is $C$. tuberculatus, but in it the punctation of the head and thorax is more distinct, that of the elytra is coarser and more irregular, near the sides particularly, there are no striae, and the posterior tubercles differ; its whole surface is more glossy, and the interantennal suture is obsolete near the sides.

Length, 7 $\frac{1}{2} \mathrm{~mm}$.; breadth, $3 \frac{1}{2} \mathrm{~mm}$.

Stewart Island. Unique. Found by Mr. W. Trail.

\section{Cerodolus sulcisternus sp. nov.}

Convex, oblong-oval, moderately nitid, glabrous; aeneo-niger, legs, antennae, and palpi rufo-castaneous.

Head narrower than thoracic apex, distinctly but not closely punctate. Thorax nearly twice as broad as long, finely margined, veryenty curvedly narrowed anteriorly, almost straight and without any sinuation behind, the apex subtruncate, only very slightly emarginate, with obtuse but nearly rectangulat angles: hase widely bisinuate, its angles almost rectangular and areommodated within the excavation just inside the humeral margin; its surface finely punctured, much more finely than the head, even more so and more distantly towards the sides and base, with a slight transverse impression between the middle and each side of the base. Soutellum transverse, nearly smooth. Elytra slightly wider than thorax at the base, thrice its length, gradually narrowed and a little uneven but not nodose behind the posterior femora, their margins most distinet near the base: their whole surface irregularly and finely punctate, minutely wrinkled behind; each elytron with 7 series of distinct punctures, about 20 in each row, these become obsolete at the extremity, near the suture they almost form striae, near the lateral margin there is a series of fine punctures.

Underside nigrescent, shining, abdomen fuely and moderately closely punctured, prosternum nearly smooth, its process distinctly bisuleate but with its hind margin entire.

Antemnae almost as long as the head and thorax, 3rd joint evidently longer than 4th or 5th, 9th and 10th longer than broad but not quite as long as the 8th, the terminal elongate-oval.

C. genialis (2059) is certainly the nearest species, but it is rather larger, the thorax is wider at the base, and is more distinctly and closely punctate, and the antemae are stouter. The prosternal process also is different, being more like that of $C$. aeneus (2060), in which, however, it is flatter and simply depressed throughout, whereas in $C$. sulcistermus it is almost elongate-oval, and the ridge between the grooves is on a lower plane than the margins.

Length, $6 \mathrm{~mm}$. ; breadth, $2 \frac{2}{3} \mathrm{~mm}$.

Gordon's Knob, near Nelson; 15th November, 1914. Four examples found by Mr. 'I'. Hall.

3857. Miesopatrum dubium sp. nov. Mesopatrum Broun, Man. N.Z. ('oleopt., p. 1355.

Oblong, nearly plane above, subopaque; varying from fusco-testaceous to rufo-fuscous, tarsi and antemne of the latter hue, tibiae fusco-testaceous above, dark fuscous near the extremity; with many minute pale setae.

Head seemingly closely and coarsely punctate when examined from above but appearing granulate when viewed sideways, interantennal groove distinct. Thorax in the middle nearly twice as broad as long, base widely 
but not deeply bisinuate, with slightly projecting rectangular angles, apex subtruncate in the middle but with its angles extending to the transverse eyes; its sides broadly flattened, widest at or before the middle, each with about 6 moderate indentations; disc transversely convex, but somewhat impressed or flattened along the middle, its sculpture irregular, nowhere very close, consisting apparently of minute asperities. Elytra oblong, considerably narrowed and subvertical behind, more than double the length of thorax, a little broader than it is at the base, and slightly incurved there, with obtuse shoulders; they are without definite striae or punctures, but have irregular series of minute, somewhat unequal asperities or granules; there is a slight lateral plica at each shoulder, and near each side, behind the middle, there are 2 or 3 slight, suboblong elevations, these are sometimes confluent, and unite with the horizontal nodosity at the top of the posterior declivity, just inside and below this nodosity there is a dark angular depression.

Underside infuscate, its granular seulpture becoming finer from front to rear. Prosternum broadly grooved between the coxae. The suture between the intermediate coxae is obsolete. Basal ventral segment not twice as long as the next and subtruncate between the coxae, tth shortest, the broad sides are coarsely subseriate-punctate or gramulate according to the point of view.

Antennal joints $7-10$ transverse, abruptly shorter than preceding ones, the terminal subconical.

The almost wholly nigrescent surface of the typical species (2376) distinguishes it.

Length, 6-6 $\frac{1}{2} \mathrm{~mm}$. ; breadth, $2 \frac{2}{3} \mathrm{~mm}$.

Gordon's Knob, Nelson; 15th November, 1914. Three specimens obtained by Mr. T. Hall. A fourth measures $7 \frac{1}{2} \mathrm{~mm}$. by $3 \frac{1}{2} \mathrm{~mm}$., and is almost entirely íusco-testaceous.

\section{Group Oedemeridae.}

3858. Sessinia brookesi sp. nov. Sessinia Pascoe, Journ. Entom., 11, p. 45 .

Depressed, elongate, subopaque, variegate; pubescence slender, elongate, tawny-grey, closer on the elytra than on the thorax, flavescent on the head; elytia dull fuscous, faintly olivaceous when alive, the suture and lateral margins pale testaceous; head and thorax a little nitid, fusco-fulvous, the former with a large interocular spot, the latter with a broad vitta along the middle, and its sides, fusco-piceous; legs, antemna, and palpi fuscous, the knees and tips of the palpi testaceous, femora fulvescent near the base.

Head of about the same length as thorax, finely punctate. Thorax slightly longer than broad, widest and moderately romded betore the middle, base and apex feebly medially emarginate; closely and funely punctate, with a entral impression at the base. Scutellum subquadrate, testaceous. Elytra nearly double the width of thorax, four times its length, shoulder's rounded, apices strongly so and almost entirely eovering the pyordium; their close and fine punctation continuous, each elytron feebly bicostate.

Underside finely pubescent, the breast and coxae fulvescent; abdomen fuscous, its 5th segment as long as its predecessor, entire. 
Eyes prominent, transverse, obliquely oval, not emarginate in front. Mandibles anentely hifid at apex. Sntennase filiform, extending to beyond the posterior femora. Terminal articulation of maxillary palpi mueh larerer than pemultimate. straight externally, corvedly narowed from the middle to the apex inwardly. Tibiac bispinose at the extremity.

Not a true Sessinia, as are also 2853 and 3581.

Length, $11 \mathrm{~mm}$.; breadth, $2 \frac{3}{4} \mathrm{~mm}$.

Waipu Beach, near Whangarei. Three examples, amongst other Coleoptera, from Mr. Albert E. Brookes, of Mount Albert, after whom it is named. 10th January, 1914.

\section{Group Otiorhynchidae.}

3859. Nicaeana crassifrons sp. nox. Nicaeamu Paseoe, Man. N.Z. (Goleopt., p. 427.

Elongate, moderately envex, subopaque: nigrescent, antemae and legs pieco-rufous: covered with subdepressed, dark-grey squamae, some of which are suboblong, and suberect, nearly white setae.

Rostrum short and stout, very thick from above downwards, slightly meven, not pereeptibly earinate, rather finely punctured. Thorax somewhat broader than long, base and apex truncate, its sides gently and evenly rounded: dise without inequalities, with mumerous fine flattened granules, in each of these there is a minute exntral puncture. Seutellum obsolete or absent. Elytral elongate-obovate, slightly ineurved and a little wider at the base than the thorax, twice its length; apparently rather finely substriate-punctate, with simple interstices.

Scape straight, stout, gradually incrassate, attaining the centre of the "re. with deemmbent wrey setae ; basal joint of funieulus obviously thieker and slight!y longere than 2 and, joints 37 transierse: club elongate-oval.

Tibiar slightly flexuous, the front pairs quite definitely ret only moderately mueronate at the inner extremity; 2nd tarsal joint transverse, not broader than the 1st, evidently narrower than the 3rd.

The eyes being flat the outline of the head and rostrum is minterrupted. The foveiform serobes are very small. N. catoptoites (3582) is smaller and more slender, the eyes are rather large and convex, the rostrum is carinate, the serobes are deep, and the scape is flexuous.

Length (rostrum inclusive), $4 \mathrm{~mm}$.; breadth, $1 \frac{1}{2} \mathrm{~mm}$.

Moa Basin, Canterbury. Unique. Found amongst dead leaves, 20th Oetober, 1913, by Mr. 'T'. Hall.

3860. Cecyropa sulcifrons sp. nov. Cecyropa Pascoe, Man. N.Z. Coleopt,, p. 437.

Suboblong, medially contracted, opaque; piceo-fuscous, legs and antennae fusco-rufous; densely covered with irregularly mingled, tawny and dark-fuseous syuamate and short moderately thick setate, those along the sides longer and outstanding.

Rostrum not half the lenerth of thorax, subparallel, medially trisuleate in fromt of the antemane. Thorax a fourth broader than long. its sides strongly rounded, slightly constricted at apex, which, like the base, is trumeatr: without imequalitios of surface, its punctation fine, shallow, and indistinet. Elytra, at the base, slightly oblique towards the sides, rather hometer there than the thomx, wot twioe its length. with oblique shoulders. 
in the middle a fifth wider than the thorax, their sides nearly straight. somewhat abruptly narrowed but not vertical behind; with rather bursarl. moderately fincly punctured striae, and slightly concex intristices.

Legs with grey scales and elongate setae; tibiae dilated at the extremity, the anterior strongly angulate inwardly at the extremity, the outer or frontal lobe almost covering the basal joint of the tarsi.

Scape with grey scales and slender setar, gently incrassate, reaching to beyond the thoracic apex; basal joint of funiculus stouter but only slightly longer than the 2 did, joints 36 transverse, 7 th still broader; rilub short and stout, ovate, pubescent.

In C. varia (1229) the hind-body is attenuate posteriorly, the distant punctures are distinct, and the thorax has a fine discal stria. C'. seligerce (1617) has a shorter rostrum, with a well-marked elongate depression near its base, the numerous setae though short are conspicuous, and the elytral striae are narrow. In ('. striata (2862) the rostal stria is continuous, that of the thorax is very fine, the elytral striae are not at all broad, their punctation is finer, and the setae are more distinct.

Prostemum deeply emarginate. Metasternum and basal ventral segment broadly depressed, the suture between the latter and the 2nd oblique near the sides, curvate and quite definite in the middle.

Length (rostrum inclusive), $5 \mathrm{~mm}$. ; breadth, $2 \frac{1}{2} \mathrm{~mm}$.

Waipu Beach, near Whangarei Harbour. I an indebted to Mr. A. E. Brookes, of Mount Albert, for a specimen, which he found on the 10th January, 1914.

Obs. - Dr. Sharp, in his revision of Pascoe's genus (see Man. N.Z. Coleopt., p. 1174), states that the prosternum is not emarginate in front, and that the strongly arcuate suture between the 3 st and 2 nd ventral segments is obliterated in the middle. In C. sulcifroms and rach of the following species the prosternum is rather deeply emarginate, and the ventral suture he refers to is quite distinct in the middle. In this genu: there are no tubercular elevations.

\section{Cecyropa striatella sp. nov.}

Oparque. uniformly rastaneorufous; rovered with flat tawny squanare. and numerous fine suberect greyish setae, those along the sides more elongate.

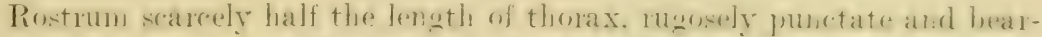

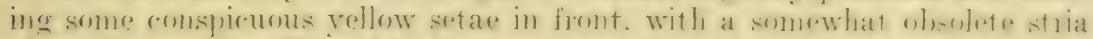
along the middle. Eyes free from thomax. marty flat. subtruncate in frout.

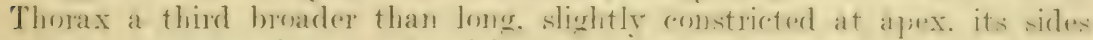
strongly and evenly curved, with a fine frontal stria extending to the middle. without risible purctation: a few srates beirg rastanemus causp a somewhat sperckled appeasabere. Elytsa just twiee the length of thorax. evidently breadere than it is at the base. their whlique shomlders somewhat obtusely ancrulate behind. widest there. their sides gradually narrowed.

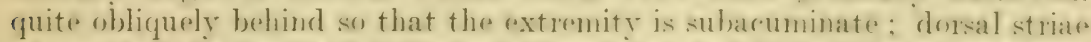
narrow and shallow and indistinctly punctate. but beroming more definite behind; the setae are numerous, but do not form regular series.

Lens with grey srales and setar; frontal lobe of anterior tibiarentirely rovering the hasal tarsal joint; external truncature of pesterior corlets half the whole width and studded with tubereles. Metasternum and basal ventral segment not depressed. 
Antemne similar to those of $C$. sulcifrons. The abbreviated thoracic stria, subangulax hind part of the shoulders, narrow elytral striae and broad, plane interstices, and the subacuminate extremity are its chief distinguishing features.

Length (rostrum inclusive), $7 \frac{1}{2} \mathrm{~mm}$. ; breadth, $3 \frac{2}{3} \mathrm{~mm}$.

Waipu Beach. One example, found by Mr. A. E. Brookes, 10th January, 1914.

\section{Cecyropa jucunda sp. nov.}

Opaque, the derm invisible except on a basal spot of the elytra which is castaneous, legs and antennae chestnut-red; densely covered with depressed fuscous and tawny seales; the former almost cover the thoracic dise, the sides and a pair of basal and apical spots are yellowish; on the hind-body the pale ones form numerous spots and almost wholly cover the sides.

Rostrum half the length of thorax, with a few apical punctures, and a shallow stria extending as far as the eyes. Thorax nearly a fourth broader than long, its sides strongly rounded, more narrowed anteriorly than at the base, with a short apical constriction, without any perceptible median stria or punctation. Elytra cordate, just double the length of thorax, slightly "matrinate and rather broader than it is at the base, just behind the oblique fhoulders they are about a fifth broader than the middle of the thorax, nearly vertical and subacuminate behind; there is no distinct dorsal sculpture except some obsolete serial punctures, the apical portion, however, is striate-punctate.

In form somewhat similar to $C$. striatella, but without any lateral dilatation behind the shomldex, and with quite different sculpture and vestiture. Joints 3-7 of the funicle are rather small and evidently transverse; the corbels of the hind tibiae are distinctly tuberculate. The elytral maculation is more irregular than that of $C$. alternata (2863) from Lyttelton, the setae are a little thicker, and the antennae are rather shorter and more slender.

On a careful examination of the thorax, near the sides particularly, some flat iridescent scales can be seen, varying from silvery grey to pink; there are others on the elytra.

Length (rostrum inclusive), $7 \mathrm{~mm}$; breadth, $3 \frac{1}{2} \mathrm{~mm}$.

Muriwai, west coast of Auckland. Unique. Found by Mr. A. E. Brookes on the 13th April, 1914.

\section{Cecyropa laticollis sp. nov.}

Opaque, rufo-castaneous, densely covered with greyish-tawny and infusrate acales. the latter forming irregular dark marks on the thomax and hindbody: fhe setale bather fine and short, but much longer alomg the sides and on the legs and scape; antennae and tarsi fusco-rufous.

Rostrum quite half the length of thorax, its fine central stria extending to the occiput, the apex elosely and moderately coarsely punctured. Thorax large, a third broader than long, slightly constricted at apex, its sides only mederately romeded, as broad behind as at the middle, but obliguely and almost abruptly narrowed near the base; the surface with minute dark specks, its mesial stria distinct but slender. Elytra searcely twice the length of thorax, rather broader than it is at the base, their obliquely narrowed shoulders without any angular posterior dilatation. their sides enently narowed backwards. but much more strongly near the subvertical 
declivity ; on each there are 3 or 4 rather broad, distinetly but not coarsely punctured striae, all prolonged to the extremity, and obtusely elevated interstices, the sculpture near the side consists of serial punctures and plane interstices. Basal ventral segment flat.

Scape with white scales; 2nd joint of the funiculus as long as the basal, joints 3-6 short and nearly equal, 7 th broader.

The shape and nuswal breadth of the thorax distinguishes this species; behind the middle it is almost if not quite as broad as the widest part of the elytra, and instead of being curvedly narrowed behind the middle, as is generally the case, it is not contracted till close to the base, but there rather abruptly and transversely.

Length (rostrum inclusive), $7 \frac{1}{2} \mathrm{~mm}$.; breadth, $3 \frac{1}{2} \mathrm{~mm}$.

Waipu Beach; 10th January, 1914. Another diseovery by Mr. A. E. Brookes.

3864. Tigones nasalis sp. nov. Tigones Brom. Man. N.Z. Coleopt., p. 855. (Protophormus Sharp, Man. N.Z. Coleopt., p. 1178.)

Opaque, moderately robust. castaneous; densely covered with depressed variegated squamae and many suberect greyish setae; the squamae are chiefly light rufo-fuscous, darker between the hind thighs, but paler though not grey behind these; apex of rostrum, the antennae, and tarsi fuscorufous.

Rostrum a third shorter than thorax, feebly earinate along the middle, with rather dark scales; scrobes large, quite open above; the apex dilated, nearly as broad as the head, its central portion irregularly, longitudinally, and closely rugose. Eyes less distant from the thorax than they are from each other. Thorax very little broader than long, base and apex truncate, a little narrowed before the middle, nearly straight behind; the surface with numerous short irregular rugae, or small tubercles, and with a broad longitudinal impression behind the middle, this is divided by a central, rufescent, closely punctured ridge. Scutellum narrow, pallid. Elytra more than double the length of thorax, rather wider than it is at the base, considerably narrowed and deflexed behind, with simple apices; they are rather finely striate-punctate. the suture and 3rd interstices are a little elerated at the base, 3rd and 5th interstices slightly raised, but not nodiform. near the top of the posterior declivity.

Scape dull, closely punctate, scarcely reaching the thoracic apex; funiculus rather stout, basal joint rather larger than the next, 3rd still shorter, joints 4-7 as broad as long, subobconical; club elongate-oval.

Tibiae flexuous, minutely serrate inwardly near the extremity, the anterior mueronate, the others expanded at the apex, the posterior without any visible external truncature of the corbels.

Nearly as large as Sharp's Protophormus robustus (2091), and nearly related thereto, but with different vestiture. finer elytral seulpture, and without posterior nodosities.

o. Length (rostrum inclusive), $7 \frac{1}{2} \mathrm{~mm}$.; breadth, $3 \mathrm{~mm}$.

Stewart Island. A single specimen found by Mr. W. Trail during the summer of 1913.

3865. Tigones citimus sp. nov.

Elongate, nearly plane; rufo-piceous, legs and tarsi fusco-rufous, antemate and rostral apex piceo-rufous; thickly covered with depressed rupreous seales and moderately clongate, principally decumbent setace. 
Rostrum a third shorter than thorax, carinate along the middle, the apex finely punctate. 'Thorax as long as broad, slightly dilated noar the middle. the hase bismuate; its rentral rama does not quite reach the apex and becomes indistinct behind, at each side of it there is a shallow impression, the sculpture concealed. Scutellum elongate, pale yellow. Elytra oblong, a good deal narowed behind, with slightly divergent but not prolonged apices, they are quite twice the length of thorax, rather broader than it is at the base. which is bisinuate; distinctly but not ressely seriate-punctate, each puncture has a narrow greyish seale within it; 3rd interstices obtusely elevated at the base, plane along the middle, horizontally moliform on top of the declivity, wheh is broadly comvex. but not vertical, along the middle; 5th interstices simple.

Scape with elongate greyish scales and erect setae, gradually incrassate and attaining the thoracic apex; 2nd joint of tuniculus rather shorter than the basal, neither very elongate, joints 3.7 short and submoniliform; club elongate-oval, indistinctly quadriarticulate.

This somewhat resembles 3118 , but the squamae are almost wholly of a reddish-coppery hue, the grey scales covering the sides of the elytra and posterior declivity in that species being absent. The terminal nodosities of the 3rd interstices are much less conspicuous and do not project beyond the subcurvate declivity, which in 3118 is vertical, with prolonged apices, and the 5th interstices are simple in this species. The joints of the funiculus are evidently shorter. The space between the external cilia of the posterior corbels is very narrow.

The scrobes, as seen from above, are deep and widely open, and they continue broad and smooth more than half-way to the eyes, and therefore do not correspond exactly with the typical species of either Platyomida or Tigones, and in Sharp's Protophormus they are described as being "brevissimae." As those of 3118 are similar it must be placed with this species.

Length (rostrum inclusive), $8 \mathrm{~mm}$. ; breadth, $2 \frac{1}{2} \mathrm{~mm}$.

Iromt Iffeed: th February, 1914. Linique. Foumd hy Mr. T. Hall.

Note-As 1521 was described as Tigones caudata, 3118 must have its mame altered to Tigones asteliae.

\section{Tigones thoracica sp. nov.}

Stout, unasperate, the derm slightly nitid, fusco-rufous, legs and tarsi chestnut-red; covered with depressed tawny squamae, those on the thoracic dise of a light-coppery hue, bordered near the sides with some fuscous ones which also form small spots on the declivity, on the summit of the last there are some grey ones, these, however, do not form a definite fascia; the setae are erect, mostly pale.

Rostrum a third shorter than thorax, earinate along the middle. Thorax subeylindric, base and apex truneate, a little broader than long, slightly narrowed in front, without distinct rugae; an indistinctly raised space extends from the base and tapers towards but does not reach the apex, it is quite bare and closely rugose-punctate. Scutellum distinct, greyish.

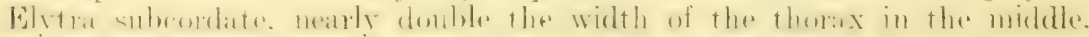
thrice its length, with slightly oblique shoulders, the apices slightly prolonged and dehiscent; they are striate-punctate, with nearly simple inter-

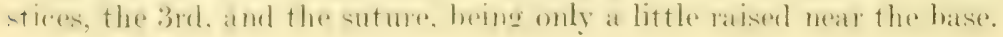


Tibiae setose, the anterior rather longer than the others, which are more flexuous and minutely denticulate.

Scape nearly straight, bearing decumbent and erect grey setae; basal joint of funiculus stouter and slightly longer than the next, 4 th slightly longer than the 3rd or following ones, which are moniliform ; club elongate.

Male--Elytral apices subacuminate but searcely at all prolonged; rostral earina broader, grooved along side; the bare thoracic space not sulcate in front.

T. candata (1521) has more prolonged, rather thickly spiniform elytral apices; there is only a nodiform bare spot near the base of the thorax; and a considerable proportion of the squamae, when cleaned with benzine, appear shining brassy.

Length (rostrum inclusive), $6 \mathrm{~mm}$. ; breadth, $2 \frac{1}{3} \mathrm{~mm}$.

Kuriwai Bush, Wyndham. One of each sex found by $\mathrm{Ir}_{\mathrm{r}} \mathrm{J}$. H. Lewis on the 21st September and 18th October, 1914.

\section{Tigones variata sp. nov.}

Opaque, moderately slender ; legs and antemnae fusco-rufous, the body apparently concolorous, the thorax having an elongate bare space of that colour extending from the base and becoming narrower towards the middle; densely covered with variegated depressed squamae, principally copperybrown, the sides of the thorax, and the posterior; more or less greyish, on the elytra there are a few greyish-blue scales; the setae neither very numerous nor conspicuous, suberect and flavescent.

Rostrum a third shorter than thorax, finely carinate. Thorax of equal length and breadth, slightly wider near the middle than elsewhere, without inequalities. the bare mesial space distinctly punctured. Scutellum suboblong, greyish. Elytra oblong, not thrice the length of thorax, quite a third broader than it is, with oblique shoulders, the apices somewhat dehiscent and moderately acuminate; rather finely and regularly striatepunctate, 3rd interstices slightly elevated near the base, not nodiform behind.

Scape nearly straight, setigerous; 3rd joint of the funicle shorter than 2nd; club elongate-oval. Legs like those of $T$. thoracica.

Male-Rostral carina more distinct. Elytral apices not prolonged. Underside with grey seales and setae, some of the former pinkish. Fifth ventral segment flat, strongly rounded behind, evidently longer than the 3rd and 4th together.

The nearest allies are T. cervina (1525). T. obscura (2383), and T. Philpotti (3121). The first possesses an interrupted thoracic ridge and thick divergent. elytral apices. The second is more robust, and the thorax is broader than long and simple. The 3rd has a dark obtuse thoracic ridge. and the hand arross the top of the posterior declivity is composed of bluish-grey scates.

ㅇ․ Length (rostrum inclusive), $5 \mathrm{~mm}$; ; breadth, $1 \frac{2}{3} \mathrm{~mm}$.

Kuriwai Bush. Six examples found by Mr. and Mrs. J. H. Lewis, 18th October. 1914. In some males the clothing is much less ratregate, chiefly infuscate-grey. In the typical female the seales when hrushed with benzine appear rufo-cupreous.

\section{Tigones murina sp. nov.}

Elongate, rather stout, opaque; piceous, antennae fusco-rufous; densely dothed with infusmate-grey and grey squamae, these latter somer 
what concentrated from the 3rd elytral interstices to the sides, but not forming a well-marked fascia, in front of the posterior declivity; the setae rather slender and, except on the antennae and legs, not conspicuous.

Rostrum a third shorter than thorax, distinctly but not broadly carinate along the middle and, like the unimpressed head, rather finely and closely punctured. Thorax just as long as broad, a little marowed in front. its surface funcly punetate. and with short irregular rugite. Soutellum distinet, usually subquadrate. Elytra oblong, a third broader than thorax at the hase, fully double its length. posterion deelivity moderately narow but not vertical, apices broad in the male, only feebly acuminate and dehiscent in the other sex; they are moderately coarsely, closely, and regularly striatepunctate, 3rd interstices moderately elevated, rather more distinctly in front of and as far as the top of the declivity, but not nodiform there, 5th rather less elevated behind and plane near the base.

Antennae elongate, 2 nd joint of funiculus as long as the basal, 3rd but little shorter. the following ones obeonical, all rather lomere than broad; club elongate.

Legs elongate, like those of the preceding species, but with a few minute denticles inside the anterior pair.

Underside with grey scales and setae, the 3rd and 4th segment almost without scales.

A rather large species, recognizable by its long antennae, well-marked elvtral punctation. rather elongate elevations of the 3rd interstices, and almost uniformly coloured vestiture, which in some examples is more fuscous than the type.

o. Length (rostrum inclusive), $7 \mathrm{~mm}$.; breadth, $2 \frac{1}{2} \mathrm{~mm}$.

Clipping's Bush, east of Kingston. Mr. T. Hall obtained nearly a dozen individuals, but only a single female, on the 29th January, 1914.

\section{Tigones assimilis sp. nov.}

Opaque, fusco-rufous, antennae and tarsi inchusive, these latter never nigrescent; the vestiture nearly similar to that of $T$. murina, varying individually from greyish to fuscous, the thorax generally with a broad dark streak along the middle, and with a fine stria there, the dise without rugae. Scutellum oblong. Elytra more finely striate-punctate than those of $T$. murina, 3rd interstices with similarly elongated posterior elevations; but the 5th are prolonged, somewhat swollen and curved inwardly below the terminal elevations of the 3rd, and in line with these the sides are broader. The rostral carina is indistinct. The legs are more slender, the tibiae less distinctly denticulate, the anterior are nearly straight, being curved only below the middle. Antennae shorter, joints 5-7 scarcely at all longer than broad.

Length (rostrum inclusive), $6 \frac{1}{2}-7 \mathrm{~mm}$; breadth, 2-21 $\mathrm{mm}$.

Moa Basin, Canterbury; 20th October, 1913. Five examples found by Mr. 'T. Hall.

\section{Tigones setosa sp. nov.}

Opaque, fusco-piceous, legs and tarsi fusco-rufous, antennae rather darker, rostral apex dark red; covered with depresed fusco-testaceous and some darker squamae; the setae yellowish-grey, numerous, suberect, rather conspicuous but not very elongate. 
Rostrum indistinctly carinate, normal. Thorax uneven, rather short, broader than long, slightly wider near the middle than elsewhere, a little impressed across the front, with a short longitudinal depression on the middle and a slight swelling behind; the dark scales congregated between the middle and sides near the base. Scutellum small, grey. Elytra subcordate, hardly double the width of thorax in their broadest parts, a little narrowed near the base, much narrowed behind and, conjointly, subacuminate at the apex, almost thrice the length of the thorax; apparently rather distantly and finely striate-punctate, 3rd and 5th interstices only obsoletely elevated, the setae regularly seriate right to the extremity.

Antennae short, scape stout; basal joint of funiculus thicker and rather longer than the next, 3rd rather longer than broad, the others beadlike but not transverse; club elongate-oval.

Legs with scales and greyish setae, tibiae slightly flexuous, the hind pairs distinctly denticulate along the inside.

Near T. osculans (1522), more rough-looking, the setae much more conspicuns, the scape evidentir thicker, rostrum not perceptibly carinate, tarsi shorter, and with denticulate tibiae, whereas those of 1522 are simple.

Length (rostrum inclusive), $5 \frac{2}{3} \mathrm{~mm}$. ; breadth, $2 \frac{1}{3} \mathrm{~mm}$.

Longwood Range, Southland. Unique. Found by Mr. A. Philpott in December, 1913.

\section{Tigones longiceps sp. nov.}

Elongate, opaque, fusco-piceous, antennae and tarsi fusco-rufous ; covered with depressed squanae, which for the most part are rellowishbrown, but fuscous ones form a lateral patch near each hind thigh; the setae are somewhat flavescent, erect on the elvtral nodosities, decumbent on the dorsum.

Rostrum a thind shorter than thorax, distinetly earinate. Eyes slightly convex, the space between the hind part of each and the thoracic margin equals the length of the eve. Thorax slightly broader than Iong, a little wider before the middle than elsewhere; rather finely punctate, obtusely ridged along the middle, without obrious rugae. Sentellum subtriangular. Elytra oblong, almost thrice the length of thorax, a fourth broader than it is at the base, with slightly eurvedly narrowed shoulders, gradually narrowed from the hind thighs backwards, not quite vertical behind, apices obtuse; apparently rather finely seriate-punctate, 3rd interstices elevated at the base, obsoletely along the middle, terminating at the summit of the declivity as elongate, horizontal, but not prominent nodositien, just. outside and below each of these there is a minute crest.

Tibiae nearly straight externally, the hind pairs funely dentienlate along the inner side.

Scape funely setose; 2nd joint of funiculus as long as the basal, 3rd evidently shorter, joints 17 short and submoniliform: club rlongate-oval.

Ordinarily the interval between the thorax and the eye is little more than half as great as it is in this species. The larese smooth serolbes nearly

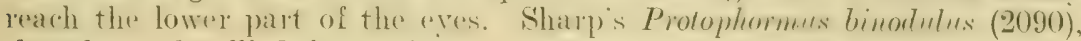
though nearly allicd, is smaller.

Length (rostrum inclusive), 7-8 mm.; breadth, $2 \frac{1}{3}-2 \frac{2}{3} \mathrm{~mm}$.

Harris Saddle, near Routeburn; $4,200 \mathrm{ft}$. A pair found by Mr. T. Hall on the 12th February, 1914. In one there are many brassy-grey squamae. 
3872. Epitimetes cupreus sp. nox. Epritimetes Piscoe. Mrun. N.\%. ('oleopt., pp. $435,1184$.

Robust, oblong, opaque, piceous, antennae and tarsi fusco-rufous; densely covered with small, depressed, dark-coppery scales, and numerous decumbent setae of a lighter cupreous hue.

Rostrum half the length of thorax, somewhat dilated and finely setose in front, boadly lomgitudinally bi-impressed behind, where its carina is much more conspicuous than it is in front. Thorax a sixth broader than long, widest near the front and there almost as broad as the dilated portion of the elytra just behind the shoulders, its sides stiehtly narowerl towards the remonded hind angles, more entraeted at the apex; its dise quite free from rogate. with a broad mintermeted ehannel from base to apex. Sentellum minute. Elytra double the leneth of thorax, medially emarginate at the base. the obtuse houlders rather bloader than it is. just begind each of these there is a slight, flat, lateral dilatation, posterior declivity moderately narowed but not rertical: ther are moderately finely and regularly seriate-punctate; 3rd interstices slightly elevated along the middle, more distinetly at the base, and teminating as distinet nodosities on top of the declivity: 5th plane in front, nodiform behind. and with a shorter, more rotundate nodosity lower down; the suture convex but not quite nodiform just below the top of the declivity.

Legs with coppery scales and greyish setae; femora robust, the anterior particular!y : tibiae bent inwardly and acuminate at the extremity. the hind pair with a very prominent tooth on the inside near the base, and below this thickly ciliate with elongate, rather slender fulvescent setae.

Basal 2 joints of funiculus slender and equally elongate, joints 3-7 obconical; club densely pubescent, about as long as joints $3-7$ of funiculus together.

Underside fuscous. Metasternum plane, very short. Basal ventral segment truncate between the widely distant coxae, medially sinuate behind, broadly depressed, the 2nd rather shorter, 3rd and th moderately abbreviated and, together, rather shorter than the 5th, which is longitudinally impressed.

The first part of the description, apart from other details, shows that this is materially different from Pascoe's E. lutosus (763); whilst Sharp's E. malefieldi (2099). described. I suspeet, from the female. can be separated at once by its rugose thorax, and the stongly raised sides of the elytrat near the shoulders.

o. Length (rostrum inclusive), $10 \mathrm{~mm}$. ; breadth, $3 \frac{1}{2} \mathrm{~mm}$.

Mount Hutt, Canterbury. A single male discovered by Mr. T. Hall in December, 1911. The speries of this semus are exeessively rate and seem to be confined to Canterbury.

\section{Epitimetes foveiger sp. nov.}

Oblong, convex, the derm piceous and slightly nitid, funiculus and tarsi chestnut-red; thickly covered with small grey scales and numerous grey setae, many of the latter erect.

liostrum half the lengeth of thorax, with a distinst earina alomg the

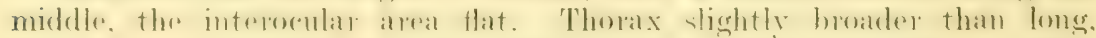
moderately contracted in front; uneven, with a large impression near each side in front, another at the base, and the still larger and deeper median one before the middle has obtusely elevated lateral borders, the basal half 
is coarsely rugose. Elytra oblong, more than double the length of thorax, evidently wider than it is at the base, medially incurved there, with slightly narrowed, obtusely prominent shoulders, the declivity is enrvate so that the extremity is somewhat inflexed; the sutural pair of striae on each elytron are moderately coarsely and closely punctured; 3rd interstices moderately elevated, somewhat prominent at the base, distinctly nodose on top of the declivity; the 5 th simple at the base, rather less elevated, and less distinctly nodiform behind, but prolonged, though not very obviously, half-way down the declivity; between these interstices the sculpture consists of irregular foveae, some extend right across the interval, there are only about 6 altogether; the lateral sculpture is not as coarse as the sutural; the suture is obtusely elevated behind.

Smaller than E. grisealis (3260), with nearly white dothing, the frontal thoracic depression and the elytral sculpture different.

Length (rostrum inclusive), $6 \frac{1}{2} \mathrm{~mm}$.; breadth, $2 \frac{2}{3} \mathrm{~mm}$.

Oakden, near Mount Algidus. One found amongst a miscellaneous collection made by Mr. Roderick Lrquhart and Mr. Hall on the 9th Oetober, 1913.

\section{Platyomida dorsalis sp. nov. Platyomilla White (sym. Empaeotes} Pascoe), Man. N.Z. Coleopt., p. 441.

Robust, piceous, antennae and tarsi piceo-rufous; densely covered with dull, small, depressed cupreo-fuscous squamae, and some longer flavescent ones on the rostrum, the head, and elytral nodosities.

Rostrum as long as thorax, with a well-developed median carina. Thorax very slightly broader than long, very little wider before the middle than elsewhere, nearly straight behind, rather more narrowed in front; without rugae or tubercles, the broad central chamnel deeper in front than behind, the sides of the depression obtusely elevated. Scutellum small. Elytra a third broader than thorax at the base, nearly thrice its length. with simple apices, posterior declivity much narrowed and vertical, their sides uneven; the sutural region is flat, each elytron has 6 dorsal series of distant, distinct yet moderately fine punctures, in each of which there is a small brassy seale; 3rd interstices elevated at the base and projecting slightly over the thorax, with a pair of oblong nodosities near the middle. and terminating in large horizontal prominences on top of the declivity: 5th plane at the base, moderately binodose behind thr middle, their terminal nodosities not as thick as those of the 3rd but projecting obliquely outwards, each side underneath less distinctly trinodose : the declivity has a pair of moderate nodosities just below the summit and another pair near the extremity; these are the principal ones.

Femora slender near the base; tibiae feebly flexuous, minutely dentieulate inwardly, with erect greyish setae: posterior corbels with duplieate eilia and distinct outer truncature. Scape subelavate setigerous, barely reaching the back of the eye. Second joint of the funiculus as long as the 1st, joints 3-7 gradually diminish ; elub elongate-oval. Oeular lobes feebly developed.

Underside nigreseent, with fulveseent and reddish seales and paler sertae. Metasternum with a foveiform impression behind. Fifth ventral segment longer than 3rd and the combined, irregularly and closely punctured. much narrowed towards and distinctly emarginate at the extremity. 
Differentiated from $P$. binodes (776) (Empaeotes crispatns Pascos) by the absenee of rugosely tubereular thoracis seulpture, and from $P$. brevicornis by the less rotundate eyes and anteriorly prominent 3rd elytral interstices, \&c. $P$. humeralis (3119) may be at once separated by the broadly margined frontal portion of the sides of the hind-body, and the pair of outstanding sutural prominenges betow the top of the posterior declivity.

Length (rostrum inclusive), $11 \mathrm{~mm}$. ; breadth, $4 \frac{1}{2} \mathrm{~mm}$.

Mount Moa, Canterbury. One, taken off' a tree at night by Mr. T. Hall, 20 th October, 1913.

\section{Platyomida cuprealis sp. nov.}

Subopaque, the derm somewhat glossy black; covered with small, depressed, coppery squamae, and bearing also some more elongate setiform ones on the elevated parts; funiculus red, tarsi piceous.

Rostrum a little expanded anteriorly, slightly shorter than thorax; the central carina distinct, with an elongate impression along each side of its basal half. Thorax of the same length and breadth, only vere slightly wider before the middle than behind, sently narrowed anteriorly: the surface only slightly asperate but without discernible punctures or rugae, the discal channel interrupted, broader and deeper in front than behind. The sunken scutellum small. Elytra oblong, gradually narrowed towards the base, which is a third broader than that of the thorax, just thrice its length, their sides scarcely at all uneven, much narrowed and vertical behind; only a single series of small interrupted punctures can be seen along each side of the suture, the single ones between the common 3rd and 5th interstices are very coarse, rather shallow and irregular, the double series near the sides are also irregular but only moderately coarse; 3rd interstices shightly porrect but distinctly elevated at the base, with a pair of elongate elevations along the middle, the terminal nodosities are moderately large and horizontal but hardly extend beyond the top of the declivity; 5th flat near the base, but extending obliquely backwards as almost continuous ridges, their teminations not quite as prominent as those of the $3 \mathrm{rd}$, and not projecting outwardly as in $P$. dorsalis; the declivity has a pair of distinct nodosities near the top and some small tufts lower down.

Antennae finely setose; scape gradually and slightly incrassate towards the extremity; joints 3-7 of the funicle obconical, all longer than broad;

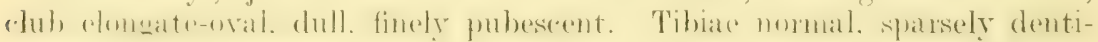
eulate inwardly.

Underside nigrescent, the greater portion thickly covered with bright

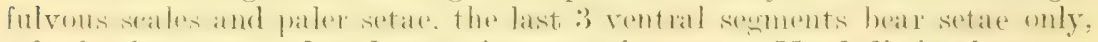
5 th elosely punctured and emarginate at the apex. Head distinctly transversely rugose.

The elytral sculpture is manifestly different from that of any recorded species. When quite fresh the scales no doubt are of a reddish-coppery hue. The 5th elytral interstices, and the row of coarse punctures between each of them and the $3 \mathrm{rd}$, are, I think, quite exceptional characters.

o. Length (rostrum inclusive), $10 \frac{1}{2} \mathrm{~mm}$; ; breadth, $4 \frac{1}{2} \mathrm{~mm}$.

Mistake Basin, Canterbury. One example, minus an antenna, found hy Mr. T'. Hall on the 9th October, 1913, amongst dead leaves on the eround. 
3876. Platyomida fuscella sp. nov.

Stout, opaque, piceous, antennae piceo-rufous; covered with tawny depressed and a few setiform squamae.

Rostrum a little expanded anteriorly, a third shorter than thorax, with a median ridge which does not extend more than half-way towards the front and ends in an elongate interocular impression. the apex finely rugosepunctate. Thorax a little dilated before the middle, more narrowed in front than behind, without perceptible rugae or punctures: discal rhamnel medially interrupted, rather broader and deeper in front than behind; its length rather less than the breadth. Elytra nealy thrice the length of thorax, almost double its width in the middle, with enrvedly narowed shoulders, so that the true base hardly exceeds that of the thorax, their sides sliwhtly uneven, gently narrowed behind the middle. more abruptly at the declivity, which is vertical; each elytron has 6 series of dorsal, moderate punctures; 3rd interstices slightly porrect and obtusely elevated at the base, indistinctly raised behind the middle, terminating as large horizontal nodosities on top of the declivity; 5th moderately binodose behind the middle, terminal nodosities less prominent than those of the 3rd and directed backwards: the derlivity with 2 pairs of small nodosities, the upper larger and nearer to each other than the lower.

Antennae finely setose, 6th and 7 th joints of funiculus obconical, hardly longer than broad, shorter than those of $P$. dorsalis. Tibiae denticulate inwardly.

Underside nigrescent, with brassy scales and setae. Fifth ventral segment closely and rugosely punctured. much longer than 3rd and th. its apex broadly rounded.

The shorter rostrum, its broad abbreviated ridge, the distinct interocular impression, rounded humeral angles, less flattened dorsum, \&c., differentiate it.

ㅇ. Length (rostrum inclusive), $11 \mathrm{~mm}$.; breadth, $4.1 \mathrm{~mm}$.

Routeburn. Tnique. Found by Mr. T. Hall on the 13th February. 1914.

\section{Platyomida rectirostris sp. nov.}

Opaque, piceous, antennae and tarsi rufo-piceous; densely covered with small, depressed, obscure coppery, and more setiform paler squamae.

Rostrum parallel, almost as long as thorax, with a fine but distinct median earina. Thoxax cylindric, apparently elongate, really of equal length and breadth, only slightly dilated before the middle; dise without rugae or tubereles, its central chammel broad, rather deep, and alnust uninterrupted from base to apex, with obtusely raised borders, near each side behind the middle there is a transverse impression, no punctation is risible. Scutellum small. Elytra oblong-oval, their sides somewhat uneven. gradually narrowed towards the base. which is a little and irregularly ineurved and but little broader than that of the thorax; ther are more than double its length, narrowed and vertical behind; they are moderately distinctly and somewhat irregularly seriate-punetate: 3rd interstions elevated at the base, trinodose along the middle, and ending in larese, nearly horizontal protuberances on top of the posterior declivity: 5th binodose behind the middle, the terminal nodosity rather smaller than that of the 3rol and extending obliquely outwards; declivity with a pair of smaller modosities near the summit, and another pair near the extremity.

Antennae similar to those of $P$. dorsatis; legs rather long and slender. 
Inderside shining black, thickly elothed with depressed flavescent scales and eorlse greyish setae; metasternum medially impressed; 5th segment broadly rounded at the apex.

Much narrower than $P$. dorsalis, the elytral base particularly, their punctation less sharply defined, thorax longer, the rostral carina more slender, \&e.

․ Length (rostrum inclusive), $9 \mathrm{~mm}$.; breadth, $3 \frac{1}{2} \mathrm{~mm}$.

Moa Basin. Unique. Obtained from leaf-mould by Mr. T. Hall on the 20th Oetober, 1913.

Obs.-In this and some other species the interstitial nodosities near the middle of the elytra are subject to variation: those on the left elytron only are deseribed.

3878. Platyomida hystricula sp. nov.

Opaque, fusco-piceous, antennae and tarsi fusco-rufous; densely covered with depressed infuscate and tawny squamae, and with longer paler ones which are most conspicuous on top of the posterior declivity; the legs bear greyish outstanding setae; surface rough and uneven.

Rostrum a third shorter than thorax, slightly dilated anteriorly, its slender carina much concealed by the squamae. Eyes slightly prominent. Thorax slightly broader than long, more narrowed in front than behind; meven, with some small obtuse tubercles: the discal chamnel larger and deeper in front than near the base, with broadly raised borders. Elytra oblong-oval, almost thrice the length of thorax, scarcely any wider than it is at the hase. with rurvedly narowed shoulders, their sides with only a single but only slightly prominent nodosity, placed behind each shoulder; the derlivity narowed but not usually vertical. with romgh sales and 2

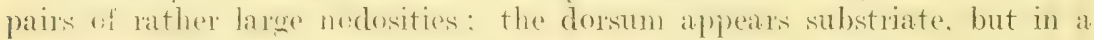
denuded specimen rather coarse oblong punctures are visible; 3rd interstices nodiform at the base, binodose near the middle, the terminal nodosities moderately large but not overhanging the declivity; 5th simple at the base, binodose near the middle, not prominent behind.

Underside, except the bare punctate mesosternum, thickly covered with depressed yellowish and paler elongate scales; 5th segment longer than 3rd and 4th, closely punctured, its apex truncate.

Scape subclavate at the extremity, attaining the back of the eye; 2nd joint of funiculus slightly longer thim 1 st. joints:; 7 submoniliform, all rather longer than broad. Tibiae flexuous.

I mather snall polgh-lowking spereses distinguishable be the rather large subapieal nodosities. the inemspremons terminations of the 5th interstices. and uneven thorax. The scrobes are well developed in front, but there is a squamose space near each eye, and therefore nearly resemble those of P. amole (1.45). It should be lueated near P. hemiltoni (3261).

Length (rostrum inclusive), $7 \frac{1}{2}-8 \mathrm{~mm}$; breadth, $2 \frac{1}{2}-3 \frac{1}{3} \mathrm{~mm}$.

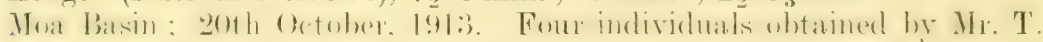
Hall from leaf-mould.

\section{Platyomida sulcicollis sp. nov.}

Opaque, rather elongate; piceous, antennae pitchy-red, tarsi fuscoIufous; squamae principally cupreo-fuscous, flavescent or tawny on the head and rostrum, the sides of the thorax, and the shoulders, similarly pale but more elongate on top of the declivity. 
Rostrum like that of $P$. hystricula but rather longer and narrower. Head somewhat flattened between the eyes. Thorax slightly longer than broad, widest before the middle, distinctly narrowed behind, rather les, so in front; median channel narrow throughout, without obviously raised borders; dise not quite even, though some of the scales are coarser than others, causing a slightly asperate appearance, there are no definite tubercular elevations; the frontal and some of the lateral scales are ereet. Elytra oblong-oval, subvertical behind, with eurvedly narrowed shoulders so that the base is but little broader than that of the thorax, they are more than double its length, their sides are free from inequalities; they appear rather finely biseriate-punctate near the suture, even less distinetly so towards the sides; 3rd interstices only moderately nodiform at the base, binodose near the middle, the terminal large, horizontal, and tipped with pale elongate scales like those on the 5th, which, however, are much less prominent, their median nodosities irregular, larger on the right elytron there is a single pair of small nodosities near the top of the declivity, and some coarse scales lower down.

Legs elongate and slender, scape gradually clavate.

The more elongate thorax, its subsulciform discal channel, and the absence of tubercular asperities distinguish it from $P$. hystricula. The eyes. though rather larger, are nearly flat. The rostrum is relatively longer, and the scrobes are smooth and shining almost to the eves. The funiculus is quite perceptibly stouter, its 2 nd joint is as thick as the 1 st but not longer, joints 3-7 are submoniliform but hardly any longer than broad. In $P$. hamiltoni (3264) the sides of the elytra are uneven, and the thoracie sculpture is entirely different.

Length (rostrum inclusive), $7 \frac{1}{2} \mathrm{~mm}$. ; breadtl, $2 \frac{1}{2} \mathrm{~mm}$.

Hollyford, near Routeburn. A single specimen found amongst decaying leaves by Mr. T. Hall on the 26th February, 1914.

\section{Platyomida latipennis sp. nov.}

Opaque, piceous, antennae rufo-piceous; covered with depressed, obscure, tawny-grey scales, and moderate, somewhat curled setae.

Rostrum subparallel, a third shorter than thorax, thickly clothed, its central carina with a groove along each side. Head finely punctate. Thorax slightly broader than long, cylindrical, very slightly broader near the middle than elsewhere; dise very finely punctate, not at all impressed along the middle, somewhat uneven but without distinet tubercles or rugae. Scutellum subquadrate. Elytra nearly double the width of thorax at the base, nearly thrice its length, their sides almost straight to beyond the hind thighs, where ther are only slightly broader than at the base. much narrowed and subvertical belind; they are moderately coarsely seriate-punetate, with minutely punctured intervals, 3rd interstices moderately elevated but not distinctly nodiform at the top of the declivity, 5th flat at the base, even less elevated behind than the 3rd.

Soape straight, very gradually and slightly thickened, attaining the back of the eye; hasal joint of funiculus equalling the 2nd, ateh only twice as long as broad, 3rd and the slightly longer than hroad, joints 5- 7 shorter: chub elongate-oval. Tibiate very slightly flexuous; posterior corbels quite cavernous, the space between the cilia narrower than in $P$. binodes. Eyes Iongitudinally oval, distant from thorax. Scrobes deep in front, becoming shallow and minutely sculptured towards, yet extending to, the eyes ; in $P$. binodes (776) they are smooth. 
Prosternum deeply incurved. Second ventral segment much shorter than the basal. The squamae and setae of the underside greyish.

The description of Sharp's P. simulatrix (2100) is to some extent applicable to this speeies, which, however, is differentiated by the broad shoulders, more slender scape, short basal joints of the funiculus, and less sharply defined scrobes.

Length (rostrum inclusive), $8 \mathrm{~mm}$. ; breadth, $3 \frac{1}{3} \mathrm{~mm}$.

Seareliff, ('anterbury. One found amongst dead leaves on the ground on the 19th October, 1913, by Mr. 'T. Hall.

3881. Protolobus nodosus sp. nov. Protolobrs Shliarp. Man. N.Z. ('oleopt., p. 1188.

Oblong, uneven, opaque; rufo-piceous, tarsi and antennae fusco-rufous, scape darker; covered with depressed greyish-tawny and infuscate scales and sappr matter; the setare moderately coarse. irregularly distributed, erect on the elytral nodosities, subdepressed on the dorsum, rellowish-ingev.

Rostrum broad, half the length of thorax, not perceptibly carinate. Thorax slightly broader than long, widest near the middle, rather more narrowed, and repressed, in front than behind, somewhat uneven, with a broad more or less interrupted rhannel along the middle. Scutellum triangular. Elytra oblong, double the length of thorax, quite a third broader than it is at the base in the female, rather less in the male, narrowed and vertical behind; their true seulpture invisible, appearing substriate; 3rd interstices slightly and unevenly elevated. terminating as conspicuous horizontal nodosities on the summit of the declivity, those on the 5th smaller and placed more in advance.

Legs stout, bearing infuscate seales and setae, tibiae mucronate, minutely dentirulate along the inner side, posterior corbels not distinetly ravernous.

Scape stout, setose, reaching the thoracic apex; 2nd joint of funiculus more slender than the basal but almost as long as it is, 3rd slightly longer than broad, the others shorter, 7th quite transverse; club triarticulate, ovate, not elongate.

Underside with greyish scales and setae. Prosternum rather short, widely emarginate, with contiguous coxae. Metasternum short. Basal segment large, subtruncate between the widely distant coxae, twice the length of the 2 nd, the suture between them straight, the 5th longer than the $3 \mathrm{r}$ d and 4 th rinited.

In a specimen denuded with the point of a needle the thorax is seen to be finely granulate, and the elytra irregularly striate-punctate. The eyes are small and distant from the thoracic apex.

This well-marked species can be readily identified by its differently formed, medially grooved thorax and nodose elytra.

Male. $-3 \frac{1}{2} \mathrm{~mm}$. by $1 \frac{1}{2} \mathrm{~mm}$. Elytral disc more uneven.

f. Length (rostrum inclusive), $4 \mathrm{~mm}$. ; breadth, $1 \frac{3}{4} \mathrm{~mm}$.

Mount Algidus, Canterbury ; 3rd December, 1913. Mr. T. Hall secured seven examples from leaf-mould.

38.82. Catoptes subplicatus sp. nex. ('aloples Sethonherr. Man. N.Z. Coleopt., p. 428 (Irenimus Pascoe, p. 443).

Elongate, opaque, piceous, antennae and tarsi fusco-rufous; densely covered with depressed, circular, nigrescent or dark-grey squamae and 
some erect, inconspicuous setae, the elytra bear series of quite distinct, subdecumbent grey ones, and outstanding coarser setae form a sutural fringe on the declivity.

Rostrum slightly contracted near the middle, nearly a third shorter than thorax, finely carinate. Thorax of the same length and breadth, distinctly sinuate and narrowed behind, where, near each side, there is a more or less perceptible carina; its surface without inequalities, the fine irregularly rugose sculpture hidden by the covering. Scutellum minute or obsolete. Elytra twice the length of thorax, very stightly wider than it is at the base, considerably narrowed but not vertical behind; they are moderately seriate-punctate, 3rd interstices slightly elevated at the base, the 5th, in the female, indistinctly so behind.

Legs slender. Scape attaining the thoracic margin. Second joint of funiculus almost as long as the basal ; 3rd and th distinctly, the following ones slightly, longer than broad; club elongate-oval, quadriarticulate, the terminal joint small.

Male.-Basal ventral segment broadly depressed, 5th as long as 3rd and 4 th together, with a shallow depression along the middle. Prosternum deeply incurved.

Fem.-Broader, $2 \frac{1}{2} \mathrm{~mm}$. Fifth segment shorter, transversely concave at the base, rounded behind.

Sharp's Brachyolus longicollis (2120) is no doubt very similar, but the vestiture must be very different. C. constrictus (3126) is the only other near ally, but the hind-body is more asperate.

o. Length (rostrum inclusive), $6 \frac{1}{2} \mathrm{~mm}$. ; breadth, $2 \mathrm{~mm}$.

Moa Basin. Several specimens taken from leaf-mould by Mr. T. Hall during October, 1913.

\section{Catoptes dehiscens sp. nov.}

Elongate, moderately convex, opaque, piceous, tarsi and antennae fuscorufous; covered with round, depressed, irregularly distributed, nigrescent and pale reddish-grey scales, the latter most numerous, smoky-black ones predominate across the summit and along the middle of the posterior declivity; the setae decumbent and greyish.

Rostrum a third shorter than thorax, subparallel, distinctly carinate along the middle. Thorax slightly broader than long, oviform, a little wider before the middle than elsewhere, free from inequalities, its punctation invisible. Scutellum distinct. Elytra thrice the length of thorax, slightly ineurved, and of about the same width as it is at the base, gradually narrowed posteriorly, with individually rounded. somewhat dehiscent apices; they are rather finely striate-punctate, interstices simple on the disc, the 2 nd and $3 \mathrm{rd}$, and the suture, slightly convex but not at all nodiform near the commencement of the hind slope.

Scape straight, just reaching the thoracis apex: basal joint of funiculus a little thicker but scarcely any longer than the elongate 2 nd. 3rd and 1 th longer than the following ones, 7 th obconical, longer than broad; club elongate.

Legs rather long, femora medially elavate: front tibiae longest. arehed extemally. somewhat bent inwardly below the middle, the others medially dilated, posterior denticulate along the inside, the corbels without any distinct interval between the cilia. 
Inderside black, with reddish-grey seales and slender elongate greyish setae. Prosternum widely emarginate. Metasternum medially depressed. Basal seement rather longer than the next, depressed along the middle, its apical suture sinute, 5th longer than $3 \mathrm{rd}$ and 4 th rombined, elosely punctate and setose, rounded behind.

I rather large species, distinguishable by the broadly romded dehiscent elytral apices.

o. Length (rostrum inclusive), $8 \mathrm{~mm}$. ; breadth, $2 \frac{1}{2} \mathrm{~mm}$.

Mount Jick, Lake Wakatipu. Unique. Found by Mr. 'T. Hall anongst decaying leaves, at a height of $3,500 \mathrm{ft}$., on the 17th March, 1914.

\section{Catoptes robustus sp. nov.}

Robust, oblong, moderately convex, opaque; nigrescent, antennae and tarsi rufo-fuscous; covered with tawny-grey and dark squamae, these latter, with the exception of a grey central spot, eover most of the thoracic: dise, and a large space on the summit of the posterior slope : the distinct decumbent grey setae form series on the elytra.

Rostrum subparallel, only feebly dilated in front, a fourth shorter than thorax, indistinctly carinate. Eyes free from thorax, subrotundate, nearly Hat. Thorax of equal length and breadth, rounded and widest before the middle, more narowed behind than in front, whout pereptible inequalities, its punctation invisible. Scutellum absent. Elytra oblong, widely incurved and slightly broader at the base than the thorax, just double its length, narrowed but not quite vertical behind. with divergent but not at all prolonged apiees: on each elytron the are 6 dorsal series of moderately roarse punctures, 3rd interstices only feebly elevated, 5 th subnodose behind, the suture broadly ret only slightly elevated near the top of the declivity. with a few erect grey setae, but not distinctly erested there.

Scape stout, bearing greyish setae, just attaining the apex of thorax; basal 2 joints of the funicle stout, equal, twiee as long as broad, joints 3-7 abruptly shorter, hardly any longer than broad; club elongate.

Legs moderately elongate; tibiate slightly flexuous, the anterior minutely denticulate inwardly, posterior corbels with a very narrow space between the cilia.

Underside covered with grey scales and elongate setae. Prosternum dereply medially emarginate. IFetasternum and basal segment of about equal lebeth. both broadly yet slightly impressed, the latter almost trumcate between the coxae, the next rather shorter, its frontal suture oblique at the sides, subangulate in the middle; the 5th as long as 3rd and 4th together, with a shallow impression along the middle.

Ocular lobes moderately developed. Scrobes subapical, deep in front, directed obliquely towards but not reaching the eyes.

This, as well as $C$. dehiscens, cannot remain permanently together in ('aloples: they are not referrable to Inophloeses, but should oceupy an intermediate position. Ls only single specimens of the same sex are available: and as 1)r. Sharp deseribed some aberrant speceies of Brachyolus, which I have not seen, it is not advisable to add another to these closely related genera.

o. Length (rostrum inclusive), $8 \frac{1}{3} \mathrm{~mm}$.; breadth, $3 \mathrm{~mm}$.

Nistake Basin, Canterbury. Inique. Found by Mrr. T'. Hall on the 9th October, 1913, amongst dead leaves. 


\section{Catoptes albosparsus sp. nov.}

Opaque, nigrescent, less and antennae dark fusco-rufous: the clothing variegate, consisting chiefly of depressed fuscous squamar; rather pales brown ones cover a great portion of the thorax, the suture, and the 3rd and 5th interstices of the elytra, and whitish ones form several small spots on the dorsum; setae numerous. short, erect, and fuscous principally, but there are many quite white conspicuous ones also.

Rostrum a third shorter than thorax, very slightly dilated at the antennal insertion, straight elsewhere, thickly covered with scales and setae which render the carina indistinct. Thorax oviform, a little broader than long, with a slight longitudinal depression at the base, its punctation encealed. without inequalities. Scutellum white. Elytra oblong, quite twice the lemgth of thorax, slightly broader, and subtrumeate, at the base, moderately narowed but not rertical behind; the suture only slightly elevated behind and bearing a few white setae just below the top of the declivity, 3rd interstices only feebly raised, each terminating in a blackish spot, bordered behind with grey, but not distinctly nodiform there; they are apparently striate-punctate.

Scape stout, normal; 2nd joint of funiculus slightly longer than the hasal, 3rd a little longer than broad, joints 4 short and moniliform; club elongate. setae.

Legs stout, tibiae slightly flexuous and bearing numerous short erect

Ocular lobes moderate. Eyes subrotundate, just free from thorax. Scrobes short, subapical, visible above. Posterior corbels normal.

The first part of the description will at once lead to its identification.

Length (rostrum inclusive), $44_{2}^{1} \mathrm{~mm}$.; breadth, quite $1 \frac{1}{2} \mathrm{~mm}$.

Ben Lomond. Enique. Found hy MI. T. Hall, 6th March, 1914, at an elevation of nearly $4,000 \mathrm{ft}$.

\section{Catoptes pallidipes sp. nov.}

Subovate, without inequalities, opaque; fuscous, legs and tarsi fuscotestaceous, antennae fusco-rufous; covered with depressed, infuscate and grey squamae, the paler ones irregularly distributed on the dorsum but almost entirely covering the posterior declivity; the setae short, greyish, mostly decumbent.

Rostrum a third shorter than thorax, parallel, squamose, obsoletely carinate, transversely depressed at the base. Thorax oviform, slightly broader than long, its soulpture hidden. Scutellum subtriangular. Elytra rather broad, subeordate, nearly thrice the length of thorax, the hase oblique towards the suture, rather broader than that of the thorax, with eurvedly narrowed shoulders, not rertical behind; they are finely striate-punctate; with simple interstices, the suture, howerer, is somewhat conrex along the declivity and suberistate half-way down.

Srape stout, barely reaching thoracic apex, with deemmbent setar ; 2nd joint of funiculus as long as the 1st, neither elongate, joints $3-7$ short; club elongate-oval.

Oeular lobes slightly developed. Eyes just free from thorax, subrotundate, rather large, flat. Serobes short, visible above. Lespin moderate, tibiae slightly flexuous.

This is about the smallest species as yet made known. The hind-body is, proportionally, rather broad. 
Length (rostrum inclusive), $3 \frac{1}{\mathrm{~m} m} \mathrm{~m}$; breadth, $1 \frac{1}{2} \mathrm{~mm}$.

Nownt Algidus. ('anterbury: "25th September, 1913. Another unique from Mr. 'T. Hall.

\section{Catoptes flaviventris sp. nov.}

Opaque, without inequalities; fuscous, rostral apex rufeseent, legs and antemate fusco-testaceous: demsely elothed with depressed fuscous squamae, but just below the summit of the posterior declivity there is a broad band of paler brown scales; the small serial setae on the elytra are white and decumbent but suberect behind.

Rostrum subparallel, only feebly dilated in front, a third shorter than thorax, not in the least depressed at the base, obsoletely earinate. Thorax oviform, slightly broader than long, its seulpture invisible, with some minute whitish setae on the dise. Sentellum small. Elytra quite twice the length of and a third broader than the thorax, incurved and distinctly broader than it is at the base, narrowed but not vertical behind: apparently striatepunctate, with simple interstices, the suture somewhat convex behind.

Underside fusco-testaceous, with pale scales and slender elongate setae. Prosternum deeply emarginate, with contiguous coxar. Basal segment as long as the metasternmm. both broadly impressed along the middle, and rather shorter, its frontal suture sinuate, 5th as long as 3rd and 4th combined, rounded behind.

This resembles $C$. pallidipes in structural details with the exception of the ocular lobes, which are obsolete. The eyes, antennae, and legs are similar. The hind-body is more oblong and narrower, and there is no basal depresion of the rostrim. The only example extant has strongly developed supplementary mandibles, the left being eurved and acute at the extremity.

$\hat{j}$. Length (rostrum inclusive), $3 \frac{1}{2} \mathrm{~mm}$.; breadth, nearly $1 \frac{1}{2} \mathrm{~mm}$.

Mount Ilgidus. I single individual found br Mr. T. Hall on the 25 th September, 1913.

\section{Catoptes nigricans sp. nov.}

Opaque, nigrescent, antemnae fusco-rufous, legs pitchy-red; covered with ashy wales nealy ats datk as the derm, and with deenmbent erevish setae, these give the rostrum a speekled appearance.

Nearly allied to $C$. flaviventris. The rostrum feebly carinate along the middle. 'Thorax as long as broad. Scutellum small, indistinct. Elytra hardly double the length of thorax, slightly broader than it is at the base, distinctly substriate-punetate, interstices simple. Eyes rather smaller and more distant from the thorax.

Underside black, nitid, with white scales and elongate setae. Prosternum moderately incurved. Basal segment rather longer than metasternum, depressed along the middle, 2nd flat, both distinctly punctate.

$\hat{o}$. Length (rostrum inclusive), $33_{2}^{1} \mathrm{~mm}$.; breadth, $1 \frac{1}{2} \mathrm{~mm}$.

Searcliff: 19th Oetober, 1913. Two from Mr. Hall, one damaged.

3889. Brachyolus bicostatus sp. nov. Brachyolus White, Man. N.Z. Coleopt., p. 1194.

Elongate, convex, opaque, piceous, antemne and tarsi fusco-rufous; covered with depressed, infuseate-tawny scales, and coarse, decumbent, greyish setae, those on the legs erect. 
Rostrum half the length of thorax, thick, slighty narowed and finely setose at the apex. with an indistinet median rarina. Thorax very slightly broader than long, obtusely rounded at or just before the middle. slightly narrowed behind; with coarse, short, irregular rugae, and a somewhat interrupted but not deep central chamnel, and an oblique frontal impression near each side. Elytra oblong, twice the length of thorax, incurved and a little broader than it is at the base, so that the shoulders. though obtuse, seem slightly porrect, a good deal narrowed and rertical behind; they are coarsely seriate-punctate; 3rd interstices slightly elevated along the middle, evidently incrassate and raised at the base and terminating as distinct nodosities on the summit of the declivity; the 5th simple at the base, the posterior nodosities more horizontal than those of the 3rd and not extending as far back; the suture slightly oblique and thickened at the base and somewhat elevated behind as far as the middle of the declivity.

Scape straight, gradually incrassate; basal joint of funiculus as long as the next, 3rd slightly longer than broad, joints $4-7$ moniliform, elub elongate-oval. Posterior corbels thickly ciliate but not cavernous.

With the exception of the less-developed ocular lobes, this species corresponds with the generic diagnosis; the body, however, is unusually elongate. In the male. $6.2 \mathrm{~mm}$. by $21 \mathrm{~mm}$. the thorax is less romoled, almost straight behind, with a more distinct mesial chammel. Fifth rentral segment much more finely setose than the others.

․ Length (rostrum inclusive), $7 \mathrm{~mm}$.; breadth, $2 \frac{3}{4} \mathrm{~mm}$.

Mount Dick; 17th March, 1914. Mr. T. Hall. One of each sex, found in leaf-mould.

\section{Brachyolus terricola sp. nov.}

Opaque, piceous, antemae and tarsi fusco-rufous ; densely (onvered with depressed greyish and tawny squamae above. the sictes of elytra with dark fuseous ones; the short, erect setae on the thorax and sides of elytra usually fuscous, those on the raised elytral interstices are testaceous or greyish.

Rostrum rather shorter than thorax, distinctly medially carinate. Thorax nearly a third broader than long. a little wider before the middle than elsewhere; slightly transversely impressed near each side in front, longitudinally at the middle of the base, the dise without definite rugae or punctation. Elytra more than double the length of thorax, with oblique shoulders, so that the base is hardly wider than that of the thorax; not asperate, their serial punctures rather shallow near the suture, coarser towards the sides: 3rd interstices somewhat elevated and terminating as prominent modosities on top of the declivity. usually infuscate there. and below that point distinctly ridged half-way towards the sightly dohisent apices, the 5th with smaller terminal nodosities.

Scape with infuscate or greyish setae; 2nd joint of funiculus as long as the hasal. 3rd and th longer than the following ones. ith subtriangular. hardly longer than broad; club elongate.

This does not anree with any of Sharpe's descriptions of 2116 to 2120 inchisive. In $B$. sigleaticn (3127) the rostral carina is quite fine: it differs in other details as well. B. fuscipretus (3597) may be distmenished he its thoracic carina.

Length (rostrum inclusive), $6 \frac{1}{2} \mathrm{~mm}$. ; breadth, $2 \frac{2}{3} \mathrm{~mm}$.

Moa Basin. Another of Mr. T. Hall's novelties; 20th October, 1913. 


\section{Bryodrassus gen. nov.}

Body moderately convex, elongate-oblong, fincly squamose.

Rostrum half the length of thorax, stout, a little dilated anteriorly. Scrobes subapical, quite visible and deep in front, directed downwards but not extending to the eyes. Thorax truncate at apex, nearly so at the base, with well-developed ocular lobes and vibrissae. Scutellum small, sunken or indistinct. Elytra elongate-cordate, slightly incurved at the base, the shoulder's a little broader.

Legs moderately elongate. Femora simple. Anterior tibiae rather longer than the others, enved externally, not distinctiy mucronate; corbels of the posterior with double cilia, the outer trureature distiret but not broad. Tarsi thickly setose below, penultimate joint bilobed.

Scape inserted rear the apex, mederately stout, very gradually

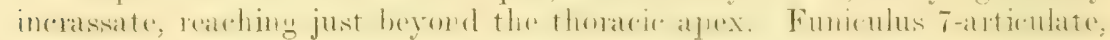
basal 2 joints about equally elongate but not slender, the others as long as broad. Club elongate-oval, indistirctly triarticulate.

Mandibular scar visible. Mentum large, filling the buccal cavity Palpi entirely concealed. Prosternum deeply emarginate in front. Anterior coxae prominent, distinctly separated; intermediate nearly as Iar apart as the widely distant posterior pair, all about equidistant from front to rear. Netastemum micderately elongate. Abdomen elongate, basal segment larger than 2nd, the suture sinuous; 3rd and 4th with deep straight sutures, each evidently shorter than 2nd, together fully as long as 5th.

The distinctly separated front coxae, emarginate prosternum, not at all abbreviated metasternum, well-developed ccular lobes, the well-marked mandibular scar, and cavernous posterior corbels are characters which, taken together, separate this from all the New Zealand genera of the Otiorhynchidae.

\section{Bryodrassus miricollis sp. nov.}

Opaque, nigro-fuscous, antemnae and tarsi piceo-rufous; covered with depressed, infuscate and tawny squamae, and with some longer pale ones on the elytral suture and interstices behind the middle; on the thoracie dise there are many short, erect, fuscous setae.

Rostrum rather thick from above downwards near the apex and studded with outstanding greyish setae there; the median rarina distinct, the surface rather flat alongside it. Eyes subrotundate, free from thorax. Head short, narrowed to the same width as the rostrum. Thorax nearly a fourth broader than long, its sides moderately and evenly rounded, with a slight apical constriction; there is a distmet median groove extending from the front to the middle, the rest of the senlpture romsists of nearly regular transverse striae and thicker squamose intervals; the pale scales are concentrated along the sides, but are scattered on the disc. Elytra just double the length of thorax, with a short sinuation behind each shoulder, hardly any broader than the middle of thorax, gradually narrowed towards the subvertical posterior declivity; they are regularly and moderately fincly seriate-punctate; the suture is a little elevated behind, and the 3rd interstices throughout, the 5th less distinetly.

Legs squamose and bearing also subereet squamifom setae; the anterion tibiae with many slender elongate setae along the inside, the other pairs somewhat flexuous. 
Underside with tawny-grey scales and short setae; metasternum and basal segment of abdomen broadly depressed. 2nd finely transversely rugose, 5th with subgranular seulpture.

No other New Zealand weevil has such remarkable thoracis: sculpture.

Length (rostrum inclusive), $6 \mathrm{~mm}$.; breadth, $2 \frac{1}{2} \mathrm{~mm}$.

Western Springs, near Auckland. Found by Mr. A. E. Brookes. clinging to moss, on the 20th March, 1914. One only.

\section{Inophloeus fuscatus sp. nov. Inophloeus Pascoe, Man. N.Z. Coleopt., p. 439.}

Oblong. opaque, piceo-fuscous, antemae and tarsi fusco-rufous; covered witb depressed. light and dark fuscous squamae, the pale ones usually most numerous on the rostrum and frontal part of thorax; the setae on the elytra are decumbent and grevish, those on the thorax and rostrum are short, erect, and dark.

Rostrum rather more than half the length of thorax, only slightly dilated in front. the median earina distinct, the lateral ones much less so. Head convex. Thorax hardly at all broader than long, a little wider before the middle than elsewhere, gradually narrowed behind; the median channel distinct near the base, nearly obsolete in front. its sculpture consists of small whtuse tubercle; or rugae behind, in many of these there i; a minute setigrerous puncture, the apical sculpture is finer. Scutellum obsolete. Elytra (oblong, quite double the length of thorax, somewhat incurved and evidently broader than it is at the base, the sides only slightly curvedly narrowed there, wather gradually narrowed backwards, more strongly near the subvertical declivity. apices not definitely divergent; dorsum nearly plane. distinctly seriate-punctate; 3rd interstices costiform, moderately nodose on top of the declivity and prolonged as a slight ridge nearly to the extremity; 5th mather less costiform. but with more elongate and horizontal posterior elevations, the 7th form obtuse lateral margins; the suture is somewhat elevated behind.

Antennae finely setose; scape gradually incrassats and attaining the back of the eye; 2nd joint of funiculus almost as long as the basal, 3rd lunger than broad, joints $4-7$ shorter, obemical: club elongate-oval, quadriarticulate.

Legs with coppery or greyish scales and grey setae; tibiae flexuous, posterior corbels with only a linear interval between the cilia. Prosternum deeply emiarginate.

This may be separated from species of about equal size by the absence of any sutural projection on the summit of the posterior declivity.

o. Length (rostrum inclusive), $9 \mathrm{~mm}$; ; breadth, $3 \frac{1}{3} \mathrm{~mm}$.

Skipper's, east of northern part of Lake Wakatipu. Mr. M. O. Pasco, of Queenstown, kindly sent me a number of coleoptera that had been collected by Mr. E. Samsbury. They were in a bottle with alcolol and had heen shaken, so that they became entangled, and unfortunately, with the exception of the pair of weerils described above, the finer species were too much mutilated when got out of the bottle to be of much use.

3893. Inophloeus collinus sp. nov.

Elongate, nearly plane above, opaque; nigrescent, antemne and tarsi rufo-piceous; densely covered with small, depressed, grerish-brown 
squamae, and with a few yellowish-grey, suberect setae, which are most conspicuous on top of the posterior declivity and along the sth interstices of the elytra.

Rostrum a third shorter than thorax, moderately carinate along the middle. Thorax of equal length and breadth, widest and rounded before the middle, a good deal narrowed behind; without inequalities or distinct punctation, but with a well-marked chammel from base to apex. S'cutellum minute. sunken. Elytra slightly broader than thorax at the base, nearly thries its length, their sides nearly straight, gently narrowed near the base, the declivity narrower but not vertical, with simple apices; each has 6 dorsal series of suboblong, moderately fine, distant punctures; 3rd interstices feebly elevated at the base, a little darker but not distinctly nodiform on top of the declivity; the 5th flat near the base, rather more but quite horizontally nodiform behind; the suture slightly and obtusely elevated farther back.

Scape very gradually incrassate, extending to the back of the eye; 2nd joint of funiculus quite as long as the 1st; club dull, elongate.

Anterior tibiae flexuous, rather longer than the others, with rather bright reddish scales.

The rather plain surface, simple apices, and elongate form, taken together, are distinctive.

우. Length (rostrum inclusive), $10 \frac{1}{2} \mathrm{~mm}$. ; breadth, $3 \frac{1}{3} \mathrm{~mm}$.

Gordon's Knob, near Nelson; 15th November, 1914. Found by Mr. T. Hall.

A second individual, measuring $9 \frac{1}{2} \mathrm{~mm}$. by $2 \frac{2}{3} \mathrm{~mm}$, has the thorax irregularly rugose, and the elytra with quite oblong punctures: this, no doubt, is the male.

\section{Group Rhyparosomidae.}

3891. Lithocia ciligera sp. nov. Lithocia Broun, Man. N.Z. Coleopt., p. 1470.

Subopaque, piceous, tibiae fusco-rufous, antennae rather darker, club rufescent; irregularly clothed with unequal, infuscate and tawny-yellow setae.

Rostrum arched, subparallel, as long as thorax, with a slender median carina, its frontal portion obsoletely bicarinate, the setae fuscous, but there is a small tawny spot in front of the rather flat eyes. Thorax of about equal length and breadth, gradually narrowed behind, more abruptly in front, near which it is widest, the base slightly but widely emarginate; dise: a little uneven, moderately coarsely and irregularly punctured, finely in front; elongate, outstanding, woolly tawny setae cover the sides and are most conspicuous before the middle, at the apex they form a pair of crests. Elytra as wide as thorax at the base, double its length, much narrowed but not vertical behind; each with a distinct basal sinuation, so that the shoulder seems slightly porrect; near the suture, on each, there are 2 or 3 more or less visible series of coarse punetures, the declivity is much more finely punctate and substriate; the sides are uneven, there is a pair of oblong basal nodosities, and another shorter pair, on each elytron, situated obliquely between the basal one and the outer commencement of the hind slope, there are a few setigerous inequalities elsewhere; moderately elongate tawny setae form a horizontal fringe across the top of the posterior slope. 
Legs setigerous, tibiae only slightly curved externally, murronate at extremity.

Scape medially inserted, slender near the base, clavate at apex, attaining the back of the eye, with some outstanding setae. Funiculus stout, with distinct setae, 2 nd joint a little shorter than 1 st, joints 3-6 subquadrate, 7 th slightly larger; club short, ovate, finely pubescent, its terminal joints small.

This differs from L. fimbriata (2549) in having the apical portion of the rostrum less flattened and carinate; the setae on the funi-le are coarser, the thorax is widely emarginate at the base; the elytral nodosities are dissimilar, and instead of being distinctly bicristate at the summit of the hind declivity this species has a flavescent fringe right across it.

Length (rostrum inclusive), $5 \frac{1}{2} \mathrm{~mm}$. ; breadth, $2 \mathrm{~mm}$.

Mount Earnslaw, near Lake Wakatipu. The type was taken amongst dead leaves on the ground by Mr. T. Hall on the 5th February, 1914, at a height of $1,000 \mathrm{ft}$.

\section{Lithocia setirostris sp. nov.}

Subopaque, castaneous, thorax, and the elytra along the middle, and the legs and antemnae, light chestnut-red, sometimes paler ; setae irregularly disposed, elongate, varying from fulvescent to tawny, and forming 4 elongate tufts on the summit of posterior declivity.

Rostrum rather thickly setose behind the scrobes, partly concealing the median carina, in front obsoletely tricarinate, bare and smooth at the apex. Thorax about as long as broad, of the lisual form, base truncate; moderately coarsely, not closely, but irregularly punctured, more finely in front, medially impressed at the base; disc thinly setose, the sides and apex fringed with outstanding setae. Elytra oblong-oval, nearly vertical behind, of same width as thorax at the base, twice its length; "almost regularly striatepunctate, more finely behind, with simple interstices; the base with a pair of elongate setigerous elevations, the dorsum and sides with about a dozen unequal tufts, in addition to the conspicuous posterior ones.

Legs more elongate and finely setose than those of $L$. ciligera, anterior tibiae slightly yet definitely curved externally. Scape with distinct outstanding setae; funiculus with a few slender ones, joints $3-6$ rather more bead-like than those of the preceding species.

Underside dull rufo-fuscous, with depressed grerish setae. Basal rentral segment somewhat depressed and finely rugose in front, the next almust quite smooth, 5th indistinctly punctate, with a shallow apical fovea.

The type is quite fresh and clean; ordinarily the specimens are fuscous, and obscured by dried sappy matter which is difficult to clear off.

The thickly clothed basal half of the rostrum, and the conspicuous tufts on the summit of the subvertical posterior declivity, are good differentiating character's.

Length (rostrum inclusive), 5-5 $\frac{1}{2} \mathrm{~mm}$. ; breadth, $1 \frac{3}{4} \mathrm{~mm}$.

Hollyford. A dozen specimens procured from leaf-mould by $\mathrm{Mr}_{\mathrm{r}} \mathrm{T}$. Hall, on the 18th February, 1914, at a height of 1,000 ft.

\section{Lithocia basalis sp. nov.}

Elongate, subopaque, piceo-rufous; irregularly clothed with outstanding, obscurely fulvescent setae, these form tufts somewhat similar to those of $L$. setirostris. 
Rostrum amost as long as thorax, its frontal half a little dilated, its distinct basal carina fringed with setae. Thorax a fifth longer than broad. a little wider before the middle than elsewhere, somewhat abruptly contracted in front, slightly and very gradually narrowed behind, its base sharply truncate; dise rather closely, coarsely, and deeply punctured, more finely in front, with a rather deep basal impression. Elytra just double the length of thorax, rather wider near the posterior femora than in front, somewhat abruptly narrowed and subvertical behind; the base is quite truncate and a little broader than that of the thorax, and there the sides for a short distance, when examined from above, appear straight and abruptly narrower than the part behind it; the basal depression is smooth and deep, it occupies half the width, and is bordered by the rather sharply elevated 3rd interstices, which, however, are simple further back; the 5th are a little uneven behind the middle and terminate as oblong but not conspieuous nodosities; the inner pair of serial punctures, on each elytron. are oblong, the others are less regular, the declivity is substriate.

Scape with coarse pale setae; 2nd joint of funiculus as long as the basal, the others rather broader than long; club ovate.

Legs elongate, bearing rather slender erect setae, slightly àrched externally, indistinctly mucronate, the anterior rather more elongate, and distinctly narrowed outwardly at the extremity; the penultimate tarsal joint, like that of $L$. setirostris, though excavate above, is not lobate, being truncate at the apex.

The description of the basal portions of the thorax and elytra is sufficiently characteristic. The thorax is rather longer and narrower than usual, and its seulpture differs from that of L. setwostris.

Length (rostrum inclusive), $5 \frac{1}{2} \mathrm{~mm}$. ; breadth, $1 \frac{2}{3} \mathrm{~mm}$.

Iount Dick, Lake Wakatipu. A solitary individual dimcorederl by Mr. T. Hall, amongst dead leaves, on the 17th March, 1914.

\section{Lithocia rectisetosa sp. nov.}

Subopaque, nearly plane, fusco-testaceous; bearing numerous single. straight, erect, nigrescent setae, and a pair of distant pale crests on the summit of the posterior declivity.

Rostrum arched, rather shorter than thorax, its frontal half dilated. the basal indistinetly carinate and covered with short, pale, curled setae. Thorax of equal length and breadth, widest before the middle, somewhat abrupty matrowed in front, more gratually buhind, rery slight!y meren, distinctly but irregularly punctate. Elytra hardly double the length of thorax, a good deal narrowed but not quite vertical behind, each with a basal notch inside the shoulder for the accommodation of the thoracic angle, so that the shoulders appear to clasp the base of the thorax; they are, except at the sides, quite regularly and distinctly seriate-punctate but becoming substriate behind; scutellar region depressed, 3rd interstices evidently elevated at the base.

Legs with a few pale, slender, outstanding setae, tibia only slightly flexuous, distinctly mucronate at the extremity, the hind pairs especially.

Scape moderately stout, very gradually incrassate; club short, subrotundate, indistinctly articulate.

There ean be no difieulty in identif ring this remarkable little species.

Length (rostrum inclusive), $3 \frac{3}{4} \mathrm{~mm}$. ; breadth, $1 \frac{1}{2} \mathrm{~mm}$.

Mistake Basin, Canterbury. Unique. Found by Mr. 'T. Hall, amongst decaying leaves, on the 9th October, 1913. 
3898. Lithocia nigricrista sp. nov.

Subopapue, fusco-testaceous, thorax more rufencent, tibiar pale rellowisis, rostrum fusco-rufous, antemnae paler; the thorax with 3, the elytra with numerous small black erests.

Rostrum as long as thorax, subparallel, arched, a little flattened and finely tricarinate in front, rather strongly carinate behind. Thorax as lons as broad, widest before the middle, the sides nearly straight behind; dist moderately roarsely and closely punctate; pale woolly setae form a fringr along each side and a pair of apical crests ; on the dise, behind the middle. there are 2 small black erests and another in advance. Elytra rather wider than thorax at the base, the sinuosity inside each shoulder occupied by the thoracic angle, they are nearly twice the length of thorax, and near the middle a third broader than it is, they are quite obliquely narrowed, but not at all vertical behind; each elytron is moderately coarsely triseriatepunctate near the suture, the hind slope more finely and substriate; 3rd interstices elevated at the base and, like the shoulders, covered with curled but not elongate black setae, similar setae form 3 distinet dorsal crests, and a small pair near the suture; there are others near the sides, all the interstices below the top of the declivity bear similar erests, th outer ones the largest, and there are others near the extremity; just on top of the declivity fine grey setae form a band between the $3 \mathrm{rd}$ interstices: the apices are subacuminate.

Antennae with dark setae; scape rather slender near the base, clavate at the extremity ; 2nd joint of funiculus not quite as long as the 1st, joints 3-6 broader, 7 th rather more so ; club ovate.

This remarkably distinct species may be readily recognized by its numerous black crests. The head has a triangular fovea at the base.

Length (rostrum inclusive), $6 \mathrm{~mm}$. ; breadth, $2 \frac{1}{2} \mathrm{~mm}$.

Mount Dick, Lake Wakatipu. A single specimen, found by Mr. T. Hall. amongst dead leaves on the ground, on the 10th March, 1914.

\section{Abrotheus gen. nov.}

Rostrum arched, elongate, rather longer than thorax, subparallel, rather broader near the base than elsewhere. Scrobes foveiform, quite lateral, situated just behind the middle. Eyes obliquely oval, slinhtly prominent. not quite as distant from the thoracic apex as they are from each other. scape inserted behind the middle, attaining the front of the ere, slender near the base, clavate at the extremity. Funiculus 7 -articulate, 2nd joint slightly longer than the basal, joints 3-6 subquadrate and about equal, 7th larger, narrowed towards its base. Club short, ovate, indistinctly articulate near the extremity. Thorax oblong, base and apex truncate, without ocular lobes. Scutellum absent. Elytra of the same width as thorax at the base, subpyriform. Legs moderately elongate. tibiae indistinctly mucronate. Tarsi moderately short, penultimate joint not dilated. excavate above, entire, or only feebly emarginate at the apex.

Prosternum incurved in front, with contiguous prominent coxae. Metasternum very short. Abdomen elongate, basal segment subtruneate between the widely distant coxae, the suture between it and the cqually large 2nd fune yet distinct and strongly sinnate in the middle. 3rd and to thery short and, together, little more than half the length of the 5th.

The type of this genus must be located between Phrymixus and Pachyprypmus, which latter it most nearly resembles. 


\section{Abrotheus placitus sp. nov.}

Elongate, nearly plane above, subopaque; nigro-fuscous, antennae, tarsi, and rostral apex fuseo-rufous; irregularly elothed with somewhat curled, pale testaceous squamae.

Rostrum nearly nude in front, elsewhere thickly covered with coarse, elongate, rough-looking seales, indistinetly erested near the base. Thorax a little longer than broad, hardly any wider before the middle than behind; dise almost smooth, with an indistinct eentral ridge, covered with short scales, extending from the front to the elongate basal depression, it is nearly bare alongside the ridge, but the sides are covered with coarser eurled squamae. Elytra twice the length of thorax, widest and unevenly rounded behind the posterior femora, gradually narrowed towards the slightly incurved base, more narrowed but not vertical behind; the broad basal depression is bordered at each side with a fincly squamose ridge, a similarly squamose streak "xtends backwards from each shoulder; on each elytron about 10 unequal crests are formed of coarse, bent, setiform scales, the intervals are nearly bare; on the basal portion there are some coarse punctures, behind these, each elytron is finely bistriate almost to the extremity, there are some scales but no distinct crests on the posterior declivity. Legs coarsely elothed.

Basal 2 ventral segments dark fuscous, a little nitid, with a few distant minute punctures and short tawny setae.

Length (rostrum inclusive), $6 \mathrm{~mm}$. ; breadth, $2 \mathrm{~mm}$.

Waitakerei Range; 26th April, 1914. I am indebted to Mr. A. E. Brookes, of Mount Albert, for the specimen he found near the reservoir.

\section{Halliella gen. nov.}

Body subpyriform, uneven above. Rostrum strongly arched, stout, as long as thorax, its basal half rather narrower than the frontal. Scrobes median, foveiform, slightly expanded and quite open above. Head short, narrowed anteriorly. Eyes small, lateral, nearly flat, oviform, free. Scape stout, gradually clavate, attaining the back of the eye. Funiculus 7-articulate, 2nd joint nearly as long as the 1st, moderately elongate, joints 3-6 transversely quadrate, 7th suboblong; club short, ovate, its small apical joints indistinct. Thorax as long as broad, base and apex trumeate, without oeular lobes. Seutellum absent. Elytra oblong-oval, truncate at base, hardly at all wider than thorax there. Legs moderately elongate; femora medially incrassate; tibiae subflexuous, mucronate at extremity; tarsi short, rather broad, basal 2 joints strongly transverse, the penultimate sub-bilobed, also broad.

Prosternum incurved in front, coxae large, prominent and contiguous. Middle coxae distinetly, posterior widely separated. Metasternum very short, without any pereeptible suture between it and the short basal ventral segment, the 2nd segment large, oblique towards its sides, angulate and medially depressed in front; 3rd and th with straight deep sutures, exceedingly short, together little more than half the length of the 5 th.

The serobes are like those of Lithocia and, ensequently, very different from those of Phrynixus and styphlotelus. In this last genus, which somewhat resembles IIalliella, there is no sign of any suture between the 1 st and 2nd ventral segments; the elytra are evidently ineurved at the base, thus 
leaving a distinct median gap between it and the thorax, and the humeral angles are porrect.

This genus is named in honour of MLr. T. Hall in recognition of his valuable scientific discoveries.

\section{Halliella squamipes sp. nov.}

Opaque, fuscous, antennal club rufescent; sparingly clothed with depressed, flavescent squamae, these are slender on the hind-body but coarse on the thorax, there are also numerous suberect, coarse ones which form several crests.

Rostrum subcarinate behind, with a basal crest and a pair of interantennal ones, its frontal portion bears very small scales. Thorax somewhat narrowed anteriorly, medially impressed at the base, its punctation neither close nor coarse, the intervals, except near the base and apex, are more or less fuely tuberculate; there is a prominent crest at each side of the apex, and the scales are concentrated along the sides so as to form a streak on each right to the base, sometimes there is a small median erest on the disc. Elytra quite double the length of thorax, subvertical behind, the scutellar region a little depressed; they are indistinctly punctate, but have, on each, 2 or 3 irregular series of minute tubercles, the posterior declivity is broadly substriate; erect scales form oblique humeral crests, there are a pair of median crests near the suture, another larger pair, on each elytron, nearer the side and about equidistant from the base and each other, and a similar pair on top of the side; on the summit of the declivity there is a transverse series of 5 unequal crests, the sutural ones the smallest, just below these, at each side, there is a more elongate one.

Scape with depressed elongate squamae, the funiculus setose, club finely pubescent. Legs with irregularly concentrated scales, thus obscuring their true shape.

Underside dull smoky black, irregularly squamose; abdomen rather finely and irregularly punctate; metasternum rugose, sides of prosternum distantly and minutely tuberculate.

Fem.--Rostrum almost nude and finely punctate in front of the antennae, which are implanted just behind the middle, without crests there; elytra substriate-punctate near the suture.

Length (rostrum inclusive), $7 \frac{1}{2} \mathrm{~mm}$. ; breadth, $3 \mathrm{~mm}$.

Hollyford. A dozen specimens, some damaged, found amongst decaying leaves, \&c., by Mr. T. Hall on the 18th February, 1914.

\section{Halliella antennalis sp. nov.}

Opaque, dark fuscous; funiculus slightly, the club distinetly rufescent.

Elytra with a broad scutellar depression which is thinly squamose at each side, they are substriate-punctate; the 3 inner series of punctures, on each elytron, are very coarse and deep, the exterior are irregular but equally coarse, the posterior declivity much more fincly biseriate; on the suture and 3rd interstice there are about 10 minute tubercles, there are some others near the side, and two rows along the declivity; the slender squamae are depressed and unevenly distributed, the coarser erect ones form an elongate humeral crest, the 4 th is binodose and scaly, the 3rd, on top of the declivity, is moderately nodiform and squamose, a little lower down, on the side itself, there is a larger scaly prominence, the side of the dise is also uneven. 
The legs and thorax are like those of $H$. squamipes, but the punctation is coarser, the rostrum is longer, and the tarsi are just as broad.

Antennae more slender and elongate, 2 nd joint of funiculus as long as the hasal, joints 3 -6 rather longer than broad, 7 th broader.

The almost foveiform elytral serulpture and more olongate antennal articulations render its identification a comparatively easy matter. My specimen is somewhat abraded; quite fresh samples, therefore, may possess more crests.

o. Length (rostrum inclusive), $8 \frac{1}{2} \mathrm{~mm}$; breadth, $3 \frac{1}{2} \mathrm{~mm}$.

Mistake Basin, west of Mount Algidus. Found on the 9th Ortober, 1913. by Mr. T. Hall. Unique as yet.

\section{Halliella longicollis sp. nov.}

Elongate, rather narow, opaque; nigrescent, antennar, tibiae, and tarsi obscure fusco-rufous; squamae scanty, depressed, elongate, and inconspicuous on the dorsum, more erect, but not coarse, on the front and sides of the thorax, and forming about 6 small flavescent erests on top of the posterior declivity ; tibiae with numerous setae only.

Rostrum almost as long as thorax, without crests, finely squamose, with a distinct median carina. Thorax oblong, nearly a fourth longer than broad, a little narrowed in front; rather coarsely and closely punctured, with narrow rugose intervals, impressed longitudinally at the base. Elytra truncate and of the same width as thorax at the base, twice its length, subrertical behind, rather broader behind the posterior femora than elsewhere, gradually narrowed towards the base; they are coarsely seriatepunctate, with a pair of elongate basal elevations, the shoulders nearly similarly raised, each elytron indistinctly trinodose on the dise.

The essential characters are in accordance with $H$. squamipes, but the body is more elongate and narrower. The antennae are quite as slender as those of $H$. antennalis and of similar structure. The tibiae bear setae only, they are slightly curved externally, distinctly bent inwardly near the extremity and mucronate; the tarsi are less expanded, and the basal ventral segment is relatively longer.

In its natural condition the type was covered with a tough film, which hatd to be scraped off with the point of a needle before the seulpture could be seen.

Underside dark fuscous. Prosternum only moderately incurved. Metasternum rather longer than that of $H$. squamipes. Abdomen more rongate. basal 2 segments connate but with an obsolete suture which is oblique towards the sides, both are of about equal length, and are very distinctly and moderately closely punctured and minutely setose, 5th nearly double the length of $3 \mathrm{rd}$ and 4 th combined, finely and resely pmotate. Tarsi finely setose.

Fem. $-8 \mathrm{~mm}$. by $2 \frac{1}{2} \mathrm{~mm}$.

o. Length (rostrum inclusive), $7 \mathrm{~mm}$; breadth, $2 \frac{1}{3} \mathrm{~mm}$.

Ben Lomond. Found by Mr. T. Hall amongst decaring regetahlo matter, at a height of $4,000 \mathrm{ft}$, on the 3rd March, 1914. One of each sex only.

3903. Bantiades morosus sp. nov. Buntiades Broun, Man. N.Z. Coleopt.. p. 1371 .

Suboblong, narrowed anteriorly, a little uneven, opaque; fuscous, the dorsum sparingly clothed with depressed straw-coloured setae, those on the 
sides and legs infuscate and greyish, longer, coarser, and somewhat curled: antennae, tarsi, and base of femora more or less castaneo-rufous.

Rostrum stout, nearly as long as thorax, a little dilated in front, closely and coarsely punctured, appearing slightly asperate, with a fine median carina. Head immersed up to the small transverse eyes. Thorax moderately contracted in front, of equal length and breadth, the disc a little uneven, with a pair of frontal and broader basal impressions; its punctation distinct and close in front, more distant and shallow behind. Elytra just double the length of thorax, incurved at the base, the prominent shoulders rather broader than it is, their sides indistinctly curved, considerably narrowed and subvertical behind; dorsum nearly plane, irregularly and coarsely punctate, the sutural striae well marked behind, with a pair of distinet basal nodosities, $3 \mathrm{rd}$, 4 th, and 5 th interstices only slightly nodiform on top of the declivity.

Legs stout, femora strongly dentate; tibiae slightly flexuous, the anterior with stout terminal hooks; tarsi short, penultimate joint somewhat expanded and lobate. Antennae like those of the typical species (2396), inserted near the apex. Scrobes quite visible in front.

Underside fuscous, with distant shallow punctures and elongate strawcoloured setre. Anterior coxae slightily separated. Second ventral segment equalling the 1st in length, its frontal suture distinct throughout, oblique at the sides, obtusely angulate in the middle, 5th longer than the preceding two combined, with a well-marked fovea. Palpi quite visible.

An obscure-looking species, most nearly approaching $B$. cupiendus (3601), smaller, much darker, the elytral punctation very irregular and interrupted, and with the suture between the ventral basal segments remarkably distinct.

Length (rostrum inclusive), $4 \mathrm{~mm}$; breadth, $1 \frac{2}{3} \mathrm{~mm}$.

Mount Algidus, Canterbury. Unique. Found amongst decaying leaves by Mr. T. Hall on the 25th October, 1913.

\section{Bantiades cylindricus sp. nov. Buntiades Broun, Man. N.Z.} Coleopt., p. 1371.

Subcylindric, slightly convex, subopaque; fuscous, antennae light ferruginous, legs flitvo-fuscous; irregularly clothed with fine, mostly decumbent, yellow setae.

Rostrum a third shorter than thorax, nearly half its width, subparallel, fincly tricarinate. Thorax a little longer than broad, subeylindrical, slightly contracted in front, truncate there, the base somewhat ollique towards the sides; dise moderately elosely and coarsely punctate. subcarinate along the middle in front. Elytra oblong, with obtuse shoulders, arcuateemarginate and hardly any wider than thorax at the base. twice its length. moderately narrowed and subvertical behind: they are distinetly seriatepunctate, with only about 6 punctures in each row; in line with the hind thighs, an oblique, bare space extends backwards from each towards the suture, behind this the setae form several unequal tufts: the seutellat region is hardly at all depressed, but there is a slight elevation at each side of it.

Antennae with pale elongate setae; 2nd joint of funiculus quite oblong but scarcely as long as the basal, remaining joints short; club short, ovate, its apical articulations small. Legs of normal structure.

Underside nigro-fuscous. Metasternum and basal segment of abdomen eoarsely punctured, apical suture of the latter oblique at the sides, effaced in the middle. 
The umusually narrow form, the absence of nodosities, rather elongate thorax, and the conspicuous posterior patches of bright-yellow pubescence are distinctive.

Length (rostrum inclusive), $5 \mathrm{~mm}$.; breadth, $1 \frac{2}{3} \mathrm{~mm}$.

Gordon's Knob, near Belgrove. Mr. 'I. Hall secured a pair of specimens from deraying leave at a leight of about 2,000 ft., on the 15 th November, 1914.

\section{Bantiades notatus sp. nov.}

Oblong, rather narrow, the hind-body broader than thorax, slightly convex, subopaque; rostrum and antennae rufo-testaceous, legs fuscotestaceous, anterior pair uniformly paler; thorax and elytra fuscous, these latter with a straight, somewhat nitid, bare space between the posterior femora, and, just behind this, with a pale, sometimes rufescent, broad, triangular area covered with fine suberect grey setae; the rest of the surface is thinly clothed with suberect yellow setae, but on the front of thorax they are more concentrated.

Rostrum stout, subparallel, almost as long as the thorax, without perceptible carinae. Thorax slightly longer than broad, a little contracted in front, base subtruncate; uneven, irregularly and moderately coarsely punctured, with a central carina extending from the front to the subquadrate basal depression, which is obtusely elevated at each side. Elytra almost obovate, distinctly incurved at the base so that the shoulders are slightly porrect and rather broader than the thorax, they are twice its length. their sides are only slightly curved as far as the hind thighs, but the declivity is evidently narrower and subvertical; their basal half is coarsely seriate-punctate, with about 5 punctures in each series, the declivity is punctate-striate, the scutellar region is broadly depressed.

Smaller than $B$. cylindricus and differing in form, the thorax distinctly narrower than the hind-body, which is without the bright-yellow posterior tufts seen in that species. The antennae and legs are similar. Both species are narrower than usual.

Length (rostrum inclusive), $4 \mathrm{~mm}$. ; breadth, $1 \frac{1}{2} \mathrm{~mm}$.

Gordon's Knob. Two examples from Mr. T. Hall.

3906. Abantiades gratulus sp. nov. Abantiades Broun, Bull. 1, Part III, p. 216, N.Z. Inst., May, 1914.

Opaque, slightly convex; rufo-fuscous, sometimes paler; covered with flavescent, depressed, rather small, setiform squamae; antennae and tarsi somewhat rufo-testaceous.

Rostrum moderately slender, as long as thorax, punctate, with a fine median earina, the outer ones indistinet, its apical portion rufecent. Thorax widest near the front, gradually narrowed behind, with a short apical contraction; dise slightly uneven, with an indistinct stria along the middle, transversely depressed in front; its breadth nearly a fifth more than the length. Scutellum minute or obsolete. Elytra not twice the length of thorax, evidently broader than it is at the base, their sides curved and distinetly incrassate there, gradually narrowed and deflexed behind; apparently seriate-punctate; 3rd interstices with a promirent basal and a pair of elongate elevations, the central least distinct, the last ending at the top of the hind slope; the 5th simple near the base, also trinodose, the rentral elevation longest, the posterior terminating below the top of the 
slope, near each side, behind the middle, there is a pair of shorter ones; near the extremity there is a distant median pair of small nodosities, and a single one at each side.

Underside piceous, abdomen with somewhat curled, yellow, setiform scales; basal segment rather longer than the next, which is broadly grooved along the middle, the suture between them is sinuous; in the female the 5 th has a broad shallow fovea, but the 2nd segment is unimpressed.

Nearly allied to $A$. nodipenis (3605), more robust, with thicker legs and more flexuous tibiae, the anterior, instead of being nearly straight, are more arched above and sinuate near the middle on the outside, and medially curved inwardly ; their tarsi are broader, and their claws distinctly appendiculate.

In a specimen denuded with the point of a needle the thoracic sculpture is seen to consist of slightly convex, very irregular, short rugae, and that of the elytra to consist of subquadrate, rather coarse, serial punctures.

Length (rostrum exclusive), $3 \mathrm{~mm}$; ; breadth, $1 \frac{2}{3} \mathrm{~mm}$.

Scarcliff and Mistake Basin, Canterbury. Five taken from vegetable matter on the ground by Mr. T. Hall during October and November, 1913.

\section{Rachidiscodes gen. nov.}

Convex, medially narrowed and depressed. Rostrum arched, elongate, a third longer than thorax, rather slender, parallel, slightly dilated at the point of antennal insertion. Scrobes beginning before the middle, deep there, obliquely prolonged underneath. Head short, globose below. Eyes subrotundate, lateral, not prominent, with distinct facets, the space between each and the thoracic apex equalling their own length. Thorax without ocular lobes, elongate, oviform, apex and base truncate, the latter with slightly raised margins. Scutellum absent. Elytra scarcely any wider than thoras at the base, subpyriform, the height of the rertical posterior declivity quite equals the length of the dorsum.

Scape elongate and slender, incrassate near the extremity, inserted before the middle, attaining the front of the ere. Funiculus 7 -articulate, 2nd joint longer than the basal, 3rd and th oblong; the others moniliform, 7th larger than 6th; club moderately large, subovate, distinctly pubescent. obsoletely articulate.

Legs very elongate; femora simple; tibiae nearly straight, feebly mucronate; tarsi rather narrow, basal joint oblong, the penultimate cleft almost to the base but not expanded, terminal longer than the basal.

Prosternum emarginate, elongate, the coxae contiguous, very prominent, situated near the base. Metasternum short. Abdomen elongate, basal segment nearly double the length of 2 nd in the middle, subtruncate between the moderately distant coxae, its apical suture distinct, medially sinuate; 5th transversely quadrate, subtruncate at apex, broadly foveate behind. longer than the short $3 \mathrm{rd}$ and 4 th combined; 6 th shorter, finely margined, rounded behind, concave in the middle, much bent upwards. Palpi minute, straight, quite visible.

The type of this remarkable little weevil should be located between Rachidiscus and Rhystheus. It most nearly resembles the former, but is at once separable by its long slender rostrum. Rhystheus is of subcylindrical outline, with hyaline eyes. 


\section{7 . Rachidiscodes altipennis $\$ 11,110 \mathrm{~V}$.}

Nitid, nearly glabrous, having only a few yellowish scales on the thorax

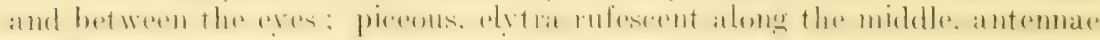
and legs light castaneous.

Rostrum smooth in front, bisulcate behind, and with an additional lateral stria that might be mistaken for the scrobe. 'Thorax a third longer than broad, widest at the middle; its seulpture consists of moderate punctures and obtusely elevated intervals. Elytra not double the length of thorax, strongly arched and on a higher plane than it is, rounded, widest, and most convex behind the middle, and becoming very narrow at the extremity; on each elytron there are 4 rather broad, deep, apparently impunctate dorsal striae, those along the sides are less distinct; interstices convex, the pair near the suture are convex from base to apex, the 3rd becomes indefinite near the base, the th behind.

ô. Length (rostrum exclusive), $2 \frac{1}{3} \mathrm{~mm}$.; breadth, $1 \mathrm{~mm}$.

Hollyford; 18th February, 1914. Described from a single male found by Mr. T. Hall amongst fallen leares.

\section{Allaorops gen. nov.}

Minute, convex, glabrous. Rostrum arched, stout, as long as thorax. Scrobes open above, dilated between the middle and apex, obliquely prolonged underneath. Eres small, depressed, indistinct, lateral, their distance from the thoracic apex equals their own length. Thorax without ocular lobes, as long as broad, oviform, base and apex truncate. Scutellum absent. Elytra only a third longer than thorax, as broad as it is, and slightly emarginate, at the base, subovate, strongly arched and subvertical behind.

Scape stout, gradually incrassate, inserted between the middle and apex and reaching the front of the eye. Funiculus 7-articulate, 2 nd joint oblong, as lome as the basal, the others suecessively incrassate. thanswerse. Club oblong-oval.

Femora elongate, simple. 'libiae straight, also long, indistinctly mucronate. Tarsi rather short, intermediate joints transverse, penultimate not at all expanderl, exratvate above near the apex only terminal nearly as broad and as long as the preceding two united, with minute curved claws.

Prosternum elongate, emarginate in front, coxate large, prominent, and contiguous, situated in the middle. Metasternum short. Abdomen

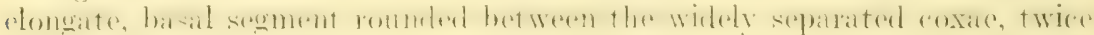
the length of the next in the middle, its hind suture distinet and almost straight, 5th longer than the deeply divided short 3rd and 4th together, transversely quadrate, finely marginate, medially emarginate at apex.

Resembles Allaorus in contour, structurally more nearly allied to Rachidiscus, but easily separable therefrom by the rostrum being

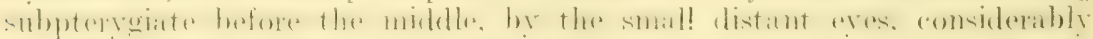
less medially narrowed body, different tarsi. \&c.

3908. Allaorops carinatus sp. nov.

Nitid, oblong, slightly narrowed towards the middle, glabrous; nigropiceous, legs pitchy-red, antemnae and tarsi fusco-rufous. 
Rostrum apparently smooth. Thorax rounded and widest near the middle, base-submarginate; dise with minute dense sculpture and many coarse but not deep punctures. Elytra widest behind the middle, each with four broad, deep, impunctate dorsal striae, the suture and interstices cariniform and touching the slightly raised basal margin.

Funiculus and club with pale pubescence, the legs with a few short hairs.

Basal ventral segment with minute dense sculpture and a few coarsc shallow punctures.

Length (rostrum exclusive), $1 \frac{1}{2} \mathrm{~mm}$. ; breadth, $\frac{2}{3} \mathrm{~mm}$.

Hollyford; 18th February, 1914. Another of Mr. T. Hall's numerous discoveries amongst decaying leaves. Unfortunately, it is unique.

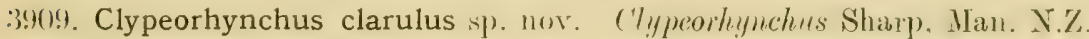
Coleopt., p. 1210.

Subopaque, castaneo-rufous, sides of thorax and elytra fuscous ; irregularly clothed, chiefly with decumbent. slender and elongate, rather bright fulvescent squamae.

Rostrum stout, almost equalling thorax in length, its frontal half somewhat expanded, apex nearly nude and quite red. Head immersed up to the eyes, with a small fovea between them. Thorax of equal length and breadth. only slightly dilated before the niddle, nearly straight behind: the surface a little uneven, irregularly and moderately coarsely punetured, with a pair of moderate nodosities, bearing suberect scales, before the middle, the central channel deeper in front than behind. Elytra double the length of thorax, their shoulders obliquely curved so that the base is hardly broader than that of the thorax, they are a good deal narrowed and deflexed behind: on each elytron there are $t$ dorsal series of granules which in some aspects give the elytra a somewhat punctate-striate appearance; the sutural region is depressed at the base, the 2 nd and 4 th interstices are a little elevated there; the scales are most apparent on the interstices but become coarser, suberect and sometimes greyish behind.

Legs elongate, femora moderately clavate; tibiae flexuous and acuminate. tarsi rather short.

Scape flexuous, attaining the thoracic apex, clavate at the extremity and bearing many elongate squamae; basal joint of funiculus not quite half the length of the seape nor double the length of the elongate 2 nd. the Brol and 4 th, sometimes the 5th, longer than broad, 6th and 7 th sulmumiliform; club ovate, not elongate, triarticulate.

Of about the same size as $C$. cordipemis (2394), much brighter, frontal suture of rostrum less distinct, scape more clavate, \&e.

Length (rostrum inclusive), 5-5 $\frac{1}{2} \mathrm{~mm}$. ; breadth, nearly $2 \mathrm{~mm}$.

Iomit Dick. Two fommd amonest decaving vergetahle matter. br IIr. 'T. Hall, at a height of $1,100 \mathrm{ft}$, on the 10 th March, 1914.

\section{Clypeorhynchus merus sp. nov.}

Opaque, fuscous; base of femora, tibiae, tarsi, funiculus, and club chestnut-red; squamosity slender, decumbent, irregularly distributed. subseriate on the hind-body, usually tawny-grey, rarely fulvescent.

Rostrum rather shorter than thorax, subcarinate along the middle. rufescent and nearly nude in front. Thorax subcylindric, a little narrowed anteriorly, nearly straight hehind: median rhamel shallow. antero-lateral 
nodosities not distinct, without well-defined punctation. Elytra elongatesubeordate, with oblique shoulders, somewhat incurved at the base, hardly any broader than thorax there, twies its length; indefinitely striate, without distinct punctures or granules, the interstices finely and irregularly asperate.

Legs and antennae like those of $C$. clarulus, but, owing to the dull fuseous surface and indefinite seulpture. very different from that speries in appearance.

Underside castaneous, with elongate yellowish scales. Basal and 2nd abdominal segments distinetly but not rosely punctate, the lst the larger, Brd and th nearly smooth, ach shorter than 2nd, 5th subtruncate behind, 6th short and coneave. Prosternum deeply emarginate. Metasternum broadly impressed.

Length (rostrum inclusive), $5 \mathrm{~mm}$.; breadth, $1 \frac{3}{4} \mathrm{~mm}$.

Mount Dick. Found by Mr. T. Hall amongst dead leaves, at an elevation of 2,200 ft., on the 17th March, 1914.

\section{Clypeorhynchus setosus sp. nov.}

Elongate, subdepressed, subopaque; fusco-castaneous, tibiae, tarsi, and antemnae light chestnut-red, restral apex piceo-rufous; thinly covered with decumbent, rather short, flaveseent setae. and some brighter, coarser, suberect ones which are most conspicuous on the hind part of elytra.

Rostrum rather shorter than thorax, distantly punctate, bearing squamiform setae, medially carinate, the sides indistinctly so, with an angular interantennal impression; its apical portion nearly nude, convex in the middle. sparingly and finely punctate. Head immersed nearly up to the transverse, obliquely oval eyes. Thorax of equal length and breadth, a little wider before the middle than elsewhere, nearly straight behind; median rhannel nearly equally distinet throughout antero-lateral nodosities almost obsolete, its punctation coarse but shallow, finer in front, the intervals minutely and densely sculptured, the sides more thickly setose than the dise. Scutellum small, triangular. Elytra thrice the length of thorax. not twice its breadth, with slightly enrvedly narowed shoulders, very little broader than it is at the base, gradually but considerably narrowed behind the posterior femora, with strongly prolonged dontiform apices; on each elytron there are 5 dorsal distinctly punctured striae, the outer usually more coarsely punctured than the sutural, all finer near the extrenity : interstices more or less finely punctured, the 2nd, at the base, and the shomlders a little elevated, th similarly throughout, 5th depressed near the base.

Antennae slender, finely setose, normal, but with the 6th joint of funirulus rather larger than contiguous ones; club clongate-oval. Leegs elongate. tibiae slightly flexuous.

Fem.-Elytral apices simple.

C. caudatus (3282) only has equally prolonged elytral apices; it is, however, a larger insect, with granular thoracic sculpture, elytral interstices also, but more finely granulate.

j. Length (rostrum inclusive), $8 \mathrm{~mm}$.; breadth, $2 \frac{1}{2} \mathrm{~mm}$.

Ben Lomond. Three examples taken from leaf-mould by $\mathrm{Mr}$. T. Hall, at an altitude of $4.000 \mathrm{ft}$., on the 3rd March, 1914. 


\section{Clypeorhynchus nitidellus sp. nov.}

Convex, slightly nitid; rufo-castaneous, middle of thorax and elytra infuscate; irregularly and sparingly clothed with short, depressed, fulvescent setae, and some erect, elongate, darker ones.

Rostrum stout, rather shorter than thorax, indistinctly sculptured, feebly bicarinate, dark red and almost smooth in front. Eyes subdepressed, rather large, subrotundate, with an intervening impression. Thorax very little longer than broad, slightly wider before the middle than behind, subconstricted in front; with a broad but not deep frontal impression which becomes quite narrow behind; its punctation moderate, shallow and slightly rugose, with some longitudinal rugae in front, and with a moderate nodiform elevation near the middle of each side; the setae are most conspicuous at the apex, on the nodosities, and along a line towards each shoulder. Elytra oblong-oval, with slightly oblique shoulders, scarcely at all broader at the base than the thorax, almost thrice its length; they are evidently and nearly quite regularly punctate-striate from base to apex; with slightly convex, nearly smooth interstices, the 2 nd and 4 th are a little elevated and thickly setose at the base, which is a little depressed at the suture; the setae do not form definite patches.

Scape flexuous, rather slender, gradually incrassate, with a few slender erect setae; basal joint of the funicle distinctly flexuous and rather longer than the next, 3rd and 4th shorter than 2 nd yet elongate, the following ones longer than broad; club elongate-oval. Legs normal, tibiae moderately flexuous.

The somewhat shining surface, the oviform, obviously punctate-striate elytra, the shallow thoracic channel and punctation, combined with the perfectly natural and equally flexuous basal articulation of each antenna, are sufficient for immediate recognition.

Length (rostrum inclusive), $8 \mathrm{~mm}$. ; breadth, fully $2 \frac{1}{2} \mathrm{~mm}$.

Routeburn, north of Lake Wakatipu. Unique. Taken off trees along with other Coleoptera during the night of the 16th February, 1914, by Mr. T. Hall.

\section{Clypeorhynchus halli sp. nov.}

Subelongate-oval, subopaque ; castaneo-fuscous, antennae and tarsi rufocastaneous, rostrum nigrescent; sparingly clothed with flavescent, depressed, very short squamiform setae, and with longer, coarser, and sometimes suberect ones near the sides and behind.

Rostrum almost smooth and glabrous in front, finely tricarinate behind, the central carina, however, hardly extends forwards as far as the middle; there is no perceptible punctation. Head simple, not foveate. Thorax hardly longer than broad, of the usual shape, distinctly, rather closely and coarsely purctured, with narrow smooth intervals, dorsal channel shallow and somewhat medially interrupted. Scutellum small. Elytra oblongoval, incurved at the base so that the shoulders appear slightly porrect; they are wider than the thorax but hardly thrice its length, with moderately prolonged, dentiform, quite divergent apices; their striae are subcrenatepunctate and deeper at the base than behind; interstices broad, with minute subgranular sculpture.

Somewlat similar to C. setosus, darker, joints 5-7 of the funiculus equally small a'd beadlike, rostral carinae different, thorax more deeply and distinctly punctate; the elytra shorter, more incurved at the base, their 
shoulders prominent, the interstices searcely differ from one another, the apices are less proloneged. but instead of being straight or slightly ineurved at the extremity they are obviously divergent.

Length (rostrum inclusive), $7 \mathrm{~mm}$.; breadth, nearly $21 \mathrm{~mm}$.

Hollyford; 18th February, 1914. Found at night on a mossy tree by Mr. 'I'. Hall, whose name has been wiven to it.

3914. Dermotrichus multicristatus sp. nov. Dermolrichus Sharp, Man. N.Z. Coleopt., p. 1205.

Opaque, fusco-piceous, rostrum, antennae, and legs fusco-rufous; irregularly elothed with depressed. Alender, and longer, suberect flaveseent squamae.

Rostrum strongly arched, nearly as long as thorax, slightly dilated and indistinetly punctured before the middle, convex of obtusely carinate behind, with some small squamate. Eves small, with distince facets, subrotundate, less distant from the thorax than from each other. Head short, narrowed anteriorly, minutely bicristate. Thorax not longer than broad, widest near the middle, about equally narrowed before and behind, base truncate, medially depressed there, with a few fine punctures in front; the scales so concentrated as to form a pair of small apical crests, an elongate central one, and a shorter pair at each side of it. Scutellum invisible. Blytra oviform, nearly double the width of thorax in the middle, twice its longth. very slightly broader than it is at the base, medially depressed there deflexed, but not abruptly so, behind; their punctate striae are rendered indistinct by the squamae, which are eoncentrated in lines along the middle, but form elongate conspienous erests inside the shoulders, on top of the declivity there is a transverse series of about 8 unequal crests; just below these, at each side, there is a larger one ; these are the principal ones, but there are others near each side and on the posterior declivity.

Legs with depressed greyish seales and a few setae; front tibiae nearly straight, the others slightly flexuous and distinctly mucronate.

Scape rather slender, flexuous, moderately clavate, attaining the front or centre of the eye, with a few fine elongate decumbent squamae; basal joint of funiculus thicker but scarcely longer than the next, joints 3-6 transversely quadrate, 7th larger; club densely pubescent, rather large: subpyriform, apical articulations indistinct.

Underside dull fuscous, finely and sparingly squamose. Prosternum emarginate in front. Metasternum truncate in front, very short, hardly longer than the coxae. Second ventral segment larger than the 1st, its frontal suture oblique fowards the sides and subangulate in the middle. 3 d and th togetherevidently shorter than 5th, which is slightly rufescent. with an obtuse elevation each side of the middle.

Fem.-Rostrum slightly longer than thoxax.

The squamose vestiture should perhaps exclude this species from Dermotrichus; the typical species, D. mundulus (2133), I have not seen. The legs and antennae, I presume, are piceous, the elytra seem to be withont punstation or striar ; it measures $3 \mathrm{~mm}$. in length-whether the rostrum is included or not I cannot state.

Length (rostrum inclusive), $4 \mathrm{~mm}$.; breadth, $1 \frac{3}{4} \mathrm{~mm}$.

Mount Earnslaw and Hollyford. About two dozen specimens, from Mr. T. Hall. 


\section{Dermotrichus elegantalis sp. nov.}

Elongate, gradually narrowed medially, slightly convex, opaque ; fuscous, legs, antennae, and rostrum fusco-rufous; covered with depressed, short, tawny squamae, and bearing numerous crests.

Rostrum arched, slightly expanded in front in the male, subparallel in the female, as long as the thorax, nearly smooth and glabrous before the antennae, behind finely trisuleate and bearing 4 longitudinal series of small transverse squamas. Head short, narrowed anteriorly, with a pair of small crests. Eyes free from thorax, lateral, small, subrotundate, nearly flat. Thorax slightly longer than broad, a little wider near the middle than elsewhere, rather more curvedly narrowed in front than behind; longitudinally depressed at the base, its moderately distant punctation concealed by the squamae; it has a pair of small apical crests, 3 before the middle still smaller, and similar scales form a streak along each side. Elytra elongate-oval, deflexed and a good deal narrowed behind, of the same width at the base as the thorax, quite double its length; neither striae nor punctures are visible, the basal depression is rather broader than that of the thorax, and is bordered with concentrated squamae, these form another basal streak near each side and a pair behind; on the summit of the declivity 4 distinct, but not very large, median crests are formed of longer woolly scales; there are usually 2 smaller pairs lower down, and each side, near the top, is more or less distinctly tricristate.

Scape moderately slender, clavate at the extremity, indistinctly squamose, inserted before the middle and attaining the middle of the eye. Second joint of funiculus as long as the lst, joints 37 indistinctly separated, apparently subquadrate; club large, subpyriform.

Underside dull dark fuscous, sparingly and finely squamose. Metasternum short, subtruncate behind. Second ventral segment in the middle as long as the basal, its frontal suture oblique at the sides, angulate in the middle, and with a median fovea behind; 3rd and 4th very short, with straight deep sutures, 5th shorter than 2 nd.

The elongate form, remarkable vestiture, and the foveiform scrobes, which, however, are prolonged to the eyes as squamose grooves, might warrant the exclusion of this rather elegant species from Demotrichus.

Length (rostrum inclusive), $5 \frac{1}{2} \mathrm{~mm}$.; breadth, $1 \frac{2}{3} \mathrm{~mm}$.

Moa Basin, (anterbury. Six examples found by Mr. 'T. Hall amongst decaying leaves on the ground; 20th' October, 1913.

3916. Phygothalpus philpotti sp. nox. Phygolhalpus Boum, T'ıns. N.Z. Inst., vol. 45, p. 117.

Suboblong-oval, with a slight silky gloss; nigrescent, antennae and tarsi piceous; moderately covered with depressed fusco-fulvous setae interningled, on the elytra, with a few grey patches, and with some short erect ones, those behind more conspicuous and longer.

Rostrum a third shorter than thorax, its frontal half subovate and pterrgiate, the apical portion shining, finely punctured, and bearing a few erect yellowish setae, coarsely and irregularly punctate behind; with a slight median atrina, the sublateral mes less distinet, all somewhat convergent towards the shallow interocular fovea, the interantennal fovea distinct. Eyes flat, lateral. Thorax scarcely any broader than long, a little wider before the middle than elsewhere. rather more narrowed in front than behind, with a broad discal chammel which is even more expanded 
at or behind the middle, and a feeble oblique impression near each side in front; its punctation moderately close but not coarse, more closely and rugosely at the sides, diseal interstiess nearly smooth. Seutellum distinet, triamgular. Elytra oblong-oval, considerably but gradually narrowed behind. with diveregent, slightly produced apices, they are rather broader than thorax at the base, thriee its length: rather coarsely and somewhat irregularly striate-punctate, much more finely towards the extremity, interstices minutely asperate, the 3rd and 5th, and the suture behind the middle, a little elevated.

Antennae much stouter than those of the type of the genus, $P$. sulcicollis (3287): seape subelasate for half its length; basal joint of funiculus uearly double the length of the next, joints $4-7$ submoniliform.

Underside shining, black, with numerous fine greyish setae, irregularly punetate. Prostermum transversely swollen in front of the coxae. Basal 2 segments of abdomen and hind part of metasternum broadly depressed. Tarsi with many elongate hairs in addition to the ordinary short dense vestiture.

Rather larger, evidently more shining and variegate than $F$. majusculus (3765), the vestiture brighter, the thorax less alosely punctate. with smooth intervals, and its central channel even broader; elytra feebly undulate on some parts, with less regular sculpture, the interstices more finely and distantly asperate.

ㅇ, ô. Length (rostrum inclusive), $9 \frac{1}{2}-10 \frac{1}{2} \mathrm{~mm}$. ; breadth, $3-3 \frac{1}{2} \mathrm{~mm}$.

Mount clenghearn, 3,500 ft. to $5.000 \mathrm{ft}$.. Hunter Range. south-west of Lake Wakatipu. I single pair found during January 1914, by Mr. A. Philpott, whose name has been siven to it. Infortmately, he encomented bad weather, so that very few insects could be got.

\section{Phygothalpus granissimus sp. nov.}

Elongate, subovate, nearly plane above, subopaque; black, legs and antemnar piceons: very thinly elothed with ineonspienons. slender, suberect, ashy setae, and a few coarser tawny ones near the sides, those on the rostrum elongate and flavescent.

Rostrum a third shorter than thorax, its frontal half only slightly dilated; tricarinate, coarsely, rugosely but not deeply punctured behind; there is a triangular interantemat forea: the appial portion rather alosely and distinctly punctate. Head elosely and rugosely punctured, with an elongate median fovea. Thorax widest before the middle, more narrowed in front than behind, a fifth broader than long; its whole surface rugosely granulate, with a small puncture in each granule, with a broad, shallow, obligue frontal impression near each side, discal rhammel narrow and shallow behind, a little broader and deeper in front. Scutellum small, triangular. Elytra subtruncate at the base, a little wider than thotax there. fully theiee its lengtl. grardually narowed posteriorly, with divergent. slightly produced apices, the portion in rear of the posterion femora almost double the length of that in front of them; each elytron is irregularly quadricostate, the external costa is distinct at the base (shoulder), the others are not, all are verr chosely and fondy gramulate but heeome obsolete behind. the suture, though depressed at the hase, is distinctly elevated nearly to the extrenity ; the interstiens are irregularly, unerually, and rlosely for the most part finely granulate, the larger granules form 4 or 5 series more or less interrupted apparently by punetiform impressions. the hind slope is almost seriate-punctate. 
Scape moderately slender, straight, subclavate at extremity, hardly reaching the back of the eye; 2nd joint of funiculus elongate and slender yet shorter than the 1st, the 3rd much shorter, joints 4-7 submoniliform; club large, oblong-oval.

The rostrum is slightly longer and more parallel than that of $P$. philpotti, and therefore less oviform in front; the antennae are more slender and the tibiae less flexuous. There can be little difficulty in identifying this species owing to the close gramular sculpture, and the unusual length of the elytra behind the posterior femora.

Length (rostrum inclusive), $10 \frac{1}{2} \mathrm{~mm}$.; breadth, $3 \frac{1}{2} \mathrm{~mm}$.

Mistake Basin, west of Mount Algidus. Unique. Found by Mr. T. Hall at an elevation of $3,000 \mathrm{ft}$.

\section{Phygothalpus sulcipennis sp. nov.}

Suboblong-oval, slightly nitid; nigrescent, antemnae and tarsi piceous; moderately closely covered with depressed, rather small but elongate ashy squamae.

Rostrum indistinctly tricarinate, somewhat longitudinally rugose and punctate behind, the apex finely and closely. Head gradually narrowed anteriorly, distinctly and closely punctate, with a small central fovea. Eyes verr slightly eonvex, quite lateral, the lower space between each and the thorax almost smooth. Thorax of equal length and breadth, just perceptibly broader near the front than behind, slightly obliquely narrowed in front; with a linear median impression which becomes obsolete behind the middle, moderately closely but not coarsely punctate, without superficial inequalities, the base a little rounded. Scutellum small but distinct. Elytra oblong-oval, slightly broader than thorax at the base, nearly thrice its length; regularly and distinctly punctate-striate, interstices slightly convex, finely punciate.

Scape flexuous, gradually incrassate, attaining the back part of the eye, bearing fine grey setae : basal joint of the funicle not double the length of the elongate 2 nd, 3rd slightly longer than 4th, the following ones beadlike. Tth rather transverse; club elongate-oval. Tibiae slightly flexuous, the anterior indistincty mucronate, the others expanded and inwardly prominent at the extremity.

The even surface of the thorax, its abbreviated and slender discal chamnel, and smooth interstices, the evidently striate elytra, the slightly flexuous and obsoletely mucronate front tibiae, and the presence of moderately developed ocular lobes distinguish it.

Length (rostrum inclusive), $8 \frac{1}{2} \mathrm{~mm}$.; breadth, $3 \frac{1}{3} \mathrm{~mm}$.

Mount Dick. A single specimen found by Mr. T. Hall under a stone, at an elevation of 4,000 ft., on the 10th Narch, 1914.

3919. Nestrius sulcirostris sp). nox. Nestrims Broun. Man. X.Z. ('oleopt., p. 1480 .

Elongate, moderately convex, subopaque; fuscous, rostrum and thorax usually more rufescent, antennae and legs fusco-rufous; rather thinly clothed with moderately slender. grevish-rellow, ereet and subdepressed setae.

Rostrum rather shorter than thorax, parallel, impunctate, broadly and rather deeply sulcate from the antemme to its hase, which is on a lower level than the head. Thorax oriform, a little broarler before the middle 
than elsewhere, broadly but unevenly impressed along the middle, with about a dozen large foveiform impressions on its disc. Scutellum absent. Elytra oviform and, near the middle, a third broader: than the thorax, but little broader than it is at the base, barely double its length, subvertical behind; they are moderately striate-punctate, quite striate behind, 2 nd interstices somewhat elevated at the base.

Legs moderately elongate, finely setose; femora medially subclavate: tibiae rather slender, slightly swollen but not denticulate inwardly, indistinctly mueronate at the extremity; terminal joint of the tarsi as long as the others combined, the penultimate bilobed, their soles with elongate setae.

Scape normal, implanted near the apex, with slender erect setae; 2nd joint of funiculus almost as long as the basal, joints 3-7 successively shortened, the 7 th slightly longer than broad: club ovate, fincly pubescent. indistinctly articulate.

Underside fuscous, slightly nitid, with a few fine suberect fulvescent

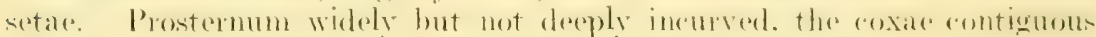
and situated near the base. Mesosternum finely punctate, abdomen almost smooth. Metasternum short, medially depressed, angulate between the intermediate coxae. Basal segment with a few fine punctures, obtusely elevated and subtruncate between the coxae. medially sinuate behind. somewhat longer than the next, 3rd and th moderately developed, together as long as the 2 nd, evidently longer than the 5th, which is subtruncate and minutely ciliate at the apex.

In $N$. sempes (2559) the thomx is nearly if not quite as broad as the hind-body, with numerous conse punctures, the elytra are narrower and more elongate; the hind legs are rather thickes, and the tibiae strongly mueronate at the extremity and denticulate along the inside; the 2nd joint of the funiculus is hardly any longer than the 3rd but evidently shorter than the 1st; the underside also differs in the male, the 3rd and 4th segments being abbreviated and, conjointly, shorter than the 5th, which is bisinuate at the apex so that the 6 th is distinet. In $N$. crassicomis (3766) the scape is incrassate and shorter, and the oblong elytra appear abruptly narrowed at the base. Phyllodytes has the penultimate tarsal joint entire underneath. the rostrum is slightly pteregate. and the ores are just frees.

Length (rostrum inclusive), $4 \mathrm{~mm}$. ; breadth, $1 \frac{1}{2} \mathrm{~mm}$.

Hollyford; 20th February, 1914. Found by Mr. 'T. Hall amongsi decaying vegetable matter, and usually covered with tawny sappy matter which eoneeals the rostral channel. \&e.

\section{Nestrius prolixus sp. nov.}

Narrow, elongate, attenuate posteriorly, slightly convex, subopaque: rufo-castancous, sometimes more infuscate, antennic rufous, legs fuscotestaceous; sparingly clothed with depressed, fine yellowish, and a few erect, infuscate setae.

Rostrum a third shorter than thorax, stout, slightly dilated at the point of antennal insertion, its central groove finely margined and prolonged as far as the back part of the eyes. 'Thorax a third longer than broad, slightly wider before the middle than elsewhere, not constrieted in front; coarsely and elosely punctate. Elytra very elongate-cordate, twice the length of thorax, very little broader than it is at the base, somewhat areuateemarginate there, considerably narrowed and subvertical behind; rather 
closely striate-punctate, interstices lather narrow, a pair on each elytron usually elevated at the base, the scutellar region depressed.

Legs elongate, tibiae simple, indistinctly mucronate.

Underside castaneous, with many fine yellow setae. Prosternum elongate, moderately coarsely but not deeply punctured, its roxae contiguous. Metasternum moderately short, hroadly impressed. Abdomen very elongate, basal segment broadly depressed in the middle. nearly double the length of the 2nd, their suture sinuate; 3rd and 4th together longer than 2 nd, with deep sutures; 5th subquadrate, coarsely punctate, byodly rounded and minutely eiliate behind: 6th semieirular. concave at the base. finely punctate behind.

Easily separable from $N$. sulcirostris by the elongate contour, subacuminate hind-body; unimpressed thorax, but with more numerous punctures, different ventral segments, \&c.

o. Length (rostrum inclusive), $4 \frac{1}{2} \mathrm{~mm}$.; breadth, $1 \frac{1}{4} \mathrm{~mm}$.

Gordonis Knob, near Nelson. Half a dozen examples taken by Mr. T. Hall from fallen leaves, on or about the 15th November, 1914. In its natural condition it is smeared with sappy matter, so that the rostral groove and elytral sculpture are partly hidden.

\section{Inososgenes gell. $110 \mathrm{v}$.}

Body elongate, subparallel, slightly convex. Head immersed up to the small transverse eyes. Rostrum stout, slightly shorter than thorax, slightly dilated in front, parallel behind. Scrobes subapical, quite visible and open above, distinctly prolonged to the eyes. Scape inserted near the apex, attaining the eye, stout, straight, gradually incrassate. Funiculus 7-articulate, basal joint longer and thicker than the next, joints 3-7 transversal; club short, ovate. Thorax without ocular lobes, truncate at apex, nearly so at the base, oviform. Scutellum absent. Elytra oblong, incurved and rather broader than thorax at the base. not vertical behind.

Legs moderately stout and elongate; femora unarmed, subclavate at the middle; tibiae slightly flexuous, uncinate; tarsi finely setose underneath, penultimate joint excavate above but not lobate.

Prosternum elongate, very deeply emarginate in front, broadly impressed along the middle, the coxae large, prominent, contiguous, and situated near the base. Intermediate coxae moderately, the posterior widely, separated, all about equidistant from front to rear. Metastemum very short. Basal ventral segment truncate between the coxae, very large, 2nd rather shorter. on a slightly higher level. the frontal suture indefinite. apparently oblique at the sides, 3rd and th moderately well developed. with straight sutures and, together, shorter than the 5th. Epipleurae linear.

Nearly related to the minute Sosgenes carinalus (2556), in which, however, the rostrum is not in the least dilated anteriorly, its apex is smooth, shining. and abruptly matked off behind like (Yypeorhynchus. the scrobes are not open above, and the deep prosternal depression has almost sharply raised lateral horders.

\section{Inososgenes longiventris sp. nov.}

Opaque, nigro-piceous, antennae and tarsi fusco-rufous; sparingly clothed with subdecumbent tawny setae, those on the legs erect. 
Rostrum punctate, with a distinet carina from its base to the antennae, tricarinate between these, rufesernt in front. Thorax a fifth longer than broad. moderately roarsely and closely punctate, the intervals more or less rugese, finer in front. "Elytra nearly double the length of thorax, their sides almost straight to beyond the posterior femora, moderately narrowed behind, their obtuse shoulders slightly porrect. 3rd and 5th intersties obtusely clevated near the base; ther are finely and definitely striate behind, but the dorsal seulpture being obseured by a film of sappy matter is rendered indistinct; when the surface is scraped with the point of a needle, and looked at from above, there seem to be series of punctures-these, however, when carefully examined sideways appear to be transformed into granules, as is often the case in some of the Colydiidae, in the genus Coxelus especially.

Underside nigrescent, sparingly setose. Basal ventral segment broadly impressed along the middle, more coarsely but less closely punctured than the 2 nd, the punctation of the 5th is shallow. The thick palpi are quite visible bevond the mentum.

Thorax with a fine earina which beromes indistinct towards the base.

Length (rostrum inclusive), $5 \frac{1}{2} \mathrm{~mm}$. ; breadth, $1 \frac{2}{3} \mathrm{~mm}$.

Momut Dick, near Lake Wakatipu. 'Two deteeted amongst dead leaves on the ground, at a height of $3,500 \mathrm{ft}$., by Mr. T. Hall on the 17th March, 1914 ,

3922. Sosgenes discalis sp. nov. Sosgenes Broun, Man. N.Z. Coleopt., p. 1474 .

Elongate, transversely convex, subopaque; with a few fine, pale, inconspicuous setae; fusco-rufous, rostrum paler, antennae and tarsi fulvescent.

Rostrum rather shorter than thorax, gradually and slightly narrowed anteriorly. its apical portion smonth and shining, olsewhere dull, with dense minute sculpture, nearly plane or only feebly grooved along the middle. Thomax nearly a third longer than broad. subovitorm. widest before the middle. nearly straight hehind, a good deal but not abruptly contracted in front: the (hamel alomg the middle broad. not verr deeps. sometimes indistinetly divided lenethwars, at earh side of this, near the middle, there is a small elevation and another can be seen near the base, its punctation is shallow and somewhat irregular. Elytra nearly double the length of thorax, slightly wider than it is at the base; each with 5 dorsal series of relatively large, suboblong punctures, the sutural indistinct; interstices subermate, the lst throughout, the others more or less abbreviated behind, the suture also slightly elevated.

Antennae normal, with slender greyish hairs.

3. Legs stout, posterior tibiae ciliate inwardly, inerassate above the middle. 'Tarsi short and narrow, penultimate joint not expanded, slightly excavate above at the apex, the terminal fully as long as the basal 3 combined, with nearly straight elaws.

Underside indistinetly punctate, with a few fine setae. Anterior and intermediate coxae very prominent, the latter distinetly separated, the posterior widely. Metasternum large. Basal segment of abdomen broadly

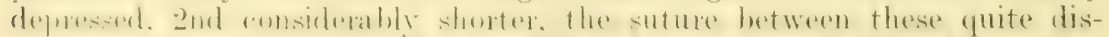
time and simate in the middle. the end widely anarginate behind.

Fem.-Tibiae nearly straight, the posterior without cilia. 
The discal sculpture of the thorax and the distinct suture between the 1st. and 2nd ventral segments are its prinsipal distinguishing features.

Length (rostrum inclusive), $2 \frac{1}{3} \mathrm{~mm}$. ; breadth, $\frac{2}{3} \mathrm{~mm}$.

Searcliff, near Mount Algidus. Half a dozen males and two females taken from cotton-plants, at an elevation of 2,000 ft., by Mr. T. Hall on the 19th October, 1913. This is the first South Island sperefer of the genus.

3923. Rystheus notabilis sp. now. Rysthers Broun, Man. X.Z. ('olerpt., p. 1218.

Elongate, subeylindric, a little depressed towards the middle. slightly nitid; castaneo-rufous, the posterior declivity, sides, and an irregular space along the middle of the hind-body more or less piceo-fuseous, rostrum piceo-rufous; thinly clothed with decumbent, fine, fulvescent setae, but quite densely across the hind part of the posterior nodosities, the setae on the thoracic apex much coarser and closer than on the dise.

Rostrum strongly arched, rather longer than thorax, very slightly expanded and flattened and finely punctate in front, roarsely and subseriately punctured, and obsoletely and irregularly tricarmate behind. Head inmersed up to the eves. gradually narrowed to the same width as the rostrum. nearly smooth, with an oblong fovea behind. Eyes almost flat, obliquely oval, quite hyaline. Thorax a little longer than broad, slightly wider before the middle than elsewhere; with a pair of obtuse medial nodosities, the sculpture granular there, but moderately coarsely and distantly punctired behind, the anterior sculpture distant and less definite; a shallow central channel extends from base to apex. Elytra of the same width as thorax at the base, which is medially emarginate and depressed, thus leaving a small gap between them and the truncate base of the thorax, they are abruptly vertical behind, the sides less so; the sides have series of distinct distant punctures, but along the middle the sculpture is more or less irregularly granular; there is a pair of moderate nodosities in line with the hind thighs and a less distinct pair before the middle, the pair on the summit of the declivity are prominent and conspicuous, on the hind face there are several unequal granules.

Scape implanted before the middle of the rostrum, slightly flexuous, slender, clavate at the extremity; funiculus stouter, its 2nd joint longer than the 1st, joints 3-6 subquadrate, 7th rather larger; chlo oblomw-oral, densely pubescent, obsoletely articulate.

Legs elongate, femora arched above, the front pair rather longer ihan the others; tibiae slightly flexuous, minutely serrate inwardly, distinctly mucronate at the extremity.

Underside with depressed yellowish setae. Prosternum light castaneous, coarsely and distantly punctate. Abdomen fusco-testarenus, neatry plane indistinetly sculptured, its segments with straight sutures, the hasal segment much larger than the metasternum, obtusely angulate between the coxae. 2nd nearly as long as 3rd and th thembined. 5th rather longer than 2nd. Epipleurae quite linear.

This remarkable insect is more robust than $R$. ocularius (2148), the type of the genus, which latter has altogether different sculpture, its front legs are relatively longer, and their tibias are more curvate externally. and the 2 nd joint of the funicle is more slender and elongate.

Length (rostrum exclusive), $5 \frac{1}{2} \mathrm{~mm}$.; breadth, nearly $2 \mathrm{~mm}$.

Hollyford, near Routeburn. Two obtained from leaf-mould on the 19th February, 1914, by Mr. 'T. Hall. 


\section{Group Cylindrorimnidan.}

3924. Tocris pascoi sp. nov. Tocris Broun, Ann. Mag. Nat. Hist., ser. 7. vol. 14, p. 115.

Oblong, moderately convex and nitid; black, antennae rufo-piceous, basal 3 joints of tarsi fusco-rufous; irregularly covered with depressed, rather small, nearly white squamae.

Rostrum moderately coarsely, elosely, and rugosely punctured, obtusely

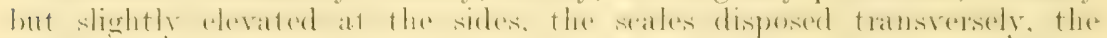
broadly triangular trontal space nude and finely punctate; mandibles straight inwardly, obtuse at the extrenity. Head with a smooth interocular fovea. Thorax just a seventh broader than long, obtusely prominent and widest hefore the midelle, sinater hetween that part and the base, which is teebly rounded, apex truncate; with a slightly raised, almost smooth median spot near each side, and a nearly similar pair, prolonged backwards, on the middle, separated by a longitudinal line, and the finely punctate apical portion almost bare; the rest of its surface with moderately distinet, irregularly distributed punctures, the intervals minutely puncetate. Elytra scarcely thrice the length of thorax, the base slightly incurved and broader than it is, a fifth wider behind the posterior femora, with simple apices; each elytron bicostate as far as the top of the declivity, these are finely punctate, the side is alse costiform but "urved inwadly behind, the suture is somewhat broadly elevated behind the middle and a little thickened near the apex; the interstices are densely squamose, each has a series of coarse but not deep purctures at each side.

This most nearly resembles $T$. hamiltoni (3289), but is smaller, with somewhat different sculpture and whitish vestiture. The basal 2 joints of the tarsi are cordate, the penultimate longer and deeply bilobed. The 2nd joint of the funicle is as long as the basal, joints 3-7 are very gradually shortened and thickened hut nome are moniliform: (chub elongate-oral. finely pubescent.

Length (rostrum inclusive), $15 \mathrm{~mm}$. ; breadth, $5.1 \mathrm{~mm}$.

Bold Peak, north-west of Lake Wakatipu. My specimen was received on the 9th March, 1914, from Mr. M. O. Paseoe, of Queenstown, whose name it now bears.

\section{Group Molytidae.}

3925. Lyperobius aciphyllae sp. nov. Lyperobius Paseoe, Man. N.'. Coleopt., p. 444.

Nigrescent, slightly nitid; elytral interstices thickly covered with depressed, pale tawny scales, the thorax thinly and irregularly.

Rostrum at thied shopter than flomax, moderately parsely and rugosedy punetured; with a large but not deep impression in front of the antennae and a fovea at the bise. between these there is a smooth but not sharply marked carina. Thorax slightly broader than long, widest before the middle, shightly and gradually narrowed behind, rather abruptly contracted and subangularly emarginate at the apex; its surface a little uneven, with an ante-basal impression, a larger but more shallow one at each side near the middle, and another near the front; the punctation is coarse, irregular, and rugose, the slightly raised parts near the middle, however, have but few punctures; the base is feebly but widely emarginate. Elytra oblongoval, rather wider than thorax at the base, more than twice its length; each

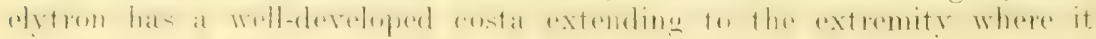


forms an angle at its junction with the other from the lower part of the side, the 2nd costa is shorter but extends to below the top of the declivity, the side of the dorsum is costiform and curved inwardly below the 2 nd, the suture also is costiform, all these are minutely and distantly punctate; interstices nearly seriate-granulate.

Underside shining black, with minute setae; basal 2 ventral segments medially depressed, the 1 st not double the length of the 2nd, mederately finely and closely punctured, 2nd obsoletely in the middle, 3rd and th each shorter than 2 nd with very deep sutures, 5th more closely punctate with a large fovea extending to the truncate apex and bearing a small rufescent crest at each side, 6th short.

Basal joint of funiculus nearly double the length of 2 nd, joints $3-5$ transverse, 6th and 7th larger. Basal joints of tarsi slender near the base, twice the length of the transverse 2 nd.

$L$. hudsoni can be at once separated by its 3 squamose streaks along the more finely sculptured thorax; its 3 dorsal interstices are thickly squamose, but the 4 th, or lateral, is often interruptedly or obsoletely squamose; the ventral segments have a patch of pale scales at the sides, there are none at all on $L$. aciphyllae.

Length (rostrum inclusive), $18 \mathrm{~mm}$. ; breadth, $7 \frac{1}{2} \mathrm{~mm}$.

Garvie Mountains. I am indebted to Mr. James Speden, of Gore, for my specimen, and three of $L$. hudsoni (3447) which prove that that species varies much as regards the elytral squamosity.

\section{Lyperobius fallax sp. nov.}

Subopaque, nigrescent, sparingly clothed with small, depressed, tawny or greyish squamae.

Rostrum finely punctate and unimpressed in front of the antennae, moderately coarsely but not deeply and not at all rugosely punctured behind, each puncture is filled with a flat scale so that the surface appears even, instead of being asperate as in $L$. aciphyllae. Thorax with an irregrular, narrow, snooth space along the middle and ending at the basal impression, the sculpture near the sides consists chiefly of very irregularly formed impressions and equally irregular smooth intervals.

Fifth ventral segment unimpressed. Second joint of funiculus almost as long as the 1st.

With the above exceptions it is similar to the preceding species.

Length (rostrum inclusive), $18 \mathrm{~mm}$. ; breadth, $7 \mathrm{~mm}$.

Mount Miromiro; elevation, 6,000 ft. Two examples, kindly sent to me, saturated with alcohol, by Professor C. Chilton, and set aside as a variety of $L$. carinatus.

\section{Lyperobius spedenii sp. nov.}

Robust, oblong-oral, suboparque; thinly sothed with depressed. minute, greyish squamae; nigrescent, antennae and tarsi nigro-piceous.

Rostrum almost as long as thorax, dilated in front, moderately but not deeply punctured, with an elongate basal and a smaller interantemal fovea. Eyes strongly transverse, rather flat. 'l'horax only very slightly broader than long. gradually narowed fom the hase to the ahruptly eontraved apex, which. like the base, is medially emarginate: with an ill-riefuned smooth central line not reaching the ajex. its punctation irregular but not coarse, becoming closer and confluent near the sides and front. Elytra 
oblong-oval, very little wider than thorax at the base, twice its length, with very broadly rounded apices; each clytron has two obvious. finely punctured costae, the side, and the suture except at the base, are also costiform; the broad interstices are distinctly, almost seriate-granulate, on some parts confluently, behind the middle. and sometimes near the base. they are subcostiform.

Scape gradually incrassate, attaining the front of the eye. First and 2nd joints of funiculus equal, twiee as long as broad. joints 3-7 transverse, the last largest; club short, ovate. Tibiae flexuous.

Underside black; abdomen irregularly and finely punctate and bearing minute straw-coloured setae, 5th segment with a large central fovea, apex obtusely elevated at each side of the middle.

As large as L. hutioni (783), but, owing to the peculiar shape of the thorax, and granulate elytra, very different from it and other allied species.

Length (rostrum inclusive), $29 \mathrm{~mm}$. ; breadth, $12 \mathrm{~mm}$.

Garvie Mountains, near Blue Lake. A single example found on Aciphylla simplex by Mr. James Speden, of Gore, in whose honour it has been named.

\section{Group ErirhinidaE.}

3928. Erirhinus celmisiae sp. nov. Erirhinus Schoenherr, Man. N.Z. Coleopt., p. 449.

Convex, elongate-ovate, nitid, subglabrous, bearing only a few fine inconspicuous setae; rufo-fuscous, legs and antennae of a lighter hue, the elytra sometimes fusco-testaceous.

Rostrum moderately slender, arched, rather shorter than thorax, longitudinally punctate, with an indistinct central carina. Head short, gradually narrowed anteriorly. Eyes transversely oval, rather flat. Thorax of about equal length and breadth, without ocular lobes, widest at the middle, more narrowed in front than behind, base and apex truncate; rather finely and not closely punctured. less closely along the middle. Sorutellum snall. Elytra oblong-oval, quite double the length of thorax. a little wider than it is at the base, apices obtusely rounded; they are moderately finely striatepunctate, with nearly plane, minutely punctate interstices.

Legs stout, femora unarmed; tibiae mucronate, distinctly setose; tarsi setose underneath. penultimate joint broadly bilobed. claws appendiculate at the base.

Scape inserted between the middle and apex, attaining the eye; basal joint of funiculus nearly twice the length of 2 nd. Brel and th slightly longer than hoad. joints 57 moniliform; relub ovate. broad. quadriarticulate, fuscous.

Underside nitid, fuscous, finely punctate and setose. Prosternum triangularly but not deeply emarginate in front; coxae prominent, contiguous, placed near the base. Metasternum depressed and suleate along the middle. Basal segment broadly rounded between the coxae, broadly depressed in the middle, rather longer than the next, the suture sinuate, sod and th thenether longer than ghd, 5th with a shallow impresion along the middle.

Fem.-Rostrum more slender, finely punctate, rather longer than thorax ; scape implanted just before the middle.

With the exception of the prosternal emargination and slight abdominal disparities, this species accords with the diagnosis of Erirhimes, but in facies it is ummistakably different from all the New Zealand species. 
ô. Length (rostrum exclusive), $4 \mathrm{~mm}$. ; breadth, quite $1 \frac{1}{2} \mathrm{~mm}$.

Moa Basin. Eight examples taken from the heart of flowers of the mountain-daisy (Celmisia) by Mr. T. Hall during October, 1913.

\section{Eugnomus bryobius sp. nov. Eugnomus Schoenherr, Lacord, Hist.} des Ins. Col., Tom 6, p. 500.

Robust, moderately convex, opaque, variegate; usually rufo-castanerus, with a large fuseous space, sometimes reaching the suture, at or just before the posterior femora, thoracie dise darker than the sides, chub and terminal joints of tarsi nigrescent. the scape more rufescent than funiculus; squamosity depressed, somewhat oviform. flavescent and slender on the rostrum and thoracic dise, sometimes griseous on the elytra, and in some examples mingled with short slender setae.

Rostrum moderately arched, a little expanded in front, rather longer than thorax, coarsely punctate, apex nearly smooth and shining, with an elongate interantennal fovea. Eves prominent, subrotundate, the space between them and the thorax rather less than their own length, with a well-marked depression between them above. Thorax evidently constricted in front, a little broader than long, base and apex truncate, its sides nearly straight behind: closely and moderately coarsely punctured, the squamae at the sides rotundate and paler than those on the disc. Scutellum oblong. Elytra somewhat biareuate at the base, about double the width of thorax there, more than thrice its length, considerably narrowed behind, with singly rounded apices; they are moderately fincly and closely punctatestriate, with the suture and 3rd and 5th interstices more or less obtusely elevated. Pygidium exposed, finely punctate, subquadrate or elongateobeonical.

Legs moderately elongate; femora clavate and obtusely angulate but not dentiform underneath. Scape slightly flexuous, attaining the middle of the eve. Funiculus 7 -articulate, basal joint thicker and slightly longer than elongate 2nd. joints 3-7 gradually diminish. none, however, are transverse or moniliform. Club elongate-oval, its 1 st joint narrowed towards the base and much longer than the next, 3rd also elongate.

Tnderside slightly convex, thickly covered with elongate grey squamae, more slender and filiform on the 5 th abdominal segment, which has a rotundate apical fovea. Mesostemal process quadrate between the middle coxae, truncate or slightly emarginate behind.

Scrobes subapical, not definitely prolonged below.

Readily distinguishable by the robust form, obtusely elevated suture and alternate clytral interstices, differently formed femora, \&r.

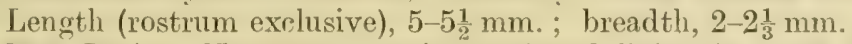

Ioa Basin. Numerous speemens found living in moss on the hanks of the stream, by Mr. T. Hall, on the 20th October, 1913. There is a considerable amount of variation amongst the individuals. but I fail to detert true specific differences.

\section{Eugnomus alternans sp. nov.}

Subdepressed, rather short and broad, opaque; fuscous, head and rostrum, the elytral suture, and the club piecous. seape and lexs castaneous; irregularly clothed with depressed. ererish, elongate. setiform squamate.

Rostrum only feehly arehed, parallel, slighty longer than thorax. mather finely punctate, subcarinate along the middle, smooth at apex, with an 16*-Bull. No. 1. 
elongate interantennal fovea. Head broader than rostrum, not double the length of the moderately prominent, subrotundate eyes. Thorax scarcely any broader than long, slightly narrowed anteriorly, evidently anstricted at apex, muderately coatraly and rlosely punctured. the squamae coarser near the sides than on the middle. Scutellum oblong. Elytra nearly double the width of thorax at the base, thrice its length, rounderd and deflexpl behind; the suture and alternate interstices moderately broad, slightly and obtusely elevated, more or less finely and irregularly punetured. seemingly with a series alongside each; the equally broad intervals much more thickly arovered with rather coarser, yet elongate. seales right to the extremity.

siape slightly flexuous. gradually thickened. barely rearehing the middle of the eye. Basal joint of funiculus nearly double the length and breadth of the next, 3rd and ith hardly longer than hroal, joints 6 and 7 a little broader than 5th; club elongate-oval, large, densely pubescent, intermediate joint shortest.

Posterior femora angulate and spiniform, the middle pair obtusely angulate, anterior subclavate. Niddle and hind tibiae slightly expanded and nigrescent at the extremity.

Easily recognizable by an examination of the elytra. We have no others like it.

Length (rostrum inclusive), $4 \frac{1}{2} \mathrm{~mm}$. ; breadth, $1 \frac{1}{2} \mathrm{mmm}$.

Nount Dick, Wakatipu. One taken off a flowering shrub, at an elevation of 2,500 ft., by Mr. T. Hall on the 10th March, 1914.

\section{Eugnomus tristis sp. nov.}

Opaque, nigrescent, thorax slightly rufescent, legs and scape rufocastaneous, funiculus and club infuscate; rather thinly covered with donessed, elongate, orerish setae and a few erect infusate ones, but leaving nearly bare an irregular dark faseia near the hind thighs.

Rostrum shightly longer than thorax, parallel, indistinetly punctured. Fres pondinge subotundate, more distant from thorax than from earh other. Thorax slightly broader than long, very little constricted in front, distinctly and closely punctured. Scutellum sblong. Elytra thriee the length of thorax. considerably and abruptly boader than it is at the base, curvedly narrowed behind, with singly rounded apices; they are finely punctate-striate, with minutely granulate interstices.

Anterior femora ravate and minutely dentate underneath, the others angulate and spiniform; tibiae straight.

Scape slender, straight, very gradually thickened; basal joint of funiculus stouter but not much longer than the elongate 2nd, 3rd and 4th longer than broad, joints 5-7 moniliform; club large, oblong-oval, finely pubescent.

Underside piceous, with numerous elongate, depressed, greyish scales and setae. Filth segment of abdomen as long as mereding 2 together, obtusely triangular, only obsoletely impressed behind.

Most nearly allied to E. aspersus (2404), but smaller, darker, and less speckled, with more slender antennae, more prominent eyes, the head much less deeply impressed, the thorax less regularly narrowed anteriorly, and the underside different.

Length (rostrum inclusive), $4_{2}^{1} \mathrm{~mm}$.; breadth, $1 \frac{1}{2} \mathrm{mmm}$.

Mount Alfred, north of Lake Wakatipu. Four shaken off flowering shrubs on the th February, 1914, by Mr. T'. Hall. 
3932. Oreocharis fasciata sp. nov. ()ieochuris Broun, Man. X.Z. (indupt., p. 864 .

Opaque, fuscous; scape, base and apex of femora, all the tibiae, and basal joint of tari chestnut-red; densely covered with depressed tawny, sometimes greyish srales. with the exreption of the rostrum, a fascia near the hind thighs, the shoulders, and sometimes the elytral suture: whir h bear ineonspicuous, decumbent, dark ashy hairs.

Rostrum slightly arched, subparallel, rather longer than thorax, indistinctly punctate, slightly rarinate along the middle. with sender yellowish hairs. Head narrowed anteriorly, nearly double the length of the slightly prominent, longitudinally oval eyes. Thorax of about the same length and breadth, constricted in front, base and apex truncate, its punctation moderately coarse and close. Scutellum oblong. Elytra nearly double the width of thorax at the base, thrice its length, gradually curvedly narrowed behind; distinctly punctate-striate, interstices simple, finely punctured. Pygidium obtusely triangular, punctate.

Scape extending to back part of eye. Funiculus 6-articulate, basal joint distinctly thicker and longer than 2nd. the next rather shorter. joints 4-6 submoniliform. Club densely pubescent, oblong, nearly as long as funiculus.

Anterior femora subclavate, intermediate obtusely angulate, sometimes slightly dentiform below, the posterior strongly angulate and sumiform ; hind tibiae slender near the base. evidenty dilated along their front face. Tarsi with the penultimate joint strongly bilobed. 2nd triangular.

Abdomen distinctly punctate. orvered with grevish forther-like squanae and depressed slender setae. The breast with more flavescent seales.

The rather short form, the dark elytral fascia, and remarkable abdominal vestiture are distinctive.

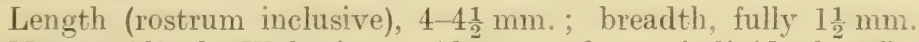

Mount Alfred, Wakatipu. About a dozen individuals off flowering shrubs. Mr. T. Hall; 4th February, 1914.

\section{Oreocharis congruens sp. nov.}

Subopaque, castaneo-rufous, head and thorax rather darker, funiculus and club infuscate; elytra with numerous decumbent, elongate, slender, fulvescent setae, and a pair of blackish crests on the 2nd interstices at the top of the posterior declivity; thorax more thinly clothed but with some pale scales across the base and along the middle; seutellum similarly squamose.

Rostrum as long as thorax, a little contracted just behind the antennae, nearly smooth at the apex. moderately masely pumetate and sliphtly

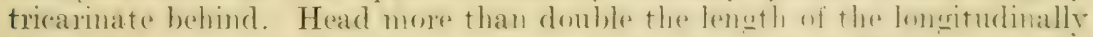
oval eyes, unimpressed between them. Thorax as long as broad, gradually narrowed anteriorly, slightly constricted in front; with a shallow impression near each side behind the middle, closely and miderately coarsely punctured. Scutellum oblong. Elytra not twice the width of thorax at the base, four times its length, gently narrowed behind, with broadly

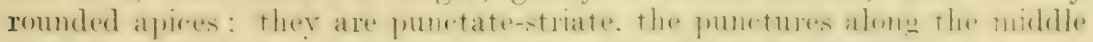
of each elytron are subquadrate and rather close, those near the suture less distinct; interstices funcly and closely punctate. Ith and bith confluent and slightly elevated behind. Pygidium brnadly triangular. 
Scape flexnous and gradually incrassate; club elongate, nearly as long as the funicle, its 3rd joint hardly as long as its predecessors combined; funiculus as in $O$. fasciata.

Anterior femora clavate, the others strongly angulate and spiniform below. 'libiae like those of preceding species.

Similar to $O$. bicristata (1621), decidedly more elongate, with longer antennae, rostrum more distinctly tricarinate, the eyes less rotundate and convex, head and thorax darker, the elytra rather longer and more striate.

Length (rostrum inclusive), $6 \frac{1}{3} \mathrm{~mm}$; breadth, $1 \frac{3}{4} \mathrm{~mm}$.

Mount Dick. One captured by Mr. T'. Hall on a flowering shrub, at an altitude of $2.500 \mathrm{ft}$., on the 10th Narch, 1914.

\section{Group Cryptorhynchidae.}

3934. Tychanus lunalis sp. nov. Tychams Pascoe, Man. N.Z. Coleopt, p. 498.

Convex, uneven, opaque; piceous, antennae and tarsi dark rufous; thickly corered with depressed. orerlapping, tawny and infuseate squamae, those of the latter colour predominate on the after part of the elytra, there are also some erect ones on the elevated parts.

Rostrum stout, subparallel, as long as the thorax, covered with overlapping infuscate scales, apparently coarsely punctate except at the apex, which bears only a few short brassy setae. Thorax a third broader than long, somewhat abruptly contracted in front; with a distinet longitudinal carina behind, a median pair of distinct erests, one at each side in line with these, and a smaller pair at the apex, its punctation invisible. Scutellum small. Elytra quite double the length of thorax, of the same width as it is at the base, broader behind the posterior femora, narrowed and declivous behind; along the middle rather finely and distantly substriate-punctate; 3rd interstices with concentrated squamae near the base; on the 5th a curved ridge extends inwardly, between this and the suture there are 3 small crests, these, conjointly, form an interrupted sublinate ridge extending from near the shoulder to the middle of the dise; on the summit of the hind slope there is a small dark crest on each of the 3rd, 4 th, and 5 th interstices, and, lower down, a pair of small, pale ones; a few fine, erect, black scales can be seen near the base and sides.

Legs stout and elongate, squamose, femora dentate underneath. Scape implanted just before the middle and attaining the front of the eye. Second joint of funiculus nearly double the length of the short 1st, joints 4-6 rather larger than the short 3rd, the terminal rather broader than the penultimate; club ovate, rather small.

With the exception of $T$. quadratus (1515), this is the smallest species of the genus. It is distinguishable by the antemnal structure, the thoracie carina, and sublumate elytral ridge.

Length (rostrum exclusive), 3! $\mathrm{mm}$. ; breadth, $2 \mathrm{~mm}$.

Ilount Nlgidus, Canterbury. Unique. Found on the 3rel December, 1913, by Mr. T'. Hall, amongst leaf-monld.

3935. Ectopsis foveigerus sp. nov. Ectopsis Broun, Man. N.Z. Coleopt., p. 719

Convex, subeylindric, opaque; piceous, antemnae and tarsi piceorufous; densely covered with depressed, principally fusco-ferruginous 
squamae, but becoming a little paler, and mingled with a few greyish ones, just in front of the posterior declivity, which is not at all pallid.

Rostrum stout, quite parallel, slightly arehed, squamose almost to the closely punctured apex. Thorax of nearly equal length and breadth, abruptly contracted in front, remaining portion subquadrate, very slightly narrowed towards the base; with an obsolete longitudinal elevation between the middle and each side, its punctation invisible. Scutellum small, transrerse, greyish. Elytra oblong, nearly twice the length of thorax, but little broader than it is at the base, the shomlders only slightly porrect. posterion declivity broad and sloping downwards; each clytron witl a pair of obtuse basal elevations which become indefinite towards the middle; their punctation not deep, very irregular, coarse and foveiform, with a transverse series of about 10 behind the posterior femora; the declivity somewhat uneven but without distinct sculpture, on the summit there is a pair of widely distant small black spots, about half of the scales are nearly as dark.

Scape implanted near the apex, hardly reaching the eye, with slender greyish setae; 2nd joint of funiculus not longer than 1st, twice as long as broad, joints 3-7 transverse; club short, ovate. Legs stout, rather short; the tibiae with a short fringe of fulvous setae near the extremity.

The rostrum shorter, thicker, and more parallel than that of $E$. simplex (2969), the thorax evidently longer, elytral sculpture different, the chub remarkably short.

3. Length (rostrum exclusive), $6 \frac{1}{2} \mathrm{~mm}$. ; breadth, $2 \frac{2}{3} \mathrm{~mm}$.

Wangaroa. I am indebted to Mr. L. T. Griffin, F.Z.S., for the specimen he found, along with other species. amongst dead regetable matter, on the 3rd April, 1914.

3936. Getacalles baccatellus sp. nor. Getaculles Broun, Man. X.Z. ('oleopt., p. 1380 .

Oblong, moderately convex, asperate, opaque; piceous, antennae and tarsi fusco-rufous; covered with depressed, small, more or less brownish squamae, and with short outstanding ones varying from greyish to b]ack on the sides and elevated parts; on the thorax, near the sides, there are a few scales of almost pearl-like lustre.

Rostrum stout, subparallel, about a third shorter than thorax, dark rufous, closely and coarsely punctured and squamose, more finely and with fine setae near the extremity. Thorax a third broader than long, its frontal half abruptly contracted to about half the width of the basal; with a median pair of short, rather indistinct crests, its punctation hidden Scutellum almost white. Elytra oblong, just double the length of thorax, the shoulders slightly prominent and rather wider than it is at the base, a little broader behind the posterior femora, eonsiderably narower and subvertical behind; they are coarsely seriate-punctate; 2nd interstices slightly elevated at the base, $3 \mathrm{rd}$ and 5th with about 3 small erests on each, the others also somewhat asperate so that the punctures near the sides become disorganized; just before the top of the declivity there is a nigrescent transterse spot, and another just below it extends almost right across it.

Legs stout, femora more or less dentate underneath, the anterior most distinctly. Soape gradually incrassate, with a few fine erey setate; 2nd joint of funiculus as long as the 1st, 7 th rather broader than its predecessors; club finely pubeseent, wate, rathere short and broad, its basal joint largest. 
Underside thickly eovered with tawny scales, but with dark ones at the sides uf the intermediate segments. Metastermum short, broally depressed in the middle. Second segment rather shorter than the basal, its frontal suture obtusely angulate in the middle.

The cortrsely seriate-punetate elytra, white seutellum, rather short and broal antennal club, and the almost pearl-like seales on the thorax, taken together, render it distinet.

Length (rostrum exclusive), $3_{2}^{1} \mathrm{~mm}$.; breadth, $2 \mathrm{~mm}$.

Scarclift, near Mount Algidus. Found by Mr. T. Ha 1 amongst decaying leaves; 20th September, 1913. Apparently rare. The lustrous scales are more easily seen when brushed with benzine.

\section{Getacalles foveiceps sp. nov.}

Oblong, asperate, opaque; piceous, antennae, tibiae, and tarsi more or less fusco-rufous; covered with overlapping, depressed, slightly variegated light-brown scales, the erect ones tawny and dark fuscous, the dark ones most conspicuous on the thorax and across the elytral declivity.

Rostrum slightly shorter than thorax, thickly squamose nearly to the apex. Head apparently depressed, owing to the minute pair of interocular crests. Thorax a third broader than long, its frontal half abruptly contracted, with an indistinct longitudinal carina near its base; the hinder portion twice as broad, indistinctly bicristate on the middle in front. Soutellum greyish. Elytra oblong, twice the length of thorax, their thick porrect shoulders rather wider than it is at the base, considerably narrowed and vertical behind; the sutural punctation seriate, that near the sides coarser and very irregular; 3rd interstices tricristate, their posterior crests most prominent, 5th somewhat similarly crested, the terminal one placed lowe down and usually larger than that of the 3rd, 2nd interstices slightly elevated at the base.

Differentiated by the rather longer and narrower club than that of $G$. baccatellus, the absence of lustrous scales, the more vertical declivity, finer sutural punctation, more prominent erests, and interocular fovea.

Length (rostrum exclusive), $3 \frac{1}{2} \mathrm{~mm}$.; breadth, $2 \mathrm{~mm}$.

Clipping's Bush, Kingston. 'Two, found on the 29th January, 1914, by Mr. 'T. Hali.

3938. Crisius posticalis sp. nov. Crisizs Paseoe, Man. N.Z. Coleopt., p. 500 .

Piceous, rostrum and antennae rufescent, tarsi more infuscate ; covered with depressed, small, rotundate, principally ferruginous scales on the elytra, but with coarser suberect ones on the shoulders and uneven parts; those on the thoracic dise elongate and depressed, but forming a pale streak near each side, the others form a pair of median and apical crests.

Rostrum as long as thorax, a little dilated and ridged near the base, the apical half in the male very finely longitudinally rugose and with an interantennal groove, in the female bare near the apex only, which part is quite minutely and distantly punetate. Thorax rather broader than long, its frontal portion moderately contracted, sometimes, owing to the presence of coarse lateral squamae behind, appearing abruptly narrowed;

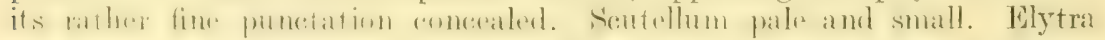
rather more than twice the length of thorax, widest just behind the oblique shoulders, at that point a third broader than the thoracic base, gradually 
narrowed posteriorly; there are about 10 rather slight, unequal, squamose elevations before the middle, the largest yet not very prominent pair are about equidistant from the suture and base, a smaller pair are close to the scutellum, there are also a few small crests near the top of the hind slope; near the shoulders the punctures are moderately conse, irregular, and mingled with blackish granules, along the suture and the hind slope the punctation is serial and quite regular.

Antennae short; seape subclavate, just reaching the front of the eye; funiculus finely pubescent, 2nd joint not longer than the basal, 5th small, 7 th broader than the transverse 6 th; club rather short.

Underside piceous, irregularly elothed with yellowish scales. T'he perpendicular borders of the pectoral canal extend as far as the back part of the middle coxae. Metasternum about the length of the basal segment, which is truncate in front, nearly bare and broadly depressed in the middle; the next is not much longer than the 3rd or 4 th, and bears a conspicuous tuft of squamae on the middle.

According to Sharp's description of C. obesulus (2184) there are, on the basal and external portions of the elytra, rows of punctures interrupted by the inequalities of the surface. In C. posticalis; in addition thereto, there are regular series of punctures along the suture and the hind slope, so I think this species is distinet. Iy opinion is eonfimed by an examina tion of the figure which acconpanied the original description in the Trans. Roy. Dub. Soc., 1886.

Length (rostrum exclusive), 5-5 $\frac{1}{2} \mathrm{~mm}$. ; breadth, $3-3 \frac{1}{2} \mathrm{~mm}$.

Hollyford. Three sperimens found amonget deraying leares a the 19th February, 1914, by Mr. T. Hall.

3939. Xenacalles nigricans sp. nov. Xemaculles Brom, Trans. N.Z. Inst.. vol. 45, p. 146.

Opaque, black, rostrum piceo-rufous, antennae and tarsi rufescent; covered chiefly with nigrescent squamae, but depressed tawny ones form a streak near each side of the thorax and on the shoulders, sometimes a few are scattered over its dise ; coarse, elongate, tawny ones form a conspicuous, horizontal, sutural crest on the summit of the posterior declivity and a pair of smaller ones a little in advance; there are also some erect blackish setiform ones near the sides, and 2 or 3 very small, intensely black crests appear on the intermediate interstices of the elytra, between the middle and the base.

This resembles $X$. simplex (3455), but the rostrum is rather shorter and more closely punctate throughout, and the scape is medially inserted. Thorax of equal length and breadth, widest at the base, gradually narowed towards the front, closely and moderately coarsely punctured. Elytra almost double the length of thorax, of the same width as it is at the base, slightly broader behind the shoulders, gradually vet comsiderably narmed. but not quite vertical behind; with moderate, indistinctly punctured striae. Legs slightly variegate. with numerous dark squaniform setac. Eyes subrotundate, nearly flat.

Prostemum entirely dull-black. The scales on the abdomen are almost wholly nigrescent, except the greyish ones near the sides of the basal 2 segments, and they are less coarse and rather more elongate than in 3455 .

The common triangular, sometimes diamond-shaped, mark seen in varieties of 1427 is, owing to the coloration, rather indefinite, in 3455 it is 
quite obsolete. $X$. nodifer (3456) has considerably longer legs, and a pair of distant, conspicuous nodosities on the hind part of the elytra.

Length (rostrum exclusive), $4 \mathrm{~mm}$.; breadth, $1 \frac{2}{3} \mathrm{~mm}$.

Clipping's Bush, near Kingston. 'Two were found by Mrr. 'I'. Hall, amongst leaf-mould, on the 29th January, 1914.

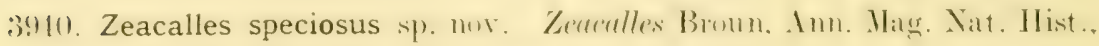
ser. 6, vol. 12, p. 379 .

Ovate, opaque, elytra very convex and ureven, variegate; rostrum piceo-rufous, thorax and elytra piceous, legs fusco-rufous, antennae and tarsi fulvescent; thorax covered with depressed nigrescent squamae, but with some elongate fused-fulvous ones along the sides and with short ereet. valiegate setiform ones: elytrat almost wholly covered with depressed fulvescent squamae and erect, variegate ones on the elevated parts, sides, and posterior declivity; there are also a pair of oblique, intensely black crests at the base, and a few small dark spots behind.

Rostrum nearly as long as thorax, with sublinear, rather fine seulpture, squamose at the base. Thorax without inequalities, apparently punctate, of the same length and breadth, gradually narrowed from its base to the rounded apex. Scutellar region slightly depressed and blackish. Filytra on an abrupty higher level than the thorax. hardly any broader than it is at the base, not twice its length, gently narrowed behind the middle, posterior declivity rather narow, almost vertical, its height equalling the length of the dorsum; they are seemingly striate-punctate; 2nd interstices slightly elevated, with conspicuous erests on top of the declivity, 3rd more elevated at the base but not erested behind, sometimes with a small dark spot on the middle, the other interstices also uneven.

Legs normal, fusco-rufous, with elongate, flavescent, setiform squamae.

Seape stout, a good deal thickened near the extremity, implanted just behind the middle: 2nd joint of tunieulus as long as the hasal. Brd and th slightly longer than broad, the others moniliform, 7th quite transverse.

Underside piceous, with flavescent setiform squamae. Pectoral canal profound, its vertical borders extending as far as the hind part of the interniediate coxae. Second ventral segment on nearly the same plane as the basal, only a third of its length, its frontal suture nearly straight, 3rd and 4th together only half the length of the transversely quadrate 5th.

The contrast in coloration, the abruptly elevated elytra, the prominent posterior crest on the 2nd interstices, and the uneven but not distinctly raised outer ones make it easily recognizable.

Length (rostrum exclusive), $2 \frac{1}{2} \mathrm{~mm}$. ; breadth, $1 \frac{1}{2} \mathrm{~mm}$.

Ina Basin. (anterbury: 20th Octoher. 1913. (If this remarkable little werevil two examples were taken hy Mr. Hall from amongat decaring leaves on the eround: one of them- mutilated, unfortunately- is mounted on its back.

3911. Acalles sternalis sp. nov. Acalles Schoenherr, Man. X.Z. Coleopt., p. 488.

Convex, suboblong, the derm nitid, piceous; covered to a large extent with depressed, small, eoppery or rufesent squamae; but short, erect, blackish ones oceupy most of the anterior portion of thorax and the base of the elytra near the seutellum, they also form an interrupted band across 
the top of the lind declivity, a pair of spots lower down, 4 shost tufts along each side. and a few less distinet spots on the dorsum; antennae and tarsi fusco-testaceous.

Rostrum dark rufous, subparallel, slightly arreded, stout, of about the: same length as thorax; with an indistinct median rarina. it is longitudinally rugose-punctate, more finely punctate near the apex. Thorax more or less abruptly contracted in front. with a pair of small appical crests. it is

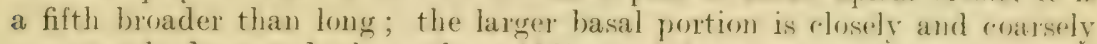
punctured, depressed along the middle, and has a pair of short median rrests in front. Sorutellum invisible, its region depressed. Elytra suboblong, on a higher plane than the thorax, more than twice its length, hardly any broader than it is at the base, with somewhat oblique shoulders, modriatrly narrowed but only subvertical behind; they are moderately roarsely substriate-punctate with slightly uneven interstices.

Leas stout yet elongate. squamose. tibiae nearly straight. tarsi rather narrow. Scape inserted at or just before the niddle. flexuous, gradually incrassate, attaining the front of the ere ; 2 nd joint of funirulus as long as the 1st. 3rd slightly longer than 4 th or 5 th, the terminal hroder than the transverse 6th: (-lub ovate apparently triarticulate. hasal joint larogest

Underside piceous, with short tawny scales, elosely punctured. The alevated borders of the rostral canal extend to the niddle of internediate coxae. Second ventral segment quite half the Jength of the flat hasal. smmetimes without any definite suture, 5th as lomg as 3rd and 4 th rombined, truncate at apex. Metasternum deeply concave in the middle.

Of about the same size as $A$. australis (2180), but differing greatly in coloration. sculpture, and restiture, and more esperially in strinal strurture.

Length (rostrum exclusive), $3 \frac{1}{2} \cdot 4 \mathrm{~mm}$.; breadth, $2-2 \frac{1}{3} \mathrm{~mm}$.

IIount Alfred, Ben Lomond. and Mount Eamslaw. during February and March, 1914, at elevations varying from $2.000 \mathrm{ft}$. to $4.000 \mathrm{ft}$. Found by Mr. T. Hall amongst dead leaves on the ground. The description has been derived from a clean, perfectly fresh example; most of the others are smeared with sappy matter, and therefore appear much less brightly rolonced and indistinctly marked. lut the sternal structure is comstant

\section{Acalles nodigerus sp. nov.}

Convex, rufo-piceous, antennae and tarsi fusco-rufous; covered with small, fulvescent, depressed. and suberect but not elomgate squamae on the elevated parts.

Rostrum about as longr as thorax. stout. somewhat medially narowerl, rufescent, hare and finely punctate near the extremity. Head impresed between the eren. Thorax a third broader than long, somewhat abmutly contracted in front. bieristate there; the larges hasal poution elosely hut not conasely punctured. depressed and with an indistinct carina alomig the middle, there is a urodosity at each side and on the front a median pair of squamose ones. Filytra suberdate. ronvex. with sububligue squanume shoulders. sightly broaler at the hase than the thoma. more than fwee its length. rather gradually narrowed and subrertiral behind. their sides uneven; the dorsum with series of conare. rathere elose. subquadrate puncetures, these become finer hehind; 3rd interstices with 4 unergual. squanose nodosities. the oth lese distinntly trinodose. Fenora gronved. the anterior angulate below. 
Scape similar to that of $A$. stematis, 2 nd joint of funiculus more elongate, slightly longer than the 1 st, 3 rd and ith subquadrate, 7 th broader than 5 th or 6 th ; club ovate, triarticulate.

Underside piceous, finely squamose. Basal 2 ventral segments flat, closely punctured, the 2nd evidently shorter, its frontal suture sinuate; 5th longer than 3rd and th together, its punctation shallow, covered with fulvous scales, its apex truncate, 6th short but distinct.

In form this more nearly resembles the smaller A. bicristatus (3636) than A. sternalis, but it has a broader rostrum and different sculpture, \&c. A specimen was carefully scraped with the point of a needle so that the true sculpture could be ascertained and described.

Length (rostrum exclusive), $4 \mathrm{~mm}$. ; breadth, $2 \frac{1}{2} \mathrm{~mm}$.

Ronteburn, 13th February, 1914, one; Hollyford, 19th February, 1914, three. Found by Mr. T'. Hall amongst leaf-mould.

\section{Acalles zenomorphus sp. nov.}

Elongate-oval, convex, dull piceous, antennae and tarsi fusco-rufous; elytria rather thinly elothed with depressed, small, obscure greyish seales, but with some more conspicuous but not coarse ones near the base; the sides of the thorax covered with more elongate, slender, brassy scales, the dise with a few depressed ashy setae.

Rostrum arched, stout, slightly expanded towards the base and apex, as long as the thorax; indistinctly earinate along the middle, longitudinally rugose, more finely punctate and rufescent in front. Thorax slightly bisinuate at the base, a fifth broader than long, somewhat gradually contracted in front: distinetly and irregularly punetured behind, quite distantly, and a little nitid and reddish in front; its broad median impression is deeper at the base, and divided along the middle by a rather broad smowth space, the apical and median pairs of nodosities are very obtuse and indistinctly crested. Elytra obovate, more than double the length of the thorax, of the same width as it is at the base, rather wider before the middle, gradually narrowed towards the subvertical declivity; they are only moderately substriate-punctate, the suture is somewhat elevated below the summit of the hind declivity, 3rd interstices finely crested at the base but without distinct nodosities, the 5th obtusely nodiform at or just below the top of the declivity; near the sides, before the middle, they are indistinctly trinodose or crested.

Antennae and legs similar to those of $A$. nodigerus, but with simple instead of angulate anterior femora.

Underside piceous, the last 3 segments reddish, thinly clothed with distinct yellow setae; very irregularly punctate, 2nd segment with a transverse series of rather coarse punctures behind, 5th closely punctate; basal segment large, subtruncate and broadly impressed in front, rather distantly punctured there, its apical suture apparently sinuate but very indefinite. Rostral cana! and metasternal cavity like those of $A$. stemalis.

The peculiar form and scanty vestiture are unmistakably different from our allied species.

Length (rostrum exclusive), $3 \frac{2}{3} \mathrm{~mm}$. ; breadth, $2 \mathrm{~mm}$.

Ben Lomond. Found amongst decaying leaves on the ground, between 2,000 $\mathrm{ft}$. and 4,000 ft. in height, by Mr. 'I'. Hall on the 7th March, 1914. Evidently rare, and probably representing a distinct genus. 
3944. Acalles dentigerus sp. nov.

Oval, compact, convex, opaque; piceous, antennae and tarsi piceorufous; covered with depressed yellowish-brown and palo testaceous squamae; the pale ones cover the head, the basal half of rostrum, form an indefinite streak near each side of the thorax and a longitudinal yet short line at the middle of its base; there are many erect, but not elongate, infuscate setae on the thorax and near the sides of the elytra; each elytron behind the middle, midway between the suture and side, has a pair of erest. formed of coarser, erect, pale setae, the larger is placed on the commencement of the hind slope.

Rostrum nearly as long as thorax, a little expanded in front, obtusely ridged along the middle. Head flat between the eyes. Thorax a fourth broader than long, moderately but not abruptly narrowed in front, indistinctly bisinuate at the base, neither closely nor coarsely punctured. Elytra of the same wilth as thorax at the base, quite twice its length, the posterior slope nearly half of the whole length; they are seemingly moderately seriate-punctate; on their basal portion, alongside the suture, there are nearly a dozen small granules, and a slight ridge just outside of the more central crests, on each.

Scape medially inserted, attaining the centre of the eye, rather stout, gradually incrassate, bearing erect setae; 2nd joint of funiculus as long as the 1st, both evidently elongate, 4th slightly longer than 3rd, joints 5-7 as long as broad; club elongate-oval.

Legs with erect squamiform setae, posterior femora with a denticle underneath.

Underside with pale depressed scales. Pectoral canal deep, extending to front of intermediate coxae, with perpendicular, strongly curved borders between these. Basal segment longer than the next, broadly depressed along the middle, the interrening suture slightly sinuate, 5th with fin. setae near the extremity.

Smaller than A. veratrus (2173), with different clothing, narrower tarsi, ridged rostrum, and finely dentate hind thighs. In A. maritimus (2174) the scape is much shorter, implanted behind the middle of the rostrum, which at that point is quite perceptibly dilated, its head is unimpressed, the thorax is shorter, and, albeit gradually, is much more narrowed anteriorly. All three are placed in section $\mathrm{i}$ in my cabinet.

Length (rostrum exclusive), $5 \mathrm{~mm}$; ; breadth, $3 \mathrm{~mm}$.

Muriwai, west coast of Auckland. A single example found by Mr. A. E. Brookes, of Mount Albert, on the 13th April, 1914.

\section{Group Cossonidae.}

3945. Allaorus impressus sp. nov. Allaoms Broun, Man. N.Z. Coleopt., p. 1494 .

Subovate, rather elongate, moderately convex, ritid; with a few pale, very slender, inconspicuous hairs; the individuals vary from chestnut-red to piceo-rufous, those of the latter hue have the middle of the elytra piceous; antennae and tarsi usually of a paler red than the legs, the club piecous.

Rostrum stout, a little arched, a third shorter than thorax, slightly expanded anteriorly in the male, parallel in the female, rather fincly punc:tate, almost smooth in front, without any transverse basal impression. Thorax nearly a third longer than broad, moderately and gradually nar- 
rowed before the middle, base and apex truncate, without ocular lobes; the dise moderately rlosely and coarsely punctured, more finely in front. Scutellum minute or absent. Elytra slightly wider than thorax at the base, nearly twice its length, posterior declivity much narrowed and sub-

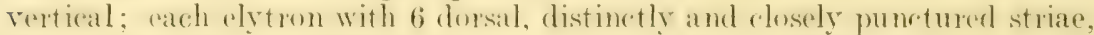
sometimes almost crenate-punctate; interstices narrow, minutely and distantly punetured, 3ril, 5th, and 7 the slightly elevated near the base ; on each elytron, before the middle, there is almost always a broad oblique impression.

Underside usually piceous, rather closely and coarsely punctate, 2nd abdominal segment. less closely, 3-5 more finely, nearly smooth; 2nd large yet shorter than the basal.

Eyes free from thorax, lateral, slightly prominent, obliquely oval and quite distinct. Scape implanted before the middle, barely attaining the eye. Basal joint of funiculus stout, the next rather longer than broad, slender at the base, joints 3-6 short, 7th evidently larger; club ovate. Penultimate tarsal joint expanded and sublobate. In the type of the cenus the penultimate tarsal joint is scarcely at all broader than the 2 nd, the claws are very minute, and the eyes are flat and indistinct.

Length (rostrum inclusive), $2 \frac{1}{2} \mathrm{~mm}$.; breadth, $1 \mathrm{~mm}$.

Gordon's Knob, near Nelson. Mr. Hall obtained several specimens from leaf-mould in November, 1914.

\section{Group Lamimidae.}

3946. Somatidia spectabilis sp. nov. Somalidia Thomson, Man. N.Z. Coleoptera, p. 600.

Elongate, narrow, moderately convex, subopaque, variegate; dark fuscous, the knees and basal 3 joints of antennae rufo-castaneous, remaining joints of the latter fuscous, but testaceous at the base; tibiae and tarsi testaceous, the former with a dark apical and larger basal spot; femora somewhat variegate, chiefly castaneous; the body is covered with inconspicuous, depressed, slender, ashy pubescence mingled with grey, which last forms some spots on the hinder-part of the elytra, the sides near the extremity, however, are pale testaceous; on each side of the thorax, behind the middle, there is a pale round spot, there is a cordiform one on the middle of the apex, and at the middle of the base another of the same chocolate hue as the scutellum.

Head unimpressed and coarsely punctate above, vertical in front. Thorax of equal length and breadth, moderately rounded and widest at the middle, without inequalities, coarsely punctured. Elytra elongateoval, sradually sloping and attenuate from the hind thighs hackwards, of the same width as the thorax at the base. fully twiee its length, but hardly at all broader than it is in the middle; their basal half is coarsely and irregularly punctate, the hinder portion, of each, has a duplicate series of equally coarse, distant punctures extending almost to the apex; on each clyton a distinct costa extends nearly half-way along the middle of the basal half; in addition to the ordinary pubescence they bear numerous dark, erect, rather short and slender setae.

Antennae with fine pubescence and pale setae; they attain the top of the hind declivity, their elongate 3 rd joint almost reaches the base of the thorax, the the is slightly longer than the next. Legs rather elongate. 
This remarkable species stands alone. The elongate contour, superficial variegation, and distinet sculpture are unmistakably different from any of our described species.

o. Length, $5 \frac{1}{2} \mathrm{~mm}$. ; breadth, $1 \frac{1}{2} \mathrm{~mm}$.

Mount Dick. A solitary male found amongst decaying leaves by Mr. T. Hall on the 10th March, 1914.

\section{Somatidia flavidorsis sp. nov.}

Elongate, medially narrowed, moderately convex, slightly nitid, variegate; the legs and greater portion of elytra flavescent, but with the humeral region and sides as far as the middle, the sides behind the posterior femora, and an irregular space on top of the hind slope but not extending to the sides, of nearly the same silky fuscous hue as the thorax, the tibiae with similar spots near the base and apex; the depressed elytral pubescence is hardly noticeable and corresponds with the derm in colour, that of the head and thorax is greyish; there are no erect setae.

Head distantly punctate, plane above, with a distinct central stria. Thorax very little broader than long, widest and moderately rounded before the middle, a little narrowed behind; dise only slightly convex, not at all tuberculate, with 4 shallow indistinct impressions near the middle, its punctation distinct, distant, and irregular. Elytra elongate-(,val, of the same width as thorax at the base, more than twice its length, only slightly wider than it is before the middle; they are without crests, their punctures though not coarse are sharply marked, distant from each other, almost regularly seriate, but become confluent towards the extremity.

Antennae stout, reaching to just beyond the hind thighs, bearing short greyish setae and pubescence, and, except the almost wholly blackish 3rd and th joints, quite unspotted chestnut-red ; their 3rd joint is scarcely double the length of the 4th, which latter attains the base of the thorax. Legs rather elongate.

This is another peculiar species without any near ally, and can be separated from the others by the sharply impressed serial punctation of the elytra and nigrescent 3rd and 4th antennal joints.

ô. Length, $4 \frac{3}{4} \mathrm{~mm}$. ; breadth, $1 \frac{2}{3} \mathrm{~mm}$.

Ben Lomond. Unique. Found by Mr. T. Hall, on the 3rd March, 1914, amongst leaf-mould.

\section{Somatidia suffusa sp. nov.}

Elongate, moderately eonvex, slightly nitid, without inequalities of surface; the head, sides of thorax, and about half of the elytra fuscous, the dorsal area of these last between the middle and hind thighs, and the hind slope rufo-castaneous, the marks not well defined; these light parts bear conspicuous, depressed, tawny pubescence so disposed as to cause a distinctly spotted appearance, there are also a few ereet greyish setae behind; legs and antennae fusco-testaceous, tibiae slightly bimaculate.

Head with a few fine punctures in front, and a median stria above. Thorax of about equal length and breadth, widest and rounded before the middle, gradually narrowed towards the base; with very few fine scattered punctures and a central forea in front of the base. Scutellum quite triangular, rather large. Elytra elongate-oval, more than double the length of thorax, of the same width as it is at the base, but broader than 
it before the middle, gradually depressed and attenuate posteriorly; they are rathere finely subseriate-punctate behind the middle, indistinetly so near the base.

Antennae stout, quite immaculate, extending to beyond the posterior femora; their $3 r$ joint reaches the base of the thorax and is nearly twice the length of the 4th, which is slightly longer than the 5th. Legs stout, tibiae finely setose below the middle.

In general outline this approaches $S$. flavidorsis, but the elytra before the middle are rather broader than the smaller thorax, the scutellum is larger, and the sculpture and coloration, as well as the antennal structure, are essentially different.

$\hat{o}$. Length, $4 \mathrm{~mm}$. ; breadth, $1 \frac{1}{2} \mathrm{~mm}$.

Heaven's Gate, near Mount Earnslaw. Another of Mr. T. Hall's uniques, obtained from decayed leaves at an elevation of $1,200 \mathrm{ft}$. on the 6th February, 1914.

\section{Somatidia femoralis sp. nov.}

Body moderately elongate and convex, a little shining and uneven; castaneous, dark fuscous along the sides and on the posterior slope, but with the sides of the latter light chestnut; the middle and hind thighs testaceous, the former with an infuscate median mark, the front pair castaneous and stouter than the others; the tarsi and lower part of the tibiae testaceous, the latter with the usual dark marks; pubescence distinct, depressed, tawny grey, not forming definite spots; there are no erect setae.

Hearl broadly depressed between the antennae, dark fuseous, distantly punctate in front. Thorax as long as broad, its sides gently rounded; distinctly but not clessely and irregularly punctured, slightly uneren, with a small, very obtuse, sometimes greyish tubercle near each side behind the middle. Elytra moderately elongate-oval, double the length of thorax, a third broader than it is in the middle; moderately coarsely subseriatepunctate nearly to the extremity; each elytron with a small crest nearly in line with both the middle and hind thighs, and just outside and below the posterior one a slight obtuse plica extends nearly to the apex.

Intennae only slightly longer than the body, with slender greyish setae and pubescence, they are chestnut-red, with fuscous apices from the 4th joint onwards, the 3rd is more spotted and extends beyond the base of the thorax, 4th rather shorter than the preceding but longer than the following one.

No other recorded species is exactly like this. It may be distinguished from others of equal size by the quadricristate hind-body and obtuse subapical costae.

Length, $4 \frac{1}{2} \mathrm{~mm}$; breadth, $1 \frac{2}{3} \mathrm{~mm}$.

Moa Basin, Canterbury. The specimen was found on the 3rd December, 1913, by Mr. T. Hall, amongst dead leaves.

Obs.-In a second example from Unknown Land, beyond Moa Basin, the hind part and sides of the elytra right to the base form a continuous blackish mark, but the subapical costae are obsolete. 'This, I think, is merely a varietal form of the type.

\section{Somatidia oscillans sp. nov.}

Subnitid, rather stout, slightly convex, a little uneven; light castaneous, with a fuscous mark on each elytron just behind the posterior femur, this 
is largest at the side and nearly reaches the suture; the lower part of the shoulders and basal half of the sides of thorax are also fuscous; antennae and legs fusco-testaceous, the former with the tips of joints 4-11 infuscate, tibiae with rather small spots; pubescence depressed, distinct, of a tawny grey on the lighter parts and forming spots on the posterior declivity.

Head distinctly and broadly concave between the antennae, without perceptible punctation. Thorax of equal length and breadth, its sides gently rounded; dise moderately finely, distantly, and irregularly punetate, with a pair of small median nodosities, and a broad but not conspicusous swelling at each side behind the middle. Scutellum broadly triangular. Elytra widest at the middle, where they are a fourth broader than the thorax, but only very slightly wider than it is at the base, twice its length, gradually declivous behind; the suture along the basal half is obtusely elevated, near the middle of this part, on each, there is a slight elongate elevation which is fuscous in the centre, in line with this, on the top of the declivity, there is another; their punctation is moderately coarse and irregular.

Antennae as long as the body, the infuscate $3 \mathrm{rd}$ joint just reaches the shoulder, the 4th is shorter than 3rd but evidently longer than 5th.

This somewhat resembles $S$. picticomis (2994), from Invercargill, which measures $4 \frac{1}{2} \mathrm{~mm}$. by $2 \mathrm{~mm}$, and has a narrower head; its thorax is coarsely and closely punctured in front and has neither discal not lateral norlosities, its scutellum is more elongate, the elytral suture is perfectly flat, and the vestiture is rather finer.

Length, $5 \frac{1}{2} \mathrm{~mm}$. ; breadth, $2 \mathrm{~mm}$.

Eveline Glacier, beyond Routeburn. Mr. T. Hall scraped a specimen off a tree covered with moss and lichen, at a height of $3,000 \mathrm{ft}$., on the 14th February, 1914.

Obs.-The following varieties of 2994 occur in adjacent localities, all but one represented by single individuals in Mr. Hall's collections.

Var. A.-Mount Alfred. $4 \mathrm{~mm}$. by $1 \frac{2}{3} \mathrm{~mm}$. Thorax widest and broadly rounded before the middle, coarsely and closely punctured in front. Elytra without median erests or spots, but with a slight elevation along the middle of the basal half of each. Male.

Var. B.-Ben Lomond. $4 \frac{1}{2} \mathrm{~mm}$. by $2 \mathrm{~mm}$. Fem. Coloration more dusky throughout. Head broader between the antennae. Thrax with a pair of small median nodosities, frontal punctation very coarse. Elytra almost entirely maculate, without any posterior dark area, but with a pair of minute crests on the summit of hind slope in addition to the median ones.

Var. C.-Routeburn. $4{ }_{2}^{1} \mathrm{~mm}$. by $2 \mathrm{~mm}$. Antennae almost immaculate, their 4th joint a third longer than 5th.

\section{Somatidia obesula sp. nov.}

Broad, moderately convex, thorax and elytra narrowed and of the same width at their junction, without erests or elevations, nitid; dorsum dark fusco-rufous, sides of thorax and elytra dark fuscous, as are also the humeral region, the interrupted fascia arross the top of the posterior declivity, and its middle portion; it is irregularly clothed with depressed fulvesecent hairs, and moderately elongate erect setae.

Head as broad as thoracic apex, distantly punctate. Thorax a third broader than long, rather strongly rounded and widest just before the 
middle. uradually nawrowed behind; moderately elosely and eoarsely punetate. less closely near the base and sides, the intervals minutely soulptured. Elytra twice the length of thorax, about a third broader than it is in the middle. moderately and irregularly punctate, subseriately near the suture.

Antennae almost as long as the body, fusco-rufous, finely pubescent, and setose joints 5 10 with pale pubesenene near the middle; the elongate Brel joint just reaches the thoracie base. Ith and 5 th hardly any longer than following ones.

Femora fusco-rufous, robust, slender near the base; tibiae testaceous, darker at the base and near the extremity.

Distinguishable from s. Intula (2582), an Auckland species, by its shorter, hroader. and differently senlptured thorax, slightly shorter 3rd antemal joint, and more thinly clothed surface.

ㅇ. Length, $3 \frac{2}{3} \mathrm{~mm}$. ; breadth, $2 \frac{1}{2} \mathrm{~mm}$.

Belgrove, near Nelson. One found amongst dead leaves on the 24th October, 1914, by Mr. 'T. Hall.

\section{Somatidia laevinotata sp. nov.}

Elongate, moderately nitid and convex; thinly covered with very fine greyish pubescence, but with a yellow spot on the middle of the thorax and another at its base, without elongate setae.

Head fuscous, distinctly punctured, with a fine stria along the vertex. Thorax as long as broad, widest and slightly rounded at the middle, moderately coarsely and irregularly punctate, with a large, dark. smootli space in the centre, the rest of its surface dark fusco-rufous. Scutellum triangular. Elytra hardly double the length of thorax, slightly wider than it is at the base, oblong-oval, the suture a little elevated at the base; each elytron with about a dozen coarse irregular punctures on the dark fuscous basal half, those behind a little finer but not quite seriate; across the top of the declivity there is a broad dark space, the remainder of the surface is of a pale reddish hue.

Antennae rather shorter than the body, finely pubescent and setigerous, fusco-rufous; their elongate 3rd joint attaining the shoulder, 4th rather longer than 5th, these and the following ones are infuscate at the extremity.

Femora slender at the base, clavate and dark fusco-rufous beyond; tibiae testaceous, the base and a subapical spot on each rufo-fuscous, they bear some slender yellowish setae.

When compared with the male of $S$. halli (3663) the hind-body is seen to be less attenuate posteriorly, it is shorter, but slightly wider than the thorax at the base, without any testaceous marks; the thorax is rather less ennex and only moderately broader at the middle than elsewhere, and is at once separable by its smooth discal area; the antennae are thicker, the basal joint especially; the head is less flattened, but it is narrower between the less widely distant antennal tubercles; generally there is a minute swelling or crest on the middle of each elytron at the summit of the hind face. which is flatter but more declivous.

In the female, which differs even more strongly from the same sex of 366:3. the 3rd joint of the antemnae just reaches the thoracie base, the hindbody is alnost wholly of a light-reddish-chestnut colour, the dark posterior fascia being less definite.

Length, $5 \frac{1}{3} \mathrm{~mm}$. ; breadth, $1 \frac{3}{4} \mathrm{~mm}$.

Glenhope, near Nelson; 23rd November, 1914. Mr. T. Hall amongst vegetable matter on the ground. 
3953. Somatidia parvula sp. nov.

Convex, moderately elongate, thorax and elytra equally narrowed at the base, nitid; sparsely clothed with depressed yellowish-grey pubescenre; almost entirely fusco-rufous, the legs rufo-testaceous.

Head indistinctly punctate. Thorax of equal length and breadth, subrotundate, more narrowed near the base than in front; irregularly, distinetly, but not at all elosely punctate, nearly smooth along the middle. Seutellum small, triangular. Elytra elongate-oval, double the length of thorax, at the middle scarcely any wider than it is, with only a few fine punctures on the basal half, near the suture.

Antennae stout, as long as the body, without maculation, finely pubescent and setose; 3rd joint elongate, reaching the shoulder, the 4 th distinctly longer than 5th. Legs stout, tibiae finely setose and unspotted.

Underside chestnut-red, with fine greyish pubescence, smooth, basal segment largest, the next longer than $3 \mathrm{td}$ or 4 th ; 5th as long as the preceding 2 combined, feebly rounded and finely margined behind; 6 th paler.

Fem.-Thorax oviform, more coarsely punctate; elytra, before the middle, broader than the thorax; antennae not reaching the extremity of the body.

Differs from its nearest ally, S. mbella (3660), in being smaller, its thorax (male) less strongly rounded and with fewer punctures, the elytra shorter, tibiae immaculate, and with the 4 th antennal joint longer than the 5th.

c. Length, $3 \mathrm{~mm}$.; breadth, quite $1 \mathrm{~mm}$.

Glenhope, near Nelson. Six individuals taken from leaf-mould, 23rd November, 1914, by Mr. T. Hall.

\section{Group Cryptocephalidae.}

3954. Bryobates rugidorsis sp. nov. Bryobates Broun, Man. N.Z. Coleopt., p. 873 .

Nitid, glabrous, dark cyaneous; legs and basal joint of antennae fulvous, remaining joints dark fuscous but paler just at the base, tarsi infuscate.

Head irregularly punctate, with a distinct interantennal depression. Eyes transversely oval. Thorax a third broader than long, apex truncate. its angles not at all prominent; base medially truncate but slightly eurved trowards the sides, so that its angles appear obsolete; sides finely marginate, a little curvedly narrowed towards the base; its surface slightly uneven, moderately coarsely and elosely but irregularly punctured. Scutellum partly hidden, smooth. Elytra very slightly broader than thorax at the base, twice as broad behind, with rounded apices, so that an evident sutural gap exists; their punctation rather finer than that of the thorax, and more or less longitudinally rugose throughout. Pygidium obtusely triangular, its punctation rather shallow.

The type of the genus, $B$. coniformis $(1555)$. has fine but quite distinct humeral and hasal margins, these are indefinite in this species, in which. moreover, the elytral seulpture is markedly different, the apices are more strongly rounded; the eyes are rather smaller and more transversal: the legs and antennae are more slender, and these latter less maculate.

Length, $4 \mathrm{~mm}$.; breadth, $2 \frac{1}{2} \mathrm{~mm}$.

Stairease, the southern portion of the Remarkables, near Kingston; 15th March, 1914. Found by Mr. T. Hall. A second example does not agree with the type. 


\section{Group Chrysomelidae.}

39.). Allocharis praestans sp. nuv. Allocheris Nhatrp, Man. N.Z. (oolenpt., p. 1306 .

Convex, oblong-oval, glabrous, shining; aeneo-piceous, sides of elytra rufescent, the base slightly so; antennae and legs castaneo-rufous, femora and base of tibiae more infuseate.

Head immersed up to the transverse, coarsely facetted eyes; it is finely and irregularly punctate, with a eurved longitudinal stria near each antema. 'Thorax not twice as broad as long, its apex widely yet slightly

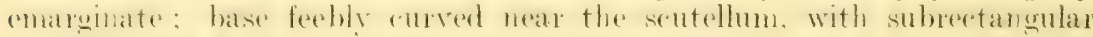
anghes: sides fincly margined. nearly straight. only feobly sinuate near the middle, curvedly narrowed in front; basal and apical margins very fine, the latter obsolete in the middle; its surface irregularly and moderately finely but not elosely punctured. Seutellum smooth, eurvilinearly triangular. Elytra slightly wider than thorax at the base, nearly thrice its length. "urvedly narrowed behind, with somewhat singly rounded apices; eark with a short seuteflar and 9 series of distinet but not roarse punetures, some of these are disorganized, none quite reach the extremity, the 5th is substriate or foveiform at the base; interstices minutely and remotely punetured.

Legs stout, tibiae gradually incrassate towards the extremity. Antennae nearly glabrous as far as the 6 th joint, which is only very slightly smaller than contiguous ones.

Underside castaneous, nitid, with some minute slender setae. Prosternum flat along the middle, finely rugose behind the coxae, medially emarginate at the base. Metasternum strongly rounded between the coxare, medially impresied behind. Abdomen fincly and distantly punctate, terminal segment more closely and pubescent at the extremity.

In A. marginata (2294) the serial punctures apparently are finer, the sides of the thorax are paler than the dise. which is shining brassy. instead of being almost black as in this species. The thorax of $A$. morosa (2295) has distinctly coarser and closer sculpture, some of the punctures are coarser than the elrtral ones. and its apex is more incurved.

Length, 5-5 $\frac{1}{2} \mathrm{~mm}$. ; breadth, $2 \frac{1}{2}-3 \mathrm{~mm}$.

Moa Basin. Three sperinens found by Mr. T'. Hall on the 20th Oetober. 1913. Var., Mistake Basin (one): Sides of elytra fusco-testaceous, as are the tibiae below the middle, the rest of the legs being fuscous.

\section{Allocharis subsulcata sp. nov.}

Oblong-oval, convex, only moderately nitid; nigro-piceous, legs and sides of elytra, the base slightly, castaneo-rufous, antennae rather paler.

Head nearly as wide as the thoracic apex, very finely and irregularly punctate. Thorax at third broader than long. its sides almost quite straight. gradually and slightly narrowed anteriorly, the base a little oblique towards the subrectanenlar angles: it is irregularly and finely punctured. Scutellum smooth. subcordate. Elytra slightly broader than thorax at the base, twiee its length: their serial punctures distinet and forming more or less obvious but not quite regular striate : interstioes more distincetly yet minutely punctured near the extremity than elsewhere.

Antennae stout, 6th joint not perceptibly smaller than 5th.

Cnderside pieeous. sparingly and fuely pubescent and punetate, femora inclusive. Prosternum slightly ronvex along the middle, truncate behind. 
Metasternum obtusely angulate in front between the roxac. Basal segment of abdomen as, long as the following 3 united, 5th longer than 4th, 6 th short, with a well-marked median fovea.

The relatively broad head. gradually anteriorly narrowed and less transverse thorax. suibstriate elytra. and differences of the lower surface render it distinct.

Length, nearly $5 \mathrm{~mm}$; breadth, $2 \frac{1}{2} \mathrm{~mm}$.

Old Man Range, Otago. Two somewhat damaged specimens found by Mr. J. H. Lewis at a height of $4,000 \mathrm{ft}$.

\section{Allocharis nigricollis sp. nov.}

Shining, only moderately convex; head and thorax aeneo-niger, elytra fuscous or piceous, with fusco-testaceous lateral borders, the base less evidently pallid, legs and antennae almost similarly testaceous, the knees somewhat infuscate.

Head and thorax finely and irregularly punctate, the elytra finely and seriately.

Thorax a third broader than long, its sides nearly straight, anterior angles rounded, posterior subrectangular. Elytra slightly broader than thorax at the base, thrice its length, with minute distant interstitial punctures.

Enderside piceous, slightly aeneous, finely and distantly punctate and pubescent. Prosternum flat along the middle, finely biseriate-punctate, a little emarginate at the base. Metasternum strongly rounded in front between the coxae. Sixth abdominal segment short and broad, widely concave.

Of about the same size at $A$. limbata (2296), but easily separable therefrom by the much darker colour and undiluted sides of the thorax, which in 2296 are broadly testaceous or fulvescent. The elytral punctation of this species is a little finer, that of the thorax less distant; the antemnal articulations from 6-10 are less elongate, broader at the extremity, and therefore more obconical.

Length, $4 \frac{1}{2}-5 \mathrm{~mm}$.; breadth, $2 \frac{1}{3} \mathrm{~mm}$.

Ben Lomond (three), Mount Dick (one), taken by Mr. T. Hall from leafmould, at an altitude of about 4,000 ft., during March, 1914.

\section{Allocharis picticornis sp. nov.}

In most details like $A$. nigricollis. Thorax a third broader than long, its apex truncate. without the least projection of its angles, each side with a slight median sinuation. Elytra feebly substriate. The apices of joints 38 of the antennate dark fuscous. the following ones almost wholly but not so darkly infuscate.

Length, $4 \frac{1}{2} \mathrm{~mm}$. ; breadth, $2 \mathrm{~mm}$. 1914 .

Ben Lomond. A single specimen found by Mr. T'. Hall on the 5th Mareh,

\section{Allocharis media sp. nov.}

Oblong-oval, only moderately convex, nitid; head and thorax aeneonigrer, the latter slightly infuscate near the front angles; elytra piceo-fuseous, somewhat bronzed, the base and sides light castaneous; legs and antennae fusco-testaceous, joints $3-8$ of the latter with infuscate tips. 
Like A. picticornis, but with the thorax widely emarginate in front so that its angles seem slightly pominent, the sides without any simusity ; elytra moredefonitely suleate. their apices distinctly rounded separately.

The hind-body of $A$. subsulcata is less narrowed posteriorly so that the general contour is less oval, and the elytral punctation is rather more distinct and regular.

Its proper position is between these species.

Length, $4 \frac{1}{2} \mathrm{~mm}$. ; breadth, $2 \frac{1}{3} \mathrm{~mm}$.

Ben Lomond. Another of Mr. Hall's novelties. Unique.

\section{Allocharis fuscipes sp. nov}

Convex, oval, shining, aeneo-niger; sides of elytra, the legs, and antennae light rufo-fuscous, joints 3-11 of these last, and the palpi, darker at the extremity.

Thorax a third broader than long, subtruncate in front, its sides nearly straight, a little eurvedly narrowed in front; finely yet distinctly and somewhat irregularly punetured, less distinedly near the sides. Sectellum smooth, subcordate. Elytra almost thrice the length of thorax, a little wider at the base. gradually namowed behind the middle, with singly romoled apices; they are dather finely, on some parts inclistinetly, seriate-punctate. obsoletely near the extremity; interstitial punctation indistinct.

Nuch smaller, more oval, and rather more convex than A. maestans, uniformly darker, the legs and antemnate especially, the surfare evidently bronzed, with finer seulpture.

Length, $4 \frac{1}{2} \mathrm{~mm}$. ; breadth, $2 \frac{1}{2} \mathrm{~mm}$.

Moa Basin. Canterbury. Another species represented by a solitary individual, captured by Mr. Hall on the 20th October, 1913.

\section{Allocharis robusta sp. nov.}

Oblong-oval, only moderately convex, nitid; aeneo-fuscous; the front margins of thorax. its sides broadly, the base and sides of elytra, the antemnae palpi. and leass more or less fusco-testaceous; the elytial suture rufescent.

Head almost as broad as thorax, uneven, broadly impressed along the middle, irregularly and finely punctured. Thorax short, nearly twice as broad as long; its sides slightly curvedly narrowed in front, straight behind, posterior angles subrectangular; the apex widely but feebly sinuate towards each of the obtuse angles, the margin fine yet definite in the middle. where there is a slight sinuesity in one examplo. in the ofther feeshy remeded there dise, the sides finely rugose. Seutellum smooth. Elytra nearly thriee the length of thorax, very little broader than it is at the base; they are relatively rather fonely but not quite regularly seriately punctured, interstion minutely and indistinctly punetate; there is a distinet impression inside each shoulder.

Antemae longer than the head and thorax, joints 5-10 elongate and filiform.

Prosternum bisuleate between the coxae, truncate behind. Metasternum finely transversely rugose, grooved along the middle. Fifth segment of abdomen double the length of fourth. distinetly rugose-punctate at the sides, 6th short, densely pubescent. 
This is the largest species as yet made known. The well-marked impressions on the head and near the shoulders, the nearly testareons and peculiarly formed thoracic apex, and reddish elytral suture distinguish it Hom Sharp's A. marginata (2294). A. morosa (2295) ran be at onere separated by the totally different roloration, and the rloser and rather roarser sculpture of the head and thorax.

Length, $6 \mathrm{~mm}$. ; breadth, $3 \frac{1}{2} \mathrm{~mm}$.

Lake Wakatipu; exact locality unknown. The pair of old, dried, slightly damaged specimens were kindly presented to me by Mr. Alexander Purdie, M.A. Not a single specimen of this genus has, as yet, been found in the North Island.

\section{Allocharis tarsalis sp. nov.}

Oblong-oval, moderately convex, glabrous, nitid; aeneo-niger, legs, antennae, and palpi rufo-castaneous.

Head and eyes almost as broad as thoracic apex, irregularly, moderately finely, but not rlosely punctate, broadly yet slightly impressed between the eyes. Thorax a fourth broader than long, its sides slightly rounded. finely but more distinctly margined than the base and apex, the latter subtruncate but with its obtuse angles a little advanced and depressed, the base slightly and widely bisinuate with rectangular angles; disc irregularly, moderately closely and finely punctate. Scutellum rurvilinearly triangular, smonth. Elytra oblong-oval, of the same width or just perceptibly broader than it is at the base, thrice its length; each with a short scutellar and 9 series of moderately fine punctures, these, however, become more irregular and finer behind.

Underside castaneo-fuscous, shining, very sparingly and finely pubescent. Basal segment of abdomen largest, the next 3 nearly equal, ith longer than its predecessor. finely margined and strongly bisinuate behind, 6th short and semicircular. Miesosternum only visible as a rurved transverse ridge between the broad subtruncate prostemal process and the rounded front of the metasternum.

Antennae longer than head and thorax, stout, finely pubescent, basal joint thick and subpyriform. 2nd evidently shorter than the following ones.

Basal joint of anterior and intermediate tarsi cordate, longer than broad, that of the posterior pair less cordiform, 2nd small and triangular, the penultimate excavate above, entire underneath.

Terminal articulation of maxillary palpi subtruncate.

The tarsal structure and subtruncate apex of the last joint of the maxillary palpi should perhaps exclude this species from Allochuris.

Length, $7 \mathrm{~mm}$. ; breadth, $3 \mathrm{~mm}$.

Gordon's Knob, near Belgrove. The specimen described above is no doubt a male. It is one of Mr. T. Hall's captures. on or about the 15 th November, 1914.

3963. Caccomolpus nigristernis sp. nov. Caccomolpus Sharp, Man. N.Z. Coleopt., p. 1308.

Convex, broad, subovate, glabrous, shining; aeneo-niger, legs and antennae rufo-testaceous.

Head and eyes almost as broad as front of thorax, with a few fine punctures, bi-impressed between the eyes. Thorax about thrice as 
broad at longe apex widely emarginate, base feebly sinuate or oblique near each side, with rectangular angles; its sides funely margined, slightly curvedly narrowed towards the obtuse anterior angles; the surface finely, irregularly, and distantly punctate. Scutellum smooth, distinct, triangular. Elvtra of the same width as thorax at the base, more than double its length, distinetly margined and rurvedly narrowed behind: ther are irregularly and moderately coarsely subseriate-punetate nearly to the apices, the base, however, is nearly smooth at the middle, the intervals between the series are more finely, irregularly, and distantly punctured.

Legs stout, tibiae areuate externally and, at the extremity, bearing some rellowioh pubesence. Basal joint of tarsi moderately enlarged, that of the anterior subcordate, the 2nd very small. Underside concolorous.

At first sight I thought this might be Sharp's C. globosus (2297), but the form semingly is less rotundate, whilst the nigrescent stemm and moleride of the head, and irregular sculpture of the elytra, prove it to be distinct.

ô. Length, $3 \mathrm{~mm}$. ; breadth, $2 \frac{1}{3} \mathrm{~mm}$.

Hollyford. A single male found by Mr. T. Hall, on the 19th February, 1914, amongst decaying vegetable matter.

\section{Caccomolpus hallianus sp. nov.}

Convex, broadly oval, nitid; aeneo-niger, antennae and legs rufotestaceous.

Head finely punctate and usually bi-impressed between the eyes, and with a median longitudinal depression behind. Thorax nearly thrice as broad as lons ; dise distinetly and moderately finely punctate, the sides obsoletely. Seutellum smooth. Elytra rather more than thrice the length of thorax, with irregular series of fine punctures, these are not coarser than those on the thorax and are nearly absent from the sides, middle of the base, and apices, the interstices even more finely, distantly, and irregularly punctate; pygidium somewhat exposed.

Theleride nigro-aeneous and somewhat iridesent. more or lese finely punctate and, femora inclusive, with fine depressed setae: prosternum obtusely convex between the coxae.

Considerably larger than $C$. nigriventris, less glossy and aeneous, and with manifestly finer elytral punctation. that of the thorax, howerer. is more distinet.

Tibiae strongly arched externally, but not angulate, the anterior distinctly punctate and pubescent below the middle; basal tarsal joints of the male dilated, that of the anterior rather longer than broad and therefore less broadly cordiform than in $C$. nigriventris.

Length, $5 \mathrm{~mm}$.; breadth, $3 \frac{1}{2} \mathrm{~mm}$.

Iroumt I)ick, Lake Wakatipu. I femate, taken br Mr. 'T. Hall from decaying leaves on the 29th January, 1914, and three others, including the male, during two days collecting on that mountain during March.

\section{Caccomolpus fuscicornis sp. nov.}

Nitid, aeneo-niger; legs and antemnae fuscous, the former more l'ufescent.

This most nearly resembles the same sex of $C$. hallianus, but is differentiated by the namower elytral apices, which cover the prosidium. 
and by the more regular though equally fine serial punctures; these are continued aimost to the extremity of the elytra and are more or less visible even at the base, where, between the suture and 1st series, there is a short row of fine punctures. The dark antemnae and legs are manifestly different.

o. Length, $4 \frac{1}{2} \mathrm{~mm}$; ; breadth, $3 \frac{1}{3} \mathrm{~mm}$.

Mount Dick. A single female from Mr. T. Hall.

\section{Caccomolpus substriatus sp. nov.}

Shining, aeneo-niger; legs, antennae, and palpi fusco-rufous, as is the clypeus usually.

Head without definite impressions, finely and distantly punctate. Eyes transverse, moderately convex, with distinct facets. Thorax quite twice as broad as long; disc finely ret distinctly but irregularly punctate, obsoletely towards the sides. Scutellum smooth. Elytra thrice the length of thorax and concealing the prgidium; at the base the serial punctures are indistinct, ther are somewhat irregular, but behind the middle, in the female particularly, assume the form of broad shallow striae, which are not wholly obliterated even on the posterior declivity : interstitial punctures very irregular.

Tibiae of the male, the intermediate and posterior, strongly arched below the middle; basal joint of anterior tarsi subcordate, longer than broad.

The less transverse thorax, different and coarser elytral sculpture, and unexponsed mrgidium. distinguish this from $C$. halliams. The underside is not at all iridescent, the middle of the prosternum is less convex, and the intermediate abdominal segments are scored with many longitudinal striae.

Length, $4 \frac{1}{2} \mathrm{~mm}$. ; breadth, $3 \frac{1}{3} \mathrm{~mm}$.

Ben Lomond. A single pair. and a mutilated nale now mounted on its back, were detected amongst decaying vegetable rubbish on the 6th March, 1914, by Mr. Hall at a height of about 2,000 ft.

\section{Caccomolpus tibialis sp. nov.}

Convex, subrotundate, nitid, bronzed-black; legs and antennae rufotestaceous, base of tibiae more rufescent.

Head with a few minute punctures only. Thorax nearly thrice as broad as lomg: dise distinctly and irresularly but not eoarsely punctate. nearly smooth at the sides, the apex with a transverse series of about a dozen wellmarker punctures. Scutellum smooth, not elongate. Elytra nearly thrice the length of thorax; distinetly and somewhat irregularly but not coarsely seriate-punctate. the pumctation equally evident but confused at the extremity, less distinct at the base, the interstitial punctures finer and irregular.

Male-- Anterion tibiate evenly arenate the middle and hind pairs slender near the base, obtusely angulate and incrassate, the former especially, below the middle; basal joint of front tarsi elongate-subcordate.

The nearest ally. C. flectipes (3667), taken on Mount Hutt in ('anterbury, is larger, its head is rather closely punctate, the sculpture of the elytra is less definite: the middle and hind pairs of tibiae are not only thicker but are also slightly twisted below the middle. and the front pair. 
instead of being simply curvate, are obtusely angulate externally. The series of coarse punctures across the front of the thorax in C. tibialis is another peculiar feature.

o. Length, $4 \mathrm{~mm}$. ; breadth, $3 \mathrm{~mm}$.

Mount Dick. Unique. Another of Mr. T. Hall's captures on or about the 13th March, 1914.

\section{Caccomolpus viridescens sp. nov.}

Convex, broadly oval, glabrous, nitid; greenish-black, head of a more brassy hue; labrum, palpi, and legs fusco-rufous, antennae fulvescent.

Head smooth near the eyes, finely punctate-rugose elsewhere. Thorax more than twice as broad as long, apex widely incurved and finely margined, the sides gradually natrowed, but not distinctly rounded towards the front. posterior andes rectangular ; dise finely and irregulaty punctured, the sides nearly smooth. Scutellum short. Elytra of the same width as thorax at the base, more than thrice its length, broadly rounded behind, their margins most distinct near the shoulders; each with 3 or 4 inner series of moderately fine punctures which scarcely reach the extremity, the external series less distinct and more irregular, the intervals minutely and rather distantly punctate. Pyoidium slightly exposed, rufescent.

Tibiae with distinct yellowish pubescence below the middle; the anterior straight inwardly, slightly dilated and rurved outwardly, the others slender near the base, dilated and obtusely angulate, the intermediate especially, outside below the middle. Tarsi simple.

Antennae longer than head and thorax, finely pubescent towards the extremity ; basal joint stout. ("nrved on the inside, $2 n d$ nealy thrice as long as broad, joints 3-5 about equally slender and elongate, 6-10 longer than broad, narrowed towards the base, the terminal elongate-oval.

Underside finely and irregularly punctured, with very fine inconspicuous setae; metasternum flat, rather longer than the basal segment, which is truncate in front and nearly equals in length the following 3 tengether.

This, owing to the tibial structure, should be placed near $C$. flectipes (3667), which. howerer, is of a faintly resldish-bronze hue. with a larger scutellum, \&c. C. tibialis has shorter antemme and coarser sculpture.

The specimen described above, judging by its tarsi, is apparently a female.

Length, $5 \frac{1}{2} \mathrm{~mm}$. ; breadth, $3 \frac{1}{2} \mathrm{~mm}$.

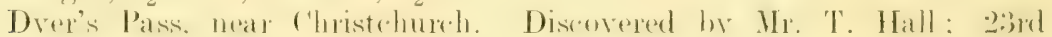
August, 1914.

\section{Group Galerucidae.}

3969. Allastena eminens sp. nov. Allastena Broun, Man. N.Z. Coleopt., p. 1318.

Oblong, subdepressed, nitid; nigro-aeneous, the tibiae and basal 4 joints of antemnare fuseo-testaceous: remainme joints, the tarsi. and femorab more infuscate; sparingly clothed with elongate, slender, suberect, tawny pubescence.

Head nearly as broad as front of thorax, smooth behind, with a few fine interocular punctures and a distinct channel between the antemnal orbits. Thorax a third broader than long, apex truncate; the base nearly so, marginate and a little rounded near the sides so that its angles are some- 
what obtuse; the sides nearly straight and finely margined, anterior angles slightly incrassate; its surface moderately finely and irregularly but not closely punctured, with a transverse basal impression at each side and a longitudinal one between the middle and each side behind. Seutellum smooth, subtriangular. Elytra oblong, rather broader than thorax at the base, almost four times its length, slightly rounded near the broadly curved apices; their punctation rather coarser and much closer than that of the thorax, with slightly rugose interstices. Pygidium not exposed.

Antennae filiform, extending backwards beyond the middle thighs, 2nd joint longer than broad, nearly as long as 3rd, the following ones Ionger, about equally elongate, and more pubescent.

Legs moderately stout and long; front and middle tibiae almost straight; the posterior medially curvate inwardly, obtusely prominent externally at the apex which is deeply grooved for the accommodation of the basal tarsal joint, this joint is large, narrow and almost straight above but extends considerably downwards, 2nd longer than the broadly grooved penultimate; claw appendiculate at the base.

The thoracic impressions, more coarsely and rugosely sculptured elytra, filiform antennae, more distorted and outwardly prominent posterior tibiae, and the larger basal tarsal joint distinguish this species from A. piliventris (3782).

Length, $3 \mathrm{~mm}$.; breadth, quite $1 \mathrm{~mm}$.

Moa Basin, Canterbury. Unique. Discovered by Mr. T. Hall on or about the 20th October, 1913. A second example does not accord exactly either with this or 3782 . All the species, unfortunately, are represented by single specimens; none have been found in the North Island.

3970. Luperus halli sp. nov. Luperus Geoffroy, Man. N.Z. Coleopt., p. 631.

Oblong, subdepressed, glabrous, coarsely sculptured, nitid; rufoviolaceous, legs and basal joint of antennae more cyaneous; remaining joints and tarsi usually more or less infuscate.

Head not as broad as front of thorax, with obtuse antennal elevations: nearly smowth or only finely striguse behind, with an oecipital longitudinal groove. Thorax a third broader than long, its sides nearly straight and distinctly margined; ajex truncate, with slightly thickened subrectangular angles: base feebly medially emar.inate, a little rounded or oblique towards the sides. its angles nevertheless are nearly rectangular ; dise a little uneven but without nodosities. closely and moderately coarsely punctured, and with very irregular smooth rugae near the middle. Scutellum triangular, smooth. Elytra oblong. subparallel, with broadly rounded apices. rather broader than thorax, more than four times its length; they are closely but not coarsely punctate near the base. beyoud this the interstices become rugose and very irregular, towards the sides and extremity the sculpture is even coarser; there is an impression near each shoulder.

Tibiae almost straight, finely pubescent; tarsi narrow, theix 2 nd joint particularly, the penultimate shorter and broader.

Antennae filiform, reaching the hind thighs, 2nd joint rather shorter than 3rd, the following ones longer, about equally elongate, pubescent.

Underside shining, rufo-violaceous, with some elongate greyish hairs; abdomen finetr punetate and transversely strigose. jth sement double the length of 1 th : metastermum eroured along the middle. 
Near L. asperellis (3020), the antennal orbits less convex and convergent in front, the head not rugose, thorax not binodose, elytral sculpture much coarser more irregular and rugose. 3020 is rather larger, it is darker, less rufescent. and has thicker antennae.

Length, $5.1 \mathrm{~mm}$. ; breadth, $2 \frac{1}{2} \mathrm{~mm}$.

Searcliff and Hoa Hill. Several specimens captured during October, 1913, by 11r. T. Hall, in whose honour it has been named. One example is almost wholly fiery red.

\section{Luperus dilucidus sp. nov.}

Oblong, subdepressed, nude, shining; cyaneous, legs and basal joints of antemae rufo-testaceous; remainder of the latter, the palpi, front of head, and terminal joint of tarsi nigrescent

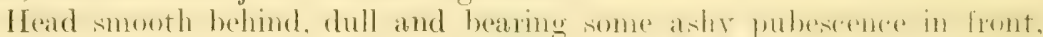
antennal orbits obtuse; it is nearly as wide as front of thorax, but the eyes are less prominent than usual. Thoma a thigd broader than lone, its sides evidently and almost regularly rounded; apex truncate, the base nearly so in the middle but a little curved towards the sides, its angles, though the lateral margins are somewhat inclassate there. are nearly obsolete; dise remotely and minutely punctured, the base with a few lialerer ret rather fine punctures, there is a distinct basal depression near each side. Elytra with rounded shoulders so that the base is scarcely at all wider than that of the thorax, they are rathe: more than thrice its length, with broadly rounded apices; their whole surface densely and minutely sculptured, and with shallow and rather fine punctures near the base and suture; there is an elongate impression within each shoulder, and the sides of the suture are broadly impressed.

Antennae moderately stout, pubescent, extending to beyond the middle femora, 2nd joint shorter than 3rd, the following ones equal, elongate. Legs moderately stout, tibiae straight.

Readily recognizable by the sharp contrast in coloration, the almost evenly curvate sides of the thorax, and dense but fine elytral seulpture.

Length, $5 \frac{1}{2} \mathrm{~mm}$. ; breadth, $2 \frac{1}{4} \mathrm{~mm}$.

Unknown Land, beyond IIoa Basin. One perfect specimen and a second damaged, both from Mr. Hall.

\section{Luperus cyanescens sp. nov.}

Nitid, nude, nigro-cyaneous, antemne and head nigrescent, femora dark fuscous, tibiae and basal joints of tarsi fusco-testaceous.

Thorax truncate in front, its sides nearly straight behind, a little curved anteriorly, base slightly rounded towards the sides, its angles indefinite; it is distantly and very irregularly punctate, most of the punctures are minute, those near the base and sides are more distinct; near each side, before the base, there is a rather large, somewhat flattened elevation. Wilstar rather broader than thorax at the hase. with romoled shoulders and broadly rounderd aphess: their punetation distinet. though moderately fine and close throughout, a little rugose, with smooth intervals.

Antennae filiform, attaining posterior femora, th joint evidently longer than 3rd.

Underside greenish-blue, with grey pubescence. Abdomen finely

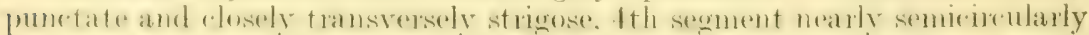

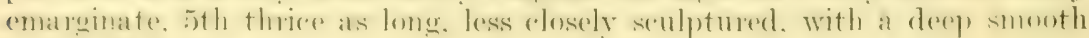
eavity from base to apex. 
The thoracic punctation is similar to that of $L$. dilucidus; this species has a basal impression near each shoulder but none at all alongside the suture, its eyes are more prominent, the antennae are more elongate and slender; it is, therefore, independently of general appearance, essentially different.

Length, $5 \mathrm{~mm}$.; breadth, $2 \mathrm{~mm}$.

Moa Basin. One; another of Mr. Hall's discoveries on the 20th October, 1913. Var. (one): Sides of thorax almost regularly curved, but without lateral elevations.

\section{Luperus gracilipes sp. nov.}

Nitid, dark cyaneous, legs and antennae fuscous.

Head, including the large prominent eyes, not appreciably narrower than the widest part of thorax. smooth behind, the forehead nigreserent, with a few ashy hairs. Thorax a third broader than long, somewhat wider at the middle than elsewhere, a little narrowed towards the front and base. the latter very slightly curved near the sides, with obtuse angles, lateral rims well developed; discal punctation minute and obsolete before the middle, more distinct, irregular, and unequal near the base and sides, broadly impressed near the anterior angles. Srutellum subtriangular. small. Elytra broader than thorax at the base. four times its length, apires broadly roundea; they are moderately closely and distinctly but not coarsely punctured, with smooth intervals, more finely near the shoulders, where they are broadly but not deeply impressed.

Antemae pubescent throughout. filiform and slender. extending beromd the hind thighs.

Legs long and slender, tibiae straight, basal joint of posterior tarsi nearly double the length of the 2 nd.

The large and prominent eyes, the frontal thoracic impressions, the slender antennae and long legs. in conjum tion, render this speries distinct. The thoracic sculpture is similar to that of $L$. cyanescens.

Length, $4 \frac{3}{4} \mathrm{~mm}$. ; breadth, $1 \frac{3}{4} \mathrm{~mm}$.

Hoa Basin. Unique. From Mr. Hall ; 20 th October, 1914.

\section{Luperus minor sp. nov.}

Elongate, slender, shining; dark cyaneous, head aeneous, legs pale fuscous, antennae darker.

Thorax a third broader than long. its sides rather funely mareined. nearly straight. a little narrowed behind. anterior and posterior angles subuectangular; the surface very minutely and closely sculptured on some parts. Elytra with obtusely prominent shoulders, rather wider at the hase than the thorax. nearly five times its length, dehiscent near the patremity. arrices apparently narrow: oblique near the suture. rounded extemally : moderately finely and rlosely punctate, with an elongate implesion near each shoulder. the punctures more distant there.

Though nearly allied to $L$. gracilipes this species is much smaller, the head is nearly as broad as the thorax but the eress are less prominent, the thorax is rather smaller and is only indistinetly sculptured anrwhere. the elytral apices are very different. the shoulders apperar to extend a little

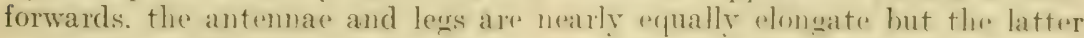
are paler.

Length, $3 \frac{1}{2} \mathrm{~mm}$. ; breadth, $1 \frac{1}{3} \mathrm{~mm}$.

Ioa Basin. Another species from Mr. Hall; one example only. 
3975. Luperus quadricollis sp. nov.

Elongate, nitid, aeneo-cyaneous, legs and antennae fuscous.

Head nearly as broad as thoracic apex, not quite smooth. Thorax of about equal length and breadth, slightly convex. its sides finely margined, not quite straight. very feebly and evenly rounded. the base slightly rurved towards the sides. with obtuse angles: dise distantly and finely ret quite definitely punctate. Srutellum small, triangular. Elytra rather broader than thorax at the base. hardly four times its leneth. with broadly rounded apices, shoulders not prominent but searcely at all narrowed or rounded; they are moderately finely. chosely, and ruensely punctured. less distinctly and closely near the shoulders, which are without any well-marked impressions.

Antennae not reaching posterior femora, moderately slender, their 3rd joint short, hardly any longer than 2nd; joints 4-11 about equal.

Legs moderately elongate, tibiae straight; basal joint of posterior tarsi as long as 2nd and 3rd.

The small size, subquadrate, evenly convex thorax, different shoulders, less elongate and slender legs and tarsi, and somewhat abbreviated 3rd antennal articulation, serve as good distinguishing characters.

Length, $3 \frac{1}{3} \mathrm{~mm}$. ; breadth, $1 \frac{1}{3} \mathrm{~mm}$.

Moa Basin. Another unique from Mr. T. Hall.

\section{Luperus xenoscelis sp. nov.}

Subdepressed, moderately elongate and nitid; viridi-cyaneous, tibiac and basal half of antennae light fuseous. renaining joints and the femora darker.

Head as broad, the large eyes inclusive, as front of thorax, with a few fine punctures just behind the eyes, and some fine hairs, antennal orbits slightly elevated. Thorax subquadrate, a little broader than long, its sides distinctly marginate. neary straight. only vere slightly narrowed behind. front angles slightly incrassate, base slightly rounded near the sides so that its angles are not quite rectangular; dise without depressions, finely yet quite distinetly, moderately elosely but irregularly punctured, more distantly between the middle and sides, between many of these punctures there are a few minute ones. Scutellum small. Elytra thrice the length of thomax. rather broader than it is at the base. the shoulders seareely at all, the apies broadly rounded; their surface plane. suture simple, moderately closely and rather finely punctate, with very minutely sculptured interstices.

Antennae extending to beyond intermediate femora, their $3 \mathrm{rd}$ joint scarcely any longer than the suboviform 2nd; joints $1-11$ moderately clongate, each slightly narrowed towards the base.

Legs moderately stout; posterior tibiae below the middle, along their front face, distinctly curved and dilated, less so at the extremity; tarsi moderately thick.

'This must be placed after $L$. insolitus (3668) and $L$. dilutipes (3780), in both of which the elytral suture is thickened and somewhat elevated, besides differing in minor details. The present species is differentiated

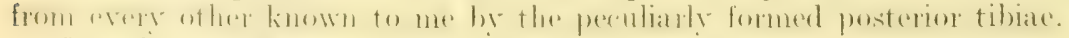

Length, $33_{2}^{1}-3_{4}^{3} \mathrm{~mm}$; breadth, $1 \frac{1}{2} \mathrm{~mm}$.

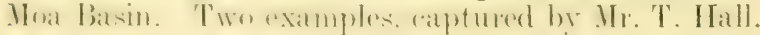


3977. Luperus perplexus sp. nov.

Nitid, aeneo-niger, tibiae and basal joint of tarsi fusco-testaceous.

Head narrower than thorax, with some grey hairs in front. 'Thorax a third broader than long, the base a little curved near its sides, so that its angles, notwithstanding a slight thickening of the lateral margins. appear indefinite; it is very little wider before the middle than behind, where it is nearly straight; dise distantly, rather finely and irregularly punctate, rather more closely and less finely near the sides, near each of which, in front of the base, there is generally a slightly raised spot. Elytra nearly four times as long as thorax, broader than it is at the base, their shoulder's and apices rounded; they are distinctly, moderately finely and closely punctured and more or less transversely rugose, and there is a broad impression at the inner side of each shoulder.

Antennae nigrescent, attaining the posterior femora, or not, according to sex, 2nd joint a little thicker and shorter than 3rd, the others filiform.

Legs moderately stout and elongate, tibiae almost straight, tarsi rather narrow.

Length, 5-6 mm. ; breadth, $2 \frac{1}{2} \mathrm{~mm}$.

Scarcliff, Moa Basin, and adjacent localities; numerous specimens found by Mr. T. Hall.

Obs.-The first example was captured at Broken River, Canterbury, by Mr. J. H. Lewis, and was labelled $3021 \mathrm{in} \mathrm{my} \mathrm{collection,} \mathrm{and} \mathrm{its} \mathrm{description.}$ intended for the Ann. Mag. Nat. Hist., ser. 8, vol. iv, September, 1909, having been onitted it is included amongst the variable nembers of this species. In one variety the slight swelling of the thorax near each hind angle is quite nodiform, in other cases it is obsolete; in another individual there is a pair of nodosities near the middle of the thorax. Three specimens labelled "Var. B" are of a shining brassy hue.

\section{Luperus pygidialis sp. nov.}

Subdepressed, shining, sparingly clothed with fine, decumbent and suberect, greyish hairs; aeneo-niger, legs and antennae light rufo-testaceous. the terminal joints of antennae and tarsi slightly infuscate.

Head nearly smooth behind, with a well-marked interocular furrow, it is rather narrower than the front of thorax; eyes not prominent. Thorax a third broader than long, with moderately marginate. slightly rounded sides, the base a little curved near the sides, with obtuse angles; dise irregularly, moderately finely and rlosely punctate, more closely near the sides, without inequalities. Elytra almost four times the length of thoma. rather broader than it is at the base, a little wider behind, with subtruncate or broadly rounded apices; they are distinetly. rather fincly and moderately rugosely and closely punctured, rather more coarsely behind than along the middle of each, but are without definite intrahumeral impressions. Pygidium obviously protuberant, minutely and densely seuptured. with a deep broad furrow along the middle.

Antennae reaching to beyond intermediate femora, moderately stout, and joint shorter than the next, joints 4-10 hut little lomger than 3rd. each slightly narrowed towards the base.

Legs moderately long, tibiae almost straight. 
Underside nigro-ieneous, finely sculptured, with elongate pubescence. Fourth abdominal segment nearly semicircularly emarginate, 5th twice as long. almost oboonical, with a small subapical fovea, 6th narrow and elongate.

The remarkable, deeply sulcate pygidium by itself is sufficient for immediate separation from any of the preceding species. It is distinctly pubescent, rather smaller, much more nigrescent, but with more brightly coloured legs and shorter antennae than $L$. cheesemani (3150). The other near ally, $L$. obscurus (3151), ean $b$ - at once distinguished by the incurved elytral base, prominent shoulders, dissimilar coloration, \&c.

Length, $3 \frac{1}{2} \mathrm{~mm}$. ; breadth, $1 \frac{1}{2} \mathrm{~mm}$.

Queenstown, Lake Wakatipu. Half a dozen specimens, from Mr. M. O. Pasco and Mr. A. Philpott; January, 1914.

\section{Luperus mediocris sp. nov.}

Nitid, bearing very few, inconspicuous, greyish hairs; aeneo-cyaneous, tibiae fusco-testaceous, femora and antennae fuscous.

Head rather narrower than front of thorax, slightly rugose, with outstanding ashy hairs in front. Eyes large but not prominent. Thorax a third broader than long, the sides moderately marginate and very slightly curved, base a little oblique near the sides, with subrectangular angles; dise without pereeptible inequalities, irregularly. distantly, and very finely punctured. Elytra four times the length of thorax, a little broader than it is at the base, rather wider behind, with broadly rounded apices; distinctly, moderately finely and closely punctate. slightly rugose, more finely near the alnost unimpressed shoulders. and with a few minute interstitial punctures. Pygidium only slightly exposed.

Antennae moderately slender, extending beyond middle thighs, 3rd joint evidently shorter than 4th, but longer than 2nd. Legs and tarsi moderate, tibiae straight.

L. oleareae (2304), though larger and stouter, seems to be the most nearly allied species. Sharp's L. aenescens (2316) has fusco-testaceous antennae and a long, narrow, horizontal pygidium.

Length, $4 \frac{1}{2} \mathrm{~mm}$.; breadth, $2 \mathrm{~mm}$.

Unknown Land, west of Moa Basin. Four found by Mr. T. Hall in October, 1913. 


\section{NEW ZEALAND INSIITUTE.}

B U L L E T I N N o. 1 .

\section{DESCRIPTIONS, OF}

\section{NEW GENERA AND SPECTES}

OF

\section{COLEOPTERA.}

\section{PART YI.}

BY MA.TOR I. BROUN, F.E.S.

EDITED AND PUBJISHED, UNDER THE AUTHORITY OF THE BOARD OF GOVERNORS OF THE INSTITUTE.

ISSUED 15th JUNE, 1921.

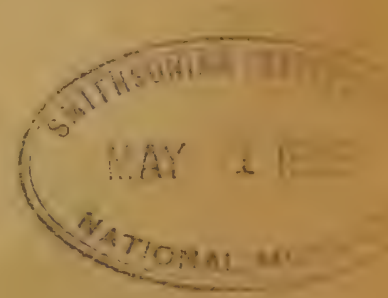

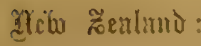

MAROUS F. MARKS, GOVERNMENT PRINTER, WELLINGTON. 
NEW ZEALAND INSTITUTE.

\section{BULLETINS.}

Under the title "Bulletins" the Board of Governors of the Nerr Wenland Institute hopes to issue, from time to time, important papers which for any reason it is deemed desirable not to include in the yearly volume of the Transactions. The bulletins will be uniform in size and general style with the Transactions of the New Zealane Institute, but will appear at irregular intervals, and each bulletin will be complete in itself and be separately paged. The bulletins will no be issued free to members of the Institute, but may be obtained by them at a reduction on the published price. 


\title{
NEW ZEALAND INSTITUTE.
}

\author{
BULLETIN No. 1, PART YI.
}

ISSUED 15TH JUNE, 1921.

\section{DESCRIPTION S}

oF

\section{NEW GENERA AND SPECIES OF COLEOPT'ERA.}

\author{
By Major T. Broun, F.E.S.
}

\section{PART VI.}

THE preparation of this paper, owing to the prolonged microscopical study necessary in describing such a large proportion of small species of Pselaphidae, Cryptorhynchidae, \&c., has given me constant occupation for almost an entire year.

It contains descriptions of ten new genera and 173 species. All the new genera, and 140 of the species, are the result of Mr. T. Hall's skill and untiring perseverence, during the winter as well as the more favourable and pleasanter collecting seasons. Mr. A. E. Brookes, of Mount Albert, discovered eleven, Mr. A. Philpott, of Invercargill, six, Mr. H. W. Simmonds, of Wellington, six, Mr. J. H. Lewis, one; the remainder belong to my own collection.

The delay in publishing my last paper, the work of 1914, added greatly to the difficulties encountered when investigating the structural details of the species enumerated in the following list. Only those actually engaged in scientific work of this kind can form any idea of the complications created by inability to refer to printed descriptions of previously named members of an Order now known to exceed four thousand species. Even the nomenclature, especially when species belong to genera represented in other parts of the world, has become a very troublesome undertaking.

Mount Albert, Auckland,

Thos. Broun.

20th January, 1916.

17-Bull. No. 1. 


\section{LIST OF NEW GENERA AND SPECIES.}

\section{SPIIAERIDIIDAE.}

3980. Saphydrus consonus Broun.

3951. ", collaris Broun.

HELOPHORIDAE.

3952. Hydraenodes spinipennis Broun.

STAPIITINIDAE.

3983. Quedius urbanus Broun.

3984. , iridescens Broun.

\section{Paederidae.}

3985. Hyperomma subcaecum Broun. 3986. lobatum Broun.

3987. " " picipenne Broun.

3988. , discrepans Broun.

3989. Dimerus vicinus Broun.

\section{OXYTELIDAE.}

3990. Coprostygnus curvipes Broun. 3991.

,

Psellaphidae.

FARONINI.

3992. Exeirarthra parviceps Broun.

3993. Sagola bilobata Broun.

3994. , tenebrica Broun.

3995. " subcuneata Broun.

3996. , , strialis Broun.

3997. ", rectipennis Broun.

3998. , valida Broun.

3999. " cilipes Broun.

4000. ", foveiventris Broun.

4001. , striatifrons Broun.

4002. ", cordiceps Broun.

4003. ", fagicola Broun.

4004. ", ignota Broun.

4005. , furcata Broun.

4006. ", aemula Broun.

4007. ", fasciculata Broun.

4008 . " minuscula Broun.

4009. ", acuminata Broun.

4010. , rufescens Broun.

4011. " bipuncticeps Broun.

4012. ", affinis Broun.

4013. " planipennis Broun.

4014. " brevifossa Broun.

4015. ., arboricola Broun.

4016. ", remixta Broun.

4017. ", planicula Broun.

4018. ", lineiceps Broun.

4019. Stenosagola planiocula Broun. $4020 . \quad$ oblongiceps Broun. 4021. " " griseipila Broun.

DUPLE.TINI.

4022. Euplectopsis crassulus Broun. 4023. Plectomorphus scitiventris Broun. 4024.

4025 .

4026.

$+027$ anguliferus Broun. rugiceps Broun. insignis Broun. collinus Broun.
4028. Vidamus simplex Broun. 4029. " ovicollis Broun. 4030. ", muscicola Broun. 4031. " " nitidus Broun. 4032. ,, fossalis Broun.

4033. Gabata bifoventa Broun. 4034. ", parallela Broun. 4035. Eleusomatus vidamoides Broun. 4036. , , oculatus Broun. 4037. ", subcaecus Broun. 2482. Notes on male Broun. $1890 . \quad$, Broun. 1891. ", Broun.

BRACHYGLUTINI.

4038. Eupinogitus sulcipennis Broun. 4038. Var. E. picescens Broun. 4039. Neosampa granulata Broun. 4040. Anabaxis minor Broun.

\section{Silphidda}

4041. Inocatops impressus Broun. 4042. Isocolon frontale Broun. 4043. ", modestum Broun.

\section{Nitidulidae.}

4044. Neocercus electus Broun. 4045. Inopria halli Broun.

404f. , notata Broun.

\section{Colydidda.}

4047. Ulonotus discalis Broun. 4048. Notoulus discors Broun. 4049. Allobitoma halli Broun. 4050. Glenentela costata Broun. 4051. Vitiacus subcaecus Broun. 4052. ," posticalis Broun. 4053. ,, purus Broun. 4054. $\quad, \quad$ suturalis Broun. 4055. ", setarius Broun.

4056. " " lateralis Broun.

\section{LATHRTDIIDAE}

4057. Rethusus fulvescens Broun.

\section{BYRRHIDAF.}

4058. Nosodendron seriatum Broun.

MelolonthidaA.

4059. Odontria halli Broun.

4060. Xylostygnus brookesi Broun.

DASCYLILDAE.

4061. Atopida villosa Broun. 4062. " pallidula Broun. 4063. " " montana Broun. 4064. Veronatus sternalis Broun. 4065. , reversus Broun. 4066. ", apterus Broun. 4067. ", brevicollis Broun. 4068. ,, versicolor Broun. 4069. ", vestitus Broun. 
'T'ENEBRIONIDAE.

4070. Syrphetodes thoracicus Broun. $4071 . \quad$, pensus Broun.

\section{DIAPERIDAE.}

4072. Menimus pubiceps Broun.

\section{Salpingid AE.}

4073. Salpingus aterrimus Broun. 4074. Agapy tho foveicollis Broun.

\section{OTIORHYNCHIDAE.}

4075̃. Cecyropa litorea Broun. 4076. Tigones bicostellus Broun. 4077. Platyomida philpotti Broun. 4078. Aporolobus scapalis Broun.

\section{RIIYTAROSOMIDAE.}

4079. Phrynixus squamalis Broun. 4080. ", humilis Broun. 4081. ", amoenus Broun. 3278. Var, P. binodosus Broun. 4082. Erymneus terrestris Broun. 4083. Allostyphlus jugosus Broun. 4084. Phrynixodes scruposus Broun. 4085. Bantiades rectalis Broun. 4086. , , trifoveatus Broun. 4087. Rachidiscodes glabrus Broun. 4088. Clypeorhynchus dorsalis Broun. 4089 . bicarinatus Broun. 4090. Dacnophylla sparsa Broun. 4091. Nestrius zenoscelis Broun. 4092. ", simmondsi Broun. 4093. Phygothalpus striatus Broun. 4094. ", anthracinus Broun. 4095. Getopsephus costifer Broun.

4096. ", funestus Broun.

\section{HYLOBIIDAE.}

4097. Bryocatus quadricollis Broun. $4098 . \quad$ rubidus Broun. 4099. ,, elegans Broun. $4100 . \quad$ " humeratus Broun. 4101. " " lugubris Broun. 4102. " " crassirostris Broun.

\section{Erirhintdae.}

4103. Erirhinus dilucidus Broun. 4104. :, altivagans Broun. 4105. ", leucocomus Broun. 4106. Dorytomus vittatus Broun. 4107. Aneuma rufa Broun.

$4108 . \quad, \quad$ oblonga Broun. 4109. ", rostralis Broun. 4110. , conspersa Broun. 4111. Eugnomus atratus Broun. 4112. Hypotagea tibialis Broun

\section{BETLIDS1:}

4113. Pachyura brookesi Broun.

\section{HAPLONYCHIDAE.}

4114. Geochus pictulus Broun. 4115. ", apicalis Broun.

4116. ", certus Broun.

4117. ", convexus Broun.

\section{CRYPTORHYACHIDAE.}

4118. Acalles humeralis Broun. 4119. " anceps Broun. 4120. ,, cilicollis Broun. 41:1. Tychanus obscurus Broun. 4122. Crisius contiguus Broun. 4123. ," eximius Broun. 4124. Allanalcis variatus Broun. 4125. ,, seticollis Broun. 4126. ", albipictus Broun. $4127 . \quad$ ", melastictus Broun. 4128. ", blanditus Broun. 4129. Atylodes asaphus Broun. 4130. Zeacalles aeratus Broun. 4131. ", coarctalis Broun. 4132. ", finitimus Broun. 4133. " " bisulcatus Broun. 4134. " " seruposus Broun. 4135. ", latulus Broun. $4136 . \quad, \quad$ inornatus Broun. 4137. ", parvus Broun. 4138. , , cordipennis Broun.

\section{Cossonidae.}

4139. Eucossonus constrictus Broun. 4.140. , , sulcicollis Broun. 4141. ", masalis Broun. 4142. ", disparilis Broun, 4143. ", oreobius Broun. 4144. Allaorus carinifer Broun.

\section{ANTHRIBIDAE.}

4145. Anthribus halli Broun.

\section{LAMIIDAE}

4146. Somatidia maculata Broun.

4147., longula Broun.

4148. ", rittigera Broun.

4149 . " pennulata Broun.

\section{Cirrsomelidae.}

4150. Caccomolpus subcupreus Broun $4151 . \quad, \quad$ amplus Broun. 4152. $"$ cinctiger Broun. 


\section{Group Sphaerididdae.}

Saphydrus Sharp. Man. N.Z. Coleopt., p. 1014.

3980. Saphydrus consonus sp. nov.

Subolblong. slightly wider near the hind thighs than elsewhere, moderately convex and nitid. "losely and distinetly hut not coarsely punctate; nigrescent, sides of thorax broadly testaceous; apical portion of elytra and their lateral margins, the labrum, palpi, antennae, and tarsi more or less light rufo-fuscous; legs piceo-rufous, club dull fuscous.

Head much narrower than thorax, almost as long, gently narrowed in front of the moderately prominent eyes, forehead truncate. Thorax fully twice as hroad as long, its sides finely margined and gradually narrowed anteriorly, apex widely emarginate, with obtuse angles, the base widely bisinuate, its angles obsolete. Scutellum elongate, distantly and minutely puncetere. Elytra more than thrice the length of thorax, hardly any hroader than it is at the base, with distinet, slightly reflexed lateral margins: their serial punctures close, indistinct on some parts, substriate on others, sutural striae well marked behind; pubescence ashy, fine and inconspicuous.

Basal joint of antennae cylindric, its exposed portion rather longer than the elongate-oval second, which is thicker and slightly longer than the next, fourth and fifth short but not as broad as the transverse sixth ; club laxly articulated, densely and minutely pubescent, basal two joints equal, subquadrate, the terminal longer, subconical. Tibiae finely spinose externally.

Underside dull nigro-fuscous, thinly elothed with fine ashy hairs. Mesosternal process acuminate in front, with a curved carina extending backwards towards the ontside of each of the middle coxae. Posterior femora distinctly pubescent but not closely punctate.

Sharp's S. suffusus, judging by description, is smaller, different in form and coloration, and its punctation seems to be coarser. S. obesus, 1818 , is at once separable by the dense punctation of the lower surface of the posterior femora.

Length, $6 \mathrm{~mm}$. ; breadth, $3 \frac{1}{4} \mathrm{~mm}$.

Buller River, near Glenhope. A single individual from Mr. T. Hall; 17th January; 1915.

\section{Saphydrus collaris sp. nov.}

Nitid, rufo-fuscous; sides of thorax, the lateral margins and apical portion of elytra chestnut-red; lecs piceo-rufous, antennac, palpi, and tarsi nearly so, club dull fuscous; with slender, ashy, inconspicuous pubescence.

Nearly allied to $S$. consonus in form, but with more convex elytra, the seneral punctation is not pereeptibly different but the elytral striae are rather more definite, and the uncovered portion of the basal joint of the antennae is distinctly longer than the second. Thoracic angles less romeded, the anterior obtusely rectangular, the posterior nearly so and therefore very different from those of $S$. consonus.

Lnderside, except the pale prostermum, piceous, clothed with ashy pubesenere, posterior femora pubeseent but not distinetly punctured.

Length, $5 \frac{1}{2} \mathrm{~mm}$.; breadth, $3 \mathrm{~mm}$.

Waiorongomai. Nount Te Aroha; March. 1894. A single specimen found by myself. 


\section{Group Helophoridae.}

\section{Hydraenodes gen. nov.}

Mentum large, plane, subquadrate, without prominent anterior angles. Maxillary palpi very long, basal joint minute, subglobular; second very elongate, gradually incrassate, about half of their whole length: third twice as long as broad, thickened towards the extrenity, fourth longer and more slender. Mandibles very short, arched. Labrum large, transverse, with a deep narrow median notch, rounded in front towards the sides, its basal suture fine and indefinite. Head horizontal, narrowed anteriorly. Eyes rotundate, prominent, situated at the sides near the base. Antennae 9, articulate, slender, little more than half the length of the maxillary palpi; basal joint suberlindric, second as long, verr slightly thicker, third about as long as second but more slender, fourth simple, shorter than third, slightly longer than fifth, sixth and seventh small, eighth larger, subquadrate. ninth oblong, these therefore appear to form a biarticulate club. Thorax of equal length and breadth, its sides somewhat explanate and on a lower level than the disc, obtusely angulate ntar the middle, sinuate and distinctly narrowed towards the obtusely rectangular posterior angles, apex slightly rounded in the middle and somewhat oblique near the obtuse angles, base truncate. Scutellum indistinet or absent. Elytra oblong-oval, hardly any wider than thorax at the base, but with obtusely dentiform but not projecting shoulders, broadly rounded behind, with a spiniform process on the suture near the extremity. Legs elongate, minutely pubescent; tibiae almost straight, the intermediate pair, on the inside, with a distinct though somewhat obtuse angulation between the middle and apex. Tarsi slender, almost equalling the tibiae in length, basal two joints short, the fifth as long as all the others united, with simple claws. Abdomen composed of seven segments, 2-4 subequal, the next two rather longer, sixth medially emarginate behind, seventh short and broad, slightly emarginate. Prosternum with obtusely prominent front angles, truncate between them; anterior coxae contiguous, the intermediate moderately separated, the intervening process cariniform.

I have no species of Hydraena in my collection for comparison, but judging by the generic diagnosis (Lacord., Hist. des Ins. Coleopt., vel. 1, p. 469) this differs in several details.

\section{Hydraenodes spinipennis sp. nov.}

Elongate, medially narrowed, slightly convex, nitid, glabrous above; piceo-niger, legs and palpi fusco-rufous, antemnae testaceous, tarsi more rufescent.

Head, eyes included, nearly as broad as the widest part of thorax, almost as long as it is, with a few fine punctures and an elongate impression alongside each eye; labrum smooth, rather less nitid. Thorax finely margined, disc irregularly and moderately coarsely punctate, more distantly before the middle, with a transverse impression in front, the sides with an obtuse, subrotundate, apical elevation and an elongate basal forea. Elytra more than twice the length of thorax. distinctly seriate-pumctate, rather more coarsely than the thorax, less distinctly behind.

Underside dull-blackish, with numerous very short, depressed brassy setae, but the sixth and apical half of the fifth segment are glahrous and shining; metasternum impressed along the middle. 
Horelophus walkeri, discovered at Reefton by Commander J. J. Walker, R.N., I have not seen, but the admirable deseription published by MI. d'Orchymont enables me to state that it is abundantly distinct.

Length, $2 \frac{1}{3} \mathrm{~mm}$. ; breadth, $\frac{2}{3} \mathrm{~mm}$.

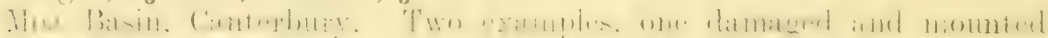

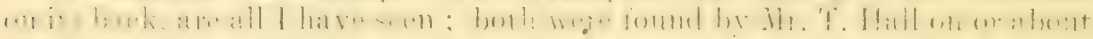
the 20th. October, 1913.

\section{Group Staphyltivida.}

Quedius Stephens. Lacord., Hist, des Ins. Coleopt., vol. 2, p. 84. 3983. Quedius urbanus sp. nov.

Elongate, aeneo-niger, head and thorax shining, elytra rather dull with infuscate pubescence, hind-body similarly clothed but slightly iridescent; mandibles rufeseent; labrum, legs, and antennae fusco-castaneous; the terminal and basal three joints of these last, and the tarsi, more or less light fusco-rufous, palpi paler.

Head subrotundate, rather broader than long, tripunctate between the front of the eyes and alongside each, bipunctate at the base. Thorax

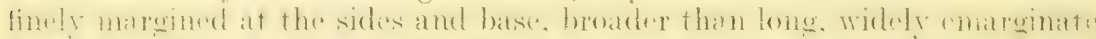

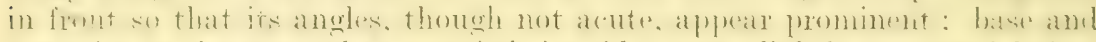

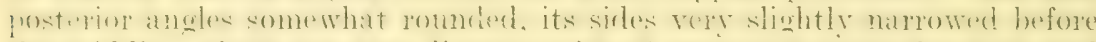
the mildi: : there are two distant paime of puncelures near the alpex and on the michle, a basal pair mear each angle and a more distant pain before

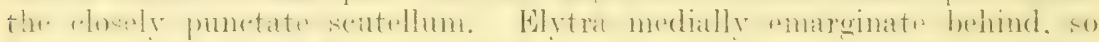

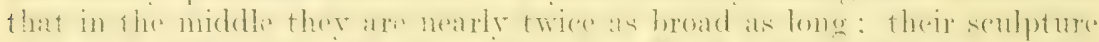

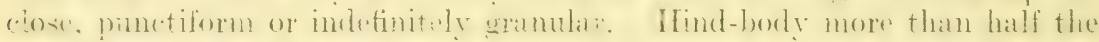

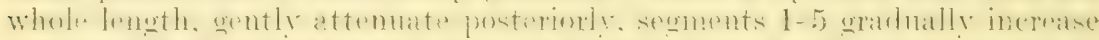

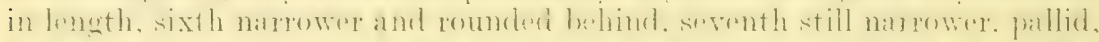

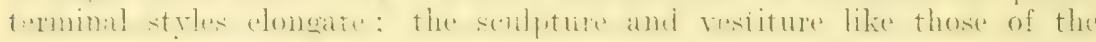
elytra.

Labrum short, medially notched, with elongate, dark setae, and pale membranous appendage. Clypeus very short. Eyes more than half the length of the head. Anterior tarsi widely expanded and hairy. Antennae rather slender, just reaching the thoracic base.

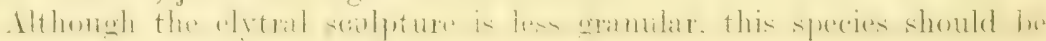
nlaced near 1845 in Section VIII.

Length, $13 \mathrm{~mm}$; ; breadith, $2 \frac{1}{5} \mathrm{~mm}$.

Glenhope; 18th July, 1915. One, found by Mr. 'T. Hall.

\section{Quedius iridescens sp. not.}

Elongate, slightly convex, nigrescent; head and thorax glossy, subaeneo-niger; hind-body beautifully iridescent, its terminal two segments rufescent; the mandibles, labrum, tarsi, and basal three joints of antemne more or less reddish, remaining joints of these last dull fuscous; lews

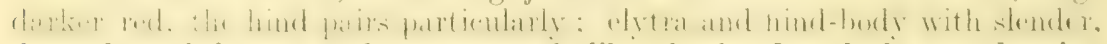
decumbent infuscate pubescence, and, like the head and thorax, bearing many elongate upright setac.

Head and mandibles about a third longer than thorax, nearly as broad at it is, hardly at all rounded; with two, or three, punctures alongside "ach eye and two larger ones behind each, and a pair of basal ones. Thorax

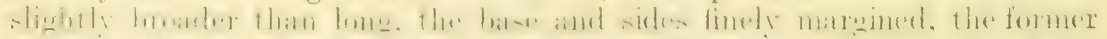

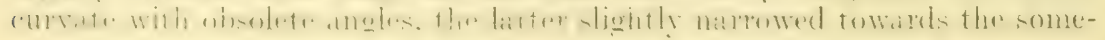


what deflexed, obtuse front angles; there are two or three small punctures near each side of the apex, a pair before the middle of the disc, three at the base, and a distinct lateral one in front of the middle. Scutellum large, triangular, punctate. Elytra subquadrate, only slightly longer and broader than thorax, apices oblique towards the somewhat raised and incrassate suture; they are moderately finely and closely punctate. Hindbody nearly half the whole length, tapering posteriorly, with moderate terminal styles, its six visible segments sculptured like the elytra.

Eyes hardly half the length of the head. Labrum widely emarginate. Antennae shorter than the head and thorax, second joint thicker than the next and almost as long, fourth and fifth rather longer than the following ones. Anterior tarsi moderately dilated, basal joint of the posterior longer than the second.

Easily recognized by the rather brightly iridescent hind-body, rufescent terminal segments, and raised elytral suture.

Length, $10 \mathrm{~mm}$. ; breadth, nearly $2 \mathrm{~mm}$.

Glenhope; 12th September, 1915. One, found by Mr. T. Hall.

\section{Group Paederidan.}

Hyperomma Fauvel. Hist. Nat. de l'Austral. et Polynes., Caen, $1877-79$, p. 67.

\section{Hyperomma subcaecum sp. nov.}

Elongate, slightly convex, nitid; castaneo-rufous, palpi, antennae, and legs testaceous; thinly clothed with slender greyish pubescence.

Head oblong, very gently narrowed anteriorly, with obtuse hind angles. nearly smooth along the middle, distantly but distinctly punctate elsewhere. Thorax a third longer than broad, not wider than the head, with rounded angles; disc with a series of about five punctures along each side of the middle, the lateral punctation more irregular. Scutellum smooth, triangular. Elytra of about equal length and breadth, a third shorter than thorax, with curvedly narrowed shoulders, apices subtruncate; their suture fine yet definite; each elytron with four punctures near the suture, those near the sides less regular. Hind-body half the entire length. irregularly and distantly punctate, terminal segment narrower than the others, the styles prominent.

Antennae shorter than the head and thorax, second joint evidently shorter than first but fully as long as the third, joints 6-10 subquadrate, eleventh longer, conical. "Tibiae setigerous; basal four joints of anterior tarsi only moderately dilated.

Mandibles shorter than the head, falciform, each with a prominent median inner tooth. Eyes mimute, placed on the upper part of the sides not far from the antennar, these therefore enable this species to be at oner separable from the type of the genus, the Australian $H$. Tacentimm. and all the New Zealand ones.

Length, $5 \mathrm{~mm}$.; . breadth, $\frac{2}{3} \mathrm{~mm}$.

Glenhope, near Nelson. Two samples found by Mr. T. Hall on the 30th March, 1915.

\section{Hyperomma lobatum sp. nov,}

Elongate, shining black, mandibles rufous, legs and apieal segment of ahdomen castaneous, the labrum, jalyi, and tarsi testaceous, antemae more rufescent than these last. 
If and, exclusive of mandibles, rather longer than broad, its sides straight, posterior angles curvedly narrowed; there are two pairs of punctures on the forehead, the inner much smaller than those near the antennae, it is smooth along the middle, but there are some coarse punctures near the sides. Thorax a third longer than hroad, with straight sides and rounded angles; with a nearly regular series of about thirteen punetures along rach side of the middle, which has several minute indistinct punctures, lateral punctation irregularly biseriate. Scutellum smooth. Elytra small, almost as broad as thorax, a third shorter, their shoulders curvedly narrowed, apices truncate; each elytron has three somewhat irregular series of punctures, about six in each. Hind-body nearly half of the whole length, irregularly but not deeply punctate ; basal segment very short, the following four subequal, nearly quadrate, sixth slightly longer; seventh as long but narrower, with a subtriangular incision extending to its base, the extremity of each side is rounded and appears lobate; the supplementary or eighth segment occupies the incision and is prolonged almost as far as the terminal styles; the corresponding ventral segments are similar, their predecessor is smooth and slightly impressed along the middle.

Antennae shorter than head and thorax. Mandibles elongate, each bidenticulate at the base and with an imner, acute, prominent tooth behind the middle. Labrum short, with a deep central notch. Labial palpi very slender. Eyes moderate, not large, nearly flat, indistinctly facetted. Anterior tarsi setigerous, their basal four joints distinctly dilated, the intermediate ones rather larger than the basal or fourth, fifth short and slender; posterior tarsi elongate, their second and third joints, together, slightly longer than first.

More slender than 2708, H. sanguineum (Ann. Mag. Nat. Hist., ser. 6, vol. xiv, p. 425), the head smooth in the middle, the inner teeth of the mandibles not truncate at the extremity, the anterior tarsi similar to those of other species, but the bilobate seventh dorsal segment is utterly unlike that of any New Zealand member of the genus.

o. Length, $7 \frac{1}{2} \mathrm{~mm}$; breadth, $1 \frac{1}{4} \mathrm{~mm}$. 1915 .

Glenhope. A solitary male discovered by Mr. T. Hall on the 3rd March,

\section{Hyperomma picipenne sp. nov.}

Elongate, nitid, fusco-rufous, elytra piceous, mandibles rufescent, the palpi. legs. and basal two joints of antemnae fusco-testaceous, remaining artirulations more infuscate; pubeseence ashy, berommg thicker towards the end of the hind-body, scanty but erect on the head and thorax.

Irad, aceluding the mandibles, subquadrate, with rounded posterior angles, its sides nearly straight; there are four punctures between the antrmate, the immer pair the smaller, these distinct ones near each "ree, and a few others near the sides and base. Thorax a third longer than broad, as much longer than the head, its sides straight, basal angles curvedly narrowed, the anterior less so; dise smooth along the middle, with a row of about a dozen punctures along each side of it, those near the sides irregular. Scutellum smooth. Elytra as broad as thorax, fully a third shorter. shoulders aurvedly narrowed, apices truncate, distinctly but somewhat irregularly punctured. Hind-hody half the whole length, distantly and irrecularly punctate, hasal segment hardly at all exposed. 2-5 transvers ly quadrate, sixth rather lomger, serenth shorter and nalrower, rounded bebind, simple underneath, terminal styles prolonged. 
Antennae distinctly pubescent, short; basal joint not as long as following two combined. Anterior tarsi with the basal three joints as long as broad, not expanded, penultimate smaller, the terminal nearly as long as all the others. Eyes moderate, nearly flat, with distinct facets. Mandibles elongate, bidenticulate at the base, the inner, prominent tooth of each subacute and placed between the middle and base.

The shorter head differentiates this species from all but $H$. dispersum (2454); the mandibles of the latter, however, though bidenticulate at the base, are without the common elongate inner teeth.

‥ Length, $6 \frac{1}{2} \mathrm{~mm}$.; breadth, $1 \mathrm{~mm}$.

Mount Alfred, near Lake Wakatipu; 4th February, 1914. The single female before me is another of Mr. T. Hall's discoveries; elevation, 4,200 ft.

\section{Hyperomma discrepans sp. nov.}

Subparallel, shining; hind-body subaeneo-piceous, the head and thorax more nigrescent, mandibles rufous; labrum, palpi, antennae, and tarsi rufo-testaceous; legs castaneous; pubescence ashy and depressed on the hind-body, very scanty and suberect elsewhere.

Head slightly longer than broad, its sides nearly straight, curvedly narrowed behind; with four interantennal punctures, the inner pair small, there is a pair close to each eye and another nearer the middle more distant from each other, behind the eyes and across the base there are several distinct punctures, there are also minute ones on the middle. Thorax not broader than the head, a third longer, with straight sides and moderately rounded angles; along either side of the middle there is a series of about thirteen definite punctures, those near the sides are less numerous and irregular, between the rows there are many minute punctures. Scutellum smooth. Elytra truncate and as broad behind as the thorax, with curvedly narrowed shoulders, they are distinctly but only subseriately punctate. Hind-body half of the entire length, irregularly but distinctly punctured, basal segment half as long as the transversely quadrate following four, sixth rather longer; seventh narrower, membranous, pale, and rounded at the extremity, with a triangular but small impression there, this in some aspects seems to be an incision; the corresponding ventral segment has a pair of pale cylindrical appendages which, though visible from above, are much smaller than the coarsely setose styles.

Mandibles, eyes, and palpi similar to those of $H$. picipenne; basal joint of antennae almost as long as the next two combined. Tibiae irregularly and finely spinulose, the intermediate pair most distinetly. Anterior tarsi setigerous, their basal four joints moderately dilated, each transversal.

This, like $H$. lobatum, is another species in which the seventh dorsal segment, and the corresponding ventral one, together, form the principal distinguishing feature.

o. Length, $8 \frac{1}{2} \mathrm{~mm}$. ; breadth, $1 \frac{1}{3} \mathrm{~mm}$.

Glenhope. A single male only, captured by Mr. T. Hall on the 20th December, 1914.

\section{Dimerus Fauvel. Trans. N.Z. Inst., vol. 44, p. 401.}

3989. Dimerus vicinus sp. nov.

Elongate, slightly convex; head, thorax, and elytrat shining chestnutred and nearly glabrous; less much paler, palpi, antemma, and aursi 
fulvescent; hind-body half the whole length, eastaneous, covered with fine decumbent yellowish hairs.

Head shorter and slightly broader than thorax, its sides gently rounded;

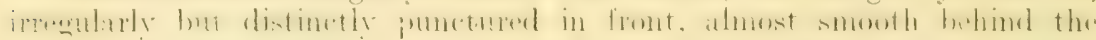
middle but with a row of finer punctures across the base, lateral sculpture somewhat rugose; each antemnal tubercle is prolonged as a carina as far back as the eyes, and there is a short stria alongside it. Thorax truncate at base and apex, slightly longer than broad, gradually narrowed posteriorly, with indistinct lateral margins; along each side of the middle there is a straight, deep, indefinitely quadripunetate groove which does not reach the base or apex, and a pair of detached shallow punctures in front; near each side a simple groove extends from the base, it is a little curved outwardly in front but does not reach the apex. Elytra nearly twice as broad as long, truncate behind, eurvedly narrowed towards the base, which has: transverse series of small marginal punctures, the sutural striae are fine,

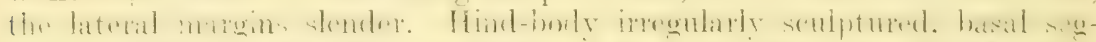

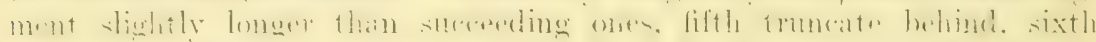
sonewhat retracted, nilrower, widely emarginate, seventh obtusely triangular, with minute yet quite definite terminal styles.

Eyes lateral, with distinct facets, occupying more than half the length of the head. Nandibles fully as long as the head, curved, slender and acute towards the extremity, each with a median tooth which, though moderately elongate, projects so little inwardly that it may escape notice unless examined from the side.

In $D$. bisulciceps (3823) the head is broadly grooved near the sides, the thoracic grooves are broader and impunctate, and the middle pair, instead of being straight, are bent obliquely outwards in front. D. stilbus (3037), a North Island species, is smaller, the mandibles are shorter but the inner tooth of each is more prominent and extends in front of the middle, and the central thoracic grooves are more distant from each other near the base than in front.

Length, $3 \mathrm{~mm}$.; breadth, $\frac{1}{2} \mathrm{~mm}$.

Kiwi Bush, near Glenhope. One individual only, found by Mr. T. Hall on the 4th May, 1915.

\section{Group Oxytelidide.}

\section{Coprostygnus Sharp. Man. N.Z. Coleopt., p. 1027.}

3990. Coprostygnus curvipes sp. nov.

Elongate, subdepressed, glabrous, nitid; black, the legs, clypeus, and basal six joints of antennae castaneous, remaining joints dull fuscous and densely pubescent, palpi and tarsi rufo-testaceous.

Head, including the moderately prominent eyes, almost as broad as thorax, elosely and distinctly punctured near the eyes, very irregularly and more distantly on the vertex, with a short broad groove along the middle hohind. Thorax sarerely as lomg as hroad, fmely maremed, widest and somewhat rombled near the middle. slightly sinuate and narrowert towards the rectangular posterior angles, base and apex truncate; with a sballow central and a pair of basal impressions, the one at each side is dewerer and hats a slight nowliform elevation in front, the dise distinetly but irregularly punctured so that some parts are nearly smooth. Elytra about a fourth longer than broad at the sides, arcuate-emarginate at the extremity, nearly at thimb lomerer and hroader than thorax: on abeh dytron there are 
seven well-marked, apparently punctate, dorsal striae, some are obsolete at the base,- but the punctures there are quite definite; interstices moderately convex, the suture and adjacent two are slightly swollen, but not tuberculate at the extremity. Hind-body twice the length of elytra, not quite as broad at the base, its punctation moderate and shallow; lateral margins strongly reflexed, within these each of the basal four segments las a minute flattened granule, the fifth is carinate along the middle and ends as a narrow strongly elevated tubercle.

Tibiae with numerous fine setiform spines; the posterior pair evidently curved, sightly thichened towards the extemity, minutrely subserrate inwardly.

Antennae stout, as long as head and thorax, the basal two joints obconical, the second about half the size of the first, the sext moniliform and distinctly broader: fourth and fifth transwersely quadrate, abruptly enlarged, about couble the bulk of the third ; sixth hardly any larese than third, quadrate; joints $7-9$ oblong, rather narrower, tenth shorter, eleventh ovate.

Iore sender than C. sculptipemis (1838) and differing in sirval detaik, more especially in the form of the posterior tibiae, which in the same sex of 1838 are quite straight. The male of C. optandus (2457) may be at once recognized by the pair of large elevations near the middle of the clytra, the pair of small tubercles at the extremity of the second and third dorsal segments, the depression arross the base of the third, and the simple, more Coprophilus-like antennae.

o. Length, $6 \frac{1}{2} \mathrm{~mm}$. ; breadth, $1 \frac{1}{3} \mathrm{~mm}$.

Unknown land west of Iount Algidus. Mr. T. Hall found thr. sperimen on the 30th October, 1913.

\section{Coprostygnus picipennis sp. nov.}

Nitid, castaneo-rufous, e]rtra nigro-piceous, jalpi and leces rufo-testareous.

Head fusco-rufous, nearly as loroarl as thorax, distinctly but not coarsely punctured. Thorax slightly broarler than long, finely marginate. veri little wider and rounded at the middle than elsewhere. gradually narroweil towards the rectangular posterior angles: distinctly but very irregularly punctured. some parts nearly smooth, with a large impression near aach side, two basal and a pair of oblique frontal ones, all rather shallow and not sharply limited. Scutellum distinctly punctate. Elytra oblous. sul trunsate behind, a third longer and broader than therax; their striae depe and punctate. interstieres rompex. without tuberenlar inerualities. Hincibodr like that of $C$. concipes but less definitely scolptured. in somm lights appearing mimutrely gramulates the slightly zaiserl, sulangulate hasal pom. tion of the first expensed sement nearly smoreth. just hehind that part there is a small transverse tubercle, on the extremity of the fifth there is a short, narrow upright tubercle.

Tibiae straight, the anterior pair thicker than the others, all with more or less fine spiniform setae on the outside.

Antennae as long as head and thorax, moderately stout, with rellow pubescence and slender setae; basal joint double the size of the obconical second; third obtusely triangular, evidently broader at its apex than the

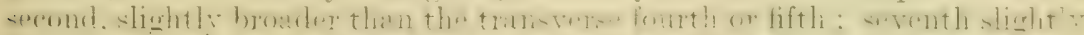

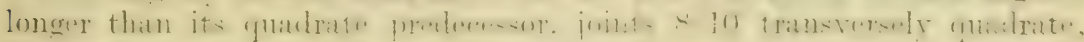
the terminal somewhat elongate-conical. 
The manifestly different coloration, rather small abdominal tubercles, and different antennal structure, the fourth and fifth joints not being ahruptly enlared, will enable entomologists to separate this from the same sex of recorded species.

o. Length, $5 \mathrm{~mm}$. ; breadth, $1 \mathrm{~mm}$.

Glenhope. A single male found by Mr. T'. Hall on the 30th August, 1915.

\section{Group Pselaphidae.}

FARONINI.

Exeirarthra Broun. Man. N.Z. Coleopt., p. 1054.

\section{Exeirarthra parviceps sp. nov.}

Elongate. slightly and interruptedly narrowed anteriorly, nitid ; castaneorufous, olytra and antemnae paler, legs still more so, tarsi yellow, palpi fusco-testaceous; pubescence yellowish, elongate and suberect behind.

Head much shorter and narrower than thorax, narrower in front of the moderately small, prominent eyes, hardly at all narrowed behind, with somewhat rounded hind angles; frontal channel extending as far as the front of the eyes, rather narrow throughout, separating the somewhat elevated tubercles, which, however, are rather broad and flat above; oceipital foveace moderately lare but punetiform. Thorax of about equal leneth and breadth, oviform, rather more narrowed anteriorly than hehind, indistinctly punctate; its subangular median fovea connected with the small, punctiform lateral ones by a curvate impression. Elytra finely punctate, oblong, slightly narrowed near the shoulders; sutural striae fincly punctate natr the base, rather broader and deeper there than behind, with a small basal puncture alongside each, the dorsal tripunctate but hardy attaining the middle. Hind-hody as long as elytra, its third segment rather broater and longer than the others, fimely punctate, the first with minute brassy scales, the true basal one just visible at the extremity of the elytra, fourth and fifth deflexed and, conjointly, obtusely triangular. Legs similar to those of $E$. angustula.

Antenmae rather shorter than head and thorax, moderately slender, very little thickened towards the extremity; basal joint stout, less so near the apex, a third longer than the oblong-oval second; the next only about half the size of it prenterescor ; joints 1 (i difler but little, eighth slightly broader, ninth and tenth transverse, eleventh broken off.

Rather smaller than $E$. angustula (3824), the head evidently so, and with more rounded posterior angles, the eyes also are much smaller, and the antennac are shorter, joints $2-5$ notably so.

$\hat{o}$. Length, $1 \frac{2}{3} \mathrm{~mm}$.; breadth, quite $\frac{1}{3} \mathrm{~mm}$.

Nount Hope, near Nelson. Unique. Found by Mr. T. Hall on the 14th February, 1914, at an elevation of nearly $4,000 \mathrm{ft}$.

Sagola Sharp. Man. N.Z. Coleopt., p. 131.

3993. Sagola bilobata sp. nov.

Elongate, subdepressed, nitid; pubescence yellowish, elongate and suberect; head and thorax rufous, elytra lighter red, ablomen infuseate, thr. Femora sightly so, tibiale fusco-testaceous. tarsi and palpi flarescent, antemae castaneo-rufous. 
Head trigonal, rather short, its hind angles projecting outwardly as far as the widest part of thorax; frontal channel oblong, deep, extending as far as the middle of the eyes, much narrower between the slightly raised antennal tubercles, occipital foveae rather large. Eyes moderately large and prominent. Thorax cordiform, about as long as broad; median fovea subrotundate, deep, the lateral ones oviform but not prolonged beyond the middle, the basal pair of punctures small and alnost confluent with the median fovea. Elytra oblong, double the length of thorax, nearly twice its breadth, only slightly narrowed near the base, apices truncate, their surface finely and irregularly punctate; sutural striae well marked, finely punctured near the base. usually with a distinct basal puncture alongside each, the suture minutely punctate, dorsal striae prolonged as far as the middle, composed of two or three impressions, the posterior largest. Hind-body as broad as elytra but shorter, the first visible segment shorter than the following ones, with minute brassy scales.

Antennae longer than the head and thorax, with slender hairs, basal joint rufous, cylindric, as long as the second and third together, the former oblong-oval, the latter small and moniliform; joints 5-8 slightly broader and shorter than the oblong-oval fourth and fifth, ninth and tenth more or less transversely quadrate.

Underside pubescent, finely and indistinctly punctate; metasternum, and sometimes the abdomen, infuscate. Head with a basal pair of lobes extending forwards, and bearing a yellow fasciculus between and in front of them. Metasternum elongate. Segments 2-4 of abdomen subequal, fifth slightly shorter, sixth short, slightly emarginate, all without impressions; supplementary one broadly triangular, the operculum convex.

This must be placed in Section III, next to S. genalis (1157), which most nearly resemhles it.

Some specimens though immature and nearly testaceous usually have the metasternum infuscate.

o. Length, $1 \frac{2}{3} \mathrm{~mm}$.; breadth, $\frac{1}{2} \mathrm{~mm}$.

Nounts Dick, Alfred, and Earnslaw, near Lake Wakatipu. About a dozen males found by Mr. T. Hall amongst decared leaves, at elevations of over 1,000 ft., between the 26th January and the 17th March, 1914, most of them on Mount Dick.

\section{Sagola tenebrica sp. nov.}

Elongate, interruptedly narrowed anteriorly, shining; pubecence yellow, elongate and suberect, thicker on the hind-body ; head and thorax rufopiceous, elytra rufous, abdomen and antennac fusco-rufous. lews and paly infuscate, tarsi testaceous.

Hrad nearly as large as thorax, subtrigonal, but with obtuse hind angles: frontal channel deepe, moderately broad, extronding as lar as the back of the eyes, considerably narrowed between the nearly flat tubereles. occipital fovear punctiform and distant. Eyes moderate. Tleorax rouncled and widest before the middle. suberordate; median forea subquadrate and uniting with the small 1 asal punctures, lateral foreate dese but not extending forwards to the middle. Elytra a third longer and broader than thorax, gradually narrowed towarcls the base, menly plane; sutural striae deref, simple, the clorsal extend to the midrlle and comsist of a lasal puncture and elongate impression. Ifind-body slightly hrobder and a third longer than elytra, nearly horizontal, first segment simple, rather shorter than second, third longer than adjoining ones, fifth small and narrow. 
Antemna slightly thickened towards the extremity, equalling the head and thorax in leneth basal joint twiee as long as broad, the next broadly oval, third nearly as long but narrower and obconical, fourth ohlong-oval, joints 5-s narrowed towards the apex and laxly articulated, ninth and tenth transversely quadrate, the last subconical.

Ventral sexments 2-5) subequal, sixth larwe, obtusely triangular. Underside of head broadly depressed and pubeseent near its base for half of its width.

This should follow st. major (246), but as the hind angles of the head do mot project outwards it does not angere exactly with the orthodox members of Sinction III. The dark coloration of itself will mable entomologists to separate it from the other species of that section.

․ Length, $2 \frac{1}{2} \mathrm{~mm}$. ; breadth, nearly $\frac{2}{3} \mathrm{~mm}$.

Noa Basin, Canterbury ; 20th October, 1913. A solitary female, from Mr. 'I'. Hall.

\section{Sagola subcuneata sp. nov.}

Nitid, subcuneiform; light castaneo-rufous, legs and antennae paler, tarsi and palpi yellow; pubescence yellow, elongate and suberect, scanty on the head and thorax.

Head narrower than thorax, oviform, with obtuse hind angles; frontal channel deep, oblong, slightly narrower between the antennal tubercles, these are moderately elevated and almost in contact at the extremity, it extends to beyond the back of the moderately large and prominent eyes, and, when viewed from behind, appears to be united to the pair of punctiform occipital foveae. Thorax widest at or near the middle, of about equal

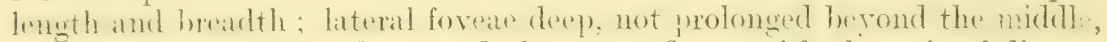
the median one subquadrate and almost confluent with the pair of distant basal punctures. Elytra nearly plane, oblong, nearly double the length of thorax, rather broader than it is at the base, very gradually expanded backwards, finely and indistinctly punctate; sutural striae deep, with a

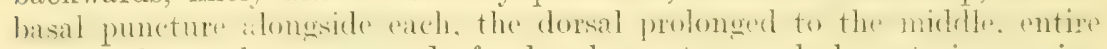
on one elytron but composed of a basal puncture and elongate impression on the other. Hind-body rather shorter but slightly broader than elytra, finely and distantly punctate, first visible segment with minute brassy scales, shorter than the second or third, the remaining ones somewhat deflexed.

Antennae fully as long as the head and thorax. but little thickened towards the extremity, basal joint red, twice as long as broad, second fourth and fifth almost equal, suboblong-oval, joints 6-8 slightly shorter, ninth and tenth transverse, eleventh largest, normal; the third obconical, slightly narrower but scarcely any shorter than contiguous ones.

Underside of head with a transverse groove in front of the eyes, otherwise unimpressed, thinly ciliate across the base. Abdomen distinctly pubescent, second segment shorter than third or fourth; fifth shorter, sixth also short, the suture between them indistinet; serenth small, obtusely triangular.

The rather narrow oviform head excludes this species from Section $\mathrm{X}$. It cannot be placed in Section VIII with Raftray's S. punctulata, which has the frontal ehannel distinetly furcate. Section XIV is composed of species with the thorax oviform, but it is cordate in S. subcuneata; a new section, therefore, must be made for its reeption. The third antennal joint is rather large, and the ill-defined suture between the fifth and sixth 
ventral secments might lead to the supposition that the type is a fromale, but the squamase on the first exposed dorsal segment show that it is a male. o. Length, $-2 \frac{1}{2} \mathrm{~mm}$. ; breadth, $\frac{3}{4} \mathrm{~mm}$.

Moa Basin; 20th october, 1913. Another unique, found by Mr. T. Hall.

\section{Sagola strialis sp. nov.}

Elongate. rather narrow. nitid ; light rufous, abdomen somewhat castaneous, antennar and logs rather paler, tarsi and palpi rellow; pubesence yellow, elongate and suberect.

Head subovate, rather shorter than thorax but nearly as broad, gradually narrowed behind the moderately prominent eyes, with obtuse hind angles: frontal channel deris), only moderately broad, extending to behind the back part of the eyes, much narrower between the almost flat tubercles, occipital foveae free, punctiform and small; the neck finely bipunctate. Thorax cordate, widest before the middle, a little longer than broad; median forea rotundate. bisal punctures free, lateral fovele derp, hardy reaching the midhin. Elytrat at third longer and broader than thorax, suboblong, mently narrowed towark the base, the suture minutely punctured : sutural strias broar and deep, the dorsal apparently entire, or with a small basal punctire, they are rather broad and deep at the base. prolonged to bevond the midrle and become narrow and shallow behind: near the siate of each elvtron the is another but less distinct stria which does not reach either base or apex. Hind-body fully a third longer than elytra, third segment rether longer and broader than the others, fourth and fifth considerably narrowed posteriorly and only slightly deflexed.

Antennae moderately slender, longer than the head and thorax; basa! joint crlindric. narly as long as the following three combined, second stout, suboblong-oval, third evidently smaller, fourth and fifth similar to the second but not quite as thick, joints 6-8 narrowed apically, ninth and tenth transverse, broader than preceding ones, eleventh normal.

Underside distinctly pubescent behind. Head flat behind the eyes, thinly fringed at the hase. Tentral segments 2-t increase, fifth shorte: than fourth, sixth still shorter and narrower, seventh semicircular.

The presence of supplementary outer striae. and the unusually elongate. rlorsal ones, form. in combination. a sufficiently definite character for the separation of this species from all but MI. Raffray's S. fiomtatis (Revere d'Entom., Jan., 1903, p. 23). His species is not represented in my collection, but the description shows that the head and antennar are materially different.

o. Length, $2 \frac{1}{3} \mathrm{~mm}$.; breadth, quite $\frac{1}{2} \mathrm{~mm}$.

Moa Hill, Canterbury; elevation 4,000 ft. Found by Mr. T. Hall on the 20th November, 1913-a single male.

\section{Sagola rectipennis sp. nov.}

Narrow, elongate, nitid, elytra and abdomen straight-sided: rufous, bind-body more infuscate, antemnae and legs light chestnut-red, palpi and tarsi yellow; pubescence yellow, elongate and suberect. longer and more erect behind.

Head shorter than thorax, obliquely narrowed in front of the laroe eres. very slightly narrowed behind them, with obtuse hind angles, distantly and funcly punctate; frontal channel oblong, deep, extending nearly as far as the back part of the eyes. and prolonged forwards so that the nearly 
plane tubercles appear widely separated, occipital foveae distinct, free. Thorax suboviform, rather longer than broad, widest at or just before the middle, indistinctly punctate; lateral foveae deep, not extending beyond the middle, the median one subrotundate, sometimes slightly angulate in front, basal punctures free. Elytra elongate, not double the length of thorax, the suture finely pluripunctate, indistinctly so beyond; sutural striae deep, with a basal puncture near each, the dorsal not prolonged beyond the middle and consisting of a basal puncture and elongate impression. Hind-body as long as elytra, more convex, fourth segnent longer than third but not quite as broad and sometimes a little retracted, the first visible qne shorter than second, with minute brassy scales.

Legs moderately elongate, tibiae with distinct fulvous pubescence, posterior pair more, yet only slightly, curvate and expanded below the middle.

Antennae hardly any longer than head and thorax, gradually incrassate ; basal joint almost twice as long as broad, second suboblong-oval, third smaller, slender at the base, fourth and fifth subglobular and nearly equal; joints 6-8 usually narrowed apically and more laxly articulated, ninth and tenth quite transverse.

Inderside castaneo-rufous, distinctly pubescent, finely punctate. Head with a transverse elevation in front of the eyes, bipunctate just bebind this, simple elsewhere. Metasternum elongate and convex, grooved along the middle. Abdomen elongate, basal segment quite visible, 2-4 increase, fifth almost as long as fourth, sixth retracted and hardly discernible in my reversed specimen, seventh large, the operculum distinct, rather narrow, extending the whole length.

This belongs to Section XIV and most nearly resembles $S$. longicollis (3369), from near the north side of Mount Ruapehu, but it is larger, with longer and less incrassate antennae, different ventral segments, \&c.

Var.-Thorax slightly shorter, its median fovea subtransverse.

o. Length, $2 \frac{1}{2} \mathrm{~mm}$. ; breadth, $\frac{1}{2} \mathrm{~mm}$.

IIount Alfred, north of Lake Wakatipu. Three examples secured by Mr. T. Hall on the 9th February, 1914.

\section{Sagola valida sp. nov.}

Rohust, subdepressed, nitid; with elongate suberect pubescence; head and thorax fusco-rufous, elytra much lighter, hind-body chestnut-red, legs and antennae paler, palpi flavescent.

Head about as large as thorax, curvedly narrowed behind, posterior angles obsolete, abruptly contracted in front so that the eyes are very prominent there; finely and distantly punctate, frontal groove moderately broad and deep, extending beyond the back part of the eyes and somewhat narrowed there, occipital foveae rather narrow; antennal tubereles raised but flat above, separated by a narrow groove. Thorax slightly broader than long, widest before the inddle; distantly and finely punctate ; lateral foveac derep, not raching the middle of the sides, the median one rotundate, basil punctures frew. Elytra rather longer than broad, a third longer than thorax, a little narrowed before the middle, finely junctured ; sutural striae moderately broar and derpe the dorsal consist of a basal puncture and larerer impressom, they hardy attain the middle. Hind-body slightly longer than clytrat, as broad ats they are, hasal serment with mimute brassy scales, nearly as long as the second, third scarcely any longer, the others consider- 
ably narrowed and deflexed. Legs moderately stout, tibiae slightly arched externally.

Antennae about as long as head and thorax, basal joint rufous, thicker, and double the length of the oviform second, third narrower than its predecessor but nearly as long, joints 4-6 subequal, 7-10 laxly articulated, transversely quadrate, 11 subconical.

Ventral segments 3-5 nearly equal, fifth with a lateral impression behind, sixth short, not deeply emarginate apparently, the suture indistinct, seventh obtusely triangular. Head with a distinct curvate cavity in front of the eyes, and an oblique groove inside each of the latter, the triangular central space is gradually narrowed and elevated behind, where it ends as a hooklike spine, which, however, is somewhat obscured by fine yellow pubescence.

A rather large species belonging to Section IX in the present arrangement, but differing from $S$. bifoveiceps (3489), the type of which is preserved in the British Museum, from $S$. nitida (3364), also from Greymouth, and S. opercularis (3698), from Rakaia Gorge, in several details, the lower surface of the head especially.

o. Length, $3 \mathrm{~mm}$; breadth, $\frac{4}{5} \mathrm{~mm}$.

Mount Owen, 27th December, 1914, one; two others from Woodhen Bend, 20th June, 1915, were also found by Mr. T. Hall. The latter locality, near Glenhope, yielded some other interesting novelties.

\section{Sagola cilipes sp. nov.}

Robust, shining, distantly and very finely punctate; head and thorax rufous, palpi, antennae, and legs light chestnut-red, abdomen nearly similar, elytra bright fulvous; pubescence bright yellow, conspicuous, more slender, decumbent, and disposed transversely on the head.

Head rather narrower than thorax, curvedly narrowed behind the eves, which are prominent in front, its hind angles obsolete; frontal channel obscured by the pubescence, subcuneiform, extending to beyond the back part of the eyes, narrower there, antennal tubercles a little elevated, oblique and almost touching each other in front, occipital foveae rather large, elongate, narrowly separated. Thorax cordate, rather broader than long, widest near the front; lateral foveae deep, extending to the middle but only indistinctly prolonged forwards, the median one subangular, becoming narrow and almost reaching the basal margin, basal punctures free, moderately large. Elytra as broad behind as they are long, a third longer and broader than thorax, distinctly narrowed before the middle and with subrotundate posterior angles; sutural striae broad, deeper at the base, the suture minutely punctate, dorsal impressions extending to the middle but not distinctly interrupted, seemingly tripunctate. Hind-body slightly longer than elytra, basal segment with minute brassy scales, rather narrower and shorter than the next, third hardly as long as fourth, the terminal obtusely triangular.

Legs robust, tibiae arcuate externally, the posterior with moderately coarse rigid setae, so that the inner extremity appears to project backwards.

Antennac stout, equalling the head and thorax in length; basal joint red, finely punctate, not double the length of the subobconical second, third obconical, narrower and a little shorter, fourth oblong-oval, joints 5-8 rather shorter, the ninth and tenth almost transversely quadrate: eleventh normal.

Underside light chestnut-red, distinetly pubescent. Fead with a broad interocular furrow, and a transverse basal depression occupring half of the 
whole width, this, however, is divided by a central carina. Metasternum rather short and convex. Ventral segments 2-4 subequal, fifth nearly as long, slightly and widely emarginate, sixth slightly longer, deeply emar-

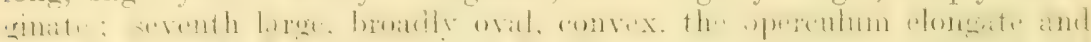

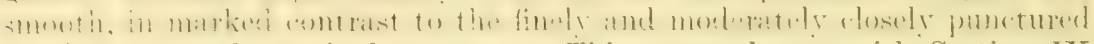
penultimate and terminal segments. This agrees better with Section IX than II.

$\hat{o}$. Length, $3 \frac{1}{4} \mathrm{~mm}$; ; breadth, quite $1 \mathrm{~mm}$.

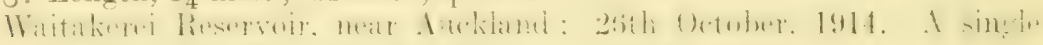
individual found by Mr. A. E. Brookes under fallen timber.

\section{Sagola foveiventris sp. nov.}

Nitid, elongate; clytra and abdomen subparallel, the former only

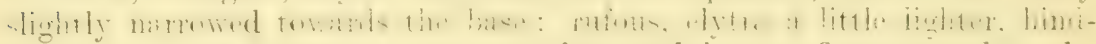
body, legs, and antennae castaneo-rufous, palpi more flavescent than the tarsi ; pubescence clongate, slender, yellow, suberect behind.

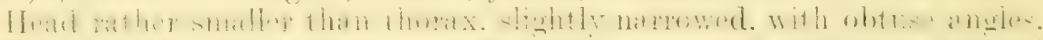

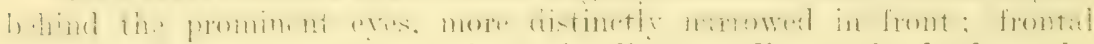
wamnel subquadrate, not very large, hardly extending as far back as the yes, prolonged as a distinct but not broad groove between the almost plane tubereles, occipital foveae iree, well marked and rather elongate. Thoras

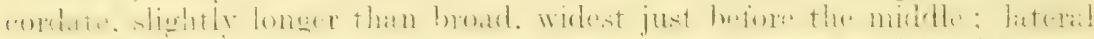

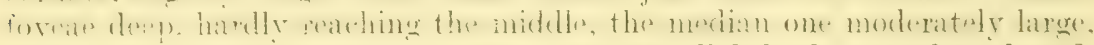
subrotundate, basal punctures free. Elytra slightly longer than broad, is third larger than thorax; sutural striae deep and simple, the dorsal

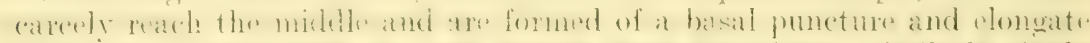

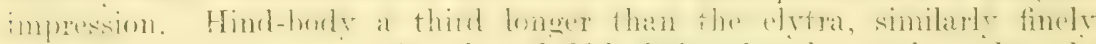

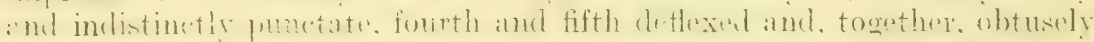
triangular, the basal with minute brassy seales, slightly sherter than the following ones. Legs slender and elongate, tibiae straight.

Intrman quite as long as bead and thorax: hasal jomt not twice ase

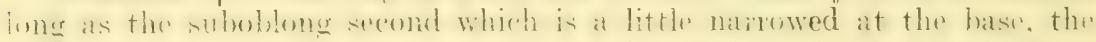
mext nearly as long but narrower and contracted at the base and apex; fourth distinctly narrowed towards the apex, joints 5-7 of similar form but rather broader, 8-10 subquadrate, the terminal normal.

Underside finely and distantly punctate, castaneo-rufous, pubescent. Head with a broad interocular groove. Ventral segments 2-5 subequal; fourth and fifth on the middle, at the extremity, closely and very distinctly punctate, in some aspects appearing minutely granulate; sixth evidently

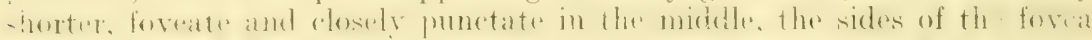

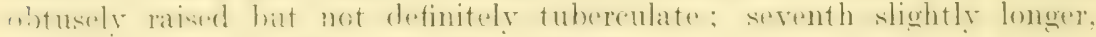
obtusely triangular, the operculum oblique.

The remarkable sculpture of the ventral segments is distinctive and rxactly alike in both specimens, but in the reversed one the fourth antennal joint is much less narrowed towards the apex, the fifth nevertheless is broader at the base. It belongs to Section X.

o. Length, $3 \mathrm{mmm}$; ; breadth, $\frac{4}{5} \mathrm{~mm}$.

Hollyford, north of Lake Wakatipu. Two males secured by Mr. T. Hall on the 19th February, 1914.

4001. Sagola striatifrons sp. nov.

Nitid, elongate, rather narrow, of interrupted outline; pubescence subdepressed, elongate, fulvescent, more slender on the head and thorax; 
antennae, head, and elytra rufous, thorax dark fusco-rufous, hind-bod:rufo-castaneous, legs more or less light chrstnut-red, palpi more flavescent than the tarsi.

Head rather smaller than thorax, slightly narrowed behind the eres. more obliquely in front, with obtuse hind angles; antemnal tubercles plane, the chammel between them linear and uniting with the rather small fovea which hardly extends as far as the back of the cyes, ocripital foveap oblong. quite free. "Thorax cordate, slightly longer than broad, widest before the" middle ; lateral forear deep and axtending to the mirdelle, the wentral one. subrotundate and moderately large, basal puncture cistinct, fren. Filytra nearly a third longer and broader than thorax, distinetly narrowerl before the middle; sutural striae deep, simple, the dorsal, consisting of a basal puncture and elongate impression, are hardly prolonged as far as the middle. Hind-body quite a thire longer than the elytra. not quite as broad at the base, first three segments subequal, fifth contigrably narowed. Legs moderately slender.

Antennae fully as long as the head and thorax, gradually incrassate from the third joint onwards; basii joint not double the length of the oblongoral second, third narrower and obconical, fourth like therecond in shaje: joints 5-7 suberual, narrowed apically, $s-10$ nearly transversely quadrate, 11 subconical, often acuminate.

Fem.-Underside pubescent, chestnut-red. Head transwersely imferesed, impressed in front. Abdomen elongate, third segment slightly longer than seconả, fifth shorter, narrowed behind, sixth narrow, elongate-conical, minutely punctate and pubescent behind, but without a discrernible. sutur. there.

Male.-Sixth segment shorter and narrower than fifth, medially emarginate; seventh small, obtusely triangular. operculum narrow and oblique, indistinct.

This also belorgs to Section X, and appears like S. misella (248) and other Grevmouth species, but, besides other details, is differentiated by its narow frontal groove.

o. Length, $3 \frac{1}{4} \mathrm{~mm}$. ; breadth, nearly $1 \mathrm{~mm}$.

Harris Saddle, Hollyford, \&c. Several obtained by Mr. T. Hall at elevations of 1,100 ft. to 4,200 ft. during February, 1914.

\section{Sagola cordiceps sp. nov.}

Robust, shining, indistinctly punctate : rufous, hind-body more infuscate. antemnae and legs light chestnut-red, tarsi and palpi yellowish; puhescence distinct, elongate, suberect, fulvescent.

Head obcordate, about as large as thorax, gradually narrowed anteriorls; hind angles obtuse, a little depressed and directed slightly hatchwards: frontal channel deepe. moderately broad. extending ats far at the hack of the eyes, with a short narrow basal prolongation, clightly narrowed hetween the forhly raised antemmal tubercles. Which arre alumst contiguous at tler extremity; the base somewhat incurved and depressed so that the free oceipital foveate appear slightly angulate behind. Thorax cordate, of ahout sepual length and breadth. widest hefore the middle: median forea latre..

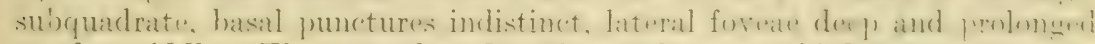
to the middle. Elytra as broad as long, almost a third longer than the thorax, somewhat narrowed before the midlle: sutural striare derp. with hasal puncture alongside atehe the dorsal extend as far as the mislde an: a consist of a basal puncture and elongate in!mesum ; the suture minute? 
punctate. Hind-body fully a third longer than elytra, not quite as broad at the base, first three segments subparallel. Legs moderately slender and elongate, tibiae slightly arched externally.

Intemate equalling head and thorax in length, moderately slender; basal joint quite twice as long as broad, the next oblong-oval, third obeonical but smaller, fourth oblong-oval, fifth rather broader; joints 6-8 subequal, slightly narrowed apically, ninth and tenth transverse, eleventh subconical.

Underside rufescent, finely punctate, with yellow pubescence. Head with a broad sublunate frontal depression. Metasternum rather short and convex. Abdomen elongate, segments $2-5$ subequal, sixth large, finely pubeseent and punctate at the extremity, glabrous across the middle.

If the specimen had been a male I should have had no hesitation in forming a new section for it; at present it may be placed in Section III. The head if transposed would be quite cordate, the eyes are scarcely at all prominent, and the common basal punctures of the thorax are indistinct.

ㅇ. Length, $3 \mathrm{~mm}$. ; breadth, $\frac{4}{5} \mathrm{~mm}$.

Mount Alfred; 9th February, 1914. Found by Mr. T. Hall. Unique.

\section{Sagola fagicola sp. nov.}

Nitid, elongate, more or less indistinctly and finely punctate, with yellowish subdepressed pubescence; varying from rufous to light chestnutred, antennae and legs paler, palpi and tarsi yellow.

Head nearly as broad as thorax, subquadrate behind the antennae, hardly at all narrowed behind the slightly prominent eyes; frontal channel broad and deep, scarcely extending further than the back of the eyes, a little narrower between the slightly raised tubereles, which, however, almost touch each other at the extremity; oceipital foreae distinct, free. Thorax about as broad as long, widest before the middle: lateral foveae deep, hardly "xtending to the middle, the median one subrotundate, basal punctures small, sometimes free. Elytra fully a third longer and broader than thorax, sightly narrowed towards the hase; sutural striae deep, the dorsal, composed of a basal puncture and elongate impression, hardly extend as far as the middle. Hind-body slightly longer than elytra, quite as broad, fourth and fifth segments deflexed and, together, obtusely triangular, the basal three incrase in length. Legs moderately slender and elongate. simple.

Antemate rather longer than head and thorax, very slightly incrassate; basal joint twice as long as broad but not double the length of the subovate second, third evidently narrower, shorter, and bead-like; fourth and fifth subohlong-oval and slightly longer than succeeding ones, which are somewhat narrowed apically; ninth and tenth subquadrate, eleventh subconical.

Cind rside cistatne-rufous, distinctly pubesecnt. If ead with an interocular furrow and a broad, pubescent basal depression. Metasternum molerately chomeate. Third and fourth rentral segments longer than second, fifth similat, sixth shorter, seventh obtusely triangular, the operenlum small or indistinct.

This small species differs more or less from all the members of Section $V$, to which it belongs.

o. Length, $1 \frac{3}{4} \mathrm{~mm}$; breadth, $\frac{1}{2} \mathrm{~mm}$.

Mount Dick, Lake Wakatipu. A dozen individuals found amongst

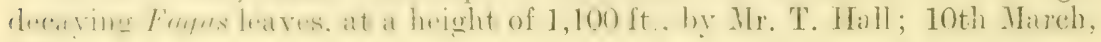
1914. 
400t. Sagola ignota sp. nov.

Nitid, rather slender and elongate, narrowed anteriorly; with distinct, pale-yellow, subdepressed pubescence behind; light castanco-rufous, palpi and tarsi yellow.

Head shorter and rather narrower than thorax, hardly at all narrowed behind the rather large and prominent eyes, with obtuse posterior angles, only slightly contracted anteriorly; nearly plane, with a pair of well-marked and rather large foveae behind the middle; antemnal tubercles broad, distinctly elevated, the moderate groove between them appears to end as an angular fovea, which, however, is not prolonged backwards as an ordinary frontal channel. Thorax oviform, slightly longer than broarl, widest at the middle; lateral foveae deep, scarcely reaching the middle, the median one subrotundate, not definitely connected with the small basal punctures. Elytra oblong, a little narrowed before the mirddle, a third longer and broader than thorax, indistinctly punctate; sutural striae deep, with a small basal puncture alongside each, the dorsal prolonged to beyond the middle, each consisting of a basal puncture and elongate impression. Hind-body a third longer than elytra, not quite as broad at the base, third segment rather larger than the basal, the hinder ones considerably narrowed. Legs simple, slender and elongate.

Antennae not longer than head and thorax, stout; basal joint not twice as long as broad, second and fourth thick and subglobular, third much smaller and, like the.second, with a short basal stalk ; joints 5-10 gradually incrassate, eleventh subconical.

Underside chestnut-red, pubescent. Head with an interocular groove and a broad depression at the base. Abdomen elongate, segments 2-1. subequal, fifth rather shorter, sixth short, seventh obtusely triangular.

The almost entire absence of the ordinary frontal channel, the oviform thorax, and strongly elevated antennal tubercles render this species abundantly distinct, so that a separate section will be instituted for its reception.

ot. Length, $2 \frac{1}{3} \mathrm{~mm}$. ; breadth, $\frac{1}{2} \mathrm{~mm}$.

Routeburn, north of Lake Wakatipu. One only, found by Mr. T. Hall ; 16th February, 1914.

\section{Sagola furcata sp. nov.}

Elongate, elytra and hind-body almost parallel, both distinctly punctate : pubeseence pale grevish-yellow, slender and suberect; shining, rufous. antennae and legs light chestnut-red, tarsi and palpi flavescent.

Head nearly as broad as thorax, genae nearly straight, with obtuse hind angles, narrowed anteriorly, indistinctly punctate ; antrinnal tulsercles broad. slightly elevated yet flat above, the distinct. but not broad, groove between them is divergent just behind them, forming a pair of oblique grooves which extend almost to the base and obliterate the common occipital fovalu. Eyes moderately large and prominent. Thorax sulueredate, rather broader than long; the basal portion much contracted and straight-sided so that the lateral foveace are indefinite, but a distinct stria extends from the hase nearly to the front, thus marking off the dise from each of the rounded sides; median fovea subrotundate. large, not distinctly uniting with the small basal punctures. Elytra oblong, rather broarler and fully a thirel longer than thorax: sutural striae derpe, with a basal puncture aloneside each, the dorsal apparently entire and extending to the minthe. Hinclbody slightly broader and honger than elytra. basal sement shorter than the next, with minute squanae, second and third subequal, remaining 
ones slightly deflexed and much narrowed behind. Legs moderately elongate and slender.

Antennae not longer than head and thorax, gradually thickened; basal joint twice as long as broad but not double the length of the obconical seromel, third of similar form but considerably smaller, the next suboblongoval and slightly longer than any of the following ones; joints 8-10 subquadrate, the terminal normal.

Underside of head with an interocular groove and broad basal depression. Ventral segments 2-5 slightly increase, sixtl short, apparently with

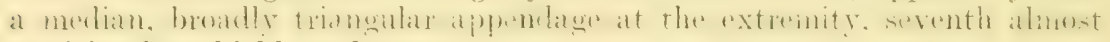
semicircular, thickly pubescent.

This must be located in Section VIII, along with M. Rafiray's S. punclulate (Rev. d'Entom., Jan., 1893). I have not seen his species, no doubt from Greymouth, but the antennae differ, the median thoracic fovea is very large, with a slight anterior prolongation, and the third ventral segment has a subrugose, subtriangular median space.

o. Length, $2 \frac{1}{3} \mathrm{~mm}$. ; breadth, quite $\frac{1}{2} \mathrm{~mm}$.

Belgrove, near Nelson. Unique. Discovered by Mr. T. Hall on the 24 th October, 1914.

\section{Sagola aemula sp. nov.}

Head as large as thorax, obtusely trigonal, the obtuse hind angles slightly wider than the eyes, it is finely but indistinctly punctate; frontal channel deep, extending almost as far back as the moderately large and slightly prominent eyes, it is moderately broad, a little narrower between the slightly raised tubercles, these almost touch each other at the extremity: occipital foveae rather large and subangular. Thorax cordate, of equal length and breadth, widest before the middle; lateral foveae deep and prolonged to the middle. the median one subquadrate and almost conneresed with the small basal punctures. Elytra oblong, fully a third longer than thorax; sutural striae deep, finely tripunctate at the base, with a basal puncture alongside each; the dorsal are prolonged nearly to the middle and are tripunctate. Hind-body a third longer than elytra, its first segment not quite as broad, nearly covered with minute brassy scales, rather shorter than the next, fourth and fifth somewhat deflexed and considerably narrowed. Legs simple.

Antennae quite as long as the head and thorax; basal joint hardly twice as long as broad, not double the length of the stout subglobular wenel, third narrower but seareely any shorter. subovate: joints 1 is

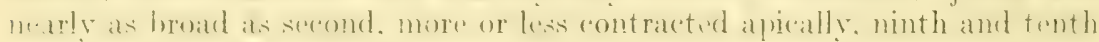
transversely quadrate, the terminal subconical.

Fem.-Head less trigonal, but with its hind angles hardly any narrower

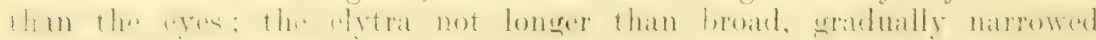
towards the base.

Male.-Ventral segments 2-5 subequal, sixth much shorter, subtruncate behind; seventh longer, obtusely triangular, the opereulum obliquely oblong. Head with a broad depression across the middle, this is straight

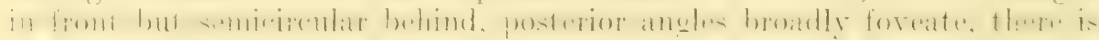
no fringe behind.

The coloration, vestiture, and general form are similar to those of S. halli (3518), but the shape of the head is different, the frontal chamnel not being medially expanded is rather narrower, it is sharply limited behind, whereas in 3518 there is a narrow basal prolongation, and the underside is 


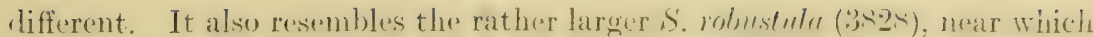
it should be-placed in Section III after $S$. major (246).

ô. Length, $2 \frac{1}{2} \mathrm{~mm}$. ; breadth, $\frac{3}{4} \mathrm{~mm}$.

Iistake Basin, (anterbury. Found hy Mr. T. Hall on the !th Oetober, 1913.

\section{Sagola fasciculata sp. nov.}

Elongate, moderately narrow, shining; rufous, legs and antennae light chestnut-red, tarsi and palpi yellow; pubescence s.llowish. wongate, shender and suberect.

Head rather smaller than thorax, curvedly narrowed behind the moderately prominent eyes, posterior angles obsolete; frontal channel deep, extending further than the back of the eyes, moderately broad, much

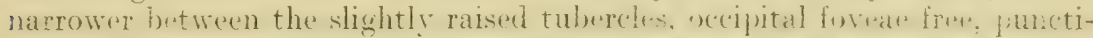
form. Thorax cordate, rather longer than broad. widest before the midrile; lateral fovea deep, hardly attaining the middle, the median one subrotundate but almost uniting with the basal punctures. Eltrat oblong. a third longer than thorax. slightly narrowed towards thr hasir. irrenglarly and finely punctate; sutural striae deeper and broader near the base than elsewhere, the dorsal hardly reach the middle and are formed of a basal puncture and elongate impression. Hind-body as long as elytra, a little narrower at the base, third segment slightly lareer than second. the first with minute brassy scales, fourth aud fiftb deftexirl and, together obtusely triangular. Legs simple.

Antennae rather longer than head and thorax, moderately slender; basal joint rufous. its length fully double the width, siecond oviform, stout, scarcely longer than broad, third similar but considerably sinaller; joint: 4-7 differ but little, more or less narrowed ajsically, eighth slightly shorter and broader but not quite as broad as the transverse ninth and tenth, eleventh subconical.

Fem.-Head rather less curved behind, elytra a little shorter.

Underside chestnut-red, with distinct pubescence. Head with a deep punctiform depression at each side of the base of the mentum : the part between the eves on a slightly higher level than the sides, broadly romidul behind and bearing conspicuous, bushy, yellow pubesence behind. Ahdomen finely punctate, segments $2-4$ increase; fifth shorter, widely emarginate, sixth about as long, seventh short, obtusely triangular.

Rather more slender than other members of Section IX, the head less strongly curved behind, and brightly fasciculate underneath.

o. Length, $2 \frac{1}{4} \mathrm{~mm}$. ; breadth, quite $\frac{1}{2} \mathrm{~mm}$.

Glenhope, near Nelson. One pair discovered by Mr. T'. Hall on the 2oth December, 1914, and another male on the 20th Fehruary, 1915. In another variety the thorax is as broad as long. but the elytra are rather longer.

\section{Sagola minuscula sp. nov.}

Nitid, elongate; rufous, antennae and legi light chestnut-red, palpi and tarsi yellow; with subdepressed, elongate. yellowish pubescence.

Head rather smaller than thorax, obliquely narrowed in front of the moderately prominent eyes, not distinctly narrowed behind them but with rounded hind angles: frontal chamnel extending as far back as the eyes. rather deep and broad but becoming a litthe narrower between the slightly raised tubercles; occipital foreate punctiform, frem. Thorax of about equal 
Length and brealth, widest before the middle; lateral foveae deep, hardly reaching the middle, the median one subrotundate, not distinctly uniting with the basal punctures. Elytra oblong, a third longer than thorax, slightly and gradually narrowed towards the base, their punctation shallow but relatively coarse; sutural striae deep throughout, the dorsal barely attain the middle and consist of a basal puncture and elongate impression. Hind-body as long as elytra. less distinctly punctate, third segment slightly longer and broader than second, fourth and fifth somewhat deflexed and, together, obtusely triangular. Legs simple.

Antennae slightly longer than head and thorax, rather slender; basal joint red, not twiee the length of the oviform second, third small, usually subglobular, fourth and fifth oblong-oval; joints 6-8 slightly broader and narrowed apically, ninth and tenth transverse, the terminal subconical.

Underside chestnut-red, finely pumctate and pubeseent. Head grooved betwen the eves and bi-impressed behind. Abdomen elongate, segments 2-5 subequal, sixth nearly as long but narrower, seventh short and broad.

This small species may be placed in Section $V$ near $S$. rectipes (1878), which was found at Tairua on the east coast of Auckland about forty years ago and has not been met with since.

o. Length, $1 \frac{3}{4} \mathrm{~mm}$. ; breadth, $\frac{1}{2} \mathrm{~mm}$.

Heaven's Gate, near Mount Earnslaw. Five specimens found on the 5 th Fehruary, 1914, by Mr. T. Hall, who also sent three from Mount Alfred. In these the wing-ases are less distinctly punctured, and the third antennal joint is longer than broad.

It Staircase, the southern end of the Remarkables, Mr. Hall obtained a dozen specimens with the median thoracic fovea subquadrate and the antennae a little more incrassate. These are not sufficiently distinct for specific separation from S. minuscula.

\section{Sagola acuminata sp. nov.}

Nitid, elongate, rather narrow, of interrupted contour; rufous, antemnae and legs light chestnut-red, palpi and tarsi fusco-testaceous; pubescenes yellow, elongate and suberect.

Head rather smaller than thorax, nearly straight behind the moderately prominent eyes, with obtuse hind angles; frontal channel sulciform between the plane tubercles, and not perceptibly broader at its termination in line with the back of the eyes; occipital foveae free, distinct, suboblong. Thorax subeordate, slightly longer than broad, widest at or just before the middle; lateral foveae deep, barely reaching the middle, the median one subrotundate, not distinctly uniting with the small basal punctures. Elytra of about equal length and hreadth, moderately narrowed towards the base. slightly longer than the thomax, indistinctly punctate; sutural striae deepe bipunctate at the hase ; the dorsal apparently entire and seareely attaining the middle, outside each of these there is another feroly impressed stria. Hinchody slightly narrower than elytra at the base, nearly double their foneth, segments second and third slightly inerease. fourth as lome but

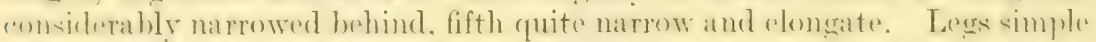
and elongate.

Antennae equalling head and thorax in length, moderately slender; basal joint not double the length of the oviform second, the next nearly similar but smaller: joints $4-7$ differ but little. the fourth more distinctly oviform, 8-10 transversely quadrate, a little broader than preceding ones, eleventh subconical. 
Undersidr chestnut-red, with greyish pubesence. Head with a slightly curved interocular groove. Abdomen elongate, segments 2-4 suberqual, fifth almost as long as fourth but much narrowed behind, sixth still narrower but as long; seventh rather short and narrow.

In facies this resembles $S$. misella (248) and its immediate allies, so that, notwithstanding its nearly straight genae, I place it with them in Section X. The narrow frontal chamnel, undivided dorsal striae, shallow outer ones, and the prolongation of the terminal segment form good distinguishing features.

o. Length, $2 \frac{2}{3} \mathrm{~mm}$. ; breadth, $\frac{2}{3} \mathrm{~mm}$.

Routeburn; 16th February, 1914. Unique. Another of Mr. T. Hall's numerous discoveries.

\section{Sagola rufescens sp. nov.}

Nitid, moderately robust; rufous, hind-body fuscr-rufous, antennae and legs chestnut-red, tarsi and palpi fusco-testaceous; pubescence yellow, elongate and suberect.

Head subovate, nearly as large as thorax, gradually narrowed in front of the prominent eyes, nearly straight behind them, posterior angles rounded, it is only slightly convex; frontal channel deep, extending as far back as the eyes, only moderately broad, of almost the same width to the extremity of the plane tubercles; occipital foveae well marked, quite free. Thorax of about equal length and breadth, oviform, widest at the middle; lateral foveae deep but hardly attaining the middle, the median one subquadrate and almost touching the basal punctures. Elytra about as broad as they are long, nearly a third longer than thorax, a good deal narrowed towards the base; sutural striae deep throughout, the dorsal reach the middle and consist of a basal puncture and elongate impression. Hind-body a third longer than elytra, fully os broad, basal three segments slightly increase, fourth as long as third but much narrowed behind, fifth obtusely triangular. Le'gs moderately stout and elongate, tibiae slightly arched externally.

Antennae not longer than head and thorax, rather thick; basal joint not twice as long as broad, the next subquadrate, third much smaller; joints 4-6 nearly equal, somewhat narrowed apically, seventh and ejghth slightly broader but not quite as broad as the transverse ninth or tenth, eleventh normal.

Underside rufescent. Head with an interocular groove and bipunctate at the hase. Abdomen clongate, segments 2-4 slightly increase, fifth nearly as long but narrowed bohind, sixth obtusely triangular. with an oval central fovea.

The subovate head and thorax. rather thick antennae, and the fovea along the middlo of the sixth rentral segment, in conjunction, will load to its recognition. As there are no minute squanmes on the first visible dorsal seament I consider the specimen to belong to the femshe sex: the wentral fovea in that sex is, however, abnormal. It should at present be located in Section XIV.

q. Lèngth, $2 \frac{3}{4} \mathrm{~mm}$. ; breadth, $\frac{3}{4} \mathrm{~mm}$.

Staircase, nearly ten miles north of Kingston; obtained on the 13th March, 1914, by Mr. T. Hall. Unique.

4011. Sagola bipuncticeps sp. nov.

This closely resembles the male of $S$. acmula but exhibits the following differences:- 
Head underneath with a distinct punctiform depression at each side near the base of the mentum and an intervening transverse groove, a shallow fovea at each hind angle, and a broad flat space across the middle, the basal portion is broadly depressed and thinly pubescent. Ventral segments 2-4 slightly increase, fifth a little shorter; sixth short, truncate behind, seventh obtusely triangular, the operculum large and broad.

S. fasciculata, from Glenhope, is similarly bipunctate near the base of the mentum, but otherwise is very different and referable to another section.

o. Length, $2 \frac{1}{2} \mathrm{~mm}$. ; breadth, $\frac{2}{3} \mathrm{~mm}$.

Ilount Algidus, Canterbury. A solitary specimen found by Mr. T. Hall on the 25th October, 1913.

\section{Sagola affinis sp. nov.}

Nitid, head and thorax infuscate-red, elytra, hind-body, and antennae castaneo-rufous, legs paler, tarsi and palpi flavescent; pubescence yellow, elongate and suberect.

Head obliquely narrowed anteriorly, almost straight behind, its obtuse angles as wide as the prominent eyes; frontal channel moderately broad and deep, it is continued as far back as the eyes, but is not perceptibly narrowed till near the extremity of the slightly raised tubercles, which do not touch each other in front; occipital foveae free and subangular. Thorax slightly longer than broad, widest before the middle; lateral foveac deep and extending to the middle, the median one subquadrate but not uniting with the small basal punctures. Elytra scarcely any longer than broad, a third longer than thorax, slightly narrowed before the middle: sutural striae deep, simple, with a basal puncture alongside each, the dorsal consist of a basal puncture and elongate impression but do not attain the middle. Hind-body as long as elytra, not quite as broad at the base, terminal segments obtusely triangular, second and third subequal, the first shorter and covered with minute brassy squamae. Legs elongate and moderately slender; posterior tibiae obliquely narrowed near the outer extremity and closely ciliate there.

Antennae as long as the head and thorax, moderately slender; basal joint not double the length of the thick oviform second, third nearly as long but more slender. fourth and fifth oblong-oval; joints 6-8 slightly shorter and broader, ninth and tenth transverse and laxly articulated, eleventh subconical.

This speecies belongs to seetion $\mathrm{V}$, but the underside, including the head. is similar to that of $S$. bipmenticeps. The posterior angles of the head, however, though as wide as the thorax, are not wider than the eres. the form therefore is not trienal ; the frontal chammel is less narrowed betweren the tubercles, the thorax is slightly longer. and the dorsal striae of the elyt rat are shorter and consist of two impressions only.

o. Length, $2 \frac{1}{2} \mathrm{~mm}$; ; breadth, $\frac{2}{3} \mathrm{~mm}$.

Ilount Noidus. Lnimue. Found by Mr. T'. Hall on the 25th october, 1913.

\section{Sagola planipennis sp. nov.}

Shining, elongate, rather narrow and flat, elytra and hind-body subparallel; castaneo-rufous, antennae paler, legs fusco-testaceous, tarsi and palpi flavescent; clothed with greyish-yellow, subdepressed pubescence.

Head rather smaller than thorax, obliquely narrowed in front of the moderately smatl, sighty prominent ryes, nearly straight behind them, 
with rounded hind angles; frontal channel derep and moderately brocirl, a little narrower between the slightly raised tubercles, it extends as far back as the eyes but leaves the punctiform occipital foveae quite free. Thorax subeordate, widest just before the niddle, hardly any longer tha: broad; lateral foveae deep, rather small, not reaching the middle, the median one rotundate but not large, the smatl basal punctures free. Elstrat very slighty longer than broud, quite a third longer than theras, gent!y narrowed before the middle, plane; sutural striae well marked, with a basal puncture alongside each, the dorsal consist of a basal puncture and

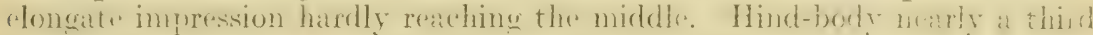
longer than elytra, its basal three segments slightly increase, fourth and

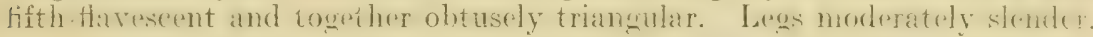

Antennae rather longer than head and thorax, somewhat incrassate from the eighth joint onwards; basal joint not twice the length of the oblong-oval second, the next more slender. lenger than broarl. fourth rather smaller than second; joints 5-7 a little thicker, narrowed apically, 8-10 transverse, eleventh subconical.

Underside chestnut-red. Head with a transverse groove in front of the "Yes, thinly pubescent behind. Abdomen elongate. semplnents 2-5 swhequal, sixth obtusely triangular, hairy.

This may be placed temporarily in Section $\mathrm{V}$, but the absence of the male renders its systematic position somewhat doubtful.

ㅇ. Length, $2 \frac{1}{3} \mathrm{~mm}$.; breadth, $\frac{1}{2} \mathrm{~mm}$.

Hount Oakden, Canterbury. A single female found by Mr. Roderic Urquhart on the 23rd October, 1913.

\section{Sagola brevifossa sp. nov.}

Elongate, subcumeiform, nitid; rufous, hind-body chestnut-red, legs and antennae paler, tarsi and palpi yellow; pubescence yellow, suberect and elongate.

Head rather smaller than thorax, suboviforu. sighty marowed behind the moderate eyes, with obtuse hind angles; frontal channel moderately broad and deep, extending further back than the eyes and becoming narrower between the moderately elevated tubercles, these meet at the extremity: occipital fovea free, punctiform. Thorax subrate. videst near the middie, of about the same length and breadth: lateral foreare deep, but hardly reaching the middle, the median one short, broader than long, indistinctly connected with the basal punctures. Elytra subohlome. a third longer than thorax, gently narrowed towards the base; sutural striae deep, minutely punctate, with a small basal puncture alongside each, the dorsal extend to the middle and consist of a basal puncture and elongate impression. Hind-body slightly longer and broader than elytra, finely punctured; first segment with minute brassy scales, much shorter than the second or third, the others somewhat deflexed. Legs simple.

Antennae rather longer than head and thorax, moderately slender; basal joint red, fully twice as long as broad, nearly double the length of the subovate second, the next smaller, almost obconical; fourth and fifth oblong-oval, joints 6-8 only slightly thicker and shorter, a little

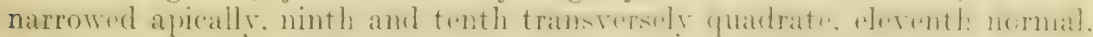

Ventral segments $3-5$ subequal, sixth short, serenth obtusely triangular. Head, undermeath, broadly grooved in front, pubescent behind.

As the thorax is more oviform than cordate, this species should be placed in Section XIV. It differs considerably from S. reclipennis, S. rufescens: 
and the following one. Its principal peruliarity is the short, transwersely quadrate median fovea of the thorax. The basal antennal joint is rather long, and the head is subovate.

ô. Length, $2 \frac{1}{3} \mathrm{~mm}$; ; breadth, $\frac{2}{3} \mathrm{~mm}$.

Routeburn; 16th February, 1914. One, found by Mr. 'T. Hall.

\section{Sagola arboricola sp. nov.}

Nitid, elongate, irregularly narrowed anteriorly; rufous, hind-body castaneous, antenuae and legs light chestnut-red, tarsi and palpi fuscotestaceous, these last rather darker; pubescence yellow, elongate and suberect.

Head almost obcordate, gradually narrowed anteriorly, almost as long but scarcely as broad as the thorax, with obtuse hind angles; eyes rather surall and only slightly prominent; frontal chamel deep, not extending as far back as the eyes, moderately broad, somewhat narrowed between the slightly raised thibereles, these do not touch at the extremity occipital foreae free', very small and punctiform. Thorax oviform, slightly longer than broad, widest at the middle; lateral foveae deep, hardly reaching the middle, the median rotundate, rat!ere small and not in contact with the small basal punctures. Elytra of nearly equal length and breadth, a third longer than thorax, rlistinctly narrowed towards the base, indistinctly punctate; sutural striate deep, the dorsal tripunctate and attaining the middle. Hind-body slightly longer than elytra, first segment shorter than second or third, remaining ones deflexed and, together, subtriangular. Legs simple, moderately elongate and slender.

Antennae as long as head and thorax, moderately slender; basal joint not double the length of the thick obconical second, the next similar in form but evidently smaller, fourth and fifth almost oblong-oval, eighth rather smaller than sixth or seventh, ninth and tenth transversely quadrate, eleventh subconical.

Fem.-Underside of head with a transverse groove in front and a broad basal depression. Prosternum truncate in front. Ventral segments 3-5 subequal, sixth large, obtusely triangular.

In a second female the head and thorax are darker, the frontal channel is rather broader and extends as far back as the eves, and the oceipital foveae are well marked; the dorsal striae of the elytra also differ, being only bipunctate.

The oviform thorax shows that this belongs to Section XIV. It is, however, altogether different from S. rufescens and $S$. rectipennis, and almost equally so from the North Island exponents of the section.

s. Length, $2 \frac{1}{3} \mathrm{~mm}$, ; breadth, $\frac{2}{3} \mathrm{~mm}$.

Hollyford; 19th February, 1914. Taken off standing moss-covered trees, along with other species, at a height of $3,500 \mathrm{ft}$.

\section{Sagola remixta sp. nov.}

Elongate. moderately robust, dytra and hind-hody subparallel, shining; lead and thorax somewhat fusco-rufous, hind-body castaneous, elytra (hestmut-red, loges and antemate rather paler than plytra, palpi and tarsi testaceous; pubescence yellowish, slender, clongate and suberect.

IInal ahmost as laree as therax, obliquely narrowed anteriorly, cenae nearly straight and as wide as the moderately large, slightly prominent "Yes, with rombled hind angles; frontal channel extending quite as far 
back as the eyes, moderately broad and deep between them, narrower hetween the somewhat elevated tubercles, these almost meet at the extremity; occipital foveae quite distinct, free, subangular. Thorax cordate, widest before the middle, of almost equal length and breadth; lateral foveae deep and attaining the middle, the median one subquadrate but not uniting with the basal punctures. Elytra slightly longer than broad, a third longer than thorax, very slightly narrowed before the middle: sutural striae deep, with a basal puncture alongside each, the dorsal scarcely reach the middle and consist of a basal puncture and elongate impression. Hind-body as long as elytra, the terminal segment small and rather narrow, the first with minute brassy scales at its base and shorter than the second or third, which are equal. Legs moderately elongate and slender.

Antennae as long as head and thorax, moderately slender; basal joirt twice as long as broad but not double the length of the oblong-oval second, third much narrower than adjacent ones, oviform, longer than broad, fouth oblong-oval; joints 5-7 slightly broader and somewhat narrowed apically; eighth rather smaller than the trunsversely quadrate ninth and tenth, eleventh larger, quadrate, but with a short apical appendage.

Underside rufescent. Head with a median transverse groove, the space behind it gradually elevated, rounded behind and thickly fringed with bright fulvous hairs, posterior angles flat. Abdomen moderately elongate, second segment rather short, the following three about equal, sixth shorter, seventh convex, obtusely triangular.

This is more slender than the northern S. laminafa (2469), the coloration is materially different, but the general form and sculpture, including the under-surface of the head, are nearly the same. S. halli (3518), another near ally, is stouter, but its thorax is manifestly broader near the front, and the frontal channel is less expanded between the eyes. All three belong to Section XII.

ô. Length, $2 \frac{1}{3} \mathrm{~mm}$. ; breadth, $\frac{2}{3} \mathrm{~mm}$.

Mount Owen, south of Nelson. A single specimen was obtained by Mr. T. Hall on the 27 th December, 1914, during a toilsome journey of three days, including the frequent wading through icy streams.

\section{Sagola planicula sp. nov.}

Elongate, rather flat, elytra and hind-body parallel, nitid; light fuscofulvous, legs and palpi flaveseent; with slender, suberect, grevish pubescence.

Head nearly as large as thorax, almost straight just behind the moderate eyes but with rounded posterior angles; antennal tubercles slightly elevated, rather flat and broad above, the dividing linear groove extending as far back as the middle of the eyes, the distinct punctiform occipital foreae separated by a cariniform elevation. Thorax cordate, widest before the middle, of about equal length and breadth ; lateral foveas small and punctiform, the median one subquadrate, not perceptibly uniting with the basal punctures. Elytra subquadrate, a third longer than thorax, only slightly narrowed near the base, finely punctate; sutural striae deep throughout, the dorsal indistinctly divided and scarcely attaining the middle. Hindbody a third longer than the wing-cases, minutely and distantly punctured. broadly marginate, segments 2-4 successively increase, fourth and fifth deflexed and, together, obtusely triangular. Legs elongate and slender.

Antennae not longer than head and thorax, very gradually thickened towards the extremity; basal joint hardly twice as long as broad, the next stout, a little longer than broad, slender at the base, third similar in 
slape but much smaller; joints 4-6 submoniliform and about equal, seventh and eighth rather broader, narrowed apically, ninth and tenth still broader, transverse, eleventh subconical.

Underside like the upper surface in colour. Head with a deep frontal groove across it. Metasternum rather short and convex. Abdomen elongate, fourth segment largest, fifth shorter; sixth very short in the middle but

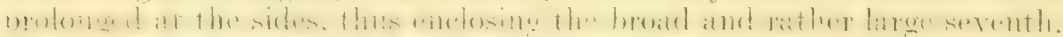

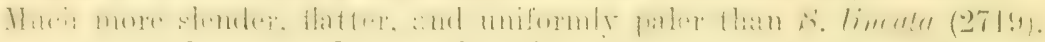
The antemme shorter and somewhat different in structure, the thoracic lateral foveae smaller, and the elytra shorter; the first exposed dorsal segment is without minute brassy squamae.

ô. Length, $2 \mathrm{~mm}$. ; breadth, $\frac{1}{2} \mathrm{~mm}$.

Nount T'e Aroha, Auckland. A single individual, taken by myself, in November, 1910 , at a height of $2,000 \mathrm{ft}$.

\section{Sagola lineiceps sp. nov.}

Elongate, moderately shining; head and thorax rufous, elytra and hind-

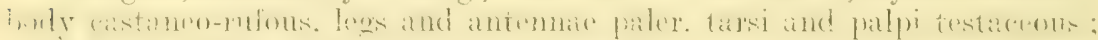

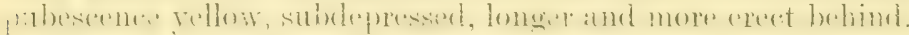

Head almost as broad as thorax, slightly narrowed behind the moderately

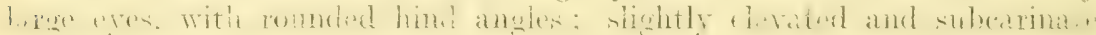
along the middle, the linear frontal groove extending from the front of

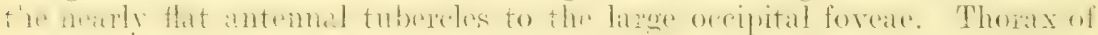
about equal length and breadth, widest at or before the middle; median

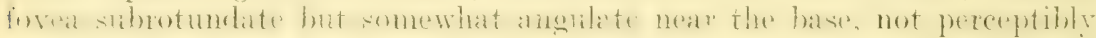
connected with the basal punctures, lateral foveae rather small and punctiform. Elytra subquadrate, slightly narrowed near the base, a third longer than thorax, finely punctate; sutural striae rather broader and deeper near the base than behind, the dorsal rather short, not reaching the middle and not distinctly divided. Hind-body quite as broad as and a third longer than elytra, distinctly punctate, third segment longest, the first simple.

Antennae rather longer than the head and thorax, moderatcly stout, very slightly incrassate towards the extremity: basal joint twice as long as broad but not double the length of the oviform second, third oviform but

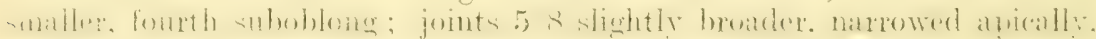

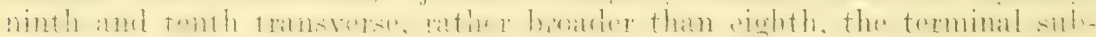
conical.

Differs from S. carinata (3482), (Ann. Mag. Nat. Hist., ser. 8, vol:' $x$, p. 622), the type of which is in the British Huseum, in coloration, more distinctly punctate, its head broader, with the slender frontal channel more prolonged backwards, the lateral foveae of the thorax smaller, the elvtra

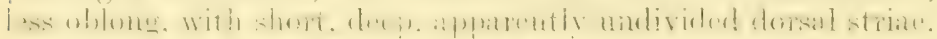

7. Length, $2 \frac{1}{2} \mathrm{~mm}$; ) breadth, $\frac{2}{3} \mathrm{~mm}$. Hall.

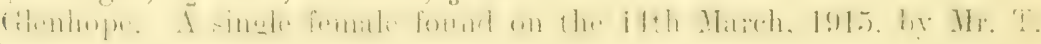

\section{Stenosagola wen. nov.}

Nearly approximated to Sagola but presenting the following differences :-

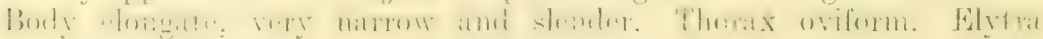
subquadrate, their dorsal striae undivided, short and subpunctiform. Hindbody about double the length of the elytra. Antennae never longer than 
the head and thorax, basal joint stout and rather short, joints 3 and 6 ; "sually 4 also, smaller than the contiguous ones, the frininal three, or fir evidently more expanded than their predecessors.

This genus will inchude Section XVI of Sagola, anmprising s. gracitis (2173), S. crassicomis (3372), and s. comata (3374). This last specter, owing to the connate antennal tubercles, may be considered aberrant.

\section{Stenosagola planiocula sp. nov.}

Nitid, finely but not closely punctate; castaneo-rufous, antemnae paler, legs testaceous, tarsi and palpi yellow; pubescence yellowish, elongate and subdepressed, longer and more erect on the hind-body.

Head rather longer than broad, obcordate, cradually narrowed anteriorly, with obtuse hind angles; frontal channel extending as far back as the eye, deep and moderately broad, a little narrower between the distinctly separated and elevated antennal tubercles; occipital foveae quite free ani punctiform. Eyes flat. Thorax oviform, fully a third longer than broad. widest near the middle; lateral foveae deep, not reaching the middle, the median one moderately large, subquadrate, basal punctures minute or obsolete. Elytra subquadrate, shorter and hardly any broader than thorax, slightly narrowed towards the base; sutural striae rather broad and deep at the base, the dorsal short and subpunctiform. Hind-body quite double the length of elytra, rather wider behind than they are, basal three segments successively increase, fourth paler and slightly shorter than third, fifth retracted.

Legs moderately stout in proportion to the bulk of the insect; tibiae somewhat expanded and arched outwardly below the middle, the posterior obliquely narrowed externally near the extremity.

Antennae shorter than the head and thorax; basal joint not double the length of the subrotundate, thick second, the next very small, fourth slightly larger but not as large as the fifth; sixth smaller than seventh, both transverse, eighth distinctly broader than seventh but not as broad as the transverse ninth or tenth, eleventh subquadrate, rounded at the extremity, not as long as the preceding two combined.

Head, underneath, with a transverse furrow before the eves and a central fovea at its base. Alodomen elongate, first segment short and partly covered by the femora, 2-4 increase, fifth nearly as large as fourth ; sixth and serenth retracted, the latter broad but very short.

o. Length, $1 \frac{2}{3} \mathrm{~mm}$.; breadth, $\frac{1}{3} \mathrm{~mm}$. 1914.

Glenhope, neai Nelson. One found by Mr. T. Hall on the 10 th Derember.

\section{Stenosagola oblongiceps sp. nov.}

This rather smaller species resembles S'. planiocula hut differs ats follows:-

Eres more distinct and slightly convex. Hrad ohlong, its sides straight behind the eves, with nearly rectangular hind angles. Thorax slight]! shorter, its median fovea not as deep and angular. Antennae shorter: fourth joint nearly as large as fifth, sixth distinctly smaller than contiguou. ones, seventh and eighth transverse but not as broad as the following ones. Basal ventral segment quite visible, sixth obtusely triangular, its opereulum oblong.

3. Length, $1 \frac{1}{2} \mathrm{~mm}$; ; breadth, $\frac{1}{3} \mathrm{~mm}$.

Glenhope; 10th December, 1914. Also from Mr. T. Hall. 


\section{Stenosagola griseipila sp. nov.}

Xitid, light rhestmut-red, antemnate and lecre paler. tarsi and palpi yellow ; pubescence greyish, rather short and suberect.

Head slightly curvedly narrowed hehind, gradually anteriorly; frontal channel subquadrate, hardly extending as far as the front of the eyes; oceipital foveare quite free, distinet and punctiform. Artemal tubercles comnate, forming a sort of ridge across the front of the head. Eres minute, but somewhat convex and distinct. Thorax slightly longer than broad, oviform: lateral forcate small and punctiform, the median one subrotundate and rather small, apparently slightly prolonged or angulate in front, basal punctures free but small. Eilytra subquadrate, moderately narrowed towards the base; sutural striae deep there, the dorsal punctiform but oblong. Hind-body nearly double the length of elytra, without dark marks.

Antemate with the third, fourth, and sixth joints very small and moniliform, seventh and eighth slightly broader than fifth, but not as broad as the transverse ninth and tenth, eleventh large, subquadrate.

Differentiated from S. connata (Ann. Mag. Nat. Hist., ser. 8, vol. viii, p. 503) by its minute eyes, narrower head, shorter elytra. \&c

Length, $1 \frac{1}{3} \mathrm{~mm}$. ; breadth, $\frac{1}{3} \mathrm{~mm}$.

Makatote, near Erua. One (February, 1910) in my own collection.

\section{EUPLECTINI.}

Euplectopsis Raffray. Gen. Ins. (Wytsm.), Pselaphidae, p. 82. 4022. Euplectopsis crassulus sp. nov.

Robust, slightly convex, elytra and hind-body parallel and evidently broader than thorax, nitid, indistinctly punctate; the female dark rufous, legs and antemnate chestmut-red, tarsi and palpi fulveseent, the male of a lighter hue; pubescence conspicuous, yellow, suberect.

Head smaller than thorax, narrowed in front of the prominent eyes, nearly straight behind them, posterior angles obtuse: interocular foveace indistinct and confluent with the flat portion, this is proloned and separates the elevated and distant antemal tubercles, its hinder portion is unevenly convex. Thorax slightly longer than broad, suboviform, widest at the midd!la more narrowed in front than behind; the groove along the middle is sharply marked but very narrow, it extends from near the apex to the larow antr-basal lossil. which is divided by a central carina; lateral foreae lare. ench with a shallow frontal prolongation and a fine transverse stria connecting it with the central fossa. Elytra subquadrate, slightly contracted at the shoulders; sutural striae deep and broad at the base, with a slight plica between each and the short, broad intrahumeral impression. Hind-body shorter than elytra, basal segment almost as large as the next, medially impressed at the base and with a fine nearly semicireular earina there, remaining segments deflexed.

Femora robust, the posterior less so; anterior tibiae gently dilated inwardly to below the middle but narrowed at the extremity ; the intermediate pair gradually but considerably expanded, deeply notehed at the extremity, the external portion not as thick as the inner but rather longer, with the tarsus attached to its apex.

Intemnae shorter than the head and thorax; the exposed portion of the

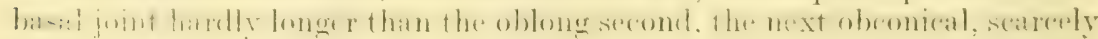
longer than broad; joints $1-6$ short and moniliform, seventh and eighth hardly any broader, narrowed apically; ninth quadrate, double the size 
of preceding one but scarcely broader than the transverse tenth, eleventh longer than preceding two combined, subconical and acuminate.

Underside chestnut-red, distinctly pubescent. Head, in both sexes, studded with small granules, with an indistinct longitudinal carina and many erect grey setae which are minutely knobbed at the end. Prosternum finely longitudinally carinate.

Male.-Metasternum impressed along the middle. Basal ventral segment ciliate behind but almost covered by the femora, segments 2-4 rather short, fifth still shorter; sixth rather longer, semicircularly emarginate, seventh large, broad, its operculum distinct, oblong; these terminal segments finely yet distinctly punctate.

Fem.- Ninth antennal joint hardly as large as the penultimate. Sixth ventral segment smooth behind, punctate elsewhere. Logs moderately stout, simple.

Shorter and relatively broader than the northern E. schizocnemis (3203), its nearest ally. It is more distinctly pubescent; the head and thorax are shorter, and the former has no cariniform elevation. The ninth antennal joint, in the male, is considerably larger than the tenth.

o. Length, $1 \frac{3}{4} \mathrm{~mm}$. ; breadth, $\frac{2}{3} \mathrm{~mm}$.

Glenhope. Four examples found by Mr. T. Hall; 14th Narch, 1915.

Plectomorphus Raffray. Gen. Ins. (Wytsın.), Pselaphidae, p. 105. 4023. Plectomorphus scitiventris sp. nov.

Nitid, moderately elongate, subparallel, slightly convex; rufous, legs and antennae light chestnut-red, tarsi and palpi testaceous; pubescence mostly elongate and subdepressed, mingled with a few long erect setae, elytral apices closely fringed with short yellow setae.

Head smaller than thorax, subquadrate behind the widely separated antennal tubercles, genae straight, with obtuse angles; it is uneven, distinctly punctured, and somewhat elevated at the sides, the foveae are mor or less united to the frontal depression. Eyes small but prominent. Thorax subcordate, about as long as broad, widest before the middle; discal groove moderately deep and broad, extending from the apex to the large basal fossa, lateral foveae prolonged as grooves almost to the front; there is no distinct punctation. Elytra quadrate, a third longer than thorax, slightly narrowed near the base; sutural striae and humeral impressions very broad and deep at the base, these latter very short. Hind-body nearly as long and broad as the elytra, basal segment slightly longer than second, the others deflexed and curvedly narrowed posteriorly. Legs moderately elongate, simple.

Antennae equalling the head and thorax in length; basal joint red, stout, hardly any longer than the oblong-oval second, the next smaller yet longer than broad, contracted at the base; joints $4-8$ small and bead-like, fifth and seventh a trifle larger; ninth and tenth larger, transverse; the terminal nearly as long as preceding four combined, evidently acuminate.

Underside rufescent, terminal ventral segments and head distinctly pubescent, the latter coarsely punctate and with a large angular forea behind. Prosternum with a fine longitudinal carina. Basal ventral segment ciliate and partly covered by the femora, second as long as third at the sides, somewhat obliquely swollen at each side of the middle, correspondently depressed and ciliate behind; third with a central triangular flat lamina in front and a curvate impression at each side of it; fourth 
and fifth very short and widely incurved; sixth as long as preceding two together, semicircularly emarginate, seventh transversely oval.

Fem.-Ventral segments simple.

The smaller, differently shaped head and remarkable abdominal segments at once distinguish this from previously recorded species.

Length, $1 \frac{1}{2} \mathrm{~mm}$. ; breadth, $\frac{1}{2} \mathrm{~mm}$.

(ilenhope, Nelson. Several specimens obtained by Mr. 'T. Hall on the 14th and 30th March, 1915.

\section{Plectomorphus anguliferus sp. nov.}

Moderately convex and robust, nitid; castaneo-rufous, legs and antennae paler, thorax and hind-body more infuscate; pubescence yellow, distinct, suberect, mingled with longer outstanding hairs.

Head large and, including the moderately prominent eyes, nearly as broad as the widest part of thorax, genae oblique or curvedly narrowed behind, its sides somewhat elevated from the antennae to the eyes; the foreae large, indistinctly prolonged towards the smooth, flattened frontal portion, the hind part appears convex and angularly prominent in the middle. Thorax subcordate, about as long as broad, widest before the middle, more gradually and less narrowed behind than in front; discal groove well marked, extending from near the apex to the deep angular fossa, which attains the basal margin and with the usual stria connecting the latter with the large lateral foveae, these are prolonged as grooves nearly to the front. Elytra a third longer and broader than thorax, somewhat narrowed near the shoulders, indistinetly punctate; sutural striae broad, deep, foveiform, and almost duplicate at the base; the dorsal also deep and broad there but becoming shallow towards the middle. Hind-body about as broad as the elytra but shorter, deflexed and rounded behind. basal segment slightly longer than the next, with a transverse impression in front. Legs elongate; anterior femora more robust than the others, the tibiae oblique and bearing short fulvescent setae near the inner extremity.

Antennae moderately slender, equalling the head and thorax in length; basal joint stouter but hardly any longer than the oblong second, the next rather longer than fourth, fifth distinetly longer than adjacent ones, seventh rather larger than sixth, eighth smallest; ninth and tenth evidently broader than preceding ones, the terminal subconical and acuminate, as long as preceding two together.

Male.-Underside rufo-castaneous, distinetly pubescent. Head with a slender central carina which nearly reaches the rotundate basal fovea. Prosternal carina sometimes indefinite. Metasternum flattened or slightly foveate in the middle. Posterior trochanters more distinetly spined than the others. Second ventral segment gradually angulate towards the middle and overlapping the third there, its apex with an upright spiniform process ; fourth longer than the next, both widely incurved behind; sixth rather longer than fourth, almost circularly emarginate, seventh obtusely triangular.

Fem.-Ventral segments 2-5 diminish, the sixth short and broad.

P. Iongiceps (3497), deseribed from a female specimen from Greymouth, and now preserved in the British Museum, is nearly allied, but differs in colour, elytral sculpture, and antennal structure.

Length, $2 \mathrm{~mm}$.; breadth, $\frac{2}{3} \mathrm{~mm}$. 
Routeburn, 16th February, 1914; Hollyford, and Staircase, near Lake Wakatipu; Moa and Mistake Basins, in October, 1913; and Mount Algidus, in Canterbury. About forty specimens found by Mr. T. Hall.

\section{Plectomorphus rugiceps sp. nov.}

Resembles $P$. anguliferus in general appearance, more uniformly chestnut-red, palpi and tarsi fulvescent, more thickly pubescent, but less nitid.

Head suboblong, rugosely punctate, rather narrower than thorax, curvedly narrowed behind the distinct but not prominent eyes, slightly narrowed anteriorly, its sides gradually raised from the eyes to the antennae; the foveae prolonged as broad grooves to the forehead. Thorax subcordate, of about equal length and breadth, widest before the middle, nearly as much but more gradually narrowed behind than in front; lateral foveae prolonged anteriorly, the deep discal channel extends from the apex to the angular fossa which becomes linear at the basal margin, the transverse ante-basal groove well marked. Elytra a third longer and broader than thorax, curvedly narrowed at the shoulders, indefinitely and very finely subgranulate; sutural striae broad and well marked but not distinctly foveiform at the base, the dorsal also broad but very shallow towards the middle. Hindbody as broad as elytra at the base, shorter, with similar sculpture, deflexed and rounded behind.

Legs moderately stout and elongate, distinctly pubescent, tibiae slightly arched externally.

Antennae as long as the head and thorax; basal joint cylindrical, thick, almost double the length of the next, joints $3-7$ of one antenna not agreeing with those of the other; eighth slightly longer than broad, tenth slightly shorter than the oblong-oval ninth, the terminal subconical, elongate and acuminate.

Underside of head with rugose sculpture and a large angular basal depression, and, like the prosternum, without a distinct carina. Metasternum medially impressed. Ventral segments 2-5 gradually diminish, fifth widely incurved; sixth longer than fifth, transversely impressed, semicircularly emarginate; seventh large, transversely oval..

This differs from each of our North Island species in several details, whilst the unusually elongate basal joint of the antennae and abdominal structure, combined, differentiate it from those recorded from the South.

o. Length, $2 \frac{1}{3} \mathrm{~mm}$; ; breadth, $\frac{2}{3} \mathrm{~mm}$. 1914.

Glenhope. One only, discovered by Mr. T. Hall on the 10th December,

\section{Plectomorphus insignis sp. nov.}

Robust, slightly convex, nitid; chestnut-red, antennae and legs paler, palpi and tarsi testaceous; sparingly clothed with moderately short. subdepressed, yellowish-grey hairs.

Head suboblong, nearly as broad as thorax, slightly narrowed behind the moderately prominent eyes, with obtuse hind angles : interocular foveac broadly prolonged anteriorly, its sides, and the hind portion which projects in the middle as far as the eyes, are obtusely convex and on about the same plane throughout. Thorax of abont equal length and breadth, subcordate, widest before the middle, obliquely narrowed in front, gradually behind; central groove well marked, extending from near the apex to the large subangular basal fossa which reaches the hind margin, lateral foveae 18*-Bull. No. 1. 
prolonged to the front, connecting stria normal. Elytra subquadrate, a little narrowed near the shoulders, a third longer and broader than thorax, without definite punctation; sutural striae deep and broad, foveiform at the base, the dorsal equally broad and deep but becoming shallow towards the middle. Hind-body shorter than elytra, nearly as broad, basal three segments subequal. Legs moderately stout; tibiae somewhat arehed externally, the intermediate with a short stout calcar extending obliquely inwards near the extremity. Female simple.

Antennae as long as head and thorax; basal joint short, but little longer than the oblongr-oval second, the next obconical, more slender than the second but quite as long; joints 4,6 , and 7 rather small, suboviform, eighth shorter, fifth oblong-oval, distinctly longer than adjacent ones; ninth nearly twice as broad as its predecessor but not as large as the penultimate, the terminal large, broader than tenth, subconical and acuminate.

Underside concolorous, finely pubescent. Head with a subquadrate basal fovea and a slender median carina. Prosternum longitudinally carinate. Metasternum angularly impressed behind. Second ventral segment larger than third, both widely incurved and fringed with short brassy setae behind, third curvedly depressed at each side of the middle, which, however. is subangulate there so as to partly cover the central depression of the fourth, which is rounded behind in the middle; fifth longer than fourth, truncate behind in the middle, and with a broad central depression ; sixth large, with a small but distinct basal impression, circularly emarginate and enclosing the minutely and densely punctate seventh, which has a narrow operculum. Trochanters spined.

The type of the genus, $P$. spinifer (2476), is certainly the nearest species, but it is of more parallel outline, it has longer antennae with more elongate terminal joints, its eyes are more convex, the head is more obliquely narrowed, the middle tibiae are more conspicuously calcarate, but the remarkable abdominal structure is nearly the same.

o. Length, $2 \mathrm{~mm}$. ; breadth, $\frac{2}{3} \mathrm{~mm}$.

Oakden, near Mount Algidus; 23rd September, 1913. One of each sex in a collection from Mr. Roderic Urquhart and Mr. T. Hall.

\section{Plectomorphus collinus sp. nov.}

Small, nitid; castaneo-rufous, antennae and legs paler, tarsi and palpi testaceous; pubescence yellow, somewhat curled.

Antennae shorter than the head and thorax; second joint oblong, as long and stout as the basal, the next slightly longer than broad, narrowed near its base; joints 4-8 small, subquadrate, nearly alike; ninth rather larger than eighth but not as broad as the penultimate, eleventh large, subconical, acuminate.

Underside of head with upright greyish setae, most of these minutely knobbed at the extremity; its large basal fovea prolonged anteriorly. Prosternum carinate along the middle. Metasternum unimpressed, convex. Second ventral segment with numerous short brassy setae; $3-5$ widely incurved behind, the third almost as long as the second; sixth larger than fifth, almost circularly emarginate and enclosing the large seventh. Trochanters simple apparently.

Fem.-Ventral segments 2-5 diminish, sixth large, simple. Head broader. 
With the exception of the antennal and abdominal structure the male is very similar to that of $P$. scitiventris. It is rather larger, the head is more oblong, evidently narrower than the thorax and apparently impunctate. The mesial thoracic groove is slightly broader near the apex than it is at the large basal fossa. The elytra are rather shorter and more narrowed near the base, where their striae are more foveiform.

Length, $1 \frac{3}{4} \mathrm{~mm}$. ; breadth, nearly $\frac{2}{3} \mathrm{~mm}$.

Staircase, southern part of the Remarkables; altitude, 3,500 ft. Four specimens, found by Mr. T. Hall on the 13th March, 1914.

Vidamus Raffray. Gen. Ins. (Wytsm.), Pselaphidae, p. 89.

4028. Vidamus simplex sp. nov.

Nitid, very finely and irregularly punctate, moderately robust; head and thorax rufo-fuscous, the antennae, legs, and elytra near the base castaneo-rufous, remainder of these last and the hind-body more infuscate; pubescence yellow, slender and subdepressed.

Head quite as broad as thorax, somewhat curvedly narrowed behind the eyes, hind angles obsolete; the foveae prolonged as broad grooves which are confluent in front. Thorax relatively small, slightly longer than broad, widest before the middle, more, and quite obliquely, narrowed in front than behind; ante-basal depression rather large, angular, with a broad groove extending to the base, and a fine stria connecting it with the lateral foveae which are prolonged beyond the middle, basal punctures distinct, free. Elytra oblong, slightly narrowed before the middle, fully a third broader and longer than thorax; sutural striae broad, with a small basal puncture alongside each, intrahumeral impressions broad and deep at the base but becoming shallow and indistinct towards the middle. Hind-body rather shorter than but as broad as the elytra, basal segment a little longer than second, slightly depressed right across its base, remaining ones deflexed and a good deal narrowed behind. Legs simple, moderately slender.

Antennae slender, almost equalling the head and thorax in length; basal joint a little stouter but hardly longer than the oblong second; joints 3-5 slightly decrease, all oblong, 6-8 shorter; ninth distinctly larger than eighth yet much smaller than the laxly articulated tenth, eleventh largest, acuminate.

Underside simple. Ventral segments 2-4 diminish, fifth shorter; sixth semicircularly emarginate, seventh obtusely triangular, the operculum large.

The North Island species $V$. calcaratus (3210) and V. trochanteralis (3380), as well as the southern $V$. gracilipes (3830), possess distinctive sexual characters which are lacking in $V$. simplex, which, however, most nearly resembles 3830 . This last (383i)) has the head less narrowed posteriorly, the elytra are not as large, the intrahumeral impressions are not distinctly prolonged backwards, the intermediate tibiae are armed with a small but quite definite calcar at the immer extremity, and the coloration is different.

o. Length, $2 \frac{1}{2} \mathrm{~mm}$.; breadth, $\frac{3}{4} \mathrm{~mm}$.

Routeburn; 16th February, 1914. Described from a single male discovered by Mr. T. Hall.

4029. Vidamus ovicollis sp. nov.

Elongate, slightly convex, elytra and hind-body, together, oblong-oral, nitid; piceo-rufous, base and suture of elytra more rufescent, legs and antennae obscure rufo-testaceous; pubescence subdepressed, yellowish-grey. 
Head as large as thorax, oblong, gently narrowed anteriorly, hind angles rounded, antennal tubereles widely separated and moderately clevated, eres rather flat; the pair of deep broad grooves are confluent in front and obliterate the common foveat. Thorax suboviform, rather longer than broad, rounded and widest near the middle; ante-basal fossa deep, transverse, angular, with a curvate stria connecting it with each of the large lateral foveae which extend forwards to the middle, its hase tripunctate. Elytra oblong, fully a third longer than thorax, not greatly paceeding it in width, slightly narrowed before the middle, finely and irregularly puncetured; sutural striae deep, punctiform at the base, with two small basal punctures alongside each, the intrahumeral impressions very short, each with a minute inner puncture. Hind-body enrvedly narrowed and deflexed posteriorly, much shorter than elytra, basal three segments subequal, the first finely but distinctly punctate. Legs moderately stout and clongate, tibiae unarmed, slightly arched externally

Antennae shorter than the head and thorax; their thick basal joint seareely longer than the oblong-oval second, the next slightly longer than broad; joints 4-8 small and bead-like, fifth and seventh a little larger than the others; ninth transverse, broader than its predecessor but not as large as the tenth, the terminal subconical, large and acuminate.

Readily distinguished from $V$. brevitarsis (261), V. armiferus (3381), and Reitter's Euplectus incertus (3211), belonging to my Section II, by its rather larger size, different hue, and oviform hinder part of the body.

ㅇ. Length, $1 \frac{2}{3} \mathrm{~mm}$. ; breadth, $\frac{1}{2} \mathrm{~mm}$.

Routeburn; 16th February, 1914. Mr. T. Hall captured a solitary female off a mossy tree.

\section{Vidamus muscicola sp. nov.}

Subdepressed, elytra and hind-body subparallel, the former moderately coarsely and unevenly, the latter rather elosely and distinctly hut finely punctate; it is a little nitid, castaneo-rufous, with paler antennae and legs, and greyish, decumbent, distinct pubescence.

Head oblong, not quite as large as thorax, narrowed in front of the rather large but not prominent eves, with obtuse hind angles; interocular foveae distinct, prolonged and confluent in front; antennal tubercles oblique, narrowed and almost in contact at the extremity. Thorax subcordate, rather longer than broad, widest before the middle, obliquely narrowed anteriorly; the well-marked transverse ante-basal groove connects the laree lateral fovear, these are deep near the middle but shallow at the base, there is no central fossa, but a longitudinal groove extends from the transverse one to the base. Elytra oblong, rather broader than the widest part of thorax, slightly eurvedly narrowed near the base; sutural striae broad and deep, punctiform at the base, humeral impressions very short and broad. Hind-body shorter than but nearly as broad as elytra, the true basial membranous segment partly exposed, second and fourth segments rather lonerer than third, the second vith a trancverse median depression at the base, the others deflexed.

Legs moderately stout, intermediate tibiae with a distinet spiniform process near the inner extremity; basal two joint of the tarsi thicker than the third.

Antennae like those of $V$. onicollis, but with their last joint much less acuminate. 
Underside of head with a basal foveae. Ventral segments 2-4 diminish, fifth as long as fourth; sixth rather longer, seventh short and broad, the operculum oval but small.

Most nearly resembles V. armiferus (3381), (Ann. Mag. Nat. Hist., ser. 8, vol. viii, p. 692), but differing considerably in colour. 'The' head of 3381 is curvedly narrowed behind the eyes and eonsequently more ovate, the interocular foveae are less distinctly prolonged, its thorax is oviform, the second exposed dorsal segment is subcarinate along the middle and depressed at the sides.

o. Length, $1 \frac{1}{2} \mathrm{~mm}$. ; breadth, nearly $\frac{1}{2} \mathrm{~mm}$.

Routeburn; 16th February, 1914. Found by Mr. T. Hall on a mossy tree. Unique (unfortunately).

\section{Vidamus nitidus sp. nov.}

Shining, slightly convex, moderately robust; dark fusco-rufous, legs and antennae chestnut-red; pubescence yellow, suberect.

Head suboblong, quite as large as thorax, hind angles rounded; deeply and hroadly bisulcate so that the foveae are effaced; antennal tubercles slightly elevated, extending obliquely inwards, gradually depressed but not uniting in front. Eyes situated at the middle, moderately large but not prominent. Thorax subcordate, widest before the middle, gradually narrowed behind, about as long as broad; ante-basal fossa transverse, with a groove extending to the base, which is distinctly bipunctate; lateral foveac large, with a shallow prolongation to beyond the middle. Elytra suboblong, evidently longer and broader than the thorax, somewhat narrowed before the middle, finely punctured, most regularly along the suture; sutural striae broad and deep near the base, punctiform there, each with a basal puncture alongside, dorsal striae broad and deep near the base, indistinctly prolonged to the middle. Hind-body very finely punctured, nearly as broad as elytra, a third shorter, basal two segments equal, the others narrowed and deflexed. Legs elongate, moderately slender.

Antennae as long as head and thorax; first joint stout, not longer than the oblong-oval second; joints 3-7 evidently longer than broad, eighth small and bead-like; ninth rather larger but not as broad as the next, cleventh large, subconical and acuminate.

$V$. bryophilus (3531) and V. gracilipes (3830) are broader and more robust, and differ otherwise. $V$. simplex (male) is also more robust, its head is less oblong, the eyes are more prominent, the thoracic median fossa is much larger, and the sixth joint of the antennae is smaller than the contiguous ones.

f. Length, $2 \frac{1}{3} \mathrm{~mm}$. ; breadth, quite $\frac{2}{3} \mathrm{~mm}$.

IIount Algidus, Canterbury. A single female found by Mr. T. Hall; 3rd December, 1913.

\section{Vidamus fossalis sp. nov.}

Nitid, slightly convex, of irregular contour, finely and unevenly punctate; rufo-castaneous, antennar, palpi, and legs paler; pubescence greyish, subdepressed.

Head about as large as thorax, obliquely narrowed in front of the moderately large eyrs, subquadrate behind them, posterior angles obtuse; the foveae not sharply defined, but prolonged as deep, broad grooves 
which are confluent in front; antemnal tubercles widely separated, somewhat elevated, they extend inwardly on a slightly lower plane so as to form a continuous frontal ridge. Neck short. Thorax subcordate, rather longer than broad, widest before the middle, gently narrowed behind; lateral foveate deep, prolonged quite as far as the middle, the transverse connecting stria nearly straight and forming the front of the triangular ante-basal fossa; the basal margin tripunctate. Elytra oblong, slightly narrowed towards the base, a third larger than thorax; sutural striae broad and deep, punctiform at the base, where there is a puneture alongside each, intrahmmeral impressions deep and rather short, each with an indistinct inner puncture; their punctation a little eoarser in the female. Hind-body almost as broad as elytra, rather shorter; basal segment as long as the next, apparently tri-impressed across the base, indistinctly so in the female, the others deflexed and narrowed. Legs moderately stout and elongate.

Antennae rather shorter than the head and thorax; basal joint stout, rather longer than the oblong-oval second, the next obconical, small, yet slightly longer than broad; joints 4-8 submoniliform, fifth and seventh slightly larger than adjoining ones; ninth larger than its predecessor but not as large as the transversely quadrate tenth, the terminal large, subconical and acuminate.

Underside of head with a large fovea behind the middle. Ventral segments 2-5 subequal, sixth semicircularly emarginate, seventh obtusely triangular, the operculum oblong.

Fem.--Elytra rather more brightly coloured.

The deep triangular ante-basal fossa will lead to its recognition.

o. Length, $2 \mathrm{~mm}$; ; breadth, quite $\frac{1}{2} \mathrm{~mm}$.

Greymouth. A single male was received from M. Raffray, of Rome. The female, which belongs to the British Museum, was sent to me with a request that I would identify it. Both specimens were found by the late Mr. R. Helms.

Gabata Raffray. Gen. Ins. (Wytsm.), Pselaphidae, p. 90.

4033. Gabata bifoveata sp. nov.

Nitid, light fusco-rufous, elytra of a brighter red, antennae and legs obseure rufo-testaceous; finely but quite distinctly punctate, moderately robust; pubescence greyish, rather short, slender, suberect.

Head longer than thorax, fully as broad, slightly narrowed in front of the eyes, genae straight, hind angles obtuse; the foveae well marked, prolonged and confluent in front, antennal tubercles widely separated, the neck very short and obsolete. Thorax subcordate, its length and breadth about equal, rounded and widest before the middle; post-median fossa angular, with a very slender basal prolongation, lateral foveate deep, hardly touching the base, ach with a shallow indistinct impression in front of the middle and the usual transverse connecting stria, base bipunctate. Elytra oblong, nearly plane, evidently longer and rather broader than thorax; sutural striae deep, punctiform at the base, where "ach elytron is tripunctate, the external puncture is coarser than the others and forms the humeral impression. Hind-body a third shorter than elytra, basal three segments subequal, the first depressed right across its base. Legs moderately stout, middle tibiae slightly subangulate near the inner extremity. 
Antennae shorter than the head and thorax, rather slender; basal joint stout, longer than the oblong-oval second, the next rather longer than broad; joints $4-8$ bead-like, fifth and seventh slightly larger than adjacent ones; ninth larger than eighth but not as broad as the transverse tenth, the terminal large, subconical and acuminate.

Underside chestnut-red, with greyish pubescence. Head with an angular impression along the middle. Metasternum longitudinally depressed. Ventral segments 2-4 slightly diminish, fifth shorter, sixth semicircularly emarginate, longer than fifth, seventh broad, the operculum also; the third and fourth with a distinct median fovea, and their margins slightly curved and elevated behind.

ऊ. Length, $2 \mathrm{~mm}$; ; breadth, nearly $\frac{2}{3} \mathrm{~mm}$.

Routeburn. A single male discovered by Mr. T. Hall on a mossy tree on or about the 16th February, 1914.

This genus, which is very closely allied to our Vidamus, was founded on a single South African species, G. semipunctata, by M. Raffray in 1898.

\section{Gabata parallela sp. nov.}

Subdepressed, elongate, elytra and hind-body parallel, only moderately shining, irregularly and finely punctate; head, thorax, and hind-body fusco-rufous ; elytra light chestnut-red, legs and antennae paler; pubescence distinct, subdepressed, greyish-yellow.

Head as large as thorax, narrowed in front of the eyes, with rounded hind angles; the foveae prolonged as broad grooves which are confluent in front; antennal tubercles widely distant, the neck distinct. Thorax cordate, of about equal length and breadth, widest near the front, gradually but distinctly narrowed backwards; ante-basal fossa angulate, not at all transversal, with a groove extending to the base and a slight frontal prolongation; lateral foveae subrotundate, distant from the base, basal punctures large but rather indefinite. Elytra flat, oblong, a little broader and quite a third longer than thorax, distinctly but not coarsely punctured; sutural striae moderately deep, punctiform at the base, bipunctate there between each and the very short impression near each shoulder. Hind-body rather shorter than elytra, basal three segments subequal and nearly horizontal. Legs moderately stout, the intermediate tibiae with short brassy setae and subangulate near the inner extremity.

Antennae similar to those of $G$. bifoveata.

Underside rufo-castaneous, finely pubescent. Head with a deep angular depression along the niddle. Metasternum longitudinally impressed. Ventral segments $2-4$ subequal, the second and third with a shallow median fovea, fifth shorter than any of the preceding ones; sixth large, decply emarginate, seventh obtusely triangular, operculum oblong-oval.

The subparallel outline, distinctly cordate thorax, and flat elytra differentiate this species. The lateral foveae of the thorax are situated at the middle, whilst the ventral ones are less obvious than those of $G$. biforeata and occur on different segments.

o. Length, $2 \mathrm{~mm}$. ; breadth, $\frac{1}{2} \mathrm{~mm}$.

Routeburn; 16th February, 1914. One obtained by Mr. T. Hall off a moss-covered tree.

Mr. Hall also found three of Vidamus spinipes (3018), which should be placed in Gabata. 
Eleusomatus Rafiray. Gen. Ins. (Wytsm.), Pselaphidae, p. 112. 4035. Eleusomatus vidamoides sp. nov.

Shining, indistinctly punctate; castaneo-rufous, legs, antennae, and palpi of a much lighter hue; pubescence greyish, slender and subdepressed.

Head as broad behind as the middle of thorax, gradually narrowed anteriorly, with obtuse hind angles, the well-marked foveae prolonged and confluent in front. Eyes small and rather flat. Thorax oviform, longer than broad; the distinct transverse groove between the rotundate lateral foveae scarcely at all enlarged, not extending backwards in the middle. Elytra rather broader but hardly any longer than thorax, gently narrowed towards the base; sutural striae broad and deep, at the base especially, intrahumeral impressions indistinctly prolonged backwards. Hind-body as broad and fully as long as elytra, only moderately narrowed posteriorly, the first exposed segment with a transverse median depression at the base, the following three successively diminish.

Legs elongate. Antennae longer than those of $E$. ovicollis (3725), but of similar structure.

Ventral segments 2-4 diminish; fifth shorter, truncate behind; sixth not much longer, curvedly narrowed behind.

Of rather narrow, elongate contour, and less acuminate posteriorly than other species. The head large and Vidamus-like in seulpture and shape; the thorax without any longitudinal groove, and the ante-basal fossa not prolonged backwards.

o. Length, quite $1 \frac{1}{2} \mathrm{~mm}$. ; breadth, fully $\frac{1}{3} \mathrm{~mm}$.

Routeburn. Unique. Taken off a moss-covered tree by Mr. T. Hall on the 16th February, 1914.

\section{Eleusomatus oculatus sp. nov.}

Elongate, subfusiform, depressed, distinctly but finely punctate, nitid: light castaneo-fulvous, hind-body more castaneous, legs, antennae, and palpi fulvescent; pubescence subdepressed, greyish.

In most details this closely resembles $E$. ovicollis $(3725)$, but the eyes are larger and more prominent, the head is broader behind and apparently more contracted in front, the elytra are a third longer than the thorax: the fifth ventral segment is semicireularly cmarginate so that its sides clasp the rotundate sixth, whereas the fifth in 3725 is truncate behind, and the sixth is free and obconical.

o. Length, $1 \frac{2}{3} \mathrm{~mm}$. ; breadth, nearly $\frac{1}{2} \mathrm{~mm}$.

Mistake Creek, near Mount Algidus. A single specimen obtained by Mr. 'T. Hall along with four of $E$. mirollis (all males) on the 19 th October, 1913.

\section{Eleusomatus subcaecus sp. nov.}

Elongate and narrow, subdepressed, nitid, finely and irregularly punctate; pale chestnut-red, antennae and legs fulvescent, tarsi and palpi pale yellow; pubescence greyish, decumbent, distinct.

Head shorter than thorax, nearly as broad behind the small eyes, cradually narrowed in front of them, posterior angles obtuse ; interocular fovear rather small, indistinctly prolonged forwards; antennal tubereles widely s.parated, somewhat elevated, smooth and shining. Thorax suboviform, rather longer than broad, rounded and widest before the middle; ante-basal fossa angulate and extending almost to the basal margin, united to the rotundate lateral foveae by the usual linear impression. Elytra 
subquadrate, rather broader and a third longer than thorax, a little narrowed towards the base: sutural striae well mark d. foveiform at the base, intrahumeral impressions moderately deep and indis inctly prolonged. Hind-body rather longi $r$ than elytra, nearly as broad, curvedly narrowed but not acuminate behind, first visible segment with a sublunate hasal impression, but hardly any longer than the next. Legs elongate, tibiae somewhat arched externally. Antennae of normal structure, like those of 3725 .

Ventral segments $2-1$ subequal, fifth rather shorter, truncate; sixth longer than fifth, curvedly narrowed behind.

Not so narrow as $E$. vidamoides, it head less oblong, the thorax shorter and rather broader before the middle. It is less fusiform than E. oxicollis; with a larger and broader head.

$\hat{o}$. Length, $1 \frac{1}{2} \mathrm{~mm}$. ; breadth, quite $\frac{1}{3} \mathrm{~mm}$.

Mount Hope, Nelson; 7th March, 1915. A single specimen from Ir. T. Hall.

OBs.-E. caurlatus (2482) erroneously treated by M. Rafiray (Gen. Ins. (Wytsm.), Pselaphidae, p. 112) as the female of $E$. allocephalus (1890). I removed my remaining specimen of that species (2482) from the cardboard and carefully examined it under the microscope. Its ventral structure is as follows:-

Male.-Second segment distinctly longer than third, fourth almost semicircularly emarginate, much shorter than its predecessor; fifth similar to fourth, much shorter in the middle, its sides clasping the basal portion of the sixth, which is about four times the length of the fifth and gradually narrowed towards the extremity.

Male.-E. allocephalus (1890). Ventral segments 2-4 successively diminish, fourth widely emarginate; fifth longer than fourth, transversely impressed, semicircularly emarginate and almost wholly enclosing the broadly oviform sixth.

Male.-E. acuminatus (1891) Ventral segments 2-4 diminish; fifth shorter than fourth, truncate behind; sixth free, about double the length of fifth.

\section{BRACHYGIUTINI.}

\section{Eupinogitus gen. nov.}

Body moderately elongate and convex, interruptedly narrowed anteriorly, elytra and hind-body, together, quite oviform.

Head rather large, slightly narrowed in front of the prominent eyes, curvedly narrowed behind them, vertex distinetly bifoveate. Thorax oviform, with an angular median impression near the base, and an oblique stria proceeding from it to the deep fovea at each side. EJvtra rather broader than long, eurvedly narrowed towards the base. with well-marked sutural and dorsal striae.

Maxillary palpi stout and elongate; basal joint minute, second elongate. slender near the base, clavate at the extremity; third subglobular and thick; fourth truncate at the base, elongate-oval and acuminate, with a minute acicular terminal appendage. Antennae cleven-articulate in both sexes. Mandibles dentate inwardly.

Male.- Tnderside of the head with a longitudinal carina. Metasternum truncate between the widely distant posterior coxae, the depression along the middle with obtusely elevated lateral borders. Basal ventral segment concealed by the femora, ciliate behind; second nearly as long as the third 
and fourth combined, fifth semicircularly emarginate, very short in the middle: sixth large, with a straight membranous median suture behind (less befinite in another example), seventh shorter, obtusely triangular, finely marginate behind.

'This genus is nearly related to Eupines and Raffray's Physe. The latter name. unfortunately, as I informed M. Raffray, has long been preoecupied, so that he may have substituted another.

Enpinogitus can be easily separated by its oviform thorax, longer elytra, and remarkably deep sutural and dorsal striae.

\section{Eupinogitus sulcipennis sp. nov.}

Shining, finely and irregularly punctured ; usually (astaneo)-rufous, with rather paler antennae and legs, tarsi and palpi testaceous; pubescence yellow, distinct and subdepressed.

Head quite as long as thorax, almost as broad in line with the eyes, the foreae between these rather large, rotundate and fincly pubescent; it is broadly impressed between the wide? separated antenmal tubercles. Thorax whest near the middle, hardly at all longer than broad, lateral foveate large and subrotundate. Lilytra a third longer than thorax; sutural striace broad throughout, punctiform at the base, dorsal striae also deep but not reaching the apices, near the outside of each of these there is a shallow angular impression. Basal doraal segment rather larger than second, with a small median depression at its base, the others deflexed.

Legs elongate, intermediate tibiare gently thickened in the male, truncate at the extremity and somewhat angulate inwarlly; the posterior, in both sexes, with slender terminal spines.

Antennae as long as head and thorax, finely pubescent; basal joint stout, not double the length of the oblong second; joints 3-7 clongate and slender, differing but little, eighth shorter, nearly as long but not as broad as thr next, tenth still broader, subquadrate, eleventh large, subovate.

Male.-Underside with distinct yellow pubescence. Basal ventral segment smooth, sixth with a shallow median fovea, finely punctate behind, seventh closely.

Length, $2 \mathrm{~mm}$. ; breadth, $\frac{3}{4} \mathrm{~mm}$.

Staircase, southern and of the Remarkables; $3,500 \mathrm{ft}$. Both sexes obtained by Mr. T. Hall ; 15th March, 1914.

E. picescens, var. ô. Body rufo-piceous, antennae infuscate, theix fifth joint quite definitely longer than the contiguous ones. Unique.

\section{Neosampa gen. nov.}

Body elongate, slightly convex. Head broader than thorax, subquadrate. broadly rounded behind, vertical in front, truncate between the almost plane, widely distant, antemnal tubercles. Eyes situated behind the middle, moderately prominent. Thorax oviform, with a longitudinal suleus, but without any transverse stria to connect it with the subrotundate lateral foveate. Elytra oblong, with distinet sutural striae and short intrahumeral impressions. Hind-body composed of fine visible dorsal segments, and an additional membranous one usually concealed beneath the elytra.

Antennae 11, articulate in both sexes, half the entire length of the body. moderately stout, their terminal three joints more distinetly pubeseent than the others and forming a narrow elongate club; basal joint cylindric, hardly twice as long as broad, the next smaller, longer than broad, 
narrowed at its base; joints 3-7 quite oblong, eighth quadrate; ninth and tenth generally oblong, the latter sometimes shorter, the termirial very elongate-oval, yet scarcely as long as preceding two combined.

Mandibles broad near the base, curvate and acute towards the extremity, each minutely quadridentate inwardly.

Maxillary palpi of only moderate length, their basal joint minute, secrond clongate and gradually incrassate, the next short, subquadrate, fourth elongate-oval and pubescent. claws.

Legs simple; hasal joint of tarsi short, the others elongate; with single

Male-Underside of head with an obtuse tubercle near each side, at the base, of the subquadrate mentum. Prosternum not carinate along the middle. Ventral segments 2-5 diminish, the first covered by the femora; the second with a band of minute brassy scales across its extremity; sixth twice the length of fifth at the sides, deeply emarginate at the middle, rounded towards the sides; seventh broadly conical, occurying the emargination of the sixth, and in my reversed specimen somewhat depressed.

II. Paffray in his collection at Pome has upwards of 130 genera of Euplectini. The elongate antennal articulations of Neosumpa, its oviform, uni-sulcate thorax, ample elytra, Eupines-liks head, simple prosternum, and the structure of the ventral segments of the male, taken together, differentiate the present genus.

\section{Neosampa granulata sp. nov.}

Nitid, elytra and hind-body subparallel, the whole surface with minute, but not close, granular or tubercular sculj,ture; rufo-castaneous, tarsi and palpi a little paler: the pubescence yellow, distinct, moderately elongate, erect behind.

Head plane in front, the ill-defined foveae prolonged forwards as broad grooves but becoming obsolete near the forehead. Thoras of about equal length and breadth, widest near the milddle; discal groove shallow and narrow in front, expanded and foreiform behind. Elytra hardly twice the length or breadth of thorax, a little narrowed near the base; sutural striar subpunctiform at the base, liumeral impressions broad there, indistinctly prolonged towards the middle, with feebly cariniform inner borders. Hindbody shorter than elytra, remotely and indefinitely sculptured; first uncovered segment in both sexes, at the base, with a median depression, this is subtulyerculate at each side; second rather shorter, the others deflexed.

Underside nitid, metasternum rather thickly pubescent and broadly impressed along the middle.

Fem.- Sixth ventral segment simple, larger than fifth; almost the only character which differentiates that sex from the male.

Length, $2 \mathrm{~mm}$.; breadth, $\frac{2}{3} \mathrm{~mm}$.

Boulderstone Cleek and Scarcliff, near Mount Algidus. Four individuals found by Mr. T. Hall on the 18th October, 1913.

Anabaxis Raffray. Gen. Ins. (Wytsm.), Pselaphidae, p. 252 4040. Anabaxis minor sp. nov.

Suboblong, slightly convex, nitid ; light castaneo-rufous, tarsi and palpi flavescent; sparingly clothed with greyish, rather short, drepresed, and a few longer suberect hairs. 
Head nea ly as large as thorax, slightly narrowed anteriorly, curvedly narrowed behind the large prominent eyes, bifoveate between them, flattened or broadly impressed between the widely separated, slightly raised antennal tubercles, with a fovea-like impression just behind each of the latter. Thorax cordiform, of about equal leneth and breadth, rounded and widest before the middle; trifoveate near the base, the transversal connecting stria obsolete. Elytra subquadrate, much broader than thorax, somewhat narrowed before the middle, indistinctly punctate; sutural striae distinet, slightly punctiform at the base, where there is a small puncture alongside each; intrahumeral impressions short, moderately broad and deep. Hind-body as broad as elytra, shorter; basal segment horizontal, half the length of the elytra, and as long as the other deflexed segments combined. Legs moderately elongate, simple.

Antennae about as long as head and thorax, rather slender, finely pubescent; basal joint but little longer than the oblong second ; joints 3-5 more slender than the second but almost as long, sixth and seventh shorter but rather larger than the small eighth; ninth larger, yet smaller than the subquadrate tenth, terminal subconical, largest.

Smaller than A. euplectoides (1869), the thorax less dilated before the middle, with smaller basal foveae, the antennae shorter, the legs more slender, and the coloration uniformly paler.

Length, $1 \frac{1}{3} \mathrm{~mm}$; ; breadth, $\frac{1}{2} \mathrm{~mm}$.

Mount Hope, near Nelson; 14th February, 1915. One, found by Mr. T. Hall amongst snow-grass.

\section{Group Silphidae.}

Inocatops Broun. Man. N.Z. Coleopt., p. 1066.

\section{Inocatops impressus sp. nov.}

Nitid, oblong-oval, moderately convex, depressed across the middle, impunctate; rufous, antennae and legs rufo-testaceous, tarsi flavescent; covered with elongate, suberect, fulvous pubescence; antennae and tibiae finely setose.

Head moderately elongate, about a fourth of the width of thorax. Eyes minute. Thorax a third broader than long, curvedly narrowed before the middle, with depressed and indistinct front angles; base depressed and bisinuate near the middle, truncate towards the rectangular angles; lateral margins fine and somewhat indistinet; at the middle of the base there is a large but not deep impression. Elytra oblong-oval, double the length of thorax, of about the same width as it is at the base, the shoulders angular but on a lower level; the broad seutellar depression extends along the suture but becomes much narrower towards the middle.

Front and middle tibiae straight inwardly, the latter pair slightly cxpanded and oblique at the extremity; the posterior slender at the base, gently curved along the inside, quite oblique at the outer extremity, tarsi rather longer than the others.

Antennae stout, rather longer than the head and thorax, second joint fully as long as the basal; third oblong, shorter than preceding one but longer than fourth, the fifth and seventh larger than sixth or cighth, ninth and tenth much broader, the terminal rather longer at one side than the other. 
This most nearly resembles the female of $I$. separatus (3838) from Mount Hutt, but is distinguishable by the obvious thoracic impression, narrower head and differently formed posterior tibiae.

Length, $2 \frac{1}{4} \mathrm{~mm}$.; breadth, quite $1 \mathrm{~mm}$.

Pakuratahi, near Wellington. One, taken from leaf-mould by Mr. H. W. Simmonds ; 2nd January, 1915.

Isocolon Broun. Man. N.Z. Coleopt., p. 1070.

\section{Isocolon frontale sp. nov.}

Compact, oval, moderately convex, nearly glabrous, with a few fine, indistinct setae along the slender lateral margins, nitid; light castaneous; the labrum, forehead, and apical portion of elytra flavescent; antennae, legs, and tarsi obscure rufous, terminal tarsal joints paler.

Head as broad as thoracic apex, narrowed before the eyes, finely and irregularly punctate; forehead finely margined and rather deeply incurved, the enclosed space pale testaceous and truncate in front. Eyes large, transversely oval, not prominent. Thorax nearly twice as broad as long, gently narrowed anteriorly, base truncate, with almost rectangular angles, the apex slightly sinuate behind the eyes, its angles obtuse; disc distantly, irregularly, and rather finely punctate, a few punctures on the basal half more distinct than the others. Scutellum smooth, broadly triangular. Elytra nearly thrice the length of thorax, of the same width as it is at the base and closely applied thereto, gradually narrowed posteriorly; sutural striae well marked nearly to the apices, their serial punctation rather close and distinct, less so behind; interstices plane, distantly and very finely seriate-punctate.

Tibiae distinctly expanded towards the extremity, spinulose externally, the anterior with about three fine spines only, but an additional and stouter one projects from the outer extremity. Basal three joints of front tarsi moderately dilated, penultimate very small but not discernibly bilobed.

Antennae stout, basal joint no longer than the next, third more elongate, fourth shorter, fifth and sixth short and moniliform; seventh, ninth, and tenth abruptly enlarged, transversely subquadrate, eighth very short, scarcely more than half the width of contiguous ones, the terminal conical.

This resembles the North Island species I. hilaris (1912) in most respects, but differs considerably in coloration; the enlarged antennal joints are hardly any darker than the others. An examination of the frontal portion of the head will at once lead to its identification.

Length, $2 \frac{1}{2} \mathrm{~mm}$. ; breadth, $1 \frac{1}{5} \mathrm{~mm}$.

Mount Algidus, Canterbury. One example only, found by Mr. T. Hall on the 3rd December, 1913.

\section{Isocolon modestum sp. nov.}

Oblong-oval, only moderately convex, nitid, with fine lateral margins and a few inconspicuous setae alongside; fuseo-testaceous, the head and middle of thorax piceo-fuscous ; mandibles, legs, and basal half of antennae rufescent, remaining joints nigrescent and slightly glossy; tarsi somewhat rufo-testaceous, their last joint and the palpi paler.

Head short, slightly and widely emarginate in front, with a groove alongside each eye but without distinct punctation. Thorax subtruncate at base and apex, the breadth about double the length, slightly narrowed towards the front, with obtuse angles; dise with a few scattered, unequal, 
rather fine punctures. Seutellum distinct, obtusely triangular. Elytra thriee the length of thorax, with seven series of fine but distinct punctures on each in addition to those of the sutural stria. Pygidium invisible.

Antennae as long as head and thorax, basal joint free, oblong, the next almost us large, but not as long as the almost obconical third, fourth and fifth subquacirate, sixth transversely moniliform, these bear fine erect setae ; seventh, ninth, and tenth abruptly and considerably dilated, transversely quadrate, eighth very short, not quite as broad as adjacent ones, eleventh conical, longer than the tenth but hardly as broad.

Legs normal; penultimate tarsal joint very small, entire underneath, excavate above in front for the insertion of the slender fifth, claws simple, the soles finely setose; basal three joints of the anterior pair moderately dilated.

Underside finely punctate and pubescent, prosternum testaceous, other parts fuscous.

Labrum transverse, simple. Maxillary palpi with moderately elongate, subacuminate terminal joints, the penultimate subquadrate. Mentum transverse. Prosternum widely emarginate, its flanks unimpressed, the coxae contiguous and situated near the base. Mesosternum medially carnate. Intermediate and posterior coxae only slightly separated. Abdomen with six visible segments.

More oblong and less convex than preceding species, the dilated antennal joints evidently larger.

o. Length, $2 \frac{2}{3} \mathrm{~mm}$; ; breadth, $1 \frac{1}{3} \mathrm{~mm}$.

Woodhen Bend, near Glenhope; 20th June, 1915. Another of Mr T. Hall's discoveries. Unique, unfortunately.

\section{Group Nitidulidae.}

\section{Neocercus gen. nov.}

Elongate, subdepressed, pygidium covered.

Antennae stout, nearly as long as head and thorax, inserted below the edices of the forehead at a little distance from the eyes, 11-articulate; basal joint thickest, scarcely any longer than broad, third obconical, rather longer than the subquadrate second, both rather thicker than the following ones, which, however, are not slender; fourth subquadrate, just perceptibly longer than the transversely quadrate joints 5, 6, and 7 , eighth slightly smaller; ninth and tenth transverse, nearly double the width of preceding one, the terminal oblong, slightly broader and evidently longer than ninth and tenth combined. Mixillary palpi very short, stout, penultimate joint subquadrate, the terminal rather longer and tapering towards the extremity.

Femora pubescent, stout, dilated and grooved underneath at the extremity ; tibiae setigerous, straight, gradually expanded, briefly spined at the extremity. Tarsi pentamerous in both sexes, basal three joints of the anterior or in the male densely and finely setose underneath, first largest, transversoly cordate, third rather shorter than second, the next narrow and short, fifth slender, as long as the dilated basal three together, with simple claws: the other pairs less expanded. Fem.: Basal three joints subcordate, only moderately dilated.

Head as broad as thoracie apex, abruptly narrowed anteriorly ; epistome widely emarginate; labrum very short, truncate in front. Eyes prominent, rotundate, rather large, situated near the base. Thorax transversely quad- 
rate, apex truncate, base feebly rounded, without discernible lateral margins. Scutellum strongly transverse. Elytra elongate-oblong, rather broader than thorax at the base, curvedly narrowed behind.

Mentum very short, with a slightly prominent acute denticle in the middle, oblique towards the sides, with distinct but hardly dentiform angles there. Anterior coxae nearly as far apart as the intermediate, the intervening process with slightly raised lateral margins, it is nearly straight behind and in contact with the broader, subquadrate mesosternal process. Metasternum clongate, grooved along the middle. Abdomen with five segments, the basal largest and acutely angulate between the coxae, 2-4 subequal, fifth slightly longer than fourth, with a rotundate fovea.

This genus cannot be located in the vicinity of the cosmopolitan Brachypeplus or Carpophilus, in both of which the elytra are considerably abbreviated. Xenoscelis, instituted by Wollaston for a single species found on the Canary Islands, is also represented by one in New Zealand, but though both have the pygidium covered they differ otherwise from the following one. In Neocercus the eyes, underneath, have semicircular elevated borders, these behind do not project beyond the eyes, but in front thev terminate as acutely dentiform projections which are quite visible when the insect is examined from above. This character of itself distinguishes Neocercus from every other genus of the Nitidulidae known to me.

\section{Neocercus electus sp. nov.}

Nitid, thinly and irregularly clothed with elongate, decumbent yellow hairs; head, thorax, and base of elytra dark rufous, legs and antennae paler; of a lighter red across the elytra before the middle, about half the length in the female, less in the male, the space behind dark fuscous.

Head distantly punctate on the middle, distinctly bi-impressed. Thorax rather broader than long, its sides slightly rounded, without definite angles; distinctly and moderately closely punctured at the sides, very irregularly on the middle, quite remotely there on some parts; with a rather broad and deep longitudinal impression which, near the base, is divided by a smooth space so that that part seems to be bifoveate. Elytra thrice the length of thorax, with obtuse shoulders, finely marginate, their punctation evenly distributed, as distinct as that of the thorax; in both sexes, on each elytron, there is an oblique transverse impression behind the posterior femur; in the female an additional but broader one near the suture at the middle.

Underside fusco-rufous, irregularly and distinctly punctured, thinly. covered with yellow hairs.

Length, $3 \frac{1}{2} \mathrm{~mm}$. ; breadth, $1 \frac{1}{3} \mathrm{~mm}$.

Mount Algidus, 14th October, 1913, one male; Mount Owen, 26th December, 1914, one female; both found by Mr. T. Hall.

\section{Inopria gen. nov.}

Body robust, suboblong-oval, moderately convex.

Head gradually narrowed anteriorly; forehead depressed and slightly notched in front. Labrum invisible. Eyes moderately prominent, subrotundate. Mandibles very thick at the base, strongly arched, acute and simple at the extremity. Mentum transverse, very slightly rounded in front, without central or lateral angulations. Maxillary palpi only moderately elongate, basal joint small, the penultimate rather shorter than second 
and ohlicye at the extremity, the terminal as long as preceding two, subslindric, slightly eurved, truneate at apex; the labial similar. Antemnal furrows deep and straight alongside the eyes and extending some distance behind them. Prosternum widely emarginate in front; its process prolonged, rather broad, and gradually expanded behind the coxae, its apex trumeate. Front of mesosternum slightly depressed at the sides but not in the middle. Intermediate coxae rather widely separated, almost as far apart as the posterior. Abdomen composed of six segments, the basal largest, subtruncate between the coxae, 2-4 nearly equal, fifth widely emarginate, sixth short, concave at the base.

Antennae 11-articulate, basal joint stout but cylindrical, second just oblong but not as thick; joints 3-5 more slender than preceding one, rather longer, equally elongate, sixth and seventh small, eighth short, at the apex almost as broad as the ninth, which, like the tenth, is strongly transverse and about thrice the width of the seventh, the terminal not quite as broad but with an indistinctly separated, broadly triangular apical appendage.

Femora robust, the posterior especially, strongly arched in front, grooved underneath; posterior tibiae stout, curvate, very oblique at the extremity, bispinose there; the anterior considerably but gradually expanded, subtruncate at apex, the outer angle prominent, elosely and distinctly crenulate along the outside.

Anterior tarsi with the basal three joints broadly dilated, the third deeply emarginate, fourth similarly emarginate but very small, fifth slender, as long as all the others, the claws thickened at the base, the other tarsi almost similar; the expanded joints underneath with dense sponge-like vestiture and many setae, and at the sides with patehes of feather-like appendages, these are quite conspicuous in both sexes even when examined above.

Thorax transverse, the base truncate and resting on the elytra. Seutellum broadly triangular. Elytra oblong, not broader than thorax, curvedly narrowed behind, in the female obliquely narrowed and somewhat prolonged.

\section{Inopria halli sp. nov.}

Oblong, moderately convex, subnitid, finely and closely punctate; with some slender, decumbent, inconspicuous hairs; nigrescent, with a fuscotestaceous spot at each anterior angle of the thorax; palpi, antennae, and legs more or less rufo-piceous.

Head subtrigonal, about half the size of thorax, broadly longitudinally impressed near each side. Thorax nearly twice as broad as long in the middle, apex medially subtruncate, its obtuse angles prolonged to the eyes, the sides distinetly margined and slightly rounded, rather more narrowed anteriorly than behind, posterior angles indefinite, lateral channels narrow. Elytra almost as broad as thorax, not twice its length, with distinct lateral margins and narrow channels, which, however, become obsolete near the rxtremity; on each elytron there are three or four feebly impressed dorsal striae, these become effaced behind, there the suture is slightly elevated.

Underside nitid, black, irregularly and moderately finely punctured, femora inclusive. Metasternum broadly depressed behind, with a subcariniform elevation in the middle of the hollow. Basal ventral segment closely punctate and more thickly pubescent than the others, metasternum and femora more thinly clothed. 
Fem.-Posterior tibiae quite as thick, gradually narrowed towards the subtruncate extremity, hardly at all curved; tarsi with rather less dilated basal articulations; elytral apices subacute and somewhat prolonged.

Length, $5 \frac{1}{2} \mathrm{~mm}$; ; breadth, $2 \frac{2}{3} \mathrm{~mm}$.

Mistake Basin, 20th October, 1913; Nount Algidus, 3rd December. 1913: Routeburn, 11th Ferbuary, 1914. Four males and one female: two of the former sex damaged. The first specimen was taken from a kea's nest at the end of a rocky cavern. I have much pleasure in attaching the discoverer's name to this species.

4046. Inopria notata sp. nov.

Oblong-oval, slightly convex, somewhat nitid, finely and closely punctate ; fusco-castaneous; legs and mandibles testaceous, sides of thorax interruptedly so, as are also, on each elytron, a median basal spot, a transverse undulate ante-median mark, and a less definite one behind: antennae light brown, club dark and opaque; pubescence slender, obscure yellowish, mingled with some coarser depressed setae.

This differs materially from the female of $I$. halli in coloration and vestiture. The elytra are more numerously substriate and their apices equally acuminate. The lateral channels of the thorax are moderately broad and concave, which is not the case in 1 . halli, and the anterior tibiar are more distinctly serrate along the outside.

․ Length, $5 \frac{1}{2} \mathrm{~mm}$. ; breadth, quite $2 \frac{1}{2} \mathrm{~mm}$.

Buller River flat, near Glenhope. One, found by Mr. T. Hall on the 17 th January, 1915.

\section{Group Colyditdae.}

Ulonotus Erichson. Man. N.Z. Coleopt., p. 186.

\section{Ulonotus discalis sp. nov.}

Oblong, subopaque; fuscous, antennae and legs fusco-rufous; clothed with decumbent, obscurely fulvescent squamiform setae.

Head gently narrowed anteriorly, finely granulate. Eyes moderately large and prominent. Thorax, lateral lobes exclusive, slightly longer than broad, deeply sinuate behind the eyes; disc convex, with rather indistinct flattened granules; the central large angular depression is somewhat narrowed near the apex, sulciform behind but slightly expanded at the base, which is bi-impressed near the middle; frontal lobe entire, not half the whole length, obliquely narrowed anteriorly and acutely projecting as far as the front of the eyes; second narrow, placed behind the middle, equidistant from the first and the rectangular basal angle. Scutellum subquadrate. Elytra oblong, rather broader than thorax, lobes inclusive. fully double its length, with obsoletely crenulate margins; on each elytron, between the suture and side, there is an oblong elevation tipped with grey setae, inside this there is a narrower one; in line with the former and the hind femur there is a nodosity, and another at the commencement of the posterior declivity; outside these there are three equidistant nodules, the first is at the middle, the last on top of the declivity, which is also uneven : the sculpture consists apparently of irregular series of small granules.

Legs moderately slender, tibiae nearly straight, with fine curled setae. Antennae shorter than thorax, finely setose; basal joint stout, half hidden above, the next subquadrate, third elongate but not twice as long as fourth. joints 5-8 submoniliform; club oblong. 
The very unequal thoracic lobes and discal sculpture, in conjunction with the arrangement of the elytral nodosities, distinguish this species.

Length, $4 \mathrm{~mm}$. ; breadth, $1 \frac{1}{2} \mathrm{~mm}$.

Routeburn, north-west of Lake Wakatipu. My specimen, with a tibia broken off, was found by Mr. T. Hall on the 11th February, 1914.

\section{Notoulus Broun. Man. N.Z. Coleopt., p. 183.}

4048. Notoulus discors sp. nov.

Oblong, moderately convex, opaque; fuscous, legs infuscate-red, antennate and tarsi paler; irregularly clothed with depressed yellow, and greyish, curled, suberect setae, these latter most conspicuous, and forming on the elytra a pair of elongate basal crests and four subrotundate ones on top of the posterior declivity.

Head fully half the width of thorax, indistinctly sculptured, somewhat dilated in front of the prominent eyes and covering the basal joint of the antemmas. Thorax a third broader than long, base and a pex slightly rounded in the middle, the latter bisinuate, its subacute angles extending to the front of the eyes; its sides explanate, the anterior lobe half the whole length, the second very much shorter ; dise on a higher plane, indefinitely granulate, with three rounded basal impressions, the central one smallest, there are two froutal ones, and a large but shallow and irregular one along the middle. Elytra oblong, eurvedly narrowed behind, double the length of thorax, slightly broader than it is at the base, with rounded shoulders; no definite dorsal sculpture can be seen, but behind the middle there are a few irregular infuscate spots.

Antennae about the same length as thorax, second joint hardly longer than broad, third slender, distinctly longer than following ones, joints 6-8 small and bead-like, ninth transverse and slightly broader; club abruptly enlarged, basal joint transversely quadrate, the other subrotundate.

N. crassulus (3405) is broader, the sides of the thorax are less flattened, the discal impressions are deeper, and each elytron has a large nigrescent mark.

Length, $2 \mathrm{~mm}$.; breadth, $\frac{4}{5} \mathrm{~mm}$.

Titirangi. One, from Mr. A. E. Brookes ; 21st November, 1914.

\section{Allobitoma gen. nov.}

Elongate, convex along the middle, the sides explanate. Antennae 11-articulate, basal joint just visible above; second stout, suboblong, fourth and fifth shorter than third yet distinctly longer than broad, sixth shorter, joints 7-9 moniliform; club abruptly biarticulate, its basal joint thrice the width of the ninth, the terminal not quite as broad, rather short, its apex rounded. Epistome sinuate in front. Labrum transverse. Mandibles bifid at extremity. Maxillary palpi thick, terminal joint subacuminate, not at all securiform. Eyes small but distinct. I'horax lobate. Elytra elongrate-subcordate, with thick prolonged apices. Legs robust, tibiae without apical spines.

Prosternal process moderately broad, extending just behind the coxae. Metasternum short, but little longer than the basal ventral segment, which is rather longer than any of the following ones, fifth strongly rounded behind. Epipleurae broal. Intemnal eavities deep, prolonged straight backwards beyond but not encroaching on the eyes. 
In Bitoma the body is elongate, parallel, and glabrous. The sides are not explanate, the thorax is without lobes, the tibiae are slender and finely bispinose at the extremity, the epipleurae are quite linear alongsid" the abdomen, and the antennal eavities are not prolonged behind the eyes. In Ulonotus the terminal joint of the maxillary palpi is securiform, the antennal cavities are obliquely prolonged, and the antennal club is triarticulate. Allobitoma must be located between these, near Notoulus, which also differs in appearance and structure.

\section{Allobitoma halli sp. nov.}

Subopaque, obscure ferruginous, irregularly clothed with minute brassy setae; moderately elongate, convex along the middle, with granular sculpture, the elytral apices dehiscent, thick and prolonged.

Head subquadrate. Thorax, including the explanate sides, a third broader than long, deeply sinuate behind the eyes; disc nearly plane along the middle, with a pair of prominent, almost horizontal apical elevations which extend a little backwards, and with a small, quite transverse depression close to the middle of the base; each side has a deep median notch, the frontal portion is trilobed, the hind part is about as long as the other and, in front, extends as far outwards, the side, however, is only a little sinuate towards the obtusely prominent hind angle. Elytra of the same width as thorax at the base, rather broader behind the curvedly narrowed shoulders, gradually narrowed posteriorly, with subserrate margins, they are $2 \frac{1}{2}$ times the length of the thorax; each elytron has an elongate basal ridge, and another farther back but nearer the side, the top of the posterior declivity is strongly nodose; their granular sculpture is seriate, but near the sides minute tubercles are discernible.

Legs very thick, bearing numerous grey setae; basal three joints of tarsi about equal and, together, hardly as long as the fourth.

In its natural condition it is encrusted with tawny-grey sappy matter which conceals the sculpture, even the thoracic lobes are only vaguely defined.

The only species at all similar in facies, 325, Tarphiomimus acuminatus, will no doubt be placed in another genus apart from Tarphiomimus.

Length, $4 \frac{1}{2}-5 \mathrm{~mm}$. ; breadth, $1 \frac{1}{2}-2 \mathrm{~mm}$.

Glenhope; 20th December, 1914. It is with pleasure that I attach the name of its discoverer, Mr. T. Hall, to this remarkable little creature, now represented by two individuals.

\section{Glenentela Broun. Man. N.Z. Coleopt., p. 1089.}

\section{Glenentela costata sp. nov.}

Oblong, broad, opaque; pale rufo-fuscous, legs and antennae light red and fincly setose, tarsi testaceous; in its natural condition covered with greyish sappy matter which is difficult to scrape off.

Head half the width of thorax, irregularly and finely granulate, slightly impressed along each side of the middle; labrum rufescent, prominent, rather narrow and smooth; mandibles minutely bifid at the extremitr. Thorax quite a third broader than long, its sides nearly straight behind, curvedly narrowed before the middle; base widely sinuate towards its rectangular angles, apex subtruncate in the middle but with its thick prominent angles extending to the small eyes; dise transversely conver, with a pair of costae, these are elevated in front, much less so, and composed 
of granules, towards the base; the sides are deeply and broadly coneave, with some finer granules than those on the middle, lateral margins thick, reflexed, and gramulate. Elytra subquadrate, of the same width as thorax at the base, more clevated, not double its length, their sides granulate but not explanate, narrowed and vertical behind; on each elytron there is a distinet median costa from the base nearly to the extremity, outside each of these a series of granules appears to form another which does not reach the base or apex, the suture also is slightly raised; the general seulpture is more or less seriate-granulate.

Antennae short, the exposed portion of the basal joint thicker but hardly longer than the suboblong second, third as long but more slender, joints 4-9 short and moniliform, club abruptly enlarged, its terminal joint smaller than the basal.

Underside dark fuscous. Head broadly impressed along the middle, with bright yellow pubescence there. Prosternum with a transverse groove near the apex. Basal ventral segment sinuate behind, not longer than the next in the middle, both indefinitely granulate; third shorter, with deep sutures, fourth very short and flat, fifth with a large angular fovea at each side, these segments minutely sculptured.

Like $G$. serrata (1940) in general appearance, the antennal elevations smaller, thorax a little shorter and not so deeply bisinuate in front, elytral sculpture not as coarse but more evidently granular; the prosternal groove across the front is absent in 1940, which has a triangular impression in front of the coxae.

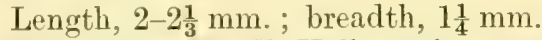

Glenhope. Mr. T. Hall got four examples from decaying leaves on the 18th July, 1915.

\section{Vitiacus Broun. Man. N.Z. Coleopt., p. 1087.}

\section{Vitiacus subcaecus sp. nov.}

Elongate, on a higher plane along the middle than at the sides, lateral margins studded with granules, subopaque; uniformly castaneo-rufous, with very few inconspicuous setae.

Head narrower than thorax, slightly contracted and truncate in front, covered with coarse flattened granules. Labrum smooth, transversely quadrate. Thorax slightly broader than long, its sides almost straight, just a little wider before the middle, curvedly narrowed towards the prominent anterior angles; apex bisinuate, the base nearly similar, so that the posterior angles seem to be directed backwards; disc covered with coarse, slightly flattened granules, the sides not concave, finely and irregularly granulate. Elytra nearly double the length of thorax, scarcely any broader than it is at the base and closely applied thereto ; their sides nearly straight and slightly explanate as far as the hind thighs, behind these distinctly but not abruptly narrowed; the seulpture appears to consist of series of subquadrate punctures, these however in other aspects seem to be granules, alongside the basal part of the suture these form single rows but become duplieate behind; the longitudinal interstices nearest these, being only indistinctly elevated, cannot be termed costae, but they become obviously costiform near the extremity so that the declivity appears depressed in the centre.

Legs moderately elongate and slender, finely setose, tibiae slightly curved externally, tarsi moderately thick. 
Antennae shorter than thorax, finely setose, basal joint scarcely at all visible above, second thick, subquadrate, third oblong and more slender, evidently longer than fourth, joints $5-8$ short, ninth slightly broader and oblique; club short and broad, a little dilated inwardly, both joints transverse, the apical not quite as broad as the basal.

Underside irregularly granulate, with some fine yellowish setae. Prosternum carinate and bisulcate between the coxae. Metasternum with a quadrate median depression behind. Epipleurae broad and granulate. Abdomen with deep sutures, segments 2-4 broadly impressed in the middle. Terminal joint of maxillary palpi subovate. Eyes indistinct.

In the type of the genus there is a smooth basal transverse groove on the head, and the elytra are quite costate. $V$. costicollis is also smaller, with the thorax bicostate.

Length, $3 \frac{1}{3} \mathrm{~mm}$. ; breadth, $1 \frac{1}{3} \mathrm{~mm}$.

Hollyford. One, taken off a mossy tree on the night of the 20th February, 1914, by Mr. T. Hall.

\section{Vitiacus posticalis sp. nov.}

Subopaque, dark fuscous along the middle, the sides, legs, antennae, and head somewhat rufescent, with a few fine flavescent setae.

In appearance somewhat similar to $V$. subcaecus, but rather larger and with more prominent eyes; these in most species, however, owing to their coarse but not very convex facets, are not easily distinguishable from the adjacent granular sculpture.

Thorax with almost straight sides, curvedly narrowed towards the obtusely prominent front angles, the posterior angles obtusely rectangular but not projecting backwards; disc impressed along the middle, with two series of broad flattened granules behind, more irregularly and numerously granulate in front, this part has costiform borders; just outside these costae, behind the middle, the granules are flat and indistinct, but on the sides they are coarser and closer than in $V$. subcaecus. Elytra just twice the length of thorax, the base medially emarginate but straight towards the obtusely rectangular shoulders; their sides nearly straight and a little explanate to beyond the hind thighs, but on each elytron, near the extremity, a lateral swelling with finely granulate margins covers the lower posterior portion of the true side; the suture is sharply defined but becomes thickened and slightly convex near the top of the declivity, and along either side of it there is a single series of about twelve very distinct granules, each series has a well-marked outer carina from the base nearly to the declivity, and nearer the side, between the hind thigh and extremity, there is a short costa; the declivity is thickly bicostate, with singly rounded apices.

Underside fuscous, metasternal impression large, abdomen almost entirely without granulation.

The thoracic and elytral costae, unmistakable granulation, and posterior dilations are distinctive. The antennal club also differs, the terminal joint, instead of being narrower than the basal, is quite as broad, and both are evidently dilated inwardly; the ninth joint is oblique at the base.

Length, $3 \frac{1}{2} \mathrm{~mm}$. ; breadth, $1 \frac{1}{2} \mathrm{~mm}$.

Hollyford; 20th February, 1914. One in Mr. Hall's collection.

\section{Vitiacus purus sp. nov.}

Subopaque, fuscous, the head, antennae, and legs fusco-rufous; with a fer fine pale setae. 
Head with coarse flattened granules. Thorax of about equal length and breadth, its sides nearly straight, rounded towards the obtuse front angles, apex only moderately sinuate behind the small "yes, base widely but not deeply bisinuate, with obtusely rectangular angles; dise only moderately convex, covered with coarse, subrotundate, somewhat flattened granules, the broad but not at all coneave sides less coarsely granulate. Elytra not double the length of thorax, as broad as it is at the base, with oblique shoulders, very gradually narrowed backwards; they are seriate-granulate or punctate; the suture is very slightly elevated on top of the declivity, and outside it, a little farther in advance, on each elytron, there is a similar short elevation which represents the usual first costa; the declivity is concave in the middle and has a thick, somewhat curved costa near each side.

Antennae short, finely setose, second joint stout and subquadrate, third a little longer but thinner, longer than either fourth or fifth, joints $6-8$ transverse, ninth slighter broader, symmetrical; club not distinctly dilated inwardly.

A small species with simple sculpture, oblique shoulders, and different antennae.

Length, $2 \frac{1}{2} \mathrm{~mm}$; breadth, $1 \mathrm{~mm}$.

Hollyford; 16th February, 1914. Mr. Hall has been unable to secure more than one.

\section{Vitiacus suturalis sp. nov.}

Elongate, subopaque, fusco-rufous, with fine flavescent setae.

Head gradually narrowed in front of the antennae, with coarse flattened granules and distinct fulvous setae. Thorax slightly broader than long, deeply sinuate behind the indistinct but coarsely facetted eyes, with somewhat rounded front angles; its sides nearly straight, only slightly curvedly narrowed anteriorly, base bisinuate, with rectangular angles; disc bicostate, most evidently in front, the intervening space with double series of coarse flattened granules, the sides a little concave, with nearly similar sculpture. Elytra double the length of thorax, very slightly wider at the base, with obtusely rectangular shoulders, they are a little broader before the hind thighs but gradually narrowed posteriorly; their sculpture apparently consists of a combination of seriate granules and punctures, the suture is elevated along the declivity, the dorsal pair of costae enclose duplicate series of granules between each and the suture, they are distinct as far as the summit of the declivity, rather less so behind; outside each of these, behind the posterior femur, there is an abbreviated costa.

Smaller than $V$. posticalis, the sides of the thorax concave, the granulation different throughout, the elytral suture and costae also differ, and the lateral dilations near the apices of that species are obsolete or altogether absent. The ninth antennal joint is not oblique, and the club is less, though distinctly, dilated inwardly. It differs, too, in several details from the older species, 1937, 2501, and 2774.

The tibiae are destitute of spines, but, like other members of the genus, are furnished with a cluster of fine setae at the extremity.

Length, $3 \mathrm{~mm}$. ; breadth, $1 \frac{1}{5} \mathrm{~mm}$.

Mount Owen. A single individual found by Mr. T. Hall on the 27th December, 1914. 
4055. Vitiacus setarius sp. nov.

Nigro-fuscous, slightly nitid, antennae, legs, and labrum fusco-rufous; thinly clothed with fine, decumbent yellowish setae, which are most conspicuous near the sides; lower surface rather thickly setose.

Head indistinctly granulate, longitudinally impressed near each side. Thorax slightly broader than long, the sides straight behind, a little broader near the front, slightly curvedly narrowed towards the obtuse anterior angles, apex widely but not deeply sinuate behind the small eyes, posterior angles rectangular; disc distinctly depressed from the apex to behind the middle and partly smooth there, the coarse flattened granules become less coarse and close near the broadly concave sides. Elytra oblong, subovate, with obtusely rectangular shoulders, very slightly broader than base of thorax, quite twice its length, a little wider near the hind thighs than elsewhere, lateral channels narrow but quite visible nearly to the extremity; their sculpture granular or punctiform according to the point of view; on each elytron the costa near the suture extends from base to apex; the second, near the hind thigh, is short and obsolete, the third, in front of it, is short and narrower; the suture is somewhat costiform on top of the declivity, which appears bi-impressed near the extremity; from the apex, just above the side margin, a granular carina extends obliquely towards but distant from the thigh.

Basal four ventral segments almost smooth, each with a slight obtuse elevation between the middle and side; fifth encircled by a sublunate appendage or supplementary segment, as is the case in other species described in this paper.

Hore elongate than $V$. costatus (1937), the head without the smooth basal line; the thorax less deeply emarginate behind the eyes, discal impression larger and deeper but not prolonged backwards as a fine stria, as in 1937, its granulation coarser and more flattened; the second elytral costa obsolete; the legs are rather thicher, and the antennal club unsymmetrical.

Length, $3 \frac{1}{2} \mathrm{~mm}$. ; breadth, $1 \frac{1}{3} \mathrm{~mm}$.

Erua, near Waimarino. Two examples found amongst decaying forestleaves in January, 1909 and 1910.

\section{Vitiacus lateralis sp. nov.}

Elongate, a little broader near the front of thorax than elsewhere, sparingly clotled with fine fulvescent setae, slightly nitid; dark fusco-rufous, the labrum, antennae, and legs more rufescent.

Head with indistinct, flattened granules; eyes slightly convex but small. Thorax a third broader than long, very gently narrowed towards the bisinuate base, which has rectangular angles; apex finely eiliate, almost truncate, with obtuse but only moderately prominent angles; somewhat unevenly but not deeply impressed before the middle, with coarse granular sculpture there; sides more broadly coneave in front than behind, the granulation not much finer than that of the disc. Elytra of the same width as thorax at the base, twice its length, shoulders obtusely rectangular, a trifle wider before the hind thighs, gradually narrowed posteriorly; the slender suture is obviously thickened at the summit of the declivity, the distinct costa nearest it extends from base to apex but is curved outwardly in line with sutural elevation, the short second costa begins at the hind thigh but does not reach the extremity, where there is a short plica near its side; there is only a single series of granules along each side of the suture, the others are 
less regular: the sides are more explanate near the base than at the apices, each, near the margin, bears a regular series of distinct granules.

Gnderside fuseo-rufous, the breast and basal ventral segment granulate.

The subtruncate thoracic apex and somewhat flattened sides of the elytra are its principal distinguishing features. Ninth antemnal joint oblique.

Length, $3 \mathrm{~mm}$. ; breadth, $1 \frac{1}{3} \mathrm{~mm}$.

Lirua; January, 1909. One in my own collection.

\section{Group Lathrididdae.}

Rethusus Broun. Man. N.Z. Coleopt., p. 835.

4057. Rethusus fulvescens sp. nov.

Nitid, fulvescent, the tibiae, tarsi, and terminal joints of antennae slightly infuscate; thinly elothed with subdecumbent, slender, pale hairs, and a few erect, elongate, darker setae.

Head as broad as thoracic apex, moderately coarsely but not closely punctured, abruptly narrowed and deflexed in front of the large prominent eyes. Thorax rather longer than broad, very deeply constrieted between the middle and base, laterally prominent before the middle, base and atpex truncate; dise somewhat uneven, its punctation like that of the head. Seutellum large and broad. Elytra oblong-oval, double the width and thriee the length of thorax, with rounded, distinetly elevated shoulders ; coarsely subseriate-punctate, more finely behind; each with a slight obtuse clevation near the base and a pair on top of the posterior declivity, the side also is a little uneven.

Antennae as long as head and thorax, finely setose, second joint subelongate-oval, nearly as long as the basal but not as thick; joints 3-7 more slender, each longer than broad, eighth small; club elongate, loosely articulated.

From the typical species, $R$. pictulus (1485), this differs materially in colour and sculpture, the surface is less uneven, the small nodosities of the elytra are almost entirely absent instead of being numerous and conspicuous. The shoulders though elevated are not nodiform as in $R$. lachrymosus (1486), which, moreover, has several small elytral nodosities like those of 1485 .

Length, $2 \mathrm{~mm}$.; breadth, $\frac{3}{4} \mathrm{~mm}$.

Titirangi, Auckland. One, found by Mr. A. E. Brookes, of Mount Albert (2nd October, 1915), amongst dead leaves.

\section{Group Byrrhidae.}

Nosodendron Latreille. Man. N.Z. Coleopt., p. 242.

\section{Nosodendron seriatum.}

Convex, oblong-oval, fincly and densely punctate, moderately nitid, minutely and indistinctly pubescent; black, legs and antennac rufo-piceous.

Ilead longer than thorax, gradually narrowed anteriorly, slightly biimpressed in front. Eyes flat. Thorax twice as broad as long, its sides finely margined and gradually narrowed towards the front, which is truncate in the middle but with its acute angles extending to the middle of the eyes, posterior angles obtusely rectangular. Scutellum large, triangular, acute at the extremity, with smooth edges. Elytra four times the length of thorax, as wide as it is at the base : ath clytron with ten series of moderate 
punctures, the second abbreviated, the inner ones obsolete near the middle, the others, towards the extremity, are transformed into feeble striae.

Antennae longer than the head, their thick basal joint just visible above, second nearly twice as long as broad, third slender and elongate, as long as the following four combined, fourth and fifth longer than broad, the next two shorter and obconical; eighth short and broad, prolonged inwardly; club triarticulate, oblong, minutely and densely pubescent, basal joint transversely quadrate, the next shorter and slightly broader, the terminal largest, obtusely subconical.

Tibiae finely denticulate externally and bearing fulvescent setae, the anterior sinuate outwardly below the middle and more curvedly expanded inwardly than the others.

Underside black, slightly nitid, distinctly, rather finely and closely punctate, the last ventral segment with yellow pubescence. Prostrinal process straight and narrow. Flanks of metasternum curvedly expanded inwardly in front, narrow behind.

This no doubt is nearly allied to Sharp's $N$. zealandicum (1964), from Greymouth, but as I have not seen any specimens from that locality, and as it is described as having only some abbreviated series of fine punctures on the basal portion of the elytra, I think $N$. seriatum must be distinct.

Length, $5 \frac{1}{2} \mathrm{~mm}$. ; breadth, $3 \frac{1}{3} \mathrm{~mm}$.

Mount Hope; 7th March, 1915. One, found by Mr. 'T. Hall.

\section{Group Melolonthidae.}

\section{Odontria White. Man. N.Z. Coleopt., p. 265.}

\section{Odontria halli sp. nov.}

Oblong, slightly convex, opaque, head somewhat nitid; rarying from fusco-testaceous to light brown, in the former case the alternate elytral interstices have oblong dark spots, in both examples there is a large dark frontal mark on the thorax; occiput and legs testaceous, antennae and tarsi rufo-testaceous; pubescence pale yellowish and infuscate, mostly decumbent on the elytra, but with longer erect setae along their sides and on the head and thorax.

Head coarsely and irregularly punctured; clypeus subtruncate in front, with reflexed margins. Thorax finely punctate, nearly twice as broad as long, finely marginate, rather more narrowed before the middle than behind, base widely bisinuate, with obtusely rectangular angles, apex widely incurved. Scutellum large, finely punctured. Elytra of the same breath as thorax at the base, almost four times its length, gradually expanded posteriorly, with subtruncate apices; their whole surface finely punctate; on each elytron there are four dorsal striae, the others are obsolete. Pygidium exposed.

Anterior tibiae tridentate externally, the others hear tufts of spiniform setae ; tarsi and claws normal.

Antennae 8-articulate, basal joint elongate, half hidden ahove, slender near the base, clavate at the extrenity; second short and thick; third slender and very elongate, attached near the middle to the apex of the second, its basal portion shorter than the other and projecting forwards; cluk composed of five equally elongate, distinctly pubescent leatlets.

The South American genera Sericriles and Listromyx also possess fivejointed clubs, but the antennae themselves are 9-articulate. Sericospilus in facies closely resembles Eusoma, both have eight-jointed antennae and in the male, a quadriarticulate club, but the peeculiar form of the fourth 
antennal joint in the male of Sericosprlus is almost exactly the same as that of the third in Odontria halli, which has a pentamerous club.

Fem.-Third antennal joint moderately elongate, its base attached to the apex of the second, fourth and fifth short, both dentiform in front.

Length, $13 \mathrm{~mm}$; breadth, $7 \mathrm{~mm}$.

Glenhope. Two males found on the 18th July. 1915; one female afterwards. Named in honour of Mr. 'T. Hall, who discovered all three specimens.

Xylostygnus Broun. Man. N.Z. Coleopt., p. 956.

4060. Xylostygnus brookesi sp. nov.

Suboblong-oval, moderately convex, nitid; with numerous minute, inconspicuous greyish setar above, its sides and basal joint of antemnar with some longer outstanding ones; castaneo-rufous, slightly aeneous, antennae paler.

Head moderately closely and coarsely punctured, nearly smooth between the eyes; the clypeus more closely, with well-developed reflexed margins, its sides narrowed anteriorly, the apex truncate. Thorax in the middle about twice as broad as long but with the subacute anterior angles extending as far as the centre of the eyes, posterior angles rectangular, base slightly bisinuate and finely marginate, the sides but little curved, somewhat sinuously narrowed behind the middle, sometimes slightly asperate near the front; discal punctation like that of the head but a little irregular, not as close between the middle and sides, its apex smooth. Scutellum broadly triangular, smooth behind. Elytra slightly broader than thorax at the base, thrice its length, rather wider and gently rounded at the sides, broadly truncate behind; coarsely but not seriately punctured, sutural striae obsolete. Pygidium vertical, hardly visible from above, not closely punctate.

Anterior tibiae bidentate and, like the longer tarsi, bearing some yellow setae.

Underside similar, with some elongate yellow setae on the femora and front of prosternum, the latter with its triangular basal process acutely projecting between the almost contiguous coxae. Metasternum coarsely punctate towards the sides, nearly smooth and impressed along the middle. Basal segment of abdomen almost covered by the femora, 2-5 slightly diminish, with some linear longitudinal impressions, sixth very short.

Differentiated from $X$. piceous $(1723)$ by its somewhat shining aeneorufous surface, less evenly rounded sides of thorax, rather more prominent posterior angles, obsolete sutural striae of the elytra, and slightly different sculpture.

Length, $9 \frac{1}{2}-10 \mathrm{~mm}$. ; breadth, $5 \frac{1}{2} \mathrm{~mm}$.

Takapuna seaside, near Auckland; 17th March, 1915. It bears the name of its discoverer, Mr. A. E. Brookes, of Mount Albert. I have seen three specimens, all but one without antennae, which are of normal structure, rather short, 9-articulate, the last three forming the rather short rlub.

\section{Group Dascyllidae.}

Atopida White. Man. N.Z. Coleopt., p. 311.

4061. Atopida villosa sp. nov.

Oblong, slightly convex, covered with slender, very long, upright, yellowish-grey hairs; hrad, thorax, and scutellum dull, light chestnut-red; 
elytra nitid, testaceous, broadly infuscate along the middle; antennae and legs rufo-testaceous; mandibles rufous, with piceous tips.

Head large, excluding the mandibles, slightly longer than thorax, nearly as broad, closely and moderately distinctly granulate, each granule with a central puncture. Eyes nearly flat, rather small, situated elose to the antennae. Thorax twice as broad as long, only slightly sinuate inside the subacute, slightly depressed anterior angles; the base more deeply bisinuate, so that its angles seem to project backwards; its sides fincly marginate, rather more narrowed behind the middle than in front; closely punctategranulose. Scutellum triangular, less distinctly sculptured. Elytra oblong, evidently broader than thorax, four times its length, coarsely and irregularly punctured; the base is finely margined and subtruncate, but the shoulders are abruptly though obtusely prominent just outside the thoracic angles.

Antennae longer than head and thorax, finely pubescent; basal joint short and stout, second but little longer than broad, third shorter than fourth, joints 5-10 about twice as long as broad, shorter than fourth, eleventh more elongate.

The pale membranous space below the forehead is strongly transverse, the labrum is moderately short and deeply emarginate in the middle, the mandibles are almost wholly exposed and apparently tridentate near the base, and my specimen is quite apterous.

The only other species from Wellington in my collection, A. basalis (3244), has decumbent vestiture, the coloration is manifestly different, the elytral base still more so. A. hirta (564) is considerably smaller. A. suffusa (3071) has larger eyes, shorter pubescence, and simple shoulders. A. grahami $(3070)$ is easily separable by its unusually prominent labrum. These are the nearest allies, and all, I believe, have wings.

Length, $5 \frac{1}{2} \mathrm{~mm}$. ; breadth, $2 \frac{1}{2} \mathrm{~mm}$.

Pakuratahi, near Wellington. One, found by Mr. H. W. Simmonds (2nd January, 1915) amongst decaying leaves on the ground.

\section{Atopida pallidula sp. nov.}

Oblong, slightly convex, nitid; elytra testaceous, their suture somewhat rufescent; head, thorax, scutellum, and basal four joints of antennae pale chestnut-red, remaining joints light brown, mandibles rufous; pubescence rather short, subdepressed, yellowish.

Head, mandibles exclusive, about as long as thorax but not as broad, finely and closely granulose-punctate. Labrum short, deeply and widely emarginate. Thorax nearly twice as broad as long, slightly emarginate behind the eyes, anterior angles a little depressed, not acutely prominent; base subtruncate or only feebly bisinuate, with rectangular angles; its sides finely margined and slightly curved, but almost straight at the base; moderately closely, distinctly, yet rather finely punctured, with a few small granules near the basal margin; there is a large but shallow impression in front of the scutellum, and a transverse one near each hind angle. Scutellum subtriangular, finely punctate. Elytra oblong, four times the length of thorax, a little broader than it is at the base, with rounded and slightly elevated shoulders; moderately closely punctured, much more coarsely than the thorax, indistinctly behind.

Antennae elongate, basal joint thick, oblong, the next very small, third as long as fourth or following ones. 
Rather smaller than A. impressa (3418), much paler, the thorax with less prominent front angles and very different diseal impressions. Terminal joint of labial palpi attached to the preceding one at almost right angles.

Length, $5 \frac{1}{3} \mathrm{~mm}$. ; breadth, $2 \mathrm{~mm}$.

Bluff, Southland. A single specimen, found by Mr. A. Philpott on the lst December, 1914.

\section{Atopida montana sp. nov.}

Elongate, moderately convex; thinly covered with slender, elongate, more or less erect, pale-yellowish hairs; head and thorax subopaque and tufescent; elytra nited, fusco-testaceous, the suture nigrescent, each elytron with a pale-brown, indefinite, subapical mark; legs and antennae subtestaceous.

Head, mandibles exclusive, much longer than thorax but hardly as broad, distinetly punctate-granulose, closely near the sides, less so on the middle. Labrum moderately developed and semicireularly emarginate, but leaving the rufous mandibles exposed even at the base. Thorax twice as broad as long, apex subtruncate, with nearly rectangular but not prominent, slightly deflexed angles; its sides slightly rounded, a little narrower behind than in front, posterior angles rectangular; its sculpture is like that of the head, hut there is a smooth spot on the middle and a more flattened one at the base. Seutellum elongate. Elytra nearly six times the length of thorax, rather broader than it is at the base, the shoulders obtuse but embracing the thoracic angles; they are rather coarsely and irregularly punctured, quite finely near the extremity.

Antennae longer than the head and thorax, basal joint stout, oblong, twice the size of the next, third elongate yet shorter than the following, slightly infuscate ones.

Underside finely and indistinctly granulate, somewhat infuscate.

Terminal joint of the labial palpi attached at about right angles to the inmer side of the penultimate, which is finely setose and subtruncate at the extremity.

In coloration this resembles the much smaller $A$. dorsalis (2023), in which, moreover, the granulation of the head and thorax is simple, a good deal finer and more distant.

Length, $4 \frac{1}{2} \mathrm{~mm}$. ; breadth, $1 \frac{1}{2} \mathrm{~mm}$.

Mount Owen. Found by Mr. 'T. Hall, at a height of 5,500 ft., on the 27 th December, 1914. In my second specimen the smooth thoracic spots are absent, and the shoulders do not extend forward so as to clasp the posterior angles of the thorax-possibly only sexual disparities.

Veronatus Sharp. Man. N.Z. Coleopt., p. 314.

\section{Veronatus sternalis sp. nov.}

Elongate, slightly convex, subopaque; irregularly covered with decumbent rollow pubescence; fuseo-rastaneous. lews. antennar, and palpi paler, mandibles rufous.

Head, excluding the mandibles, rather shorter than thorax, evidently narrower, a little uneven, elosely and moderatedy finely puncetured. Thorax nearly twiee as broad as long. apex subtruncate, slightly sinuate towards the olutuse angles, these hardly extend as far forward as the middle; the sides fincly margined and gently curved; base subtruncate in the middle, somewhat sinuate towards the nearly rectangular angles; dise closely 
and finely punctate, with a narrow impression along the middle. Scutellum subtriangular, finely punctate. Elytra just five times the length of thorax, rather broader than it is at the base, with rounded shoulders; they are quite obsoletely costate, closely and finely punctate, but subgranulose near the base, apical sculpture finer and more distant.

Nearly allied to $V$. nubitus (2525), which near the base and sides of the thorax has some distinct, slightly separated granules, each with a central puncture. In $V$. sternalis the pale membranous space between the emarginate labrum and forehead is equally large; the antennae extend beyond the intermediate femora, and their third joint, though elongate, is evidently shorter than the fourth; the elytra are only obsoletely costate; prosternal process, behind the coxae, rather slender, only about half the width of that of $V$. nubilus, mesosternal cavity smaller but deeper; abdominal sculpture indefinite.

Length, $10 \mathrm{~mm}$. ; breadth, $3 \frac{2}{3} \mathrm{~mm}$.

Buller River bank, near Glenhope; 17th January, 1915. Two (one mutilated), found by Mr. T. Hall.

\section{Veronatus reversus sp. nov.}

Elongate, moderately shining, unevenly covered with rather fine greyishyellow pubescence, finer and less conspicuous on the elytra; rufo-castaneous, elytra and basal half of thorax more infuscate, femora fusco-testaceous, tibiae and antennae light chestnut-red.

Head, mandibles exclusive, nearly as long as thorax, finely punctate, more closely near the eyes than on the middle, with a large, shallow, triangular impression occupying most of its frontal half. Thorax nearly twice as broad as long, very similar to that of $V$. sternalis in shape, but with more rounded anterior angles, the posterior less rectangular, its central furrow more definite from base to apex, slightly bi-impressed near the base, its punctation not quite as distinct and close. Elytra five times the length of thorax, rather broader than it is at the base, which, like the suture and scutellum, is paler than the dorsum; they are quite obsoletely costate, their punctation fine and close behind the middle, much finer and more distant near the base and not at all granular there. Antennae almost reaching the posterior femora.

Underside light yellowish-brown, with fine grevish pubescence, indistinctly sculptured. Mesosternal cavity triangular, in $V$. stemalis it is nearly diamond-shaped, prosternal process similar.

Manifestly distinct from $V$. sternalis in coloration and vestiture, more nitid, the general sculpture finer, that of the basal portion of the elytra especially.

Length, $10 \mathrm{~mm}$. ; breadth, $3 \frac{1}{2} \mathrm{~mm}$.

Buller River. A single specimen found by Mr. T. Hall on the 17th January, 1915.

4066. Veronatus apterus sp. nov.

Oblong, narrowed anteriorly, slightly convex, shining; light chestnutred, elytra and femora more flavescent, thorax infuscate behind the middle. mandibles and labrum rufous; head and thorax with fine, depressed yellow hairs, elytra almost nude.

Head moderately closely and distinctly but not coarsely punctate, slightly uneven, truncate just in front of the antennae; labrum very little longer than the strongly transverse, pale membranous space behind it, 
apparently entire, with a distinct yellow fringe in front. Thorax in the middle twice as broad as long, much more finely and distantly punctured than the head, its sides finely margined and slightly rounded, base and apex widely bisinuate, posterior angles rectangular, the anterior more obtuse. Scutellum subtriangular, longer than broad, minutely punctate. Elytra with rounded shoulders, a little broader than thorax at the base, more than five times its length, broadest behind the posterior femora, each with a lateral impression near the middle thigh; moderately coarsely and closely punctate.

Antennae finely pubescent, extending beyond the middle femora; basal joint subconical and thick, second smaller, half the length of third, which is rather shorter than the fourth.

Underside pale flavo-castaneous, finely punctate and pubescent. Fifth ventral segment with a dark central impression and a transverse one between it and each side.

This differs greatly from either of the preceding species, and may be recognized by the lateral impressions of the elytra and those on the terminal ventral segment. It is wingless.

Labial palpi not furcate, basal joint elongate and gradually thickened, second oblong and much thicker, third as long as preceding one, hardly as broad at its base, tapering towards the acute extremity. Prosternal process projecting, moderately broad, but much narrower behind and entering the triangular mesosternal impression; the anterior lamina is broad in front, but becomes quite acute and cariniform before reaching the middle of the coxae which are continguous there.

Length, $8 \mathrm{~mm}$. ; breadth, $3 \frac{1}{2} \mathrm{~mm}$.

Routeburn; 13th February, 1914. Taken from underneath logs, at an elevation of $1,500 \mathrm{ft}$., by Mr. T. Hall. Two examples, one damaged and mounted on its back.

\section{Veronatus brevicollis sp. nov.}

Oblong, moderately convex, nitid; light castaneo-rufous, elytra and femora a little more flavescent, labrum and mandibles rufous: sparingly clothed with slender, decumbent yellow pubeseence, elytra nearly glabrous.

Head narrower than thorax, moderately closely and finely but quite distinctly punctate, more closely near the eyes, feebly impressed along the middle; the pale membranous space in front slightly shorter than the emarginate labrum. Thorax nearly thrice as broad as long, its apex widely but not deeply sinuate, and somewhat depressed, towards the obtuse angles, subtruncate in the middle; sides finely margined and gently eurved, the base broadly rounded at the middle, slightly but widely bismuate or oblique, with subrectangular angles; discal seulpture nearly the same as that of the head but not quite as close, indistinctly punctate-granulose across the base. Seutellum triangular, not longer than broad, finely punetate. Elytra oblong, curvedly narrowed behind, finely marginate, with rounded shoulders, almost six times the length of thorix, rather broader than it is at the base; their punctation more distinet than that of the thorax but only moderately coarse.

Antennate clongate, finely pubescent, extronding backwards beyond intermediate femora, of normal structure.

Easily recognized by its rather large size, almost uniform coloration, strongly transverse thorax, with unusual basal seulpture, and equilateral scutellum. 
Length, $9 \frac{1}{2} \mathrm{~mm}$.; breadth, $4 \mathrm{~mm}$.

Harris Saddle, near Hollyford. A single inclividual, found under a log by Mr. T. Hall; 12th February, 1914.

\section{Veronatus versicolor sp. nov.}

Oblong, moderately convex, nitid; fusco-castaneous, thoracic dise darker, the head, sides of thorax, and elytral suture more rufescent; base and sides of elytra behind the middle somewhat testaceous; antennae and legs light chestnut-red; pubescence yellow, thinly distributed, almost alosent on elytra.

Head slightly flattened in front, indistinctly longitudinally impressed behind. moderately finely but distinctly punctured, more finely behind than in front; labrum distinctly emarginate in the middle, longer than the membranous space at its base, so that the mandibles during repose are half covered by it. Thorax more than twice as broad as long, widely bisinuate at base and apex, anterior angles obtuse, the posterior rectangular; it is more finely and distantly punctured than the head, still more finely and distantly towards the sides, obsoletely punctate-granulose near each side of the base, with a feeble impression along the middle. Scutellum as broad as long, finely punctate. Elytra oblong, rather wider near the hind thighs than elsewhere, broadly rounded behind, so that the apices are subtruncate near the suture, they are five times the length of thorax, rather broader than it is at the base, with rounded shoulders; their punctation is moderately close, much coarser than that of the thorax, but much finer on the base and shoulders. Antennae normal, rather shorter than those of the preceding species.

The variegation, somewhat enlarged labrum, and subtruncate elytral apices are distinctive.

Length, $8 \mathrm{~mm}$. ; breadth, $3 \frac{1}{2} \mathrm{~mm}$.

Hollyford. One, found on the 18th February; 1911, amongst plantroots, by Mr. T. Hall.

\section{Veronatus vestitus sp. nov.}

Elongate-subovate, slightly convex, nitid; densely and finely punctate; rather thickly covered with elongate, subdepressed yellowish pubescence, and some longer, slender, erect setae; light chestnut-red, antennae and tarsi more flavescent, the back part of the head and thorax infuscate.

Head densely and finely but quite perceptibly punctured; labrum short, distinctly emarginate; mandibles rufous, shining, each evidently bidentate inwardly, the hinder tooth broader than the other. Thorax in the middle just twice as broad as long, its anterior angles only slightly more obtuse than the rectangular basal ones, the bast broadly rounded at the middle, the apex less rounded, its sculpture even finer and closer than that of the head. Scutellum equilateral. Flytra $4 \frac{1}{2}$ times the length of thorax, slightly broader than it is at the base, a little wider near the posterior femora, considerably curvedly narrowed behind, their sculpture close and fine and appearing subgranular near the base.

The first part of the description indicates its distinguishing features.

Length, $7 \frac{1}{3} \mathrm{~mm}$. ; breadth, $3 \mathrm{~mm}$.

Glenhope; 3rd February, 1915. A solitary specimen from Mr. T. Hall.

19-Bull. No. 1 . 


\section{Gromp 'l'enerrionidae. \\ Syrphetodes Pascoe. Man. N.Z. Coleopt., p. 351.}

4070. Syrphetodes thoracicus sp. nov.

Opaque, fuscous, palpi, antennae, and tarsi infuscate red ; covered with small, depressed, pale-tawny, obscurely rufescent, and infuseate squamae, the pale ones somewhat concentrated on the posterior slope and forming small specks on the dorsum.

Head narrower than thorax and, like it, without visible sculpture, broadly impressed in front. Thorax in the middle only a sixth broader than long, but with the subacute anterior angles extending as far as the centre of the eyes, it is only a little broader at the middle than

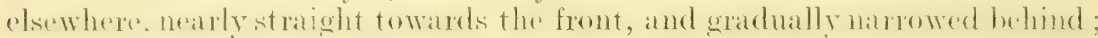
base subtruneate, but somewhat sinuate near the acutely rectangular angles; dise moderately convex, obtusely elevated behind the middle, the sides explanate; under a strong lens some minute black granules can be seen. Scutellum very transverse, each side dark and convex. Elytra oblong, nearly thrice the length of thorax, almost double its width at the base, with rounded but not at all tubereulate honders, the ir sides nearly straight, moderately (urvedly narrowed behind, with a short sisural waly at the extremity; their sides somewhat explanate, each with ten large foveae; on each elytron outside the scutellum there is a moderate oblong nodosity, another near the middle, and in line with these, on the top of the hind slope, there is a distinct nodiform elevation and a smaller one inside of it. there are also two small ones below these last; the surface towards the sides is irregularly uneven; the discal sculpture is not at all seriate and seems to consist of punctures and granules.

Antennae as long as the head and thorax, basal three joints with rellow, coarser setae than the following ones, the terminal there with sender pubeseences: basal joint thick and subquadrate, the second noarly similar but smaller, third longest, more than double the length of preceding one, ninth and tenth obennical, rather broader than cighth, the terminal romgateoval. Tibiae nearly straight, with some pale spots.

Though somewhat similar to $S$. nodosalis (2838) this is distinguishable by its longer, natrower, and differently shaped tholix, rounded hit not nodiform shoulders, and indefinite dorsal punctation. In 2838, moreover, the apex of the thorax is emarginate in the middle, its sides are widest behind the middle and distinctly sinuate towards the posterior angles.

Length, $11 \frac{1}{2} \mathrm{~mm}$.; breadth, $5 \mathrm{~mm}$.

Mount Hope, near Nelson. My specimen was found by Mr. T. Hall on the 14th February, 1915.

\section{Syrphetodes pensus sp. nov.}

Subnitid, variegate, somewhat infuseate, but so covered with small, depressed, fulveseent, and ferruginous squamae that it appears unusually

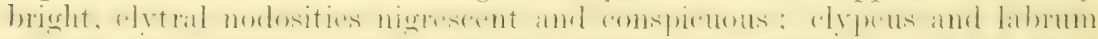

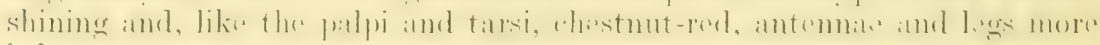
infuscate.

Head narrower than thorax, broadly impressed between the distinctly raised antennal tubereles. Eyes quite prominent. Thorax, excluding the subacute anterior angles which project as far as the front of the eyes, $2 \mathrm{x} \mathrm{mm}$. long by $4 \frac{1}{3} \mathrm{~mm}$. broad; apex with a deep median noteh; the sides explanate, widest some distance behind the middle, distinctly sinuate and 
narrowed towards the subacute rectangular posterior angles, grardually narrowed anteriorly, base sinuate near each side; disc obtusely elevated

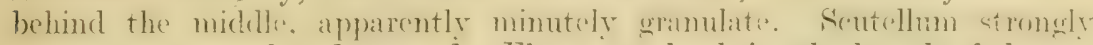
transverse, somewhat depressed. Elytra nearly thrice the length of thorax,

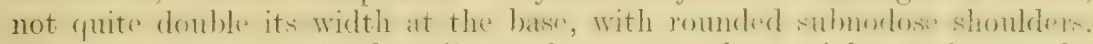
their sides rather pale, broadly explanate, nearly straight as far as the hind thighs, slighty enredly narrowed brhind, whith a hroul sutural noteh at the extremity; the dorsum when looked at from above appears subseriate-punctate, in other aspects granulate; on each elytron there is a row of three prominent nodosities, the first outside the scutellum, the next on the middle, the third on the summit of the declivity, where there is a smaller one nearer the suture; between the inner row and the side there are two others, each a little in advance of the hindmost inner pair; hind slope uneven, with a blackish streak along each side of the suture; the sides have ten transverse foveae.

Differentiated from S. thoracicus by its shorter, broader, differently formed thorax and conspicuous nodosities, and from other allied species by its much brighter derm and vestiture. In S. punctatus (2530), which measures $9 \times \pm m m$, the elytra are definitely seriate-punctate, the clypeus, labrum, and palpi are piceous.

Length, $11 \mathrm{~mm}$; ; breadth, $5 \frac{1}{2} \mathrm{~mm}$.

Erua, near Waimarino. One, found under the bark of a $\log$ at the end of January, 1911.

\section{Group Diaperidae.}

Menimus Sharp. Man. N.Z. Coleopt., p. 360.

\section{Menimus pubiceps sp. nov.}

Convex, oval, widest behind the shoulders, nitid; rufo-piceous, the base and apical portion of elytra and sides of thorax evidently palir; liabrum, epistome, and tibiae more or less chestnut-red, antennae darker, femora fusco-testaceous; lytra with a few suberect slender setae, the head finely yet distinctly pubescent.

Head subopaque, narrower than thorax, finely but quite definitely and rather distantly punctate. Thorax not twice as broad as long, gradually narrowed antriorly, slightly bisinuate at apex, base truncate, lateral margins gently thickened backwards; dise apparently smooth, really finely and distantly punctured. Seutellum broadly triangular. Elytra twice the length of thorax, of the same width as it is at the base and closely applied thereto, curvedly narrowed behind the posterior femora, their margins much more slender there than at the base; they are irregularly, rather finely, but moire distinctly punctured than the thorax.

Eyes distinct. Antemnae stout, eighth and ninth joints enlarged, subtransverse, tenth rather longer and subrotundate.

Underside, femora inclusive, distinctly but not densely pubeseent, the metastirnum and head most distinctly punctate. Prosterial process moderately broad and plane.

Var.-Titirangi, 2nd October, 1915; four examples from Mr. A. L. Brookes. Nigro-piceous, lateral margins and legs fusco-testaceous or nearly so.

The subopareue, pubescint head and other details distinguish this species from $M$. dubius $(660)$.

Length, $4 \mathrm{~mm}$.; breadth, $2 \frac{1}{4} \mathrm{~mm}$.

Hunua Range, Auckland; November, 1887. Three specimens in my own collection. 


\section{Group Salpingidae.}

Salpingus Illiger. Man. N.Z. Coleopt., p. 398.

4073. Salpingus aterrimus sp. nov.

Subdepressed, very narrow and elongate; glossy black, the clypeus, tibiar, and basal six joints of antemmae somewhat castaneous, remaining joints of these last dull fuscous, tarsi and palpi fusco-testaceous; it bars very few, slender, erect, rather short, inconspicuous greyish setae.

Head, "yes inclusive, as broad as thorax, gradually narrowed anteriorly, distinctly and moderately closely punctate, bi-impressed between the antennae; clypeus smooth. 'Thorax about as long as broad, widest near the front, gradually narrowed backwards, base and apex truncate; distinctly but not very closely punctured; the basal foveae cause an alppearance of slight constriction. Scutellum smooth. Elytra with obtuse shoulders, broader than thorax at the base, almost thrice its length, quite parallel, appiees broadly rounded; each elytron with six series of distinct punctures, these do not attain the apices, the sutural ones rather shorter than the others, there is a slight sutural depression at the base and another near the extremity.

Antennae as long as head and thorax, with slender outstanding setae; basal joint stouter than the next, third rather longer than contiguous ones, seventh subglobular, evidently broader than sixth, but smaller than the following ones, eleventh oval, these enlarged articulations densely and finely pubescent.

Much smaller and more slender than 1212.

Length, $2 \frac{2}{3} \mathrm{~mm}$. ; breadth, $\frac{2}{3} \mathrm{~mm}$.

Glenhope. Unique. Found on 1st August, 1915, by Mr. T. Hall.

\section{Agapytho gen. nov.}

Anterior coxae as distinctly separated as the intermediate, the intervening process grooved near each side.

Epistome subquadrate, somewhat prolonged and narrowed anteriorly, truncate in front, depressed at the base. Eyes entire, rotundate, moderately prominent. Maxillary jalpi moderate, penultimate joint transverse, the termiual as long as preeeding two, slightly tapering towards the subtruncate apex; the labial very thick and short, their last joint oblong, truncate at extremity. Mandibles not prominent, bifid at apex. Antennae almost as long as head and thorax, rather stout; basal joint rather thick, not longer than broad, third obconical; joints 2, 4, 5, and 6 subequal and transversely rotundate, righth slightly smaller than seventh; ninth and fenth distinctly broader than eighth, transiersely quadrate, the terminal conical. Thorax apparently longer than broad, dilated behind the nidalle, truncate at apex. Scutellum not triangular, strongly transverse. Elytra clongate, rather broader than thorax at the hase. Legs moderate. tibiae nearly straight, indistinctly bispinose at the "xtremity; terminal joint of posterior tarsi evidently longer than the basal three together, claws simple.

The North Ameriean Crymodes is the only other genus that has distinctly separated anterior coxae; but as it, as well as the other two genera in Lacordaire's Pythides rats, have securiform terminal joints to the maxillary palpi, Agapytho must be placed in the Salpingidate at present, the separation of the front coxae, however, is abnormal. 
4074. Agapytho foveicollis sp. nov.

Elongate, slightly convex, nitid; thinly clothed along the middle of the elytra with fine erect yellow hairs, near the sides they are subdepressed, thicker, and greyish, on the thorax they are quite yellow but unerenly distributed; fusco-fulvous, sometimes darker, about half of the outer part of each elytron irregularly fuscous.

Head as broad behind as the front of thorax, rather shorter, narrowed and moderately prolonged before the antennal insertion; distinctly but not coarsely or closely punctured. Thorax obtusely angulate and widest behind the middle, at that point as broad as it is long, lateral margins most distinct there, slightly sinuate towards the subrectangular posterior angles, base truncate in the middle but oblique near the sides; disc obtusely convex along the middle, feebly bi-impressed in front, very distinctly biforeate near the base, its punctation like that of the head. Elytra rather broader than thorax at the base, fully twice its length, subparallel, eurvedly narrowed behind; their sculpture not seriate, similar to that of the thorax, finer behind.

Underside rufo-castaneous, with fine greyish pubescence. Head smooth behind the middle, prosternum transversely rugose and punctate, metasternum rather more coarsely and closely punctured than the abdomen.

Var.-Darker, elytra to a large extent infuscate.

Length, $2 \frac{3}{4}-3 \mathrm{~mm}$. ; breadth, $1 \mathrm{~mm}$.

Routeburn, 11th February, 1914; Hollyford, 23rd February, 1914. Altogether about eight specimens, captured by Mr. T. Hall. Not at all similar to any New Zealand member of the group, and easily distinguishable by the pair of well-marked thoracic foveae.

\section{Group OtIoRHYNCHidaE.}

Cecyropa Pascoe. Man. N.Z. Coleopt., p. 437.

\section{Cecyropa litorea sp. nov.}

Opaque, varying from rufo-piceous to fuscous; densely covered with tawny-grey, flat, rotundate squamae and many suboblong, scale-like decumbent setae; legs and antennae obscurely rufescent, bearing whitish scales and setae; the sides of the body also setigerous.

Rostrum about half the length of thorax, more or less rufescent and slightly asperate in front, with a few erect yellowish setae there, and with a slender median stria behind. Thorax nearly a fourth broader than long, widest and strongly rounded at the middle, rather more gradually narrowed behind than in front, very slightly constricted at the apex; without visible sculpture. Scutellum small. Elytra cordiform, the hase fully as broad as the widest part of thorax, almost twice its length, their shoulders rather wider and oblique but not conspicuously dilated: they are distinctly punctate striate from base to apex.

Seape very gradually incrassate, extending to beyond the thoracic apex; second joint of funiculus hardly at all shorter than the stout basal, joints 3-7 transverse, seventh rather broader than the others; club short, quadriarticulate.

Anterior tibiae nearly straight, the apical dilatation covers the basal tarsal joint, the other pairs expanded at the extremity ; external truncature of posterior corbels moderately broad and very coarsely ciliate. 
Underside with greyish and infuscate scales and setae, the dark ones somewhat concentrated along the middle. Prosternum distinctly emarginate in front. Interior coxae narrowly but quite definitely separated.

Of about the same size as C. sulcifrons (3860) but without the three short frontal striae of the rostrum, the thorax is rather shorter, the elytra longer, with less convex interstices. In some examples the vestiture is more infuscate than that of the type, and in others forms inconstant dark marks on the thorax and elytra.

Var. C. tuberigera.-Basal ventral segment largest, rather flat, truncate and a little depressed between the widely distant coxae, and with a pair of minute tubercles at its posterior margin; second as long as the following

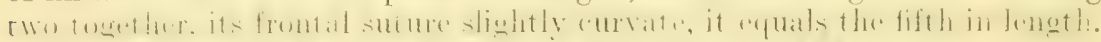

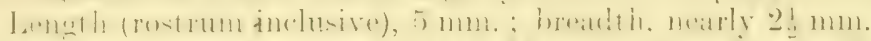

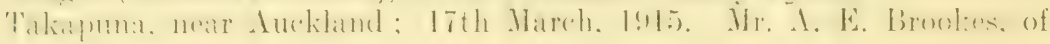
Nount Albert.

Tigones Broun. MIan. N.Z. Coleopt., p. 855. (= Protophormus Sharp. Man. N.Z. Coleopt., p. 1178.)

\section{Tigones bicostellus sp. nov.}

Opaque, nigro-fuscous, antemnae fusco-rufous, tarsi fuscous ; irregularly

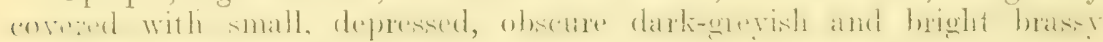
squamae, these latter most conspicuous near the eyes, and with many decumbent yellow setae which are subseriate on the elytra.

Rostrum fully half the length of thorax, its apical portion moderately pterygiate; irregularly punctate, obtusely elevated along the middle and somewhat grooved near each side. Thorax without ocular lobes, base and

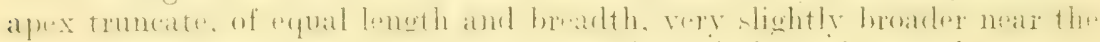

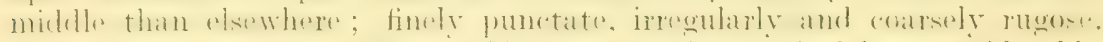

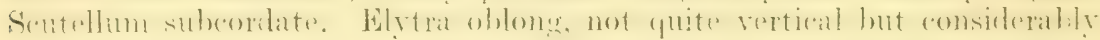
narrowed behind, nearly thrice the length of thorax, not twice as broad as it is at the base; they are nearly plane along the middle, moderatcly coatrily wriate-punctate, with minutely setilytured intervals: third and

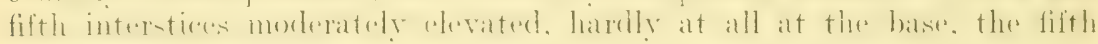
terminate on top of the posterior declivity, the others lower down, none are nodiform, apices simple. Tibiae minutely dentieulate near inner extremity.

Scape implanted near the apex, scarcely reaching the front of thorax,

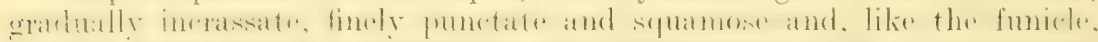

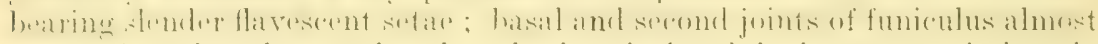

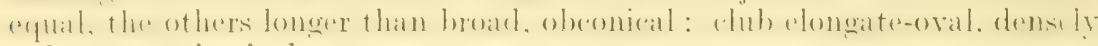
pubescent, triarticulate.

Scrobes open above, broad and shallow towards but not quite reaching the eyes. Posterior corbels without any distinct external truncature. Eyes longitudinally oval, somewhat oblique, less distant from the thorax than from each other.

This is very dissimilar to Sharp's three species of Protophormus. The costiform elytral interstices, without nodiform elevations, simple apices, and the minute brassy seales, which become quite bright when brushed with benzine, taken together, are good distinctive features. The specimen

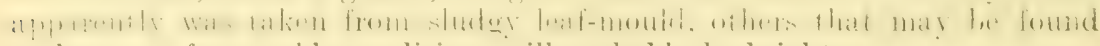
ander more favourable conditions will probably be brighter.

Leneth (rostrum inclusive), $8 \mathrm{~mm}$. ; breadth, $3 \mathrm{~mm}$.

Glenhope. Another of Mr. 'T. Hall's novelties; 20th Angust, 1915. 
Platyomida White. (Syli. Empaeotes Pascoe. Man. N.Z. Coleopt., p. 441.)

4077. Platyomida philpotti sp. nov.

Derm nitid, nigrescent; covered with small, flat, circular squamae, varving from light hlue and green to coppery red, these on the rivtat jaller and of less metallic lustre; antennae rufo-piceous.

Rostrum as long as thorax, moderately dilated in front, its fine central carina ending in a linear interocular impression, which extends to the occiput. Thorax very slightly broader than long, base and apex truncate, rather wider near the front than elsewhere; with a shallow median groove extending from the front to the middle, and a broader but ess distinct basal impression; dise rather finely and irrentarly punctumele only wry slightly uneven. Scutellum subquadrate. Jilytra nearly double the wirlth and thrice the length of thorax, with somewhat rounded shoulders, con-

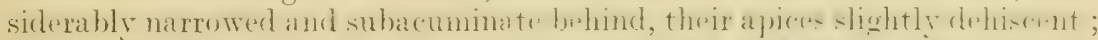

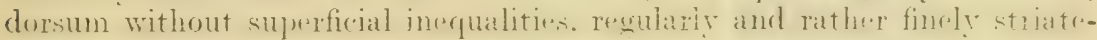
punctate; third interstices a little broader than the others, the fifth only obtusely convex behind.

Tibiae sightly flexuous. finely denticulate inwardly, the interval lutwen the duplicate cilia of the posterior corbels rather narrow.

Scape straight, very gradually thickened, attaining the back of the eye; basal two joints of funiculus equal, joints $3-7$ obconical; club elongateoval, opaque, finely and densely pubescent.

Scrobes quite onen a bove at the a jex, alnosi reaching the front and lower part of the eyes, which are oblique, and truncate in front. Ocular lobes obsolete.

Underside similar to the upper surface in colour and clothing.

This handsome species is easily separable from all the others by the absence of superficial inequalities and the iridescent vestiture.

Length (rostrum inclusive) $13 \mathrm{~mm}$.; breadth, $4 \frac{3}{4} \mathrm{~mm}$.

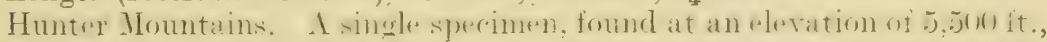

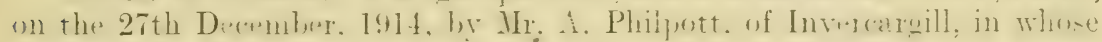
honour it has been named.

\section{Aporolobus Sharp. Man. N.Z. Coleopt., p. 1186.}

\section{Aporolobus scapalis sp. nov.}

Oblong, moderately convex, opaque; fusco-niger, below as well as above, funiculus and tarsi rufescent; covered with dark ashy, minute, depressed squamae; the elytra also bear series of suberect, grey, coarse squamiform setae. those on the rostrum and thorax di-posed irrenglarly.

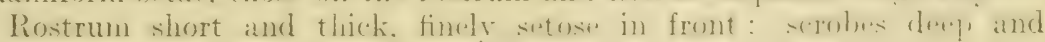
foveiform, subapical, directed towards the upper part of the eyes, where they become shallow. Eras oblique, broadly oval. not prominent. Thera: hardly broader than long, somewhat rounded at the sides, rather more narrowed in front than behind, base and apex truncate, without visible seulpture. Scoutellum absent. Elytra oblome, ristinetly wider than therax at the base, just twice its length. inuch eurvedly narrowed and sulwertical behind, they are apparently finely punctate-striate, hut do not eover the pygidium.

Scape very thick, implanted near the apex and reaching the front of thorax, covered with grey seale-like natter and erect squaniform sitate 
funiculus with slender grey setae, basal joint very stout, the next obconical but only half as large, joints 3-7 strongly transverse; club short and broarl. fimely pubeseent, indistinctly articulate.

Pascoes Trachyphloews porulus (75:3), judging by its description, must have very different vestiture. His $T$. imitus (75) 1 ), the true of $A$ porolobus, is stated to be of the "same size and shape but with a remarkably stout scape"; in A. scapalis the scape is even thicker than that of 754 , and the chothing is entirely different; the exposure of the pyegdium is probathly abnormal.

Length (rostrum inclusive), $4 \mathrm{~mm}$; ; breadth, $1 \frac{1}{2} \mathrm{~mm}$.

Glenhope. One from Mr. T. Hall ; 20th August, 1915.

\section{Group Rhyparosomidae.}

Phrynixus Pascoe. Man. N.Z. Coleopt., p. 432.

\section{Phrynixus squamalis sp. nov.}

Subovate, moderately convex, subopaque; rufo-piceous, rostrum more nitid and rufescent, antennae and tarsi light infuscate red; irregularly clothed and crested with rufo-fulvous and pale feather-like squamae.

Rostrum as long as thorax, moderately slender and arched, slightly narrowed behind the middle, very fimely punctate in front, with a pair of minute crests just in front of the antemae, the squamae behind separated along the middle by a flat line which extends backwards between the eyes. Thorax a third broader than long, somewhat contracted near the apex, its sides nearly straight but uneven behind, base truncate; dise very irregularly punctured, the bare spaces smooth, an elongate crest along the middle does not reach the feeble basal impression, alongside this there is a pair, and there is a single crest near each side at the middle. Elytra subcordate, deflexed and attenuate posteriorly, slightly broader than thorax at the base, more than double its length : their shoulders are not prominent but are covered with pale, erect, quite feather-like seales, similar ones occur on the dorsum and hind slope, on the top and sides they become conspicuous: the punctation is somewhat irregular, not quite seriate above, but the hind slope is punctate-striate. Pygidium castaneous, two segments uncorered, these are smooth, the last is strongly transverse.

Scape flexuous, elongate and slender but clavate at the extremity, inserted just before the middle and extending to the centre of the eye, with fine depressed scales only; basal two joints of the funicle rather slender and equally elongate, third rather shorter than the transwerse following ones, serenth rather broader than the base of the club, which is suborate, narroved towards its base, densely and minutely pubeseent, and indistinctly articulate.

Underside castaneous, with flarescent squamae. Prosternum emarginate. Metasternum truncate behind. Basal rentral segment broadly rounded and depressed in front, deeply incurved medially behind, so that in the middle it is only half the length of the larese smooth second, fifth longer than preceding two combined, densely and minutely sculptured, with short fine setae.

Srerobes quite lateral and foreiform, situated just before the middle. There are no ocular lobes. Tibiae not perceptibly mueronate. The usual basial depression of the thorax and elytra, so conspicuous in Phrynixus, ar" almost entirely absent. Thr abiominal structure and abbreviated 
thorax are also aids to identification. The exposure of the pygidium is probably abnormal.

Length (rostrum exclusive), $5 \mathrm{~mm}$.; breadth, $2 \frac{1}{2} \mathrm{~mm}$.

Howard Goldfield, Nelson. Two, found by Mr. T. Hall on the 10th May, 1915 ; one mounted on its back.

\section{Phrynixus humilis sp. nov.}

Subovate, moderately convex, opaque; fuscous, rostrum rufescent, antennae and legs pale fuscous; irregularly clothed with pale-tawny squamae, some fulvescent ones on the thorax and along the middle of the elytra, and feather-like greyish ones on the shoulders and hinder portion of elytra.

Smaller than $P$. squamalis, with more obscurely coloured vestiture, which on the thorax and rostrum is similarly disposed. The elytra, however, are less cordiform, the posterior declivity is nearly vertical, their shoulders are obriously though rather obtusely porrect, their punctation is finer and more distant, and the posterior striae are indistinct.

The rostrum and antennae are relatively shorter, the scape attains the front of the eye, the femora are equally slender at the base and clavate in the middle, the pygidium is not exposed; the scrobes, tibiae, \&c., are like those of $P$. squamalis.

Underside light castaneous, with depressed tawny scales. Abdomen rather convex, basal segment subtruncate between the coxae, medially incurved behind, less reduced than in $P$. squamalis ret distinctly longer than the second.

In a second specimen, probably the female, the elytra are subquadrate, being only slightly longer than broad, and the coarser squamae are more concentrated on the summit of the declivity, which appears (quite vertical.

Length (rostrum exclusive), $3 \frac{1}{2} \mathrm{~mm}$. ; breadth, $2 \mathrm{~mm}$.

Howard Goldfield; 10th May, 1915. A single male, from Mr. T. Hall.

\section{Phrynixus amoenus sp. nov.}

Elongate, moderately convex, opaque; piceous, antennae and tarsi fusco-rufous; irregularly clothed with small, depressed and suberect $f \cdot r-$ ruginous squamae, the shoulders with an oblique crest on each formed of pale, upright, futher-like scales, similar ones form a pair of prominent tufts on the top of the posterior declivity, and lower down, at each side, there is a rather larger rufescent one.

Rostrum nearly a third shorter than thorax, arched, a little narromer behind than in front, which is nearly bare and indistinctly aculptured, the basal portion has a ferruginous median squamose ridge, and just b. fore the antemae there is a pair of quite minute pale crests. Thorax apparently elongate, ret only slightly longer than broad, evidently narrower than elytra, its sides almost in might behind, slightly wider and unerenly squamove before the middle, its base truncate; disc irrogularly punctate, with three frontal ridges which extend to beyoud the middle, the central one is rufercent and slender, the others more prominent and mixed with pale scale's, there is a median depression at the base. Elytra unevenly oblong-oval, each side being quadricristate, nearly double the length of thorax, rertical behind, they are bisinuate at the base, scarcely any wider than the thorax there, and the shoulders are not perceptibly porrect; dorsum nearly jlane, with a few minute granules, broadly impressed at the base, irregrulanly punctate and bearing, besides the prominent ones, a few small unequal 
crests; posterior declivity quite striate, the seales concentrated as small spots.

Seape medially inserted, attaining the back of the eye, slender and flexuous near the base, clarate near the extremity without erect setae;

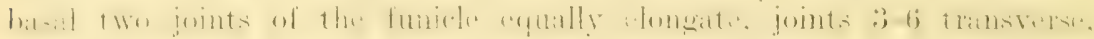
seventh larger, club small.

Legs elongate, tibiae mucronate and bearing somewhat rufescent curled setac; penultimate joint of tarsi excavate above, entire and finely hispid below.

Underside dull black, with a few short, depressed fulvescent setae. Prosternum hardly at all emarginate. Basal two ventral segments connate

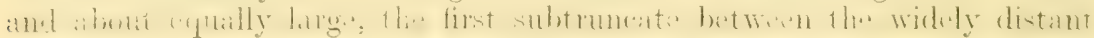
coxne, its hind suture obliterated in the middle and, near the sides, represented by oblique series of punctures only, both segments nearly smooth in the middle, punctate elsewhere; fifth finely and elosely.

This fine species very well accords. with the generic diagnosis, but cannot easily be confounded with any other.

Length (rostrum exclusive), $4 \frac{1}{2} \mathrm{~mm}$. ; breadth, $2 \frac{1}{3} \mathrm{~mm}$.

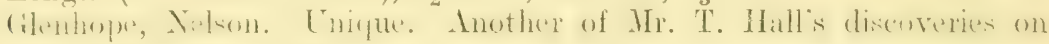
the 23rd November, 1914.

Phrymixus binodosus (3278) var.-From Mr. Hall I have three varietal specimens, captured on the 20th December, 1914, and 20th February, 1915, at Glenhope. These differ as follows from the type :-

Rostrum with a pair of small greyish erests before and behind the antennae. Thorax with a central ridge which is slender in front but broader at the middle, where it ends. In addition to the pale humeral ridge and prominent posterior nodosities there are about five very unequal dorsal elevations on each elytron; one at the base is quite elongate. In one, mounted on its back, the basal two ventral segments are connate as usual, but their coarse punetation is nearly absent in the middle.

It is evident that the type, which was found at Broken River, had been rubbed or damaged, and that the Glenhope specimens represent the species in its perfect condition.

\section{Erymneus Poscoe. Man. N.Z. Coleopt., p. 435.}

\section{Erymneus terrestris sp. nor.}

Subovate, moderately elongate, slightly convex, opaque; piceous, antennae and tarsi fusco-rufous; clothed with small, decumbent, light reddish-brown squamae, the erests consist principally of greyish, suberect, woolly seales; legs with curled rufescent setae.

Rostrum a third shorter than thorax, its anterior half slightly expanded, 1h. basal portion finely longitudinally andinate, and baring a pair of minute crests just behind the antennae and a larger one in front of the eyes. Thorax slightly longer than broad, somewhat contracted in front, mode-

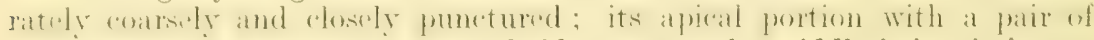
distinct crests and a narrow central ridge, across the middle it is tricristate, the longitudinal basal depression has obtusely raised, but not definitely

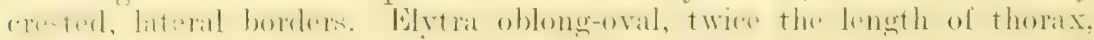
almost double its width near the middle, the base bisinuate; on each

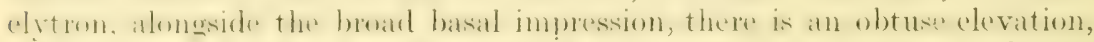
the oblipue. slightly porrect shoulder is coverect with greyish suberect squamae, which form two, sometimes three, somewhat rounded crests which extend from the humeral ridge towards the suture, and a pair of incon- 
spicuous ones on top of the declivity, the outer one a little lower than the inner; the other somewhat nodiform incqualities are subseriate and unequal; the punctation where visible is coarse and irregularly serial, the declivity is more finely punctured but striate.

Scape flexuous, moderately stout, clavate at the extremity, without neret setae, implanted at or before the middle and reaching the back of the flat ere, which is distant from the thorax; basal two joints of funiculus almost equally elongate, joints 3-6 more or less transverse, seventh larger; club short, ovate.

Underside piceous, coatrely and moderately dosely punctate; abdomen with obscurely rufescent, depressed, setiform scales, its serond secoment as long as the first, the frontal suture obtusely angulate in the middle, third and fourth very short, fifth foveate behind. Prosternum slightly incurved. Mentum subquadrate, palpi uncovered.

$E$. irregularis (2391), from the Northern Wairoa, is the nearest species, but its eves are more convex and placed more on the upper surface, the basal joint of the funicle is shorter than the second; the thorax is shorter, and the outer ridge near the side extends to the hind angle, though less distinct there than in front.

Length (rostrum exclusive), $5 \frac{1}{2}-6 \mathrm{~mm}$. ; breadth, $2 \frac{2}{3}-2 \frac{3}{4} \mathrm{~mm}$.

Glenhope, Nelson. Three individuals obtained by Mr. T. Hall on or about the 10th December, 1914.

\section{Allostyphlus gen. nov.}

Rostrum as long as thorax, moderately stout and arched. Scrobes foveiform, quite open above, but prolonged as distinct grooves almost to the upper and front part of the eyes, they begin between the middle and apex. Antennae rather slender and elongate; scape slender, gradually incrassate near the extremity, implanted between the middle and apex and reaching the back of the eye; basal joint of funiculus almost as long as the next, joints 3-7 slightly longer than broad; club subovate, narrowed towards its base. Eyes rather small, subrotundate, oblique, the space between them and the thorax equals their own length. Thorax suboblong, slightly wider before the middle than elsewhere, base and apex truncate, without ocular lobes. Scutellum absent. Elytra cuneiform, elongate, of the same width as thorax at the base, medially emarginate there, their outer half obtusely porrect.

Tibiae mucronate, somewhat arched externally. Tarsi finely setose underneath, second joint transverse, penultimate longer, moderately dilated, "xcavate above, slightly emaremate at the extremity, ('ntire below. "Nentum subquadrate, palpi exposed.

In the European styphlus the tarsi have sponger soles, their pemultinate joint is bilobed, the scrobes differ, and joints $3-7$ of the funicle are very short. It is allied to Halliella, but the antemnal insertion is less pterygate, situated further forward, and prolonged almost to the eye; the antennae are more elongate and slender; the third tarsal joint is less transverse; and the general form, instead of being pyriform, is almost quite cuneate.

\section{Allostyphlus jugosus sp. nov.}

Elongate, nearly plane above, the sides and posterior declivity vertical, opaque; piceous, antennae and tarsi fusco-rufous; irregularly covered with tawny scale-like matter, slender decumbent and coarser erect setae, 
on top of the hind declivity there are four conspicuous crests formed of feather-like elongate scales, the outer ones a little lower than the inner pair.

liostrum somewhat axpanded at and in front of the antemal insertion, buhind parallel, convex alones the middle, thickly elothenl. hut without

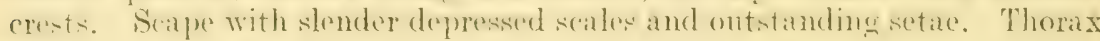
slightly longer than broad, a little contracted at the apex, very gently narrowed behind, with a erest at each side near the front; disc irregularly and rather chosely punctate, and hearing severai ninute tubercles; apex bicristate and with a longitudina! mesial ridge before the middle and

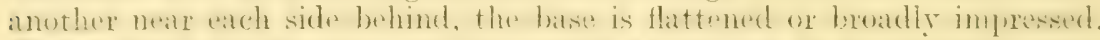
Elytra twiee the length of therax, widest at the top of the dedivity very gradually narrowed towards the base, which is medially depressed, at each side of the depression a longitudinal ridge extends towards the middle. their sides are ridged from the base to beyond the hind thighs; dorsum apparently with series of subohlong punctures and irregularly studded with minute tubereles, declivity substriate.

Fom.-Rostrum slightly longer, hardly at all dilated in front. antemuae implanted just before the middle, posterior declivity nitid, not vertical, but obviously punctate-striate. Underside coarsely and closely punctured, with depressed tawny squamae.

o. Length (rostrum inclusive), $6 \frac{1}{2} \mathrm{~mm}$. ; breadth, $2 \frac{1}{3} \mathrm{~mm}$.

Mount Owen, 27th December, 1914, a single male; the female from Glenhope. We are indebted to Mr. T. Hall for the discovery of both specimens.

\section{Phrynixodes gen. nov.}

Body uneven, suboblong, roughly squamose. Rostrum arched, as long as thorax. Scrobes foveiform, lateral, situated between the middle and extremity. Head globose below, not much broader above than the rostrum. Eyes free from thorax, longitudinally oval. Thorax broader than long, narrower than elytra, base truncate, without ocular lobes. Scutellum absent. Elytra suboblong, closely applied to thorax. humeral angles only slightly and obtusely porrect, posterior declivity vertical.

Legs moderately elongatr, femora subclavate berond the middle, tibiae indistinctly mucronate. Tarsi funely setose underneath, basal joints short, the penultimate moderately expanded, deeply exeavate abow, cmarginate in front but not truly bilobed.

Scape implanted between the middle and apex, flexuous and slender, incrassate near the extremity, attaining the thoracic apex. Funiculus 7 -articulate, second joint as long as the first, 3-6 as long as broad, moniliform, serenth slightly larger; club distinet, wrate, triatticulate.

Prosternum deeply angularly emarginate. Metasternum short. AbAnmen moderately elongate, basil sement larest, truncate in front between the widely distant coxae, its hind suture deep and straight, like the following ones, second nearly as long as the well-developed third and fonth together, fifth rather longer than second. Hentum subquartrate, the thick rigid maxillary palpi quite uncovered.

The position of the scrobes, more slender antennat, feebly porrect humeral angles, and different penultimate tarsal joints do not agree with the diagnosis of Phrynitus, and, moreover, the remarkable ventral segments differentiate it from that genus and all its near allies. 
4084. Phrynixodes scruposus sp. nov.

Opaque, piceous, antennae and tarsi fusco-rufous; thickly covered with obscure tawny, coarse, depressed and suberect woolly squamae, and erect setae.

Rostrum very slightly expanded, nearly nude and fincly punctate in front, behind the antennae with a median carina which, however, is invisible until the coarse covering has been seraped off. Scape with moderate outstanding setae. Thorax closely and distinctly junctured, its frontal portion, owing to the crest at each side, appears contracted, it is slightly narrowed and nearly straight behind; there is a pair of prominent anical crests, and near the middle another pair more distant from each other, the centre of the base is flat. Elytra twice as long as thorax, a third broader than it is near the middle, only slightly wider at the base, with oblique shoulders, the dorsum scarcely any longer than broad; scutellar region depressed, with a crest at each side of it, on each elytron between the form and the side there is a larger crest, another in line with it behind the middle, and a more prominent one on the summit of the hind declivity ; the sides also are uneven, the largest crest is near the top of the declivity; the dorsum, though unevenly cristate, is nearly plane but on a higher level than the thrax. it is coarsely subseriate-punctate, the declivity is finely striate-punctate.

Underside piceous, covered with a tawny deposit and coarse elongate squamae. Fifth rentral segment with a large apical fovea and pair of crests.

In its natural condition the sculpture is invisible, even the crests are indefinite; a second specimen having been obtained was carefully cleaned and described as above.

Length (rostrum exclusive), $5-5 \frac{1}{2} \mathrm{~mm}$.; breadth, $2 \frac{1}{2}-3 \mathrm{~mm}$.

Glenhope ; 23rd November, 1914. Mr. T. Hall is the discoverer.

Bantiades Broun. Man. N.Z. Coleopt., p. 1371.

\section{Bantiades rectalis sp. nov.}

Subcylindric, without nodosities; dull fuscous, rostrum and thorax rather more rufescent, legs sometimes paler, antennae rufous; sparsedly clothed with suberect grey setae, these are more concentrated across the top of, and half-way down, the posterior declivity.

Rostrum thick, somewhat arched, nearly as long as thorax, slightly narrowed near the middle, coarsely punctured, indistinctly tricarinate. Head immersed lip to the small transverse eyes. Thorax slightly longer than broad, a little contracted in front; moderately clowly and coarsely punctured, with a fine carina from the apex to the base. Elytra emarginate at the base, slightly wider than thorax, a good deal narrowed but not vertical behind; they are regularly seriate-punctate; third interstices a little elevated near the base ; the punctures, like those of the thorax, filled with pale scale-like matter.

Scape thinly setose, not reaching the eye; basal joint of funiculus slightly longer and thicker than the second, joints $3-7$ stout and transverse ; club short, oviform. Legs normal.

Underside opaque, fuscous, with a few pale setae; conrsely punctate as far as the extremity of the large basal ventral segment, the next much more distantly and fincly, fifth with shallow irregular punctures and a broad central impression. 
Fem.-Rostrum parallel, a trifle narrower and longer, and, like the thorax, more definitely carinate.

Ilurh smaller than B. cylimlicus (3901) and B. motalus (39).5), and with different sculpture and vestiture.

$\hat{0}$. Length (rostrum inclusive), $3 \frac{2}{3} \mathrm{~mm}$.; breadth, $1 \frac{1}{3} \mathrm{~mm}$.

Kiwi Bush, fifteen miles north of Glenhope. Five specimens obtained by Mr. T. Hall on the th May, 1915.

\section{Bantiades trifoveatus sp. nov.}

Oblong, moderately broad, slightly uneven, somewhat nitid; rostrum piceous, elytra fuscous, thorax obscurely rufescent, its apex usually testaceous, antennae rufescent, legs fusco-fulvous; irregularly clothed with distinct flavescent setae, scanty and decumbent on the thorax, but on the hind part of the elytra they are mingled with white, become suberect, and more concentrated across the top of, and below, the posterior declivity, the sides bear curled infuscate setae.

Rostrum arched, parallel, fully the length of the thorax in the female, a little shorter and less parallel in the other sex, coarsely punctate and obsoletely tricarinate. Head immersed up to the transverse eyes. Thorax of equal length and breadth, contracted in front, each side with a nodiform prominence near the front and a notch just behind it; disc uneven, its basal portion broadly and distinctly trifoveate, with a pair of broad oblique impressions before the middle, all the intervals obtusely elevated, the apical portion distinctly but not coarsely punctured. Elytra oblong, abruptly narrowed but not vertical behind, almost double the length of thorax, broader, less so at the base, which is arcuate-emarginate so that the shoulders appear slightly porrect, their sides a little uneven; disc with series of coarse punctures, from five to seven in each row, inner series quite regular, third interstices nodiform at the base, posterior declivity more finely sculptured.

Underside nigro-fuscous, with numerous distinct pale setae. Metasternum s'ort, depressed in the middle, with coarse shallow punctures. First ventral segment large, rather flat, truncate and coarsely punctured between the coxae, much more distantly and finely behind; second similarly finely punctate, its frontal suture well marked throughout, obtusely angulate in the middle; fifth longer than preceding two combined, with a shallow median impression.

Antennae and legs of normal structure.

This is manifestly different from $B$. rectalis, with relatively more slender antennae. In bulk and general appearance it most nearly resembles our northern $B$. suturatis (3143) and the southern $B$. conprendus (3604), but is eavily distinguishable from both he the trifoveate basal hall of the thorax.

․ Length (rostrum inclusive), $4: 2 \mathrm{~mm}$.; breadth, nearly $2 \mathrm{~mm}$.

Kiwi Bush. A single pair found by Mr. T. Hall along with $B$. rectulis.

Rachidiscodes Broun. Part V, Bull. 1, N.Z. Inst.

\section{Rachidiscodes glabrus sp. nov.}

Nitid, nude, elytra very convex; rufo-piceous, legs pitchy-red, antennae light chestnut-red.

Rostrum half the length of body, moderately slender and arched, very slightir dilated at thre antemal insertion, before the middle. smooth. Head short, gradually narrowed to the width of rostrum. Thorax truncate at 
base and ynex, without ocular bohes, only slightly longer than broarl, a little. dilated at the middle, irregularly and, relatively, moderately coarsely punctured. Eistra oviform, double the length of thorax, much more eonvex, strongly arched above and behind, scarcely perceptibly broader than it is at the base and closely adapted thereto; each elytron with four dorsal, deep, distinctly punctured striae extending from base to apex; interstices convex, the one near the suture depressed and narrowed and not reaching the basal margin.

Basal ventral segment largest, cuneate between the coxae, slightly depressed and springly punetate in the middle, and on a higher level than the second, which is not twice the length of the third or fourth, fifth with short, depressed grey setae and a few punctures. Intermediate coxae slightly separated, as large and prominent as the anterior.

This differs as follows from $R$. altipennis (3907):-

Rostrum not sulcate. Fyes large, nearly flat, with coarse facets, almost touching the thoracic margin, not widely separated above. Head not crested. Scape only reaching the front of the eye Elytra distinctly punctate-striate. Penultimate tarsal joint excavate in front, apparently "ntire and finely setose underneath, fourth ahmost as thick, not longer than preceding two together, the claws small and strongly bent downwards.

Length (rostrum exclusive), $2 \mathrm{~mm}$.; breadth, $1 \mathrm{~mm}$.

Glenhope; 10th December, 1914. Three, found by Mr. T. Hall.

\section{Clypeorhynchus Sharp. Man. N.Z. Coleopt., p. 1210.}

\section{Clypeorhynchus dorsalis sp. nov.}

Elongate, rather narrow, slightly convex, subopaque, without crests, nodosities, or oufstanding setale; thinly clothed with flavescent, decumbent setae, those along the sides more squamiform and with a tendency to concentrate in irregular patches on the hinder part of the elytra ; fuscous, antennae and tibiae usually castaneo-rufous.

Rostrum a third shorter than thorax, rather coarsely and closely punctured and indistinctly tricarinate behind the antemas, slightly dilated, finely punctate, nitid and rufo-piceous in front. Thorax very little longer than hroad, slightly wider before the middle than lsewhere. more gradually narrowed towards the truncate base than in front; dise moderately closely and coarsely punctured, the shallow impression along the middle somewhat deeper near the a pex. Scutellum small. Elytra elongate, douhle the length of thorax, hardly a fourth broader before the middle, scarcely any wider at the base, with feebly narrowed shoulders, from thence very gently narrowed towards the hind slope, with simple apices; dorsum nearly plane, the striar with suboblong rather shallow pumctures: intersticus somewhat uneven, the third slightly elevated behind the middle, and, like those outside them, bearing series of small, sometimes indistinct, granules.

Scape flexuous, slender, gradually incrassate beyond the middle. with a few erect setae, it reaches the thoracic apex. Basal joint of funiculus evidently longer than the next, third and fourth rather longer than following ones; club elongate-oval. Tibiac distinctly dilated inwardly above the middle.

Male-Underside nitid, rufo-piceous, finely setose, moderately elosely punctate. Prosternum strongly incurved in front. Metasternum broadly impressed behind. Basal ventral segment broadly depressed, longer than second, the suture slightly sinuate, third and fourth together as long as second, 
fifth longer, truncate behind, sixth short, obtusely rounded behind, closely and finely punctate.

The female of $C$. selosus (3911) most nearly resembles this species, but the maln, owing to its conspieuously prolonged elytral apices, is manifestly dissimilar. The first part of this description indicates the chief differences between $C$. dorsalis and other species.

Length (rostrum inclusive), 6-6 $\frac{x}{2} \mathrm{~mm}$. ; breadth, $2 \mathrm{~mm}$.

Iount Hope, Nelson. Seven specimens found on the 14th February, 1915 (some of them damaged), by Mr. T. Hall.

\section{Clypeorhynchus bicarinatus sp. nov.}

Elongate, moderately narrow, elytra nearly plane along the middle: slightly nitid; nigro-fuscous, tarsi and antemnae chestnut-red; irregularly clothed with depressed flatescent setae, those near the sides rather coarser and, on top of the posterior declivity, on each elytron, near the suture, forming a pair of small contiguous crests and a less conspicuous one on the fifth interstice.

Rostrum nigreseent and finely punctured in front, behind with a pair of fine carinas which converge near the eyes. Thorax a little more dilated hefore the middle than in C. dorsatis, otherwise similar. Scutellum narrow. Elytra nearly thriee the length of thorax, nowhere twice as broad, of the same width as it is at the base, with elightly curvedly narrowed shoulders, gradually narrowed as far as the hind thighs, more but not abruptly towards the slightly dehiscent apices; the strias near the suture with finer and more distant punctures than those towards the sides; interstices feebly asperate, second and fourth slightly elevated at the base, the third behind the middle but broadly depressed near the top of the declivity so that the fourth seems more convex there.

Underside black, nitid; second ventral segment rather longer than

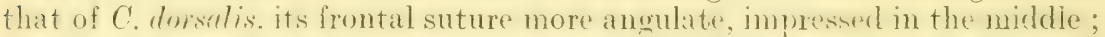
fifth transversely impressed behind, broadly rounded at the apex, sixth short and broad; the metasternum, basal segment, and punctation like those of the preceding species.

Larger than $C$. dorsalis, the elytra almost elongate-cordate, much more attenuate and nearly vertical behind, and bearing small crests, the dark tibiae only slightly dilated inwardly below the knees, \&c. In both species the ocular lobes are slightly developed.

Length (rostrum inclusive), $8 \mathrm{~mm}$. ; breadth, $22 \mathrm{~mm}$.

Mount Owen; 5,500 ft. One with damaged antennae, discovered by 11r. T. Hall on the 27th December, 1914.

\section{Dacnophylla Broun. Man. N.Z. Coleopt,, p. 1471.}

4090. Dacnophylla sparsa sp. nov.

Subopalepue, moderately convex; covered with clongate, fulvesent and

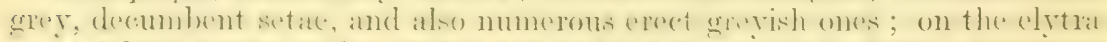
several bate spets render visible the shining piece-rufous derm; antemae and tarsi fusco-rufous.

Iiostrum nearty a third shorter than thorax, stout, subparallel, almost Glabrous in front of the antennae, behind these as thickly elothed as the head, somewhat depressed at the base. Thorax of equal length and breadth, widest neatr the front, gradually narrowed behind, base and apex truncate; moderately coarely punctured, the interstices mimutely and densely seulp- 
tured; there is a pair of distant grey crests before the middle. Scutellum obsolete. Elytra cordiform, quite double the length of thorax, of the same width as it is at the base, about a third broader behind the shoulders; near the suture they are striate but not quite regularly punctate, less distinctly near the sides. Legs moderately elongate, tibiae simple.

Scape inserted between the middle and apex, attaining the front of thorax, gradually incrassate, with a few outstanding setae. Basal joint of funiculus only slightly longer than second, both elongate, the next two oblong, 5-7 shorter; club ovate, fourth joint small.

Underside nitid rufo-piceous, with flavescent setae, distinctly but not closely punctate. Metasternum short, medially depressed, with a deeper transverse fovea near the apex and another in front. Basal two ventral segments rather deeply depressed along the middle, with subcarinate borders, second evidently the shorter, its frontal suture obliterated in the middle, distinct at the sides, the flat fifth as long as preceding two, sixth short.

D. variegata (2903) is easily separable by the acuminate elytra, more robust legs, and thick extremity of posterior tibiae.

o. Length (rostrum inclusive), $4 \frac{1}{2} \mathrm{~mm}$. ; breadth, $1 \frac{1}{2} \mathrm{~mm}$.

Woodhen Bend, Glenhope; 20th June, 1915. Three, from Mr. T. Hall.

Nestrius Broun. Man. N.Z. Coleopt., p. 1480.

4091. Nestrius zenoscelis sp. nov.

Elongate, narrow, moderately convex, subopaque, usually fuscous, middle of femora testaceous, tarsi and antennae infuscate red; thinly clothed with pale minute seales and erect setae, in unabraded clean specimens the thorax bears fine pubescence.

Rostrum a third shorter than thorax, slightly narrowed towards the middle, moderately broad, a little arched above, indistinctly bicarinate, its true sculpture much hidden by the somewhat curled, fine, irregularly distributed setae. Head short, with an interocular forea. Eres subrotundate, small, free from thorax, distant from each other, moderately convex. Thorax oblong-oval, a third longer than broad, slightly contracted in front. base and apex truncate, without ocular lobes; disc broadly impressed near the front and base, very irregularly and coarsely punctate. Elytra oblong-oval, not double the length of thorix, subtruncatis, or slightly arenate-emarginate, and of about the same width as it is at the base, moderately narrowed but not quite vertical behind; with series of moderately coarse subruactrate punctures; third interstices, and the suture at some distance from the base, slightly elevated.

Seape straight, implanted near the apex, extending berond the front of the thorax, with pale erect setae; second joint of funicuius rather longer than third but shorter than the first, joints $4-7$ subublong; club mocheratily large, ovate, indistinctly articulate.

Front pairs of tibiae nearly straight, not jerceptibly mucronate; the posterior curvedly dilated inwardly along the middle, abruptly and decply notched near the extremity, their apical portion quite transverse, truncate behind, and slightly projecting inwardly.

Underside shining, more or less infuscate. Prosternum cmarginate, with a few coarse punctures. Mctasternum truncate behind, triangular between the middle coxae. Basil rentral segment flat or broadly depressed, truncate between the widely distant coxiae, the suture between it and the 
shorter second rather indistinct, both distinctly but not closely punctate, the next two abbreviated, with deep straight sutures, fifth longer than

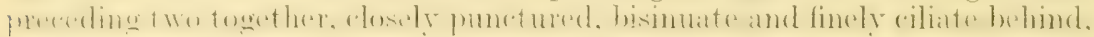
sixth shorter but well developed and rufeseent.

The remarkable structure of the posterior tibiae at once differentiates this from all the other members of the genus.

Fem.-Legs simple, often fusco-testaceous, separable from the same sex of $N$. sulcirastris (3919) by its medially yet slightly narrowed rostrum, and by the slightly longer and natrome? ilomat and clytrit so that the whole. outline is more eylindrical.

o. Length (rostrum inclusive), $3 \frac{1}{2}-4 \mathrm{~mm}$. ; breadth, $1 \frac{1}{3} \mathrm{~mm}$.

(ilonlune and kiwi bush, near Xelson. Vight eximples, fomel by MIr. T. Hall between the 10th December, 1914, and the 4th May, 1915, amongst decaying vegetable matter on the ground, and invariably smeared with sappy matter.

\section{Nestrius simmondsi sp. nov.}

Elongate, rather narrow, slightly convex and nitid; castaneo-rufous, sides of elytra rather darker; legs fuscous, middle of femora and base of tibiae much paler, nearly fusco-testaceous; thinly clothed with erect pale infuscate setae.

Rostrum a third shorter than thorax, stout, somewhat arched, slightly narrowed towards the middle, with a median groove from the antennae to the base. Eyes minute, widely distant from each other. Thorax truncate at base and apex, rather longer than broad, a little wider before the middle than elsewhere; dise broadly but not deeply impressed along the middle, coarsely triseriate-punctate, each series consists of about five punctures, lateral sculpture irregular. Elytra oblong-oval, almost double the length of thorax, scarcely any wider than it is at the base; distinctly and rather dowely substriate-punctate, scutellar region somewhat depressed. Legs elongate, tibiae simple, nearly straight, indistinctly mucronate.

Underside subupatue. rufo-fuseous, with a few short rellowish setar. Metasternum with a deep transverse depression behind. Basal segment of abdomen medially incurved belind, rather longer than the next, fifth more closely and finely punctate.

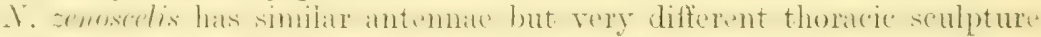
and tibiae. N. prolixus (3920) is distinguishable by its larger size, subacuminate hind-budy, irregular punctation of thorax, \&c.

Length (rostrum inclusive), $3-3 \frac{1}{3} \mathrm{~mm}$. ; breadth, $1 \mathrm{~mm}$.

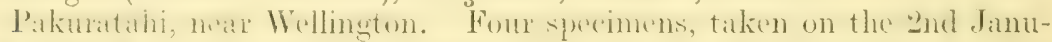
arr, 1915, from deralying forest-leaves, along with several other speecies, by Mr. H. W. Simmonds, whose name has been given to it.

Phygothalpus Broun. Trans. N.Z. Inst., vol. 45, p. 117.

\section{Phygothalpus striatus sp. nov.}

Suboblong-oval, slightly convex, moderately nitid; fusco-niger, antennae

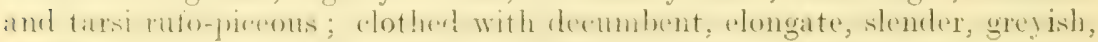
brassy, coppery, and pale-greenish squamae, which, however, are not very conspicuous.

Rostrum quite a third shorter than thorax, with linear sculpture, and a slender central carina extending from the antennae to the small interocular fovea, its apical portion finely punctate. Head very finely and 
sparingly punctured. Thoma very little longer than broad, slighty wider near the front than elsewhere, gently narrowed towards the base, more contracted at the apex; rather closely, distinctly but not coarsely junctured, less clowely alongside the obsolete median aroove. Elytra neary double the width and thrice the length of thorax, somewhat curvedly narrowed near the base, which is only a little broader than the thorax there. a good deal narrowed posteriorly, with simple apjes; their striae are rather broad and dee ]), indefinitely punctate, and become shailow lehind ; interstices moderately convex, irregularly and finely sculptured.

Underside glossy black, with fine depressed setae. Prosternum deeply emarcinate. Basal ventral segment broady dejesesed in the middle, longer than the second there; third and fourth shorter, each transversely impressed and with a punctiform fovea at the sides; fifth large, finely transversely rugose near the bise, closely and distincty punctate bebind.

Pather larger than $P$. sulcipenmis (39is), with more varisuated, brighter, and longer vestiture; deeper and apparenty impunctate lytral striae and convex interstices; thorax slightly longer but only obsoletely sulcate; legs with suberect setar; scape straight, basal joint of funiculus rather longer, the third and fourth shorter, club very elongate-oval.

$\hat{0}$. Length (rostrum inclusive), $11 \frac{1}{2} \mathrm{~mm}$. ; breadth, $4 \mathrm{~mm}$.

Hunter Mountains, sonth-west of Lake Wakatipu. One, found by Mr. A. Philpott at a height of nearly 6,000 ft. ; 27 th December, 1914.

\section{Phygothalpus anthracinus sp. nov.}

Shining black, below as well as above, antennae and tarsi piceo-rufous ; sparingly clothed with decumbent, slender greyish scales, and a few erect straw-coloured setae behind; suboblong-oval, only moderately convex.

Rostrum and head, together, of the same length as thorax, the former moderately finely, densely, and confluently punctured near its sides, irregularly above, with an obtuse central carina extending from the rather broad and deep interantennal impression to the well-narked fovea between the eres, its apical portion, and the head, finely and more regularly punctate. Thorax of equal length and breadth, widest before the middle, more gradually narrowed behind than in front; closely and somewhat rugosely punctured near the sides, much more distantly and finely along the middle, where a well-marked groove extends from behind that joint nearly to the apex. Elytra nearly thrice the length of thorax, not double its breadth, curvedly narrowed near the base, the hind slope a good deal but not abruptly narrowed, with simple apices; they are coarsely striate-punctate to berond the middle, much more funely behind; interstices irregularly and vers finely rugose, the pair nearest each side of the suture almost plane, the others moderately convex, the third with an elongate depresion along the inner side of each before the middle.

This is more glossy and considerably larger than its nearest ally, $P$. nitidulus (376t). The thorax is proportionately shorter and broacler: the elytra are more narrowed near the base, the punctures there are more quadrate, and the third interstices instearl of heing flat are, like the outer ones, convex. The antennare are more elongate, the scale is flexuous, the basal two joints of the funiculus are longer, the third is distinctly longer than broad, and the fifth and sixth, in place of heing transrersely rotundate, are oriform. The metastermm and basal two rentral serments are broadly depressed.

o. Length (rostrum inclusive), $11 \frac{1}{2} \mathrm{~mm}$. ; breadth, $4 \frac{1}{3} \mathrm{~mm}$. 
Eyre Mountrins, near Lake Wakatipu. My specimen was discovered

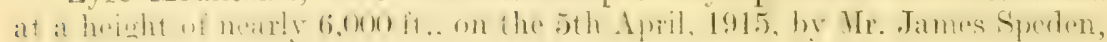
of Gore, who also found six of Lypernbius carinatus (1236) at the roots of Aciphylla spedeni at the same time. In a second specimen, perhaps repre-

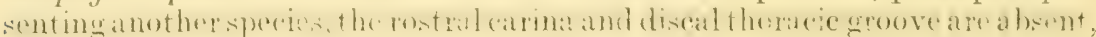
the elytral pumctation is finer, and the legs more slender and less flexuous.

\section{Getopsephus Broun. Trans. N.Z. Inst, vol. 15, p. 106.}

4095. Getopsephus costifer sp. nov.

Nitid, black, antennae rufo-piceous; nearly nude, with a few short: slender greyish setae behind.

Rostrum a third shorter than thorax, the broad punctate grooves along the middle are separated by a broad smooth carina which, at its base, is divided by the slender prolongation of the interocular fovea. Head very fincly and distantly punctured. Thorax quite as long as broad, its sides nearly straight, a little contracted at the apex; with a broad groove from front to base but becoming narrower near the middle, very finely and irregularly punctate before the middle; irregularly and feebly rugose behind, more strongly and unevenly towards the sides. Scutellum distinct, suhquadrate. Elytra oblong, thrice the length and nearly double the width of thorax, very slightly narrowed towards the base, a good deal narrowed posteriorly, with broad dehiscent apices; distinctly striate-punctate, the four outer series of punctures coarse and distinctly separated, the imner pair, on each elytron, a little smaller, all become finer behind but do not reach the extremity; interstices convex, finely and irregularly punctate, the fifth quite antiform behind the middle and anding abruptly below the summit of the declivity. Tibiae slightly flexuous, finely denticulate inwardly, and bearing distinct greyish setae.

Underside, and femora, with some fine ro!mded greyish scales and short setae.

Differs from the type of the genus (3273) by its rather longer thorax, obviously striate-punctate elytra, costiform fitth interstices, and dehicent apices.

Length (rostrum inclusive), $11 \mathrm{~mm}$.; breadth, $4 \frac{1}{3} \mathrm{~mm}$.

Hunter Mountains; 27th December, 1914. A single individual, found by $\mathrm{Mr}$. A. Philpott at an altitude of $5,500 \mathrm{ft}$.

\section{Getopsephus funestus sp. nor.}

Oblong, moderately convex, subopaque; black, antennae and tarsi rufo-piceous; densely covered with depressed, small, dark ashy squamae and numerous slender, suberect grey setae.

Rostrum closely, rather finely and somewhat rugosely punctate, with a mesial carina which nearly reaches the narrow interocular fovea. Thorax of about eguil length and breadth, widest before the middle, more gradualiy narrewed behimel than in front, base and apex truncate; dise slightly and evenly convex, its rather fine punctation hidden, the central channel interrupterl and narrow; the sides coarsely and rugosely seulptured. Seutellum smail. Elrtra nearly thriee the length of thorax, slightly arcuate-(marginate and a litte broader than it is at the base, gently expanded towards the hind thighs, considerably narrowed but not quite vertical behind, with simple a plices: ther are rather distantly and coarsely striate-punctate. nore fincly near the suture and along the posterior declivity; third and fifth interstices slightly elevated, not nodular behind. 
Femora slender near the base, subclavate beyond; tibiae mucronate, nearly straight, not perceptibly denticulate inwardly.

Scape implanted near the apex and attaining the middle of the eye ; basal two joints of funiculus equal, 5.7 moniliforme : rlub rlongatersval.

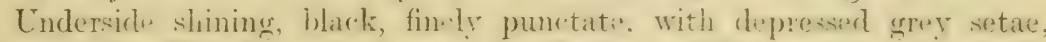
those on the fifth abdominal segment subereset and flavesent, in the male it is slightly emarginate behind, sixth broad and very short.

Var. A.-Thorax subcylindrical, nearly smooth, and glossy in front, discal furmow almost rominuous, fifth rentral segment broadly impresseri at each side.

Tai. B.-Thorax coarsely juguse behind. fifth rentral sionent marked like var. A, but with acuminate elytra. Only a single specimen of each variety has been found, both damaged.

In $G$. acuminatus (3273) the rostrum has a broad groove along each side of the carina, the thorax is somewhat glossy, with coarsi, irregular, but not tubereular sculpture behind, but the punctation is fine, the discal impression is short, the hind-body is acuminate, and the lower surface bears lustrous scales.

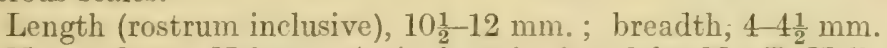

Mount Owen, Nelson. A single pair, found by Mr. T. Hall, at a height of 5,000 ft., on the 27 th December, 1914.

\section{Group Hylobinde.}

Bryocatus Broun. Bull. 1, Part III, N.Z. Inst., p. 218.

\section{Bryocatus quadricollis sp. nov.}

Subovate, rather elongate, moderately convex, opaque; fuscous, antennae faintly rufescent, club darker; irregularly covered with tawny-grey scale-like matter.

Rostrum rather longer than thorax, parallel, stout, fusco-rufous, finely and indistinctly punctate in front, sruamose at base. Thorax subquadrate, about a third broader than long, it sids slightly rounded; broadly, ret only slightly, transwersely impressed in front, with indistinct granular sculpture, the middle infuscate. Elytra nearly thrice the length of thorax, very little wider than it is at the base, subtruncate there, gradually widened towards the hind thighs, narrowed but not quite rertical b.hind: they are distinctly striate, with rugose, nearly plan interstices, these, on some parts, being irregularly covered with scald-like matter, appear uneren, but they are really without nodiform elevations.

Legs stout, tarsi and antennal club broad.

In $B$. nodicollis (3610), which most nearly resembles this species, the legs, tarsi, and club are more elongate, the rostrum is narrower, the hindbody is almost cordiform, and the thorax when examined from the front is seen to be binodose on the middle.

Length (rostrum inclusive), $1 \frac{1}{2} \mathrm{~mm}$. ; breadth, $\frac{1}{2} \mathrm{~mm}$.

Howard Goldficld, Nelson. This minute weevil is unique; it was discovered by Mr. T. Hall on the 10th May, 1915.

\section{Bryocatus rubidus sp. nov.}

Rufe cent, antemnae and tarsi rather dirker, subnitid; unerenly and sparingly clothed with a greyish scale-like film. 
Rostrum rather longer than thorax, stout, slightly narrowed towards the base, closely and finely sculptured, obsoletely in front. Head narrowed anteriorly, finely punctate. Eyes small, oblique. Thorax a third broader than long, its sides distinctly rounded and widest at the middle, slightly impressed across the front; moderately coarsely and somewhat transversely punctured. Elyta seamely any wider than thorax at the base,

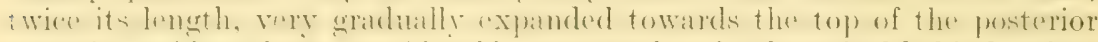

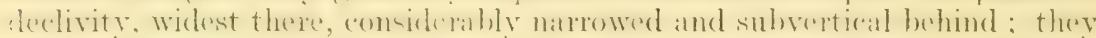

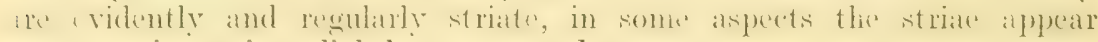
punctate, interstices slightly convex and rugose.

Most nearly related to $B$. quadricollis as regards general form, but the rostrum differs, the sides of the thorax are distinctly rounded and its seulpture is essentially difterent.

Length (rostrum inclusive), $1 \frac{3}{4} \mathrm{~mm}$. ; breadth, $\frac{2}{3} \mathrm{~mm}$. 1915 .

Glenhope. Another of Mr. 'T. Hall's discovertese, on the 19th Lugust,

\section{Bryocatus elegans sp. nov.}

Convex, opaque, covered principally with small light fusco-rufous squamae, or scale-like matter; the apex of thorax and a streak along the middle, and all "xeept the appeal portion of the rostrum, more flaveseent; a few single greyish scales form specks on the thorax and elytral interstices, on the thoracic apex there are about six depressed blackish setae.

Antennae and tarsi nigrescent.

Rostrum as long as thorax, stout, arched, parallel; pitchy red and bearing a few slender pale setae in front. Thorax subovate, of equal length and brealth, distinctly widest at the middle, obliqurly narrowed tomards the base and apex, without superficial inequalities, quite truncate at apex. Elytra subovate, double the length of thorax, a little wider than it is at the base, a third broader behind the posterior femora, considerably narrowed and subvertical behind; they are finely striate, along each side of the suture there are three small oblong nodules, the third and fifth interstices are elevated, the former from the base almost to the apex, the latter to the top of the posterior declivity, on each there are about five short, upright, greyish seales, the interstices near the sides are less elevated.

Scape inserted between the middle and apex, reddish near the base, cnly moderately thick, (rub oblong-oval. Eres of moderate size, obliquely: oval, not prominent, widely distant above, quite free from the thorax.

There is no similar described species. The peculiar elytral sculpture is distinctive.

Length (rostrum inclusive), $2 \frac{2}{3} \mathrm{~mm}$. ; breadth, $1 \mathrm{~mm}$.

Hoa Basin; 20th Oetober, 1913. One, taken off a mossy tree by Ir. T. Hall.

\section{Bryocatus humeratus sp. nov.} film.

Subopaque, nigrescent, irregularly clothed with a greyish scale-like

Rostrum hardly as long as thorax, moderately stout and arehed, parallel. Thorax oviform, as long as broad, obtusely rounded and widest at the midelle. its sculpture moderately dose, consisting appotrently of small flat

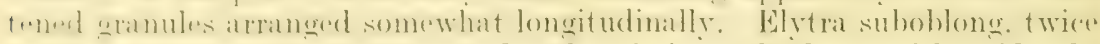
as long as thorax, distinctly broader than it is at the base, with evidently 
elevated, slightly porrect shoulders, their sides very gradually expanded and about a third wider behind the posterior femora than the thoracic base, manifestly narrowed but not vertical behind; their striae are moderately deep but not perceptibly punctured; third interstices moderately elevated from base to apex, each with four spots of scale-like vestiture, fifth very narrow near the base, broader behind the middle but not attaining the apex.

Legs and antennae normal, club ovate. Eyes rather small and flat, just free from thorax.

No other species resembles it. The raised and unusually prominent humeral angles form its chief differentiating character.

Length (rostrum inclusive), $2 \frac{1}{2} \mathrm{~mm}$; ; breadth, $1 \mathrm{~mm}$.

Mount Algidus. One, found by Mr. T. Hall; 25th September, 1913.

\section{Bryocatus lugubris sp. nov.}

Suboblong, entirely black, subopaque, thinly covered with an obscure ashy deposit, and bearing a few dark curled setae along the sides.

Rostrum thick, as long as thorax, parallel, finely asperate. Eyes small, narrow, just free. Thorax subovate, slightly broader than long, a little wider at the middle than elsewhere; slightly transversely impressed in front, closely, moderately coarsely, and rugosely punctured, and with a linear impression along the middle. Elytra oblong, rather broader than thorax at the base, twice its length, a good deal narrowed and deflexed behind; they are subpunctate-striate, interstices rugose, the third and fifth slightly elevated and broader than the others.

Antennae stout, moderately elongate, club oblong-oval.

Its nearest ally is $B$. crassirostris.

Length (rostrum inclusive), $2 \frac{1}{3} \mathrm{~mm}$. ; breadth, $\frac{3}{4} \mathrm{~mm}$.

Moa Basin ; 20th October, 1913. Another of Mr. T. Hall's discoveries.

\section{Bryocatus crassirostris sp. nov.}

Oblong, without superficial inequalities, dull fusco-niger, antennae and tarsi black; covered with nearly circular, depressed, inconspicuous, dark and obscure greyish squamae.

Rostrum rather shorter than thorax, nearly as broad as the head, parallel, minutely asperate. Eyes flat, quite lateral. Thorax suborate, hardly at all longer than broad, its punctation concealed by the squamae, some of which form a dull greyish streak along the middle in front of the base. Elytra rather broader than thorax, about twice its length, slightly incurved at the base, subvertical and curvedly narrowed behind; with rather deep but not perceptibly punctured striae; interstices transversely rugose, the third slightly more elevated than the others and rather thicker at the base, the second becomes quite linear and does not reach the base.

Antennae short and thick, basal joint of funiculus oblong but thick, club oblong-oval. Terminal joint of the tarsi extending but little beyond the broad divergent lobes of the third, the claws very small.

Smaller than $B$. lugubris, its rostrum shorter and broader; antennae shorter, funiculus with broader joints; thorax without any central groove; second elytral interstices abbreviated and narrowed.

Length (rostrum inclusive), $1 \frac{3}{4} \mathrm{~mm}$.; breadth, nearly $\frac{2}{3} \mathrm{~mm}$.

Hunter Mountains, south-west Otago. A solitary specimen, found by Mr. A. Philpott, at a height of about 6, (ink) ft., on the 2ith December. 1914. 


\section{Group Erirhinidae.}

Erirhinus Schoenherr. Man. N.'T. Coleopt., p. 449.

\section{Erirhinus dilucidus sp. nov.}

(Oblong, moderately convex, subnitid; nigro-fuscous, the thoracie apex, suture, and extremity of elytra more or less rufo-fuscous; elytra with a pale, almost ivorv-like basal spot on each of the third interstices, an interrupted cured fascia before the middle, and a more conspicuons one just below the summit of the posterior declivity equally pallid; lexs variegate, femora at the base and the lower half of tibiac pallid, the mpper part of these latter dark fuscous; antennae and tarsi rufo-testaceous, but the club and first joint of funiculus are infuscate; pubescence scanty, slender, ashy, and inconspicuous.

Rostrum moderately arched and slender, subparallel, a third longer than thorax, slightly bisulcate and punctate behind the antemnae. Thorax truncate at base and apex, a little broader than long, contracted in front, with somewhat rounded sides, rugosely but not coarsely punctate. Scutellum small and smooth. Elytra almost thrice the length of thorax, distinctly broader than it is at the base, gradually narowed and deflexed behind: "vidently punctate-striate, the third and fourth striae confluent just behind the first fascia.

Scape implanted near the apex, attaining the front of the eye, slender, a little thicker near the extremity; funiculus with fine dark setae, basal joint longer and eonsiderahly stouter than the moderately elongate seeond, third and fourth slightly longer than the short following ones; club oblong-oval, densely pubescent, triarticulate.

Underside pubescent; breast fuscous, abdomen testaceous. Prosternum widely incurved. Metasternum plane. Basal ventral segment rather longer than serend, subtruncate between the coxae. third and fourth, singly, slightly shorter than second, together shorter than fifth.

Ocular lobes absent. Eyes coarsely facetted, slightly prominent, subrotunchate: situated on the upper surface elose to the thorax, distant from each other aloont half the width of the rostrum. Legs of moderate length, normal ; tarsi with finely setose soles, claws strongly dentate at the base.

The coloration and markis render it distinet from all other allied species

Length (rostrum exclusive), $2 \frac{1}{2} \mathrm{~mm}$. ; breadth, $1 \mathrm{~mm}$.

Therdhen Bend, near filculiope. A ingle individual, found by Mr. 'T. Hall on the 20th June, 1915.

\section{Erirhinus altivagans sp. nov.}

Elongate, moderately convex and nitid; nigrescent, femora fuscocastaneous, tibiac and tarsi paler; elytra with a few erect minute grey setae, the sides of thorax with longer subdepressed ones.

Rostrum arched, parallel, moderately stout, as long as thorax, finely

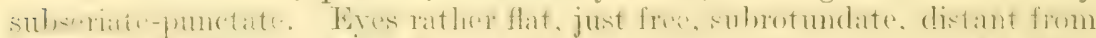
wach other. 'ihomax rather broader" than long, slightly rounded and a little broader before the middle than alsewhere, more eontracted in fromt than behind, bise and apex truncate, distinctly and moderately elesely puncetured. Scutellum small and rather narrow. Elytra oblong, more than double the length of thorax, rather wider than it is at the base, gently burmwed belind; distinctly and closcly substriate-punctate, intersties nearly plane, minutely seriate-punctate.

Antennae more or less rufescent; scape inserted between the middle and apex; basil joint of funiculus nearly twiee the length of the second, 
joints 3-7 transverse ; club suboblong-oval, quadriarticulate, terminal joint very small.

Legs stout, tibiae distinctly mucronate, the two hind pairs flexuous.

E. celmisice (3928) is larger, more glossy, and differs in colour. The elytral punctation is rather finer, not as close, and beromes somewhat vague behind; in $E$. altivagans it is distinct from base to apex, and the apices are not individually rounded. Both species structurally are like 2917, E. spadiceus (Ann. Mag. Nat. Hist., ser. 8, vol. 4, p. 132).

Length (rostrum exclusive), $2 \frac{2}{2}-3 \mathrm{~mm}$. ; breadth, $1 \frac{1}{3} \mathrm{~mm}$.

Mount Hope, Nelson. One of each sex, taken near the summit on the 14th February, 1915, by Mr. T. Hall.

\section{Erirhinus leucocomus sp. nov.}

Suboblong-oval, moderately convex and nitid; usually of a light rufufuscous hue, elytra with ill-defined dark marks, these most obvious bahind, legs and antennae fusco-fulvous; pubescence rather unequally distributed, transversely on the thorax; fine, suberect, and pale yellow along the middle of the elytra, but white, coarser, and irregular on other parts.

Rostrum quite as long as thorax, arehed, moderately slender, subparallel, punctate-striate from the base to the antemnal insertion. Thorax rather broader than long, base and apex truncate, its sides moderately rounded; moderately coarsely but not closely punctured. Seutellum distinct but small. Elytra oblong, curvedly narrowed posteriorly, nearly thrice the length of thorax, a third broader than it is at the base; distinctly striatepunctate, interstices nearly plane, minutely seriate-punctate.

Legs with fine setae, femora with a small denticle underneath; tibiae slightly mucronate and flexuous; claws appendiculate at base.

Scape rather slender, a little thickened at the extremity, inserted between the middle and apex and reaching the centre of the eye; funiculus with fine white setae, basal joint longer and stouter than the next, third and fourth small and subquadrate, the following ones slightly broader and shorter; club hardly at all infuscate, nearly ovate.

Fem.- Rostrum rather more slender, yuite the length of head and thorax together, similarly but more finely sculptured, scape implanted at or just before the middle. In one example the thorax is rather shorter, and its pubescence, like that of the head, is bright yellow. Underside piceous, abdomen sometimes more rufescent, more or less transversely rugose and distantly punctate, with decumbent white setae which become coarser near the sides; second ventral segment longer than either third or fourth, the fifth with a shallow median fovea.

Ocular lobes absent. Eyes rather flat, oval.

The conspicuous, almost silvery seale-like hairs, which do not form spots, render this distinct from other New Zealand species.

o. Length (rostrum exclusive), $2 \mathrm{~mm}$. ; breadth, $1 \mathrm{~mm}$.

Buller River, near Glenhope. Mr. 'T. Hall secured five individuals on the 17th January, 1915.

Dorytomus Germar. Lacord., Hist. des Ins. Col., vol. 6, p. 477. 1106. Dorytomus vittatus sp. nov.

Subelongate-oval, moderately eonvex and nitid, very thinly clothed with slender, inconspicuous grey hairs; testaceous, antennac and tarsi very 
little infuscate; along the middle of the thorax and elytra there is a dark fuscous streak, this, near the base of the latter, is somewhat expanded.

Rostrum as long as thorax, parallel, moderately slender and arched, its serial punctation rather shallow. 'Thorax of equal length and breadth, narrowed and slightly constricted in front, its sides moderately rounded near the middle and gradually narrowed behind, base and apex truncate; its punctation along the middle distinct, rather fine but not close, that near the subopaque sides less definite. Scutellum nigrescent. Elytra oblong, gradually narowed backwards, fully a third broader than thorax at the base, nearly three its length ; distinctly striate-punetate, interatices nearly plane, minutely punctured.

Scape inserted near the apex and just reaching the eye; basal joint of funiculus evidently longer and thicker than the next, joints 3-7 decrease in length ; club elongate-oval, quadriarticulate.

Femora strongly angulate and with a small tooth on each underneath, tibiae mueronate.

Underside testaceous and sparingly pubescent. Metasternum grooved along the middle. Basal two segments of abdomen rather deeply and broadly depressed.

Fem.- Rostrum a third longer than thorax, more shining and finely seulptured. Scape implanted between the middle and apex. Femora less dilated and not perceptibly dentate. Ventral segments simple.

Pascoe's D. trilobus (799) is somewhat similar, but can be at once distinguished by its rather strongly rounded, transverse thorax.

$\hat{3}$. Length (rostrum inclusive), $4 \mathrm{~mm}$. ; breadth, $1 \frac{1}{3} \mathrm{~mm}$.

Ben Lomond. Two males and one female, found by Mr. T. Hall at a height of 4,000 ft. ; 13th March, 1914.

Aneuma Pascoe. Man. N.Z. Coleopt., p. 455.

\section{Aneuma rufa sp. nov.}

Convex, elongate-oval, somewhat nitid; rufous, scape fulvescent, funiculus and tarsi infuscate; the head and sides of thorax covered with yellow, subdecumbent, rather coarse and elongate setae, those on the thoracic disc very slender and scanty; elytra thinly clothed with suberect, moderate, yellow setae, and also bearing some scattered squamiform grey ones.

Rostrum as long as thorax, feebly arched, moderately slender, subparallel; seriate-punctate, almost smooth along the middle and in front.

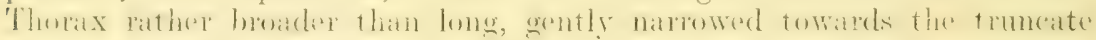
front, moderately coarsely and closely punctured. Scutellum pubescent.

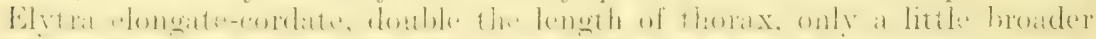

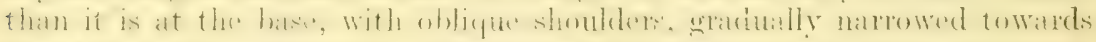

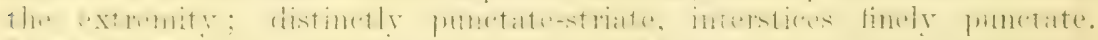

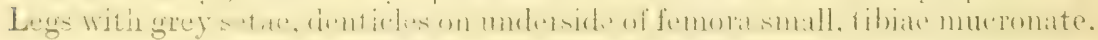
nearly straight.

Scape straight, very slightly thickened towards the extremity, inserted between the middle and apex and reaching the front of the eye; funiculus longer, with fine grey setae, basal joint larger than second, third and fourth hatrily longer thath broal, fifth and soventh moniliform; rhub ovate.

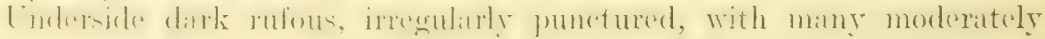
coarse grey setae, those on prosternum more flaveseent and forming a coarse fringe on the basal half of the femora; prosternal emargination with spiniform front angles. 
A. enubescens (3137), the nearest species, is larger and of a paler red, its rostrum is evidently broader, \&c. $A$. mfa is distinguished by its conspicuous femoral cilia.

Length (rostrum exclusive), $2 \frac{1}{3} \mathrm{~mm}$. ; breadth, quite $1 \mathrm{~mm}$.

Glenhope. Eight eaptured by Mr. T. Hall during 1915.

\section{Aneuma oblonga sp. nov.}

Oblong, subnitid; rostrum and thorax rufous, elytra light chestnutred, legs fulvescent, antennae and tarsi sometimes infuscate; thinly clothed with fine yellowish or greyish setae, these are suberect on the elytrii.

Rostrum stout, subparallel, nearly as long as thorax, irregularly punctate behind, subseriate towards the front. Thorax rather broader than long: its sides somewhat rounded, a little narrower before the middle than behind; moderately coarsely and closely punctured. Scutellum oblong. Elytra oblong, curvedly narrowed behind the posterior femora. quite twice the length of thorax, broader than it is at the base; distinctly punctate-striate, interstices finely punctate, slightly convex, nearly plane at the base. Legs and antennae normal.

Prosternal emargination rather short, its fornt angles obtusely spiniform. Basal ventral segment flat, the fifth with a shallow fovea.

Altogether unlike $A$. rufa in form and vestiture. It should be placed near A. erubescens (3137), which, however, is of a darker red, the legs particularly, the rostrum is longer and stouter, and the hind-body is broader.

Length (rostrum exclusive), $2 \frac{1}{2} \mathrm{~mm}$.; breadth, quite $1 \mathrm{~mm}$.

Mount Algidus, 14th October, 1913, and Scarcliff, 20th October, 1913. One from each locality, found by Mr. 'T. Hall.

\section{Aneuma rostralis sp. nov.}

Subopaque, suboblong; fuscous, more or less tinged with red, legs fusco-testaceous, rostrum reddish; elytra covered with subdecumbent, distinct greyish hairs, those on the thorax much more elongate and slender and disposed transversely.

Rostrum a third longer than thorax, slender and parallel, slightly arched, bisulcate and finely punctate from the base to near the apex, the central linear space almost flat. Thorax a third broader than long, its sides moderately rounded, moderately closely and distinctly punctured, more distantly along the middle. Scutellum small. Elytra oblong, thrice the length of thorax, distinctly broader than it is at the base, rounded behind; punctatestriate, interstices nearly plane, minutely subseriate-punctate.

Underside fusco-rufous, moderately finely but not closely punctured, with greyish setae. Metasternum transversely strigose. Basal ventral segment broadly impressed, the second in the middle distinctly longer than third or fourth. Prosternal canal with elevated lateral borders, not at all spiniform in front.

Seape straight, slender, implanted between the middle and apex; funiculus with fine grey setale, basal joint thicker and rather longer than wecom?. joints 3-5 subquadrate, sixth and seventh shorter and a little broader; club elongate, oblong-oval.

Fem.-Rostrum distinetly arched, more slender, double the length of thorax, almost smooth, shining, pale reddish. Seape very elongate and slender, inserted behind the middle; basal joint of funiculus nearly twice the length of the elongate second.

o. Length (rostrum exclusive), $2 \frac{1}{2} \mathrm{~mm}$. ; breadth, quite $1 \mathrm{~mm}$.

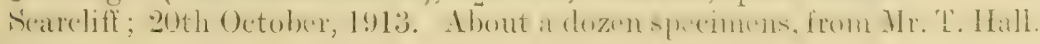




\section{Aneuma conspersa sp. nov.}

Suboblong, moderately convex and nitid, variegate; subferruginous, each elytron with an oblique infuscate fascia extending from the side, before the middle, and meeting its fellow at the commencement of the hind declivity ; antemmae of a lighter hue, club fuseous; thorax and base of elytra thinly covered with distinct, decumbent, yellowish setae, these latter, behind, are sprinkled with coarser, greyish, more or less erect setae.

Rostrum as long as thorax, moderately slender and arehed, parallel, not smooth, rather indefinitely sculptured. Thorax of about equal length and breadth, a little contracted in front, distinctly and closely punctured. Scutellum distinct. Elytra oblong, curvedly narrowed behind the posterior femora, nearly thrice the length of thorax, not quite double its width at the base; distinctly striate-punctate, interstices nearly plane. Legs with subdepressed greyish setae, femora unarmed.

Scape inserted between the middle and apex and attaining the centre of the eye; basal joint of funiculus evidently thicker and nearly twics the length of the next, joints 3-5 rather longer than broad, sixth and seventh bead-like; club oblong-oval.

Underside rufescent, with mumerous depressed grey setae, distinctly punctate, the terminal segment quite closely. Prosternal emargination deep, without spiniform front angles; second ventral segment hardy as long as the following two combined.

Fcm.-Rostrum a third longer than thorax, more slender and shining, very finely subseriate-punctate, obsoletely carinate along the middle. Antennate also more slender and elongate, implanted just before the middle. Terminal ventral segment with a shallow median fovea.

Almost entirely different from recorded species, recognizable by the coloration, vestiture, and subfasciate elytra.

$\hat{o}$. Length (rostrum exclusive), $3 \mathrm{~mm}$. ; breadth, $1 \frac{1}{2} \mathrm{~mm}$.

Mount Moa and Point Hill, both west of Mount Algidus. Ten examples, captured by Mr. T. Hall during October, 1913.

\section{Eugnomus Schoenherr. Man. N.Z. Coleopt., p. 458.}

\section{Eugnomus atratus sp. nov.}

Elongate, moderately convex and nitid; black, scape and tarsi piceous; clothed with depressed, elongate, rather coarse, grey or quite white squamae.

Rostrum about a third longer than thorax, subparallel, only slightly dilated at the extremity, closely punctate, obsoletely carinate along the middle. Eyes longitudinally oval, not prominent, as widely distant from each other as they are from the thoracic apex. Thorax rather broader than long, gradually narrowed before the middle; distinctly, irregularly, but not very closely punctured. Scutellum oblong. Elytra thrice the length of thorax, nearly twice as broad, moderately narrowed behind; distinctly striate-punctate, the stria near each side of the suture rather deep. Pygidium somewhat exposed.

Legs clongate, femora clavate but not dentate underneath.

Scape inserted near the apex, attaining the back of the eye, gradually inclastite; funiculus with outstanding nigrescent setae, basal joint laterest, the next suboblong; joints 3-7 moniliform, 5-7 transverse; club densely pubsent, indistinctly quadriarticulate, equalling the funiculus in length.

This species can be identified by its shining black derm, rather coarse nearly white vestiture, and very elongate antennal club. 
․ Length (rostrum inclusive), $4 \frac{2}{3} \mathrm{~mm}$.; breadth, $1 \frac{1}{2} \mathrm{~mm}$.

Hunter Mountains; 5,000-6,000 ft. A single female, taken by Mr. A. Philpott on the 27th December, 1914. A second example sent for inspection measures $3 \frac{1}{2} \times 1 \frac{1}{4} \mathrm{~mm}$; it is probably the male.

Hypotagea Pascoe. Man. N.Z. Coleopt., p. 4 6.

\section{Hypotagea tibialis sp. nov.}

Elongate-oval, moderately conver and nitid; rufous, rostrum, antennae, and legs of a rather lighter red; elytra thinly covered with white, erect, slender setae mingled with coarser ones, those on the head and sides of thorax decumbent, moderately thick and elongate, on the thoracic disc there are only a few inconspicuous, very slender and elongate ones.

Rostrum slightly longer than thorax, paralle], moderately slender and arched; distinctly subseriate-punctate, more irregularly near the apex, almost smooth along the middle. Thorax a third broader than long, slightly rounded, a little narrowed towards the truncate apex, distinctly and moderately closely punctured. Scutellum small. Elytra elongatecordate, quite double the length of thorax, slightly broader than it is at the base, gradually narrowed posteriorly; evidently punctate-striate, interstices convex, finely punctate.

Scape elongate and slender, straight, inserted between the midle and apex and attaining the front of the eye; funiculus longer, with slender grey hairs, second joint moderately elongate yet shorter than the stouter first, joints 3-5 longer than broad, sixth and seventh shorter and bead-like ; club fuscous.

Anterior legs longest, the femora unarmed, the others with a median tooth; tibiae mucronate, the anterior curved but not crenate, the intermediate with a small obtuse angulation on the inside above the middle, so as to appear bisinuate, the posterior dentate and finely ciliate inwardly.

Underside dark glossy red, distinctly and irregularly punctured, bearing many decumbent white setae. Prosternum with a simple emargination, its coxae contiguous. Metastermum moderately elongate, uneven, depressed along the middle. Basal ventral segment longer than fifth, in the middle twier the length of second, strongly rounded between the coxias, flat; the next three equal, the terminal with a large fovea behind.

Pascoe's $H$. rubida (804), according to the description, has apparently simple posterior tibiae, the front pair crenate, and the rostrum rugosely punctate.

o. Length (rostrum exclusive), $3 \mathrm{~mm}$; ; breadth, $1 \frac{1}{3} \mathrm{~mm}$.

Glenhope; 23rd November, 1914. One example, from Mr. '1. Hall. A second damaged specimen, with a longer rostrum but similarly formed antennae and tibiae, was also found by him at Moa Basin, Canterbury, on the 20th October, 1913.

\section{Group Belidae.}

Pachyura Hope. Gen. Ins. (Wytsm.), Belidae, 1909, p. 7.

\section{Pachyura brookesi sp. nov.}

Subdepressed, elongate, narrowed anteriorly, shining: rostrum metallic coppery-red, purplish at the extremity; thorax violaceo-rufous, head more rufescent; elytra viridescent, the sides and some of the transwerse grooves tinged with red. Pubescence elongate and rather coarse, fulvescent, 
irregularly distributed, covering the sides of the thorax and forming a

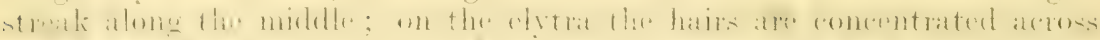

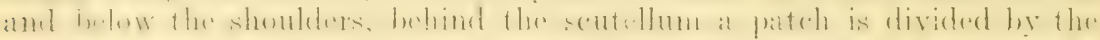

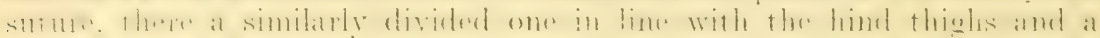
larger oblique one a little in advance extends forwards towards the side,

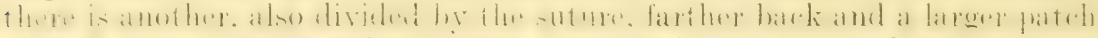

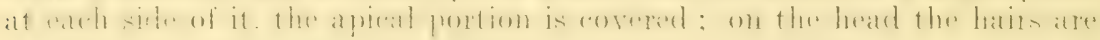
more slender and scattered; legs fusco-rufous, tarsi darker.

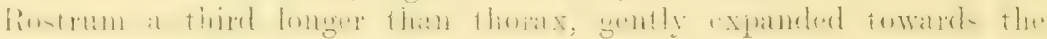
bidentate apex, obtusely angulate at the antenmal insertion, near the base;

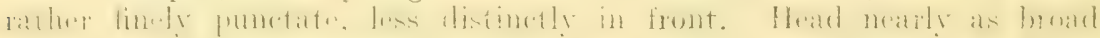
as thorax, very coarsely and closely punctured, with raised interstices. Eyes large and prominent. Thorax rather broader than long, gradually narrowed towards the truncate apex, base strongly bisinuate; disc coarsely, very irregularly transversely rugose, punctate. Scutellum transverse, punctate

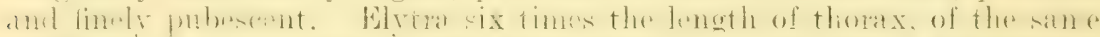

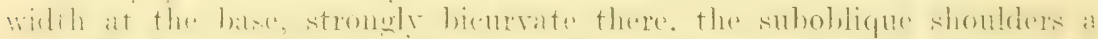

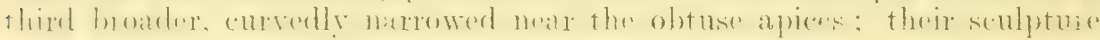
consists of elevated, somewhat irregular transverse rugae and punctate intervals.

Antennae somewhat infuscate, second joint shorter than the basal and hardly as thick, joints 3-7 elongate, gradually decreasing in length, eighth elongate-triangular, ninth and tenth oblong, eleventh rather shorter but with a conical terminal appendage.

Femora covered with slender fulvescent setae, tibiae and tarsi with shorter nigrescent ones.

Underside with fulvescent vestiture, very dense along the sides of the breast, the abdomen with bare shining spots; metasternum cupreo-violaceous, grooved along the middle.

The sculpture is coarser than that of $P$. aenescens (3770), the surface is more brightly coloured, the vestiture is quite differently arranged, joints 5-8 of the antennae are shorter, the tibiae are not serrate inwardly, the thorax is less transversal, the rostrum is longer, but its basal punctation is not close.

Length (rostrum inclusive), $10 \mathrm{~mm}$. : breadth, $2 \frac{1}{2} \mathrm{~mm}$.

Titirangi, Auckland. One example, found on the 18th September, 1915, by Mr. A. E. Brookes, of Mount Albert, whose name has been given to it.

\section{Group HAPLONYCHidae.}

Geochus Broun. Man. N.Z. Coleopt., pp. 445, 1221.

\section{Geochus pictulus sp. nov.}

Subovate, broad, narrowed anteriorly, widest behind the shoulders, moderately convex and nitid; sparingly clothed with decumbent and suberect, yellowish-grey, slender scales; flavo-castaneous, the thorax with a dark fuscous spot at each side near the base ; each elytron similarly dark,

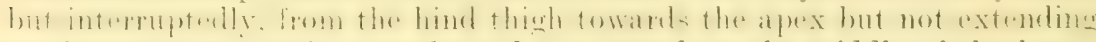
to the suture, sometimes prolonged as a streak to the middle of the base;

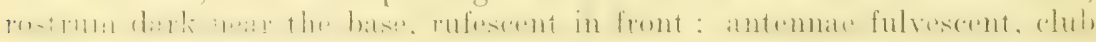
slightly infusente.

Rostrum quite half the length of thorax, stout, broader near the apex than behind, indistinctly sculptured, with four series of small scales 
converging towards its base. Thorax a third broader than Iong, distinctly but not abruptly narrowed before the middle, base somewhat rounded; distinctly but not closely punctured, nearly smooth along the middle, within each puncture there is a minute seta, the squante are irregularly disposed, almost absent from the middle. Elytra double the length of thorax, of about the same width as it is at the base and closely applied thereto, nearly twice as broad behind the shoulders, posterior declivity considerably narrowed and subvertical; they are evidently and moderately closely striate-punctate, quite striate behind, and with convex interstices there.

Legs long and thick; femora with depressed, tibiae with more erect grevish setae, the anterior pair broad and very oblique near the onter extremity.

Second joint of funiculus more slender than the basal but nearly as long, the next slightly longer than broad, joints $1-7$ small and subghobular; basal joint of chib seircely more thim half the size of the quadrate second, the terminal narrower.

Underside nitid, sparingly and finely setose, dark near the middle, rufescent elsewhere. Prosternum incurved in front, flat and not at all canaliculate, the globose coxae nearly as far apart as the intermediate; the posterior more distant. Mesosternum so formed as to appear broadly bilobed. Metasternum very short. Basal ventral segment largest, subtruncate between the coxae, its punctation transversely subseriate; second a third shorter, its frontal suture indefinite, longitudinally rugose behind.

G. setiger (2889), (Ann. Mag. Nat. Hist., ser. 6, vol. 12, p. 295), though somewhat similar in colour, bears curled setae, and the front tibiae are gradually narrowed towards the extremity. G. squamosus (2539) is almost wholly fuscous or piceous, the elytra are not so broad but are more convex along the suture, and the second ventral segment is relatively shorter with a more definite frontal suture. These three spereses are members of the series, or section, in which the elytra are not flattened towards the sides.

Length (rostrum inclusive), $2 \mathrm{~mm}$.; breadth, $1 \frac{1}{3} \mathrm{~mm}$.

Huia, near Auckland. Mr. A. E. Brookes, of Mount Albert, found this species on the 10th April, 1915, amongst dead leaves on the ground.

\section{Geochus apicalis sp. nov.}

Nitid, moderately convex, broadly oval, widest near the hind thighs; thinly elothed with distinet wellowish setate, these are dectmbent on the

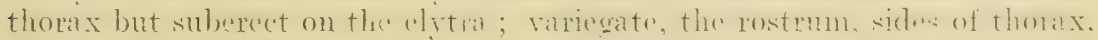

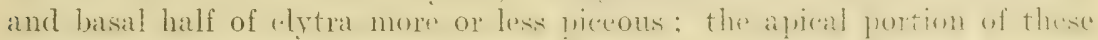
last, the antennae, and tarsi somewhat fulrescent ; thoracic dise dark rufous, legs and club fuscous.

Rostrum normal. with four flat almost smooth lines converging tomards the eyes, which are large and plane with coarse facets, the space between

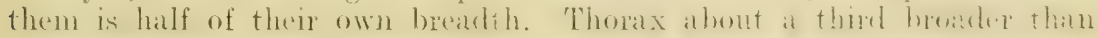
long, narrowed anteriorly, moderately coarsely punctured, more distantly

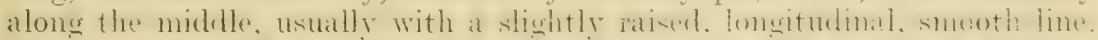
Elytra indistinetly wider than thoma at the batse. which is obligue wowats the shoulders, their sides rounded and a little depressed but not explanate,

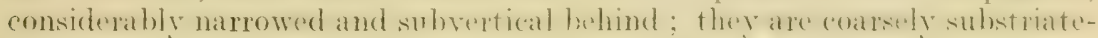
punctate, evidently striate behind, interstices convex but not nodiform at the summit of declivity. 
Seape short, half the length of the funicle, clavate at the extremity; basal joint of funiculus as thick as the apex of the scape but slender at its base, seond rather longer, its hasil half slender, third and fourth very sliegthe longer than the following moniliform omes, seventh a little hroarler;

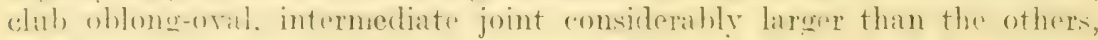
the first distinctly defined.

Anterior tibiae externally prominent at the middle, narrowed towards the extremity.

Underside piceous, irregularly and coarsely punctate, with a few minute greyish setae. Second ventral segment shorter than the basal, its frontal suture distinet, subangulate in the middle; in other respects similar to G. pictulus.

This should be located near G. variegatus (3615), which, however, is larerer. with the darkest portion of the elytra behind instead of at the base, and with nodiform interstices on top of the declivity, as is also the case in the much darker $G$. posticalis (3291).

Length (rostrum inclusive), $1 \frac{4}{5} \mathrm{~mm}$. ; breadth, $1 \frac{1}{4} \mathrm{~mm}$.

Gordon's Knob, near Nelson; 15th November, 1914. Discovered by Mr. T. Hall.

\section{Geochus certus sp. nov.}

Varicgate, subovate, broadest near hind thighs, slightly convex, subnitid; very sparingly clothed with greyish setiform scales, suberect on elytra, depressed on the thorax, where they are concentrated near the sides.

Rostrum piceous, much shorter than thorax, trisulcate, the intervals rather flat and convergent behind. Thorax pieeous at the sides, rufescent on the dise; with moderately coarse but not elose punctures, each with a minute seta; it is almost a third broader than long, narrowed anteriorly, a little more contracted in front, feebly curved at the base. Elytra hardy double the length of thorax, of about the same width as it is at the base, arcuate-emarginate there, the sides somewhat indistinctly margined, subvertical and considerably natrowed behind; dorsum nearly plane but uneren; they are piceous at the sides and behind, but of a light-chestnut hue across the top of the posterior declivity and along the middle; on each elytron the third interstice is slightly elevated from the base to the middle, the space between it and the suture, when examined sideways, is seen to be rather coarsely quadripunctate; this interstice is again, and like the second, elevated behind the middle, the others are subnodrse on top of the declivity; the external dark basal portion is irregularly m..... and has a pale medim spot, there are only two well-marked striae on ach, both behind the middle.

Tibiae with outstanding grey setae, the front pair angulate externally at the middle.

This well-marked species can be separated from the others by the jeculiar elytral seulpture. It should be placed near ('r. plagialus (2389).

Length (rostrum inclusive), $1 \frac{4}{5} \mathrm{~mm}$. ; breadth, $1 \frac{1}{4} \mathrm{~mm}$.

Howard River, near Gleuhope. The unique specimen was taken from leaf-mould by Mr. T'. Hall on the 27th March, 1915.

\section{Geochus convexus sp. nov.}

Subovate, moderately broad, wider near the hind thighs than elsewhere, evenly convex, without elytral nodosities or definite lateral margins ; 
subopaque, piceous, the thoracic apex, extremity of elytra, and the antennae rufescent; sparingly elothed with suberect, somewhat curled, tawny setae.

Rostrum indistinctly sculptured, of normal form. Thorax a third broader than long, gradually narrowed towards the front, moderately but not at all closely punctured. Elytra searcely twice the length of thorax, just as wide as it is at the base, their sides moderately rounded, a good deal narrowed but not vertical behind; distinctly striate-punctate, quite striate behind, with simple interstices. Tibiar without external prominenees.

This small species may be known by the absence of special features, even the tibiae being simple.

Length (rostrum inclusive), $1 \frac{1}{2} \mathrm{~mm}$. ; breadth, $1 \mathrm{~mm}$.

Mount Te Aroha. Three, found by myself, during October, 1911, on the ground amongst dead leaves, at an altitude of about $1,000 \mathrm{ft}$.

\section{Group Cryptorhynchidae.}

Acalles Schoenherr. Man. N.Z. Coleopt., p. 488.

\section{Acalles humeralis sp. nov.}

Robust, convex, subovate, uneven, subopaque, the derm nitid, nigrescent; covered to a great extent with small, depressed, obscure ferruginous squamae, but the basal portion of each elytron from the third interstice to the shoulder is unevenly clothed with coarser, pale-tawny scales; antennae and tarsi light fusco-rufous.

Rostrum moderately broad and arched, slightly narrowed towards the middle, as long as thorax, rufescent; its distinct punctation not seriate but disposed longitudinally and becoming finer near the extremity, with a fine mesial carina. Eyes free, subrotundate, nearly flat. Thorax hardly a third broader than long, its contracted frontal portion with a pair of small greyish crests; its basal half with a pair of dark median crests and an indefinite median carina; the front of each side, of this basal part, has a dark crest, and the short outstanding scales extend from it along the side to the base; its moderately coarse punctation is almost hidden. Scutellum indistinct. Elytra of about the same width as thorax at the base, a little broader behind, fully double its length, their sides nodose, posterior declivity sloping and narrowed; they are irregularly and coarsely subseriate-punetate; third and fifth interstices unequally and obtusely bieristate behind the middle, the hind one of the fifth is placed nearly half-way down the declivity, the suture is plane, but the rest of the surface is slightly asprerate and bears a few small black granules.

S incrisisate near the extremity, almost glabrous; funiculus finely setose, its basal joint obconical, thicker but shorter than the rlongate second, third and fourth oblong, joints 5-7 moniliform, the seventh rather broader than the oiners yet considerably narrower than the ovate, triarticulate club.

Legs elongate, with slightly variegated squamae, femora broally grooved underneath; tarsi rather narrow, not spongi-like below, penultimiate joint only moderately expanded and lobate.

Pectoral canal profound, its thick vertical borders almost touching the posterior coxale. IIetasternum concave and almost invisible batween the coxae. Abdomen covered with greyish and ferruginous scales, its first segment twice the length of second, their suture nearly straight, fifth as long as the moderately developed third and fourth togrether, with a latroge fovea at each side. 
This specios is unmistakably distinet from Tylodes and Acalles and probabir represents a new genus, but this camnot be determined until the issue of Wytsman's Gen. Ins., group Cryptorhynchidae.

o. Length (rostrum exclusive), $3 \frac{2}{3} \mathrm{~mm}$. ; breadth, $2 \frac{1}{3} \mathrm{~mm}$.

Howard Goldfield. A single specimen, found by Mr. 'T. Hall on the 10th May, 1915.

\section{Acalles anceps sp. nov.}

Convex, subovate, uneven, opaque; derm nigrescent, antennae and tarsi pale ferruginous; thickly covered with small, depressed, tawny and rufo-fuscous squamae, those of the latter colour predominate along the clytral suture and top of posterior declivity, the coarser suberect ones are of both colours; legs with outstanding, pale, coarse setae.

Rostrum as long as thorax, arched, moderately broad, slightly and gradually narrowed behind the middle, dark red and finely punctate before the antennae, with variegated squamae and a fine median carina behind them. 'Thorax rather broader than long, abruptly contracted and indistinctly bicristate in front, the middle of the broader portion with a pair of distinct crests, and in line with these there is a smaller erest at each side; it is broadly impressed along the middle, the coarse irregular punctation is much concealed. Scutcllum not distinct. Elytra subcordate, broader than thorax at the base, their shoulders oblique and covered with pale upright seales, posterior declivity subvertical but not abruptly contracted, they are fully twice the length of the thorax and much more convex; their irregularly seriate punctures are partly hidden, third interstices tricristate, but with another erest just below the summit of the declivity, in line with this one there is one on the fifth besides the pair on the dorsum, the sides also are uneven.

Antemne rather short, fincly setose; seape implanted before the middle, scarcely reaching the eye; basal joint of the funicule stout, obconical, not as long as the clongate second, third slightly longer than broad, joints 4-7 transverse, seventh broadest; club ovate, triarticulate, its basal joint half of the whole length.

Underside black, with elongate tawny scales. Rostral canal with clevated borders in line with the back of the middle coxae. Metasternum broadly concave behind. Second ventral segment much shorter than the first, hardly as long as the following two combined, fifth longer, with a distinct fovea at each side.

If the femora had been distinctly dentate underneath this speeies would have been placed in Crisius. 'Two species of Acalles resemble this one: the first, $A$. bicrisficeps (3636), may be at once separated by its very elongate-oval club; the other, A. nodigerus (3942), is a larger and more brightly coloured insect with nodiform elytral elevations.

Length (rostrum exclusive), $3 \frac{1}{2} \mathrm{~mm}$. ; breadth, $2 \mathrm{~mm}$.

Howard Goldfickd, aighteen miles from Glenhope. One, discovered by Mr. T. Hall on the 10th May, 1915.

\section{Acalles cilicollis sp. nov.}

Convex, subovate, widest near the shoulders, considerably narrowed but not abruptly deflexed behind the posterior femora, opaque; nigresent, antemuar and tarsi fuseo-rufous; thickly covered principally with overlapping fusco-formginous squamate. the sides of thoracic dise densely and coitrsely fringed with somewhat testaceous seales, basal half of elytrat with a few scattered equally pale ones, and bearing also many erect fuscous setae. 
Rostrum slightly longer than thorax, moderately arehed, a little broader at the bare apex than at the base, with obscure squamae and a few erect fuscous setac. Thorax conical, subtruncate at base, quite a third broader than long; the disc nearly plane, moderately closely and coarsely punctured, the lateral cilia not covering the true sides in front. Scutellum absent. Elytra cordate, nearly thrice the length of thorax, distinctly broader than it is at the base but with oblique shoulders; apparently striate-punctate, with a few small black granules near the base; from each shoulder towards the commencement of the posterior declivity the squamae form a slightly raised curve, this, behind, has a blackish border, there is a more irregular curvature in front, another dark fuscous streak near each hind thigh extends half-way towards the suture.

Seape medially inserted; basal two joints of funiculus equally elongate, joints 3-7 moniliform, club oblong-oval. Legs elongate, with coarse, fuscous, outstanding setae; femora only moderately dentate.

This species, with the exception of the medially implanted scape, almost accords with Crisius. The thoracic dise, owing to the short lateral cilia, appears triangular; there is no frontal constriction. The head is impressed between the eyes.

Length (rostrum exclusive), $5 \mathrm{~mm}$. ; breadth, $3 \mathrm{~mm}$.

Green Bay, near Auckland. One, found by Mr. A. E. Brookes on the 2nd January, 1915.

Tychanus Pascoe. Man. N.Z. Coleopt., p. 498.

\section{Tychanus obscurus sp. nov.}

Oblong-oval, moderately convex, subopaque; fusco-piceous, rostrum and front of thorax rufescent, tarsi and antennae chestnut-red; thinly clothed with depressed squamae, those on thorax and base of elytra pale testaceous, remainder of elytra with small, flat, inconspicuous, dark ashy ones, the sides of thorax, and the hind-body, with a few suberect pale scales.

Rostrum arched, gently narrowed towards the middle, slightly shorter than thorax, fincly punctate and shining in front of the antennae, more closely and coarsely behind, obsoletely carinate along the middle. Thorax a sixth broader than long, its frontal half somewhat depressed and abruptly contracted, the basal portion rather more closely and coarsely punctured, and with a slight carina along the centre. Scutellum very short. Elytra oblong, gradually narrowed and deflexed behind, double the length of thorax, very little broader than it is at the base; distinctly subseriatepunctate, with a few minute granules near the base, interstices nearly plane, their apical portion with many dark, outstanding but rather short squamiform setae.

Seape inserted just before the middle; basal joint of funiculus thicher and a third shorter than the elongate second, third and fourth slightly longer than following two, seventh rather broader, quite transverse; club elongate-oval.

Legs elongate, with pale coarse setae; femora strongly dentate underneath; tarsi narrow.

This obscurely clothed species may be placed near T. lunalis (3934), in which, however, the club is shorter and the third joint of the funiculus unusually short.

Length (rostrum exclusive), $4_{2}^{\frac{1}{2}} \mathrm{~mm}$. ; breadth, $2 \frac{1}{4} \mathrm{~mm}$.

Rakaia Gorge. One, from Mr. 'I'. Hall ; 27 th September, 1912. 
Crisius Pascoe. Man. N.Z. Coleopt., p. 500.

\section{Crisius contiguus sp. nov.}

Convex, subovate, uneven; piceous, covered with flat, subrotundate, ovellapping squamar, mestly of a suryish-tawny hue, those botween the midelle of the clytan and the top of the posterior declivity light rufo-fuscous; legs and antennae fusco-rufous.

Rostrum moderately broad and arched, subparallel, very slightly narrowed near the middle, equalling the thorax in length; rufescent and closely punctate in front of the antennae, squamose behind them. Thorax a third broader than long, its anterior half abruptly contracted and slightly bicristate at the apex; the basal portion, in front, with a pair of obvious crests, and a central obtuse carina extending to the base, its punctation quite hidden. Scutellum small or indistinct. Elytra fully double the length of thorax, of the same width as it is at the base, a third broader in the middle, their sides uneven, posterior declivity much narrowed and subvertical; they are moderately striate-punctate; the faintly rufescent squamae terminate as a curve just at the commeneement of the declivity ; the interstices between the middle and the base though somewhat irregularly elevated are not definitely crested.

Scape inserted between the middle and the apex, barely reaching the eye ; second joint of funiculus almost double the length of the first, third and fourth suboblong, joints 5-7 transverse, the last rather broader than sixth; club elongate-oval, its basal joint as long as the remaining two combined.

Legs normal, femora angulate and dentiform.

This accords with Crisius with the exception of the narrow elytral base; in this respect it agrees better with Tychame, which, however, has a manifest scutellum and medially implanted seape.

A careful serutiny of the overlapping squamae and the sublunate termination of the pale ferruginous ones on the after-part of the elytra will lead to its identification.

Length (rostrum exelusive), $4 \mathrm{~mm}$.; breadth, nearly $2 \frac{1}{2} \mathrm{~mm}$.

Glenhope; 3rd March, 1915. One, found by Mr. 'T. Hall.

\section{Crisius eximius sp. nov.}

Subovate, rather narrow, convex, opaque; rufo-piceous, antennae and tarsi paler; densely covered with depressed fulvo-ferruginous, and a few suberect greyish squamate, those on the clytra overlapping, the posterior declivity greyish.

Rostrum as long as thorax, arched, subparallel, obtusely convex along the middle, rather flat and slightly emarginate in front, squamose elsewhere. Thorax a filth broader than hong, contracted, slightly depressed, and distinctly bicristate in front; its basal portion with similar crestr, the one at cateh side indistinct; dise apparently closely punctured, with a slight central ridge behind, its base slightly bisinuate. Scutellum obsolete. Elytra of the same width as thorax at the base, a litte wider behind the posterior femora, twice its length, more convex than it is, considerably narrowed and deflexid behind; appanty narrowly striate-punctate, third and fifth interstiens a little chevated at the base, all slightly ratised near the top of the declivity.

Smaller and narrower than its nearest ally, $C$. contiguus, the squamosity much brighter, the summit of the posterior declivity without any trace of 
a dark border. Legs and antennae similar. Mentum small, the thick flavescent palpi quite visible.

Length (rostrum exclusive), $3 \frac{1}{2} \mathrm{~mm}$. ; breadth, $1 \frac{2}{3} \mathrm{~mm}$.

Glenhope ; 18th July, 1915. A single example, from Mr. T. Hall.

\section{Allanalcis Broun. Trans. N.Z. Inst., vol. 45, p. 141.}

\section{Allanalcis variatus sp. nov.}

Convex, subovate, broadest near the shoulders, tapering towards both extremities, without crests or inequalities, opaque ; fuscous, densely covered with depressed elongate squamae, mostly of a pale brick-red hue, and with some scattered, erect white ones; sides of thorax and elytra nigrescent, usually with an angular, large, fuscous spot on each side of the posterior declivity; rostrum and legs more or less piceous, antennae and tarsi light infuscate red.

Rostrum stout, about as long as thorax, slightly narrowed towards the middle, minutely asperate. Thorax of equal length and breadth, slightly narrowed towards its rounded apex, the base oblique at each side, its moderately coarse and close punctation scarcely discernible. Elytra cordate, nearly double the length of thorax, just as wide at the base, broader near the shoulders, considerably narrowed but not vertical behind; with narrow, indistinctly punctured striae and feebly elevated interstices.

Legs coarsely setose, tibiae nearly straight inwardly. Penultimate tarsal joint broadly expanded, grooved above along the middle, entire and densely setose underneath, the terminal rather slender and attached to the base of the third, with small claws. Antennae of normal structure.

Underside piceous; basal segment large and flat, coarsely punctate, with tawny scales, the second very short, indistinctly separated and on the same plane, fifth rufescent, finely punctate.

This resembles the Auckland $A$. incultus (2572), which has tawny or infuseate yellow squamae, in place of infuscate red as erroneously recorded in the printed description. A. variatus is larger, the thoracic base is not truncate, the posterior declivity is more sloping, and the squamae are elongate.

Length (rostrum exclusive), $2 \frac{1}{3} \mathrm{~mm}$. ; breadith, $1 \frac{1}{3} \mathrm{~mm}$.

Glenhope, near Nelson. About ten examples were detected amongst decaying forest-leaves by Mr. T. Hall, most of them during the winter of 1915 .

\section{Allanalcis seticollis sp. nov.}

Subopaque, nearly plane above, posterior declivity subvertical; more or less infuscate red, elytral striae quite rufescent; the thorax with "longate, decumbent, reddish seales near the sides, paler and more distant ones towards the middle, which bears depressed fulvescent setale. Elytral dise with elongate-oval, tawny-fulvous squamae, whitish ones extend from the shoulders backwards and are then irregularly curved inwardly as far as the third interstices, these are bordered behind by nigreseent ones, white scales cover, but unevenly, about half of the declivity.

Thorax as long as broad, only very slightly narrowed before the middle, relatively coarsely and closely punctured. Elytra cordate, not twice the length of thorax, on about the same level; on each there are three wellmarked dorsal striae, and near the side two series of elongate impressions.

21-Bull. No. 1. 
This is smaller than $A$. variatus, though similar in form and structure, the legs are not as thick, the dorsum is flatter and without upright white scales, and the thoracic punctation, owing to the scanty and more slender vestiture, is quite easily seen.

Length (rostrum exclusive), $2 \mathrm{~mm}$; ; breadth, quite $1 \mathrm{~mm}$.

Woodhen Bend, near Glenhope. One, found by Mr. T. Hall on the 20th June, 1915.

\section{Allanalcis albipictus sp. nov.}

Convex, subovate, widest just behind the shoulders, opaque; derm piceous, but densely covered with depressed, ruther coarse and elongate squamae, these are chiefly light rufo-fuscous, but white ones cover the posterior declivity along the middle, an irregular large area extending along the side of each elytron from the base to the lind thigh, a spot acrosis the third and fouth interstices near the midd!e, and an indefinite streak near each side of the thorax, in addition to minute scattered specks; antennae and tarsi light rufo-fuscous.

Rostrum a third shorter than thorax, moderately broad, gradually narrowed towards the middle, squamose. Thorax slightly broader than long, gradually narrowed anteriorly, its coarse and close punctation entirely hiJden. Elytra cordate, hardly double the length of thorax, of the same width as it is at the base, which is slightly oblique towards the sides, much broader in line with the middle femora, a good deal narrowed and subvertical behind; their striae seem rather narrow, third interstices slightly raised near the base, the second behind the middle.

Antennae, legs, and tarsi of normal structure, penultimste tarsal joint grooved above, densely setose and apparently entire underieath so that the terminal joint is only visible at the extremity.

Nearly related to the North Island A. incultus (2572), but differing from it and other species by the conspicuous patches of white squamae, some of which are erect.

Length (rostrum exclusive), $2 \frac{1}{4} \mathrm{~mm}$. ; breadth, $1 \frac{1}{2} \mathrm{~mm}$.

Glenhope. A solitary individual, obtained by Mr. T. Hall on the 30th August, 1915.

\section{Allanalcis melastictus sp. nov.}

Convex, subovate, widest in line with the hind thighs; elytra castaneous, thorax and rostrim darker, antennate and tarsi paler than clytua ; splationsity dense and coarse, depressed on the therax, subereet on som. partof the elytra, to a rreat extent light rufo-fuscous, more rufescent near the sides, base of rostrum, and legs; but with the following blackish spots, two pairs on the basal half of thorax, on each elytron, one inside the shoulder, on the third interstice a median one, and another but larger on top of the declivity, where there are a few small specks lower down.

Rostrum nearly as long as thorax, subparallel, stout, scarcely at ail arched, squamose, with minute flavescent setae at the apex. Thorax about a third broader than long, a little contracted and depressed in front, the sides behind nearly straight; slightly elevated at each side of the middle, its punctation concealed. Blytra on a higher plane than the thorax, subcordate, twice the length of thorax, of the same width as it is at the base, vertical and much narrowed behind; distinctly striate, interstices slightly convex, the third rather more so and thicker than the others. 
Legs long and thick, the anterior longest, the hind pairs of femora with a dark spot near the base and an obscure greyish one on the middle; penultimate tarsal joint moderately expanded, longitudinally excavate above but not distinctly bilobed. Antennae normal, seaje very short.

This small speeies may be known by the distinct blackish maculation.

Length (rostrum exclusive), $1 \frac{2}{3} \mathrm{~mm}$.; breadth, quite $1 \mathrm{~mm}$.

Titirangi, near Auckland. The only specimen I have seen was found by Mr. A. E. Brookes, of Mount Albert, on the 18th September, 1915.

\section{Allanalcis blanditus sp. nov.}

Elongate-ovate, moderately convex, broader behind the shoulders than elsewhere; derm nitid, piceo-rufous, tarsi and club fusco-rufous, antennae paler ; elytra and sides of thorax thickly covered with elongate, decumbent, somewhat rufo-fulvous scales, each elytron with an obscure greyish, interrupted, oblique fascia extending from near the side, before the middle, but not reaching the suture in front of the posterior declivity, thoracic disc thinly clothed with more slender squamae.

Rostrum rather shorter than thorax, stout, rugosely punctate. Thorax of about equal length and breadth, gradually narrowed anteriorly, moderately coarsely and closely punctured. Elytra cordate, almost double the length of thorax, hardly any broader than it is at the base, narrowed but not quite vertical behind: apparently punctate-striate, interstices slightly convex, the pair nearest the suture a little thicker than the others behind.

Antennae and tarsi of normal structure, the scape inserted at or just before the middle.

Rather narrower than ordinary species, with very little variegation, the elytra on almost the same level as the thorax.

Length (rostrum exclusive), $2 \frac{1}{5} \mathrm{~mm}$. ; breadth, $1 \frac{1}{5} \mathrm{~mm}$.

Glenhope; 19th August, 1915. One only, found by Mr. T. Hall.

\section{Atylodes Broun. N.Z. Inst., Bull. 1, Part II, p. 137, 1914.}

\section{Atylodes asaphus sp. nov.}

Convex, subovate, slightly nitid; rufous, antennae paler, somewhat testaceous, club piceous; sparingly clothed with suberect, yellowish setiform squamae.

Rostrum shorter than thorax, hardly at all arched above, moderately stout, subseriate-punctate behind, indistinctly in front, its sides subcarinate towards the eyes. Thorax slightly broader than long, somewhat contracted and a little depressed before the middle, its sides rounded behind; relatively coarsely and closely punctate. Elytra cordate, a half longer than thorax, truncate and of the same width as it is at the base, narrowed and subvertical behind; each clytron has five deep, apparently impunctate dorsal striat and convex interstices, those between the sutural and second striae do not reach the base.

Femora rather long and thick, the anterior longest, with short, slightly curled pale setae; tibiae slightly flexuous, uncinate, with more erect setare; penultimate tarsal joint very widely dilated.

Second joint of funiculus as long as the thicker first, the following ones small and subequal; club large, subovate, densely pubescent, indistinetly articulate.

Underside dull piceous, distantly punctate and setose, fifth ventral segment rufescent, very minutely sculptured, with a small fovea behind. 
The specimens in their natural condition are dull fuscous, but when freed from extraneous substances present the appearance described above. They are only about half the bulk of $A$. foveiger (3461).

Length (rostrum exclusive), $1 \frac{1}{4} 1 \frac{1}{2} \mathrm{~mm}$. ; breadth, $\frac{3}{4} \mathrm{~mm}$.

Pakuratahi, near Wellington. Taken from leaf-mould by Mr. H. W. Simmonds on the 2nd January, 1915.

\section{Zeacalles Broun. Ann. Mag. Nat. Hist., ser. 6, vol. 12, p. 379.}

4130. Zeacalles aeratus sp. nov.

Compact, very convex, subpyriform, slightly nitid ; fusco-rufous, dytra and legs paler, rostrum rufous, antemnar rufo-testaceous; covered mostly with -mall, depressed, rather bright brassy squamae, but grey ones form a streak along each side of the thorax and clytra as far as the hind thigh, where it bends inwardly; there is an elongate blackish basal spot inside each shoulder, and three irregular spots near the extremity.

Rostrum scarcely at all arched above, almost as long as the thorax, with a few scales at its base, fincly subseriate-punctate towards the front. Thorax as long as broad, truncate at the base, gradually narrowed anteriorly, distinctly and moderately closely punctured. Scutellum absent. Elytra of the same width as thorax at the base, closely applied thereto, quite twice its length, on an abruptly higher plane, widest near the middle, narrowed and vertical behind; sutural striae narrow, second somewhat incurved behind the middle; the interval between these striae evidently swollen before the middle, and terminating on top of the posterior declivity as a large horizontal nodosity; the other striae are slender and indefinite.

Legs with numerous pale squamiform setae; femora long, stout and unarmed, tibiae nearly straight, uncinate; basal joints of tarsi small, the penultimate broadly dilated, excavate above, densely setose and apparently entire underneath.

Underside obscurely rufescent, with some pale coarse squamae. Pectoral canal profound, its sharply elevated hind borders extending as far as the back part of the intermediate coxae. Basal ventral segment largest, truncate behind, the second short, yet slightly longer than third or fourth and on the same level as they are.

The grey lateral streaks, nigrescent marks, and elytral nodosities resemble those of the North Island Z. binodosus (3139), with the exception of the dark posterior spots, but the elytral striae of that species are moderately broad and deep, and the second are not incurved behind. The bright brassy scales of $Z$. aeratus distinguish it from all its allies.

Length (rostrum exclusive), $2 \frac{1}{3} \mathrm{~mm}$. ; breadth, $1 \frac{1}{4} \mathrm{~mm}$.

Woodhen Bend, near Glenhope; 20th June, 1915. Taken from leafmould by Mr. T. Hall. Two examples, one of them damaged and now mounted on its back.

\section{Zeacalles coarctalis sp. nov.}

Elongate, rather narrow, the elytra, at or before the middle, very little broader than the thorax, very convex, slightly nitid, not densely elothed; light infuscate red, rostrum rufous, antennae and tarsi rufo-testaceous; the depressed flaveseent squamae on the basal half of elytra much smaller than those on the thorax; rather larger grey scales form an indefinite lateral streak from the front of thorax to the commencement of the 
posterior declivity, and are irregularly distributed over the back part of the elytra.

Rostrum as long as thorax, moderately broad, smooth near the middle, punctate elsewhere. Thorax as long as broad, quite truncate at base, gently narrowed anteriorly; distinctly and closely punctate near the middle, less so near the front and sides. Elytra just double the length of thorax, on a ligher level, vertical behind; there are two indistinctly punctured, straight, well-marked striae along each side of the suture, the sculpture beyond these is indefinite; second interstices moderately horizontally nodose and bearing some coarse suberect scales, the nodosities therefore seem more prominent than they are in reality. Legs proportionally rather thick.

This small member of the binodose series may be recognized by its rather narrow form, the elytra, though narrower than those of $Z$. binodosus (3139) at the middle, are broader near the apices.

Length (rostrum exclusive), $1 \frac{2}{3} \mathrm{~mm}$. ; breadth, $\frac{2}{3} \mathrm{~mm}$.

Retaruke, west of Erua, near Waimarino. Mr. W. J. Guinness kindly collected and sent a bagful of decaying leaves, out of which I picked out a specimen, in March, 1910.

\section{Zeacalles finitimus sp. nov.}

Elongate-ovate, convex, slightly nitid; light infuseate red, rostrum rufous, antennae and tarsi somewhat rufo-testaceous; not thickly covered with depressed, moderately elongate, obscurely rufescent and greyish scales, these latter form an ill-defined oblique strcak from behind each shoulder towards the suture, across the top of the declivity there are nearly a dozen upright grey scales besides some slightly infuscate ones lower down; legs with coarse greyish setae.

Rostrum about as long as thorax, finely punctate. Thorax slightly broader than long, of the usual shape, its punctation distinct near the middle of the base, less so elsewhere, with a fine carina along the middle but not attaining the apex. Elytra nearly twice as long as thorax, rather broader than it is near the middle, more convex, narrowed and vertical behind; each elytron near the sliture with a pair of straight, apparently punctate striae, and about three series of fine punctures towards the side; second interstices slightly nodose at the summit of the posterior declivity. Legs normal.

Considerably smaller and less evidently variegated than $Z$. carinellus (3647); and easily separable from $Z$. coarctalis by its broader and more ovate elytra, relatively less robust legs, and thoracic carina.

Length (rostrum exclusive), $1 \frac{2}{3} \mathrm{~mm}$. ; breadth, $\frac{3}{4} \mathrm{~mm}$.

Woodhen Bend. One, found by Mr. T. Hall amongst decaying leaves on the 20 th June, 1915.

\section{Zeacalles bisulcatus sp. nov.}

Subovate, convex, subopaque; piceous, legs fusco-rufous, antennae obscure rufo-testaceous; covered with decumbent, fuseo-fulvous and grevish squamae, these latter form an oblique, not sharply marked fascia on each clytron, extending backwards from near the middle thigh but not reaching the suture; on top of the declivity a few coarse, upright grey scales form a crest on each elytron; some curled, suberect, coarse, slightly infuscate setae occur along the sides and on the front of the thorax; there is an 
elongate, nigrescent basal spot half-way between the suture and shoulder on each elytron.

Rostrum dull rufo-piceous, minutely asperate, indistinctly carinate along the middle. Thorax slightly broader than long, slightly more narrowed before the middle than behind; moderately coarsely and closely punctured, with a few grey scales at the middle of its base. Elytra oviform, twice the length of thorax, a trifle wider than it is at the base, rather wider before the middle, narrowed and vertieal behind; each elytron has a single wellmarked sutural stria which becomes finer towards the extremity.

Legs elongate, moderately stout, tibiae with outstanding squamiform greyish setale; penultimate joint of tarsi transverse, fully twice as broad as the basal ones, excavate above, apparently entire below.

As there are only two erests on the posterior diclivity this species can be readily separated from $Z$. binodosus and its near allies; the single stria on each elytron, the smooth shining interstice alongside it, the unusual number of suberect seales on the front of the thorax, and the dark roughlocking rostrum, in conjunction, render it distinct.

Length (rostrum exclusive), $2 \mathrm{~mm}$. ; breadth, $1 \frac{1}{4} \mathrm{~mm}$.

Howard Goldfield, Nelson. Another species found by Mr. T. Hall on the 30th March, 1915, and represented by a solitary individual-a male, no doubt.

\section{3t. Zeacalies scruposus sp. nov.}

Subovate, convex, subopaque; piceous, antennac and tarsi more or less rufo-testaceous; vestiture variegate, thorax with fusco-fulvous squamate, mingled with coarser and suberect grey ones, its sides with man! cutstanding pale fuscous setae; elytra similarly setose, the thick patch of fusco-fulvous squamae near each shoulder is composed of smaller scales than those on the thorax, and there is an oblique grey prolongation of acich towards the middle, and several coarse blackish, erect ones are visible; there is a nigrescent scutellar spot, and a narrower one between it and anch should $2{ }^{2}$, and others near the sides behind; several erect dark setae can be seen, there are also some erect seattered white scales, which, on top of the posterior declivity, are concentrated on the nodosities there.

Rostrum squamose at the base, with minute flavescent setae in front, rufesent, of normal form. Thorax nearly a third broader than long, grarlually narrowel anteriorly, its moderately coarse and close punctation hidden. Elytra broadly oval, just twice the length of thorax, a third broader near the middle, on a higher level, vertical behind; their striac are indistinctly punctats and mueh concealed, the interval between the sutural and second is nodiform behind. Penultimate tarsal joint not definitely lobate.

Z. varius (2957) is the only species at all like this, but the marks are very different, the erect setae are slender and elongate, the thorax is longer, the elytra narrower, and the insect itself is more elongate-oval than Z. scruposus.

Length (rostrum exclusive), $2 \mathrm{~mm}$. ; breadth, $1 \frac{1}{3} \mathrm{~mm}$.

Gordon's Knob, Nelson; 4,000 ft. Found by Mr. T. Hall on the 15 th November, 1914. Unique.

I second specimen, not in as good condition as the type, is less definitely variegated, its thorax is a trifle longer, there are three wellimpressed striae on each elytron and three rows of punctures near the side. It probably represents another species. 


\section{Zeacalles latulus sp. nov.}

Subpyriform, rather broad, subopaque; fuscous, rostrum piceo-rufous, antennar rufo-testaccous, legs fusco-rufous; covered principally with depressed infuscate-tawny scales; some rather paler, not quite grey, form an indefinite streak along the middle of the thorax and ancther near each side, there is a broader space near each shoulder; inside the latter there is a black streak, and in line with it, behind the middle, three cr four small black crests; there are also numerous upright, rather short, dark squamifcrm setae, these are most conspicuous near the sides and in front.

Rostrum subseriate-punctate. Thorax rather broader than long, gradually narrowed towards the front, apparently closely and coarsely punctured. Elytra of the same width as thorax at the base, brcader near the midcle, twice its length, on a higher plane, narrowed, vertical, ard slightly inflexed behind; on each elytron there are two well-marked striae near the suture, the squamosity renders the others indistinct; interstices with a few minute punctures, the second somewhat swollen and bearing dark, short, suberect scales at the top of the declivity but not actually nodiform there.

Legs long and stout, with grevish squamiform setae; jenultimate tarsal joint broadly expanded, excavate above, setose but not distinctly bilobed undermeath.

Scaje short, gradually inrassate, medially inserted, and reaching the front of the eye; funiculus longer, second joint as long as the basal but more slender, joints 3-7 become slightly shorter and broader; club large, oblong, indistinctly articulate.

A rather broad species, distinguishable by the black spots along the micille of each elytron amongst the indefinitely variegated vestiture.

Length (rostrum exclusive), $2 \frac{1}{3} \mathrm{~mm}$. ; breadth, $1 \frac{1}{2} \mathrm{~mm}$.

Woodhen Bend. One, found by Mr. T. Hall ; 20th June, 1915.

\section{Zeacalles inornatus sp. nov.}

Convex, subovate, narrowed anteriorly, elytra slightly nitid; fuscorufous, antennae rufo-testaceous, club infuscate; thinly covered with defressed, elongate, tawn! and grey squamae, and many erect, but not elongate, infuscate grey setae.

Postrum as long as thorax, rather broad, squamose near the base, fincly punctate in front. Thorax slightly broader than long, of the usual form, coarsely and closely punctured, the greyish scales are most mumereus near the sirles but do not form streaks. Elytra subovate-glblong, only a fourth longer than broad, just double the length of thorax, of the same width as it is at the base, very littl.. broad.r ncar the middl., gradually wevated from th" bas", subvertical behind; ther are evidently punctate-striate from base to apex, the inner three on each most distinct; interstices a little convex but not nodiform, the few grey scales on the summit of the declivity do not form defiuite crests.

Legs normal, thick, with coarse grey setae; penultimate tarsal joint broad, excavate above, apparently entire underneath.

Scape medially inserted; serond joint of the funicle hardly as long as the basal, joints $3-6$ small and subruadrate, seventh slightly broader, club oblong.

Rather broader than $Z$. coarctalis, elytra not on an abruptly higher l.vel than the thorax, without nodosities or crests, the restitur" without obvious rariegation.

Length (rostrum exclusive), $1 \frac{2}{3} \mathrm{~mm}$.; breadth, $1 \mathrm{~mm}$.

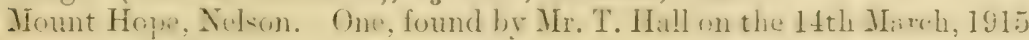


Zeacalles Broun. Ann. Mag. Nat. Hist., ser. 6, vol. 12, p. 379. 4137. Zeacalles parvus sp. nov.

compact, convex, subovate, narrowed anteriorly, opaque, without erests or nodosities ; nigro-fuscous, antennae and tarsi light rufo-fuseous ; covered with subdepressed, relatively coarse, suboblong, grevish-tawny squamae: those on the legs fuscous.

Rostrum longer than thorax, rather broad, hardly at all arched above, its seulpture indistinct. Eves free from thorax, not prominent. Thorax of about equal length and breadth, gradually narrowed anteriorly, its punctation concealed. Elytra subrotundate, as wide as thorax at the bise, rather broader near the middle, more convex, a third longer, vertical and somewhat narrowed behind; quite distinctly striate.

Antennae very finely pubescent; scape short and stout, incrassate towards the extremity, not attaining the eye; basal joint of funiculus twice as thick as the next but hardly any longer, joints 3-7 transverse, seventh as broad as the elongate club, the basal joint of which is longer than the following two combined.

Legs long and thick, the anterior pair especially; penultimate tarsal joint broadly expanded, excavate above, apparently entire below.

This small species can be separated from the others by its rather broad rostrum and distinctly striate, subrotundate elytra.

Length (rostrum exclusive), $1 \frac{1}{2} \mathrm{~mm}$. ; breadth, $1 \mathrm{~mm}$.

Huia, Manukau Harbour. One individual, obtained from leaf-mould by Mr. A. E. Brookes, of Mount Albert, on the 10th April, 1915.

\section{Zeacalles cordipennis sp. nov.}

Subelongate-ovate, moderately and evenly convex, subopaque ; castaneorufous, rostrum dark red, legs fuscous, antennae and tarsi infuscate red; clothed with deprosised setiform seales, these are fulvescent on the rostrum, thorax, and middle of elytra, on these last they become tawny-grey near the sides; there are only very few erect, coarse yellow setae on top of the posterior declivity, which, however, do not form crests; the other erect setae at the sides are more infuscate.

Rostrum as long as thorax, only slightly arched, distinctly longitudinally punctate behind, more finely and irregularly near the extremity. Eyes moderately large, distant above. Thorax of equal length and breadth, gradually narrowed anterioly, base truncate, closely and distinctly punetured. Elytra cordate, of the same width as thorax at the base, rather broader near the shoulders, twice its length, not more convex than it is, vertical, but not abruptly so behind; their striae, though well marked, are not definity punctured, and become obsolete behind; the interstice near each side of the suture is thickened and slightly elevated at the base.

Legs long and stout, bearing erect, coarse infuscate setac. Antennac medially inserted; second joint of the funiculus as long as the first, seventh broader than the subquadrate sixth; club oblong, somewhat narrowed towards the base, with small apical articulations.

In this genus the elytra are usually more arched above than the thorax; this is not the case in this species, and, moreover, they are quite cordiform.

Length (rostrum exclusive), $2 \frac{1}{3} \mathrm{~mm}$. ; breadth, $1 \frac{1}{2} \mathrm{~mm}$.

Howard Goldfield, near Nelson. Unique (unfortunately). Another of

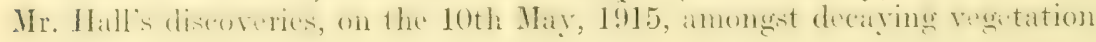
on the ground. 


\section{Group Cossonidat.}

Eucossonus Broun. Man. N.Z. Coleopt., p. 870.

\section{Eucossonus constrictus sp. nov.}

Subdepressed, elongate, opacjue ; dark fusco-rufous, antennae and tarsi light chestnut-red; sparingly clothed with decumbent, yellowish setae.

Rostrum dull, minutely and densely sculptured, with fine frontal punctures; a third shorter than thorax, stout, distinctly narrowed behind the antennal insertion, near the middle. Head with a few fine punctures and setae. Eres slightly convex. Thorax nearly a third longer than broad, its larger basal portion oviform, the constriction in front large and desap, base truncate; rise plane or only feebly impressed along the middle, minutely and densely sculptured, its punctation coarse but shallow, the dilated apical portion not perceptibly punctured. Scutellum small, subrotundate. Elytra nearly twice the length of thorax, truncate and a little wider than it is at the base, parallel, moderately curvedy narrowed behind ; distinctly and closely striate-punctate; interstices minutely rugose, the third slightly elevated throughout, fifth less distinctly, not at all behind.

Scape evidently flexuous ; second joint of the funicle rather longer than the basal, joints $3-5$ a little longer than broad, club moderately subelongateoval.

Underside almost plane, subopaque, nigro-piceous, coarsely but not deeply punctured, with densely and minutely sculptured intervals, with a few fine grevish setae; the thoracic constriction quite as deep as it is above.

This is much larger than Sharp's Sericotrogus setiger (934). E. antenualis (3140), the nearest ally, has thicker antennae, the rostrum is only slightly narrowed behind, and the thorax is longer and less "vidently junctate. The rather large and deep frontal constriction of the thorax is the chief distinguishing feature of this species.

Length (rostrum inclusive), $3 \frac{1}{3} \mathrm{~mm}$; breadth, $\frac{2}{3} \mathrm{~mm}$.

Belgrove, near Nelson. The type was found by Mr. T. Hall on the $2 t$ th October, 1914, along with the larger $\left(4 \times \frac{3}{4} \mathrm{~mm}\right.$.) mutilated specimen, from which the description of the underside has been taken.

\section{Eucossonus sulcicollis sp. nov.}

Elongate, subdepressed, slightly nitid; rostrum and thorax rufous, legs more infuscate; elytra, antennae, and tarsi light chestnut-red; sjarsely covered with flavescent setae, decumbent and disposed transversely on the thorax, longitudinally and suberect on the elytra.

Rostrum nude, shining, and finely punctate in front, rather dull with minute sculpture, and subseriate-punctate brehind; it is a thirc shorter than thorax, hardly at all arched above, moderately narrow, a little dilated behind the middle, where the antennae are inserted. Head gradually narrowed anteriorly, with a few setae, the occiput impunctate. Thorax a thiril longer than broad, moderately constrieted near the apex, the remaining portion oviform, base subtruncate ; distinctly but not deeply or clowely punctured, the intervals minutely sculptured. the a jex alnost inimunetate; along the dise from the constriction to the base there is a well-marked impression which is widest at the middle. Scutellum distinct hut mall. Elytra parallel, rather broader than thorax at the base, which is slightly arivate, quite double its length, moderately narrowed behind : di-tinet! y. bat not coame'y striate-punetate, interstices rather narow and finely mere-e. the third slightly elevate throughout. 
Seape evidently flexuous, attaining the thoracic apex; second joint of funieulus distinctly longer than the basal, joints $3-5$ longer than broad; club elongate-oval, rather narrow, quadriarticulate.

Mule.-- Slightly darker. Rostrum dull, dark rufous, densely and minutely seulptured, finely punctate, moderately stout in front, gently narrowed behind ; scippe nedially inserted. In E. constrictus the rostrum is manifestly more contracted behind the antemnal insertion, the thoracie constriction is larger and deeper, so that the oviform basal portion is shorter and more rounded. One found at Belgrove.

The female most nearly resembles the type of $E$. discalis (3141), also a female; the latter, however, is more opaque, its thorax is flat instead of being depressed along the middle, and the antennae differ.

+. Length (rostrum inclusive), $3 \frac{2}{3} \mathrm{~mm}$. ; breadth, $\frac{2}{3} \mathrm{~mm}$.

Howard Goldfield, near Glenhope. A single fenale, captured by Mr. T. Hall ; 10th May, 1915.

\section{Eucossonus nasalis sp. nor.}

Subdepressed, elongate; rostrum and thorax dark fusco-rufous, antennae and tarsi paler; elytra a little shining, light chestnut-red; irregularly clothed with distinct, mostly decumbent, bright-yellow setae.

Rostrum opaque, with dense minute sculpture and fine punctures, a third shorter than thorax, a good deal, yet gradually, narrowed behind the middle; its frontal half rather broad and parallel, nearly plane above, with a feeble interantennal impression. Occiput large, nearly smooth. Eyes widely separated, slightly convex. Thorax fully a third longer than broar, wather deeply constricted near the apex, oviform behind; flat and nearly glabrous along the middle, minutely and densely sculptured, and with numerous, rather distant, well-marked punctures. Scutellum subrotundate. Elytra almost twice the length of thorax, slightly arcuate-emarginate and rather broader than thorax at the base, their sides straight as far as the curvedly narrowed posterior declivity; finely striate-punctate, interstices rugose, the third, and the suture, slightly elevated.

Scape medially inserted, flexuous, moderately stout; second joint of the funicle evidently longer than the basal, third and fourth rather longer than fifth; club elongate-oval.

The male of $E$.gracilis (2420) has the scape shorter, thicker, and nearly straight; the rostrum narrower and more parallel, the occiput less convex, and the sides of the thorax less rounded.

A careful examination of the anterior half of the rostrum will show how it is differentiated from other recorded species, in these. ordinarily, it is somewhat convex.

ô. Length (rostrum inclusive), $3 \mathrm{~mm}$.; breadth, $\frac{2}{3} \mathrm{~mm}$.

Wyndham, Southland. Mr. J. H. Lewis sent me a specimen of this species along with a varietal form of $E$. elegans (2419) on the 19 th Oetober, 1914.

\section{Eucossonus disparilis sp. nov.}

Depressed, subopaque; infuseate red, antennac and tarsi of a lighter hue; thinly clad with yellow, decumbent, slender setae.

Rostrum a third shorter than thorax, its frontal half moderately broad, parallel, finely punctate and slightly nitid; the basal opaque, with minute dense sculpture, distinctly medially incurved. Occiput rather short. Eyes 
small, widely distant above. Thorax rather longer than broad, the deep frontal constriction at each side connected above by a fine apparently raised line; the basal portion oviform, not longer than broad, flat, densely and minutely sculptured, its punctation moderately distinct, rather distant and irregular. Scutellum small. Elytra twice the length of thorax, a little broader than it is at the base, slightly arcuate-emarginate there, their sides straight as far as the posterior declivity; dorsum nearly flat, finely rugose, closely striate-punctate.

Scape medially inserted, only moderately flexuous; second joint of funiculus rather longer than the basal, third and fourth slightly longer than fifth ; club normal.

Underside piceo-rufous, slightly nitid, rather distantly and moderately coarsely punctured, with fine grey setae, basal ventral segments medially flat.

Fem. $-2 \frac{3}{4} \mathrm{~mm}$. by quite $\frac{1}{2} \mathrm{~mm}$., slightly shining, elytra light chestnutred; rostrum rather longer and more slender, finely punctate, slightly dilated at the antennal insertion, behind the middle: without any transverse raised line between the thoracic constrictions.

The male of this small species may be identified by the distinct incurvature of the sides of the rostrum behind the middle, and the raised line across the constricted portion of the thorax. The female specimen may not really belong to this species.

o. Length (rostrum inclusive), $2 \frac{1}{2} \mathrm{~mm}$. ; breadth, $\frac{1}{2} \mathrm{~mm}$.

Howard Goldficld. A single example of each sex, found by Mr. T. Hall; 10th May, 1915.

\section{Eucossonus oreobius sp. nov.}

Elongate, subdepressed, subopaque; fusco-rufous, the sides of elytra, the tibiae, tarsi, and antennae light chestnut-red; irregularly clothed witl elongate, mostly decumbent, yellow setae.

Rostrum stout, fully a third shorter than thorax, a little narrowe? behind, opaque, finely punctate. Thorax a third longer than broad, evidently constricter in front; glabrous and only slightly impressed along the middie. densely and minutely sculptured, distinctly and moderately coarsely punctured. Scutellum distinct. Elytra double the length of thorax, rather broader than it is at the base, slightly biareuate there; minutely sculptured and rugose, distinctly but not coarsely striate-punctate, quite striate neal the extremity.

Scape flexuous, implanted at or just before the middle; second joint of funiculus as long as the first, third and fourth slightly longer than broad; club normal.

Underside slightly nitid, piceous, prosiernum and last three ventral segments more rufescent; moderately closely and coarsely punctured, the intervals more or less minutely sculptured, with some fine grey setae; metasternum with a linear impression along the nidde behind; basal two segments with a shallow median impression, the suture between them indistinct.

Fem.- Rostrum rufous, somewhat nitid, finely and moderately closely punctate, not smooth along the middle, rather more dilated at the antemnal insertion, behind the middle, than in the same sex of $E$. cleguns (2419).

The female of $E$. oreobius is undoubtedly nearly allied to the type of 2.19-also a female-which was found at a low level on the eastem seashore in habit, therefore, these species differ considerably. 
o. Length (rostrum inclusive), $3 \mathrm{~mm}$. ; breadth, $\frac{2}{3} \mathrm{~mm}$.

Ben Lomond. 'Taken from leaf-mould by Mr. 'T'. Hall, at an altitude of $5,05 \% \mathrm{ft}$., on the 31st January, 1914.

\section{Allaorus Broun. Mon. N.Z. Coleopt., p. 1494.}

\section{Allaorus carinifer sp. nov.}

Elongate-subovate, moderately convex, nitid; with very few slender, pale setae ; castaneo-rufous, darker at the sides, tarsi paler, club piceous.

Restrum stout, subparallel, rather shorter than thorax, only slightly arched; finely subseriate-punctate, more finely and distantly in front. Thorax rather longer than broad, very little wider just before the middle than behind, a little contracted in front, batse truncate; relatively coarsely, closely, and somewhat rugoscly punctured, quite finely near the apex, with a fine, not sharply marked carina along the middle of the dise. Scutellum quite visible but small. Elytra hardly twice the length of thorax, of the same width at the base, a little broader near the middle, much narrowed and deflexed behind, with simple apices; distinctly crenatestriate, the punctures rather large so that the minutely and distantly punctate interstices appear somewhat uneven.

Underside nitid, piceons, mederately cearsely but not closely punctured, each puncture lias a fine seta, fifth ventral segment, minutely and distantly punctate.

Penultimate tarsal joint moderately dilated, excavate above, but not definitely bilobed, apparently an unceliable character owing to tha difticulty in removing extrancous matter from the soles. The eyes are slightly convex and larger than those of the type of the genus, A. uryuharti (2577), being more like those of $A$. impressus (3945), which, however, is a much larger insect, with the alternate interstices of the elytra somewhat elevited. The distinct scultellum, too, is ahnormal, and should perhaps exclude this species from Allaorus.

Length (rostrum inclusive), $2 \mathrm{~mm}$. ; breadth, $\frac{2}{3} \mathrm{~mm}$.

Pakuratahi. A single pair, from Mr. H. W. Simmonds; 2nd January, 1915

\section{Group Anthribidat.}

Anthribus Geoffroy. Mrn. N.Z. Coleopt., p. 515.

\section{Anthribus halli sp. nov.}

Robust, oblong, convex, subopaque, without nodiform elevations ; nigrescent, legs castaneous, each of the tibiae with a greyish spot near the middle and another at the extremity, antonnate rufo-cestaneous ; rostrum and front of thorax covered with distinct reddish-brown and greyish decumbent setre, the latter with an elongate white spot at the middle of the base, and a dark merian erest; elytra with short similarly vamiegated vestiture, and bearing, on rach, about eight small crests, three of which are h] helish; myedium larere, rertical, oblong, corored with grey depressed setie.

Rostrum a third shorter than thorax, broad; dilated anteriorly, its apex emareninate; it is chesely but imesularly punetured, and has an abbreviated but indistinct median carina. Eyes prominent, entire, obliquely oval. Thorax slightly broader than long, its sides moderately rounded, a good

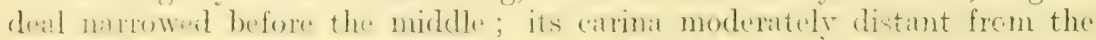


elytra, forming rounded posterior angles and prolonged towards the middle of each side, it is finely and irregularly punctured. Scutrllum small and indistinct, covered with white setae. Elytra rather broader than thorax at the base, nearly twice its length, gently narmowed backwards, apices subtruncate; finely, irregularly, substriate-punctatr. Tarsi moderately broad, their second joint emarginate, lobes of the third narrow.

Antennae shorter than the rostrum and thorax, immaculate; exposed portion of the basal joint shorter than the elengate-oval second, joint 3-8 elongate, gradually and slightly shortened and thickenerd; clui, moderately broad, its first joint longest, elongate-triangular.

This is congeneric with Sharp's A. bromini (961), but it is considerably larger and differently clothed and marked. It is smaller than $A$. rutis (965), but is without elytral nodosities. It should be placed between these species.

Length (rostrum inclusive), $5 \mathrm{~mm}$. ; breadth, $1 \frac{3}{4} \mathrm{~mm}$.

Glenhope, near Nolson; 16th Mar, 1915. One, found by Mr. T. Hall, in whose honour it has been named.

\section{Group Lamidide.}

Somatidia Thomson. Man. N.Z. Coleopt., p. 600.

\section{Somatidia maculata sp. nov.}

Convex, moderately elongate and nitid, without crests; usually testaceous, elytra with a large fuscous basal mark not reaching the sides, an angular one near each hind thigh not extending to the suture, and a few small but much paler spots behind; thorax sometimes liglit castaneous joints 3-11 of the antennae with infuscate tips; pubescence yellowish, irregularly distributed, slender and decumbent, without outstanding setae.

Head sparingly punctate, slightly concave between the antennal tubercles. Thorax oviform, slightly broader than long, widest near the middle, gently narrowed behind; dise only slightly convex, distinctly and irregularly but nowhere closely punctate. Scutellum short, triangular. Elytra oviform, quite double the length of thorax, a third broader in the middle, of the same width as it is at the base, rather more convex; their punctation on the basal half like that of the thorax but subseriate near the suture, rather finer elsewhere, the dark spots nearly nude. Femora arched above, slendir near the base; tibiae reddish near the knees and with a darker subapical spot.

Antemnae as long as the body, rather shorter in the female; their third joint more infuscate than the others and ratending beyond the base of the thorax, fourth nearly a third longer than the next.

Male.-Fifth ventral segment rounded and finely margined belind, sixth short and broad.

Fem.-Thorax shorter, elytra broader.

S. testacea (2998), the nearest spercies, is much larger, rather darher now, differenty marked, subopaque, and the elytra are minutely quadricristate.

๙. Length, $3 \frac{2}{3}-4 \mathrm{~mm}$.; breadth, $1 \frac{2}{3}-1 \frac{3}{4} \mathrm{~mm}$.

Glenhope, 10th December, 1914; Burnt Hill. 25th April, 1915; and Howard Goldfield, 10th May, 1915. Eight examples, found amongst leafmould by Ar. T. Hall, some slighty darker or less definitely maculate than the typical pair. 


\section{Somatidia longula sp. nov.}

Elongate, subcylindric, only moderately convex, shining; rufeseent, legs and antennare light rufo-castaneous and almost unspotted; very thinly clothed with slender greyish hairs, which on the elytra are suberect.

Head finely punctate, neirly plane between the distant antennal tubercles. Thorax oviform, of cqual length and bieadth, its sides only moderately rounded; irregularly and distinctly but not closely punctate. Sratellum indistinct. Elytra elongate-oval, twice the length of thorax, of the same width as it is at the base, but not any broader than the thorax in the middle, gradually narrowed behind the posterior femora; with a series of moderate punctures along each side of the suture as far as the midde but very few elsewhere.

Antennae nearly as long as the body, their third joint attains the base of the thorax, fourth longer than fifth.

Easily recognizable by the almost concolorous body and abnormally narrow elytra. It should be located near S. rubella (3660) and S. parvula (3953).

\section{Length, $2 \frac{2}{3} \mathrm{~mm}$. ; breadth, $\frac{3}{4} \mathrm{~mm}$.}

Glenhope. A single individual, found by Mr. T'. Hall on the 23rd November, 1914.

OBs.-S. laevinotata (3952): A varietal specimen, found by Mr. T. Hall on the 10th May, 1915, near the Howard Goldfield, has been labelled "S. humcrata." It measures $6 \times 2 \frac{3}{4} \mathrm{~mm}$., the smooth thoracic space becomes narrower and convex behind, and the shoulders are incrassate and lightly prominent so ats to $b$. manifestly broud re than the bas of the thorax.

\section{Somatidia vittigera sp. nov.}

Elongate, only moderately convex, slightly nitid; testaceous, but with the head, the sides of the thorax, except in front, a somewhat interrupted streak along the outside of each elytron, a basal spot, and three near the hind thigh, nigreseent; second antemmal joint and base of tibiar slightly rufescent, these latter with a blackish spot below the middle; pubescence fine, subdecumbent, yellowish-grey.

Head punctate, reddish behind, as are the antennal tubereles. Thorax of about equal length and beadth, broadest and sirongly rounded before the middle, considerably narrowed towards its base; dise "venly convex, distinctly and irregularly punctate, the broad dark lateral areas nearly in contact at the middle of the base. Scutellum indistinct and short. Elytra unusually narrow, twice the length of thorax, as wide as it is at the base, nowhere broader than the middle of thorax, their sides only feebly rounded, gently deflexed and narrowed posteriorly; dorsum distinetly subseriate-punctate, the four discal series on each reduced to a single one near the apex; the dark lateral vitta behind becomes irregularly broader downwards, and is closely biseriate-punctate; on each, at the middle of the base, there is a distinct, short, black costa.

Antennae shorter than the body, moderately stout, finely pubescent, thire joint longest but not reaching the thoracic base, fourth slightly longer than following ones.

S. flavidorsis (3947) has even shorter, reddish antennae, but the third and fourth joints are nigrescent, the thorax is of a silky fuscous hue, the elytra are rather broader than the thorax but are without basal costae.

Length, $4 \frac{1}{2} \mathrm{~mm}$. ; breadth, $1 \frac{1}{2} \mathrm{~mm}$.

Glenhope; 1st August, 1915. I am indebted to Mr. 'T. Hall for the specimen deseribed above. 
4149. Somatidia pennulata sp. nov.

Convex, oblong, moderately narrowed and depressed towards the middle, nitid; rufo-castaneous, sides of thorax and elytra more or less infuscate; tibiae and tarsi fusco-fulvous, antennae almost concolorous, the tibias above and near the extremity only slightly infuscate, palpi flavescent; pubescence decumbent, less so on the hinder half of the elytra, where there are a few erect, rather short and slender setae, of nearly the same yellowish hue as the rest.

Head nearly as broad as thorax, vertical and irregularly punctate in front. Thorax of about equal length and breadth, widest before the middle, well rounded there, gradually narrowed behind; its punctation distinct and irregular, nowhere very close. Scutellum triangular, rather small. Elytra oblong-oval, rather wider just behind the posterior femora than elsewhere, of the same width as thorax at the base, just twice its length; irregularly and rather distantly punctured, the common dark lateral and apical marks are nitid but not at all sharply defined. Legs with slender yellowish setae, femora clavate beyond the middle, antrior tibiae slightly arched externally.

Antennae almost as long as the body, with fine pubescence and slender elongate pale setae; third joint elongate and attaining the thoracic base, fourth slightly longer than fifth.

Underside fusco-rufous, finely sculptured, with decumbent, yellowish, feather-like pubescence. Basal ventral segment quite as long as the intermediate ones united, fifth shorter, medially emarginate behind.

Distinguishable by the somewhat indefinite dark marks and featherlike vestiture above and below.

o. Length, $4 \frac{1}{2} \mathrm{~mm}$. ; breadth, $1 \frac{4}{5} \mathrm{~mm}$.

Glenhope. Tiwo specimens, from Mr. T. Hall ; 19th August, 1915.

\section{Group Chrysomelidae.}

Caccomolpus Shaip. Man. N.Z. Coleopt., p. 1308.

\section{Caccomolpus subcupreus sp. nov.}

Suboblong-oval, moderately convex, glabrous, nitid; somewhat cupreoniger, labrum and legs castaneous, antennae of a lighter hue.

Head smooth behind the antennac, finely punctate along the midd!e, more closely in front. Thorax in the middle $2 \frac{1}{2}$ times broader than long, bas slightily but widely bisinuate, with acutely rectangular angles, its finely margined sides straight but gradually narrowed towards the prom nent and less acute anterior angles; dise finely but irregularly punctured, w:y sparingly, almost smooth, towards the sides. Scutellum small. Elytra gratually cuivedly narrowed posteriorly, of the same width as thorax at the base; each with a short scutellar and nine series of distinct but not consse punctures, the outer pair irregular, all olsolete near the extremity. Pygidium slightly exposed.

Antennae rather longer than the head and thorax; basal oint thick, arched inwardly, second shortest; joints 3-6 nearly twice as long as broad, almost equal, the following four broader at the extremity, the terminal longer, elongate-oval,

Legs stout, finely setose; anterior tibiae distinctly curved externally ; the others moderately slender near the base, very gently curved outwardly 
to below the middle. evidently dilated and obtusely prominent there, narrower near the extremity; basal joint of all the tarsi large, oblongcordate.

Less convex and more oblong than 3964 (C. hallianus) and of a more coppery or rufescent black, rather longer than the male, with more subangular tibiac, and quite definitely seriate-punctate clytra.

o. Length, $5 \mathrm{~mm}$. ; breadth, $3 \mathrm{~mm}$.

Glenhope. I single male, from Mr. Hall ; sth June, 1915.

\section{Caccomolpus amplus sp. nov.}

Oblong-oval, moderately convex and nitid; aeneo-niger, elytra more viridescent, legs rufo-castaneous, antennae much paler.

This is rather larger, of more oblong contour, and a little less shining than C. subcupreus. The thorax is a third shorter than the elytra, it is rather more coarsely punctured; the elytra are slightly flatter, their punctation less rewalar, and the seutellar series consist of about ten punctures instead of four; the scutellum in place of being short is quite oblong; the coloration is notably different; the proidium is similarly exposed; and the hind pairs of tibiac are only moderately dilated below the middle. It is not at all like the more glossy $C$. viridescens (3948).

Length, $6 \mathrm{~mm}$. ; breadth, $3 \frac{1}{2} \mathrm{~mm}$.

Glenhope. Unique. Discovered by Mr. T. Hall on the 3rd Mareh, 1915, minus a leg and terminal joints of antennae.

\section{Caccomolpus cinctiger sp. nov.}

Nitid, nude, broadly oval, convex; fusco-niger, the sides, above and below, the legs, and antennae fusco-testaceous.

Head broadly impressed in front, subsulcate behind, finely punctate along the middle, smooth near the eves. Thorax fully twice as broad as long. base slichtly oblique towads its rectangular angles, the sides graduall! narrowed anteriorly, only very slightly curved near the front; dise very

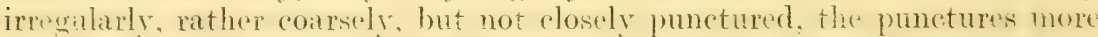
elongate at each side of the base, nearly smooth between each side and the middle. Scutellum suboblong, impunctate. Elytra slightly wider than thorax at the base, a little broader before the middle, gradually narrowed posteriorly; each with a small basal impression between the middle and shoulder, their punctation irregular, rather fine and indefinite, more distinctly and subseriately near the sides.

Legs stout, finely setose; anterior tibiae arched outwardly, the others evidently curvedly dilated brow the middle, narly straight inwardy; hasal joint of the tarsi hardly as broad as the prenultimate. Antemia rather more slender than those of $C$. subcupreus but otherwise similar.

Unmistakably different from every other member of the genus.

Length, $4 \frac{1}{2} \mathrm{~mm}$.; breadth, $3 \mathrm{~mm}$.

Glenhope. My spremen is another of Mr. 'T. Mall's captures, on the 20th December, 1914. A second example was badly crushed and somewhat immature.

By Authority: Marcus F. Marks, Government Printer,-1921.

$[400 / 4 / 21-18669$ 


\title{
NEW ZEALAND INSTITUTE.
}

\author{
BULLETIN No. 1 .
}

\section{DESCRIPTIONS OF \\ NEW GENERA ANI) SPECIFS \\ or \\ COLEOPTERA. \\ PART YII.}

BY MA.TOR 'T. BROUN. F.E.S.

EDITED AND PUBLISHED UNDER THE AUTHORITY OF THE BOARD OF GOVERNORS OF THE INSTITUTE.

ISSUED 7th SEPTEMBER, 1921.

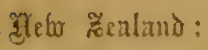

MARCUS F. MARKS, GOVERNMENT PRINTER, WELLINGTON

Wy. WeStey aXd SON, 28 Essex Street, Strand, LoNdoN W.C. 


\section{NEW ZEALAND INSTITUTE.}

\section{BULLETINS.}

Under, the title "Bulletins" the Board of Governors of the New Zealand Institute hopes to issue, from time to time, important paper: which for any reason it is deemed desirable not to include in the yearly volume of the Transactions. The bulletins will be uniform in size and general style with the Transactions of the New Zealanc Institute, but will appear at irregular intervals, and each bulletin wil be complete in itself and be separately paged. The bulletins will no be issued free to members of the Institute, but may be obtained by them at a reduction on the published price. 


\title{
NEW ZEALAND INSTITUTE.
}

\author{
BULLETIN No. 1, PART VII.
}

IsSued 7Th September, 1921.

\section{DESCRIPTION S}

OF

\section{NEW GENERA AND SPECIES OF COLEOP'TERA.}

\author{
By MaJor T. Broun, F.E.S.
}

\section{PART VII.}

Durisg the year 1916 six new genera and 102 species of New Zealand beetles have been brought to our knowledge. Their names are recorded in the following list.

The new genera, Vidamorles, Chaetosomodes, Neoevas, and Euacalles were instituted for the reception of species discovered by Mr. T. Hall: Exonastus for two from Mr. A. C. ('Connor; and Allocinops for one from Mr. A. E. Brookes.

Nore than half of the total number of species were secured by Mr. T. Hall; the next large collection, including some from Mr. Hamilton. of the Dominion Museum, and Mr. W. G. Howes, of Dunedin, came from Mr. A. C. O'Connor, of Wellington; Mr. A. E. Brookes, of Mount Albert, Mr. A. Philpott, of Invercargill, and Mr. Cuthbert Fenwick, of Dunedin, also contributed.

Thos. Broux.

Mount Albert, Auckland,

13 th December, 1916.

22-Bull. No. 1. 


\section{I.IST OF NEW GENERA AND SPECIES.}

\section{Cicindelidaf.}

4153. Cicindela hamiltoni Broun. 4154. , ezonata Broun.

\section{Conemacaxtionate.}

4155. Mecodema femorale Broun. 4156. ," veratrum Broun. 4157. " " punctellum Broun. 4158. , insulare Broun.

\section{Anchomenidae.}

4159. Anchomenus arnaudensis Broun. 4160 . ", hallianus Broun.

\section{Feroxidae.}

4161. Pterostichus fenwicki Broun.

\section{'LOLINI.}

4162. Zolus labralis Broun.

4163. Tarastethus robustus Broun.

\section{BEMBIDIIDAE}

4164. Cillenum alacris Broun.

\section{Pselaphidate. FARONINI.}

4165. Sagola dissonans Broun. 4liti. ," distorta Broun.

EUPLECTINI.

4167. Euglyptus sublaevis Broun. 4168 .,$\quad$ longiceps Broun. 4169 . $\quad . \quad$ abnormis Broun. 4170. Dalma graniceps Broun. 4171. Vidamodes furvus Broun.

\section{BRACHYGIUTINI.}

1172. Eupines clemens Broun. 4173. Byraxis halli Broun.

\section{SilthIILA.}

417. Choleva crenatella Broun. H17.\% ,, itectipes Broun.

Hiti. . curvigera Broun. 117\%. Mesocolon strigicollis Broun. 1178. .. nitidulus Broun. 1179. .. labralis Broum.

\section{Histerida.}

4180. Epierus spinellus Broun.

\section{Colymimat.}

- 4181. Bitoma morosa Broun.

\section{PyCNOMERIDAE.}

4182. Pycnomerus parvulus Broun.

Passandridae.

4183. Chaetosomodes halli Broun.

\section{MELOLONTIIDAE.}

4184. Odontria nesobia Broun. 4185. Eusoma piliventris Broun.

\section{MELYRIDAe.}

1186. Dasytes violascens Broun. $4187 . \quad, \quad$ clavatus Broun.

\section{Salpingidar}

4188. Salpingus nigricans Broun.

\section{RHIPIPHORIDAE.}

4189. Allocinops brookesi Broun.

\section{OTIORHYNCHIDAE.}

4190. Nicaeana cordipennis Broun. 4191. Tigones longipes Broun. 4192. Epitimetes bicolor Broun. 4193. ," densus Broun. 4194. Exonastus amplus Broun. 4195 . , fumidus Broun. 4196. Neoevas celmisiae Broun. 4197. Zenographus albinotatus Broun. 4198. Hygrochus monilifer Broun. 4199. Catoptes lobatus Broun. 4200. Brachyolus nodirostris Broun. 4201 . ", obscuvus Broun. 4202. Inophloeus cuprellus Broun. $4203 . \quad$.. obsoletus Broun. 4204. ., sexnodosus Broun. 4205. .. festucae Broun.

\section{Critydrorminidat.}

4206. Phacophanus o'connori Broun. 4207 . , inornatus Broun.

\section{HYLOBIIDAF.}

4208. Bryocatus niticollis Broun. 4209. .. iridescens Broun. 4210. ", rugosus Broun. 


\section{Rí́xarosomidae}

4211. Phrynixus conspicuus Broun.

4212. , blandus Broun.

4213. Bradypatae subnodifer Broun.

4214. ", impressum Broun.

4215. Araeoscapus subcostatus Broun.

4216. Dermotrichus vicinus Broun.

4217. ", curvirostris Broun.

4218. Astyplus brevicornis Broun.

4219. Halliella cuneata Broun.

4220. Clypeorhynchus tenuiculus Broun.

4221. ", furvus Broun.

4222. Inososgenes acerbus Broun.

\section{Erirhinidae.}

4223. Dorytomus australis Broun.

4224. Simachus placens Broun.

4225. Eugnomus albisetosus Broun.

4226. Caenophanus carbonarius Broun.

\section{CRYPTORHYNCHIDAE.}

4227. Mesoreda laminata Broun. 4228. Euacalles cristatus Broun. 4229. Tychanus complexus Broun. 4230. , simulans Broun. 4231. , terricola Broun. 4232. Crisius dives Broun.

4233. ", longulus Broun.

4234. Sympedius minor Broun.

4235. Getacalles eucoelius Broun.

4236. " fulvisparsus Broun.
CRYPTORHYNCHIDAE-continned.

4237. Getacalles grisealis Broun.

4238. Tychanopais dealbatus Broun.

4239. Acalles brevipennis Broun.

4240. " hopensis Broun.

4241. ", bicostatus Broun.

4242. " " binodes Broun.

4243. ", sticticus Broun.

\section{ANThribidae.}

4244. Dysnocryptus setigerus Broun.

\section{Cerambycidate.}

4245. Aemona separata Broun.

\section{LAMIIDAE.}

4246. Xylotoles submicans Broun.

4247. Somatidia placita Broun.

4248. , , origana Broun.

4249. ", oedemera Broun.

4250. " o'connori Broun.

4251. " " commoda Broun.

\section{EuMOLPIDAE.}

4252. Peniticus plicatus Broun.

\section{Chrysomelidae.}

4253. Aphilon sternalis.

4254. Caccomolpus montanus Broun. 


\section{Group Cicindelidae.}

Cicindela Linné. Man. N.Z. Coleopt., p. 1.

\section{Cicindela hamiltoni sp. nov.}

Oblong, subdepressed, subopaque: head and thorax viridescent and slightly nitid; elytra with numerous shallow greenish punctures, the intervals fusco-rufous and bearing many minute darker granules; lateral bands pale cream-coloured, quite uninterrupted from base to apex, between the base and the middle slightly expanded. behind the middle with a short angular dilatation, which, however, cannot be termed a fascia. Legs, palpi, and basal joints of antennae shining, coppery red or dark green, terminal articulations of these last dull nigro-fuscous. The head and thorax bear some white setae similar to those on the legs.

Head, including the prominent eyes, longer and slightly broader than thorax, broadly depressed between the eyes, longitudinally strigose alongside these, elsewhere densely, finely, and irregularly rugose or subgranular. Labrum pallid, transverse, subtruneate in front, with a simple triangular median tooth in the male, the outer angles obtuse. Thorax a fourth broader than long, its sides moderately rounded, somewhat abruptly contracted behind, more depressed across the base than near the apex, with a fine stria along the centre, its sculpture is dense, fine, irregularly rugose or subgranular; the duplicate lateral margins are for the most part distinct, but the upper or inner become obsolete towards the base. Scutellum large, triangular, minutely and closely sculptured. Elytra oblong. slightly wider behind than at the base, a third broader and nearly five times longer than thorax, curvedly narrowed apically, with acute, slightly projecting sutural spines, lateral bands with many concolorous punctures.

Fem.-Labrum fulvescent, with an indistinct short tooth at each side of the fuscous central one, the apex therefore appears bisinuate at each side; apical sutural spines of elytra variable, either quite indefinite or forming acute but not prolonged angles.

This species is differentiated by the quite uninterrupted lateral bands, and the absence of the usual elytral fasciae. It should be placed near $C$. austromontana (10). To the unaided eye it appears fuscous, but when brushed with benzine and examined under a good lens presents the appearance described above.

ふ. Length, $9 \mathrm{~mm}$.; breadth, $3 \frac{1}{3} \mathrm{~mm}$.

Mouat's Lookout, Awatere River Basin. Discovered, at a height of about .5,700 ft., by Mr. H. Hamilton, of the Dominion Museum, after whom it is named. One of each sex.

\section{Cicindela ezonata sp. nov.}

Oblong, slightly convex, somewhat nitid, almost ylabrous ; head and thorax fuscous, with some vaguely rufescent spots; elytra fusco-niger, faintly rufescent near the sides, without any trace of the common pale lateral borders; the fasciae fulvescent, the median one, on each elytron, bicurate but not quite attaining the suture, the subapical irregular and rather short, the humeral lunule rather narrow and semicircular. Basal joints of palpi yellowish, the torminal bright green. Tegs with some fine white setare, more or less viridescent, as are the basal four joints of antennae, remaining articulations testaceous or infuscate. 
Head distinctly longitudinally strigose, the occiput mure finely and irregularly sculptured, with very large outstanding eyes. Labrum with a triangular central tooth, and a pair of elongate setae beside it, the front oblique tuwards the sides. Thorax apparently narrow, weally of about equal length and breadth, its sides indistinctly margined and hardly at all rounded, a little contracted near the base and apex, disc almost smooth, with a longitudinal stria not quite reaching the apex or base, the latter bisinuate. Scutellum large, smooth. Elytra double the width of thorax at the base, nearly thrice its length, obliquely narrowed towards the rounded apices, with short sutural spines; they are shightly convex along the middle behind; on each elytron an irregular series of about six moderate punctures extends from the base as far as the median fascia, there are also numerous smaller, irregularly distributed, viridescent punctures; behind that fascia there are many larger, round, green spots, these are closer towards the side.

This species is chiefly remarkable for the entire absence of the normal pale lateral bands of the elytra, and the unusually narrow thorax, the latter characteristic is rendered more obvious by the strongly developed, Scopodes-like eyes.

๙. Length, $10 \mathrm{~mm}$. ; breadth, $3 \frac{1}{2} \mathrm{~mm}$.

Greymouth. The only specimen I have seen is the type in the Dominion Museum at Wellington, which was sent to me for identification.

\section{Group Cnemacanthidae.}

\section{Mecodema Blanchard. Man. N.Z. Coleopt., p. 7.}

\section{Mecodema femorale sp. nov.}

Elongate, moderately nitid, slightly convex; black, palpi, antemnae, tibiae, and tarsi rufo-piceous; the femora, front and middle coxae, and posterior trochanters rufous.

Head narrower than thorax, with moderately prominent eyes; the forehead evidently longitudinally sulcate, interocular rugae irregular but well marked, the occiput distantly and finely punctate. Thorax only slightly broader than long, widely incurved in front, its sides not crenulate, nearly straight to behind the middle, gradually narrowed behind that point, more distinctly at the base, with obtuse angles; marginal channels narrow, scarcely at all expanded in front, with setigerous punctures; disc nearly plane, obsoletely transversely striate, more definitely at the sides, the wellmarked central groove hardly attains the base or apex, across the latter there are many shallow abbreviated grooves, a few of these howerer between the midlde and sides are deeper and longer; basal fossae deep, somewhat elongate, situated close to the sides, the space between them with several irregular but not deep punctiform impressions. Elytra oblong-oval, more than double the length of thorax, rather broader than it is at the base; their striae rather shallow and finely punctured, a little deeper near the sides; third, fifth, and seventh interstices rather broader than the others, more elevated behind, but becoming indefinite towards the irregular apical sculpture, there are three or four coarse punctures brtween the seventh interstice and the smooth space near each side, the marginal punctures are irregular, quite indistinct before the middle.

Underside glossy black; flanks of prosternum and mesosternum moderately elosely and distinctly punctate, abdomen sparingly and more lightity. terminal segment feebly trans versy striate. quadripunctate at the extremity. 
M. striatum (2600) is well differentiated by its more elongate form, its atra though gradually am considerably narrowed posteriorly, and, moreover, have impunctate but musually deep and regular striax.

Length, $19 \frac{1}{2} \mathrm{~mm}$. ; breadth, $5 \frac{1}{2} \mathrm{~mm}$.

Hump Ridge, Southland; elevation, $3,500 \mathrm{ft}$. A single specimen, from Mr. Cuthbert Fenwick, of Dunedin ; 20th January, 1916.

\section{Mecodema veratrum sp. nov.}

This is similar to $M$. femorale in general form and coloration, but it is smaller, smoother, and duller.

The labrum is very short, slightly emarginate in front, with five coarse punctures. The head has only a single definite groove alongside each eye, the foreheral is depressed in the middle but is only unisuleate at the sides. and the occipital punctation is closer and finer. The thorax is of the same shape, the basal fossae are shorter, do not reach the basal margin, and have numerous fime punctures near them; the mesial furrow though distinet is more slender, but there are no linear impressions acress the disc. The elytra are rather more regularly and finely sculptired, the alternate interstices are but little broader than the others, flat near the suture, and less convex behind than those on $M$. femorale.

The ventral segments are quite smooth, as is the middle of the breast, but its sides are moderately closely and distinctly but not coarsely punctured.

Both species differ materially from $M$. infimare (3471), being less elongate and glossy, differently sculptured, and with bronder, much less oviform elytra.

o. Length, $17 \mathrm{~mm}$. ; breadth, $5 \mathrm{~mm}$.

Hunter Mountains, south-rvest of Lake Wakatipu. One example, from Mr. A. Philpott, who was also kind enough to present me with his type of M. infimate.

\section{Mecodema punctellum sp. nov.}

Robust, slightly convex, nitid; black, antennae, palpi, and tarsi rufopiceous.

Head, mandibles exclusive, nearly the length of thorax, including the prominent "yes as broad as its apex: the surface a little uneven, with irregular rugae near the sides, deep longitudinal ones in front, and an indefinitely punctate transverse depression behind not extending as far as the eyes, behind these the genae are somewhat swollen; labrum slightly emarginate and coarsely sex-punctate. Mandibles closely, obliculely, and finely rugose. Thorax cordate, truncate in front, a fifth broader than long, widest near the front, gradually narrowed to beyond the middle, evidently sinuateangustate behind, the base slightly emarginate at the middle but rounded towards the subrectangular angles; dise almost smooth, the central groowe well marked and very nearly if not quite touching the base and apex, both of which have fine longitudinal striae, there is an obligue impression nar "ach anterior angle and a subrotundate one near each side before the middle. basal fossat mederately large ; lateral margins suberenulate, the chammels moderately broad, with many setigerous punctures. Elytra oblongeroval. finely maremed. fully twier the length of thorax, at little broader ; on eareh wetron them are six dorsal, rather shallow, fincly punctured striae, the sutur, third and fifth interstices are nearly twier as broad as the others, and some what elivated at the base, serenth narrower but more convex inside the 
shoulder and with two or three larger punctures; the lateral punctation is a little coarser and less regular than the dorsal, the common smooth costa near the side does not reach the base, but there three granular elevations occur; the sculpture though irregular is not at all coarse or deep near the extremity.

Antennae shorter than the head and thorax, pubescent from the fourth joint onwards. Outer angle of anterior tibiae more prominent than that of the intermediate, the posterior simple.

Underside almost smooth, the abdomen finely and irregularly wrinkled.

The elytral sculpture of Castelnau's $M$. alternans accords better than that of any other species, but the similitude almost ceases there.

Length, $39 \mathrm{~mm}$. ; breadth, $12 \mathrm{~mm}$.

Stephen Island. Described from a single female found by Mr. A. C. O'Connor, of Wellington, on the 15th September, 1916.

\section{Mecodema insulare sp. nov.}

Elongate, medially narrowed, slightly convex and nitid; black, palpi, antennae, and legs rufo-piceous.

Head narrower than thorax, nearly smooth, with rather shallow frontal striae and only one or two rugae near each eye; labrum sex-punctate, nearly truncate. Thorax cordate, only a fifth broader than long, base and apex subtruncate, its sides rather finely margined and sex-punctate but not at all crenulate, only feebly rounded and only slightly wider near the front than at the middle, rather gradually narrowed towards the obtuse hind angles; its surface almost smooth, having only about four shallow longitudinal basal striae, the central groove is distinct but does not extend to either base or apex, basal foveae very small, quite punctiform. Elytra oblong-oval, with curvedly narrowed shoulders, slightly broader than thorax at the base, quite double its length; their striae are rather deep, distinctly and closely punctured, the outer three, on each, are rather deeper with narrower and more convex interstices, the usually smooth space outside the eighth stria does not reach the shoulder and has numerous moderate punctures, behind especially, apical sculpture irregular.

Antennae short, not extending as far as the middle of thorax, joints 5-11 finely and scantily pubescent and bearing a few fulvescent setae.

Anterior tibiae smooth, with distinctly prominent outer angles, the others slightly asperate, the hind pair hardly at all angulate. Basal four joints of front tarsi cordiform, the first three with prominent external angles.

Underside shining black, almost smooth, having only a few obsolete transverse striae on the front of the prosternum and terminal segment, which is bipunctate at each side of the middle at the apex. Mentum tooth simple. Terminal joint of maxillary palpi elongate, truncate at extremity.

In appearance this is more like Metaglymma doulli (2611) than any other member of the group, but the latter has rather broader and deeper elytral striae and more convex interstices, and, moreover, the last joint of the palpi is shorter and more oviform. Dr. Sharp states in his description of Mecodema sulcatum (1764) that its "thorax has a basal prolongation," it must therefore differ from $M$. insulare.

o. Length, $20 \mathrm{~mm}$. ; breadth, $6 \mathrm{~mm}$.

Stephen Island. One, minus a leg, sent by Mr. A. C. O'Connor on the 29th October, 1916. 


\section{Group Anchomenidae.}

\section{Anchomenus Bonelli. Man. N.Z. Coleopt., p. 20.}

\section{Anchomenus arnaudensis sp. nov.}

Subdepressed, nitid, black, leges rufo-piceous, palpi and tarsi light red, the labrum, mandibles, and basal three joints of antemnare pitchy-red, remaining joints dull fusco-rufous.

Head, including the large prominent eyes, almost as broad as thorax, with well-marked frontal impressions; labrum distinctly emarginate. Thorax only a trifte broader than long, base and apex subtruncate, a little wider before the middle than elsewhere, slightly eurvedly narrowed anteriorly. gradually narrowed towards the subacutely rectangular posterior angles; the discil furrow extends from near the base to beyond the oblique suleiform frontal impressions; basal fossae large, extending from the somewhat reflexed lateral margins more than half-way towards the middle of the base. each with a slightly curved impression which tapers towards the front. Elytra oblong-oval, thrice the length and in line with the hind thighs, double the width of thorax, gently narrowed towards the base, obliquely narrowed posteriorly, with obtuse apices; their striae are impunetate, (quite distinct, and irregularly confluent behind, the seutellar ones are short; interstices nearly plane, the third usually quadripunctate.

Tarsi fincly grooved above. The antennae barely attain the middle femora, their seventh joint reaches the thoracic base. The shoulders are narrow. With the exception of $A$. otagoensis (54) it has no near ally; the clytral striae of 54 are narrower and more sharply impressed, the antennae are longer, and these, like the legs and palpi, are of an obscurely tawny hue.

o. Length, $11 \mathrm{~mm}$.; breadth, $4 \mathrm{~mm}$.

Mount St. Arnaud, Nelson; elevation, 5,000 ft. A single male, found by Mr. 1. Hall ; 15th June, 1916.

\section{Anchomenus hallianus sp. nov.}

Oblong, slightly convex; shining black, mandibles, antennae, legs, and palpi rufo-piceous, these last with fulvescent tips.

Head narrower than front of thorax, exclusive of the large prominent eres, with well-narked frontal impressions, fincly punctate and wrinkled between the eyes; labrum almost straight and sex-punctate in front. Thorax a third brodder than long, base truncate, apex moderately emarginate, the sides well rounded, widest at or just before the middle, but somewhat incurved towards the distinct rectangular posterior angles, lateral margins well developed and moderately reflexed; dise with faint transverse striae, the central groove ends in the curvate frontal impression and does not reach the base, which has large foveae. Scutellum triangular. Elytra rather broader than thorax at the base, almost thriee its length, tapering "vidently but gradually near the apices; they are deeply striate, with elongate scutellat striae; interstiens convex, the thind, fifth, and seventh rather broater than the others; marginal channels broad, with about five moderate punctures near the kase and as many coarser ones behind.

Antennae dintinetly pubeseent from the fourth joint onwards, extending to just beyond the middle thighs.

Trominal joints of palpi a little shorter than usual and truncate at apex. Thorax with a single setigerous puncture on each side before the middle and another at the hind angle. Basal three joints of anterior tarsi morlerately expanded, narrowed towards the base, the first longest, with 
sponge-like vesture underneath along the middle but fringed with setae at the sides. Apical ventral segment at the extremity with a single setigerous puncture at each side of the middle. These characters, in conjunction, distinguish this from the other species of Anchomenidue.

o. Length, $13 \mathrm{~mm}$; breadth, $4 \frac{3}{4} \mathrm{~mm}$.

Rotoiti, Nelson. Named after its discoverer, Mr. T. Hall. One male only; 26th July, 1916.

\section{Group Feronidae.}

Pterostichus Bonelli. Man. N.Z. Coleopt., p. 31.

4161. Pterostichus fenwicki sp. nov.

Subdepressed, elongate-oblong, shining; black, palpi, antennae, and tarsi rufo-piceous.

Head, and mandibles, nearly as long as thorax, rather narrower, with elongate frontal impressions and a few fine interocular rugae. Thorax as long as broad, subquadrate, slightly wider before the middle than elsewhere, very gradually narrowed behind, posterior angles only very slightly prominent, base and apex a little incurved; discal furrow well marked but not reaching the front, basal fossae large and elongate, duplicate, the inner the larger, both extending to the basal margin. Scutellum striate at base. Elytra rather more than double the length of thorax, slightly wider than it is at the base, with dentiform shoulders, evidently sinuate-angustate near the extremity; they are moderately finely punetate-striate, the first and second as well as the fifth and sixth are somewhat disorganized and appear subcatenulate, the fourth and seventh interstices are a little broader than the others and become irregular or subcatenulate posteriorly, the lateral punctation is fairly regular and coarse. Femora stout, the anterior and postericr particularly, the latter obtusely angulate underneath.

Mesosternum closely and finely punctured, remainder of underside nearly smooth; the terminal ventral segment with a single apical puncture at each side of the middle.

Larger than $P$. impiger (1563), without occipital punctation, the subapical sinuosities of elytra more abrupt and deeper. In $P$. edax (2332) the thorax is rather shorter with more rounded sides. Its systematic position is near these in Section II, having two setigecous punctures on each side of the thorax.

o. Length, $14 \mathrm{~mm}$. ; breadth, $4 \frac{1}{2} \mathrm{~mm}$.

Hump Ridge, Southland; 20th Tanuary, 1916. One example, from Mr. Cuthbert Fenwick, of Dunedin, whose name it bears.

\section{Group ZoLins.}

Zolus Sharp. Man. N.Z. Coleopt., p. 1000.

4162. Zolus labralis sp. nov.

Subovate, elongate, moderately convex and nitid; piceo-niger, the suture, and lateral margins of elytra and thorax, the base of the latter, and the mandibles rufescent; logs, antennae, and palpi more or less light rufoeastaneous.

Head nearly as long as thorax and, including the moderately prominent eyes, as broad as its apical portion, the interocular impressions alongate 
and well marked, the carinae also distinct. Labrum widely emarginate and quadripunctate in front, its length only a fourth of the breadth. Thorax an eighth broader than long, base and apex truncate, its sides distinctly margined, a little wider near the middle than elsewhere, gently curvedly narrowed anteriorly, nearly straight, only feebly sinuate, towards the rectangular posterior angles, these do not extend outwards as far as the margins of the shoulders; discal groove distinct at the base but not attaining the apex, where there are several abbreviated, fine, longitudinal striae; basal region moderately closely and finely punctate, the large fossae distinctly carinate outside. Scutellum broally triangular, smooth. Elytra oviform, quite double the length of thorax, a third broader than it is at the midclle, with strongly rounded apicas, marginal chamnels moderately broad; they are finely, yet quite definitely punctate-striate, interstices nearly plane, the third tripunctate; there are about four larger punctures at the sides near the base and extremity.

The remarkably abbreviated and widely incurved labrum, with only four in place of six setigerous punctures, is its principal distinguishing character. Dr. Sharp's Z. helmsi has impunctate elytral striae, and the inner angle of the basal tarsal joint of the male is rather more prolonged. $Z$. atralus (1796) has larger and more convex eyes, its measurement is $8 \frac{1}{2} \mathrm{~mm}$. by $3 \frac{1}{2} \mathrm{~mm}$. Z. subopacus (3689) and $Z$. ocularius (3808) are manifestly different. Z. femoralis (2658), (Ann. Mag. Nat. Hist., ser. 6, vol. 14, p. 311), is the nearest species.

o. Length, $8 \mathrm{~mm}$.; breadth, $3 \mathrm{~mm}$.

Mount Roberts, Nelson. A solitary individual, found by Mr. T. Hall on the 28th December, 1915.

Tarastethus Sharp. Man. N.Z. Coleopt., p. 1003.

\section{Tarastethus robustus sp. nov.}

Nitid, black, legs, antennae, and mandibles rufescent, tarsi and palpi of a lighter hue.

Head subovate, narrower and rather shorter than thorax, irregularly and very finely wrinkled behind, with moderate frontal impressions; labrum twice as broad as long. Thorax a fourth broader than long, its sides fincly marginate. widest and rounded at the middle. curvedly narrowed towards the front, "vidently sinuate-angustate behind, posterior" angles rectangular; base slightly emarginate at the middle, apex subtruncate; discal groove rather fine. not reaching the base or apex, the basal pergion rather fincly and irregularly rugose and punctate. the fossare situated between the middle and sides, rather large but shallow. Elytra convex, double the length of thorax, a third broader at the middle, rather wider than thorax at the base, their sides rather strongly rounded, evidently marginate and channelled; on each elytron there are seven dorsal, regular, impunctate, rather sharply marked striae; interstices nearly plane, the third slightly tripunctate, the posterior plica normal.

In general form almost similar to Sharp's T. puncticollis (1799), rather larger, the lateral thoracic margins considerably finer, the basal sculpture and fossae less distinet; labrum shorter; elytral striae very different; the antennae and anterior tibiae stouter.

Length, $7 \frac{1}{2} \mathrm{~mm}$. ; breadth, $3 \frac{1}{3} \mathrm{~mm}$.

Mount livberts, Nelson; 28th Decenber, 1915. A single male. fomd by Mr. T. Hall during a wet, stormy journey. 


\section{Group Bembiditdae.}

\section{Cillenum Leach. Man. N.Z. Coleopt., p. 59.}

\section{Cillenum alacris sp. nov.}

Nitid, moderately elongate and convex, medially narrowed; fusconiger, but with the sides of elytra, the palpi, legs, and basal half of antennae. more or less pale testaceous or greyish, remaining joints of these last, and the mandibles, somewhat infuscate.

Head, including the large eyes, as broad as thorax, smooth, with elongate interocular impressions. Thorax of about equal length and breadth, rounded and widest before the middle, gradually, yet more, narrowed behind than in front, with distinct lateral rims and slightly prominent posterior angles, base and apex truncate; the discal groove rather slender, the base transversely depressed and scored with fine rugae, the fossae small and placed near the angles. Scutellum rounded behind. Elytra twice the length of thorax, slightly broader than it is, and minutely dentiform, at the base, a third wider just behind the curvedly narrowed shoulders, gradually narrowed backwards; the lateral margins are slender, but the sides are explanate behind the middle and end abruptly as obtuse projections just before the true apices, these are oblique, and each has a short sinuosity close to the side; dorsal striae moderately deep and finely punctate, but becoming shallow or obsolete on the pale posterior portion; interstices slightly convex, the third tripunctate; each elytron has a short scutellar stria.

This differs considerably in coloration and other details from C. albescens (118) and $C$. chalmeri (1568); this latter has the sides of the wing-cases much less expanded. Dr. Sharp's C. batesi (Trans, Roy. Dub. Soc., Nov., 1886) is a synonym of $C$. chalmeri (Man. N.Z. Coleopt., April, 1886).

․ Length, $5 \mathrm{~mm}$.; breadth, $1 \frac{2}{3} \mathrm{~mm}$.

Karekare, west of Auckland; 23rd February, 1916. Mr. A. E. Brookes, of Mount Albert, who gave me three specimens (all females), informs me that they were very active and difficult to catch.

\section{Group Pselaphidae.}

FARONINI.

Sagola Sharp. Man. N.Z. Coleopt., p. 134.

\section{Sagola dissonans sp. nov.}

Elongate, of interrupted outline, slightly convex, nitid; castaneorufous, antennae and legs paler, palpi and tarsi fulvescent; clothed with elongate, decumbent and a few upright fulvescent hairs.

Head nearly as large as thorax, genae not quite straight, hind angles somewhat rounded: antennal tubercles broad, flat, and subtruncate in front, the slender stria dividing them hardly extends backwards as far as the middle, and is replaced behind by an obtuse carina, the foveae are large, each occupring more than half of the space between the middle and side; punctation indistinct. Eves moderately prominent. Thorax of about equal length and breadth, narrowly cordate, widest before the middle, without definite punctation; the post-median fovea rotundate, moderate, not touching the pair of distinet basal punctures, lateral foveae rather small, not prolonged as far as the middle. Elytra hardly any longer than thorax. much broader behind than at the base, finely and indistinctly 
punctate; with deep sutural striae, intrahumeral impressions entire, seareely at third of the whole length. Hind-body nearly double the length of elytra, third visible segment rather larger than the others. Legs simple.

Antennae as long as the head and thorax, slightly thickened towards the extremity, with outstanding slender setae; basal joint stouter than the oblong-oval second but not twice its length, third small yet rather longer than broad, fourth oblong-oval, not quite as broad as fifth, joints 6-10 laxly articulated, 6 8 lenticular, ninth and tenth transverse, eleventh conical.

Underside with elongate suberect pubescence. Head with a deep transverse groove. Ventral segments $2-4$ successively enlarged, fifth widely incurved behind. not half the length of fourth in the middle, sixth as long as fifth, more deeply emarginate, seventh obtusely triangular.

This does not agree with any of the members of Section III, beginning with S. lineata (2719), on account of the large foveae on the head, the short subcuneiform elytra, and abbreviated intrahumeral impressions, \&e.

$\hat{o}$. Length; $2 \frac{1}{2} \mathrm{~mm}$.; breadth, quite $\frac{1}{2} \mathrm{~mm}$.

Tauherenikau Bush, near Featherston. Mr. T. Hall, whilst undergoing military training. managed to collect several lots of leaf-mould; these he brought to my house at Mount Albert on the 6th October, 1916, and out of one parcel I picked out a single male of this distinct species.

\section{Sagola distorta sp. nov.}

Subdepressed, moderately broad, of irregular contour, nitid ; castaneorufous, legs and antennae paler, elytra, tarsi, and palpi fulvous; thinly covered with elongate, decumbent and suberect, fulvescent hairs.

Head large, its hind angles projecting straight outwardly further than the widest part of thorax so that a deep gap exists between them, and between each angle and moderately large prominent eye there is an evident sinuation; antemnal tubercles somewhat elevated and distinctly separated, the deep triangular central channel becomes linear between the small punctiform occipital foveae. Thorax broadly cordiform, with strongly rounded sides but almost abruptly contracted at the base; the subquadrate fovea behind nearly unites with the small basal punctures, lateral foveae deep but not extending forward as far as the middle. Elytra minutely and irregularly punctured, but little longer than thorax, slightly wider than it is at the base, a fourth broader behind; sutural striae weil marked, with a basal puncture alongside each, the intrahumeral impressions apparently divided, rather short, not prolonged to the middle. Hindborly a third longer than the elytra, equally broad but acuminate behind. first visible segment without scale-like vestiture, slightly shorter than the next.

Legs moderately elongate; posterior tibiae sinuate externally near the base and gradually thickened below the middle.

Antennae rather longer than head and thorax, moderately stout, with slender setae; basal joint stout, nearly double the length of the broadly oxal serond, third small, fourth slightly longer than following ones, 5-8 subequal, ninth and tenth scarcely any larger than their predecessors, terminal conical.

Tnderside of head uneven across the middle, the posterior angles somewhat impressed. Basal rentral segment partly uncovered, 2-1 subequal, 
fifth and sixth a little shorter, rather broad, both truncate behind, seventh longer and narrower, its operculum narrow and oblique.

Nearly allied to $S$. angulifer (3363), the antennal structure different, as is the under-surface of the head, the intrahumeral impressions are deeper and more than half the whole length of the elytra, and the hind tibiae are simple. The head of 3363 when carefully examined is seen to be materially different; there is no sinuation between the smaller eyes and the hind angles, which latter, moreover, are somewhat outwardly curved behind so that the space between them and thorax is considerably larger. In $S$. eminens (2724) the sixth ventral segment is nearly the length of the fifth, but it is semicircularly emarginate and encloses the small seventh, which has a broad operculum.

o. Length, $2 \frac{1}{3} \mathrm{~mm}$. ; breadth, $\frac{2}{3} \mathrm{~mm}$.

Tauherenikau; 6th October, 1916. One of this remarkable species also obtained from Mr. Hall's leaf-mould.

\section{EUPLECTINI.}

Euglyptus Broun. Man. N.Z. Coleopt., p. 1411.

\section{Euglyptus sublaevis sp. nov.}

Oblong, attenuate towards both extrennities, slightly convex, nitid: rufous, elytra paler and brighter, antennae and legs light chestnut-red: sparingly covered with short, decumbent, flavescent hairs.

Head obliquely narrowed behind the large prominent eyes, more contracted in front, its distinct punctation much concealed by the slender pubescence, the tubercles almost contiguous in front, but separated behind by a deep channel which becomes broader towards the eyes. Thorax as broad as long, widest and obtusely subangulate before the middle, obliquely and much more narrowed in front than behind; the discal furrow deep and broad, lateral foveae deep and extending from the base to the frontal dilatation, there is no distinct ante-basal transverse impression. its whole surface smooth. Elytra suboblong, about double the size of thorax, gradually narrowed before the middle, but rather broader than it is at the incurved base, they, are apparently without punctation; sutural striae distinct, with a short basal carina outside each, the dorsal impression moderately deep, rather broad near the base, obsolete behind, its external carina more elevated and thicker at the shoulder than behind. Hindbody a third shorter than elytra, as broad as they are at its base, without visible punctures, the segments subequal, the basal two slightly transversely impressed in front. Legs elongate and slender.

Antennae equalling head and thorax in length, basal joint slightly longer and stouter than the oblong-oval second, the next nearly as long but more slender and distinctly narrowed towards its base, fourth and fifth shorter and oviform, seventh slightly larger than the bead-like sixth or eighth; ninth abruptly enlarged, not quite as broad as the tenth, which is rather closely attached to the large conical acuminate terminal one, these threes distinctly pubescent.

Larger than $E$. elegans (2460), the head not broader than the thorax and less abruptly contracted in front, the sides of the thorax more prominent before the middle, and the punctation almost altogether absent.

Length, $2 \mathrm{~mm}$.; breadth, $\frac{2}{3} \mathrm{~mm}$.

Lake Rotoiti, Nelson. One, found by Mr. T. Hall on the 5th Mar, 1916. 


\section{Euglyptus longiceps sp. nov.}

Nitid, rufous, antennae and legs light chestnut-red, palpi and tarsi testaceous; pubescence greyish or pale brassy, decumbent, slender on some parts, minutely squamiform on others.

Head oblong, not quite as long or broad as thorax, nearly straight behind the small "yes, with obtuse hind angles, more narrowed anteriorly, moderately distinctly and closely punctate; the pair of fovease, situated farther back than the eyes, prolonged as a broad furrow between the tubercles. Thorax rather longer than broad, widest before the middle, gently narrowed backwards, quite obliquely in front; its punctation moderately coarse and close, median channel broad, extending from the base almost to the apex, lateral foveae large, quite half the whole length, the transverse impression near the base is obsolete. Elytra oblong, a third longer and broader than therax, narrowed before the middle, incurved and rather broader than it is at the base, impunctate; sutural and dorsal striae equally broad, deeper near the base than behind, the outer carina, on each elytron, thick at the base, perfectly distinct at the extremity but distant from the side, the inner carina less sharply developed. Hindbody a little shorter than the wing-cases; apparently smooth, with subequal segments, the first transversely impressed at the base. Le ge clongate and slender, tibiae slightly expanded towards the extremity.

Underside chestnut-red. Head with a large basal impression which is prolonged, but becomes narrower, along the middle. Prosternum slightly carinate. Metasternum convex. Basal ventral segment ciliate, partly covered by the femora, segments $2-5$ diminish, sixth broad, simple.

In size and general form nearly similar to $E$. sublaevis; the elytra darker, their carinae ohviously more definite; the shape and sculnture of the head and thorax different; the eyes small; the antennae, club inclusive, are stouter.

E. costifer (2725), (Ann. Mag. Nat. Hist., ser. 6, vol. 12, p. 166), is considerably smaller, its eyes too are smaller, all the joints of the antennae are more slender, the ninth is evidently narrower at the extremity, and the legs are less elongate.

․ Length, almost $2 \mathrm{~mm}$. ; breadth, $\frac{2}{3} \mathrm{~mm}$.

Waimarino, Main Trunk Railway. One female only, found by myself amongst dead leaves during January, 1909.

\section{Euglyptus abnormis sp. nov.}

Elongate, narrowed anteriorly, slightly convex, nitid, almost smooth; light chestnut-red, antemne and legs paler, palpi and tarsi testaceous: pubescence scanty, decumbent, flavescent.

Head subovate, widest in line with the moderately large eyes, just behind the middle, more narrowed in front than behind; indefinitely sculptured, seemingly minutely and distantly granulate, without distinct foveae or frontal channel, the tubercles convex and moderately separated. Thorax impunctate, oviform, longer than broad, obtusely rounded and widest at the midell: ; with a deep ante-basal impression betwen the large lateral forease. Elytra ciblong, fully a third longer and broader than thorax, somewhat narrowed towards the base yet rather wider than it is there, apparently smooth; sutural striae well marked, deeper at the base, intrahumeral impressoms short, deepe, and broad, with subearinate borders. IImb-bodr shorter than elytra, its secments subequal, the first transversely impressed at the base. Legs elongate and slender. 
Antennae equalling head and thorax in length, their second joint as long as the rather thicker first, third rather shorter, narrowed towards its base, fourth shorter than fifth, which latter equals the third, 6-8 small and moniliform; ninth much enlarged, narrowed towards its apex, tenth still broader, strongly transverse, eleventh about as long as preceding two combined, conical and acuminate.

Underside concolorous. Prosternum feebly carinate. Metasternum large. convex. Basal ventral segment ciliate, not fully uncovered, second largest, 3-5 successively decrease, sixth about as long as second, its deep emargination occupied by the subquadrate operculum.

This somewhat resembles some of the Scydmaenidae. In form and sculpture it differs greatly from the type of the genus, 2460. The rather narrow, oviform thorax has a well-marked transverse depression in front of the base, but there is hardly any trace of the usual conspicucus channel along the middle.

Euglyptus is well described by M. Raffray in Wytsman's Gen. Ins., Pselaphidae, p. 51.

ô. Length, $1 \frac{1}{2} \mathrm{~mm}$. ; breadth, nearly $\frac{1}{2} \mathrm{~mm}$.

Rotoiti and Mount Slips, Nelson. Three, obtained by Mr. T. Hall, 24th December, 1915, and 5th May, 1916, one of them damaged and mounted on its back.

Dalma Sharp. Man. N.Z. Coleopt., p. 134; Gen. Ins. (Wytsm.), Pselaphidae, p. 102.

\section{Dalma graniceps sp. nov.}

Nitid, castaneo-rufous, legs and antennae paler, tarsi testaceous; pubescence yellow, distinct and suberect; body moderately elongate and subdepressed.

Head smaller than thorax, obliquely narrowed behind the rather prominent eyes, the foveae between these prolonged forwards, its sculpture consists of distant, fine, rotundate granules. Thorax as long as broad, widest before the middle, more gradually narrowed behind than in front, apparently minutely, sparingly, and indefinitely granulate; lateral foveae situated between the base and the middle, only indistinctly prolonged beyond that point; the central angular fovea is large and deep, and the rather broad furrow proceeding from it nearly reaches the apex but is more slender there. Elytra about a third longer and broader than thorax, a little narrowed towards the base, with rounded shoulders, their sculpture fine and indistinct; sutural striae well marked, the impression near each shoulder moderately deep and broad, with a cariniform elevation separatiug it from the sutural stria. Hind-body of about the same length and width as the elytra, indistinctly sculptured, its first uncovered segment has a depression across the base.

Antennae as long as head and thorax; basal joint rufous, stout, cylindric, half as broad as long, the next equally thick and almost oblong, third rather smaller, obconical; joints $4-6$ transversely moniliform and almost "qual; seventh and eighth strongly transverse; ninth latgest, subquadrate. somewhat curvedly narrowed towards its imner extremity, foveate near inner side underneath; tenth quadrate, obviously smaller, its basal and apical angles at one side slightly prominent; terminal joint as long as preceding two combined, elongate-conical and acuminate.

Underside concolorous, apparently finely punctate, distinctly pubesent. Head distantly and finely granulite, bearing some outstanding elongati 
vellow sedare angularly impressed behind. Prosternum carinate along the imiddle. Metastermum convex, not at all impressed. Basal ventral segment concealed by the femora, second and third subequal, the next rather shorter, fifth widely incurved, sixth slightly longer. also widely emarginate, seventh broad, its opereulum oblong.

Much less robust than $D$. pubescens (24.1), its logs evidently more slender, the head more obliquely narrowed behind. the thorax narrower and more oviform, the sculpture manifestly different, and the antennal structure dissimilar. $D$. gigantea $(3530)$ may be separated very easily.

o. Length, $2 \mathrm{~mm}$; breadth, quite $\frac{1}{2} \mathrm{~mm}$.

Near south of Lake Rotoiti, Nelson. T'wo males, discovered by Mr. T'. Hall on the 21st April, 1916.

\section{Vidamodes gen. nov.}

Body slightly convex, elongate, subparallel, narrowed anteriorly. Head hardly as large as thorax, subquadrate behind the antennae, with obtuse hind angles, somewhat abruptly contracted just before the eyes; uneven above, the foveae not prolonged or confluent in front. Antennal tubercles rather small and distant. Eyes not prominent, situated at or just behind the middle. Thorax suboviform, with a transverse stria connecting the angular basal and oviform lateral foveae, the discal impression elongat: but not touching the basal fovea or apex. Elytra oblong, with well-marked sutural striae and intrahumeral impressions. Hind-body as broad as elytra. rather shorter, basal three segments nearly horizontal and equal, the others deflexed.

Maxillary palpi moderate; basal joint small ; the next elongate, gradually incrassate; third transverse, not at all triangular, rather broader than the extremity of second; fourth longest, elongate-oval, with a minute acicular apical appendage.

Antennae 11-articulate, shorter than the head and thorax; basal two joints stout, second oblong-oval; third small, only slightly longer than broad, joints 4-7 also small, moniliform, eighth shorter; ninth d stinctly larger, not as broad as the more transverse tenth; the terminal largest. conical and acuminate, as long as preceding three united.

Prosternum not carinate. Basal ventral segment exposed, ciliate behind, acutely projecting between the moderately separated coxae; second and third equal, moderately large, fourth half as long: fifth widely incurved. much shorter than fourth in the middle: sixth larese, semicircularly emarginate, seventh subrotundate. Anterior tarsi with the second joint gradually thickened; the posterior pair more elongate and slender.

It should be placed between Euplectopsis and Vilamus.

\section{Vidamodes furvus sp. nov.}

Nitid, rufo-fuscous, hind-body darker, palpi, antemnate, and tarsi testaceous; clothed with fine, decumbent, greyish hairs.

Head uneven, finely punctate, the interocular foveae, when examined sideways, appear to be separated by a cariniform elevation which is prolonged anteriorly. Thorax rather longer than broad, widest before the middle, indistinctly punctate. Elytra about a third longer and broader than thorax, with curvedly narrowed shoulders, apparently impunctate, 
intrahumeral impressions rather short and deep. Basal dorsal seguent transversely impressed at the base.

Legs moderately elongate, tibiae slightly curved and expanded below the middle.

Underside nitid, fuscous, trochanters and coxac somewhat testaceous; indistinctly punctate, with greyish pubescence. Head incurved behind, with a small central fovea there; it is abruptly contracted in front of the eyes, fincly and closely punctate, and bearing many rellowish, slender, suberect setae.

Female unknown as yet.

Length, $1 \frac{1}{3} \mathrm{~mm}$. ; breadth, $\frac{1}{3} \mathrm{~mm}$.

Near Lake Rotoiti, Nelson. Four males, found amongst decaying forest-leaves by Mr. T. Hall on the 3rd June, 1916.

\section{BRACHYGLUTINI.}

Eupines King. Gen. Ins.(Wytsm.), Pselaphidae, p. 206.

4172. Eupines clemens sp. nov.

Nitid, moderately convex, impunctate, with a few short greyish hairs behind; rufous, antennae and legs paler, tarsi testaceous.

Head somewhat curvedly narrowed behind the moderately prominent eyes, which extend outwardly almost as far as the thorax; with a pair of distinct but small interocular foveae, and a transverse frontal impression. Thorax of about equal length and breadth, rather wider before the middle than elsewhere, more gradually narrowed behind than in front, with a transverse basal impression at each side. Elytra about double the size of thorax, rather broader than it is at the base, curvedly narrowed before the middle; with distinct sutural striae, and elongate, though sometimes indefinite, intrahumeral impressions. Hind-body shorter than elytra, narrowed and deflexed behind. Anterior tibiate curvedly expanded inwardly, almost straight externally.

Antennae finely pubescent, not longer than the head and thorax; basal joint hardly exceeding the oblong second in length, third nearly as long but narrowed towards its base; joints 4,6 , and 7 not longer than broad, fifth rather larger yet scarcely at all oblong, eighth and ninth smaller than the quite transverse tenth, the terminal large, subacuminate, as long as preceding three together.

Underside nitid, chestnut-red, minutely and distantly punctate. Metastemum with a large subquadrate depression not reaching the base, its obtusely raised borders terminate as small tubercular elevations near the inner part of the posterior coxae. Basal ventral segment covered, second largest, unimpressed; third and fourth equally short, fifth distinct at the sides, invisible at the middle, sixth with a transverse median impression, as long as the third and fourth combined.

Superficially very much like Dr. Sharp's Bryaxis grata (240), but the head is less quadrate, its frontal impression and the foveae are quite definite, the eyes are more prominent, the antennas are a third shorter, their intermediate joints differ, so do the front tibiac, and, moreover, on the underside of 240 an almost uninterrupted broad depression extends from the base of the metasternum to the middle of the sixth segment.

o. Length, $1 \frac{1}{2} \mathrm{~mm}$. ; breadth, $\frac{2}{3} \mathrm{~mm}$.

Glenhope and near Lake Rotoiti, Nelson. Another of Mr. T. Hall's discoveries during 1915: The males rather rare. 
Byraxis Reitter. Gen. Ins. (Wytsm.), Pselaphidae, p. 206.

\section{Byraxis halli sp. nov.}

shining, rufo-piceous, without discernible foveae or punctures, with very few inconspicuous grey hairs.

Head rather smaller than thorax, a little narrowed behind; eyes not prominent. Thorax of about equal length and breadth, a little wider at the middle than elsewhere. Elytra about twice the size of thorax, suboblong, curvedly narrowed to the width of thorax at the base, apies truncate, with sutural striae and a shallow impression inside each shoulder. Hindbodr apparently short, considerably deflexed, basal segment rather larger than any of the others.

Legs moderately elongate, posterior tibiae slightly arched below the middle.

Antennae not longer than head and thorax, bearing some fine setae; basal joint oblong, stout, second transverse but not as short as third or fourth; fifth very large, strongly transverse, its width double the length, its inner prolongation slightly rounded at the extremity and rather larger than at its junction with the contiguous ones; joints $6-8$ transverse but irregular, seventh rather broader, eighth with a slender basal spine extending outwards; ninth slightly thicker than eighth at the base but greatly enlarged, and prolonged inwardly, or outwardly, as much as the fifth, slightly curved in front, the thick portion near the middle with a distinct straight spine directed backwards; tenth rather smaller than ninth, subrotundate or subconical, minutely asperate.

Underside similar to the upper surface in colour and clothing. Anterior trochanters distinctly spined. Metasternum broadly and rather deeply depressed, with a minute upright spine on the centre of its hind margin. Basal ventral segment invisible, second as deeply but not as widely depressed as the metasternum, the eavity with more sharply raised lateral borders, as long as the following three combined; sixth longer than fifth in the middle, with a transverse depression.

This belongs to Section XVI, comprising 3052, 3535, and 3536. The antennal structure and sculpture of the lower surface will at once lead to its recognition. Joints $6-10$ of the antennae are liable to be twisted, so that it is difficult to decide which is the true upper side; this causes the prolongation of the ninth joint to be external in one antenna but the reverse in the other.

o. Length, $1 \frac{1}{2} \mathrm{~mm}$. ; breadth, nearly $\frac{2}{3} \mathrm{~mm}$.

Fem. - Rather more slender, hind tibiae similar. Basal joint of antennae oblong but no thicker than the shorter second, third obconical, longer than the short fourth; fifth rather larger; sixth and seventh beadlike and transverse, eighth slightly broader and shorter, ninth distinctly broader, about half the size of the transverse tenth, the eleventh conical, largest, as long as preceding three together and more evidently pubescent. Underside simple.

Mount St. Arnaud, Nelson. 'Two males and four females; 15th June, 1916. Named in honour of Mr. T. Hall, the indefatigable naturalist who has brought to light a great many interesting forms of Pselaphidae, some of which still remain unnamed. 


\section{Group Silphidae.}

Choleva Latreille. Man. N.Z. Coleopt., p. 151.

4174. Choleva crenatella sp. nov.

Oblong-oval, slightly 'convex, moderately nitid; fuscous, the head, hind angles of thorax, legs, palpi, and basal half of antennae light castaneorufous; sparingly clothed with decumbent, elongate, slender flavescent hairs.

Head immersed up to the eyes, trigonal, finely, distantly, but quite definitely punctate, interantennal suture straight and slender. Eyes prominent, occupying the extremity of the lateral angles. Thorax almost twice as broad as long, its sides nearly straight behind, slightly curvedly narrowed towards the obtuse anterior angles, base subtruncate, its rectangular angles just perceptibly directed backwards; its sculpture very fine, consisting apparently of minute distant granules. Scutellum small. Elytra with rounded shoulders, nearly thrice the length of thorax, of about the same width at the base, tapering gradually towards the singly rounded apices, which do not cover the pygidium; sutural striae well marked but becoming finer behind, they are transversely strigos', each line minutely crenulate.

Antennae as long as head and thorax, finely pubescent, gradually incrassate and infuscate from the third joint onwards; basal three joints (longate, the first slightly longer and thicker ; sixth quadrate, a little shorter than fourth or fifth, seventh larger than sixth, eighth extremely short, ninth and tenth slightly shorter and broader than seventh, the terminal conical.

Tibiae finely setose, bispinose at the extremity, the anterior almost straight but gradually thickened, posterior more slender, the intermediate distinctly curved. Basal three joints of front tarsi cordate and strongly dilated, the fourth much less so ; the posterior pair longer and more slender than the intermediate.

Underside light chestnut-red, with depressed yellowish pubescence, minutely and indistinctly sculptured. Mesosternum not carinate. Abdomen with six visible segments, the last minutely granulate.

o. Length (head exserted), $2 \frac{1}{3} \mathrm{~mm}$. ; breadth, quite $1 \mathrm{~mm}$.

Rotoiti, Nelson. Two males, one damaged and mounted on its back, found by Mr. T. Hall on the 3rd June, 1916.

\section{Choleva flectipes sp. nov.}

Oblong-eval, slightly attenuate posteriorly, slightly convex, suboparque, head and thorax moderately nitid; covered with depressed elongate hairs, those on the thorax yellowish, darker and feather-like on the elytra; fuscous, the head, sides of thorax, and base of elytra more or less rufescent, legs and antennae chestnut-red.

Head trigonal, distinctly but not closely punctate, the interantemual and frontal sutures straight. Thorax hardly twice as broad as long, apex slightly but widely emarginate with rounded, slightly deflexed angles, the sides finely margined and moderately curvedly narrowed before the middle; base feebly bisinuate so that its angles extend but little backwards; its sculpture indefinite and distant, appearing minutely granulate. Scutellum small, triangular. Elytra almost thrice the length of thorax, very cradually and only moderately narrowed towards the broadly rounded apices; sutural 
striac moderately distinct, the general sculpture transverse, crenate-strigose. Pygidium covered.

Femora stout; intermediate tibiae strongly arcuate; anterior tarsi with the basal three joints dilated, fourth small, basal joint of the middles pair thicker than that of the posterior.

Antennae very similar to those of $C$. crevatella.

Underside fusco-rufons, the grey ish pubescence suberect on the abdomen, which has six subequal segments. Mesosternum subcarinate, rather long. Metasternum short, so that the intermediate coxae are much more distant from the front than they are from the hind pair.

The abbreviation of the metasternum, strongly arched middle tibiae, and indefinitely sculptured thorax, in combination, render this easily separable from other New Zealand species.

o. Length (head exserted), $3 \mathrm{~mm}$.; breadth, $1 \frac{1}{3} \mathrm{~mm}$. Hall.

Rotoiti, Nelson; 5th February, 1916. Unique. Found by Mr. T.

\section{Choleva curvigera sp. nov.}

Oblong-oval, somewhat attenuate posteriorly, only moderately convex, nitid; rufo-castaneous, the labrum, palpi, legs, and basal half of antennate more flavescent, terminal half of these last only slightly infuscate.

Head trigonal, distinctly punctate, flat in front, with a curved impression extending from behind one antenna to the other so that its back part seems a little elevated, the interantennal and frontal sutures definite and straight. Therax half as long as broad, its very finely margined sides curvedly narrowed anteriorly, not quite straight behind, apex subtruncate, with slightly deflexed rounded angles, the base obsoletely sinuate with only slightly prolonged angles; disc finely and distantly granulate. Elytra thrice the length of thorax, as wide as it is at the base, tapering gently towards the singly, well-rounded apices which do not cover the pygidium; their sculpture distinct, transversely crenate-strigose, sutural striate obsolete behind, quite definite elsewhere. The body sparingly elothed with elongate decumbent yellowish hairs.

Tibiae finely setigerous, the middle pair moderately curved. Basal three joints of tarsi cordate, distinctly dilated and deeply emarginate in front, fourth small, fifth slender, half the whole length.

No similar species has hitherto been made known. An examination of the head will at once lead to its identification. The antennae no not differ much from those of the preceding species.

ڤ. Length (head exserted), $3 \mathrm{~mm}$.; breadth, nearly $1 \frac{1}{3} \mathrm{~mm}$.

Rotoiti; 5th February, 1916. A single male only, from Mr. T. Hall, found, like the others, amongst decaying forest-leaves.

\section{Mesocolon Broun. Man. N.Z. Coleopt., p. 153.}

\section{Mesocolon strigicollis sp. nov.}

Oblong-oval, only moderately convex, subopaque; head and thorax nigresent and slightly nitid, elytra rufo-fuscous, the legs, palpi, and basal half of antennae fusco-rufous; covered with slender decumbent ashy pubescence.

Head trigonal, as broad as thoracic apex, the flat eyes forming the extremities of the laterally prominent basal angles; it is moderately closely and finely yet quite distinctly punctured. Thorax with the breadth double 
the length, very gently narrowed towards the obtuse anterior angles, these are slightly deflexed so that the lateral curvature, when viewed from behind. appears greater than it really is, apex and base subtruncate, the latter onlyfeebly sinuate near the sides, posterior angles very little prolonged; its surface finely, transversely crenate-strigose. Scutellum distinct, triangular. Elytra thrice the length of thorax, as broad as it is at the base, slightly curvedly narrowed towards the broadly rounded apices; with fine sutural striae, their sculpture similar to that of the thorax.

Antennae shorter than head and thorax, moderately stout, basal three joints subequal, sixth slightly shorts and broader than preceding two, seventh subquadrate, quite as large as ninth or tenth, the terminal conical, usually paler than the infuscate enlarged joints, eighth small, strongly transverse.

Front and hind tibiae nearly straight, the middle pair only slightly curved, bispinose ; basal joint of anterior tarsi oblong, moderately dilated, second short, third and fourth small, but little thicker than the elongate fifth, basal joint of the intermediate slightly thicker than that of the posterior.

Fem.-Front tarsi shorter and more slender than the other pairs.

Underside fuscous, subnitid, with yellowish-grey pubescence. Mesosternum finely carinate. Ventral segments 1-4 subequal, fifth semicircularly emarginate behind, very short in the middle, sixth rather narrow, subtruncate behind, as long as the third.

Most nearly allied to $M$. puncticeps (278), which has the thoracic apex rounded.

o. Length, $3 \mathrm{~mm}$. ; breadth, $1 \frac{1}{3} \mathrm{~mm}$.

Rotoiti, Nelson. Found by Mr. T. Hall on the 10th March, 1916.

\section{Mesocolon nitidulus sp. nov.}

Oblong-oval, only moderately convex, nitid; almost uniformly light chestnut-red, terminal half of antennae a little infuscate; pubescence decumbent, yellowish-grey.

Head distinctly but not closely punctured, the interantennal suture quite definite. Thorax half as long as broad, base and apex subtruncate, posterior angles not perceptibly prolonged; its surface nearly smooth, apparently remotely and very minutely granulate. Scutellum triangular. Elytra broadly rounded behind, with well-developed sutural striae and transversely crenate-strigose sculpture.

Antennae as long as the head and thorax, longer than those of $M$. strigicollis, rather more slender, but - with almost similarly formed articulations.

Unmistakably different from $M$. strigicollis in facies; the thorax a trifle shorter, more truncate and with less rounded angles in front, its sculpture materially different; elytral apices not visibly individually rounded, sutural striae deeper; scutellum broader, and the eyes more distinctly faceted.

9. Length, $2 \frac{1}{2} \mathrm{~mm}$.; breadth, $1 \frac{1}{4} \mathrm{~mm}$.

Near Howard River, Nelson; 10th May, 1915. A single female, from Mr. T. Hall.

\section{Mesocolon labralis sp. nov.}

Oval, convex, narrowed posteriorly, nitid; thinly elothed with subdepressed, slender and elongate rellowish-grey hairs; fuscous, the head 
and hind angles of thorax light castaneo-rufous, the palpi, tarsi, hasal half and eighth joint of antemnate more or less testareous, tibiac piceo-rufous.

Head obtusely trigonal, with shallow distant punctures, interantennal suture obsolete and seemingly incurved, that of the foreherad straight and distinet. Labrum larese, transverse, emarginate in front. Wyes subrotundate, large and prominent. Thorax about twice as broad as long, "venly curvedly narrowed towards the obtuse anterior angles so that its apex is only about a third of the width of the base, which is subtruncate. with rectangular angles: disc almost smooth. being finely distantly, and indefinitely punctate. Seutellum indistinet and small. Elytra of the same breadth as thorax at the base, $2 \frac{1}{2}$ times its length, quite narrow at the extremity, transversely crenate-strigose, with distinct sutural striae.

Femora rather short; tibiae straight, bispinose; tarsi elongate and slender.

Antennae as long as head and thorax, their terminal half finely pubescent and bearing slender outstanding setae; basal five joints slender and elongate. fifth only twice as long as broad; sixth and seventh obconical, the latter much the larger, eighth small, obviously narrower than contiguous ones, ninth and tenth large, suboblong, the terminal longer, subconical.

Underside finely pubescent, shining brown terminal segments rufescent. Mesosternal carina slender, prolonged to between the middle coxar. Metasternum short. Abdomen composed of six subequal visible segments, sixth narrower yet broadly triangular.

Maxillary palpi moderately slender, basal articulation smallest, second slightly stouter and longer than third, gradually thickened towands the extremity, the terminal rather longer than its predecessor, as broad at its base but tapering towards the apex.

The only specimen extant, being a female, its generic location must be left in doubt until the male can be obtained. The structure of the labrum suguests relationship to Catopsomorphus and Agyrtes, both exotic and not procurable for comparison here. At present it must be placed in my second section of Mesocolon, consisting of Nos. 279, 280, 281, 282, 1703, 2489, and 2756.

f. Length, $3 \mathrm{~mm}$.; breadth, $1 \frac{1}{2} \mathrm{~mm}$.

Glenhope, Nelson; 1st August, 1915. One, from Mr. T. Hall.

\section{Group Histerimate.}

Epierus Erichson. Man. N.Z. Coleopt., p. 163.

\section{Epierus spinellus sp. nov.}

Nitid, glabrous, suboblong-oval, moderately convex, finely but not closely punctate; black, legs and basal joint of antennae dark rufous; palpi, tarsi, and slender tibial spines fulvescent.

Head small, forehead truncate in fiont and distinctly marked off from the transverse and more coarsely seulptured labrum. Thorax about twice as broad as long. it.s sicles timely margined and gradually narrowed anteriorly, apex widely rmarginate so that its subacede angles appear prominent, the

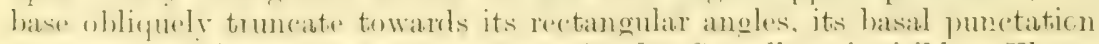
rather more distinct than that of the head. Seutellum invisible. Elytra double the length of thorax, of the same width at the base, trunceate behind: each elytron has six fine striae, none reach the extremity, the sutural is straight, the others somewhat curved, the inner three are more or less 
indistinct at the middle, between the first and second there is sometimes a short basal stria. Pygidium vertical.

Antennae implanted just in front of the eyes, basal joint about half of the whole length, gradually but considerably dilaterl towards the extremity; the next oblong, thicker but hardly longer than third, 1-8 small; alub densoly pubeseent, oblong-oval, quite obsoletely articulate, sometimes pale.

Tibiae setose inwardly, finely spinose externally, about a dozen on the anterior pair, which are rather more curved and expanded than the intermediate, the posterior rather slender.

Underside shining black, minutely punctate. Prosternum finely margined and grooved and slightly incurved between the coxae, emarginats behind ; chin-piece moderately developed; antennal cavities deep, situated below the anterior angles. IIesosternum obtusely angulate in the mirddle in front, minutely erenulate behind. Metasternum large, truncate behind. Basal ventral segment longer than remaining four combined.

Length, $3 \frac{1}{2} \mathrm{~mm}$. ; breadth, $2 \mathrm{~mm}$.

Stephen Island. Another of Mr. A. C. O'Connor's captures, during September, 1916.

\section{Group Col YDIIDAE.}

Bitoma Herbst. Man. N.Z. Coleopt., p. 192.

\section{Bitoma morosa sp. nov.}

Oblong, moderately convex, without tubercular elevations, opaque; nigro-fuseous, antennae and legs dark, somewhat rufo-fuscous ; irregularly clothed with depressed, obscure greyish squamiform setae, the antennat with darker outstanding setae.

Head immersed up to the large, moderately prominent eyes which extrend outwardly almost as far as the anterior angles of the thorax, it is subquadrate, shorter than the thorax and somewhat narrowed towards the front, nearly plane above, with obsolete granular sculpture and slightly elevated antennal tubercles. Thorax of about equal length and breadth. wjdest belhind the middle, more gradually narrowed in front than behind. apex strongly bisinnate, with subacute angles, the base rounded and withnut perceptible angles, its sides only very slightly flattened; dise moderately convex, with a broad irregular channel from the apex towards the base, which is bi-impressed, it is distantly, finely, and indefinitely sculptured. Seutellim subrotundate. Elytra oblong, just double the length of thorax, evidently broader than it is at the base, which is incurved, with obtuse shoulders; their sculpture consists apparently of serial punctures.

Antennae shorter than the head and thorax, basal joint partly concealed from abeve, the next much shorter, equally stout, subrotundate; third nearly twice as long as broad; fourth and fifth rather shorter, obconical, sixth to eighth short and subglobular, ninth rather broader, transverse: tenth twice as large as ninth, also transverse, eleventh smaller and subrotundate.

Tibiae straight, without distinet terminal spines; basal joint of tarsi rather longer than third, fourth longer than the preceding thee united.

This may be placed near $B$. distincta (318), which, however, has the sides of the thrax somewhat explanate and the elytral vestiture quite different.

Length, $2 \frac{1}{2} \mathrm{~mm}$; breadth, $1 \mathrm{~mm}$. 1916.

Lake Rotoiti, Nelson. One, found by Mr. T. Hall on the 17th March, 


\section{Group Pychomeridae.}

Pycnomerus Erichson. Man. N.Z. Coleopt., p. 208.

\section{Pycnomerus parvulus sp. nov.}

Elongate, subparallel, slightly convex, subopaque, with some minute inconspicuous setae; nigro-piceous, antennae and legs piceo-rufous.

Head subquadrate, its punctation moderately coarse and close, rather shallow, less distinct in front. Thorax slightly longer than broad, base and apex subtruncate, a little wider before the midde than chewhere, very andenty narrowed backwards: anterior angles not aeutely prominent, the posterior obtuse and indefinite; lateral margins, in front especially, much less distinct than the basal; disc coarsely but only moderately closely punctured, less deeply near the sides, the broad and rather shallow longitudinal impression indistinctly divided along the middle. Scutellum indefinite. Elytra oblong-oval, double the length of thorax, rather broader than it is at the base, which is slightly ineurved, humeral angles not prominent; the punctation of the deep striae is not sharply defined but appears elongate; interstices finely punctate, slightly convex, scarcely broader than the striae, the second bent outwardly at the extremity.

Antennae shorter than thorax, with short slender setae; basal joint hardly visible above, the next thick and strongly transverse; third almost as broad, narrowed at its base, slightly longer than the following six, all of which are strongly transverse; tenth large, quadrate, but not at all transverse, eleventh very short.

Resembles $P$. froutalis (2504), in which the tenth antennal joint is transverse, its head is rather shorter and broader with more rotundate frontal impressions, and the eyes and anterior angles of the thorax are more prominent. Both species belong to Section I.

Length, $2 \frac{1}{4} \mathrm{~mm}$.; breadth, $\frac{2}{3} \mathrm{~mm}$.

Karekare, west coast, near Auckland; 23rd February, 1916. Unique. Found by Mr. A. E. Brookes.

\section{Group Passandridae.}

\section{Chaetosomodes gen. nov.}

Elongate, subdepressed, bearing numerous ereet slender setae. Head nearly as long as thorax and, including the "yes, not as broad as it is. Labrum short, widely emarginate. Eyes entire, prominent, somewhat transversal. Antemnate stout, equalling the head and thorax in length, with many slender setar ; basal joint thickest, slightly longer than broad, the next very short; joints 38 subecpual, moderately elongate, somewhat narrowed towards the base, ninth and tenth slightly broader, eleventh subovate. Thorax transverse, a fourth broader than long, rather wider behind the middle than elsewhere, its sides moderately curved, without perceptible margins; apex truncate, the base also in the middle, but marerinate, and so broadly rounded towards the sides that there are no traces of posterior angles. Scutellum oblong, convex, smooth. Elytra almost thrice the length of thorax, finely marginate, broadly rounded at the rextrunity, with obtuse, not at all prominent humeral angles. Pygidium expeserd, romeded behind. Leegs moderate; femora much thicker near the base than at the "xtremity; anterior tibiae slightly and gradually expanded, each with a short calcar at the inner extremity and only about 
three minute denticles along the outer edge. Tarsi pentamerous, the clongate terminal articulation as long as the basal four combined; claws stout, considerably thickened underneath at the base.

Undoubtedly nearly related to Chaetosoma, but the terminal joints of the palpi are thicker and subsecuriform; the mandibles are quite half the length of the head, they. are strongly curved and acuminate towards the extremity, and each has a prominent inner tooth near the apex; the thorax is remarkably different, and the humeral angles are quite without dentiform projections.

\section{Chaetosomodes halli sp. nov.}

Shining, black, legs and palpi chestnut-red, mandibles and antennate piceo-rufous; each elytron with five smooth flavescent spots, the first, at the base, and a pair just behind it are somewhat rounded; the fourth is transverse, situated on the middle, but does not extend to the suture; fifth subapical, subrotundate, larger than the basal ones.

Head with moderately coarse, close, rather elongated punctures, but with a smooth spot close to each eye, and the forehead nearly smooth across the front. Thorax similarly punctured on the middle, less closely towards the sides. Elytra with almost quite regular series of moderately coarse rotundate punctures, these become a little finer near the apices, but are almost entirely absent from the yellowish spots.

Underside black, nitid; prosternum rather coarsely and closely punctured, abdomen irregularly, some parts smooth.

Length, $10 \mathrm{~mm}$. ; breadth, $2 \frac{1}{2} \mathrm{~mm}$.

Lake Rotoiti, Nelson. This, the finest New Zealand species of the group, is named in honour of Mr. T. Hall, who found a single individual on the 5th February, 1916.

\section{Group Melolonthidae.}

Odontria White. Man. N.Z. Coleopt., p. 265.

\section{Odontria nesobia sp. nov.}

Subovate, widest behind the posterior femora, moderately convex and shining; rufo-castaneous, the head more rufescent, antennae, palpi, and legs more or less fusco-testaceous; thinly covered with distinct, rather elongate, decumbent and erect, flavescent setae.

Most nearly resembles $O$. puncticollis (3743), but differing in some respects from the female of that species.

Eyes very finely faceted. Clypeus coarsely, closely, and rugosely punctured. Thorax rather more coarsely but not as closely punctate. the base more angulate at the middle and more strongly bisinuate, its hind angles are subrectangular, instead of being obtuse or rounded. Seutellum almost smooth. Elytra thrice the length of thorax, more gradually and less dilated posteriorly, their apices subtruncate so that the sutural angles are almost rectangular in place of being rounded; the sutural striae are well marked, the others are obsolete, the punctation is rather coarser.

Underside fusco-testaceous, the breast with numerous elongate yellow hairs, these become finer and more distant on the abdomen. Metasternum with a slender nigreseent carina along the middle, finely and closely punetured. Abdomen finely and distantly punctate but with some longitudinal 
rugae near the base; first segment partly covered by the femora, second slightly longer than following ones, fifth shorter than fourth instead of bing longer, sixth short, distinctly but widely angulate at the middle of the apex.

Antennae short, structurally like those of $O$. puncticollis.

ㅇ. Length, $14 \mathrm{~mm}$. ; breadth, $7 \frac{1}{2} \mathrm{~mm}$.

Stephen Island. Mr. A. C. O'Connor obtained several specimens on the 15th May, 1916, and on subsequent occasions, but no males were found.

\section{Eusoma White. Man. N.Z. Coleopt., p. 265.}

\section{Eusoma piliventris sp. nov.}

Oblong, subdepressed, somewhat nitid, with some elongate, erect, fulvescent setae on the head and along the sides of the thorax and elytra; fusco-testaceous, hinder half of head nigrescent, thorax with a large very irregularly formed fuscous discal area, the elytra with series of irregular dark spots, some of which are slightly violaceous.

Head moderately finely and irregularly punctured between the eres, smooth behind them; clypeus distinctly, rather closely and rugosely punctate, with reflexed margins, subtruncate in front. Thorax finely marginate, nearly twice as broad as long, widely emarginate in front, its acute angles clasping the basal part of the eyes; base widely but slightly bisinuate, with obtusely rectangular angles, the sides only slightly rounded, nearly straight behind; moderately and irregularly punctured. Scutellum large, almost smooth, infuscate behind, rufescent at the base. Elytra oblong. of same width as thorax at the base, thrice its length, their subtruncate apices usually covering the pygidium; they are moderately finely subseriate-punctate; on each elytron there are about six costae, half of them rather less distinct than the others; the suture nearly smooth in front but with a series of fine punctures along the side, the interval between it and the first costa is broader than the others, more coarsely and irregularly punctured, and has larger dark marks.

Anterior tibiae tridentate externally, the uppermost smallest; tarsi about double the length of the tibiae.

Basal joint of antennae clavate at apex, nearly twice the length of the thick second, third slender, shorter than first; fourth fully as long as preceding ones combined, attached to the apex of the third, so that the portion which projects forwards and inwards is not more than a third of its whole lengtb; club with four equally elongate, closely pubescent leaflets, each obviously longer than the rest of the antennae.

Underside nitid, testaceous, with numerous elongate fulvescent hairs.

In the male of $E$. aenealis (2806), (Ann. Mag. Nat. Hist., ser. 8, vol. 3, p. 397), the third antennal joint is almost as long as the fourth, which at the inside of its base is united to the apex of the third, its basal portion forms an angle only, instead of a prolongation as in $E$. pitiventris and Sharp's Sericospilus advena (1987). 'The elytral sculpture of this species is distinetive.

Length, $8 \mathrm{~mm}$; ; breadth, $3 \frac{1}{2} \mathrm{~mm}$.

Martinborough, mat Wellington: 10th . Lugust, 1916. Described from a specimen found by Mr. A. C. O'Connor, who afterwards sent two other specimens, one of which was lost; the remaining one is a little more infuscate above. 


\section{Group Melyrida}

Dasytes Paykull. Man. N.Z. Coleopt., p. 328.

\section{Dasytes violascens sp. nov.}

Subdepressed, elongate, opaque ; dark violaceous, antennae and tarsi somewhat piceous; pubescence short, curled, grevish, more scanty on thr head and thorax.

Head, including the large, prominent eyes, evidently broader than thorax, slightly bi-impressed in front, finely and distantly punctate. Thorax of equal length and breadth, widest and obtusely angulate before the niddle. deeply constricted in front, slightly narrowed behind, posterior angles subrectangular but obtuse, base and apex truncate, lateral and basal margins not sharply defined; its punctation like that of the head, the whole surface densely and minutely sculptured. Scutellum rather small. subquadrate. Elytra thrice the length of thorax, rather broader than it is at the base, a little wider near the hind thighs, their broadly rounded apices not covering the prgidium; they are distinctly and moderately closely punctured.

Legs long and slender, with dark pubescence; tarsi fully equalling the tibiae in length, basal joint of the anterior with a short curvate prolongation underneath.

Antennae elongate, reaching backwards to the middle thighs; basal joint stout, second subquadrate, third and fourth equal, rather more serrate than the following ones.

Distinguishable at once from $D$. helmsi (2035) by its smaller size, more cyaneous hue, nearly white vestiture, much broader head, longer antennae, \&c. The eyes are entire, and the claws are thickened underneath for half their length.

o. Length, $4 \mathrm{~mm}$; ; breadth, $1 \frac{1}{2} \mathrm{~mm}$.

Mount Owen, Nelson. One only, caught by Mr. T. Hall on the 26th December, 1914.

\section{Dasytes clavatus sp. nov.}

Elongate, slightly convex, nitid, covered with moderately slender, subdecumbent greyish setae; fuscous, faintly aeneons, the legs and basal third of antennae more or less chestnut-red.

Head, the large prominent eyes inclusive, slightly broader than the widest part of thorax, broadly bi-impressed in front: finely ret distincely and moderately closely punctured. Thorax as broad as long. widest and obtusely prominent at or just behind the middle, widely contracted in front of that point, its margins obsolete there but more definite behind and at the base; its sculpture like that of the head. Scutrlum transwerse. Elytra with obtusely porrect shoulders, thrice the length of thorax, broader than it is at the base, only slightly wider near the hind thighs, their broadly rounded apices covering the abdomen; each side of the suture, near the base, and the shoulders are slightly and quite obtusely elevated, their punctation is a little coarser than that of the thorax.

Antemne finely pubescent attaining the intermediate femora. moderately stout; basal joint subpyriform, the next nearly as long as the third. which is rather shorter than fourth: joints 5-10 slightly subserrate, the terminal conical, about double the size of the penultimate, its basal half concave underneath. 
T'arsi similar to those of $D$. violascens, as are the posterior angles of the thorax.

The abnormal bulk of the last antennal joint differentiates this from all the New Zealand species.

o. Length, $3 \frac{2}{3} \mathrm{~mm}$. ; breadth, $1 \frac{1}{2} \mathrm{~mm}$.

Boulderstone ('reek, near Scarclifi, Canterbury : 20th October, 1913. Unique. Discovered by Mr. T. Hall.

\section{Group Salpingidat.}

Salpingus Illiger. Man. N.Z. Coleopt,, p. 398.

\section{Salpingus nigricans sp. nov.}

()blong, slightly convex, subglabrous ; glossy aeneo-niger, legs and basal joints of antennae rufo-piceous, the dilated terminal three of the latter darker, palpi fusco-testaceous.

Head. including the prominent eyes, almost as broad as the thorax. narrowed anteriorly, distinetly punctate, less so, but more transversely, in front. Thorax cordate, not. broader than long, basal margin distinct. pesterior angles indefinite but not rounded; disc rather coarsely and somewhat rugosely punctured, but with an obvious smooth linear space along th:: centre. Scutellum broad, rounded behind. Elytra oblong, just double the length of thorax, a third broader than it is; slightly transversely impressed before the middle, the suture more deeply at the base, they are coarsely striate-punctate. more irregularly at the base, obsoletely behind. Claws slightly thickened near the base.

Antennae evidently shorter than the head and thorax, very finely pubescent; basal joint stout, suboblong, the next longer, 3-5 longer than broad, subequal; joints 6-8 smaller and moniliform; ninth and tenth much larger, eleventh as broad, subconical.

Underside shining black, its pubescence scanty, slender and grey. The breast coarsely, the abdomen less distinctly punctate.

S. aterimus (1073), also unique, is easily recognizable by its elongate narrow contour, finer sculpture, and quadriarticulate club.

Length, $2 \mathrm{~mm}$. ; breadth, $\frac{2}{3} \mathrm{~mm}$.

Lake Rotoiti, Nelson. Described from a single specimen obtained by Mr. 'T. Hall on the 5th May, 1916.

\section{Group Rhipiphoridae.}

\section{Allocinops gen. nov.}

Antennae implanted near the eyes but distant from the clypeus, 11-articulate, the basal four joints short and thick and, together, only a third of the length of any of the lobes proceeding from the following ones; basal joint only slightly longer than hroad, the next as long bott just a little narmwer, third obtusely triangular, slightly shorter and hroader than second. fourth strongly transwerse, as hroad as the alpex of the third. Head large, nearly vertical in front of the antennae, subquadrate behind, with somewhat dedexed, obturely prominent hind angles. Labrum small but quite exposed between the large curved mandibles. Clypeus very short, with a definite suture between it and the forehead. Eyes prominent, transverse, truncate in front. without atm preptible amargination. 'Terminal joint of maxillary palpi oblong-oval. 'Thorax slighty broader than long. deeply bisinuate and widest at the laise gradually narrowed towards the alpex which is only it third as broad as the occiput, its posterior angles somewhat prolonged 
so as to clasp the outside of the shoulders. Scotellum large, the middle of the base sharply depressed longitudinally and smooth, with finely carinate. lateral borders. Elytra four times the length of thorax, gradually narrowed posteriorly, with strongly rounded, dehiscent apices, which do not cover the terminal abdominal segment.

Legs slender and elongate. Anterior tibiae simple, the others finely bispinose at the extremity. Tarsi pentamerous, slender, longer than the tibiae, their claws thickened underneath for two-thirds of their length, the remainder curved and slender.

None of the genera in Lacordaire's four tribes agree with Allocinops, which, indeed, is more approximated to the New Zealand Rhipistener (p. 416, Man. N.Z. Colsopt.). In the typical species, R. luguluris Sharp (731), the basal four joints of the antennae are relatively slender and elongate. they differ in shape, and, united, are about twice the length of the lobes of the succeeding ones; its head is quite oviform, with obsolete posterior angles; the eyes are not at all transverse, they are only very slightly convex and are emarginate inwardly; the hind angles of the thorax are less prolonged; the scutellum is simple, and the tibiae are describer as heing spurless.

\section{Allocinops brookesi sp. nov.}

Elongate, widest near the middle, clothed with decumbent, slender, dark ashy pubescence; head and thorax quite nitid and black, but with the posterior angles of the latter slightly rufescent; elytra less shining, nigro-piceous, their shoulders and costae slightly reddish; antennal lobes dull black, densely and minutely sculptured and pubescent; legs piceorufous, tibial spurs and the claws castaneous.

Head finely, rather distantly and irregularly punctured, with a broad subinterrupted median groove trom the antennae to the base. Thorax similarly punctate, finely margined at the base; with an obtuse longitudinal clevation behind the middle, and a broad depression between it and each of the convex basal angles. Flytra finely and irregularly punctured, a ach tricostate, the costa nearest the suture extends from the base to the middl:? the next hardly reaches the extremity, the third is less distinct, it extrnds from the middle backwards but becomes obsolete behind.

All the New 'Lealand Rhipiphoridae possess ample wings.

Length, $13 \mathrm{~mm}$.; breadth, $3 \frac{1}{2} \mathrm{~mm}$.

Karekare, west coast, near Auckland ; 23rd Tebruary, 1916. Unique. ('aught by Mir. A. E. Bronkes, of Mount Albert, after whom it is named.

\section{Group Otiorhynchidae.}

Nicaeana Pascoe. Man. N.Z. Coleopt., p. $427^{\circ}$

\section{Nicaeana cordipennis sp, nov.}

fonvex, of irregular contour, slightly uitid ; nigreserent, legs and antenniare rufo-piceous, slub paler ; sparingly clothed with dark ashy and a few white scales, and with some suberect greyish setae.

Rostrum short, of the same width as the head at the base, gently narrowed antreriorly, finely, distantly, and indistinctly punctate, with a few white setae in front. Eyes widely separated. rotundiate slightly anvex. Thorax of equal length and breadth. apex and hase truncate. the iattire margined, its sides moderately rounderd; its sculpture apparently gramular. 
with a minute puncture in some of the granules. Seutellum indistinct. Elytra cordate, a third broader than thorax, just twice its length, considerably ret gradually narrowed, and deflexed posteriorly ; finely but not closely sriate-punctate, substriate alongside the suture, interstices plane. Tibiae flexucus, dilated at the extremity, the anterior acuminate inwardly : third tarsal joint bilobed and moderately expanded.

Scape glabrous, inserted near the apex and attaining the centre of the eve, distinctly thickened and somewhat bent at the extremity : basal joint of funiculus nearly twice as long as broad, second subquadrate, 3-7 transverse: club elongate-conical.

Undersid" opaque, blatkish, rovered with elongate greyish scales and slender setae. Basal ventral segment only slightly longer than second in the middle, truncate between the widely separated coxae, third and fourth together rather longer than the reddish fifth.

Most nearly allied to $N$. crassifroms (3859), in which the thorax is slightly transverse, the elytra much narrower, the eye small and flat, and the scape simple.

Longth (rostrum inclusive), $3 \frac{2}{3} \mathrm{~mm}$. ; breadth, $1 \frac{1}{2} \mathrm{~mm}$.

Alexandra. Two, from Mr. O'Connor; one broken; both found by Mr. W. G. Howes, of Dunedin.

\section{Tigones Broun. Man. N.Z. Coleopt,, p. 855. Syn. Protophormus Sharp (p. 1178).}

\section{Tigones longipes sp. nov.}

Elongate, moderately convex, somewhat nitid; rufo-piceous, legs and antennae more rufescent; clothed rather unevenly with small, repressed, flavescent scales and a few coarse setae.

Rostrum a fifth shorter than thorax, gradually yet obviously dilated anteriorly, with a distinct carma along the middle, longitudinally rugose but not definitely carinate near the sides. Scrobes quite open above at the apex, extending obliquely downwards but not reaching the eyes. Thorax just as long as broad, slightly narrowed behind the middle, with some moderate verrucose rugae. Scutellum small. Elytra twice the length of thorax, almost a third broader, their shoulders curvedly narrowed to the same width as the thoracic base, the declivity a good deal narrowed but not quite vertical, with simple apices; they are moderately coarsely subseriate-punctate: third interstices indistinctly elevated but terminating as large, reddish, horizontal nodosities on the summit of the declivity, fifth similar, the nodosities much smaller and not extending as far back, on each of the apices there is a reddish, small, subnodiform spot.

Legs rather elongate, with yellowish setae; femora slender near the base, subclavate at the middle ; tibiate only slightly flexuous, the anterior inwardly acuminate, posterior corbels without any discemible truncature between the ciliae.

Scape nearly straight, a little incrassate near the extremity, implanted near the apex and reaching the front of thorax; basal joint of funiculus rather longer and stouter than second, joints $3-7$ slightly longer than broad; club elongate-oval, as long as the preceding four joints combined.

Underside piceous, clothed like the upper surface. Basal ventral segment broadly rounded between the coxae, lonerer than second in the middle, fifth nearly double the length of third and fourth together, subtruncate behind, sixth quite distinct, with a deep central fovea. 
Described from a single specimen mounted on cardboard minus an antenna. In unabraded fresh examples the squamae probably are more numerous and of a brighter brassy hue. The legs are unusually elongate, and the rufescent spots on the elytral apices have not been noticed in other species.

§. Length (rostrum inclusive), $6 \mathrm{~mm}$.; breadth, $2 \mathrm{~mm}$.

Styx Saddle, near Ross. Found by Mr. H. Hamilton.

Epitimetes Pascoe. Man. N.Z. Coleopt., p. 435.

\section{Epitimetes bicolor sp. nov.}

Robust, suboblong, narrowed anteriorly, only moderately convex, opaque ; fusco-niger, funiculus piceo-rufous, tarsi rufo-castaneous ; covered with depressed nigrescent and tawny-grey squamae, those of the latter colour predominate along the lower sides and on a large space of the elytral disc ; the setae are mostly decumbent and greyish, but suberect ones form spots on the posterior declivity, the fuscous ones are less conspicuous.

Rostrum fully a third shorter than thorax, moderately dilated and closely but finely punctate in front, obtusely tricarinate behind. Eyes subrotundate, quite free from thorax, widely distant from each other. Thorax slightly broader than long, somewhat narrowed near the truncate apex; the discal depression broad and deep in front, narrower behind, the frontal one near each side is broad and more coarsely punctured than the space between them, the basal portion is slightly rugose. Elytra oblong, $2 \frac{1}{2}$ times the length of thorax, much narrowed and vertical behind, the base evidently incurved so that the obtuse shoulders seem slightly porrect and distinctly broader than the thoracic base; they are seriate-punctate, third interstices elevated at the base, obsoletely elsewhere, and, like the fifth, ending as short horizontal prominences on the top of the posterior declivity, this has the suture obtusely elevated nearly to the extremity.

Legs moderately elongate and slender, with minute scales and many setae, femora subclavate, tibiae flexuous, the posterior with some minute denticles near the inner extremity, the two hind pairs of tarsi slender.

Scape dull, rather slender, gradually thickened, implanted near the apex and just reaching the thoracic apex; basal two joints of funiculus equally elongate, 3-7 diminish, yet rather longer than broad; club elongate-oval, triarticulate.

Underside fuscous, covered with small flat tawny-grey scales and slender setae. Prosternum moderately emarginate. Metasternum short. Basal segment of abdomen truncate between the widely separated coxae, nearly double the length of second, their suture straight, third and fourth together longer than second, fifth nearly as long as the basal. Mentum subcordate, broadly impressed and occupying the buccal cavity so that only the tips of the palpi are visible. Posterior corbels with narrow intervals between the ciliae.

The female of $E$. watiefieldi (2099) most nearly resembles the specimen described above, but it is smaller, differently clothed and sculptured, and the funicle and club are shorter. The tawny-grey area on the middle of the elytra is absent in other species.

․ Length (rostrum inclusive), $9 \mathrm{~mm}$. ; breadth, $3 \frac{2}{3} \mathrm{~mm}$.

Martinborough, near Wellington. My specimen was sent on the 10th August, 1916, by Mr. A. C. O'Connor. 
4193. Epitimetes densus sp. nov.

Opaque, fuscous, legs and funiculus rufo-castaneous; densely clothed with small, flat, greyish and shightly infuscate scales, and subdepressed grey setae.

Restrum stout, about half the length of thorax, a little dilated in front, broadly bisulcate and distinctly tricarinate. Thorax of exual length and breadth, a little uneven, without obvious crests or rugae, the broad channel not as deep in the middle as at the base or apex, broadly bi-impressed in front, its punctation invisible; the sides are moderately rounded and slightly wider before the middle than elsewhere. Scutellumi small. Elytra $2 \frac{1}{2}$ times longer than therax, nearly a fourth broader, arcuate at the base, with obtusely porrect shoulders, very slightly narrowed backwards, much mote so and subvertical near the extremity; distinctly but not coarsely seriate-punctate; third interstices obtusely elevated at the base and ending as moderate horizontal nodosities, with fine grey setae, rit the summit of the declivity, the fifth are not distinctly raised at the base, they are similarly nodiform, but below each, behind, there is a small greyish crest. the suture is broadly elevated half-way down the declivity. Antennae like those of $E$. bicolor.

Anterior tibiae considerably bent inwardly at the extremity, fringed with fine yellow hairs and mucronate there, along the inside they are distinctly tridenticulate, and slightly dilated above the middle, the other pairs are moderately flexuous, the posterior without denticles.

Underside obscure rufo-castaneous. covered with round flat scales and slender grey setae, some of the former are of metallic lustre. Basal ventral segment broadly impressed, the next little more than half as long and obtusely angulate at the middle in front, fifth nearly as long as the basal, truncate and foveate behind and with a shallow groove along the middle, the supplementary lunate, concave.

Fem. $-6 \frac{1}{2} \times 2 \frac{1}{2} \mathrm{~mm}$. Humeral angles curvedly narrowed and less prominent. Front tibias less bent, not denticulate inwardly, the posterior pair more minutely denticulate than the intermediate.

3. Length (rostrum inclusive), $6 \frac{1}{2} \mathrm{~mm}$.; breadth, $2 \mathrm{~mm}$.

Iartinborough; 29th October, 1916. Two males and a female, the latter sent separately by Mr. A. C. O'Connor.

Obs.-In the males of $E$. lutosus (763) and $E$. cupreus (3872) the posterior tibiae on the inside, near the base, are armed with a spiniform tooth, and below this are obviously ciliate; the male of $E$. densus therefore is manifestly different. In the other sex the hind tibiae of all the known species are more or less denticulate only, but the front pair are simple.

\section{Exonastus gen. nov.}

Rostrum stout, about a fourth shorter than thorax, only slightly dilated in front. Serobes deepe. quite open above near the apex, extending obliquely. backwards but not reaching the eyes. 'Thorax transverse, without definite ocular lobes, base and apex truncate. Scutellum distinct, quadrate. Elytra subcordate, abruptly broader than thorax at the base, with acuminate but not prolonged apices. The duplicate cilia of posterior corbels as widely separated as those of Epitimetes or Platyomida.

It differs from Tigones (Protophormus) Sharp by the less pterygiate rostrum and the broad external truncature of the posterior corbels, and from Platyomida by the abbreviated scrobes, \&c. 


\section{Exonastus amplus sp. nov.}

Robust, moderately convex, without superficial inequalities, opaque; apparently rufo-fuscous, antennae and tarsi fusco-rufous; thickly and almost uniformly covered with depressed, obscure tawny squamae, and rather paler erect setae.

Rostrum a fourth shorter than throax, with a slender indistinct carina along the middle, closely, rugosely, and longitudinally punctured in front, and bearing very slender apical pale setae. Eyes slightly prominent, not at all elongate, fully twice as distant from each other than they are from the thoracic apex. Thorax nearly a third broader than long, slightly rounded and broader at or behind the middle than elsewhere, rather narrower in front than behind; with a shallow impression along its frontal half, and many bare punctures visible amongst the squamae, some of these punctures near the sides, when looked at in different lights, appear transformed into minute dark tubercles. Elytra large, nearly double the width of thorax at the base, thrice its length, distinctly narrowed and curvedly deflexed behind, with slightly divaricate apices; they are rather finely punctate-striate, with nearly plane interstices, being only slightly convex along the posterior declivity.

Tibiae briefly mucronate, the posterior pair more distinctly denticulate than the others along the inner face.

Scape straight, very gradually incrassate, just reaching the thoracic apex; basal two joints of funiculus equally elongate ; $3-7$ obconical, third slightly longer; club elongate-oval, triarticulate.

Underside densely covered with greyish scales and slender setae. Basal ventral segment subtruncate between the widely separated coxae, medially incurved behind, longer than the next, third and fourth together rather shorter than second or fifth. Mentum subovate; palpi invisible. Supplementary mandibles well developed.

Length (rostrum inclusive), $11 \mathrm{~mm}$.; breadth, $4 \frac{1}{2} \mathrm{~mm}$.

Martinborough, near Wellington. One female, sent by Mr. A. C. O'Connor; 31st October, 1916.

\section{Exonastus fumidus sp. nov.}

Rufo-piceous, legs and tarsi fusco-rufous; almost covered with dull smoky brown scales, there being only a few scattered tawny-grey ones on the elytra, similarly pale ones encircle the eres, cover the scutellum, form a patch on the hind angles of the thorax and a short fringe across its base : many of the setae are dark fuscous, others greyish.

The rostral carina though slender is definite, the frontal sculpture is less longitudinal and not at all strigose. The humeral angles are more rounder and not quite as broad, the third and fifth interstices are slightly but obtusely clevated, and there is a minute greyish scale $i$ each of the serial punctures of the elytra. The tarsi are more slender. The form and peculiar sculpture of the thorax are, however, precisely similar to those of $E$. amplus, so that $E$. fumidus may prove to be only a variety thereof.

우. Length (rostrum inclusive), $10 \mathrm{~mm}$; ; breadth, $4 \frac{1}{4} \mathrm{~mm}$.

Martinborough. Mr. O'Connor also forwarded another, mounted on cardboard, measuring $8 \times 3 \frac{1}{4} \mathrm{~mm}$. : this probably is the male. 
Neoevas gen. nov.

Rostrum not pterygiate, half the length of thorax. Head of about the same wilth as the thoracie apex, rather broader, but not abruptly so, than the rostrum. Scrobes deep, just oblong, beginning at some distance from the apex and ending at the middle of the rostrum, they are situated at the upper part of the sides and quite open above. Eyes widely separated above, just free from the thorax, slightly prominent, obliquely-oval or somewhat rotundate. Thorax with feebly developed ocular lobes, base and apex truncate. Scutellum small. Elytra oblong, slightly incurved and rather broader than thorax at the base, considerably narrowed near the simple apices.

Scape straight, very gently incrassate, inserted between the middle and apex, attaining the front of thorax. Funiculus 7 -articulate, basal joint twice as long as broad, the next similar, third and fourth rather shorter, seventh slightly broader than the submoniliform fifth and sixth; club elongate-oval, triarticulate.

Femora moderately elongate, subclavate. Tibiae flexuous, the anterior mucronate, with about four denticles along the insiale; posterior corbels concave, without external truncature. Tarsi with brush-like soles, penultimate joint dilated and bilobed.

Mentum subquadrate, not concealing the rigid palpi. Anterior coxae placed at the middle of the emarginate prosternum, prominent and contiguous, the intermediate pair moderately, the posterior widely separated. Metasternum short. Basal ventral segment rather larger than second, subtruncate between the coxae, its hind suture simuate; third and fourth, united, hardly longer than fifth, with deep straight sutures.

In the type of II aplolobus (2122) the rostrum is short and so gradually dilated to the same width as the head that it would be difficult to specify the line of demarcation; the scrobes are subapical, placed more on the upper surface and therefore more approximated above, and the seape is subnodose at the extremity. Catoptes (750) has somewhat different scrobes, the mandibular sear is quite visible, and the external truncature of the posterior eorbels though very narrow is quite discernible, and has double cilia; in my Catoptes furms (2385) the posterior corbels have the truncature more distinct, and so is the mandibular scar.

\section{Neoevas celmisiae sp. nov.}

Suboblong, only moderately convex, opaque; nigrescent, antennae and tarsi rufo-piceous; densely covered with depressed, rather small, inconspicuous, dark ashy squamae; the elytra, in addition thereto, bear series of decumbent, rather short greyish setae, those on the rostrum and thorax are irregular and slightly coarser.

Head and rostrum nearly plane and, together, a fourth shorter than thorax, the apical portion of the rostrum elosely punctate; mandibles moderately prominent, subacute at the extremity. Thorax of erqual length and breadth, rounded and widest before the middle, sinuate-angustate behind, without superficial inequalities, closely and finely but not definitely seobetured. Elytrat just double the length of thorax, hardly a third broader where widest, their sides only ferbly curved, considerably contracted near the extremity; they are distinctly striate-punctate, interstices nearly plane, the third and fifth and the suture are, however, slightly clevated behind the middle. 
Underside somewhat glossy black, with numerous grey setae, the breast and basal two segments with scales as well, irregularly punctate. Basal two segments impressed.

o. Length (rostrum inclusive), $6 \frac{1}{2}-8 \mathrm{~mm}$. ; breadth, $2 \frac{1}{2}-3 \mathrm{~mm}$.

Mount Roberts, Nelson; 28th December, 1915. A dozen specimens taken by Mr. T. Hall at a height of 4,000 ft., feeding on the flower-buds of the mountain-daisy.

\section{Zenographus Broun. N.Z. Inst. Bull. 1, Part IV, p. 326.}

\section{Zenographus albinotatus sp. nov.}

Oblong, moderately convex, nitid; black, partly covered with similarly dark inconspicuous squamae, elytral interstices distinctly marked with numerous irregular patches of small white scales.

Rostrum quite a third shorter than thorax, stout, arched, moderately dilated and finely punctured in front, the carina along the middle ending at the elongate interocular fovea. Eyes subrotundate, more distant from each other than from the thoracic apex. Thorax only a trifle broader than long, slightly wider and rounded before the middle than elsewhere, gently narrowed towards the subtruncate base; disc irregularly punctate, more closely on some parts than others, a little uneven, with a few coarse irregular rugae and impressions and a well-marked groove from base to apex, it has only a few white or feebly iridescent scales. Scutellum small. Elytra oblong-oval, quite $2 \frac{1}{2}$ times the length of thorax, somewhat incurved and rather broader than it is at the base, moderately narrowed and curvedly deflexed behind, with dehiscent apices; each elytron is tricarinate, the external one is less distinct than the others at the base, all are less evident near the apex, the intervals have large irregular punctiform impressions, which, however, become much finer and more regular behind, where there are a few fine setae.

Underside shining black, finely punctate, with decumbent grey setae, mesosternum with small scales. Basal ventral segment truncate between the widely distant coxae, broadly impressed behind, the second across the middle; fifth almost as long as preceding two together, nearly straight behind, sixth short and broad.

Antennae similar to those of $Z$. metallescens (3756), the club as long as preceding three joints of funiculus, tapering towards the extremity, indistinctly quadriarticulate.

In $Z$. metallescens the vestiture is altogether different, the thoracic dise is more uneven, and the elytral punetures are less coarse but almost quite regular. In this species the anterior tibiae are mucronate, and the ocular lobes are moderately well developed.

c. Length (rostrum inclusive), $9 \frac{1}{2} \mathrm{~mm}$. ; breadth, $3 \frac{2}{3} \mathrm{~mm}$.

Old Man Range, Otago. One, forwarded by Mr. A. C. O'Commor on the 21st August, 1916, but found by Mr. W. G. Howes.

\section{Hygrochus Broun. Man. N.Z. Coleopt., p. 702.}

\section{Hygrochus monilifer sp. nov.}

Oblong, slightly convex, subopaque; piceous, antennae chestnut-red ; covered with depressed, slender coppery seales and suberect wrevish setate, which latter form six small tufts across the summit of the posterior declivity.

Rostrum a fourth shorter than thorax, half its width, parallel ; obtusely carinate and broadly bisulcate along the middle behind. Thorax very 
slightly broader than long, subquadrate, only a little wider before the middle that behind; slightly uneven, with a ridge along the middle, and four shallow frontal dipressions, without visible punctation. Scutellum transverse, flavescent. Elytra fully double the length of thorax, about a third broader near the middle, a little broader than it is at the base, slightly narrowed behind the shoulders, more obviously narrowed and survedly deflexed posteriorly; they are moderately coarsely subseriatepunctate, without gramular elevations, third interstices slightly elevated at the base; there is a small greyish pateh near each hind thigh, the extermal erests are a little larger than the others on the top of the declivity, which is variegated.

Seape straight, very gradually thickened, reaching the back of the eye ; basal two joints of funiculus subequal, 3-7 short and moniliform; club elongate-oval.

Underside dark fuscous, irregularly punctured, covered with slender, depressed, somewhat brassy scales. Prosternum subtruncate, coxae contiguous, their cavities open in front; posterior coxae more distant than the middle pair. Basal ventral segment flat, truncate between the coxae, longer than the next, their suture sinuate, third and fourth together shorter than fifth, which is rugose.

This should be placed near $H$. cordipennis (3125): the squamae are less rufescent, the shoulders are more prominent, joints $3-7$ of the funiculus bead-like, club longer, \&c.

Length (rostrum inclusive), $6 \mathrm{~mm}$. ; breadth, $2 \frac{1}{3} \mathrm{~mm}$.

Wadestown. One, from Mr. A. C. O'Connor, of Wellington; 21st August, 1916.

Catoptes Schoenherr. Man. N.Z. Coleopt., p. 428.

\section{Catoptes lobatus sp. nov.}

Elongate, only moderately convex, opaque; nigrescent, antennae fuscovufous, scape and club dull, tarsi castaneo-rufous; densely covered with fusco-fulvous squamae and decumbent greyish setae.

Rostrum about a fourth shorter than thorax, gradually dilated anteriorly, obtusely carinate along the middle. Thorax slightly broader than long, widest and rounded before the middle; a little uneven, with a moderately broad channel from base to apex, deeper behind than in front, and an oblique frontal impression towards each side, its punctation apparently is rather fine, near each side of the base there are a few coarse obtuse rugae. Seutellum small. Elytra elongate-suberdate, $2 \frac{1}{2}$ times the length of thorax, a fourth broader, but with oblique shoulders so that the base is scareeny wider than that of the thorax, considerably narrowed and subvertical behind, with slightly dehisent, obtuse apices; dorsum a little muven, moderately seriate-punctate, third interstices moderately elevated neir the bise, nodose on top of the declivity, fifth slightly elevated from before the middle backwards, its terminal nodosity much smaller than that of the third, both of them infuseate but paler behind, the suture moderately prolonged beyond these.

lates alongate. With numerons setar, anterior tibiae distinctly mueronate.

Sheape seticerous, very eradually thickened, attaining the thoracic apex; laral joint of funiculus rather stouter but not longer than the next joints 3-5 obconical, longer than broad, sixth and seventh rather shorter; club elongate-oval, indistinctly quadriarticulate. 
Underside piceous, covered with pale-tawny depressed scales and long setae. Prosternum distinctly emarginate. Metasternum moderate. Abdomen elongate, second segment rather shorter than the basal, its frontal suture obtusely angulate in the middle, equalling the third and fourth combined, fifth also as long, slightly emarginate at apex, sixth small; the first segment broadly depressed, second flat.

Posterior corbels without any definite external truncature. Eyes nearly flat, subrotundate, free from thorax, widely distant from each other. Scrobes deep, open above near the apex, becoming narrow and vague halfway towards the lower front of the eyes. Ocular lobes well developed.

This does not agree with the descriptions of the six species placed by Dr. Sharp in Catoptes and Brachyolus, and there are none exactly similar in my own collection.

Length (rostrum inclusive), $6 \mathrm{~mm}$. ; breadth, $2 \frac{1}{3} \mathrm{~mm}$.

Wadestown; 10th August, 1916. One, from Mr A. C. O'Connor, of Wellington.

Var.-Another specimen from the same source, but received after the above description had been prepared, is covered with darker, dull, lightcoppery brown scales; the third and fifth elytral interstices are rather more distinctly and less interruptedly elevated, and there is a slightly raised swelling at each side of the scutellum.

Brachyolus White. Man. N.Z. Coleopt., p. 432.

\section{Brachyolus nodirostris sp. nov.}

Oblong, only moderately convex, opaque; piceous, antennae fuscorufous, tarsi chestnut-red; densely covered with depressed fusco-fulvous squamae, those on the thoracic dise rather darker but with an oval yellowish central spot; there are numerous setae also, mostly slender, decumbent and greyish, the others short, dark, and erect.

Rostrum half the length of thorax, closely punctate and bearing long. slender grey hairs in front, densely squamose behind; on each side, above, an elongate swelling oceupies the space between the scrobs and eye, and along the centre there is a narrower one, the base is a little depressed. Thorax of equal length and breadth, slightly wider before the middle than elsewhere, base a little curved, apex truncate; feebly impressed near each side in front, but without other inequalities or rugae. Scutellum distinct, yellowish. Elytra oblong, widely incurved and slightly broader than thorax at the base, only about a fourth broader near the middle, almost double its length, considerably narrowed and subvertical behind; they are regularly. but not coarsely striate-punctate; third and fifth interstices rather broader than the others, obsoletely elevated near the base, more distinctly behind. where they terminate as small horizontal prominences on top of the declivity, the suture also is slightly raised there, very few small fuscous spots occur behind.

Legs thickly squamose and setigerous, some of the scales metallic, tibiate flexuous, the anterior mucronate.

Scape straight, very gradually thickened, inserted near the apex and attaining the thoracic margin, bearing fuscous setae and some what lustrous scales; funiculus slightly longer, its basal two joints subequal, third and fourth slightly longer than the following bead-like ones; club elongate-oval. indistinetly quadriarticulatè.

Underside nearly plane throughout, subnitid, thinly covered with depressed fusco-fulvous squamae and suberect greyish setate. Prosternum 
deeply emarginate, with contiguous coxae, the intermediate pair moderately; posterior widely separated. Metasternum short. Basal segment of abdomen truncate in front, slightly longer than second, their suture subangulate in the middle; third and fourth together rather longer than second or fifth. Mentum large, narrowed backwarke, filling the buccal cavity. Palpi nearly invisible

Mandibular scar distinct. Ocular lobes moderately developed. Scrobes oblong, deep, subapical, quite visible above. Posterior corbels not distinctly cavernous.

The rather brightly coloured vestiture and the peculiar rostrum, taken together, distinguish this species from others in my collection. In Dr. Sharp's species, 2117 and 2118, the third elytral interstices project over the base of the thorax, the others described by him are sufficiently distinct from $B$. nodirostris. The members of this genus and Catoptes are hardly separable in many instances.

Length (rostrum inclusive), $4 \frac{1}{3} \mathrm{nim}$. ; breadth, $1 \frac{2}{3} \mathrm{~mm}$.

Stephen Island. A single specimen, found by Mr. A. C. O'Connor on the 15th May, 1916.

\section{Brachyolus obscurus sp. nov.}

Oblong, nearly plane above, opaque; piceous, antennae and tarsi fuscorufous; densely covered with depressed, small, chiefly pale grevish-brown squamae, and a few scattered grey ones, on the thorax some elongate, depressed blackish ones can be seen, on the elytral suture the scales are coppery, just below the summit of the posterior declivity there are generally two dark patches; there are no erect setae.

Rostrum quite half the length of thorax, slightly dilated in front. Thorax slightly broader than long, a little wider near the front than elsewhere; sometimes slightly uneven, with a shallow impression along the middle which becomes deeper at the base, the punctation completely hidden. Scutellum small. Elytra oblong, twice the length of thorax, widely incurved and slightly broader than thorax at the base, a little wider nura the middle, obliquely narrowed and subvertical behind; moderately finely and rather irregularly seriate-punctate; fifth interstices indistinctly elevated, ending abruptly, somewhat thickened but not elevated on top of the declivity.

Antennae with pale fuscous setae; scape dull, straight, gradually incrassate.

Underside densely covered with infuscate-grey, depressed scales and paler setae. Basal ventral segment subtruncate in front.

In form and structural details very similar to $B$. nodivostics, but differires greatly therefrom in appearance and sculpture, and with the rostrum simple.

Length (rostrum inclusive), $4 \frac{1}{3} \mathrm{~mm}$.; breadth, $1 \frac{2}{3} \mathrm{~mm}$.

Tauherenikau Bush, near Featherston. 'Ihree specimens, obtained by Mr. 'T. Hall ; 5th September; 1916.

Inophloeus Pascoe. Man. N.Z. Coleopt., p. 439.

4202. Inophloeus cuprellus sp. nov.

Elongate, slightly convex, opaque; nigro-fuscous, legs and antennae rufo-piceous; densely covered with small, flat, pale-coppery squamae, the posterior declivity with moler tawny vestiture; the setale mostly grevish 
and decumbent, longer and outstanding on the declivity, on the thorax they are suberect, fuscous, but very short and inconspicuous.

Rostrum parallel, a third shorter than thorax, distinctly but obtusely tricarinate from the base to the antennae. Thorax as long as broad, widest and broadly rounded near the front, gradually narrowed backwards; the surface a little uneven, its central groove well marked near the base but indefinite in front. Scutellum very small. Elytra oblong, considerably narrowed and subvertical behind, slightly narrowed near the emarginate base, which is rather broader than that of the thorax, they are 21. times its length and about a fourth broader; they are evidently seriate-punctate, the suture is somewhat elevated, quite distinctly alongside the scutellum, the fifth interstices are only feebly and gradually raised behind the middle and end as obtuse horizontal prominences on the summit of the declivity; the apices are simple.

Scape gradually incrassate, barely reaching the back of the eye, with infuscate setae; basal two joints of funiculus equally elongate, 3-7 obconical, club elongate-oval, indistinctly quadriarticulate.

Legs elongate; anterior tibiue longest, somewhat bent inwardly near the extremity, the others flexuous, the flavescent setae numerous towards the apices.

Underside piceous, the tawny pubescence somewhat concentrated on the metasternum and flat basal two segments, fifth segment almost as long as the first, broadly grooved from base to apex.

Closely allied to $I$. collimus (3893), the surface smoother and brighter, the rostrum broadly bisulcate and tricarinate above, the thorax irregularly uneven yet not at all tuberculate, the suture of the elytra a little elevated, and the vestiture uniformly paler.

o. Length (rostrum inclusive), $10 \mathrm{~mm}$.; breadth, $3 \frac{1}{4} \mathrm{~mm}$.

Speargrass Creek, near Lake Rotoiti, Nelson. A single specimen, obtained by Mr. T. Hall; 13th June, 1916.

\section{Inophloeus obsoletus sp. nov.}

Elongate, moderately convex, subopaque; nigrescent, antemnae and tarsi piceo-rufous; covered with depressed, obscure greyish squamae, those on the rostrum faintly rufescent and submetallic; the setae mostly decumbent and tawny, but longer and greyish on the declivity.

Rostrum parallel, a third shorter than thorax, its apex finely, closely, and rugosely punctured, slightly convex along the middle but not carinate. Thorax of equal length and breadth, broadly rounded and widest before the middle, gradually narrowed towards the base, which is a little depressed at each side ; it is distantly and finely punctate, with a subrotundate shallow depression near each side behind the middle, the discal groove distinct at the base but obsolete a short distance in advance. Scutellum very small. Elytra nearly thrice the length of thorax, a third broader, the shoulders slightly but obtusely porrect and rather broader than the thoracic base, the sides somewhat oblique just behind these, nearly straight to berond the hind thighs, the declivity much rontracted and eurvedly deflexed, with simple apicas; they are distinctly substriate-punctate, the suture is slightly obtusely elevated; third and fifth interstices somewhat nodiform on top of declivity, the former a little clevated near the base, the latter plane there and only very slightly raised behind.

Scape with slender grey setae, attaining the back of the eye; second joint of funiculus obviously longer than the basal, third rather lomere than 
the obconical following ones; club clongate-oval, obsoletely quadriarticulate. Tibiae flexuous.

Underside nigreseent, with short depressed tawny setae. Fifth segment not longer than second, lightly impressed behind the middle.

Like $I$. cuprellus the ocular lobes are well developed, the posterior corbels have duplicate "xternal eilia but the space between these is very narrow. $I$. obsoletus is well differentiated by the absence of rostral carinae and grooves and the elongate second joint of the funiculus. The scales on the rostrum, as well as some of those on the thorax, seem to indicate that fresh unabraded specimens will prove to be considerably brighter and more metallie than the one found during winter amongst decaying leaves.

Length (rostrum inclusive), $10 \mathrm{~mm}$. ; breadth, $3 \frac{1}{2} \mathrm{~mm}$.

Speargrass Creek; 13th June, 1916. One only, found by Mr. T. Hall.

\section{Inophloeus sexnodosus sp. nov.}

Oblong, slightly convex, opaque; thickly covered with small, depressed, greyish or obscure tawny squamae and setae, some setae on the thorax erect but very short and infuscate; antennae and tarsi rufo-piceous, the body fuscous or nigrescent.

Rostrum robust, as long as thorax, hardly at all dilated in front, not carinate; scrobes open above near the apex but prolonged obliquely downwards more than half-way to the eyes. Thorax very slightly broader than long, base and apex subtruncate, rather wider near the front than elsewhere, nearly straight behind; dise somewhat uneven, with some wart-like elevations, the bare spots as finely punctured as the rostrum, the longitudinal groove often obsolete on the middle. Scutellum distinct. Elytra $2 \frac{1}{2}$ times the length of thorax, very little broader than it is at the base, more than a third broader behind the oblique shoulders, their sides gently rounded as far as the hind thighs, somewhat sinuate just behind these, the declivity much narrowed and almost vertical, with slightly prolonged, thick, divergent apices; dorsum distinctly striate-punctate, third interstices obtusely raised at the base, the fifth only slightly and interruptedly behind, and terminating as a large horizontal nodosity, the nodosity on the third, though smaller, is as large as that on each side of the suture, these are on nearly the same plane as the summit of the declivity, which is darker than the dise; half-way down the pale declivity there is a pair of nodosities, and one at the side just underneath the larger one on the fifth interstice.

Scape setigerous, gently incrassate, reaching the back of the eye; the clongate second joint of funiculus hardly as long as the basal, joints 3-7 obconical, successively shortened; club elongate-oval, triarticulate. Anterior tibiae slightly curved externally, the others flexuous.

Underside fuscous, covered with depressed pale-tawny seales and elongate setae. Prosternum incurved in front. Basal ventral segment broadly rounded betwern the coxale, slightly sinuate behind, rather longer than second, fifth longer than third and fourth together, much narrower, finely punctate.

Fem. - Elytral apices less dehiscent and prolonged, the posterior mordosities not quite as prominent, prosternum more deeply emarginate. $7 \frac{1}{3} \times 3 \mathrm{~mm}$.

Ocular lobes well developed. Posterior corbels with duplicate cilia, the interval narrow. 
The six horizontal nodosities across the nigrescent top of the posterior declivity, and the simple rostrum, differentiate this species.

o. Length (rostrum inclusive), $9 \mathrm{~mm}$. ; breadth, $3 \frac{2}{3} \mathrm{~mm}$.

Karekare, west coast, Auckland; 23rd. February, 1916. Three examples, from Mr. A. E. Brookes, of Mount Albert.

\section{Inophloeus festucae sp. nov.}

Robust, slightly convex, opaque; piceous, tarsi and antennae fuscorufous; densely covered with small depressed, light-coppery or fuscotestaceous squamae and a few short grey setae, on the thorax there are many erect, short, dark setae, elytral nodosities fuscous.

Rostrum a fifth shorter than thorax, moderately dilated in front, with a slight carina along the middle; scrobes quite open above near the apex. Thorax subtruncate at base and apex, very little broader than long, slightly wider near the front than elsewhere; with coarse irregular, wart-like rugae, and a moderately well-marked groove from base to apex. Scutellum indistinct. Elytra suboblong, somewhat incurved and rather wider than thorax at the base, fully a third broader just behind the obliquely narrowed shoulders, very gently narrowed towards the declivity which is obliquely contracted and vertical; they are nearly plane above, moderately seriatepunctate, some of the punctures longer and coarser than the others, the suture slightly elevated at the base and again below the top of the declivity; third interstices also a little elevated at the base, with a small nodosity on top of the declivity, fifth hardly at all raised but terminating a little farther forward than the third, as larger horizontal nodosities.

Basal two joints of funiculus almost equally elongate, third and fourth rather longer than the following ones; club elongate-oval, indistinctly quadriarticulate.

Ocular lobes distinct. Eyes almost flat, widely distant from each other. Tibiae flexuous. Cilia of posterior corbels rather narrowly separated.

Underside thickly covered with depressed tawny-grey scales and elongate setae. Structurally like $I$. sexnodosus; fifth ventral segment simple.

In one example pale spots occur between the elytral punctures.

Length (rostrum inclusive), $10 \frac{1}{2} \mathrm{~mm}$.; breadth, $4 \frac{1}{2} \mathrm{~mm}$.

Stephen Island; 17th September, 1916. Several, found by Mr. A. C. O'Connor feeding on tall fescue and the tops of ngaio (Myoporum) shrubs.

\section{Group Cxlindrorhinidae.}

Phaeophanus Broun. Man. N.Z. Coleopt., p. 792.

\section{Phaeophanus o'connori sp. nov.}

Robust, moderately convex and elongate, opaque; nigrescent, thickly covered with depressed, hair-like, mostly coppery-brown squamae, those along the sides and on the posterior declivity always paler, sometimes whitish, the thorax with a white streak along the centre, legs irregularly spotted with grey.

Rostrum as long as thorax, considerably dilated in front, the broad channel along the middle, which is wider in front than behind, has costiform lateral borders from the antennal insertion to the eves.

Thorax, including the conspicuous ante-median prominence at each side, a fifth broader than long, base and apex subtruncate; with an obtuse carina along the middle, which, however, becomes cosolete behind, the basal half is irregularly uneven but without visible punctation; before the 
middle, inside each of the lateral prominences, there is an clongate obtuse elevation; a few coarser, mostly suberect, darker seales can be seen. Sintellum distinet, usually white. Elytra oblong, 21 times the length of thorax, slightly broader and trisinuate at the base, a third broader near the michle, narrowed but not vertical behind: along the middle of each clytem there is a numerously interrupterl costa which becomes nodiform on top of the declivity, another, usually less distinct, near the side terminates as a larger lateral prominenos a little farther back, there are also many smaller tubercular elevations on the side; the punctation though coarse is shallow and variable, near the base there are some minute black granules.

Seape rather slender, slightly thickened towards the extremity, inserted near the apx and hardly touching the eve; basal two joints of funiculus alout equally olongate, 3-7 rather longer than broad, with ereet ferruginous setae: (lub dull, densely pubescent, ovate, quadriarticulate.

Prosternum deeply emarginate. Basal segment of abdomen obtusely angulate between the coxae, in the middle only a sixth longer than second, their suture sinuate, third and fourth together as long as fifth.

Ocular lobes well developed. Mentum rather small, subcordate, not covering the thick palpi. The thick mandibles bidentate at the lower extremity. Anterior tibiae briefly mucronate.

Length (rostrum inclusive), $23-27 \mathrm{~mm}$. ; breadth, $8-9 \mathrm{~mm}$.

Stephen Island. This fine weevil is named in honour of Mr. A. C. ()'('onnor, who found it on the 15 th September, 1916, feeding on tall fescue and the leaves of trees.

\section{Phaeophanus inornatus sp. nov.}

Elongate, opaque, nigro-fuscous, antennae and tarsi fusco-rufous ; unevenly elothed with small, depressed fusco-testaceous squamae and somes coarser elongate ones.

Rostrum similar to that of $P$. o'connori, the groove along the middle ending in a fovea-like interantennal impression, with about six punctures only. Thorax of equal length and breadth, widest but only obtusely so near the front, base and apex truncate; a little uneven, without visible punctation or granulation, with a pair of obtuse central tubercles, and a less distinet but more elongate clevation near each side a litole fauther forward. Scutellum triangular. Elytra olsong-oval, at the middle a third hroader than the widest part of thorax, hardly any wher than it is at the base, 21 times its length, suhvertical behind. not wholly eovering the hroad

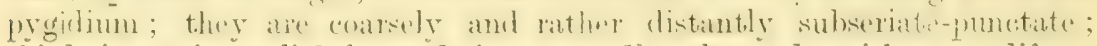
third interstices slightly and interruptedly elevated, with a nodiform elevation on the commencement of the declivity, and again interruptedly

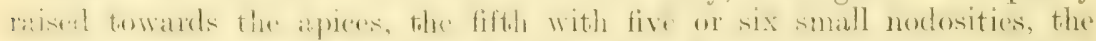
terminal as large as that of the third but placed a little farther back; the sides bear small irregular nodosities.

Underside dull black, more densely squamose than the upper surface. Prosternum deeply incurved. Second ventral segment hardly as long as the basial bute rather longer than the third and fourth combined.

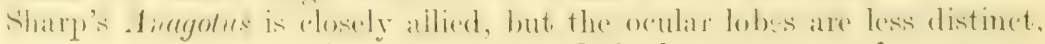
the eyes are more approximated above, and the legs are more elongate.

This species most nearly resembles $P$. migosus. (1414).

Length (rostrum inclusive), $14-16 \mathrm{~mm}$; ; breadth, 5-51 $\mathrm{mm}$.

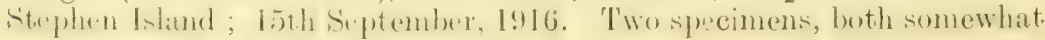
damaged, from Mr. A. C. O'Connor. 
Group HyLobitdae.

Bryocatus Broun. N.Z. Inst. Bull. 1, Part III, p. 218.

\section{Bryocatus niticollis sp. nov.}

Convex, broadest near the shoulders; aeneo-niger, legs piceous, antennae and tarsi dull black; rostrum and thorax more obviously glossy than elytra; sides of thorax with some dull greyish scales, similar ones form a large irregular mark on each elytron from the side, before the middle, towards the suture, ancther extending from the apex as far as the hind thigh has its central portion bare.

Rostrum as long as thorax, a third of its width, moderately arched, apparently smooth, with some grey setae near the extremity. Head rather broader than rostrum, globose underneath, brassy at its sides. Eyes large, obliquely oval, slightly prominent in front. Thorax of equal length and breadth, widest and almost straight from the base to the middle, gently narrowed towards the truncate apex. Scutellum invisible. Elytra subcordate, twice the length of thorax, very gradually narrowed from the shoulders to beyond the hind thighs, more strongly narrowed and deflexed behind, in line with the shoulders they are nearly double the width of the thoracic base, which they seem to overlap; they are finely striate, with plane interstices, but near the base they are more coppery and minutely rugose.

Femora robust; tibiae flexuous, mucronate inwardly, the anterior pair especially, and finely denticulate inwardly, they are nearly covered with grey squamae and dark setas; tarsi with prominent setae. Scape slightly flexuous, funiculus normal, with a few dark setae.

Underside dark castaneous, with obscure greyish squamae. Basal ventral segment depressed along the middle, nearly double the length of second, the suture slightly sinuate but definite, fifth foveate behind.

Not quite as large as $B$. amplus (3612), but more convex, without elytral nodosities, and quite glossy. The sculpture of the thorax consists of small squares; some of these are irregularly angulate, but all are flat and fit neatly together. This minutely tessellate appearance will enable it to be at once separated from every recorded species.

Length (rostrum inclusive), $3 \frac{1}{3} \mathrm{~mm}$.; breadth, $1 \frac{1}{3} \mathrm{~mm}$.

Near Lake Rotoiti, Nelson; 28th December, 1915. One example, from Mr. T. Hall; another, received subsequently, but much mutilated, was mounted on its back.

\section{Bryocatus iridescens sp. nov.}

Subovate, only moderately convex; the elytra, and a streak between the middle and each side of the thorax, covered with flat grey squamae; remainder of thorax and the rostrum nigrescent but beautifully iridescent; elytral interstices with very few depressed dark setae, the legs with grey scales and dark setae, tarsi and funiculus black, with similarly black setae, the scape nearly glabrous and nitid.

Thorax slightly longer than broad, oviform, rather narrower in front than behind, its base oblique towards the sides. Elytra quite cordate, double the length of thorax, a little wider behind the shoulders than elsewhere, the base oblique towards the sides and a fourth broader than that of the thorax; they are finely striate, the suture is depressed at the base but slightly and obtusely elevated as far as the top of the declivity, third and fifth interstices slightly wider than the others and nearly plane; on each elytron, near the declivity, there is an irregular, dark, brightly iridescent spot. 
Underside covered with depressed greyish scales, the bare spots iridesant. Metasternum and hasal abdominal segment broally depressed along the middle, the next segment about half as long. fifth indistinctly foveate behind.

This correspends with $B$. niticollis as regateds sex, structure of antemuar, and length of rostrum; the elytra, however, instead of being nearly double the breadth of the thorax at the base, are only a little broader, and the coloration, below as well as above, is dissimilar.

o. Length (rostrum inclusive), $3 \frac{1}{3} \mathrm{~mm}$. ; breadth, $1 \frac{1}{2} \mathrm{~mm}$.

Buller Terrace, near Rotoiti, Nelson. One, sent by Mr. T. Hall on the 1st. Tuly, 1916.

\section{Bryocatus rugosus sp. nov.}

Oblong, convex, minute, opaque, apparently glabrous; nigro-piceous, tarsi and funicle dull black.

Rostrum as long as thorax, broad, arched, closely and relatively coarsely but not deeply punctate. Thorax subqualrate, slightly constricted in front, about a third broader than long; closely, irregularly, and coarsely punctate-rugose, with a moderate groove along the midale. Elytra just twice the length of thorax, only slightly broader than it is at the base, somewhat broader in line with the hind thighs, narrowed and subvertieal behind; they are rather broadly striate, with the suture as well as the second and fourth interstices more elevated than the others but rather narrow, the surface more or less minutely asperate.

Legs rather coarsely and closely sculptured, with a few dark setae.

Scape short, subclavate; basal joint of funiculus unusually laren about half the whole length, joints 2-t short and subequal; club large, oblongoval.

Underside suboparqu', almost nude; nigrescent, femora faintly iridescent : with rather coarse but ill-defined eoriaceous senlpture. Hetasternum and basal ventral segment broadly depressed along the middle.

This minute, rugosely sculptured species may be easily separated from other exponents of the genus by the defieient fifth and sixth joints of the funiculus; their absence, and the enlargement of the basal one, if similar examples are brought to light, may render generic separation necessary.

o. Length (rostrum inclusive), $1 \frac{1}{2} \mathrm{~mm}$. ; breadth, $\frac{2}{3} \mathrm{~mm}$. Hall.

Buller 'Terrace. Unique. Forwarded on the 1st July, 1916, by Mr. T.

\section{Group Riyparosomida.}

Phrynixus Pascoe. Man. N.Z. Coleopt., p. 432.

\section{Phrynixus conspicuus sp. nov.}

Subovate, moderately elongate, opaque; the derm castaneous and slightly nitid, antennae, tarsi, and apical half of rostrum fusco-rufous;

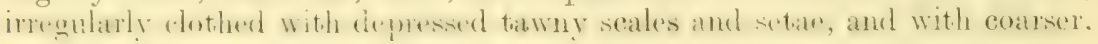
erect, woolly setae which form erests.

Rostrum rather longer than thorax, arched, nearly plane and slightly broaler before the anternate than behind, minutely tricristate on the middle. mone distincely and longitudinally crested towarls the eres. which are flate Thorax oblonis, a fourth longer than broud, its slightly uneven sides a little narrowed anteriorly, base truncate; disc nearly plane, broadly but not

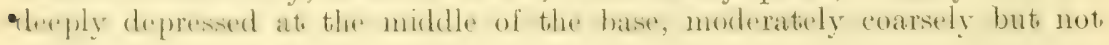


closely punctured, with a few minute dark tubercles near the sides, the apex with a pair of conspicuous woolly crestes. Elytra unevenly oblongoval, a third longer and broaker than thorax, narrowed but not vertical behind, the base emarginate, the woolly crested shoulders though slightly porrect are but little broader than the thoracic base; they are irregularly and rather coarsely seriate-punctate and bear some minute tubercles, the declivity is more fincly striate-punctate : on each plytron, besides indistinct inequalities, there are a subrotundate, lark median nodosity near the suture, a pair of crests on the commencement of the posterior declivity, and a larger and more woolly one at the side a little lower down; there are some other crests on and near the side.

Scape medially inserted, almost touching the thoracis apex, subclavate at extremity; second joint of funiculus elongate, not perceptibly shorter than the basal, joints 3-6 short and subequal, seventh rather larger; club subovate, narrowed towards the base, indistinctly articulate, finely setose. Legs normal, the tibiae coarsely tufted.

Underside castaneous, sparingly setigerous. Abdomen apparently impunctate, its second segment rather longer than the first, its frontal suture depressed and obtusely anculate at the middle, fifth much paler, longer than third and fourth united.

The form and sculpture of the thorax render it easily separable from 1508,4081 , and other near allies.

Length (rostrum inclusive), $7 \mathrm{~mm}$. ; breadth, $2 \frac{2}{3} \mathrm{~mm}$.

Mount. St. Arnaud, south of Lake Rotoiti, Nelson. A single individual, captured by Mr. 'T. Hall ; 15th June, 1916.

\section{Phrynixus blandus sp. nov.}

Elongate, subovate, only slightly convex, subopaque; fusco-rufous, rostrum rufo-piceous; irregularly covered with depressed, light ferruginous squamiform setae, those along the midrlle of the elytra disposed in three slightly interrupted broad streaks nearly to the top of the posterior declivity, which bears a series of six horizontal tufts, and below these a transverse row of smaller ones; towards the outside of each elvtron there are about five suboviform patches, and a pair of elongate basal ones.

Rostrum finely carinate along the middle, quite as long as thorax, arched, moderately slender, its frontal portion very gradually and slightly expanded, nearly nude and finely punctate at the apex. Thorax suboblong. only a trifle longer than broad, very little contracted in front, slightly narrowed behind, base and apex truncate; with a few small granules, moderately coarsely and closely punctate, with a rather deep impression at the hase; the setae mostly irregular, but forming a central streak before the middle and an oblique one from each hind angle to the apex. Elytra elongate-subovate, bate slightly incurved, shoulders obtucely and indistinctly porrect and only slightly broader than the base of thorax, more than double its length, a third broader near the middle, distinctly narrowed but not vertical behind, where they are punctate-striate; dorsum substriate and apparently punctate near the suture as seen from above, but appearing seriate-granulate when examined sideways. Lrgs with curled setae; posterior tibiae moderately mucronate.

Scape medially inserted and attaining the back of the eye, moderately slender and flexuous, wradually subclavate, with depressed sctae: funiculus with a few erect setae, second joint longer than the basal, 3-6 short, 
seventh lareer, subquadrate; club short, ovate, with small apical articulations.

Underside fuscous, abdomen more or less rufescent, with numerous depreseed yellowish setate: moderately coarsely but not closely punctured. Intasternum and abdomen on almost the same plane thromghout, the segments like those of $P$. conspicuus.

This comes near the northern $P$. longulus (3128), but the legs are less elongate, the elytra are not deeply bisinuate at the base and are less vertical behind, \&e. In both species the ryes are nearly flat, just fres from the thoracic apex, and rather more approximated than in the trpe of the genus, 759 .

Length (rostrum inclusive), $5 \mathrm{~mm}$.; breadth, nearly $2 \mathrm{~mm}$.

Mount Owen. One, found by Mr. T. Hall on the 27th December, 1914.

\section{Bradypatae Broun. Man. N.Z. Coleopt., p. 1206.}

\section{Bradypatae subnodifer sp. nov.}

Subopaque, fuscous, the rostrum, antennae, tarsi, thoracic disc, and indistinct elytral nodosities rufeseent; irregularly clothed, almost spotted, with yellow, decumbent, and rather longer suberect setae.

Rostrum arched, equalling the thorax in length, finely carinate along the middle, slightly expanded and finely seulptured in front, biseriatepunctate behind. Head small, half the width of thorax above, globose underneath. Thorax of the same length and breadth, abruptly contracted in front, apex emarginate, gradually narrowed behind, base truncate; coarsely and closely punctured, more finely in front; the coarser setae irregularly concentrated in front and along the sides and forming three crests across the middle, the centre of the base a little depressed. Elytra oviform, almost double the length of thorax, fully a third broader at the middle, hardly any broader than it is at the base, narrowed and subvertical behind; seutellar depressed and smooth, with raised setigerous lateral borders; they are rather indefinitely and irregularly striate-punctate, more distinctly striate behind; the setae form several very small tufts along the middle and six across the summit of the posterior declivity; near the outer side of each elytron there are about six reddish, rather small, setigerous nodules.

Legs setose, tibiae slightly curvate externally, briefly mucronate.

Scape implanted before the middle, reaching the back of the eye, flexuous, subclavate at apex, without erect setae; second joint of funiculus quite as long as the basal, joints 3-6 short and subequal, seventh distinctly longer and broader; club ovate, obsoletely articulated.

Undersidr fuscous, with depressed flaveseent setae. Prosternum deeply "marginate, the prominent contiguous coxae situated nearer the base than in my reversed speceimen of $B$. capitalis (1512), and the intermediate coxae are more widely separated. Second ventral segment rather longer than the basal, with a few rather fine irregular punctures, its frontal suture quite definite and angulate in the middle, the basal not depressed along the middle, not rugose, and not as coarsely punctured as that of 1512 ; the fifth is nearly double the length of third and fourth together, broadly impressed behind and thickly hairy. The head above is not distinctly constricted behind the flat eres, the elytra are without distinct granules, and their interstices are not subcarinate as in 1512

Length (rostrum inclusive), $4 \frac{1}{2} \mathrm{~mm}$. ; breadth, $1 \frac{2}{3} \mathrm{~mm}$. Hall.

Kiwi Bush, near Glenhope, Nelson; 4th May, 1915. Found by Mr. T. 


\section{Bradypatae impressum sp. nov.}

Subopaque, the rostrum, antennat, thorax, and rows of elytrul punctures, or granules, rufescent, the rest fuscous; irregularly clothed with flavescent setae, the thoracic erests nearly similar to those of $B$. subnodifer.

Rostrum nearly smooth in front, bisulcate, subcarinate, and with lines of fine setae brhind. Head short and narrow, slightly constricted bebind the eyes, with an obtuse crest between these. Thorax of about equal length and brearlth, base and apex truncate, moderately contracted in front, somewhat rounded and widest near the front, gradually narrowed behind the middle; its surface uneven, having before the middle a pair of almost smooth depressions, and one at each side near the front, the basal impression is shallow, the punctation of the hinder portion close and moderately coarse. Elytra oviform, twice the length of thorax, a third broader in the middle, of almost the same width as it is at the base; vertical and punetate-striate behind; the dorsum with ill-defined sculpture, appearing seriate-punctate as seen from above, granular when examined sirleways, scutellar depression with elevated and finely setose lateral borders. there are no distinct nodules towards the sides; the six small tufts across the top of the posterice declivity are horizontal, there are two rather larger subrotundate lateral crests on each elytron, one in line with the six inner ones, the other lower down, and there are a few others between the base and hind thighs.

Antennae like those of $B$. subnodifer but with the club rather larger, broader before the middle, and indistinctly biarticulate at the apex.

Differentiated from $B$. subnodifer by the rather shorter rostrum, more anteriorly constricted head, the almost smooth thoracic impressions, the absence of rufescent elytral rodules, and by the hind declivity being more perpendicular.

Basal ventral segment flat, second slightly convex, both almost impunctate; fifth subtruncate behind, its median depression subcristate at its sides; the sixth short, broadly curved behind. Intermediate coxae less widely separated than those of $B$. subnodifer.

o. Length (rostrum inclusive), $3 \frac{2}{3} \mathrm{~mm}$. ; breadth, $1 \frac{1}{2} \mathrm{~mm}$.

Mount Slips, near Rotoiti, Nelson. Unique: Found by Mr. T. Hall on the 29th December, 1915, amongst decaying leaves.

\section{Araeoscapus Broun. Ann. Mag. Nat. Hist., ser. 6, vol. 12, p. 299.}

\section{Araeoscapus subcostatus sp. nov.}

Opaque, moderately convex, medially narrowed; nigro-fuscous, antemnat and tarsi dark fusco-rufous; sparingly and irregularly clothed with flavescent, decumbent, and suberect curled setae, these lattir almost form crests.

Rostrum arched, as long as thorax, broader before the antennal insertion than behind, which is slightly tricarinate and coarsely punctate, its apical portion somewhat flattened and nearly bare. Head shert, narrowed anterionly. Eyes just frep from thorax, laterat, small, subrotumelate, only slightly convex. Thorax of about equal length and breadth, base subtruncate, rather wider before the middle than elsewhere, more gradually narrowed bebind than in front; disc a little uneven, integularly and coarsely punctured and with some minute tubereles, and indistinctly triosstate natr the middle. Elytra wiform, truneate and rery slightly broter than thorax at the base, more than twice its length, fully a third broader near the midde, considerably narrowed and curvedly deflexed behind: 
on each elytron there are two inner series, about five in each, of oblong punctures, the other series are interrupted by minute tubercles and erests ; third interstices thickly elevated and setigerous at the base, interruptedly and much less obviously behind, scutchlar region depressed; across the top of the posterior declivity there are usua!ly six minute horizontal tufts, a lateral, more nodiform and prominent one in line with these and a similarly setigerous one just below it; towards each side of the basil half the surface is meven and setigerous, the declivity is substriate-punctate.

Legs moderately stout and elongate, with decumbent setae only ; tibiae nearly straight, mucronate.

Scape inserted between the middle and apex, flexuous, gradually subclavate, extending to the middle of eye ; basal joint of funiculus thicher but hardly longer than the next, joints 3-6 transverse, seventh distinctly larger; club subovate, not elongate, its apical joints very small.

Fem.-Underside piceo-fuscous, with a few fine greyish setae. Abdomen almost quite smooth, second segment longer and flatter than the basal, its frontal suture obtusely angulate in the middle, fifth longer than third and fourth together, with a minute apical fovea. The mentum and submentum subquadrate and about equal. Palpi uncovered. Rostrum rather' longer, more slender and subparallel.

Male.-Metasternum and basal ventral segment broadly depressed in the middle, fifth minutely granulate, and with a broad apical depression.

The nearest species is $A$. ocularius (3603).

Length (rostrum inclusive), $4 \mathrm{~mm}$; breadth, $1 \frac{1}{2} \mathrm{~mm}$.

Glenhope, Nelson; 20th December, 1914. Mr. T. Hall found about eight specimens altogether, a few of which were caught on Mount Slips and adjacent localities.

Dermotrichus Sharp. Man. N.Z. Coleopt., p. 1205.

\section{Dermotrichus vicinus sp. nov.}

Opaque, elongate-subovate, slightly convex; fuscous, rostrum and thorax more rufescent, antennae and tarsi infuscate-red; thinly covered with short, depressed, flavescent squamiform setae, and coarser suberect ones which form crests.

Rostrum as long as thorax, arched, subnitid, nude, finely punctate, and moderately expanded in front. obtusely bicarinate along the middle behind the antennae and with another carina at each side, the intervals with small squamae. Eyes just free, small, subrotundate, with a pair of minute crests between them. Thorax slightly broader than long, a little wider before the middle than elsewhere, narrower in front than behind; slightly uneven, basal impression not deep, its punctation moderately coarse but shallow and distant, the front almost smooth; the coarser setae form a pair of small apical crests, and three just before the middle. Elytra oviform, curvedly deflexed and attenuat: behind, 2.1 times the length of thorax, a third broader at the middle, of the same width as it is at the base, which is subtruncate; they are obsoletely seriate-punctate, substriate behind; the suberect coarse setar are congregated in patehes, of which there are three near each shoulder, eight or ten form an interrupted transverse series behind the middle, the series farther back is nearly absent across the middle but prominent at the sides, and there are two series near the extremity alongside the suture.

Leegs with depressed scale-like setae; posterior tibiae more obviously acuminate than in the female. 
Scape slender and flexuous but subclavate towards the extremity, inserted quite before the middle and reaching the centre of the eye; basal joint of funiculus rather thicker but not longer than the next, joints 3-6 short and indistinctly separated, seventh larger, subquadrate; club subpyriform, considerably narrowed towards the base, obsoletely articulated.

Underside dull dark fuscous, with a few fine setae, metasternum coarsely punctate; abdomen almost smooth, basal segment slightly raised and truncate between the coxae and with some coarse short rugae near its base, second evidently larger, its frontal suture distinct and obtusely angulate at the middle, fifth nearly double the length of third and fourth together, transversely depressed near the broadly rounded apex.

Fem.-Thorax not broader than long, rostrum equalling it in length, longer and more parallel than that of the male.

There can be no doubt that this is distinct from Sharp's $D$. mundulus (2133), the thorax not being longer than broad, the foremost elytral fascia is placed behind the middle, and, moreover, the thorax and elytra of 2133 seem to be impunctate.

o. Length (rostrum inclusive), $4-4 \frac{1}{2} \mathrm{~mm}$; ; breadth, quite $1 \frac{1}{2} \mathrm{~mm}$.

Mount St. Arnaud, Nelson; elevation, 5,000 ft. Two males and a female, found amongst leaf-mould on the 15th June, 1916, and two or three others near Lake Rotoiti.

\section{Dermotrichus curvirostris sp. nov.}

Subovate, moderately convex, opaque ; fuscous, the rostrum, antennae, and tarsi fusco-rufous, middle of femora fulvescent; irregularly clothed with subdepressed, short, flavescent setae, which on the elytra form longitudinally disposed crests.

Rostrum rather longer than thorax, strongly arched, almost bare and finely punctate in front, indistinctly tricarinate just behind the antennae and with a nodule between these and the eyes, this in fresh unabraded individuals probably forms a crest. Head short; eyes small and subrotundate. Thorax nearly a third longer than broad, subovate, more gradually narrowed behind than in front; a little uneven, the basal depression not deep, its punctation coarse, shallow, and irregular, with uneven, indistinctly granular intervals; it is bicristate in front, tricristate across the middle, none of the tufts are very conspicuous. Elytra subovate, nearly $2 \frac{1}{2}$ times the length of thorax, very slightly broader than it is at the base, almost double that width near the hind thighs, considerably narrowed, subvertical, and quite striate behind; dorsum indefinitely punctate, but with series of small granules, scutellar depression with a ridge of concentrated setae at each side, and another just behind but outside each of these, across the top of the posterior declivity there are seven crests, the outer ones the largest, there is another small one nearly in line with these on the outside of each elytron, and another just below and as large as the outermost of the transverse series, besides several small ones towards the extremity.

Legs elongate, the middle and hind tibiae very distinctly mucronate.

Scape medially inserted, flexuous, subclavate at the extremity; basal joint of funiculus hardly as long as the second, the others gradually dilated but very indefinite, so that there may be only five or six instead of seven joints ; club ovate, narrow at its base.

Underside fuscous, with short yellowish setae, fifth segment reddish; second segment rather longer than the basal, its frontal suture obtusely 
anculate and depressed, fifth transversely impressed and broadly rounded behind, sixth short.

The rather small flat eyes, more strongly arched rostrum, more indefinitely articulated funiculus, less squamiform vestiture, different seulpture, more acutely prominent tibial spurs, and fulvescent femoral bands distinguish this from Sharp's D. mundulus (2133) and D. vicinus.

Length (rostrum exclusive), $3 \mathrm{~mm}$. ; breadth, $1 \frac{2}{3} \mathrm{~mm}$.

Wadestown, near Wellington. One individual, from Mr. A. C. O'Connor.

Astyplus Broun. Man. N.Z. Coleopt., p. 1209.

\section{Astyplus brevicornis sp. nov.}

Cuneiform, opaque; nigro-fuscous, antennae and tarsi fusco-rufous ; thinly clothed along the middle with depressed tawny setae, but the sides of the thorax from the base to beyond the middle are covered with coarse, somewhat infuscate cilia, these are prolonged to the apex as pale crests which project over the head but do not extend to the sides, a similar fringe covers the side of each elytron from the base towards the middle and again behind the posterior femur.

Rostrum strongly arched, a fourth shorter than thorax, nearly flat, finely punctured, and rather broader in front than behind, with a pair of interantennal crests, these are continued backwards, become convergent, and form a single ridge near the eyes; on each side between the scrobe and the eye there is a short ridge. Thorax truncate at the base, slightly longer than broad, rather narrower in front than behind; dise almost flat; but appearing a little uneven owing to the coarse punctation and short irregular rugae. Elytra truncate at the base but with obliquely porrect shoulders, a third longer than thorax, a third broader at the top of the vertical posterior declivity; on each elytron there are three series of coarse subquadrate punctiform impressions, the declivity is more finely substriatepunctate, there are also a few minute tubercles; third interstices slightly raised and crested on top of the declivity, there is another crest outside, the suture also is crested, and there is a pair of small nodosities on crests in line with the hind thighs. Legs with tufts of coarse setae.

Basal two joints of funiculus moderately and equally elongate, 2-6 short and subequal, seventh evidently longer than broad; club ovate, apparently undivided.

Underside with a few fulvescent setae, the basal and terminal ventral segments redelish, the rest dark. Basal segment impunctate, second nearly as long, depressed and subangulate at the middle in front, fifth subtruneate and finely punctured behind. The rufescent palpi exposed in front of the mentum.

Smaller than A. conicus (2137), the rostrum and antennae obviously shorter and stouter, basial two joint of funiculus shorter, the thorax less depressed at the base, \&c.

Length (rostrum inclusive), $7 \frac{1}{2} \mathrm{~mm}$.; breadth, $3 \mathrm{~mm}$.

Mount Slips, near Lake Rotoiti. Nelsom. A single speecimen of this curious weevil was found by Mr. 'T' Hall on the 29th December, 1915, at a height of about $2,700 \mathrm{ft}$.

\section{Halliella Broun. N.Z. Inst. Bull. 1, Part V, p. 424.}

4219. Halliella cuneata sp. nov.

Elongate, subcuneiform, nearly plane yet a little uneven above, opaque; fuscous, antennae and tarsi fusco-rufous; irregularly clothed with tawny 
scale-like matter and, along the middle, with very slender hairs, the setae near the sides and on the legs more distinct, erect, and infuscate, some longer and paler ones form four horizontal tufts on the summit of the posterior declivity, and usually a lateral one just before it.

Rostrum arched, as long as the thorax, only slightly broader but flatter . before the antennal insertion than behind, which, though convex, is not definitely carinate, its apex nude. Thorax oblong, but only slightly longer than broad, a little broader near the front than behind, somewhat narrower at the apex; disc irregularly moderately coarsely but not very closely punctate, flattened or subdepressed at the base, there is a pair of small apical crests, one before the middle, and another but less distinct one at each side in front. Elytra widest near the posterior declivity, gradually narrowed so as to be hardly any broader than the thorax at the base, which is subtruncate, the shoulders being only very slightly prominent, the scutellar region is depressed, ther are almost double the length of the thorax, vertical and narrowed behind; they are coarsely substriate-punctate, more evidently striate behind; there is a short elevation on each side of the scutellar region, and another but not very obvious one extends from the shoulder as far as the hind thigh, the external crests on top of the declivity are a little larger and lower than the inner pair; some minute tubercles are discernible.

Scape inserted before the middle and reaching the thoracic apex, flexuous, rather slender, gradually incrassate, with a few outstanding setae; second joint of funiculus quite as long as the basal, joints 3-6 short and subequal, seventh very little larger; club indistinctly triarticulate, ovate.

Underside dull fuscous, with some fulvescent short setae. Abdomen coarsely but not deeply punctate, its second segment rather shorter than the basal, its indistinct frontal suture rounded in the middle, fifth rufescent, more finely and closely punctured, without any definite impression.

On comparison with $H$. longicollis (3902) this is seen to be smaller and more cuneiform, the rostrum and antennae are more slender, the punctation is not as coarse or close, in some aspects the thoracic sculpture appears finely verrucose. The mentum is strongly transverse in front and does not reach the apex, its basal portion is larger. In the type of Halliella (3900) the quadrate frontal portion of the mentum almost attains the apex, the palpi project, so as to be visible from above, and the middle coxae are not as widely separated. These discrepant details almost justify the creation of a distinct genus for this species.

o. Length (rostrum inclusive), $5 \frac{1}{3} \mathrm{~mm}$. ; breadth, $1 \frac{3}{4} \mathrm{~mm}$.

Near Lake Rotoiti, Nelson; 19th May, 1916. A second specimen, caught on Mount St. Arnaud, at a height of $5,000 \mathrm{ft}$., on the 15 th June, 1916, also by Mr. T. Hall, measures $7 \times 2 \frac{1}{4} \mathrm{~mm}$.; in it the fifth ventral segment has a longitudinal impression, the vestiture is more fulvescent, and the thorax seems to be free from wart-like inequalities. It is the female of this species, I believe, so far as I can judge at present.

Clypeorhynchus Sharp. Man. N.Z. Coleopt., p. 1210.

\section{Clypeorhynchus tenuiculus sp. nov.}

Elongate, moderately convex, opaque; fuseous, legs and scape fuscorufous, tarsi and funiculus paler; sparingly clothed with decumbent flavescent setae.

Rostrum arched, almost as long as thorax, slightly nitid, rufescent. finely punctate and dilated in front, with a slender carina along the middle 
behind. Head narrowed anteriorly, its punctation moderately coarse but shallow; there is an elongate impression between the nearly flat eyes. 'Thorax a little longer than broad, truncate at base and apex, slightly broader near the front than behind, the sides very gradually narrowed backwards, more distinctly in front; dise coarsely and irregularly punetured, with narrow rugose intervals, its central chamel modelate, a little deeper near the apex than elsewhere. Scutellum invisible. Elytra clongatecordate, twice the length of thorax, very slightly wider at the base than it is, gradually narrowed and curvedly deflexed posteriorly: their striar are shallow and broad but not very definite, and apparently impunctate; second interstices a little elevated near the base, third rather farther batek. all are more or less minutely asperate or uneven.

Scape with a few pale setae, very gently incrassate, almost touching the thoracie apex; basal two joints of the funcle moderately and equally elongate but, together, barely half the length of the scape, $3-7$ successively shortened; club moderately elongate, triarticulate.

Tibiae flexuous, the anterior slightly mucronate, the others indistinctly so.

Underside nitid, piceo-rufous, with some depressed grey setae. Metasternum and first ventral segment obviously depressed, distinctly and moderately coarsely punctate; second shorter than first, their suture sinuate, fifth nearly double the length of third and fourth combined, truncate at apex, punctate and coarsely transversely rugose; sixth short and broad, more finely but longitudinally rugose.

The rostral carina, antennal structure, peculiar ventral sculpture, and the slight tibial mucro, even of the anterior, in the male, are its principal characters. The setae are not concentrated in patches on the elytra as is the case in the type of the genus, C. gracilipes (2138), and its close allies: and in the sole example before me the setae are just a little closer near the sides than on the dise.

o. Length (rostrum exclusive), $5 \mathrm{~mm}$.; breadth, $1 \frac{3}{4} \mathrm{~mm}$.

Upper Hutt. One, from Mr. A. C. O'Connor, on 21st August, 1916.

\section{Clypeorhynchus furvus sp. nov.}

Subopaque, moderately elongate and convex; fuscous, antennae and last two joints of tarsi pale fusco-rufous: sparingly and irregularty clothed with flavescent, suberect, scale-like setae.

Rostrum a third shorter than thorax, dilated before the middle, deflexed and almost smooth in front, finely tricarinate behind. Head short. boadly impressed between the subrotundate, nearly flat eyes. Thorax of equal length and breadth, only slightly wider before the middle than behind, apex truncate, base feebly curved; its punctation coarse, with slightly rusose interstiess, discal chamed moderately deep in front and hehind. Sintellum obsolete. Elytra oblome-oval, narrowed and subvertical hehind. just double the length of thorax, very little broader than it is at the base, nearly a third broader before the middle; they are indefinitely striate, when examined sideways they appear to be formed of small granular asperities; second interstices slightly obtusely elevated at the base; the yellow setae are very unevenly distributed, with a tendency to form small patehes, behind particularly; posterior declivity without discernible sculpture.

Scape finely setose; basal joint of funiculus fully a third the length of

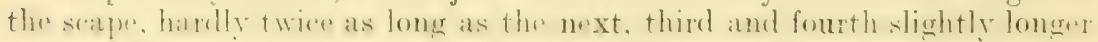


than broad, 5-7 shorter and moniliform; club clongate-oval, indestinctly quadriarticulate.

Legs moderately elongate, tibiae slightly mucronate.

Underside nigrescent, with straw-coloured setae. Prosternum moderate]y emarginate, coarsely and closely punctate, coxar cquidistant from front to rear. Metasternum short, medially depressed. Basal segnent truncate and depressed between the widely distant coxae, apjarently longer than second, their suture indistinct, third and fourth only moderately abbreviated, together as long as the fifth, which is grooved along the middle.

Var.-21st August, 1916. $3 \frac{1}{2} \times 1 \frac{1}{3} \mathrm{~mm}$. Head and rostrum with coarse shallow punctures, elytra irregularly seriate-punctate, most of the punctures oblong.

Length (rostrum inclusive), $4 \mathrm{~mm}$. ; breadth, $1 \frac{1}{2} \mathrm{~mm}$.

Titabi Bay, Wellington. One, sent by Mr. A. C. O'Connor on the 10th August, 1916.

\section{Inososgenes Broun. N.Z. Inst. Bull. 1, Part V, p. 439.}

\section{Inososgenes acerbus $\mathrm{sp}$. nov.}

Elongate, morlerutely convex, subopaque; nigro-fuscous, antennae and tarsi fusco-rufous; very scantily clothed with short, suberect, obscurely fulvescent setae.

Rostrum as long as thorax, only slightly arched, parallel, finely punctate and piceo-rufous in front of the antennae, relatively coarsely punctured and moderately distinctly tricarinate behind them. Thorax scarcely longer than broad, slightly widened before the middle, gradually narrowed behind, somewhat contracted in front, base and apex truncate; coarsoly and closely: punctate, more finely in front, with a mesial depression at its base. Scutellum absent. Elytra almost oblong-cval, double the length of thorax: slightly wider than it is at the base, a little oblique towards the shoulders, a third broader near the middle, gradually narrowed behind; their coarse subseriate punctation rendered irregular by small rugae or granules, liut substriate along the posterior declivity; third interstices subrarinate, fifth less so, on each elytron there is a basal depression between these, and a scutellar one.

Scape inserted near the apex, hardly reaching the eye, slightly flexuots. gradually incrassate; funiculus finely setose, basal joint thicker and rather longer than second, joints 3-7 transwerse, gradually expanded; club ovate: indistinctly articulate, finely pubescent.

Legs elongate, femora simple, tibiae uncinate, tarci rather narrow, their penultimate joint excavate above, emarginate at apex but not divided ninderneath.

Underside slightly nitid, blackish, coarerly punctate. with a fow fulvecent setae. Prosternal depression broad, without hind margins. not extending berond the coxae. Posterior coxar more widely sepurated than the intermediate. Metasternum short. Basal abdominal sement widely truncate brewen the coxae, second sliglitly shorter, its fromtal suture apparently straight but very fine, third and fourth very short, with deep straight sutures.

This cannot be placed in Sosgenes (Man. N.Z ('oleropt., p. 1476). which has the frontal portion of the rostrum distinctly marked off as in Clypeorhynchus (Man. N.Z. Coleopt., p. 1210); but as it accords better with 
Inesosgemes it is platerel in it, but in this speeces the serobes are hardly visible above.

Length (rostrum inclusive), $3 \frac{1}{2} \mathrm{~mm}$. ; breadth, $1 \frac{2}{3} \mathrm{~mm}$.

Warlestown, near Wellington. A single speeimen, sent by Mr. A. C. O'Connor on the 10th August, 1916.

\section{Group Erirhinidat.}

Dorytomus Germar. Man. N.Z. Coleopt., p. 453.

\section{Dorytomus australis sp. nov.}

Subovate-oblong, moderately convex, suhopaque; thinly clothed with sender greyish hairs, the lytra with series of erect, rather coarser, yellowish, erey setae; body mostly testaceous, but with a streak along the middle of thor:tx, a pair of spots in line with the hind thighs, and a smaller pair just bulow the summit of posterior slope dark fuscous, base of elytra and thorax slightly infuscate, rostrum and antennae fulvescent.

Rostrum fully a third longer than thorax, parallel, arched, rather slender, punctate behind the antennae, feebly carinate along the middle. Thorax a third broader than long, its sides moderately rounded, more obviously narrowed in front than behind, base and apex truncate, without perceptible ocular lobes; distinctly punctured, less closely along the middle, the intervals minutely sculptured, pubescence yellowish, coarser near the sides. Seutellum suboblong, fuscous. Elytra oblong, gradually narrowed behind, broader than thorax at the base, quite thrice its length; their shallow, rather closely punctate striae become deeper behind, the fourth and fifth interstices end abruptly so that there appears to be a depression on each elytron behind them. Femora angulate and subdentate.

Scape moderately slender, implanted just before the middle and reaching the eve; basal joint of funiculus thicker and longer than the elongate second, third oblong, fourth shorter, 5-7 transversely moniliform; club oblongoval, triarticulate.

Underside light castaneous, with slender grey hairs. Metasternum grooved along the middle. Second ventral segment shorter than the basal, rather flat across the middle, its frontal suture slightly sinuate, third and fourth as distinctly punctured as the fifth.

The fuscous marks and seriate setae are distinctive.

Length (rostrum inclusive), $3 \frac{1}{3} \mathrm{~mm}$. ; breadth, $1 \frac{1}{4} \mathrm{~mm}$. Howes.

Dunedin. One, sent by Mr. A. C. O'Connor, found by Mr. W. G.

\section{Simachus Broun. Man. N.Z. Coleopt., p. 963.}

4224. Simachus placens sp. nov.

Suboblong-oval, moderately convex, subnitid; antennae, tibiae, and elvtra fulvescent; these last with a large basal spot not extending to the sides, the suture and apieal portion, and an elongate spot just behind each of the posterior femora, and all the thorax, more or less rufo-fuscous; the rostrum and femora of a lighter hue; pubescence yellowish, rather more slender and elongate, and disposed transversely on the thorax.

Rostrum a fourth longer than thorax, arched, parallel, moderately slender, substriate-punctate. Thorax a third broader than long, moderately rounded and widest before the middle, base and apex straight, without ocular lobes; distinctly and closely punctate. Seutellum suboblong. 
Elytra evidently broader than thorax at the base, nearly thrice its length, gradually narrowed behind the posterior femora, with broad apices; distinctly punctate-striate, the striae rather deeper behind.

Scape slender, somewhat thickened near the extremity, inserted hefore the middle and just reaching the eye ; basal joint of funiculus stoutre than the next and twice its length; third and fourth moniliform, only slightly longer than broad, sixth rather broader than fifth; chu oblong-oval, triarticulate.

Femora edentate but clavate; anterior tibiae feebly mucronate, the posterior rather more inwardly curved than the others; claws strongly dentate.

Underside fusco-rufous, abdomen lighter, distinctly punctate, with grey pubescence. Prosternum emarginate. Basal ventral segment rather longer than second, their suture slightly sinuate; third and fourth together rather longer than second, with straight sutures.

The most prettily marked member of the genus.

Length (rostrum inclusive), $2 \frac{3}{4} \mathrm{~mm}$. ; breadth, $1 \mathrm{~mm}$.

Rotoiti, Nelson; 26th July, 1916. One, discovered by Mr. T. Hell.

Eugnomus Schoenherr. Man. N.Z. Coleopt., p. 458.

\section{Eugnomus albisetosus $\mathrm{sp}$. nov.}

Subopaque, moderately elongate and convex; thinly covered with decumbent white setae; rostrum nigrescent, its apex and the thorax dark rufous; tibiae, elytra, and scape chestnut-red ; funiculus and femora more or less infuscate.

Rostrum slightly arched, rather longer than thorax, a little dilated in front, finely punctate. Head unimpressed. Eyes moderately prominent, widely separated. Thorax a third broader than long, its sides moderately rounded, considerably constricted in front, distinctly and very closely punctured. Scutellum oblong, closely punctate. Elytra oblong, broader than thorax at the base, thrice its length, rounded behind ; punctate-striatex, interstices finely rugose.

Anterior femora subclavate, the posterior strongly angulate and dentate underneath, the intermediate less so.

Scape slender, very gently thickened towards the extremity; basal joint of funiculus stouter and slightly longer than second, joints 3-7 diminish; club very elongate, indistinctly quadriarticulate.

Underside with depressed grey setae; breast picenus, abdomen rufescent.

The short, anteriorly contracted thorax, white vestiture, and elongate club are good distinguishing characters.

Length (rostrum inclusive), $4 \frac{1}{2} \mathrm{~mm}$. ; breadth, $1 \frac{1}{2} \mathrm{~mm}$.

Buld Peak, near Lake Wakitipu. One, found by Mr. H. Thanilton, of the Dominion Nuseum.

Caenophanus Broun. Man. N.Z. Coleopt., p. 796.

4226. Caenophanus carbonarius sp. nov.

Elongate, subovate, slightly comvex, suboparque : "vonly but not densedy clothed with depressed, rather short and slender greyish, and many crest, usually darker, but not conspicuous setae; nigrescent, the knees, tarsi, and parts of the antennae piceo-rufous.

Rostrum but little arched, subparallel, rather shorter than thorax, indistinetly tricarinate, with a longitudinal interantemal impression, more 
fincly and irregularly punctured in front than behind. Head broader than rostrum, as long as broad, distinctly punctate. Eves moderately prominent, quite as distant from the thorax as from each other, longitudinally oval. Thorax seareely longer than broad, constricted in front, its sides nearly straight behind, the punctation close and moderately coarse. Scutellum elongate. Elytiat oblong-oval, thrice the lengtih and double the breadth of thorax; striate-punctate near the suture, less striate towards the sides; interstices nearly plane, irregularly and minutely punetured. Pygidium somewhat exposed.

Scape inserted between the middle and apex, barely reaching the back of the ere, slender, cradually incrassate, very finely setose; funienlus more distinetly setign rous, basal joint much stouter but not longer than the elongate second, joints $3-6$ gradually decrease in length, seventh subrotundate; elub indistinctly quadriarticulate, clongate.

Underside blackish, with slender depressed grey hairs. Metasternum transversely strigose. Abdomen finely punctate, basal segment largest, obtusely angulate in front, its hind suture slightly sinuate, with a shallow central depression, fifth rather longer than third or fourth, sixth short and broad.

๙. Length (rostrum inclusive), $5 \mathrm{~mm}$; ; breadth, $1 \frac{2}{3} \mathrm{~mm}$.

Mount Hutt, Canterbury. Two, one broken, from Mr. T. Hall; 27 th February, 1912.

Obs.-A specimen sent to the late F. P. Pascoe about thirty years ago was returned to me labelled "Cyttalia griseipila," under which name I retained it. Many years afterwards, having obtained a copy of Pascoe's papers on the Australian ('uculionidae, I thought there must be some error, so I forwarded a specimen to the British Museum for comparison with Pascoe's types. Mr. G. Arrow kindly informed me that it did not belong to Cyflalia, and that it was unknown there, so this species, similar to but smaller than the one first sent to London, is now placed in my genus Caenophanus.

\section{Group Cryptorhynchidae.}

Mesoreda Broun. Man. N.Z. Coleopt., p. 1235.

\section{Mesoreda laminata sp. nov.}

Convex, oblong-oval, opaque; piceous, antennae and tarsi piceo-rufous ; covered with depressed, tawny-grey and blackish squamae, and short erect, mostly nigrescent setae; the dark scales form irregular spots on elytra.

Rostrum a third shorter than thorax, stout, rather finely punctate, a little narrowed behind, so that the scrobes are quite visible above. Eyes more distant from each other than from the thorax, large, nearly flat, subtruncate in front, rounded behind. Thorax a fourth broader than long, widest and hisinuate at the base. curvedly narrowed anteriorly, somewhat but not abruptly contracted and slightly depressed in front; closely but not coarsely punctate. Scutellum nearly oval. Elytra trisinuate at base, slighty wider than thorax there, quite twice its length, moderately narrowed but not vertical behind; rather finely striate-punctate, third interstices slightly and obtusely elevated.

Seape straight, moderately stout, nearly glabrous, inserted before the middle and reaching the front of the eye; basal two joints of funiculus of about expal length, first slightly stouter, both obconical; 3-7 transversal; club elongate, indistinctly quadriarticulate. 
Legs with coarse greyish setae, tibiae uncinate, the anterior longest, intermediate with a dentiform projection above the middle and another at the outer extremity.

Underside nitid, dark fuscous, closely punctured, with coarse depressed grey setae. Mesosternal lamina subquadrate, feebly emarginate in front. Metasternum moderate, with a median depression behind. Basal segment broadly rounded between the widely distant coxae, not double the length of second, slightly sinuate behind, third and fourth together as long as second or fifth. Palpi fully exposed.

In Oreda the lateral dilatation of the rostrum, behind the middle, alniost conceals the scrobes from above. This species resembles $M$. setigera (865), but is more oviform, with more slender antennae, and can be at once separated by the mesosternal lamina.

Length (rostrum exclusive), $5 \frac{1}{3} \mathrm{~mm}$. ; breadth, $2 \frac{1}{2} \mathrm{~mm}$.

Wellington; 21st August, 1916. My specimen is another of Mr. A. C. O'Connor's discoveries.

\section{Euacalles gen. nov.}

Scrobes lateral, beginning before the middle and prolonged to the front of the eye. Scape inserted before the middle and attaining the front of the eye, gradually incrassate, glabrous. Funiculus rather longer, second joint slightly longer than the moderately stout first, rather slender, third and fourth rather longer than broad, joints 5-7 shorter and slightly broader. Club elongate, with three small indistinct apical articulations. Orular lobes and scutellum absent. Femora unarmed, long and thick, grooved underneath. Tarsi with narrow basal joints, the penultimate expanded, excavate above, emarginate at apex, entire underneath; claws small; soles setigerous. Pectoral canal profound, its raised hind borders reaching the middle of intermediate coxae. Metasternum very short, so that the middle and hind coxae almost touch each other. Second ventral segment half the length of the basal, their suture feebly sinuate, third and fourth together rather longer than preceding one and as long as the fifth.

The absence of the scutellum, and the truncate thoracic base, prevent the following species being placed in Sympedius, but the penultimate tarsal joint being entire underneath shows that its true position must be remote from all the Acalles allies.

\section{Euacalles cristatus sp. nov.}

Convex, compact, subovate, without setae, thickly covered with depressed, and suberect squamae: on the rostrum and thorax they are mostly infuscate or quite black, but between the middle and sides of the latter the suberect scales are tawny or obscurely fulvescent and almost form crests; the depressed tawny or pale fuscous scales predominate on the elvtra, whilst the suberect nigrescent ones form an elongate basal crest on each of the third interstices, a short one on top of the posterior declivity, and a sutural one near the apex, on the fifth there are three short ones, at the side there are three elongate streaks, the longest between the hind thigh and shoulder, this last bears pale suberect squamae only: the derm is blackish, the antennae, club inclusive, are fulvescent, the tarsi rather darker.

Rostrum moderately broad, suhparallel, equalling the thorax in length, slightly arched, nearly nude, rufescent, and fincly punctate in front, 
minutely asperate behind. Thorax a little broader than long, somewhat contracted in front, the sides nearly straight behind, coarsely and closely punctate. Lilyta slightly broader than thoma at the base, twier its length,

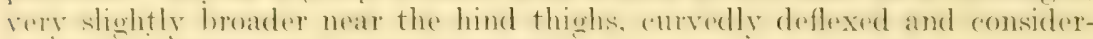
ably narrowed behind, striate-punctate.

Underside covered with coarse pale squamae.

Length (rostrum exclusive), $2 \frac{1}{2} \mathrm{~mm}$.; breadth, $1 \frac{1}{2} \mathrm{~mm}$.

Rotoiti, Nelson. Another of Mr. 'T. Hall's discoveries. Described from a single example found on the 3rd June, 1916.

Tychanus Pascoe. Man. N.Z. Coleopt., p. 498.

\section{Tychanus complexus sp. nov.}

Convex, subovate, rather broader near the hind thighs than elsewhere, opaque; piceous, antennae and tarsi fusco-rufous; densely covered with variegated, depressed, overlapping squamae, elytra with many small crests, in addition to the more prominent ones, formed of short erect scales.

Rostrum a fourth shorter than thorax, stout, slightly arched, subparallel, closely punctate and nearly bare in front, with a central tawny squamose ridge behind the antennae, this being bordered by more fuscous squamae cause the sides to appear broadly sulcate towards the eyes. Thorax slightly broader than long, its anterior half almost abruptly contracted, base slightly bisinuate; dise only slightly uneven, with a slender ridge along the middle of the basal portion, which becomes testaceous behind; its coarse punctation completely hidden by the scales, these are principally rufo-fuscous, but there is an irregular blackish spot across the middle, and the sides and apex are tawny-grey, there are also many erect, short fuscous setae but no definite crests. Scutellum minute. Elytra double the length of thorax, very little broader at the base, with feebly porrect humeral angles, considerably yet gradually narrowed and curvedly deflexed behind; they are coarsely and interruptedly seriate-punctate; un each there are two dark elongate basal crests, and another behind and between these, there are three rotundate brown ones across the summit of the posterior declivity but distant from the suture, which is rufo-fuscous behind, the whole posterior declivity is speckled with nigrescent and greyish seales; behind the middle of the dorsum the greyish squamae are numeious but do not form a well-defined patch. Femora stout and elongate, dentiform below, tarsi rather narrow.

Scape inserted just behind the middle, rather short; basal two joints of funiculus about equally elongate and slender; club elongate-oval, indistinctly quadriarticulate.

Underside covered principally with tawny scales. Hind border of rostral canal extending to front of middle coxar. Mrotasternum very short. Second vent ral segment shorter than the basal but rather longer than third and fourth combined.

The complex variegation and peculiar rostral ridge are good distinguishing features.

Length (rostrum exclusive), $6 \mathrm{~mm}$.; breadth, $4_{3}^{2} \mathrm{~mm}$.

Wadestown, near Wellington. Described from a specimen forwarded by Mr. A. C. O'Connor; 10th August, 1916.

\section{Tychanus simulans sp. nov.}

Opacue, jiceous, antennate and tarsi fusco-rufous; covered with depressed, werlapping, and crect scales, these latter nigrescent, the former variegated 
brown above but tawny-grey on the sides of the thorax, on the rostrum they are fusen-fulvous and elongate, and on the elytral suture behind the middle fusco-rufous.

Rostrum as long as thorax, similar to that of $T$. complexus in structure and vestiture. Thorax quite a third broader than long, its basal half double the width of the frontal, as closely but more coarsely punctured, the disc a little uneven but without definite crests and not at all carinate along the middle. Scutellum indistinct. Elytra at the base not discernibly broader than thorax, fully twice its length, widest in line with the hind thighs, considerably narrowed and deflexed posteriorly; they are coarsely seriate-punctate, more finely and substriate behind ; each elytron is unequally tricristate between the base and middle, and bears a curved series of small crests extending along the side and across the top of the posterior declivity, the one on the third interstice is rather larger than the others, and there is a much less distinct series half-way down the declivity, all these are blackish.

Scape implanted at the middle, attaining the front of the eye, gradually incrassate; second joint of funiculus slightly longer than the basal, third and fourth oblong, fifth obconical, sixth and seventh transverse; club ovate, indistinctly 4-jointed. Femora dentiform.

Underside piceous, with tawny and fuscous squamae, structurally like T. complexus.

Length (rostrum exclusive), $4 \mathrm{~mm}$.; breadth, $2 \frac{1}{2} \mathrm{~mm}$.

Titahi Bay, near Wellington. Unique. Sent on the 10th August, 1916, by Mr. A. C. O'Connor.

\section{Tychanus terricola sp. nov.}

Convex, oblong-oval, opaque ; piceous, antennae and tarsi fusco-rufous ; densely covered with subrotundate, depressed, overlapping squamae, these are chiefly of a rufo-testaceous hue but rather darker on the thorax, which has also many erect, blackish, setiform ones similar to those on parts of the elytra, half-way down the posterior declivity particularly, where they form an irregular transverse streak.

Rostrum as long as thorax, arched, moderately stout, slightly dilated anteriorly, densely squamose, obtusely ridged along the middle. Head impressed between the eyes. Thorax a fourth broader than long, base bisinuate, the frontal half almost abruptly contracted and fringed with pale elongate scales at the apex; disc nearly plane, irregularly and moderately coarsely punctate, with a flavescent streak along the middle of its basal portion. Scutellum indistinct. Elytra on a higher level than the thorax just behind the base, somewhat uneven, of the same width as it is at the base, fully twice its length, rather broader near the hind thighs than elsewhere, strongly curvedly deflexed behind; apparently subseriatepunctate, third interstices with an obtuse nodiform elevation before the middle, in line with the fifth there is an obtuse nodosity, or crest, on each elytron, on the summit of the declivity, from this point erect dark scales form an interrupted irregular streak towards each shoulder. Femora distinctly dentate underneath.

Scape medially inserted, attaining the eye, gradually thickened, setose ; basal joint of funiculus slightly shorter than the elongate second, third and fourth evidently longer than the following three, which are longer than broad; club elongate-oval.

Most nearly approaches $T$. squamosus (3638), from central Canterbury. 
Length (rostrum exclusive), $5 \frac{1}{2} \mathrm{~mm}$; breadth, $3 \frac{1}{3} \mathrm{~mm}$.

Tauherenikau Bush, near Featherston. One only, picked out of leafmould collected by Mr. T. Hall, who kindly brought it to my house at Mount Albert on the 6th October, 1916.

\section{Crisius Pascoe. Man. N.Z. Coleopt., p. 500.}

\section{Crisius dives sp. nov.}

Convex, subovate, widest at the shoulders, subopaque; piceous, rostrum, antennae, and tarsi dark fusco-rufous; covered with depressed, small, variegated squamae, most of these are rufous, but along the middle of the elytra they are more fulvescent, those between the middle and sides of thorax are also fulvescent but more elongate, usually there is a small flarescent patch near the middle of the femora.

Rostrum stout, arched, a little dilated near the base, almost as long as thorax, nearly bare and finely punctate in front. Thorax nearly a third broader than long, its frontal half abruptly contracted, rounded and obtusely bicristate at apex; its basal portion with a pair of similar crests in front, these however are obliquely prolonged to the base, the crest at each side in front is more prominent than the central pair; dise apparently close] y punctate and with a blackish carina from base to apex. Scutellum small. Elytra cordiform, $2 \frac{1}{2}$ times the length of thorax, their somewhat elevated, rounded shoulders are rather broader than the thoracic base, they are gradually yet evidently narrowed and nearly vertical behind; dorsum moderately coarsely seriate-punctate, the sides more coarsely ; third interstices indistinctly and interruptedly elevated before the middle but terminating as distinct clongate horizontal nodosities on the top of the posterior declivity, just below each of these there is a minute one, and a longer crest near the apex, on the fifth there are three small clevations, which however are more conspicuous than others near the base, some of which have grey scales.

Femora dentiform underneath; tibiae bent above, the hind pairs fringed externally with dark seales above the middle; tarsi normal, rather narrow.

Scape implanted before the middle, flexuous and gradually incrassate; suecond joint of funiculus hardly any longer than the thicker basal, joints 3-6 shorter and subequal, seventh broader; club moderately elongate, quadriarticulate.

Undersid nigrescent, with minute rufous squamae. Raised borders of pectoral canal extending as far as the back part of middle coxae. Basal vintral sement irrecularly punctate, depressed in front. of about the same length as second, which is but little longer than third and fourth together.

This richly coloured species is distinguishable by the posterior prolongation of the central thoracic crests.

Length (rostrum exclusive), $4 \frac{1}{2} \mathrm{~mm}$.; breadth, $2 \frac{3}{4} \mathrm{~mm}$.

Wadestown, near Wellington. A single example, sent to me on the 10th August, 1916, by Mr. A. C. O'Connor.

\section{Crisius longulus sp. nov.}

Opaque, irregularly oblong-oval, only moderately convex; nigro-fuscous,

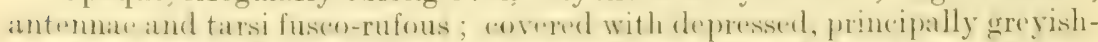
lawny squanse. those on the rostrum and lower sides of thomx more fulvescent; legs variegate, the hinder pairs of femora having broad grey and fuscous bands. 
Rostrum arched, as long as thorax, very gently narrowed towards the middle, piceous, bare and closely punctate in front; with a fine carina along the middle and an oblique less distinct one near cach side, its base bicristate. Thorax a fifth broader than long, its frontal half abruptly contracted, base subtruncate; disc nearly level, its punctation concealed with a ferv short, suberect, squamiform blackish setae, and a distant pair of small crests across the front of its broal basal portion. Scutellum indistinct. Elytra $2 \frac{1}{2}$ times the length of thorax, about a fourth broader, the somewhat elevated oblique shoulders of about the same width as thorax at the base, their sides a little uneven but subparallel to the commencement of the sloping, gradually narrowed posterior declivity; they are subseriatepunctate, third interstices, between the base and hind thighs, with three subrotundate crests, the hindmost obscurely fulvescent, the others dark, the fifth with similar erests but placed farther back, and with a small grey one on top of the declivity, where there is another grey spot near the side. Tarsi rather narrow, penultimate joint slightly broader.

Scape slender, inserted hetween the uiddle and apex, attaining the front of the eye; basal joint of funiculus shorter than second, 3-7 decrease in length; club elongate.

Underside nigrescent, with pale-tawny scales and setae. Abdomen elongate, second segment much shorter than the basal and not much longer than the third or fourth.

In form this most nearly approaches the northern C. variegatus (892), but the vestiture is entirely different. C. humeralis (3320) may be at once separated by its much shorter oviform club, \&c.

Length (rostrum exclusive), $7 \mathrm{~mm}$.; breadth, $3 \frac{1}{2} \mathrm{~mm}$.

Stephen Island. One, found by Mr. A. C. O'Connor on the 17th September, 1916.

Sympedius Pascoe. Man. N.Z. Coleopt., p. 499.

\section{Sympedius minor sp. nov.}

Convex, compact, opaque; nigrescent, basal half of thorax rufescent, antennae and tarsi light fuseo-rufous; densely covered with more or less overlapping, variegate, principally dark fuscous squamae, and short (rect setae.

Rostrum only slightly expanded near the base, a third shorter than thorax, nearly smooth and bare before the antennae. Thorax a third broader than long, depressed but not abruptly contraeted in front, with a pair of prominent, palish apieal crests; the basal half with some reddish, suberect scales in front and greyish ones at the sides, and a pair of dark oblique marks noar the middle of the base; it is very distinctly and closely punctate. Seutellum distinct. Elytra hardly at all broader than thorax at the base, twice its length, almost straight to beyond the hind thighs, curvedly deflexed and narrowed behind, their punctation quite hidden ; the quarlate basal space is pale reddish-brown, there is a pair of small obtuse elevations before the middle and another in line with the hind thighs.

Scape rather short and stout, gralually thickened, inserted just before the middle but not reaching the eye : basal joint of funiculus stouter and slightly longer than the next, joints 3-7 transverse; club oblong-oval, finely pubescent, triarticulate.

Underside covered with depressed fuscous and grevish seales. Pertoral vanal deep. extending to front of middle coxae. Third and fourth ventral 
secoments only moderately abbreviated, together as loner as the semicirenlar fifth.

This small species most nearly resembles ste rectirostris (2953). but has shorter antennae, \&c.

Length (rostrum exclusive), $2 \frac{1}{2} \mathrm{~mm}$. ; breadth, $1 \frac{1}{3} \mathrm{~mm}$.

Speargrass Creek; 13th June, 1916. One, from Mr. T. Hall.

Getacalles Broun. Man. N.Z. Coleopt., p. 1380.

4235. Getacalles eucoelius sp. nov.

Convex, subovate, a little uneven, opatque ; piceons, rostrum piceo-rufous, antennae and tarsi infuscate red; covered with small, depressed, variegated squamae, chiefly rufo-fuscous and a few scattered greyish ones, but the erect ones are more nigrescent and form crests except on the shoulders, where they are testaceous.

Rostrum arched, as long as thorax, subparallel, stout, constricted at the base; nude and finely punctate in front, subcarinate along the middle behind. Head immersed up to the eyes, with a fovea between these. Thorax a third broader than long, subtruncate at the base, coarsely and closely punctate; its frontal half abruptly contracted, moderately bicristate at the apex; the basal portion, across the front, with a pair of central crests and one at each side, along the middle there is a distinct carina. Scutellum small, greyish. Elytra subcordate, $2 \frac{1}{2}$ times the length of thorax, not pereeptibly wider than it is at the base, quite a fourth broader behind the oblique, raised shoulders, a good deal yet gradually narrowed and subvertical behind; seriate-punctate alongside the suture, interruptedly towards the sides, substriate behind; second interstices obtusely elevated near the base, the dorsum with several small, irregular, obtuse crests, and four or five along each side.

Antennae finely setose; scape flexuous and slender near the base, gradually thickened, inserted quite before the middle and just attaining the front of the eye; basal joint of funiculus stouter but not longer than the elongate second, joints 3-5. decrease in length, sixth and seventh transverse and moniliform; club subelongate-ovate, its basal articulation as large as the other three combined.

Legs setigerous; femora long and stout, deeply grooved underneath, the anterior with a small denticle; tibiae uncinate, nearly straight; basal two joints of the tarsi narrow, third moderately dilated and bilobed.

Underside dark fuscous, prosternum and coxae more rufescent, abdomen moderately coarsely punctate, with many depresied, small, greyish squamiform setae.

Peretoral canal profound, its elevated borders extending to the back part of the intermediate coxate. Metasternum with a broad curved ridge between the middle and hind coxae, so that the centre is quite concave. Basal ventral segment flat in the middle, double the length of the second, which is depressed at the sides, the suture between feebly sinuate; third and fourth moderately abbreviated, together longer than the second. both with straight, deep sutures, fifth with a foveiform depression at each side. Tarsi finely setese underneath. Mentum transverse in front. its basal half quadrate yet narrower. Palpi thick, quite uncovered.

This does not agree very well with Getacalles, and will ultimately, no doubt, form the type of another genus. The condiform hind-body, subrarinate restrum, interocular fovea, the thoracice carina. elytral crests, and obvious metasternal cavity render it distinct. 
Length (rostrum exclusive), $4 \mathrm{~mm}$; ; breadth, $2 \frac{1}{2} \mathrm{~mm}$.

Mount St. Arnaud, Nelson. Evidently rare. Mr. T. Hall, when on the summit on the night of the 28th June, 1916, was exposed to a snowstorm, and on descending next day met with such miserable weather that scarcely any insects could be found.

\section{Getacalles fulvisparsus sp. nov.}

Suboblong, convex, opaque; nigrescent, antennae and tarsi fusco-rufous ; densely covered with more or less overlapping variegated squamae.

Rostrum a little shorter than thorax, arched, stout, parallel, nearly bare and closely punctate in front, coarsely punctate and covered with dark fusco-rufous scales, so as to appear somewhat asperate behind. Thorax nearly a third broader than long, its anterior half abruptly contracted and bearing some short upright blackish and tawny coarse setae; the squamae on the basal portion variegated light brown with nigrescent lateral spots, each side in front with outstanding somewhat fulvescent scales, and in line with these a pair of small rotundate crests, the erect setae are like those in front. Scutellum conspicuous, grey. Elytra oblong, almost double the length of thorax, rather broader at the base, a fourth wider near the middle, with obtusely porrect shoulders, considerably narrowed and subvertical behind; they are coarsely subseriate-punctate, but owing to the numerous small irregular crests the surface appears aneven; the prevailing hue is fuscous, the suberect fulvescent scales form most of the crests, but very black spots occur, on the posterior declivity particularly; on the lower part of each side, between the middle and hind thighs, there is a conspicuous fulvescent patch.

Antennae finely setose; scape slightly flexuous, reaching the centre of the eye ; the funich very similar to that of $G$. eucoelius ; club oblong-oval, basal joint half the whole length. Femora all dentate underneath.

Underside nigrescent, coarsely and moderately closely punctured, covered with greyish and fulvescent squamae, these latter cover the middle of segments $2-4$ as well ns the front and sides of the fifth. Rostral canal extending to the front of middle coxae, the very broad semicircular borders extend from the back of the front coxae to the middle of the intermediate. Metasternum very short. Basal ventral segment angulate between the coxae, nearly twice the length of the next, both flat, their suture sinuate, third and fourth together as long as second or fifth. Mentum small, so that the thick, rigid fulvous palpi are wholly exposed.

The nearest species, $G$. indequalis (2575), is smaller and less variegated, the basal half of its thorax has a dark carina along the middle in front, and each elytral puncture has a minute greyish scale in it.

Length (rostrum exclusive), $4 \frac{1}{2} \mathrm{~mm}$. ; breadth, $2 \frac{1}{3} \mathrm{~mm}$.

Wadestown, near Wellington. 21st August, 1916. One, sent by Mr. A. C. O'Connor.

\section{Getacalles grisealis sp. nov.}

Convex, oblong, opaque; fuscous, tibiae, tarsi, and antennae pale rufofuscous; covered with decumbent ohscure grevish squamar and suberect short squamiform setae.

Rostrum normal, slightly shorter than thorax, with suberect scales except at the reddish apex. Thorax fully a third broader than long, its basal half nearly double the width of the frontal, with some ereet, slightly infuscate setae, a little uneven, but without definite crests. Scutellum 
small, subrotundate, greyish. Elytra oblong, narrowed and subvertical behind, twiee the length of thorax, a little broader than it is at the base : slightly uneven, subseriate-punetate, third interstices feebly elevated or (Pested near the top of the declivity, with a transverse intervening fuscous mark; at or just below the summit there are four obtuse elevations, the external ones larger than the others; there are also a few dorsal obtuse elevations between the third interstices and sides. Femora somewhat dentiform underneath.

Scape implanted near the apex and reaching the front of the ere ; basal joint of funiculus thicker but not longer than the next, 3-6 moniliform and subequal, seventh rather shorter and broader; club oblong-oval, basal joint half of the whole length.

Underside dark fuscous, moderately coarsely and closely punctured, with greyish scales. Hind border of rostral canal not broad; otherwise like $G$. fulvisparsus.

But little larger than $G$. minor (2411), which has quite regular series of elytral punctures.

Length (rostrum exclusive), $2 \frac{2}{3} \mathrm{~mm}$.; breadth, $1 \frac{1}{2} \mathrm{~mm}$.

Titahi Bay ; 10th August, 1916. One, from Mr. A. C. O’Connor.

Tychanopais Broun. Man. N.Z. Coleopt., p. 1379.

\section{Tychanopais dealbatus sp. nov.}

Compact, oblong, moderately convex, opaque; nigrescent, antennae and tarsi fusco-rufous; densely covered with depressed, small, principally dark fuscous and coppery squamae, the lower sides of thorax with white scales; the setae are numerous, short and erect, mostly pale fuscous.

Rostrum a third shorter than thorax, broad, a little arched, slightly and gradually narrowed towards the middle, its punctation rather coarse but shallow. Thorax only a trifle broader than long, somewhat rounded but only very little broader at the middle than behind, a good deal but not abruptly narrowed and slightly depressed in front, apparently coarsely and closely punctured, with very few white scales on the disc. Scutellum absent. Elytra oblong, not double the length of thorax, bisinuate and slightly broader than thorax at the base, with slightly porrect shouldirs. narrowed and subvertical behind; they are rather distantly and coarsely subseriate-punctate, more finely along the posterior dcclivity, which has a pair of small, obtuse, black crests near the middle; interstices not elevated, but the third and fifth end on the summit of the declivity as small dark crests, each of the inner ones has about two erect, coarse grey setae, the outer bear fusco-fulvous setae; on the dorsum, near the sides particularly, there are several small patches of fulvescent squamiform setae.

Legs elongate but stout, thickly covered with suberect, fulvescent, scalelike setae; femora strongly dentate at the middle underneath, so as to appear semicircularly notched near the extremity; front tibiae uncinate, somewhat dilated inwardly at the middle, the posterior broadly cavernous at the extremity.

Scape moderately slender, implanted between the middle and apex and reaching the front of the ere: basal joint of funculus very little thicker and just pereptibly lonere than the elongate second. 3 - T gradually becentere shorter and broader ; elub ovate. rather short. indistinctly quadriartiendate. basal joint half the whole length.

Underside nigrescent, nearly plane; sides of prosternum covered with white, the metasternum and abdomen with reddish-coppery squamae. 
Elevated borders of pectoral canal extending to the middle of intermediate coxae. All the coxae equidistant from front to rear. Metasternum short. First ventral segment broadly rounded between the very widely separated coxae, nearly twice the length of second, their suture sinuate, third and fouth short, together equalling the fiftl. Femora broadly grooved apically half their length. Soles of tarsi thinly setose. Mentum subquadrate, rather small; palpi uncovered.

Easily separable from $T$. pictulus (2409) by the less brightly criloured vestiture, simple elytral interstices, less abruptly contracted anterior half of thorax, and by the white seales which cover the lower sides of the thorax.

Length (rostrum exclusive), $4 \mathrm{~mm}$.; breadth, $2 \mathrm{~mm}$.

Martinborough. I am indebted to Mr. A. C. O'Connor, of Wellington, for the only specimen I have seen; 21st August, 1916.

Acalles Schoenherr. Man. N.Z. Coleopt., p. 488.

4239. Acalles brevipennis sp. nov.

Convex, broad, subovate, opaque, without crests or tubercles ; nigrescent, covered with depressed fusco-ferruginous squamae and erect setae, but with an irregular, grey, curved band extending from one hind thigh to the other; antennae and tarsi light red.

Rostrum a third shorter than thorax, rather broad, gradually narrowed towards the centre, nitid, rufo-piceous, smooth and subcarinate along the middle, biseriate-punctate and bearing grey scales near the sides. Thorax as long as broad, widest behind the middle, more gradually narrowed in front than behind, base truncate; its surface closely punctate. Scutellun apparently absent. Elytra subrotundate, only a third longer and broader than thorax, slightly wider than it is at the base, vertical behind; almost striate-punctate, third interstices costiform, fifth indistinctly so.

Legs long and stout; femora grooved underneath, longer than the tihiae; bearing numerous erect, greyish, squamiform setae. Tarsi short, gradually expanded, penultimate joint bilobed; claws minute.

Scape medially inserted, subclavate at the extremity, attaining the eye. Basal joint of funiculus stouter and rather longer than second, third and fourth slightly longer than broad, fifth to seventh successively dilated; club pubescent, elongate, with minute terminàl articulations.

Underside piceous, coarsely punctate, with a few coarse grey setae. Rostral canal profound, its elevated borders reaching the intermediate coxae. Metasternum very short. Basal ventral segment large. broadly rounded between the coxae, subtruncate behind, second short yet as long as the abbreviated following two together, fifth narrower, nearly as long as the basal.

The short, subrotundate hind-body, with its posterior grey fascia, the minute claws. and obsolete hind tibial spurs are good differentiating characters.

Tength (rostrum exclusive), $1 \frac{2}{3}-2 \mathrm{~mm}$.; breadth, $1-1 \frac{1}{4} \mathrm{~mm}$.

Lalie Rotoiti, Nelson: 28th December. 1915. Five indivirluals, taken from leaf-mould by Mr. T. Hall

\section{Acalles hopensis sp. nov.}

Oblong, convex, opaque; fusco-niger, antennac and tarsi infuscate red : covered with depressed, somewhat overlapping, variegated squamae, principally obsenre greyish or fuscous, but the crests on the head and a 24-Bull. No. 1. 
broad band on top of the posterior declivity are tawny, there are also numerous erect scale-like setae, some of which form crests.

Rostrum as long as thorax, arched, moderately stout, very slightly narrowed towards the centre, squamose behind the antennae, punctate in front. Head immersed up to the eyes, bicristate. Thorax a fifth broader than long, widest before the middle, nearly straight towards the truneate bise, distinctly contracted in front; a little uneven above, moderately coarsely and closely punctate, with a pair of small median crests. Scutellum grey. Elytra oblong, almost double the length of thorax, of the same width as it is at the base, with slightly oblique shomlders, a fourth broader near the middle, posterior declicity considerably narrowed but not quite vertical; they are coarsely striate-punctate near the suture, irregularly towards the sides, obsoletely behind; third and fifth interstices more or less evidently tricristate above.

Legs with many erect squamiform setae, some paler than others; femora unarmed, longer than the tibiae, all of which are uncinate. Tarsi moderately broat, thickly setose, penultimate joint bilobed, rather thicker than preceding ones; claws small.

Scape elongate, implanted just before the middle, reaching the eye, rather slender, very gradually incrassate; basal joint of funiculus moderately stout, seareely any longer than the next, third longer than fourth or fifth: sixth and seventh short, the latter as broad as the oblong-oval, triartieulate club.

Underside blackish, punctate, with greyish squamae. Pectoral canaldeep, extending to the middle coxae. Basal ventral segment largest, second as long as the moderately abbreviated third and fourth combined, fifth broad, rounded behind. When mounted on cardboard, with the rostrum stretcherd out, an obvious sinuosity is seen at the front side of the thorax behind the eye, and the part below is distinctly rounded; in this instance, therefore, the ocular lobes are well developed.

This belongs to the same section as Pascoe's $A$. intutus (866) and $A$. australis (2l80), but in the latter the scape is short and inserted behind the middle of the broader rostrum, the thorax is less contracted in front, the elytral inequalities are dissimilar, the funiculus is more slender and differently formed, and the conspicuous interocular crests are absent.

Length (rostrum exclusive), $3 \frac{3}{4} \mathrm{~mm}$; ; breadth, $2 \mathrm{~mm}$.

Glenhope, Nelson. Described from a specimen found by Mr. T Hall on the 3rd March, 1915.

\section{Acalles bicostatus sp. nov.}

Convex, subovate, opaque; black, tarsi fusco-rufous, antennae paler ; the squamas mostly depreseer and dark ashy: but near eareh side of the thorax, and indefinitely along the middle, they form a curvate streak of a tawny-grey hur, ated on the second and third interstiens of the rytrat and the middle of the posterior declivity they are similarly rallid; the short,

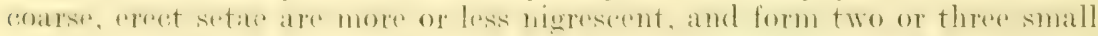
crests on each elytron, and a still smaller, indistinct pair on the centre of the thorax.

Rostrum a third shorter than thorax, feehly arched, slightly narrowed towards the midclle, irregularly punctate near the sides and in front, with pales sales near the base. Thorax subeonical, slightly broader than long, videst and obtusely rombed behind the midlle, gradually narrowed anteriorly, nearly straight towards the truncate base : dise without inequali- 
ties, moderately coarsely and closely punctured. Seutellum small, greyish. Elytra of the same width as thorax at the base, nearly twice its length, a little broader near the hind thighs, much narrowed and nearly vertical behind; sutural striae indistinct, the others well marded, their punctation, though apparently conres, is indefinite; the second interstiees are hroadly costate from the base to the summit of the posterior declivity, the third from the base towards the middle, these bear some pale erect scales.

Legs similar to those of $A$. hopensis; underside also nearly the same, the second segment a trifle longer.

Scape short, inserted behind the middle, gradually incrassate, just reaching the front of the eye ; basal joint of funiculus slightly longer than the next, third distinctly shorter, the following three still more so, serenth more transverse; club oviform, with small apical articulations.

Another near ally of $A$. australis, but the shape of the thorax, the elytral sculpture, and general coloration are essentially different. The pale well-developed elytral costae are distinctive.

Length (rostrum exclusive), $3 \mathrm{~mm}$. ; brearth, $1 \frac{1}{2} \mathrm{~mm}$.

Karekare, west coast of Auckland; 23rd February, 1916. My specimen was caught by Mr. A. E. Brookes.

\section{Acalles binodes sp. nov.}

Convex, compact, subovate, dull ; nigrescent, tarsi and antennae dark fusco-rufous; closely covered with overlapping, scarcely at all varegated fuscous scales, and short erect setae, which are greyish on the legs.

Rostrum a fourth shorter than thorax, arched, broad, feebly expanded anteriorly, its punctation coarse and close except at the apex. Thorax a third broader than long, its anterior half almost abruptly contracted, with some coarse setae but not distinctly crested in front, the basal half carinate along the middle, apparently coarsely and closely punctured, its base a little depressed and subtruncate. Scutellum absent. Elytra double the length of thorax, of the same width as it is at the base and closely applied thereto. their sides slightly rounded, broadest behind the middle, subvertical and much narrowed posteriorly; they are very coarsely and irregularly punctate and uneven, and bear on top of the declivity a pair of large, nearly horizontal, widely distant crested nodosities.

Legs elongate, femora grooved underneath near the extremity, tibiae uncinate, tarsi rather narrow.

Scape inserted behind the middle, short and stout, just reaching the front of the eve; basal two joints of the funicle equally elongate. the others moderately short and gradually thickened; club ovate, triarticulate.

Underside blackish, coarsely and closely punctate, covered with tawngrey squamae, some of which form a pair of obtuse crests on the basal ventral segment. Coxae about equidistant from front to rear. The elevated borders of rostral canal extend to the middle of intermediate coxae. Basal segment rounded in front. sinuate behind, chviously larger than second, 2-4 on a lower level, together as long as fift!. Ifentum apparently narrow: palpi fully exposed.

The nearly concolorous, dusky, overlapping squamae, conspicuous postering nodosities and rather broad subasperate rostrum, male it necessary to locate it in a section of the genus by itself.

Length (rostrum exclusive), $3 \frac{1}{2} \mathrm{~mm}$. ; breadth, $2 \frac{1}{3} \mathrm{~mm}$.

Martinborough. I am indehted to Mr. A. C. O'Connor for a specimen; 21st August, 1916. 


\section{Acalles sticticus sp. nov.}

Opaque, moderately convex, medially contracted; the derm picenrufous and somewhat nitid, but densely covered with seale-like matter of a fulvo-fuscous hue and many upright, elongate dark setae; the rostrum strining red, antennate and tarsi fulrescent, club funconts; nytra with ten small spots formed of small erect blackish seales.

Rostrum about as long as thorax, slightly arched, gradually narrowed towards the middle, indistinetly carinate and with linear sculpture behind, ror fincly an! remotely punctured in front. Thorax searenly longer than broad, base and apex truncate, rounded and widest at or just behind the middle, more gradually narrowed in front than behind, without inequalities, moderately coarsely and closely punetate. Elytra of the same width as thorax at the base, a third longer and broader, cordate, not vertical behind; apparently striate-punctate, distinctly so alongside the suture.

In wes with renet fuscous setae, femora long and thick, tibiae much shorter, tarsi rather slender.

Seape short and stout, gradually thekened, glabrous, implanted behind the middle but not reaching the eve ; funiculus longer, bearing dark setar, basal joint much thieker but hardly longer than the next, both narrowed towards the base, joints 3-6 small, successively shortened, seventh still shorter, strongly transverse : club dull, oblong-oval, indistinctly articulate, densely pubescent.

This, on account of its conical thorax and cordate hind-body, is placed in proximity to A. comptus (2565); it is, howerer, rather smaller and relatively broader, with different vestiture, and can be identified without difficulty by the minute black elytral crests.

I.neth (rostrum exclusive), $2 \mathrm{~mm}$. Freadth, quite $1 \mathrm{~mm}$.

Inomit st. Amand. Nolson. Deseribed from at single spresimen taken from leaf-mould by Mr. T. Hall on the 15th June, 1916.

\section{Group Anthribidae.}

\section{Dysnocryptus Broun. Man. N.Z. Coleopt., p. 1258.}

\section{Dysnocryptus setigerus sp. nov.}

Convex, suboblong, nitid; testaceous, with the following fuscous marksan imenular one aleress the midelle of thorax, the sutural striae of the elytra and a fascia in line with the hind thighs but interrupted near the suture;

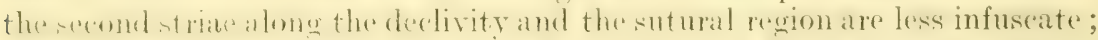

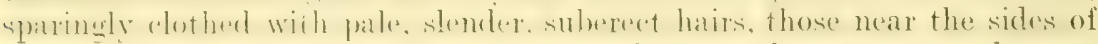
the after-part of elytra are slightly coarser, there are also many very elongate upright ones.

Head and rostrum deflexed, fuscous, minutely asperate. Thorax almost

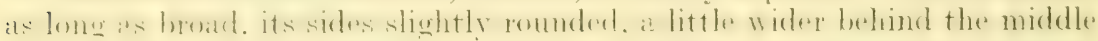
than in front; moderately coarsely and closely punctate, paler between the middle and apex than behind; its carina almost evenly curved, not angulate at the middle or the sides. Scutellum absent. Elytra about a third longer and broader than thorax, truncate at base, apices nearly so, their sides rounded; they are evidently punctate-striate, most of the

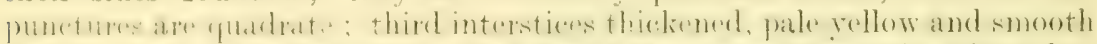

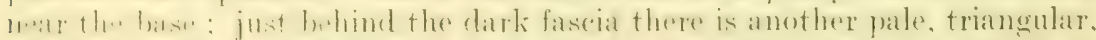

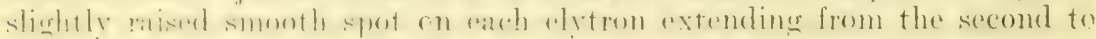
the fourth striae. Legs light fuscous, tarsi slightly rufescent. 
Antennae as long as head and thorax, a little infuscate from the third joint onwards, with a few slender outstanding fuscous setae ; first joint slender at the base, broadly dilated inwardly towards its extremity, second nearly similar but smaller; joints $3-8$ evidently longer than broad, slender for half of their length, seventh and eighth slightly shorter and stouter; club well defined, its basal joints unsymmetrical, articulated outside the middle, the first slightly longer and more triangular than serond, the terminal subconical.

Underside fuscous, with fine greyish pubescence.

Most nearly allied to $D$. pallidus (2218), but the hind-body is less rotundate and less vertical behind, the striae are deeper and their punctures coarser and quadrate ; the general coloration is darker, and the clongate upright setae are conspicuous.

Length (rostrum exclusive), $2 \mathrm{~mm}$.; breadth, $1 \mathrm{~mm}$.

Titahi Bay, Wellington. One, sent by Mr. A C. O'Connor on the 10th August, 1916.

\section{Group Ceramibcinae.}

Aemona Newman. Man. N.Z. Coleopt., p. 570.

\section{Aemona separata sp. nov.}

Elongate, subdepressed, subopaque; light castaneo-rufous, elytra tostaceous, mandibles rufous with nigrescent inner edges; head irregularly covered with bright fulvous pubescence, that of the thorax of a paler yellow, clytra with depressed greyish hairs.

Thorax subquadrate, not longer than broad, apex truncate, base bisinuate, its sides slightly rounded before the middle and somewhat sinuate between that part and the base; dise with indefinite sculpture, not at all transversely rugose, impunstate, only very slightly and irregularly uneven, but on each side in front there is an obtuse, subrotundate, slight elevation, and a pair of more obsolete ones between these. Elytra five times the length of thorax, almost double its breadth at the base, parallel, with broadly rounded apices; their whole surface is moderately elosely punctate, rather more coarsely before the middle than behind.

Underside light rastaneous, with greyish pubescence, impunctate, the prosternum with some short feeble inequalities; intermediate coxae moderately widely separated, the intervening proeess with a sharp semicircular notch behind.

Antennae very slightly longer than the body, their fourth joint rather shorter than contiguous ones.

This distinct speeies may be identified by the coloration, and the shape and sculpture of its thorax.

Length, $18 \mathrm{~mm}$. ; breadth, $4 \frac{1}{2} \mathrm{~mm}$.

Miuggie 'Terrace, near Iake Rotoiti, Nekon: 23rd December. 1915. One, eaptured by Mr. T. Hall.

\section{Group Lamidate.}

Xylotoles Newman. Man. N.Z. Coleopt., p. 592.

\section{Xylotoles submicans sp. nov.}

Elongate, nitid, aeneo-fuscous, antennae more rufeseent and irregularly, but not eonspisuonsly, spotted with grey pubesenen ; thinly elothed with fine greyish hairs, each elytron, in addition thereto, has an oblique, inter- 
rupted pateh of fulvous pubesenere before the middle, and another helind the posterior femora, neither of these reach the suture, seutellum similarly clothed.

Head broadly impressed and striate along the middle, its pubescence rollowish-grey. Thorax a little longer than broad, slightly constrieted near the base and apex, foebly romeded near the middle, with a fow fine puncetures. Whora slightle wider than thorax at the base. 2 ? times its length, gradually narrowed behind, with sharply rounded, somewhat dehiscent apiees: sutural striae obsolete at the base, each olytron with an indistinct costa not far from the suture, the coarse punctures between these extend backwards to the middle, those near the shoulder are more irregular and closer.

Third joint of antennae attains the shoulder, in the male the seventh extends to the apex, in the female the eighth hardly reaches the apex.

Underside shining aeneo-niger, with a distinct patch of fulvous pubescence on each side of the basal four segments of the abdomen.

This should be placed near $X$. humeratus (1034). The thorax is longer, the shoulders less reetungular, and the apices more prolonged and divaricate. but not as strongly so as those of $X$. mudus or rugicollis.

o. Length, $8 \mathrm{~mm}$; ; breadth, $2 \frac{1}{3} \mathrm{~mm}$. ㅇ. $12 \times 3 \mathrm{~mm}$.

Stephen Island; 15th September, 1916. One of each sex, from Mr. A. C. O'Connor.

\section{Somatidia Thomson. Man. N.Z. Coleopt.. p. 600.}

\section{Somatidia placita sp. nov.}

Robust, medially narrowed, without erect setae; rufo-castaneous, the antennae, greater portion of tibiae, and the tarsi of a lighter hue ; head and thorax rather more nitid than the elytra; pubescence fine, depressed, flavescent, nearly absent from the occiput, thoracie dise, and basal half of elvtra.

Head rather narrower than thorax, almost perfectly smooth, with a fine stria along the middle. Thorax of equal length and breadth, widest and rounded at or just behind the middle, very gently narrowed anteriorly, rather strongly behind; dise only slightly romsex, with some well-markerl, but not roarse, distant punctures, which, however, are almost entirely a bient along the eentre. Seutellum sharply triangular. Elytra oblong-oval, double the length of thorax. with obliquely curved shoulders, so that the batse is scarcely at all broader than that of the thorax, they become rather narrower towards the broad apices; their punctation is like that of the thorax, nowhere close, but inore indistinct behind, the posterior seutiform mark is fuscous: on each elytron there is only a single minute dark crest nearly in line with the hind thigh, but on the middle there is a quite minute obsolete elevation which may, in perfectly fresh unabraded examples, be the base of an additional crest.

Antennae without maculation, hardly extending beyond the elytra

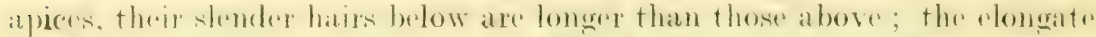
third joint at ains the shoulder. the fifth is shorter than fourth.

The punctation is similar to that of $S$. pinguis (3349), but the general contour is more like $S$. lonyipes (1054).

Length, $8 \mathrm{~mm}$.; breadth, $2 \frac{3}{4} \mathrm{~mm}$.

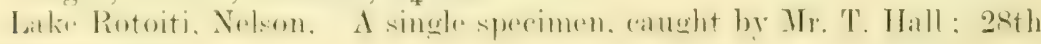
December, 1915. 


\section{Somatidia origana sp. nov.}

Jilongate, moderately convex, subopaque; rather thinly covered with decumbent, grevish, rather short and slendor hairs: castaneo-rufous, the head, a broad space on each side of the thorax from before the middle and nearly touching the other at the base, a large basal spot on each elytron from the side to the middle, and a few lateral spots near the apex, are nigresent; legs testaceous, tibiae slightly rufescent above, the subapical spot blackish; antennae unspotted

Head and eyes hardly as broad as thorax vertex coarsely punctate and slightly uneven, the forehead not flattened, broadly but slightly convex along the middle. Thorax of equal length and breadth, obtusely rounded and widest before the middle, more gradually narrowed behind than in front; irregularly, moderately coarsely but not closely punctate. Scutellum very small. Elytra elongate-oval, of the same width as thorax at the base, about a fourth broader than it is at the middle, twice its length; they are without crests, but on each of the dark basal areas there is a short iongitudinal elevation; their punctation near the base is as coarse as that of the thorax, it becomes finer behind and almost ceases at the extremity, it is not quite seriate, and is more distant than that of the thorax.

Antennae stout, with fine greyish pubescence and some rather longer hairs; they just pass the hind thighs, their third joint barely reaches the thoracic base, the fourth is slightly longer than fifth, tenth shorter than eleventh.

The nearest species, S. flavidorsis (3947), has a fine groove along the lorad, the punctation is more distant and finer, and almost seriate on the elytra ; the antennae, coloration, and other details also differ.

Length, $4 \frac{2}{3} \mathrm{~mm}$. ; breadth, $1 \frac{2}{3} \mathrm{~mm}$.

Mount St. Arnaud, Nelson. My speeimen was eaught by Mr. T. Hall on the 15th June, 1916.

\section{Somatidia oedemera sp. nov.}

Robust, convex, oblong, medially depressed and narrowed, without (rests or superficial inequalities, somewhat shining; cupreo-fuscous, antennate and femora rufo-fuscous, tibiae and tarsi paler; pubescence greyish, unevenly distributed, mingled with longer suberect hairs.

Head about half the width of thorax, minutely and densely punctate and with some larger punctures and a fine stria along the middle. Thorax large, slightly broader than long, widest and rounded near the front, a good deal narrowed and depressed behind; irregularly and moderately coarsely punctured, more closely in front than on the middle. Scutellum small, triangular. Elytra of the same width as thorax at the hase, hardly twice its length, widest behind the posterior femora, strongly curvedly deflexed behind; their punctation subseriate alongside the suture, more distant and finer than that of the thorax.

Femora slender near the base, very strongly clavate beyond; tibiac stcut, only slightly infuseate above; anterior tarsi rather broad, basal joint dilated and cordate.

Antemna finely pubescent, immaculate, not quite the length of the body: third joint hardly reaching thoracic hase, fourth and fifth subequal, longer than following ones.

Underside rufo-fuscous, abdomen darker but with a brassy tinge. Prosternal precess nearly plane, that of the mesosternum subparallel. Basal ventral segment as long as the following three combined; fifth longer 
than fourth, truncate behind, sixth of nearly similar length, with a transverse median fovea.

The short thorax and wytra, remarkably dilated femora, tarsal structure, and abbreviated metaste rmum will enable entomologists to identify it readily.

o. Length, $4 \frac{1}{2} \mathrm{~mm}$. ; breadth, nearly $2 \mathrm{~mm}$.

Wadestown, near Wallington. A single male sent on the 10th August, 1916. Another of Mr. A. C. O'Connor's novelties

\section{Somatidia o'connori sp. nov.}

Hlongate, narrow, moderately convex, subopaque; castaneous, but with the sides of the elytral dorsum from behind the base fo near the extrenity, and a band across the top of the hind slope nigrescent; antemnat of a paler chestnut hue near the base, but with the apical half of joints 5 -10 dark fuscous, the basal almost testateous; femora fuscous, as is the upper portion of the tibiae, the lower part and the tarsi testaceous; pubescence mostly short, depressed and greyish, flavescent on the back of the head, on the front of thorax, and along the middle near the base, and forming about six small elytral crests, tivo of these, however, are dark at the base.

Head with very few fine punctures and a thin median carina in front, rather darker and broadly bisuleate above. Thorax oviform, verv slightly longer than broad, evidently more convex and wider at the middle than clsewhere, distinetly but not closely punctate, even less elosely just behind the middle. Seutellum yellowish, clongate, triangular. Elytra of same width as thorax at the base, fully double its length, very elongate-oval, before the middle only slightly broader than the thorax; their punctation is subseriate, as distinet as that of the thorax but a little finer towards the apices; third interstices indistincetly elevated, with an obtuse blackish crest tipued with yellow before the middle on each, and a small yellow one on top of the hind slope, half-way between these but nearer the outside there is another small yellow one.

Legs clongate: femora slender near the base, moderately clavate beyond; batsal joint of anterior tarsi hardly as broad as the second.

Antennae nearly as long as the body, their elongate third joint does not reach the thoracic base, fourth rather longer than fifth. In 1052 and 3345 the third antennal joint just passes the shoulder.

Underside dark fuscous; abdomen elongate, basal sogment in the middle double the length of the next, $2-4$ become shorter and narrower, their pubescence vellow at the extremity. Coxar fuseo-rufous. Mesosicrnal process cuneiform, tapering towards the back of the middle coxae. Prosternal process slightly arehed and obtusely carinate along the middle.

This should be placed near S. angusta (1052), which, however, has the thorax more finely and quite closely punctured. S. nodularia (3345) has a pair of smooth nodules on the thorax, and in both of these the back of the head is drpressed and ustably intensely black. The structural details of the lower surface are also very different.

Length, $5 \frac{1}{2} \mathrm{~mm}$; breadth, $1 \frac{2}{3} \mathrm{~mm}$.

Wadestown, near Willinenton. One, forwarded on the Loth August, 1916. by Mr. A. C. O'Connor, after whom it is named.

\section{Somatidia commoda sp. nov.}

Robust, only moderately convex. without in 'qualities, subnitid; cupreofarenes the tibian, exeept at the hase: and tarsi fulvescent, basal three joints of antmone rufescent, remaining ones paler but not distinctly spotted; 
pubescence vellowish, decumbent, irregularly disposed on the elytra, the ereet setae slender.

Head nearly as broad as thoracic apex, almost plane between the antennae, with a few punctures. Thorax very"slightly broader than long. rounded and widest near the front, gradually narrowed behind the middle; distantly, irregularly, and moderately coarsely punctured. Scutellun triangular. Elytra subelongate-oval, posterior declivity vertical below the middle, they are $2 \frac{1}{2}$ times the length of thorax, and just perceptibly narrower than it is at the base, the punctation like that of the thorax but more seriate ; the lateral space behind each shoulder, the fascia across the top of the declivity, and the suture below it, though darker than the rest of the surface, are not sharply defined.

Antemnae with fine greyish pubeseence above and many longer hairs underneath; they hardly reach the end of the elytra, the third joint just attains the shoulder, the fourth is uot discernibly longer than fifth.

Femora slender at the base but very strongly clavate beyond, the anterior particularly.

Underside cupreo-fuscous, with slender, elongate grey pubeseence. Basal ventral segment in the middle rather longer than the following three together, fourth somewhat incurved behind, fifth rather longer than fourth, subtruncate, sixth very short, slightly emarginate.

Fem.-Thorax rather shorter, less strongly rounded near the front, with more punctures, femora much less clavate. Fifth ventral segment closely and finely punctate, with a broad shallow groove behind, notehed at the apex, longer than preceding two. $5 \frac{1}{2} \times 2 \frac{1}{2} \mathrm{~mm}$.

The femora are similar to those of $S$. oedemera, but the general appearance is more like that of S. crassipes (1438), which, however, is longer and flatter $\left(7 \times 2 \frac{1}{2} \mathrm{~mm}\right.$. $)$; its thorax is a fourth broader than long and less gradually narrowed behind the middle, the posterior declivity is less abrupt, the fourth antennal joint is rather longer than the fifth, and the fifth rentral segment is longer than the preceding two combined and medially emarginate at the extremity.

3. Length, $6 \mathrm{~mm}$.; breadth, $2 \frac{1}{2} \mathrm{~mm}$.

Trentham, near Wellington. The male was discovered by Mr. T. Hall on the 13th November, 1916, just before he embarked for Europe as a volunteer of the 19th Reinforcement, but he had previously secured two females whilst in training at Tanherenikau on the 17th September, 1916.

\section{Group Lumolpidae:}

\section{Peniticus Sharp. Man. N.Z. Coleopt., p. 626.}

\section{Peniticus plicatus sp. nov.}

Convex, oviform, glabrous, nitid ; irregularly fuseous and testaceous; the legs, antennate middle of thorax, the elytral streaks and apices of the latter hue.

Head dark, fincly and unevenly punctured. Thorax a third loroader than long, apex truneate, the base nearly so. wirlest and rounded at the middle, more narrowed in front than behind, anterior angles deflexed. the posterior distinetly prominent and with a setigerous puneture at the extremity; the surface moderately. irregularly, and rather distantly punctate. Scutelium large. smooth. Elytra truncate and of the same width as thorax at the bisse, fully twice its length, rather broader near the hind thigh: than elsewhere, considerably narrowed and deflexed posteriorly ; distinctly 
subseriate punctate, more irregularly at the batse, substriate behind; fifth ntristices with, on aach, an clongate raised plical ending in at slight depression before the midelle, the rematining portion continued batekwards but less whated and becoming obsolete near the extremity, there is another elongate plica ontside the first but fartber from the base, the outer interstices are slightly elevated and interrupted.

Antemae longer than the head and thorax, stout, second joint small, scarcely any longer than broad, 3-11 subequal, fourth not shorter than third.

Underside coppery brown, with depressed, slender grey pubescence. Basal ventral segment about as long as the following three united, subtrunarte between the coxae. fourth slightly incurved behind, in the middle about half the length of third; fifth paler, rather longer, somewhat bisinuate at the apex, sixth as long, concave in the centre, broadly rounded behind but not reaching the elytral apices.

Ilore clomgate-oval thin the type of the gentes (1101), and at enee distinguishable from it, as woll as $P$. antiques. byo its projecting pesterior angles of the thorax, which are like those of the larger P'. robustus (1103).

Length, $5 \mathrm{~mm}$. ; breadth, $2 \frac{1}{2} \mathrm{~mm}$.

Silverstram, neat Wellington. One example, from Alr. A. C. O'Comme; 31 st October, 1916.

\section{Group Chrysomelidae.}

Aphilon Sharp. Man. N.Z. Coleopt., p. 629.

\section{Aphilon sternalis sp. nov.}

Convex, subrotundate, glabrous, shining; aeneo-niger ; legs, antennac, and palpi testaceous.

Head finely and distantly punctate, obliquely bi-impressed behind. Thorax not twice as broad as long, widest at the somewhat rounded base, its sides finely margined. gradually but hardly at all curvedly narrowed towards the subareute front angles, atpex finely margined and distinetly inetirved, posterior angles acutely reetangular; dise distantly and lightly punctured, apparently almost smooth near the sides and base. Seutellum triangular, flat and smooth. Elytra just double the length of thorax, of the same width as it is at the base : distinctly but irregularly seriate-puncetate, the imner row on each searcely extending be yond the middle, all become less distinct buhind, almost obsolete in the female, interstices irregularly and more finely punctured.

Tibiae fincly setose, shightly curved "xternally, a little expanded towards the extremity; basal joint of all the tarsi evidently enlarged, that of the anterior suberdate, the others more oblong, the penultimate bilobed.

Anteunae as long as head and thorox, basal joint stout, rnther longer than the mext, joint s 3-6 elongate and slender, the others gradually thickened. eleventh largest, oblong-oval.

Underside aeneo-niger, with some short, slender greyish hairs, which are more numprous on the paler fifth semment. Mesostermum very short, aroused across the middle, its front margin feebly angulate there. Metastrenum rather coitrisely punctate ; sixth segment short and indefinite.

The interocular impressions, smooth-looking thorax. and coarsely punctured metasternum, taken together, are distinetive.

$\hat{o}$. Length, $3 \frac{1}{3} \mathrm{~mm}$. ; breadth, nearly $2 \frac{1}{2} \mathrm{~mm}$.

Titirangi. Auckland. Ir. 1. E. Brookes found a pair on the 3rd June, 1916, and retains the female. 
Caccomolpus Sharp. Man. N.Z. Coleopt., p. 1308.

\section{Caccomólpus montanus sp. nov.}

Convex, broarlly oval, glabrous, nitid ; black, palji, antennae, and legs castaneo-rufous.

Head, and eyes, nearly as broad as thoracic apex; plane, finely and slightly rugosely punctate on the middle. 'Thorax finely margined and incurved in front, with slightly obtuse angles, its sides more distinctly margined, gradually narrowed from the rectangular posterior angles to the apex, its breadth more than twice the length: its punctation irregular, moderately fine, distinet on the dise, almost absent near the sides, closer across the base. Scutellum subtriangular, smooth. Elytra of the samo width as thorax at the base, just thrice its length, well margined; they are distinctly, subseriately punctate, interstices irregularly, more finely and distantly, the basal punctures near the sides are usually rather coarser, but the sides are almost smooth; with the exception of a male, the rufescent pygidium is quite exposed and bears some short greyish hairs.

Antennae slightly longer than head and thorax, finely pubescent, moderately slender, gradually dilated towards the extremity ; basal joint stout, subpyriform, the next slightly longer than broad; joints 3-5 longer, more slender than following ones, the terminal elongate-oval, longer than tenth.

Tibiae broadly grooved, the anterior curved externally, the others, especially the intermediate, obtusely angulate below the niddle, more slender above than at the extremity, where they are finely seulptured and pubescent. Basal joint of tarsi enlarged, (longate-cordate; second small and transverse, third rather longer, bilobed.

Underside shining, aeneo-niger, distantly punctate, with some fine short greyish hairs. Fifth ventral segment shorter than the basal but as long as the preceding three together. subtruncate and finely margined behind; sixth short and broad, concave in the middle. Prosternal precess margined, truncate behind, its subacute angles extending laterally behind the coxae. Mesosternum with its fine front margin slightly curved, with a 1 ransverse groove between it and the thicker hind one. Epipleurae nearly smooth, very broad but quite linear at the extremity.

The sixth ventral segment and exposed pyoidium are unusual characters. o. Length, $5 \mathrm{~mm}$. ; breadth, $3 \mathrm{~mm}$.

Mount St. Arnaud, Nelson. Four examples, two of each sex, found by Mr. T. Hall on the 15th June, 1916.

Marcos F. Makks, Government Printer, Wellington-1921.

$[400 / 8 / 21-13255$ 



\title{
NEW ZEALAND INSTITUTE.
}

\author{
B ULLETIN No. 1.
}

\section{DESCRIPTIONS}

OF

\section{NEW SPECIES OF COLEOPTERA.}

PART YIII.

BY MAJOR 'I'. BROUN, K'T.L.H., F.E.S.

EDITED AND PUBLISHED UNDER THE AUTHORITY OF THE BOARD OF GOVERNORS OF THE INSTITUTE.

ISSUED 1st MARCH, 1923.

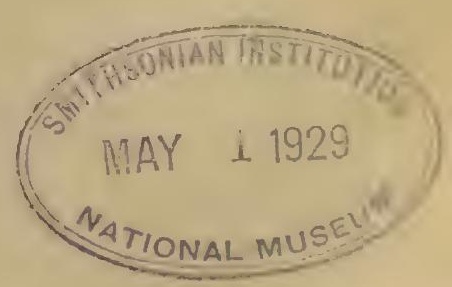

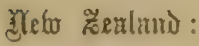

W. A. G. SKINNER, GOVERNMENT PRINTER, WELLINGTON,

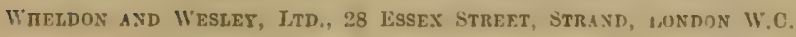




\section{NEW ZEALAND INSTITUTH}

\section{BULLETINS.}

Under the title "Bulletins" the Board of Governors of the New Zealand Institute hopes to issue, from time to time, important papers which for any reason it is deemed desirable not to include in the yearly volume of the Transactions. The bulletins will be uniform in size and general style with the Transactions of the New Zealand Institute, but will appear at irregular intervals, and each bulletin will be complete in itself and be separately paged. The bulletins will not be issued frec to nembers of the Institute, but may be obtained by them at a reduction on the published price. 


\title{
NEW ZEALAND INSTITUTE.
}

\author{
BULLETIN No. 1, PART VIII.
}

ISSUED 1ST MARCH, 1923.

\section{E S C R I P T I O N S}

OF

\section{NEW SPECIES OF COLEOPTERA.}

By Major T. Broun, Kt.L.H., F.E.S.

\section{PART VIII.}

HAving been personally elosely acquainted with the late Major T. Broun and his work for a number of years past, Mrs. Broun and her daughters the Misses Broun have placed in my hands his last manuscripts for systematic arrangement and numbering, so that the descriptions of the new species which form the subject of this paper could be placed in the Printer's hands for publication.

The present paper does not record any new genera, but 68 species are described as new to science. This now brings the total of the known New Zealand beetles to 4,323 species - a rather remarkable number when we consider the isolated geographical position of the Islands.

One species (Recyntus reitteri) included in this paper had been described by Dr. Sharp as far back as 1882 , but had been overlooked, and in consequence inadvertently omitted from previous lists.

This paper concludes practically the life's work of a very able scientist, whose love of nature, and enthusiasm in his work on the New Zealand Coleoptera, has gained for him a position in the first line of the world's entomologists. His unique collection of New Zealand beetles. 
containing as it does the types of about 3,500 species described by himself, as well as numerous specimens of species described by various other authors, will for ever stand as a monument to his zeal and untiring devotion to scientific research, and should be ereatly apjoreciated by all students of New Zealand Coleoptera.

The descriptions contained in this paper are entirely the work of the late Major T. Broun, with the exception of Quedlius ohiaensis, which, unfortunately, was only partly described, and neessitated the writer completing it. If any errors should oceur in the systematic arrangement of the species I must accept full responsibility.

The following gentlemen contributed material for the preparation of this paper: The late Mr. T. Hall, 21 species; Mr. A. C. O'Connor, 13; Mr. G. V. Hudson, F.E.S., 4; Mr. A. Philpott and Mr. J. Ford, 2 each; Professor Hilgendorf, Mr. L. T. Griffin, F.Z.S., the late Mr. Hehms, and Mr. H. Hamilton, 1 each; and the writer, 22.

In conclusion, I wish to express my grateful appreciation of my late friend's kindness in supplying me with much valuable aid and information, at all times very generously and considerately extended to me whenever required.

Okauia, Matamata, Waikato,

Albert E. Brooks.

1st August, 1921. 


\section{IIST OF NEW SPECIES.}

Cnemacantimane.

4255. Mecodema validum Broun.

4256. " occiputale Broun.

4257. " cassense Broun.

4258. " antenriale Broun.

4259. " longricolle Broun.

4260. " philpotti Broun.

4261. " ventriculum Broun.

4262. " " subaeneum Broun.

\section{Feronidae.}

4263. Pterostichus truncatulus Broun.

\section{Pogonidae.}

4264. Tarastethus eplicatus Broun.

4265. ", fuscipes Broun.

4266. $\quad, \quad$ insularis Broun.

\section{TACHYPORIDAE.}

4267. Conurus morosus Broun.

4268. ", antennalis Broun.

4269. " seminudus Broun.

StAPHYLinidae.

4270. Quedius badius Broun.

4271. " " bryocharis Broun.

4272., maorinus Broun.

4273. " ohiaensis Broun.

4274. $"$ slipsensis Broun.

Pederidat.

4275. Hyperomma flavipes Broun.

Pselaphini.

4276. Pselaphus cavidorsis Broun.

Brachyolutint.

4277. Byraxis acceptus Broun.

Silphudae.

4278. Isocolon oruruensis Broun.

\section{SYNCHITIDAE.}

4279. Ulonotus affinis Broun. 4280. ", aemulus Broun. 4281. Gathocles fuscus Broun. 4282. " interruptus Broun. 4283. Syncalus solidus Broun.

4284. Recyntus reitteri Broun.

\section{Aesalinae.}

4285. Mitophyllus insignis Broun.

\section{Clemidae.}

4286. Phymatophaea hudsoni Broun. 4287. 4288. 4259 .

nigricornis Broun.
$" \quad$ brericollis Broun.
formosa Broun.

\section{Anthioidae.} 4290. Cotes halliana Broun. 4291. " bullata Broun.

OTIORHYNCIIDAT. 4292. Catoptes apicalis Broun.

RHYPAROSOMIDAE.

4293. Lithocia stictica Broun.

4294. Clypeorhynchus bifoveatus Broun.

HYLOBIDAE.

4295. Bryocatus plicatus Broun.

4296. " crassipes Broun.

4297. ", angustus Broun.

4298. " " fordi Broun.

4299. " diversus Broun.

4300. " " thoracicus Broun.

4301. " " ovipennis Broun.

Haplonychid AE.

4302. Geochus rufipictus Broun.

CYLINDRoRHINIDAE.

4303. Homodus posticallis Broun.

4304. " Inngicornis Broun.

4305. $\quad$;, cuprealis Broun.

\section{Frirhinidae.}

4306. Erirhinus obscurus Broun.

4307. " subconicollis Broun.

4308. " " poecilus Broun.

4309. Etheophanus optandus Broun.

4310. " nitidellus Broun.

4311. " " cbscurus Broun.

\section{Apionidae.}

4312. Apion terricola Broun.

\section{CRyptorhyNChIDAE.}

4313. Acalles brookesi Broun.

4314. Sceloitolichus decorus Broun.

4315. " pyriformis Broun.

4316. Hatasu tuberusa Broun.

\section{LAIIIDAE.}

4317. Xylotoles a picalis Broun.

4318. " " pygmaeus Broun.

4319. Somatidia fulvipes Broun.

4320. ", crassicollis Broun.

\section{HaLTICINAE.}

4321. Trachytetra frontalis Broun.

4322. " robusta Broun.

4323. Plyyllotreta paspaliae Broun. 


\section{Group Cnemacanthidae.}

Mecodema Blanchard. Man. N.Z. Coleopt., p. 7.

4255. Mecodema validum sp. nov.

Flongate, slightly convex, head and thorax nitid, elytra subopaque; black, palpi, antennae, and legs piceo-rufous.

Head finely punctate behind the moderately prominent eyes, longitudinally rugose near these and on the forehead, the vertex feebly transversely and irregularly rugose. Thorax apparently elongate, very little broader than long, widest near the front, curvedly narrowed towards the base, which has straight sides and obtusely rectangular angles; mareinal ehamnels almost equally narrow, the sides indistinctly crenulate; anex slightly and widely emaruinate, base subtruncate, a little rounded towards its angles; discal stria distinct, not attaining either base, or apex, deepened and somewhat expanded at its extrenities, the surface nearly smooth, with only faintly marked striae across it, those near the sides rather more distinct, the usual frontal and basal longitudinal striae almost obsolete, basal fossae moderately large. Elytra oblong-oval, nearly thrice the length of thorax, rather broader than it is near the middle, with numerous very fine irregular linear impressions; the four finely punctured inner striae hardly reach the extremity, the fourth is the shortest, these striae, the third and fourth particularly, are broader and deeper near the base so that the interstices become quite costiform there; the sixth interstice is narrower and more convex throughout and has three or four punctures on or near it, and the broader interval between it and the fifth has double series of punctures, the outer the coarser; the smooth lateral costa does not reach either base or apex. and between it and the sixth interstice the duplicate series of punctures are rather deeper, none, however, very coarse.

Underside shining black, the prosternum with a few shallow rugae across the middle, its flanks irregularly punctate in front, its process concave along the middle, mesosternum rugose-junetate, metasternum less distinctly so, abdomen finely irregularly strignse, its last segment quadripunctate at the apex.

This most nearly resembles $M$. acuductum (2602), but is larger, with much more complex alytral sculpture, and, moreover, the thoracic margins are not distinctly crenulate.

Length, $30 \mathrm{~mm}$. ; breadth, $9 \mathrm{~mm}$.

Ohakune, 30th December, 1916. One specimen only; found by Mr. A. E. Brookes, of Mount Albert.

\section{Mecodema occiputale sp. nov.}

Elongate, slightly convex, moderately nitid; black, antennae, palpi, and tarsi rufo-piceous.

Head narrower than thorax, nearly smooth, with a pair of shallow median punctures between the very prominent eyes, alongside each of the latter there are two or three moderate longitudinal rugare and a single dere setigerous puncture; the back part appears depressed and is rather sharply limited by a slightly curved stria extending from the hinder portion of one eye to the other; the frontal rugae are inconstant, but the common punctures on the labrum are well marked. Thorax a sixth 
broader than long at the middle, a good deal rounded but evidently contracted and straight-sided at the base, lateral channels narrow, the margins hardly at all crenulate, base and apex a little incurved; its surface almost smooth, discal stria distinct but not reaching the apex, the usual curvate frontal transverse impression is scarcely visible except near the angles; basal fossae deep, rather narrow, extending to the base, with well-defined margins. Elytra oblong-oval, slightly broader than thorax, nearly thrice its length; regularly punctate-striate, their three outer striae deeper and more distinctly, but not very coarsely, punctured than the inner five, and their interstices rather narrower and more convex, the sculpture more irregular behind, the space outside the eighth stria is smooth but does not reach the shoulder, marginal punctation similar to that of the nearest stria.

Underside almost quite smooth; the last ventral segment at the apex bipunctate at each side of the middle.

The very definite frontal limitation of the occiput is its chief characteristic.

Length, $23 \mathrm{~mm}$.; breadth, $7 \mathrm{~mm}$.

Tokaanu. Two sent (one damaged) by Mr. A. C. O'Connor on the 6th April, 1918.

\section{Mecodema cassense sp. nov.}

Shining, slightly convex; black, the antennae, palpi, labrum, legs, and trochanters rufescent.

Head nearly smooth, with moderate inter-ocular rugae, the longitudinal ones on the forehead, and the setigerous punctures on the labrum well marked. Thorax a sixth broader than long, widest near the front, gradually curvedly narrowed backwards, more and subsinuously narrowed near the obtuse basal angles; lateral margins entire, the channels narrow but slightly expanded in front, base and apex a little incurved; disc almost smooth, without visible apical or basal striae, the central groove moderate, abbreviated at both extremities; basal fossae deep, subrotundate, rather small and situated close to the angles. Elytra oblongoval, slightly broader than thorax, 21 times its length; the four inner striae on each are slender and almost impunctate, rather deeper at the base, with plane interstices; the outer are deep, the seventh and eighth though not very coarsely, are closely and more distinctly punctured than the sixth, with narrower and more convex interstices, apical sculpture irregular; the usually smooth lateral space has four or five punetiform impressions.

Underside glossy black, nearly quite smooth, terminal rentral segment at the extremity with two distinct punctures, and two others, close together, nearer each side. Outer angles of front and middle tibiae distinctly prominent.

Fem.-Less glossy. Terminal ventral segment truncate behind, with four almost equidistant punctures there. Length, $21_{2}^{1} \times 6 \mathrm{~mm}$.

Nearly allied to 11 . cognatum (2603), but with more outstanding eres, smoother thorax, much finer elvtral sculpture, more asperate intermediate tibiae, and differently marked terminal ventral segment.

o. Length, $23 \mathrm{~mm}$.; breadth, $7 \mathrm{~mm}$.

Cass, Canterbury side of West Coast railway, amongst tussock-grass. One of each sex, both damaged, sent by Professor Hilgendorf on the 23rd July, 1917, and 4th January, 1918. 


\section{Mecodema antennale sp. nov.}

Nitid, black, legs and antennae piceous.

Rather broader than $M$. cassense and, though very similar thereto, differing in having only a single groove alongside ach eye. The antennate are notably thicker. The basal fossae of the thorax are deeper, more (longate, and extend to the base, where they are more definitely marginate. The sixth elytral striae are deeper than the inner ones but are not as distinctly punctured as those of $M$. cassense, and the seventh interstices are sometimes coarsely tripunctate. The last abdominal segment has only four apical punctures.

Length, $24 \mathrm{~mm}$; ; breadth, $7 \frac{1}{2} \mathrm{~mm}$.

Gordon's Pyramid, Mount Arthur; 4,500 ft. Found by Mr. A. C. O'Connor on the 13th January, 1918.

\section{Mecodema longicolle sp. nov.}

Elongate and narrow, slightly convex; nitid, black, antennae and tarsi piceous, palpi more rufescent.

Head, including the prominent eyes, nearly as broad as thorax, irregularly rugose near the eyes, with numerous moderately coarse punctures behind them, the frontal longitudinal grooves deep; labrum rather short. Thorax almost as long as broad, its sides only slightly rounded, narrowed, but not at all abruptly, towards the obtuse hind angles, its base medially emarginate and obliquely curved outwards, lateral channels slightly expranded behind the middle, the margins obsoletely crenulate, apex subtruncate; disc finely irregularly transversely striate, the apical and basal longitudinal striae indistinct, the central groove well marked and verv nearly reaching both base and apex, posterior foveae small and shallow, situated close to the angles. Elvtra elongate-oval, 2.1 times the length of thorax, a fifth broader; moderately subseriate-punctate, some of the punctures rotundate, others elongate, the usual smooth lateral space on each somewhat indefinite.

Underside shining; flanks of prosternum moderately elosely punctate, basal segments of the abdomen with a few shallow punctures, the terminal finely transversely striate and, at the extremity, with a pair of punctures on each of the middle; mesosternum densely rugose-punctate.

Antennae distinctly pubescent from the fifth joint onwards. Anterior and middle tibiae slightly prominent at the outer extremity.

This, though somewhat similar to Sharp's M. metallicum (1760), a Greymouth species, may be at once separated therefrom by the absence of any well-marked basal contraction of the thorax, which, moreover, in 1760, has nearly straight sides, and by its longer and more coarsely sculptured elytra.

Length, $17 \mathrm{~mm}$.; breadth, $5 \mathrm{~mm}$.

Mount Egmont. A single damaged individual, found by Mr. G. V. Hudson at an elevation of $3,000 \mathrm{ft}$.

\section{Mecodema philpotti sp. nov.}

Elongate, moderately convex and nitid; black, antennae and legs piceous, palpi with rufescent tips.

Head, excluding mandibles, almost as long as thorax, not much narrower, nearly smooth along the middle, each side broadly longitudinally depressed and evidently irregularly rugose, the frontal sulci well marked, those near the eyes somewhat irregular; the transverse area behind the eyes is rather closely and moderately finely punctate, the occiput feehly 
and irregularly wrinkled. Eyes moderately prominent, the genae somewhat swollen behind them. Thorax only a sixth broader than long, its sides slightly crenulate and flattened, gently eurved to behind the middle and sinuously narrowed towards the obtusely rectangular basal angles; discal groove distinct, not attaining the feebly emarginate base or apex, the common longitudinal striae obsolete near the latter, the basal ones distinct; the surface with fine transverse striae, more feebly impressed before the centre than elsewhere; posterior fossae rather elongate and deep, extending to the basal margin and distinctly wrinkled, near each anterior angle there is an impunctate transverse impression. Elytra elongate-oval, 2.1 times the length of thorax, only a little broader than it is near the middle; they are rather finely punctate-striate, third and fifth interstices rather broader and more convex than the second, fourth and sixth narrow and convex, seventh as convex as fifth but narrower, with four or five more or less obvious punctures, the usual smooth lateral space on each is narrow and not distinctly marked off from the series of marginal punctures.

Antennae stout, evidently pubescent from their fourth joint onwards.

Flanks of prosternum closely and moderately fincly punctate, the rest of the lower surface, except the closely sculptured mesosternum, irregularly and finely striate, the last abdominal segment quadripunctate at its extremity.

Length, $30 \mathrm{~mm}$. ; breadth, $9 \mathrm{~mm}$.

Bluff. A damaged specimen, picked up dead, on the 1st December, 1914, by Mr. A. Philpott, whose name has been attached to it. The elytral sculpture is distinctive.

\section{Mecodema ventriculum sp. nov.}

Elongate, slightly convex and nitid; black. Antennae and legs nigropiceous, tips of palpi rufescent.

Head nearly as broad as front of thorax, forehead smooth, coarsely longitudinally rugose near the moderately prominent eyes in front, punctate right across behind these, the occiput with distinct irregular linear impressions; labrum rounded in front. Thorax very slightly broader than long, wider near the middle than elsewhere, incurved at apex, lateral margins only moderately rounded and crenulate, abruptly narrowed towards the subrectangular posterior angles; disc almost smooth on the middle, irregularly transversely striate towards the sides, with numerous short frontal and basal striae, the central groove well marked but hardly attaining the base or apex, basal foveae deep, not quite reaching the hind margin. Elytra slightly broader than thorax, twice its length, finely marginate, strongly curvedly narrowed behind; their sculpture very irregular, each indefinitely biseriate-punctate alongside the suture, with unequal, prineipally large foveiform impressions towards the sides, marginal punctation much finer and closer.

Underside shining. Prosternum smooth along the middle, broadly and deeply sulcate between the coxae, its flanks closely rugose-punctate, as are those of the mesosternum. Sides of metasternum and basal ventral segment moderately punctate; fourth segment finely transwersely strigose at the base, with several short rather deep, longitudinal apical striae which almost obliterate the pair of setigerous punctures at each side.

This may be placed near $M$. venator (1452).

o. Length, $25 \mathrm{~mm}$; ; breadth, $8 \mathrm{~mm}$. F.E.S.

Nelson. A single male specimen received from Mr. G. V. Hudson, 
4262. Mecodema subaeneum sp. nov.

Elongate, slightly convex, shining arneo-niger: palpi, antennas, and tarsi piceous.

Head narrower than thorax, constricted and evidently punctate behind the prominent eyes, the forehead distinetly longitudinally striate, somewhat rugose near the eyes, labrum subtruncate in front; mandibles moderately wrinkled. Thorax only slightly broader than long, rather more cmarginate at the base than the apex. its sides finely margined, not distinctly erenulate, only slightly wider before the middle than elsewhere, moderately contracted near the obtuse basal angles; dise nearly smooth in front, only slightly transversely striate behind, longitudinally at the base; dorsal furrow well marked but obsolete at the apex, basal fossae narrow and placed close to the sides. Elytra oblong-oval, a third longer but only slightly broader than thorax, with distinct margins; irregularly seriate-punctate, the inner series rather finer than those towards the sides.

Underside nitid, mesosternum and flanks of prosternum distinctly punctate, terminal ventral segment bipunctate near each side of the apex.

Basal four joints of antennae almost glabrous, all the palpi truncate at the extremity. Mentum finely bidentate in front. Basal three joints of anterior tarsi moderately prominent externally, posterior tibiae not expanded at the extremity.

Most nearly resembles $M$. aeneoniger from Mount Maungatua, but in 1453 the palpi are more slender, the foveae of thorax are broader and (evidently punctate, the elytra are much more finely and distantly sculp)tured, the outer angles of the intermediate tibiae are more prominent, and the whole surface is more glossy.

o. Length, $19 \mathrm{~mm}$. ; breadth, $5 \frac{1}{2} \mathrm{~mm}$.

Martinborough. A single specimen from Mr. A. C. O'Connor.

\section{Group Feroninat.}

Pterostichus Bonelli. Man. N.Z. Coleopt., p. 31.

4263. Pterostichus truncatulus sp. nov.

Elongate, slightly convex, nitid; black, elytra faintly rufescent, palpi and tarsi piceous.

Head narrower than thorax, smooth, frontal impressions well marked; labrum widely emarginate. Eyes prominent. Thorax only slightly broader than long. widest hefore the middle, its sides distinctly and equally marginate, gradually curvedly narrowed and feebly sinuate towards the rectangular posterior angles, base less widely incurved than the apex; surface almost smooth, central groove nearly attaining the front and base; basal fossate deep), rather elongate, situated nearer the sides than the middle and not reaching the hind margin. Elytra elongate-oval, nearly a third broader than thoma, alnost thrice its lenegth, the shoulders dentiform and slightly broader than the thoracic base, apices broadly truncate; each elytron with seron dethite, apparently impunctate strias: interstices nearly plane, the third inner not quite as wide as the others, the lateral punctiform sculpture irregular.

This belongs to the section having the sides of the thorax bisetose. 'The scutellum is only obsoletely striate. The terminal ventral segment is hijumetale at dach side of the middle at the apex. The somewhat externally 
asperate intermediate tibiae, and remarkable truncature of the elytral apices, render its identification comparatively easy. It should be placed near 1171.

우. Length, $21 \mathrm{~mm}$. ; breadth, $7 \frac{1}{2} \mathrm{~mm}$.

ILount Owen, Nelson; 26th December, 1916. The unique specimen bas been left unnamed in the hope of obtaining the male, but as its discoverer, Ir. T. Hall, one of our gallant volunteer soldiers, was killed in action in France on the 20th August, 1917, we are not likely to see the male during my lifetime.

\section{Group Pogonidae.}

Tarastethus Sharp. Man. N.Z. Coleopt., p. 1003.

\section{Tarastethus eplicatus sp. nov.}

Convex, nitid; black, apical portion of elytra, the labrum, and mandibles more or less rufescent, antennae and palpi testaceous.

Head smooth, eyes moderately large and prominent; labrum transversely quadrate, finely sex-punctate and setigerous in front. Thorax nearly a third broader than long, its sides distinctly margined and rounded, widest at the middle, more gradually curved towards the somewhat projecting posterior angles; discal groove well marked but not attaining the apex, basal fossae large and broad and; like the space between them, distinctly and moderately closely punctate. Elytra a fourth broader than thorax, fully double its length, strongly margined at the base and sides, these latter moderately rounded; the two inner striae on each are rather deeper than the others, the external ones are obsolete, their punctation is rather fine and becomes indistinct behind: interstices nearly plane, the sutural much narrower than adjoining ones, the third unipunctate before the mirdle, the common subapical plicare are obsolete.

Underside shining, posterior trochanters testaceous, abdomen with a few longitudinal linear impressions but without punctation.

T. amplipennis (3170) is very similar in many respects. T. eplicutus, however, is considerably smaller but relatively broader, its eyes are more prominent, the elytral striae are not as deep or broad, and the interstices are less convex. The ocular and thoracic setae are alike in both species, neither las setae at the hind angles.

․ Length, $5 \mathrm{~mm}$.; breadth, $2 \frac{1}{3} \mathrm{~mm}$.

Pakarau, 19th May, 1918. One female discovered there by Mr. A. E. Brookes, of Mount Albert, who also submitted for insuection a second female taken at Kaingaroa.

\section{Tarastethus fuscipes sp. nov.}

Shiningr piceo-nicer : palpi, antemnae, and tarsi fulvescent, legrs chestnut red but with the tibiae infuscate along the middle.

Head shorter than thorax, quite half its width, impunctate, with deel elongate interocular grooves. Thomax slighty broader than long, base and apex truncate, with distinct lateral margins, wirdest at the middle. moderately sinuate behind, posterior angles rectangular, the anterion. somewhat depressed: discal groove expanded behind hut not attaining the base or apex. basa! punctures numerous. irrecular. and extending from one angle to the other, so that the moderately deep foveae are somewhat indefinite. Scutellum obsolete. Elytra oviform, convex, with distinct 
rufescent margins and apices, double the length of thorax and a third broader at the middle; the inner pair of striae, on each elytron, moderately definite and distinctly punctured, the other series of punctures are finer, those near the sides obsolete; posterior carinae rather fine.

Underside nitid. Middle of mesosternum coarsely bipunctate at each side of the slender central carina. Sides of ventral segments with large impressions, the terminal bipunctate and setose at each side of the middle at the apex.

Previously set aside as a varietal form of Sharp's 7 . laeviventris (1800), but when more carefully examined found to be dissimilar. The sculpture differs, and the thoracic setae are absent.

Length, $5 \mathrm{~mm}$. ; breadth, $2 \frac{1}{3} \mathrm{~mm}$.

Belgrove, near Nelson. Discovered by the late Mr. T. Hall on the 24th October, 1914.

\section{Tarastethus insularis sp. nov.}

Nitid, nigrescent, legs and elytral margins dark reddish, antennae and tarsi fulvescent, palpi paler.

Head evidently narrower than thorax, smooth, with the common interocular sulci. Thorax slightly broader than long, widest and rounded near the middle, distinctly margined, evidently narrowed behind, but straight near the rectangular posterior angles, base and apex truncate; dorsal stria not reaching the apex or base, the latter moderately closely punctate, the usual foveae short but not sharply defined. Scutellum invisible. Elytra oviform, well margined, more convex than the thorax, almost twice its length, slightly broader than it is at the base, not double its width at the middle; they are moderately substriatepunctate, less distinctly so towards the sides, the series beyond the third considerably finer near the base, the subapical plicae rufesent and distinct. Terminal ventral segment bisetose at the extremity.

After comparison with several other species I fail to find any that are exactly similar.

Length, $5 \frac{1}{2} \mathrm{~mm}$. ; breadth, quite $2 \frac{1}{2} \mathrm{~mm}$.

Chetwood Island. Described from a female found by Mr. A. C. O'Connor during July, 1917.

\section{Group Tachyporidae.}

Conurus Stephens. Man. N.Z. Coleopt., p. 96.

\section{Conurus morosus sp. nov.}

Elongate, subopaque, without perceptible sculpture; clothed with decumbent dark ashy pubescence, the hind-body with many nigrescent outstanding setae; nigro-fuscous, basal two joints of the antennae fulvescent.

Head as broad as front of thorax, obliquely narrowed anteriorly. Thorax mather broader than long. very gradually narrowed towads the truncate apex, the base subtruncate, with obtuse angles. Elytra a third longer than thorax, not quite as wide as it is at the base, straight-sided, apices obtusely rounded towards the suture, with fine shallow indistinct punctures. Hind-body with pale apical margins. 
Antenmae longer than head and thorax, second joint a little shorter than contiguous ones, fourth slightly longer than third, joints 5-10 gradually expanded and shortened, subtriangular, the terminal subconical. Maxillary palpi fuscous.

Easily recognizable by its elongate elytra and dark subopaque surface. Length, $4 \mathrm{~mm}$.; breadth, $1 \frac{1}{2} \mathrm{~mm}$.

Rotoiti; 28th December, 1915. A single individual found by the late Mr. T. Hall.

\section{Conurus antennalis sp. nov.}

Subopaque, rufo-castaneous, the mandibles, palpi, antennae, and legs of a lighter hue; covered with slender, depressed, pale ashy pubescence, the hind-body with numerous dark elongate setae.

Thorax a third broader than long, gently curvedly narrowed anteriorly, somewhat bisinuate in front so that the angles appear subrectangular, the base subtruncate, its obtusely rectangular angles slightly broader than shoulders, without distinct sculpture. Elytra a third longer than thorax, very slightly narrowed backwards, their apices slightly oblique towards the sutures. Eyes inwardly truncate above, prolonged obliquely downwards.

Antennae rather longer than head and thorax, second joint about a third shorter than the adjoining ones, joints $3-5$ about equally elongate, sixth slightly longer than broad, 7-10 rather shorter and broader, the terminal subconical, larger than preceding ones.

Nearly related to $C$. austerus (178), but readily distinguishable by the antennal structure.

Length, $4 \mathrm{~mm}$. ; breadth, $1 \frac{2}{3} \mathrm{~mm}$.

Hunua; 1st January, 1916. Mr. A. E. Brookes, of Mount Albert, is the discoverer.

\section{Conurus seminudus sp. nov.}

Shining, rufo-piceous; antennae and tarsi pale fuscous, but the former with the basal four joints, as well as the palpi, more testaceous; hind-body with fine ashy pubescence and dark slender setae, the rest of the surface glabrous.

Head with a few minute, hardly discernible, distant punctures. Eyes subrotundate. Thorax a little broader than long, gradually curvedly narrowed towards the front, slightly sinuated near the subrectangular angles, its base subtruncate, with similar angles: smooth on the middle, finely and indistinctly punctured near the sides. Elytra of about the same width and length as the thorax, slightly narrowed backwards, subtruncate behind; their seulpture closer and rather more perceptible than that of the thorax.

Antennae about as long as the head and thorax, basal four joints almost equally elongate, the next rather shorter and stouter, joints 7 -10 shorter and rather broader, eleventh suboblong.

The small size and uniformly dark shining surface are distinctive.

Length, $2 \frac{3}{4} \mathrm{~mm}$. ; breadth, $1 \mathrm{~mm}$.

Belgrove; 24th October, 1914. Another of the late Mr. T. Hall's discoveries. 


\section{Group Staphylinidae.}

Quedius Leach. Lacord., Hist. des Ins. Coleopt., Tom. 2, p. 84. 4270. Quedius badius sp. nov.

Nitid, elongate, only slightly convex; light rufocastaneous, head a little darker, hinder portion of elytra irregularly infuscate; these latter and the hind-body with subdepressid yellowish-orey pubescence.

Head subovate, as broad and long as thorax, truncate in front, the labrum short and apparently entire; with a rotundate punctiform central impression in line with the front of the eyes, hipunctate alongside these, less distinctly so behind. Eves somewhat convex, searcely half the lemeth of the sides of the heat. Thorax of equal length and breadth, its sides very finely margined and nearly straight, the apex widely emarginate so that its angles, though obtuse, appear prominent, the base morterately curved, its angles obsolete; there are two apical punctures, two or three along each side of the middle, and about four across the base. Scutellum triangular, large, its centre closely punctate. Elytra not longer than broal, slightly and qualually narrower anteriorly, the apices obligne towards the suture: their punctation not very close, moderately coarse but shallow. Hinf-hody elongate, its seulpture like that of the wing-eases, but bearing slightly longer and more slender pubescence; terminal styles long.

Antennae of about the same length as head and thorax, basal three joints almost equally elongate, t-6 gradually decrease, $7-10$ obconical, hardly any longer than broad, the terminal slightly larger, obliquely cut awav at the extremity.

Anterior tarsi short, their basal four joints broadly expanded. Underside rufo-castaneous, sixth ventral segment rounded behind.

Notwithstanding its shorter wing-cases, more convex eyes, and prominent anterior thoracic angles, this species is placed in proximity to $Q$. fuscatus (1839).

$\hat{o}$. Length, $10 \mathrm{~mm}$; ; breadth, $2 \mathrm{~mm}$.

Gordon's Pyramid, Mount Arthur; 4,500 ft.; 13th January, 1918. Mr. A. C. O'Connor obtained two exactly alike; one he retained.

\section{Quedius bryocharis sp. nov.}

Elongate, head and thorax shining aeneo-niger, elytra, legs, and antemnate castaneous, these last with paler and more rufescent basal joints ; hind-hody slightly variegated castaneo-fuscous and, like the elytra, clothed with long subdepressed, obscure yellowish pubescence.

Head oviform, not broad, as long as but narrower than thorax; bipunctate alongside each eve, and with a single puncture a little further back but not in line with the others, the back part also bipunetate; under a strong lens the surface appears densely, finely, transversely strigose. Eves oblong-oval, half the length of the sides. Labrum medially but not depply ematginate, with outstanding hlack and yollowish setar in front. Therax slighty hoader than long, broadly romeded and finely margined at the biase, with obsolete angles, its sides gently curvedly narrowed towards the truncate apex; with a pair of small apical punctures at each side of the middle, a discal pair before the middle, and about six across the base. Scutellum triangular, large. Elytra not longer than broad, rather wider than thoras behind, apices oblique fowards the suture; their sculpture moderately close but not definitely punctiform. Hind-body seulptured like the elytra. 
Antennae as long as the head and thorax, basal joint longer than second or third, joints 6-10 subquadrate. Anterior tarsi with the hasal four joints moderately expanded.

Underside pubescent, sternum blackish; abdomen castaneous, it. sixth segment longest, rounded behind, terminal styles clongate. Femora, tor)chanters, and coxae more or less testaceous.

Somewhat similar to $Q$. hirtipennis (3692) but with much less dilated anterior tarsi, differently sculptured thorax, much less briontly clothed wing-cases, \&c.

Length, $6 \mathrm{~mm}$.; breadth, $1 \frac{1}{2} \mathrm{~mm}$.

Ben Lomond; 13th March, 1914. Found on a moss-covered tree, at an elevation of $4,500 \mathrm{ft}$., by the late $\mathrm{Mr}$. T. Hall. Unique.

\section{Quedius maorinus sp. nov.}

Elongate, slightly convex; head and thorax glossy bronzed-black, elytra and hind-body pitchy-black, the latter slightly iridescent; legs piceous, the knees and tarsi more rufescent; basal joint and tips of the second and third of the antennae reddish, the others dull blackish, mandibles rufous.

Head oviform, as long as thorax, rather broader than it is in front, quadripunctate alongside each eye, bipunctate behind; labrum with long dark setae, not perceptibly emarginate, and with moderately large pale membranous frontal border. Eyes oval, only slightly convex, half the length of the hearl. Thorax almost as long as broad, widest near the finely margined slightly rounderl base, gradually narrowed and depressed towards the truncate apex, posterior angles rounded; there are about six small basal and a pair of discal punctures hefore the middle. Elytra suhquadrate, a little broader than long, slightly narrowed towards the base, apices slightly oblique towards the suture; closely and finely punctate, clothed with fine dark depressed pubescence, the suture is slightly elevated and seems to have a shallow stria at each side. Hind-body finely sculptured and pubescent. Scutellum large, triangular, punctate.

Antennae attaining the base of thorax, third joint rather longer than others, joints 4-10 successively shortened, longer than broad.

Male-Penultimate ventral segment emarginate, the paler terminal notched at the extremity. Basal joints of anterior tarsi moderately dilated.

Like $Q$. ambiguus (2704), which is distinguishable by the pair of distinct interocular punctures, longer eyes, 3 r re flavescent véstiture, rather small scutellum, and brighter abdomen.

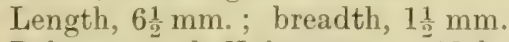

Pakarau and Kaiangaroa; 12th May, 1918. Found by Mr. A. E. Brookes, of Mount Albert.

\section{Quedius ohiaensis sp. nov.}

Elongate, nitid; black, mandibles rufescent, antennae, legs, and palpi piceous, claws testaceous.

Head oblong-oval, about a third shorter and narrower than thorax with a pair of rather fine punctures between the eyes, a pair alongside these, and about four behind them. Labrum black, short, with a deep narrow groove along the midlle. Eyes rather flat, extending half-way 
from the antennae to the back of the bead. Thorax of about equal length and breadth, of the same shape as that of Q. maorinus; along each side of the middle there are three or four punctures, two outside these, the front margin bipunctate, three or four on each side, and as many at each side of the base, all but the discal ones are very small. Scutellum large. Elytra subquadrate, slightly broader than long, each oblique towards the suture; they are finely punctate, with depressed, slender, dark ashy pubescence. Hind-body elongate, with black terminal appendages, its sculpture indistinct, the clothing like that of the wingcases. Hind-hody longer than from head to apices of elytra, last segment slightly tapering, subtruneate at extremity. Terminal appendages long. Antennae reaching back to the middle of thorax, clothed with fine dark pubescence, similar in colouring to the elytra; basal joint long, third not as long as first, second half as long as third, fourth not quite as broad as fifth. Joints 6-10 broad and of equal length, terminal longer than the preceding and tapering. Anterior tarsi castaneous, the four basal joints slightly expanded.

Length, $13 \mathrm{~mm}$; breadth, $2.5 \mathrm{~mm}$.

Taken at Lake Ohia, North Auckland, with $Q$. optatus, by A. E. Brookes on the 18th February, 1918.

\section{Quedius slipsensis sp. nov.}

Elongate, subdepressed; head and thorax nitid, aeneo-niger, with a few slender, erect, dark setae; elytra, hind-body, legs, palpi, and basal three joints of antennae castaneous, remaining joints of these last more infuscate; elytra and hind-body clothed with subdepressed yellowish pubescence.

Head oviform, as long as thorax but evidently narrower, distinetly bipunctate alongside ach eye, and obliquely so between each of the latter and the base; clypens medially emarginate and fringed with flavescent hairs in front. Eyes hardly at all convex, half the length of the head. Antennae equalling the head and thorax in length, with blackish pubescence, basal joint evidently longer than second or third, fourth and fifth rather longer than $6-10$, which are subquadrate, the terminal elongateconical. Thorax very little longer than broad, gently narrowed towards the obtuse depressed anterior angles, the base and its angles somewhat rounded, disc moderately bipunctate before the middle, quadripunctate at the base. Scutellum large, triangular, closely punctured. Elytra quite as long as broad, slightly narrowed towards the base, not broader than thorax there, apices oblique towards the suture, their punctation rather fine and shallow. Hind-body nearly half of the whole length, finely punctate, last segment strongly rounded behind, terminal appendages elongate. Anterior tarsi only moderately expanded.

Nearly allied to Q. fuscatus (1839), but readily separable by the entirely nigrescent head and thorax, differently formed antennae, less distinct elytral sculpture, \&c.

Length, $6 \frac{1}{2} \mathrm{~mm}$; breadth, $1 \frac{1}{2} \mathrm{~mm}$.

Mount Slips, Nelson. Unique. Captured by the late Mr. T. Hall on the 24th December, 1915. 


\section{Group Pederidae.}

\section{Hyperomma Fauvel.}

\section{Hyperomma flavipes sp. nov.}

Elongate, narrow, subparallel, slightly convex, nitid, with a few slender, decumbent, infuscate hairs; castaneo-rufous, legs, antennae, and palpi flavescent.

Head, excluding mandibles, oblong, with obtuse hind angles and several unequal punctures, those on the vertex minute. Mandibles nearly as long as the head, curved, each with a small inner tooth at the base. Eyes subrotundate, quite lateral, rather small. Thorax twice as long as broad, with obtuse angles; triseriate-punctate along each side of the middle, the inner series most regular, each consisting of about ten punctures. Elytra scarcely any longer than broad, with curvedly narrowed shoulders and truncate apices; irregularly subseriately punctate. Hind-body half of the whole length, closely punctate, more finely than the elytra, its terminal two segments more finely and distantly.

Antennae shorter than the head and thorax.

Of about the same size as the South Island species, $H$. subcaecus (3985), but at once separable therefrom by its quite distinct eyes, longer mandibles and legs.

Length (mandibles excluded), $5 \mathrm{~mm}$.; breadth, $\frac{1}{2} \mathrm{~mm}$.

Oruru, North Auckland. A single individual found by Mr. A. E. Brookes on the 6th October, 1918.

\section{Group Pselaphini.}

Pselaphus Herbst. Gen. Ins. (Wytsm.), Pselaphidae, p. 304.

4276. Pselaphus cavidorsis sp. nov.

Nitid, nearly nude, castaneo-rufous, antennae, palpi, and tarsi more flavescent.

Head slightly longer than thorax but not quite as broad, bifoveate between the small coarsely facetted eyes, medially depressed, convex behínd, with elevated antennal tubercles, indistinctly punctate. Thorax oviform, rather longer than broad, evidently dilated near the middle, smooth. Elytra subtriangular, longer than thorax, equalling it in width at the base, twice as broad behind; their basal portion concave, depressed and finely, but quite obviously, pubescent at the extremity, with fine sutural striae behind. Hind-body fully as broad as the apical portion of the elytra, its basal segment as long as they are, with broad lateral margins, remaining segments deflexed and short.

Antennae less than half the length of the body, finely pubescent towards the extremity; basal joint about as long as the following three taken together, second nearly as stout but shorter than the first, both of these closely and minutely sculptured; joints 3-7 rather longer than broad, 8 rather shorter, 10 a little shorter and broader, the terminal large, oviform and acuminate.

Maxillary palpi rather longer than the antennae, basal joint short and slender, second more clavate at the extremity than the base, third short and thick; fourth half of the whole length, slender near the base, very 
aradually incrassite for fully a third of its whole length and quite obtuse almost truncate, at the apex.

Tnderside shinimer, basal segment of the abdomen thickly covered with vellow pubesecenee. second deeply incurved, third large, slightly and widely incurved, as are the short fourth and fifth; sixth large, its opereulum large and transversely oval.

'This species is readily distinguishable by the structure of its abdomen and palpi. It must be located in a section apart from the others.

ô. Length, $2 \mathrm{~mm}$. ; breadth, $\frac{1}{2} \mathrm{~mm}$.

Oruru, North Auckland. A single male found by Mr. A. E. Brookes amongst decaying vegetable matter on the 6th October, 1918.

\section{Group Brachyglutini.}

Byraxis Reitter. Gen. Ins. (Wytsm.), Pselaphidae, p. 206.

\section{Byraxis acceptus sp. nov.}

Nitid, moderately convex, impunctate, with a few short greyish hairs on the hind-body; rufo-piceous, elytra, legs, and antennae more rufescent, tarsi fusco-testaceous.

Head and moderately prominent eyes as broad as thorax, subquadrate, with obtuse hind angles; nearly plane, with a pair of interocular foveae, and another smaller pair within the frontal impression. Thorax slightly longer than broad, rather broader at the middle than elsewhere, with distinct lateral foveae near the base. Elytra quite double the length and breadth of thorax, narrowed towards the base, with distinct sutural striae only. Hind-body short, considerably deflexed, basal segment largest.

Legs elongate, rather slender, finely pubescent, posterior tibiae longer than the others, somewhat curved and thickened below the middle.

Antennae longer than the head and thorax, basal joint cylindric, rather stouter and longer than the oblong second, third and fourth shorter, narrowed towards the base, fifth about as long as second, sixth slightly longer than the quadrate seventh, eighth transverse; ninth very large, subquadrate, but with its short basal portion a third narrower, its apex subtruncate, but, owing to the presence of setae, appearing minutely prominent outwardly, it is impressed or foveate along the inside; tenth conical, rather smaller than ninth, with a small subacute tubercle underneath near the outside of its apex.

Underside rufo-castaneous, smooth, with some slender yellowish hairs; anterior trochanters finely spinose. Metasternum large, convex, its broad posterior depression more shallow towards the front. First visible ventral segment largest, distinctly bituberculate before the middle.

B. diversa (2739) (Ann. Mag. Nat. Hist., ser. 6, vol. 12, p. 174) has differently formed antemate, and the ventral tubercles are placed near the extremity of the first visible segment. $B$. munda (236), the other member of the same section, has an oblong terminal joint, longer than the ninth, and the other eight articulations of the antennae are stouter and shorter.

o. Length, $1 \frac{1}{3} \mathrm{~mm}$. ; breadth, $\frac{2}{3} \mathrm{~mm}$.

Rangiriri, Waikato; 10th May, 1916. Collected with other Coleoptera by Mr. A. E. Brookes. 


\section{Group SilphidaE.}

Isocolon Broun. Man. N.Z. Coleopt., p. 1070.

\section{Isocolon oruruensis sp. nov.}

Nitid, oblong-oval, moderately convex, glabrous; castaneous, elytra irregularly infuscate.

Head behind almost as broad as front of thorax, with a few fine punctures there; its anterior portion much paler, narrower, deflexed and strongly incurved between the antennae. Eyes subrotundate, quite lateral, slightly convex and facetted. Thorax nearly twice as broad as long, base and apex subtruncate, with obtuse angles, its sides finely margined, slightly curvedly narrowed in front; irregularly, sparingly, and finely punctate. Scutellum triangular, flat and indistinct. Elytra double the length of thorax, of almost the same width as it is at the base, finely marginate, gradually narrowed posteriorly and entirely covering the abdomen; with slender sutural striae, finely and subseriately punctate, less evidently near the sides and apex.

Antennae equalling the head and thorax in length, with slender pale pubescence; basal joint but little stouter or longer than the next, third scarcely any longer, joints 4-6 rather shorter, 7 distinetly broader, obconical, 8 very short, not as broad, 9 and 10 quite transverse, the terminal rather longer and narrower than 10.

Femora, except the posterior, scarcely visible from above; tibiae finely pubescent, bicalcarate inwardly at the extremity, spinose externally ; tarsi pentamerous, not broadly expanded, fourth joint of the anterior pair smaller than that of the posterior, terminal joints slender, nearly as long as the others taken together.

Terminal joint of maxillary palpi almost as stout as the penultimate but twice its length.

Underside finely and thinly pubescent. Coxae contiguous. Mesoand metasternae of almost equal length. Basal segment of abdomen a little longer than any of the following three, fifth rather longer than fourth.

Length, $2 \frac{1}{3} \mathrm{~mm}$.; breadth, $1 \mathrm{~mm}$.

Oruru, North Auckland. Discovered by Mr. A. E. Brookes, amongst decaying leaves, on the 6th October, 1918.

\section{Group Synchitidae.}

Ulonotus Erickson. Man. N.Z. Coleopt., p. 186.

\section{Ulonotus affinis sp. nov.}

Elongate, moderately convex, subopaque; rufo-fuscous, antennae, palpi, and legs fusco-rufous; irregularly covered with short suberect rellowishgrey setae.

Head indistinctly sculptured, labrum prominent and rufescent. Thorax only slightly broader than long, apex strongly rounded in the middle, rather deeply emarginate towards the subacute prominent angles; its sides slightly flattened, finely crenulate, gently widened from the front to behind the middle, from thenee distinetly narrowed backwards, but with a slight angular dilatation in front of the base ; disc irregularly and finely granulate, quadri-impressed, the longest depression before the mididle, the smallest close to the base, the other pair behind the middle. Scutellum small. Elytra rather broader than thorax, more than twice its length, 
subparallel; moderately substriate-punctate, many of the setae concentrated so as to form several small patches. Tibiae straight, with a few inconspicuous greyish setae.

Antennae rather shorter than the head and thorax, the exposed portion of the batsal joint but litte longer than the next, third longer than fourth or fifth, eighth shorter than preceding one.

This, owing to the shape of the thorax, should be placed near Dr. Sharp's larger W. discedens (332).

Length, $4 \frac{1}{2} \mathrm{~mm}$. ; breadth, $1 \frac{2}{3} \mathrm{~mm}$.

Martinborough. A single specimen sent by Mr. A. C. O'Connor on the 25th August, 1918.

\section{Ulonotus aemulus sp. nov.}

Elongate-oblong, slightly convex, subnitid; nigrescent, thoracic lobes reddish; the whole surface moderately granulate and apparently nude, the sides and tibiae with short, curled dark setae.

Head half the width of thorax, with slightly prominent eyes. Thorax a third broader than long, the frontal lobe of each side half of the whole length and projecting as far as the front of the eye; the next equidistant from the frontal and basal, both of which are dentiform and rather slender, the latter forms the posterior angle: disc trifoveate at the base. the irregular frontal depression extends from the basal foveae to the apex. Scutellum nearly rotundate. Elytra double the length of thorax, obliquely narrowed behind, lateral margins finely serrate; near each side of the suture there is an elongate basal elevation, and behind the middle, on each elytron, there are seven distinet though not large tubercles, besides about three indistinct and smaller nodules.

Antennae with fine dark setae, third joint more slender but as long as the second, the thick basal joint just visible from above, fourth and fifth rather longer than broad, 6-8 moniliform; club elongate-oblong, triarticulate.

This undoubtedly should be located near the North Island species I. asper (335), which it most nearly resembles, but 335 is quite dull, more variegated, and the elytral tubercles are not only less numerous and prominent, but as they bear greyish setae they appear more conspicuous.

Length, $3 \frac{1}{2} \mathrm{~mm}$. ; breadth, $1 \frac{1}{2} \mathrm{~mm}$.

Belgrove. Unique. Found by the late Mr. T. Hall on the 10th December, 1914.

\section{Gathocles Broun. Man. N.Z. Coleopt., p. 1086.}

\section{Gathocles fuscus sp. nov.}

Oblong, moderately convex, subopaque; fuscous, antennae and tarsi infuscate red; sparingly clothed with short, slender flavescent setae.

Head half the width of thorax, narrowed anteriorly, finely granulate. Labrum transverse, smooth, obscurely rufescent. 'Thorax moderately gramulate, a third broader than long, base moderately bisinuate, lateral margins thick, slightly reflexed, rather more rounded in front than behind, anterior angles projecting as far as the eyes, the posterior rectangular; dise convex, with a depression extending from base to apex, widest at the middle, the basal portion with a pair of short, somewhat curved elevations. ficutellum small. Elytra oblong, double the length of thorax, slightly broader, much narrowed and depressed behind; subseriate-granulate, third 
interstices distinctly elevated at thr base and behind, and with a pair of smaller elevations near the extremity, fifth interstices similarly raised behind. Tibiae finely setose; basal tarsal joint but little longer than the next.

Antemnae short, thinly and fincly pubescent, second joint stout, as long as the exposed portion of the basal, fifth slightly longer than third or fourth, the others moniliform; club abruptly enlarged, basal joint a little broader but not longer than the other.

Underside, except the last four abdominal segments, distinctly but not coarsely granulate. Mentum large, a little longer than broad. Process of prosternum broadly bisulcate. Netasternal process broadly triangular, its oblique frontal margins somewhat raised and thickened. Basal ventral segment subacuminate in front of the coxae.

Nearly allied to $G$. nodosus (1936), but the body concolorous, the elytra more distinctly and regularly granulate, \&c.

Length, $3 \mathrm{~mm}$.; breadth, $1 \frac{1}{2} \mathrm{~mm}$.

Mount Dick, near Kingston. Captured by the late Mr. T. Hall, at an elevation of $3,500 \mathrm{ft}$., on the 17 th March, 1914.

\section{Gathocles interruptus sp. nov.}

Oblong, moderately convex, opaque; rufo-fuscous, antennae and tarsi rufescent; thinly clothed with suberect, slender yellowish setae.

Thorax rather broader than long, deeply emarginate in front, its angless prolonged to just beyond the distinctly facetted eyes, the sides finely crenate, rounded and widest at the middle, somewhat sinuate towards the slightly prominent hind angles, its base deeply sinuate near the sides; disc unevenly convex along the middle, with granular sculpture, its sides broadly and deeply concave, the lateral margins, however, are elevated, though on a lower plane than the disc. Elytra oblong, about a third longer than broad, nearly vertical and evidently narrowed behind, with obtuse slightly prominent shoulders, lateral margins finely crenulate but not expanded; dise closely and moderately coarsely seriate-punctate; each elytron with a feebly curved basal ridge just outside the second series of punctures, a small nodosity on top of the posterior declivity, a still smaller a little in advance, and another ridge extending from near the base to the top of the hind declivity, which bears a pair of smaller nodules half-way down.

Underside piceous, its margins reddish, with some fine flavescent hairs and granular sculpture. Sides of prosternum deeply concave nearly to the base, semicircularly emarginate in front. Intermediate coxae less distant than the anterior, the frontal space broadly grooved. Metasternal process subtriangular, with somewhat elevated margins. The interval between the posterior coxae quadrangular, with slightly raised margins.

Length, $3 \mathrm{~mm}$. ; breadth, $1 \frac{1}{2} \mathrm{~mm}$.

Wellington. Found by Mr. A. C. O'Connor ; 24th April, 1916.

Syncalus Sharp. Man. N.Z. Coleopt., p. 200.

\section{Syncalus solidus sp. nov.}

Convex, compact, suboblong-oval, nitid; fusco-piceous, the labrum, legs, and basal joint of antennae fusco-rufous, remaining joints of these last, the palpi, and tarsi of a paler red; very irregularly clothed with depressed, usually fulvescent, and erect similarly bright or fuscous setate, in well-preserved examples suberect fulvescent setae form several crests on the elytra; on the tibiae the setae are inconspicuous and depressed. 
Head with numerous somewhat flattened granules. Labrum large, almost smooth. Eyes convex, subtransverse. Thorax about twice as broad as long, its sides entire, flattened, gradually curvedly narrowed towards the subateute prominent front angles, the base widely bisinuate, with subrectangular angles; it is mearly smooth and indistinctly grooved along the middle, but the sides are closely granulate, the front less distinctly so, the transverse basal impression is generally sex-punctate. Sentellum minute. Elytra about double the length of thorax, only slightly broader than it is at the base, with rectangular, somewhat flattened, nearly smooth shoulders: there are eight series of rather coarse punctures on each elytron, the sutural a little finer.

Underside sparingly clothed with depressed slender fulvescent setae, the femora more thickly, abdomen nearly nude. Prosternum distinctly and rather closely granulate, its process broad, plane, and prolonged slightly behind the coxae, it is almost a fourth of the whole width; mesosternal lamina about equally broad; basal ventral segment very broadly rounded between the coxae.

The species in their natural condition are encrusted with sappy matter, fibres, and dirt, which must be removed before their true sculpture can be seen.

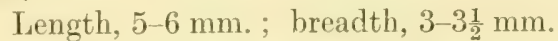

Tairua, Hunua Range, Waitakere, and Pakarau, all localities in the Auckland Province.

N.B.-Sharp's S. optatus (359) is described as having long erect setae on the tibiae, whereas in S. solidus they are depressed and inconspicuous. In his S. hystrix (361) the elytral punctures are much coarser than those of 359 , but in my denuded specimen of 361 I find these punctures are not as coarse as those of $\$$. solidus. St. politus (360) is distinguishable by its light chestnut hue and fuscous alternate interstices of the elytra. S. oblongus (35.3) has the prosternum covered with coarse flattened granules and its process depressed along the middle; the abdomen is finely sculptured and bears numerous depressed greyish hairs.

\section{Recyntus Broun. Man. N.Z. Coleopt., p. 764.}

4284. Recyntus reitteri Sharp. Trans. Ent. Soc., London, 1882, p. 80.

Subquadratus, crassus, elytris elevatis, fusco-niger, superne in elytris tuberculis maximis et inaequaliter fulvo-tomentosus, setulisque erectis adspersus, antennis pedibusque rufis.

Length, $4 \mathrm{~mm}$. ; breadth, $2_{5}^{3} \mathrm{~mm}$.

Antennae rather stout, quite red; club strongly triarticulate. Thorax very uneven, sinuate on each side in front, so that the middle much covers thre head, narrowed in front, the surface much hispid, especially at the sides, the side behind the middle divided by a deep transverse fissure; the part in front of this fissure is produced backwards, so as nearly or quite to touch the portion behind the fissure, and so as to leave internal to this point of contact a window or opening through the surface of the thorax, which, however, is frequently concealed by being filled up with an exudation, or with the vegetable substance amongst which the insect lives; in front of the hind angle the thorax is mueh narrowed, and the hind angle projects backwards as a large triangle. Elytra with very large and greatly elevated tubercles, which bear a coarse tomentum; between the tubercles are numerous, rather indefinite but large, punctures or pits, and the 
surface is also sprinkled with numerous conspicuous erect setae. Undersurface opaque, but without clothing. Tibiae setose externally.

Greymouth; No. 65, Helms.

"This very remarbable insect I first received from Mr. Reitter, of Vienna; and, supposing it might go into the genus synculus, proposed to call it Syncalus reitteri. I find, however, it departs much from syncalus by the more approximate middle and hind legs, and I have therefore called it Acosmetus reitteri, as it agrees tolerably well with the characters assigned by Broun to this generic name. Whether it be really congeneric with Broun's two species of the genus is doubtful, as I have seen neither of them."

N.B.-The above description was inadvertently omitted by me in its proper place, and Dr. Sharp probably failed to notice my descriptions of Nos. 340, 341, and 342, together with my notification that I considered these three species represented a distinct genus, which I named Recyntus. Dr. Sharp referred his species to my genus -tcosmetus (Man. N.Z. Coleopt., p. 197).

In Recyntus the coxae are scarcely more than half as far apart as they are in Syncalus; the mesosternal process is triangular and subacute (in 341 quite acute) between the coxae - that of the metasternum, as well as that of the basal ventral segment, are triangular.

In Recyntus tuberculatus (340) the second lateral lobe of the thorax does not touch the obliquely narrowed frontal one; it extends straight outwards in front, is not prolonged backwards at the extremity, but at its base projects backwards so as to form an obvious posterior angle. The shoulders are somewhat elevated; they extend outwards as far as the thoracic lobes, but, though porrect, are quite distant from the second.

In $R$. insignis (341) the second thoracic lobe, at the outside, is in contact with the frontal, and is prolonged backwards so that it almost touches the porrect shoulders of the elytra.

In Sharp's species, $R$. reitteri, the humeral angles are almost rectangular and quite distant externally from the second thoracic lobe, which, at the outside, touches the frontal one.

The above notes will simplify the identification of these remarkable species.

\section{Group AEsalidae.}

Mitophyllus Parry. Trans. Entom. Soc., London, 1845.

\section{Mitophyllus insignis sp. nov.}

Oblong, moderately convex, subopaque; nigrescent, with irregular, chiefly straw-coloured vestiture.

Head fully a third narrower than thorax and, exclusive of mandibles, not half its length, widely emarginate and somewhat depressed in front, with a truncate prominence over the insertion of each antenna not extending outwardly as far as the eye; closely and moderately coarsely punctate, the erect setae longer near the eyes than elsewhere. Thorax about a third broader than long, its slightly erenulate and flattened sides, obliquely narrowed near the rectangular hind angles, more gradually towards the front, its base widely and slightly bisinuate: the broad slightly convex smooth space along the middle becomes quite narrow in front, its punctation is like that of the head, but there are about four more or less smooth spots on the disc; the coarse subdepressed setae 
are irregularly disposed and beeome more squamiform and closer near the sides. Ficuteilum oblong, rounded behind, closely punctate. Elytra oblong, almost double the length of thorax, rather broader than it is, widely incurved at the base; their punctures not quite as close as those of the head and many apparently filled with depressed squamae, the subdepressed setae are shorter and more rufescent than those on the thorax and are most numerous behind the middle, on each elytron there are also over a dozen small patches of pale setiform squamae.

Mandibles quite a half longer than the head, widely distant at the base, unevenly curved, their basal half thickened but not distinctly dentiform externally; each bidentate at the extremity, the lower tooth horizontal, the upper rather longer and almost upright, just behind each of the latter there is another longer but thicker and elevated prominence on the inside which is almost bidentate.

Underside nitid, black, moderately coarsely and closely punctate, and bearing coarse, rather short, greyish setae.

This most nearly resembles $\boldsymbol{M}$. cristatellus (3848), but the mandibles are entirely different, and the general punctation is coarser.

o. Length (mandibles included), $11 \mathrm{~mm}$. ; breadth, $4 \frac{1}{2} \mathrm{~mm}$.

Gordon's Pyramid, Nelson. A solitary male sent for examination by Mr. A. C. O'Connor, who found another in January, 1918, at a height of $4,000 \mathrm{ft}$.

\section{Group Cleridae.}

Phymatophaea Pascoe. Man. N.Z. Coleopt., p. 334.

4286. Phymatophaea hudsoni sp. nov.

Elongate, slightly convex, nitid, bearing many erect, slender greyish hairs; of a peculiar violaceous-coppery hue, the head, the thorax behind the middle, and the lateral prominences of an infuscate red; each elytron, just before the hind thigh, with a large coarsely punctate yellow spot not reaching the outer margin or suture; palpi and antennae flavescent, but with the apical portion of each joint of the club fuscous; legs also variegate, the basal portion of the femora and tibiae, and the first tarsal joint testaceous, the remaining parts infuscate.

Head finely and irregularly punctate; eyes prominent. Thorax of about equal length and breadth, obviously dilated at each side behind the middle; smooth along the middle, its sides closely sculptured, with elongate impressions and punctures. Scutellum short, its sides punctate. Elytra a third broader than thorax, nearly four times its length; each obtusely elevated alongside the suture near the base, moderately coarsely subseriate-punctate to beyond the hind thighs, smooth behind.

Antennae half the length of the body, finely pubescent, basal joint stout, scarcely double the length of the next, 35 about equally elongate, 6 and 7 rather shorter, 8 subquadrate; club two-thirds of their whole length, its joints successively decreasing.

The nearest species, $P$. fulcipalpis (613), is little more than half as larese, its head is closely punctate, the thorax is a third longer than broad, and the coloration is materially different.

Length, $6 \mathrm{~mm}$. ; breadth, $2 \mathrm{~mm}$.

Karori, Wellington. A single specimen found on the 21st March, 1917, by Mr. G. V. Hudson. 
4287. Phymatophaea nigricornis sp. nov.

Nitid, head and thorax purple; elytra bright dark-greenish-blue, each with a slightly raised, oblique fulvous spot before the middle and almost touching the suture, and another longer fascia extending from the side more than half-way towards the suture; legs and tarsi dark purple, antennae infuscate black; sparingly clothed with slender upright infuscate hairs.

Head finely and closely punctured between the prominent eyes, less distinctly and more distantly behind. Thorax, including the lateral prominences behind the middle, of almost the same length and breadth, more obliquely narrowed behind than in front, finely and irregularly punctured, nearly smooth along the middle. Elytra about thrice the length of but hardly a third broader than thorax, straight-sided; with the usual basal elevations, their distinct subseriate punctation extends to the hind thighs but becomes much finer and more distant behind.

The nigrescent antennae, dark legs, fulvous elytral fasciae, \&c., differentiate this from $P$. violacea (608) and Sharpe's $P$. hilaris (609).

Length, $5 \frac{1}{2} \mathrm{~mm}$. ; breadth, $1 \frac{1}{2} \mathrm{~mm}$.

Moreri, south-western Otago. Described from a specimen found by Mr. H. Hamilton, of the Dominion Museum, Wellington.

\section{Phymatophaea brevicollis sp. nov.}

Shining, fulvescent, head and thorax rather more rufescent, the posterior transverse fasciae of the elytra, except at the external margin, surrounded by a broad bright purple band extending to the suture; terminal three joints of the tarsi and antennal club, except the narrow basal portion of the latter, nigrescent; pubescence seanty, erect, slender and greyish.

Head rather finely and closely punctured, nearly smooth behind. Thorax slightly broader than long, a little constricted in front, its sides somewhat depressed and curved for nearly half of its whole length; disc smooth, finely and sparingly punctate elsewhere. Scutellum transverse. Elytra quite thrice the length of thorax, a third broader, slightly expanded backwards, their apices subtruncate near the suture so that the ventral segment is much exposed; they are distantly and moderately punctate in front, more finely behind, the posterior fasciae and their purple margins are, however, nearly smooth; the oblique ante-median spots are elevated, the larger basal elevations are obtuse and the space between them slight] violaceous.

Most nearly allied to $P$. ignea (1397); differentiated therefrom by its more robust form, evidently broader thorax, and subtruncate elytral apices.

Length, $7 \frac{1}{2} \mathrm{~mm}$. ; breadth, $2 \frac{1}{2} \mathrm{~mm}$.

Bluff. A single specimen, sent by Mr. A. Philpott, of Invercargill.

\section{Phymatophaea formosa sp. nov.}

Body brilliant purple, the ante-median spots and posterior fasciae of elytra bright yellow, the antennae, including the basal portion of the joints of the club fulvescent, club elsewhere dull fuscous; femora fuscoviolaceous but dark fulvous at the base, tibiae also dark fulvous but nigrescent near the extremity, the hinder pairs much less so; tarsi nigrescent; sparingly clothed with inconspicuous slender erect infuscate setae. 
Head distinctly and closely punctate. Thorax of almost equal length and breadth, evidently contracted in front and behind, the somewhat flattened, obtusely curved middle portion of its sides half of its whole leneth: its surface irregularly, rather finely, but quite visibly munctured. secutellum dull. Elytrat thrice the length of thorax, a third broader behind, with large obtuse basal elevations, their punctation as far as the posterior fasciae quite distinct, rather distant and subseriate, each elytron at the base is more coarsely tripunctate, and near the apex there is a large shallow impression.

This, no doubt, is most nearly allied to Sharp's P. hitaris (609), found only near Christchurch; but, besides being larger, the sculpture seems materially different, and the dilatation of the sides of the thorax oecupying half of its length seems sufficient to justify specific separation.

Length, $9 \mathrm{~mm}$.; breadth, $3 \mathrm{~mm}$.

Ohakune. My specimen was found by Mr. A. E. Brookes on the 1st January, 1917.

\section{Group ANTHICIDAE.}

Cotes Sharp. Man. N.Z. Coleopt., p. 410.

\section{Cotes halliana sp. nov.}

Elongate, very slightly convex and nitid; elytra fusco-fulvous, the head, thorax, and antennae more rufescent, legs and palpi testaceous; elytra covered with depressed and erect, elongate fulvescent hairs, head and thorax more thinly elothed.

Head, eyes inclusive, rather broader than thorax, indistinctly punctate. Thorax slightly longer than broad, very deeply and rather sharply constricted behind the middle; its punctation shallow, moderately coarse, but not very close. Scutellum subtriangular, rather short. Elytra quite thrice the length of thorax and twice its width, curvedly narrowed towards the base and scarcely any broader than the thorax there, apices broadly rounded but not covering the pygidium; their punctation subseriate, coarser and deeper than that of thorax but becoming finer and indistinct behind the middle.

Of about the same size as $C$. distincta (2070), which, however, is more rufescent and has the basal portion of the thorax piceous, its punctation also, of the thorax particularly, is much finer, and the antennae are longer and nore slender. In C. hallicua the basal articulation is stouter but scarcely longer than the third, which is slightly longer than joints $1-6$, joints $7-10$ are about repual to one another, rach longer than broad and narrower towards the base, the terminal elongate-oval.

Length, $5 \mathrm{~mm}$.; breadth, quite $1 \frac{1}{2} \mathrm{~mm}$.

Trentlatm; jth Norember, 1916. One of the last species discovered by the late Mr. T'. Hall just prior to his emharkation for France, where he was killed in action on the 20th August, 1917.

\section{Cotes bullata sp. nov.}

Elongate, slightly convex, nitid; elytra fulvescent but evidently yellow near: the base; head and thorax pale castaneous; antennae, palpi, and lens flaverent; pubeseenee elongate, slender and suberect, and of the same hue at the derm on the elytra, more decumbent and much more scanty on the head and thorax. 
Head apparently impunctate, including the large prominent eres evidently broader than the thorax, which is rather longer than broad, deeply constricted behind the middle and with some small punctures near the base. Elytra elongate, the extremity and shoulders rounded, nearly double the width and thrice the length of thorax; their punctation irregular, rather fine yet distinct, but hardly extending backwards as far as the middle; there is an obtuse elevation on each near the base so that the yellow space behind it as well as the suture seem depressed. Pygidium hardly at all exposed.

Antennae stout, with pale outstanding slender setae; basal joint finely punctate, thicker and rather longer than second, third rather longer than adjoining ones, fifth and sixth slightly broader than fourth, the following four more obconical, eleventh longest and subacuminate.

Near C. crispi (727), rather more robust, with stouter somewhat differently formed antennae, their basal joint much thicker, the eyes more prominent and larger, and the scutellum larger. The basal elevations of the elytra are absent in 727 , which, moreover, has an infuscate fascia behind the middle of each elytron.

Length, $3 \frac{1}{2} \mathrm{~mm}$.; brearth, quite $1 \mathrm{~mm}$.

Palkarau, North Auckland; 19th May, 1918. Described from a specimen found by Mr. A. E. Brookes.

\section{Group Otionhynchidae.}

Catoptes Schoenherr. Man. N.7. Coleopt., p. 428. Syn. Irenimus Pascoe (p. 443).

\section{Catoptes apicalis sp. nov.}

Fuscous, funiculus and tarsi castaneo-rufous; covered chiefly with small depressed fusco-testaceous squamae, rarely fulvescent, these, howerer, along the third and fifth interstices of the elytra gradually become darker, so that the nodosities on these at the summit of the posterior declivity are quite fuscous, the declivity itself, however, is covered with yellowishgrey scales and short setae like those on the third and fifth interstices as well as those on the thorax.

Rostrum a third shorter than thorax, subparallel, obtusely carinate along the middle. Thorax slightly broader than long, wider before the middle than elsewhere, base and apex truncate; its surface apparently impunctate, a little uneven, more or less distinctly channelled along the middle. Scutellum small. Elytra oblong, more than double the length of thorax, their rounded shoulders rather broader than it is at the base, their sides nearly straight, posterior declivity considerably narrowed hackwards, its lower half vertical, the upper slightly curved but extending as far backwards, or nearly so, as the apex; they are distinctly but not coarsely seriate-punctate.

Scape attaining the back of the eye, gradually incrassate, dull, fincly setose: basal two joints of the funiculus about equally but moderately elongate, 3-7 slightly longer than broad; club elongate-ovate, qua!riarticulate.

Underside light castaneous, metasternum and basal two rentral segments covered with small light coppery scales and a few short grey setar, the other segments setigerous. Prosternum deeply emarginate. Basal rentral segiment subtruncate between the coxie, slightly longer than the second 
which, in front, is oblique towards the sides. The specimens vary in coloration.

Nearly related to C. posticalis (2106) and C. lobatus (4191) but smaller than either.

Length (rostrum included), $4 \frac{2}{3} \mathrm{~mm}$.; breadth, $1 \frac{3}{4} \mathrm{~mm}$.

Stephen and D'Urville Islands; September, 1915. Sent recently by Mr. A. C. O'Connor for examination.

\section{Group Rhyparosomidae.}

Lithocia Broun. Man. N.Z. Coleopt., p. 1470.

\section{Lithocia stictica sp. nov.}

Opaque, moderately convex; light fusco-castaneous, the elytra with several nigrescent spots and small crests, and on the summit of the posterior declivity with four erests of the same yellowish-grey hue as those on the dise and along the sides of the thorax.

Rostrum arched, equalling the thorax in length, subcarinate along the middle, its anterior half trisulcate and rather broader than the basal which, behind the middle, bears a small greyish erest. Thorax rather broader than long, apparently widest before the middle, gradually narrowed towards the subtruncate base; a little uneven, very irregularly and coarsely punctate, almost smooth near the sides, with a pair of frontal and more distant median crests, the sides thickly fringed with coarse as well as slender greyish setae. Elytra subtruncate and only slightly wider than thorax at the base, twice its length, much narrowed but not quite vertical behind; the coarse discal punctures are seriate near the suture, irregular towards the sides, those along the posterior declivity are finer and substriate.

Underside light chestnut red, with some rather fine grey setae, the base of the front femora and a large common spot on the middle of the first and second ventral segments nigrescent, hoth of these segments are smooth on the middle but irregularly punctate near the sides, the base of the first has an additional series of coarser impressions, fifth segment finely and closely punctured.

This should be placed near 2549, the type of the genus, but is distinguishable by its maculate elytra.

Length (rostrum excluded), $4 \mathrm{~mm}$.; breadth, $2 \mathrm{~mm}$.

Wadestown; March, 1916. Described from an individual forwarded by Mr. A. C. O'Connor on the 25th August, 1918.

\section{Clypeorhynchus Sharp. Man. N.Z. Coleopt., p. 1210.}

\section{Clypeorhynchus bifoveatus sp. nov.}

Subnitid, fuscous, antennae and tarsi more rufescent; sparingly clothed with decumbent slender yellow setae, but with coarser suberect ones on the rostrum, near each side of the thorax, and forming numerous small patches on the elytra, behind especially, each shoulder densely covered with a narrow band of more minute ones.

Rostrum equalling thorax in length, its hinder portion nearly straight; the anterior bare, rather broader, almost half the whole length, shining reddish, finely and distantly punctate. Head immersed almost to the eyes, with a narrow fovea between them. Thorax rather longer than 
broad, wider just before the middle than elsewhere, base and apex truncate; somewhat depressed along the middle, moderately and irregularly punctured, but in some aspects appearing granulate. Elytra slightly bisinuate at the base, with oblique shoulders, the length about double the breadth, very gradually narrowed towards the vertical posterior declivity. which is striate; discal sculpture indefinite, in some aspects appearing to consist of duplicate series of about six punctures or granules at each side of the suture, scutellar region depressed.

Tibiae somewhat flexuous, acuminate and bent inwardly at the extremity.

Antennae nearly as long as the head and thorax; scape with fine grey hairs, flexuous, its distinctly clavate apical portion a third of its whole length; basal joint of funiculus fully twice the length of the next, a little bent, quite clavate at its apex, joints 3-7 diminish; club elongate.

Underside nitid, irregularly punctate, finely and sparingly pubescent, terminal ventral segment with an elongate median fovea.

The rather longer, nude apical portion of the rostrum, clavate scape and basal joint of the funiculus, the occipital and ventral foveae, and indefinite thoracic and elytral sculpture, conjointly, distinguish this species from others of about equal bulk.

Length (rostrum included), $6 \mathrm{~mm}$; breadth, $2 \mathrm{~mm}$.

Orepuki. Described from a specimen forwarded by Mr. A. C. O'Connor on the 16th October, 1918.

\section{Group Hylobiddae.}

\section{Bryocatus Broun. Part III, Bull. 1, N.Z. Inst., p. 218.}

\section{Bryocatus plicatus sp. nov.}

Subopaque, moderately convex, of interrupted contour; nigrescent, basal half of rostrum and the thorax covered with greyish-tawny scalelike matter, the legs slightly darker; elytra with numerous depressed, transversely disposed, hardly discernible grey setae and irregular spots of similar hue; antennae and tarsi black.

Rostrum as long as thorax, moderately stout, slightly narrowed towards its base, indefinitely sculptured and with a few fine grey hairs in front. Thorax of about equal length and breadth, sharply truncate and not at all depressed in front, slightly wider before the middle than elsewhere, its sculpture apparently granular. Elytra nearly double the length of thorax, slightly incurved and evidently broader than it is at the base, their sides nearly straight to beyond the hind thighs, much narrowed and subvertical behind; they are distinctly striate, third and fifth interstices broader than the others, all finely rugose, each shoulder with a short, slightly curved, elevated plica.

Scape rather slender, implanted before the middle.

This need only be compared with B. hmmeralus (4100). which is larger, its rostrum is quite parallel and obviously broader, the antennae are distinctly shorter and thicker, the front of the thorax is narrower, subdepressed, and somewhat rounded. The posterior declivity is longer and less vertical, and the humeral clevations are not only prolonged almost to the hind femora but also project a little in advance of the elytral base.

․ Length (rostrum included), $2 \frac{1}{3} \mathrm{~mm}$.; breadth, nearly $1 \mathrm{~mm}$.

Rose Hill, near Methven; 20th November, 1912. A single fernale found under moss by the late Mr. T. Hall. 


\section{Bryocatus crassipes sp. nov.}

Subelongate-oval, moderately convex, subopalque; nigresent, the basal half of the rostrum, a eentral streak along the thorax and another near each side and the greater part of the elytra covered with depressed grevish scale-like or sappy matter.

Rostrum almost as long as thorax, thick, parallel, its frontal balf somewhat shining and indistinctly sculptured. Thorax slightly longer than broad, a little wider near the middle than elsewhere, rather more narrowed in front than behind, moderately coarsely punctured. Elytra slightly broader than thorax at the base, twice its length, narrowed and subvertical behind; they are distinctly striate, with plane, finely rugose interstices.

Legs rather shorter and thicker than those of 3608 , the tibiae somewhat dilated inwardly near the middle and bearing a few slender, curled dark setae. Antennae also short and stout.

o. Length (rostrum included), $2 \mathrm{~mm}$.; breadth, $\frac{4}{5} \mathrm{~mm}$.

Staircase, the southern portion of the Remarkables, north of Kingston. A single male obtained by the late Mr. T. Hall on the 15th March, 1914, from moss, at a height of 2,100 ft.

\section{Bryocatus angustus sp. nov.}

Suboblong, slightly convex, opaque; fuscous, rostrum rufescent, antemnae and tarsi black, thorax with an obseure grevish streak along the middle, the elytra with a few setae, and several small spots behind of similar colour.

Rostrum as long as thorax, only moderately thick, parallel, indistinetly sculptured. Thorax a little longer than broad, rather wider near the middle than at the base, gradually narrowed anteriorly, moderately coarsely punctate. Elytra oblong-oval, searcely at all broader than thorax at the base, a little broader near the middle, just twice its length, much narrowed and subvertical behind; distinctly striate, with rugose interstices, third and fifth slightly broader than adjacent ones.

Legs stout. Scape moderately elongate and slender.

Cuderside fuscous, fifth ventral segment reddish, plane, truncate at apex.

Narrower and much less medially contracted than other species.

$\hat{o}$. Length (rostrum included), $2 \frac{1}{4} \mathrm{~mm}$. ; breadth, $\frac{3}{4} \mathrm{~mm}$.

Featherston; 17th September, 1916. Unique. Found in the bush near the military camp by the late Mr. T. Hall.

\section{Bryocatus fordi sp. nov.}

Convex, medially contracted and depressed, a little nitid, subglabrous; piceo-rufous, antennae and tarsi piceous, club nigrescent.

Rostrum slightly longer than thorax, moderately stout, subparallel, somewhat narrowed near the base only, apparently smooth. Head narrowed anteriorly. Thorax of about equal length and breadth, widest at or before the middle, moderately coarsely and closely punctured. Elytra slightly wider than thorax at the base, nearly a third broader near the middle, posterior declivity narrowed but not vertical; with wellmarked striae and rugose rather narrow interstices, the third and fifth, however, somewhat broader.

Legs moderately long but not slender. Scape elongate, funiculus with

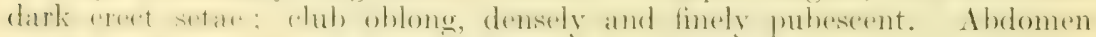
closely and moderately coarsely punctate, its last segment not foveate. 
․ Length (rostrum included), $2 \frac{1}{3} \mathrm{~mm}$.; breadth, $\frac{3}{4} \mathrm{~mm}$.

Pokaka: 22nd March, 1917. Mr. James Ford during several months collected bags of leaf-mould at different places along the Main Trunk Railway for Mr. A. E. Brookes, of Mount Albert, who examined the contents of the bags. In recognition of Mr. Ford's services in thus securing several new species this one has been named in his honour. Only a single female has been obtained.

\section{Bryocatus diversus sp. nov.}

Subnitid, pitchy black, the thoracic apex and legs of a reddish coppery hue, antennae and tarsi nigrescent.

Rostrum slightly longer than thorax, distinctly arched and narrowed behind, finely and distantly punctate. Head rather coarsely rugose. Thorax very slightly longer than broad, a little dilated near the middle, somewhat constricted in front, closely and coarsely punctured. Elytra double the length of thorax, distinctly broader than it is at the base, their sides nearly straight to beyond the hind thighs, evidently narrowed but not vertical behind; with deep striae and rugose interstices, third and fifth rather broader than the others and united at the base, which the second and fourth do not reach, these peculiarities, however, are less apparent on the right elytron.

Legs and antennae moderately stout and elongate.

The bald surface is very much darker than that of $B$. fordi, the rostrum is quite obviously narrowed behind the middle, the thorax is rather more closely punctured and almost abruptly contracted in front, and the form of the hind-body differs considerably, it is, however, the most nearly allied species.

+. Length (rostrum included), $2 \frac{1}{2} \mathrm{~mm}$.; breadth, $\frac{3}{4} \mathrm{~mm}$.

Rakaia Gorge, near Methven; 1st November, 1912. One female taken from amongst moss by the late Mr. T. Hall.

\section{Bryocatus thoracicus sp. nov.}

Subopaque, moderately convex and elongate; nigrescent, the head and more than the basal half of rostrum covered with greyish fine scalelike matter, the thorax much more scantily so; the elytra with several small raised spots of the same colour on the sut: re and interstices behind the middle, most of these spots have a suberect central white seta, on the sides of the body and legs there are some dark setae.

Rostrum slightly shorter than thorax, parallel, moderately stout. Thorax rather longer than broad, somewhat indefinitely limited in front. oviform, rather more gradually narrowed anteriorly than behind; its sculpture consists apparently of small granules. Elytra almost double the length of thorax, slightly wider than it is at the base, with slightly elevated shoulders, their sides nearly straight; they are moderately striate, with finely wrinkled interstices, the third and fifth a little broader and more convex than the others, there are about four grey spots on the third, only two on the outer ones.

Scape inserted between the middle and apex, moderately stout and long, with fewer dark setae than the funiculus; chub oblong-oval. Lens elongate. 
Underside with obscure greyish vestiture. Fifth ventral segment plane, truncate behind.

Somewhat similar to $B$. plicatus, with a thicker rostrum; longer, narrower, and differently formed thorax; shorter and stouter antennae; its longer hind-body with less distinctly raised shoulders.

Length (rostrum included), $2 \frac{2}{3} \mathrm{~mm}$. ; breadth, $\frac{3}{4} \mathrm{~mm}$.

Rakaia Gorge; 27th September, 1912. Another of the late Mr. 'T. Hall's novelties, probably a male.

\section{Bryocatus ovipennis sp. nov.}

Opaque, fuscous, unevenly clothed with greyish scale-like matter and a few suberect setae, antennae and tarsi nigrescent.

Rostrum stout, parallel, as long as thorax, with some fine grey setae near its extremity. Thorax of about equal length and breadth, a little wider before the middle than in front, moderately coarsely punctate, slightly uneven, without distinct inequalities. Elytra $1 \frac{1}{2}$ times the length and breadth of thorax, slightly broader than it is at the base, much narrowed and subvertical behind; distinctly striate, third and fifth interstices a little broader than the others, each of these and the suture with three small elevations, the subapical ones the smallest, the larger ones nearly form transverse rows between and behind the posterior femora. Antennae moderately short, legs elongate.

Underside apparently with granular sculpture; fifth ventral segment large, its subrotundate fovea occupying half of its whole surface.

Its proper position is between $B$. jugosus (3609) and $B$. burrowsi (3762); it is much loss robust than either, and differs a good deal in details of sculpture.

o. Length (rostrum included), $1 \frac{4}{5} \mathrm{~mm}$. ; breadth, $\frac{4}{5} \mathrm{~mm}$.

Bell Rock, near Methven; 5th September, 1912. A single male taken from moss on the face of a steep rock by the late Mr. T. Hall.

\section{Group Haplonychidae.}

Geochus Broun. Man. N.Z. Coleopt., p. 445.

4302. Geochus rufipictus sp. nov.

Subprriform, slightly convex, moderately shining; piceous, but with the front and middle of thorax and elevated portions of elytra castaneorufous, antennar and tarsi fusco-rufous; sparingly clothed with slender. inconspicuous, short grey setae.

Rostrum shorter than thorax, narrowed behind, grooved along the front, indistinctly sculptured. Thorax rather broader than long, widest at the base, gradually narrowed anteriorly, closely and moderately coarsely punctured. Elytra of the same width as thorax at the base, a third hroader at the summit of the subvertical declivity which is much narrowed towards the extremity; each elytron has five series of relatively coarse subyuadrate punctures. serond and third interstices somewhat elevated throughout, the fourth with a small median spot, and a longer one on the mext also elevated; the three outer interstiees are distinctly nodiform on the top of the posterior declivity, which is punctate-striate near the suture but irregularly punctured near the side. 
Legs dark, all the tibiae obtusely angulate above the middle.

Scape slender but quite nodose at the extremity; funiculus considerably longer, its basal joint as long as the next but about twice as stout, joints 3-7 decrease in length; club elongate-oval, finely pubescent.

The elytral sculpture is distinctive.

Length (rostrum included), $2 \mathrm{~mm}$. ; breadth, $1 \frac{1}{2} \mathrm{~mm}$.

Wadestown. A single specimen received from Mr. A. C. O'Connor, of Wellington, on the 16th October, 1918.

\section{Group Cylindrorhinidae.}

Homodus Broun. Man. N.Z. Coleopt., p. 703.

4303. Homodus posticalis sp. nov.

Opaque, piceo-fuscous, legs and scape fusco-rufous, tarsi and funiculus more ferruginous and nitid; covered for the most part with depressed, somewhat elongated, small, bright coppery scales, the rostrum with small tawny, the head with coarser similarly coloured squamae, there are also a few, mostly pale, upright setae.

Rostrum stout, quite half the length of thorax, obtusely ridged along the middle, the subtriangular bare clypeal portion distinctly defined. Head nearly as broad as front of thorax. Eyes obliquely oval, moderately prominent, free. Thorax narrower than hind-body, its length and breadth about equal, only slightly wider near the front than elsewhere, base and apex truncate; its surface apparently impunctate, a little uneven, having a broad shallow median impression behind, and a somewhat rounded one near each basal angle. Scutellum small. Elytra somewhat incurved at the base, hardly any wider there than the thorax, scarcely twice its length or greatest breadth, with slightly curvedly narrowed shoulders, their sides very gently narrowed towards the subvertical, much narrower posterior declivity; disc rather coarsely and distantly, but not deeply, seriatepunctate; on each elytron nearer the suture than the hind thigh there is a very small dark elevation, on top of the declivity there is another near the middle and a larger one close to the side with pale setae, there are also a few small tawny tufts lower down, the suture is obtusely elevated there; the area between the pair of obtuse elongate basal elevations has a few minute dark granules.

Legs with infuscate setae, tibiae flexuous, the anterior distinctly mucronate at the extremity, and irregularly denticulate along the inner side.

H. fumeus (1238) has altogether paler vestiture, its thorax is rather more cylindrical and bears several small tubereular elevations, an oblique depression extends from the front of each eye to the hind part of the head, and the anterior tibiae are much less curvedly bent near the extremity.

Underside covered with slender coppery scales. Mentum larger than in 2149. Hygrochus rermcosus, truncate in front and behind, it fills the buccal cavity and conceals the palpi. Mandibular scar present. Posterior corbels with external truncature.

Length (rostrum included), $6 \frac{1}{2} \mathrm{~mm}$.; breadth, $2 \frac{1}{2} \mathrm{~mm}$.

Pakarau; 19th May, 1918. I have only a single specimen, found by Ur. A. E. Brookes, of Mount Albert. 


\section{Homodus longicornis sp. nov.}

Opaque, only slightly convex; piceous, funiculus and tarsi ferruginous, legs and seape darker; almost wholly covered with depressed, small, dull coppery squamae, those on the rostrum more fulvescent and elongate, the erect setae are fuscous, but on the posterior elevations they are of a tawny grey.

Rostrum parallel, half the length of thorax. Head broadly subdepressed between the eyes. Thorax an eighth longer than broad, distinctly but not abruptly contracted at the apex, widest and slightly rounded behind that part, very gently narrowed towards the truncate base; it is slightly uneven, with a broad shallow channel along the middle, and on denuded parts quite impunctate. Seutellum small. Elytra incurved and hardly any broader at the base than the thorax, almost twice its length, a little broader behind the shoulders than elsewhere, very slightly narrowed backwards, more strongly so towards the extrenity: the two sutural series of punctures on each are moderately coarse and distant, they are rather shallow and almost become striae behind, the punctation towards the sides is indistinct and irregular, the posterior inequalities resemble those of $H$. posticalis.

Scape gradually incrassate, attaining the thoracic apex; basal two joints of funiculus equally elongate, 3-7 oviform, slightly longer than broad; club oblong-oval.

Basal ventral segment plane, nearly a third longer than the next, truncate between the widely distant coxae, which almost touch the sides; second slightly medially angulate in front, not longer than third and fourth together, fifth as long as the basal, slightly and widely emarginate behind so that the short supplementary one is quite exposed. The slender metasternal scales are fulvescent, those on the basal abdominal segment are more variegated and tinged with green.

The antennae are evidently more elongate than those of $H$. posticalis, which has joints 3-7 almost transversal. The rostrum is longer; the thorax also seems longer, its apical portion is more contracted, and there are no lateral impressions at the base. The posterior declivity is more gradual.

o. Length (rostrum included), $7 \frac{2}{3} \mathrm{~mm}$. ; breadth, $2 \frac{3}{4} \mathrm{~mm}$.

Pakarau; 10th March, 1918. Another of Mr. A. E. Brookes's novelties.

\section{Homodus cuprealis sp. nov.}

Oblong, moderately convex; piceous, antennae and tarsi fuscorufous; covered with depressed, moderately elongate, bright coppery or brassy squamate; the wytral posterior elevations with suberect greyish setal.

Rostrum a third shorter than thorax, quite half its width, slightly dilated at the antennal insertion, broadly impressed alongside the median ridge, and bearing some greyish setae at its apex. Eyes quite free from thorax, moderately prominent, oblong-oval. Thorax very slightly broader than long, widest before the middle, slightly narrowed towards the truncate base, more obliquely so in front; without perceptible punctation, but, like the rostrum, ridged along the middle, broadly impressed alongside the frontal half, and with a few short impressions behind; there are some greyish setae along the sides. Scutellum short. Elytra double the length but not quite twice the breadth of thorax, considerably narrowed but not quite vertical behind; they are moderately subseriate-punctate; each is somewhat binodose on 
top of the posterior declivity, and lower down a pair of dark bare spots are visible, the apices are setigerous. Legs with pale setae.

Scape dull, setose, gradually incrassate, attaining the back of the eye; basal joint of the funiculus slightly longer than the next, joints 3-7 short and moniliform; club subacuminate.

Underside covered chiefly with elongate brassy scales and greyish setae, third and fourth abdominal segments with setae only. Mandibular scar present. Mentum truncate in front, rounded behind. Palpi invisible. Metasternum short. Basal ventral segment almost plane, broadly rounded in front, nearly double the length of second, the suture nearly straight; fifth elongate, with a rather shallow apical fovea. Posterior coxae widely separated. Hind tibiae simple.

Length (rostrum included); $6 \frac{1}{2} \mathrm{~mm}$. ; breadth, $3 \mathrm{~mm}$.

Stephen Island; 9th September, 1916. A single specimen from Mr. A. C. O'Connor on the 25th August, 1918.

\section{Group ErirhinidaE.}

Erirhinus Schoenh. Man. N.Z. Coleopt., p. 449.

4306. Erirhinus obscurus sp. nov.

Oblong-oval, slightly convex; fusco-testaceous, the funiculus, the thorax except the base and apex, a large basal spot on each elytron, a more elongate one near the hind thigh, and sometimes a smaller subapical spot, infuscate; covered with distinct, decumbent greyish-yellow setae which, on the thorax, are disposed transversely.

Rostrum rather longer than thorax. Moderately slender and arched, subseriate-punctate. Head short, globose below. Eyes slightly prominent, just free from thorax; inwardly truncate. Thorax a third broader than long, slightly wider near the middle than elsewhere, distinctly but not closely punctate. Scutellum small. Elytra oblongoval, a little broader than thorax at the base, fully thrice its length, distinctly striate-punctate.

Underside fuscous, rather distantly and finely punctate. Prosternum entire. Metasternum and basal segment of abdomen broadly depressed, second segment nearly straight in front, not longer than third and fourth together.

Male.-Scape inserted at about a third from the apex of the rostrum and reaching the eye; basal joint of funiculus thicker and rather longer than following two united, 4-7 short; club ovate. Femora clavate but not distinctly dentate below.

In form somewhat similar to $E$. cenorhinus (1532), which, however, is readily distinguishable by its remarkably arched rostrum.

Length (rostrum included), $3 \frac{1}{2} \mathrm{~mm}$.; breadth, quite $1 \mathrm{~mm}$.

Staircase, south of Remarkables. Found by the late Mr. T. Hall, at an elevation of 2,100 ft., on the 15th March, 1914.

\section{Erirhinus subconicollis sp. nov.}

Oviform, slightly convex, subopaque; testaccous. Scutellum fuscous; each elytron with a transverse subapical spot, three suboblong ones near the hind thigh, and a longer one near the base, sometimes prolonged towards the suture in the female, of similar dark colour; thinly clothed with greyish, decumbent, moderately elongate setae.

27-Bull. No. 1. 
Rostrum slightly longer than thorax, moderately slender, substriate Thorax rather broader than long, rather wider behind the middle than at the base, more gradually narrowed anteriorly, base and apex truncate; moderately coarsely and closely punctate. Scutellum small, nitid. Elytra nearly thries the length of thorax, rather broader than it is at the base, gradually narrowed behind the posterior femora; distinctly punctate-striate.

Scape implanted between the middle and apex and attaining the middle of the "ye: basal joint of funiculus evidently longer and stouter than the next, third and fourth subquadrate, seventh broader than preceding ones; club oviform, triarticulate. Legs normal.

Underside infuscate, with greyish setae. Second ventral segment not as long as third and fourth together, its frontal suture obtusely angulate in the middle.

Fem.-Rostrum almost double the length of thorax, rather more arched and slender than that of the male; scape more elongate and slender, inserted just before the middle.

Nearly allied to $E$. stramineus (1249), the thorax less transverse and differently formed, the antennal insertion nearer the apex of the rostrum, which is shorter, and with different elytral spots.

o. Length (rostrum included), $2 \frac{3}{1} \mathrm{~mm}$.; breadth, $1 \mathrm{~mm}$.

Lake Ohia, North Auckland; 4th February, 1918. Mr. A. E. Brookes is the discoverer.

\section{Erirhinus poecilus sp. nov.}

Elongate, moderately convex, only slightly nitid, variegate: rostrum fuseo-rufous, thorax reddish-brown; elytra with a somewhat interrupted fascia between the middle and hind thighs, and another across the posterior declivity of a testaceous hue, both with fuscous or piceous frontal and hind borders; tibiae with a fuscous spot below each knee; sparingly clothed with slender decumbent yellowish hairs.

Rostrum moderately arched and slender, a third longer than thorax, slightly striate. Head immersed up to the eyes, globose below. Thorax truncate at base and apex, oviform, its length and breadth about equal, slightly narrower in front than behind, distinctly and closely punctate. ficutellum subtriangular. Elytra evidently broader than thorax at the base, nearly double its length, gradually narrowed towards the distinctly rounded apices; they are evidently striate, but the striae apparently are without punctures. Tibiae slightly flexuous, without terminal spurs. Penultimate tarsal joint broad, bilobed.

Scape inserted near the apex, slender; basal joint of funiculus fuscous, longer and stouter than the next, third and fourth rather longer than broad, the last three short and monoliform; club elongate, indistinctly four-jointed.

Underside light fuscous, shining, with slender greyish pubescence; abdomen finely punctate, basal segment longer than second, rounded between the coxae, medially impressed behind, third and fourth rather shorter than second, which is shorter than fifth.

In coloration and general appearance this is somewhat similar to E. acceptus (1251), but differentiated by its almost contiguous and less prominent eyes; these, in 1251, are widely separated. It also differs from E. acceptus by its longer and more slender rostrum, much longer and more oviform thorax, de.

Length (rostrum included), $3 \frac{1}{2} \mathrm{~mm}$; breadth, $1 \frac{1}{4} \mathrm{~mm}$.

McClennan's Bush, Canterbury; 26th February, 1912. Another of the late Mr. 'T. Hall's numerous discoveries. 
Etheophanus Broun. Man. N.Z. Coleopt., p. 1232.

4309. Etheophanus optandus sp. nov.

Compact, moderately convex, subopaque; rufo-castaneous, antennae and legs inclusive; thinly clothed with rather paler subdepressed hairs and erect dark setae, but, on each elytron, there is a pair of distinct grey spots between the middle and hind femora, and a curved fascia of similar hue between the hind thighs, formed of erect and decumbent hairs; just behind each hind thigh there is a dark lateral spot.

Rostrum nearly equalling thorax in length, slightly arcuate, a little broader in front than behind, indistinctly suleate. Head immersed up to the flat eyes, which are longer than broad. Thorax of almost equal length and breadth, nearly gradually narrowed anteriorly, its base slightly curved; the surface densely and minutely sculptured but without perceptible punctation. Elytra subcordate, slightly incurved and broader at the base than the thorax, a third longer and broader, narrowed and subvertical behind; they are striate near the suture and behind.

Femora elongate but stout, tibiae obtusely angulate externally near the base, penultimate tarsal joint broadly expanded.

Antennae finely pubescent, basal joint of funiculus stouter and longer than the next.

A little larger than previously described species, and distinguishable therefrom by the impunctate thorax, elytral fascia, and tibial structure, \&c.

Length (rostrum excluded), $2 \frac{2}{3} \mathrm{~mm}$. ; breadth, $2 \mathrm{~mm}$.

Hollyford, south-west Otago. Unique. Found at an elevation of 1,000 ft., on the 23rd February, 1914, by the late Mr. T. Hall.

\section{Etheophanus nitidellus sp. nov.}

Subovate, convex, moderately nitid; fusco-castaneous, basal half and sides of posterior portion of the elytra piceo-fuscous, antenmae and tarsi "omewhat rufescent; scantily clothed with short sublepressed and longer outstanding fuscous setae.

Rostrum as long as thorax, only slightly narrowed behind, indistinctly grooved. Thorax subconical, of about equal length and breadth, slightly contracted in front, its base feebly rounded; minutely and densely sculptured, and with a few shallow indefinite punctures. Elytra cordate, somewhat incurved and a little broader at the base than the thorax, hardly twice its length, posterior declivity subvertical: they are rather distinctly striate from base to apex.

Tibiae without external prominences, their basal tarsal joint moderately expanded. Basal joint of funiculus rather thicker and longer than the next; club fuscous, ovate, finely pubescent.

In $E$. striatus (3138) the thorax is evidently punctate, but the elytral striae are obsolete before the middle. E. punctiventris (3627) has a considerably broader rostrum, the thorax is distinctly punctured and more oviform, and the elytra are suboblong instead of cordiform and rather coarsely striate-punctate.

Length (rostrum excluded), $2 \mathrm{~mm}$; ; breadth, $1 \frac{1}{\mathrm{~d}} \mathrm{~mm}$.

Mount Alfred. One example only, secured by the late Mr. T. Ha!l on the 3rd February, 1914. 


\section{Etheophanus obscurus sp. nov.}

Subovate, moderately convex; elytra quite dull, fuscous, a little paler and more rufesent acrosis the top of the posterior deelivity and along the sides; remaining parts fusco-rufous, antennate rather paler ; thinly clothed with slender yellowish and coarser erect setae.

Rostrum rather longer than thorax, slightly narrowed behind, indefinitely sulcate. Thorax subconical, about as long as broad, base subtruncate, minutely and densely seulptured, and with a few indistinct punctures. Elytra slightly incurved and broader than thorax at the base, almost double its length, the declivity subvertical ; they are broadly striate along the midelle and hehind, seriate-punctate near the base. Tibiare, except the posterior, obtusely angulate externally near the base. Basal joint of funiculus rather stouter and longer than the next, club oblongoval.

This obseurely coloured species is separable by the elytral seulpture.

Length (rostrum excluded), $2 \frac{1}{2} \mathrm{~mm}$.; breadth, $1 \frac{2}{3} \mathrm{~mm}$.

Harris Saddle, south-west Otago. Unique. Found by the late. Mr. T. Hall on the 12th February, 1914.

\section{Group Apionidat.}

Apion Herbst. Man. N.Z. Coleopt., p. 466.

\section{Apion terricola sp. nov.}

Minute, elongate, very convex, the elytra especially; glabrous, shining, nigrescent, rostrum, antemnar, and legis piceo-rufous, its punctiform seulpture obsolete.

Rostrum rather longer than thorax, arched, stout, cylindrical, slightly narrower in front. Head of equal length and breadth, gradually narrowed to almost the same width as the rostrum. Fres as far apart as they are from the thorax, prominent, subrotundate. Thorax truncate at base and apex, a little longer than hroad, rounded. widest, and most convex at or before the middle, its basal half much constricted and depressed. Scutellum absent. Elytra oval, apparently truncate and of the same width as thorax at the base, about double its length and almost twice as broad and convex near the middle.

Scatpe inserted evidently before the middle, attaining the eve, moderately stout, subdavate at the extremity. Funiculus hairy, basal joint slightly longer than second and twice as thick; third at apex as broad as fourth, both together slightly longer than seeond; fifth to seventh transverse. seventh broadest: (hub abruptly enlareed, subovate, apparently triarticulate,

Lexs elongate, simple. 'Tarsi elomgate, seeond joint of the anterior at little shorter than the basal, the third with long narrow lobes, fourth narrow, longer than the first. Underside dull, with a few slender grey hairs. Prosternum truncate in front, the coxae prominent, the intermediate also contiguous, the posterior distinctly separated. Basal two ventral segments apparently connate, large, third and fourth very short.

This remarkalsle little wervil disagrees with sos in nearly all sperefife details of form and sculpture.

Length (rostrum included), $2 \mathrm{~mm}$. ; breadth, $\frac{1}{2} \mathrm{~mm}$.

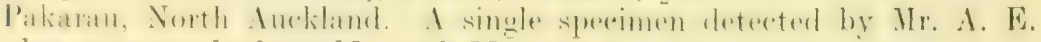
Brookes amongst leaf-mould; 19th May, 1918. 


\section{Group Cryptorhynchidae.}

Acalles Schoenh. Man. N.Z., Coleopt., p. 488.

4313. Acalles brookesi sp. nov.

Ovate, compact, convex; piceous, antemnae and tarsi fusco-rufous; covered mostly with subrotundate, depressed, pale-reddish scales, suberect greyish ones, however, form a broad subinterrupted fascia behind the middle femora, and blackish ones usually form three crests near the middle of the base on each elytron; the whole surface in addition bears numerous erect setae, most of which are nigrescent.

Rostrum of about the same length as thorax, moderately broad, subparallel or slightly narrowed backwards, punctate and thinly squamose. Head slightly impressed between the eyes. Thorax nearly a third broader than long, contracted, but not abruptly so, in front; its coarse punctation is concealed by the variegated vestiture, which is obscurely fulvescent, or paler on the sides than on the dise, between these parts the basal half is nigrescent or fuscous, the apex is almost bicristate. Elytra subcordate, double the length of thorax, rather broader than it is at the subtruncate base but with oblique shoulders, posterior declivity not vertical; they appear to be finely striate, but on denuded portions elongate distant punctures are visible.

Scape implanted behind the middle, attaining the eye, gradually incrassate, with pale setae; the funiculus longer, its basal two joints equally elongate, remaining ones gradually shortened, submoniliform; club oblongoval.

This cannot be referred to Tychanus or Sympedius owing to the absence of the scutellum. In Crisius the antennae are inserted before the middle of the rostrum, but the general form and other details more nearly accord with it.

Length (rostrum excluded), $5 \mathrm{~mm}$.; breadth, $3 \mathrm{~mm}$.

Pakarau, North Auckland; 24th March, 1918. Named in honour of its discoverer, Mr. A. E. Brookes, of Mount Albert.

[Note.-I subsequently found two more specimens of this species, in the same locality, and I retain them in my collection.-A. E. B.]

\section{Scelodolichus Broun. Man. N.Z. Coleopt., p. 495.}

\section{Scelodolichus decorus sp. nov.}

Subnitid, very convex; nigrescent, antennae and tarsi fulvescent; bearing, the legs inclusive, numerous upright, elongate, blackish setare, the disc covered with decumbent, elongate yellow squamae, the sides and hinder portion with many small patches of nearly white scales.

Rostrum subparallel, almost as long as thorax, moderately stout, smooth and shining. Head globose underneath, hardly visible above. Thorax oviform, narrower than elytra, a third longer than broad, or nearly so, rather wider behind the middle than elsewhere; closely and distinetly punctate, but with a smooth carina along the middle, irregularly and seantily elothed with grey and yellowish scales. Elvtra suberdate, nearly double the length of thorax, of about the same width as it is at the base, widest before the middle, not quite vertical behind; moderately finely, but not very distinctly seriate-punctate.

Scape short, inserted behind the midlle, subchate near the extremity ; funiculus fully double the length of scape, second joint as elongate as the

28-Bull. No. 1. 
subpyriform tirst, thind and fourth slightly longer than broad, joints 5-7 short; club oblong-oval.

Legs very elongate, femora nearly wholly visible from above. Tarsi rather narrow, penultimate joint moderately dilated.

This is distinguishable from all the other speeies of the genus by the conspicuous, cordiform, densely squamose area on the basal half of the hind-body.

Length (rostrum excluded), $3 \mathrm{~mm}$. ; breadth, $1 \mathrm{~mm}$.

Pakarau, North Auckland. A single specimen found by Mr. A. E. Brookes, of Mount Albert; 19th May, 1918.

\section{Scelodolichus pyriformis sp. nov.}

Subpyriform, very convex, subnitid; nigreseent, rostrum and legs rufous, antemnae and tarsi paler; sparingly and irregularly clothed with subereet, longate, spey, and more slender depressed flaveseent seales, and many outstanding dark fuscous setae, legs inclusive.

Rostrum almost equalling the thorax in length, moderately broad, vory gradually expanded towards the extremity, apparently smooth, with a few minute squamae near its base. Thorax slightly broader than long, widest at the truncate base, gradually narrowed anteriorly; moderately but not very closely punctate. only obsoletely earinate along the middle. Filytri oviform, almost double the length of thorax, searcely any wider than it is at the base, widest near the middle, curvate and subvertical hehind; they are fincly, rather distantly, but not very definitely seriatepunctate.

Seape short and subclavate; basal joint of the funiculus evidently stouter and rather longer than seeond, third and fourth very little longer than broad, the others short; club suboblong-oval. Legs normal.

Though somewhat similar to S. villosus (1288), the latter is at once separable by the obviously punctate-striate elytra and a slight dilatation of the rostrum at the point of the antennal insertion. S. setosus (1287) is more clongate, its hind-body especially, and the linear space along the middle of the thorax is smooth and shining, almost cariniform.

Length (rostrum excluded), $2 \frac{1}{2} \mathrm{~mm}$.; breadth, $1 \frac{1}{2} \mathrm{~mm}$.

Pakilatu: 21th Mareh, 1918. Unique. Another of Mr. A. E. Brookes's discoveries.

Hatasu Broun. Amm. Mag. Nat. Hist., ser. 8, vol. iv, p. 384.

4316. Hatasu tuberosa sp. nov.

Suboblong, moderately convex, opaque: nigro-fuscous, unerenly clothed with small, mostly depressed, tawny squamae.

Rostrum rather shorter than thorax, closely punctate and nearly nude in front. Thorax of about equal length and breadth, widest just before the middle, slightly narrowed behind, somewhat abruptly contracted anteriorly, base subtruncate; dise apparently impunctate, with a pair of quite olstuse frontal and median elevations wheh hear short suberect, faintly rufescent scales. Elytra double the length of thorax, about a fifth broader near the middle, more convex there, posterior declivity not vertical; on each elytron there are two obtuse tubercles, one behind the other, situated near the suture, and another further from the suture in line with the hind thigh, in addition to these there are several smaller but very unequal nodiform elevations, outer side also uneven, a few irregular coarse punctiform impressions being visible. 
Underside apparently impunctate, with depressed, slightly enomeater: pale tawny scales; second vental segment slightly shorter than first, both subangulate, and depressed at the middle, in the former one the impression is prolonged backwards, third and fourth together a little shorter than second. Between the intermediate coxae there is a slight longitudinal ridge.

Mentum transversely quadrate, the peduncle twice as long, quite as broad and incurved in front, slightly narrowed behind. The scrobes begin near the apex and are prolonged to the front of the eyes. Palpi thick, fully exposed, bearing conspicuous fulveseent sotar. Scape gently incrassate, inserted near the apex and attaining the front of the cye. Basal and second joints of funiculus almost equally elongate, third rather longer than broad, joints 46 transversely noniliform, seventh much broader; club oblong-oval, quadriarticulate.

Well differentiated from $H$. dorsale (2962) by the numerous unequal nodiform elytral elevations and slight structural modifications.

Length (rostrum excluded), $10 \mathrm{~mm}$.; breadth, $5 \mathrm{~mm}$.

Gordon's Pyramid, Mount Arthur; $4,500 \mathrm{ft}$. Two found l,y Mr. 1. ('. O'Connor on the 13th January, 1918.

\section{Group Lamimae.}

Xylotoles Newman. Man. N.Z. Coleopt., p. 592.

\section{Xylotoles apicalis sp. nov.}

Elongate, slightly convex and nitid; pale fusco-castaneous, sides of elytra feebly infuscate, antennae and legs rather more fulvescent; clothed with depressed greyish pubescence and a few erect setae.

Head vertical in front, with a fine longitudinal stria behind. Thorax very little broader than long, base and apex truncate, its sides obtusely prominent behind the middle and rather more constricted behind than in front; its surface closely and finely strigose, with a central groove little more than a third of its whole length, its basal portion slightly depressed. Scutellum subtriangular. Elytra scarcely any broader than thorax at the base, nearly four times its length, gradually narrowed behind the posterior femora, each subacute at the extremity, with a triangular sutural gap between them there; they are irregularly subseriatepunctate to beyond the hind thighs, but without definite sutural strias.

Antennae finely pubescent and bearing also a few erect, slender grey setae on their basal half; their third joint just passes the shoulder, the ninth attains the apex.

The almost concolorous derm, and triangular apical notch between the elytra distinguish it.

Length, $6 \frac{1}{2} \mathrm{~mm}$. ; breadth, $1 \frac{1}{2} \mathrm{~mm}$.

D Urville Island. A single specimen forwarded by Mr G. T. Hudson, found on the 21st March, 1917.

\section{Xylotoles pygmaeus sp. nov.}

Elongate, subeylindrical. slightly nitid, obecure coppery, antemmate and legs fusco-testaceous, thinly covered with subdepressed slender greyish hairs.

Head apparently smooth, obsoletely grooved behind. Thorax about a third longer than broad, only slightly wider near the middle than wsewhere, 
without visible punctation, with a feeble ante-basal stria. Scutellum small, trimgular. Elytra quite thrice the length of the thorax, scareely any wider than it is at the base, sradually narrowed near the extremity; aich strongly rounded there: rather closely and distinctly subseriatepunctate to beyond the hind thighs.

Antemnae rather shorter than the body, their third joint longer than the fourth.

Distinguishable from all the other small species by the conspicuous elytral punctation.

Length, $4 \mathrm{~mm}$. ; breadth, $1 \mathrm{~mm}$.

Swanson Bush. A single specimen from Mr. A. E. Brookes, of Mount Albert.

Somatidia 'Thomson. Man. N.'. Coleopt., p. 600.

4319. Somatidia fulvipes sp. nov.

Elongate, convex, obviously medially narrowed and depressed, nitid; fuscous, palpi and legs fulvescent; unevenly clothed with subdepressed yollowish-erey pubescence which, on the wing-cases, is more concentrated between the femora and apices than elsewhere but leaving a lateral spot near ach thigh and the suture nearly bare, there are also many erect setae of the same hue.

Head finely and sparingly punctured, broadly impressed between the antemma. Thorax oviform, of about equal length and breadth, strongly rounded at the middle, considerably narrowed towards the front and base, more so near the latter; closely and moderately coarsely punctured, and bearing a small but obvious spine at each side behind the middle. Scutellum minute. Elytra of the same width as thorax at the base, twice its length, very little broader near the middle, sparingly punctured alnost to the apices.

Antennae stout, not longer than the body, finely pubescent and bearing many outstanding setae; basal joint stout, elongate-ovate, the next very short, third longest, attaining the thoracic base, fourth searcely any longer than following ones.

Abdomen rufo-fuscous, with decumbent pale pubescence; basal segment rather longer than 2 \& together, fifth transverse yet longer than fourth, slightly emarginate behind, the evident gap between it and the extremity of the elytra occupied by the semicircular terminal segment.

Most nearly resembles S. spinicoll is (2271), considerably smaller, the hind-body relatively shorter, the thorax more closely punctate, and with very much paler legs and antennae.

Length, $3 \frac{2}{3} \mathrm{~mm}$.; breadth, $1 \frac{1}{2} \mathrm{~mm}$.

Great Barrier Island. Found in leaf-mould by Mr. A. E. Brookes.

\section{Somatidia crassicollis sp. nov.}

Nitid, fuscous, thorax more rufescent, antennae chestnut red, legs paler, basal portion of tibiar infuscate; sparingly clothed with depressed greyish hairs and erect setae.

Head short, distinctly grooved behind, with only a few distinet pmetures. Therax ahout a fourth broader than long, its sides moderately and almost equally romuled, each side with a distinct though small spine just lowind the midelle; it is moderately coarsely and closely punctate. Scutellun triangular, small. Elytrat of the same width as thorax at the base, 
just double its length, rather more convex, widest before the middle, subvertical behind; evidently subseriate-punctate, rather distantly so, to behind the middle, the subtriangular nigrescent spot near each hind thigh rather long.

Antennae stout, somewhat shorter than the body, with greyish pubescence and outstanding setae; basal joint much stouter than the third, the latter attaining the shoulder and nearly double the length of any of the following ones.

The thorax is shorter and much less narrowed towards the base and apex than in s'. fulvipes and $S$. heteratha (2997), the latter, moreover, is a narrower species with more slender thoracic spines.

Length, $3 \mathrm{~mm}$.; breadth, $1 \frac{1}{3} \mathrm{~mm}$.

Wangaroa. Described from a specimen found in leaf-mould collected for me by Mr. L. T. Griffin, F.Z.S., on the 3rd April, 1914.

\section{Group Halticinae.}

Trachytetra Sharp. Man. N.Z. Coleopt., p. 1311.

\section{Trachytetra frontalis sp. nov.}

Subovate, moderately convex and nitid; fusco-testaceous, elytra along the middle and terminal joints of antennae fuscous.

Thorax rather broader than long, moderately coarsely and closely punctate; with obtuse basal angles, the anterior deflexed and hardly visible when looked at from above. Scutellum short, curvate behind. Elytra not thrice the length of thorax, scarcely any wider than it is at the base; coarsely and closely punctate, almost as coarsely near the apices.

Underside pale fuscous, sparingly clothed with greyish hairs; abdomen finely irregularly transversely rugose. Prosternal process narrower than that of $T$. rugulosa (1116), that between the middle coxae also narrower and more convex.

Somewhat similar to $T$. rugulosa, in which, however, the thorax is almost transversely quadrate with the anterior angles quite visible from above; the scutellum is usually, in 1116 , minute or obsolete.

Length, $2 \frac{1}{4} \mathrm{~mm}$. ; breadth, $1 \frac{1}{3} \mathrm{~mm}$.

Belgrove, near Nelson; 20th October, 1914. Another of the late Mr. 'T. Hall's numerous novelties.

\section{Trachytetra robusta sp. nov.}

Convex, subovate, nitid, glabrous, castaneous.

Head smooth, with a well-marked longitudinal groove belind the antennal insertion; the transverse hinder portion convex. Thorax nearly twice as broad as long, apex subtruncate, the base slichtly curved towards its obtuse angles; the sides distinctly margined, a little curvedly narrowed and deflexed anteriorly: dise ajparently smooth, with only a few minute scattered punctures. Scutellum indistinct, very short and broad. Filytra cordate, slightly wider than thorax at the base, widest before the middle, gradually narrowed posteriorly, fincly margined, their length thrice that of the thorax; moderately ('oarsely and irregularly junctate, more finely and distantly behind. Pygidium covered.

Legs fincly pubescent, posterior tibiate grooved externally. Mesosternal process broad and plane. 
Considerably broader than T. rugulose, with stouter legs and antennae, relatively shorter thorax, and more ample cordiform elytra.

Length, $2 \frac{1}{2} \mathrm{~mm}$. ; breadth, $1 \frac{1}{2} \mathrm{~mm}$.

Pokako, Main Trunk Railway; 22nd February, 1916. A single specimen picked out of leaf-mould, collected by Mr. James Ford, and handed over to me by Mr. A. E. Brookes, of Mount Albert.

Phyllotreta Chevrolat. Man. N.'L. Coleopt., p. 635.

4323. Phyllotreta paspalae sp. nov.

Compact, convex, subelongate-oval, nitid, glabrous; nigro-aeneous, pesterior femora fuscous, darker than the others, tibiae fusco-testaceous, basal half of antennae fulvescent.

Head finely and closely punctate. Eyes large, oblong-oval, slightly prominent. Thorax a third broader than long, base somewhat rounded, with rectangular angles, its sides distinctly margined, slightly curvedly narrowed and deflexed anteriorly, the apex widely but slightly sinuate towards the rectangular angles; its whole surface distinctly and moderately closely punctate. Scutellum short, rounded behind. Elytra at the base as broad as thorax, thrice its length; distinctly striate-punctate, and with some irregular sutural punctures near the base. Pygidium exposed, grooved along the middle.

Antennae half the length of the body, rather slender, distant at the base, implanted on the plane surface near the front and inner side of the eyes, second joint only slightly shorter than the elongate first or third, the remaining joints elongate and subequal.

'osterior femora strongly dilated, the tibiac subangulate on the outside below the middle, underneath that point excavate for the reception of the basal tarsal joint, which is longer than the next, third bilobed, fourth stender, shorter than first, elaws not obviously appendiculate; front tibiac simple, with smaller spurs.

Underside distinctly punctate, its pubescence grey.

Prosternal process broad, grooved along the middle, prolonged almost to the middle coxae, which are as far apart as the anterior. Metasternum moderate, its distinct curved frontal margin extending between the middle coxae. Basal ventral segment nearly as long as the following four together.

'This cannot be placed in any New Zealand genus, neither can it remain in Phyllolvela. on account of the more widely separated anterior coxae and externally clavate posterior tibiae.

Length, $3 \mathrm{~mm}$.; breadth, $1 \frac{1}{2} \mathrm{~mm}$.

Lake Ohia, North Auckland. Deseribed from four specimens found by Mr. 1. E. Brookes, of Mount Albert, who canght them on Paspelum plants.

By Authority: W. A. G. Skinver, Government Printer, Wellington.-1923.

$[300 / 11 / 21-16816$ 
· 



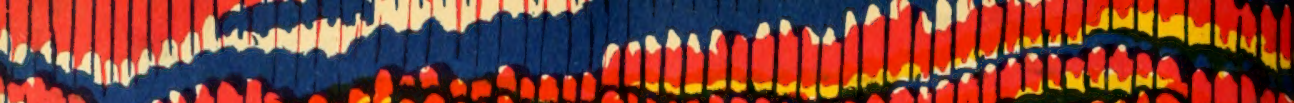

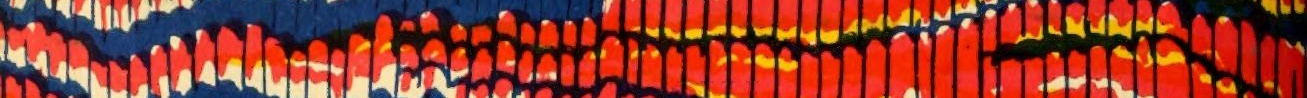

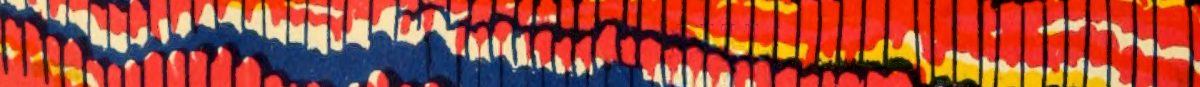

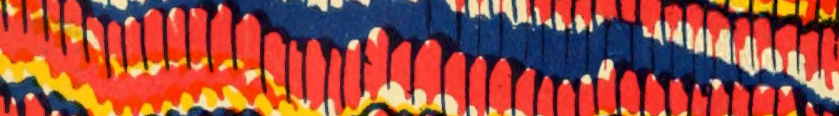

S. 1 (1)

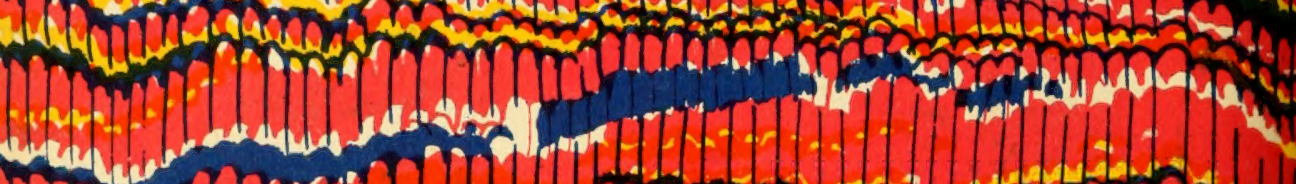

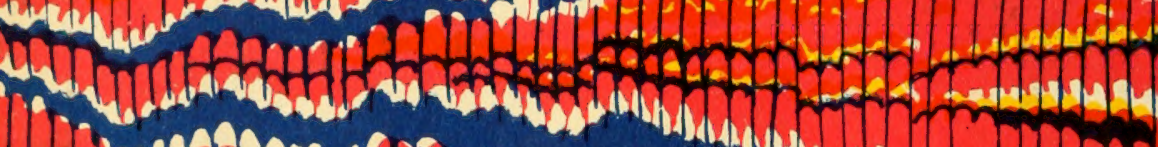

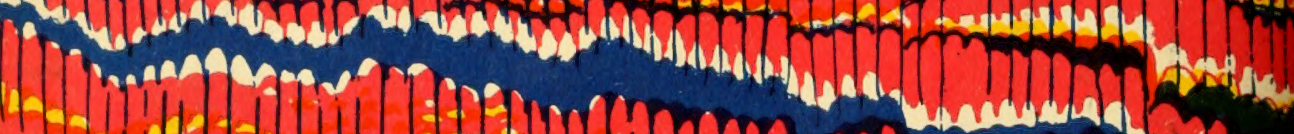

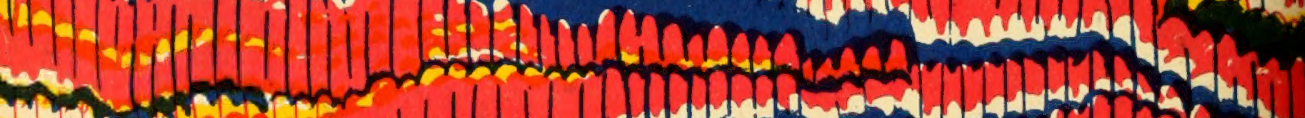

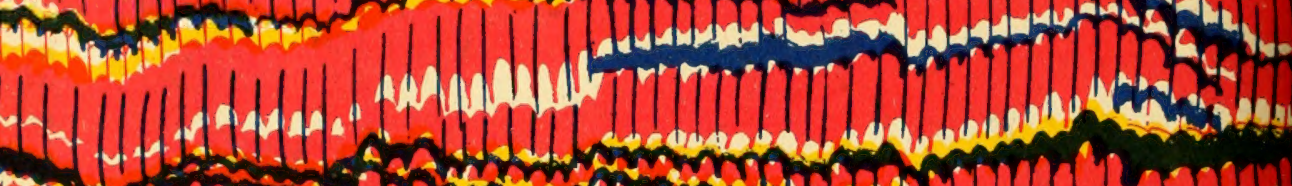

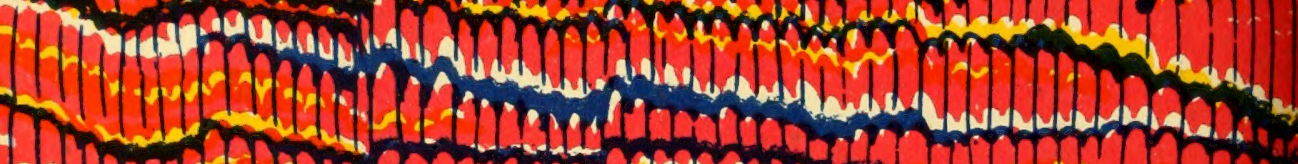

4.

. प्रम Dow

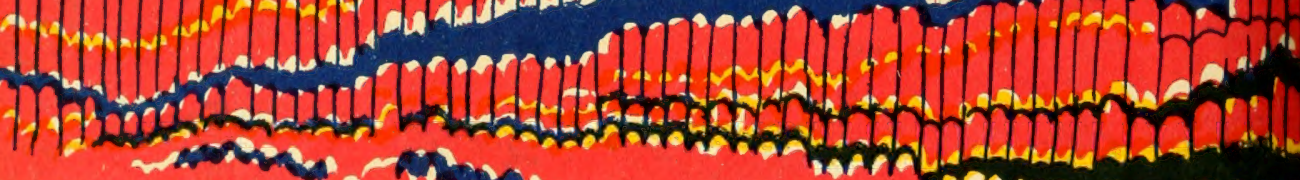

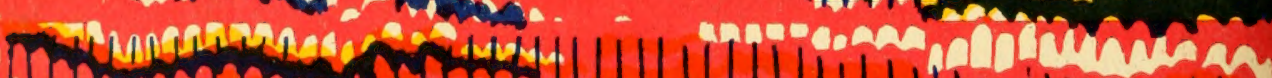

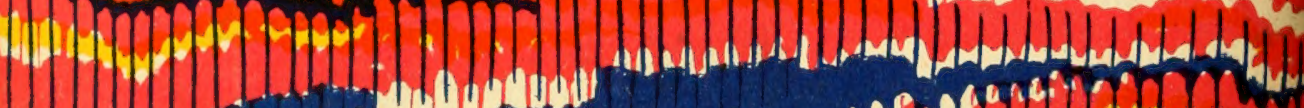

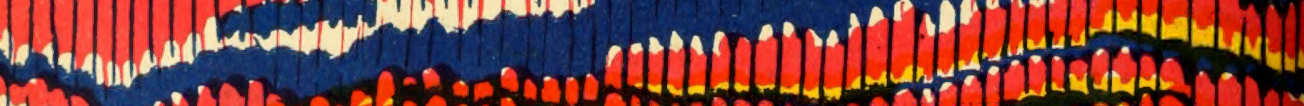

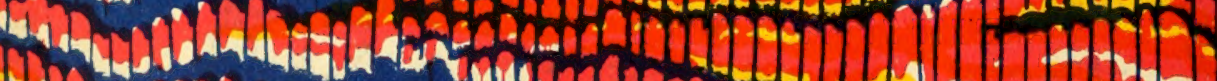

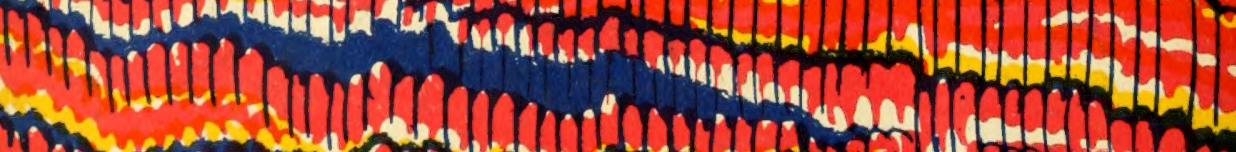
W Matom

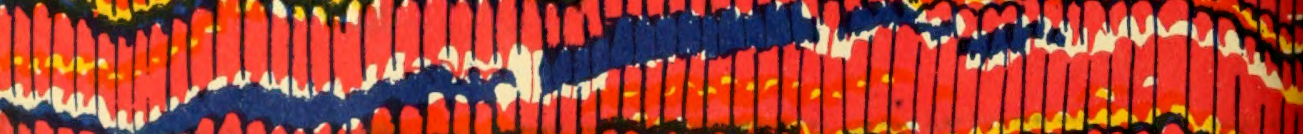
Mr

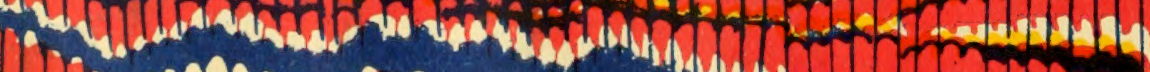


Whanh

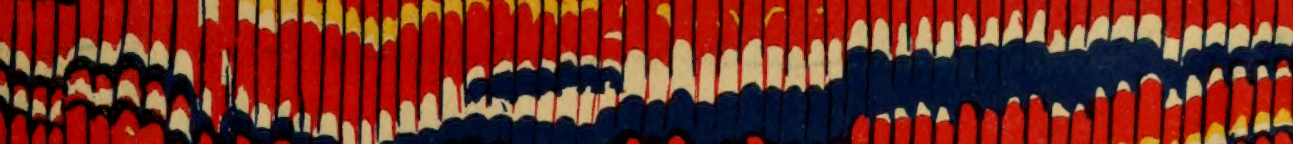

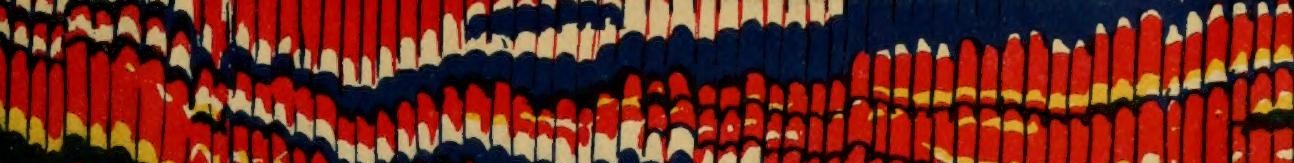
atr 4

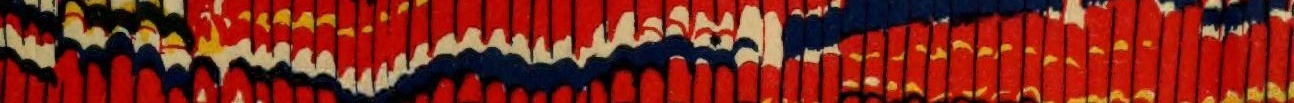

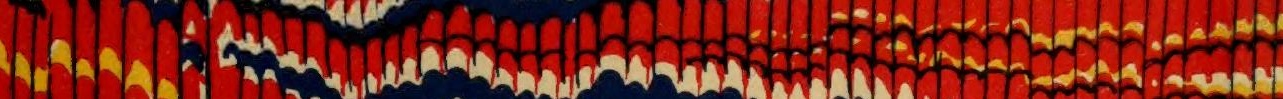

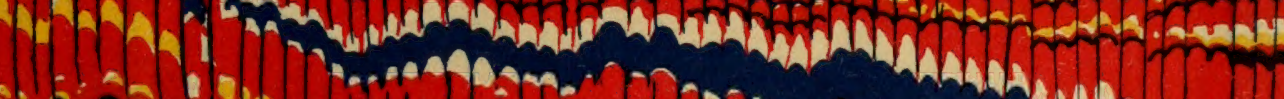

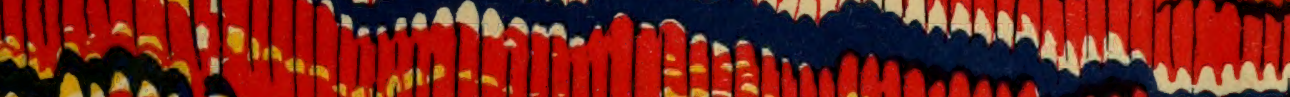
anis hine

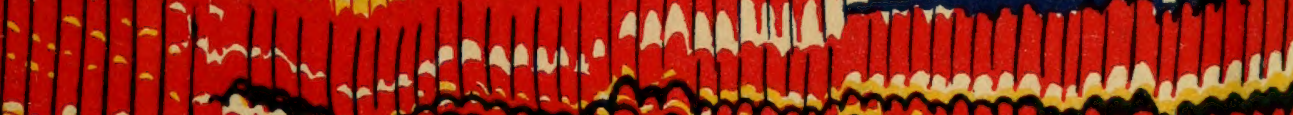
201 - th

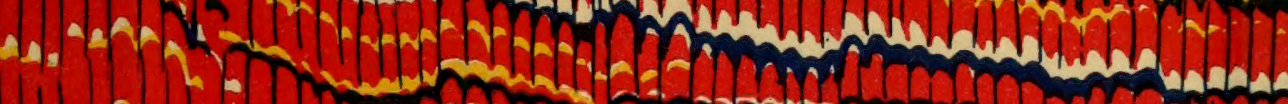
and Wha a

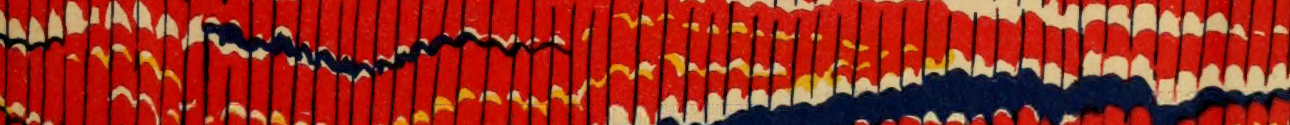
- nat

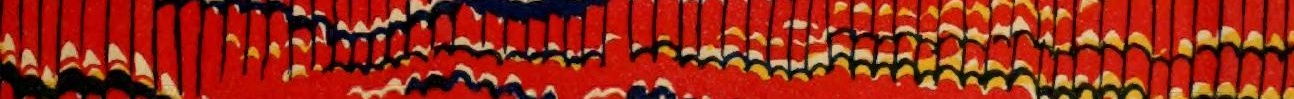

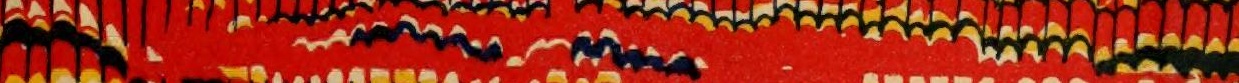
mare

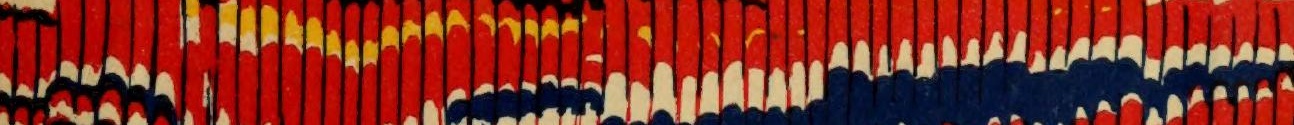

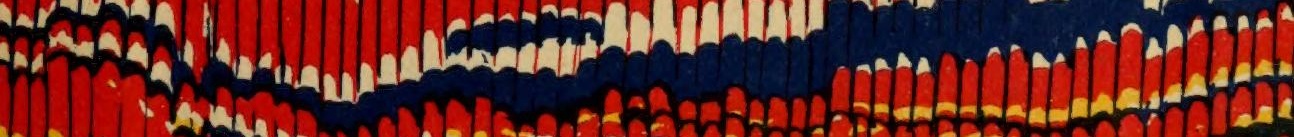

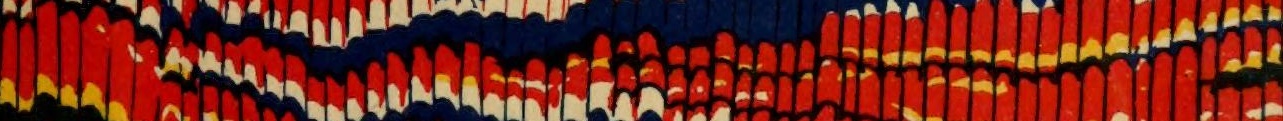
A

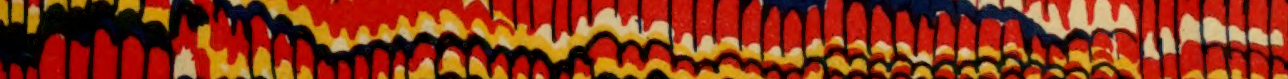

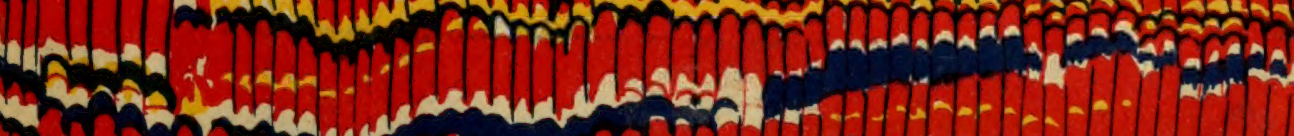


SMITHSONIAN INSTITUTION LIBRARIES

30088006755714

$3 \quad 9088 \quad 00675 \quad 5714$ 